Departament d'Història Moderna i Contemporània

\author{
UAB \\ Universitat Autònoma \\ de Barcelona
}

\title{
EL MOVIMENT VEÏNAL AL BARCELONÈS NORD (1954-1987)
}

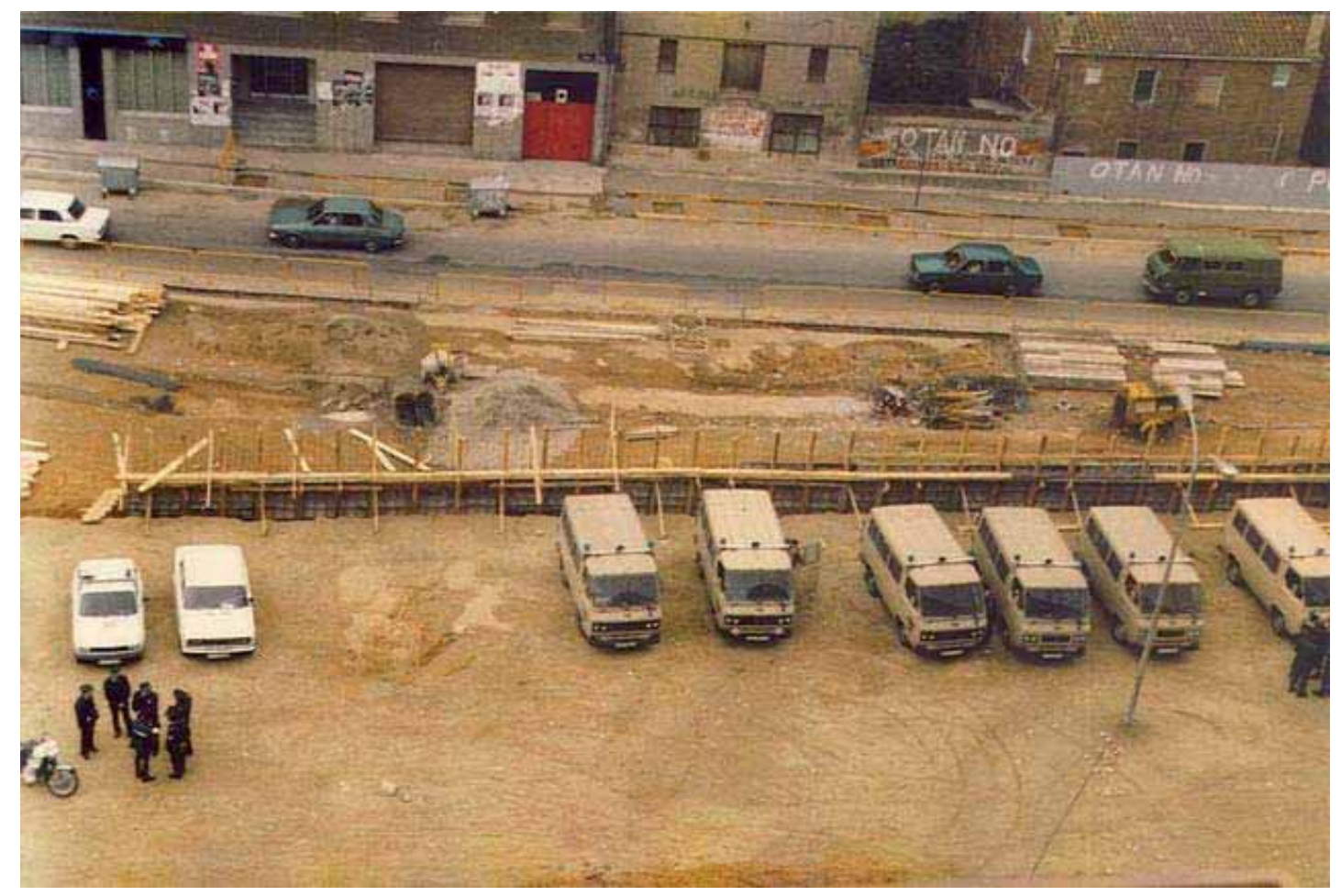

TESI DOCTORAL presentada per: JOSÉ MIGUEL CUESTA GÓMEZ dirigida per: MARTÍ MARÍN I CORBERA 

Als meus avis, mare i pare, per decidir buscar un futur millor i anar a viure a Sant Roc i Llefià (Badalona) respectivament. Sense ells aquest treball no existiria.

A la meva companya, al meu fill, als amics, amigues, companys, companyes, camarades i, en general, a tots els que lluiten per aconseguir una societat lliure, justa i igualitària. 


\section{Índex}

0. Introducció i agraïments

p. 11

I. El moviment veïnal en el seu context

1.1. Els debats a l'entorn del franquisme i el procés de canvi polític

.p. 21

1.2. Els debats a l'entorn del moviment veïnal i els moviments socials o populars p. 38

1.3. I al Barcelonès Nord? p. 65

II. Els orígens del moviment veïnal al Barcelonès Nord p. 79

2.1. Les condicions objectives: Immigració, treball i classe a Badalona, Santa Coloma de Gramenet i Sant Adrià de Besòs. Una lluita diària ..p. 79

2.2. Les condicions subjectives: hegemonia cultural, pensament, consciència, associacionisme i organització.

2.3. L'associacionisme "familiar" promogut per la dictadura p. 124

2.4. El paper de l'Església, dels catòlics de base i de les organitzacions antifranquistes.

2.5. Del moviment obrer als primers intents: Comissions de Veïns, Comissions Obreres de Barri i Centres Socials. ..p. 179

III. L'esclat reivindicatiu del moviment veïnal. ...p. 205

3.1. Un punt d'inflexió: els anys setanta .p. 205

3.2. Centres Socials, Comissions de Barri, Associacions de Veïns i partits polítics. Tots alhora? ..p. 236

3.3. Molt més que unes simples demandes de serveis: model de societat i referents culturals. Consciència de classe, anticapitalisme i democràcia

3.4. Les principals lluites veïnals fins la mort de Franco. .p. 297

3.5. Badalona, Santa Coloma de Gramenet i Sant Adrià de Besòs: un procés similar? .p. 357 
IV. El moviment veïnal durant la primera part de la transició: el seu moment culminant

4.1. La crisi del franquisme i el paper de l'oposició antifranquista.

“¿Atado y bien atado?”.

4.2. El procés de canvi polític. Quin paper va jugar el moviment veïnal? p. 388

4.3. Les organitzacions polítiques i la seva visió del moviment veïnal.

Gèrmens de la futura crisi? la demanda d'ajuntaments democràtics i poder popular..

4.4. Lluites veïnals i reivindicacions polítiques al Barcelonès Nord: el franquisme local desbordat. ..p. 453

4.5. Els primers ajuntaments democràtics i el paper del moviment veïnal p. 525

V. El moviment veïnal als anys vuitanta: una crisi real però magnificada p. 569

5.1. L'Impacte de la crisi econòmica: atur i delinqüència. Crisi de valors. Consciència de classe contra consumisme i individualisme? p. 569

5.2. El paper dels partits polítics al Barcelonès Nord. La crisi de l'esquerra revolucionària i l'escissió del PSUC. Els "altres" protagonistes: PSC-PSOE i CiU. p. 600

5.3. Associacions autònomes i actives o dependents i sumisses. La pugna política pel control de les associacions ..p. 631

5.4. Malgrat tot mobilitzacions: les principals lluites veïnals al Barcelonès Nord als anys vuitanta. .p. 657

VI. Conclusions ..p. 719

VII. Bibliografia p. 737

VIII. Annexos ..p. 783 

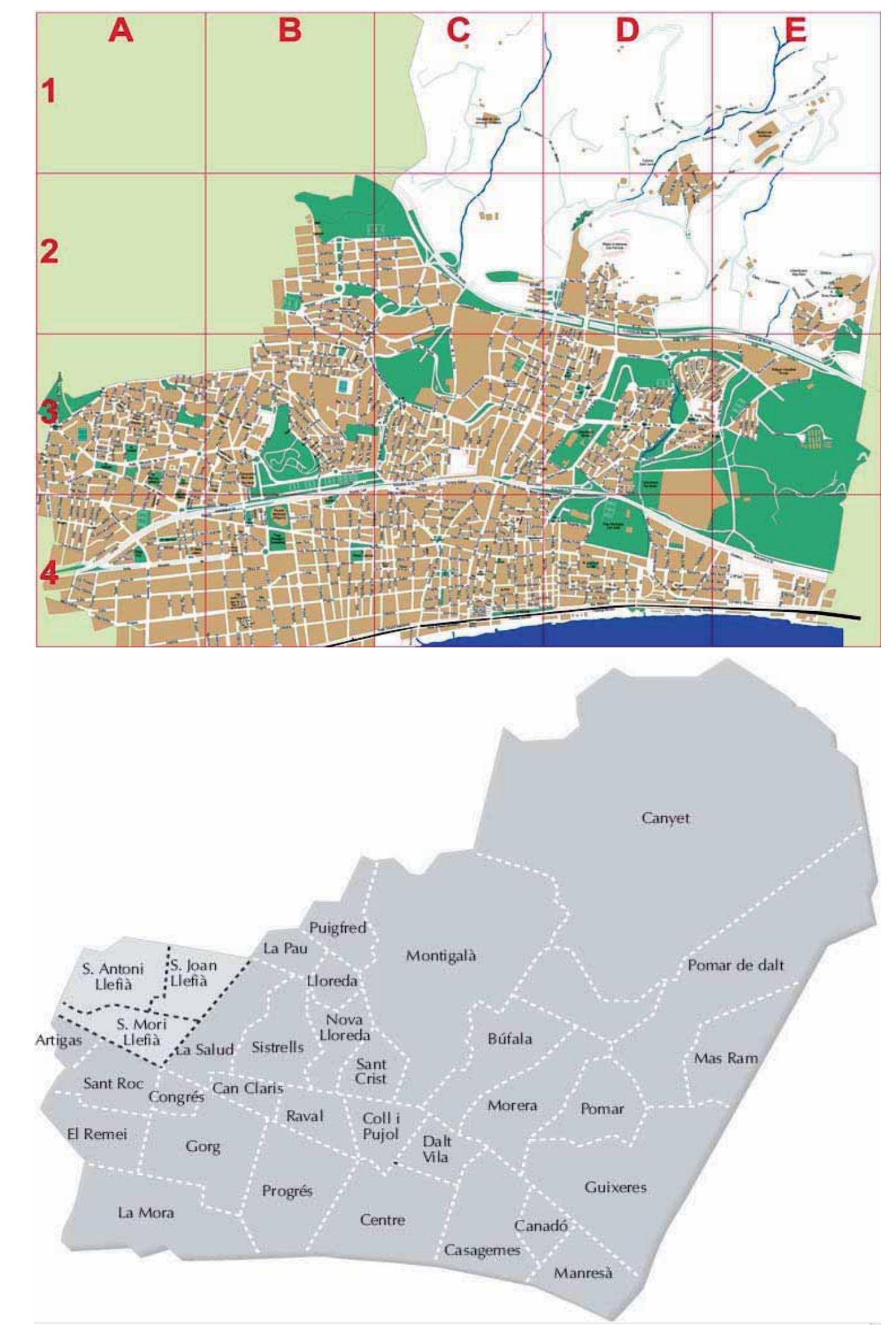

Badalona i els seus barris. 


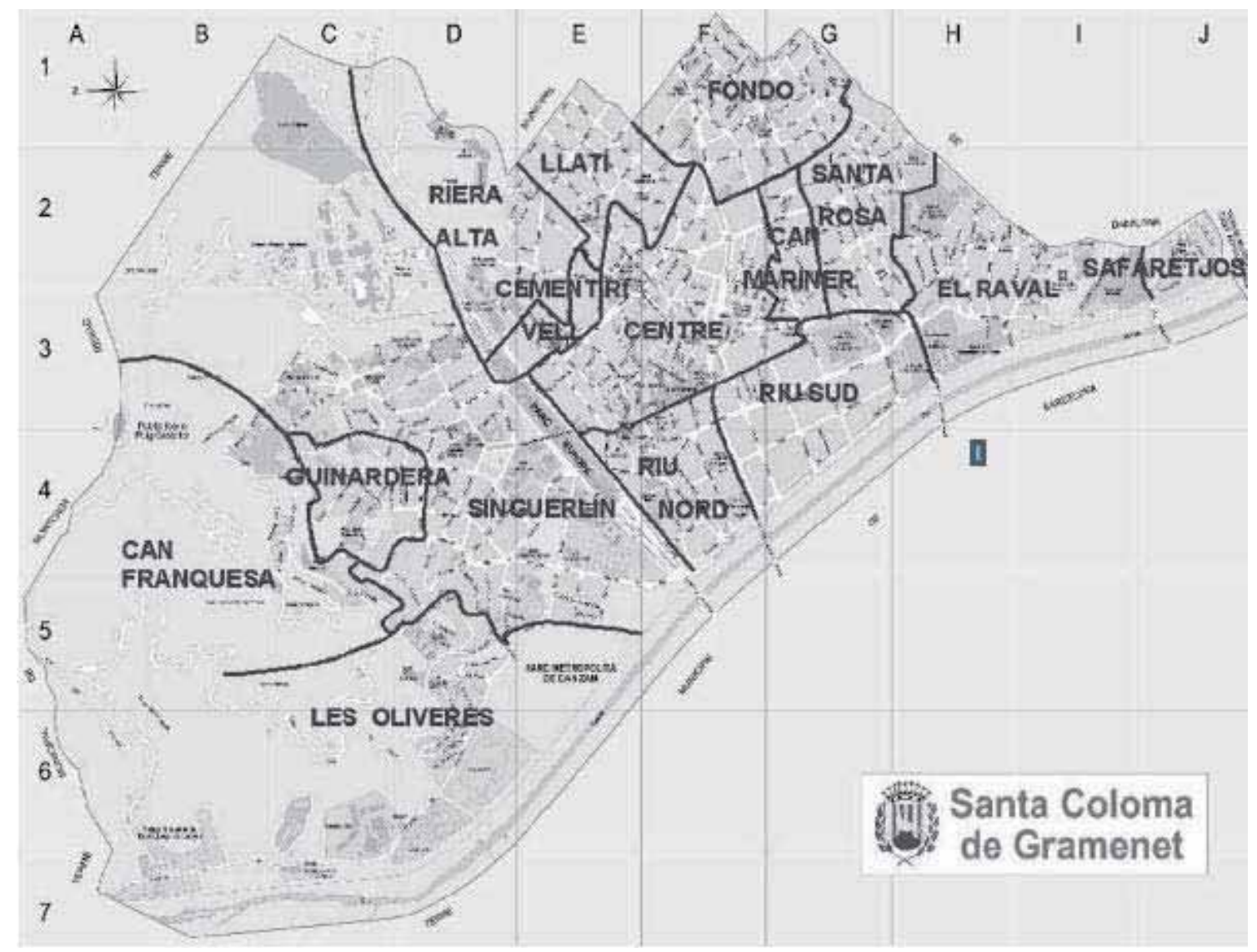

Santa Coloma de Gramenet i els seus barris.

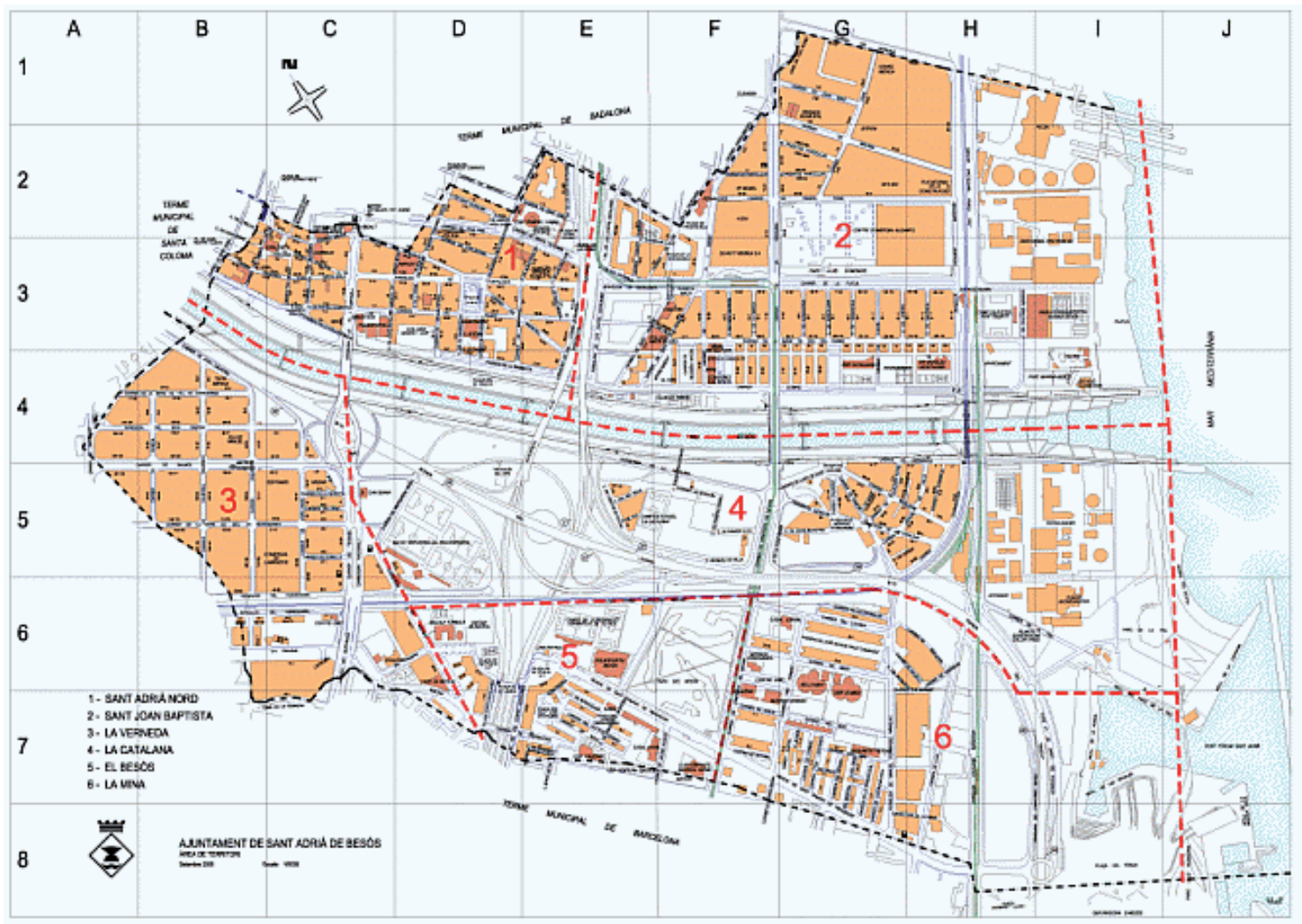

Sant Adrià de Besòs i els seus barris: 1-Sant Adrià Nord; 2- Sant Joan Baptista; 3- La Verneda; 4- La Catalana; 5- El Besós i 6- La Mina. 


\section{Abreviatures}

ACF: Asociación de Cabezas de Familia

AC: Acción Comunista

ACO: Acció Catòlica Obrera

ADIGSA: Administració, Promoció i Gestió, Societat Anònima

AGA: Archivo General de la Administración

AHGCB: Archivo Histórico del Gobierno Civil de Barcelona

AHMTB: Arxiu Històric Museu Torre Balldovina (Santa Coloma de Gramenet)

AHPCE: Archivo Histórico del Partido Comunista de España

AMPA: Associació de Mares i Pares d'Alumnes.

ANC: Arxiu Nacional de Catalunya

AP: Alianza Popular

API: Agencia Popular Informativa

ASAB: Arxiu Municipal Sant Adrià de Besòs

ASCG: Arxiu Municipal Administratiu de Santa Coloma de Gramenet.

AVV: Associació de Veïns

CAP: Centre d'Atenció Primària

CCBB: Comissions de Barri

CEU: Centre d'Estudis d'Urbanisme

CEUMT: Centre d'Estudis Urbanístics, Municipals i Territorials

CCOO: Comissions Obreres

CIDUR: Centro de Documentación Urbana y Rural

CiU: Convergència i Unió

CEPEC: Col·lectiu d'Escoles per l'Escola Pública Catalana

CMB: Corporació Metropolitana de Barcelona

CNT: Confederació Nacional del Trabajo

COB: Comissions Obreres de Barri

COJ: Comissions Obreres Juvenils

CSC: Convergència Socialista de Catalunya

EUB: Esquerra Unida de Badalona

FAVB: Federació d'Associacions de Veïns de Badalona 
FAVGRAM: Federació d'Associacions de Veïns de Santa Coloma de Gramenet FOC: Front Obrer de Catalunya

FSF: Força Socialista Federal

GA: Grupos Autónomos.

GOA: Grupos Obreros Autónomos

HOAC: Hermandades Obreras de Acción Católica

IC: Iniciativa per Catalunya

INV: Instituto Nacional de la Vivienda

JCC: Joventuts Comunistes de Catalunya

JOC: Juventud Obrera Católica

LCR: Lliga Comunista Revolucionària.

MB-AHC: Museu de Badalona - Arxiu Històric de la Ciutat

MB-AJMC: Museu de Badalona - Arxiu Josep Maria Cuyàs

MDM: Movimiento Democrático de Mujeres

MCE/MCC: Movimiento Comunista de España/ Moviment Comunista de Catalunya

OCE-BR: Organización Comunista de España-Bandera Roja

OIC: Organización de Izquierda Comunista

ORT: Organización Revolucionaria de los Trabajadores

OSE: Organización Sindical Española

OSH: Obra Sindical del Hogar

PCC: Partit dels Comunistes de Catalunya

PCE: Partido Comunista de España

PCE(i): Partido Comunista de España Internacional

PMV: Patronato Municipal de la Vivienda

PMVRL: Patronato Municipal de la Vivienda de Renta Limitada.

PSC-C: Partit Socialista de Catalunya (Congrés)

PSOE: Partido Socialista Obrero Español

PSUC: Partit Socialista Unificat de Catalunya

PTE/PTC: Partido de los Trabajadores de España, Partit del Treball de Catalunya

SGM: Secretaria General del Movimiento

TUSA: Transportes Urbanos Sociedad Anónima.

ZUR: Zona d'Urgent Reindustrialització. 


\section{Introducció i agraïments.}

Aquest treball que teniu entre les mans es sumarà a una sèrie d'investigacions que en els darrers anys han tractat de superar les mancances que hi havia en l'estudi del moviment veïnal. Un servidor es sentiria profundament agraït si es pensés que el present estudi ajuda a completar més la recerca en aquest àmbit, encara que sigui treballant un marc territorial molt local.

He d'admetre que dins les motivacions que m'han empés a aquesta recerca hi ha un factor personal -i sentimental, si és vol- que no es pot menystenir. Segurament, tot va començar fa molts anys, allà per la dècada dels seixanta, quan quatre persones -els meus avis paterns i pare des d'Extremadura per una banda i la meva mare des de Galícia per una altra- van decidir anar a Catalunya a la recerca d'un futur millor que el que podien albirar als seus llocs d'origen, tal com van fer tantes i tantes persones al llarg del segle anterior. I de la mateixa manera que moltes altres persones, van anar a viure als suburbis i barris situats als extraradis de les ciutats catalanes, aquells que els hi eren més assequibles al seu reduït poder adquisitiu. Uns barris que van haver de lluitar molt per aconseguir unes mínimes condicions dignes de vida en un context molt difícil, en els darrers moments de l'última dictadura feixista del continent europeu i en un període d'incertesa política però també d'il·lusió i esperances per aconseguir un futur millor.

Va ser inicialment en aquests barris, poblats majoritàriament pels que Paco Candel anomenà "els altres catalans" on es va desenvolupar el moviment veïnal. Un moviment que se'ns dubte va contribuir a la millora de les condicions de vida de la població que hi vivia. Jo era massa petit per recordar-me però anys després, en converses de sobretaula a casa dels meus pares apareixia de tant en quant el record a tal manifestació o a tal tall de trànsit per aconseguir les anhelades escoles o la il·luminació i asfaltat tant necessaris al barri.

Però el moviment veïnal no es mobilitzava només per qüestions de immediatesa diària. Va contribuir notablement al desgast i a la impossibilitat de perpetuació de la dictadura un cop mort Franco. Va anar més enllà de reivindicar els serveis més bàsics i fins i tot va exigir el canvi polític en especial en l'àmbit local -uns ajuntaments democràtics- i proposar noves formes d'organització social i 
econòmica enfrontades al model econòmic capitalista imperant.

Quan semblava que aquest moviment ciutadà estava en el seu punt àlgid, determinats esdeveniments van aturar la seva progressió i posaren el germen de la seva posterior crisi. El paper subordinat al qual es va relegar a l'associacionisme veïnal en el nou context polític així com altres factors (paper de determinats partits polítics, crisi econòmica, auge de l'individualisme, entre d'altres) van iniciar una etapa on l'associacionisme veïnal va perdre una part important de la seva força. Ara bé, això no va significar la seva desaparició total. A vegades s'ha exagerat la crisi del moviment veïnal fins al punt que sembli que als anys vuitanta no existien conflictes ni mobilitzacions. El present treball arriba fins aquells anys demostrant, en part, que aquesta percepció no es correspon pas amb la realitat. Les vivències personals m'indicaven clarament que els vuitanta no van ser un oasi, ja que per exemple al 1986 es va produir un conflicte molt important al meu barri -Llefiàdurant tres mesos que va deixar un profund impacte i del qual encara se'n parla avui en dia: l'anomenada "batalla de Trafalgar" de la qual ja vaig parlar en la meva Tesina de doctorat ${ }^{1}$.

He posat en evidència que els meus orígens i la meva residència en un barri d'una determinada ciutat han influït de manera molt important en la tria del meu objecte d'estudi. Però no puc negar que també ha estat una determinada manera de pensar i una ideologia -si és vol- la que ha ajudat també en aquesta decisió. Una visió del món, de la societat i de la història on els protagonistes són les classes populars, la gent senzilla, aquella que sovint ha estat menystinguda o obviada en l'explicació dels grans fets històrics, aquella que és la que de manera majoritària produeix la riquesa amb hores i hores de treball per benefici d'uns tercers. Sens dubte aquesta percepció de la societat ha influït també en la tria del tema de la meva investigació.

El fet que el meu estudi es centri en el denominat Barcelonès Nord (subcomarca "no oficial" que agrupa els municipis de Badalona, Santa Coloma de Gramenet i Sant Adrià de Besòs) està motivat per una banda pels motius sentimentals que he esmentat al començament. Les meves vivències personals han

1 José Miguel Cuesta Gómez: El moviment veïnal a Llefià (Badalona), Tesina de Doctorat inèdita, UAB, Bellaterra (Cerdanyola del Vallés), setembre de 2010. 
estat un fet imprescindible. Però no es pot negar que el subjecte d'estudi oferia prou motius propis per ser investigat, apart de concentrar un volum de població gens menyspreable de més de quatre cents mil habitants ${ }^{2}$. I aquí em refereixo tant a l'important moviment veïnal que es va desenvolupar a la seva si com a les seves característiques en les tres ciutats abans esmentades. Aquest va tenir en elles una gran força superant, en part, els tempos cronològics que es solen associar amb aquest moviment popular i que no solen anar més enllà dels anys setanta.

La tria del Barcelonès Nord constitueix un acte de reconeixement a aquesta realitat territorial sovint poc coneguda pel fet de viure a l'ombra de la gran Barcelona. També m'oferia la possibilitat d'observar les diferents característiques que va tenir el moviment veïnal en totes tres ciutats així com la seva diferent evolució política un cop establert els primers ajuntaments democràtics. Per indagar en el perquè d'aquestes diferències "a posteriori" s'ha fet un anàlisi de les condicions socio-econòmiques, dels processos previs d'autoorganització i empoderament popular així com el paper de les diferents forces polítiques en tots tres municipis. Però és innegable que malgrat les semblances que podem trobar, a cada municipi trobem particularitats que ens permeten fer exercicis comparatius en un espai relativament reduït. Fins i tot dintre de cada municipi podrem trobar com el moviment veïnal evoluciona de manera particular segons el barri i el tipus d'associació. De manera que als anys vuitanta dintre del teixit associatiu veïnal hi havia unes diferències importants en funció de les persones que encara treballaven en les associacions. La meva investigació vol indagar també en el perquè -malgrat la crisi real del moviment veïnal- va haver-hi AVV's que mantingueren una notable capacitat de mobilització i incidència.

Però abans d'arribar a aquests anys relativament poc estudiats, cal veure com es va gestar el moviment veïnal en els darrers anys del franquisme i com va adquirir la força i capacitat de mobilització que va tenir en especial a la dècada dels setanta. Per començar el primer capítol de la meva investigació analitza, per una banda, les diferents interpretacions que s'han fet del franquisme i del procés de canvi polític cap a una monarquia parlamentària (popularment conegut com a

2 La població de les tres grans ciutats del Barcelonès Nord segons el Padró Municipal a data de 11-2012 és: Badalona 220.977 habitants; Santa Coloma de Gramenet 120.593 habitants i Sant Adrià de Besòs 34.482 habitants. 
Transició) en tant van ser el context on es va desenvolupar el propi moviment veïnal. A continuació serà el torn d'analitzar els debats i interpretacions que s'han fet a l'entorn del propi moviment veïnal -en tant moviment social o popular- i la seva relació i interacció amb altres sectors de la població organitzats o mobilitzats. Tot això en el context del Barcelonès Nord.

El segon capítol es centra en els orígens del moviment veïnal en aquest territori. Analitzo les condicions objectives -materials- existents en Badalona, Santa Coloma de Gramenet i Sant Adrià de Besòs i com les greus deficiències i desigualtats existents -fomentades o tolerades per les institucions franquistes- van agreujar la situació i les condicions de vida de milers de persones que arribaren seguint diferents fluxos migratoris. La política de construcció d'habitatge engegada pel franquisme als anys seixanta va ser insuficient i els greuges existents van ser, sens dubte, un factor clau pel desenvolupament d'un moviment veïnal reivindicatiu.

Però pel sorgiment d'aquest calien més factors. Era necessari que sectors importants de la població prenguessin consciència de que havien de lluitar i mobilitzar-se per aconseguir solucionar aquests problemes i fer-ho en un context hostil, en una dictadura. Va ser un procés que no es va fer de la nit al dia i que va haver de superar diversos entrebancs. Per començar, l'intent del franquisme de crear un associacionisme veïnal controlat i submís a les autoritats locals així com la dura repressió que aquest exercia i que alguns sectors conservadors del present -per oportunisme polític- han tractat de minimitzar. La ineficiència d'aquest associacionisme veïnal franquista en solucionar els problemes dels barris així com la seva subordinació als ajuntaments li va restar credibilitat. Aquest conglomerat d'entitats "col·laboracionistes" -per dir-ho així- ja va ser infiltrat en alguns casos per persones "desafectes". Per altra banda, el paper dels catòlics de base i de determinades parròquies així com de grups de persones actives -en alguns casos antics represaliats o procedents del moviment obrer- i també posteriorment dels partits polítics va ser determinant en el sorgiment d'un moviment popular als barris amb voluntat de confrontació amb les autoritats locals, que va emergir amb força als anys setanta si bé els seus fonaments s'havien anat covant la dècada anterior. 
El tercer capítol tracta precisament de l'inici d'aquest esclat reivindicatiu que es va donar durant la dècada dels setanta i que va posar les autoritats franquistes locals entre l'espasa i la paret. Va ser Santa Coloma la que va iniciar el període amb les massives mobilitzacions per la construcció d'un ambulatori i hospital a la ciutat -procés que va ser vital pel sorgiment d'unes Comissions de Barri clandestines i anticapitalistes- si bé ràpidament s'hi va sumar Badalona i Sant Adrià de Besòs. $\mathrm{A}$ Badalona, la ciutat més poblada del Barcelonès Nord, la lluita de barris perifèrics com Pomar, Llefià, La Salut, La Pau o Sant Roc per millorar la seva situació va ser pionera mentre la ciutat més petita -Sant Adrià- tingué unes condicions peculiars per la situació en que es trobaven els barris situats al marge dret del riu Besòs, que també van destacar per la seva primerenca mobilització. Les semblances i diferències d'aquests processos en les tres ciutats són analitzats amb detall. També dedico una atenció especial en aquest capítol i en el següent -i en general a tot el treball- al paper que va tenir la dona en la lluita dels barris i com, si bé al començament se li va adjudicar un major protagonisme per la divisió masclista de les tasques de reproducció i cura, progressivament des de les vocalies de dones de les diferents associacions es va anar adquirint una major consciència de l'explotació i discriminació que patia la dona, sent la base pel sorgiment de diversos grups feministes en els anys posteriors.

El quart capítol es centra precisament en el moment més àlgid del moviment veïnal, coincidint amb la crisi del franquisme i els anys on es va configurar el procés de canvi d'una dictadura feixista a una monarquia parlamentària. En aquest període el moviment ja havia desenvolupat un corpus reivindicatiu i ideològic que anava més enllà de reivindicacions urbanístiques i de serveis bàsics. Es qüestionava obertament l'ordre socio-econòmic vigent així com les autoritats polítiques hereves del franquisme. Les mobilitzacions van desbordar obertament les autoritats franquistes locals, obligades a "aguantar el tipus" pel Govern Civil i controlades -parcialment- pels partits polítics recentment legalitats. No obstant, en aquest mateix moment i en especial a partir de la legalització dels diferents partits polítics al 1977, va començar un debat sobre quin havia de ser el paper de les associacions veïnals en un context d'ajuntaments democràtics. La qüestió no és banal ja que es van donar diferents plantejaments sobre si havien de ser uns 
organismes de contrapoder popular, amb capacitat de cogestió de determinats serveis municipals o unes organitzacions amb una tasca més limitada, que en cap moment pogués controlar o fiscalitzar el poder polític local. Aquí segurament tindrem una de les causes de la futura crisi del moviment veïnal. La constitució dels primers ajuntaments democràtics serà un fet que també tindrà incidència en el moviment popular, amb la marxa de no pocs dirigents veïnals cap els consistoris, en alguns casos convençuts que des de les institucions es podien solucionar els problemes de les ciutats, subordinant el paper de les entitats veïnals.

El capítol cinquè es centra en els anys vuitanta, un període poc estudiat fins el moment. Una època on s'ha generalitzat la idea que el moviment veïnal entra en una crisi molt profunda i que contrasta amb la dècada anterior per una suposada absència de conflictivitat important. La importància de la greu crisi econòmica i les seves greus conseqüències pel que fa a l'atur i a l'augment de la delinqüència -magnificada aquesta pels sectors conservadors per aconseguir un enduriment penal i enfortir la ideologia dretana- així com el paper de determinades formacions polítiques d'esquerres s'analitza en aquest capítol. I si bé és cert que als anys vuitanta hi ha una crisi real de l'associacionisme veïnal amb un descens notable de persones associades i mobilitzades, els fets ens demostren -si més no al Barcelonès Nord- que va haver-hi molts matisos. Als anys vuitanta va haver-hi conflictes molt importants amb la implicació d'associacions de veïns. En especial d'aquelles que per diferents motius havien mantingut un esperit reivindicatiu i no havien estat "cooptades" per algunes organitzacions polítiques més interessades en tenir unes corretges de transmissió i unes associacions submises i subordinades. A nivell genèric aquests conflictes estaven motivats per operacions urbanístiques o per la conservació de serveis públics però tot i tractar-se de qüestions aparentment tant quotidianes, sempre va resultar implícit -i fins i tot explícit- que des de aquestes associacions es defensaven propostes d'aprofundiment democràtic que contrastaven amb la rigidesa i limitació de les administracions locals. Al Barcelonès Nord veurem com els esdeveniments polítics locals van incidir en el teixit associatiu i en la relació d'aquest amb el poder polític. L'evolució política diferent de tots tres municipis ens permetrà fer una perspectiva comparada.

Apart de les aportacions ja apuntades per investigacions precedents a la 
meva sobre l'origen, desenvolupament i capacitat de mobilització del moviment veïnal durant els anys seixanta i setanta així com la seva capacitat d'erosió i deslegitimació del poder franquista a nivell local, vull aprofundir sobre els motius de la posterior crisi del moviment així com el paper que van tenir-hi els partits polítics en els anys vuitanta. Alguns partits o fraccions de partit van mirar de controlar el moviment veïnal en tant en quant encara era una plataforma que agrupava centenars de ciutadans on es podia fer proselitisme polític. Aquest control es va utilitzar tant per intentar impedir que es promoguessin accions i mobilitzacions contra el poder local o com per a justament el contrari, quan era el rival polític el que controlava els ajuntaments. Mentrestant altres persones i organitzacions van continuar apostant per l'organització popular -fracassat electoralment el seu intent de ser present en les institucions- i des de aquest moviment popular resistent va sorgir la renovació, en forma d'altres experiències organitzatives com van ser agrupacions feministes, de joves, de gais i lesbianes, entre d'altres. En el darrer capítol de Conclusions faig un resum del que considero que són les principals aportacions que he volgut exposar en la present tesi.

Encara que la historiografia ha dedicat molt temps a l'anàlisi i interpretació de la dictadura franquista, al procés de canvi polític conegut popularment com a Transició i al desenvolupament de determinats moviments populars que es van donar en el seu si (en especial l'obrer i l'estudiantil), pel que fa al moviment veïnal encara no s'ha arribat a un nivell d'aprofundiment similar, tot i que els darrers anys estan apareixent tota una sèrie de treballs -recollits al primer capítol i a la bibliografia que adjunto- amb la voluntat de suplir aquesta mancança. Com he esmentat abans, el present treball s'ha d'adscriure a aquest procés.

Per desenvolupar aquesta investigació he treballat en molts diversos àmbits car les fonts necessàries per aprofundir la recerca es troben disperses en multitud de referències bibliogràfiques, arxius, biblioteques així com en la memòria oral de dels seus protagonistes, molts dels quals, per sort, encara poden donar-nos el seu testimoni. En aquest sentit ha estat vital la consulta d'arxius històrics com l'Arxiu Nacional de Catalunya, el Archivo General de la Administración (Alcalà de Henares), o l'Archivo del Gobierno Civil de Barcelona (amb la inestimable ajuda d'Ivan Bordetas i Anna Sánchez per la documentació que em van facilitar 
procedent d'aquest) i d'altres de més especialitzats com el Centre de Documentació (CEDOC) i l'Hemeroteca de la Biblioteca de Ciències de Comunicació de l'UAB, el fons del Centre d'Estudis Històrics Internacionals de la UB (CEHI-Pabelló de la República), l'Arxiu Històric de CCOO de la Fundació Cipriano García o el Archivo Histórico del PCE (Madrid). Per la naturalesa local del meu estudi la consulta de l'Arxiu Històric de la Ciutat de Badalona, l'Arxiu del Museu Torre Balldovina i l'Arxiu Municipal Administratiu de Santa Coloma de Gramenet i l'Arxiu Municipal Administratiu de Sant Adrià de Besòs han estat imprescindibles. Encara més. La consulta de projectes com Gramenet TV, així com de l'Arxiu Històric de Llefià (Badalona), o l'Arxiu Històric i Centre de Documentació de La Mina i del Camp de la Bota (Sant Adrià), impulsats per entitats i persones amb una voluntat de recuperar la memòria històrica dels barris i les lluites que es van desenvolupar, han estat també una font d'ajuda inestimable.

De la mateixa manera en aquesta investigació ha estat molt important la recerca de fonts orals. L'entrevista a antics membres del moviment veïnal -que en alguns casos encara no han abandonat el món associatiu-, militants de partits polítics diversos, cristians de base i capellans obrers, alcaldes i alcaldesses dels tres municipis (en especial del període democràtic), ha estat d'un gran valor. He entrevistat a més de quaranta persones pel meu compte aprofitant la meva proximitat amb el marc local d'estudi i la meva coneixença del teixit associatiu existent -fragments de les quals he transcrit literalment- i alhora he fet servir les entrevistes realitzades pel Centre d'Estudis sobre les Èpoques Franquista i Democràtica (CEFID) del fons "Construint la ciutat democràtica: el moviment veïnal durant el tardofranquisme i la transició (1964-1980)" i de la “Col·lecció Història Oral i militància sindical. Biografies Obreres" de l'Arxiu Històric de CCOO, en especial, la d'aquelles persones del Barcelonès Nord.

Per acabar aquesta introducció voldria fer tota una sèrie d'agraïments a aquelles persones que han contribuït a la realització d'aquesta recerca. Alguns ja els he fet implícitament a l'inici d'aquest capítol, com es el cas dels meus progenitors, els quals, van ser determinants -indirectament si es vol- pel desenvolupament d'aquest treball. Seguint aquest patró també ho hauria de fer a 
totes aquelles persones que han lluitat, lluiten i lluitaran per aconseguir una societat i uns Països Catalans més justos i igualitaris i que d'alguna manera em van influenciar per que el meu interès investigador es dirigís cap a l'estudi d'aquella població sovint marginada i menystinguda en els discursos oficials.

Segurament hi haurà que pensarà que la meva ideologia ha pogut condicionar la meva investigació. I és cert, tant cert com que qualsevol investigació, incloses les de les anomenades "ciències pures" també ho està per molt imparcials que es vulguin presentar. Sempre és més honest reconèixer el nostre condicionament ideològic que voler-nos presentar com a jutges imparcials totalment objectius quan ningú ho pot ser. Aquest reconeixement, però, no hauria d'anar renyit amb un treball honest i exhaustiu. Si més no, aquesta ha estat la meva voluntat.

Deixant de banda aquestes apreciacions, torno a la qüestió dels agraïments. He de començar per Denise, la meva companya. La seva paciència i comprensió ha estat d'una inestimable ajuda i suport en els moments més durs en la elaboració d'aquesta recerca. Sense els seu suport aquesta Tesi segurament no hauria arribat a bon port. També al meu director, en Martí Marín i Corbera, l'ajuda del qual ha estat inestimable per l'orientació d'aquest treball, tot respectant la meva independència.

De la mateixa manera ho he de fer amb els i les companyes del CEFID, i en especial, a aquells que han estudiat també el moviment veïnal -Ricard Martínez i Iván Bordetas- sense que per això menystingui el suport i els ànims de la resta d'investigadors: Ximena, Carlos, Pau, Andrea, Helena, Guillermo i Chen. Amb els dos primers he pogut intercanviar opinions, experiències i fins i tot documentació i papers, fet que els he d'agrair profundament. Amb la resta de companys he compartit uns anys de camaraderia que no oblidaré mai.

Els meus profunds agraïments a totes aquelles entitats i persones que han ajudat en aquesta recerca. Començaré per les del meu barri -Llefià- amb les quals encara tinc un vincle profund malgrat la distància geogràfica actual. En especial a l'AVV de Sant Antoni de Llefià i a l'Arxiu Històric de Llefià -del qual vaig ser un dels membres fundadors ${ }^{3}$ - per recuperar i difondre la història del barri, de les seves

3 L'Arxiu Històric de Llefiscós es va constituir com entitat el 2007. Es pot consultar el seu extens fons documental a www.llefia.org/arxiu. 
lluites i per facilitar-me l'ús i consulta de la seva documentació. A l'Arxiu Històric i Centre de Documentació de La Mina i del Camp de la Bota, una altra iniciativa sorgida des de el teixit associatiu per recuperar la història d'aquest maltractat barri i d'aquells que van desaparèixer com el Camp de la Bota -i en especial a Josep Maria Montferrer, el seu President ${ }^{4}$. També a les diferents associacions veïnals del Barcelonès Nord que m'han prestat la seva ajuda permetent-me accedir a la seva documentació i facilitant-me el contacte amb persones susceptibles de ser entrevistades, com per exemple les de Nova Lloreda i Lloreda.

A les persones treballadores dels organismes oficials del Barcelonès Nord que també m'han facilitat documentació necessària pel meu estudi: en especial a Montserrat Carreras i Maria Dolors Sabater de l'Arxiu Històric de la Ciutat de Badalona, Rosa Delgado i Xavi Luis de l'Arxiu Municipal Administratiu de Santa Coloma de Gramenet, a Magda Clavell de l'Arxiu Històric del Museu Torre Balldovina; a Pere Guaita i Albert Martínez de l'Arxiu Municipal de Sant Adrià de Besòs. Sense la seva col·laboració no hauria tingut l'accés a una documentació local molt important.

A Juan Manuel Garcia y Javier Tébar de l'Arxiu Històric de CCOO i a Cristina González de l'Arxiu de la Fundació Rafael Campalans i als responsables i treballadors de l'Arxiu Nacional de Catalunya (en especial a Rosa M. Cruellas), del CEHI-Pavelló de la República i del Archivo General de la Administración (Alcalá de Henares) per l'ajuda en la consulta dels seus fons.

Un agraïment especial per a totes les persones que van dedicar una part no menyspreable del seu temps a lluitar per aconseguir uns barris, unes ciutats i una societat més justa i que s'han avingut a prestar el seu testimoni per aquesta recerca. També a aquelles persones que en general han prestat el seu testimoni independentment de la seva ideologia però que també van ser protagonistes de la història local i comarcal ${ }^{5}$.

A totes i a tots, moltes gràcies.

4 L'Arxiu Històric i Centre de Documentació de La Mina i del Camp de la Bota es pot consultar a http://www.desdelamina.net/arxiuhistoric/

5 A l'Annex faig un recull de totes les persones entrevistades. 


\section{El moviment veïnal en el seu context.}

"Em cal, doncs, explicitar una hipòtesi de partida sobre el caràcter del règim, encara que només hagi d'explorar-lo parcialment. La hipòtesi és que efectivament el franquisme fou la versió espanyola d'un règim feixista. El camp en què incidiré serà únicament el terreny de l'administració local, comprovant fins a quin punt pot considerar-se que fou un exemple d'administració feixista, tant per la seva singularització respecte de l'abans i el després de l'administració local espanyola com per la comparació amb el cas italià, que en fou el primer i un dels de durada més llarga (1922-1945)."

“El proceso de Transición partió de la profunda crisis de la dictadura, pero el resultado final no estaba ni mucho menos predeterminado"7

"Igualment, el moviment veïnal es va convertir en un dels principals espais de participació política de les classes populars, especialment important per aquells sectors que no podien intervenir tan directament en la resta de moviments socials que operaven en aquelles dates." ${ }^{\prime \prime}$

\subsection{Els debats a l'entorn del franquisme i el procés de canvi polític.}

Per entendre i situar en la seva perspectiva el moviment veïnal o, en la terminologia de l'època, el moviment popular ciutadà ${ }^{9}$, és necessari fer una aproximació a dos aspectes de vital importància. Per una banda, l'anàlisi del context on es va desenvolupar aquest moviment i per una altra, les característiques pròpies del moviment veïnal en tant moviment social o popular. Ara ens centrarem en el primer d'aquests dos aspectes.

6 Martí Marín i Corbera: Els Ajuntaments franquistes a Catalunya, Pagès editors, Lleida, 2000, p. 31-32.

7 Pere Ysàs: "La crisis de la dictadura franquista", dins Carme Molinero (ed.): La transición, treinta años después. De la dictadura a la instauración y consolidación de la democracia, Ediciones Península, Barcelona, 2006, p. 58.

8 Iván Bordetas Jiménez i Anna Sánchez Sorribas: "El moviment veïnal en (la) Transició, 19741979" dins Carme Molinero i Pere Ysàs (coords.): Construint la ciutat democràtica. El moviment veïnal durant el tardofranquisme i la transició, Icària, Antraazyt, Barcelona, 2010, p. 163.

9 Aquesta terminologia va ser utilitzaa de manera freqüent durant els anys setanta en les publicacions i anàlisis dels partits polítics. Un exemple concret es pot veure a Maria J. Olivé: "Santa Coloma de Gramenet. Conflictes i moviments urbans", Serra d'Or (6-1975) (sense esmentar les obres d'autors contemporanis com Manuel Castells i Jordi Borja, les obres dels quals esmento més endavant). 
Parlar del franquisme i la seva natura és entrar en un terreny -dit amb paraules planeres- relliscós. Nombroses són les polèmiques que envolten el debat sobre la dictadura que durant una quarantena d'anys va governar amb mà de ferro els destins de l'Estat espanyol. Polèmiques en gran part condicionades per les discussions sobre les característiques del règim i també pel desequilibri existent en les temàtiques del franquisme que han estat treballades profusament. En no pocs casos, la ideologia es barreja amb la historiografia, si bé aquest fet és més evident en la història que es divulga pels mitjans de comunicació de masses que la feta en l'àmbit acadèmic, on si més no, les diferents ideologies existents queden més matisades pel discurs científic que es fa servir, però sense que això negui la seva influència. En aquest sentit em limitaré a dir que personalment em situo en la corrent historiogràfica -minoritària, encara-, que ha definit al franquisme com un règim feixista -si més no durant els seus primers anys, ja que pel que fa a les etapes posteriors les opinions, dins aquesta corrent, ja no són tant unànimes-. En tot cas, amb el meu treball mostraré com el franquisme encara als anys seixanta presentava unes característiques feixistes en la voluntat d'enquadrar i mobilitzar -a la seva manera- sectors amplis de la població en benefici propi ${ }^{10}$.

$10 \mathrm{Hi}$ ha diverses obres i autors que han estudiat aquestes característiques molt feixistes de la dictadura franquista. Carme Molinero i Pere Ysàs han destacat com les organitzacions de masses d'enquadrament del franquisme no eren tant diferents que les dels estats feixistes (de fet es va prendre el model de la Itàlia feixista per crear-les), al igual que les polítiques d'adoctrinament on sobretot pel que fa a la joventut i la dona, no hi ha pràcticament diferències amb la Itàlia feixista i l'Alemanya nazi. Veure: Carme Molinero i Pere Ysàs: Productores disciplinados y minorias subversivas: clase obrera y conflictividad laboral en la España franquista, Siglo XXI, Madrid, 1998; Carme Molinero: La Captación de las masas: política social y propaganda en el régimen franquista, Cátedra, Madrid, 2005; Carme Molinero i Giuliana di Febo (eds.): Nou Estat, nova política i nou ordre social: feixisme i franquisme en una perspectiva comparada, Fundació Carles Pi i Sunyer d'Estudis Autonòmics i Locals -CEFID-UAB, Barcelona, 2005. Sobre el paper de la dona en el franquisme: Carme Molinero: "Mujer, franquismo, fascismo. La clausura forzada en un "mundo pequeño"', Historia Social, núm. 30, 1998, p. 97-117; Teresa Gallego: Mujer, falange y franquismo, Taurus, Madrid, 1983; R. Rosario Sánchez: Mujer española, una sombra de destino en lo universal, Universidad de Murcia, Madrid, 1990. Sobre la Secció Femenina: E. Bosch i V. A. Ferrer: El model de dona a la Secció Femenina. Implantació a les Illes Balears (1939-1975), Universitat de les Illes Balears, 1997; Antonieta Jarne: La Secció Femenina a Lleida, Pagès Editors, Lleida, 1991; E. Jiménez: "La mujer en el franquismo. Doctrina y acción de la Sección Femenina" en Tiempo de Historia, núm. 83, 1981; Kathleen Richmond: Las mujeres en el fascismo español. La Sección Femenina de la Falange, 1934-1959, Alianza ensayo, Madrid, 2004. Sobre altres organismes i institucions franquistes: Ángela Cenarro: Los niños del Auxilio Social, Espasa, Pozuelo de Alarcón, 2009; La sonrisa de Falange: Auxilio Social en la Guerra Civil y en la postguerra, Crítica, Barcelona, 2006; Miguel Ángel Ruíz Carnicer: El sindicato español universitario (SEU), 1939-1965: la socialización política de la juventud universitaria en el franquismo, Siglo XXI, Madrid, 1996. Sobre els Ajuntaments franquistes: Martí Marín i Corbera: Els ajuntaments franquistes a Catalunya, Pagès editors, Lleida, 2000. Sobre el poder judicial: 
Tal com afirmava Iván Bordetas en la seva Tesi Doctoral, el franquisme presenta un gran desequilibri tant en les temàtiques com en les cronologies estudiades $^{11}$. Mentre determinats aspectes $\mathrm{i}$ dates han estat estudiades profusament, altres no ho han estat tant. El mateix autor, citant un article de Carme Molinero i Pere Ysàs ${ }^{12}$ de finals dels anys noranta, esmentava els tres camps on els coneguts investigadors indicaven que calia fer una major recerca: les actituds polítiques contra la dictadura, les condicions de vida i treball de la població i, per últim, la conflictivitat i els moviments socials.

Afirmava també que si bé en el primer dels camps hi havia ja una extensa bibliografia, en el segon dels camps no s'havia arribat al mateix nivell tot reconeixent els avenços fets d'ençà 1998. Per últim, pel que fa l'estudi de la conflictivitat i dels anomenats moviments socials, constatava, com molts altres investigadors, que també s'ha produït un diferent nivell d'estudi i anàlisi pel que fa, per posar un exemple prou clar, entre l'estudi del moviment obrer i el moviment estudiantil respecte l'anomenat moviment veïnal, al qual fins i tot se'l va arribar a nomenar "parent pobre dels moviments socials"13.

El moviment obrer té una llarga tradició d'estudi historiogràfic, i el seu revifament amb força als anys seixanta amb el naixement de les Comissions Obreres no es pot negar, així com el seu paper en l'erosió de la dictadura que va

Mónica Lanero Taboas: Una Milicia de la justicia: la política judicial del franquismo (1936-1945), Centro de Estudios Constitucionales, Madrid, 1996. Sobre el sindicat vertical i la seva propagada: Álex Amaya Quer: El Acelerón sindicalista: el aparato de propaganda de la Organización Sindical Española entre 1957 y 1969, Asociación de Historia Contemporánea : Centro de Estudios Políticos y Constitucionales, Madrid, 2013. Sobre la repressió juntament amb estudis locals i provincials: Ricard Vinyes: Irredentas, las presas políticas y sus hijos en las cárceles de Franco, Col-lecció Historia: Temas de Hoy, Madrid, 2002; Julian Casanova (Coord.): Morir, matar, sobrevivir: la violencia en la dictadura de Franco, Crítica, Barcelona, 2004; El pasado oculto: fascismo y violencia en Aragón, 1936-1939, Siglo XXI, Madride, 1993; Julian Sanz Hoya: La construcción de la dictadura franquista en Cantabria: instituciones, personal político y apoyos sociales (1937-1951), Universidad de Cantabria, Santander, 2009; Francisco Cobo Romero i Teresa Maria Ortega López: Franquismo y postguerra en Andalucía oriental: represión, castigo a los vencidos y apoyos sociales al régimen franquista, 1936-1950, Universidad de Granada, Granada, 2005, entre d'altres.

11 Iván Bordetas Jiménez: Nosotros somos los que hemos hecho esta ciudad. Autoorganización y movilización vecinal durante el franquismo y el proceso de cambio político, Tesi Doctoral, Cerdanyola del Vallès, UAB, 2012, p. 25-28.

12 Carme Molinero y Pere Ysàs, "La historia social de la época franquista. Una aproximación", Historia Social, 30 (1998), p. 122-154.

13 Manuel Ortiz, "Movimientos sociales y sociabilidad en Castilla-La Mancha durante el segundo franquismo" en Abdón Mateos y Ángel Herrerín (eds.), La España del presente: de la dictadura a la democracia. II Congreso Internacional de la Asociación de Historiadores del Presente. Torrescaballeros: Asociación de Historiadores del Presente, 2006, p. 322. 
tenir en aquest el seu principal enemic. Per tant, es comprensible que hagi estat estudiat de manera més exhaustiva ${ }^{14}$. Pel que fa al moviment estudiantil, tot i que no s'acosta al nivell d'estudi del moviment obrer -tal com vaig dir en la meva tesina de doctorat- ha tingut un nivell de recerca no menyspreable per diversos factors, entre ells per que sovint ha interessat l'estudi d'un espai, l'universitari, que tradicionalment havia estat un "forjador d'elits" polítiques i econòmiques (una argumentació certament classista). En els darrers anys s'han fet noves aportacions en la seva recerca ${ }^{15}$. En canvi, pel que fa al moviment veïnal la situació encara resta

14 Davant la impossibilitat de resumir en una nota a peu de pàgina la bibliografia referent al moviment obrer i demanant disculpes anticipadament per les omissions destacaré: Sebastian Balfour: La dictadura, los trabajadores y la ciudad. El movimiento obrero en el área metropolitana de Barcelona (1939-1988), Edicions Alfons el Magnànim, València, 1994; José Babiano: Emigrantes, cronómetros y huelgas. Un estudio sobre el trabajo y los trabajadores durante el franquismo (Madrid 1951-1977), Siglo XXI, Madrid, 1995; David Ruiz (dir.): Historia de Comisiones Obreras, Siglo XXI, Madrid, 1993; Carme Molinero i Pere Ysàs: Productores disciplinados y minorías subversivas. Clase obrera y conflictividad laboral en la España franquista, Siglo XXI, Madrid, 1998; José Antonio Pérez, Los años del acero. La transformación del mundo laboral en el área del Gran Bilbao [1958-1977]. Trabajadores, convenios y conflictos. Biblioteca Nueva, Madrid, 2001; Xavier Domènech: Quan el carrer va deixar de ser seu. Moviment obrer, societat civil i canvi polític. Sabadell 1966-1976, Publicacions de l'Abadia de Montserrat, Barcelona, 2002, Clase obrera, antifranquismo y cambio político, Los Libros de la Catarata, Madrid, 2008 i Cambio político y movimiento obrero bajo el franquismo. Lucha de clases, dictadura y democracia (1939-1977), Icària, Barcelona, 2012; Javier Tébar Hurtado (ed.): El movimiento obrero en la gran ciudad. De la movilización sociopolítica a la crisis económica, El Viejo Topo, Barcelona, 2011.

15 Sobre el moviment estudiantil val la pena destacar: Materiales: "Documentos del movimiento universitario bajo el franquismo", núm. 1 extraordinari, 1977; Jose Mํㅡ Colomer: Els estudiants de Barcelona sota el franquisme, Curial, Barcelona, 1978; Salvador Giner: "Libertad y poder político en la universidad española: el movimiento democrático durante el franquismo", Sistema núm. 24/25, 1978; José Ma Maravall: Dictadura y disentimiento político. Obreros y estudiantes bajo el franquismo, Alfaguara, Madrid, 1979; Arturo Camarero: "La expansión del movimiento estudiantil en Madrid. Formas de movilización y organización con los estudiantes", Revista Internacional de Sociología (1981); Ricardo Montoro: La Universidad en la España de Franco (1939-1970). Un análisis sociológico, Centro de Investigaciones Sociológicas, Madrid, 1981; Juan José Carreras: La universidad española bajo el régimen de Franco, Institución Fernando el Católico, Zaragoza, 1991; Francisco Fernández Buey: "Els moviments estudiantils a Espanya, 1966-1975", L'Avenç, núm. 146, 1991; Ernesto Portuondo: "Forja de rebeldes. Una aproximación a los orígenes de las vanguardias militantes del radicalismo de izquierdas en la segunda mitad de los sesenta: el movimieno estudiantil (1964-1970)" a Jose Ma Auge y declive de la izquierda revolucionaria en España (1964-1992), Los Libros de la Catarata, Madrid, 1992; Benito Sanz i Ramón Rodríguez Bello (ed.): Memoria del antifranquismo. La universidad de Valencia durante el franquismo 1939-1975, Universitat de València, 1999; Sergio Rodríguez Tejada: "Estratègies d'oposició i moviment estudiantil antifranquista: una reflexió des de el cas valencià" a Recerques núm. 44 (2004); Pere Ysàs: Disidencia y subversión. La Lucha del régimen franquista por su supervivencia, 1960-1975, Crítica, Barcelona, 2004, en especial el capítol "La rebelión de los estudiantes", p. 1-46; José Álvarez Cobelas: Envenenados de cuerpo y alma. La oposición universitaria en Madrid (1939-1970), Siglo XXI, Madrid, 2004; Elena Hernández Sandoica, Miguel Ángel Ruiz Carnicer y Marc Baldó Lacomba: Estudiantes contra Franco (1939-1975). Oposición política y movilización juvenil, La Esfera de los Libros, Madrid, 2007 i Sergio Rodríguez Tejada: Zonas de libertad. Dictadura franquista y movimiento estudiantil 
lluny de ser satisfactòria malgrat que en els darrers anys han aparegut nous estudis dels quals parlaré posteriorment. La majoria d'aquestes noves obres es centren en àmbits locals, situació que és en gran part comprensible i en la qual tanmateix s'hauria d'incloure aquesta mateixa recerca. De fet, va ser durant les darreries del franquisme així com els anys posteriors de la dècada dels setanta el moment de major eclosió del moviment veïnal als barris. Però com tindrem ocasió de veure, aquest no va desaparèixer als anys vuitanta.

Es el moment de fer alguns comentaris sobre les diferents interpretacions sobre el tardofranquisme i el procés de canvi polític, ja que la meva investigació es circumscriu en les corrents que han destacat la importància de la crisi que estava patint la dictadura en els seus darrers anys així com de la mobilització social que la va condicionar, al igual que els esdeveniments que es van donar posteriorment a la mort de Franco.

Però no tothom ha compartit aquesta visió. Alguns politòlegs i sociòlegs que han volgut fer d'historiadors han arribat a negar l'existència d'una crisi del franquisme o l'havien circumscrit únicament a l'àmbit institucional. Així Juan José Linz afirmava sense cap rubor el següent:

"España no había experimentado una derrota militar o la inminencia de la misma, como Portugal, Grecia y más tarde Argentina. Aunque existan movilizaciones populares, huelgas y un modesto foco terrorista, la presión contra el régimen era probablemente menor que en otras transiciones, como por ejemplo la coreana y las más recientes del este de Europa (...) el régimen tenía una considerable estabilidad y salvo la sucesión de Franco por su muerte, no se encontraba en una profunda crisis." ${ }^{16}$

Mentrestant, Cayo Sastre sostenia amb un argumentari similar que:

“Finalmente hay que considerar que en 1975 el régimen no había quebrado; simplemente vivía una crisis de sucesión y una necesidad de adaptación para la que algunos sectores de la coalición autoritaria buscaban soluciones des de la década de los años $60^{m 17}$

És més, segons el mateix sociòleg un sectors amplis de la població en la Universidad de Valencia, Universitat de València, València, 2009.

16 Juan J. Linz: "La transición a la democracia en España en perspectiva comparada" a R. Cotarelo (comp.): Transición política y Consolidación Democrática, España (1975-1978), Centro de Investigaciones Sociológicas, Madrid, 1992, p. 435-436.

17 Cayo Sastre: Transición y desmovilización política en España (1975-1978), Universidad de Valladolid, Valladolid, 1998, p. 60. 
conservaven un bon record del dictador Francisco Franco i mostrava apatia i desinterès per les qüestions polítiques. Aquestes conclusions les extreia a través d'unes enquestes:

\begin{abstract}
“Tampoco el régimen estaba atrincherado y Franco dejaba un buen recuerdo en la memoria de amplios sectores de la población apareciendo como un gobernante venerable (López Pintor, 1982:103). Según una encuesta realizada por ICSA-GALLUP inmediatamente después de la muerte de Franco, para un $82 \%$ de los españoles la muerte de Franco supuso dolor, pena y una pérdida irreparable, y un $60 \%$ estaba tranquilo frente a un 26 \% que mostraba preocupación (...) la transición política no vino precedida durante todo el periodo de cambio político de un estado anímico social que, sin sufrir variaciones importantes durante todo el periodo de cambio político, estuvo dominado por la apatía política." ${ }^{18}$
\end{abstract}

Tot i que s'ha de reconèixer que el franquisme va tenir una base social i un suports més amplis del que moltes persones es pensen -una altra semblança amb els feixismes italià i alemany-, resulta molt qüestionable que aquest autor tregui conclusions a partir del resultat d'unes enquestes que, independentment de la seva metodologia, estan fetes en una dictadura. La opinió dels i les entrevistades estava fortament condicionada per la por a expressar-la públicament ja que n'eren ben conscients del que podia passar si manifestaven hostilitat envers el règim. A més, les enquestes no són l'únic indicador per mesurar un possible malestar social.

Lluny de destacar la intensa conflictivitat social que va existir en el tardofranquisme, tota una sèrie d'autors s'han destacar per negar, menysvalorar o minimitzar l'acció col-lectiva, situant-la com a molt en un segon pla de manera secundària respecte altres factors que per ells van ser més importants per la fi de la dictadura. Autors com José Félix Tezanos destaquen la modernització econòmica que es va produir als anys seixanta i setanta -gairebé relacionant-la sempre amb les mesures liberalitzadores del règim- com a factor fonamental pels canvis polítics que s'havien de donar en la dècada posterior i que havien de conduir mecànicament a l'establiment d'una democràcia parlamentària ${ }^{19}$. Altres autors

18 Cayo Sastre: Transición y desmovilización política en España (1975-1978), Universidad de Valladolid, Valladolid, 1998, p. 60.

19 José Félix Tezanos: "La crisis del franquismo y la transición democrática", a José F. Tezanos, Ramón Cotarelo i Andrés de Blas (eds.): La transición democrática española, Sistema, Madrid, 1989, p. 9-28. 
-com Santos Julià, José Carlos Mainer, Víctor Pérez, Robert Fishman, Jorge Benedicto Millán- sostenen que aquesta modernització va afavorir el sorgiment d'una cultura "liberal-democràtica" en la classes treballadora, en les classes populars i en les capes intermèdies de la societat ${ }^{20}$. Tot i que el concepte "cultura democràtica" es presta a múltiples interpretacions ja que no tothom ho entén de la mateixa manera ni l'associa als mateixos valors, caldria aclarir quins criteris es fan servir per mesurar-lo. De nou un sociòleg, Víctor Pérez Díaz utilitzava unes enquestes de finals de franquisme, amb la fiabilitat dubtosa que ja hem comentat, per afirmar que la "cultura democràtica" dels ciutadans de l'Estat espanyol era "dèbil" ${ }^{21}$, a més de fer una assimilació entre "cultura democràtica" i "moderació social" força qüestionable:

"Así, en España, dos clases de ideologías tuvieron que desaparecer previamente: por parte de la derecha, el nacionalcatolicismo y, por parte de la izquierda, el radicalismo social. Ambas habían generado en los años treinta un modo de hacer política, militante y polarizadora, que se puede llamar 'política absoluta', incompatible con el nuevo régimen." ${ }^{22}$

És cert que determinats autors van matisar aquestes opinions ja de ben antuvi. Per exemple, ja al 1979 Raymond Carr i Juan Pablo Fusi, tot i que havien centrat el seu interès en demostrar que el procés democratitzador va sorgir de la

20 Santos Julià: “Obreros y sacerdotes: cultura democrática y movimientos sociales de oposición”, a Javier Tusell, Alicia Alted i Abdon Mateos (coords.): La oposición al régimen de Franco. Vol. II, UNED, Madrid, 1990, p. 147-159 i “Orígenes sociales de la democracia en España”, Ayer núm. 15 (1994), p. 165-188; amb José Carlos Mainer: El aprendizaje de la libertad, Alianza, Madrid, 2000; Víctor Pérez Díaz: La primacía de la sociedad civil. El proceso de formación de la España democrática, Alianza, Madrid, 1993; Robert Fishman: Organización obrera y retorno a la democracia en España, Siglo XXI i Centro de Investigaciones Sociológicas, Madrid, 1990; Jorge Benedicto Millán: "Sistemas de valores y pautas de cultura predominantes en la sociedad española (1976-1985)" a José Félix Tezanos, Ramón Cotarelo i Andrés de Blas (eds.): La transición democrática española..., p. 645-678.

21 Víctor Pérez Díaz: La primacía de la sociedad civil... p. 47. El mateix autor no havia dubtat en qualificar als règims de l'Europa oriental de la guerra freda de "totalitaris" mentre que qualificava al franquisme "d'autoritari", donant-me la impressió que ho fa per una qüestió ideològica. No obstant, la tesi "de la II a República víctima dels extremismes" ja va ser exposada per historiadors com Gabriel Jackson: Catalunya republicana i revolucionària (1931-1939), Grijalbo, Barcelona, 1982; Breve historia de la guerra civil española, Grijalbo, Barcelona, 1986; La República española y la guerra civil: 1931-1939, Crítica, Barcelona, 1990; Paul Preston: La Destrucción de la democracia: reforma, reacción y revolución en la Segunda República, Alianza, Madrid, 1987; La Guerra civil española 1936-1939, Plaza\&Janés, Barcelona, 1987; La Guerra civil española, Base, Barcelona, 2006 i Hugh Thomas: La Guerra civil española, Ruedo Ibérico, París, 1961; La Guerra civil española: 1936-1939, Urbión, Madrid, 1979; La Guerra civil española: 19361939, Grijalbo, Barcelona, 1985.

22 Víctor Pérez Díaz: La primacía de la sociedad civil..., p. 20. 
mateixa classe dirigent franquista, no negaven la situació de greu crisi que estava patint el franquisme en els seus darrers anys:

"No se trataba, por tanto, tan solo de una crisis de gobierno, sino de algo mucho más profundo: de una verdadera crisis de régimen que había comenzado con las discusiones sobre las asociaciones en 1967-1969. España era un estado católico donde la Iglesia condenaba al régimen; un Estado que prohibía las huelgas y donde estas se reproducían por miles; un Estado antiliberal que buscava alguna forma de legitimidad democrática; un Estado cuya ideología, según dijera Fernández Miranda en 1971, era un "socialismo nacional integrador" y que había, sin embargo, transformado a España en una sociedad capitalista." ${ }^{23}$

Malgrat això, ambdós autors es van centrar en l'anàlisi del paper de les diferents "famílies" i dirigents franquistes en el procés de canvi polític, minimitzant el paper de l'oposició, dels moviments socials o populars i dels partits polítics, en especial els d'orientació comunista. Per ells el fracàs de la reforma del primer govern de la monarquia es va deure més a la lleialtat franquista d'Árias Navarro que a les grans mobilitzacions promogudes per l'oposició democràtica, encara que no neguin la seva existència. El paper de Adolfo Suárez i Juan Carlos de Borbón resulta per ells fonamental per "l'èxit" del procés de canvi polític. A més de limitar-lo cronològicament fins a les eleccions a Corts de juny de 1977, moment en que encara era vigent la majoria de la legislació franquista i sense recordar que en aquestes eleccions hi havia partits prohibits que es van haver de presentar amb la fórmula "d'agrupació d'electors". La proximitat d'aquest estudi amb els fets estudiats s'hauria de tenir en compte, ja que les persones de les quals destaca el protagonisme necessitaven construir-se d'un "relat" que els legitimés davant sectors amplis de la població i fes oblidar alguns passats incòmodes.

En aquesta línia de justificar determinades persones i institucions cal situar una corrent que encara puja un esglaó més en situar a la Corona i a Juan Carlos de Borbón com a la persona que pràcticament va fer possible el canvi polític. Tres dels màxims exponents d'aquesta visió són Carlos Seco Serrano, Charles T. Powell i Manuel Pastor ${ }^{24}$, que també van contribuir de manera notable a fer un discurs

23 Raymond Carr i Juan Pablo Fusi: España de la dictadura a la democracia, Barcelona, Planeta, 1979, p. 253.

24 Carlos Seco Serrano: “La Corona en la transición española”, en Javier Tusell i Álvaro Soto (eds.): Historia de la Transición, 1975-1986, Alianza Editorial, Madrid, 1996, p. 138-158; Charles T. 
legitimador de la figura del rei. Per sort, aquestes visions estan actualment molt qüestionades en el món acadèmic.

Entre els mateixos historiadors que no han destacat el paper de la mobilització social existeix un bloc que combinen diversos factors en les seves explicacions del procés del canvi polític del franquisme a la monarquia parlamentària: modernització econòmica, extensió de l'anomenada "cultura democràtica" en les capes populars, paper de les elits del franquisme i de l'oposició, context internacional propici... però destacant els esdeveniments polítics interpretats amb una concepció elitista en el sentit de centrar-se en personalitats concretes: de nou el rei, Suárez... i també alguns líders de l'oposició com Carrillo. La conflictivitat social i la mobilització de masses no es sol esmentar o si es fa es de manera secundària. Així ho fan Javier Tusell, Juan Pablo Fusi, Jordi Palafox i Carlos Barrera, entre d'altres ${ }^{25}$.

Ja he insinuat abans els matisos que podem trobar per la definició del que aquests autors anomenen "cultura democràtica", fins i tot sense entrar a debatre profundament el significat del terme en l'àmbit de la filosofia política -no hi hauria prou espai per fer-ho aquí ni és l'objectiu d'aquest treball-. Tot i que el concepte aquí és utilitzat com una descripció politòloga bàsica que el descriu com un "sistema constitucional amb divisió de poders i parlament triat per sufragi universal", sembla massa simple associar aquest concepte a la "modernització econòmica", ja que hi ha prou exemples de programes modernitzadors executats per dictadures i de com aquests no tenien per què generar nous valors democràtics, sent els "agents conscienciadors" uns altres ${ }^{26}$. Això no vol dir que no s'hagin de tenir en compte els importants canvis econòmics que es van donar a

Powell: El piloto del cambio. El rey, la monarquía y la transición a la democracia, Planeta, Barcelona, 1991; Manuel Pastor: "Las postimetrías del franquismo" en Ramon Cotarelo (comp.): Transición política y consolidación democrática en España (1975-1985), Centro de Investigaciones Sociológicas, Madrid, 1992, p. 31-46.

25 Javier Tusell: La transición española a la democracia, Historia 16, Madrid, 1991; "La transición a la democracia en España como fenómeno de Historia política”, Ayer, núm. 15 (1994), p. 55-76; La Transición a la democracia (España 1975-1982), Espasa Calpe, Madrid, 2007; Juan Pablo Fusi, Sergio Vilar i Paul Preston: De la dictadura a la democracia: desarrollismo, crisis y transición (1959-1977), Información y revistas, Madrid, 1983; Juan Pablo Fusi i Jordi Palafox: España: 18081996. El desafio a la modernidad, Espasa Fórum, Madrid, 1997; Carlos Barrera: Historia del proceso democrático en España. Tardofranquismo, transición y democracia, Fragua, Madrid, 2002.

26 Carme Molinero: El régim franquista: feixisme, modernització i consens, 2a edició ampliada i revisada, Eumo i Universitat de Girona, Vic - Girona, 2003. 
l'Estat espanyol, sobretot a la dècada dels seixanta i que juntament amb altres factors, va afavorir un procés de contestació social creixent com la que trobarà en les seves etapes finals la dictadura. Però d'aquí a justificar o fer equivalències entre "economia desenvolupada" i democràcia parlamentària de tall "occidental" hi ha un món. Per que si no, com va ser possible l'ascens del feixisme al país més "avançat" socialment i econòmicament -Alemanya- a l'Europa d'entreguerres? Com s'expliquen doncs les dictadures del continent americà no anglosaxó dels anys seixanta, setanta i vuitanta, fin i tot en els estats més "desenvolupats" com Brasil, Xile, Uruguai i Argentina?

No obstant, hi ha altres interpretacions molt diferents. Pel que fa la qüestió de la "modernització" i la millora de les condicions de vida de les capes populars durant els anys seixanta que el franquisme havia intentat convertir en font de legitimació política, investigadors com Carme Molinero i Pere Ysàs van demostrar que als anys 40 i 50 el règim havia fet just el contrari: durant la postguerra el franquisme havia fet retrocedir de manera alarmant la situació de les classes treballadores i populars ${ }^{27}$. Pere Ysàs, per la seva part, ha treballat en especial l'actitud repressiva del franquisme en els seus darrers anys d'existència, precisament aquells on va haver de fer front a una dissidència i conflictivitat ascendent, en especial en el moviment obrer, l'estudiantil, els intel-lectuals, sectors de l'església., demostrant la incompatibilitat del l'estat franquista amb qualsevol tipus de discrepància ${ }^{28}$. Per que en efecte, malgrat les visions anteriors que tendien a minimitzar-la, la conflictivitat va anar in crescendo en els darrers anys del franquisme, sense que els intents del règim per canalitzar la desafecció tinguessin gaire èxit. Per posar només un exemple, no deixa de ser curiós que durant els anys setanta en un estat on les vages estaven legalment prohibides es perdessin més

27 Carme Molinero i Pere Ysàs: "Pàtria, justicia i pan": nivell de vida i condicions de treball a Catalunya, 1939-1951, La Magrana, Barcelona, 1985 i "La població catalana a la postguerra: creixement i concentració, 1939-1950, Avenç núm. 102 (1987), p. 38-46.

28 Pere Ysàs: Disidencia y subversión. La lucha del régimen franquista por su supervivencia, 19601975, Crítica, Barcelona, 2004; "Conflictividad social, oposició política i crisi de la dictadura" en Jordi Font (dir.), Història i memòria: el franquisme i els seus efectes als Països Catalans, Publicacions de la Universitat de València/Centres d'Estudis Comarcals de Banyoles, València/Banyoles, 2007, p. 239-260; “El régimen franquista frente a la oposición”, Documentos de Trabajo. Cuadernos de la España contemporánea, 3 (2007). Veure també Pere Ysàs: "La crisis de la dictadura" en Carme Molinero (ed.): La Transición, treinta años después..., p. 27-58. 
hores de treball per aquestes que en d'altres estats europeus on aquesta si era legal ${ }^{29}$.

La repressió contra els moviments socials i populars va centrar molt l'interès de les autoritats franquistes, conscients de que s'estaven jugant la seva supervivència tal com ens explicava el treball de Pere Ysàs. El franquisme estava molt bé informat pels diferents serveis d'intel-ligència de la tasca desenvolupada per les diferents forces antifranquistes a les fàbriques i als barris de les grans ciutats $^{30}$. Però malgrat la repressió que es va exercir el franquisme necessitava oferir alguna cosa més a una població que presumia descontenta. D'aquesta manera, es van fer algunes reformes per intentar dotal al règim d'una base popular, fet que va intentar patrimonialitzar la Secretaria General del Movimiento. Les reformes es van fer en diversos àmbits, com el sindical, el municipal i el "familiar". Serà en aquests dos darrers on centraré més l'atenció del meu treball en la mesura que tindrà una interacció més directa amb el meu subjecte d'estudi, el moviment veïnal. No obstant, i malgrat els esforços que es van fer, aquestes reformes no van ser suficients per aturar el creixent sentiment de dissentiment i conflictivitat, sobretot per que des de el franquisme existia una por a perdre el control de la situació i a que, de fet, la participació popular i el control democràtic eren contraris als principis fonamentals de la dictadura.

D'aquesta manera, el franquisme va haver fer servir cada vegada més la repressió per mantenir el control, amb l'agreujant que el context europeu dels anys seixanta i setanta no era tant propici per l'exercici indiscriminat d'aquesta i que moltes vegades el que s'aconseguia reprimint era generar més desafecció. El cas es que aquesta línia historiogràfica ha demostrat que la desafecció estava tant estesa fins al punt que la dictadura no estava només en crisi per l'anomenat fet biològic, sinó per que l'antifranquisme estava estès en capes àmplies de la societat. I això ha

29 Carme Molinero i Pere Ysàs: Productores disciplinados y minorías subversivas. Clase obrera y conflictividad laboral en la España franquista, Siglo XXI, Madrid, 1998. Veure també, "Movimientos sociales y actitudes políticas en la crisis del franquismo", Historia Contemporanea, 8, 1992, p. 269-279.

30 Un exemple el podem trobar en un document que serà citat més endavant en aquest treball. Es tracta del denominat Plan Barrio, que analitzava l'actuació de les forces antifranquistes als barris, ja fos en les denominades Comissions de Barri o en les Associacions de Veïns. Archivo General de la Administración (AGA), Fons Gabinete de Enlace del Ministerio de la Gobernación, Caixa 42/8906, Dossier 7 sobre Comités de Barrio. El document no està signat però si datat a l'octubre de 1973. Existeix una versió posterior de l'any 1975. 
estat així per molt que per diversos historiadors, sociòlegs i politòlegs (no parlem ja dels mitjans de comunicació de masses) hagin volgut minimitzar aquest fet i negar-li la importància que va tenir no només en la crisi de la dictadura, sinó en l'evolució dels esdeveniments del procés de canvi polític ${ }^{31}$. No deixa de ser curiós -a nivell d'anècdota si es vol- que des de sectors de l'esquerra crítica es coincideixi a valorar el procés de canvi polític com un "pacte entre elits" tal com afirmen sectors més conservadors. Però evidentment fent anàlisis diferents per arribar a aquesta conclusió i reconeixent la importància de la contestació social a la dictadura i posant l'èmfasi en el que van anomenar "la traïció dels líders"32.

L'anàlisi de la conflictivitat va servir a tota una sèrie d'autors el qüestionament de les interpretacions més elitistes del procés de canvi polític, de l'anomenat "relat canònic de la transició" (aquell que centrava el protagonisme del procés del canvi polític en la monarquia, les "elits reformistes" del franquisme i a vegades, en les elits polítiques de l'oposició). José Maria Maravall ja havia estat un pioner en aquest sentit, al igual que Joe Forewaker i Sebastian Balfour, havent posant un especial èmfasi en l'estudi del moviment obrer ${ }^{33}$. A la crítica al "relat oficial" de la Transició es van van sumar persones d'altres disciplines com el periodista Gregorio Morán l'any $1991^{34}$. Però ha estat als darrers anys quan des de

31 Aquesta minimització de la conflictivitat social durant el franquisme ha cobrat un nou auge amb el nou "revisionisme històric" fomentat pels sectors més reaccionaris de l'Estat espanyol. Apart de la minimització, sobretot per els mitjans de comunicació, del paper de les mobilitzacions, els moviments socials i les lluites i un "retorn a l'estudi de les elits", el manteix antifranquisme ha arribat a ser banalitzat com si fos una activitat banal, quan la gent hi participava majoritàriament per motius altruistes i s'arriscava a perdre la feina, la llibertat i fins i tot la vida. Veure Carme Molinero: "Present i futur de la Historiografia sobre el règim franquista. Balanç sobre algunes línies d'investigació i els seus resultats” en Jordi Font Agulló (dir.): Història i memòria: el franquisme i els seus efectes als Països Catalans, Universitat de València, València, 2007, p. 285-302.

32 Exemples d'això els trobem a Miquel López Crespí: No era això. Memòria política de la Transició, Edicions el Jonc, Lleida, 2001; Joel Bagur i Xavier Díez (eds.): La gran desil·lusió, El Cep i La Nansa, Vilanova i la Geltrú, 2005 i AA.DD.: De l'esperança al desencís: La Transició als Països Catalans, El Jonc, Lleida, 2006 i a Alfredo Grimaldos: Claves de la Transición 1973-1986 [para adultos]. De la muerte de Carrero Blanco al referéndum de la OTAN, Península, Barcelona, 2013.

33 José Maria Maravall: La política de la transición 1975-1980, Taurus, Madrid, 1981; Joe Forewaker: La democracia española, Arias Montano, Madrid, 1990; Sebastian Balfour: La dictadura, los trabajadores y la ciudad. El movimiento obrero en el área metropolitana de Barcelona (19391988), Edicions Alfons el Magnànim, València, 1994 i més recentment juntament amb Óscar J. Martin García: "Movimientos sociales y transición a la democracia: el caso español” en Rafael Quirosa-Cheyroze, La sociedad española en la Transición. Los movimientos sociales en el proceso democratizador, Biblioteca Nueva, Madrid, 2011, p. 43-62.

34 Gregorio Morán: El precio de la transición. Una interpretación diferente y radical del proceso que condujo a España de la dictadura a la democracia, Planeta, Barcelona, 1991. El mateix autor havia publicat una biografia molt crítica sobre Adolfo Suárez ja a l'any 1979: Adolfo Suárez. Historia de 
la disciplina històrica s'ha posat més interès en l'estudi de la conflictivitat estesa en d'altres àmbits, com serà posteriorment el moviment veïnal. El treball de Martí Marín i Corbera ens demostra com l'administració local franquista de nombroses poblacions importants va estar cada vegada més superada per la contestació popular als barris ${ }^{35}$. Un altre autor, Xavier Domènech, destaca per les aportacions que fa en aquesta mateixa línia pel que fa a l'estudi de la ciutat de Sabadell i en especial sobre l'articulació d'una societat civil antifranquista organitzada en diversos camps als anys setanta, condicionant, com ja s'ha dit, la crisi del franquisme i l'agenda del procés de canvi polític. Ens explica com els anys seixanta van ser crucials per que s'anés creant una consciència antifranquista i una conflictivitat obrera que s'estendrà posteriorment -sobretot als anys setanta- al moviment veïnal als barris ${ }^{36}$. I va ser aquesta conflictivitat i oposició la que va impedir que el procés de canvi polític anés -si més no inicialment- com haurien volgut les elits procedents del franquisme, incloent a Adolfo Suárez i a Juan Carlos I de Borbón:

\footnotetext{
“Tanmateix, el que és important de retenir és que el canvi polític no fou generat per unes elits polítiques del règim i de l'oposició que tenien una imatge clau del que volien abans d'iniciar-se la transició; sinó que aquest canvi polític fou generat per la gent que decidí lluitar contra el franquisme i marcà l'agenda política sense la qual cap govern no podia pretendre sobreviure; que aquests canvis no tenen la base en el canvi econòmic i social generat durant els anys seixanta, sinó en la gent que interactuant aconseguí establir un model de lluita contra el règim diferent del que havia fracassat en dècades anteriors." ${ }^{37}$
}

Segons Domènech el que estava plantejant l'oposició antifranquista era una esmenta a la totalitat, una batalla contra el franquisme per aconseguir l'hegemonia -parlant en termes gramscians- social, cultural i política. Tot i això, segons aquest investigador a l'oposició li va mancar força en el conjunt de l'Estat per aconseguir

una ambición, Planeta, Barcelona, 1979.

35 Martí Marín i Corbera: Els ajuntaments franquistes a Catalunya. Política i administració municipal, 1938-1979, Pagès Editors, Lleida, 2000.

36 Xavier Domènech: Quan el carrer va deixar de ser seu. Moviment obrer, societat civil i canvi polític. Sabadell (1966-1976), Publicacions de l'Abadia de Montserrat, Barcelona, 2000 i Clase obrera, antifranquismo y cambio político. Pequeños grandes cambios, 1956-1969, Los Libros de la Catarata, Madrid, 2008.

37 Xavier Domènech: Quan el carrer va deixar de ser seu..., p. 375. 
el trencament que es defensava i davant d'aquest fet, una part va optar per pactar amb el govern Suárez en comptes de seguir treballant per aconseguir aquest trencament en un espai més llarg de temps. Uns altres estudis com els fets per Nicolás Sartorius i Alberto Sabio tornen a insistir sobre la importància de la conflictivitat en el final del franquisme i el procés de canvi polític, si bé contemplen un marc cronològic molt limitat ${ }^{38}$. Més endavant, quan esmenti els estudis concrets fets sobre el moviment veïnal destacaré les aportacions de dos autors catalans que s'insereixen també en aquesta línia que destaca la importància de la conflictivitat social com a element indispensable per impedir la continuïtat del franquisme: Ricard Martínez i Muntada i Iván Bordetas Jiménez ${ }^{39}$.

A nivell de l'Estat espanyol altres autors com Manuel Ortiz Heras, José Antonio Castellanos López i José Martín Garcia coincideixen en gran part amb les

38 Nicolás Sartorius i Alberto Sabio: El final de la dictadura. La conquista de la democracia en España (noviembre de 1975-junio de 1977), Temas de Hoy, Madrid, 2007.

39 Ricard Martínez i Muntada: El moviment veïnal a l'àrea metropolitana de Barcelona durant el franquisme i la Transició: el cas de Sabadell (1966-1976), Tesina presentada al Programa de Doctorat de l'Institut Universitari d'Història Jaume Vicens Vives de la Universitat Pompeu Fabra, juny de 1999; "El moviment veïnal a Sabadell durant el tardofranquisme, 1966-1976: 'Todos los barrios unidos para conseguir sus derechos" (I y II), Arraona, núms. 24 i 25 (2001), p. 65-87 i 75-97; "Capítol III. El moviment veïnal en el tardofranquisme i la transició: conflicte, identitat obrera i valors alternatius" a Enric Prat (coord.): Els moviments socials a la Catalunya contemporània, Publicacions i edicions de la Universitat de Barcelona, Barcelona, 2004; "El movimiento vecinal en el tardofranquismo: acción colectiva y cultura obrera. Propuestas y problemas de interpretación." a M. E. Nicolás Marín i C. González Martínez (coords.): Ayeres en discusión. Temas clave de Historia Contemporánea hoy, Universidad de Murcia, Múrcia, 2008. "Construir futurs. La dimensió anticapitalista del moviment veïnal" a Carme Molinero i Pere Ysàs (coords.): Construint la ciutat democràtica. El moviment veïnal durant el tardofranquisme i la transició, Icària, Barcelona, 2010, p. 265-317 i "Movimiento vecinal, antifranquismo y anticapitalismo", Historia, trabajo y sociedad, núm. 2 (2011), p. 63-90. Iván Bordetas Jiménez: "El viatge: canals d'informació, rutes, condicions i arribada" a Martí Marín (dir.): Memòries del viatge 1940-1975, Ajuntament de Sant Adrià de Besòs, Museu d'Història de la Immigració de Catalunya, 2009, p. 33-50; "Habitatge i assentaments, de la postguerra a l'estabilització" a Martí Marín (dir.): Memòries del viatge..., p. 51-69; Del suburbio al barrio: los orígenes del movimiento vecinal en Barcelona, Tesina de Doctorat, UAB, Bellaterra, setembre de 2009; "El movimiento vecinal en el tránsito de la resistencia a la construcción de alternativas", Historia del Presente, 16 (2010), p. 43-61; “'Ni tú ni yo somos nadie si tú y yo no somos nosotros': los orígenes del movimiento vecinal en Catalunya" a A. Barrio Alonso; J. De Hoyos Puente i R. Saavedra Arias (eds.): Nuevos horizontes del pasado: culturas políticas, identidades y formas de representación, Universidad de Cantabria, Santander, 2011; «Las Asociaciones de Vecinos son la mejor escuela de formación deciudadanos conscientes». El moviment veïnal durant el tardofranquisme i la transició", Plecs d'Història Local, 141 (abril de 2011), p. 5-7; "De la supervivència a la resistència: la gestació del moviment veïnal a la Catalunya franquista" i amb Anna Sánchez Sorribes: "El moviment veïnal en (la) transició, 1974-1979" a Carme Molinero i Pere Ysàs (coords.): Construint la ciutat democràtica.., p. 35-112 i 159-261; Nosotros somos los que hemos hecho esta ciudad. Autoorganización y movilización vecinal durante el tardofranquismo y el proceso de cambio político, Tesi Doctoral, UAB, Bellaterra, juliol 2012. 
idees expressades anteriorment: que el procés de canvi polític conegut com a Transició no va ser conduït exclusivament per les elits sinó que va ser quelcom més complex on van interactuar diversos factors -i en aquesta línia es critica a la sociologia nord-americana que tendeix a les anàlisis elitistes i a la negació de subjectes col-lectius ${ }^{40}$-. Per aquests i per altres autors si de cas el protagonisme de les elits reformistes del franquisme i dels dirigents dels partits polítics majoritaris es va donar en un període més concret que començaria, sobretot, a la tardor de 1976. El període crucial per ells seria el que va d'aquesta data fins a la primavera de 1977, que és quan es debatrà amb major o menor profunditat la reforma política (sense que quedés del tot definida) i les condicions per fer eleccions amb sufragi universal a Corts. Alhora no menystenen l'aparició d'una consciència col-lectiva, de classe, de barri o simplement d'explotats i perjudicats per un sistema injust, procés on els militants polítics que participaven en els moviments socials i populars de protesta van tenir un paper molt important ${ }^{41}$.

Manuel Pérez Ledesma també comparteix l'opinió de que va ser la força d'aquests moviments socials la que va forçar la crisi de la dictadura i el canvi democràtic. Per ell la diversitat de la desafecció i de les diferents formes de protesta ens demostren que aquesta anava molt més enllà del moviment obrer pròpiament dit implicant a altres sectors de la societat (intel-lectuals, estudiants, professionals liberals, etc.) però refusant la dicotomia entre "nous" i "vells" moviments socials a la qual faré referència més endavant. En canvi, com intentaré demostrar en aquesta tesi, no coincideixo plenament amb la seva percepció en que la desmobilització posterior va ser una "tornada a la normalitat un cop aconseguit els objectius previstos"42. Sense negar que una part del moviment pogués tindre aquesta percepció, crec que hi ha altres factors que van incidir en el declivi del moviment veïnal. Destacaria l'impacte de la crisi econòmica i els canvis ideològics que van fer els partits majoritaris d'esquerres, més proclius ara a la "moderació i el

40 Manuel Ortiz Heras, José Antonio Castellanos López i Óscar José Martín García: “Historia social y política para una transición. El cambio desde abajo y la construcción de una nueva autonomia: Castilla-La Mancha"; Historia Actual On Line, núm. 14 (tardor 2007), p. 115-126.

41 Manuel Ortiz Heras, José Antonio Castellanos López i Óscar José Martín García: "Historia social y política para una transición...”, Historia Actual On Line núm. 14 (tardor 2007), p. 117-119.

42 Manuel Pérez Ledesma: "Viejos y nuevos movimientos sociales en la Transición" en Carme Molinero (ed.): La Transición, treinta años después. De la dictadura a la instauración y consolidación de la democracia, Península, Barcelona, 2006, p. 117-151. 
consens" $^{\prime 4}$. Factors que sens dubte van tenir a veure en que aleshores es va anomenar el desencanto.

Un dels objectius d'aquest treball era veure fins a quin punt va arribar a questa desmobilització i crisi del moviment veïnal. I com tindrem ocasió de veure, si més no al Barcelonès Nord, aquesta no va ser total ni es va donar per igual en diferents àmbits i territoris. Van haver-hi episodis de conflictivitat i mobilització veïnal als anys vuitanta comparables amb les de la dècada anterior, si bé en un context polític diferent i amb unes motivacions més defensives. Fins al moment, la majoria d'estudis dedicats a la les etapes finals del franquisme i al procés de canvi polític no havien aprofundit gaire en els anys vuitanta. És cert que nombrosos autors provinents en la seva majoria del camp de la historiografia social ja havien plantejat superar les cronologies limitades i acotades que estudiaven el procés de canvi polític en el període 1975-1977/1979 i proposaven, com a mínim, començar els estudis en la dècada dels seixanta per entendre que va ser en aquesta on es van iniciar els processos necessaris per comprendre millor els esdeveniments posteriors $^{44}$. Aquesta corrent diferència notablement els tempos, de manera que separa, a grosso modo, un període llarg de societat mobilitzada i un altre posterior a mitjans de 1976, on s'inicia un temps curt adscrit més exclusivament al canvi polític $^{45}$. En canvi no hi ha gaires estudis que proposin superar aquesta cronologia pels anys vuitanta ${ }^{46}$. I d'aquí el meu interès en arribar a aquesta dècada.

En canvi si que hi ha un major consens historiogràfic en admetre que des de mitjans de 1976 van ser les elits les que va anar adquirint progressivament un major protagonisme en el procés de canvi polític, encara que curiosament això es

43 Un anàlisi molt interessant dels canvis ideològics experimentats pel PCE i el PSOE el trobem a Juan Antonio Andrade Blanco: El PCE y el PSOE en (la) transición. La evolución ideológica de la izquierda durante el proceso de cambio político, Siglo XXI, Madrid, 2012.

44 Iván Bordetas: Nosotros somos los que hemos hecho esta ciudad..., p. 35.

45 Ismael Saz: "Y la sociedad marcó el camino. O sobre el triunfo de la democracia en España (19691978)" a Rafael Quirosa-Cheyroze: La sociedad española en la Transición. Los movimientos sociales en el proceso democratizador, Biblioteca Nueva, Madrid, 2011, p. 29-42.

46 Algunes excepcions pel que fa al moviment veïnal: Constantino González Morell: Democracia i barrio. El movimiento vecinal en Valladolid (1964-1986), Universidad de Valladolid, Valladolid, 2013. Més recent és la Tesi Doctoral de Marc Andreu Acebal: El moviment ciutadà i la transició a Barcelona: la FAVB (1972-1986), tant que no he pogut prestar-li l'atenció que es mereixia en assabentar-me de la seva existència quan estava acabant de redactar el present treball. Veure una entrevist al seu autor a La Vanguardia 11-4-2014 [http://www.lavanguardia.com/local/barcelona/20140411/54405688721/marc-andreumovimiento-vecinal-transicion-barcelona.html]. 
pugui donar des de posicions divergents en altres aspectes, com per exemple les que havien negat l'existència d'una forta mobilització i conflictivitat social anterior com les que l'havien destacat ${ }^{47}$. I que també se'n puguin extreure conclusions diferents com que el resultat final del procés de canvi polític va ser el que havia de ser o pel contrari, que el desenvolupament i conclusió d'aquesta no estava pas predeterminat i que va tenir moltes ombres. De fet, cada vegada aquest procés està sent cada vegada més qüestionat en tant que "fet modèlic", com ens havia volgut fer creure l'esmentat relat canònic de la Transició difós sobretot per determinats partits polítics i mitjans de comunicación ${ }^{48}$.

Els profunds nexes de comunicació que hi ha entre el discurs polític actual i els fets d'aleshores així com el paper que hi juguen els mitjans de comunicació de masses no han sigut la millor ajuda per difondre les investigacions i els debats que s'han donat a l'acadèmia i fer-los accessible a un públic més general. Aquest fet per si sol ja necessitaria també d'un estudi profund -que no li toca a aquesta investigació-. Veure com qüestions que ja han estat superades en el debat acadèmic encara troben predicació en el discurs polític i els mitjans de comunicació, arribant fins al punt que certes persones que es vanten de ser historiadors s'entesten encara avui en dia en justificar el franquisme des de postures de dreta o extrema dreta ens hauria de fer reaccionar ${ }^{49}$. Urgeix fer una tasca de difusió en els mitjans de comunicació de masses i en general de cara a la majoria de la població de tots els avenços que s'han fet en el camp historiogràfic en l'estudi del franquisme, l'oposició antifranquista i els diferents moviments socials -entre ells el veïnal- en tant van acabar provocant la seva crisi i condicionant profundament el procés de canvi polític i fins i tot èpoques posteriors.

47 Iván Bordetas ens esmenta a la seva Tesi autors tant diversos com Javier Tusell, Manuel Redero, Manuel Ortiz, Óscar Martin, Xavier Domènech i José Álvarez Junco. Nosotros somos los que hemos hecho esta ciudad... p. 36, nota 31.

48 Un exemple d'aquest qüestionament és l'obra de Mariano Sánchez Soler: La Transición sangrienta. Una historia violenta del proceso democrático en España (1975-1983), Ediciones Península, Barcelona, 2010. L'autor quantifica 2.663 víctimes de violència política durant aquest període, sent mortals 591.

49 El cas més conegut és, sens dubte, el de l'ex-membre del GRAPO (i qui sap si d'alguna cosa més), Pío Moa, entestat en criminalitzar a les esquerres de la Segona república per així justificar i legitimar el cop d'estat, la guerra civil i la dictadura franquista. 


\subsection{Els debats a l'entorn del moviment veïnal $i$ els moviments socials o populars.}

Un cop fetes aquestes reflexions sobre el franquisme i el procés de canvi polític, és el moment de centrar-nos en els estudis fets sobre el moviment veïnal i la seva relació amb el conjunt del que s'ha anomenat genèricament com "moviments socials o moviments populars". Però és necessari començar parlant sobre els debats generats al voltant d'aquests darrers de manera genèrica.

Què entenem per "moviment social o popular"? L'explicació segurament no és pas tant senzilla com podria semblar. A la Tesina esmentava la definició que feia Sidney Tarrow per començar a a parlar-ne:

"Mi intención es argumentar aquí que el mejor modo de definir a los movimientos es como desafíos colectivos planteados por personas que comparten objetivos comunes y solidaridad en una interacción mantenida con las élites, los oponentes y las autoridades" 50

Aquesta definició genèrica s'ha vist complementada per la que feien als anys noranta des d'altres disciplines com la Sociologia i les Ciències Polítiques. Així autors com Doug McAdam, John D. McCarthy i Mayer N. Zald havien destacat també per afirmar que pel sorgiment i desenvolupament dels "moviments socials" calia tenir en compte tres grups de factors: l'estructura d'oportunitats polítiques (les variables que dins un sistema polític afavoreixen o no el sorgiment $i$ desenvolupament d'una acció col·lectiva); les formes d'organització i estructures de mobilització existents (formals i informals) així com els anomenats "processos emmarcadors" entesos com aquells que afavoreixen l'aparició d'una consciència col-lectiva que construeix tota una sèrie de valors comuns que afavoreixen la mobilització $^{51}$.

Certament la definició de "moviment social" a vegades s'ha fet servir d'una manera massa descriptiva i sota el seu paraigües s'amaguen sovint realitats molt

50 Sidney Tarrow: El poder en movimiento. Los movimientos sociales, la acción colectiva y la política, Alianza, Madrid, 2004, p. 21. La cursiva és de l'original.

51 Doug McAdam, John D. McCarthy y Mayer N. Zald, “Oportunidades, estructuras de movilización y procesos enmarcadores: hacia una perspectiva sintética y comparada de los movimientos sociales" en D. McAdam, J. D. McCarthy y M. N. Zald: Movimientos sociales: perspectivas comparadas, Istmo, Madrid, 1999, p. 23-28. 
diferents. A vegades s'ha volgut generalitzar el seu us per amagar un concepte, el de la "lluita de classes" que molts volen donar per "superat" tot i que la realitat actual ens demostra -si més no al meu parer- que està plenament vigent ${ }^{52}$. El que sí es cert és que els darrers estudis que hem esmentat i d'altres han posat un major interès en les anomenades "condicions subjectives" i més en concret en l'anàlisi de quins eren els protagonistes dels diferents moviments així com la seva percepció de la realitat els valors i la seva cultura, entre d'altres aspectes ${ }^{53}$. Es cobria així una mancança d'interpretacions anteriors d'alguns autors marxistes contemporanis de l'aparició del moviment veïnal -no pas del Marxisme en el seu conjunt- que posaven gairebé tota la seva atenció en les anomenades "condicions objectives". No obstant, això no ens hauria de fer oblidar tampoc la importància de les condicions materials, ja que normalment són la combinació de diversos factors -objectius i subjectius- el que determina l'aparició de moviments populars de protesta. Altres pensadors marxistes han reconegut la importància d'aquest conjunt de factors ${ }^{54}$.

Els contemporanis de l'aparició del moviment popular ciutadà, com era mencionat en moltes ocasions el que avui entenem per moviment veïnal (d'aquí també que jo també faci servir sovint aquesta terminologia) tenien molt clar que aquest tenia una potencialitat i capacitat transgressora amb l'ordre social i polític establert i era en aquest sentit que no tenien dubtes en catalogar-lo com un moviment social concret, ja que s'entenia que aquesta característica era una condició indispensable ${ }^{55}$. En aquell moment, el pensament marxista tenia un major prestigi i les seves teoritzacions influenciaven fins $\mathrm{i}$ tot en alguns casos a funcionaris de l'administració de l'Estat ${ }^{56}$. Però pel que fa al que ens interessa, cal destacar les aportacions de dos sociòlegs marxistes contemporanis per la

52 Antoine Artous, Henri Wilno, Sabine Fortino, Patrice Cuperty: Classe obrera, salariat, lluites de classe, Edicions del 1979, Barcelona, 2012.

53 Alessandro Piazzorno: "Identidad y interés", Zona Abierta núm. 69 (1994), p. 135-152; Scout Hunt, Robert Benford i David Snow: "Marcos de acción colectiva y campos de identidad en construcción social de los movimientos", p. 221-252 i Bert Kandermans "La construcción social de la protesta y los campos pluriorganizativos", p. 183-220, a Enrique Laraña i Joseph Gusfield (eds.): Los nuevos movimientos sociales. De la ideologia a la identidad, CIS, Madrid, 1994.

54 Antoine Artous, Henri Wilno, Sabine Fortino, Patrice Cuperty: Classe obrera...

55 Iván Bordetas: Nosotros somos los que hemos hecho esta ciudad..., p. 38.

56 José Maria Berriatúa: Las asociaciones de Vecinos, Madrid, Instituto de Estudios de la Administración Local, 1977 i Luis Morell: "Movimientos sociales urbanos. Presupuestos para su análisis", Revista de Administraciones Públicas, 84 (1977). Aquest segon un alt funcionari de la dictadura que havia exercit de Director General de Sanidad i de Secretario Técnico del Ministerio de Presidencia del Gobierno a principis dels anys setanta. 
importància que van tenir en el desenvolupament d'un marc teòric interpretatiu per l'esmentat moviment veïnal així com per les respectives organitzacions polítiques amb les quals simpatitzaven o fins i tot militaven activament. Ens referim a Manuel Castells i Jordi Borja.

Manuel Castells, proper al PCE, va analitzar el fenomen urbà a nivell mundial, però en el cas de l'Estat espanyol es va especialitzar en l'anàlisi de la ciutat i l'àrea metropolitana de Madrid. Jordi Borja -militant, del PSUC, de Bandera Roja i de nou al PSUC als anys setanta, i participant actiu del moviment popular- ho va fer amb Barcelona. Ambdós autors estaven fortament influenciats per Henry Lefebvre, que havia plantejat una original versió de la qüestió urbana. Va definir el marc urbà, apart del seu caràcter espacial, com un lloc on es desenvolupava la lluita de classes i això es veia reflectit en el mateix urbanisme. Aquest no era, doncs, una cosa asèptica merament tècnica, sinó que estava fortament influenciat per la ideologia, voluntat i interessos de les classes dominants ${ }^{57}$. Així que, per Lefebvre, la classe obrera havia necessàriament de subvertir una situació que actuava en contra de les seves condicions de vida i els seus interessos ${ }^{58}$.

Castells als anys setanta -com Lefebvre- situava el moviment social urbà (i dins d'aquest el veïnal) en un context de lluita de classes. Ho definia com un:

“(...) sistema de prácticas contradictorias que controvierten el orden establecido a partir de las contradicciones específicas de la problemática urbana"59

Des de una òptica estructuralista fortament influenciada per Louis Althusser, relacionava la problemàtica urbana amb el capitalisme i les seves contradiccions estructurals, ja que segons ell el mateix capitalisme era incapaç de garantir la producció i redistribució dels mitjans de consum col·lectiu imprescindibles per la vida quotidiana, així com el paper que jugava per acció o omissió el mateix Estat en aquesta redistribució, en la mesura que responia a la mateixa lògica capitalista.

Castells, com molts altres pensadors de l'època, subordinava, en gran mesura, el moviment veïnal a d'altres moviments populars -com l'obrer- que ell considerava que tenien més potencialitat per canviar la dominació exercida per les

57 Henry Lefebvre: La revolución urbana, Alianza, Madrid, 1972, p. 97.

58 Henry Lefebvre: El derecho a la ciudad, Península, Barcelona, 1969, p. 133.

59 Manuel Castells: Movimientos sociales urbanos, Siglo XXI, Madrid, 1977, p. 3. 
classes dirigents. Posteriorment alguns autors com Ricard Martínez, han posat en qüestió aquest fet així com els excessos teoricistes i reduccionistes de les seves interpretacions ${ }^{60}$. Però també s'ha de tenir en compte que en les seves primeres interpretacions tant Castells (com també Jordi Borja) eren contemporanis als fets i per tant no tenien l'accés al material d'arxiu que disposem els investigadors en l'actualitat.

El cas és que posteriorment, Castells va fer matisos a les seves primeres aportacions per intentant superar les fortes influències estructuralistes de les seves anàlisis primerenques. Va relativitzar la importància de la lluita de classes dins els moviments urbans, reconeixent que hi havia altres factors que també els condicionaven: certs aspectes de cultura urbana, el paper dels subjectes protagonistes dels mateixos moviments, amb un èmfasi especial al paper de les dones, els joves, etc. Castells va matissar també el seu primer discurs, on posava una forta accentuació en el discurs de classe, valorant ara més el component interclassista dins del denominat moviment veïnal o moviment popular urbà ${ }^{61}$. No negaré aquí que el moviment veïnal va tenir un component interclassista en determinats llocs i moments, però crec que també és necessari tenir en compte que en determinats barris, ciutats i moments, aquest moviment popular tenia una forta consciència de classe treballadora. Aquesta investigació mirarà d'aprofundir en aquesta qüestió encara que sigui en un marc local.

Jordi Borja, militant actiu als anys setanta tant d'organitzacions polítiques com del mateix moviment veïnal coincidia en aquell moment en gran part amb les anàlisis de Castells. Com veurem, el mateix Borja va destacar també per l'anàlisi del moviment veïnal a la ciutat de Barcelona. Aquest va posar un especial èmfasi en destacar el paper de les Associacions de Veïns com un espai de socialització i d'educació cívica i democràtica, avançant alguns dels posicionaments que sobre el moviment veïnal es van fer posteriorment:

"Por su sola existencia juegan un papel de educación cívica y democrática. Su funcionamiento abierto, su carácter de organizaciones de base, el régimen asambleario para las decisiones importantes y el método electivo para la selección de

60 Ricard Martínez i Muntada: El moviment veïnal a l'àrea metropolitana de Barcelona: el cas de Sabadell (1966-1976), p. 11.

61 Manuel Castells: La ciudad y las masas. Sociología de los movimentos sociales urbanos, Alianza, Madrid, 1986. 
los dirigentes, las múltiples formas de participación activa (comisiones y grupo de trabajo, delegaciones, etc.), todo ello confirma una escuela de democracia para todos los ciudadanos" ${ }^{\prime 2}$

El caràcter democràtic del moviment veïnal ha estat una de les característiques més destacades tant per Jordi Borja com d'altres investigadors posteriors, tot i que al meu parer, a vegades sota aquest discurs s'ha negligit o s'han deixat de banda inexplicablement altres vessants que va tenir també el moviment popular ciutadà, com va ser una visió contrària i/o profundament crítica al sistema econòmic capitalista o un fort component de classe, si més no en determinats barris i ciutats. Dins d'una nova onada de treballs sobre el moviment veïnal a Catalunya i a l'Estat espanyol -fonamental ja doncs en el segle XXI-, autors com Ricard Martínez i Muntada o Iván Bordetas Jiménez han plantejat aquesta qüestió en obres que he esmentat anteriorment i de les quals parlaré més endavant ${ }^{63}$. Entremig, en especial als anys vuitanta, va decréixer l'interès per l'estudi d'aquest moviment en un moment en que aquest semblava perdre la força que havia tingut abans llevat d'alguna excepció puntual. No va ser fins els anys noranta que va començar a recuperar-se l'interès pel moviment veïnal, com veurem.

Borja assenyalava també el paper que van tenir els partits polítics d'esquerres i el treball dels seus militants per l'aparició i continuïtat de moltes associacions veïnals, tot això en el context de forta repressió dels darrers anys del franquisme i també durant el procés de canvi polític ${ }^{64}$. Coincideix amb Castells en l'anàlisi del paper de l'Estat com a instrument de classe. També en va parlar del moviment veïnal com un moviment que no era específicament de la classe treballadora ni revolucionari, sinó que valorava el seu component interclassista, referint-se a les anomenades "classes mitjanes" i fins i tot la petita burgesia que també en van formar part ${ }^{65}$. Personalment prefereixo fer servir el concepte de capes intermèdies al de classe mitjana ja que crec de que la classe no només la defineix el seu poder adquisitiu, sinó com afirma Antoine Artous, la pertinença a la

62 Jordi Borja: Qué son las Asociaciones de Vecinos, Barcelona, La Gaya Ciencia, 1977, p. 19.

63 Veure nota 39, on esmento les obres més significatives d'ambdós autors.

64 Jordi Borja: Qué son las Asociaciones de Vecinos, p. 48.

65 Jordi Borja: Movimientos sociales urbanos, Ediciones Siap-Planteos, Buenos Aires, 1975, p. 121122. 
classe treballadora no està determinada per les activitats específiques de producció de tal o qual grup social, sinó pel seu lloc en les relacions socials de producció $^{66}$. De la mateixa manera, segueixo fent servir el terme classe treballadora, si bé amb una visió amplia tal com la definia Henri Wilno:

\begin{abstract}
"Si ens aferrem al simple criteri de ser un assalariat que executa tasques, sent menys estrictes pel que fa als ingressos i a les condicions de vida, podem considerar que el proletariat ampliat inclou, a més dels obrers i dels empleats, una part de les professions intermèdies i alguns assalariats qualificats com a "quadres" (directius). D'altra banda, si bé una part dels membres de les "professions intermèdies" i dels "quadres" conserven condicions salarials més favorables, han patit un procés de "desclassament" en les seves condicions laborals, fins i tot en la vida quotidiana." ${ }^{67}$
\end{abstract}

El terme "classe mitjana" és per mi massa indeterminat i a vegades el seu abús pot tendir a que s'apliqui en ocasions per designar sectors de població que son -seguint les visions abans exposades- classe treballadora. Evidentment aquest tema donaria per tota una altra tesi. Però per aquest motiu faig servir el termes esmentats juntament amb el de "capes o classes populars".

Per Jordi Borja el component cultural tenia una importància fonamental en el moviment veïnal, fet molt vinculat a la presa de consciència de la seva situació injusta per part de sectors de la població, aquells que patien les conseqüències de les contradiccions del capitalisme i de la dictadura franquista en les ciutats. I no només això, sinó de la seva capacitat per oposar-se a aquesta situació i lluitar per revertir-la. Tot i reconèixer la seva importància, Borja també li va atorgar un paper secundari i subordinat al moviment veïnal en el futur que ja s'albirava amb els partits polítics legalitzats i les eleccions municipals a l'horitzó. Aquest punt serà més profundament tractat quan parlem dels inicis de la crisi d'aquest moviment en el present estudi, però ja s'entreveu que les postures d'aquest estaven condicionades per posicionament del PSUC respecte els moviments populars i la seva aposta per l'institucionalisme un cop legalitzat. Iván Bordetas, en la seva Tesi Doctoral així ho afirma:

"En última instancia, lo que se estaba planteando era una estrategia de partido, un

66 Antoine Artous: "Retorn a l'ànàlisi marxista” dins AA.DD. : Classe obrera, salariat, lluites de classe, Edicions del 1979, Barcelona, 2012, p. 24.

67 Henri Wilno: "Algunes qüestions relacionades amb les classes socials avui”, a Classe obrera, salariat.... p. 54. 
análisis que ya no contemplaba ni la dualidad de poder ni el poder popular y que veía en los movimientos sociales la base de acción para la actuación de la organización política en el proceso de transición (....). Estas líneas interpretativas llevarían a afirmar a parte de estos teóricos que también tenían altas responsabilidades de partido -Borja era el encargado del área de movimiento popular y política municipal en el PSUC- que el tiempo de los movimientos sociales tal y como se habían entendido hasta el momento había llegado a su fin, que se tenían que reformular sus objetivos y prácticas, incluso su sentido, planteando, en parte, que, más allá de lo estrictamente reivindicativo, la existencia del movimiento vecinal respondía a una lógica de lucha antifranquista y democrática." ${ }^{68}$

El que no es pot negar és que tots dos autors, Castells i Borja, van deixar una empremta molt profunda en els anys setanta. De manera que molts altres estudis d'aquells anys estaven fortament influenciats pels seus postulats. L'urbanista Marçal Tarragó -també militant del PSUC- va destacar per la relació dels moviments socials amb el context polític amb el qual desenvolupar, de manera que si bé reconeixia la diversitat dels seus objectius, superant els esquematismes que hem esmentat anteriorment, també la seva profunda relació i interacció amb l'acció política del context de l'època, com era la crisi del franquisme i la lluita contra la dictadura ${ }^{69}$. Però en la mesura que el procés de canvi polític es va anar consolidant l'estudi sobre el moviment veïnal va caure en un estadi "d'hibernació" durant els anys vuitanta. En el perquè d'aquest fet segurament van intervenir diversos factors. Per una banda, en la mesura que aquest moviment popular va quedar relegat a un segon pla pel protagonisme dels partits polítics havien adquirit en el nou entramat institucional el seu poder d'atractiu va decaure entre els sociòlegs del moment. No va ser un fet singular. Per exemple, els debats i estudis a l'entorn de la immigració a Catalunya i als Països Catalans, que havien estat molt importants als anys setanta van patir un procés similar, en la mesura que el moviment migratori també es va estancar. La presència del PSA en les primeres eleccions catalanes havia mantingut un cert focus d'interès per aquesta qüestió, però progressivament va anar decaient. Va haver de passar un cert temps, gairebé una dècada, per que, ara des de la disciplina històrica es reprenguessin els estudis sobre la immigració i també sobre

68 Iván Bordetas: Nosotros somos los que hemos hecho esta ciudad..., p. 44.

69 Marçal Tarragó: Política urbana y luchas sociales, Avance, Barcelona, 1976. 
el moviment veïnal.

Sembla evident que els esdeveniments polítics, econòmics i socials del moment influeixen també en la recerca científica de i en els seus temes d'interès. No obstant, cal dir que això no significa que no puguin existir recerques sobre temes que no són tant presents en el discurs dels mèdia. De fet ja va passar aleshores, ja que als anys vuitanta van existir estudis que van ser pioners en la recerca sobre el moviment veïnal dels quals parlarem més endavant. Paral-lelament en els anys vuitanta es van començar a estudiar altres moviments que estaven "d'actualitat" en aquells anys, com l'antimilitarista, el feminista i l'ecologista, que com veurem, en determinats casos havien sorgit de les mateixes associacions veïnals.

Als anys noranta, superat el relatiu "buit" d'estudis dels vuitanta, els treballs sobre el moviment veïnal (i altres moviments populars) van reaparèixer. Una sèrie d'autors han volgut estudiar-lo en tant que el relacionaven amb el que es va començar a anomenar "nous moviments socials". Aquesta terminologia no és neutra, ja que el terme "nou" té unes connotacions positives que en aquest cas es va fer servir per contraposar-lo als "vells moviments", amb el qual s'identificava al moviment obrer $^{70}$. Uns altres coincidint o no amb aquesta terminologia feien el seu èmfasi en remarcar com el moviment veïnal va tenir un caràcter antifranquista i va servir com a "escola de democràcia" on es van poder aprendre unes pràctiques polítiques que no es podien exercir als espais "participatius" que oferia la dictadura, i que un cop consolidada la democràcia, van perdre la seva raó de ser.

Altres historiadors en canvi han volgut remarcar l'important component de classe que tenia aquest moviment així com la seva complexitat i capacitat per qüestionar la societat capitalista existent, remarcant que van ser quelcom més que unes "escoles de democràcia" predeterminades mecànicament a esvair-se i perdre la seva força un cop consolidat el procés de canvi polític durant els anys vuitanta com en no poques ocasions s'ha volgut remarcar ${ }^{71}$. En aquesta darrera visió emmarcaria el meu treball que analitza el moviment veïnal fins ben entrat els anys

70 Aquesta crítica ja la va fer Manuel Pérez Ledesma a "Viejos y nuevos movimientos sociales en la transición” en Carme Molinero (ed.): La Transición, treinta años después, Península, Barcelona, 2006. Tot i que segons el context, a vegades les concepcions positives i negatives aplicades a aquests conceptes de "nou" i "vell" es poden invertir.

71 Veure nota 39. 
vuitanta.

Però per tenir una perspectiva més endreçada de tota la historiografia i el debat que s'ha fet a l'entorn del moviment veïnal i els anomenats moviments socials, segurament serà més aclaridor fer un recull dels estudis que es van fer seguint un ordre cronològic, començant pels pioners i contemporanis als fets, un conjunt de monografies i publicacions que analitzaven, per una banda, les condicions de vida i la problemàtica urbana de les grans ciutats (llevat de les ja esmentades), i per una altra les que estudiaven el mateix el moviment veïnal. Alhora esmento les diferents aportacions i debats que van anar-se donant, com a mínim, de les que es van fer referents a diferents ciutats catalanes, sent conscient que s'han fet estudis d'altres ciutats de l'Estat espanyol sobretot pel que fa al cas de les ciutats de Madrid i Bilbao, i que d'entrada no esmentaré exhaustivament aquí ${ }^{72}$.

En l'àmbit català l'àrea més estudiada ha estat -com no podia ser d'una altra manera- la ciutat de Barcelona i el seu cinturó. Cal tenir en compte que molts d'aquests estudis es van fer des d'una perspectiva d'acció social i política contemporanis als fets que s'intentaven analitzar. Va haver-hi un cas pioner, encara que fos des d'una òptica molt peculiar, com va ser el compendi i publicació de les ponències i col·loquis de la denominada "Setmana del Suburbi" promoguda per la Diòcesi de Barcelona ${ }^{73}$. Aquesta es va fer al febrer de 1957, i tot que mostrava les dures condicions de vida als barris perifèrics, amb l'existència endèmica del barraquisme, la manca d'escoles i dels serveis més elementals, les solucions que es proposaven eren molt parcials i en cap cas qüestionaven l'ordre polític i social llevat d'alguna excepció molt puntual. Més tard aquesta òptica serà molt diferent.

A mitjans dels anys seixanta començaran a aparèixer publicacions crítiques amb el model urbanístic que s'estava aplicant. Així es va donar per exemple a les revistes del Col-legi d'Arquitectes de Catalunya i Balears (Cuadernos de arquitectura) i del Col•legi d'Aparelladors i arquitectes Tècnics de Barcelona (CAU). Ja al 1965 la primera d'aquestes dues publicacions dedicava un monogràfic als

72 Per la consulta d'aquests estudis a Madrid i Bilbao veure la lectura de la Tesi Doctoral d'Iván Bordetas: Nosotros somos los que hemos hecho esta ciudad..., esmentada anteriorment, en especial del capítol "A vueltas con el franquismo, el cambio político y los movimientos sociales: un estado de la cuestión", p. 25-76, la lectura del qual m'ha estat d'una inestimable ajuda per la redacció d'aquesta primera part de la meva Tesi.

73 Rogelio Duocastella: Los suburbios 1957. Compendio de las ponencias y coloquios desarrollados durante la "Semana", Barcelona, 1957. 
diferents barris de Barcelona $^{74}$. En aquesta van aparèixer en un primer apartat, articles de Francesc Candel, Jordi Pujol i Jaume Nualart on tractaven d'oferir una panoràmica general dels barris barcelonins ${ }^{75}$. El segon apartat en canvi constava d'anàlisis concretes fetes per arquitectes sobre les urbanitzacions construïdes als diferents barris de Barcelona i les seves rodalies. Unes anàlisis que, com era d'esperar, eren força negatives. Però aquestes afirmacions no es limitaven només a qüestions tècniques sobre la construcció dels polígons d'habitatges, sinó que també s'apuntava a explicar com era possible que es donessin aquestes situacions, de manera que la publicació d'aquest va generar una certa polèmica ja que en el fons s'estava posant en entredit l'actuació de les autoritats polítiques pertinents que per acció o omissió havien permet aquesta situació. A tall d'exemple podem veure fins a quin punt la seva anàlisi tenia una forta càrrega ideològica crítica amb les oligarquies de l'època:

\begin{abstract}
“En Catalunya, como en toda sociedad capitalista, la integración pierde sentido o virtualidad por tratarse de una sociedad de clases con "intereses, proyectos y creencias muy distintas" en la que las tensiones entre intereses contrapuestos generan, en todo momento, nuevas formas de segregación y clasificación social, los cuales, por distintos caminos llegan a informar de hecho -aparte magníficas y democráticas teorías de intelectuales ilusos- un urbanismo de clase para una sociedad dividida en clases." ${ }^{76}$
\end{abstract}

Cronològicament, el següent estudi que cal destacar és la Tesi Doctoral de José Olives ${ }^{77}$. L'autor manifestava una visió marxista sobre l'aparició del moviment veïnal i la seva importància sobretot en els barris obrers així com el paper que en aquest van tenir els i les militants dels partits polítics d'esquerres, negant, si més no en part, "l'espontaneïtat" d'aquest (un tema sobre el qual anirem parlant al llarg del present estudi).

Paral-lelament, en aquests anys setanta van anar apareixent tota una sèrie de

74 AA. DD.: Cuadernos de arquitectura núm. 60 (segon trimestre de 1965) i 61 (tercer trimestre de 1965).

75 Francesc Candel: “El Amazacotamiento" (p. 5-8); Jordi Pujol: "Integración y urbanismo" (p. 9-12) i Jaume Nualart: "Concepto de ciudad" (p. 13-16) a Cuadernos de Arquitectura, núm. 60 (2on Trimestre de 1965).

76 José E. Donato: “Barrios Altos de San Andrés”, Cuadernos de Arquitectura y Urbanismo, núm. 60, p. 39.

77 José Olives: El Movimiento social urbano. Barcelona 1969-1972, Tesi Doctoral publicada en 1973. Un resum d'aquesta va aparèixer a la revista Papers núm. 3 (1974), p. 275-323. 
treballs i estudis crítics amb l'urbanisme que s'estava desenvolupant a la ciutat de Barcelona de Porcioles, alcalde que va marcar una època i va deixar una empremta negativa a la ciutat que tindria conseqüències durant molts anys ${ }^{78}$. Entre aquests, sens dubte cal destacar els apareguts a la revista del Col·legi d'Aparelladors i Arquitectes Tècnics de Barcelona (CAU), ja que apart de les anàlisis de les barrabassades urbanístiques que es feien en aquells anys, va destacar per documentar les diferents lluites veïnals que s'estaven donant a la ciutat, a més d'entrar a analitzar les característiques del propi moviment popular ciutadà, com per exemple la seva creixent politització. A tot això s'havia de sumar una crítica demolidora a les autoritats franquistes per la seva complicitat i responsabilitat directa de la penosa situació de molts barris i ciutats. El "Pla d'Ordenació Urbana de Barcelona i la seva zona de influència" de 1953 (conegut popularment com el "Pla Comarcal") i en especial els Plans Parcials derivats d'aquests però que el modificaven sempre a benefici de les immobiliàries són justament denunciats. Ja que en efecte, van esdevenir instruments al servei d'aquestes i de l'especulació immobiliària i el benefici de les classes benestants i en perjudici de les classes treballadores i populars. És a dir, es denunciava la subordinació de la inversió pública als interessos privats que ostenten el poder polític i econòmic en un sistema capitalista ${ }^{79}$.

Pel que fa al moviment veïnal, cal dir que els primers estudis que es van fer eren contemporanis als fets i tot i estar encapçalats per sociòlegs de l'època, en no pocs casos estaven també fets des d'una òptica militant ja que diversos autors eren

78 "La Gran Barcelona” CAU, 10, (novembre-desembre 1971); Círculo de Economía, Gestión o caos: el área metropolitana de Barcelona. Barcelona: Ariel, 1973. Francesc Martí i Eduard Moreno, Barcelona, ¿a dónde vas? Barcelona: Dirosa, 1974; Salvador Tarragó, En defensa de Barcelona. Barcelona: Aedos, 1974, Jesús Ynfante, Los negocios de Porcioles. Las sagradas familias de Barcelona. Toulouse: Monipodio, 1974; J. M. Alibés, Manuel J. Campo Vidal, Eugeni Giral, Josep M. Huertas Clavería, Rafael Pradas, Salvador Tarragó: La Barcelona de Porcioles. Barcelona: Laia, 1975. Aquesta obra ja havia aparegut com monogràfic en la revista CAU, 21, (setembre-octubre 1973), p. 29-107. Altres aportacions interessants pel cas de Madrid: Mario Gómez-Morán y Cima, "Política de suelo y especulación”, Ciencia Urbana, 3 (maig-juny 1969), p. 27-34; Eduardo Leira, Jesús Gago e Ignacio Solana, "Madrid: cuarenta años de crecimiento urbano" i J. Montes Mieza, M. Paredes Grosso y A. Villanueva Paredes, "Los asentamientos chabolistas en Madrid", Ciudad y Territorio, 2-3 (1976), p. 43-66 y p. 159-172 respectivament; Miguel Roiz: Segregación social en Madrid. Madrid: Castillote editor, 1973. Per Santa Coloma de Gramenet, ciutat que entra en l'àmbit del meu estudi: Xavier Valls i Maria J. Olivé: “Santa Coloma de Gramenet. La lógica de un caos", Ciudad y Territorio, 3 (1977), p. 91-96.

79 Jordi Borja i Marçal Tarragó: “V. La planificación urbana”, CAU núm. 10 (novembre-desembre de 1971), p. 80-91. 
els mateixos protagonistes, sent el cas més conegut el de Jordi Borja. Ja el 1975 el número 34 de CAU feia un anàlisi de la seva organització, dels conflictes passats i presents a la ciutat de Barcelona en els seus diferents districtes i barris, destacant la capacitat de les AVV's de liderar les aspiracions populars i ser les "interlocutores vàlides" dels veïns i veïnes davant les autoritats ${ }^{80}$. Són significatives les interpretacions dels autors de com l'existència dels conflictes va anar en paral·lel a l'adquisició d'una major consciència de classe, procés marcat també per una doble (o triple) vessant: la constatació de que les autoritats no donaven resposta als problemes existents per que estaven al servei dels interessos dels "poderosos" (o d'alguns sectors concrets dintre d'aquests poderosos, ja que dins les classes benestants també hi havia pugnes pel control de l'aparell polític i econòmic); la ineficàcia dels canals existents per presentar reclamacions (falta d'institucions representatives i democràtiques) i per últim, l'experiència i exemple que podia oferir el moviment obrer en les seves lluites laborals ${ }^{81}$. És més, l'experiència del conflicte, la desproporcionada repressió que exercia el règim davant reivindicacions tant senzilles com podien ser uns semàfors o un enllumenat va anar polititzant cada cop sectors més amplis de la població, que si bé no seran -en la seva majoria- militants d'un partit polític si que aniran adquirint una consciència política determinada que els hi farà exigir unes llibertats polítiques i l'exigència d'un règim democràtic ${ }^{82}$.

Aquest procés culminarà amb l'aparició al maig-juny de 1976 a la mateixa revista CAU núm. 37 d'un dossier amb el títol "Una alternativa democràtica per Barcelona" on partint de l'anàlisi de diferents àmbits que afecten a la vida urbana, s'ofereix un model alternatiu de ciutat, profundament lligat a un canvi del poder polític que superés la dictadura i fins i tot anés més enllà de la "democràcia formal representativa" (o si més no, impliqués una democràcia molt més profunda i representativa que la merament "formal") ja que s'apostava clarament per la participació dels moviments socials i populars en la gestió i control del poder

80 "Las Asociaciones de Vecinos y la organización del movimiento popular", CAU núm. 34 (novembre-desembre de 1975), p. 51-54.

81 "Conflictos urbanos, conciencia política. A modo de conclusiones", CAU núm. 34 (novembredesembre 1975), p. 113-115.

82 “Conflictos urbanos, conciencia política...", CAU núm. 34 (novembre-desembre 1975), p. 113-115. 
polític, ja fos en l'àmbit municipal o en instàncies administratives superiors ${ }^{83}$.

El mateix any 1976 apareixia un altre treball col-lectiu sobre el moviment veïnal: La Lucha de barrios en Barcelona ${ }^{84}$, que tot i parlar del caràcter espontani de les primeres mobilitzacions veïnals, reconeix la importància tant de l'existència d'un teixit social previ als barris com el paper dels cristians de base, les organitzacions polítiques clandestines i de la influència i exemple del moviment obrer, que des de els anys seixanta amb l'aparició de les Comissions Obreres havia esdevingut un exemple a imitar en altres camps de lluita. A cavall entre 1976 i 1977 es publicava una altra obra per part dels periodistes Josep M. Huertas i Jaume Fabré, especialitzats en el moviment popular ciutadà: Tots els Barris en 7 volums, on s'explicava l'a història dels barris barcelonins i de les lluites que el van configurar ${ }^{85}$.

Havia esmentat amb anterioritat que la dècada dels vuitanta havia estat especialment estèril en la publicació de treballs sobre el moviment veïnal, però que hi havien excepcions. De fet és en aquests anys quan comença a fer-se un estudi en clau acadèmica del moviment veïnal, ja que les obres anteriors havien estat escrites per contemporanis i militants del mateix moviment popular ciutadà o de partits polítics concrets i des d'una òptica més militant que historiogràfica. Autors com Josep Martí i Anna Alabart van fer les primeres aportacions en aquest sentit. Josep Martí presentava l'any 1981 la seva Tesina amb el títol Relació entre Associacions de Veïns i partits polítics. Barcelona 1970-19806. Respecte aquest treball com ja va fer l'investigador Iván Bordetas, considero que Josep Martí cau en l'error d'equiparar "politització" a la presència de militància "de carnet" dels partits polítics en les associacions, sense analitzar altres nivells de politització no tant formals ${ }^{87}$. Aquest fet el fa extreure unes conclusions esbiaixades, si més no parcialment. L'autor destaca també per la divisió que fa del moviment veïnal per diferents etapes: 11960-1969, etapa on sorgeixen associacions pioneres però des-coordinades entre si; 2- 1970-1972, eclosió del moviment veïnal amb l'aparició de nombroses 83 CAU núm. 37 (maig-juny 1976), p. 15-118.

84 Equipos de Estudio: La lucha de barrios en Barcelona, Elias Querejeta Ediciones, Barcelona, 1976. 85 Josep M. Huertas i Jaume Fabre, Tots els barris. 7 vols. Barcelona: Edicions 62, 1976-1977.

86 Josep Martí: Relació entre Associacions de Veïns i partits polítics. Barcelona 1970-1980, Tesina de Cap d'Estudis a l'Escola de Ciències Socials de l'ICESB, 1981.

87 Iván Bordetas: Del suburbio al barrio: los orígenes del movimiento vecinal en Barcelona, Tesina de Doctorat, UAB, setermbre de 2009, p. 28-29. 
associacions gràcies als militants del PSUC, Bandera Roja i la seva acció a les Comissions de Barri; 3-1973-1977,màxim auge del moviment i 4-1977-1980, etapa de "despolitització" i abandó de molts militants per dedicar-se a la lluita electoral.

D'Anna Alabart cal destacar la seva Tesi Doctoral presentada en 1982 a la Universitat de Barcelona titulada Els barris de Barcelona i el moviment associatiu veïnal. Alabart havia destacat per defensar en les seves obres l'interclassisme del moviment veïnal, l'existència d'altres subjectes identificadors col-lectius que no fossin la classe social i en l'assoliment d'objectius no estrictament econòmics. En aquest cas l'autora agafa una característica que certament es va donar en el moviment veïnal -en especial quan aquest estava ja més estès fins i tot a barris clarament interclassistes- i en fa la norma, obviant que en no poques ocasions, en especial en els seus inicis i en determinades zones, el component de classe obrera era molt important en l'incipient moviment veïnal. En tot cas, l'autora si comenta, en aquest primer treball i d'altres posteriors la importància del paper de les mateixes AVV's en la generació d'una identitat de barri i de ciutadania, així com la tasca dels partits polítics en la seva gestació i desenvolupament, negant qualsevol espontaneïtat del moviment, sobretot en el seu període de major eclosió ${ }^{88}$. La mateixa autora proposa una periodització que a grans trets seria: naixement (1969-1975); extensió, progressiva politització i multiplicació d'associacions (1975-1977) i inici de la crisi (1977-1980). Totes aquestes tesis van ser reafirmades per l'autora en un article aparegut a finals dels noranta titulat "Els moviments socials urbans a Catalunya" publicat a Revista Catalana de Sociologia núm. 7 (juliol 1998) on també feia un esment al fenomen ocupa i on afegia una quarta etapa pel que feia al moviment veïnal (greu crisi i revifament a partir del 1979). Alabart en feia esment a les causes que ella creia que havien estat determinats per la defallida del moviment popular ciutadà:

"Les causes de la crisi van ser moltes i diverses. Cal esmentar des de la crisi econòmica -que capficava molts veïns absorts pel problema de trobar una ocupació-, fins a la pèrdua d'objectius clars per part d'un moviment que, especialment en la tercera etapa, s'havia volcat en aconseguir la democràcia, passant pel desencís de molts i la professionalització d'altres. També ens podem referir a la manca

88 Anna Alabart: Els barris de Barcelona i el moviment associatiu veïnal, Tesi Doctoral, Universitat de Barcelona, 1982 i "Els moviments socials urbans a Catalunya", Revista Catalana de Sociologia, núm. 7, juliol 1998, p. 9-28. 
d'experiència en l'acció que els moviments tenien dins d'un marc democràtic" ${ }^{\text {"99 }}$

Autors com José Álvarez Junco o Enrique Laraña coincideixen amb aquestes visions que s'esforçaven en demostrar que els anomenats "nous moviments socials" tenien altres referencialitats que la classe social com a element identificador i que no només tenien el component materialista o econòmic en les seves demandes ${ }^{90}$. Les principals crítiques que es poden fer a tots aquests treballs -algunes de les quals ja s'han comentat abans- és que posen massa èmfasi en demostrar el caràcter interclassista del moviment veïnal, fet que no es pot negar però tampoc es pot obviar que -al meu parer- també va tenir un fort component de classe, si més no en determinats barris. També se'ls hi pot discutir l'adscripció del moviment veïnal als anomenats "nous moviments socials", com ja havia apuntat Manuel Pérez Ledesma. Aquest mateix autor també havia afirmat que molts dels trets que es consideren propis dels "nous moviments", és a dir, aquells trets d'identificació col·lectiva que no són estrictament els de "classe social" (i aquí podien entrar tot un seguit de categories que tot i estar influenciades per la classe social, no depenen només de conceptes estrictament econòmics com la cultura, la nació, la religió, el sexe, l'edat...) ja es donaven en altres èpoques i moviments socials "antics".

De la mateixa manera, no totes les mobilitzacions d'altres períodes històrics menys actuals tenien uns objectius estrictament econòmics. De fet, en no poques ocasions el moviment obrer clàssic no estava centrat exclusivament en "la fàbrica" sinó que també eren elements importants els espais de residència i convivència com els barris obrers i les ciutats on les contradiccions de classe eren també molt presents. No s'ha de menystenir tampoc la influència que sectors intel-lectuals van tenir en l'articulació d'aquest, o el fet que determinats moviments que ara ens poden semblar molt recents, com el feminisme o l'antimilitarisme ja eren molt presents en altres moments històrics.

Autors com Tyler Stovall o David Harvey han demostrat com el sentiment comunitari local no és pas una novetat de la segona meitat del segle XX sinó que 89 Anna Alabart: "Els moviments socials urbans a Catalunya", Revista Catalana de Sociologia, núm. 7 (7-1998), p. 18-19.

90 José Álvarez Junco, “Movimientos sociales en España....”, p. 425-426 i Enrique Laraña, La construcción de los movimientos sociales, Alianza, Madrid, 1999. 
era present en moltes tradicions anteriors ${ }^{91}$. El primer ens va mostrar l'existència d'una comunitat força cohesionada a una localitat obrera de la perifèria de Paris (Bobigny) en un període tant precoç com 1920-1940, mentre que el segon ens explicava com el sentiment comunitari local es va donar durant tot el segle XX.

Per acabar, recullo una reflexió que va més enllà del marc historiogràfic i que obre un debat que donaria per tot un treball de recerca que no es pot fer en aquestes pàgines però que ha despertat el meu interès: un pensador marxista actual, Antoine Artús argumentava al voltant dels anomenats "nous moviments socials" que en no poques ocasions:

\footnotetext{
"La referència als "nous moviments socials" és sovint una manera de dir que la categoria lluita de classes llegada pel marxisme ha quedat obsoleta. I es fa marcant els períodes històrics de la manera que hem vist: el període de la "societat industrial", del "fordisme", hauria estat el del moviment obrer estructurat a partir del conflicte treball/capital; els "moviments socials" seien la forma adaptada pels conflictes socials dins les societats postindustrials" ${ }^{\prime 2}$
}

En una línia diferent amb aquestes postures sobre nous i vells moviments socials, es podria incloure una darrera aportació feta als anys vuitanta: la de Ricard Vinyes en un article titulat "Un exemple de cultura democràtica i societat urbana a Barcelona (1953-1977)", on feia una interessant hipòtesi, inserint el moviment veïnal del tardofranquisme i el període de canvi polític en la tradició organitzativa de les classes populars catalanes, si més no l'existent des de finals del segle XIX, i en la seva voluntat i capacitat d'oferir altrenatives socio-polítiques a les dures realitats que sovint va haver de patir, com va ser per exemple la mateixa dictadura franquista ${ }^{93}$.

Cal esmentar, ni que sigui breument, els treballs de Víctor Urrutia pel que fa al

91 Tyler Stovall: "Friends, Neighbors, and Communists': Community Formation in Suburban Paris during the Early Twentieth Century", Journal of Social History, vol. 22, núm. 2, hivern de 1988; David Harvey: Urbanismo y desigualdad social, Siglo XXI, Madrid, 1979.

92 Antoine Artous: "Retorn a l'ànàlisi marxista" dins AA.DD. : Classe obrera, salariat, lluites de classe..., p. 44. Tanmanteix, aquest autor criticava a sociòlegs com Alain Touraine per, segons ell, "negar que determinats conflictes laborals en fossin "moviments socials" per haver-se superat el nivell fordista de producció i no basar-se la conflictivitat actual en l'explotació laboral sino en les orientacions culturals de la societat".

93 Ricard Vinyes: “Un exemple de cultura democràtica i societat urbana a Barcelona (1953-1977)", Revista de Catalunya, núm. 21 (juliol-agost de 1988), p. 50-60. 
conjunt del moviment veïnal al País Basc i també a Tomás R. Villasante ${ }^{94}$. Aquest darrer, apart de remarcar els orígens del moviment popular tant en els activistes que hi van participar provinents de les tres crisis (del Marxisme, de l'Església i la Universitat) com en la profunda crisi urbanística existent producte de les arbitrarietats franquistes, va proposar un model d'anàlisi de la participació en el moviment veïnal dividint la població implicada en diferents grups: els animadors (militants antifranquistes i "professionals"), els sectors actius (població arrelada al barri que assumeixen l'acció activa un cop són conscients de la situació injusta i de la necessitat de la mobilització per revertir-la) i, per últim, la base potencial (aquells que no participen diàriament del moviment però són susceptibles de ferho a les mobilitzacions que es desenvolupin). A més, l'autor analitzava la base ideològica, obrerista i contrària al capitalisme que es va desenvolupar en el moviment popular ciutadà, així com el seu paper en la lluita contra la dictadura. També és interessant, pel cas madrileny les aportacions de Mari Carmen Garcia Nieto, en especial les seves hipòtesis sobre el sorgiment del moviment veïnal en els barris d'autoconstrucció a través de tres elements que ella considera fonamentals: l'existència d'una solidaritat veïnal -per l'ajuda mútua imprescindible per exemple en la construcció de la primera barraca, en el treball en obres col-lectives pel barri davant la indiferència o passivitat de les autoritats, o teixida en la sociabilitat al carrer-, les xarxes de paisanatge que van fomentar els moviments migratoris i per últim el paper que van tenir els moviments apostòlics de base i militants de partits polítics clandestins per conscienciar i organitzar el moviment veïnal ${ }^{95}$.

Una altra aportació al debat feta en aquests anys, en relació amb aquest darrer punt, va ser l'obra de la investigadora nord-americana Alice Gail Bier, que posava l'èmfasi en els factors externs al mateix moviment veïnal per explicar el seu sorgiment $^{96}$. En especial feia esment a la "Ley de Asociaciones" de 1964 com a

94 Víctor Urrutia Abaigar: El movimiento vecinal en el área metropolitana de Bilbao, Instituto Vasco de Administración Pública, Oñati, 1985 i "Transformación y persistencia de los movimientos sociales urbanos", Política y Sociedad, 10(1992), p. 49-56; Tomás R. Villasante: Las comunidades locales: análisis, movimientos sociales y alternativas, Instituto de Estudios de la Administración Local, Madrid, 1984.

95 Ma a Carmen García-Nieto, "Marginalidad, movimientos sociales, oposición al franquismo. Palomeras, un barrio obrero de Madrid, 1950-1980" en J. Tusell, A. Alted i A. Mateos (coords.), La oposición al régimen de Franco. Tomo II, UNED, Madrid, 1991, p. 269-285.

96 Alice Gail Bier, Crecimiento urbano y participación vecinal. Madrid: CSIC, 1980 i “«Vox populi»: el desarrollo de las Asociaciones de Vecinos en España", Papers: Revista de Sociología, núm. 11, 
factor fonamental per entendre el posterior auge del moviment ciutadà. Aquesta tesi va ser continuada en anys posteriors per altres investigadores com Pamela Radcliff, que sostenia idees similars ${ }^{97}$. En la present investigació tindré ocasió de parlar d'aquesta qüestió.

Com ja he dit, tot aquest panorama va començar a canviar als anys noranta, sobretot en la seva segona meitat. Pel que fa a l'estudi del moviment veïnal a Barcelona va aparèixer el llibre de Josep M. Huertas i Marc Andreu: Barcelona en lluita. El moviment urbà 1965-199698. Un altre estudi contemporani és el de Miquel Domingo i Maria Rosa Benet, titulat Barcelona i els moviments socials urbans ${ }^{99}$. L'obra fa un seguiment exhaustiu de les principals reivindicacions veïnals als diferents barris de la ciutat de Barcelona des de l'any 1966 a 1987. Les seves tesis més polèmiques són, segurament, l'afirmació de que el moviment veïnal no va desenvolupar una concepció global de ciutat, del fet urbà -tesi al meu parer que és molt discutible ja que en diverses ciutats si que es va arribar a fer propostes alternatives ben estructurades, com va ser per exemple el Pla Popular de Santa Coloma de Gramenet del qual parlaré en el present treball-. També ho és el fet que afirmin que la crisi posterior del moviment popular urbà era un fet "normal" i "previsible" en la mesura que es consolidava el procés de canvi polític i la "normalitat democràtica". Fins al punt que afirmen que als anys vuitanta ja no es pot parlar de moviment veïnal, sinó d'associacionisme veïnal, ja que:

"No és pot confondre un moviment social amb un associacionisme veïnal, si no hi ha finalitat política, ni objectius globals que plantegin un canvi social, ni manifestacions, ni assemblees. Ni s'arrossega ja tot un barri al carrer per causes tan dispars com la reivindicació de l'Estatut o la demanda d'un autobús. Sobretot, cal no oblidar-ho, quan durant molt de temps amb aquest tipus d'accions hom podia ser agredit i/o detingut per la policia, i fins i tot processat" ${ }^{100}$

No obstant, la realitat contradiu gran part d'aquestes afirmacions, com

1979, p. 169-183.

97 Pamela Radcliff: Making democratic citizens in Spain: civil society and the popular origins of the trPansition, 1960-78, Basingstoke, Hampshire [England] ; New York : Palgrave Macmillan, 2011.

98 Josep M. Huertas i Marc Andreu: Barcelona en lluita. El moviment urbà 1965-1966, FAVB, Barcelona, 1996.

99 Miquel Domingo i Maria Rosa Bonet: Barcelona i els moviments socials urbans, Mediterrània, Barcelona, 1998 i també "Urbanisme i participació" a Revista Catalana de Sociologia, núm. 7 (71998), p. 73-89.

100 Miquel Domingo i Maria Rosa Bonet: Barcelona i els moviments socials urbans..., p. 80. 
pretenc demostrar amb el present treball sobre el mateix Barcelonès nord. Si bé ningú pot negar que hi ha haver-hi una crisi en el si del moviment veïnal, el cert és que aquesta no va ser tan uniforme. Certament als anys vuitanta els plantejaments de canvi global de societat seran febles en el moviment veïnal existent, però el meu estudi demostrarà que si que continuaren havent mobilitzacions de sectors amplis de població en determinats barris i ciutats del Barcelonès Nord per reivindicar equipaments, transports públics o poder decidir en com es feien les millores urbanístiques -com per només posar tres exemples van succeir al barri del Besòs (Sant Adrià) al 1984 i al 1990, al de Pomar (Badalona) al 1985 i al de Llefià (Badalona) el 1986- i on la policia va intervenir exercint en determinats casos nivells de violència comparables als de la dictadura, que van comportar l'agressió física -amb greus lesions- i la detenció de diverses persones.

En canvi, Josep Martínez Barceló en feia una interpretació força diferent a l'exposada pels dos darrers autors -en gran part comprensible per la seva militància política a Bandera Roja i en les mateixes associacions de Trinitat Nova i Nou Barris- recuperant la visió polititzadora i de reivindicació democràtica de les AVV's ${ }^{101}$. L'autor també proposa una nova i peculiar periodització del moviment veïnal: des de finals dels seixanta fins 1979 ("moviment de barris") i posterior a 1979 on segons ell es configura un "moviment ciutadà". En la mesura que el moviment va saber coordinar la lluita dels diferents barris configurant una sèrie de reivindicacions i idees que si oferien un projecte polític alternatiu al que havia estat vigent durant la dictadura també a nivell local: els ajuntaments democràtics. Això si, amb una concepció de la democràcia més participativa que la que va acabar esdevenint-se en la realitat. Aquesta qüestió, la democràcia participativa a nivell local, va ser de nou analitzada pels autors del llibre 10 anys d'Ajuntaments democràtics (1979/1989): elements per a un balanç publicat per la Federació de Municipis de Catalunya a l'any $1989^{102}$, i serà un factor que també tindré en compte en el present treball, sobretot quan entri a analitzar la crisi del moviment veïnal.

De manera paral-lela als anys noranta van començar a aparèixer estudis des

101Josep Martínez Barceló: "Del Moviment ciutadà i de la democràcia local. Moviments socials i democràcia local", Revista Catalana de Sociologia núm. 7 (7-1998), p. 29-72.

102 Oriol Nel·lo (dir.) i Victor Farré i Ballarin et. al.: Deu anys d'Ajuntaments democràtics (1979/ 1989): elements per un balanç, Federació de Municipis de Catalunya, Barcelona, 1989. 
de la Sociologia o les Ciències Polítiques que aportaven noves definicions del que s'entenia per "moviment social" (com he recollit a l'inici del capítol amb l'esment d'autors com Sidney Tarrow ${ }^{103}$ ) o sobre els tres factors que afavorien el desenvolupament d'aquests, l'estructura d'oportunitats polítiques, les formes d'organització i estructures de mobilització i per últim els processos emmarcadors (DougMcAdam, John D. McCarthy y Mayer N. Zald ${ }^{104}$ ). Aquests estudis han aportat una major riquesa i complexitat a l'anàlisi dels diferents moviments populars, superant les antigues visions més esquemàtiques que intentaven explicar el sorgiment d'aquests gairebé exclusivament pels condicionants objectius i materials.

Per una altra banda, ja des de el anys vuitanta i en especial als noranta van començar a aparèixer nombroses monografies sobre el moviment veïnal d'altres localitats i barris, així com les experiències i memòries dels seus propis protagonistes $^{105}$. Va ser sobretot als anys noranta, coincidint en no pocs casos amb els aniversaris de nombroses associacions existents que van aparèixer nombroses obres de caràcter local. Per exemple el 1996, coincidint amb el 25è aniversari de l'AVV de Ca n'Anglada (Terrassa) es va publicar el llibre Ca N'Anglada. Lluita d'un barri. Història social de Ca N'Anglada: el Moviment Veïnal: 1950-1995, que tot i ser una publicació editada per la mateixa associació i podria caure en l'autoafirmació, es tracta d'un estudi força acurat. Es pot adscriure perfectament a aquelles visions interpretatives que destaquen la importància del moviment veïnal com a moviment social antifranquista i "escola de democràcia", sense obviar el fort component de classe existent, contradient les interpretacions que obvien o minimitzen aquests fets $^{106}$. En aquesta línia cal esmentar, pel cas català les obres Per les llibertats i la democràcia. La lluita del moviment associatiu a Cornellà de Llobregat i Una ciutat dormitori sota el franquisme. Santa Coloma de Gramenet 1939-1975 (de la qual

103Sidney Tarrow: El poder en movimiento...

104Doug McAdam, John D. McCarthy y Mayer N. Zald, "Oportunidades, estructuras de movilización..." en D. McAdam, J. D. McCarthy y M. N. Zald, Movimientos sociales..., p. 23-28.

105Veure la bibliografia recollida per Iván Bordetas: Nosotros somos los que hemos hecho esta ciudad..., p. 61, nota 101.

106César Ballarín Elchano, Just Casas i Soriano i Manuel Màrquez i Berrocal: Ca N'Anglada. Lluita d'un barri. Història social de Ca N'Anglada. El Moviment Veïnal: 1950-1995, AVV de Ca N'Anglada, 1996. 
parlaré més endavant) ${ }^{107}$.

L'us de la font oral serà recurrent en aquestes obres, de la mateixa manera que ho van fer altres estudis centrats en barris de determinades ciutats com va ser els casos d'Angelina Puig pel que fa a Torre-romeu (Sabadell) o Josep Lligades pel barri de Cerdanyola, a Mataró ${ }^{108}$. Aquests estudis venien a remarcar, encara que des de diferents òptiques, la importància dels orígens de classe -en aquests casos molt vinculats al fet migratori ja des de la postguerra- pel que fa al desenvolupament del moviment veïnal. Un fet que també va treballar Xavier Domènech, si bé des d'una perspectiva de presa de consciència, en les seves diferents obres on es valora la importància de les diferents xarxes per la construcció d'una identitat col-lectiva (de barri) estretament lligada amb la identitat obrera que també s'estava reforçant a través de la lluita impulsada des de les Comissions Obreres ${ }^{109}$.

Si aquests treballs posaven en manifest la relació entre el moviment obrer i el moviment popular ciutadà (i també el paper dels militants d'organitzacions clandestines), altres estudis recents també s'han dedicat a posar de relleu el paper que van tenir determinats sectors de l'Església en la gestació de la protesta als barris. Així la recerca sobre organitzacions com la JOC, la HOAC, les comunitats

107Pere Guaita Jiménez: Per les llibertats i la democràcia. La lluita del moviment associatiu a Cornellà de Llobregat.: Ajuntament Cornellà de Llobregat, Cornellà de Llobregat, 2008 i Grup d'Història José Berruezo: Una ciutat dormitori sota el franquisme. Santa Coloma de Gramenet 1939-1975, Carena, Santa Coloma de Gramenet, 2006. Un recull sobre més obres d'aquesta índole publicades al conjunt de l'Estat espanyol es poden veure a Iván Bordetas: Nosotros somos los que hemos hecho esta ciudad..., p. 66, nota 113.

108Angelina Puig Valls: Naixement i creixement dels barris perifèrics a les ciutats industrials de Catalunya. Història viva de Torre Romeu, Sabadell. Tesina inèdita de doctorat, Universitat Autònoma de Barcelona, 1989 i De Pedro Martínez a Sabadell: l'emigració, una realitat no exclusivament econòmica. 1920-1975. Tesis doctoral inèdita, Universitat Autònoma de Barcelona, 1990. Josep Lligadas, Cerdanyola, el barri gran de Mataró, 1920-2000. Construir la vida des de la immigració dels anys 50, Patronat Municipal de Cultura, Mataró, 2000.

109Xavier Domènech, "La reconstrucció de la raó democràtica. Del suburbi a la ciutat", C. Molinero i P. Ysàs (coords): Construint la ciutat democràtica. El moviment veïnal durant el tardofranquisme i la transició, Icària, Barcelona, 2010, p. 113-155 i “Orígenes. En la protohistoria del movimiento vecinal bajo el franquismo", Historia del Presente, 16 (2010), p. 27-41. Altres obres seves que tracten aquesta temàtica: Cambio político y movimiento obrero bajo el franquismo. Lucha de clases, dictadura y democracia (1939-1977), Icaria, Barcelona, 2012; Clase obrera, antifranquismo y cambio político. Pequeños grandes cambios, 1956-1969, Los Libros de la Catarata, Madrid, 2008; Pequeños grandes cambios. Movimiento obrero y cambio político en la década de los sesenta. Materiales para una historia desde abajo y una perspectiva desde Catalunya, Tesi Doctoral, UAB, Cerdanyola del Vallès, 2006; Quan el carrer va deixar de ser seu. Moviment obrer, societat civil i canvi polític. Sabadell (1966-1976), Publicacions de l'Abadia de Montserrat, Barcelona, 2002. 
cristianes de base, el paper de determinats capellans destinats a barriades obreres, dels Centres Socials que es van impulsar també ha estat molt important per conèixer els prolegòmens i el posterior desenvolupament del moviment veïnal ${ }^{110}$. Altres estudis han recollit la importància del fet migratori en el desenvolupament futur del moviment veïnal, en especial en aquells barris i ciutats que en van ser els principals receptors de població provinent d'altres indrets de l'Estat espanyol, ja sigui recollint fonts orals ${ }^{111}$ o estudis més acadèmics ${ }^{112}$.

En aquesta línia de recuperació i valoració de la consciència de classe treballadora dins els orígens i el desenvolupament del moviment veïnal, es pot considerar l'aportació, -pionera en el seu moment de realització, l'any 1999- de Ricard Martínez i Muntada centrada en l'estudi del moviment veïnal a Sabadell però sense menystenir els aspectes que aquest tenia en comú amb el que es donava en el mateix període en altres ciutats ${ }^{113}$. En la seva Tesina de Doctorat Martínez destacava entre d'altres aspectes la capacitat del moviment veïnal tant en la generació d'una consciència comunitària i d'identitat pròpia, amb un fort component de classe, com el fet que el mateix moviment és una expressió de l'autoorganització popular que va afavorir, de retruc, l'extensió d'una consciència democràtica que topava fortament amb els valors i pràctiques del franquisme a nivell municipal. Per l'autor és important destacar que el moviment veïnal fou capaç d'incloure i promoure tota una sèrie de valors i propostes que, en no poques

110 Pel que fa al cas català: Emili Ferrando Puig: Cristians i rebels. Història de l'HOAC a Catalunya durant el franquisme (1946-1975), Mediterrània, Bcn, 2000; Francisco Martínez Hoyos: La JOC a Catalunya. Els senyals d'una Església del demà (1947-1975), Mediterrània, Barcelona, 2000; José Fernández Segura: La participación de los católicos en el movimiento obrero de Barcelona (19461978). Tesis doctoral, 2005.

111Sense ànims de ser exhaustiu: Jaume Botey: Cinquanta-quatre relats d'immigració, Diputació de Barcelona i Centre d'Estudis de l'Hospitalet, Barcelona, 1986; Emili Ferrando Puig i Juan Rico Márquez: Les Comissions Obreres en el franquisme: Barcelonès Nord 1964-1977, Publicacions de l'Abadia de Montserrat, Barcelona, 2005; Montserrat Carreras, Emili Ferrando i Joan Villarroya: La immigració a Badalona durant el segle XX, Museu de Badalona, Badalona, 2006 i Lluís Burilo e Isabel Graupera: Històries de vida. Fonts orals de la lluita obrera i l'antifranquisme al Baix Llobregat. [s.l.], Fundació Utopia Joan N. García-Nieto, 2008.

112 Martí Marín (dir.): Memòries del viatge [1940-1975], Museu d'Història de la Immigració de Catalunya i Sant Adrià de Besòs, Sant Adrià de Besòs, 2009.

113Ricard Martínez i Muntada: El moviment veïnal a l'àrea metropolitana de Barcelona durant el tardofranquisme i la transició: el cas de Sabadell (1966-1976), Tesina presentada al Programa de Doctorat de l'Institut Universitari d'Història Jaume Vicens Vives de la Universitat Pompeu Fabra, juny de 1999. Un resum d'aquesta es pot trobar a l'article del mateix autor "El moviment veïnal a Sabadell durant el tardofranquisme, 1966-1976: todos los barrios unidos para conseguir sus derechos", Arraona núms. 24 i 25 (2001). 
ocasions, qüestionaven la lògica capitalista imperant a més de plantejar, si més no a nivell de ciutat, models alternatius, encara que amb certes limitacions. Segurament foren els sectors més militants el que tenien més clar aquests conceptes, ja que també en aquells anys -com en l'actualitat- hi haurà una pugna a nivell cultural entre els diferents valors existents i models de societat proposats en el si de la classe treballadora i les classes populars, tal com ens ho recordava el mateix autor:

"Una altra qüestió es fins aquest punt aquesta transmissió a sectors més amplis de la població es realitza amb èxit. Sobre aquest particular hem remarcat que quan definíem el complex de valors present en el moviment veïnal no preteníem establir que aquest complex configurés el conjunt de la cultura obrera de l'època estudiada. Ben al contrari, l'hem de mostrar en pugna amb altres valors i elements conjunturals que tendien a la integració i al conformisme amb l'estat de les coses vigent, dins d'una comprensió de la cultura com un camp de forces en el qual s'enfronten i interactuen diversos projectes i referents. Hem explicat aquesta pugna i els límits amb què topen les propostes alternatives amb la qüestió del consumisme i les dificultats per fer operatives formes de lleure diferents a les convencionals"114

La influència de la concepció del pensador marxista Antonio Gramsci en la lluita per l'hegemonia cultural queda patent en l'anterior paràgraf, de la mateixa manera que mostra les contradiccions i limitacions existents en el pensament contrari al capitalisme i el conseqüent sistema de valors associat dins els sectors populars i treballadors. No obstant, moltes vegades s'ha minimitzat el fet de que el moviment veïnal era quelcom més que una reivindicació de "democràcia” i d'aquí la importància dels estudis que recullen aquestes aportacions. El mateix Ricard Martínez en aportacions més recents que esmentaré més endavant s'ha encarregat d'anar remarcant aquest fet ${ }^{115}$. I és que en efecte, des de començaments del segle XXI s'han fet més aportacions pel que fa al moviment veïnal.

114Ricard Martínez i Muntada: El moviment veïnal a l'àrea metropolitana de Barcelona..., p. 274.

115Ricard Martínez i Muntada: "El moviment veïnal a Sabadell durant el tardofranquisme, 19661976: 'Todos los barrios unidos para conseguir sus derechos"' (I y II), Arraona, 24 i 25 (primavera i tardor de 2001), p. 65-87 y 75-97 respectivament; "El moviment veїnal en el tardofranquisme i la transició: conflicte, identitat obrera i valors alternatius" en E. Prat (coord.), Els moviments socials a la Catalunya contemporània, Universitat de Barcelona, Barcelona, 2004, p. 71-91; "Construir Futurs. La dimensió anticapitalista del moviment veïnal" a Carme Molinero i Pere Ysàs (coords.): Construint la ciutat democràtica. El moviment veïnal durant el tardofranquisme i la transició, Barcelona, Icària, $2010 \mathrm{i}$ "Movimiento vecinal, antifranquismo $\mathrm{y}$ anticapitalismo", Historia, trabajo y sociedad, 2 (2011), p. 63-90. 
Un exemple són les aportacions fetes per Albert Recio i Andrés Naya, concretades en un article publicat a la revista Mientras Tanto titulat "Movimiento vecinal: Claroscuros de una lucha necesaria"116. Les seves hipòtesis coincideixen amb les que destaquen el paper del moviment veïnal amb la resta de moviments populars en provocar la crisi del franquisme i condicionar l'agenda del procés de canvi polític. Ara bé, resulta particularment interessant les aportacions pel que fa a la crisi del moviment veïnal a partir de les municipals del 1979 (tot i que com veurem, altres hipòtesis avancen aquesta data a 1977). Afirmen -si bé no aporten documentació al respecte- que partits com el PSUC van donar la consigna en diverses localitats de que els seus militants abandonessin les AVV's per centrar-se en el treball en les institucions, però no creu que aquesta sigui la única raó de la davallada del moviment i que els motius reals van ser més complexes: la limitació dels quadres dels partits per estar als diferents fronts de lluita i haver de prioritzar, l'abandó voluntari de la militància veïnal causat pel desencanto, juntament amb altres factors com la pèrdua d'atracció del moviment veïnal per sectors més polititzats, l'abandó del suport de tècnics i professionals que assessoraven al moviment...No obstant, el nucli de la seva argumentació estava centrat en que els nous representants polítics recelaven d'un moviment organitzat des de la base i autònom que pogués organitzar sectors amplis de població fora del seu control. És a dir, que recelaven d'un projecte de democràcia més representativa que superés el marc de la "ruptura pactada" assolit amb el procés de canvi polític ${ }^{117}$.

Al 2010 es publica un treball col-lectiu que tractava directament sobre el moviment veïnal amb la participació d'autors que ja han estat esmentats anteriorment (Iván Bordetas, Xavier Domènech, Ricard Martínez) i d'altres com Anna Sánchez ${ }^{118}$. L'obre recollia i actualitzava les aportacions anteriors fetes per aquests autors en diversos articles. En el cas d'Iván Bordetas, cal afegir que tant en aquesta obra com en la seva Tesi Doctoral posterior de l'any 2011 -ja esmentada en aquestes línies anteriorment- apostarà per destacar la hipòtesi d'una primerenca

116Albert Recio i Andrés Naya: "Movimiento vecinal: Claroscuros de una lucha necesaria”, Mientras Tanto, núm. 91-92 (2004), p. 63-81.

117 Albert Recio i Andrés Naya: “Movimiento vecinal: Claroscuros...", Mientras Tanto, núm. 91-92 (2004), p. 69-70.

118 Carme Molinero i Pere Ysàs (coords.): Construint la ciutat democràtica. El moviment veïnal durant el tardofranquisme i la transició, Icària, Barcelona, 2010. 
autoorganizació veïnal als barris obrers i perifèrics forçada per les necessitats immediates, en sobre la qual van intervindre posteriorment diversos factors (organitzacions catòliques de base, militants de partits polítics) però destacant aquest primer aspecte, tal com afirmava ell mateix:

\begin{abstract}
"En esta investigación, por contra, vamos a intentar analizar estas iniciales prácticas vecinales no tanto como asistenciales sino como muestras de autogestión y autoorganización, base del empoderamiento popular que se vivió en esos barrios desatendidos y que, en última instancia, ni se abandonarían completamente ni se transformarían del todo en exigencias a las autoridades una vez definidos y aprehendidos los derechos que les habían sido arrebatados, sino que se transmutarían en nuevas prácticas autogestionarias presentes en toda la cronología."119
\end{abstract}

Cal reconèixer que es tracta d'una hipòtesi interessant, tot i que caldrà contrastar-la per veure si es va donar a tot arreu per igual i que també caldrà veure fins a quin punt estaven implicats en aquesta primerenca autoorganització persones militants de partits polítics que s'implicaven en el seu barri molt abans de que les seves respectives organitzacions haguessin teoritzat sobre aquest aspecte. Innovadora també és la seva proposta de situar la data de 1977 -i no de 1979- com a inici de la crisi del moviment veïnal, en la mesura que a partir de la legalització dels partits polítics es començarà a dirimir quin paper el reservava a les AVV's un cop havia la perspectiva de les eleccions i la futura participació en les institucions. L'aposta gairebé exclusiva d'optar per la via institucional que van fer molts partits, inclòs el PSUC, va implicar deixar en un paper secundari un associacionisme veïnal que no es volia com contrapoder popular a les futures institucions democràtiques. L'any 2011 apareixerà també un monogràfic a la revista Història del Presente sobre el moviment veïnal on Xavier Domènech i el mateix Bordetas remarcaven aquestes afirmacions fetes anteriorment ${ }^{120}$. Per la seva banda Ricard Martínez insistia en la dimensió anticapitalista que va desenvolupar el moviment veïnal, anant molt més enllà d'una simple reivindicació democràtica, malgrat les mancances existents:

"Això, per descomptat, no equival a postular que hi hagués un projecte revolucionari o

119Iván Bordetas: Nosotros somos los que hemos hecho esta ciudad... p. 68.

120Xavier Domènech, "Orígenes. En la protohistoria del movimiento vecinal..." e Ivan Bordetas, "El movimiento vecinal en el tránsito de la resistencia a la construcción de alternativas", Historia delPresente, 16 (2010), p. 43-61. 
simplement socialista, complet i acabat, que fos assumit per amplis sectors de masses. Les expressions d'anticapitalisme que hem descrit abarquen des de formulacions que s'aproximarien a aquell tipus de projectes fins a reivindicacions concretes que, sense aproximar-s'hi, sí que qüestionen implícitament el sistema socioeconòmic vigent $\mathrm{i}$ tendeixen a alterar-lo: sense haver-hi sempre una consciència plena d'estar-ho fent, es va aixecar una escala de valors alternativa a la dominant."121

Una altre aspecte on s'han fet noves aportacions és en la perspectiva de gènere relacionada amb el moviment veïnal. I és que l'anàlisi del paper de la dona en la conflictivitat social ha pres un major interès en l'actualitat en contrast amb la manca d'atenció que se li va donar en altres períodes i que no deixa de ser un reflex de la profunda herència patriarcal que encara tenim en la nostra societat. Ja autors com Sebastian Balfour havien remarcat el paper de la dona en les lluites als barris però va haver de ser una investigadora, Giuliana di Febo, qui fou pionera en un estudi més acurat de la participació femenina, superant una visió superficial que només reconeixia la participació de la dona en les mobilitzacions veïnals (i també en menor mesura, obreres) ${ }^{122}$. Di Febo de fet havia centrat les seves investigacions en quines havien estat les actituds de les dones davant la voràgine repressiva el franquisme, que va ser doblement -o triplement- opressor per elles. I en aquest cas, com el franquisme va tenir un especial interès en restringir la dona en espais petits i en relegar-la a les tasques de reproducció i recuperació psico-somàtica de la força de treball, l'articulació de xarxes informals en aquests espais per part de les mateixes dones va ser un factor important per la seva posterior participació més activa en un moviment com el veïnal.

Aquest moviment oferia una major facilitat per conjugar les tasques familiars (que es feien recaure en la dona) amb la vida associativa en un espai proper com el barri. I tot i que, com deien algunes investigadores, aquesta participació no tenia per què qüestionar la tradicional divisió de rols segons el sexe $\mathrm{e}^{123}$, l'articulació

121Ricard Martínez: "Construint futurs. La dimensió anticapitalista del moviment veïnal" a Carme Molinero i Pere Ysàs (coords.): Construint la ciutat democràtica..., p. 312.

122 Giuliana di Febo: "La lucha de las mujeres en los barrios en los últimos años del franquismo. Un ejemplo de utilización de la «Historia de género»" a Javier Tusell, Alicia Alted, Abdón Mateos (coordinadors): La Oposición al régimen de Franco: estado de la cuestión y metodología de la investigación, Tomo II. Madrid: UNED, 1990, p. 251-260 i "Resistencias femeninas al franquismo. Para un estado de la cuestión", Cuadernos de Historia Contemporánea, vol. 28 (2006), p. 153-168. 123Temma Kaplan: "Luchar por la democracia: formas de organización de las mujeres entre los 
d'espais femenins així com la seva participació en lluites populars en especial des de les Vocalies de Dones, va posar els fonaments per l'aparició d'un posterior moviment feminista més polititzat i explícit ${ }^{124}$. Tot això sense comptar els estudis que s'han dedicat a estudiar específicament organitzacions polítiques de dones ${ }^{125}$, que sens dubte van ajudar a una major conscienciació social i política malgrat les limitacions que van tenir, sense obviar la importància d'aquells espais i xarxes informals femenines que també van ser molt importants en aquest procés, així com les experiències d'anteriors mobilitzacions obreres amb participació de la dona ${ }^{126}$.

Diferents van ser les darreres aportacions de Pamela Radcliff -autora ja esmentada anteriorment- que va dedicar-se a l'estudi de les Asociaciones de Amas de Casa però sense matisar l'ús instrumental que tenien aquestes en el seu origen (perpetuar la subordinació femenina als seus rols tradicionals però amb uns altres mètodes) $)^{127}$. A l'analitzar aquest tipus d'associacions adscrites al Movimiento conjuntament amb les associacions veïnals que van tenir un caràcter clarament contestatari, l'autora tracta de trobar les semblances que podien tenir ambdós tipus d'associació, que resumeix en l'afirmació que totes dues estaven interessades

años cincuenta y los años setenta" a Anna Aguado (ed.), Mujeres, regulación de conflictos y cultura de la paz, Universitat de València, València, 1999.

124Ma Ángeles Larumbe: Las que dijeron que no. Palabra y acción del feminismo en la Transición, Prensas Universitarias de Zaragoza, Zaragoza, 2004; Mary Nash: Dones en transició. De la resistència política a la legitimitat feminista: les dones en la Barcelona de la Transició, Ajuntament de Barcelona, Barcelona, 2007 i més recentment: Eva Fernández Lamelas: Vocalies de Dones de Barcelona a la Tranisició Democràtica: una experiència emancipadora. Tesina de doctorat, Universitat Autònoma de Barcelona, Barcelona, 2009.

125Francisco Arriero: "El movimiento democrático de mujeres: de la lucha antifranquista a la conciencia feminista (1964-1975)" en Actes del Congrés La transició de la dictadura franquista a la democràcia. Barcelona, 20, 21 i 22 d'octubre de 2005, UAB-CEFID, Barcelona, 2005, p. 253263; "El Movimiento Democrático de Mujeres: del antifranquismo a la movilización vecinal y feminista", Historia, Trabajo y Sociedad, 2 (2011), p. 33-62; Pilar Díaz: "La lucha de las mujeres en el tardofranquismo: los barrios y las fábricas", Gerónimo de Uztariz, 21 (2005), p. 39-54 i Vicenta Verdugo Martí: "Organizaciones de mujeres en Valencia durante la transición. Prácticas y formas de acción" en José María Ortiz, Javier Ugarte y Antonio Rivera (coords.), Movimientos sociales en la España contemporánea, Abada, Madrid, 2008.

126Claudia Cabrero: "Género, antifranquismo y ciudadanía. Mujeres y movimiento vecinal en la Asturias del desarrollismo y el tardofranquismo", Historia del Presente, 16 (2010), p. 9-26. Pel que fa a la participació de la dona en lluites obreres: "Asturias, las mujeres y las huelgas", J. Babiano (ed.), Trabajo, género y movimiento obrero durante el franquismo, Fundación 1o de Mayo / Los Libros de la Catarata, Madrid, 2007, p. 189-244.

127 Pamela Radcliff: "La construcción de la ciudadanía democrática: las Asociaciones de Vecinos en Madrid en el último franquismo." en Actes del Congrés La transició de la dictadura franquista a la democràcia. Barcelona, 20, 21 i 22 d'octubre de 2005, UAB-CEFID, Barcelona, 2005 i més recentment: Making democratic citizens in Spain. Civil society and the popular origins of the transition, 1960-78, Palgrave Macmillan, London, 2011. 
en una major participació popular en els assumptes públics. Em sembla una afirmació força simplista que no recorda la voluntat d'enquadrament de la població que tenia tot règim feixista i el propòsit real del foment d'aquestes associacions que s'ocultava darrera la reforma legislativa de l'any 1964, tal com afirmava uns quants anys abans el ministre franquista José Solís, que no era altre que impedir el ressorgiment dels partits polítics i eixamplar la base social del franquisme alhora que s'aprofitava per mirar d'enfortir el paper del partit únic ${ }^{128}$.

Els estudis i la bibliografia sobre moviments populars que valdria la pena de tenir en compte, tanmateix, es troba escampada per molts altres països amb problemàtiques socio-urbanes similars. Iván Bordetas en la seva tesi recollia les nombroses aportacions fetes pels casos portuguès, italià i xilè tot i no arribar a desenvolupar-les per les limitacions de temps i espai que li imposaven l'elaboració de la tesi ${ }^{129}$.

\subsection{I al Barcelonès Nord?}

En l'apartat anterior he fet esment a la bibliografia existent sobre el moviment veïnal des d'una manera força genèrica. Ara bé, existeixen estudis i publicacions que s'hagin centrat en analitzar aquest fenomen al Barcelonès Nord, és a dir, a les ciutats de Badalona, Santa Coloma de Gramenet i Sant Adrià de Besòs? Si que hi han algunes publicacions, si bé la majoria tracten el moviment veïnal per separat -ciutats o barris- o relacionat amb alguna altra qüestió. Per aquest motiu he volgut fer un apartat específic, tractant separadament les tres ciutats. Faré esment també a altres tipus de fonts, com la premsa local, que ha estat una inestimable ajuda per suplir les carències de les fonts bibliogràfiques.

La primera cosa a dir en aquest aspecte seria que en la bibliografia general de caire acadèmic que ha tractat sobre el moviment veïnal hi ha una presència

128Secretaría General del Movimiento: "Información Confidencial sobre el proyecto de Decreto de Asociaciones de Cabeza de Familia", (4 de marzo de 1958), Archivo General de la Administración (AGA), Fondo Presidencia, caixa 51/18374, Dossier "Asociaciones de Vecinos Cabezas de Familiares". El subratllat és de l'original. L'any 1958 la Secretaría General del Movimiento estava ocupada por José Solís Ruiz.

129Iván Bordetas: Nosotros somos quienes hemos hecho esta ciudad..., p. 75, notes 134-137. 
gairebé nul·la de Badalona, Santa Coloma i Sant Adrià. En general les ciutats més treballades han estat Barcelona, Madrid i algunes més darrerament. Pel que fa a la ciutat més gran, Badalona, aquests precisament no proliferaven. Si més no que l'analitzessin de manera directa i amb visió global de ciutat. No obstant, tal com vaig afirmar aleshores el que si que hi ha és nombrosa bibliografia que tracta el tema de l'associacionisme veïnal o bé des de un nivell més "amateur" (sense que això les desmereixi) o d'una manera més parcial -per barris o associacions concretes- o esmentada en altres obres que estudien per exemple el moviment obrer o la immigració a la sub-comarca. Anem a pams.

En general trobem diferents tipus de treballs: els monogràfics dedicats a algun barri o associació editats per les pròpies AVV's o la Federació d'Associacions de Veïns de Badalona amb algun tipus de suport institucional (Ajuntament o Generalitat); els editats per alguna entitat pública de manera directa, ja sigui pel mateix Ajuntament o algun organisme lligat a la Generalitat com el Departament de Benestar Social que tracten de determinats barris; els monogràfics dedicats a diferents barris apareguts en mitjans de comunicació d'abast local; publicacions autoeditades per persones que van ser protagonistes de les mateixes lluites veïnals i finalment alguna publicació més acadèmica que tracta, ni que sigui parcialment, sobre el moviment popular ciutadà a Badalona.

La FAVB de Badalona va editar al 1998 Associacionisme veïnal a Badalona on s'intentava recollir la trajectòria històrica de les diferents associacions de veïns des de la seva aparició fins al moment de la data de publicación ${ }^{130}$. Editat aprofitant la commemoració del trentè aniversari de la fundació de la Federació badalonina, no es tracta d'un treball acadèmic -és una obra de difusió genèrica- però ajuda si més no a conèixer les diferents associacions existents per barris i districtes de la ciutat més important del Barcelonès Nord. De la mateixa manera, algunes associacions han editat llibres explicant la seva pròpia història, com la de La Pau ${ }^{131}$, la de la Ronda de Sant Antoni de Llefià $^{132}$, la del Manresà ${ }^{133}$, o han publicat reculls de

130 José Baeza: Associacionisme veïnal a Badalona, FAVB, Badalona, 1998.

131Julio Molina: La Paz: Historia de un barrio, Asociación de vecinos La Paz, Badalona, 1994.

132 José Baeza: 25 anys de la nostra història, 1977-2002. Associació de Veïns de Sant Antoni de Llefià i Adjacents, AA. VV. Ronda de Sant Antoni de Llefià, Badalona, 2002.

133Frederic Sabater, Josep Soler, Quim Olivares, [et al.]: Història del barri de Manresà de Badalona, Associació de Veïns del Barri de Manresà, Badalona, 2006. 
premsa sobre notícies del barri com en el cas de Pomar ${ }^{134}$.

Existeixen algunes obres publicades per l'Ajuntament de Badalona o la Generalitat que tracten, encara que sigui indirectament, sobre el moviment popular ciutadà. L'Ajuntament de Badalona va editar l'any 1989 una proposta didàctica sobre tots els barris de la ciutat, i a l'any 1999 un llibre sobre el barri de La Salut ${ }^{135}$. La Generalitat i en concret el Departament de Benestar Social va editar, dins la col·lecció "Els barris d'Adigsa" (l'empresa pública encarregada de la rehabilitació i manteniment dels barris de l'antiga Obra Sindical del Hogar) tres llibres dedicats a tres barris: Sant Roc, El Bruc/Bufalà i Pomar, tots tres l'any 1995 ${ }^{136}$. Malgrat l'evident intenció que té aquesta col-lecció d'elogiar l'obra rehabilitadora de l'empresa de la Generalitat, no es pot negar que molts dels conflictes i lluites veïnals dels anys setanta i fins i tot vuitanta es veuen reflectides en les seves pàgines i fins i tot les lluites entre les diferents organitzacions polítiques pel seu control. Molt diferent és, en canvi, una publicació de l'Ajuntament de Badalona de l'any 1976 la qual esmento per que no deixa de ser reflex del seu moment ${ }^{137}$. Amb el "suggerent" títol de Badalona. Población, vivienda, transportes, enseñanza, economía pública local aquesta publicació tractava d'elogiar i justificar la feina feta des de l'Ajuntament en un moment on aquest era fortament qüestionat pel moviment popular ciutadà en diversos fronts. Les autoritats locals també van entreveure la necessitat de promocionar-se en un moment d'incertesa política ja que s'intuïa alguna possibilitat de canvi en les normes de joc polític després de la mort de Franco. Martí Marín ja feia esment a aquesta situació quan explicava les maniobres de Juan Antonio Saramanch per crear una força política pròpia i las reunió del Governador Civil Sánchez-Terán amb aquest i els alcaldes de les

134Asociación de Vecinos de Pomar de Badalona: Pomar, 25 años. La nueva Badalona. Pomar: aún una esperanza. 1967-1992 fiestas conmemorativas del 23 de mayo al 23 de junio, Generalitat de Catalunya, Departament de Bennestar Social, [Barcelona?], [1992?]

135Jaume Solà i Campmany, Dolors Soler i Escudé, Montserrat Oriol i Sabater: Els Barris de Badalona: proposta didàctica per el seu coneixement, ( 9 vol.), IME. Ajuntament de Badalona, Badalona, 1989 i Joan Sillero Parejo: La Salut "el barri", Ajuntament de Badalona, Badalona, Maig 1999.

136Marc Andreu i Acebal: El Bruc/ Bufalà; Carles Mas: El Pomar; Joan Tudela: Sant Roc tots tres dins la col-lecció Els Barris d'Adigsa, volums 7, 27 i 37, respectivament, Generalitat de Catalunya, Departament de Benestar Social. La direcció editorial va ser feta per Eugeni Madueño i Jaume P. Sayrach, persones que van estar implicades al teixit associatiu als anys seixanta, setanta i vuitanta i de les quals faré esment en el present treball.

137Excmo. Ayuntamiento de Badalona: Badalona. Población, vivienda, transportes, enseñanza, economía pública local, Badalona, 1976. 
principals ciutats que integraven la Diputació de Barcelona ${ }^{138}$.

Pel que fa a testimonis dels mateixos protagonistes dels fets, cal destacar diversos treballs. Alguns d'inèdits i contemporanis als fets explicats com el de Miguel López Parra, Historial Barrio Sistrells 1924-1960. Asociación de Vecinos 1960-1974 que data de l'any 1976. L'autor va ser membre d'aquesta associació i a més, militant de la CNT, fet que ens dona la visió d'una primerenca infiltració en aquest tipus d'entitats, un aspecte realment poc conegut fins el moment ${ }^{139}$. En la mateixa línia de treballs inèdits hi ha el que es va fer l'any 1987 sobre un altre barri i associació veïnal: Història d'un barri, història d'una associació. Sant Mori de Llefià (1974-1987). És interessant per que un dels seus autors -Pedro Jesús Fernàndez- va ser el primer president de l'AVV de Sant Mori de Llefià i ens explica el funcionament intern de la mateixa associación ${ }^{140}$. També mereixen un especial esment els treballs de Felipe Guerrero, membre del Centre Social i posterior Ateneu Popular de Sant Roc sobre el mateix barri, Sant Roc (1989) i Sant Roc: 25 anys de Lluita (1991), editades pel Centro Cultural San Roque i l'Ateneu de Sant Roc respectivament ${ }^{141}$. Un altre cas a destacar -sobretot per que es un estudi més voluminós, publicat i distribuït en format llibre- és l'obra de Juan Rico Màrquez, militant veïnal i de CCOO: Llefià. De la barraca a la dignidad, de l'any $2010^{142}$. És un un llibre interessant de memòries que ens explica la història del barri des de els seus orígens anys anys vint fins ben entrat els anys vuitanta del segle XX.

Per que fa als estudis acadèmics, cal dir que no són molt abundants. Existeixen obres genèriques sobre la història de Badalona feta per historiadors coneguts localment com Josep Mํㅡㄹ Cuyàs i Tolosa i Joan Villarroya ${ }^{143}$. En les obres d'aquest darrer, més recents, es fa esment de les mobilitzacions veïnals. Als anys

138Martí Marin i Corbera: Els Ajuntaments franquistes a Catalunya, Pagès editors, Lleida, 2000, p. 451-455.

139Tot això segons Diego Guerrero Castaño, entrevistat el 20-11-2013. Ell mateix també va militar a la CNT i al moviment veïnal i en l'actualitat encara és actiu a l'AVV de Nova Lloreda Nord. Un altre testimoni, el de Francisco Rodríguez, que va ser membre de la primera AVV legal de Badalona (la de Lloreda) -entrevistat el 21-6-2013- ens confirma aquesta apreciació.

140 Emma Planas Alsina i Pedro Jesús Fernàndez: Història d'un barri, història d'una associació. Sant Mori de Llefià (1974-1987), Estudi Inèdit, 1987.

141Felipe Guerrero: Sant Roc, Centro Social Cultural San Roque, Badalona, 1989 i Sant Roc: 25 anys de lluita, Ateneu Popular de Sant Roc, Badalona, 1991.

142Juan Rico Márquez: Llefià. De la barraca a la dignidad, Autoeditat, Badalona, 2010.

143De les seves obres destaco: Josep Maria Cuyàs i Tolosa: Història de Badalona. Vols. VII-VIII, Badalona, 1982 i Joan Villarroya: Revolució i Guerra Civil a Badalona, Ajuntament de Badalona, 1986 i Història de Badalona, Museu de Badalona, 1999. 
vuitanta també es va publicar un estudi demogràfic fet per Magda Sevillano Bustins, que ens serveix per veure la importància de la immigració en determinats barris de la ciutat.

Segurament ha estat des de el Museu de Badalona on s'han fet més publicacions amb voluntat acadèmica o divulgadora de la història de la ciutat i dels seus barris. A més de l'obra de Joan Villarroya Història de Badalona, el Museu ha editat dues monografies sobre diferents barris de la ciutat: Canyet: un vell poble de Judit Barrera i Meya i Dalt de la Vila, Badalona de Jaume Sunyol i Sampere ${ }^{144}$. Però en clau de ciutat ens aporta més informació sobre el moviment popular ciutadà la publicació La immigració a Badalona que, editada pel Museu de la ciutat l'any 2006 recull tota una sèrie de testimonis orals sobre les migracions del segle $\mathrm{XX}$ i on el reflex de la pèssima situació dels barris perifèrics de la ciutat així com de les lluites veïnals que es van desenvolupar en aquests és molt important ${ }^{145}$. També en la revista del Museu El Carrer dels Arbres van aparèixer articles que feien esment al moviment veïnal o a aspectes que en van tenir relació com l'urbanisme, l'ensenyament, la immigració, la Transició... -entre ells el que vaig escriure jo mateix quan estava elaborant la Tesina de doctorat ${ }^{146}$.

Les publicacions periòdiques de caire local han editat també en alguna ocasió monogràfics dedicats a la història dels diferents barris de la ciutat. I en aquestes no solen faltar referències a les lluites veïnals. En especial la Revista de Badalona va anar publicant periòdicament articles dedicats als diferents barris i al començament del nou segle (en concret l'any 2001) una nova col-lecció de monogràfics dedicada als diferents districtes de la ciutat ${ }^{147}$. La revista Alhora també va fer alguna publicació en el mateix sentit ${ }^{148}$. En canvi, la premsa contemporània de l'època, sobretot la dels anys setanta, estava plena de referències i notícies sobre el moviment popular ciutadà. I la mateixa publicació local Revista de Badalona és

144Judit Barrera i Meya: Canyet: un vell poble, Museu de Badalona, Badalona, 2001 i Jaume Sunyol i Sampere: Dalt de la Vila, Badalona, Museu de Badalona, 2006.

145 Montserrat Carreras, Emili Ferrando Puig i Joan Villarroya: La immigració a Badalona durant el segle XX, Museu de Badalona, Badalona, 2006.

146José Miguel Cuesta Gómez: "Immigració i moviment veïnal a Llefià: més història de la que us penseu", Carrer dels Arbres, 3era. Època, núm. 19 (desembre 2008). Els altres articles són referenciats a la bibliografia.

147 Revista de Badalona núms. 3422-3424 i 3426-3430 (febrer-abril i juny-novembre de 2001).

148Com per exemple el dedicat al barri badaloní de Llefià. Veure AA.DD: "La Historia hablada del Barcelonès Nord. Llefià", Alhora. Àlbum 1995. 
una font important per la nostra recerca, sobretot a partit del procés de canvi polític i durant els anys vuitanta. Apart de la pròpia premsa dels barris editada per les mateixes associacions, cal destacar l'efímera publicació Comarca Expres que en la seva curta vida (desembre 1976-juny 1977) va ser un referent pel moviment popular ciutadà.

Pel que fa a la segona ciutat del Barcelonès Nord, Santa Coloma de Gramenet, trobem, a nivell de publicacions, una situació semblant a la badalonina. Tenim, per una banda, aquelles que s'han fet des de l'Ajuntament o alguna altra institució pública, i per una altra les fetes pels mateixos protagonistes dels fets i les fetes per historiadors, amb una notable presència d'investigadors locals. Tot seguit ho veurem.

No hi ha moltes publicacions fetes per l'Ajuntament o alguna altra institució que tractin d'una vessant historiogràfica la història de de la ciutat. Existeix una publicació de Joan Vilaseca i Segalés però aquesta, malauradament, no arriba a tractar amb profunditat el segle XX, que pel nostre treball és la part que més ens interessa ${ }^{149}$. Altres publicacions tenen més una voluntat d'estudi socio-econòmic 0 de voluntat "propagandista" -si es vol- per mostrar l'obra de l'Ajuntament democràtic o de la Generalitat ${ }^{150}$.

En canvi, existeix un llibre editat per l'Ajuntament de Santa Coloma i escrit per un dels protagonistes del moviment popular ciutadà, en tant va ser simpatitzant o proper als GOA ("Grupos Obreros Autónomos") i membre de les Comissions de Barri, de les quals parlaré més endavant. Es tracta del llibre de Marcelo López Ródenas Historia social de la Santa Coloma moderna 1954-1979151. És una obra escrita, com no pot ser d'una altra manera, des de una òptica militant,

149Joan Vilaseca i Segalés: Història General de Santa Coloma de Gramanet, Ediciones Metropol, Barcelona, 1985.

150Estudi de les necessitats i alternatives en matèria d'educació especial a Santa Coloma de Gramenet, Departament d'Ensenyament de la Generalitat de Catalunya, Barcelona, 1983; Perifèria o marginalitat : tres anys d'urbanisme municipal a Santa Coloma de Gramenet (19841987), Servei d'Urbanisme i Habitatge. Ajuntament de Santa Coloma de Gramenet, Santa Coloma de Gramenet, 1987; Deu anys millorant Catalunya des de Santa Coloma de Gramenet, Ajuntament de Santa Coloma de Gramenet, Santa Coloma de Gramenet, 1989; Santa Coloma viva : la transformació diària de la ciutat del demà, Ajuntament de Santa Coloma de Gramenet, Santa Coloma de Gramenet, 1991. (Cito només les que es van publicar en els anys on es centra aquest estudi o immediatament posteriors).

151 Marcelo López Ródenas: Historia Social de la Santa Coloma moderna 1954-1979, Regidoria de Cultura de l'Ajuntament de Santa Coloma de Gramenet, Santa Coloma de Gramenet, 1982. Molt recentment, l'any 2013, s'ha fet una reedició del mateix llibre. 
però que resulta imprescindible per conèixer els anys setanta a la ciutat colomenca així com la seva situació socio-econòmica i les importants mobilitzacions i lluites polítiques que es van desenvolupar. La voracitat especulativa i el creixement desmesurat -va ser la ciutat que va experimentar la rebuda d'un major nombre de població de manera proporcional- van fer d'aquesta ciutat el prototipus de "ciutat dormitori" per excel-lència. El paper dels "capellans obrers", dels cristians de base (JOC i HOAC), dels Centres socials, dels militants dels partits i organitzacions polítiques, de la Comissió Unitària per la lluita de l'Ambulatori, de les Comissions de Barri, de les Associacions de Veïns... es veuen reflectides en l'obra.

$\mathrm{Hi}$ ha una producció literària feta pels protagonistes dels fets força interessant. Apart de l'anterior autor, dos sacerdots de l'època (un dels quals va ser posteriorment alcalde de Santa Coloma durant 12 anys) han fet publicacions amb temàtiques relacionades amb el moviment veïnal, ni que sigui indirectament. Jaume P. Sayrach, sacerdot durant molts anys al barri del Fondo i un dels impulsors de la revista Grama ha publicat alguns llibres que recullen les seves experiències. En concret em refereixo a En el Fondo. Parròquia de Sant Joan Baptista (Sta. Coloma de Gramenet 1965-1979) i L'Esperança d'una Església pobra i evangèlica: (Santa Coloma de Gramenet), 1965-1980 ${ }^{152}$. El primer recull l'experiència personal en la parròquia del barri més populós de Santa Coloma, en el qual va exercir de rector i com veurem, va impulsar nombroses iniciatives des de l'església i el mateix Centre Social que es va crear. El segon es un recopilatori de textos i articles publicats per ell mateix on es veu el seu pensament, reflex d'un sector de l'església de caire progressista que va tenir molta força a la ciutat.

En la mateixa línia podem trobar les obres d'un altre sacerdot que tindrà un paper molt important en la ciutat, ja que fins i tot esdevindrà alcalde al 1979 amb el PSUC. Es tracta, com no, de Lluís Hernàndez. Una publicació recull els seus escrits més importants apareguts en diversos mitjans gairebé coincidint amb el període de la seva alcaldia: Escrits, 1980-1992 / Lluís Hernández : l'alcalde de la transformació de Santa Coloma de Gramenet ${ }^{153}$. Aquesta ens serveix per fer-nos una

152 Jaume P. Sayrach: En el Fondo. Parròquia de Sant Joan Baptista (Santa Coloma de Gramenet 19651979, Edicions Fòrum-Grama, Santa Coloma de Gramenet, 2001 i L'esperança d'una Església pobra i evangèlica: (Santa Coloma de Gramenet, 1965-1980, Edicions Fòrum-Grama, Santa Coloma de Grament, 2007.

153Marcelo López Ródenas: Historia Social de la Santa Coloma moderna 1954-1979, Regidoria de 
idea del seu pensament mentre va ser alcalde, però no profunditza en la seva etapa anterior com a líder veïnal i sacerdot en el barri de Les Oliveres. Recentment va aparèixer un llibre que intenta recollir tota la seva trajectòria vital escrit per Joaquima Utrera: Lluís Hernàndez. El capellà rebel ${ }^{154}$. Efectivament, aquest llibre recull des de la seva etapa com a sacerdot a l'Equador d'on va ser expulsat pel govern -passant per sacerdot i activista veïnal a Les Oliveres- fins arribar a ser alcalde i fins i tot més enllà, però cal tenir en compte que el llibre té una clara intenció de reivindicar la seva figura i s'ha de llegir amb una certa prevenció.

En la mateixa línia de recopilar textos dels anys vuitanta en endavant es pot inscriure una publicació d'un destacat dirigent del PSUC, del PCC i posteriorment d'IC. Em refereixo a l'obra de Josep Maria 'Chema' Corral Belorado: Santa Coloma. La riba esquerra ${ }^{155}$.

Un altre protagonista dels fets, antic dirigent del MCE, del PSUC i regidor d'IC va editar recentment una publicació sobre la història del mateix barri on va residir ell i el famós "cura rojo" que va ser alcalde de la ciutat. En concret m'estic referint a l'obra de Fernando Saro Les Oliveres. Sabor a barrio 1970-1980, publicat el $2012^{156}$. El llibre ens il·lustra, des del seu punt de vista, el sorgiment i desenvolupament del moviment popular ciutadà en un dels barris més emblemàtics de Santa Coloma. Cal esmentar també una altra obra anterior per que fa a la història dels barris colomencs: la de Jordi Rovira La Guinardera, un altre barri situat a la muntanya hauria d'haver estat zona forestal en la seva totalitat ${ }^{157}$.

Des d'una òptica diferent cal destacar el treball fet pel col-lectiu d'historiadors locals "José Berruezo". Han fet una feina notable a l'hora de la recerca de la història de Santa Coloma de Gramenet, amb mètodes historiogràfics però alhora amb una clara voluntat divulgativa pel conjunt de la població. Cal destacar les seves contribucions a la revista d'Història Local Àgora ${ }^{158}$, així com en

Cultura de l'Ajuntament de Santa Coloma de Gramenet, Santa Coloma de Gramenet, 1982. 154 Joaquima Utrera: Lluís Hernàndez. El capellà rebel, Fundació Nous Horitzons, Barcelona, 2011. 155Josep Maria Corral i Belorado: Santa Coloma. La riba esquerra, Edicions l'Esguard, Santa Coloma de Gramenet, 2008. 'Chema' Corral no va destacar especialment al moviment veïnal, però va tindre un paper important en la crisi i escissió del PSUC a Santa Coloma.

156Fernando Saro: Les Oliveres. Sabor a barrio 1970-1980, Edicions Fórum Grama, 2012.

157Jordi Rovira Sánchez: La Guinardera, A.V. La Guinardera, Ajuntament de Santa Coloma de Grament, amb la col·laboració del la Direcció General d'Acció Cívica del Departament de Benestar i Família de la Generalitat de Catalunya, 2002. 158En faig un recull dels articles publicats a la Bibliografia. 
una obra col-lectiva: Una ciutat dormitori sota el franquisme: Santa Coloma de Gramenet 1939-1975 ${ }^{159}$. Existeixen capítols dedicats a les Comissions de Barri, als Grupos Obreros Autònomos (GOA), a la dona colomenca en la lluita antifranquista, a l'urbanisme, a la lluita per l'ambulatori, a conflictes obrers i al paper de la premsa local -entre d'altres-, tot recollint els articles publicats a la publicació local de caire historiogràfic mencionada anteriorment.

Precisament el paper d'una revista local, portaveu veïnal en aquest cas, Grama, ha estat objecte també de diverses publicacions. Aquesta revista és de consulta imprescindible per qualsevol estudi sobre Santa Coloma de Gramenet en aquest període i, per tant, també ho és en la meva recerca. Sens dubte va ser una de les revistes més importants "al servei del moviment popular ciutadà" de tot Catalunya (com també o va ser la sabadellenca Ca n'Oriach) i apareixerà sovint referenciada en aquestes línies. Anys després de la seva desaparició un dels seus protagonistes -Eugenio Madueño- recordava la seva història en dos obres: Grama: una experiència insòlita de periodisme popular i, conjuntament amb Joan Catà, Grama; El Maresme: dues revistes heroiques ${ }^{160}$. Cal esmentar també altres revistes colomenques que són una bona font pel nostre treball, malgrat no hagin assolit mai l'èxit de Grama -malgrat van inspirar-se en aquesta- i que es van editar als anys vuitanta, com van ser els casos de Poble (promoguda per Salvador Cabré) o Ciutat (per Josep M. Roca), L'Esquerra del Besòs o fins i tot, la segona -i breu- etapa de El Besòs: Semanario Independiente.

Existeixen altres estudis que tracten aspectes que tot i que no siguin directament el moviment popular ciutadà, en tenen relació en tant van afectar el seu desenvolupament. Alhora qüestionen -ni que sigui parcialment- la noció tant estesa de Santa Coloma com una "ciutat dormitori", per l'anàlisi de la conflictivitat obrera existent als anys setanta, en especial en el sector tèxtil o com la crisi va fer que l'economia submergida en aquest mateix sector cresqués espectacularment als anys vuitanta. Pel primer cas hi ha el Treball de Màster de Lola Carrión que

159Grup d'Història José Berruezo: Una ciutat dormitori sota el franquisme. Santa Coloma de Gramenet 1939-1975, Edicions Carena, Barcelona, 2006.

160Eugenio Madueño: Grama: una experiència insòlita de periodisme popular, Diputació de Barcelona i Ajuntament de Santa Coloma de Gramenet i Col-legi de Periodistes de Catalunya, Barcelona, 1988 i amb Joan Catà: Grama; El Maresme: dues revistes heroiques, Diputació de Barcelona i Col-legi de Periodistes de Catalunya, Barcelona, 1988. 
s'encarrega de demostrar-nos com a Santa Coloma va existir una conflictivitat obrera en un sector com el de la confecció, gens estudiat, segurament, per que les seves protagonistes eren dones ${ }^{161}$. I pel segon cas, quan les grans fàbriques tèxtils de Santa Coloma van tancar, el treball de Pere Jódar Martínez, Rocío Mendoza i Gonçal Sanz sobre la confecció en l'economia submergida dels anys vuitanta ${ }^{162}$, demostrant-nos, un cop més que ja hi havien un precedent molt estès abans que, més recentment, sectors d'una nova immigració s'especialitzessin en aquest tipus d'economia.

La qüestió urbanística també ha estat un àmbit propici per l'aparició d'estudis i publicacions fets per l'Ajuntament com el que va coordinar i compilar Ferran Navarro i Acebes Perifèria o marginalitat: tres anys d'urbanisme municipal a Santa Coloma de Gramenet ${ }^{163}$ o l'elaborat per Maria Mercé Carbonell, Albert Favà i Jordi Rovira titulat Santa Coloma de Gramenet: de poble pagès a ciutat obrera ${ }^{164}$. En una línia similar el mateix Ajuntament, encara presidit per Lluís Hernàndez, va editar una serie de petites publicacions dedicades a col-lectius específics de la població de la ciutat i a temes concrets en els anys 1989 i $1990^{165}$. Menció especial mereix també el llibre de Núria Valls Santa Coloma de Gramenet, autoretrat, de l'any 1990, tot i ser mes un assaig poètico-literari que historiogràfic ${ }^{166}$. L'obra més recent publicada amb suport del mateix Ajuntament, de la Diputació -i d'ICV- és la de la ja esmentada anteriorment periodista Joaquima Utrera: 30 anys

161Lola Carrión: La conflictivitat laboral en Santa Coloma de Gramenet des de 1968 a 1978. Treball de Màster, Universitat de Barcelona, 2008.

162 Pere Jódar, Rocío Mendoza, Gonçal Sanz: La Confecció submergida: característiques sòcioeconòmiques del sector de la confecció a Santa Coloma de Gramenet, Ajuntament de Santa Coloma de Gramenet i Eumo, Vic, 1991. El tema de l'economia submergida en aquest sub-sector era prou important per que dos anys després s'editessin noves publicacions: Pere Jódar (et al.): La Confección en Santa Coloma de Gramenet, análisis de la encuesta al subsector 1993 i La Confección en Santa Coloma de Gramenet, resumen del análisis de la encuesta al subsector 1993, Grameimpuls, Santa Coloma de Gramenet, 1993.

163Ferran Navarro i Acebes (coord. i comp.): Perifèria o marginalitat: tres anys d'urbanisme municipal a Santa Coloma de Gramenet, Servei d'Urbanisme i Habitatge, Ajuntament de Santa Coloma de Gramenet, 1987.

164 Maria Mercè Carbonell, Albert Fabà i Jordi Roriva: Santa Coloma de Gramenet: de poble pagès a ciutat obrera, Ajuntament de Santa Coloma de Gramenet, 1988.

165Publicats per l'Ajuntament de Santa Coloma de Gramenet, dins la col-lecció "Materials per al debar": La Joventut a Santa Coloma, 1989; La "Gent gran" en Santa Coloma, 1989; La dona a Santa Coloma, 1990; El comerç a la ciutat, 1990; Integració i diferenciació cultural, 1990; Comunicar en Santa Coloma, Ajuntament de Santa Coloma de Gramenet, 1990; Desigualtats socials a Santa Coloma, 1990; Santa Coloma, ciutat metropolitanta, 1990.

166 Núria Valls: Santa Coloma, autorretrat, Ajuntament de Santa Coloma de Gramenet, 1990. 
d'ajuntaments democràtics - Crònica d'una transformació - Santa Coloma de Gramenet 1979 - 2009 una obra que està feta amb una clara voluntat de reivindicar la tasca feta pels consistoris colomencs durant aquells anys ${ }^{167}$. Tal com comentava en el cas badaloní, les nombroses publicacions pròpies del moviment veïnal o de les seccions locals dels partits polítics contemporànies als fets són una font imprescindible i seran referenciades en el seu moment en el present treball.

Per últim, tenim el cas de Sant Adrià de Besòs, el més petit dels municipis del Barcelonès Nord i que durant molts anys ha viscut amb l'amenaça d'annexió a Barcelona o a Badalona. Malgrat també va tenir un creixement notable producte de la immigració del segle XX, la seva població, al voltant d'unes 30.000 persones, fa que estigui lluny de les altres ciutats de la comarca. Aquest fet també es veu reflectit en les obres que s'han publicat sobre la història de la ciutat així com del seu moviment ciutadà, de manera que apart de l'obra ja esmentada sobre les CCOO en el Barcelonès Nord, no hi ha obres fetes des d'un nivell historiogràfic pel conjunt de la ciutat -si de períodes parcials o temàtiques concretes ${ }^{168}$. . No passa el mateix en canvi pels seus barris, destacant sobretot la bibliografia als barris situats a "la dreta del Besòs" (si mirem cap el mar), el Camp de la Bota, La Catalana, el Besòs i La Mina, destacant sobre tot la publicació d'estudis socio-econòmics sobre el darrer ${ }^{169}$.

167Joaquim Utrera: 30 anys d'ajuntaments democràtics. Crònica d'una transformació. Santa Coloma de Gramenet 1979-2009, Edicions Fòrum-Grama, 2010. No veurem molta autocrítica dels primers consistoris en aquesta obra, tot i que si s'esmenta els enfrontaments que van tenir amb determinades AVV's que van continuar mantenint un to reivindicatiu.

168Joan Rovira i Costa: Historia de un pueblo en su primer milienio: resumen antológico, Ajuntament de Sant Adrià de Besòs, 2000; Hi ha també un estudi parcialment publicat sobre l'evolució de la població de la ciutat que cito més endavant.

169Als anys setanta i primera meitat dels vuitanta ja van haver-hi estudis pioners. Als anys 70: ['autor desconegut]: Estudio sociológico de La Mina, gener de 1976; un estudi del Patronato Municipal de la Vivienda, PMV. Departamento de Trabajo Social. La Mina, 1977; Montserrat Colomer Salmons, Montserrat Flaquer Badell i Maria Teresa Bassons Rabassa (assistentes socials del PMV): Problemática Infantil de La Mina, juliol 1978; [autor desconegut] Informe sobre el centro de educación especial (aulas de escolarización-La Mina) d'octubre de 1979. Arxiu Històric del de La Mina i el Camp de la Bota (AHLMICB), Caixa C-1 C-1.3. La Mina anys 70, Carpeta "Estudis sobre la Mina als anys 70". I als anys 80: Informe-Estudio realizado por el Ayuntamiento de San Adrián del Besós, 31 de març de 1980; Daniela Gutiérrez i Tina Ureña: Polígono La Mina, juny 1980 (sembla un treball d'una assignatura universitària ja que hi consta textualment "1을 AASS, Curso 79/80"). AHLMICB, Caixa C-1 C-1.4. La Mina anys 80, Carpeta "Estudis sobre La Mina anys 80" ; Fundació Família i Benestar Social: Proposta de treball comunitari per al barri de La Mina. Sant Adrià de Besòs [any exacte desconegut]. AHLMICB, Caixa C1-C1.4. La Mina anys 80, Carpeta "Anys 80. Fundació Família i Benestar Social".

Dintre d'aquests cal fer una menció al famós Pla Interdepartamental d'Actuació Especial a la Barriada de La Mina, fet per la Generalitat de Catalunya, encara que es quedés en paper mullat 
La publicació d'obres amb voluntat d'explicar la història de la ciutat per institucions públiques és escassa, i les que s'han fet tenen una clara voluntat propagandística que fins i tot entren en contradicció amb els fets reals. Un exemple d'això és l'obra Sant Adrià: 12 anys de democràcia, que editada per l'Ajuntament governat pel PSC al 1991, minimitza, quan no nega, el paper de les lluites veïnals que es van donar als anys setanta i vuitanta ${ }^{170}$.

De nou sobresurten els llibres fets pels protagonistes dels fets. Una obra pionera va ser la del sacerdot Alfred Matas Pericé sobre el barri del Besòs -on va exercir- titulada Al Sud-oest del Riu Besòs deu anys de la vida d'un barri barceloní (en aquesta zona hi havia diversos barris, un dels quals pertanyia a Sant Adrià a l'igual que una part de la Via Trajana i una zona industrial adjacent a aquesta). L'obra, de l'any 1970 ja ens mostra tota la problemàtica del sector, el paper de l'església, les comunitats cristianes de base i del primer moviment veïnal que va haver de superar l'associacionisme fomentat pel règim ${ }^{171}$.

Més recent és el llibre de Josep Maria Montferrer i Celades El Camp de la Bota. Un espai i una història ${ }^{172}$. Escolapi -com Jaume Botey i altres que van desenvolupar una important tasca social en aquest barri de barraques als anys seixanta-, mestre d'una de les escoles públiques de la Mina i actualment president de L'Arxiu Històric de La Mina i el Camp de la Bóta, el seu llibre és el precedent d'una trilogia, encara inèdita, sobre la història adrianenca vista des de un dels barris més coneguts de la riba dreta del Besòs. És una obra imprescindible per conèixer els precedents del barri de la Mina, creat precisament als anys setanta per encabir els nombrosos barraquistes que encara existien a Barcelona i les seves rodalies i en especial els que existien en aquella zona de confluència entre els termes municipals de Sant Adrià de Besòs i Barcelona. Recentment ha aparegut el primer llibre d'aquesta trilogia: La història de Sant Adrià llegida des de la Mina. Volum 1. Un espai cobejat i una història conflictiva ${ }^{173}$.

per falta d'assignació pressupostària. AHLMICB Caixa C-1 C-1.4, La Mina anys 80, Carpeta "Pla Interdepartamental 1982-83".

170 Sant Adrià: 12 anys de democràcia municipal, Ajuntament de Sant Adrià de Besòs, 1991.

171Alfred Matas Pericé: Al Sud-Oest del riu Besòs. Deu anys de la vida d'un barri barceloní, Editorial Pòrtic, Barcelona, 1970.

172Josep Maria Monferrer i Celades: El Camp de la bota. Un espai i una història, Octaedro, Barcelona, 2012.

173Josep Maria Monferrer i Celades: La història des de Sant Adrià llegida des de la Mina, Octaedro, 
A nivell acadèmic tampoc hi ha molts estudis. Llevat llevat de l'obra genèrica de les Comissions Obreres al Barcelonès Nord ja esmentada vàries vegades -important, en la mesura que la ciutat tenia un teixit industrial prou gran-, existeix, no obstant, dues Tesines de doctorat sobre l'evolució de la població de Sant Adrià de Besòs del segle XVIII fins a l'actualitat feta per Just Casas i Soriano i Manuel Mázquez i Berrocal ${ }^{174}$. Part d'aquestes obres s'han publicat parcialment en dos llibres $^{175}$. El primer d'ells, subtitulat La població: segles XVIII-XX ens és útil per veure com la immigració i la industrialització va transformar profundament aquest petit poble, així com l'impacte que tenia per ell la divisió en dos pel riu Besòs i la construcció de macropolígons d'habitatges a la seva marge dreta durant els anys setanta pràcticament aïllats amb la resta de la ciutat i més propers als Barris del Besòs i La Verneda de Barcelona amb els quals tenien més llaços en comú.

De nou, l'escassa bibliografia local pot ser complementada per altres fonts com les publicacions de l'època, destacant en aquest cas Besós, publicació feta per un grup d'ex-alumnes del col-legi Sant Gabriel de la localitat i que va arribar, al igual que Grama, a patir algun segrest i sanció i que un dels seus membres, el futur advocat Francesc Arnau del Despatx d'Assessorament Laboral i Popular (DALP) -famós per defensar a activistes i militants de moviments populars- fos processat pel TOP l'any 1969 per la publicació d'una carta adreçada al dictador ${ }^{176}$.

Menció apart mereix un treball que tot i no tractar directament sobre el moviment veïnal, en fa força referències i que és la primera -i única, fins el moment- que adopta la perspectiva del Barcelonès Nord per un estudi. Es tracta de l'obra d'Emili Ferrando Puig i Juan Rico Màrquez Les Comissions Obreres en el

Barcelona, 2013.

174Just Casas i Soriano: Història social de la població de Sant Adrià de Besòs: del segle XVIIIa la Primera Guerra Mundial, Treball de Recerca dirigit per Francesc Bonamusa, 1992 i Manuel Márquez i Berrocal:Història social de la població de Sant Adrià de Besòs : de la primera Guerra Mundial a l'actualitat, Treball de Recerca dirigit per Francesc Bonamusa, 1992.

175Just Casas i Soriano i Manuel Márquez Berrocal: Història Social de Sant Adrià de Besòs. Vol I. La Població: segles XVIII-XX, Hacer Editorial, Sant Adrà de Besòs, 1996 i Manuel Márquez i Berrocal: Història Social de Sant Adrià de Besòs. Vol III. La Transformació del territori: La producció de l'espai urbà a Sant Adrià de Besós, 1910-1940, Hacer Editorial, Sant Adrà de Besòs, 1996. Curiosament, no existeix el Volum II ni el volum IV. que no es van arribar a publicar.

176"Carta abierta pero certificada a Su Excelencia el Jefe del Estado Francisco Franco Bahamonte, Generalisimo de los Ejércitos de Tierra, Mar y Aire y Caudillo de España por la Gracia de Dios", Besós, núm. 16. Un exemplar del número segrestat (i d'altres)es pot trobar a l'Hemeroteca de l'Arxiu Municipal Administratiu de Sant Adrià de Besòs (ASAB). 
franquisme. Barcelonès Nord (1964-1977) ${ }^{177}$. Els dos autors havien destacat en el passat per la seva implicació en el teixit associatiu. Emili Ferrando, historiador i professor de secundària, havia estudiat els moviments cristians de base com la $\mathrm{HOAC}^{178}$, dels quals havia format part, mentre que Juan Rico era -i és encara avuimilitant de CCOO, del moviment veïnal i també impulsor de l'Arxiu Històric de Llefià. L'obra dedica alguns dels seus capítols al moviment popular ciutadà que s'estava teixint als barris amb les més que evidents connexions amb el moviment obrer -amb el cas més especial de Santa Coloma de Gramenet on tindran més incidència unes Comissions de Barri autònomes- tractant per separat les tres ciutats que conformen el Barcelonès Nord i recollint molt testimoni oral. És una obra de referència imprescindible per a qualsevol estudi que es vulgui fer de Badalona, Santa Coloma i Sant Adrià durant el tardofranquisme i els primers anys del procés de canvi polític.

Un cop fet aquesta extensa ressenya bibliogràfica, ja és hora de començar a veure com va sorgir el moviment veïnal en les tres ciutats del Barcelonès Nord.

177Emili Ferrando Puig i Juan Rico Márquez: Les Comissions Obreres en el franquisme. Barcelonès Nord (1964-1977), Publicacions de l'Abadia de Montserrat, Barcelona, 2005.

178Emili Ferrando Puig: Cristians i rebels. Història de l'HOAC a Catalunya durant el franquisme (1946-1975), Mediterrània, Bcn, 2000, p. 462-516. 


\section{Els orígens del moviment veïnal al Barcelonès Nord.}

"Yo cuando llegué a este barrio donde vivo [Llefià, Badalona] yo pensé que iba a ver un paraíso (...) dije jostia! Estaba peor construido que mi pueblo (...) en la parte de arriba de Llefià había un barraquismo que... imadre mía! A dónde he venido yo a parar!"179

“(...) Además de todos los recogidos en el escrito de Exposición de Motivos (que acreditan la constancia en los antecedentes del Movimiento, y en nuestras leyes fundamentales, de un principio, que luego no ha tenido adecuado desarrollo), debe añadirse que, al lado de la representación sindical, las Asociaciones de Cabezas de Familia son el único tapón serio al intento de resucitar viejas, o crear nuevas, agrupaciones políticas de tipo partidista; a la vez que permitirán implicar a un número creciente de personas en organismos del régimen."180

\footnotetext{
"Las condiciones para crear estas Comisiones son particularmente favorables. Con frecuencia leemos en los periódicos informaciones que explican acciones de protesta llevadas a cabo un día por las mujeres del Besós y de la Guineueta contra la instalación de escuelas en barracones; otro día por las mujeres de Badalona contra el "polvillo negro" que arroja la central térmica o contra la falta de agua en las zonas extremas de la ciudad." ${ }^{181}$
}

\subsection{Les condicions objectives: Immigració, treball i classe a Badalona, Santa Coloma de Gramenet i Sant Adrià de Besòs. Una lluita diària.}

És imprescindible fer un breu repàs de quin va ser el desenvolupament dels tres principals municipis del Barcelonès Nord, ja que -fent servir la terminologia

179Entrevistes a F. Lillo (2005 i 15-5-2006), antic militant del PSUC i CCOO i del moviment veïnal. Actualment milita al Partit dels Comunistes de Catalunya, Esquerra Unida i Alternativa, CCO0, és membre de la FAVB (Federació d'Associació de Veïns de Badalona) i de l'Associació de Veïns i Veïnes de Sant Mori de Llefià. José Miguel Cuesta: El moviment veïnal a Llefià (Badalona), Tesina de Doctorat, setembre de 2010, p. 122.

180Secretaría General del Movimiento: "Información Confidencial sobre el proyecto de Decreto de Asociaciones de Cabeza de Familia”, (1958), Archivo General de la Administración (AGA), Fondo Presidencia, caja 51/18374, Dossier "Asociaciones de Vecinos Cabezas de Familiares", p. 2. El subratllat és de l'original. En 1958 la Secretaría General del Movimiento estava ocupada per José Solís Ruiz.

181 Gregorio López Raimundo: “En el buen camino. Intervención ante una reunión de militantes del P.S.U. de Cataluña” (1967), AGA, Fondo Cultura, Gabinete de Enlace del Ministerio de Información y Turismo, caixa 42/9097, Dossier 5. Documentación relativa al Partido Socialista Unificado de Catalunya (PSUC). 
clàssica del marxisme- les condicions objectives són un factor molt important per entendre el desenvolupament del moviment popular ciutadà. Les mancances i nombrosos dèficits que patiran tots tres municipis pel desorbitat creixement que van tenir al segle XX producte de la immigració -en major o menor mesura- són un fet que cal tenir molt en compte. Això si, amb la prevenció, d'entendre que pel sorgiment del moviment veïnal serà necessari que es combinin amb uns altres factors.

L'evolució del Barcelonès Nord i dels seus tres principals municipis no es pot entendre sense un factor d'una gran importància: la industrialització i la proximitat amb la ciutat de Barcelona. Les tres localitats havien estat durant la major part de al seva història petits pobles, llevat de la veritable ciutat que va esdevenir la Badalona romana.

Els romans van fundar la ciutat de Baetulo [Badalona] durant la primera meitat del segle I abans de la nostra era, i va esdevenir una població relativament important fins ben entrat el segle II de la nostra era, arribant, fins i tot, a fer ombra a Barcino [Barcelona]. Però la crisi baix imperial i l'inici de l'Edat Mitjana va despoblar la ciutat fins esdevenir una petita població dedicada fonamentalment a l'agricultura i la pesca, centrada al nucli que avui es coneix com a Dalt de la Vila. No va ser fins el segle XVIII quan es va començar a poblar la zona més propera a la platja, un cop reduïda l'amenaça de la pirateria. En aquest segle es va experimentar un creixement econòmic i demogràfic notable. Al 1717 la vil·la de Badalona tenia només 656 habitants, però al 1787 ja eren $4.235^{182}$. La crisi de finals del segle XVIII i les contínues guerres, en especial la del Francès van afectar profundament Badalona de manera que a inicis del segle XIX la vila comptava amb una població aproximada de 2.000 habitants. Però a l'any 1900 la població havia augmentat fins als 19.116 habitants. Què havia passat? Doncs que el poble agrícola i pesquer s'havia transformat en una ciutat industrial. Tot el segle XIX és un continu creixement de població, destacant el fet que entre els anys 1840 i 1875 la població pràcticament es triplica: de 4.840 habitants es passa a 12.800. El període de creixement més intents va ser el del sexenni 1851-1857 on es va passar de 5.733 a

182Si no s'explicita una altra font, les dades sobre la població de Badalona procedeixen de: Joan Villarroya (dir.): Història de Badalona. Col-lecció Monografies Badalonines núm. 16, Museu de Badalona, 1999, p. 103-133. 
10.485 persones.

Aquest creixement no es pot entendre sense la immigració, ja que el creixement vegetatiu de cap ciutat no pot, per si sol, donar aquestes xifres. Però aquesta sempre té uns factors que la fomenten, tant el el punt de sortida com en el de destinació. L'inici del procés industrialitzador badaloní, accelerat per la inauguració del primer ferrocarril peninsular, el Barcelona-Mataró de 1848, va ser, sens dubte, la guspira desencadenant d'aquest fet. Aquesta primera immigració provenia d'altres comarques catalanes com l'Urgell, Osona, el Ripollès fins al Camp de Tarragona, el Baix Ebre i el Montsià. Era una immigració de procedència rural que va acabar configurant un barri industrial prop de la línia de ferrocarril, més enllà de l'actual avinguda Martí Pujol.

L'existència d'aquest nucli obrer es pot constatar amb la creació, l'any 1868, de la parròquia de Sant Josep. Durant la primera meitat del segle XIX Badalona havia conservat el seu caràcter pesquer tot i que ja s'havia iniciat tímidament el procés industrialitzador. Però va ser en la segona meitat del segle XIX quan aquest fenomen va ser evident. La industrialització es va consolidar i els sectors tradicionals (la pesca i l'agricultura) van perdre l'hegemonia a la ciutat. Va destacar el sector del tèxtil, si bé progressivament la indústria es va anar diversificant ${ }^{183}$.

La mecanització d'aquesta indústria va ser, com en la majoria de casos, un procés gradual ${ }^{184}$. De fet fins a ben entrat el segle XIX al tèxtil van continuar predominant els telers manuals i l'especialització en el tissatge ${ }^{185}$. A més a més, la importància del tèxtil en la industrialització que es va donar a Badalona -i de fet, a gran part del Principat- (amb predomini del cotó) va fer que classe obrera estigués

183Les primeres fàbriques "modernes" havien començat a instal-lar-se als anys 20. Amb capital barceloní, fonamentalment, es va anar industrialitzant la ciutat. Al 1845 hi havia una vintena de fàbriques, la majoria tèxtils. Al 1856 ja són 46 i al 1897 142. D'aquestes 46 eren del sector tèxtil, 41 de l'alimentació, 20 de la construcció, 13 químiques, 11 d'assaonaments, 4 metal-lúrgiques, 1 energètica, 1 vidriera i 5 d'altres. Veure Joan Villarroya (dir.): Història de Badalona, Museu de Badalona, Monografies Badalonines 16, Badalona, 1999, p. 136-138.

184De fet, a la primera potència industrial del moment, el Regne Unit, la mecanització va seguir un procés similar. Al 1803 a la Gran Bretanya només hi havia 2.400 telers mecànics; el 182014.650 i el 1833 eren 100.000. Veure Maxine Berg: La era de las manufacturas, 1700-1820. Una nueva historia de la revolución industrial británica, Crítica, Barcelona, 1987.

185A Badalona la primera màquina de vapor va ser instal-lada al $1843 \mathrm{i}$ els telers mecànics van anar augmentant progressivament. al 1862 tenim 235, al 1872625 i al 1895 1.298, mentre que en una proporció inversa els telers manuals disminueixen: al 1862 tenim 711, al $1872638 \mathrm{i}$ al 1895 només 75. Tot això mentre el nombre de fusos també creixia sense parar (6.160, $9.040 \mathrm{i}$ 19.968, respectivament en els anys anteriorment esmentats). Veure Joan Villarroya (dir): Història de Badalona...., p. 133. 
més equilibrada per sexes, desfent el "mite" que la incorporació de la dona al treball assalariat "reconegut" és un fet recent. A les empreses del tèxtil hi havia un clar predomini de la mà d'obra femenina i també una presència molt important de la mà d'obra infantil, en les precàries condicions que ens podem imaginar.

En definitiva, en acabar el segle XIX Badalona s'havia transformat d'un poble agrícola i pescador a una ciutat industrial. Aquesta transformació es va fer, com ja he dit, gràcies al capital barceloní en la seva majoria. No va existir, així, una forta burgesia autòctona ${ }^{186}$. Però el que si va existir va ser un moviment obrer que va adquirir progressiva i ràpidament una força molt important dins la societat badalonina. Com a exemple d'aquesta profunda transformació que havia experimentat Badalona, el 1897 rebia el títol de ciutat. En aquest moment l'extensió urbanitzada d'aquesta sortia ja del seu centre històric i s'estenia cap el que avui en dia encara es coneix com el barri del Progrés per la banda de la costa -el barri on s'havien situat la majoria de fàbriques, d'aquí el seu nom-, i no molt més enllà de Dalt de la Vila en direcció cap a l'interior, apart de comptar amb altres petits nuclis dispersos i de cases aïllades. Aquest creixement no es va aturar al segle XX, sinó que es va accelerar.

Pel que fa a Santa Coloma de Gramenet i Sant Adrià de Besòs la principal diferència que van tenir aquestes dues poblacions respecte Badalona és que duran el segle XIX encara van conservar moltes de les seves característiques eminentment rurals. Els orígens de Santa Coloma de Gramenet cal buscar-los en l'Edat Mitjana, tot i que havien existit nuclis de població en èpoques molt anteriors, com ens demostra l'existència del poblat ibèric del Puig Castellar (datat aproximadament del segles VI- finals de III abans de la nostra era) a l'anomenat popularment Turó del Pollo, a la serra de Sant Mateu. Posteriorment el poblament d'aquesta zona va ser dispers fins que des de les repoblacions del segle XI va

186Generalment es tendeix a parlar d'aquesta manca de força de la burgesia local en comparació amb altres ciutats de mida semblant a la de Badalona com Sabadell i Terrassa. No obstant, la importància de la burgesia autòctona de les capitals del Vallès Occidental ha estat, si més no, relativitzada. Segons Martí Marín una part de la industrialització de Sabadell i Terrassa també està feta amb capital barceloní. En el cas de Sabadell també afirma que hi ha capital procedent de zones del tèxtil tradicional en retrocés o de ciutats que en algun moment perden el lideratge com per exemple Camprodon, Béjar o Alcoi. Martí Marín: “Industrialització i migració. Burgesia i classes populars. El cas de Sabadell" dins Rosa Guinart i Montserrat Perelló (eds.): El segle XX a debat. Jornades l'Hospitalet. 75 anys de ciutat, 24, 25, 26 de gener de 2001, Quaderns d'Estudi 17, Centre d'Estudis de l'Hospitalet, l'Hospitalet, 2001, p. 129-143. 
començar a articular-se un petit poble a voltant d'una segona església romànica edificada en aquest mateix segle i la seva sagrera. La petita població va anar creixent lentament amb el transcurs dels segles. L'any 1718 només tenia 144 habitants, si bé en el transcurs del segle XVIII va experimentar un creixement notable, comptabilitzant-se l'any 1787731 habitants $^{187}$.

Al segle XIX la població colomenca va experimentar un cert creixement després del sotrac d'inicis de segle que havia reduït la població a menys de 500 habitants, però no va experimentar un augment tant fort com el de la veïna Badalona. Les raons cal cercar-les en que Santa Coloma va continuar conservant unes característiques eminentment rurals. La seva situació geogràfica, relativament aïllada de les vies de comunicació -en especial del ferrocarril- va ser determinant. De manera que a l'any 1857 comptava amb una població de 1.304 habitants. Al 1871 n'eren 1.517, al 18811.584 i cap al la fi del segle n'eren 1.510, és a dir, que fins i tot n'havia perdut població. No obstant, encara que el poble de Santa Coloma no s'industrialitzés, no es pot dir que els seus habitants en quedessin totalment al marge dels seus efectes. Les indústries tèxtils de Sant Andreu Arenal quedaven relativament a prop i es força provable que colomencs -i segurament moltes colomenques- hi anessin a treballar. Alhora, també es va produir un altre fenomen: l'estiueig de la burgesia barcelonina, en especial a finals del segle XIX, a la recerca d'espais oberts més saludables.

Sant Adrià de Besòs va ser un nucli de població encara més petit. Al 1718 tenia una població aproximada de 59 habitants, que s'havien incrementat fins a 133 l'any $1787^{188}$. Com als altres municipis del Barcelonès Nord el creixement de població -el més tímid de les tres poblacions analitzades- s'estanca pels conflictes de finals del segle XVIII i principis del XIX. La població adrianenca sembla que va patir menys aquest període convuls de manera que al 1829 s'estima que havia recuperat i superat la població de finals del segle passat, superant els 200 habitants (mentre Badalona i Santa Coloma encara no havien assolit el nivell de població que

187Si no s'explicita una altra font, les dades de població de Santa Coloma de Gramenet provenen de Joan Vilaseca i Segalés: Història General de Santa Coloma de Gramenet, Ediciones Metropol, Barcelona, 1985, p. 124, 153, 157 i 158.

188Si no s'explicita una altra font les dades de població de Sant Adrià de Besòs provenen de Just Casas i Soriano i Manuel Márquez i Berrocal: Història social de Sant Adrià de Besòs. Vol. I. La Població: segles XVIII-XX, Hacer Editorial, Sant Adrià de Besòs, 1996. 
havien tingut al 1787). Però a partir d'aquí el creixement de la població de Sant Adrià va ser lent durant tot el segle XIX, amb una petita acceleració en la segona meitat. Malgrat tenir un creixement vegetatiu positiu, durant gran part d'aquest segle Sant Adrià va mantenir un saldo migratori negatiu, fet condicionat segurament per la manca d'industrialització del poble en aquest període. Per això la població en arribar l'any 1900 encara era només de 418 habitants.

D'aquesta manera comencen el segle XX tres poblacions que havien experimentat una evolució diferent que s'havia posat de manifest en el seu dispar creixement demogràfic. Però va ser en aquest segle quan es produiren els canvis més importants, en especial gràcies als fets migratoris. Si bé als primers anys del nou segle es van continuar amb les dinàmiques anteriors i amb un creixement pausat, a partir de 1915 i sobretot de 1920 la situació va començar a canviar amb l'arribada de nous fluxos migratoris condicionats pel cicle de creixement econòmic i industrialitzador que s'estava donant. Badalona va continuar desenvolupant la seva activitat industrial a la qual ara es va sumar Sant Adrià de Besòs, on es van instal-lar diverses empreses. Si a l'any 1900 la població activa de Sant Adrià estava distribuïda en un 69,1\% en el sector Primari, un 4\% en el Secundari i un 26,9\% en el Terciari, el 1920 la distribució era de 48,5\% en el Primari, 21\% en el Secundari i 30,5 en al Terciari. Però en 1936 la distribució ja era de només un 11,6\% en el Primari, un $59,1 \%$ en el Secundari i un $29,3 \%$ en el Terciari ${ }^{189}$. El canvi havia estat notable. En contrast, Santa Coloma de Gramenet no va viure un procés tan intens d'instal·lació d'indústries en el seu terme municipal, si bé la seva població també es va anar proletaritzant. Com es pot veure en la següent taula, les tres poblacions del Barcelonès Nord van experimentar un creixement demogràfic important, sobretot a partir de la dècada dels anys vint gràcies a l'arribada de població provinent d'altres indrets del Principat, però també ara, en un volum considerable, d'altres territoris de l'Estat espanyol com l'Aragó, el País Valencià i molt especialment, Múrcia (i també, més tardanament, zones d'Andalusia i Castella). Fins al punt que el terme "murciano" es va popularitzar en aquell moment per referir-se, de manera certament despectiva, als nouvinguts d'aleshores.

189Manuel Márquez i Berrocal: Història Social de Sant Adrià de Besòs. Vol. III. La transformació del territori: la producció de l'espai urbà a Sant Adrià de Besòs, 1910-1940, Ajuntament de Sant Adrià de Besòs, L'Hospitalet de Llobregat, 2001. 
Evolució de la Població al Barcelonès Nord (1900-1940)

Badalona

1900

1910

1920

1930

1940

Santa Coloma de Gramenet

19240

20957

29361

44231

48234

Sant Adrià de Besòs

1510

1869

2728

12930

17318

Total

418

494

1073

6515

33162

63676

8342

73894

Elaboració pròpia a partir de fonts diverses que recullen els Censos dels anys esmentats.

La dècada dels anys vint va marcar sens dubte el punt d'inflexió amb la contínua arribada de població que venia a treballar en la pujant indústria o en les importants obrés públiques que s'estaven fent en aquells anys, com el metro de Barcelona o l'Exposició Universal de 1929. Una menció especial s'ha de fer en el cas de Santa Coloma de Gramenet, ja que en aquest període es van establir dins el seu terme municipal situat a l'oest del riu Besòs el barri de "Cases Barates" del Bon Pastor, dins una iniciativa feta durant aquell any 1929 de reallotjar habitants residents en barraques, fet que va incrementar notablement la població de la ciutat, tot i que al 1945 aquest barri va ser segregat i afegit a Barcelona. De fet van ser Santa Coloma i Sant Adrià les que van experimentar un creixement més accelerat, repetint les pautes que s'havien donat a Badalona en anys anteriors.

La crisi econòmica dels anys 30 i, sobretot, la Guerra Civil van suposar un breu alentiment en el creixement demogràfic de les ciutats del Barcelonès Nord. Però un cop acabat el conflicte els moviments migratoris es van reprendre amb una rapidesa inusitada i fins fa relativament poc força desconeguda, malgrat la duresa de la postguerra i la repressió que es va fer de la immigració. De fet, una de les causes de les primeres migracions es poden buscar en la duríssima repressió que va patir el món rural en determinats territoris de l'Estat espanyol. Les causes econòmiques i polítiques s'entrecreuaven i eren difícils de distingir en no pocs casos, com recull el següent testimoni ${ }^{190}$ :

"Aquí iba viendo la gente, se iba hacinando, venían no solamente por motivos de trabajo sino por motivos políticos. No podían estar en su pueblo porque cuando pasaba cualquier cosa la Guardia Civil los cogía y palizas van y palizas vienen. Yo he conocidos personas que han vivido en este barrio [Llefià, Badalona] que por tener una

190Un treball pioner en aquest àmbit va ser el d'Angelina Puig Valls: De Pedro Martínez a Sabadell: l'emigració, una realitat no exclusivament econòmica, 1920-1975, Tesi Doctoral, UAB, 1991. 
cierta tendencia política, no por crímenes ni por haber hecho más, no, por tener un pensamiento político tuvieron que salirse de su pueblo y vivirse a venir a medio escondidas en estas barracas. Aquí era imposible encontrar a alguien porque estaban hacinadas las barracas." ${ }^{191}$

Una persona que s'hagués significat políticament podia estar inclosa en llistes negres i no obtenir facilitats per obtenir feina, a més de patir un assetjament polític i social. L'opció de marxar a una gran ciutat era doncs, una opció a tenir en compte malgrat que la vida allà tampoc en fos fàcil, com veurem.

Una altra dificultat, no pas menor, que havien de superar les persones que decidien marxar era la repressió que va fer el franquisme de la immigració, si més no en un primer moment. Contràriament a un dels mites del franquisme, força popular a Catalunya, de que aquest "va fomentar la immigració per mirar d'espanyolitzar el Principat", el cert és que el franquisme va fer, durant uns determinats anys, fins a finals de la dècada dels cinquanta, just el contrari (no va ser fins les darreries del franquisme quan es va pensar en fer servir la població nouvinguda contra les reivindicacions catalanistes i d'aquí per exemple l'impuls que Fraga va donar a les "Casas Regionales"192). Dins el franquisme coexistien discursos industrialitzadors amb altres de ruralistes, que certament eren difícils de conciliar $^{193}$. Però per sobre d'aquestes hi havia la voluntat explícita de sotmetre a un ferri control polític i social a la població de l'estat. I quina millor manera que limitar el moviment de la població i fixar-la al territori? A més, dins l'esmentat discurs ruralista la ciutat es percebia com perillosa i d'esquerres. Així no ens ha d'estranyar que les autoritats, en especial el Governador Civil de Barcelona als anys 50, Felipe Acedo Colunga, engegués una política de control i deportació de població nouvinguda:

"Així, a la recerca d'immigrants sense papers -considerats d'aquesta manera per no tenir contracte de treball o estar empadronats en un habitatge no autoritzat- s'ordenà

191Testimoni de Luis Diego a Montserrat Carreras, Emili Ferrando i Joan Villarroya: La immigració a Badalona durant el segle XX. Col·lecció Monografies Badalonines núm. 19, Museu de Badalona, 2006.

192Carles Santacana: El franquisme i els catalans. Els informes del Consejo Nacional del Movimiento, Afers, Catarroja-Barcelona-Palma, 2000.

193 Martí Marín i Corbera: "Fluxos, stocs, periodicitat i orígens" dins Martí Marín (dir.): Memòries del viatge [1940-1975], Museu d'Història de la immigració de Catalunya i Ajuntament de Sant Adrià de Besòs, 2009, p. 27. 
el control i la vigilància de les principals rutes d'accés a la Ciutat Comtal, el principal punt d'arribada d'immigrants a la ciutat que concentrava la major part d'aquests contingents, i les estacions d'autobusos i trens i el port, així com els suburbis de barraques que els allotjaven." ${ }^{194}$

Imma Boj, l'actual directora -en el moment d'escriure aquestes línies- del Museu d'Història de la Immigració a Catalunya, situat a Sant Adrià de Besòs, va dedicar part de la seva recerca a investigar aquest fet, així com l'us del Pavelló de Misiones com a camp de reclusió de la població detinguda a l'espera de la seva deportación ${ }^{195}$. Segons la mateixa autora, en el període que va dels anys 1952 al 1957, un total de 15.000 persones van ser retornades als seus llocs d'origen ${ }^{196}$. Tot i que aquesta xifra ens pot semblar petita en comparació amb les 241.906 persones que van arribar a la província de Barcelona durant la dècada 1940-1950 (al conjunt del Principat la població havia crescut en el decenni 1940-1950 en un total de 349.339 habitants ${ }^{197}$ ) o les 479.613 de la dècada $1950-1960^{198}$, tampoc s'ha de menystenir: avui, la proporció d'immigrants internats i deportats fora de les fronteres de l'Estat no és pas major. Les autoritats franquistes de diferents municipis que envoltaven la capital barcelonina -entre ells alguns on centro la meva recerca- no ho feien:

"D'altra banda, alguns ajuntaments metropolitans posen el crit al cel contra les disposicions d'Acedo perquè temen que les polítiques repressives desplegades a Barcelona i a altres municipis grans de l'entorn metropolità acabin desplaçant aquesta població cap a altres ciutats més petites. Aquest serà el cas de Badalona -que fins i tot arriba a debatre en un ple una queixa formal en aquest sentit- o Santa Coloma, convertides subreptíciament en nuclis d'absorció del que la capital rebutja." ${ }^{199}$

194Iván Bordetas Jiménez: “El viatge: canals d'informació, rutes, condicions i arribada” dins Martí Marín (dir): Memòries del viatge..., p. 43.

195 Imma Boj: La represión de la inmigración en la Barcelona franquista. El pabellón de las misiones, Tesina de Màster, Barcelona, 2003.

196Imma Boj i Jaume V. Aroca: "La repressió de la immigració: les contradiccions del franquisme" dins Martí Marín (dir.): Memòries del viatge..., p. 72.

197Carme Molinero i Pere Ysàs: "La població catalana a la postguerra: creixement i concentració, 1939-1950", L'Avenç núm. 102, p. 40. En concret s'havia passat de 2.890 .974 habitants al 1940 a 3.240.313 el 1950.

198Anna Cabré i Isabel Pujades: "La població: immigració i explosió demogràfica", dins Història econòmica de la Catalunya contemporània, Vol. V, Enciclopèdia Catalana, Barcelona, 1988, p. 4852. Les dades de població arribada a la província de Barcelona en altres decennis són: 19111920: 203.704 habitants; 1921-1930: 376.081; 1961-1970: 649.597.

199Imma Boj i Jaume V. Aroca: “La repressió de la immigració...”, p. 82. 
La població que hi arribava coneixia aquests procediments, ja que o els havia viscut en carn pròpia o els havia conegut per terceres persones:

"Cuando yo llegué a la estación más inmediata de mi pueblo encontré allí a unos que los habían devuelto de Barcelona de las Misiones. Todo el que venía aquí que no era catalán yo llevaban a Misiones, al castillo de Montjuic, y allí cuando estaban muchos los devolvían a su pueblo con los trenes. [...] Entonces venía con un primo mío y dijo: "mira lo que dicen estos, que los han de vuelto de las Misiones". Y digo: "pues vamos para allá". Vine en tren, con el miedo de que cuando viniéramos a Barcelona nos llevaran a "Misiones". Cuando llegué me cogieron las maletas mis familiares y yo me fui detrás de ellos despistando el tren de Badalona para que no me cogieran para Misiones.“200

"Pero antes de venirnos nosotros, pues yo tenía un tío que estaba de Guardia Civil aquí en Cataluña, estaba en San Ferrer de la Montaña... Y entonces le escribimos a el para venir p'aquí. Primero se vino mi hermana y mi hermano (...). Mi hermana estuvo con ellos, viviendo en cuartel... Mi hermano se buscó una habitación para dormir... Y resulta ser que mi cuñao había hecho la mili aquí (...). Total que mi hermana aun no estaban casados y mi cuñao se quedó allí en el pueblo. Y le dijo mi madre que se viniera para aquí, que aquí hay mucho trabajo y total... Él se vino p'aquí y al llegar a la Estación de Francia claro... si se lo hubiera dicho a mi tío al igual no hubiera pasado nada pero (...) entonces a todos los que venían si no había nadie que los esperaba entonces los cogían y los llevaban a Montjuic (...). Entonces el al llegar aquí se ve que eso... entonces lo cogieron y estuvo unos cuantos días en Montjuic. (...) Pues en el (...) 56 o $57 \ldots$ porque nosotros nos vinimos aquí en el 55 (...). El caso es que a el lo llevaron allí y cuando aquello se llenaba, se ve que llenaban un tren y ziu... los enviaban. [de tornada]. Pero él antes de hacer el recorrido se bajó y cogió otro tren y en vez de esto... se bajó en Vilanova o no se ... Y entonces ya con sus medios vino aquí., ya pudo entrar y no..." 201

"A Barcelona fue a recogerme mi cuñado, que tenía contrato y vivienda, pero la policía me detuvo y, aunque mi cuñado se parecía a mi marido, al pedirme el libro de familia se dieron cuenta de que no era él y me llevaron a comisaría. Desde allí, cuando juntaron un grupo de gente, ya por la noche, nos llevaron a Montjuich. Aquello era una

200Testimoni de Pedro Rubio a Montserrat Carreras, Emili Ferrando i Joan Villarroya: La immigració a Badalona..., p. 158.

201Entrevista a Antonio Jurado, membre de l'Acció Catòlica Obrera i de l'Associació de Veïns de La Morera (Badalona), 14-6-2013. 
nave muy grande, como un hospital, con muchas camas a un lado y a otro, para montar. Allí había mucha más gente, era como un cuartel. Yo ya tenía muy poco ánimo, y allí lo perdí todo. Me encuentro, con mi marido por un lado, la casa desbaratada, la niña que teníamos, que se había muerto, y yo allí presa... Me eché sobre la cabeza un mantón negro que llevaba y no paraba de llorar." ${ }^{202}$

Per les persones que ho van patir van ser unes experiències dures, i que faríem bé de recordar doncs no són pas gaire diferents a les que pateixen els mal anomenats "immigrants irregulars" en l'actualitat.

En aquestes condicions tan precàries, la importància de les xarxes familiars o de paisanatge van adquirir una importància notòria. Apart dels condicionants anteriorment esmentats que impulsaven a la marxa del lloc d'origen, el coneixement d'altres persones que ja residien en el lloc de destinació era fonamental, tant pel factor d'atracció que oferien a partir del seu exemple personal, com per ajudar a sortejar les traves legals i policials del desplaçament així com per aconseguir un lloc de residència i treball. Els testimonis anteriors ens demostren com la presència -o no- d'un familiar podia ser decisiva.

Per que un cop sortejat el perill de la detenció i la deportació, la població nouvinguda havia de fer front a una altra gran dificultat. Aconseguir un lloc de residència. I aquesta no era una tasca fàcil, sobretot durant els primers moments, fins ben entrat els anys seixanta (i llavors tampoc serà una tasca satisfactòria). Les condicions per trobar una llar durant la postguerra seran molt dures. Per començar, hi haurà un profund dèficit d'habitatges, que anirà creixent progressivament en les dècades dels anys 40 i 50. Acabada la guerra s'estimava el dèficit d'aquests en la ciutat de Barcelona era de 10.700 i de 24.000 a tota la província $^{203}$, i que al 1950 aquest s'havia incrementat a 65.000 i 70.000 respectivament ${ }^{204}$. La iniciativa privada no construïa habitatges assequibles per les

202Testimoni recollit a El Ideal de Blas Infante en Cataluña, Centro de Estudios Historicos de Andalucía, Sevilla, 2008. Citat a Imma Boj i Jaume V. Aroca: “La repressió de la immigració...., p. 80.

203Iván Bordetas: "Habitatge i assentaments, de la postguerra a l'estabilització" dins Martí Marín (dir.): Memòries del Viatge..., p. 60. Les dades estan extretes del Instituto Nacional de la Vivienda: Una tierra bajo el techo. Veinticinco años del Instituto Nacional de la Vivienda en Cataluña, Ministerio de la Vivienda, Barcelona, 1964.

204Ídem. Les dades estan extretes de Carme Molinero i Pere Ysàs: "La població catalana a la postguerra: creixement i concentració, 1939-1950”, L'Avenç, núm. 102, 1987, p. 44. 
classes populars, i les autoritats franquistes van mostrar una especial desídia en aquest fet, centrant-se més en la repressió de les migracions i del barraquisme.

Per que, davant la manca d'habitatge, va ser aquesta la "solució" -si se li pot anomenar així- que es van veure obligada a adoptar la majoria de població nouvinguda (juntament amb el relloguer o el poblament en coves). A la ciutat de Barcelona aquest fet -l'infrahabitatge- va créixer espectacularment. Si bé és cert que no era un fenomen nou, ja que al 1929 ja s'havien comptabilitzat unes 6.748 barraques repartides en diferents barris barcelonins, al 1949 el "Servei de Repressió del Barraquisme" de l'Ajuntament de Barcelona les xifrava en 15.000 205 (on residien 150.000 persones segons diverses fonts eclesiàstiques ${ }^{206}$ ). Alhora es calculava que entre 4.500 i 5.000 persones residien en coves i 200.000 vivien de rellogats $^{207}$. Mentrestant, la situació de les poblacions del voltant no era pas gaire millor, ja que:

"L'any 1949 es calculava que a tot el cinturó Barceloní 26.000 persones vivien en barraques i coves: a Collblanc, Sanfeliu i la zona de la Carretera del Mig de l'Hospitalet de Llobregat; el nucli del Parapeto de Sant Adrià de Besòs, al marge est del riu; a la Salut i Llefià a Badalona; entorn a la carretera de la Roca a Santa Coloma de Gramenet; les coves de la zona Torre Mercader a Cornellà de Llobregat..." ${ }^{208}$

Ens podem imaginar les dures condicions de vida que van haver de partir els seus habitants, com ens posa del relleu els següents testimonis:

(...) Al mes o así mi madre (...) se vinieron todos. Éramos 8 hermanos y aquí no teníamos trabajo, ni casa ni nada... Veníamos huyendo de la...[inintel-ligible] y entonces nos dejaron una barraca en el Campo de la Bota (...). Y luego pues nos hicimos nosotros... entonces la playa no era muy usada en el Campo de la Bota, y estaba llena de derribos... Había una fábrica que tiraba todos los carburos desechos (...). Por allí había montones de tochos de obra... tiraban muchos escombros. Y de aquello cogimos

205Carme Molinero i Pere Ysàs: "Anys de fam i pobresa" dins Borja de Riquer (dir.): La llarga postguerra 1939-1960. Història, política, societat i cultura dels Països Catalans, vol. 10, Enciclopèdia Catalana, Barcelona, 19997, p. 131. Referenciat per Iván Bordetas a "Habitatge i assentaments...."

206Josep Castaño: Memòries sobre les JOC a Catalunya, Institut Catòlic d'Estudis Socials de Catalunya, Barcelona, 1974, p. 57. Referenciat per Iván Bordetas a "Habitatge i assentaments...".

207Carlos Trias: La Política de la vivienda del Ayuntamiento de Barcelona, Ayuntamiento de Barcelona, 1947, p. 58. Referenciat per Iván Bordetas a "Habitatge i assentaments..."

208Iván Bordetas: “Habitatge i assentaments...", p. 62. Com a font cita a Francesc Bassó, Gabriel Buixó i Oriol Bohigas: "Estudio social del problema de la vivienda en relación con las zonas afectadas por el mismo", Cuadernos de Arquitectura, núm. 15-16, 1952-1953. 
nosotros... Con el carburo hicimos y la sorra hicimos el mortero y con los materiales rotos de tocho y todo eso nos levantamos [inintel-ligible] de obra..., y con cajas de huevos le pusimos el techo, y cartón [inintel-ligible] (...). Se presentó el día de san Antón... del año cuarenta y (...) del 45 o del 46 (...) Se nos llevó el viento el techo de la barraca y nos quedamos en la calle (...) y otra vez... ${ }^{209}$

\begin{abstract}
“Cogió mi padre una vivienda, que no casa, una vivienda con un tío mío hermano de mi madre (...) en lo que era el final de la calle Lourdes, el número noventa y seis con la calle Montaña [al barri de Llefià] (...) aquello era un sótano que parecía una galería allí ni tabiques ni nada, allí los tabiques los hicimos con sacos cosidos (...) éramos diez y seis de familia, mis hermanos, mis padres, un hermano de mi madre (...) y el otro hermano de mi madre... diez y seis personas estábamos allí."210
\end{abstract}

El Barcelonès Nord es va veure, doncs molt afectat per aquesta situació. Nombrosos testimonis en donen compte de la dura realitat que es va haver de patir, ja que la situació es va perllongar en el temps fins ben entrats els anys seixanta. I no només en l'àmbit de l'habitatge. En l'àmbit laboral també es va patir una duríssima situació, en especial en els anys de la postguerra. El franquisme era, també, una dictadura de classe, i van ser les classes treballadores i populars les que van patir les conseqüències en tots els àmbits. Un dels objectius del "Alzamiento" havia estat liquidar totes les organitzacions obreres i de classe. D'aquí la prohibició de tots els sindicats i la creació d'una central única on s'englobaven patrons i treballadors i treballadores. La nova legislació franquista, com el "Fuero del Trabajo" del 9 de Març de 1938, la "Ley de Unidad Sindical" de 27 de gener de 1940 i la "Ley de Bases de la Organización Sindical" de 30 de desembre de 1940 i la Ley de Reglamentaciones del Trabajo" de 16 d'octubre de 1942, entre d'altres, van establir aquest nou marc i derogar l'anterior legislació republicana ${ }^{211}$. Les noves disposicions estaven pensades per establir una disciplina militar en l'àmbit laboral, amb la prohibició de les vagues i de les organitzacions autònomes de la classe treballadora. Les dones, encara van haver de patir una legislació més restrictiva, ja

209Entrevista a Francisco Rodríguez, 21-6-2013. Posteriorment serà membre fundador i primer President de l'AVV de Lloreda.

210Entrevista a Ángel Navarro, militant del PSUC i del moviment veïnal, 6-5-2006. José Miguel Cuesta Gómez: El moviment veïnal a Llefia..., p. 123.

211Carme Molinero i Pere Ysàs: "Patria, Justícia y Pan". Nivell de vida i condicions de treball a Catalunya. 1939-1951, La Magrana, Barcelona, 1985, p. 28-32 i 54-59. 
que se lis restringia la seva possibilitat de treballar, en especial de les dones casades, a les quals se les situava en una situació equiparable a la d'un menor o un incapacitat mental en necessitar l'autorització del marit per fer-ho o fins i tot contemplar que aquest pogués rebre el seu salari ${ }^{212}$.

Tot això es va veure reflectit en una davallada brutal del nivell de vida de les classes treballadores i populars. La sobreexplotació en jornades de 10, 12, 14, o més hores diàries de treball juntament amb la pluriocupació o les hores extraordinàries fetes per compensar el magre salari o per imposició dels patrons. La sinistralitat laboral era altíssima per la manca de seguretat i les dures condicions. Els salaris estaven dictat pel govern i no seguien ni de lluny l'alça de preus dels aliments bàsics en uns anys de cartilla de racionament i d'un estès mercat negre tolerat -si no fomentat- en molts casos per les mateixes autoritats. D'aquesta manera no ens hauria d'estranyar que els productes bàsics esdevinguessin 10 o 15 vegades més cars que al 1936 mentre els salaris reals havien disminuït significativament. I en el cas dels productes que no estaven racionats la situació havia esdevingut encara més escandalosa:

"Al final de la dècada [dels 40], la llet havia pujat un 563 per cent respecte 1936, el ous un 675 per cent, la vedella un 769 per 100, la carn de porc un 1000 per 100, el peix un 300 per 100 , les truites un 800 per 100 , el vi un 1167 per 100 . Aquests preus els feia a la pràctica inaccessibles." ${ }^{213}$

No es estrany, doncs, que aquell període fos conegut com els "anys de la fam".

Les dures condicions laborals afectaven al conjunt de la classe treballadora. Els autòctons ho passaven molt malament, però els nouvinguts solien passar-ho pitjor -si més no d'entrada- per estar en una situació més vulnerable. Lògic tenint en compte que acabaven d'arribar i no disposaven de la informació i les xarxes dels obrers autòctons o pel fet d'estar en una situació "irregular". Això es feia ser més presents en les feines més inestables o tenir un protagonisme elevat en el sector de la construcció, o en l'economia submergida (en aquest últim apartat, sobretot les dones). Però a l'igual que passa en l'actualitat, el major temps de residència ajudava a trobar feines millors i aquest fet feia que les "jerarquies laborals" no

212Carme Molinero i Pere Ysàs: “Patria, Justícia y Pan..., p. 64 i 239.

213 Ídem, p. 178. 
fossin només entre treballadors autòctons i nouvinguts -una visió certament reduccionista- sinó també, entre "vells immigrants" i "nous immigrants"214. Els darrers en arribar, tal com passa en l'actualitat, solien tenir les pitjors feines, tot i que també, una major mobilitat laboral i possibilitats de millora. El món del treball, com veurem posteriorment, serà un factor molt important de integració a la societat receptora, però també de conscienciació "de classe".

No he contemplat -fins al moment- altres variables que incideixen en la qualitat de vida com és l'estat de la sanitat o de l'educació. La gran deficiència i mancança d'aquestes, en especials als barris d'autoconstrucció era un factor que agreujava més la situació de les persones nouvingudes. Només a la província de Barcelona l'assistència sanitària -a totes llums insuficient- estava un $60 \%$ en mans privades i d'ordres religioses mentre només un $16 \%$ eren de l'Estat, un $12 \%$ de la Diputació i un 12 \% de l'Ajuntament. Hi havia -teòricament- 7,9 llits per cada 100 habitants $^{215}$. Malalties com la tuberculosi afectaven especialment la classe treballadora. Alhora, les grans deficiències en l'educació, tant en infraestructura com en continguts i metodologia pedagògica (amb uns valors contraris a qualsevol innovació i profundament controlats per l'església) també es feien sentir. Tot i això, cal tenir en compte que en la majoria dels casos la sanitat i l'ensenyament en els llocs de procedència de molta població nouvinguda era inexistent o encara més precària.

Tot això ens permet concloure que:

“(...) la brutal caiguda del nivell de vida dels treballadors no expressava solament, ni principalment, les dificultats d'una postguerra, sinó que, junt amb les duríssimes condicions de treball imposades, era la conseqüència de la política econòmica i social del règim polític establert a l'any 1939, expressió dels interessos més reaccionaris de la societat espanyola." ${ }^{216}$

Però malgrat aquestes dures condicions, la població migrada obtenia alguns avantatges en els seus nous llocs de residència respecte els seus llocs d'origen, per que si no no s'haurien pres la molèstia i el risc de desplaçar-se. L'anonimat i la feina

214Javier Tébar: “Immigració i treball a Catalunya, 1939-1975” dins Martí Marín (dir.): Memòries del viatge..., p. 112.

215Carme Molinero i Pere Ysàs: "Pàtria, Justícia y Pan..., p. 214.

216Ídem, p. 244. 
que podien obtenir en les grans ciutats van ser fonamentals per que es donessin aquests primers desplaçaments després de la guerra davant una repressió implacable que s'exercia amb més facilitat al món rural.

La segona meitat de la dècada dels 50 va representar un punt d'inflexió que es veurà reflectit sobretot a la dècada posterior. Per una banda, l'arquebisbat de Barcelona, preocupada per l'explosiva situació social que s'estava donant en aquests barris havia organitzat en l'any 1957 la "Semana del Suburbio" per analitzar la gravetat de la situación ${ }^{217}$, si bé les solucions que proposaven no anaven a l'arrel del problema i reflectien una major preocupació per problemes morals, religiosos o fins i tot polítics, com deixaven entreveure les següents paraules d'una ponència:

“(...) no tendríamos consciencia del peligro comunista y de los medios aptos para combatirlo, si todos a una no emprendiéramos una cruzada para dar vivienda , y junto con ella, una vida moral, social y ciudadana a todas estas familias. La fuerza del comunismo no está en su organización, sino en su espíritu que lo informa, que no es otro que el de despertar el odio en base a nuestras dejaciones y omisiones."218

Aquestes jornades donaren unes conclusions diverses i en alguns casos obertament contradictòries $^{219}$. Per una banda, s'insistia en el control de les migracions en la línia que havia desenvolupat fins el moment el Governador Civil:

“Por tanto, las Autoridades locales , llevadas de su buen celo, podrán exigir carta de la autoridad de origen del del inmigrante sobre la necesidad de abandonar el pueblo de origen por carecer de trabajo o imposibilidad de obtenerlo, la presentación ineludible en la Oficina de Colocación obrera, para llenar un cuestionario detallado, cuya falta revelaría un deseo de aventura o vagancia profesional y la comunicación de la empresa donde ha entrado a trabajar para completar el expediente". ${ }^{220}$

217Rogelio Duocastella (comp.): Los Suburbios, 1957. Compendio de las ponencias y coloquios desarrollados durante la Semana del Suburbio, Barcelona, [1957].

218Aurelio Joaquinet: "Influencia de la estructura económica de España en los movimientos migratorios internos" dins Rogelio Duocastella (comp.): Los Suburbios, 1957..., p. 32.

219Entre d'altres, es curiós destacar dues ponències fetes per dones i que es centraven en el paper que havien de jugar aquestes. Mentre Josefina R. Patau de Ramírez, a la seva ponència "Problema de la madre obrera en la organización de su hogar", parlava de la co-responsabilitat de l'home en les tasques domèstiques, Montserrat Sindreu a la seva ponència "Formación profesional de la mujer obrera" insistia en que la formació de les dones devia centrar-se "a las enseñanzas más propias y afines a las del hogar: corte, sastrería, plancha, confección, bordado a máquina, etc.". Rogelio Duocastella: Los Suburbios, 1957..., p. 70-71 i 125, respectivament.

220Jaime Nualart: "El aumento de la población factor determinante del problema suburbial", dins Rogelio Duocastella (comp.): Los Suburbios, 1957..., p. 24. 
Però per una altra, si més no, es reconeixia la magnitud del problema i que aquest no es podia ignorar. Per tant, d'alguna manera estava instant a les administracions a prendre mesures diferents de les que s'estaven duent a terme. De fet, la política de l'Estat havia començat a canviar durant la dècada dels 50. Al 1954 s'havia fet una "Ley de viviendas de Renta Limitada”. Més important va ser la creació, el mateix any 1957, del "Ministerio de la Vivienda” que va ser posat sota les mans d'un "camisa vieja” com Jose Luis de Arrese. Anteriorment ja s'havien creat -al 1939- el "Instituto Nacional de la Vivienda” i la "Obra Sindical del Hogar" ja amb la voluntat -teòrica- de crear habitatges per les capes humils de la població. També existia el "Instituto Municipal de la Vivienda" (posteriorment "Patronato Municipal de la Vivienda" o "Patronato Municipal de Viviendas de Renta Limitada") en Barcelona i altres municipis amb la funció de fer habitatge social. Però fins al moment l'Estat no havia posat gaire interès en aquesta feina ja que no havia dotat econòmicament a aquestes entitats per desenvolupar aquesta tasca, de manera que la xifra d'habitatges construïts havia estat ridícula ${ }^{221}$.

La situació potencialment explosiva de mitjans els anys 50, juntament amb els canvis que s'estaven donant a les polítiques econòmiques del franquisme sens dubte van influir en el canvi de política. Va ser amb la creació del "Ministerio de la Vivienda" que es va començar a donar un impuls més important a la construcció, en especial quan les autoritats van adonar-se que el fenomen migratori era imparable i es van començar a relaxar i aturar les polítiques restrictives envers aquesta. L'impuls del I Pla Nacional de l'Habitatge així com plans generals d'ordenació urbana de les principals ciutats catalanes -encara que després no s'apliquessindemostraven un cert canvi d'actitud. No obstant, encara hi haurà un dèficit important d'habitatges durant un cert temps i el barraquisme persistirà durant els anys seixanta malgrat el revifament econòmic i l'aparició de sectors de població amb un major poder adquisitiu. Serà en aquesta dècada quan es plasmaran els "Planes de Urgencia Social” i les “Unidades Vecinales de Absorción” (UVAS) per intentar cobrir el que la iniciativa privada no feia -malgrat les nombroses bonificacions- i, teòricament, posar fi al barraquisme.

221Iván Bordetas: “Habitatge i assentaments...." dins Martí Marín: Memòries del viatge..., p. 64-65. A la província de Barcelona l'OSH només havia construït 8.205 habitatges entre 1942 i 1956. 
Però el fet que es prioritzés la quantitat sobre la qualitat va originar que la qualitat de les noves edificacions deixés molt que desitjar, ja fossin d'iniciativa privada o pública. A més d'urbanitzar-se en els terrenys més inversemblants i mancats de les més elementals infraestructures i amb unes elevadíssimes densitats de població, donant com a resultat el que Francesc Candel batejà com amazacotamiento $^{222}$. Altres persones van fer servir el terme "barraquisme vertical" per descriure aquestes noves urbanitzacions sorgides el no-res i en molts casos incomunicades amb els nuclis urbans als quals en teoria pertanyien.

Un urbanisme de classes per una societat de classes ${ }^{223}$. I un urbanisme cada cop amb majors potencialitats de negoci car els fluxos de població es van accelerar més en aquesta dècada, amb l'arribada de 649.597 persones a Catalunya entre $1961-1970^{224}$, i com ens ho demostren aquestes dades sobre les poblacions on es centra el present estudi:

$\begin{array}{lcrrr} & \text { Evolució de la Població al Barcelonès Nord (1950-1981) } \\ & 1950 & 1960 & 1970 & 1981 \\ \text { Badalona } & 61654 & 92257 & 162888 & 227744 \\ \text { Santa Coloma de Gramenet } & 15281 & 32590 & 106711 & 140588 \\ \text { Sant Adrià de Besòs } & 10227 & 15801 & 24452 & 36052 \\ \text { Total } & 87162 & 140648 & 294051 & 404384\end{array}$

Elaboració pròpia a partir de fonts diverses que recullen els Censos dels anys esmentats.

Aquest gran creixement no ens hauria d'estranyar. A la ja comentada relaxació i fi de les restriccions de les migracions, cal sumar els efectes de la nova política econòmica empresa pel govern de la dictadura a partir de l'any 1959, que va esperonar encara més els moviments migratoris i el despoblament d'un camp cada vegada més mecanitzat. Amb impossibilitat de fer qualsevol tipus de reforma agrària es va accelerar la marxa cap als vells nuclis industrials de l'Estat i els nous que s'estaven creant, o també, cap altres estats d'Europa. Curiosament en un

222 Francesc Candel: “El amazacotamiento”, Cuadernos de Arquitectura núm. 60 (1965) p. 5-6.

223José. E. Donato: "Barrios Altos de San Andrés", a Cuadernos de Arquitectura núm. 60 (2on trimestre de 1965), p. 39.

224Anna Cabré i Isabel Pujades: "La població: immigració i explosió demogràfica", dins Història econòmica de la Catalunya contemporània, Vol. V, Enciclopèdia Catalana, Barcelona, 1988, p. 4852. 
període on teòricament s'estava produint un gran creixement econòmic 225 .

L'increment de la població no es va donar a la mateixa intensitat a tot arreu. Al Principat es va centrar més a la província de Barcelona i en especial al Barcelonès i comarques al seu voltant com els Vallès Occidental, el Vallès Oriental, el Maresme i el Baix Llobregat. De fet, dins el mateix Barcelonès Nord podem veure que els volums de població i el creixement d'aquesta no es va donar per igual als tres municipis. Una simple ullada a les xifres totals de població ja ho demostren però aquest fet es veu més clarament en analitzar les taxes de creixement anual acumulatiu de les diferents poblacions:

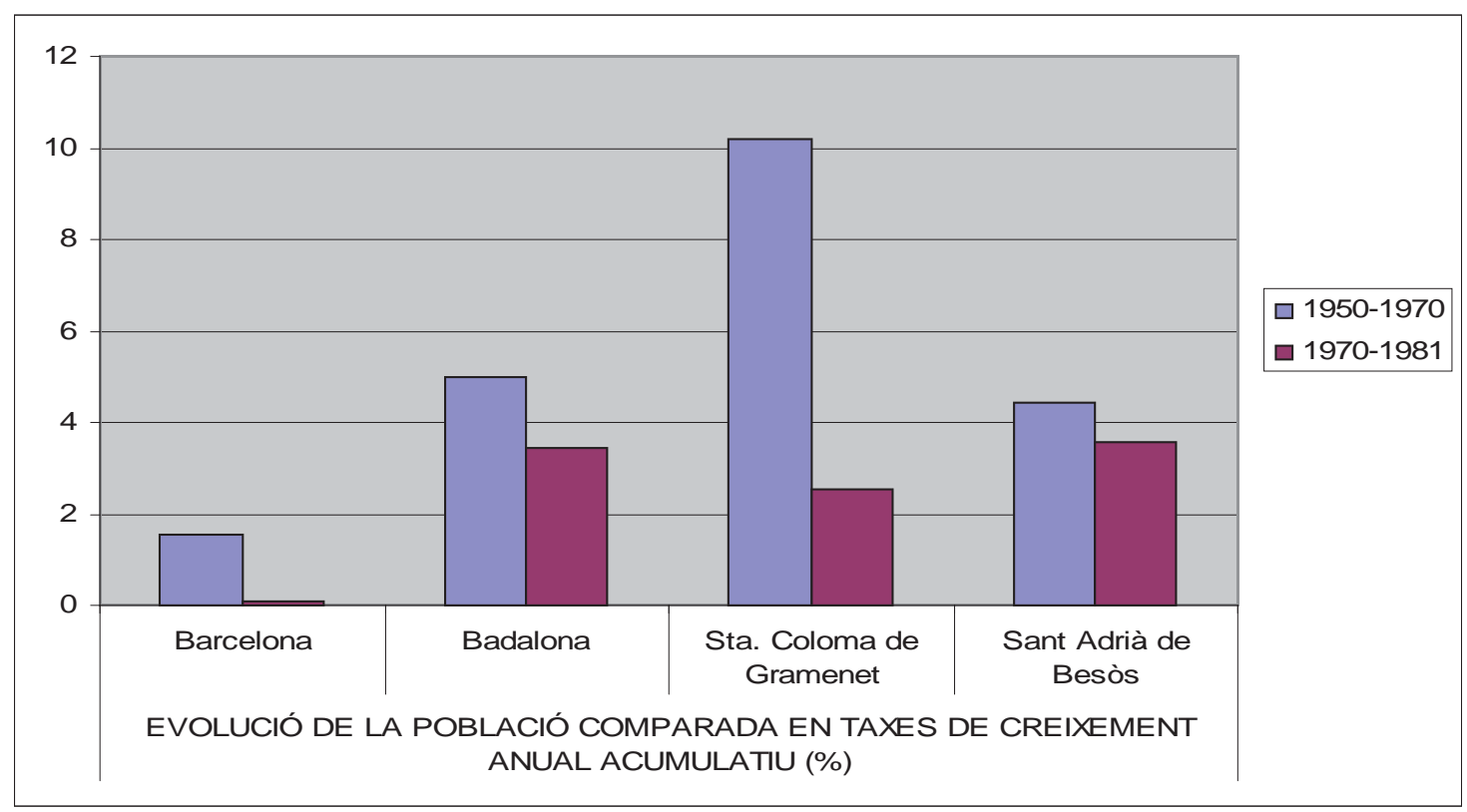

Elaboració pròpia a partir de fonts diverses.

Com es pot observar, el creixement més alt -proporcionalment- es va donar a la ciutat de Santa Coloma de Gramenet a la dècada dels 60. Un creixement que encara és més destacat si ho comparem a l'experimentat per la ciutat de Barcelona. Aquest creixement de població correspon, en major mesura, al saldo migratori que

225Per un estudi més acurat de les migracions cap a d'altres estats europeus, veure José Babiano i Ana Fernàndez Asperilla: "En manos de los tratantes de seres humanos (notas sobre la emigración irregular durante el franquismo)", dins Historia Contemporánea núm. 26, 2003, p. 35-36; Ana Fernàndez Asperilla: "Emigración como exportación de mano de obra: el fenómeno migratorio a Europa durante el franquismo", dins Historia Social núm. 30, 1998, p. 63-81 i José Babiano i Ana Fernández Asperilla: La patria en la maleta: Historia social de la emigración española a Europa, Ediciones GPS, Madrid, 2010. 
es va donar durant aquest període. Així ho podem veure per exemple en el cas de la ciutat de Badalona:

$\begin{array}{lccc}\text { Evolució demogràfica 1950-1991 } \\ \text { Anys } & \begin{array}{c}\text { Creixement } \\ \text { Creixement Vegetatiu }\end{array} & \text { Saldo Migratori } \\ 1930-1936 & 5.699 & 2.683 & 3.016 \\ 1936-1940 & 355 & -12 & 367 \\ 1940-1945 & 5.717 & 1.053 & 4.664 \\ 1945-1950 & 7.582 & 2.708 & 4.874 \\ 1950-55 & 14.744 & 4.474 & 10.270 \\ 1955-60 & 15.926 & 6.536 & 9.390 \\ 1960-65 & 32.745 & 9.991 & 22.754 \\ 1965-70 & 37.886 & 12.076 & 25.810 \\ 1970-75 & 38.979 & 10.400 & 28.579 \\ 1975-81 & 26.061 & 8.442 & 17.619 \\ 1981-86 & -4.465 & 2.534 & -7.229 \\ 1986-91 & -6.290 & 3670 & -9.961\end{array}$

Font: Elaboració pròpia a partir de les dades publicades a J. Villarroya (dir.): Historia de Badalona, Col-lecció Monografies Badalonines 16, Museu de Badalona, 1999

Pel que fa a la ciutat de Sant Adrià de Besòs també podem observar un fort creixement migratori :

$\begin{array}{ccc} & \text { Creixement de la Població en Sant Adrià de Besòs en \% } \\ \text { Anys } & \text { Creixement natural } & \text { Creixement migratori } \\ 1950 & 26,00 \% & 74,00 \% \\ 1961 & 50,00 \% & 50,00 \% \\ 1975 & 81,70 \% & 28,30 \%\end{array}$

Font: Just Casas i Soriano i Manuel Márquez Berrocal: Historia social de Sant Adrià de Besòs. Vol. I. La Població: segles XVIII-XX, Hacer Editorial, 1996.

No ha estat possible aconseguir el mateix tipus de dades per Santa Coloma de Gramenet, però tots els indicis apunten que el creixement degut al moviment migratori hauria estat encara major, en proporció, que a les altres ciutats del Barcelonès Nord.

En general, com es pot observar, l'arribada de població es va accelerar a la dècada dels seixanta i va ser aquest fet el que va condicionar l'elevat creixement de població de les tres ciutats. Aquesta arribada de població es va aturar a mitjans de la dècada dels setanta, coincidint amb l'inici de la crisi econòmica.

Sobre la procedència de la població, en aquest anys s'accentua l'arribada de població d'origen andalús (i en menor mesura castellà i extremeny) mentre que 
l'arribada de població d'altres territoris que anteriorment havien aportat població -com per exemple Múrcia- es modera. Ho podem veure amb els següents exemples. Primer en el cas de Badalona:

Procedència de la Població Badalona

$\begin{array}{lrrr} & \text { Dècada1950-60 } & \text { Dècada } 1960-70 & \text { A partir de } 1970 \\ \text { Andalusia } & 53 \% & 51 \% & 42 \% \\ \text { Castella } & 12 \% & 13 \% & 13 \% \\ \text { Resta de Catalunya } & 10 \% & 15 \% & 23 \% \\ \text { Múrcia } & 10 \% & 4 \% & 3 \% \\ \text { Extremadura } & 6 \% & 9 \% & 9 \% \\ \text { Aragó } & 3 \% & 2 \% & \\ \text { País Valencià } & 2 \% & 2 \% & 3 \% \\ \text { Galícia } & & 2 \% & \end{array}$

Font: J. Villarroya (dir.): Historia de Badalona..., p. 151. (cal tenir en compte que no consten els nascuts a la ciutat.

A Santa Coloma de Gramenet l'any 1975 per exemple hi vivien 46.680 habitants nascuts a Andalusia (un 33.8\%), 10.079 extremenys (7,29\%), 2.827 gallecs $(2,98 \%)$ mentre que els nascuts a la ciutat eren només 7.810 (un 5,6\%) Mentre que a Sant Adrià de Besòs l'any 1970 la població immigrada prové un 24 \% d'Andalusia, un 6,4\% de Múrcia, un 4,9\% de Castella la Nova (actual Castella la Manxa) i un 4,6\% d'Extremadura ${ }^{227}$. Unes proporcions menors que les altres dues ciutats del Barcelonès Nord.

Un anàlisi de la procedència de la població en perspectiva comparada de les ciutats del Barcelonès Nord el podem veure a l'obra de Just Casas i Manuel Màrquez Història Social de Sant Adrià de Besòs en el seu primer volum, a partir de del qual reprodueixo les següents gràfiques, que en son força il-lustratives per veure els diferents percentatges de població immigrada en les tres ciutats analitzades: Badalona, Santa Coloma de Gramenet i Sant Adrià de Besòs. Malauradament en part d'aquestes taules no s'especifica molt el lloc de procedència (la Comunitat Autònoma o Província), informació que s'ha de complementar amb altres taules:

226Marcelo López Ródenas: Historia social de la Santa Coloma moderna. 1954-1979, Ajuntament de Santa Coloma de Gramenet, 1982, p. 78. Cal destacar el fet que no es comptabilitza amb exactitud la població provinent de les dues Castelles, que segurament era elevada.

227Just Casas i Soriano i Manuel Márquez Berrocal: Historia social de Sant Adrià de Besòs. Vol. I. La Població: segles XVIII-XX, Hacer Editorial, 1996, p. 94. 
Origen de la població al Barcelonès Nord. Any 1950 (en \%)

\begin{tabular}{|c|c|c|c|c|c|}
\hline \multirow{4}{*}{ Badalona } & & Nascuts Municipi & Nascuts Província & Nascuts resta Províncies & Nascuts fora Estat \\
\hline & Homes & 46,31 & 16,97 & 35,98 & 0,7 \\
\hline & Dones & 43,72 & 14,86 & 40,53 & 0,86 \\
\hline & Total & 47,81 & 15,91 & 38,25 & 0,78 \\
\hline \multirow{3}{*}{ S. Coloma de G. } & Homes & 26,07 & 33,53 & 39,25 & 1,15 \\
\hline & Dones & 25,9 & 33,45 & 39,87 & 0,75 \\
\hline & Total & 25,98 & 33,49 & 39,56 & 0,95 \\
\hline \multirow{3}{*}{ S. Adrià de B. } & Homes & 21,17 & 29,9 & 41,95 & 0,96 \\
\hline & Dones & 26,72 & 27,3 & 44,59 & 1,37 \\
\hline & Total & 26,94 & 26,57 & 43,3 & 1,17 \\
\hline \multirow{3}{*}{ Barcelona } & Homes & 51,33 & 6,2 & 40,85 & 0,16 \\
\hline & Dones & 44,96 & 6,06 & 47,15 & 0,18 \\
\hline & Total & 47,81 & 6,13 & 44 & 0,17 \\
\hline \multirow{3}{*}{ Barcelona Província } & Homes & 50,34 & 13,16 & 35,28 & 1,19 \\
\hline & Dones & 44,98 & 13,52 & 40,09 & 1,38 \\
\hline & Total & 47,66 & 13,34 & 37,68 & 1,28 \\
\hline
\end{tabular}

Font: Just Casas i Soriano i Manuel Márquez Berrocal: Historia social de Sant Adrià de Besòs. Vol. I...., p. 204 (dades extretes del Cens de 1950). Els percentatges són sobre el total de cadascun dels dos sexes.

\begin{tabular}{|c|c|c|c|c|c|}
\hline \multirow{4}{*}{ Badalona } & & Nascuts Municipi & Nascuts Província & Nascuts resta Províncies & Nascuts fora Estat \\
\hline & Homes & 38,85 & 10,79 & 49,13 & 0,54 \\
\hline & Dones & 38,14 & 10,66 & 49,62 & 0,68 \\
\hline & Total & 38,49 & 10,73 & 49,38 & 1,83 \\
\hline \multirow{3}{*}{ S. Coloma de G. } & Homes & 20,02 & 22,8 & 56,23 & 0,17 \\
\hline & Dones & 20,36 & 21,8 & 56,71 & 0,19 \\
\hline & Total & 20,2 & 22,29 & 56,47 & 0,18 \\
\hline \multirow{3}{*}{ S. Adrià de B. } & Homes & 19,47 & 26,99 & 51,06 & 1,46 \\
\hline & Dones & 16,37 & 26,89 & 54,11 & 1,51 \\
\hline & Total & 17,9 & 26,94 & 52,6 & 1,73 \\
\hline \multirow{3}{*}{ Barcelona } & Homes & 50,84 & 5,43 & 40,6 & 1,72 \\
\hline & Dones & 45,55 & 5,36 & 45,56 & 1,91 \\
\hline & Total & 48,01 & 5,4 & 43,25 & 1,83 \\
\hline \multirow{3}{*}{ Barcelona Província } & Homes & 45,54 & 12,54 & 39,77 & 1,11 \\
\hline & Dones & 41,77 & 12,76 & 43,02 & 1,26 \\
\hline & Total & 12,65 & 12,65 & 41,48 & 1,2 \\
\hline
\end{tabular}

Font: Just Casas i Soriano i Manuel Márquez Berrocal: Historia social de Sant Adrià de Besòs. Vol. I...., p. 216 (dades extretes del Cens de 1960). Els percentatges són sobre el total de cadascun dels dos sexes.

Per l'any 1970 podem fer una comparació més acurada, si bé en les primeres gràfiques no surt massa detallat l'origen de la població nouvinguda, queda evident que la població que va rebre més població proporcionalment (no en volum total) va ser Santa Coloma. Igualment és aquesta població que té un nombre més reduït de nascuts en el seu propi municipi. En contrast, Badalona, tot i rebre molta població, té un volum important d'aquesta que ha nascut dins la pròpia ciutat. 
Origen de la població al Barcelonès Nord. Any 1970 (en \%)

$\begin{array}{lccccc}\text { Nascuts } & \text { Municipi } & \text { Resta Província } & \text { Resta Catalunya } & \text { Resta Estat espanyol } & \text { Fora Estat espanyol } \\ \text { Badalona } & 34,09 & 14,27 & 2,34 & 49 & 0,3 \\ \text { S. Coloma de G. } & 10,03 & 24,42 & 1,45 & 64 & 0,1 \\ \text { S. Adrià de B. } & 11,6 & 29,7 & 3 & 55 & 0,7 \\ \text { Barcelona } & 50,29 & 4,45 & 5,99 & 39 & 0,27 \\ \text { Barcelonès } & 42,51 & 8,99 & 5,08 & 43 & 0,42\end{array}$

Origen de la població al Barcelonès Nord. Any 1975 (en \%)

$\begin{array}{lccccc}\text { Nascuts } & \text { Municipi } & \text { Resta Província } & \text { Resta Catalunya } & \text { Resta Estat espanyol } & \text { Fora Estat espanyol } \\ \text { Badalona } & 33,38 & 15,22 & 1,78 & 49 & 0,62 \\ \text { S. Coloma de G. } & 15,35 & 21,9 & 1,57 & 61 & 0,18 \\ \text { S. Adrià de B. } & 8,43 & 41,45 & 1,91 & 48 & 0,21\end{array}$

Font: Just Casas i Soriano i Manuel Márquez Berrocal: Historia social de Sant Adrià de Besòs. Vol. I...., p. 227.

\section{Origen de la població al Barcelonès Nord nascuda a l'Estat espanyol. Any 1970 (en \%)}

$\begin{array}{lccccc}\text { Lloc de Procedència } & \text { Badalona* } & \text { S. Coloma de G. } & \text { S. Adrià de B. } & \text { Barcelonès } & \text { Catalunya } \\ \text { Catalunya } & 23 & 35,9 & 44 & 56,6 & 62,3 \\ \text { País Valencià } & & 2 & 2 & 2,9 & 2,1 \\ \text { Andalusia } & 42 & 35,6 & 24 & 15,4 & 16,4 \\ \text { Aragó } & & 2,5 & 3,7 & 4,6 & 3,4 \\ \text { Castella la Nova } & 13^{* *} & 4,9 & 4,9 & 3,7 & 2,8 \\ \text { Castella la Vella } & & 1,3 & 2,4 & 2,3 & 1,6 \\ \text { Extremadura } & 9 & 6,6 & 4,6 & 3,4 & 2,8 \\ \text { Galícia } & 3 & 2,1 & 2,3 & 2,3 & 1,6 \\ \text { Lleó } & 2,2 & 2 & 2,3 & 1,6 \\ \text { Múrcia } & 3 & 4,7 & 6,4 & 3,3 & 2,7 \\ \text { Resta } & & 2,2 & 3,4 & 3 & 2,8 \\ \text { Total } & & 100 & 100 & 100 & 100\end{array}$

* Les dades respecte Badalona són les mateixes que les de la taula de la pàgina 96.

** És el percentatge conjunt de les dues Castelles.

Font: Just Casas i Soriano i Manuel Márquez Berrocal: Historia social de Sant Adrià de Besòs. Vol. I...., p. 228. i JoanVillarroya: Història de Badalona..., p. 151. Cal tenir en compte que les divisions "regionals" de l'època no són iguals que les de les CCAA actuals. Castella la Vella la composaven les províncies de Santander, Burgos, Logroño, Soria, Segovia i Àvila; Castella la Nova les de Guadalajara, Madrid, Toledo, Conca i Ciudad Real; Lleó les de Lleó, Palència, Zamora, Valladolid i Salamanca; Murcia estava formada per les províncies de Albacete i Múrcia.

Encara podem filar més prim per conèixer millor la procedència de la població de les altres ciutats del Barcelonès Nord: 
ORÍGEN DE LA POBLACIÓ AL BARCELONÈS NORD NASCUDA A L'ESTAT ESPANYOL (en \%)

\begin{tabular}{lllllll}
\hline & \multicolumn{3}{c}{1981} & \multicolumn{3}{c}{1986} \\
\hline Lloc de Procedència & Badalona** & SCG & SAB & Badalona & SCG*** & SAB \\
\hline Catalunya & 55,90 & 46,06 & 53,2 & 59,02 & 49,47 & 57,1 \\
País Valencià & 1,36 & 1,15 & 1,45 & 1,23 & 1,06 & 3,71 \\
Andalusia & 24,29 & 29,45 & 23,1 & 22,29 & 27,65 & 21,38 \\
Aragó & 1,58 & 1,91 & 2,19 & 1,44 & 1,77 & 1,98 \\
Castella la Manxa* & 5,72 & 4,03 & 3,33 & 3,08 & 4,55 & 3,66 \\
Castella-Lleó* & & 1,3 & 1,59 & 2,4 & 3,16 & 3,08 \\
Extremadura & 4,03 & 6,62 & 3,83 & 3,8 & 6,18 & 3,5 \\
Galícia & 1,24 & 2,03 & 2,19 & 1,22 & 1,96 & 1,98 \\
Múrcia* & 3,28 & 3,05 & 3,85 & 2,95 & 1,61 & 2,32 \\
Altres CCAA & 1,25 & 2,25 & 3,08 & 1,6 & 1,51 & 3,71 \\
Estranger & 1,35 & & & & 1,09 & 100 \\
$?$ & & & & 100 & 100 & 100 \\
Total & 100 & 100 & 100 & & & \\
\hline
\end{tabular}

* Cal tenir en compte per l'any 1981 que Castella-Lleó era encara "Castilla la Vieja" i encara incloïa la província de Madrid. Múrcia estava composta aleshores per les províncies de Múrcia i Albacete, no estant inclosa aquesta darrera a Castella-la Manxa, aleshores encara "Castilla la Nueva".

** Les dades de Badalona de l'any 1981 corresponen a l'any 1982 i inclouen també els nascuts a l'estranger. Estan comptabilitzades juntes les dues Castelles.

*** Les dades estan en el padró de 1986 de Santa Coloma per províncies.

Elaboració pròpia a partir de Just Casas i Soriano i Manuel Márquez Berrocal: Historia social de Sant Adrià de Besòs. Vol. I...., p. 241 i Conèixer Badalona/ Conocer Badalona, Ajuntament de Badalona, Conselleria d'Estadística, 1982 i Introducció a l'estudi de la població de Santa Coloma de Gramenet segons el Padró d'Habitants de 1986. I Estadístiques poblacionals, Ajuntament de Santa Coloma de Gramenet, [1986?]

El pes de la població nouvinguda és molt important en totes tres poblacions, si bé Santa Coloma de Gramenet supera a les altres en percentatge de població rebuda i també per tenir una menor proporció de població nascuda a Catalunya. En tots tres casos destaca l'elevat nombre de població procedent d'Andalusia. No podia ser d'una altra manera en tant els andalusos van ser el contingent de població més nombrós que va arribar en el transcurs d'aquells anys. El per què va marxar tanta població d'Andalusia donaria per fer nombrosos estudis socio-econòmics sobre l'estructura productiva existent (i també sobre la repressió política que va haverhi), però sens dubte, quan s'observen les taxes d'atur que encara tenien les províncies andaluses encara a començaments de la dècada dels setanta, s'entenen moltes coses: 


\section{Atur a Andalusia a inicis de la dècada dels 70}

$\begin{array}{lccccc}\text { Província } & \text { Habitants } & \text { Població activa } & \text { \% Població activa } & \text { Aturats/aturades } & \% \text { Atur } \\ \text { Huelva } & 397683 & 141058 & 35,47 & 64682 & 49,4 \\ \text { Còrdova } & 724116 & 257206 & 35,52 & 104683 & 40,7 \\ \text { Màlaga } & 867330 & 309810 & 35,72 & 144062 & 46,5 \\ \text { Cadis } & 885433 & 287765 & 32,5 & 4962 & 33 \\ \text { Jaén } & 661146 & 238012 & 36 & 110200 & 46,3 \\ \text { Sevilla } & 1327190 & 476594 & 35,91 & 219100 & 46 \\ \text { Granada } & 733375 & 311538 & 42,48 & 91100 & 29,2 \\ \text { Almeria } & 375000 & 125176 & 33,38 & 125176 & 19,6\end{array}$

Font: Marcelo López Ródenas: Historia social de la Santa Coloma moderna..., p. 78.

Es pot dir, doncs, que les causes estrictament econòmiques aparentment van pesar més en les migracions dels anys 60-70 i les que encara es van produir en la dècada posterior fins que la crisi econòmica va reduir-les dràsticament a partir de 1975-76. No obstant, cal que matisem aquesta afirmació en el sentit de dir que, per exemple, no tota la gent que venia cap al Principat estava en una situació d'extrema misèria. També hi havia gent que venia simplement per que cercava millors expectatives de futur. La vida en la ciutat oferia uns "atractius" amb els quals el món rural no podia competir.

La població que va arribar en aquesta dècada va reforçar el component treballador de les tres ciutats del Barcelonès Nord, que existia ja des de els anys 30 del segle XX i en el cas Badaloní ja ho era en la segona meitat del segle XX. Les elevades taxes de població assalariada existent l'any 1970 ho posen de manifest:

\section{Població al Barcelonès Nord per grups professionals. Any 1970}

$\begin{array}{lcccccc} & \text { G. } 1 & \text { G. 2 } & \text { G. 3 } & \text { G. } 4 & \text { G. } \mathbf{5} & \text { G. } \mathbf{6} \\ \text { Badalona } & 2,52 & 5,06 & 81,29 & 8,43 & 1,27 & 1,4 \\ \text { S. Coloma de G. } & 1,87 & 4,51 & 79,84 & 11,41 & 1,48 & 0,86 \\ \text { S. Adrià de B. } & 3,67 & 5,11 & 74,16 & 8,27 & 1,09 & 1,68 \\ \text { Barcelona } & 4,49 & 6,73 & 78,01 & 7,3 & 1,63 & 1,81 \\ \text { Barcelonès } & 4,02 & 6,31 & 79,39 & 7,53 & 1,53 & 1,65 \\ \text { Catalunya } & 3,15 & 10,45 & 73,99 & 6,95 & 3,27 & 1,16\end{array}$

Grup 1: Patrons, Empresaris o professionals que contracten personal.

Grup 2: Empresari o professional que no contracten personal, o professional per compte propi.

Grup 3: Assalariat fix.

Grup 4: Assalariat eventual.

Grup 5: Persona que treballa, sense remuneració reglamentada, en l'empresa d'un familiar amb el que conviu.

Grup 6: Persona no inclosa en cap dels grups anteriors.

(Classificació segons el Consorci d'Informació i Documentació de Catalunya - CIDC- 1970).

Font: Just Casas i Soriano i Manuel Márquez Berrocal: Historia social de Sant Adrià de Besòs. Vol. I...., p. 233. 
Estem davant de tres ciutats amb una elevada població de classe treballadora amb taxes superiors a la mitjana catalana. Ens pot sobtar l'elevat nombre de treballadors assalariats fixes d'aleshores, sobretot si ho comparem amb el mercat laboral actual. Però en aquell període es cert que hi havia una major estabilitat laboral que en l'actualitat, sobretot en el Sector Secundari i en la població masculina. Per una banda caldria tenir en compte la legislació laboral de l'època: repressora en quant l'associacionisme obrer fora del sindicat vertical, amb una disciplina laboral militar i amb prohibició de les vagues i sindicats fora de "l'oficial" però que en canvi contemplava -teòricament- una major facilitat per al treballador per esdevenir fixe en una empresa, sobretot si era un home del sector industrial (la construcció tenia uns índex més elevats de temporalitat i a les dones se les "incentivava" a deixar la feina un cop es casaven). Per altra banda, en coincidir amb un període de creixement econòmic també era més fàcil aconseguir, amb el temps, un cert nivell d'estabilitat.

De les tres poblacions del Barcelonès Nord es pot remarcar, per una banda, el major nombre d'assalariats fixos existents a Badalona i el major nombre d'assalariats temporals de Santa Coloma de Gramenet. No són xifres excessivament diferents però potser poden fer referència al major pes de població nouvinguda -i per tant, més inestable laboralment en un primer moment- existent a la ciutat colomenca, que va ser la que va tenir uns majors volums d'arribada de població a nivell proporcional.

Si bé la població provinent de les primeres migracions va anar a treballar majoritàriament a la indústria (al Sector Secundari), durant la dècada dels seixanta podem veure com els serveis (Sector Terciari) ha anat adquirint progressivament més pes a costa de la població ocupada a les fàbriques. És l'inici d'un procés de terciarització de l'economia que tindrà continuïtat en els següents anys arribant fins l'actualitat seguint una tendència més global que s'estava donant a altres indrets del món. Amb l'agreujant de la crisi econòmica dels anys setanta i vuitanta que va afectar en especial al sector secundari i que al Barcelonès Nord, sobretot a Badalona i Sant Adrià, va comportar el tancament de nombroses fàbriques. 
Població ocupada al Barcelonès Nord per sectors econòmics en \% Any 1950.

$\begin{array}{lcccc} & \text { Primari } & \text { Secundari } & \text { Terciari } & \text { Total } \\ \text { Badalona } & 5,19 & 73,76 & 21,05 & 100 \\ \text { S. Coloma de G. } & 6,31 & 71,14 & 22,55 & 100 \\ \text { S. Adrià de B. } & 5,38 & 69,32 & 25,3 & 100 \\ \text { Barcelona } & 1,59 & 52,32 & 46,09 & 100 \\ \text { Província Barcelona } & 10,49 & 56 & 33,51 & 100\end{array}$

Població ocupada al Barcelonès Nord per sectors econòmics en \%. Any 1960.

$\begin{array}{lcccc} & \text { Primari } & \text { Secundari } & \text { Terciari } & \text { Total } \\ \text { Badalona } & 1,53 & 82,61 & 15,86 & 100 \\ \text { S. Coloma de G. } & 1,74 & 75,76 & 22,5 & 100 \\ \text { S. Adrià de B. } & 3,01 & 70,59 & 26,4 & 100 \\ \text { Barcelona } & 0,83 & 50,1 & 49,07 & 100 \\ \text { Província Barcelona } & 7,27 & 59,96 & 34,77 & 100\end{array}$

Població ocupada al Barcelonès Nord per sectors econòmics en \%. Any 1970.

$\begin{array}{lccccc} & \text { Primari } & \text { Secundari } & \text { Terciari } & \text { No Especificat } & \text { Total } \\ \text { Badalona } & 0,71 & 68,85 & 28,33 & 2,11 & 100 \\ \text { S. Coloma de G. } & 0,44 & 70,93 & 28,62 & 0,11 & 100 \\ \text { S. Adrià de B. } & 0,75 & 61,13 & 33,74 & 4,38 & 100 \\ \text { Barcelona } & 0,49 & 48,37 & 48,68 & 2,46 & 100 \\ \text { Barcelonès } & 0,47 & 52,35 & 44,11 & 3,07 & 100 \\ \text { Catalunya } & 8,82 & 53,85 & 35,47 & 1,86 & 100\end{array}$

Font: Just Casas i Soriano i Manuel Márquez Berrocal: Historia social de Sant Adrià de Besòs. Vol. I...., p. 211, 221 i 233, en base als Censos de 1950,1960 i 1970

Aquest gruix de població que va arribar als anys seixanta es va trobar amb unes condicions també molt dures. És cert que el règim va canviar de política econòmica en aquesta dècada amb una major liberalització i inversió estrangera, i que el nivell de vida de la població va anar pujant lentament. Per primera vegada l'Estat va engegar una política de promoció de construcció d'habitatges significativa davant la greu proliferació de l'infrahabitatge. Però aquests canvis es van anar fer progressivament de manera que molta població que va arribar a la dècada dels setanta encara va conèixer aquestes penoses condicions d'habitabilitat. Joan Carrera, que va el primer sacerdot de la parròquia de Sant Antoni de Llefià ho resumia molt bé les condicions amb les quals es trobava la població:

"Al Juny de 1961 em van anomenar rector d'aquesta parròquia de Llefià (...) en aquell moment el treball no era problema tothom que arribava es posava a treballar (...) una altra cosa és si els sous eren millors o pitjors (...) però es trobava feina i res mes. No es trobava ni lloc on viure, ni escoles dignes, ni serveis socials, ni serveis públics, no hi havia res, només hi havia treball (...) a Llefià hi havia un barraquisme molt dur, davant del que ara és la parròquia hi havia el carrer La Torre que era de barraques molt 
primàries, després hi havia el carrer San Cipriano (...) allà hi eren milers de persones amb unes condicions dures... Apart d'aquestes barraques més visibles després hi havia uns edificis que aparentment no eren barraques però feien uns passadissos que quan entraves a dintre et trobaves tot de barraques per allà... això era al carrer Bonavista o Bellavista, em sembla"228

Barris badalonins com l'esmentat Llefià, La Salut, Lloreda (anomenada aleshores "La Balsa"), Sistrells, La Pau (aleshores "La Immaculada"), situats a la perifèria de la ciutat més gran del Barcelonès Nord patien aquestes dures condicions que ja tenien uns precedents en les dècades anteriors on es van anar urbanitzant a base la parcel-lació i venda de terrenys per part dels seus propietaris i per l'autoconstrucció, malgrat les disposicions del Pla Comarcal del 1953. La promoció d'habitatge públic es va anar produint tímidament, primer als anys cinquanta amb la creació de petits polígons com el de "Jose Antonio Primo de Rivera al Raval" (1955) i el del "General Moscardó" al barri de Bufalà l'any 1956, amb 120 i 200 habitatges respectivament ${ }^{229}$. Aquest procés va continuar més clarament a la dècada dels seixanta, però malgrat anar reduint lentament el barraquisme, tampoc va crear unes condicions òptimes d'habitabilitat. Els nous polígons d'habitatges com els creats per l'Obra Sindical del Hogar al barri del BrucBufalà, de Sant Roc o al Pomar -aquests dos darrers van representar l'aparició de nous barris pràcticament del no-res- aviat van manifestar unes greus deficiències per la pèssima qualitat dels materials amb els quals havien estat construïts. Fins $\mathrm{i}$ tot van "provocar" la destitució de l'alcalde badaloní Josep Torres Trias el 3 de març de 1964, per que s'havia oposat al trasllat de barraquistes de Barcelona cap a Badalona per poblar aquests nous barris i havia gosat fer un escrit de protesta al Governador Civil. La majoria dels seus habitants provindran de Montjuïc, el Somorrostro, el Camp de la Bota... tot i que també hi havia persones del Barcelonès Nord afectades per l'expropiació d'habitatges per la construcció de l'autopista Barcelona-Mataró. El poder i influències de l'alcalde barceloní Josep Maria de Porcioles era en aquells moments incontestables. El nou alcalde de Badalona,

228Entrevista amb Joan Carrera, 8-5-2006. José Miguel Cuesta Gómez: El moviment veïnal a Llefià..., p. 123.

229Marc Andreu i Acebal: El Bruc Bufalà. Badalona. Els Barris d'Adigsa núm. 7, Generalitat de Catalunya, Departament de Benestar Social, 1995. 
Felipe Antoja Vigo, va acceptar l'arribada de barraquistes barcelonins a canvi de promeses de compensacions econòmiques que no es van arribar a materialitzar ${ }^{230}$. A aquests polígons gestionats per l'Obra Sindical del Hogar caldria afegir-ne els que van construir altres organismes públics a Badalona abans de 1976 i que es poden apreciar en aquest quadre:

\section{Promoció pública d'habitatge a Badalona 1953-1976}

$\begin{array}{ccccc}\text { Data Construcció } & \text { Nom } & \text { Situació } & \text { Promotor } & \text { Habitatges } \\ & & & & \\ 1955 & \text { Jose Antonio Primo de Rivera } & \text { Raval } & \text { OSH } & 120 \\ 1956 & \text { General Moscardó } & \text { Bufalà } & \text { PLVRL } & 200 \\ 1962-63 & \text { El Bruc } & \text { Bufalà } & \text { OSH } & 410 \\ 1962-66 & \text { Sant Roc } & \text { St. Roc } & \text { OSH } & 3395 \\ 1963-70 & \text { Sant Anastasi } & \text { Congrés } & \text { VCE } & 1511 \\ 1965-67 & \text { UVA en Barcelona, Badalona } & \text { Pomar } & \text { OSH } & 2000 \\ 1968 & \text { Sant Jordi } & \text { Canyadó } & \text { PLVRL } & 447 \\ 1969 & \text { Verge de La Salut (El Hoyo) } & \text { La Salut } & \text { PLVRL } & 584 \\ 1969 & \text { Verge Assumpta } & \text { St. Antoni de Llefià } & \text { PLVRL } & 212 \\ 1969 & \text { San Antonio } & \text { St. Antoni de Llefià } & \text { PLVRL } & 604 \\ 1971 & \text { Sant Jaume } & \text { Gorg } & \text { PLVRL } & 342\end{array}$

OSH: Obra Sindical del Hogar

PLVRL: Patronato Local de Viviendas de Renta Limitada (o Patronato Municipal de Viviendas de Badalona)

VCE: Patronato de Viviendas del Congreso Eucarístico

Font: Joan Villarroya (dir.): Història de Badalona, Museu de Badalona, 1999, p. 173.

Apart d'aquestes promocions la iniciativa privada va experimentar un gran auge. Els Plans Parcials ${ }^{231}$, que vulneraven les disposicions del Pla Comarcal del 1953, l'afany especulatiu i per guanys fàcils dels empresaris constructors i les seves convivències i connexions amb l'aparell polític del franquisme van propiciar la proliferació d'habitatges que en la majoria dels casos no respectaven unes condicions mínimes tant en la seva construcció com en el proveïment dels serveis més indispensables per a la seva població (sanitat, educació, higiene, neteja, comunicacions, etc.).

230Joan Villarroya (dir.): Història de Badalona, Museu de Badalona, 1999, p. 220.

231Durant aquests anys es van fer diversos Plans Parcials a Badalona: Polígon 1 (Sant Roc-Congrés, 4-2-1957); Sector Llefià (1-8-1960); Sector Caritg (30-8-1962); Sector Mont-roig (28-7-1966); Torrent de la Font (19-9-1969); Sector la Batllòria-Montigalà (22-10-1969); Illa Sant Bru, Triomf, Jovellar, Rivero (16-7-1968) i Sector Mas-Ram (9-2-1970). Només un no es va executar tal i com havia estar planejat -el de Batllòria-Montigalà- entre d'altres causes per l'oposició veïnal. Veure Joan Villarroya (dir.): Història de Badalona..., p. 172. 
El paradigma de l'especulació immobiliària durant aquests anys es va donar a la ciutat de Santa Coloma de Gramenet. Aquesta ja tenia els seus barris d'autoconstrucció i barraquisme des de feia molts anys (el Fondo, Santa Rosa, Singuerlín.... entre d'altres), però va ser durant les alcaldies de Victor Jové Miguillón (1959-1965) i, sobretot, Romero Tutusaus (1965-1970) i Juan Porta Bussoms (1970-1975), quan la voràgine especulativa es va desfermar sobre la ciutat. A Santa Coloma no van proliferar els grans polígons d'obra pública com a Badalona i -en menor mesura- a Sant Adrià. La iniciativa privada va tenir un pes major, comportant una urbanització caòtica i un afany especulatiu on els Plans Parcials servien per vulnerar descaradament el Pla Comarcal del 1953, ja des de el primer Pla Parcial elaborat el 1958 fins al darrer elaborat per l'Ajuntament franquista el $1973^{232}$. Es permutaven zones agrícoles o verdes en terrenys edificables amb una facilitat inusitada. La lluita contra alguns d'aquests plans i estafes immobiliàries (com pisos de la "cooperativa" VIPES a Les Oliveres) va esperonar l'aparició i el creixement del moviment veïnal.

Amb aquests condicionants no ens ha d'estranyar que el dèficits urbanístics en tots els àmbits a la ciutat de Santa Coloma de Gramenet fossin realment alarmants. La revista Grama en el seu número 43-44 de juliol-agost de 1972 titulat molt expressivament "Santa Coloma en peligro" (amb una portada on King Kong destruïa algunes de les edificacions més emblemàtiques de la ciutat) quantificava, barri per barri, aquests dèficits urbanístics juntament amb totes les carències en serveis públics elementals (educació, sanitat, zones verdes, oci, etc.). Serien difícils de quantificar de manera breu, així que he optat per reproduir parcialment la pàgina 35 de la mencionada revista on es fa una taula resum amb aquestes dades:

232Els principals Plans Parcials a Santa Coloma van ser: Lorenzo Serra (zona Riu Sud, 28-9-1950); Bastida (carretera Clínica Mental, 8-9-1960); Sector Noreste (zona Can Zam, Vinyes, Oliveres i Can Franquesa, 28-12-1964); Torre Balldovina i Can Jané (23-2-1967); "Disposición de volúmenes de parcelas propiedad del PMV" (Les Oliveres i Can Franquesa, 1968); "Remodelación manzana Ayuntamiento" (carrers al voltant de l'Ajuntament, 26-10-1972); Can Zam (per segona vegada, 26-6-1972) i Sector Motocross (Barri Raval-Santa Rosa, 13-7-1973). Veure a Marcelo López Ródenas: Historia Social de la Santa Coloma moderna..., p. 289. 
DEFICIT TOTAL DE STA. COLOMA DE GRAMANET EN DICIEMBRE DE 1971

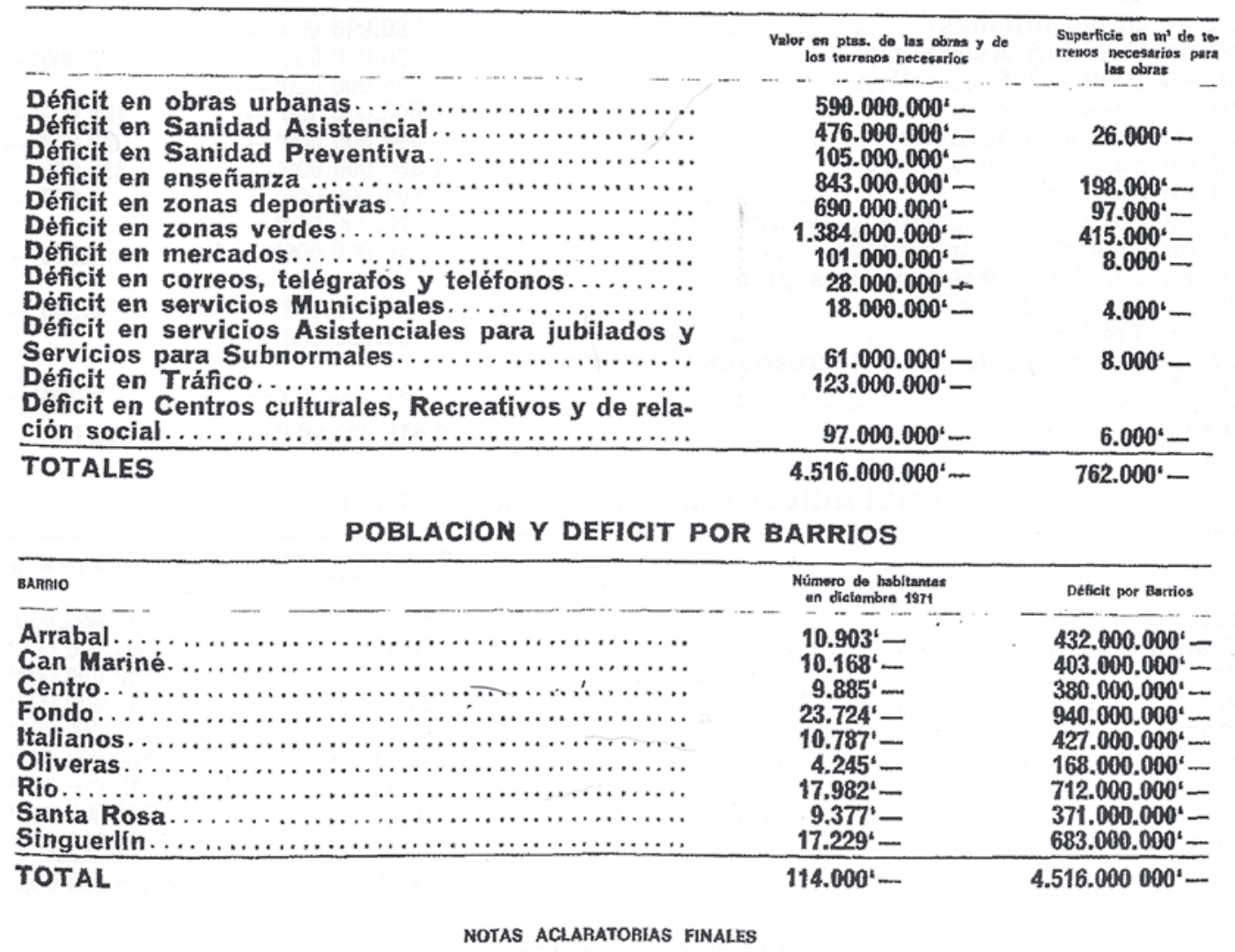

1. Santa Coloma tenía en diciembre de 1971 un déficit total de bienes colectivos de uso público de unos 4.500.000.000 de pesetas (aproximada de uso pub pesetas por habitantel.

El Ayuntamiento realiza una inversión anual do 350 \& 500 pesetas por habitante, por lo tanto, en caso de no variar substancialmente ol ritmo de inversión. se tardarian 100 años en hacer desaparecer el déficit (suponiendo que la población no aumentara).

2. La superficie de terreno necesaria para edificar los servicios de uso colectivo que precisa Santa Coloma es de unos $750.000 \mathrm{~m}^{2}$. La ciudad cuenta aún con terrenos libres y aptos para estas construcciones, pero sería necesaria su exproplación, un fuerte aumento de las inversiones municipales que permitiera llevar a cabo las obras, y una adecuada planificación del crécimiento
del Término Municipal. del Término Municipal.

Podemos afirmar que el futuro de Santa Coloma como ciudad habitable, depende del tipo de utilización de los terrenos que están aún sin edificar. Si en ellos se construyen solo viviendas insolubles.

En relación a la escasez de industrias o la inexistencla de una zona industrial en Santa Coloma conviene hacer las siguientes precisiones:

1. Que ya existe en roalidad una importante industria que produce fuertes beneficios, que es la industrla de la construcción. 2. Que la escasez de fábricas se debe a que en 1943 perdió su zona industrial del otro lado dei río Besós, que hasta esta fecha pertenecía al Termino municipal de Santa Coloma

3.2 Que puede ser beneficioso para la población el poseer una 20 industrial, siempre que no sea un detrimento de las zonas de servicios colectivos necesarios.

$4 .^{2}$ Que dado que Santa Coloma está rodeada de diversas zonas industriales muy desarrolladas y arraigadas (San Andrés, comuni. San Adrián.... es más positivo facilitar buenos accesos zona industrial, ya que ésta no supone de entrada un gran nú- mero de puestos de trabajo para la población pues éstos dependen de múltiples factores como grado de automatización de las fábricas, especialidades que requieren. etc.

3. El déficit fue calculado de acuerdo con las orientaciones de las normas legales vigentes en Urbanismo y sobre la base de (segün el censo oficial, única fuente para conocer el numero de habitantes, contaba Santa Coloma el 31.12 .1971 .

Sin embargo, tanto por las mismas autoridades, como por pe. riodistas se viene afirmando repetidamente que la cifra de pobla. ción es mucho mayor. y que oscila entre 125.000 y 150.000 ha. bitantes.

En este caso el déficit total de Santa Coloma, partiendo de 40.000 pesetas por habitante ascienderia a 7.000 .000 .000 de pesetas.

4. El estudio se refiere únicamente a bienes de uso público considerados esenciales para la población. Se han omitido edificios o servicios colectivos no estrictamente imprescindibles. tales como escuelas de formación profesional, edificios administrativos por barrios, residencias de jovenes trabajadores. etc.. y los blenes de uso individual, como canalizaciones de agua y electricidad para estos servicios, etc yectores do la poblacion ques posteriores.

5. Tampoco se incluye en el estudio al déficit de viviendas de la población. este sero te un futuro estudio. (insalubres, ruinosas, realquilados, berracas, etc).

6. Los precios de las obras se han calculado según los precios normales de construcción.

No se ha hecho asi, sin embargo, con los precios de los te. renos: se ha elegido el precio de 100 pesetas el palmo cuadra. do en lugar de 3006400 , que es el preclo actual en Santa Coloma, por considerario un posible precio de expropiación.

Grama núm. 43-44 (juliol-agost 1972). Pàgina 35. 
En contrast podria semblar que Sant Adrià de Besòs no patia dèficits tan greus, però aquesta seria una percepció errònia. La petita població, encaixonada entre Barcelona, Badalona i Santa Coloma no va tenir un creixement tant gran com les seves veïnes, però si que va viure una dualitat en especial entre els nuclis de població situats a les diferents ribes del riu Besòs. Va ser la vessant sud-oest la que va patir més els dèficits d'urbanisme, el barraquisme, l'especulació i la creació de polígons d'habitatges sense una planificació adient. Existia, ja des de els anys 20-30 l'anomenat barri de La Catalana, un barri d'auto-construït pels obrers de l'antiga central tèrmica que semblava un petit poble. El Pla Comarcal de 1953 va qualificar el terreny sobre el qual estava edificat com zona verda i aquesta situació d'irregularitat, així com el seu aïllament, va condicionar l'existència d'aquest barri fins el seu polèmic enderrocament i reconstrucció a finals del segle XX i principis del $\mathrm{XXI}^{233}$.

Existent ja als anys quaranta, les dues dècades posteriors havia crescut espectacularment una barriada de barraquistes anomenada popularment "El Camp de la Bota". Una part d'aquesta estava situada al terme de la ciutat de Barcelona però una altra ho era a Sant Adrià de Besòs, en concret el sector anomenat "El Parapeto". En aquest barri es donaven tota una sèrie de greus mancances agreujades per la precària situació social dels seus habitants. L'any 1964 comptava amb una població de 1.841 persones que vivien en 213 barraques sense aigua corrent, llum elèctrica, clavegueram, fonts.... L'any 1971 els seus habitants eren 2.104 en 275 barraques, la majoria de les quals ja comptaven amb llum elèctrica (222) però encara no tenien aigua potable ni lavabo, si bé ara si existien dues fonts públiques i 8 lavabos públics ${ }^{234}$. En aquest barri una comunitat d'escolapis va desenvolupar una tasca social important en la dècada dels seixanta.

També als anys seixanta es van impulsar tota una sèrie d'edificacions al sector anomenat "Sud Oest del Besòs". La majoria d'aquestes noves edificacions pertanyien al municipi de Barcelona, que era el que havia aprovat las seva

233Pel que fa a Sant Adrià de Besòs tinc constància del Plans Parcials de San Juan Bautista (1960, revistat al 1969) i de la "Zona Industrial sector Torrassa, Carmen, el Mar y límite con el Municipio de Badalona", [Diversos documents] (1969), ASAB, Fons 101 Ajuntament, Caixa 330, Carpeta 19.

234Josep Maria Montferrer i Celades: El Camp de la Bota. Un espai i una història, Octaedro editorial, Barcelona, 2012, p. 93. 
construcció l'any 1959 i havia començat les obres l'any següent (els darrers pisos no es van entregar fins el 1968!) . Hi haurà un barri, anomenat originalment BesòsCOBASA (pel nom de l'empresa constructora) dins el terme de Sant Adrià de Besòs, amb 2.000 habitatges que patirà les mancances habituals d'un barri sense les dotacions mínimes i el fet d'estar més "a prop" de Barcelona que del teòric municipi del qual formava part ${ }^{235}$.

Però va ser l'enderrocament de "El Parapeto" juntament amb els altres barris barraquistes de Barcelona (Pekín, el Somorrostro, Montjuic...) i la concentració en un únic macropolígon dels seus habitants el que va generar el barri de La Mina als anys setanta. Gestionat pel "Patronato Municipal de la Vivienda" de Barcelona en uns terrenys del municipi de Sant Adrià de Besòs, va ser el paradigma de la creació d'un guettho de barraquisme vertical de prop de 15.000 habitants que a més va ser durament estigmatitzat com a nucli de delinqüència. El que no és tan conegut és que aquest barri va ser protagonista de lluites veïnals molt importants, no només per aconseguir uns habitatges i un serveis imprescindibles, sinó també per la dignitat dels seus habitants.

\subsection{Les condicions subjectives: hegemonia cultural, pensament, consciència, associacionisme i organització.}

Les dures condicions materials es van haver de combinar amb altres factors per que sorgís un potent moviment veïnal organitzat. Per que si no... com és que no va aparèixer amb força als anys 40 o 50 quan les condicions de vida eren més dures? Com es que ho va fer posteriorment, després d'un període de gran creixement econòmic?.

Apart de les dures condicions de vida, per que es desenvolupi un moviment popular ampli, amb capacitat de mobilitzar grans volums de població, han d'existir uns altres processos, en especial de conscienciació col·lectiva. No és el mateix patir

235Un interessant relat del sorgiment d'aquest barri, contemporani als fets, el tenim en un dels seus sacerdots, Albert Matas Pericé, a la seva obra Al Sud-Oest del Riu Besòs. Deu anys de la vida d'un barri barceloní, Editorial Pòrtic, Barcelona, 1970. 
unes dures condicions de vida amb "resignació", que tenir-ne consciència de les causes polítiques i econòmiques d'aquestes i, el que potser és més important, manifestar la voluntat de lluitar per revertir-les. L'adquisició o recuperació d'un grau de consciència col-lectiva o consciència de classe, dins el que alguns investigadors han anomenat "processos enmarcadors" ${ }^{236}$, és un fet fonamental. El procés de construcció d'una identitat col-lectiva és trascendental per entendre el sorgiment d'un potent moviment veïnal, juntament amb altres fets i experiències que la van condicionar profundament com va ser la dura repressió de la postguerra i el record d'aquesta.

Nombrosos estudis han posat un major èmfasi en l'anàlisi d'aquests processos superant interpretacions esquemàtiques d'alguns autors marxistes contemporanis als fets que havien posat un interès gairebé exclusiu en les condicions materials ${ }^{237}$. Però és important recordar que importants pensadors marxistes com Antonio Gramsci ja havien manifestat la importància d'altres factors desenvolupant conceptes com el de "l'hegemonia cultural". Així es referia el mateix Gramsci als fets que havien afavorit l'expansió per Europa de l'impacte de la revolució francesa, i que es poden aplicar també a l'estudi del moviment veïnal:

"Mas tarde, una vez los hechos de Francia consolidaron de nuevo la consciencia, bastaba un movimiento popular en París para provocar otros análogos en Milán, en Viena, y en los centros más pequeños. Todo eso parece natural, espontáneo, a los facilones, pero en realidad seria incomprensible si no se conocieran los factores de cultura que contribuyeron a crear aquellos estados de ánimo dispuesto a estallar por una causa que se consideraba común." ${ }^{238}$

L'important pensador italià va desenvolupar més aquest concepte fins definir el que ell anomenava "Bloc Social Hegemònic" on especificava com la classe o classes dominants imposaven els seus valors i referents al conjunt de la societat fins al punt que els oprimits podien adquirir el sistema de valors fomentat pels

236Doug McAdam, John McCarty i Mayer N. Zald: Movimientos Sociales: perspectivas comparadas, Itsmo, Madrid, 1999.

237Alessandro Piazzorno: "Identidad y interés", Zona Abierta Núm. 69 (1994), p. 135-152; Scout Hunt, Robert Benford i David Snow: "Marcos de acción colectiva y campos de identidad en la construcción social de los movimientos", p. 221-252 i Bert Klandermans: "La construcción social de la protesta y los campos pluriorganizativos", p. 183-220, en Enrique Laraña i Joseph Gusfield (eds.) Los nuevos movimientos sociales. De la ideología a la identidad, CIS, Madrid, 1994.

238Antonio Gramsci: Antología. Selección, traducción y notas de Manuel Sacristán, Akal, Madrid, 2013, p. 23, dins l'escrit "Socialismo y Cultura" del 29 de gener de 1916. 
opressors, de manera que la dominació no es produeix només per la coerció sinó també per l'establiment d'una mena de “consens"239. D'aquesta manera qualsevol intent de modificar o subvertir l'ordre social establert implicarà també una "batalla de les idees" per aconseguir que sectors amplis de la població trenquin aquest "consens" i facin hegemònics una sèrie de valors alternatius que al mateix moment els impulsaran a mobilitzar-se pels seus interessos i en contra de les oligarquies que fins al moment havien imposat els seus valors en la societat i en l'aparell de l'Estat.

Arribats a aquest punt, cal que mirem d'analitzar quins eren els valors de la gent que va ser protagonista del moviment veïnal a les tres ciutats del Barcelonès Nord, tenint en compte tant els que tenien prèviament a l'establiment de la dictadura franquista i als seus llocs d'origen quan es tracti de població nouvinguda, com els mateixos valors que aquestes poblacions van anar desenvolupant en el dia a dia de les seves experiències vitals i front als intents del franquisme d'influenciarlos, ja fos amb el discurs o amb la repressió.

Em sembla evident que fins a l'establiment de la dictadura franquista, una amplia majoria de sectors populars havia desenvolupat una consciència i una sèrie de valors que entraven con conflicte amb el nou règim polític establert, en tant aquest era exponent de la victòria de la majoria de classes privilegiades que s'havien mostrar profundament hostils amb els intents reformistes que es van fer durant la Segona República. Malgrat que la duríssima repressió franquista va establir un règim de terror i de por durant la postguerra i aquest fet va condicionar per exemple la transmissió de valors de pares a fills entre els vençuts, no es pot dir que hi hagués un tall total en aquesta comunicació de valors i d'experiències. Moltes persones no ho van fer per la por, però també trobem exemples en el sentit contrari. I més encara en persones que després tindran un paper actiu en el desenvolupament de moviments antifranquistes o el mateix moviment veïnal. Les mateixes experiències familiars seran un factor determinant, com ens posen de manifest alguns testimonis personals. Experiències dures sens dubte, que en no pocs casos es remuntaven fins i tot a la Guerra Civil:

“[...] El que recordo amb més intensitat va ser el dia de l'entrada dels nacionals al

239En defensa del Marxisme, Edicions La Veu, Barcelona, 2013, p. 69-70. 
poble, allà a la plaça de l'església, amb tota la tropa de cavalleria per allà [...]. Si, em recordo d'una imatge, perquè el meu avui es va voler intentar acostar allà a la tropa i els soldats no el van deixar, ni això, i llavors jo vaig sortir corrents i em vaig poder abraçar a les seves cames i llavors em va fer dir una frase molt curiosa que... Perquè ell em deia "mochilas" quan estava a la presó i bé, i abans d'estar a la presó , ell m'agafava assegut en una cadira i em posava a sobre seu i em deia: "Arriba , mochilas". I llavors en aquell moment em vaig abraçar a les seves cames, em va mirar i em va dir: "Arriba, mochilas, busca tu libertad" i llavors en sentir la paraula llibertat un dels soldats que era per allí va dir: "Quién habla de libertad, rojillo de mierda?" I li va fotre un cop de culata als llavis, el nas va començar a sagnar , i llavors a mi em va dir que me n'anés i va ser l'última vegada que jo vaig poder veure'l... Sembla que va estar quinze dies a la presó i el van afusellar. El van afusellar, però no van poder trobar el seu cos."240

\section{O també a la dura postguerra. Una cosa era que els pares no transmetessin} explícitament la seva ideologia per por a la repressió. Però els nens fins i tot tenien més capacitat per captar la realitat de la que a vegades els atribuïm:

"Bueno, mis padres siempre habían sido personas de izquierdas, siempre. Mi padre escuchaba la Pirenaica que en aquella época se escuchaba a escondidas. Mi padre no fue una persona activa, siempre fue muy pasiva porque en aquella época hubo mucha represión por parte del franquismo y eran personas que tenían bastante miedo. En el pueblo de Morón de la Frontera hubo mucha represión y mataron a muchísima gente. Mi padre nunca nos comentaba nada de la época aquella pero a mi siempre me había interesado un pelín y escuchaba a mi padre cuando hablaba con algunos amigos, muy amigos. Pues claro allí nadie se podía mover, nadie podía decir nada y tenía que tener mucho cuidado con quien hablaba. Mi padre escuchaba a media noche la Pirenaica, tenía una radio que tenía una antena de un palo a otro y lo escuchaba "pi, pi,..." porque le cortaban la comunicación. Y veía a mi padre cómo se ponía ahí el oído escuchando ¡eh!. Y a mi a veces me gustaba escucharlo pero mi madre me decía: "no, no, ...tú, eso no es cosas de niños". Mi padre no ha sido una persona combativa pero siempre ha tenido una cierta idea de rebeldía. Debido a su cargo no lo podía mostrar mucho pero también le permitía decir cuatro cosas cuando él veía que lo avasallaban y se enfrentaba al señorito y le he visto decirle ciertas cosas, cosas que otros no se lo podían permitir porque se quedaban sin trabajo. Después de los años ves que tú heredas cierta rebeldía, como contestación a la situación que había."241

240Testimoni de Manuel González, originari de Macharaviaya (Màlaga) recollit a Montserrat Carreras, Emili Ferrando i Joan Villarrolla: La immigració a Badalona..., p. 125-126.

241Testimoni de Felipe Barrera, recollit a Montserrat Carreras, Emili Ferrando i Joan Villarroya: La immigració a Badalona..., p. 130. 
Els mateixos nens podien analitzar els fets viscuts quan es feien més grans:

\begin{abstract}
"Después de la guerra [mi padre] estuvo dos años detenido, estuvo en la cárcel y en cuarenta y cuatro, a un mes de nacer yo, lo detuvieron otra vez y lo soltaron en 1950. $\mathrm{O}$ sea que prácticamente quien tuvo que sacar parte de la familia adelante fue mi madre, porque mi padre, unos tiempos por la guerra, otros por encarcelamiento, pues ella se tuvo que poner al frente de la familia. [...] Cuando fui mayor fui comprendiendo más todas las dificultades que tuvieron mis padres. Mi padre fue muy represaliado dentro del pueblo y los pasó muy mal. Porque ser comunista en aquella época..., los falangistas se portaron muy mal con él y tuvo muchas dificultades. Mi madre siempre había estado quitándonos de la cabeza que nos metiéramos en política porque tenía miedo. Ella tenía la experiencia de su marido por estar en política y pensaba que eso podía ser malo para nosotros, tanto para mis hermanos como para mí, y siempre había procurado que no nos metiéramos en política... Mi padre murió a los sesenta años, o sea, murió joven. Había sido castigado por la guerra, castigado por la cárcel y parecía mayor. Todo lo que había pasado lo llevaba dentro, tuvo un cáncer y en dos días murió”. ${ }^{242}$
\end{abstract}

Aquestes experiències no eren pròpies només de les classes populars. Fins i tot persones provinents de classes benestants van tenir vivències que potser van condicionar la seva futura evolució ideològica. Un cas paradigmàtic podria ser el propi Jaume P. Sayrach. D'origen privilegiat, després serà un sacerdot profundament implicat en l'aparició del moviment veïnal a Santa Coloma de Gramenet. Amb un pare republicà catalanista que va ser a punt de ser afusellat pels milicians durant els primers dies de la guerra (per ser una persona benestant, i que va morir posteriorment de malaltia), una mare provinent d'una família de dretes gran propietària agrària i un germà combatent al requetè, el seu testimoni de finals de la guerra em sembla significatiu, i més si tenim en compte la seva evolució posterior:

"ens sentíem franquistes per que els rojos ens ho havien pres tot [durant la guerra] i esperàvem que en Franco ens ho tornaria tot [...]. Escoltàvem Radio Verdad cada dia [...], la ràdio d'en Franco [...]. I vam veure com entraven els nacionals per la Diagonal

242Testimoni de Manuel Armentero, recollit a Montserrat Carreras, Emili Ferrando i Joan Villarroya: La immigració a Badalona..., p. 135. Aquest serà posteriorment un dels líders veïnals més coneguts de Badalona i regidor a l'Ajuntament pel PSUC. 
[Barcelona] [...] Van pujar uns soldats a casa i lo primer que van fer anar a la bandera $\mathrm{i}$ estripar-la en dos d'espanyoles, la catalana. I vam dir, ep, aquests no són dels nostres! Perquè nosaltres érem catalans per damunt de tot. I l'endemà o demà passat van venir per matar al meu pare per [...] catalanista i republicà però com ja era mort no el van poder matar. Van agafar els seus llibres, els van posar en un munt i els van cremar, nosaltres cinc al davant [...] Vam perdre per segona vegada la guerra, la primera va ser el juliol [del 1936] i la segona el gener del 39 [...]"243

En canvi, molta població socialment benestant de Catalunya no tindrà cap problema en renunciar al seu nacionalisme català o, més simplement, al seu catalanisme lingüístic-cultural en funció dels seus interessos de classe i en col-laborar activament amb el nou estat i administració franquistes ${ }^{244}$.

Aquestes experiències fan referència la immediata postguerra, però tot i que la repressió va ser més dura en aquell moment, les vivències es podrien perllongar al llarg del temps, sobretot en aquelles persones que per l'adscripció ideològica dels seus progenitors o de les seves famílies podien quedar estigmatitzades, en especial al món rural on es pot exercir un control social més efectiu, tal com ens ho mostra el següent testimoni:

"los que éramos hijos de la gente que había estado de una manera o otra por problemas políticos en las cárceles y habían tenido la represión del franquismo y tal pues lo teníamos muy difícil (...) mi padre se fue voluntario a la guerra, luego estuvo en la cárcel (...) después de pasar siete años entre la guerra, la mili y el campo de concentración pues era un hombre que militaba en un partido político pues le engancharon y le metieron en la cárcel (...) teníamos dificultades para tirar adelante (...) a partir de los años sesenta me acuerdo que empezaron... la gente se venía para Barcelona, para Bilbao, para Alemania... pues yo ya cumplí los 18 años, me sublevé (...) en la iglesia tuve un problema (...) le dije al cura que los dineros que se gastaban en los santos se lo podían dar a los pobres... llamaron a mi padre y a una tía mía al cuartel de la Guardia Civil, que había salido de la cárcel hace poco (...) yo me quería desenvolver como persona y no estaba dispuesto a trabajar en aquellas condiciones (...) al final dijo mi familia, que se vaya, nos lo quitamos aquí de encima que nos puede buscar un problema." ${ }^{245}$

De manera que malgrat la ferotge repressió i la por existent, es pot dir que els 243CEFID, Arxiu Fonts Orals, Fons Moviment Veïnal. Entrevista a Jaume P. Sayrach. 244 Veure Martí Marín: Els Ajuntaments franquistes a Catalunya... 245Entrevista a Francisco Lillo, 15-5-2006. José Miguel Cuesta: El moviment veïnal a Llefià..., p. 137. 
canals de transmissió de valors i ideologia "generacionals", tot i sofrir un fort sotrac, no es van tancar totalment. En els casos més evidents fins i tot la militància política es va transmetre o traslladar de lloc en el cas de la població migrada. No serà estrany trobar casos de persones destacades al moviment obrer o veïnal, que ja havien iniciat els seus primers passos militants als seus llocs d'origen, ja fos a la HOAC, la JOC, al PCE o algun altre partit polític ${ }^{246}$.

Malgrat l'existència d'aquests canals de transmissió de valors i cultures polítiques, calia que es donessin altres processos per que amplis sectors de població adquirissin unes majors quotes de consciència col-lectiva superant la por a la repressió i, com veurem més endavant, les polítiques d'adoctrinament del règim, sense comptar la pròpia complexitat que comportava organitzar-se. L'experiència quotidiana del dia a dia en els nous barris (o no tant nous) receptors de població de les tres ciutats del Barcelonès nord va ser, sens dubte, molt important en aquells primers anys de la postguerra i els posteriors, on les dures condicions de vida van fer en nombrosos casos, l'aparició d'una incipient solidaritat i ajuda mútua malgrat la massificació, la inserció en un teixit urbà deshumanitzador i la diversitat geogràfica de procedències.

Fets tan elementals com ajudar-se a construir la incipient barraca en l'únic dia festiu del qual es disposava -es a dir, el diumenge- amb la participació dels membres de la família i dels veïns i paisans o cuidar-se mútuament la canalla quan s'anava a treballar davant la falta d'escoles ajudaven a teixir aquests vincles. Els mateixos veïns podien, davant la desatenció total de les autoritats, més preocupades en un primer moment en reprimir la immigració, posar-se d'acord per fer claveguerams rudimentaris o altre tipus d'iniciatives "protourbanístiques". En alguns casos aquesta mena de col-laboracions sorgien de manera més espontània i en d'altres, més endavant, instats per algun tipus d'entitat o associació. La incipient barraca del començament podria, amb el pas dels anys, convertir-se en una caseta d'autoconstrucció i amb el mateix procediment podien donar-se creixements molt ràpids de determinats barris:

246Aquest seria el cas, per posar algun exemple, de dos testimonis que vaig trobar al fons de la Fundació Cipriano Garcia (CCOO) "Biografies Obreres", en concret de Cristòbal Garcia i Gil que abans d'arribar a Santa Coloma de Gramenet ja havia estat en contacte amb l'HOAC a Màlaga, amb moviments de barris i el PCE... I també de Ángel Pérez Moreno, que militava en el PCE abans d'emigrar des d'un poble de Badajoz cap a Barcelona. 


\begin{abstract}
“Vine a Llefià en el año 58 o por ahí pero yo ya conocía este barrio de miseria porque aquí empezó a venir la gente de la postguerra huyendo de la miseria, huyendo de los caciques, huyendo de los explotadores. Tenían un amigo, un paisano que les decía: "pues mira, vente aquí a este barrio porque aquí tu mismo te podrás hacer una barraca". Poco a poco las barracas se iban haciendo un poco mejor, unos se la hacían de ladrillo, otros de cartón piedra. No habían cloacas, solamente habían en esa parte que está casi al frente de la iglesia porque ellos mismos se las hicieron. Tuvieron que pagar para conectar las cloacas de ellos con las de los otros, pero en este barrio la porquería corría por la mitad de la calle."247
\end{abstract}

En determinats casos podia ser un fet concret el que esperonava un incipient procés de conscienciació col·lectiva com ara quan persones que havien començat construint-se la barraca, que havien anat millorant progressivament fins a convertir-la en una caseta d'autoconstrucció s'assabentaven que havien estat víctimes d'una estafa i que havien fet l'edificació en un terreny on legalment no es podia construir. Això és el que els va passar a un grup de veïns del barri badaloní de Lloreda. L'amenaça de l'enderrocament imminent dels seus habitatges que tant esforços els havien costat va ser la guspira que va impulsar que s'haguessin d'organitzar per mirar d'impedir-ho:

"Al mes o así de estar aquí [es refereix al Barri de Lloreda, on l'entrevistat va anar a viure el 1953 procedent del Camp de la Bota...] me entero de que esto estaba... que iban tirando casas, que esto estaba en precario (...). De eso nos enteramos cuando hicimos las gestiones para poner agua aquí. Y entonces me enteré de eso y yo estaba desesperao. Porque yo ahora estoy entrampao con el pagar esta deuda, 15.000 pesetas [un préstec que havia demanat per comprar el terreny on va fer la casa], que ganaba yo 25 duros a la semana... Bueno, indagando me dicen 'ahí hay un grupo de hombres que se reúnen (...)'. Total, que una noche los veo aquí en la calle Navarra, ahí por debajo de la mina de Lloreda. Y hablé con ellos a preguntarle a ver... 'esto está muy mal, esto está muy mal (...)' I al sábado siguiente me presento yo en el sótano de Boada, el cabecilla principal (...) José Boada (...). I llegué allí... 'bueno señores, yo no se nada, en mi vida me he visto más gorda, yo nunca he edificao ni he tenío casa ni he tenío nada. Pero si yo en algo puedo servir..." ${ }^{248}$

247Testimoni de Luis Diego, recollit a Montserrat Carreras, Emili Ferrando i Joan Villarrolla: La immigració a Badalona..., p. 181.

248Entrevista a Francisco Rodríguez, 21-6-2013. Aquest va ser un dels membres fundadors de l'AVV de Lloreda i segons ell ja era una persona amb consciència d'esquerres aleshores. Diferent era el cas del "cabecilla" que esmenta, José Boada, que era una persona més aviat conservadora - però amb sensibilitat social- segons el testimoni de Diego Guerrero Castaño, entrevistat el 21- 
De manera que els incipients barris de barraquistes van anar transformantse, progressivament, en barris d'autoconstrucció. Aquestes barris esdevindrien unes comunitats més estables que haurien de lluitar dia a dia per la seva supervivència, especialment davant les continues amenaces que suposava la política de repressió del barraquisme i de la immigració dels anys quaranta i cinquanta. La major estabilitat de la població serà un factor que ajudarà, per una banda, al desenvolupament d'una certa consciència col-lectiva i per l'altra, a un incipient procés d'autoorganització. Encara que fos només per solucionar els problemes més elementals o les esmentades amenaces de les autoritats de l'època, més preocupades de reprimir que no pas d'ajudar a una població ja prou maltractada:

\begin{abstract}
"Los esfuerzos represores llegan tarde. Los barraquistas están organizados. En sus núcleos hay luchas por el agua, luz, alcantarillado, lavaderos, fuentes, los contratos de palabra buscan tener validez de escritura, esos espacios se llenan de socialización, de solidaridad, de tensiones, son los espacios ignorados por el resto de ciudadanos. Los barraquistas fueron protagonistas de miles de historias, algunas heroicas y otras $\sin$ final feliz, pero aguantaron carros y carretas. Tenían muy claro que tenían dignidad y no querían volver a la miseria desmedida de pueblos y aldeas. Y menos volver a sufrir la represión policial y empresarial en las plazas de cientos de localidades. Eran obreros sin calificación profesional en su mayoría, braceros que dejaron clara su voluntad de ser ciudadanos. En sus barracas y viviendas de autoconstrucción se introduce algo de higiene, aunque las aguas fecales y residuales corren por las estrechas calles y angostas cunetas, el asfaltado es escaso, las aguas enjabonadas son arrojadas a la calle, igual destino tenían las aguas de las escasas duchas y limpieza de cocinas, todo calle abajo, la depuración no existía, era un lujo, el alcantarillado era ilusión colectiva." ${ }^{249}$
\end{abstract}

Va ser aquesta necessitat de millorar les seves condicions materials, concretada en aquesta activitat "protourbanística" que es començava a fer als barris d'autoconstrucció davant les mancances i la indiferència de les administracions públiques, la que va posar una llavor que va ajudar posteriorment al naixement d'un associacionisme popular en aquestes barriades poblades

11-13.

249Juan Rico Márquez: Llefià, de la barraca a la dignidad, Autoeditat, Badalona, 2010, p. 61-62. 
majoritàriament per població nouvinguda ${ }^{250}$

Aquest fet no comportarà de manera mecànica el desenvolupament d'una consciència política crítica i antifranquista que es manifesti públicament, ja que això serà un procés més complex. Però fets com els esmentats ajudaren a anar teixint una certa consciència col-lectiva, una consciència que certament en uns primers moments podria ser força senzilla o elemental, però que sens dubte seria una base on podrien incidir altres factors en els anys posteriors. En paraules de Joan Carrera, qui va ser el primer rector de la parròquia de Sant Antoni de Llefià a partir de l'any 1961:

"Es va anar creant una feligresia bastant maca, bastant oberta, bastant popular. La gent va col-laborar molt. I això coincidia amb una barriada aquella en la qual ja hi havia una consciència cívica... almenys per les coses més elementals. Potser no s'haurien entès en qüestions polítiques o en qüestions de segons quin tipus però en canvi en solidaritat sí." 251

La percepció de les grans mancances existents en aquests barris on s'amuntegava la població nouvinguda amb juntament amb altres que havien fet el mateix procés fa anys. La progressiva percepció de que les dures condicions que patien no es trobaven generalment en els centres urbans de les poblacions del Barcelonès Nord (fet més evident a Badalona que tenia un centre històric relativament gran en comparació amb els petits nuclis originaris de Santa Coloma de Gramenet i Sant Adrià de Besòs) o en les àrees més antigues de la propera Barcelona. Tot això va ser un procés que sens dubte va ajudar també a la presa de consciència col·lectiva. De manera que, superant les anàlisis estructuralistes que es van fer en un primer moment sobre les causes del sorgiment del moviment veïnal, centrades en l'anàlisi de les dures condicions de vida del medi urbà, en altres estudis més recents prenia força l'anàlisi d'altres factors com el:

“(...) procés d'empoderament dels veïns, d'apercepció de la seva realitat de carrers sense asfaltar ni enllumenar, de barris sense escoles ni dispensaris . Això és, el procés d'articulació d'un discurs crític i d'una consciència col-lectiva a partir d'una realitat material viscuda quotidianament i fàcilment comparable amb la situació d'altres

250 Martí Marín i Corbera "Epíleg: de suburbis a barris, autoorganització, integració, protesta i politització" dins Martí Marin (dir.) Memòries del Viatge..., p. 138. 251Entrevista amb Joan Carrera i Planes, 8-5-2006. 
barris." $^{252}$

Podria semblar que amb uns dèficits existents tan evidents als barris perifèrics de Badalona, a la majoria de Santa Coloma i a gran part de Sant Adrià de Besòs, aquesta tasca de presa de consciència no hauria de ser gaire difícil. Però una cosa és prendre consciència de la pròpia situació i altre fer quelcom per canviar-la, o pel contrari, resignar-se a la situació existent. I ens estem oblidant de que estem en el context d'una de les dictadures més sanguinàries de Europa, responsable de de un màxim de 180.000-200.000 assassinats (d'aquests, 143.353 desapareguts $)^{253}$. Això sense comptar la nombrosa població que va patir presó entre 1936-1977, xifrada per alguns investigadors en més de 500.000 persones, si bé la majoria va començar a ser excarcerada després de 1944-45 ${ }^{254}$.

Però la magnitud d'aquestes xifres no ens hauria de fer oblidar un altre fet: la lluita per l'hegemonia cultural, per la construcció d'una sèrie de valors propis i cohesionadors de les classes populars s'enfrontava a d'altres obstacles que anaven més enllà de la repressió pura i dura. Havien de fer front a una sèrie de valors estesos per la ideologia dominant que tenien molts anys d'existència i el que és més, a tota una nova campanya propagandística i de captació de masses feta per la dictadura $^{255}$. Per què el franquisme, en tant que règim feixista, coneixia la importància de crear un "consens" o dotar-se d'uns suports en sectors amplis de la població, cosa que anava molt més enllà d'una dictadura de tall "tradicional" o clàssic. Per això des de el primer moment el règim va abocar esforços a allò que en el seu llenguatge es coneixia com "la captación de las masas" i es va valer, per a

252 Iván Bordetas Jiménez: "De la supervivència a la resistèmncia: la gestació del moviment veïnal a la Catalunya franquista” dins Carme Molinero i Pere Ysàs: Construint la ciutat democràtica... p. 66.

253Les dades pel que fa a les víctimes de la repressió franquista varien en funció de la dificultat que s'ha tingut fins fa poc pel seu estudi i per la manca de registres fiables. L'historiador britànic Paul Preston donava la xifra de 180.000. Eduardo Guzmán donava la xifra de 200.000 víctimes. La xifra de desapareguts comptabilitzada per l'Audiència Nacional el 16 d'octubre de 2008 era inicialment de 114.266, número que revisions posteriors van elevar a les 143.353 esmentades.

254 Manel Risques i Ricard Vinyes donaven aquesta xifra aproximada en l'exposició "Les Presons de Franco" inaugurada al Museu d'Història de Catalunya el 26 de novembre de 2003. Vinyes també ha explicat que després de 1945 la xifra de presos polítics es redueix notablement fins a 45.000 persones, arribant a no superar les 8.000 a la mort de Franco. Veure Ricard Vinyes: Irredentas: las presas políticas y sus hijos en las cárceles de Franco, Temas de Hoy, Madrid, 2002 i Presas políticas, RBA, Barcelona, 2006.

255Imprescindible per l'estudi d'aquest fet l'obra de Carme Molinero: La captación de las masas. Política Social y propaganda en el régimen franquista, Cátedra, Madrid, 2005. 
aconseguir-ho, d'un gran aparell propagandístic que volia mostrar-se com un model d'estat preocupat per la "Justícia Social". Els fets ens demostraren que la realitat era totalment diferent al que es predicava, però això no representava cap problema per les autoritats, ja que la seva principal preocupació no era la solució de les desigualtats socials, com a bon exemple de "dictadura de classe" (al servei de les classes benestants). Però en canvi si que el franquisme va mostrar una especial preocupació pel discurs i imatge que oferia. Per què tanta preocupació? Les paraules de Carme Molinero poden ser orientatives:

"La sociedad española había vivido en la primera mitad de los años 30 una intensa experiencia democratizadora que obligaba a la dictadura a desarrollar un potente discurso en torno a la justicia social, porque como señalaba Ramón Serrano Suñer: "solo un estado que pueda afirmar haberse hecho cargo del problema de la pobreza tiene legitimación para reprimir las inquietudes sociales". La centralidad del discurso social para el franquismo radica justamente ahí: en la imagen que quiere ofrecer, una imagen que no tiene por qué coincidir con la realidad de las políticas desarrolladas."256

Malgrat que la legitimació del Nuevo Estado s'havia basat en la seva victòria militar i en la ingent repressió, alguns dels seus sectors, especialment els falangistes, eren conscients que amplis sectors de la població continuaven sent hostils amb el nou règim. Per tant, tenien la preocupació de captar políticament per al règim el suport d'aquests sectors amplis de població. No podem oblidar que la ideologia feixista, que va ser adoptada pel franquisme, tenia com un dels seus pilars l'existència d'una suposada "Comunitat Nacional" (de la qual, evidentment, s'havien extirpat o eliminat els elements "perillosos") que protegia als seus membres. Aquesta mateixa idea de "Comunitat Nacional" permetia al feixisme combinar un projecte contrarevolucionari amb una política de masses ${ }^{257}$. I dins aquesta política de masses hi jugaven un paper fonamental el partit únic i les seves organitzacions com l'OSE, la Secció Femenina, etc., tant per l'enquadrament i adoctrinament de sectors amplis de població com per l'aplicació d'una determinada "política social" que "legitimés" el règim. Però les ridícules dotacions econòmiques que es van destinar, en especial, a aquestes darreres van limitar el

256Carme Molinero: La captación de las masas..., p. 12. 257Ídem, p. 19. 
seu impacte.

D'aquesta manera, sembla evident que la política de captació de masses del franquisme no va assolir l'èxit esperat, ja que la majoria de la població a la qual anava adreçada va continuar sent hostil a un Nuevo Estado al qual feien responsable de les seves penúries i misèries, així com d'un major l'enriquiment d'una minoria a costa seva. Ara bé, que fos hostil no implicava que articulés una potent oposició activa. El paper del terror repressiu durant aquells primers anys va ser un factor que cal tenir molt en compte, i en aquest sentit, el franquisme si va tenir més èxit. No obstant a mitjans de la dècada dels 50 aquesta aparent submissió va semblar posar-se en entredit amb les vagues de 1951 i 1957 o el conflicte a les Universitats. Un conflicte, aquest darrer, protagonitzat per persones que per la seva classe social "haurien" d'haver estat afectes a la dictadura.

1957 va ser, en molts casos, un punt d'inflexió important. Els canvis que es van donar en el si del règim així com en els de la política econòmica -canvis forçats per les circumstàncies de pràctica bancarrota de l'estat i un aparent revifament de la protesta social- van tenir una especial transcendència en el nostre àmbit d'estudi. Va ser també a partir d'aquell any en que es van començar a aturar les polítiques repressives de la immigració i es va engegar una política més activa del règim per intervenir als suburbis. Destacant, sens dubte, la creació del Ministerio de la Vivienda i, ara si, una major i més decidida promoció de construcció d'habitatges, un cop el règim va assumir que els "suburbis" ja eren estables i permanents i que la situació era potencialment explosiva ${ }^{258}$. Aquest fet va impulsar també una nova campanya per part de les autoritats estatals i locals del franquisme per "guanyar-se" a una població, la dels suburbis que fins al moment s'havien limitat a ignorar o reprimir malgrat els discursos propagandístics. Estava en joc el manteniment de la seva hegemonia ideològica i cultural davant d'una població que es presumia desafecta després de molts anys de desatenció.

258Martí Marín i Corbera: "Epíleg: de suburbis a barris, autoorganització, integració, protesta i politització" a Martí Marín Memòries del viatge..., p. 143. 


\subsection{L'associacionisme "familiar" promogut per la dictadura.}

Des de finals dels anys cinquanta i durant els seixanta es va dur a terme un dels darrers intents -a nivell local- per eixamplar les bases del franquisme, oferint uns canals d'enquadrament i segons el mateix règim, de "participació", amb la creació de les anomenades "Asociaciones de Cabezas de Família", amb la nova Llei d'Associacions de 1964 i impulsant les eleccions municipals al "Tercio Familiar" (sense parlar dels intents de revitalitzar l'OSE, el cas segurament més conegut ${ }^{259}$, o les eleccions a Procuradors Familiars a Corts en 1967 i les "Asociaciones políticas" dels setanta). És important analitzar aquest fet ja que serà paral-lel a uns altres processos com el ja esmentat canvi de política econòmica, canvis legislatius com les noves Lleis de Convenis i Conflictes Col-lectius (1958 i 1962, respectivament) o el que potser és més important, l'aparició d'un moviment obrer organitzat enfrontat amb la dictadura (amb l'aparició de les Comissions Obreres) i l'extensió d'un grau de consciència antifranquista que serà clau pel posterior esclat del moviment veïnal ${ }^{260}$. Del paper oficial en la creació i impuls de l'associacionisme de barri en parlaré en aquest apartat, així com del seu frustrat intent de control d'un sector de població que podia ser potencialment conflictiu.

Arribats a aquest punt sembla imprescindible fer ni que sigui un breu esment al model d'organització local que va instaurar la dictadura franquista, prenent com a referència l'estudi que va fer Martí Marín sobre els Ajuntaments franquistes a Catalunya ${ }^{261}$. Des de 1939 els Ajuntaments del Barcelonès Nord,com la resta d'ajuntaments de l'Estat espanyol, s'havien convertit en les corretges de transmissió del règim feixista recent instaurat. Aquest va aplicar a les administracions locals un principi d'autoritat incontestable a escala piramidal, eliminant qualsevol vestigi de principi representatiu més o menys democràtic. Els

259Per un major estudi d'aquest darrer aspecte, el del sindicat vertical durant aquests anys 60, veure l'obra de Àlex Amaya Quer: El acelerón sindicalista. El aparato de propaganda de la Organización Sindical Española entre 1957 y 1969, Centro de Estudios Políticos y Constitucionales, Madrid, 2013.

260 Aquests canvis que es van donar als anys seixanta són analitzats per Xavier Domènech a Clase obrera, Antifranquismo y cambio político. Pequeños grandes cambios, 1956-1969, Los Libros de la Catarata, Madrid, 2008.

261 Martí Marín: Els Ajuntaments franquistes a Catalunya, Pagès Editors, Lleida, 2000. Aquesta obra, que és la publicació de la seva Tesi Doctoral, serà citada sovint. 
Alcaldes eren nomenats a dit pel Govern Civil i havien de respondre amb una obediència absoluta. Dins els consistoris tenien molt poder deixant als regidors triats pel sistema corporatiu dels "terços" (corporatiu, sindical, familiar) en una posició molt secundària i subordinada. La jerarquia i l'obediència respecte la persona i la instància superior era el principi fonamental.

Ara bé, també cal deixar clar que aquests alcaldes eren nomenats a dit dins l'oligarquia local dels diferents municipis, en especial dins els considerats "addictes" al nou règim en funció dels seus mèrits polítics durant la II República o la Guerra Civil. Per "mèrits" s'entenia la militància en organitzacions contràries a la II República, en especial les que havien servit de base per la creació del partit únic FET-JONS (falangistes, carlistes, monàrquics "ultres" de "Renovación Española" o del "Bloque Nacional"). Uns altres mèrits no menys importants, eren haver estat considerat ex-combatent o ex-captiu, categories que donaven un dret automàtic a la militància en FET-JONS. Aquesta condició era generalment, molt ben vista pels governadors civils en la seva tria d'alcaldes, ja que era percebuda com una prova de fidelitat absoluta al nou règim.

A les ciutats industrials catalanes, on el republicanisme d'esquerres i el moviment obrer havien tingut molt protagonisme, les oligarquies locals conservadores no havien tingut prou força per presentar un grup social totalment cohesionat que garantís un control efectiu del municipi sense estar totalment "sota sospita", sovint per haver flirtejat amb el regionalisme de la Lliga. Els Governadors Civils van recórrer inicialment als "mèrits" d'excombatents i ex-captius per cobrir aquests càrrecs. Però cal dir que aquest fet no ens pot ocultar que:

"L'anàlisi d'aquestes dades ens revela que una part important del catalanisme conservador va reconvertir el seu comportament polític sense gaire escrúpols a favor d'un règim que, encara que va negar els drets nacionals de Catalunya, va salvar el fonamental, les seves propietats i interessos."262

De la mateixa manera que si analitzem la composició social dels membres

262Juan José Gallardo Romero: "Franquisme, falange i poder local a Santa Coloma de Gramenet (1939-1953)" dins Grup d'Història José Berruezo: Una ciutat dormitori sota el franquisme..., p. 71. Les dades a les quals fa referència són, en una part, les que va recopilar Martí Marín i Corbera per la seva Tesi Doctoral publicada Els Ajuntaments franquistes a Catalunya, Pagès Editors, Lleida, 2000 i que va facilitar al Grup d'historiadors colomencs a través d'un antic alumne seu, Paco Peralta. 
dels Ajuntaments, podem veure el fort biaix classista de les capes dirigents locals del primer franquisme, on dins els consistoris predominaven els propietaris industrials, agrícoles, comerciants i en molt menor mesura professionals liberals i assalariats d'alta qualificació ${ }^{263}$. Les classes benestants locals, en especial la burgesia, va aprofitar la conjuntura per fer bons negocis sota un règim que protegia els seus interessos. Tots aquests factors es donaran als Ajuntaments del Barcelonès Nord $^{264}$, on les diferents capelletes tenien enfrontaments pel control del món local ja que el control d'aquest era una extraordinària motivació per al lucre personal ${ }^{265}$. Com que els regidors dels diferents terços tenien molt poc poder davant un Alcalde amb moltes facultats, l'únic que podien intentar per apartar-lo del càrrec era recórrer a la instància superior jeràrquicament -el Governador Civildesprestigiant-lo, fins i tot amb acusacions de suposat "catalanisme"266.

263Per exemple a Santa Coloma de Gramenet dintre del període 1939-1953 es comptabilitzen 19 propietaris industrials, 12 propietaris agrícoles, 3 comerciants, 3 metges, 1 advocat, 1 flequer, 1 sastre, 1 rendista i un farmacèutic. D'assalariats comptabilitzem 6 empleats, 4 jornalers, 3 paletes, 2 encarregats d'indústria, 2 mecànics, 1 estudiant, 1 delineant, 1 oficial de l'Ajuntament i 1 sereno. Juan José Gallardo Romero: “Franquisme, falange i poder local...”, p. 72-73.

264Per més informació sobre els alcaldes del Barcelonès nord, veure la ja esmentada obra de Martí Marín: Els Ajuntaments franquistes a Calunya... p. 496-498 (Badalona), p. 514 (Sant Adrià de Besòs) i p. 519-521 (Santa Coloma de Gramenet). També Joan Villarroya: Història de Badalona..., p. 212-225; Paco Peralta: "Las luchas por los beneficios del poder político y corrupción en la Santa Coloma Franquista (1939-1951)", Àgora núm. 3 (1998) i Juan José Gallardo Romero: "Franquisme, falange i poder local.." a Grup d'Història José Berruezo: Una ciutat dormitori sota el franquisme..., p. 63-125.

265Paco Peralta: "Las luchas por los beneficios del poder..., Àgora núm. 3 (1998) i Juan José Gallardo Romero: "Franquisme, falange i poder local...", a Grup d'Història José Berruezo: Una ciutat dormitori sota el franquisme... p. 104-112.

266Alcaldes com el Badaloní Santiago March Blanch o el mateix Josep Maria de Porcioles van ser acusats de "catalanisme" pels seus rivals. Josep Maria Villarroya: Història de Badalona... i Martí Marín i Corbera: Porcioles, Catalanisme, clientelisme i franquisme. Editorial Base, Barcelona, 2005. 


\section{Ajuntament de Badalona. Alcaldes i regidors}
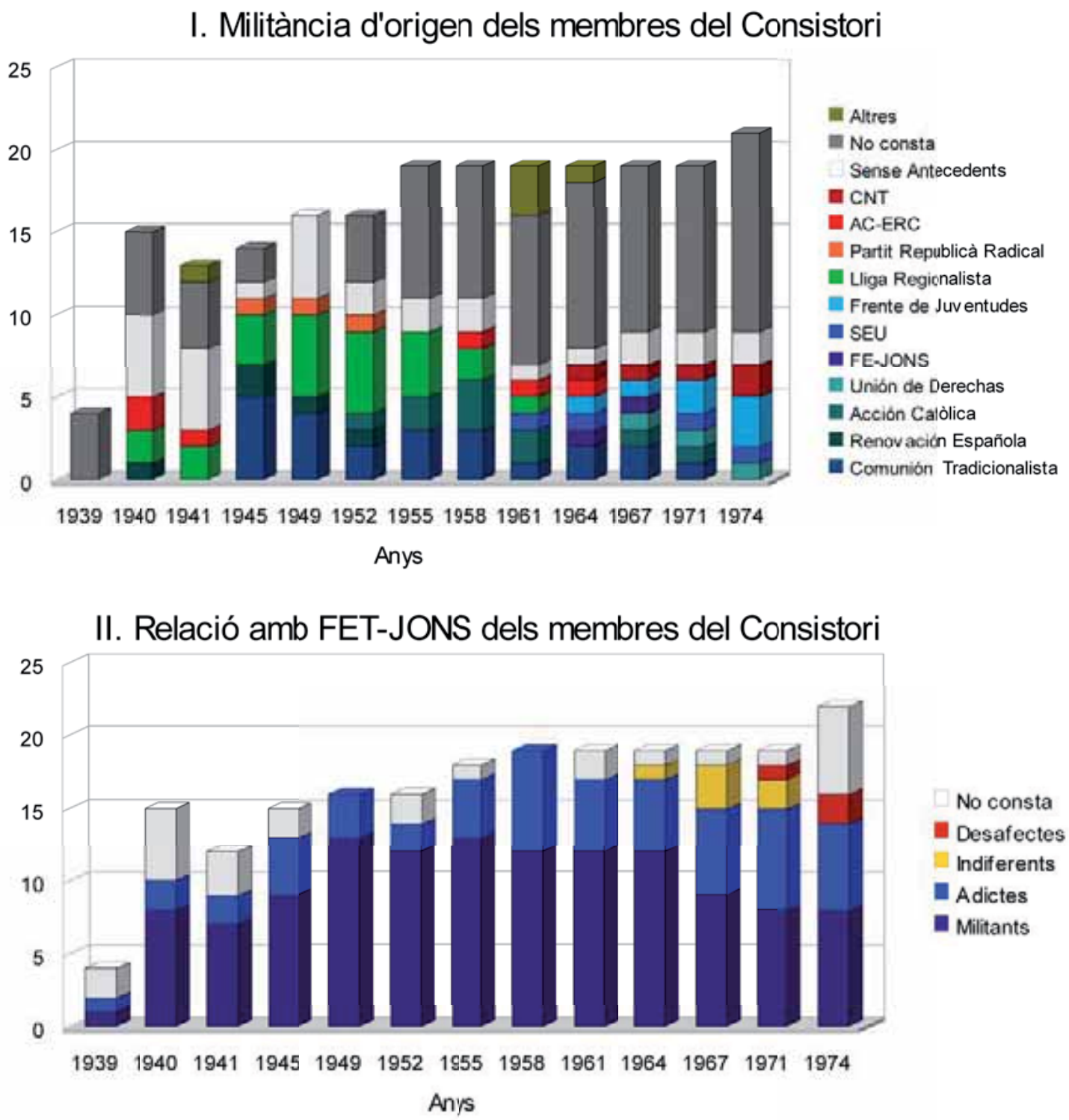

III. Relació amb la Guerra Civil dels membres del Consistori

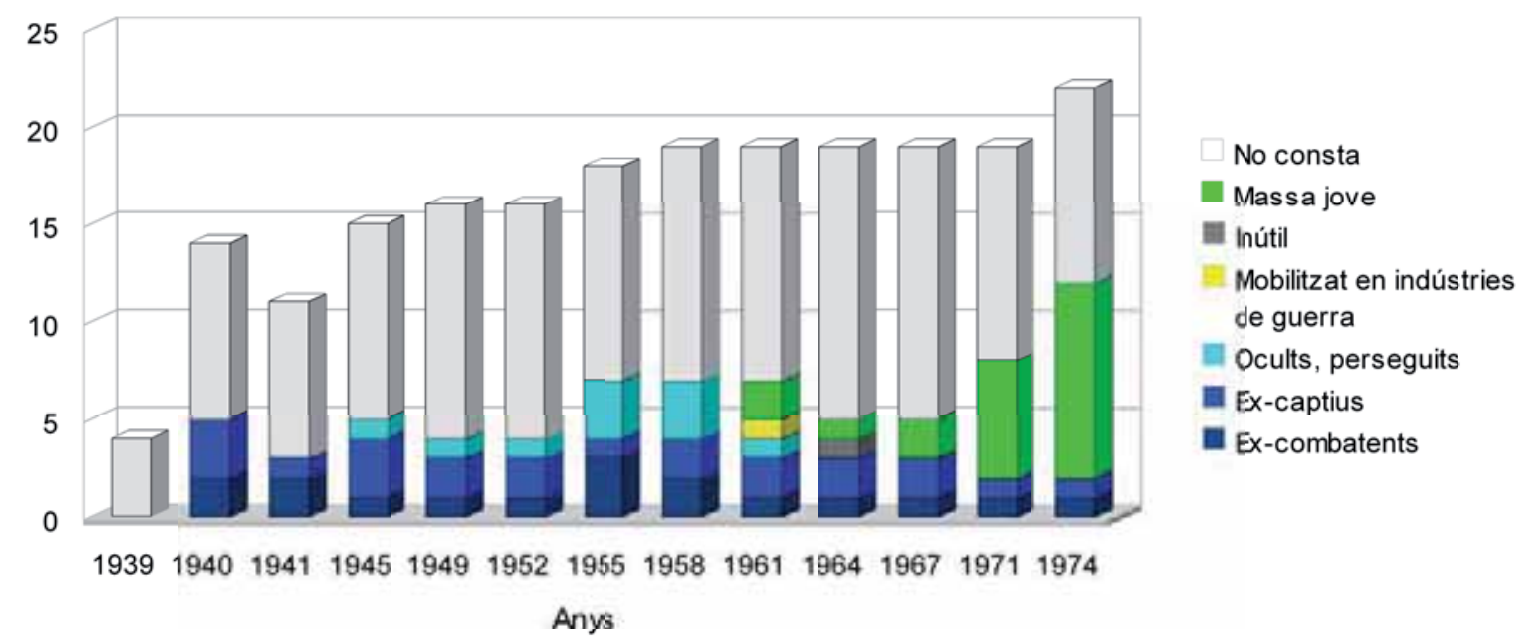




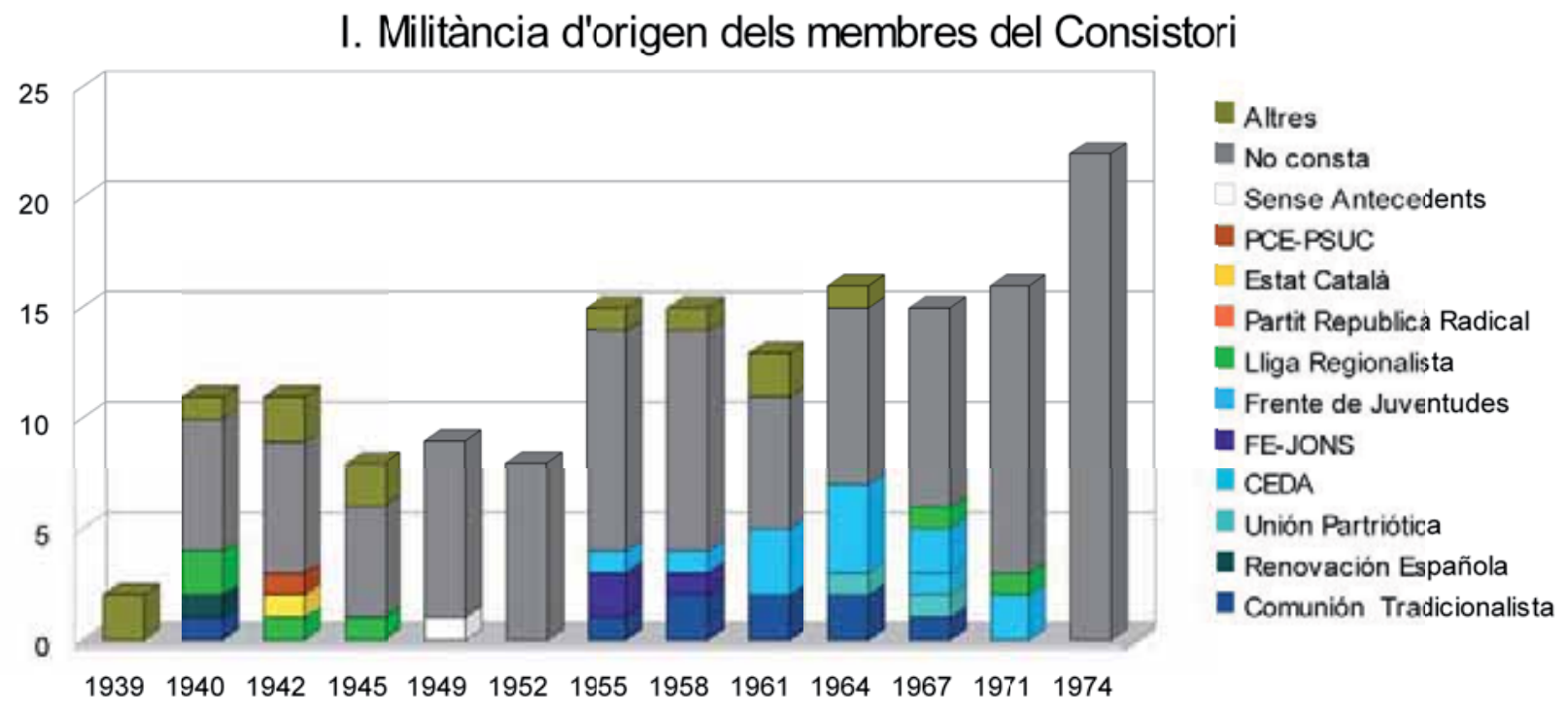

II. Relació amb FET-JONS dels membres del Consistori

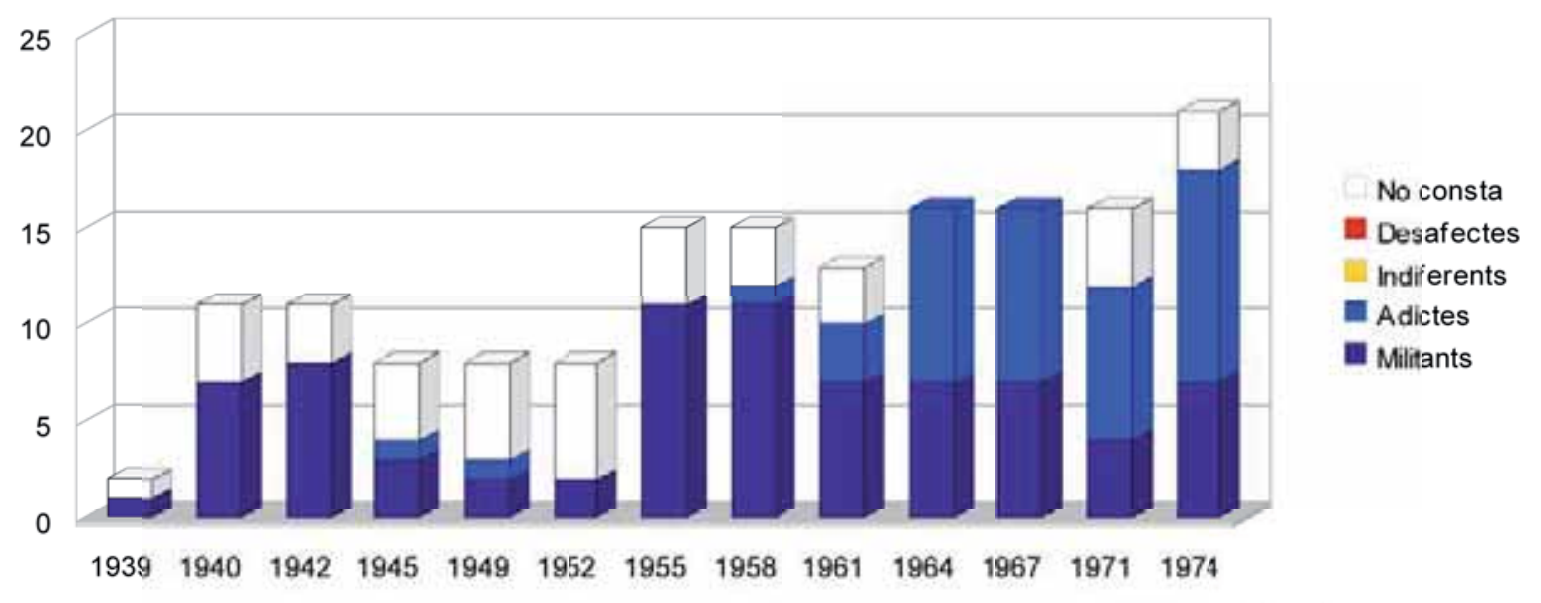

III. Relació amb la Guerra Civil dels membres del Consistori

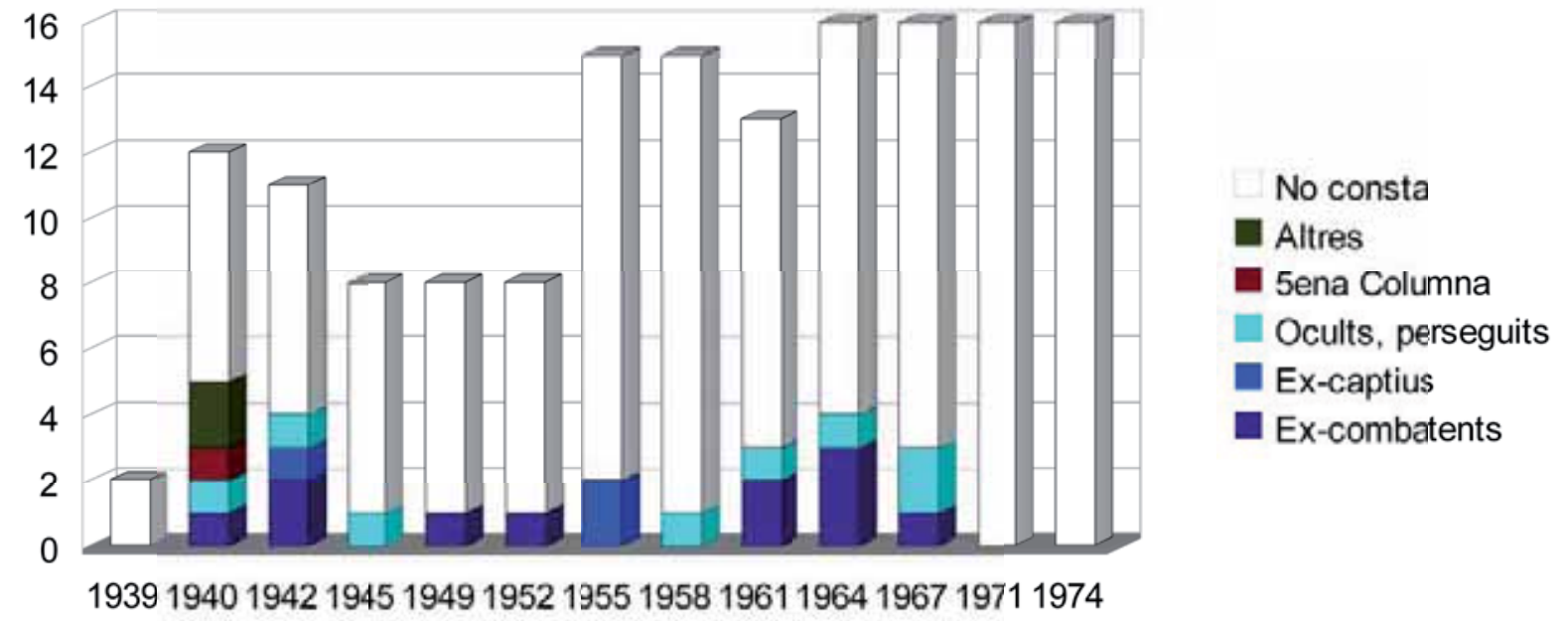




\section{Ajuntament de Sant Adrià de Besòs. Alcaldes i regidors}

I. Militància d'origen dels membres del Consistori

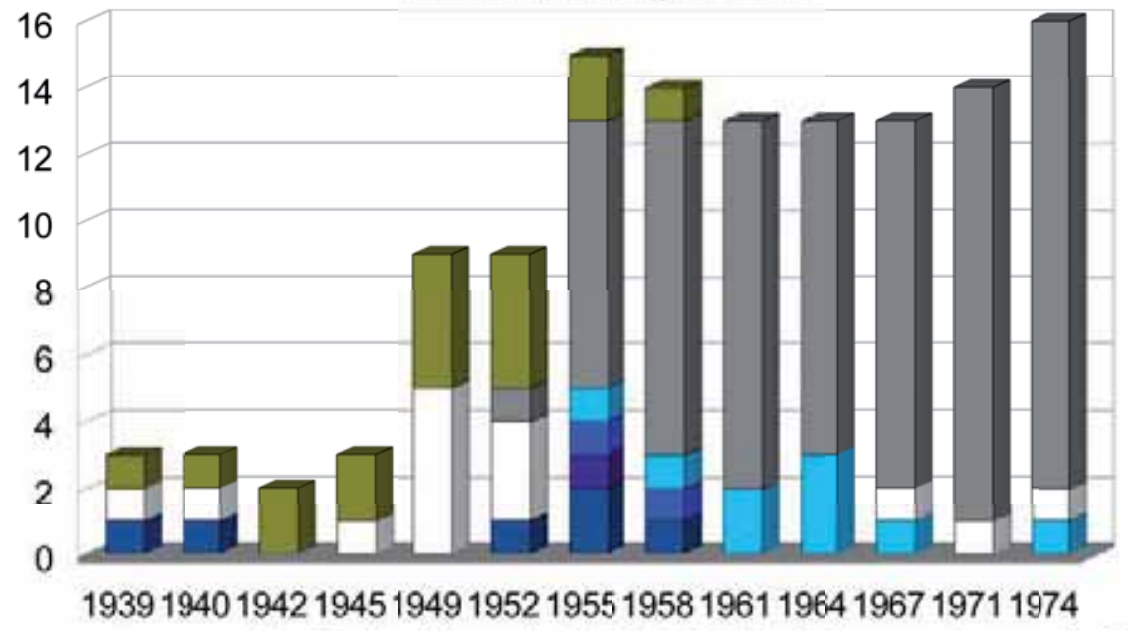

Altres

No consta

Sense Antecedents

Frente de Juventudes

SEU

FE-JONS

Comunión Tradicionalista

II. Relació amb FET-JONS dels membres del Consistori

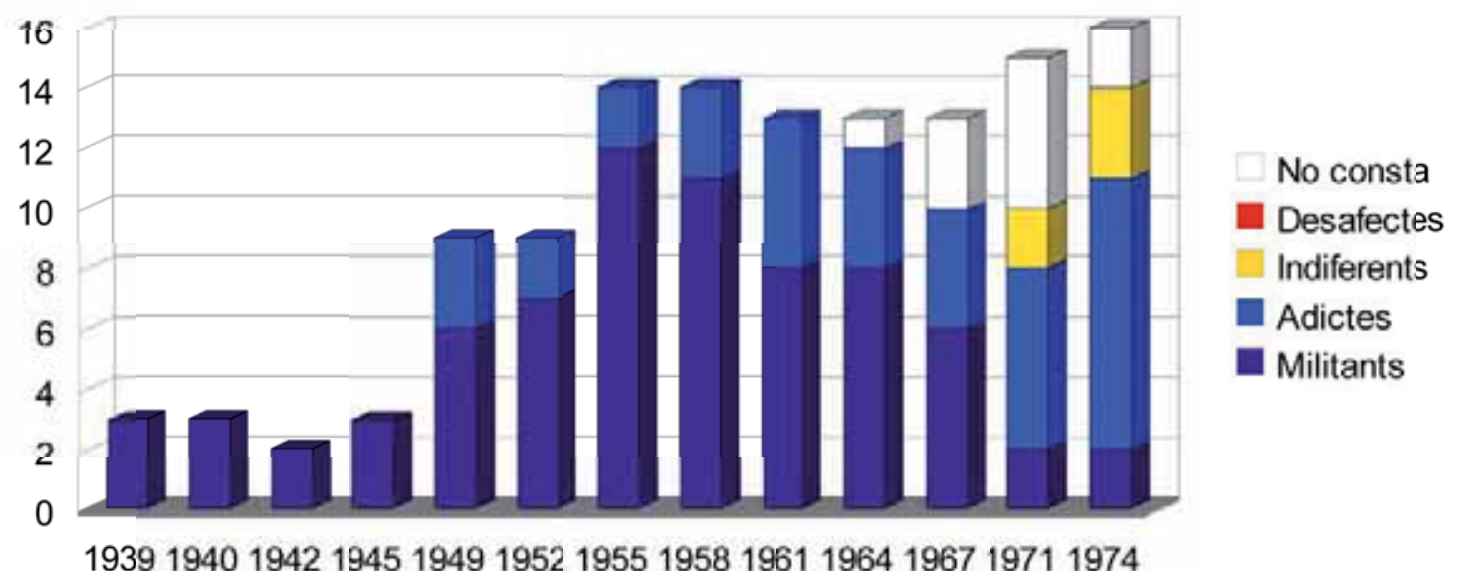

III.Relació amb la Guerra Civil dels membres del Consistori

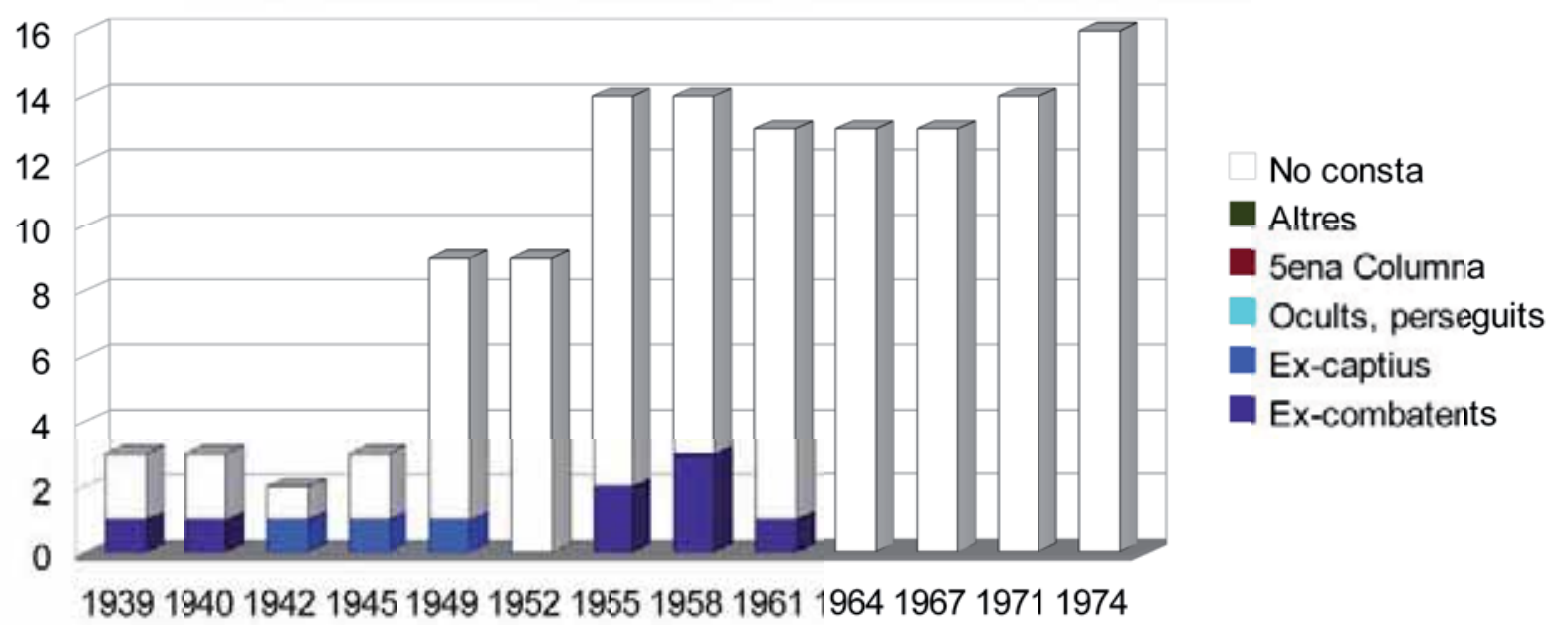

Fonts: Arxiu de la Corona d'Aragó, Arxiu Històric del Govern Civil de Barcelona i Arxiu General de l'Administració ${ }^{267}$

267Tinc que agrair al meu director de Tesi, Martí Marín, em em facilités les dades que va recopilar a l'Arxiu de la Corona d'Aragó (“Comisiones Gestoras 1939-1948"; “Elecciones Municipales 1948- 
Als anys cinquanta el Governador Civil Felipe Acedo Colunga va intentar ampliar les bases polítiques locals del franquisme, oferint càrrecs de l'administració local a persones que no tenien un perfil tant marcat per mèrits de guerra o de períodes anteriors. Cal entendre aquesta maniobra dins els canvis que estava fent el franquisme per aconseguir una acceptació internacional. Uns canvis que en molts casos eren "de façana" però que reflectien una preocupació important dels aparells estatals per aconseguir afermar la dictadura ${ }^{268}$. Però els canvis més importants no vindran fins al final de la dècada, coincidint amb altres que s'estaven donant a instàncies superiors com l'entrada dels ministres de l'Opus Dei al govern a partir de 1957 i el canvi de política econòmica amb el "Plan de Estabilización" de 1959. Amb la fi de la política repressiva envers la immigració a partir de l'any 1957, el franquisme va mirar d'exercir un major control en aquelles barriades barraquistes o d'autoconstrucció poblades per gent nouvinguda que fins al moment havien menystingut. I es va intentar fer de diverses maneres.

Una va ser impulsant, des de les Corporacions locals, una figura existent des dels anys 40, però fins al moment menystinguda: el "Alcalde de Barrio". Aquest venia a ser una mena de representant de l'Ajuntament a les respectives barriades, a través dels quals s'havien de fer les diferents gestions i peticions. Cristóbal Rizo del Castillo, que va ser Alcalde de Barri de Llefià durant els anys seixanta i part dels setanta ens ho deixava força clar:

\footnotetext{
"La misión del alcalde de barrio es una delegación de la autoridad municipal, que si bien tiene unas normas concretas que cumplir, por otra parte, el vivir de los problemas de toda índole de modo directo, le colocan en situaciones complejas que abarcan desde los problemas familiares a los de vecindad y des de los de urbanismo a los sanitarios; en fin, procurar con buena voluntad que impere la comprensión y la convivencia y, si es necesario, si el buen sentido no se impone, recurrir a la energía, si es preciso apoyada en la fuerza que la autoridad le concede, aunque afortunadamente
}

1967" i “Constitución de Ayuntamientos 1939-1965”) i a l'Arxiu del Govern Civil de Barcelona ("Administración local. Relevos de alcaldes 1962-1975"; "Administración local. Elecciones municipales, 1967-1976"; "Administración local. Ayuntamientos desde 1939"; "Gobernadores. Gobernadores civiles, 1951-1979"; “Gobernadores. Subgovernadores civiles, 1975" i "Secretaria política. Relevos de aldeldes, 1951,1963”). Sense aquestes no hauria estat possible elaborar les anteriors gràfiques.

268Per l'evolució de la dictadura imprescindibles la consulta de Carme Molinero i Pere Ysas: El règim franquista. Feixisme, modernització i consens, Eumo Editorial (2ona edició revisada i ampliada), Vic, 2003 i, dels mateixos autors La anatomía del franquismo. De la supervivencia a la agonía, 1945-1977, Crítica, Barcelona, 2008. 
estos casos son raros." 269

Alhora es va intentar desenvolupar un model d'associacionisme propi per ampliar la seva base i alhora enquadrar i canalitzar sectors importants de població. Malgrat l'aparent derrota dels postulats falangistes més "purs" al 1956 identificats amb el fracàs de José Luis de Arrese i els seus seguidors, el falangisme no només no va desaparèixer de l'escena política sinó que va contraatacar ${ }^{270}$. Un nou grup falangista, encapçalat ara per José Solís va intentar revertir la situació apropiant-se -per dir-ho d'una manera- de la "representació de les masses". Un Decret de 20 de Juny de 1957 reorganitzava els serveis de la Secretaria General del Movimiento, dintre del qual dos articles estipulaven la creació d'una Delegación Nacional de Asociaciones a la qual s'havien d'integrar totes les dependents del Movimiento existents fins aquell moment, les que volguessin adherir-s'hi a aquest i, encara, d'altres que poguessin crear-se encara per determinar (Arto 8). Alhora el decret establia la facultat de fomentar la creació i funcionament d'Associacions o entitats de "cabezas de Família", recollint el principi doctrinal de que la família era un dels canals de participació en les tasques públiques (Arto 9) ${ }^{271}$

En aquest context cal analitzar el paper que va jugar el Ministro Secretario General del Movimiento José Solís Ruiz -amb el suport de Manuel Fraga Iribarne, primer Delegado Nacional de Asociaciones ${ }^{272}$ - en l'intent de creació d'un model

269Ruiz Perich: "Entrevista a don Cristóbal Rizo del Castillo", Albada (revista editada per l'entitat Círculo Católico de Badalona) núm. 7 (juny-juliol 1962), p. 8.

270Veure el conjunt de conclusions que sobre la llarga continuïtat de la Falange estan contingudes en l'obra col-lectiva de Miguel Ángel Ruiz Carnicer (ed.): Falange. Las culturas políticas del fascismo en la España de Franco (1936-1975), Intitución Fernando el Católico, Zaragoza, 2013. Veure, igualment, el que ja havien anticipat sobre la qüestió de la crisi de 1956-62 Carme Molinero i Pere Ysàs: La anatomía del franquismo..., p. 18-39.

271 La referència està extreta d'un document posterior, segurament de Governació o Presidència on s'analitza críticament el document presentant per José Solís Ruiz: "Anteproyecto de Decreto Organizando las Asociaciones de Vecinos Cabezas de Familia; Incorporadas al Movimiento Nacional", Archivo General de la Administración (AGA), Fondo Presidencia, Caixa 52/388, p. 2. Agrair a Ximena Machado per posar-me sobre la pista d'aquesta documentació i facilitar-me algun document.

272Sobre les Asociaciones de Cabezas de Família -tot i que no comparteixo algunes valoracions generals que fa sobre el franquisme- veure Pedro Cobo Pulido: "Las asociaciones de cabezas de familia como cauce de representación: un fallido intento de apertura del régimen franquista" a Espacio, Tiempo y Forma, Serie V, Historia Contemporánea. 14,2001, p. 437-488 i Representación familiar en la época de Franco (1945-1974). Un caso de evolución de un régimer autoritario, Departamento de História Moderna y Contemporánea, Facultad de Filosofia y Letras de la Universidad de Málaga. Sobre la figura de Manuel Fraga Iribarne i la seva trajectòria dins l'aparell franquista, veure la Tesi Doctoral Inèdita de Miguel Ángel del Río Morillas: De la extrema derecha neofranquista a la derecha conservadora: los orígenes de Alianza Popular (1973- 
d'associacionisme familiar franquista subordinat al partit únic quan es debatia quines associacions estarien sota la tutela d'aquesta Delegació Nacional (alhora que també s'estava debatent la "Ley de Principios Fundamentales del Movimiento", aprovada el 17 de maig de 1958). Aquest fet, juntament amb la més coneguda proposta de revitalitzar els sindicats, demostrava que els els partidaris d'una Secretaria General del Movimiento amb més autonomia i poder estaven lluny de resignar-se.

Un primer intent va ser la elaboració d'un "Anteproyecto de Estatuto de Asociaciones del Movimiento" a finals de 1957 i principis de 1958. Aquest pretenia que les associacions adscrites al Movimiento tinguessin plena autonomia, escapant al control de Governació ara que aquest ministeri ja no estava en mans del falangista Blas Pérez sinó del militar de l'anomenat círculo de El Pardo, Camilo Alonso Vega. L'oposició d'aquest ministeri va impedir l'aprovació de l'avantprojecte, si bé es va reconèixer a la Secretaria General del Movimiento que les seves associacions només estarien sota la seva jurisdicció ${ }^{273}$.

Poc després Solís enviava als diferents ministres del govern des de la Secretaria General del Movimiento, el 4 de març de 1958 un "Proyecto de Decreto sobre las Asociaciones Familiares de Cabezas de Família incorporadas al Movimieno Nacional” als diferents ministres del govern ${ }^{274}$, que començava així:
"Ha sido un tema constante de la doctrina tradicional española, inspirada en todo momento por la doctrina de la Iglesia, la importancia de la familia como sillar fundamental en la organización de la Sociedad, y como contrapeso eficaz en los excesos de las doctrinas individualistas.
Este principio fué recogido desde el primer momento por el ideario de Falange Española, cuyos fundadores insistieron siempre en al triada de la Familia, el Municipio y el Sindicato, como bases del nuevo orden social y político orgánico, opuesto a la estructuración inorgánica de los partidos políticos. Así, decía José Antonio Primo de Rivera, en el Discurso Fundacional, pronunciado en el Teatro de la Comedia, el 29 de Octubre de 1933: "Nadie ha nacido nunca miembro de un partido político; en cambio,

1979), Universitat Autònoma de Barcelona, Bellaterra (Cerdanyola del Vallès), juny 2013 i també la Tesi Doctoral -en procés d'elaboració- Ximena Machado: Manuel Fraga Iribarne y la tentativa de aggiornamento franquista.

273Pedro Cobo Pulido: "Las asociaciones de cabezas de familia como cauce de representación..., p. 446-447.

274Carta de José Solís Ruiz a tots els ministres adjuntant la documentació pertinent. AGA, Fondo Presidencia, Caixa 51/18374, Dossier “Asociaciones de Vecinos Cabezas de Familiares”. 
nacemos todos miembros de una familia; somos vecinos de un municipio; nos afanamos todos en el ejercicio de un trabajo. Pues si esas son nuestras unidades naturales, si la familia, y el municipio y la corporación es en lo que de veras vivimos ¿para qué necesitamos el instrumento intermediario y pernicioso de los partidos políticos, que para unirnos en grupos artificiales empiezan por desunirnos en nuestras realidades auténticas?"275

Ni més ni menys que invocant la figura de Jose Antonio Primo de Rivera i recordant la voluntat orgànica d'organització i enquadrament de la població en la família, el municipi i el sindicat, Solís esmentava el magisteri de l'Església per refer els ponts amb el nacionalcatolicisme que Arrese semblava haver trencat en les disputes de 1956-57, sense renunciar a les intencions primigènies de predomini de la Secretaría General del Movimiento. Es feia referència també -entre d'altres, al punt 6 del Movimiento, a l'article XII, núm. 3 del "Fuero del Trabajo" o fins i tot a l'article 20 del "Fuero de los Españoles" que parlaven de la família i la seva "representació" 276.

El fet de que des de la Secretaria General del Movimiento es posés aquest èmfasi en un tema que havia de ser discutit en un Consell de Ministres ens posa de manifest que no estem davant d'una qüestió secundària ${ }^{277}$. No obstant, quines eren les funcions que l'avantprojecte de Decret reservava per aquestes associacions? L'avantprojecte deia textualment:

"Artículo 5ํ.- Las Asociaciones de Vecinos Cabezas de Familia tendrán las siguientes funciones:

1ạ-- Actuar como centros locales de iniciativas, en todos los asuntos de interés común, asistiendo al efecto a las corporaciones y autoridades competentes, y en particular a lo

275Secretaria General del Movimiento: "Proyecto de Decreto organizando las Asociaciones de Vecinos Cabezas de Família, incorporadas al Movimiento Nacional. Exposición de Motivos", (1958), AGA, Fondo Presidencia, Caixa 51/18374, Dossier "Asociaciones de Vecinos Cabezas de Familiares", p. 1. El subratllat és de l'original. En 1958 la Secretaría General del Movimiento estava ocupada per José Solís Ruiz. De manera que tot i que el document no està signat, és probable que sigui obra seva.

276Secretaria General del Movimiento: "Proyecto de Decreto organizando las Asociaciones de Vecinos Cabezas de Família... Exposición de Motivos", (1958), AGA, Fondo Presidencia, Caixa 51/18374, Dossier "Asociaciones de Vecinos Cabezas de Familiares", p. 2. El subratllat és de l'original.

277Fins i tot entremig la documentació que vaig poder trobar al Archivo General de la Administración, una nota manuscrita amb el segell del "Consejo de Ministros" afirmava: "es tema tan importante y tan fundamental que debiera ocupar una serie de reuniones de la Junta Política". Consejo de Ministros, [nota manuscrita], AGA, Fondo Presidencia, Caixa 51/18374, Dossier "Asociaciones de Vecinos Cabezas de Familiares". 
relativo a la promoción de los intereses de la localidad, obras públicas, ornato urbano, fomento del turismo, y otras semejantes.

2 a.- Vigilar el buen funcionamiento de las instituciones educativas, a cuyo efecto podrán cursar las oportunas propuestas o informaciones a los organismos competentes, en los que se procurará darles adecuada representación.

3a-- Asistir en lo posible a las autoridades y juntas encargadas de la beneficencia pública en todas sus formas; y proponer lo más adecuado en materia de ayuda a las familias numerosas.

4a - Asistir e informar en las cuestiones de moralidad pública, protección de menores, y cuantas afecten al ambiente moral de la localidad.

5 a.- Cualesquiera otras que reanunden en una mayor participación del vencindario en la vida comunal, y en el cumplimiento de los fines del Movimiento nacional dentro del mismo ámbito, utilizando al efecto todos los medios y recursos que permite la legislación vigente."278

En estar adscrites al Movimiento Nacional (i per tant, haver de subscriure els seus principis) no havien de representar -teòricament- cap perill pel règim. Tot $\mathrm{i}$ així la tramitació d'una llei que permetés el desenvolupament d'aquestes associacions va ser un procés lent i no reeixit, per les discrepàncies que aquestes associacions provocaven dintre del mateix franquisme, en tant que fonts possibles de fraccionalisme. Com informava un document adjunt, dins el mateix Ministeri de la Governació hi havia tres postures respecte l'avantprojecte de decret. Dues d'aquestes posaven unes certes objeccions. Una defensada per López Rodó, era de caire "legalista" en el sentit que calia una llei genèrica que definís i limités el principi d'associació. Alhora, defensava que el control d'aquestes associacions l'havia de tenir el Ministeri de la Governació. A aquesta s'afegia -tot i que en un sentit obertament contrari al de López Rodó- la postura exposada en un dictamen d'un Gabinet d'Estudis (al document original no diu de quin ministeri) escrit per José García Hernández, (falangista i ex-director General d'Administració Local amb Blas Pérez, 1951-57) que creia que les Associacions serien inoperants per les escasses funcions que se lis atribuïen. A favor en canvi es va manifestar el titular de la Direcció General de Política Interior, Blas Tello, clarament alineat amb Solís

278Secretaria General del Movimiento: “Anteproyecto de Decreto Organizando las Asociaciones de Vecinos Cabezas de Familia, Incorporadas al Movimiento Nacional”, AGA, Fondo Presidencia, Caixa 51/18374, Dossier “Asociaciones de Vecinos Cabezas de Familiares", p. 7-8. 
(un falangista de primera hora que Alonso Vega havia heretat de Blas Pérez i que seria rellevat del seu càrrec aquell mateix any en favor de José Luís Taboada, també falangista, no obstant ${ }^{279}$.

El mateix document exposava els arguments favorables a la creació d'aquestes associacions. Primer els de tipus polític, en el sentit que aquestes Asociaciones de Cabezas de Família eren l'únic tap seriós al ressorgiment d'antics partits polítics -o al sorgiment d'altres de nous- i alhora permetien eixamplar la base social del franquisme ${ }^{280}$. A nivell jurídic s'argumentava que no es contradeia la Llei d'Associacions de 1887 (que es feia servir amb unes modificacions fetes al 1941 fins l'elaboració de la nova Llei d'Associacions de l'any 1964) ja que la modificació que es va fer en el seu article 5è eximia d'aquesta norma a les organitzacions sindicals i les que estaven subjectes a la disciplina de FET-JONS. Tot plegat posa de relleu un episodi més de la lluita interna per la primacia dins del govern que es posava de manifest, més en cara, amb la resposta a algunes de les objeccions plantejades:

\begin{abstract}
"En cuanto a la objeción de que les damos pocas facultades, es característico de un espíritu negativo: si desde ahora hablásemos de su intervención en la vida municipal o provincial, o de su representación en el Consejo Nacional, etc. dirían lo contrario.

En resumen, las Asociaciones que se proponen, están justificadas políticamente; no plantean problemas por su dependencia directa de los Jefes Provinciales, que son a la vez Gobernadores; no limitan el derecho de asociación, que es obvio que subsiste para otros fines, con absoluta libertad; y se mueven dentro de la legalidad vigente, que sería intolerable querer restringir en perjuicio del Movimiento Nacional."281
\end{abstract}

Però Solís no se'n va sortir a l'any 1958. El fet de que les Asociaciones de Cabezas de Família haguessin de dependre o estar adscrites a la Secretaria General del Movimiento va tenir una forta oposició, sobretot des de Governació, que no volia que aquestes noves associacions escapessin al seu control directe. En el fons

279Secretaría General del Movimiento: "Información Confidencial sobre el proyecto de Decreto de Asociaciones de Cabeza de Familia", (1958), AGA, Fondo Presidencia, Caixa 51/18374, Dossier "Asociaciones de Vecinos Cabezas de Familiares", p. 2-3. Els perfils de García Hernández i Blas Tello es poden començar a construir amb Martí Marín:

280Veure la nota 180 a l'inici del present capítol, on apareix una cita textual del document en aquest sentit.

281Secretaría General del Movimiento: "Información Confidencial sobre el proyecto de Decreto de Asociaciones de Cabeza de Familia", (1958), AGA, Fondo Presidencia, Caixa 51/18374, Dossier "Asociaciones de Vecinos Cabezas de Familiares", p. 4. 
cal adscriure aquesta oposició també a les reticències que tenien una fracció dels franquistes, Carrero i d'altres, a perdre parcel-les de poder. Aquestes tensions dins el partit únic (o organismes dependents) i màxims dirigents estatals també es va donar en altres casos com en l'Alemanya nazi o la Itàlia feixista.

Els arguments que es van fer servir des de el Ministeri de la Governació en contra de la proposta de Solís van ser diversos: que les noves associacions no s'ajustaven al Decret de 1941 que havia modificat la Llei d'Associacions de 1887 aleshores vigent, que la creació per Decret d'aquestes Associacions contradeia l'article 16 del Fuero de los Españoles que regulava la "llibertat d'associació" i que en ser "Ley Fundamental" tenia un rang superior ${ }^{282}$. Si be l'excusa d'una suposada "restricció del dret a la llibertat d'associació", com no podia ser d'una altra manera, no s'ho creien ni ells mateixos:

"No se estima necesario utilizar el argumento de que al constituirse como tuteladas determinadas asociaciones, como las de cabezas de familia, se merme la libertad de derecho de Asociación reconocido en el Fuero de los Españoles; pero es evidente que mientras no se altere con norma de rango legal la legislación hoy vigente, no se pueden constituir las Asociaciones de Vecinos Cabezas de Familia con la simple autorización de la Secretaría General del Movimiento."283

Aquesta discussió era encara més complexa -o falaç- en tant el franquisme no tenia constitució i la interpretació de les anomenades Lleis Fonamentals estaven subjectes a l'arbitri total del mateix dictador, Francisco Franco, la paraula del qual era la veritable llei (una característica eminentment feixista). Tot era una lluita per parcel-les de poder. S'argumentava també que aquestes noves associacions solapaven les funcions ja reservades al "Tercio Familiar" de les Corporacions Locals. Però apart de tots aquests arguments ja exposats i la evident pugna pel poder existent dins l'aparell de l'Estat franquista, hi ha un altre motiu que des de Governació s'objecta en contra de l'Avantprojecte de Decret i que és fonamental: la por a crear unes associacions que no puguin controlar directament ni tampoc als

282 Ministerio de la Gobernación: "Nota sobre el Anteproyecto del Decreto Organizando las Asociaciones de Vecions Cabezas de Familia, incorporadas al Movimiento Nacional", AGA, Fondo Presidencia, Caixa 52/388, p. 1.

283 [Document no signat, però que prové segurament també del Ministerio de la Gobernación]: "Anteproyecto de Decreto organizando las Asociaciones de Vecinos Cabezas de Familia; Incorporadas al Movimiento Nacional. IV. Observaciones en cuanto al fondo del proyecto", AGA, Fondo Presidencia, Caixa 52/388, p. 5. 
seus membres, i que puguin ser utilitzades per elements "desafectes":

"Podría suponerse que lo que se intenta con esta medida es atraer a la esfera del Movimiento Nacional un conjunto de grupos personales que hagan posible la ampliación de la base del Movimiento Nacional. Tal criterio puede considerarse equívoco, puesto que lo único que cabría decir es que se enquistarán nuevos sectores a la Secretaría General que no se identificarán con la doctrina del Movimiento. En otra distinta proyección cabe preguntarse, si la base política del Movimiento Nacional , en cuanto doctrina que nutre el régimen actual, está ampliada, por ejemplo, con los propios Sindicatos. Desde el aspecto formal pudiera contestarse en sentido afirmativo, pero en cuanto pueda significar de adhesión de las masas obreras a tales principios, no cabe hacerse demasiadas ilusiones.

Pero si en el caso de la organización sindical, las razones formales son, de por sí, suficientes para encauzar, en su seno, todas las enormes y poderosas fuerzas del mundo laboral, no advertimos qué razones son las que existen ahora para abrir camino a esas Asociaciones de Vecinos Cabezas de Familia, cuya necesidad no se reclama y cuyo porvenir carece de perspectivas; pues si bien es conocida y de lamentar la general atonía y, de otra parte, la incontrolada acción de minorías disidentes, todo ello dentro de lo que hay que suponer selecto núcleo que constituyen los militantes adheridos, hemos de preguntarnos si con esas asociaciones va a conseguirse más entusiasmo, unidad y disciplina en la acción política del pueblo español."284

Es interessant observar en aquests fragments una al·lusió a la consciència que es té de la desafecció de la classe obrera respecte postulats del règim i també -potser- una de velada al les protestes universitàries de 1956-57, protagonitzades per un sector de població que per origen social el règim pressuposava com "afectes". Així, el Ministeri de la Governació concloïa les seves afirmacions de manera contundent:

“En consecuencia, por lo que afecta al Ministerio de la Gobernación creemos que las Asociaciones de Vecinos cabezas de familia, con el alcance que al parecer quiere dárseles, significan una importante transformación en el régimen de Asociaciones (hay más de 9.000 Ayuntamientos en toda España), que se escamoteará al Departamento en este punto, creándose además un peligro que puede llegar a ser de extraordinaria gravedad para el orden público, y atacando en sus propios cimientos el

284 [Document no signat, però que prové segurament també del Ministerio de la Gobernación]: "Anteproyecto de Decreto organizando las Asociaciones de Vecinos Cabezas de Familia; Incorporadas al Movimiento Nacional. IV. Observaciones en cuanto al fondo del proyecto", AGA, Fondo Presidencia, Caixa 52/388, p. 5-6. 
Régimen Local."285

D'aquesta manera, el projecte presentat per José Solís no es va aprovar inicialment. Però el debat restava obert. La qüestió s'havia considerat prou important per que els mateixos principis VI i VIII del Movimiento Nacional (aprovats el 17 de maig de 1958), reconeguessin la família com "una estructura bàsica de la comunitat nacional". I també per que la qüestió de l'associacionisme familiar es tornés a tractar en un "I Congreso de la Familia Española" el 19 de febrer de 1959 a Madrid, inaugurat pel mateix Francisco Franco. En aquest i en el II Congrés celebrat al juliol de 1960, Solís tornava a la càrrega però de nou era incapaç d'aconseguir una victòria complerta i havia de consentir que d'entrada les "Associaciones Generales de Cabezas de Família" no estiguessin adscrites formalment al Movimiento, que com a molt les podia fomentar i que n'existissin també per l'impuls de l'Església o de particulars. Es parlava també de la creació de Consells Provincials i d'un Consejo Nacional d'aquestes, contemplats com a òrgans de "consulta, promoción e i información del Estado en orden a sus fines"286. De la mateixa manera es recomanava que es desenvolupés legislativament la participació familiar. Solís, en el seu discurs de cloenda del II Congrés deixava veure les crítiques a aquestes limitacions quan afirmava, textualment:

\footnotetext{
"Yo no comprendo como alguien puede discutir la posibilidad que tenemos de ser uno de los pilares fundamentales de nuestro Movimiento. Yo no comprendo que, cuando los hombres que tenemos, porque Dios así lo ha querido, la responsabilidad de una familia y la responsabilidad de estar presentes en la defensa de sus intereses, alguien hurte esta posibilidad. Yo no comprendo cómo, cuando podemos garantizar la continuidad de una comunidad política regida por la Ley de Dios y encaminada a defender la familia, hay quién titubea y cree que esto puede hacer daño."287
}

Seguint la recomanació del II Congrés començava un procés de preparació del

285Ministerio de la Gobernación: "Nota sobre el Anteproyecto del Decreto Organizando las Asociaciones de Vecinos Cabezas de Familia, incorporadas al Movimiento Nacional", Archivo AGA, Fondo Presidencia, Caixa 52/388, p. 4.

286“Documentación Relativa a la representación de la Familia en España. Conclusiones del II Congreso de la Familia Española. Resolución I. La familia en la Doctrina del Movimiento. La Representación Familiar", AGA, Fondo Presidencia, Caixa 51/9837, p. 22.

287“Documentación Relativa a la representación de la Familia en España. Conclusiones del II Congreso de la Familia Española. Discurso del Ministro Secretario General del Movimiento en la clausura del II Congreso de la Familia Española", AGA, Fondo Presidencia, Caixa 51/9837, p. 9. 
Avanprojecte de Llei, on no només van participar persones provinents de la Secretaria General del Movimiento sinó també de la Jerarquia Eclesiàstica i algunes entitats vinculades a ella, en tant també tenien un especial interès en desenvolupar aquest tipus d'associacions per estendre la seva influència. D'aquesta manera l'Avantprojecte redactat contemplava que existissin associacions de l'Església fora de la jerarquia del Movimiento. Però quan aquest va passar pel Consejo Nacional del Movimiento el març de 1963 es van introduir una sèrie de modificacions que -un cop més- no van agradar a Governació, per que donaven més pes a la Secretaria General del partit únic que entre d'altres coses podria proposar candidats a les eleccions al Tercio Familiar a través de les Asociaciones de Cabezas de Familia. Encara va tenir una major reticència quan es contemplava la mateixa possibilitat de fer-ho amb la representació del Tercio Familiar a les Cortes, així com la seva representació en nombrosos organismes estatals. A la Jerarquia Eclesiàstica tampoc li va agradar, en tant que, si bé es mantenia la facultat de l'Església de poder fer les seves associacions familiars, li havien tret la possibilitat de proposar candidats propis per l'esmentat Tercio Familiar ${ }^{288}$, o que haguessin de sotmetre's a una Federació provincial controlada pel Movimiento:

“OCTAVA.- 1. En cada provincia, y en el seno del Movimiento, se establecerá una Federación provincial de Asociaciones Familiares, que tendrá el carácter de corporación de Derecho Público, y de la que formarán parte las generales de Cabezas de Familia, y con carácter voluntario las Asociaciones Familiares de otra índole que se adhieran a la misma." 289

Després de diversos estires i arronses, el Projecte de Llei va ser aprovat pel Govern el 12 de juny de 1964 amb alguna petita modificació. Però també havia de passar el tràmit de les Corts i aquí va ser on el projecte es va encallar per l'oposició de Governació, Presidència i part de la Jerarquia Eclesiàstica, que apart dels motius ja esmentats, no volien ni de lluny que les "Asociaciones de Fines Específicos" (com per exemple les de Mestresses de casa, pares, disminuïts psíquics...), subordinades a Governació, i les de l'Església catòlica, tot i no dependre formalment, s'haguessin 288Pedro Cobo Pulido: "Las asociaciones de cabezas de familia como cauce de representación..., p. 456.

289“Representación Pública de la Familia. Texto de las Directrices aprovadas por el Pleno del Consejo Nacional del Movimiento. Madrid, 9 de marzo de 1963", AGA, Fondo Presidencia, Caixa $52 / 388$, p. 4. 
de sotmetre a la Secretaria General del Movimiento si volien participar en la vida pública $^{290}$.

I, sobretot, el que no volien ni Governació ni Presidència és que aquestes associacions poguessin presentar candidats al Tercio Familiar, i més en un moment on es preveia regular una representació d'aquest a les mateixes Cortes com es volia fer amb la Ley de Representación Familiar. També existia el temor que poguessin constituir futurs embrions de partits polítics. Però segurament el que hi ha darrera és una por manifesta a l'existència d'un monopoli consolidat per part de la Secretaria General del Movimiento en el terreny de l'associacionisme per part del grup de Carrero Blanco (Presidència), aliat circumstancialment a Camilo Alonso Vega (Governació). Finalment, tot i que des de la SGM s'havien creat Federacions Provincials de Asociaciones de Cabezas de Familia durant l'any 1965 i fins i tot una Unión Nacional de Asociaciones Familiares l'any 1966, Governació i Presidència van aconseguir vetar que poguessin proposar candidats a les eleccions al Tercio Familiar ja fos a nivell municipal o en les Corts, si bé en aquestes es va admetre la representació corporativa familiar ${ }^{291}$, encara que fos un fet merament formal. Certament la decisió final sobre els candidats depenia del governador civil/jefe provincial del Movimiento. Com que aquest era nomenat per Governació a proposta de la SGM, s'entén encara més l'obsessió de Carrero per lliurar-se de Solís i posar-ne una altra persona més dòcil (finalment ho va aconseguir al 1969 amb Torcuato Fernàndez Miranda).

Paral-lelament a aquest procés -i estretament lligat amb ell- es va fer una nova Llei d'Associacions l'any 1964 que havia de posar ordre a tot aquest entramat legislatiu i superar la Llei de 1887 que encara es feia servir amb les adaptacions de 1941. Segons Pamela Radcliff aquest fet constituí un intent d'apertura del règim o, al menys, fou una escletxa que va esdevenir imprescindible per al futur desenvolupament del moviment veïnal ${ }^{292}$. Però la intenció de la llei, en la perspectiva més àmplia que hem pogut veure aquí, no era aquesta ni de lluny, ni

290Pedro Cobo Pulido: “Las asociaciones de cabezas de familia como cauce de representación..., p. 460.

291 Ídem, p. 473-481.

292Pamela Radcliff: Making democratic citizens in Spain: civil society and the popular origins of the transition, 1960-78, Basingstoke, Hampshire [England]; New York, Palgrave Macmillan, 2011. Aquesta autora magnifica el paper del canvi legislatiu en detriment d'altres factors. 
aquest factor, per si sol pot explicar l'aparició d'un potent moviment associatiu els anys posteriors (sense que això no signifiqui que tal i com passava a la OSE, s'intentés aprofitar la legalitat existent). Podem veure aquest fet analitzant alguns aspectes de la mateixa Llei.

El Instituto de Estudios Políticos va elaborar un avantprojecte de Llei l'any 1964 (al 1958 des de el Ministeri de la Governació s'havia presentat un altre projecte que no es va acabar d'aprovar). El present projecte contemplava un estricte control a través del Ministeri corresponent i dels Governadors Civils:

“Articulo 8:: ACCESO DE LOS REPRESENTANTES DE LA AUTORIDAD

1.La autoridad gubernativa tendrá acceso en cualquier tiempo, por representantes especialmente designados, al domicilio de una asociación, y el local en que se celebran sus reuniones. Podrá suspender toda sesión o reunión en que se cometa una infracción de orden público."293

Això sense comptar que devien facilitar un registre de socis exhaustiu a la Superioridad. De nou Presidència i Governació van fer modificacions, en especial per reforçar l'autoritat de l'Estat controlada per ells. Un exemple magnific és l'article 10 de la Llei aprovada finalment:

“Artículo 10. Disolución de las asociaciones. 1‥ Sin perjuicio de lo dispuesto en el artículo 16 de la Ley de Orden Público de 30 de julio de 1959, los Gobernadores Civiles podrán acordar la suspensión de las asociaciones por incumplimiento de sus estatutos o de sus obligaciones sociales, adopción de acuerdos o actos ilícitos o con ocasión de la comisión de delitos, supuesto que corresponderá a la Audiencia Provincial confirmar la suspensión acordada por el Gobernador Civil.

2‥ En todo caso, corresponderá a la autoridad judicial competente acordar la disolución de las asociaciones.

3ํㅡㄹ los propios supuestos contemplados en el anterior apartado 1 y sin perjuicio de lo establecido en el artículo 19 de la citada Ley de Orden Público, los Gobernadores Civiles podrá imponer sanciones hasta 25.000 pesetas, correspondiendo al Ministerio de la Gobernación el acuerdo de sanciones superiores a dicha cuantía o inferiores a la del patrimonio social." ${ }^{294}$

293Instituto de Estudios Políticos: "Anteproyecto de Ley de Asociaciones", AGA, Fondo Presidencia, Caixa 52/388, p. 5.

294“Justificación del Anteproyecto para una Ley de Asociaciones. Anteproyecto de la Ley de Asociaciones", AGA, Fondo Presidencia, Caixa 52/388, p. 19. No té segell oficial però sembla un document del Ministeri de la Governació. 
De manera, que sembla evident que no hi havia una voluntat "liberalitzadora", amb aquesta llei sinó precisament una adaptació als temps sense renunciar al control de l'aparell de l'Estat sobre el conjunt de la societat (una característica típica del feixisme). Per si hi havia algun dubte, un document intern del Ministeri de la Governació deixava clar la voluntat de la nova llei, en comparació amb l'anterior projecte de 1958:

"En suma, el nuevo Proyecto encubre, sin prescindir de él, en su suave literalidad, un régimen autoritario que se estima preciso y que en el Proyecto anterior se hacía patente, acaso de modo ostensible y poco político."295

Com es van veure reflectits aquests canvis legislatius a nivell local? Fins a quin punt van incidir-hi en el món associatiu existent? Paral-lelament a tot aquest debat intern dins l'aparell franquista, el cert és que als mateixos anys cinquanta ja havien començat a aparèixer associacions de veïns, regint-se per la legislació vigent aleshores, la ja esmentada Llei de 1887 amb les modificacions de $1941^{296}$. Va ser una casualitat la seva aparició? Segurament no. Les primeres de les que tenim constància a Badalona són les de Lloreda (1959), Sant Antoni de Llefià (1959, si bé no es va legalitzar fins 1968), Puigfred (1959), Sistrells (1961), Sant Joan de Llefià Alt (1963), Bachs-Bufalà (1963) i Bonavista (1963) ${ }^{297}$. Totes aquestes associacions van aparèixer en barris amb greus problemes urbanístics i amb elevats nivells de barraquisme i autoconstrucció. Ara bé, van sorgir per iniciativa pròpia o fomentades per les autoritats municipals, en la figura de l'alcalde de barri? Fins fa poc tenint en compte els anys en que es van crear i la composició de les seves Juntes, pensava que la majoria havien estat fomentades per les autoritats municipals o persones properes. I certament es pot constatar la presència i nexes entre els alcaldes de barri designats i aquest tipus d'associacions. Però quan he aprofundit en la meva recerca, puc afirmar, que hi ha uns quants matisos. Si bé és cert que en molts casos les seves Juntes seran controlades per persones "afectas",

295 Ministerio de la Gobernación: “Política Interior”, AGA, Fondo Presidencia, caja 52/388, p. 3.

296Un tema poc estudiat és l'existència d'associacions similars en el període anterior a la Guerra Civil i quin record es tenien d'elles. Per exemple, al barri de Llefià s'havia creat al 1930 una "Associació de Veïns i Propietaris de Llefià i Extensions", la qual sembla que va desaparèixer engolida per la fi de la guerra i la instauració de la dictadura. Veure José Miguel Cuesta Gómez: El moviment veïnal a Llefià..., p. 76-77. Més documentació d'aquesta entitat es pot trobar a l'Arxiu Històric de Llefià: $w$ ww.llefia.org/arxiu. 297 Josep Baeza: Associacionisme Veïnal a Badalona, FAVB, Badalona, 1998, p. 26. 
en no poques ocasions el seu procés d'aparició va ser més complex, igual que la seva composició, amb casos de presència en els seus organismes rectors de persones amb sensibilitat d'esquerres i fins i tot amb un present o passat de militància.

En dates tan primerenques com 1954, un testimoni ja esmentat anteriorment ens manifestava com davant el perill d'enderrocament dels seus habitatges autoconstruits en uns terrenys no qualificats com a edificables, els veïns de la barriada badalonina de Lloreda s'havien començat a organitzar en aquell mateix any per mirar d'evitar-ho. Aquesta primera associació -si fem cas al seu testimonino va aparèixer per intervenció municipal. El seu procés va ser iniciativa pròpia. Un procés força accidentat inicialment:

"Y luego vino un abogao, a los dos años o así (...) que presumía que había sido Gobernador de Mallorca en la guerra, que era republicano [la afirmació resulta òbviament incorrecta...] que el la causa de los pobres y tal. Y entonces el tio era un sinvergüenza, era un jeta... I le pudo sacar al dueño [de los terrenos] una moratoria de pago, mientras no se arreglara lo de los terrenos... mientras no se aclarara..

(...)

Y ese abogao, pues saco una moratoria de pago, y les sacó que nos pondrían la luz. No... una moratoria de pago y otra cosa más. Total, que por aquello el abogado nos quería cobrar un dineral, nos quería cobrar 80.000 pesetas o 40.000 (...) y después cobrarnos otro tanto... Eh... 'Preséntenos usted su minuta y nosotros le pagaremos conforme... Pero no nos haga usted el recibo a cada vecino...' Le cobraba 250 pesetas a cada vecino por aquello... y si en un solar habían dos.. porque muchos se compraron el solar entre dos, por que no tenían para comprárselo entre uno... Pues les cobraba a cada uno $250 \ldots$ Y nos negamos (...) a pagarle a el. Entonces llamamos a un notario, para que nos diera poderes al barrio ante notario. En el sótano este de Boada, vino el notario (...) a darnos poderes a nosotros para mirar de solucionar el asunto.

$(\ldots)$

Resulta que ese abogao cuando vió que tal... nos denuncia que estábamos repartiendo [inintel-ligible] (...)

Y por la tarde ya se había ido el notario, aparece allí el comisario con dos guardias: '¡A ver! ¡Esto que son!' una patada en la puerta y ipum!. '¡Reuniones clandestinas!' Y nos quedamos todos allí..."298

298Entrevista a Francisco Rodríguez, 21-6-2013. Membre fundador i primer President de l'AVV de Lloreda. 
Un primer intent de legalització va fracassar l'any 1957 quan es van presentar la documentació al Govern Civil perque des de l'Ajuntament, als papers adjuntats al governador una nota advertia textualment que "ojo, esto parece otra cosa"299. Si bé, per sort, l'accés a un advocat que tenia amistat amb el secretari del governador civil de Barcelona d'aleshores, Felipe Acedo Colunga, va facilitar posteriorment els tràmits de legalització de l'entitat, constituïda como tal l'any 1959, amb l'ajuda d'un advocat per la redacció dels seus Estatuts que van ser després "copiats" per altres entitats similars:

"Eso fue un gol que le metimos a Don Felipe, por que este Suarez, el abogao que vino, 'si esto no es político ni nada... si estos no buscan una asociación para ir en contra del régimen y todo eso... si son unos desgraciaos que han comprao un terreno, se han gastao sus ahorros (...) no comen para poder ahorrar las perras, y ahora tienen este problema... Estos lo que quieren es tener una fuerza jurídica para poder defenderse y poder ir a donde sea, presentarse a donde sea con un respaldo y de todos los vecinos... y constituidos en una agrupación, asociación o lo que sea'. Y este Casado Nieto pues se lo pasó... “300

Això si, després de les pertinents investigacions policials dels seus impulsors, com ens recorda el mateix entrevistat:

"Pues me llamó mi padre, y 'Paco, que es lo que pasa en Barcelona que me ha dicho el alguacil...' como en el pueblo se conoce todo el mundo, 'a pedir informes de tu hijo un hijo que tienes en Barcelona... ¿qué habrá hecho?’ “301

O com també es recull en un dels participants de la creació de l'AVV de Sistrells que tenia antecedents per haver estat exiliat:

"Un inspector de la guardia civil, en visitas sucesivas, que se efectuaban en mi propio domicilio. Deseo hacer resaltar, que dicho señor, fue en todo momento correctísimo en el cumplimiento de su deber, aunque por mi parte, jamás puse negativas a cualquier requisito que me formulara. Fueron tantas las visitas que este señor me hiciera, que lleguemos incluso a sostener conversaciones fuera del cometido, del cual él estaba encargado. Eso no quita que dicho expediente se confeccionara partiendo desde el día de mi nacimiento, hasta el día de la fecha en que quedó terminado, investigando desde

299Josep Baeza: Associacionisme Veïnal a Badalona, p. 178 i Entrevista a Francisco Rodríguez, 21-62013.

300Entrevista a Francisco Rodríguez, 21-6-2013.

301 Ídem. 
mi más prematura infancia, hasta el límite de mis últimos años, donde saliera para exilio.".302

La persona entrevistada del barri badaloní de Lloreda (Francisco Rodríguez) ens manifestava que la majoria dels pobladors del barri i de l'associació tenien una ideologia d'esquerres, com segurament no podia ser d'una altra manera quan la majoria de la població havia emigrat fugint de la misèria o de la repressió política dels seus pobles d'origen. Ara bé, això no vol dir automàticament que aquesta associació fes inicialment una política d'enfrontament oberta amb el Consistori i les autoritats, sinó que segurament, conscients de la correlació de forces del moment, van practicar una política possibilista.

A Sant Joan de Llefià Alt també hi havia un grup de veïns que es reunia clandestinament en un local del carré Urà des dels anys cinquanta i on hi havia alguna persona represaliada pel franquisme, com Juan Reina Abad, un antic militant de la CNT del qual tornaré a parlar més endavant ${ }^{303}$. D'aquí va sorgir una Junta de Veïns l'any 1954 i una de propietaris l'any 1960, fins que finalment al 1963 es va legalitzar una associació de veïns formalment presidida per una persona d'ordre com era Ramon Arjona en un procés on segurament les autoritats municipals hi van jugar el seu paper per controlar i "domesticar" un incipient moviment associatiu abans de que se'ls hi anés de les mans ${ }^{304}$.

En tots aquests casos les grans necessitats existents en els barris de l'extraradi badaloní eren un incentiu per l'autoorganització per aconseguir o reclamar els serveis més elementals. Així va passar també amb l'Associació de Bellavista, un nucli urbà on els veïns també es van haver d'organitzar per portar l'aigua i altres serveis bàsics. No obstant, aquest procés podia estar més controlat per persones properes al règim i amb nexes directes amb les autoritats:

"l'any cinquanta vuit va ser quan es va fer la primera associació de veïns, que és la del carrer Europa (...) jo vaig ser el primer Secretari i vam treballar molt pel barri, molt

302 Miguel López Parra: Historial Barrio Sistrells. 1924-1960. Asociación de Vecinos 1960-1974, p. 19. Estudi inèdit fet per un dels membres fundadors d'aquesta associació. Agraeixo a Diego Guerrero, també membre d'aquella associació que em facilités l'accés a aquest document. 303 No ho puc assegurar del cert, però és una hipòtesi força plausible extreta de l'entrevista a Francisco Rodríguez, que em va assegurar que Juan Reina Abad era del barri de Sant Joan de Llefià. A Llefià havia existit fins i tot una mena d'Associació de Veïns i Propietaris en els anys 30. 304Juan Rico Màrquez: Llefià. De la barraca a la dignidad, Autoeditat, Badalona, 2010, p. 86 i p. 201. 
molt molt (...) hi havia una gent estupenda, treballadors... després de treballar es ficaven allà (...) va fer moltes coses, els carrers (...) les clavegueres (...) hi havia el senyor Conesa que tenia una taverna, un bar, que tenia vi, i jo anava sempre amb una ampolla a buscar vi i xerràvem... que si això està malament (...) i vam començar a parlar de fer una associació, d'anar a l'Ajuntament a exposar com estava tot això. Amb altres veïns es va fer una comissió i com ens comprometíem a arreglar-ho sense pagar ni cinc l'Ajuntament ens va fer molt de cas. Després eren medalles que ells es posaven (...) i al mateix temps que es van crear les Associacions de Veïns es van crear els Alcaldes de Barri (...) al meu pare el coneixien, el senyor Estapé d'Artigues que era [Tinent d'] Alcalde d'Urbanisme, pues coneixia al meu pare d'això, d'anar a l'Ajuntament." 305

Així passava per exemple a Sant Antoni de Llefià, d'on procedeix l'anterior testimoni del fill del primer alcalde de Barri -Cristóbal Rizo del Castillo- i que va ser el primer secretari de l'esmentada Associació. Fulgencio Conesa va ser posteriorment regidor pel Tercio Familiar (i tornarà a aparèixer en el nostre estudi). Una primera Junta de Veïns ja havia fet una Comissió de Barri l'any 1957 i va impulsar l'associació el 1959, però amb predomini de persones "d'ordre"306. I semblant va ser el cas de l'AVV de Bachs-Bufalà, que va ser fomentada per José Luis Heredero, l'amo de l'empresa PIHER (una de les més importants de Badalona aleshores), que fins i tot va pagar la inscripció dels estatuts al Govern Civil ja que l'interessava resoldre uns problemes amb uns terrenys particulars. Va col-locar cop a President a un treballador seu, Antonio Forteza, que va ser posteriorment regidor pel Tercio Familiar i Tinent d'Alcalde ${ }^{307}$.

En el cas de la AVV de Puigfred sembla ser que a l'inici va respondre més a una voluntat dels habitants d'aquell barri tant precari, però aviat va ser controlada per persones franquistes ${ }^{308}$. No obstant, també va esperonar obres col-lectives amb la participació del veïnat, que si bé és cert que servia per estalviar feina, diners i

305Entrevista a Félix Rizo, 5-2-2007. José Miguel Cuesta: El moviment veïnal a Llefià (Badalona), Tesina de Doctorat, UAB, Setembre de 2010, p. 152. Ramon Arjona López havia estat Alcalde de Barri de Sant Joan de Llefià Baix.

306Una còpia d'aquest primer document de constitució de la Comissió de Veïns l'any 1957 és consultable a l'Arxiu Històric de Llefià: http://www.llefia.org/gallery/main.php? g2 itemId $=33835$

307 Marc Andreu i Acebal: El Bruc Bufalà -Badalona- Els Barris d'Adigsa núm. 7, Departament de Benestar Social, Barcelona, 1995.. p. 93-94. 308Josep Baeza: Associacionisme Veïnal a Badalona, p. 184. 
maldecaps a l'Ajuntament, també -indirectament si és vol- afavorien un procés de conscienciació veïnal en participar directament en obres fetes en benefici comú:

"I allà [es refereix al barri de la Immaculada -actualment La Pau- on estava aleshores aquesta associació] el primer contacte que vam tenir amb administracions va ser amb l'Associació de Veïns del barri, per que la casa que no es pot dir casa, que era una barraca, tenia llum però no hi havia aigua corrent, no havia claveguera, no havia asfaltat. I van conèixer l'Associació de Veïns per que (...) mentre vivia allà es va fer el clavegueram, i cada família tenia que aportar una persona, que conjuntament amb les altres famílies eren les que s'encarregaven de fer la claveguera principal del carrer. I després des de cada casa tenien l'obligació de fer la connexió a la claveguera principal." ${ }^{309}$

El mateix entrevistat ens va comentar com els veïns del barri solien tenir més simpatia per l'AVV de Lloreda -de la qual hem parlat abans- sobretot per les persones que estaven darrera, on hi havien diferents sensibilitats a més del seu peculiar procés de creació i la seva lluita per mantenir els habitatges que les autoritats volien enderrocar.

L'AVV de Sistrells va ser -com la de Lloreda- un cas especial. Ens torna a posar de manifest la qüestió de la presència de persones "no afectes" en aquestes entitats com seria el cas de Miguel López Parra, Secretari de la primera Junta i militant de la CNT que havia estat a l'exili. El Tresorer, Juan Vilaplana era comunista (simpatitzant o militant) i els Vocals Miguel Cabaco i Vicente López eren del PSUC i simpatitzant del Partit Socialista, respectivament ${ }^{310}$. Malgrat això l'esmentat Miguel Lopez Parra tenia el beneplàcit de les autoritats municipals del moment, arribant a atribuir-se ell personalment fins i tot el mèrit de fer la proposta de crear unes "Comissions de Barriada" com a antesala a les futures Associacions de Veïns. Però unes comissions que no cercaven l'enfrontament obert amb l'Ajuntament:

"Por aquel entonces [es refereix a finals dels anys seixanta, durant el mandat de Santiago March Blanch i on era tinent d'Alcalde d'Urbanisme el senyor Estapé al qual

309Entrevista a Diego Guerrero Castaño, 20-11-2013. Va ser membre de la Vocalia de Joves de l'AVV de Sistrells, de la CNT i encara és membre actualment de l'AVV Nova Lloreda Nord.

310Entrevista a Diego Guerrero Castaño, 20-11-2013. L'entrevistat ens manifesta com es va assabentar d'aquests casos molts anys després ja fos pels mateixos protagonistes (quan va entrar a la Vocalia de Joves) o per terceres persones. Ell mateix em va facilitar el document original de l'Acta de Constitució de l'Associació i casualment els noms esmentats, juntament amb el Vicepresident José Núñez Sánchez apareixen marcats amb una creu. José Núñez va ser alhora el primer Alcalde de Barri. 
feia referència un altre entrevistat] el Municipio creó una dependencia adjunta al Departamento de Urbanismo y como representante de la misma al señor Botey (...). Uno de aquellos martes, durante la visita, tuve una larga conversación con el señor Botey, le expuse que el sistema que se empleaba con las visitas era una pérdida de tiempo enorme y que además, representaba un desgaste de energía por ambas partes, en las que se abandonaba completamente el sentido práctico del porqué nos habíamos prestado a colaborar con el Municipio. Yo le razoné al señor Botey, de como era necesario formar Comisiones por Barriadas, acabando con las comisiones de calles." ${ }^{311}$

Evidentment sembla que el control dels presidents era més estricte i per això generalment solien ser persones conservadores o fins i tot en alguns casos les catalogades com a "indiferents". És el mateix amb els alcaldes de barri malgrat el cas excepcional de Joan Vilaplana, anteriorment esmentat, i que va ser Alcalde de Barri durant un breu període d'un any ${ }^{312}$.

Paral-lelament al sorgiment d'aquest tipus d'associacions i al debat sobre la regulació de l'associacionisme dins les instàncies de la dictadura, a finals dels cinquanta i sobretot als seixanta es va intentar donar un gran impuls a les eleccions municipals al Tercio Familiar, per mirar de reforçar allò que el règim denominava "democràcia orgànica". Aquesta coincidència temporal no és casual, evidentment. L'impuls d'aquestes eleccions responia també a una voluntat d'ampliar el "consens" franquista i oferir un canal, per bé que molt limitat, de promoció personal a sectors afectes al règim en l'administració local, la que a priori representava un menor perill pel franquisme per les poques competències que tenia. Alhora que propagandísticament permetia al règim presentar-se a l'exterior com "tolerant d'una certa pluralitat". Les eleccions al Tercio Familiar no eren una cosa nova, ja que les primeres s'havien fet al $1948^{313}$. El que si que era nou era el diferent context de mitjans els anys cinquanta i durant els seixanta, on el règim es va haver

311Miguel López Parra: Historial Barrio Sistrells..., p. 9-10.

312 Ídem, p. 42-43. No ho podem afirmar però potser la seva breu duració té alguna cosa a veure amb la seva ideologia. Aquesta obra ens diu que va dimitir sense aprofundir massa i que els mateixos membres de l'AVV de Sistrells -amb permís del Sr. Pagès, Tinent d'alcalde d'Urbanisme - van triar al seu successor, José Sánchez, una persona conservadora segons Diego Guerrero Castaño. Cal tenir en compte que l'obra de Miguel López Parra data de l'any 1976, quan encara hi havia dictadura i els partits polítics eren il-legals. Per tant, s'ha de llegir "entre línies" i fer interpretacions. Com veurem, fins i tot aquest alcalde de barri va ser substituït.

313 Per més informació sobre les eleccions al Tercio Familiar veure Martí Marín: Els Ajuntaments franquistes a Catalunya... 
d'enfrontar a una nova situació de creixement urbà i també de contestació. Si una manera de fer front això era oferir un model d'associacionisme (dins o fora del Movimiento) per canalitzar la nova situació dins de l'ordre establert, les eleccions al Tercio Familiar hauran de complementar ara aquesta funció en un moment on estan pujant noves generacions que no havien viscut directament la guerra.

Aquest fet es va veure per exemple a partir dels anys seixanta en les poblacions del Barcelonès Nord. A Badalona l'alcalde Santiago March Blanch havia estat cessat l'any 1961 després de diversos enfrontaments amb partidaris del seu antecessor i sobretot per unes irregularitats que va haver-hi en una votació per la renovació parcial del consistori. El seu successor, José Torras Trias (1961-1964), un altre ex-militant de la Lliga Regionalista, va manifestar una especial preocupació per crear i integrar aquest tipus d'associacionisme en les estructures municipals, fomentant segurament el seu control per persones d'ordre per així tenir més influència sobre unes barriades que havien estat molt desateses. Un pas més es va donar al 1963 quan, aprofitant que calia escollir 6 representants familiars i 6 de corporatius -en comptes dels 3 habituals ${ }^{314}$, s'obrí la possibilitat a noves incorporacions. Al 1964 la corporació Badalonina incorporava a tres presidents d'Associacions de Veïns: Antonio Forteza (AVV Bachs-Bufalà), Ramon Arjona (AVV Sant Joan de Llefià) i Fulgencio Conesa (AVV Sant Antoni de Llefià) i a José Casanellas Ors, vocal de l'AVV de Sistrells ${ }^{315}$. Una incorporació que no va respondre a les expectatives que alguns hi van posar en aquesta col-laboració amb l'Ajuntament:

\footnotetext{
"Pues nunca se consiguió tan poca colaboración de parte municipal, como en la etapa en que nuestros queridos amigos tomaron, ó debian de haber tomado parte en los comicios de nuestro Consistorio. Un gato se les comió la lengua, en fin, que más vale no "Meneallo"."316
}

Semblava que hi havia un especial interès en incorporar gent d'ordre de

314Les irregularitats produïdes a les eleccions de 1960 van fer que s'anul-lessin els candidats elegits pel Terç Familiar i en conseqüència també els del corporatiu, portant la corporació badalonina a funcionar amb un dèficit de sis regidors entre 1961 i 1964.

315 Agrair al meu director de Tesi, Martí Marín, que em facilités les dades sobre els municipis del Barcelonès Nord. 316Miguel López Parra: Historial Barrio Sistrells..., p. 47. 
l'extraradi badaloní i en mantenir una política de "bones relacions" -o simplement d'imatge- amb aquestes entitats que podien servir alhora per donar una millor opinió de l'Ajuntament en unes barriades encara amb moltes mancances i que en aquell moment estaven experimentant un creixement desorbitat per l'arribada continua de població (fet que agreujava els seus dèficits urbanístics).

Un procés similar sembla que es va donar a Santa Coloma de Gramenet durant l'alcaldia de Víctor Jove Minguillón (1959-1965). Al desembre de 1958 hi havia hagut un intent de fer algun tipus d'associació al Singuerlín seguint els exemples badalonins: un full volant convocava als veïns de l'esmentat barri a trobar-se amb el següent text:

\section{“VECINO del BARRIO de SINGUERLIN}

Si te interesa la educación de tus hijos y aprecias el valor de la religión, de la moral y la familia. Si quieres que tu barrio tenga personalidad y prestigio y que sea un remanso de paz y bienestar, asiste a la REUNIÓN de vecinos que, D. m, tendrá lugar el domingo a las 12, o, si la lluvia lo impide, el lunes a la misma hora, en el Casino Bella Estancia."

Sta. Coloma de Gramanet, 4 de diciembre de 1958"317

No he trobat més documentació al respecte. De fet, no és fins a 5 anys després que no torno a trobar referències a algun tipus d'entitat veïnal a Santa Coloma. A les eleccions al Tercio Familiar de l'any 1963 la candidatura oficial, anomenada significativament barriadas va incloure "representants" dels barris perifèrics com Albert Perich Dou (un acabalat comerciant, alcalde de barri del Singuerlín i membre del Sometent Armat), Francisco de Miguel Fajardo (president de l'Associació de Veïns de Santa Rosa, ${ }^{318}$ ) i Victor Ramos Cano, fill d'un Guardia Civil i resident al barri del Fondo. Sobre les Associacions de Veïns d'aleshores a Santa Coloma és interessant recollir el testimoni de Marcelo López Ródenas:

No (...) Esas asociaciones hubieron dos o tres (...) Hubieron dos o tres muy interesantes. Una está muy bien documentada que es la que promocionó el capellán Juan Mata a Santa Rosa, Raval (...) que era Asociación.... es deia de Vecinos y Comerciantes de la zona de Santa Rosa (...). Era una simbiosis. Fue precursora de lo

317 "Vecino del barrio de Singuerlín" [full volant] (4-12-1958), AHMTB, Fons Marcelo López Ródenas, Caixa 3, Dossier 4.

318Juan José Gallardo: "Aproximació a l'estudi de les alcaldies franquistes (1951-1975)" a Grup d'Història José Berruezo: Una ciutat dormitori sota el franquisme. Santa Coloma de Gramenet 1939-1975, Ediciones Carena, Barcelona, 2006, p. 133. 
que serían después las Asociaciones de Vecinos (...). Acogiéndose a la Ley del 64, porque entonces estaba la Ley del 64 del franquisme, pues la crearon. Singuerlín, Fondo Alto y eran... si, si, cumplían un papel. Eran como interlocutores del Ayuntamiento, en aquel momento los alcaldes de aquella zona. Hacer de interlocutores con los comerciantes. Todo sin entrar en temas... como decían alguno de ellos. No se puede hacer política... y política era todo (...).

Vamos a dar salida a las demandas de asociacionismo y tal y creamos este tipo de (...). La ley del 64 era esto. Pero La Ley del 64 era muy (...) ha estao en vigor hasta hace pocos años ¿eh? De asociacionismo, porque daba un marco muy abierto de asociación, y luego tu dentro de ese marco hacías lo que querías. Pero no, las esas primero de los años 60 eran sobretodo un intento de que la propia administración tuviera unos interlocutores antes de que se desmadrara el tema (...). alcaldes de barri... de hecho la Asociación de Vecinos y Comerciantes de Santa Rosa y la zona del Fondo, García Mata, de hecho ahí tenía el Alcalde de Barrio, que vivía en la calle, en la esquina de ulia [??]

(...)

Este alcalde de barrio estaba también en la comisión de vecinos... Estaba también el famoso doctor López, también estaba en la comisión de vecinos el famoso Lopera, un doctor muy muy querido en el ámbito de su (...). Doctor Noguera también estaba en la comisión de vecinos del Fondo... de vecinos y comerciantes de Santa Rosa... y Arrabal, si. Tú puedes decir gente del sector comerciante, reconocida... reconocida..."319

Tornant al tema de les eleccions al Tercio Familiar a Santa Coloma de l'any 1963, es prou significatiu un informe enviat al Govern Civil al respecte la candidatura:

"Una presentada por vecinos de barrios extremos de la localidad invitados por el Consistorio, para formar una candidatura de oposición al "caciquismo" de la población, apoyada por la Jefatura Local del Movimiento." ${ }^{320}$

Aquesta candidatura oficial va haver de fer front a una candidatura

319Entrevista a Marcelo López Ródenas, antic militant de les Comissions de Barri, 9-4-2013. Sobre l'Associació de Veïns de Santa Rosa tinc algunes dades que em porten a la confusió, ja que el mateix Marcelo Lòpez Ródenas parla en el seu llibre d'una Comissió de Veïns del Alto Fondo ubicada en el mateix barri fomentada pel mossèn del barri Juan Mata i presidida per un tal Enrique Mur. Malauradament no esmenta cap data de fundació. Veure Marcelo López Rodenas: Història Social de la Santa Coloma Moderna, 1954-1979, Ajuntament de Santa Coloma, 1982, p. 94.

320Juan José Gallardo: “Aproximació a l'estudi de les alcaldies franquistes (1951-1975)” a Grup d'Història José Berruezo: Una ciutat dormitori... La cita està extreta d'un document de l'Arxiu de la Corona d'Aragó (ACA), Fons del Govern Civil, Carpeta núm. 867 "Eleccions municipals a Sta Coloma de Gramenet. 23-10-1963". 
"alternativa" encapçalada per altres persones residents al Centre: Carles Valls Manich, Manuel Treserras Alchaniz i Andreu Guitart Gómez (els dos primers sestaven senyalats com a "catalanistes") i impulsada per Salvador Solé Bachs, Antoni Ferrando Ciurana, Lluís Farrarons Puigvert i Rafael Rocafull Vallès, sent el primer fill d'un antic regidor d'ERC a l'ajuntament durant la II República i per això catalogat com a "desafecte". La candidatura oficial es va imposar fent servir tots els mètodes possibles, inclosa la intimidació policial i un més que possible frau en el recompte de vots ${ }^{321}$. No podia ser d'una altra manera tenint en compte que aquest tipus d'eleccions eren qualsevol cosa menys democràtiques. Ja fos pel seu limitat cens de votants (només ho podien fer els "Caps de família”, i a partir de 1970, també les "dones casades") com per la limitació en la presentació de candidats, la manipulació de les campanyes i fins i tot de les votacions, malgrat l'aparença de "votació neta" que es volia donar. El Ministeri de la Governació enviava les oportunes directrius a seguir en cada contesa electoral:

“1a. La identificación de sus componentes con los principios fundamentales del Movimiento, entendidos en el amplio sentido que viene dándole nuestro Jefe del Estado y evitando exclusivismos.

2ª . Idoneidad, arraigo y eficacia de los posibles candidatos. Se procurará el que sean personas de solvencia moral y con los mayores conocimientos posibles, de suerte que resulten útiles a la administración municipal. Se procurará también, en cuanto sea posible, su permanencia dentro del término. Una mezcla de hombres jóvenes con personas de mayor experiencia puede también estimarse como conveniente.

3‥ Como principio debe desecharse la reelección, sin perjuicio de que sea medio para evitar otras dificultades.

(...)

5‥ Siempre que sea posible, se buscarán candidaturas abiertas, propugnándose una proclamación de candidatos con al menos el doble de puesto renovables. La aplicación del párrafo 2 del art. 55 debe considerarse como medida excepcional solamente aplicable a casos en que el orden público, o una notoria conveniencia de política local, lo aconsejen." 322

321Juan José Gallardo: "Aproximacíó a l'estudi de les alcaldies franquistes (1951-1975)" a Grup d'Història José Berruezo: Una ciutat dormitori..., p. 134-135.

322 Ministerio de la Gobernación. Dirección General de la Administración Local: "Elecciones Municipales de 1966. Circular reservada". AGA, Fondo Interior-Gobernació, Carpeta Extracto Elecciones Municipales 1966, Caixa 53/976, p. 2. Aquest tipus de directrius, les instruccions electorals reservades ja van ser exposades a Martí Marín i Corbera: Els Ajuntaments franquistes franquistes a Catalunya, p. 234-240. 
A les quals hauríem d'afegir les directrius i valoracions internes que es feien des de la Delegación Nacional de Províncias de FET-JONS el mateix l'any 1966. Queda clar, per una banda, la percepció de que aquest tipus d'eleccions podien ser utilitzades per opositors al règim:

“(...) ha de preverse que las Jefaturas Provinciales del Movimiento tendrán que desarrollar una gran actividad para la preparación política de nuestros cuadros provinciales y locales en relación con las elecciones puesto que, aún cuando se trate de unos comicios puramente administrativos, encaminados a la renovación mecánica de quienes han de regir la administración municipal, no puede olvidarse que esta coyuntura puede ser aprovechada por fuerzas políticas adversas para tratar de darles un significado esencialmente político que facilite la acentuación de sus habituales ataques al régimen." ${ }^{323}$

I també la necessitat d'un estricte control de les candidatures que és presentaven, ja que l'obligació de jurar "los Principios Fundamentales del Movimiento" no era considerada prou garantia:

"Ello plantea la necesidad inmediata de ordenar el sistema informativo con que deben contar las Jefaturas Provinciales en cada uno de los aspectos de la campaña electoral próxima a iniciarse. Una importante faceta de esta información, la constituye el conocimiento concreto y detallado de la personalidad, antgecedentes, méritos, conceptuación pública y tendencias políticas de las personas que, en cada uno de los tercios electorales, aspiran a proclamarse candidatos. Ello ha de facilitar al Mando Provincial, y en definitiva, al Mando Nacional, una idea exacta de la tónica y alcance político y social que puedan revestir las elecciones municipales."324

Tot això sense comptar l'estricte control de les taules electorals o de la "propaganda" que podien fer-se els mateixos candidats ${ }^{325}$. En aquest cas, si que hi

323Falange Española Tradicionalista y de las J.O.N.S. Delegación Nacional de Províncias: "Circular num. 10/66. Las pròximas Elecciones Municipales", AGA, Fons Ministerio del Interior. Regimen Municipal y Provincial. Elecciones Municipales, Caixa 53/1228, Dossier Eleccions Municipals 1969. Aplazamiento de las mismas.

324Falange Española Tradicionalista y de las J.O.N.S. Delegación Nacional de Províncias. José Luis Taboada García [Delegado Nacional FET-JONS a los Jefes Provinciales] (14-10-1966): “Circular num. 14/66. Infoirmación sobre datos y antecedentes de los candidatos a proclamar en las Elecciones Municipales", AGA, Fons Ministerio del Interior. Regimen Municipal y Provincial. Elecciones Municipales, Caixa 53/1228, Dossier Eleccions Municipals 1969. Aplazamiento de las mismas.

325Falange Española Tradicionalista y de las J.O.N.S. Delegación Nacional de Províncias. José Luis Taboada García, [Delegado Nacional FET-JONS a los Jefes Provinciales] (21-10-1966): “Circular 
havia una coincidència entre la Secretaria General del Movimiento i el Ministeri de la Governació. Més endavant veurem com aquestes circulars es tornen més restrictives, a mesura que alguns candidats "desafectes" aconsegueixen infiltrar-se a partir dels anys setanta. Però no avancem esdeveniments. A partir dels canvis legislatius esmentats des de mitjans dels anys seixanta van aparèixer noves entitats adscrites al règim de "Asociaciones de Cabezas de Familia" dependents del Movimiento o noves associacions veïnals regides per la nova Llei d'Associacions de 1964 (les creades anteriorment van haver d'adaptar els seus estatuts a la nova Llei).

D'aquesta manera van aparèixer, pel que fa al primer cas, a Sant Adrià una associació veïnal sota la regulació de les "Asociaciones Familiares del Movimiento" al barri del Besòs (COBASA) ${ }^{326}$, mentre que a Badalona ho van fer la Asociación de Cabezas de Familia de Badalona (1967), la Asociación de Cabezas de Familia de Alta Badalona (1968) i d'altres com les de Pomar (1968) i San Roque (1968). A Santa Coloma només tenim constància de una Asociación de Cabezas de Familia creada l'any $1969^{327}$.

Pel que fa a Associacions de Veïns no adscrites formalment al Movimiento, durant la segona meitat dels seixanta van aparèixer algunes més. A Badalona va ser el cas de les Associacions de Sant Crist (1965), Artigas (1969), Congrés Eucarístic (1969) i Juan Valera (1969) ${ }^{328}$. A Santa Coloma de Gramenet es va constituir la de Singuerlín l'any $1969^{329}$, mentre que a Sant Adrià tinc constància de l'existència de l'AVV de la Zona Industrial Montsolís a l'any 1966 , i es crearà l'AVV de La Catalana $(1968)^{330}$. Paral-lelament s'adaptaven els Estatuts de les associacions que s'havien

num. 16/66. Selección de los componentes de las Mesas Electorales" i (28-10-1966): “Circular núm. 20/66. Nomas sobre propaganda electora. Resevada”, AGA, Fons Ministerio del Interior. Regimen Municipal y Provincial. Elecciones Municipales, Caixa 53/1228, Dossier Eleccions Municipals 1969. Aplazamiento de las mismas.

326Vaig trobar una còpia dels seus Estatuts i de la constitució de la Comisió Gestora que havia de fer els tràmits per la legalització datats al juliol de 1964. No vaig trobar en canvi el document amb l'aprovació definitiva. Suposem que es va legalitzar entre 1964 i 1965 però no ho se del cert. Curiosament als anys setanta es farà una nova Associació de Veïns. "Proyecto de Estatutos de la Asociación de Vecinos del "Besos" San Adrián del Besos (Barcelona), AGA, Fondo Presidencia. Delegación Nacional de Asociaciones del Movimiento, Caixa 44/9212.

327Es poden trobar les actes de constitució de moltes d'aquestes Associacions amb la composició de les respectives Juntes i també els Estatuts a AGA, Fondo Presidencia. Delegación Nacional de Asociaciones del Movimiento, Caixes 44/9229, 44/9231, 44/9256 i 44/9271.

328Josep Baeza: Associacionisme Veïnal a Badalona, p. 26.

329Marcelo López Ródenas: Historia social de la Santa Coloma moderna..., p. 94.

330En concret he trobat documentació d'aquesta Associació a: ASAB, Fons Ajuntament, Caixa 399, 
creat a inicis de la dècada a la nova normativa ${ }^{331}$. Moltes d'aquestes associacions van tenir, en un primer moment, forta presència de persones "afectes" al règim, o si més no, de les catalogades com "indiferents". Del primer cas sabem, pel testimoni de dues persones que tindran protagonisme en la dècada posterior, de la presència de gent "afecta" al franquisme a l'AVV de Juan Valera, situada a cavall entre els barris de Llefià i La Salut ${ }^{332}$. Tot i que no he trobat testimonis directes referents a les altres associacions de Badalona, la presència a l'Alcaldia des de l'any 1964 de Felipe Antoja Vigo (alcalde fins la seva mort l'any 1974), un ex-captiu antic militant d'Acció Catòlica però aviat adherit a FET-JONS, que comptava amb el suport de la Falange local i de Santiago Udina Martorell, ens fa suposar que no s'haurien legalitzat si haguessin suposat un excessiu perill. De tota manera, no podem afirmar-ho al $100 \%$.

Pel que fa a Santa Coloma sabem que les Associacions de Veïns existents fins aleshores estaven en mans de persones "afectas" o conservadores, tot i que com veurem posteriorment, a les parròquies i Centres Socials la qüestió era molt diferent. L'alcaldia estava aleshores en mans de Antoni Romero Tutusaus (19651970) ja que el seu antecessor, Victor Jove Miguillón (1959-1965) havia estat cessat per un escàndol de corrupció en l'adjudicació de les parades del nou mercat del Fondo arribant fins i tot a ingressar pres a la Model. Tutusaus era un protegit de Lluís Valls i Taberner, amb una considerable fortuna econòmica i bones connexions amb el Ministre de Treball Jesús Romero Gorria, fet que no va impedir que demanés el seu cessament l'any 1970 pels enfrontaments existents amb el regidor -i futur Alcalde durant els anys 1975-1979- Blas Muñoz ${ }^{333}$.

L'Associació de Veïns del Barri de la Catalana de Sant Adrià de Besòs estava presidida per Agustin Bonet Manich, una persona catalogada com "indiferent" que

Carpetes 32, 46 i 47. Desconec la data de fundació de l'esmentada entitat, però pot ser anterior a 1966. Sobre l'AVV La Catalana es pot trobar documentació referent a la seva fundació a ASAB, Fons Ajuntament, Caixa 388, Carpeta Associació de Veïns de La Catalana.

331Es poden trobar les actes de constitució de moltes d'aquestes Associacions així com adaptacions d'Estatuts d'altres més antigues a la nova normativa a AGA, Fondo Ministerio de la Gobernación, Caixes 52/349, 52/359, 52/360 i 52/362.

332Entrevistes a Àngel Navarro, 21-7-2009 i Manuel Armentero, 10-4-2010. Tots dos van ser militants del PSUC, i el segon serà posteriorment president de l'AVV Juan Valera. Tots dos també van ser regidors a l'Ajuntament de Badalona als anys 80 .

333Juan José Gallardo: “Aproximacío a l'estudi de les alcaldies franquistes (1951-1975)" a Grup d'Història José Berruezo: Una ciutat dormitori..., p. 136. 
en la dècada posterior arribarà a presentar-se a les eleccions al Tercio Familiar i fins i tot a impugnar-les després d'haver-les perdut ${ }^{334}$. Però d'entrada, al finals dels anys seixanta aquesta entitat no era considerada perillosa:

\footnotetext{
“Todos los componentes de la Junta de la mencionada Asociación de Vecinos de Barriada de La Catalana son personas de orden y observan buena conducta. La información sostenida por el suscrito ha sido relevada, por los siguientes, Srs. Concejal, D. José Ma Fonoll, el exconcejal Don Manuel Prots y el Alcalde de Barrio, Sr, Caballero."335
}

La barriada de La Catalana revestia una problemàtica especial pel fet d'estar construïda sobre una zona qualificada com a Verda al Pla Comarcal de 1953, fet que va orientar les seves prioritats a aconseguir la legalització del barri. L'alcaldia de Sant Adrià havia estat ocupada en aquells anys per José Narbon Noet (1961-1966), antic militant del SEU i per Francisco Roqueta Prat (1966-1973), un industrial que havia ocupat càrrecs al sindicat vertical i que va entrar a militar a FET-JONS en ser nomenat Alcalde $\mathrm{A}^{336}$.

Tot i això, tenim constància que no totes aquestes associacions estaven tan controlades com podria semblar. En l'anomenada "Asociación de Cabezas de Familia de Alta Badalona", dos dels seus promotors -Juan Reina Abad i Pedro Ballesteros- tenien antecedents per haver militat a la CNT i al PCE-UGT, respectivament als seus llocs d'origen (Múrcia i Conca), havent estat empresonats per aquest motiu, com informava alarmat al governador civil l'alcalde badaloní Felipe Antoja Vigo:

"Debo informarle a Vd. que les he advertido de que su actuación debe limitarse exclusivamente a los fines creados y propios de aquellas Asociaciones. Sin entrometerse en otros asuntos, en cuya labor encontrarán, si es leal a nuestros principios, la total colaboración de la Alcaldía, para el mejoramiento de las Barriadas.

334Telex del Govern Civil de Barcelona al Director General de la Administració Local (9-2-1971), AGA, Fondo Presidencia. Regimen Municipal y Provincial. Elecciones Municipales, Caixa 53/1066, Extracto Elecciones Municipales 1970. IV Impugnaciones y recursos. "Elecciones Municipales 1970. Extracto Quinta relacción de recursos promovidos contra dichas elecciones, con indicación del trámite en que se encuentran. Quinta remesa de antecedentes de los mismos recursos. Año 1971". S'informa de l'estat de les impugnacions a les eleccions i en aquest cas concret de les de Sant Adrià de Besòs.

335 [Informe de la Policia Local de Sant Adrià de Besòs, 17-10-1968], ASAB, Administració General, Caixa 388, Alcaldia, Expediente: Asociación de Vecinos de La Catalana.

336Martí Marín i Corbera: Els Ajuntaments franquistes a Catalunya..., p. 514. 
Se tendrá la suficiente y discreta vigilancia para seguir de cerca sus movimientos, máxime teniendo en cuenta que la barriada de Llefià, a la cual pertenece el señor Reina, existe el párroco Rvdo. Don Juan Carrera, que es uno de los firmantes del último

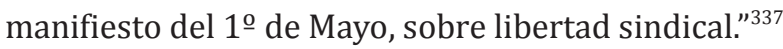

L'alcalde badaloní manifestava també que:

"(...) ha sido creada sin conocimiento alguno de la Jefatura Local del Movimiento de Badalona (...). No se conoce la celebración de ninguna Asamblea General de Constitución (...).

Evidentemente la creación de dicha Asociación de Cabezas de Familia de "Alta Badalona", nombre además que no concuerda con ninguna de las Barriadas actuales, no puede causar ningún bien a la Ciudad ni al Movimiento, y ha sido promovida por elementos resentidos" ${ }^{\prime 338}$.

Un dels nostres entrevistats ens deia al respecte de l'esmentada associació: "Si... Es que resulta que era de cuando la lucha del alcalde en contra nuestra. [es refereix a Felipe Antoja Vigo] y le contrarrestamos... Era por aquello del Tercio Familiar. Y abajo hicieron una asociación [de "Cabezas de Familia de Badalona] I pa contrarrestar hicimos la nuestra"339.

El mateix entrevistat ens confirma que Juan Reina residia a Sant Antoni de Llefià i Pedro Ballesteros ho feia al barri de La Pau (aleshores anomenat la Immaculada). Del primer ens diu que es va encarregar de les obres d'urbanització del barri de Lloreda. Francisco Rodríguez Marco apareixia també nombrat en un altre document juntament amb els esmentats Reina i Ballesteros que analitzava el procés de creació de la Federació Provincial de les Asociaciones de Cabezas de Familia:

"Los tres mencionados, viven en barriadas confines sitas en la parte alta de Badalona, sabiéndose que ya vinieron formando parte de unas Juntas de Barriada a las que el Ayuntamiento confiaba cuestiones de tipo municipal, para que informaran sobre

337Felipe Antoja Vigo (Alcalde de Badalona 1964-1974): "Asociacion de Cabezas de Familia de Alta Badalona" (5-5-1967), Archivo Històrico del Gobierno Civil e Barcelona (AHGCB), Gobernadores Civiles, Caixa 15 Iltmo. Sr. D. Felipe Antoja Vigo, Año: 1966 al 69. El document recull una sèrie d'informes sobre els promotors de l'esmentada associació.

338Felipe Antoja Vigo (alcalde de Badalona 1964-1974): "Asociacion de Cabezas de Familia de Alta Badalona" (5-5-1967), Archivo Històrico del Gobierno Civil de Barcelona (AHGCB), Gobernadores Civiles, Caixa 15, Iltmo. Sr. D. Felipe Antoja Vigo, Año: 1966 al 69 . 339Entrevista amb Francisco Rodríguez Marco, 21-6-2013. 
necesidades de urbanismo, sanidad y otras atenciones. Solo tienen antecedentes en la Comisaria del Cuerpo General de Policia de Badalona JUAN REINA ABAD, en el sentido de que salió en libertad condicional el 13-2-1944 cuando cumplía 20 años y un día por auxilio a la rebelión."340

Malgrat tot, sembla que l'entitat va ser legalitzada finalment. Això si, va trigar més d'un any en fer-ho definitivament ja que els documents i Estatus es van aprovar el 3 de març de 1967, però la inscripció definitiva en el Registro de Asociaciones del Movimiento consta l'11 de juliol de $1968^{341}$. És entre aquestes dues dates on es circumscriuen els informes enviats per l'alcalde de Badalona i la Jefatura Superior de Policia de Barcelona. Curiosament una altra font consultada, la història de l'AVV de Sistrells feta per Miguel López Parra no deixa ben parada aquesta associació de Cabezas de Familia de Alta Badalona, acusant a Juan Reina de ser un home de José Guillem Clapés, una de les persones més fosques de l'Ajuntament de Badalona ${ }^{342}$. Aquest afer, del qual ens falta més informació, si més no serveix per posar-nos de manifest la intervenció de les autoritats locals dins les entitats veïnals quan els membres de les seves direccions no eren del seu gust.

Un altre exemple ho tenim en la substitució de l'alcalde de barri de Sistrells (Badalona) -José Sánchez- per Daniel Arasa, petit comerciant del barri, en el context d'unes eleccions al Tercio Familiar on el que interessava a l'esmentat Guillem Clapés era donar suport a la candidatura d'un tal Molina ${ }^{343}$. Però es va anar més enllà: a l'AVV de Sistrells va haver-hi dos canvis de Junta al febrer de 1965 i a l'abril de 1967. Entremig va haver-hi un "cop d'estat" dins l'AVV promogut per José Guillen Clapés, ara Tinent d'alcalde d'Urbanisme, fins que va col·locar a un dels seus homes -José Sánchez de Castro- com a president de l'Associació, rellevant als

340Jefatura Superior de Policia de Barcelona: "Sobre nombramientos en la Comisión de Padres de Família de Badalona. Nota informativa "en lo referente a rumores que circulan en la localidad de Badalona sobre el nombramiento de Presidente y Vicepresidente secretario en la Comisión de Padres de Familia de dos individuos declarados enemigos del Régimen" (30-5-1967), AHGCB, Gobernadores Civiles, Caixa 65. Comarcas años 1965,1966,1967,1968. Pel que es veu es va dur a terme una Assemblea el 15 d'abril de 1967 per designar la "Comisión Ejecutiva" de la Federació Provincial de Padres de Família, a la qual van ser convocats els Presidents, Secretaris i un Vocal de cada Associació de la província de Barcelona. Pel que sembla Juan Reina hi va anar a aquesta reunió en qualitat de Vocal.

341AGA, Fondo Presidencia. Delegación Nacional de Asociaciones del Movimiento, Caixa 44/9231 342 Miguel López Parra: Historial Barrio Sistrells..., p. 66-67.

343Ídem, p. 45. 
membres més díscols de la mateixa Junta o deixant-los en llocs testimonials ${ }^{344}$. Aquest José Sánchez de Castro, juntament amb un altre membre de la Junta, Juan Teruel Tobias, eren d'ideologia clarament dretana ${ }^{345}$.

El mateix Miguel López Parra va dimitir de la Junta el 27 de novembre de 1967, a l'igual que altres membres pels enfrontaments i l'autoritarisme del nou president. Però la cosa va anar molt més enllà quan el mateix López Parra i d'altres afins van aconseguir, aprofitant les irregularitats de Sánchez de Castro i els seus (no convocar Assemblees de Socis durant tres anys apart de irregularitats econòmiques), forçar una Assemblea General l'any 1970, presentar un expedient amb totes les irregularitats comeses i aconseguir l'expulsió de José Sánchez de Castro i del seu delfí, Juan Teruel Tobías. Manuel López Parra havia anat massa lluny:

"Recuerdo que estando en la barra del bar se me acercó el señor Suarez, abogado, [el que havia aconseguit la legalització de moltes AVV's Badalonines, entre elles la pionera, la de Lloreda] y con cara de circunstancias me dijo: -Me parece que ha ido usted un poquitín lejos.- a lo que yo le contesté.- He hecho el recorrido que debía y ahora ya está hecho. Si hay algo contra mi díganlo."346

I així va ser, per que després de que s'instaurés una nova Junta sense els dos expulsats, va haver de patir fins i tot un "simulacre de detenció" a casa seva. José Guillem Clapés va enviar-li una patrulla de Policia Municipal per "requerir-lo" a una reunió al mateix local de l'Associació de Veïns dos carrers més abaix del seu domicili on hi havia també una forta presència policial:

"El panorama que se me presentaba delante de mi era de lo más alagador [sic] que yo pudiera imaginarme. Sin embargo quedé perplejo de indignación antes de saber los motivos del porqué se hallaban presentes todos los personajes que tenía enfrente de mi. Como estampados contra la pared, sentados y con rostro irónico se encontraban Reina, Castro y Juan Teruel. Mis ex simpáticos amigos, mis ex compañeros de tareas en

344Miguel López Parra: Historial Barrio Sistrells..., p. 47-54. Segons Diego Guerrero, entrevistat el 20-11-2013, el President de la Junta de 1965, Pascual Roig Antonio també era d'esquerres. Fet que juntament amb Manuel Cabaco de Vicepresident i Miguel López Parra com a Secretari la feia especialment perillosa. D'aquí la intervenció posterior. Una filla de Manuel Cabaco serà a finals dels 60 i als 70 una de les principals membres de la Vocalia de Joves de l'AVV de Sistrells -i militant del PSUC-, en la qual també va participar el mateix Diego Guerrero.

345Entrevista amb Diego Guerrero Castaño, 20-11-2013. A més el tal José Sánchez de Castro tenia força mala fama per que se sospitava que també s'havia emportat diners de l'Associació. 346Miguel López Parra: Historial Barrio Sistrells..., p. 63. 
Asociaciones de Vecinos." ${ }^{347}$

Pel que es veu Clapés estava interessat en l'expedient que es va fer servir per expulsar als seus dos protegits, que li va ser entregat en aquella tensa reunió. Com a principal responsable de les irregularitats urbanístiques en la ciutat de Badalona d'aleshores, devia tenir un especial interès en controlar les Associacions Veïnals. La presència de Reina que esmenta l'escrit de López Parra sembla contradir-se amb documents anteriors que el situaven com "desafecte", si es tracta de la mateixa persona $^{348}$. Un canvi de parer del mateix individu? Una animadversió políticopersonal? 0 Potser ens trobem alguna disputa interna dins les oligarquies municipals i els seus tentacles dins les Associacions Veïnals? Ara per ara no ho podem saber del cert. El cas és que hi han altres contradiccions com el fet de que el mateix Parra parla força bé d'un altra persona important, José Boada, membre de l'AVV de Lloreda amb el qual Francisco Rodríguez Marco, ja esmentat anteriorment, va tenir una disputa important pel lideratge de l'esmenada associació ${ }^{349}$. El mateix mes de setembre de 1970 una nova assemblea ratificava l'expulsió dels "homes de Clapés", comptant amb la presència d'una regidora elegida recentment al Terç Familiar i que formava part d'una oposició moderada al franquisme i enfrontada, per tant al Tinent Alcalde d'Urbanisme: Cecília March Blanch ${ }^{350}$.

D'aquesta manera puc concloure que les autoritats franquistes van fer un darrer intent per crear un model d'associacionisme per mirar d'enquadrar uns sectors amplis de població que fins al moment havien ignorat en la seva condició de veïns. En les barriades de barraquistes i d'autoconstrucció poblades majoritàriament per persones nouvingudes s'estaven donant incipients processos d'autoorganització per mirar de solucionar els nombrosos problemes quotidians davant els enormes dèficits existents en matèries d'urbanisme, de manca d'asfaltat, d'enllumenat elèctric, d'aigua potable, clavegueram, de transports públics, d'equipaments escolars i culturals...

347 Miguel López Parra: Historial Barrio Sistrells..., p. 66.

348Veure p. 157-158 i notes núm. 337,338, 339 i 340.

349Entrevista amb Francisco Rodríguez Marco, 21-6-2013. També Diego Guerrero Castaño, entrevistat al 20-11-2013 em va definir a José Boada com una persona "de dretes" però sensible als temes del barri.

350Miguel López Parra: Historial Barrio Sistrells..., p. 67-68. 
Davant la possibilitat que en aquestes barriades perifèriques de les grans ciutats es poguessin gestar àmbits d'associació que escapessin al seu control i que poguessin esdevenir hostils, les autoritats locals franquistes van mirar d'intervenir fomentant un model associatiu respectuós amb l'odre socio-polític vigent. Va ser un procés reeixit? Durant els anys seixanta podria semblar que, malgrat que no varen aconseguir implicar activament uns números elevats de població, si que varen aconseguir que aquest model d'associacionisme s'avingués en general a col-laborar amb les autoritats locals. Aquestes associacions inicialment van impulsar obres de millora dels barris, costejades pels propis veïns, i van evitar l'enfrontament directe amb els Ajuntaments ${ }^{351}$. Els consistoris, conscients de que necessitaven "legitimar-se" sovint les van fer servir per fer propaganda de les seves limitades actuacions. Però a la llarga, la maniobra no va reeixir per diversos motius. Segurament el principal va ser que aquestes associacions, malgrat els esforços que van fer en determinades ocasions en mobilitzar al veïnat per fer les obres, no podien solucionar els greus problemes existents als barris sense arribar a uns majors nivells de confrontació amb les autoritats municipals. I aquesta confrontació o reivindicació no es contemplava ja sigui per que els membres d'aquestes entitats eren afins al règim o, quan aquesta situació era més heterogènia, per que no es veien amb la força suficient per fer-ho.

Les Corporacions Locals tampoc anaven sobrades de recursos pel raquític sistema de finançament. Ni elles ni l'administració provincial o estatal van posar sobre la taula els diners imprescindibles que calia per potenciar aquest tipus d'associacions ni els hi van donar suficients atribucions. Les reticències existents sobre qualsevol tipus d'entitat que escapés al control governamental, encara que estigués teòricament enquadrada en la Delegación Nacional de Asociaciones del Movimiento va ser un factor important per donar poc marge a aquest tipus d'entitats. Per últim, com he pogut constatar, malgrat el ferri control existent per part de l'aparell de l'Estat, en alguns casos significatius fins i tot va haver-hi persones "desafectes" que es van infiltrar o que varen promoure aquest tipus

351Així ho hem pogut observar tant en el testimoni de Francisco Rodríguez, de l'AVV de Lloreda, formada per gent més "d'esquerres" com en el de Félix Rizo, de l'AVV de Sant Antoni de Llefià, més controlada per persones afectes a la dictadura. El cas de Sistrells, tot i estar també dintre d'aquesta lògica, sembla ser més complex pels enfrontaments que es van donar pel seu control. 
d'entitats, encara que van haver de tenir unes postures pragmàtiques en funció de la correlació de forces d'aleshores. En aquests mateixos anys s'estaven desenvolupant altres processos que a la llarga van acabar per trencar aquesta situació de bloqueig en el desenvolupament de l'associacionisme veïnal.

\subsection{El paper de l'Església, dels catòlics de base i de les organitzacions antifranquistes.}

Durant els anys 50 i, sobretot, a la dècada dels 60 van haver-hi altres actors que van incidir i afavorir el desenvolupament posterior del moviment veïnal. M'estic referint als i les membres d'organitzacions catòliques de base, als anomenats "capellans obrers" i, evidentment, als i les militants d'organitzacions polítiques clandestines, en especial les comunistes. Ja fos seguint unes consignes de les seves respectives organitzacions o actuant més individualment, el seu paper serà importantíssim per l'articulació d'un moviment popular organitzat als barris i ciutats del Barcelonès Nord, tant en les aportacions que van fer a nivell d'hegemonia cultural segons la definició gramsciana com en la vessant organitzativa. El primer aspecte va ser fonamental -junt amb els factors que ja hem comentat anteriorment- en la recuperació, adquisició o desenvolupament d'una consciència obrera i de classe, alhora que amb la seva dedicació militant es creaven o reforçaven unes estructures organitzatives estables que permetien una major aprofitament de les "oportunitats" que oferia la conjuntura del tardofranquisme ${ }^{352}$. És a dir, de les escletxes que s'estaven produint en una dictadura que estava entrant progressivament en crisi.

L'Església Catòlica havia beneït el cop d'estat de juliol de 1936 (qualificant-lo de "cruzada") i la dictadura (Franco era "caudillo de España por la Gracia de Dios"), i aquest fet li havia permès recuperar moltes parcel-les de poder o d'influència en

352Doug McAdam, John D. McCarthy y Mayer N. Zald, “Oportunidades, estructuras de movilización y procesos enmarcadores: hacia una perspective sintética y comparada de los movimientos sociales" en D. McAdam, J. D. McCarthy y M. N. Zald: Movimientos sociales: perspectivas comparadas, Istmo, Madrid, 1999, p. 23-24. Sobre les “oportunitats polítiques" vinculades als moviments socials es poden veure també els articles de Doug McAdam, Sidney Tarrow, Donatella della Porta, Anthony Oberschall i Elena Zdravomyslova recollits a la segona part del mateix llibre "II. Oportunidades políticas", p. 47-202. 
àmbits tant importants com l'ensenyament, la legislació a l'entorn del registre civil i allò que la institució entenia com "la moral pública", a més de retornar a una posició de manca completa de competència per la veritable persecució desfermada pel règim respecte d'altres confessions. Les seves organitzacions eren les úniques -apart de les vinculades a la Falange- que tenien permís per actuar de manera autònoma $^{353}$. Com va ser el procés que va permetre l'aparició de grups catòlics organitzats que van arribar a tenir un paper important en el desenvolupament del moviment veïnal i, a través seu, en l'oposició a la dictadura? Sens dubte, per entendre aquest procés cal analitzar el paper que van jugar organitzacions com l'Hermandad Obrera de Acción Católica (HOAC), la Acción Católica Obrera (ACO) o la Joventut Obrera Cristiana (JOC) per canviar, almenys parcialment, la opinió que tenia una part de l'Església sobre la classe treballadora i viceversa ${ }^{354}$.

L'Església Catòlica havia estat allunyada del món sindical i obrerista durant

353Sobre l'església a l'Estat espanyol durant el franquisme veure: Alfonso Álvarez Bolado: Para ganar la guerra, para ganar la paz. Iglesia y guerra civil 1936-1939, Universidad Pontificia de Comilla, Madrid, 1995; Jaume Barallat i Barés: L'Església sota el franquisme. Lleida (1938-1968), Pagès Editors, Lleida, 1994; Anabella Barroso: Sacerdotes bajo la atenta mirada del régimen franquista. Los conflictos político-sociales de la Iglesia del País Vasco desde 1960 a 1975, Desclée De Brouwer, Bilbao, 1996; Alfonso Botti: Cielo y dinero. El nacionalcatolicismo en España (18811975), Alianza Editorial, Madrid, 1992; W. J. Callahan: La Iglesia Católica en España (1975-1998), Crítica, Barcelona, 2002; Julián Casanova: La Iglesia de Franco, Temas de Hoy, Madrid, 2001; Xosé Chao Rego: Iglesia y franquismo. 40 años de nacional-catolicismo, TresCtres editores, Santa Comba (A Coruña), 2007; José-Andrés Gallego i Antón M. Pazos: La Iglesia en la España contemporánea/ 2, 1936-1999, Encuentro, Madrid, 1999; Feliciano Montero: La Acción Católica y el franquismo. Auge y crisis de la Acción Católica especializada, UNED, Madrid, 2000; Hilari Raguer: La pólvora y el incienso. La Iglesia y la guerra civil española (1936-1939), Península, Barcelona, 2001; Juan José Ruiz Rico: El papel político de la Iglesia católica en la España de Franco (1936-1971), Tecnos, Madrid, 1993; José Ángel Tello: Ideología y política. La Iglesia Católica española (1936-1959), Pórtico, Zaragoza, 1984.

354La HOAC va fundar-se al 1946, la JOC havia estat fundada als anys 20 a Bèlgica i França per Cardijn i l'ACO va nèixer a Barcelona el 1953. Sobre les veus crítiques dins l'Església Catòlica, veure: Jaume Barallat i Barés: L'Església sota el franquisme. Lleida (1938-1968), Pagès, Lleida, 1995; Feliciano Blázquez: La Traición de los clérigos en la España de Franco, Trotta, Madrid, 1991; Josep Castaño: La JOC en España, Sígueme, Salamanca, 1978; Javier Domínguez: Organizaciones obreras cristianas en la oposición al franquismo, Mensajero, Bilbao, 1985; Emili Ferrando i Puig: Cristians i rebels. Història de l'HOAC a Catalunya durant el franquisme (19461975), Editorial Mediterrania, Romanyà-Valls, Capellades, 2000; Basilisa López García: Aproximación a la historia de la HOAC 1946-1981, HOAC, Madrid, 1995; Pablo Martín de Santa Olalla: La Iglesia que se enfrentó a Franco. Pablo VI, la Conferencia Episcopal y el Concordato de 1953, Diles, Madrid, 2005; Xose Antonio Martínez Garcia, A Igrexa antifranquista en Galicia (1965-1975). Análise historica da crise postconciliar, Edicios do Castro, A Coruña, 1995; Mónica Moreno Seco: La quiebra de la unidad. Nacional-catolicismo y Vaticano II en la diócesis de Orihuela-Alicante, 1939-1975, Instituto Juan Gil-Albert, Alicante, 1999; Antonio Murcia: Obispos y obreros durante el franquismo, HOAC, Madrid, 1995; Pere Ysàs: "5. La disidencia eclesiástica" (p. 157-204) dins el seu llibre Disidencia y subversión. La lucha del régimen franquista por su supervivencia, 1960-1975, Crítica, Barcelona, 2005. 
tot el segle XIX i part del XX, amb molt poques excepcions. La institució havia estat fortament hostil amb les organitzacions obreres i les seves inspiracions ideològiques, laiques, si no anticlericals, ja fossin el marxistes o anarquistes. L'acceptació dels canvis socio-econòmics provocats per l'extensió del capitalisme durant el segle XIX va ser molt tardana -si és que es van acceptar en la seva totalitat-. D'aquesta manera els primers acostaments de l'Església al món obrer es van fer des d'una vessant paternalista i com a molt en alguns sectors, de "reformisme social". Aquestes posicions no qüestionaven l'ordre vigent, totalment injust respecte les classes treballadores i populars. No es d'estranyar doncs que en els rengles dels sectors més propers a l'apostolat popular existís la percepció que:

\footnotetext{
"En poques paraules, ser catòlic i ser militant obrer era una contradicció. El drama de l'Església consistia en el seu estret lligam amb les forces immobilistes del poder i de la riquesa i en la seva manca de llibertat, transparència i compromís amb els pobres. La vida anava per un costat i la fer per un altre, l'Església vivia tancada dins d'ella mateixa i el món es perdia en el ferment renovador de l'Evangeli."355
}

La Guerra Civil havia eixamplat encara més aquesta distància entre el món obrer i l'Església en especial pel seu suport incondicional a una dictadura que perjudicava enormement els interessos de les classes populars. Però progressivament van aparèixer sectors crítics dins les organitzacions d'apostolat obrer ja esmentades. No obstant, la vida de la HOAC a les poblacions del Barcelonès Nord va ser curta i precària: iniciada al 1949, pràcticament havia desaparegut al $1954^{356}$.

A finals de la dècada la dels 50, la HOAC tornarà a reactivar-se. No eren un nombre elevat de militants, de 55 a 75 militants entre 1957 i $1959^{357}$, però en el context d'un nou cicle de conflictivitat obrera, com en el del trànsit dels anys cinquanta als seixanta ${ }^{358}$, el seu missatge tenia més força. D'aquesta manera, l'any

355Emili Ferrando i Puig: Cristians i rebels. Història de l'HOAC a Catalunya durant el franquisme (1946-1975), Editorial Mediterrania, Romanyà-Valls, Capellades, 2000, p. 37.

356 He constatat l'existència de Centres de l'HOAC a Badalona, Sant Adrià de Besòs i Santa Coloma de Gramenet: El Centre Comarcal "Antoni Romeu" de Badalona que va existir de 1949 a 1952, el Centre "Sant Joan Baptista" a Sant Adrià de Besòs (1950-1952) i un altre Centre a Santa Coloma de Gramenet, el qual va existir des de 1952 però que aviat entrà en declivi a partir de 1954. Veure Emili Ferrando i Puig: Cristians i rebels..., p. 108-110.. 357 Ídem, p. 134.

358Carme Molinero i Pere Ysàs: Productores disciplinados y minorías subversivas. Clase obrera y conflictividad laboral en la España franquista, Siglo XXI, Madrid, 1998; José Babiano: 
1964 l'HOAC va recuperar el nivell de militants -140- que havia tingut al període 1949-1950, si bé els intents de fusió amb l'ACO van fracassar ${ }^{359}$.

Per altra banda una nova generació de sacerdots joves va anar forjant-se en aquells anys. Aquests, que no havien viscut directament la guerra civil, demostraran un tarannà força diferent al dels sacerdots "tradicionals" i es preocuparan per superar l'animadversió que tenia l'Església en nombrosos obrers: Joan Carrera i Planes va ser un pioner en arribar a Llefià l'any 1961. Al 1965 però va arribar un grup de sacerdots a Santa Coloma de Gramenet que tenien un important vincle entre ells i havien decidit treballar en equip, no cobrar pel seu ministeri i impulsar la JOC:

\begin{abstract}
"Nosaltres quan vam venir aquí havíem fet ideològicament una transformació... L'església pre-conciliar que era tancada en ella (...) A través de la JOC Joventut Obrera Catòlica, doncs havíem descobert que l'important no és atraure la gent si no nosaltres anar amb la gent. I que la gent era en gran part víctima de la conseqüència de l'ambient. Això és el principi de la JOC. Allò de transformar la societat per que la gent pugui viure humanament. Llavors això ja ens portava al compromís. Un compromís no polític que tenia ressonàncies polítiques, per que en una dictadura qualsevol moviment és sedició o és... se t'acaben de seguida. Així que la gent deia 'los curas comunistas'. Però nosaltres vam tenir aquesta idea i llavors érem quatre capellans que pensàvem tant semblant tots, i que vam fer un treball comú. A llavorens jo sempre dic que Santa Coloma té una base importantíssima d'aquest fet de venir quatre capellans joves en els barris obrers de Santa Coloma. A Santa Coloma hi havia el poble antic burgés molt despistat. Per que era una burgesia molt pobre. I havia l'entorn de la immigració, molt desestructurada. Un naufragi que la gent es troba a la platja sense
\end{abstract}

Emigrantes, cronómetros y huelgas. Un estudio sobre el trabajo y los trabajadores durante el franquismo (Madrid, 1951-1977), Madrid, Siglo XXI, 1995; Sebastian Balfour: La dictadura, los trabajadores y la ciudad. El movimiento obrero en el área metropolitana de Barcelona (19391988), Edicions Alfons el Magnànim, València, 1994; Carmen Benito del Pozo: La clase obrera asturiana durante el franquismo, Siglo XXI, Madrid, 1993; Félix Fanés: La Vaga de tramvies del 1951, Laia, Barcelona, 1977; Gemma Ramos: "Tranvías y conflictividad social en Barcelona (marzo de 1951). Actitudes políticas y sociales de una huelga mítica", Historia Contemporánea, núm. 5, 1991; Hilari Raguer: El Quadern de Montjuïc : records de la vaga de tramvies, Claret, Barcelona, 2001; Maria Coll: La Vaga d'usuaris de tramvies de Barcelona de 1957, Eumo, Vic, 2008; Llibert Ferri, Jordi Muixí i Eduardo Sanjuán: Las Huelgas contra Franco, 1939-1956: aproximación a una historia del movimiento obrero español de posguerra, Planeta, Barcelona, 1978; Fausto Miguélez: La lucha de los mineros asturianos bajo el franquismo, Laia, Barcelona, 1977; Ramón García Piñeiro: Los mineros asturianos bajo el franquismo: (1937-1962), Fundación 1ำ de Mayo, Madrid, 1990; Rubén Vega García (coord.): Las Huelgas de 1962 en España y su repercusión internacional, Trea i Fundación Juan Muñiz Zapico, Gijón, 2002; Juan Carlos Laviana (ed.): 1962: del Contubernio de Múnich a la huelga minera, Unidad Editorial, Madrid, 2006.

359Emili Ferrando i Puig: Cristians i rebels..., p. 151. 
casa, sense església, sense saber on anar. Aleshores les parròquies van ser com un pou més amb una gent bàsicament andalusa i extremenya que l'església era molt per ells. Tota la gent, que no cal dir en aquella època tothom anava a missa, es casava, es batejava, doncs l'església va ser un espai de llibertat que va atreure sobretot a gent jove (...) les matrimonis joves van ser importants (...) I la gent jove va ser molt important per que a la parròquia va vivificar a Santa Coloma en els seus punts sensibles, que son els barris. Va fer barri, al mateix temps fent l'opció (...) a favor de la joventut obrera, la JOC. Es va fer un gran moviment de joves, que lligava tota la joventut de Santa Coloma. “360

Es tractava de Jaume P. Sayrach (parròquia de Sant Joan Baptista, barri del Fondo), Salvador Cabré (parròquia de Sant Miquel, barri del Singuerlín), Josep Esquirol (parròquia de Sant Jaume al barri del Raval) i Joaquim Trias (parròquia de Sant Josep Oriol al barri del Riu Nord) i d'altres que s'afegiran posteriorment com Joan Morán, Antoni Antonijoan, Josep Catà (fundador de la parròquia de Santa Maria al barri de Can Mariner) o el mateix Lluís Hernàndez (fundador de la parròquia de Sant Ernest a Les Oliveres, ja als anys setanta). A Badalona i Sant Adrià no va haver-hi un equip tant fort i cohesionat de sacerdots, si bé en tenien un perfil similar als anteriors: Josep Torrella i Joan Cuadrench a la nova parròquia de Sant Sebastià de Pomar (Badalona) i diversos sacerdots vinculats al la parròquia de Sant Pere Ermengol com Joan Cuspinera o Alfred Matas que tot i estar situada a Barcelona atenia també al barri pertanyent a Sant Adrià ${ }^{361}$. Caldria fer també una menció apart a Antonio Botey, els escolapis i la seva tasca al Camp de la Bota ${ }^{362}$. Una part d'ells tenien extracció obrera i la seva experiència els havia condicionat profundament:

"O sigui que... bueno... jo recordo sortir... doncs jo sempre havia dit que jo no volia

360CEFID, Arxiu Fonts Orals, Fons Moviment Veïnal. Entrevista amb Jaume P. Sayrach, sacerdot a la parròquia del Fondo i posteriorment regidor d'Urbanisme al primer Ajuntament presidit per Lluís Hernàndez (PSUC). Veure també Jaume P. Sayrach: En el Fondo Parroquia de Joan Baptista (Santa Coloma de Gramenet) 1965-1979. Edicions Fòrum-Grama, 2001, p. 13.

361Alfred Mates Pericé: Al Sud-Oest del riu Besòs. Deu anys de vida d'un barri barceloní, Pòrtic, Barcelona, 1970 i Parròquia de Sant Pere Ermengol: Una parròquia obrera compleix 50 anys. Sant Pere Ermengol 1946-1996, [Parròquia de Sant Pere Ermengol], [Barcelona], 1997; Carles Mas: El Pomar -Badalona-... Altres sacerdots badalonins que van tenir una certa importància van ser Laureano Gibernau a la parròquia de Sant Josep (entre els barris del Centre i el Progrés) i Antonio Torner (al barri del Progrés).

362Francesc Abad: El Camp de la Bota, Fundació Esplais, Girona, 1987 [hi ha una nova edició autoeditada pel mateix autor de 2006]; Josep Maria Montferrer i Celades: El Camp de la Bota: un espai i una història, Octaedro, Barcelona, 2012, 
cobrar de Franco. I per tant jo treballava, buscava feina... Per que quan feia... abans d'entrar al Seminari jo vaig fer d'aprenent en una fàbrica de Gràcia dels 14 als 19. Que als 19 vaig entrar al Seminari. I me'n recordo que venien... era una fàbrica tèxtil no? I venien els camions de Terrassa dels tints, i recordo... però allò que et queda, '¡isi, nosotros aquí trabajando para los curas y los militares!' I es clar jo vaig dir ep! Jo no vull que ningú pugui dir que treballa per mi. Jo ja em guanyaré les garrofes. I aleshores, el primer que vaig fer va ser buscar-me feina, eh? I aleshores, que això molts capellans d'aquella època, molts (...)”363

Aquests nous sacerdots havien tingut més accés a teòlegs europeus que havien sentat les bases de la renovació que es donarà en el Concili Vaticà II $^{364}$. Aquest concili, com és sabut, va suposar la irrupció d'uns aires renovadors dins l'Església. També tenien clar que una de les seves prioritats d'actuació havien de ser el barris que estaven creixent de manera descontrolada:

"El barri és un altre lloc natural de compromís i d'acció. Els militants presten una atenció especial a la gent immigrada que s'estableix en els barris perifèrics de Barcelona i poblacions properes. Viuen l'amistat amb els seus veïns amb els quals formen veritables xarxes de solidaritat. Tots plegats denuncien les carències dels seus barris (manca d'habitatges, d'escoles, d'ambulatoris, de pavimentació, etc.) i planten cara a determinades situacions greus per què passen alguns dels seus veïns. Promouen organitzacions veïnals creant Juntes de Barriada (precedents del que més tard seran les Comissions Obreres de Barri), creen associacions d'escala, Centres Cívics i Socials, economats, lluiten contra els desnonaments i es mouen per tal d'aconseguir habitatges més dignes. Tot i això els militants ho feien des dels anys cinquanta, quan encara la classe obrera restava completament aixafada i sense possibilitat d'expressió." ${ }^{365}$

Aquest procés es donava justament amb la nova onada migratòria que va fer necessària a ulls de l'Església la creació de noves parròquies per atendre als nous potencials feligresos. I va ser a Santa Coloma de Gramenet on aquest procés de creació de noves parròquies amb uns sacerdots joves amb noves idees i un tarannà obrerista va tenir un major impacte. Les noves parròquies van desenvolupar una

363Entrevista a Joan Cuadrench, 7-4-2013. Sacerdot a la parròquia de Sant Sebastià de Pomar (1970-1980) i Sant Antoni de Llefià (1980-1996), de Badalona. 364Jaume P. Sayrach: En el Fondo. Parroquia de Joan Baptista (Santa Coloma de Gramenet) 19651979. Edicions Fòrum-Grama, 2001, p. 7-8. 365Emili Ferrando i Puig: Cristians i rebels..., p. 167. La negreta és de l'original. 
intensa activitat en aquesta dècada, amb un model de sacerdoci molt diferent del tradicional. Uns cures molts dels quals no vestien sotana, que no cobraven pels seus ministeris, que treballaven assalariadament fora de l'Església (no tots, però si un nombre important)... que fomentaven el treball amb els joves, que es preocupaven per la formació i per les mancances dels barris i les denunciaven públicament, que cedien els seus espais religiosos per reunions clandestines ja fossin de Comissions Obreres o de partits polítics... Posteriorment veurem com sota el seu impuls es fundaran nombrosos Centres Socials des dels quals es farà ja una política reivindicativa molt més agoserada i d'on sorgiran futures Associacions de Veïns.

En definitiva, una manera molt diferent de treballar a la que per exemple havia fet fins el moment el rector de la parròquia de Santa Rosa (Santa Coloma), Joan Mata. Malgrat la seva preocupació pel benestar dels seus feligresos, continuava fent servir un discurs paternalista i de col-laboració amb les autoritats, amb les quals fins i tot va impulsar una Associació de Veïns. El testimoni de Salvador Bolancer així ens ho manifestava:

“Todo esto es la época del Mata que hizo un papel importantísimo porque además hizo [inintel-ligible] importante para mandarlos a Barcelona y para que vieran, para hacer posible esa labor social. Entonces hizo una labor importante. Pero no fue capaz de adaptarse a los nuevos tiempos más reivindicativos y más de justicia social. Se quedó, digamos, en la justicia asistencial. Lo que la iglesia entendía como caridad. En la parte de la caridad. Y los otros que vinieron ya no estaban por la caridad, sino estaban por la justicia social y trabajar por la justicia social (...). Y entonces cuando vino [diu un nom que no s'entén, però suposo que deu ser José Sancho, el rector que va substituir a Juan Mata] se encontró con la parroquia muy hermetizada y tal y entonces la abrió totalmente. Y todos los locales los dio, aunque ya había locales que el otro había cedido a la juventud, el Centro Social y tal. Y entonces ya la casa parroquial la dejó para el Casal de Cultura y ahí se creó diríamos había una guardería también para gente con problemas, con problemas no, con problemas familiares, que tenían pocos recursos."366

En altres barris badalonins com Sant Roc sacerdots com Amadeu Bassols també havien desenvolupat una important tasca en aquesta línia assistencial més semblant a la de Joan Mata, si bé posteriorment el Centre Social creat per ell a 
l'esmentat barri si que tindrà una línia d'actuació molt més reivindicativa durant els anys $70^{367}$.

No era aquest -evidentment- un procés circumscrit al Barcelonès Nord. Dins de la diòcesi de Barcelona anaven apareixent grups amb unes posicions més enfrontades a la jerarquia eclesiàstica i a la dictadura ${ }^{368}$. L'Estat franquista contemplava amb preocupació aquests esdeveniments que s'estaven donant dins una institució que oficialment havia estat un dels seus puntals ${ }^{369}$. La mateixa policia va fer un seguiment exhaustiu de la XVIII Setmana Nacional de l'HOAC, celebrada a Barcelona 24-30 d'agost de 1964. De la qual reprodueixo un fragment prou significatiu:

"Propugnan por tener acceso a las escuelas, universidades, centros de enseñanza superior, cosa que hasta el momento -dicen- está reservada a los capitalistas. El obrero -señalan- no tiene derecho a la cultura, sólo tiene derecho a ser explotado por el patrono. Todo el clima de la Asamblea parece francamente demagógico. En ningún momento se hace alusión a la preocupación del Estado por la clase trabajadora y los beneficios de toda índole que para la misma se han conseguido, tales como becas, Universidades Laborales, Centros de Formación Acelerada, Residencias de Verano, etc. etc." ${ }^{370}$

Es feia un seguiment de les opinions i posicionaments de sacerdots que es consideraven desafectes, fins i tot a l'exterior. Un Informe dels "Servicios Informativos de la Dirección General de Prensa" ressenyava un article escrit per

367Joan Tudela: Sant Roc. Badalona. Els Barris d'Adigsa núm. 37, Departament de Benestar Social de la Generalitat de Catalunya. Entrevista amb Juan Jesús Guerrero, 14-6-2013. Membre del Centre Social Sant Roc i de l'Ateneu Popular de Sant Roc.

368L'any 1965 un grup de fidels de la diòcesi redactaren un manifest titulat "Missatge dels catòlics de Barcelona als Pares Conciliars" denunciant la manca de drets i llibertats fonamentals així com la repressió de la cultura catalana. Poc després 67 sacerdots (entre ells Joan Carrera) amb motiu del 1 de maig redactaren un manifest titulat "Carta oberta al món del treball i a les seves forces" on es demanava la llibertat sindical, sense oblidar fets com la Caputxinada de 1966 o la manifestació de capellans per la Via Laietana del 11 de maig, violentament reprimida. Veure Emili Ferrando Puig: Cristians i rebels..., p. 146.

369Veure Pere Ysàs: "5. La disidencia eclesiàstica", a Disidencia y subversión... p. 184-190. De fet ja el 31 d'octubre de 1959 una nota del Estado Mayor del Ejército alertava de sacerdots i seglars "perillosos" com Joan Nualart, Josep Benet, Jordi Pujol i Rogelio Doucastella, entre d'altres. Veure Estado Mayor del Ejército: "Nota a S.E. Asunto: Actividades de carácter político-social en la Diócesis de Barcelona" (Madrid, 31 d'octubre de 1959), AGA, Fons Cultura. Gabinete de Enlace del Ministerio de Información y Turismo, Caixa 42/9002 Dossier 10. Sobre las actividades político-religiosas de los sacerdotes pertenecientes a la Diócesis de Barcelona.

370AHGCB, carpeta "Organizaciones dependientes de la Iglesia", registre 5779, 28-2-1964. Referenciat a Emili Ferrando i Puig: Cristians i rebels..., p. 153, nota 14. 
Alfonso Carlos Comín en la revista Temoignage Chretien del 10 de març de 1966, qualificada de "Católico izquierdista", on entre d'altres aspectes mencionava la important tasca desenvolupada per la HOAC, la JOC i l'ACO, l'expulsió de Monsenyor Escarré així com les crítiques dels cristians progressistes al funcionament intern de la diòcesis ${ }^{371}$.

Seguint la mateixa tònica de control la Direcció General de la Guàrdia Civil informava, arran la coneguda manifestació de Capellans per la Via Laietana, l'existència d'uns fulls de denúncia d'aquells fets a la parròquia de Sant Jaume de Badalona, regida per Antonio Torner i situada al barri Congrés ${ }^{372}$.

El control exhaustiu dels sacerdots i parròquies que no eren afins al règim era habitual, com ens ho demostra un document més extens de Servicio de Información de la Comandancia de la Guardia Civil de Barcelona de febrer de 1967, anomenat significativament "Relación de Sacerdotes Progresistas y cargos que ocupan en la Archidiocesis de Barcelona". Pel que fa al Barcelonès Nord, es feien constar les següents dades:

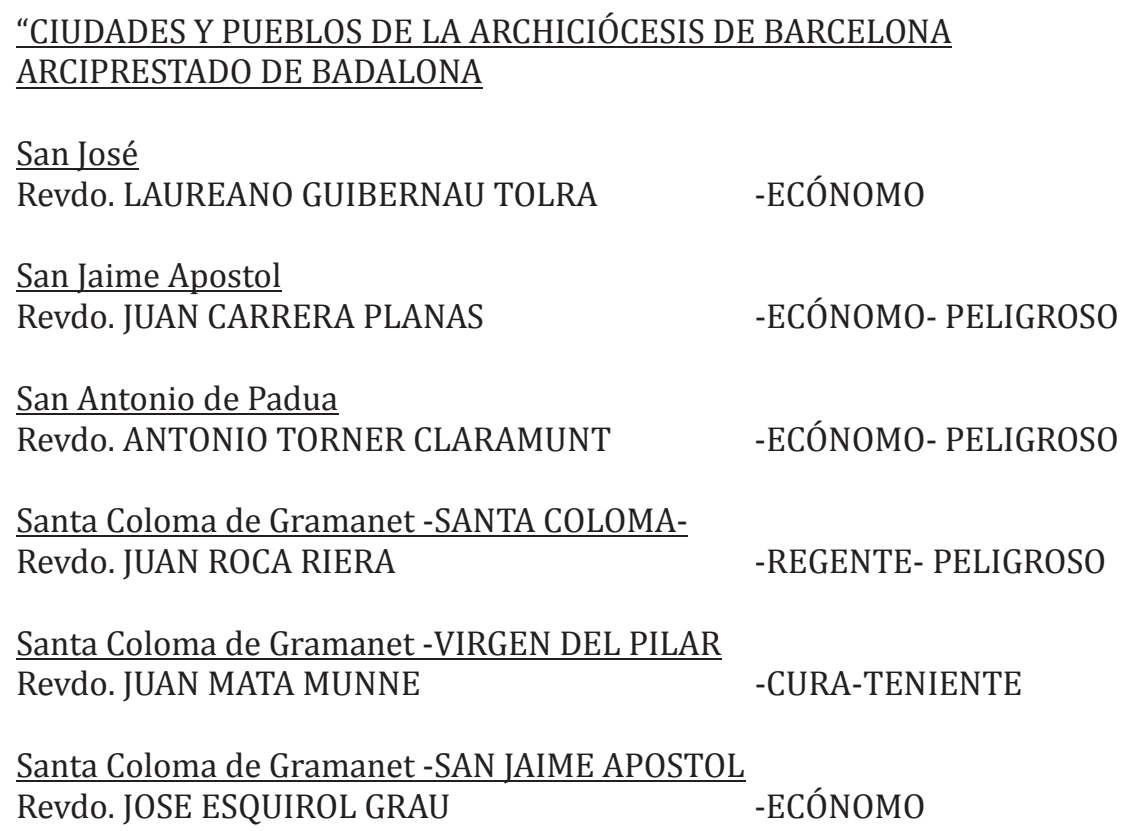

371Alfonso Carlos Comín: "Crisis en el Episcopado", article publicat a Temoignage Chretien del 10-31966, mecanografiat i adjuntat en un Informe Servicios Informativos de la Dirección General de Prensa" del 23-3-1966, AGA, Fons Cultura. Gabinete de Enlace del Ministerio de Información y Turismo, Caixa 42/08996, Dossier 21. Sobre el Arzobispo de Barcelona Gregorio Modrego.

372 “Informe de la Dirección General de al Guardia Civil al Ministro de Información y Turismo" (46-1966) [ sobre opinió i activitats de sacerdots i parròquies arran els fets de la manifestació de capellans del 11 de maig de 1966], AGA, Fons Cultura. Gabinete de Enlace del Ministerio de Información y Turismo, Caixa 42/09002, Dossier 9. Sobre las actividades del clero de la Diócesis de Barcelona. 
Santa Coloma de Gramanet -SAN JOSÉ ORIOL Revdo. JOAQUIN TRIAS BIRBA

-ECÓNOMO

Santa Coloma de Gramanet -SAN JUAN BAUTISTA

Revdo. JAIME P. SAYRACH FATJO DELS XIPRERS -ECÓNOMO- PELIGROSO

Santa Coloma de Gramanet -SAN MIGUEL ARCANGEL

Revdo. SALVADOR CABRE PUIG -ECÓNOMO- PELIGROSO

Revdo. ANDRES PAGES CASALS -COADJUNTOR-PELIGROSO"373

De fet, encara hi hagueren posicionaments més explícits com el que van fer una sèrie de sacerdots l'abril de 1967 fent una proposta a l'Arxiprestat de Barcelona d'adhesió pública a les Comissions Obreres $^{374}$, proposta a la que va donar suport Joan Carrera i Planas. 0 almenys això s'entreveu llegint un altre document d'autoria desconeguda però segurament d'algun organisme policial quan informava sobre el nomenament dels Vicaris Episcopals de Barcelona:

“Rvdo. DON JUAN CARRERA PLANAS.- De 37 años de edad. Ecónomo de la Parroquia de Sant Antonio de Pádua de Badalona. Progresista. Ha sido nombrado vicario de APOSTOLADO OBRERO. Firmante del manifiesto de 1으 de Mayo del presente año. Inteligente, activo y con mentalidad marxista; por su condición de Apostolado Obrero manejará los grupos de la J.O.C., la O.A.C. y la A.C.O., por lo que se considera puede realizar una labor sumamente peligrosa entre el elemento obrero." 375

Aquest sacerdot havia estat desenvolupant una important tasca al barri de Llefià de Badalona, on havia creat un centre sanitari a la parròquia i una Cooperativa d'Habitatges, i fins i tot havia cedit el seu temple a les reunions clandestines de CCOO. En ser nomenat Vicari d'Apostolat Obrer fou estretament

373Servicio de Información de la Comandancia de la Guardia Civil de Barcelona: "Relación de sacerdotes progresistas y cargos que ocupan en la Archidiócesis de Barcelona" (27-2-1967), AGA, Fons Cultura. Gabinete de Enlace del Ministerio de Información y Turismo, Caixa 42/08996, Dossier Dossier 22. Sobre vacantes y nombramientos de cargos eclesiásticos dentro de la Iglesia catalana, p. 9. El document conté un error ja que Joan Carrera estava a Sant Antoni de Pàdua i no a Sant Jaume Apostol.

374 “Actividades subversivas" (Barcelona) [Dues fulles] (Madrid, 31-3-1967 i Barcelona, 5-4-1967), AGA, Fons Cultura. Gabinete de Enlace del Ministerio de Información y Turismo, Caixa 42/09002, Dossier 4 sobre las actividades del clero en la Diócesis de Barcelona.

375 "Vicarios episcopales en Barcelona” (Madrid, 16-10-1967), AGA, Fons Cultura. Gabinete de Enlace del Ministerio de Información y Turismo, Caixa 42/08996, Dossier Dossier 22. Sobre vacantes y nombramientos de cargos eclesiásticos dentro de la Iglesia catalana, p. 1. En realitat, Joan Carrera no era un sacerdot marxista, ja que els seus postulats estaven més a prop d'Unió Democràtica de Catalunya (si bé cal dir que aleshores eren més "progressistes" que en l'actualitat). 
vigilat pel franquisme que el considerava un element "molt perillós". Vaig trobar un dossier personal seu a l'Archivo General de la Administración a Alcalá de Henares, però lamentablement no es podia consultar d'aquí a molts anys.

Apart d'aquest estricte control, les autoritats franquistes, amb el suport de la Jerarquia Eclesiàstica, va jugar altres cartes per mirar de contrarestar aquesta desafecció dins l'Església. Es fomentava l'aparició d'altres manifestos signats per sectors conservadors, com va ser per exemple el cas d'un document anomenat "Nuestra Opinión de Laicos Católicos, Congregantes y Padres de Familia" on es criticava durament la Caputxinada i la manifestació de capellans del 11 de maig de 1966 als quals s'acusava de còmplices del comunisme i, pel que fa al cas de la manifestació, fins i tot d'haver estat els sacerdots els que havien agredit als agents de la Policia Armada. ${ }^{376}$

O com per exemple va ser una reunió de 300 sacerdots integristes celebrada a Vic el 12 de maig de 1969, on es va elaborar una "Declaración de Principios y Criterios sacerdotales", que entre d'altres coses afirmava:

“(...) Sí, los sacerdotes debemos iluminar los grandes conceptos de la sociedad y estado, de poder y libertad, de propiedad y trabajo, de organización profesional y derechos de las sociedades subsidiarias. Pero todo esto según los principios del derecho natural, de la ética y de los documentos pontificios.

Por esto jamás los sacerdotes podremos colaborar ni directa ni indirectamente con el comunismo que por su naturaleza es intrínsecamente perverso, y aun en el supuesto de que pudiera separarse de su congénito ateísmo -lo que realmente no es posiblesiempre es antinatural. Nos parece inconcebible que el esfuerzo y el trabajo del algún sacerdote pueda significar en ningún momento una colaboración para que se implante el ateísmo y la tiranía comunista."377

376 “Nuestra Opinión de Laicos Católicos, Congregantes y Padres de Familia” i nota adjuntada (5-101966), AGA, Fons Cultura. Gabinete de Enlace del Ministerio de Información y Turismo, Caixa 42/09002, Dossier 8. Sobre las actividades del clero en la Diócesis de Barcelona. El document acabava amb aquestes significatives paraules:"Triste espectáculo el de estos sacerdotes. Triste que unos sacerdotes se presentan en la via pública con el descaro de unos vulgares gamberros y revoltosos de oficio."

377Servicio de Información del Movimiento: "Nota Informativa. Asunto Reunión Sacerdotal" (Madrid, 22-5-1969) [s'adjunta una còpia de la "Declaración de Principios y Criterios sacerdotales], AGA, Fons Cultura. Gabinete de Enlace del Ministerio de Información y Turismo, Caixa 42/9002, Dossier 4 sobre las actividades del clero en la Diócesis de Barcelona. Veure també Josep Massot i Muntaner: L'Església catalana al segle XX, Curial, Barcelona, 1975 i Jaume Barallat i Barés: L'Església sota el franquisme. Lleida (1938-1968), Pagès Editors, Lleida, 1994. 
Però malgrat la reticència dels sectors ultres i la jerarquia, el cert és que dins de l'Església van haver-hi veus discrepants, plasmades sobretot per les organitzacions d'apostolat obrer i per un nombre de sacerdots progressistes, encara que en ocasions aquest fet s'hagi magnificat. En el cas del Barcelonès Nord podem constatar aquest fet, que es va donar amb una major intensitat a Santa Coloma de Gramenet i a determinats barris perifèrics badalonins. Al 1968 s'havia creat la Federació Badalona-Santa Coloma de l'HOAC, amb un equip base de 4 militants i dos equips d'iniciació amb 10 militants més. Existia també la Federació del Besòs que incloïa el barri del mateix nom de Sant Adrià ${ }^{378}$. La mateixa HOAC l'any 1969 tenia un total de 46 equips i 252 militants, dels quals més de la meitat tenen un ferm compromís polític o sindical ${ }^{379}$.

No obstant, a finals de la dècada les organitzacions d'apostolat obrer patiran una nova crisi, ara de característiques diferents a la de finals dels cinquanta que hem esmentat anteriorment. El context del convulsions polítiques i socials viscudes l'any $1968^{380}$ també les van afectar i van provocar no poques "crisis de fe":

“(...) Els militants es pregunten: Com es pot ser fidel al mateix temps a la Classe Obrera

i a una Església aburgesada i aliada del poder polític franquista?, què aporta d'específic la fe a la lluita?, què pot aportar l'HOAC a favor de l'alliberament dels explotats més enllà del que ja aporten les organitzacions obreres?, té sentit mantenir una organització apostòlica ideològicament i organitzativament centralitzada en un moment en que estan apareixent i consolidant-se les Comunitats Cristianes de Base?, no són aquestes el seu relleu natural?, per què mantenir un tipus d'organització que projecta una ombra sospitosa sobre el món obrer i que exigeix un enorme esforç en el seu funcionament intern?, què significa en aquests moments ser cristià?"381

Per la mateixa època, a finals dels seixanta, la Jerarquia de l'Església va voler

378Emili Ferrando i Puig: Cristians i rebels..., p. 181.

379 Ídem, p. 182.

380Sobre els fets de 1968 en diferents indrets del món: José Julio Perlado: Paris, Mayo de 1968: Crónica de un corresponsal, Ediciones Internacionales Universitarias, Madrid, 2008; Manuel Garí, Jaime Pastor y Miguel Romero (eds.): 1968: el mundo pudo cambiar de base, Los Libros de la Catarata, Madrid, 2008; André Glucksmann y Raphaël Glucksmann: Mayo del 68: por la subversión permanente, Taurus, Madrid, 2008; Miguel Delibes: La Primavera de Praga, Destino, Barcelona, 1991; Giaime Pala y Tommaso Nencioni (eds.): El Inicio del fin del mito soviético : los comunistas occidentales ante la primavera de Praga, Ediciones de Intervención Cultural, Barcelona, 2008; Carlos Fuentes: Los 68: París, Praga, México, Debate, Madrid, 2005: Juan Miguel de Mora: T 68 : Tlatelolco 68 : por fin toda la verdad, EDAMEX, México, 2000 i Elena Poniatowska: La Noche de Tlatelolco : testimonios de historia oral, Era, México, 1974.

381Emili Ferrando i Puig: Cristians i rebels..., p. 208. 
recuperar el control de les organitzacions apostòliques obreres amb la imposició d'uns nous Estatuts. No es estrany que en aquest context molts dels seus integrants passessin a militar a partits polítics revolucionaris i marxistes que oferien una activitat antifranquista més "clara" - o s'integressin en aquestes noves Comunitats Cristianes de Base que no tenien un funcionament tant jeràrquic. Tot i això, al Barcelonès Nord aquests sectors encara van tenir un paper important en el desenvolupament del moviment veïnal durant els anys setanta. La fundació de la revista Grama l'any 1969 amb la cobertura de les parròquies de Santa Coloma de Gramenet -on va destacar el paper de Jaume P. Sayrach- és un bon exemple de la seva importància, pel caràcter de portaveu del moviment veïnal de l'àrea que aniria prenent. A més, durant els anys 70 es va donar un procés de confluència entre cristians i marxistes plasmat en el corrent "Cristians pel Socialisme"382 i que va acabaria propiciant en la Transició que un "cura comunista" -Lluís Hernández- fos alcalde de Santa Coloma de Gramenet.

L'altre gruix de gent que va tenir un paper important en el desenvolupament del moviment popular ciutadà van ser els militants dels partits polítics. No de tots, ja que el pes més destacat el van tenir els militants comunistes. Arribats a aquest moment és imprescindible fer un breu comentari de l'evolució del que va ser el principal partit de l'antifranquisme: el PSUC. Aquest havia experimentat un canvi important a partir del I Congrés celebrat a l'Agost de 1956, en un context internacional fortament influenciat pel XX Congrés del PCUS i la denúncia de l'estalinisme, apart de l'entrada de gent nova i més jove, fet que va comportar per exemple la creació d'un primer nucli estudiantil a la universitat ${ }^{383}$, va haver-hi un canvi d'orientació en la política seguida fins aleshores. Un dels nostres entrevistats ho deia amb les següents paraules:

382El document fundacional de gener de 1973 es pot trobar a l'AGA, Fons Cultura. Fons Gabinete de Enlace del Ministerio de Información y Turismo, Caixa 42/9010, Dossier 11. Sobre los Movimentos Apostólicos Seglares. Veure també Francisco Martínez Hoyos: La Cruz y el martillo: Alfonso Carlos Comín y los cristianos comunistas, Rubeo, [Rubí], 2009; Alfonso Carlos Comín: Obras Completas, Fundación Alfonso Carlos Comín, Barcelona, 1986-1994 i Cristianos el partido, comunistas en la iglesia, Laia, Barcelona, [1977]. També Joaquima Utrera Redondo: Lluís Hernández, el capellà rebel, Fundació Nous Horitzons, [Barcelona], 2011 i Lluís Hernández. Escrits, 1980-1992/ Lluís Hernández : l'alcalde de la transformació de Santa Coloma de Gramenet, Associació Editors Teresa Quintana, Santa Coloma de Gramenet, 1992.

383Carme Molinero i Pere Ysàs: El PSUC. El Partit de l'antifranquisme (1956-1981), L'Avenç, Barcelona, 2010, p. 24. 


\begin{abstract}
"Hacía muy poco tiempo que el partido en el año cincuenta y seis se había lanzado la consigna de la reconciliación nacional y la lucha de masas, por lo tanto el partido ya se estaba organizando digamos de forma de fundirse con las masas y a partir de los problemas concretos de los trabajadores y la gente." ${ }^{384}$
\end{abstract}

No obstant, aquest nou canvi tàctic va trigar a ser efectiu. Tot i l'auge de la conflictivitat obrera a finals dels anys 50 , no va ser fins la segona meitat dels seixanta, amb l'impuls de CCOO, i la seva implantació a la universitat que el partit va començar tenir uns nivells d'incidència no vistos fins al moment. Això, es va veure reflectit el seu creixement de militància malgrat les tensions i escissions internes ${ }^{385}$.

Al Barcelonès Nord tenim constància que el PSUC tenia ja una forta implantació des de inicis dels anys seixanta. Al 1961 es va produir l'anomenada "caiguda del duro" on van ser detinguts al voltant d'un centenar de militants del PSUC de la comarca. El nom sembla ser que prové de que el detonant de la caiguda va ser una llista amb noms de persones que havien fet aportacions de 5 ptes. per comprar joguines pels fills dels presos del penal de Burgos. Malgrat l'efecte negatiu inicial, aquest fet va fer que el partit s'organitzés millor si hem de fer cas al testimoni d'Adonio González:

"La historia del movimiento obrero es mucho más dura de lo que muchos habéis conocido.... La caída del 61 se llama la caída del duro, fue una caída absurda. Afortunadamente existió esa detención, aunque sea duro decirlo, porque si no hubieran habido esas detenciones hubiéramos acabado todos como el rosario de la aurora. Cayó gente de Badalona, de Santa Coloma, de Sant Adrià, Montcada, de Cerdanyola... Cae toda esa gente porque había una desorganización tal del Partido que... A partir de ese momento la historia del Partido se expresa en cómo hay que

384Entrevista a Àngel Navarro, 6-5-2006. Militant del PSUC, de l'AVV Juan Valera i posteriorment regidor al primer Ajuntament democràtic després de la dictadura. José Miguel Cuesta: $\mathrm{El}$ Moviment veïnal a Llefià (Badalona), Tesina de Doctorat, UAB, 2010, p. 169-170.

$385 \mathrm{Al} 1962$ el partit comptava amb 1168 militants, dels quals 800 eren de la província de Barcelona, 402 a la capital i 405 a les comarques de l'entorn. Ni l'expulsió de Semprún i Claudín al PCE ni les escissions del 1967-68 en el grup universitari que van ser l'origen del PCE(Internacional), posteriorment PTE i del grup de Bandera Roja van fer minvar la seva militància, que no va parar de créixer, arribant als 2000 militants a finals de la dècada dels seixanta malgrat la repressió exercida. Veure Carme Molinero i Pere Ysàs: El PSUC.., p. 32 i Giaime Pala: "El PSUC hacia dentro. La estructura del Partido, los militantes y el significado de la política (1970-1981)", dins VV.AA.: El PSU de Catalunya. 70 anys de la lluita pel socialisme, Assocació Catalana d'Investigadors Marxistes, 2008, p. 183 i del mateix autor El PSUC. L'antifranquisme i la política d'aliances a Catalunya, Editorial Base, Barcelona, 2011. 
organizar el Partido porque allí se conocía todo dios. Las reuniones se hacían en los bares, era algo... y menos mal que la policía nos detiene, porque esto hubiese sido terrible, terrible (...) Tothom coneixia tothom, perquè eren del mateix poble, si vols et portaré el sumari i veuràs que molta gent era del mateix poble, no és que fossin camarades, que ho eren, sinó que a més eren compadres. El d'una cèl-lula coneixia el de l'altra cèl·lula que estava a l'altra cè̀llula. I no tenien per què saber-ho (...) Estoy diciendo lo que podía haber ocurrido en el 61. Pudimos salvar al resto del partido"386

No obstant això, el PSUC ràpidament es va reorganitzar gràcies, en part al paper que van jugar en el desenvolupament de les Comissions Obreres a la comarca. Inicialment el PSUC no va prioritzar la seva actuació als barris perquè centrava la seva tasca en els espais laborals ${ }^{387}$. Això no vol dir que no hi pogués haver militants fent feina pel seu compte a les associacions o juntes de veïns existents. Un militant del PSUC dels anys seixanta ens deia això quan li preguntàvem per la ja esmentada "Asociación de Cabezas de Família de Alta Badalona":

“Esos estaban (...) en la prolongación de Dr. Bassols ... el trozo aquél que había unas casitas pequeñas hasta llegar a Circunvalación... había a la izquierda un taller de ruedas y en la derecha había la asociación esta... y ahí sabía yo que había gente nuestra...."388

Però va ser en el moviment Obrer on els militants PSUC, sobretot, van tenir una "escola de formació" en el desenvolupament de les Comissions Obreres, que posteriorment li van servir per la seva actuació als barris. Per això és interessant que expliquem el desenvolupament inicial de les CCOO al Barcelonès Nord ${ }^{389}$. De fet, des de la fundació "oficial" de les CCOO barcelonines fins a la fundació de les Comissions al Barcelonès Nord no va passar gaire temps. Ja des de finals de $1965 \mathrm{i}$ principis de 1966 s'estava treballant per crear un nucli que englobés a tota la sub-

386Testimoni d'Adonio González, recollit a Emili Ferrando Puig i Juan Rico Márquez: Les Comissions Obreres en el franquisme. Barcelonès Nord (1964-1977), Publicacions de l'Abadia de Montserrat, Barcelona, 2005. La transcripció bilingüe és com consta a la font original.

387 Carme Molinero i Pere Ysàs: El PSUC..., p. 75. Més endavant citaré algun document del propi partit al respecte.

388Entrevista a Àngel Navarro, 21-7-2009. Militant del PSUC, de l'AVV Juan Valera i posteriorment regidor al primer Ajuntament democràtic després de la dictadura.

389 Imprescindible la consulta de l'obra d'Emili Ferrando Puig i Juan Rico Márquez: Les Comisions Obreres en el franquisme... així com també la de Xavier Domènech: Clase obrera, franquismo y cambio político. Pequeños grandes cambios, 1956-1969, Los Libros de la Catarata, Madrid, 2008. 
comarca, és a dir, a Badalona, Santa Coloma de Gramenet i Sant Adrià de Besòs. Es van fer reunions a l'església de Sant Pau -a l'actual barri del Raval de Badalonaregentada per Mossèn Albert i es va crear una comissió coordinadora composada per gent que en la seva majoria pertanyia també al PSUC i que en no pocs casos trobarem més endavant participant del moviment veïnal:

"Els membres fundadors d'aquesta comissió coordinadora foren Joan Gómez, Ángel Navarro, Miquel Guerrero, Adoni González, Manuel Murcia, Tito Márquez, José Sánchez, Rafael Parra, Ángel Pérez, Miguel Morón, Ramón Jurado, Bernardo Fernández, Abilio Campos, Molina, Ochoa... Majoria absoluta d'homes de la ciutat de Badalona (el nom original de "Comisiones Obreras de Badalona y su Comarca" era expressió d'aquest fet) i de militants del PSUC". ${ }^{390}$

La fundació formal i presentació pública es va donar en el context de les eleccions sindicals de setembre 1966 on les CCOO en general van jugar un paper molt important. Un grup de sindicalistes de Barcelona i la comarca s'havien reunit el 6 d'agost en un local del Besòs per preparar les futures eleccions. En aquest context el mateix Marcelino Camacho va visitar Badalona i va mantenir una reunió multitudinària a la parròquia de Sant Antoni de Llefià amb la complicitat del ja esmentat mossèn Joan Carrera, que va oposar-se a l'entrada de la policia al recinte i que va comptar amb l'assistència de unes 500 persones segons diversos testimonis $^{391}$.

Al juliol s'havien reunit a la mateixa parròquia militants del II Sector del PSUC (que englobava la "sub-comarca" del Barcelonès Nord) que havien convocat als companys que treballaven a les empreses del territori ${ }^{392}$. A la reunió hi van ser presents 10 treballadors, dels quals quatre eren militants del PSUC. Es va decidir contactar amb més gent i fer una primera concentració davant la seu del sindicat vertical (l'OSE) a Badalona. Aviat, a començaments d'agost, ja es trobaven al voltant de 25 persones a les reunions que es feien setmanalment. El 10 d'agost es va fer la concentració abans esmentada i es va entregar un escrit de protesta per

390Emili Ferrando Puig i Juan Rico Márquez: Les Comisions Obreres en el franquisme..., p. 117.

391Cal destacar els mateixos testimonis dels protagonistes dels fets, Gabriel Màrquez, Adoni González, Lluís Diego, Miguel Guerrero, Teresa Buigas i Juan Gómez, militants de CCOO (i també del PSUC en la seva majoria) recollits a Emili Ferrando Puig i Juan Rico Márquez: Les Comisions Obreres en el franquisme... , p. 139-141.

392Xavier Domènech: Clase obrera, franquismo y cambio político. Pequeños grandes cambios, 19561969, p. 240-249. 
l'acomiadament d'un treballador de l'empresa METALGRAF.

Aquest petit èxit va esperonat el moviment obrer, que es va estendre a Sant Adrià de Besòs, on fins i tot es va aconseguir la presidència de la Secció Social del Metall de l'OSE ${ }^{393}$. Però les Comissions Obreres al Barcelonès Nord van tenir unes certes peculiaritats, condicionades pel context socio-econòmic de la comarca de manera que no van tenir la força d'altres comarques com el Vallès Occidental o el Baix Llobregat:

"La veritat, però era que les Comissions d'empresa costaven molt de crear i desenvolupar-se. Badalona no tenia en aquest moment empreses punteres que arrosseguessin a nivell de lluita, però els actes de solidaritat no faltaven quan alguna ho necessitava. D'altra banda molts treballadors veïns de la comarca tenien el seu àmbit d'actuació en empreses de Barcelona i el seu entorn, com la Maquinista, Seat, Olivetti, Macosa, Pegaso, etc. i hi exercien la seva activitat militant”394

El predomini de la petita i mitjana empresa juntament amb l'existència d'un gran nombre de persones que treballaven fora del Barcelonès Nord els hi va restar força. Però curiosament, aquest fet els hi va permetre, en el cas de Badalona, tenir una major capacitat per connectar amb sectors de la ciutat que no eren exclusivament obrers. De la mateixa manera, que la feblesa organitzativa per fàbriques va condicionar un model d'organització per zones o barris que, com veurem va afavorir el futur sorgiment del moviment veïnal.

A continuació aprofundirem en aquest aspecte així com en les primeres formes organitzatives que es van donar als diferents barris de les ciutats del Barcelonès Nord als anys seixanta i que van posar la base pel posterior desenvolupament d'un moviment popular ciutadà amb una gran força durant la dècada dels setanta.

393Xavier Domènech: Clase obrera, franquismo y cambio político..., p. 242.

394Emili Ferrando Puig i Juan Rico Márquez: Les Comissions Obreres en el franquisme... , p. 149. 


\subsection{Del moviment obrer als primers intents: Comissions de Veïns, Comissions Obreres de Barri i Centres Socials.}

Si bé és cert que la majoria d'organitzacions polítiques de caire marxista (PSUC, PCE(i), FOC...) no van considerar prioritària la seva actuació dins el terreny veïnal fins als anys setanta per la primacia que van donar al moviment obrer sindical, el cert és que als anys seixanta es van donar uns processos on en especial el PSUC si va tenir una certa actuació. I juntament amb els militants de les organitzacions cristianes de base i els capellans obrers, van marcar, sens dubte, uns precedents. Un d'aquests precedents es donarà en una organització on precisament havien començat a confluir tant els militants d'organitzacions polítiques com de les organitzacions d'apostolat obrer i altres cristians de base: les Comissions Obreres.

Ja he comentat al final del capítol anterior que les Comissions al Barcelonès Nord, en especial les badalonines tenien unes certes peculiaritats. Una d'elles va ser una major capacitat de contactar amb sectors de la ciutat que no eren exclusivament treballadors "de fàbrica". Per exemple, dins les CCOO van participar militants de la Força Socialista Federal, els quals tenien una extracció social diferent a la dels membres del PSUC, ja que eren professionals liberals o assalariats qualificats ${ }^{395}$. D'aquesta manera el moviment obrer badaloní, sobretot, va tenir de ben antuvi connexions i complicitats amb altres sectors de la ciutat, per sorpresa de les pròpies autoritats franquistes:

"Así, la concentración del 10 de agosto [de 1966] delante de la OSE seria seguida al día siguiente por una delegación de personalidades locales que, ante la sorpresa de los jerarcas, se iban a presentar también ante el Vertical para solidarizarse con los motivos de la acción obrera." 396

Pel que es veu, aquesta manifestació va ser una cosa diferent a una altra mobilització que es va donar poc després, al setembre, i que va arribar a ser posada com "exemple" pel mateix Gregorio López Raimundo o la que va ser regidora de l'oposició moderada al Tercio Familiar de Badalona Cecília March Blanch ${ }^{397}$ : la

395Xavier Domènech: Clase obrera, franquismo y cambio político..., p. 242. 396ídem.

397Veure la cita referenciada a la nota 179, referent al document de Gregorio López Raimundo: "En el buen camino. Intervención ante una reunión de militantes del P.S.U. de Cataluña” (1967), AGA, 
manifestació contra el "polsim negre" de la central tèrmica de la FECSA de Badalona que van protagonitzar un grup de dones de Badalona. Aquesta mobilització recollia un sentiment de malestar local, però d'una manera més "endreçada" i on les oligarquies locals van tenir una major capacitat de control, com reflectien uns documents interns d'organismes policials encarregats de controlar la mobilització:

"La mayoría de manifestantes pertenecen a las clases acomodadas de la ciudad, recordando entre ellas a las señoras de HEREDERO, SANTIAGO SCHILT, WALTER, así como las esposas de varios médicos y la hija del ex-Alcalde Sr. Serentill (...) Llevaban una pancarta que no se ha llegado a desplegar. El texto de la misma es la siguiente: "Saneamiento de Badalona y del Ayuntamiento" 398

Responia més a les lluites internes de les capelletes locals enfrontades amb l'Alcalde Felipe Antoja, com apuntava un document elaborat per el Sevicio de Información de la Guardia Civil sobre la mateixa manifestació:

“(...) aunque respondió a un sentimiento bastante extendido, se componía únicamente de señoras, en general de clase media acomodada e industriales, aunque algunas pocas muchachas jóvenes asistieron acompañadas de sus novios.

(...).

Este hecho obedece a un plan general organizado a la vista de la proximidad de las elecciones, y por la consideración de que el cambio de Gobernador de la Provincia puede ser ocasión para obtener una substitución de relevo del Alcalde, que es contra quien se dirigen los tiros.

(...)

Los organizadores y buena parte de las familias a las que pertenecían las manifestantes , aparte de la real preocupación por el polvo, son gente que ve con poca

Fondo Cultura, Gabinete de Enlace del Ministerio de Información y Turismo, Caixa 42/9097, Dossier 5. Documentación relativa al Partido Socialista Unificado de Catalunya (PSUC). I també Cecília March, que s'atribuia la paternitat d'aquesta manifestació a "Si las mujeres mandasen..." [entrevista], El Besós núm. 2 (8 d'agost de 1978), p. 6. Com veurem, Cecília March Blanch, germana de l'antic alcalde badaloní Santiago March Blanch (va tenir un protagonisme en els darrers anys de l'Ajuntament franquista arran la seva entrada com a regidora pel Tercio Familiar a les eleccions de 1970. Posteriorment es va vincular a la candidatura al Congrés "Pacte Democràtic de Catalunya" on anava en el número 23 de la llista i a Convergència Democràtica, fins que va renunciar-hi per discrepàncies pel paper que jugava com a Tinent d'alcalde dins el consistori de l'alcalde Alfonso Ramos i va muntar una candidatura alternativa amb el seu marit per les eleccions municipals de 1979 que no va reeixir en obtenir representació.

398 “Nota informativa: Asunto: Badalona. Manifestación de protesta por el polvo insalubre”, AHGCB, Gobernadores Civiles, Caixa 15 TRIS. Comarcas, 1966,1967. Aquest document forma part d'un recull dedicat a aquest assumpte. 
simpatía al Alcalde, desde el mismo momento de su nombramiento, e independientemente de su actuación.

(...)

La organización responde a un grupo que se mueve actualmente en el Club de Futbol Local, en otras entidades deportivas y en el casino y que formó ya de cara a anteriores elecciones y cambios políticos locales producidos en situaciones anteriores". 399

Responent a una dinàmica totalment diferent, al mateix mes de setembre, s'havia posat en marxa al Centre de la ciutat de Badalona una mena de "Comissió Ciutadana", on van participar les CCOO Badalonines amb forta presència del PSUC i la FSF, però també altres sectors dels anteriorment esmentats, des de l'Orfeó Badaloní, el Círcol Catòlic, Badalona Sardanista i els grups teatrals del Centre Sant Josep, als quals es van afegir posteriorment el Cine Club Studio, les Joventuts Musicals o la Jove Cambra ${ }^{400}$. Certament, és innegable que les CCOO de Badalona "i la seva comarca" van anar molt més enllà de l'àmbit obrer i no ens hauria d'estranyar que per exemple a l'any 1968 fins i tot tinguessin un paper destacat en actes de reivindicació cultural, com afirmava un full volant de les mateixes:

"Las Comisiones Obreras de Badalona y su Comarca, en constante lucha y preocupación por el acceso del pueblo a la cultura y a la democratización de la enseñanza, al respeto de la etnología y de la lengua vernácula de los pueblos, saludan y se congratulan de la iniciativa del homenaje al Ilustre Dr. POMPEU FABRA, que tan honorablemente se caracterizó por las libertades democráticas del pueblo catalán, y se adhieren al presente acto. Badalona, 24 de Abril de 1968 [o maig, ja que el document original està corregit a mà el mes] COMISIONES OBRERAS DE BADALONA Y SU COMARCA" ${ }^{\prime 401}$

Les CCOO aviat es van estendre també a Santa Coloma i Sant Adrià, com

399Servicio de Información de la Guardia Civil: "Nota informativa. Asunto: Manifestación pacífica de mujeres en Badalona”, AHGCB, Gobernadores Civiles, Caixa 15 TRIS. Comarcas, 1966,1967. Aquest document, com el mencionat a la nota 383, forma part d'un recull més ampli dedicat a aquesta manifestació. Cal tenir present que el President del Club de Futbol Badalona era Santiago March Blanch, que havia estat Alcalde entre 1954 i 1961, del qual ja hem parlat anteriorment.

400Emili Ferrando Puig i Juan Rico Márquez: Les Comissions Obreres en el franquisme... , p. 174-175. La Jove Cambra i el Cine Club Studio van tenir més protagonisme als anys setanta (tot i que el segon ja a la segona meitat dels seixanta va tenir una activitat notable).

401Full volant sense títol. ANC, Fons Arxiu del PSUC (230). 06. Context Social i Polític del Partit; 0602 Moviment Obrer; 06.02.01. Organitzacions de treballadors; 1567 Comissions Obreres (CCOO) Badalona i Comarca. El document original té diverses anotacions fetes a mà i en una d'elles es pot llegir "Nota: se leyó en el acto como la adhesión "de un grupo de trabajadores". 
posen de manifest nombrosos informes policials sobre intents de reunions a la parròquia de Santa Rosa de Santa Coloma, on es va convocar a una Assemblea el 29 de gener de 1967 que, davant la negativa del Bisbat va haver de fer-se als terrenys propers del Motocross (lloc de futures reivindicacions veïnals als anys 70) ) $^{402}$. Es continuaren fent reunions en espais oberts com a Ca l'Artiller, el ja esmentat Motocross o els descampats que hi havien entre Santa Coloma i Badalona als Barris del Raval, Santa Rosa i Llefià així com en determinades parròquies de les ciutats del Barcelonès $\operatorname{Nord}^{403}$. La importància de les CCOO a la comarca queda de manifest quan veiem l'activitat repressora. El vocal del Metall de Sant Adrià de Besòs, Manuel Murcia, havia estat destituït del seu càrrec per la seva vinculació amb $\mathrm{CCOO}^{404}$. Amb motiu de la celebració de l'1 de maig durant una reunió multitudinària a Ca l'Artiller, a l'espai no urbanitzat, la Guàrdia Civil va intentar detenir al militant del PSUC i de CCOO Adonio González, fet que no va aconseguir per la reacció de la gent allà present. Tanmateix va ser detingut dies després juntament amb Abilio Campos en els seus centres de treball ${ }^{405}$. El 23 de setembre tornaven a ser detinguts diversos militants després d'una reunió on havien assistit 60 persones a un descampat, probablement al Motocross ${ }^{406}$. Durant una "jornada

402Dirección General de la Guardia Civil: "Sobre reunión clandestina de comisiones obreras en Santa Coloma de Gramanet" (29-1-1967); Jefatura Superior de Policia de Barcelona: "Intento de reunión en la Iglesia de Santa Rosa de Santa Coloma de Gramenet" (Barcelona, 20 de gener de 1967); Servicio de Información de la Guardia Civil: "Aparición de hojas clandestinas en Badalona" (27 de gener de 1967). Tots els documents estan referenciats referenciats a AHGCB, NI, Caixa 20. Agraeixo a Xavier Domènech que em facilités les referències pel que fa a les CCOO del Barcelonès Nord que havia trobat dins l'esmentat arxiu.

403Un dels nostres testimonis, Àngel Navarro, entrevistat el 21-7-2009, ens confirmava l'ús de les parròquies del Fondo i Santa Rosa a Santa Coloma, a l'església parroquial de Sant Adrià de Besòs (barri de Sant Adrià Nord, a l'antic poble) i la parròquia de Sant Antoni de Llefià, ja esmentada.

404 “Cornella” (17 d'abril de 1967), AHGCB, NI, Caixa 22. És un document presentat per la Secció Local del sindicat vertical a Gavà ala delegació comarcal de Cornellà reclamant, entre d'altres coses, la restitució en el seu càrrec de Manuel Murcia Ros.

405Servicio de Información de la Guardia Civil: "Aparición de Hojas Clandestinas en Badalona" (245-1967); "Badalona” (25-5-1967). En aquesta darrer document s'expliquen els antecedents dels detinguts. Tots referenciats a AHGCB, NI, Caixa 20

406Jefatura Superior de Policia de Barcelona: "Detención de unos elementos de las "Comisiones Obreras en Santa Coloma de Gramenet". El document explica com s'havien estat realitzant reunions de les $\mathrm{CCOO}$ a la parròquia de Sant Antoni de Llefià, però en adonar-se de la presència de la Brigada Sexta van canviar les reunions a un descampat proper al sanatori de l'Esperit Sant. Aquí es va fer la reunió del dia 23 on es van produir les detencions fetes per la Guàrdia Civil i la Policia Municipal; "Detención de ocho individuos por celebración de una reunión ilegal, siendo ocupada propaganda manuscrita" (27-9-1967). En aquest document s'esmenen els noms, referències i antecedents dels detinguts: Adonio González Mateos (ja esmentat i amb nombrosos antecedents); Vicente Felipe Hernández López, Justo Pageo Garcia,Alejo Castellano 
nacional" de mobilitzacions convocada pel 27 d'octubre de 1967 va haver-hi una nova detenció davant la delegació del sindicat vertical de Badalona on s'havia concentrat un grup de persones ${ }^{407}$. Les lluites obreres d'aquests anys seixanta seran importants pel futur desenvolupament del moviment veïnal ${ }^{408}$.

El PSUC, la força hegemònica dins CCOO, sens dubte va manifestar un gran interès per la consecució d'aquesta "Comissió Ciutadana o Cívica” de la qual he parlat. Un militant del PSUC ens explicava el per què:

"En B.[adalona] se siente una gran necesidad de movilizar a las capas medias de la población, que son bastantes numerosas. La estructura social de B. si bien nos enseña que tiene un gran proletariado y por ello numéricamente es la clase más importante, también nos enseña que existen una gran variedad de capas sociales, que agrupan: servicios (publicidad, técnicos, comerciantes), profesionales (abogados, médicos, peritos) y pequeños propietarios de taller, los cuales son muy numerosos. (...) posee un especial grado de integración (generalmente habitan en el centro de la ciudad, no hablan y tienen mutuo conocimiento de su existencia).

(...)

Ha sido un hecho de masas obreras, el que ha podido hacer despertar la posibilidad de una acción concreta por parte de estos sectores pequeño burgueses. Concretamente el despido de un obrero de la empresa 'Metalgraf Española', y la consecuente huelga de sus compañeros durante un día y medio, en solidaridad con el despedido. y posteriormente su movilización recogiendo firmas y organizando una manifestación para su entrega en los Sindicatos.

De ello se desprende, en la reducida escala de B., que si el proletariado se moviliza, los sectores pertenecientes a la pequeña y media burguesía, también lo hacen en apoyo a

Blazquez; Manuel Marcos Rubiño, Antonio Arellano Salcedo, Adolfo Téllez Luna (tots aquests sense antecedents) i Ángel Navarro Rubio (aquest havia estat detingut al 1961 a la "caiguda del duro" i l'he citat diverses vegades pel que el vaig poder entrevistar personalment). Tots referenciats a AHGCB, NI, Caixa 20.

407Dirección General de la Guardia Civil: "Hojas clandestinas” (26-10-1967); Dirección General de la Guardia Civil: "Detención de un individuo en Badalona por inspectores del cuerpo general de policia" (31-10-1967); "Servicio Radiotelegráfico de la Guardia Civil. Radio número 169" (2710-1967) (on s'esmenten les fulles clandestines que convoquen a la concentració davant el Sindicat Vertical de Badalona); "Carta de el Alcalde del Ayuntamiento de Santa Coloma de Gramanet al Sr. Gobernador Civil de la Provincia" (26-10-1967), ; "Nota, Información Alcalde de Badalona" (27-10-1967); "Badalona. Intento de Manifestación" (27-10-1967); "Carta del Alcalde del Ayuntamiento de Sant Adrián de Besós a Ecmp. Sr. Gobernador Civil de la Provincia (27-101967); Dirección General de la Guardia Civil:“Aparición de propaganda clandestina en Badalona” (23-12-1967), tots ells referenciats a AHGCB, NI, Caixa 20.

408Més informació sobre les lluites obreres d'aquest període a Emili Ferrando Puig i Juan Rico Mârquez: Les Comissions Obreres al Barcelonès Nord (1964-1977)... i a Xavier Domènech: Clase Obrera, antifranquismo y cambio polítco. Pequeños grandes cambios, 1956-1969, Los Libros de la Catarata, Madrid, 2008. 
los objetivos democráticos que los primeros pretenden. Por el contrario, ante una paralización de las acciones obreras, estos mismos sectores caen el desánimo, y viéndose impotentes, paralizan sus acciones cayendo en el derrotismo, o en el mero olvido." $^{409}$

El mateix document parlava de la importància de donar a aquesta Comissió Cívica una continuïtat, de fer-la permanent. Fins i tot es marcaven els àmbits de treball per fer: el político-cultural, el cívic (entès en el sentit de condicions i qualitat de vida, ja que el document esmenta l'ensenyament, l'urbanisme, comunicacions, clavegueram, pressupost, gasos i mals olors) així com un àmbit anti-repressiu. Es considerava imprescindible posar en contacte la "Comissió Ciutadana" amb "las diversas Comisiones de Barrio existentes en la ciudad." Vol dir això que ja existien Comissions de Barri? Crec que aquest terme, en l'any 1966, no estava tant definit com en anys anteriors, però sens dubte evoca a algun tipus d'organització. Un altre fragment del document es una mica més explícit:

“CONCLUSIONES. El que existiera una Comisión Ciudadana y tuviera contacto con las Comisiones de Vecinos (...) daría lugar: a) a un acercamiento de las capas medias y de forma orgánica a las clases proletarias. b) un profundo trabajo de movilización en los casos que la realidad lo exigiera. c) a un trabajo de esclarecimiento y de agitación política facilitando las charlas en los barrios, el proselitismo y el trabajo abierto y amplio. Facilitaría una gran información, sobre todo lo que acontece, no sólo en la ciudad sino en poblaciones limítrofes, por contactos que se podrían tener mediante las Comisiones de Vecinos. Ello podría culminar en una 'RUTA' (Marcha) (...) [es refereix a una "gira per fer conferències i contactes, ja que es parla de l'existència d'altres "grups interessants" a Santa Coloma i Sant Adrià]. Los medios a aplicar para que la movilización tuviera éxito, serían evidentemente no clandestinos." ${ }^{410}$

El mateix PSUC insistia, en una reunió bilateral feta amb membres de la Força Socialista Federal (organització que tenia una certa implantació a Badalona), en la importància d'aquestes Comissions de Veïns i com aquestes havien d'estar

409“Comisión Ciudadana de B. Carta de Blas” (8-9-1966), Archivo Histórico del PCE” (AHPCE), Fons Nacionalidades y Regiones, Cataluña (PSUC), Generalidades, Correspondencia, Jacq. 1487. Agraeixo a Iván Bordetas Jiménez que em facilités l'accés a aquesta documentació que va recopilar pel la Base de Dades del Moviment Veïnal elaborada pel CEFID.

410 “Comisión Ciudadana de B. Carta de Blas" (8-9-1966), Archivo Histórico del PCE” (AHPCE), Fons Nacionalidades y Regiones, Cataluña (PSUC), Generalidades, Correspondencia. Jacq. 1487. 
coordinades amb l'esmentada "Comissió Cívica"411. Un altre document del mateix any 1966 era més explícit sobre quin havien de ser els seus objectius:

"tanto de tipo reivindicativo (problemas de viviendas, agua, alcantarillado...) como democráticos (acciones de solidaridad con la clase trabajadora, democratización de la vida municipal...). De momento funciona una Comisión Ciudadana en el centro de la ciudad (....)"1412

El mateix document informava que s'havia fet una primera reunió amb la participació de 30 persones i que es preveia una segona amb una assistència de 50 . S'informava també de el component interclassista d'aquesta, amb una majoria de participants de "capes mitjanes", alhora que s'afirmava:

(...) Se ha creado una Comisión de Enlace con las diversas barriadas, para conectar y fomentar donde no las hubiera Comisiones de Vecinos (...)." ${ }^{413}$

I encara més. Fins i tot s'esmentaven els punts a discutir en la propera reunió: un escrit de solidaritat amb els treballadors per la qüestió del salari mínim, decidint si s'afegien al fet ja per CCOO, i també, sobre la qüestió de les eleccions municipals al tercio familiar, si participar-hi o no i amb quina finalitat. Es contemplava la possibilitat de fer-ho com a un mitjà d'agitació i també la creació d'una comissió per fer un programa reivindicatiu molt en sintonia amb les mancances dels barris perifèrics de la ciutat de Badalona ${ }^{414}$.

El mateix Gregorio López Raimundo, en un llibret editat clandestinament que recollia intervencions seves a l'any 1967, i parlant del cas de la ciutat de Terrassa afirmava:

"Las Comisiones de Vecinos están llamadas a abrir nuevos horizontes al desarrollo del movimiento de masas y a facilitar la coordinación entre las diversas ramas de este.

En Tarrasa, las Comisiones de Vecinos han sido principalmente de apoyo a las C.O.

Creadas en las barriadas obreras para intentar resolver problemas como los de la falta de agua o de luz eléctrica, las Comisiones de Vecinos de Tassasa fueron desde sus orígenes una escuela de civismo. En sus asambleas públicas se abordaron no solo las

411[PSUC]: "De Badalona. Renión bilateral manternida con el FSF el día 20 de septiembre de 1966", (9-1966), AHPCE, Nacionalidades y Regiones, Cataluña (PSUC), Generalidades, Correspondencia. Jacq. 1493.

412 [PSUC]: "Informe general (CAS) [Casanovas] (Badalona)", AHPCE, Nacionalidades y Regiones, Cataluña (PSUC), Generalidades, Correspondencia. Jacq. 1494. 413Ídem.

414Ibídem. 
necesidades más inmediatas del barrio, sino los diversos problemas que interesan a los trabajadores, entre ellos la necesidad de participar en las elecciones sindicales y de crear en las empresas Comisiones Obreras permanentes, unitarias y democráticas. La fuerza alcanzada por las Comisiones Obreras de Tarrasa se deriva en gran parte del respaldo que ha supuesto y supone para ellas la existencia de las Comisiones de vecinos. $^{415}$

El mateix dirigent del PSUC afirmava la importància que tenien aquestes Comissions de Veïns per mobilitzar treballadors joves i dones. Alhora deia que existien les condicions per crear-ne Comissions de Veïns en altres indrets, entre ells Badalona, tal com recull la cita de la p. 78 i nota 181 on parlava de les manifestacions contra el "polsim negre" i de les dones de Bufalà reclamant aigua pel seu barri. A més en posava exemples concrets:

\footnotetext{
"Hace ya más de un año que se creó y viene funcionando en el Distrito V de Badalona una Asociación de Vecinos constituída por las familias que serán expropiadas para abrir la continuación de la calle Muntaner. Esta Asociación ha celebrado Asambleas públicas hasta con mil participantes, en las que se han discutido ampliamente los medios para protegerse de los incontables transtornos que ha de causarles la expropiación." ${ }^{416}$
}

Aquest carrer estava situat al barri de Bufalà, on s'havia constituït una associació l'any 1963, però que havia estat a l'empara de les oligarquies locals, ja fossin municipals o fins i tot empresarials ${ }^{417}$. No en tinc més informació però segurament va ser un intent de crear un model d'associació alternatiu al que estava promocionant el franquisme i que no va acabar de reeixir. Per que com afirmava el mateix dirigent comunista, les autoritats locals franquistes estaven fomentat associacions de veïns legals per tenir un major control dels barris i "con el fin de salir al paso del peligro que sienten supondría para ellos la proliferación de Comisiones de Vecinos extra-legales, independientes y democráticas" ${ }^{418}$.

415Gregorio López Raimundo "En el buen camino. Intervención ante una reunión de militantes del P.S.U. de Cataluña.- 1967. [és un llibret amb un recull de intervencions seves], AGA, Fons Cultura. Gabinete de Enlace del Ministerio de Información y Turismo, Caixa 42/09097, Dossier 5 Documentación relativa al Partido Socialista Unificado de Catalunya (PSUC), p. 66-69. 416Ídem.

417Marc Andreu i Acebal: El Bruc Bufalà -Badalona- Els Barris d'Adigsa núm. 7, Generalitat de Catalunya, Departament de Benestar Social, Barcelona, 1995, p. 93-94.

418Gregorio López Raimundo "En el buen camino. Intervención ante una reunión de militantes del P.S.U. de Cataluña.- 1967, AGA, Fons Cultura. Gabinete de Enlace del Ministerio de Información y 
Remarcava la importància que tindrien en aquest fet la participació de les dones i dels joves, i que la proliferació d'aquestes Comissions de Veïns era un fet molt important per desenvolupar un moviment de masses que fos capaç d'accions generalizades que "ens acostessin a la vaga nacional". Com es pot veure, es reconeixia la importància de la creació d'un moviment veïnal però se'n tenia una visió subordinada respecte a d'altres iniciatives, però ara tornem al cas badaloní.

Ja havia comentat anteriorment que el teixit socio-econòmic Badaloní (i del Barcelonès Nord en general) havia condicionat el funcionament de les CCOO, sobretot en la dificultat d'utilitzar les grans fàbriques com a espai vertebrador. No obstant, aquest fet indirectament en va afavorir un altre, el del major protagonisme de l'espai de barri, com ja he comentat:

“(...) Todos estos problemas se recogían en las asambleas que CCOO hacía en los barrios independiente de lo que trataba cada Comisión Obrera en su fábrica, que no había tantas. Había muy pocas empresas en las que los trabajadores tuvieran organizada la Comisión Obrera"419

Aquesta dinàmica es traduirà en la creació de les denominades Comissions Obreres de Barri per respondre a la dificultat d'organitzar-se a les fàbriques agrupant als obrers residents en un mateix barri. Aquest fet es va veure complementat per la integració, seguint el model anteriorment exposat per la ciutat de Terrassa, dels joves i de les dones. Ja al gener de 1967 les CCOO de Badalona i la seva comarca havien convocat a una assemblea on cridaven a participar els i les estudiants del SDEUB, a la "Asociación Democrática de Técnicos", als juristes democràtics, a les ja esmentades Comissions de Veïns i a les mestresses de $\operatorname{casa}^{420}$. De la mateixa manera, a la ciutat de Badalona de seguida van prendre un important protagonisme les anomenades "Comissions Obreres Juvenils (COJ), que de fet van ser de les primeres d'aquest tipus a Catalunya, fet que no ens ha

Turismo, Caixa 42/09097, Dossier 5 Documentación relativa al Partido Socialista Unificado de Catalunya (PSUC), p. 66-69.

419Testimoni de Miguel Guerrero a Emili Ferrando Puig i Juan Rico Márquez: Les Comissions Obreres en el franquisme..., p. 181. Només a algunes empreses badalonines relativament grans van arribar a constituir-se seccions de Comissions Obreres. Si fem cas a la documentació trobada a l'Arxiu Nacional de Catalunya només en podem trobar grups estables a la PIHER, G. De Andreis ("La Llauna"), ESESA (filial de FECSA, propietària de les centrals tèrmiques de Badalona i Sant Adrià de Besòs).

420Veure p. 182 i nota 402. 
d'estranyar quan el mateix 40 per cent dels assistents a les assemblees de les CCOO badalonines durant els anys seixanta eren joves de 18-20 anys ${ }^{421}$.

Les COJ es van gestar a Badalona i la "seva comarca" entre juny i agost de $1967^{422}$. No pas sense dificultats, ja que com revelen ja la mateixa "Carta de Blas" i documents posteriors a l'entorn de la declaració de principis d'aquestes, va existir un cert enfrontament entre els partidaris d'unes COJ autònomes de CCOO i amb un programa més radicalment socialista -segurament persones no vinculades al PSUC, militants o properes al FOC o al PCE(i)- i els membres de la JC que seguint les orientacions del PSUC no volien crear una altra organització, la volien més subordinada a CCOO i amb un programa més en la línia de treball unitari amb altres sectors socials ${ }^{423}$. També es constata un cert malestar en els mateixos joves de la JC pels canvis tàctics sobtats del PSUC al respecte, segurament per haver defensat inicialment la integració dels joves a les CCOO i criticat la COJ i després haver-la acceptat -amb condicionants, suposo-, seguint de nou consignes del Partit $^{424}$. Però deixant de banda les lluites internes, el cert és que les COJ ja van demostrar també una preocupació per actuar més enllà de la fàbrica i fer-ho també, entre d'altres àmbits, als barris poblats majoritàriament per població nouvinguda:

“(...) Pero ese mismo sistema capitalista y el Estado a su servicio, Estado que mientras subsista el actual sistema capitalista será un instrumento de dominio político y económico de la burguesía. Deja de interesarse por los trabajadores inmigrantes a la hora de dar satisfacción a sus necesidades. Necesidades que brotan de las gigantes acumulaciones humanas en barracas y chabolas y en general, de los cinturones

421Xavier Domènech: Clase obrera, franquismo y cambio político. Pequeños grandes cambios, 19561969, p. 245.

422 “Carta de Blas. Barcelona, 30 de agosto de 1967", AHPCE, Nacionalidades y Regiones, Cataluña (PSUC), Generalidades, Correspondencia. Jacq. 1656.

423 "Propuesta de declaración de principios de la COJ"; "Documento de respuesta de los jóvenes de las CO a la propuesta de declaración de principios de las COJ (elaborado en núcleo de la JC)"; "Asamblea de representantes de Jóvenes de CO"; "Comunicado de los jóvenes de CO", (10-1967), AHPCE, Movimiento Obrero, Comisiones Obreras Juveniles, Organizaciones territoriales. Cataluña. Caixa 83. Carpeta 4/3.4. Veure també Xavier Domènech: Temps d'interseccions. La Joventut Comunista de Catalunya (1970-1980), Fundació Francesc Ferrer i Guàrdia, Barcelona, 2008, p. 63-64.

424 "Sobre las Comisiones Obreras Juveniles" (30-10-1967), AHPCE, Movimiento Obrero, Comisiones Obreras Juveniles, Informes. Caixa 83. Carpeta 4/1. Tal com explica Xavier Domènech aquest document es posterior a una primera desarticulació de les COJ badalonines per la repressió policial i es dona en un context on es devia plantejar la seva reconstrucció. Tanmateix planteja que moltes de les Comissions de Barri que es van crear en aquells moments (1967-69) no eren una altra cosa que COJ "encobertes" Veure Xavier Domènech: Temps d'interseccions..., p. 62. 
obreros que rodean las grandes ciudades, carentes de los más elementales servicios urbanísticos, higiénicos y culturales. Los jóvenes trabajadores sufren particularmente esta injusticia que el sistema capitalista crea en los barrios y que se traduce para nosotros en carencia de centros sociales, culturales, bibliotecas, teatros, cine-forums, etc., y recreativos e instalaciones deportivas, etc..." ${ }^{425}$

Pel que fa a les dones, les mateixes CCOO badalonines van tenir un notable èxit en atreure-les. Si bé és cert que en uns primers moments la tasca que la direcció del PSUC i CCOO assignava a les dones estava molt relacionada amb la -encara molt masclista- visió que es tenia d'elles. No obstant, de seguida van anar adquirint una dinàmica pròpia, reunint-se pel seu compte per tractar els temes que els hi afectaven més específicament com a dones ${ }^{426}$. Serà un procés progressiu el de presa de consciència i que no esclatarà amb tota la seva força fins els anys setanta, però ja als seixanta, militants del PSUC badaloní com Teresa Buigues Poveda ja denunciaven la doble explotació i discriminació que patia la dona obrera:

"A través del cine, la radio, la prensa y la televisión, se ha ido inculcando que la mujer ha de estar quietecita en casa, sumisa y al cuidado de las cosas domésticas, que participar en otras es perder la feminidad [...] la mujer va despertando poco a poco, se va dando cuenta de que es algo y que tiene su propia dignidad. Hoy existe la Asociación Democrática de Mujeres y paso a paso se sensibilizan, arrastrando a gran cantidad de otras dispuestas a luchar por la solución de sus problemas" ${ }^{\prime 427}$

Tot i que la proclama no deixa des ser en certa mesura un xic triomfalista en quant al paper de la Asociación Democrática de Mujeres, el cert és que s'estaven donant casos de mobilitzacions protagonitzades exclusivament per dones més enllà de la manifestació -ja citada- contra el "polsim negre". Per exemple veïnes del barri de Bufalà havien anat en manifestació fins a la Plaça de la Vila per reclamar

425 "Propuesta de declaración de principios de la COJ", AHPCE, Movimiento Obrero, Comisiones Obreras Juveniles, Organizaciones territoriales. Cataluña. Caixa 83. Carpeta 4/3.4.

426En aquest àmbit, els de les dones militants, cal destacar els següents treballs de Nadia Varo Moral: "Mujeres en Huelga, Barcelona metropolitana durante el franquismo" dins José Babiano (ed.) José Antonio Pérez: Del hogar a la huelga: trabajo, género y movimiento obrero durante el franquismo, Los Llibros de la Catarata, Madrid, 2007; “El PSUC i les lluites de les dones durant el franquisme" dins M. Dolors Calvet (i altres): El feminisme al PSUC: els anys setanta i vuitanta del segle XX, Associació de Dones Periodistes, Barcelona, 2009.

427Xavier Domènech: Clase obrera..., p. 246. El text està estret d'un document titulat "Informe d'una sèrie de reunions celebrades a Badalona", AHPCE, (17-19 de desembre de 1967), Jacq. 1736. 
aigua corrent pels seus domicilis ${ }^{428}$.

Així, la línia tàctica del PSUC, en un document de desembre de 1967 recollia la importància del que ja denominava sense embuts "moviments de mases" per la creació d'una Comissió Cívica recollint el que ja es deia a la "Carta de Blas" de setembre de 1966. Partint d'una funció inicialment anti-repressiva, es volia anar molt més enllà:

"La Comisión Cívica, integrada por todas las organizaciones de masas, debe extenderse al máximo y fortalecerse. En ella, aparte de los organismos de masa ya citados (CO; COJ; MD; Expresos) deberán formar parte de las mismas: curas, personalidades de las capas medias, Cine-Club; Casino y en manera especial las Comisiones de Vecinos. Su acción: Anti-represión y lucha por las libertades, se podrá concretar en numerosos actos de tipo abierto. Firma de documentos, Recolectas, Actos públicos en Cines, Teatros, Organización de Conferencias..." ${ }^{\text {229 }}$

Però, després de fer una radiografia de les diferents forces polítiques locals s'insistia també en la creació d'una mena de Comitè Polític de Coordinació entre les diferents forces polítiques a nivell local, anticipant una línia que anys després es plasmaria a un nivell molt superior al local en l'anomenada Assemblea de Catalunya. El document continuava posant uns exemples significatius: la celebració al Casino de Badalona d'una obra de paròdia de la Guerra del Vietnam, la projecció, per part del Cine Club Studio de dues pel-lícules cubanes (amb presència del mateix Cònsol de Cuba) i del "Cuirassat Potemkin", la realització d'un Seminari sobre la Dona i actuacions de membres de la Nova Cançó catalana. Un altre paràgraf destacat del document és aquest:

"Como se han llevado a término todos estos actos? En gran parte gracias a la labor del F.S.F. y por otra gracias a algunos camaradas que lo han orientado y realizado. También gracias a muchos simpatizantes tanto del PSU como del FSF, que colaboran en esta

428Respecte aquesta mobilització tinc dades confuses de quan es va fer realment. Al llibre de Marc Andreu Acebal: El Bruc Bufalà... s'afirma que la van protagonitzar 400 dones que van marxar en manifestació cap a l'Ajuntament l'any 1964. En canvi, un document titulat "Pequeña concentración de mujeres ante el Ayuntamiento de Badalona" fet per la Jefatura Superior de la Policia de Barcelona el 2-6-1967 parla d'una concentració de 80 dones del barri de Bufalà davant l'Ajuntament de Badalona, AHGCB, Gobernadores Civiles, Caixa 65. Comarcas años 1965,1966,1967,1968. Per les altres referències sobre el mateix fet que he trobat com les del mateix Gregorio López Raimundo ja citades, m'inclino per pensar més en la segona data.

429 Comité Comarcal de Badalona de las CCOO:"Correspondencia del Com. Comarcal de Bad." (2412-1967), AHPCE, Movimiento Obrero, CCOO, CONC. Organizaciones territoriales. Caixa 85. Carpeta $1 / 3$. 
tarea. Quizás el número de militantes del FSF y el nuestro sea el mismo, pero la diferencia estriba en que mientras ellos tienen una organización especial para esto, nosotros no la disponemos. Así, quien materializa resultados como nuevos encuadramientos son ellos, y no nosotros. Concretamente en estos trabajos han colaborado: un estudiante que vive en Bad. pero trabaje [sic] en Bar.; un obrero (Ríos); un militante de Propaganda; un intelectual de Bad. Prácticamente desorganizado; y a modo muy general Aurelio. Es decir, que ninguno de ellos milita en la misma célula. No ocurre así con los del FSF." ${ }^{\prime 30}$

Aquesta nota es pot interpretar de diverses maneres. Per una banda com una aparent desorganització conseqüència de la priorització de la lluita obrera, però per altra també una capacitat individual de diferents militants del PSUC de diferents cèl-lules per tirar endavant iniciatives sense haver d'esperar a que es creés una cèl-lula especialitzada en aquest treball. Però les primeres mobilitzacions en alguns barris que es van donar a finals dels anys seixanta van esperonar a la realització d'un treball en aquest sentit. Un exemple seria l'inici de la lluita al barri badaloní de Pomar, de la Obra Sindical del Hogar l'any 1969, on un grup de veïns ja va negar-se a pagar un augment desproporcionat del lloguer:

“El maig de 1969, els veïns [del barri de Pomar] van rebre la notificació d'un increment en les quotes d'amortització que significava doblar les quantitats acordades inicialment. La resposta va ser immediata: "No podem pagar". I així ho van explicar al ministre de la Vivenda en una instància feta el 30 de juny de 1969, signada pel Centre Social de Càritas i per un bon nombre de veïns (...)" ${ }^{\prime 431}$

D'aquesta manera ja trobem fulls volants signants per las "Comisiones Obreras de Badalona y su Comarca" on es criticava al Sindicat Vertical però alhora ja es feia ressò del conflicte. Una nota escrita a mà a la cantonada d'un full volant era molt explícita:

"Nota: se han hecho 1500 hojas y se han metido en los buzones de los portales. La gente lo ha encontrao extraordinario. Los vecinos están más convencidos que nunca que no han de pagar. Salud"432.

430Comité Comarcal de Badalona de las CCOO:"Correspondencia del Com. Comarcal de Bad." (2412-1967), AHPCE, Movimiento Obrero, CCOO, CONC. Organizaciones territoriales. Caixa 85. Carpeta $1 / 3$.

431Carles Mas: El Pomar -Badalona- dins la col-lecció Els Barris d'ADIGSA núm. 27, Generalitat de

Catalunya, Departament de Benestar Social de la Generalitat de Catalunya, 1995, p. 52. 432 Comisiones Obreras de Badalona y su comarca: "Solidaridad con el barrio de Pomar" (6-6- 
És més, una acta d'una reunió immediatament posterior ens aclareix que qui van fer el repartiment eren membres de les COJ:

“Bo de Pomar.- Lunes dia 9 reparto de 1500 octavillas por las COJ en los buzones. Dicha octavilla recoge el problema del aumento del alquiler de las viviendas en el barrio, salude la firme actitud de los vecinos por negarse a pagar y llama a la formación de una C.O.B. Al día siguiente, gran expectación entre los vecinos, mostrando una mayor moral combativa." ${ }^{433}$

Com podem veure, també s'instava a la creació d'una Comissió Obrera de Barri, i de fet al mateix document s'esmentava ja l'existència d'una comissió d'aquest tipus a Santa Coloma de Gramenet. En teoria, la Comissió Obrera de Barri havia d'assumir la funció de la Comissió Obrera de Fàbrica entre els habitants d'un determinat barri amb els obrers d'aquest que no tinguessin Comissió de Fàbrica a les seves respectives feines. Però en no pocs casos aquestes COB acabaven assumint la feina que des de el Partit es volia destinar a les Comissions de Veïns. El mateix López Raimundo ho comentava en un document intern i intentava aclarir la confusió:

"En los últimos meses se aprecia un cierto estancamiento de las C.O. De Barrio en Barcelona, las cuales jugaron un papel muy positivo en la preparación de las acciones del 30 de abril y del 1er de mayo.

La crisis temporal de estas Comisiones Obreras de barro se deriva entre otras causas de la tendencia existente en algunos lugares a convertirlas en Comisiones de Vecinos o en Comités Políticos de barrio.

Las C.O. de barrio, en tanto que parte del Movimiento de C.O., son el marco de reunión y de acción de los asalariados residentes en el barrio y que trabajen en empresas donde no hay C.O. Pero desde el momento mismo en que se constituyen, tales Comisiones deben proponerse crear C.O. en las empresas en que trabaja cada uno de sus miembros y en todas las situadas en el barrio, de preferencia en las grandes.

Las C.O. de barrio han de organizar a sus miembros en Comisiones por profesión o Sindicato, los cuales deben discutir sus problemas profesionales y ligarse orgánicamente con sus respectivas C.O. de Indústria en Barcelona, es decir, los

1969), AHPCE, Movimiento Obrero, CCOO, CONC. Organizaciones territoriales. Caixa 85. Carpeta $1 / 3$. Es tracta d'un full volant d'una pàgina.

433Comisiones Obreras de Badalona y su comarca [Acta d'una reunió de CCOO de Badalona i comarca] (11-6-1969), AHPCE, Movimiento Obrero, CCOO, CONC. Organizaciones territoriales. Caja 85. Carpeta $1 / 3$. 
metalúrgicos con la Comisión del Metal, los albañiles con la de la Construcción, etc., etc. ligazón que debe ayudarles a desarrollar una actividad acorde con su carácter de órganos de las C.O.

Solo concebidas así tienen sentido las C.O. de barrio y con esta orientación debemos trabajar los comunistas al crearlas y desarrollarlas.

Ello no está en contradicción con la existencia en los barrios de Comisiones de Vecinos. Tales Comisiones, de las que deben formar parte todos los vecinos que así lo deseen, son ya en algunos lugares -y pueden serlo en mucha mayor proporción- instrumentos eficaces de lucha de los vecinos por escuelas públicas suficientes, guarderias infantiles para hijos de madres trabajadoras, transportes, alumbrado y urbanización adecuados, centros culturales, deportivos y recreativos para la juventud, etc., etc.

En cuanto a los Comités Políticos de barrio creemos que hoy por hoy no tienen sentido. Tales Comités pueden surgir y surgirán sin duda en una etapa posterior de la lucha en tanto que órganos de coordinación de los partidos, movimientos y organizaciones de masas existentes en la barriada. Pero antes de abordar ese género de coordinación han de existir los sujetos a coordinar, es decir, las Comisiones de Vecinos, las C.O. de barrio, los Clubs Juveniles y demás asociaciones de masas susceptibles de actuar coordinadamente bajo la dirección de un Comité o Comisión común."434

Una vegada més queda clara la prioritat organitzativa del PCE-PSUC de posar per davant de tot la clàssica lluita obrera a les fàbriques -considerada inequívocament "de classes"- i entendre com a secundària la de caràcter "territorial". Ja en les velles interpretacions de la Komintern d'entreguerres, les organitzacions de caràcter "territorial" esdevenien fàcilment "interclassistes" per la manca d'homogeneïtat social dels espais d'habitatge i eren les "cèl·lules de fàbrica" -que, sempre segons aquesta visió, havien fet triomfar la revolució d'Octubre- les que calia prioritzar ${ }^{435}$. Si es reuneixen els i les militants d'un determinat barri, no ens hauria d'estranyar que malgrat les consignes acabessin parlant de les

434Gregorio López Raimundo: "Detener la represión, acabar con el inmovilismo, imponer un cambio democrático. Informe presentado por Gregorio López Raimundo en nombre del Comitè Ejecutivo del P.S.U. De Catalunya, en una reunión de comunistas catalanes. Enero 1969", AGA, Caixa 42/09097, Dossier 5 Documentación relativa al Partido Socialista Unificado de Catalunya (PSUC), p. 34-35.

435Veure al respecte les instruccions trameses als diversos partits comunistes europeus per la direcció central de la Komintern a finals dels anys vint recollides a diversos llocs de Edward $\mathrm{H}$. Carr: Historia de la Rusia soviética. Las bases de una economía planificada, 1926-1929, vol. 3, parte 2, Alianza Editorial, Madrid, 1984. En alguns temes sembla que les inèrcies organitzatives passaren per damunt dels viratges tàctics fins molt tard. 
necessitats del barri, i davant les dificultats d'organitzar-se a la seva feina acabessin creant un teixit organitzatiu estable en el barri en un moment on, com hem vist, comencen a haver-hi reivindicacions veïnals. A més, en el context de certes barriades de finals del seixanta, el caràcter homogèniament obrer -en principi- dels seus habitants probablement eliminava qualsevol escrúpol de "desviació doctrinal" que pogués aparèixer en l'ànim de la militància ${ }^{436}$. El darrer paràgraf també es significatiu en diversos sentits, però sens dubte reflectia que encara hi havia molta feina a fer a les diferents barriades per desenvolupar els anomenats "moviments de masses".

El mateix any 1969, un altre document analitzava la situació del partit i dels diferents processos organitzatius engegats en diferents àmbits a les ciutats del Barcelonès Nord. El informe del "Camarada Aurelio" destacava els avenços que s'havien produït en els darrers anys. Com, aprofitant les eleccions sindicals de 1966, s'havia donat un impuls a CCOO a la comarca juntament amb els moviments de masses:

\begin{abstract}
"Hemos conseguido poner un pie unas Asambleas de CCOO con su coordinadora, las C.0.J., las Mujeres Democráticas, las Comisiones Obreras de Empresa, y ahora empezamos con las Comisiones de Barrio: Singuerlín, Santa Coloma, Llefia y con posibilitades en Sant Roque y Bufalá. Hemos igyalmente [sic] hecho marchar la
\end{abstract}

436Sobre la qüestió de la identitat obrera dels barris del tardofranquisme veure Ricard Martínez i Muntada: El moviment veïnal a l'àrea metropolitana de Barcelona durant el tardofranquisme i la transició: el cas de Sabadell (1966-1976), Tesina de Doctorat, Universitat Pompeu Fabra, 1999; "El moviment veïnal a Sabadell durant el tardofranquisme, 1966-1976: 'Todos los barrios unidos para conseguir sus derechos'” (I y II), Arraona, 24 i 25 (primavera i tardor de 2001), p. 65-87 y 75-97 respectivament; "El moviment veïnal en el tardofranquisme i la transició: conflicte, identitat obrera i valors alternatius" en E. Prat (coord.): Els moviments socials a la Catalunya contemporània, Universitat de Barcelona, Barcelona, 2004, p. 71-91; "El movimiento vecinal en el tardofranquismo: acción colectiva y cultura obrera. Propuestas y problemas de interpretación", a Ayeres en Discusión. Temas clave de Historia Contemporanea Hoy, Universidad de Murcia, Murcia, 2008; "Construir Futurs. La dimensió anticapitalista del moviment veïnal" a Carme Molinero i Pere Ysàs (coords.): Construint la ciutat democràtica. El moviment veïnal durant el tardofranquisme i la transició, Barcelona, Icària, 2010 i "Movimiento vecinal, antifranquismo y anticapitalismo", Historia, trabajo y sociedad, 2 (2011), p. 63-90. També Iván Bordetas Jiménez: Del suburbio al barrio: los orígenes del movimiento vecinal en Barcelona, Tesina de Doctorat, UAB, Barcelona, 2009; "Ni tu ni yo somos nadie si tú y yo no somos nosotros": los orígenes del movimento vecinal en Catalunya", Comunicació al X Congreso de la Asociación Historia Contemporanea, Santander, 2010; "El movimiento vecinal en el tránsito de la resistencia a la construcción de alternativas", Historia del Presente, 16 (2010), p. 43-61; "De la superviència a la resistència: la gestació del moviment veïnal a la Catalunya franquista" a Carme Molinero i Pere Ysàs (coord.): Construint la ciutat democràtica... i a Nosotros somos los que hemos hecho esta ciudad. Autoorganización y movilización vecinal durante el tardofranquismo y el proceso de cambio político, Tesi Doctoral, UAB, Cerdanyola, Juliol 2012. 
Comisión Cívica. Examinemos todos estos pasos.

Una preocupación que salta inmediatamente a la vista es la falta de profundidad de todos estos movimientos. Su estrecha base. La falta de participación de hombres independientes y el gran control que sobre todos ellos ejerce el Partido. De ahí se derivan forzosamente el carácter muy limitado que han tenido todas las acciones en Badalona. La CCOO general, la Asamblea, reune generalmente a los militantes, estos forman su gran base. Ello es lo que se debe romper. Y se dan ya los primeros pasos... Singuerlín, Llefia, ahora el día 13 en Santa Coloma... Las Comisiones Obreras Locales o de Barrio, nos permitirán acercarnos mucho más a las gentes y a los problemas cotidianos y reivindicaciones de las masas. Debemos hacer un gran esfuerzo para acercarnos más a ellas. Debemos hacer un gran esfuerzo para conseguir una mayor profundidad." ${ }^{437}$

Segons aquest document, sembla que estaven constituïdes Comissions Obreres de Barri al Singuerlín (Santa Coloma) i a Llefià (Badalona), i que havia possibilitats de fer-ne més. Però alhora es detecta una feblesa important pel que fa a l'articulació dels moviments de masses: la falta d'implicació de les mateixes "masses", o si més no, la falta d'implicació significativa de persones que no fossin militants del PSUC. I una de les maneres que s'apunta per aconseguir la implicació de sectors més amplis de població és precisament impulsar les Comissions Obreres de Barri. De les Comissions de Veïns, curiosament, no es parla.

El mateix document, en línies posteriors, analitza la situació dels diferents "moviments de masses". De les "Mujeres Democràtiques" diu que mica en mica es van obrint camí. De les COJ destaca que malgrat a Badalona han estat pioneres, i que s'ha aconseguit fer front als "fraccionalistes" (segurament referint-se als sectors no pertanyents al PSUC que ja havia mencionat abans), es troba a faltar una major implicació i mobilització dels joves de les barriades. A les COJ se'ls hi assigna una funció exclusivament agitativa. Però de nou és torna a parlar del paper de les Comissions de Barri. S'afirma, entre d'altres coses, que han de ser la base de la Comissió Obrera General de la Comarca (i això reflecteix la relativa debilitat en la implantació de les CCOO en les empreses), amb la seva pròpia estructura, organigrama i representants a la Coordinadora Comarcal. Però pel que fa a les

437“Informe del camarada Aurelio sobre la situación política y de organización del Partido en Badalona y Comarca" (1969), AHPCE, Nacionalidades y Regiones, Cataluña. PSUC, Comités Comarcales. Comité Comarcal de Badalona, Resoluciones. Caixa 63. Carpeta 1/3, p. 1. 
seves funcions s'afirmava que:

“(...). Es fundamental que cada Comisión tenga su programa de reivindicaciones y acciones a realizar: visitas al alcalde de barrio, proclamas a los vecinos, denuncias y escritos a la prensa diaria (falta de colegios, calles decentes, iluminación, transportes...). Se pueden hacer documentos y recoger firmas... se debe en definitiva agitar a la barriada..." ${ }^{438}$

I això, sembla contradir-se en gran part amb el que afirmava López Raimundo d'evitar la confusió de funcions entre COB i “Comissions de Veïns". Una constatació pràctica del que volia criticar el veterà dirigent comunista? 0 de que la única manera de vincular persones de fora del Partit a les COB era parlar de les problemàtiques que tenien als barris? El mateix "Camarada Aurelio" reconeixia que la major dificultat residia en establir Comissions d'Empresa. Es remarcava la necessitat de fer agitació i assemblees d'empresa, i -molt important- fer servir les Comissions Obreres de Barri per captar gent per la militància a les empreses (en aquest punt si que hi ha una major similitud amb el que deia López Raimundo).El document recollia també els avenços en l'articulació de la “Comissió Cívica”.

Posteriorment es feia una anàlisi interna de la situació del PSUC al Barcelonès Nord. S'analitzaven les mancances del Comitè Comarcal així com dels respectius Comitès Locals de Sant Adrià, Santa Coloma i Badalona, l'estat de les COJ en les tres localitats, que entre Badalona i Santa Coloma comptaven amb 25 militants. Tot i que es reconeixia que el creixement del Partit ha estat important, encara es considerava insuficient per fer front a les necessitats de la comarca. Hi ha detalls sobre l'organització interna en cèl-lules especialitzades o de barri. Però és important veure el punt posterior que parla de la relació amb altres agents i/o forces polítiques, on destaca sobretot la valoració negativa que es fa del treball amb la FSF en el camp de les Comissions Obreres (no així en el Moviment Democràtic de Dones, curiosament). La línia a seguir havia de ser una altra:

"La gran colaboración y ayuda no está pues con el FSF sino con los católicos: curas,

IOC. Hoac. Ahí está verdaderamente nuestro trabajo y ahí está donde debemos invertir nuestro tiempo. En este camino se deben hacer numerosos esfuerzos para que los

438“Informe del camarada Aurelio sobre la situación política y de organización del Partido en Badalona y Comarca" (1969), AHPCE, Nacionalidades y Regiones, Cataluña. PSUC, Comités Comarcales. Comité Comarcal de Badalona, Resoluciones. Caixa 63. Carpeta 1/3, p. 2. El subratllat és de l'original. 
contactos que actualmente se mantienen se acentúen, y no solamente por arriba (lo cual tiene indudablemente gran importancia) sino sobre todo y en manera especial, por la base. Ahí encontraremos hombres honrados y dispuestos a luchar, encontraremos en definitiva a la clase obrera... Seguir, ayudar y alentar el camino iniciado en la C.O. De Singuerlín es en este sentido nuestro primordial objetivo."439

El barri de Singuerlín de Santa Coloma de Gramenet era on havia anat a fer el seu treball un dels sacerdots obrers que havia esmentat al passat capítol, Salvador Cabré. I pel que s'entén del mateix document al barri hi havia una cèl-lula del PSUC que havia començat a treballar amb els catòlics de base en la creació d'aquesta Comissió Obrera de Barri. I segurament un procés similar es devia donar a Llefià, on segons un entrevistat nostre, ja en aquells anys existia "la cèl·lula del PSUC més important de Badalona"440. No obstant, en els anys posteriors no he trobat documentació de les respectives $\mathrm{COB}$, ni en les entrevistes que vaig realitzar a diferents militants en vaig trobar gaire informació més, a excepció d'una COB al Barri Besòs de Sant Adrià a inicis dels setanta ${ }^{441}$. Significa això que no van acabar de reeixir? Amb la prudència que cal -mancat de majors evidències- sembla que l'experiència no va acabar de ser del tot satisfactòria, probablement per què subordinaven la seva actuació a prioritats externes a la comunitat i esdevenien uns espais més aviat d'agitació. Però és indubtable que el contrast entre la teoria i la pràctica els va fer veure que la única manera d'aconseguir una major implicació de sectors amplis de la població dels barris era no subordinant completament l'acció en aquests a altres prioritats, sinó donant-li un paper similar a d'altres fronts de lluita "tradicionals" com l'obrer i l'universitari. El PSUC encara va trigar uns anys a copsar aquest fet ${ }^{442}$, però segurament aquestes experiències anteriors haurien de

439Informe del camarada Aurelio sobre la situación política y de organización del Partido en Badalona y Comarca" (1969), AHPCE, Nacionalidades y Regiones, Cataluña. PSUC, Comités Comarcales. Comité Comarcal de Badalona, Resoluciones. Caixa 63. Carpeta 1/3, p. 6. El subratllat és de l'original.

440Entrevista a Ángel Navarro, 6 -5-2006, militant del PSUC aleshores. La cèl-lula en qüestió tenia el nom de Ferrol. José Miguel Cuesta Gómez: El moviment veïnal a Llefià, Tesina de Doctorat, UAB, setembre de 2010, p. 164.

441Emili Ferrando Puig i Juan Rico Márquez: Les Comissions Obreres en el Barcelonès Nord..., p. 482. També he trobat un "Boletín de la Comisión Obrera de Barrio del Sector Besós", en concret el núm. 2 (setembre-octubre de 1968), on s'analitzen les principals deficiències del barri i es fa un fort discurs de classe. AHPCE, Publicaciones periódicas. Carpeta 64/23.

442 Carme Molinero i Pere Ysàs: Els anys del PSUC. El partit de l'antifranquisme (1956-1981), L'Avenç, Barcelona, 2010, p. 109-112. 
ser recordades en anys posteriors, a la dècada dels 70, quan van sorgir amb força les Comissions de Barri a Santa Coloma, primer, i Associacions de Veïns reivindicatives a tot el Barcelonès Nord, de manera paral·lela o successiva.

De tota manera, del mateix document s'extreu la necessitat de reorganitzar el PSUC per fer front a les seves mancances. Tant per desenvolupar l'impuls dels moviments de massa esmentats (COB, CO de empresa, COJ, Mujeres Democràticas, Comissió Cívica), com per les mateixes necessitats internes del Partit: enfortir la organització interna, la formació i debat de documents interns, les joventuts, l'aparell de propaganda i l'aprofundiment de la línia de col·laboració amb els catòlics de base ${ }^{443}$.

Durant la segona meitat dels seixanta, es desenvoluparà una altra iniciativa, promoguda des dels sectors catòlics de base: el desenvolupament dels Centres Socials, dependents de Càritas Diocesana o de les respectives parròquies. L'any 1966 es va fundar el primer, el Centre Social del Besòs, que va ser un Centre amb una dinàmica pròpia molt important i que de seguida va comptar amb la participació de gent jove. Al 1968 comptava amb 190 socis $^{444}$. També va existir un Centre Social al Camp de La Bota fins que els barraquistes van ser traslladats al nou barri de La Mina la dècada dels setanta. Pel que fa a Santa Coloma, l'any 1966 s'havia fundat un Centre anomenat Obra Social Singuerlín, impulsat pel sacerdot Salvador Cabré i que serà una peça clau en les reivindicacions del barri ${ }^{445}$. Per altra banda, el 30 de gener de 1967 la parròquia de Santa Rosa ja havia presentat uns Estatuts per a la creació d'un Centre Social que posteriorment tindrà molt protagonisme: el Centre Social Arrabal-Santa Rosa (inicialment només Centre

443El mateix document ens dona els noms i àrees proposades per la reforma organitzativa del Comitè Comarcal: Secretaria Política: Maceo; Organització: Díaz; Propaganda: Isidro (que a més havia d'ajudar al Comitè Local de Badalona); Masses: Almendros (que a més havia d'ajudar al CL de Sant Adrià); Dones: Natalia; Juventut: X. De responsable del CL de Santa Coloma s'esmenta a un tal Anton. Els noms, evidentment són pseudònims. Informe del camarada Aurelio sobre la situación política y de organización del Partido en Badalona y Comarca" (1969), AHPCE, Nacionalidades y Regiones, Cataluña. PSUC, Comités Comarcales. Comité Comarcal de Badalona, Resoluciones. Caixa 63. Carpeta 1/3, p. 7-8.

444Emili Ferrando Puig i Juan Rico Márquez: Les Comissions Obreres..., p. 481.

445La Obra Social Singuerlín comptava amb 210 socis el 31 de maig de 1966 que aportaven mensualment quasi 10.000 pessetes. Veure a Marcelo López Ródenas: Historia social de la Santa Coloma Moderna..., p. 136-137 i a AHMTB, Fons Marcelo López Ródenas, Caixa 3, Dossier 4. Allà es poden trobar els comunicats interns del Centre que parlen d'aquestes dades, així com els Estatuts de l'any 1969. 
Social Santa Rosa) ${ }^{446}$. Aquest va ser finalment aprovat per l'Arxiprestat de Barcelona el 8 de novembre de $1968^{447}$. A Badalona, el Març de 1968 es fundava el Centre Social Pomar, al barri del mateix nom, adherit a Càritas i amb seu a la parròquia regentada per mossèn Josep Torrella ${ }^{448}$. Parròquia que per cert, els veïns van haver d'obrir per la força el mateix mes de gener d'aquell mateix any ja que hi havia un conflicte entre l'OSH i el Bisbat (que no volia pagar una església que no havia encarregat) i l'edifici havia romàs tancat durant mesos ${ }^{449}$. Aquest Centre, amb la implicació de Torrella i també de l'Assistenta Social del Barri va desplegar una intensa activitat reivindicativa ja que a l'any següent ja es va iniciar la lluita contra l'augment de lloguers dels pisos de l'Obra Sindical del Hogar. També va engegar una publicació anomenada Pomar Convivència, que sens dubte serà pionera pel desenvolupament d'una consciència de barri i de classe. D'una manera potser un pel senzilla al començament si observem escrits com aquest:

\footnotetext{
“ELOGIO. Nuestro Barrio , salvo pocas excepciones está integrado por personal obrero con muchas dificultades económicas, debido en parte a la abundancia de niños pequeños que tienen casi todas las familias.

De la virtud del trabajo se van sacando los recursos para ir tirando de la vida y mientras.... van creciendo los "peques".

A diez años fecha todos los que hoy tienen de 5 a 10 años de edad, que son muchísimos estarán trabajando y convertirán lo que hoy es un verdadero esfuerzo en un bienestar merecido y justo que hará de nuestro Barrio obrero un barrio económicamente fuerte y saneado.

El "ELOGIO" está en ver la estima que del trabajo tienen todos los vecinos del Barrio, podemos decir, casi sin excepción."450
}

Però mica en mica, aquest procés de conscienciació s'anà radicalitzant i, a través de conflictes posteriors, afectant també a d'altres barris de la subcomarca.

446 “Centro Social del Barrio de Santa Rosa de Sta. Coloma. Estatutos" (30-1-1967), Museu Torre Balldovina, Fons Marcelo López Ródenas, Caixa 2, Carpeta Centro Social Arrabal-Santa Rosa.

447 Arzobispado de Barcelona [Document d'aprovació del Centro Social Santa Rosa], (8-11-1968), Arxiu Històric Museu Torre Balldovina (AHMTB), Donació Marcelo López Ródenas, Caixa 2, Carpeta Centro Social Arrabal-Santa Rosa.

448Carles Mas: El Pomar-Badalona. Els Barris d'Adigsa 27, Departament de Benestar Social, Barcelona, 1995, p. 125.

449Ídem, p. 48-49. i Entrevista amb Joan Cuadrench (7-4-2013). Rector juntament amb Josep Torrella de la Parròquia de Sant Sebastià de Pomar, que ens va explicar també aquesta anècdota. 450 Pomar Convivència núm. 3 (juliol 1968), p. 2. Arxiu Històric Ciutat de Badalona (Museu de Badalona), Fons Hemeroteca, Caixa 21-1-6. 
Abans d'acabar la dècada dels seixanta, un altre Centre Social veié la llum, el del Barri de Sant Roc de Badalona, fundat a l'octubre de $1969^{451}$. I els Centres Socials, apart de ser l'embrió en no pocs casos de futures Associacions de Veïns, seran també un lloc de socialització i lluita ideològica entre diferents organitzacions polítiques, que pugnaven per fer proselitisme entre les classes populars i els joves que els freqüentaven. Ja fossin entre els membres de la JOC, l'HOAC i l'ACO, el PSUC o les noves organitzacions de l'esquerra revolucionària que van experimentar un auge a partir del maig de 1968. Una d'aquestes, Bandera Roja -sorgida d'una escissió del PSUC a la Universitat a l'octubre del mateix any, si bé va trigar un temps encara en definir-se com a "partit" ${ }^{452}$ - va destacar per teoritzar ben aviat, sobretot als anys 70, sobre el Moviment Veïnal com a tal. No obstant, al novembre de 1968 ja al mateix núm. 1 de la seva publicació "Bandera Roja" apareixia un article sobre les tasques que s'havien de fer als barris de les grans ciutats:

\footnotetext{
"Es en el barrio donde el Movimiento Popular tiene su mínima y más clara expresión tanto política como organizativa. La existencia de diversas clases sociales y su respectiva relación política expone de manera clara, tanto su importancia en la lucha contra el franquismo como y el capitalismo monopolista, como los peligros que conlleva una alianza o una alianza no correcta, entre la clase obrera y estas determinadas clases sociales. Ya desde los primeros embriones de organización política en los barrios, debe cuidarse la importancia política y organizativa que debe jugar el trabajo de agitación y propaganda en las fábricas. Ahora bien, esta tarea, no debe llevar en ningún momento a despreciar posibilidades concretas de agitación y movilización a través de las necesidades asistenciales del barrio"453.
}

S'està reconeixent -potser encara d'una manera instrumental- la importància del barri com a lloc on fer una política de masses. El document continuava dient les tasques a desenvolupar en aquest: 1- Anàlisi de les condicions econòmiques i socials del barri; 2- Objectius Político-organitzatius immediats; 3- Formació

451Joan Tudela: Sant Roc-Badalona. Els Barris d'Adigsa núm. 37, Departament de Benestar Social, Barcelona, 1995, p. 116.

452José Manuel Roca: “Una aproximación sociológica, política e ideológica a la izquierda comunista revolucionaria en España”, a José Manuel Roca (ed.): El Proyecto radical : auge y declive de la izquierda revolucionaria en España (1964-1992), Los Libros de la Catarata, Madrid, 1994, p. 3368.

453Bandera Roja núm. 1 (novembre 1968): “Tareas Políticas en el Barrio”, CEHI-Pabelló de la República, Fons DDP (Sèrie documents partits polítics), Subsèrie Organización Comunista Revolucionaria (Bandera Roja), Caixa DPP (OCE (Br)) 1, Carpeta OCE (BR). Documents Interns (1968), p. 1. 
Ideològica i Propaganda política; 4- El paper de l'agitació política; 5- Aspectes legals, il-legals i clandestins del treball polític en els barris. En aquest darrer punt s'avançava una tàctica empleada després profusament als Centres Socials:

\begin{abstract}
"Para todo el trabajo de formación ideológica, propaganda y agitación, deben aprovecharse al máximo todas las posibilidades que ofrecen determinados centros culturales... del barrio, lo cual destaca la importancia que tiene el crear unos centros de Atracción Política -a través de la realización de diversas actividades- no sólo por las posibilidades de propaganda, sinó también porque facilitan la agrupación de personas, su contacto y la discusión colectiva y, por tanto, la propaganda de cara al barrio." ${ }^{454}$
\end{abstract}

Tot això trigaria encara una mica en desenvolupar-se de manera significativa. No existien encara organismes de lluita veïnal a la majoria dels barris, fossin del tipus que fossin. Però el cert és que l'aparició d'uns certs nivells de conflictivitat a finals dels anys seixanta en determinats barris per reivindicacions essencials va començar a demostrar que aquest era un espai de lluita i mobilització a tenir en compte. Una conflictivitat de la qual ja hem vist alguns exemples que superaven les formes tradicionals de petició respectuosa que algunes persones i Associacions de Veïns encara feien servir. Per posar dos exemples a l'any 1967 un veí del Barri Besòs enviava queixes i demanava solucions a l'Ajuntament de Sant Adrià -fent servir els canals establerts- per la presència d'un abocador d'escombraries proper al barri, per l'existència de pous negres o fins i tot per la presència de bars molestos $^{455}$. L'AVV de La Catalana a l'any 1968 enviava respectuoses peticions a l'Ajuntament de Sant Adrià de Besòs per que s'instal-lés una font en el mencionat barri $^{456}$. No podia ser d'una altra manera veient la composició de la seva Junta ${ }^{457}$.

No havia estat el mètode seguit per les dones de Bufalà que s'havien concentrat davant l'Ajuntament al juny de 1967, ni ho serà en altres casos que

454Bandera Roja núm. 1 (novembre 1968): “Tareas Políticas en el Barrio", CEHI-Pabelló de la República, Fons DDP (Sèrie documents partits polítics), Subsèrie Organización Comunista Revolucionaria (Bandera Roja), Caixa DPP (OCE (Br)) 1, Carpeta OCE (BR). Documents Interns (1968), p. 2.

455Cartes d'Alejandro Mateo Gómez, veí del carrer Goya, datades el 19 d'abril i el 24 de juliol de 1967. ASAB, Fons 101 Ajuntament, Caixa 372, Carpetes 11 i 12.

456[Instància presentada per Agustí Bonet Manich com a President de l'AVV La Catalana, de recent creació], Arxiu Administratiu de Sant Adrià de Besòs (ASAB), Fons 101 Ajuntament, Caixa 387, Expediente: D. Agustin Bonet Manich, en representación de la Asociación de Vecinos de La Catalana (...).

457Veure nota 335. 
exposaré breument a continuació. En algunes d'aquestes primeres protestes la JOC va tindre un protagonisme destacat. Hi havia dos grups organitzats d'aquesta entitat als barris del Fondo i Santa Rosa de Santa Coloma, que es coordinaven amb altres comunitats de Badalona i Sant Adrià ${ }^{458}$. Al juny de 1968 es va fer una trobada de la JOC de Catalunya i Balears que va acabar amb detencions policials. Dels detinguts, els germans Dolores, Salvador Bolancer i Jaume P. Sayrach eren colomencs (el segon tindrà un especial protagonisme al moviment veïnal en la dècada posterior al barri de Santa Rosa, i el darrer era el rector de la parròquia del barri del Fondo del qual ja he parlat i en parlaré més endavant) i tot i que aviat van ser posats en llibertat, unes 200 persones es van manifestar pel carrer Torras i Bages, en una de les primeres manifestacions antifranquistes que van tenir una certa rellevància pública ${ }^{459}$.

Al setembre de 1968 a Santa Coloma de Gramenet es va produir un boicot contra l'autobús "3" per la pujada del preu del bitllet ${ }^{460}$. Aquest fet, iniciat el dia 2, va comportar la detenció de dues persones, José Sánchez i Alejo Castellanos, membres de CCOO, mentre feien activitats de sabotatge als autobusos consistent en tirar claus per que punxessin les rodes d'aquests ${ }^{461}$. Malgrat no es va aconseguir la baixada de tarifa va ser un primerenc exemple de mobilització popular. Paral-lelament a la ciutat colomenca des de diversos grups de la JOC, Centres Socials i parròquies, i amb la col·laboració de nombroses persones s'estava gestant el projecte de la revista Grama que, apareguda el gener de 1969, aviat va convertirse, en la dècada posterior, en el portaveu oficial del moviment veïnal ${ }^{462}$.

Abans d'acabar la dècada es van produir altres protestes al Barcelonès Nord com les que ja havíem avançat del barri badaloní de Pomar. Aquest havia estat creat al 1967 per la Obra Sindical del Hogar dins les "Unidades Vecinales de Absorción" (UVAS) per re-ubicar la població de nuclis de barraquistes barcelonins

458Marcelo López Ródenas: Historia social de la Santa Coloma moderna..., p. 49.

459Ídem., p. 50.

460Ibídem, p. 51.

461 Ibídem, p. 52; Emili Ferrando Puig i Juan Rico Márquez: Les Comissions Obreres en el Barcelonès Nord..., p. 488.

462 Marcelo López Ródenas: Historia social de la Santa Coloma moderna..., p. 53-54. Veure també Angel Sody de Rivas: "Evolució de la premsa a Santa Coloma (1939-1979) a Grup d'História José Berruezo: Una ciutat dormitori sota el franquisme. Santa Coloma de Gramenet, 1939-1975, Ediciones Carena, 2007, p. 381-413. 
de Montjuïc, de la Perona, de la Ronda Sant Martí (al Clot), més la gent de Sant Adrià (i suposem que també de Badalona) que havien estat expropiats per la construcció de l'autopista ${ }^{463}$. Aquest barri, com tants d'altres promocionats pel sindicat vertical franquista (a Badalona, apart d'aquest i el ja esmentat de Bufalà, existia també el de Sant Roc), estava patint un procés de ràpida degradació per l'escassa qualitat de les seves edificacions. Aviat, des del Centre Social creat al maig de 1968, s'impulsaren accions de protesta per anar solucionant els problemes del barri com la falta d'enllumenat, de manteniment, de transport, etc., reivindicacions que van arribar fins i tot a les Cortes Españolas a través del Procurador pel Tercio Familiar Eduardo Tarragona ${ }^{464}$. Però va ser quan l'OSH va decidir augmentar la quota d'amortització que pagaven els veïns del polígon en més del doble, que es va iniciar un conflicte que s'allargaria durant anys de la dècada dels setanta.

Al 1969 en tenim constància de mobilitzacions veïnals impulsades per la parròquia i el Centre Social per protestar davant l'evident abús. El 9 de setembre ja va haver un primer intent de concentració de dones al barri enfront el Centre Parroquial que no es va acabar de fer segurament per la pressió policial ${ }^{465}$. Fins i tot l'Asociación de Cabezas de Familia estava en contra de la pujada, si bé encara esperava solucionar això amb la mediació i petició que no pas amb la mobilització:

L'Asociación [sic] de Cabezas de Familia de Pomar, només té una esperança: que siguin escoltats pel Cap de l'Estat, la justícia del qual no falla mai. Això i la misericòrdia del qui tot ho pot" ${ }^{\prime 466}$.

Davant la inutilitat de totes les instàncies fetes, es va imposar una mesura que enfrontava directament els veïns amb les autoritats: no pagar les amortitzacions al-legant que l'OSH no acomplia les seves obligacions i no proporcionava un contracte als inquilins. A l'agost de 1969 el $80 \%$ dels veïns no pagaven ${ }^{467}$, ja fos per un boicot conscient o per que no podien fer-ho. Fet, que va esperonar encara més,

463Entrevista amb Joan Cuadrench,7-4-2013, sacerdot adscrit a la parròquia de Pomar entre els anys 1970-1980 (amb de Josep Torrella, que era el rector).

464Carles Mas: El Pomar -Badalona-, p. 50-51.

465Antoja Vigo, Felipe (Alcalde de Badalona, 1966-1974): [Carta adreçada al Governador Civil de

Barcelona referent a una concentració de dones del barri de Pomar], AHGCB, Gobernadores Civiles, Caixa 65, Comarcas, año 1969.

466Carles Mas: El Pomar-Badalona..., p. 52-53.

467 Ídem, p 127. 
com hem vist, la participació de les COJ, les CCOO i fins i tot del PSUC mateix en el barri.

Però va ser als anys setanta en els darrers anys del franquisme, quan, per fi, es va desenvolupar un potent moviment veïnal mentre paral-lelament les diferents organitzacions polítiques copsaven per fi tot el seu potencial i decidien impulsar-lo mentre alhora competien per estendre el seu proselitisme. 


\section{L'esclat reivindicatiu del moviment veïnal.}

"Yo creo que el 23 de febrero del 71 y el 10 de marzo del 71 (...) fueron los dos acontecimientos (...) esto fue ya el poble organizado y fue el primer acto de masas de España durante el franquismo de barrio, una reivindicación de barrio, el primer acto de masas. Se puede decir que fue el primero. Para mi más importante el 10 de marzo del 71, que ahí si se contrasta que salieron varios miles de personas (...) hemos hablado de diez mil." ${ }^{\prime 48}$

“(...) LAS CC.B. PUEDEN EN UN FUTURO PRÓXIMO SER LA PRINCIPAL ARMA DE LA SUBVERSIÓN PARA CONSEGUIR LA SEPARACIÓN DEL PUEBLO Y LA AUTORIDAD." ${ }^{469}$

"Los reformistas intentan engañar a la clase obrera y desviarla de sus objetivos de clase pactando con la burguesía y utilizando a las A. de V. como plataforma legal de cara a los futuros ayuntamientos democráticos. Pretenden liquidar las organizaciones clandestinas de la clase como son las comisiones para integrar a los obreros más luchadores solo y exclusivamente en este marco legal pero nunca pensando en los intereses de los obreros que son los que luchan en contra de la explotación y opresión capitalista y esto no lo pueden asumir las A. de V." ${ }^{\prime 470}$

\subsection{Un punt d'inflexió: els anys setanta.}

Tots aquests processos de construcció del moviment popular que s'estaven donant als anys seixanta (o que fins i tot venien d'abans) es manifestaran amb molta més força a la dècada dels setanta i especialment a aquelles ciutats amb un percentatge elevat de població treballadora, com era el cas de les del Barcelonès Nord. En aquests processos el paper de la conscienciació de sectors amplis de població serà sens dubte cabdal. Ja ho he dit anteriorment: no és el mateix percebre les mancances i desigualtats existents i acceptar-les passivament que

468Entrevista a Marcelo López Ródenas, 8-4-2013. Referint-se a les massives mobilitzacions a Santa Coloma per la clínica-ambulatori de principis de 1971.

469"Resumen de conclusiones sacadas en el estudio de las comisiones de barrio y del plan de actuación propio", AGA, Fondo Gabinete de Enlace del Ministerio de Gobernación, Caixa 42/8906, Dossier 7 sobre Comités de Barrio, p. 2 (Octubre 1973).

470“Manifiesto Comisiones de Barrio de Sta. Coloma” (Setembre de 1976), Museu Torre Balldovina, Donació Marcelo López Ródenas, Caixa 1. 
percebre-les i creure en la necessitat de la lluita i la mobilització per mirar de canviar-les. Això sumat a la percepció de que la dictadura ja no era tant forta com abans i l'exemple del recent moviment obrer desenvolupat per les Comissions Obreres van ser uns fets decisius.

Pel que fa a les condicions materials de la població treballadora de les tres ciutats en les quals es centra aquest treball, durant els anys seixanta, com hem vist al capítol anterior, el franquisme va iniciar, amb molt d'endarreriment, unes polítiques per intentar reconduir una situació que era potencialment explosiva per tots els dèficits acumulats. Va ser en aquest context on es va intentar per una banda promoure un model d'associacionisme controlat per preveure o contrarestar incipients processos d'autoorganització i alhora es va desenvolupar una política de creació d'habitatges per tal d'eradicar el barraquisme. Aquesta política va tenir unes mancances molt importants, ja que es va incentivar la promoció de l'obra privada que es feia sense gaire control. Marcelo López Ródenas era molt clar en aquest aspecte en la seva obra dedicada a Santa Coloma de Gramenet:

\footnotetext{
"En tales perspectivas de rentabilidad, la inevitable acción especulativa atraerá como aves de rapiña, a las inmobiliarias de fuertes recursos financieros. En Santa Coloma se les presenta una ocasión devastadora de masías primitivas del pueblo y sus terrenos cercanos sin parcelar (...). La gran acción especulativa de los fuertes grupos capitalistas no debería hacer olvidar a las decenas de particulares que, utilizando la permisibilidad de una administración local corrompida, construirán a su antojo y provocarán al mismo tiempo, la aparición de un tremendo minifundismo en la construcción de viviendas." ${ }^{471}$
}

És més, el que solia passar era que les oligarquies locals que tenien el control del poder polític estaven fortament connectades amb el món empresarial privat que es beneficiava d'aquest nou nínxol de negoci que els oferia la construcció. La plasmació més gràfica d'aquests fets van ser els denominats Plans Parcials que generalment van servir per alterar les condicions establertes al Pla Comarcal del 1953 en benefici de les grans constructores ${ }^{472}$. Segurament va ser a la ciutat de

471 Marcelo López Ródenas: Historia social de la Santa Coloma Moderna 1954,1979, Ajuntament de Santa Coloma, 1982, p. 85.

472Veure Iván Bordetas: "Habitatge i assentaments de la postguerra a l'estabilització" i Amador Ferrer i Carme Ruiz: "Creixement urbà i planificació urbanística", tots dos a Martí Marín (dir.): Memòries del viatge [1940-1975], Ajuntament de Sant Adrià de Besòs i Museu d'Història de la 
Santa Coloma de Gramenet on aquests graus de vulneració van ser els més elevats de la subcomarca. Ja el Col-legi Oficial d'Arquitectes de Catalunya i Balears havia denunciat, per exemple, les vulneracions de legislació als Plans Parcials de Llefià o del Caritg a Badalona l'any 1970 durant l'alcaldia de Felipe Antoja Vigo ${ }^{473}$ Però sens dubte va ser durant el mandat de Juan Porta Bussoms a Santa Coloma de Gramenet (1970-1975, germà del falangista i posterior president de la Real Federación Española de Futbol Pablo Porta) quan es van fer més evidents les barbaritats urbanístiques comeses. Molt conegut va ser el cas de l'assessor d'aquest consistori, Ramon Rovira Vilamitjana, que també assessorava a nombroses empreses privades, fent-se evident les complicitats existents en nombroses irregularitats així com els nexes entre el capital privat i el poder polític local (un altre exemple serà el seu successor a l'alcaldia Blas Muñoz, 1975-1979, del qual parlaré més endavant $)^{474}$. La pressió popular feu, entre d'altres factors que a l'any 1975 tant Porta com Vilamitjana haguessin de renunciar als seus càrrecs.

Els fraus i estafes foren tristament habituals. A la mateixa Santa Coloma fou molt conegut el cas de la "Cooperativa de Viviendas para el Suburbio (VIPES)" -el nom ja és prou significatiu- en unes obres encarregades a la constructora Prats S.A. al barri de La Guinardera, que a més de les irregularitats comeses en els pressupostos de les obres, en fer fallida va provocar un greu problema als inquilins que havien comprat els pisos a un preu i que es trobaran ara amb uns inflats preus de mercat, iniciant-se així un litigi que arribarà fins els anys $80^{475}$. Similar va ser el cas que es va donar poc després al barri de Les Oliveres on la immobiliària Albica, S.A. havia venut uns pisos com a "habitatges de renda limitada" però sense les condicions que havien d'acomplir aquest tipus d'edificacions (sense comptar la pèssima qualitat i nombrosos defectes que tenien). Fet que va motivar que es

Immigració de Catalunya, 2009, p. 51-69 i 117-133. També a "I. De la supervivència a la resistència: la gestació del moviment veïnal a la Catalunya franquista" a Carme Molienro i Pere Ysàs (coords.): Construint la ciutat democràtica..., p. 35-112.

473El Col-legi Oficial d'Arquitectes de Catalunya i Balears havia denunciat aquestes vulneracions en una carta pública publicada a La Vanguardia i El Correo Catalán (30-1-1970). L'Ajuntament va fer una nota pública de rèplica publicada a La Vanguardia(1-2-1970), El Correo Catalán (3-21970) i El Noticiero Universal (3-2-1970). De nou el Col-legi Oficial d'Arquitectes va fer una contra-rèplica publicada a La Vanguardia (19-2-1970), El Noticiero Universal (19-2-1970) i El Correo Catalán(21-2-1970).

474 Marcelo López Ródenas: Historia social..., p. 93.

475Ídem, p. 96-100. 
volgués incrementar el preu als inquilins i que fou la guspira per unes mobilitzacions veïnals. Ina altra estafa recurrent solia ser quan les immobiliàries re-hipotecaven els pisos sense el coneixement dels seus ocupants, com va ser per exemple el cas de la immobiliària Montané-Aloy-Guitart ${ }^{476}$, fet que provocarà noves mobilitzacions i un conflicte força particular que es perllongà en dècades posteriors i del qual parlaré més endavant en aquest estudi: el cas Pitarque.

Però pel que fa al tema de la promoció d'habitatges "per la supressió del barraquisme", alhora que es fomentava la iniciativa privada els poders públics van promoure la construcció de macropolígons d'habitatges ja fos per l'Obra Sindical del Hogar o per "Patronatos Municipales de la Vivienda". Aquests es van fer sobretot a Badalona i a Sant Adrià de Besòs, com ja havia comentat al capítol anterior, i algunes d'aquestes promocions van significar, a la pràctica, la creació de barris completament nous, fets que van fer encara més òbvies les seves mancances per la manca de planificació i per les seves deficients comunicacions amb la resta del teixit urbà ${ }^{477}$.

La qualitat d'aquestes promocions públiques deixava molt a desitjar. Ja el mateix Col-legi Oficial d'Arquitectes de Catalunya i Balears havia denunciat les nombroses deficiències existents al dossier dedicat als barris de Barcelona a la seva revista Cuadernos de Arquitectura l'any $1965^{478}$. I no gaire més tard la revista CAU, del Col•legi Oficial d'Aparelladors i Arquitectes Tècnics de Barcelona publicava al seu número 10 un dossier titulat "La Gran Barcelona" on Jordi Borja -destacant militant aleshores de Bandera Roja- analitzava les promocions públiques de l'Obra Sindical del Hogar i afirmava que, si les promocions privades ja tenien una qualitat força lamentable per la voluntat de fer negoci dels seus promotors abaratint al màxim els costos, les promocions públiques solien ser sorprenentment encara de pitjors qualitats entre d'altres motius:

“(...) por el déficit en infraestructuras, particularmente grave en los polígonos situados en áreas no o poco urbanizadas (en la Comarca).

por la falta de servicios, aún los más imprescindibles: escuelas, comercios, transportes

476Marcelo López Ródenas: Historia social..., p. 101.

477 Veure nota 138 per que fa a la bibliografia dels barris de l'OSH badalonins.

478Cuadernos de Arquitectura, núm. 60 (2on trimestre de 1965) i 61 (3er trimestre de 1965). Les crítiques a la OSH per la pèssima qualitat dels seus habitatges, a l'urbanisme deficient i a la nul·la provisió dels serveis més elementals als polígons construïts és constant. 
públicos, ambulatorios, taxis, teléfonos...

por la falta de mantenimiento de los lugares públicos (alumbrado, zonas verdes, etc.).

Nos encontramos ante un ejemplo típico de urbanismo subintegrado, marginal.

Si analizamos la vivienda veremos como la situación de los usuarios no es mejor, ni muy diferente, de la de los ocupantes de casas autoconstruidas o barracas.

Carecen de contrato de adjudicación de venta diferida (que parece ser, es el que les corresponde). Es decir, es una ocupación que no está legalizada por título alguno.

Los bloques, de mala calidad, se deterioran rápidamente, apareciendo al cabo de pocos meses como semi-ruinosos.",779

Aquests fets ens demostren que malgrat el creixement econòmic que es va donar a la dècada dels seixanta i també la progressiva eliminació del barraquisme, això no implicava sempre una millora substancial en la condició de vida de les classes treballadores i populars que anaven a viure a aquestes noves construccions, ja fossin de promoció pública o privada. He volgut fer aquest incís abans d'abordar els dos fets -apart dels condicionants materials ja esmentats- que al meu parer seran decisius per a l'esclat del moviment veïnal: un profund procés de conscienciació col-lectiva (de classe, de barri) així com la percepció de que el context polític, amb la crisi de la dictadura franquista, oferia més possibilitats d'aconseguir millores en base a la mobilització.

Per que fa al primer dels dos processos, el de la conscienciació, va ser un procés progressiu i complex. No tothom es consciencia alhora del mateix i encara més, segurament ja hi havia gent que estava prou conscienciada per les experiències personals o per la transmissió d'aquestes. De les mancances materials ja s'era prou conscient, la novetat serà la creació d'una consciència de barri -lligada a la de classe- que aviat va esdevenir també en consciència antifranquista, procés que començarà als anys seixanta amb una multiplicitat de factors. Així, apart de les mancances materials, al capítol anterior també hem vist com s'hi afegien tres factors a tenir en compte: el paper de l'Associacionisme fomentat pel règim, el dels sectors renovadors de l'Església Catòlica i cristians de base i el dels militants de les organitzacions polítiques clandestines, ja fos actuant individualment o seguint

479Jordi Borja: "La promoción pública del hábitat marginal: las viviendas de la Obra Sindical del Hogar" a CAU: Construcción - Arquitectura - Urbanismo , núm. 10 (novembre/desembre 1971), p. 59-60. 
consignes o amb l'exemple i experiència adquirits en les Comissions Obreres.

Tot i que l'Associacionisme fomentat pel franquisme no tenia aquests objectius, s'ha de valorar que indirectament fomentés aquesta presa de consciència. Ja hem vist com en alguns casos els processos d'autoorganització veïnal eren previs a la seva creació i com fins i tot hi havia presència de persones d'esquerres dins les seves juntes. Les xarxes informals que s'havien fet servir durant els primers moviments migratoris durant els anys 40 i 50, així com la presència d'immigrants amb un passat de militància política van afavorir aquest procés on fets tan senzills com l'ajuda en la construcció de la barraca o la cura dels infants per part de familiars, veïns, paisans o coneguts havia estat un fet habitual davant la manca d'atenció de les autoritats. Més tard, les primeres Juntes de Veïns -en alguns casos amb presència de gent d'esquerres- i les posteriors Associacions de Veïns van prendre el relleu i van promoure obres de millora als barris sufragades pels propis habitants d'aquests. És cert que en la majoria dels casos no es va entrar en una confrontació directa amb l'Ajuntament, però el fet de treballar amb l'esforç i diners del veïnat en aquestes obres per fer clavegueram, asfaltat, etc., en definitiva, per dignificar i millorar el lloc en el qual vivien, segurament va afavorir, ni que fos indirectament, aquest procés. Aquest fet estava condicionat també per les "costums en comú" ${ }^{480}$, que feien que es desenvolupés un determinat tipus de consciència. Aquestes "costums en comú" tenien evidents nexes amb el passat, ja fos per la experiència pròpia o per la transmissió intergeneracional. I dins aquestes hi devien ser, amb força, el sentiment de classe i d'una hostilitat a la dictadura.

El paper dels sectors renovadors de l'Església ja ha estat comentat també al capítol anterior, en especial en aquelles parròquies dels barris de nova creació o de massiva immigració en els anys 50-60 amb la presència dels nous capellans obrers o de les "Comunitats Cristianes de Base". Aquests juntament amb els militants dels partits polítics antifranquistes -primer per compte propi i després seguint consignes més específiques al respecte- van ser cabdals en quest procés, per què van dotar als barris d'unes estructures estables que van ajudar a la conscienciació i posteriorment a la mobilització, quan es feia evident que amb la consulta i la 480Edward P. Thompson: Costumbres en común, Crítica, Barcelona, 1995. 
petició no es solucionaven els problemes. Malgrat aquests militants clandestins van prioritzar durant els anys seixanta la militància dins el moviment obrer, les experiències viscudes en aquest demostraven que es podien aconseguir millores amb les mobilitzacions, malgrat la repressió. I que era una qüestió lògica que s'intentés transportar els models de lluita que es feien servir a les fàbriques als barris on vivien els mateixos protagonistes que vivien l'explotació laboral i que patien les deficiències urbanístiques, de serveis de tot tipus, de sanitat, de manca d'escoles, etc. ${ }^{481}$. Iván Bordetas no podia resumir millor tot aquest procés:

"Així, l'important no serien tant les problemàtiques concretes que ja venien de lluny quan eren més urgents a causa del context de penúria generalitzada en què es donaven, sinó l'existència d'aquests agents de conscienciació que van actuar sobre unes determinades xarxes socials ja teixides en els barris." ${ }^{482}$

Si no tinguéssim en compte tot això, podríem caure en la temptació de sobrevalorar altres aspectes com les seves reformes legislatives a nivell laboral o associatiu, que, tot i ser importants, per si sols no poden explicar el procés que s'estava donant ja que la voluntat que s'amagava darrera d'ells no era un procés liberalitzador del règim sinó un darrer intent de donar una base popular a la dictadura mentre alhora es pretenia enfortir -en determinats casos- les estructures del partit únic. Aquest és l'error en que cau -al meu parer- Pamela Radcliff quan sobrevalora l'impacte de la legislació que va permetre la creació de les Associaciones de Cabezas de Família i similars (Amas de Casa, pares...etc.) al 1963 i les Associacions de Veïns amb la Llei d'Associacions de $1964^{483}$.

No seré jo el que negui el paper que van tenir moltes Associacions de Veïns en la propagació dels valors democràtics, però crec que l'explicació d'aquest fet no es tan mecànica. Es a dir, no es pot dir que la creació d'aquest tipus d'Associacions havia de suposar, necessàriament, l'aparició d'un moviment antifranquista. Calien

481 Iván Bordetas Jiménez: "De la supervivència a la resistència: La gestació del Moviment Veïnal a la Catalunya franquista" dins Carme Molinero i Pere Ysàs (coords.): Construint la ciutat democràtica..., p. 85.

482Ídem, p. 111-112.

483Pamela Radcliff: "La construcción de la ciudadanía democrática: las Asociaciones de Vecinos en Madrid en el último franquismo" en Actes del Congrés La transició de la dictadura franquista a la democràcia. Barcelona, 20, 21 i 22 d'octubre de 2005. Barcelona: CEFID-UAB, 2005, p. 96-102 i Makingdemocratic citizens in Spain. Civil society ant the popular origins of the trnasition, 19601978, Palgrave Macmillan, Basingstoke, Hampshire, New Yort, 2011. 
els processos de conscienciació que he comentat anteriorment per que, en especial als anys 70, aquestes entitats acabessin acomplint una funció que no era la que havia previst el franquisme amb la seva creació. I també la importància de processos previs d'autoorganització a determinats barris i la participació activa de persones i organitzacions (incloent aquí tant les d'apostolat obrer com posteriorment les organitzacions polítiques clandestines) contràries a la dictadura, que les van aprofitar per poder arribar a sectors més amplis de població. Radcliff reconeix aquest fet però sembla donar-li la mateixa importància que a altres factors quan al meu parer, tot i no ser la única explicació, és la més rellevant:

\begin{abstract}
"Thus, the contribution of economic development lay as much in the grievances created by the "autoritarian development model" as in its material benefits. Even so, it was the availability of various forms of social capital at the community level than gave residents the necessary collective tools to demand solutions to those grievances. Fromm existing models of community associations, to the Catholic Church's dense local networks, to the pool of potential community leaders among the ranks of antiFrancoist activists, all these forms of social capital provided available building blocks of imagining and constituting new forms of legal and public collective organization. The resulting "formula" is one that trascends any mono-causal explanations, from the "elite agency" focus on rational regim actors, to the "modernization" narrative of beneficent development, to the "social movement" emphasis on the anti-Francoist opposition. And, while all these factors contributed to the opening of a new space, it was the associations that assumed the protagonism of what went on in that space." ${ }^{484}$
\end{abstract}

Podem veure com es va donar aquest procés de conscienciació observant, per exemple, les diferents reclamacions que es van fer a nivell local per part de particulars o les mateixes AVV's existents. A l'Arxiu Municipal Administratiu de Sant Adrià de Besòs vaig trobar diversa documentació interessant al respecte. Ja vaig comentar com, per exemple, un veí del barri Besòs-COBASA a l'any 1967 adreçava reclamacions per diverses problemàtiques i molèsties existents al barri ${ }^{485}$. També les reclamacions amb to respectuós que s'havien fet des de una Associació de Veïns no considerada "perillosa", com era la del Barri de La Catalana ${ }^{486}$.

484Pamela Radcliff: Makingdemocratic citizens in Spain..., p. 63.

485 Veure nota 455.

486Veure notes 456 i 457. Altres reclamacions d'aquesta entitat fins arribar a l'any 1971 les podem trobar a ASAB, Fons 101 Ajuntament, Caixa 331, Carpeta 20; Caixa 347, Carpeta 37. Generalment solen ser reclamacions de tipus urbanístic. Aquestes continuaran fent-se els anys posteriors 
Aquestes reclamacions aniran "in crescendo" en els anys setanta, ja siguin les fetes per particulars, comunitats de veïns o entitats concretes com Centres Socials i Associacions de Veïns. Però es significatiu observar l'evolució del llenguatge que es fa servir, que dependrà molt, segurament, del nivell de conscienciació existent de qui formula la queixa. Es de destacar, per exemple, casos com la reclamació feta per Elias García Núñez, veí del barri Besòs-COBASA, el 30 de març de 1971. Després de recordar els nombrosos defectes de les canalitzacions, desaigües i clavegueram, que provoquen nombroses inundacions en particulars i comerços, així com les converses ja tingudes amb representats municipals i tècnics de l'Ajuntament de Sant Adrià de Besòs, la reclamació finalitzava amb les següents paraules:

"OTROSI: Si en un plazo prudencial no se nos realizan las justas peticiones que formulamos, entendemos que las solicitudes a ese Ayuntamiento son ineficaces por lo que la próxima reclamación, se efectuará, personalmente una Comisión al Excmo. Gobernador Civil." ${ }^{\prime 87}$

El canvi de to en el llenguatge és evident. Segurament no és casual el fet que en el mateix barri existís un Centre Social molt potent creat ja al 1966, i fins i tot hagi documentat referències a una Comissió Obrera de Barri ${ }^{488}$. No tothom farà servir el mateix llenguatge al adreçar-se per primera vegada a les administracions, però és significatiu veure com el to s'endureix quan les peticions no són ateses, un fet impensable anys anteriors. Fins i tot les Comunitats de Veïns endurien aquest to en les seves reclamacions, com per exemple feien els veïns de l'actual Carrer de l'Església de Sant Adrià (aleshores General Mola) en un escrit datat el 25 de febrer 1974, però fent referència a una reclamació que havia començat al desembre de l'any 1971, de nou per problemes amb un clavegueram deficient:

\footnotetext{
"Han pasado casi dos años y el Ayuntamiento $1^{\text {o }}$ no se ha dignado a contestar dicho escrito $2^{\circ}$ mucho menos se ha hecho nada para solucionar este gravísimo problema que atañe ya a la Sanidad pública y a una posible epidemia. 3ํㅡ tampoco como es natural se ha indicado nada del pago de dicha factura. Hoy nuevamente está inundada nuestra finca, pero esta vez ya no es solamente la nuestra la que debe soportar esta
}

com es pot veure a la Caixa 357, Carpeta 11 (any 1974), fins i tot mitjançant l'Alcalde de Barrio, Alfonso Chaos Campo, que va tramitar nombroses queixes dels veïns durant els anys 1972-1973 (veure Caixa 354, Carpeta 13).

487 [Instància dirigida a l'Alcalde de Sant Adrià de Besòs per Elias García Núñez] (30-3-1971), ASAB, Fons 101 Ajuntament, Caixa 347, Carpeta 23. En el document original estan subratllades. 488 Veure nota 441. 
inundación sino tambien las fincas vecinas pues el problema al no hacer nada para solucionarse se ha agravado considerablemente.

Es por todo ello que aparte de las denuncias que se presentan con esta fecha al Gobierno Civil y a Sanidad Provincial, suplicamos una vez mas que intervenga este Iltre Ayuntamiento de la forma que crea más oportuna para solucionar este problema que ha dejado de convertirse en local para alcanzar mucha mayor gravedad." 489

No podem deixar d'esmentar el paper que va tenir la revista Grama, sorgida al 1969 sota el paraigües de les noves parròquies, en aquesta tasca de conscienciació de sectors amplis de població -una conscienciació que tenia molt de classe- no només de Santa Coloma de Gramenet, sinó també les altres dos grans ciutats del Barcelonès Nord ${ }^{490}$. Ja el seu primer número dedicava un article a entrevistar a diversos joves de la ciutat sobre un tema molt conegut per la majoria de la seva població: la Immigració ${ }^{491}$. Aviat també va tractar dels problemes greus de la ciutat com la crema d'escombraries ${ }^{492}$ o les greus deficiències urbanístiques, així com la necessitat de la participació de la població en l'elaboració dels Plans Urbanístics necessaris per solucionar els greus problemes:

"Las necesidades de los hombres y mujeres de un municipio no pueden conocerse sin la participación libre de todos ellos en el trabajo de investigar estas necesidades. Entre otras cosas porque muchas veces ignoramos nuestras propias necesidades y

489[Instància presentada per Telmo Oriol Sardà] (24-2-1974), ASAB, Fons 101 Ajuntament, Caixa 352, Carpeta 6. La mateixa persona havia presentat la primera reclamació el 2 de desembre de 1971 a la qual es van afegir les reclamacions d'un altre veí, Antonio Vivo Juba (15-2-1972) i la de l'Administrador de la Finca on residia el primer denunciant, Francisco Folch Trepat (5-51972).

490El projecte original va arrencar a inicis del 1967, quan un grup de persones es reunien a l'Església Major de Santa Coloma amb la idea de crear-ne una publicació. Les reunions van continua al bar Xaconet de la Plaça de la Vila. La iniciativa va ser impulsada per Jaume P. Sayrach i amb la presència de Antoni Saura, Antoni Antonijoan, Enric Reverter, Lluís Tarrasón, Mercedes Pérez, Joan Carles Mas, Carles Viñas i Josep Tordera. Es van editar, a mà i sense dipòsit legal dos números amb el nom de L'Antena Grama el mateix any i amb una tirada molt reduïda (de fet, del primer número només es va fer un exemplar). El mateix any es va presentar la iniciativa per legalitzar la revista, tràmits que es val perllongar al 1968 fins que a l'octubre es concedien els permisos pertinents que permetrien la seva aparició -ara ja legal- al gener de 1969. Veure a Ángel Sody de Rivas: "Evolució de la premsa a Santa Coloma (1939-1979)" a Grup d'Història José Berruezo: Una ciutat dormitori sota el franquisme..., p. 396-397. Una còpia del número 2 (març 1967) de L'Antena Grama es pot consultar a AHMTB, Donació J. P. Sayrach [documentació diversa en una caixa sense inventariar tot i que està ben classificada originalment pel mateix Sayrach en diversos apartats. En aquest cas la revista la trobaríem dins la documentació dedicada a Grama]

491“La Immigración. Mesa redonda con La Redacción, Aurora González, Salvador Bolancer, Ana Saura, Paco Rueda, Maria Rosa, Juan Gavián." Grama núm. 1 (gener 1969), p. 5. 492“BACHE- La quema de Basuras”, Grama núm. 2 (febrer 1969), p. 8. 
"necesitamos" una labor de equipo, de diálogo, de opinión para poder descubrir lo que realmente necesitamos. Las necesidades de cada uno no pueden descubrirse del todo hasta que se habla de ellas con las demás personas." ${ }^{493}$

La mateixa revista descrivia les condicions insalubres de l'únic i raquític ambulatori existent a la ciutat colomenca situat en un atrotinat edifici insuficient per cobrir les necessitats d'una població que aleshores ja superava els cent mil habitants. Però la publicació denunciava que aquesta situació no tenia per què ser així, i més tenint en compte les elevades cotitzacions que els treballadors i treballadores de la ciutat feien a la Seguretat Social com es desprèn del següent diàleg:

"Desde hace siete años se ha implantado el servicio de ambulatorios. Hasta entonces la visita al médico se realizaba en el domicilio del mismo o lugar que hubiese habilitado. El incremento de los asegurados aconsejó centralizar los servicios. El Ambulatorio de Santa Coloma se ha ido quedando pequeño. La planta baja está llena de mujeres con niños en brazos.

-¿Qué medico visita ahora, señora?- pregunto.

- Ahora el de los "niños".

$(\ldots)$

- Hay mucha gente, ¿no le parece?; ¿podrá el médico atender a todos?

- ¿Y qué le va Vd. a hacer? Aquí no es "de pago".

La señora no sabe que aunque no pague al terminar la consulta, ésta es "de pago", que de los salarios que percibe (ella o su marido) se le deduce una cantidad por el concepto de "Seguros Sociales". Hace tiempo en algunos periódicos se daban cifras de fábula, respecto a lo que la Seguridad Social disponía de la cuotas aportadas por los trabajadores y las empresas." ${ }^{494}$

Els temes tractats per la revista anaven molt més enllà dels dèficits urbanístics o de serveis bàsics, ja que també aviat es va parlar de la "Promoció de la Dona", Les escoles i la pedagogia, la tercera edat, el treball, la sexualitat i altres relacionats amb la joventut, a més de per exemple la situació dels seus diferents barris, del patrimoni històric de la ciutat o entrevistes a membres de la nova cançó

493José Muntañola: “Urbanismo y realidad social en Santa Coloma de Gramenet”, Grama núm. 4 (abril 1969), p. 3. El mateix autor feia un altre article "Urbanismo en Santa Coloma de Gramenet. Falta de planificación. Por que no hay espacios verdes", Grama núm. 5 (maig 1969). 494L. Tarrasón: "El insuficiente servicio del ambulatorio del SOE", Grama núm. 4, (abril 1969), p. 9. 
com al mateix Raimon ${ }^{495}$. Podríem continuar citant articles fins a l'infinit perquè només he posat uns exemples dels seus primers números, quan encara no s'havia produït l'esclat reivindicatiu del moviment veïnal. Les autoritats municipals de Santa Coloma van intentar, sense èxit, crear una revista pròpia que podés fer de contrapés a la creixent influència de la revista Grama ${ }^{496}$ :

\begin{abstract}
"Nosaltres pensem que l'èxit de Grama, a la seva primera etapa, es va deure, a més a més del contingut temàtic de la revista, a una confluència de circumstàncies: l'inicia, en aquestes dades, d'una presa de consciència ciutadana de classe com a resposta a la caòtica situació urbanística social que vivia Santa Coloma; la falta d'un mitjà de comunicació local, legalitzat, que es fes ressò dels problemes reals del poble, i a l'estreta relació entre alguns components de la revista i l'incipient moviment social que es gestava als barris."${ }^{n 97}$
\end{abstract}

Però el seu prestigi encara augmentarà en els anys posteriors quan reculli en les seves pàgines les reivindicacions del moviment veïnal i de l'antifranquisme, fet que la portarà vàries vegades als tribunals ${ }^{498}$.

495“Mesa redonda- Por Carme Martín. La Promoción de la Mujer”, Grama núm. 5, (maig 1969), p. 5. El subtítols de l'esmentat article eren prou explícits: "La Mujer no es un instrumento. Ni una máquina. Ni una persona disminuida."; Josep Maㅡ Colomer: "Las Escuelas en Sta. Coloma”, Grama núm. 5, (maig 1969), p. 11. Un altre article al respecte en els seus primers números va ser José Termens: “Un Affaire, Las Escuelas. Maestro. ¿Profesión? ¿Vocación? ¿Negocio?”, Grama núm. 10, (octubre 1969), p. 9; Mesa redonda por J. P. Sayrach: Nuestros ancianos y sus problemas", Grama núm. 6, (juny 1969), p. 5; "Mesa redonda per J. P. Sayrach. Los aprendices reclaman una mayor preparación para la vida", Grama núm. 4 (abril 1969), p. 5 i 11; Luis Tarrasón: "El Fondo. Un barrio con pesonalidad", Grama núm. 6 (juny 1969), p. 7; Carmen Martín: "El Singuerlín", Grama núm. 7 (juliol 1969), p. 5; "El Arrabal”, Grama núm. 8 (agost 1969), p. 9; Carles Viñas: "El Puig Castellar", Grama núm. 8 (agost 1969), p. 3. 0 el cas del monestir Gòtic de Sant Jeroni de la Murtra situat al terme de Badalona: Paco Fernández y Miguel Tur: "Sant Jerónimo de la Murtra o un absurdo abandono", Grama núm. 12 (desembre 1969), p. 3; Lluís Tarrasón: "Raimon ens Parla", Grama núm. 11 (novembre 1969), p. 10 i 11.

496L'Ajuntament de Santa Coloma de Gramenet va intentar impulsar en diverses ocasions la revista Gramanet, on va abocar esforços i diners considerables, conscient del que es jugava. Però sempre va acabar tancant per falta de vendes. Més informació a Ángel Sody de Rivas: "Evolució de la premsa a Santa Coloma (1939-1979)" a Grup d'Història José Berruezo: Una ciutat dormitori sota el franquisme..., p. 398. A Badalona va tenir més èxit la revista Badalona. Boletín de Información Municipal (si més no, en mantenir-se regularment durant anys encara que fos trimestral $\mathrm{i}$ en alguns casos semestral o incús noumestral). Aquesta era una butlletí propagandístic de l'Ajuntament, sobretot en l'etapa de Felipe Antoja Vigo. A Sant Adrià va existir una altra revista municipal La Voz de San Adrián durant els anys 1973 i 1974, on tot i tenir també una voluntat propagandística, hi havia una major pluralitat i no poques vegades apareixien articles explicant el lamentable estat d'alguns barris. A tall d'exemple, un article del núm. 5 II Ėpoca (agost 1974) referent a la Mina signat amb pseudònim portava el títol: "La Mina. Chabolismo vertical. Amontonamiento de viviendas sin verdadera urbanización." (p. 5).

497Ángel Sody de Rivas: "Evolució de la premsa a Santa Coloma (1939-1979)" a Grup d'Història José Berruezo: Una ciutat dormitori sota el franquisme..., p. 397.

498Un article publicat al mes de febrer de 1972 (núm. 38) per Eugenio Madueño, on denunciava els 
A Badalona van haver de passar uns quants anys perquè sorgís alguna revista similar a la colomenca, si bé havien existit o s'havien creat algunes publicacions interessants en determinats barris ${ }^{499}$. A Sant Adrià de Besòs podem destacar, tot i que no va assolir mai la importància de Grama, el cas de la revista Besos de l'Associació d'Ex-alumnes del Col·legi “Sagrado Corazón” dels germans Gabrielistes. Publicada inicialment sense dipòsit legal des de l'any 1967 va ser força coneguda sobretot arran el segrest del número 16 (setembre de 1968) i del processament pel TOP del seu director Francesc Arnau arran un article titulat “Carta abierta pero certificada a Su Excelencia el Jefe del Estado Francisco Franco Bahamonde, Generalísimo de los Ejércitos de tierra, mar y aire; y Caudillo de España por la Gracia de Dios" ${ }^{500}$.

abusos de promotors inmobiliàris com Montané, Aloy i Guitart va acabar amb una querella interposada pels implicats que finalment van retirar. Dos mesos després Maia Victoria Aldama publicava un reportatge al núm. 39-40 titulat "Informe sobre delincuencia. Los delincuentes de guante blanco" que va ser multat am 25.000 pessetes i la imposició del nomenament per part del Ministeri d'Informació i Turisme d'un director que fos periodista. A l'abril de 1973 el número 52 surt amb el Che Guevara a la portada i la notícia de la mort de Manuel Fernàndez Màrquez a la tèrmica del Besòs, fet que li va comportar un nou expedient, a l'igual que a l'any 1974 i una nova querella l'any 1976. Ángel Sody de Rivas: "Evolució de la premsa a Santa Coloma (1939-1979)" a Grup d'Història José Berruezo: Una ciutat dormitori sota el franquisme..., p. 398-399.

499El més pròxim a una "revista de ciutat" fora del control del Movimiento (com li passava a la Revista de Badalona durant aquells anys) havia estat la -ja esmentada- revista depenent del Circulo Catòlico Albada, on durant els anys seixanta van arribar les onades procedents del Concili Vaticà II. També és important la publicació La Voz de Badalona (1959-1973), sobretot en la seva etapa final. A Llefià va existir durant els anys 1965-67 una altra publicació interessant anomenada La Torre del Huevo de la qual es van publicar 10 números i que es pot consultar a l'Arxiu Històric de Llefià (www.llefia.org/arxiu). Un recordatori especial mereix també la revista ja esmentada Pomar Convivència. No serà fins l'any 1976 que aparegui una revista comparable a Grama, com va ser Comarca Exprés. Però aquesta no va durar ni un any.

500A més de l'article esmentat, també van ser eliminats del mateix número de la revista l'Editorial titulada “País Vasco, Sr. Manzanas, Guipuzcoia, Estado de Excepción, Gora Euzcadi, E.T.A. ...” (no calen comentaris sobre el perquè, em sembla) i "Siglo XX", de Manuel Zaguirre, que parlava de les il-legals Comissions Obreres. Una còpia del número segrestat així com de l'acta de segrest es pot consultar a ASAB, Hemeroteca, Caixa Recull Premsa 1965-1978.

Francesc Arnau va ser una persona que va tenir un procés de radicalització. D'escriure articles recriminant a Josep Maria Huertas Claveria la seva descripció de Sant Adrià de Besòs (veure "Cartas al Director", Besós núm. 13, maig 1968) o criticant la homosexualitat (veure "Un español en Londres", Besós núm. 14, juny 1968) on arriba a dir textualment, entre d'altres bestieses: "porque hay una ley que protege, y por tanto fomenta, a los invertidos sexuales", va passar a ser un dels impulsors del Despatx d'Assessorament Laboral i Popular (DALP) que va destacar per defensar aferrissadament a AVV's , treballadors, insubmissos, etc. arribant fins l'actualitat.

Una altra revista interessant a Sant Adrià va ser Cercle (1968-1969), promoguda per uns membres de la Comunitat Eclesial de la ciutat i que es pot trobar a l'Hemeroteca de l'Arxiu Mnicipal Administratiu de Sant Adrià de Besòs (ASAB). En aquesta podem trobar articles del president de l'AVV de La Catalana, Agustin Bonet Manich o d'Agustí Gallart (futur membre de l'AVV de Sant Adrià Nord, Convergència Democràtica i fins i tot Alcalde als anys noranta durant un breu període). 
A aquest fet s'hauria d'afegir un altre aspecte insinuat en la conversa de la revista Grama que he reproduït: el paper de la premsa generalista. La Llei de Premsa de 1966 promoguda per Manuel Fraga Iribarne havia eliminat la censura prèvia. Això no significava que existís la llibertat d'expressió ja que s'establia tot un mecanisme de sancions posteriors en funció del que es publiqués que podia arribar a multes quantioses i el segrest de la publicación ${ }^{501}$. Aquest fet va portar al tancament de diverses publicacions a causa de les pèrdues econòmiques impossibles d'assumir que els hi ocasionaren els segrestos. Malgrat això, mica en mica diversos diaris de la premsa comercial, dita "generalista" van anar atrevint-se a fer articles on es denunciaven les grans mancances existents als nous barris que s'estaven edificant a corre cuita en les grans ciutats, així com diversos casos de corrupció que es van anar descobrint. Evidentment al principi no es podia ser massa explícit, però les irregularitats eren tan evidents que fins i tot diaris del Movimiento com Solidaridad Nacional es veien obligats a recollir aquest tipus de fets a les seves pàgines. Un exemple molt gràfic és la notícia recollida a aquest diari sobre l'incendi d'una edifici a Badalona on hi havia una indústria amb materials inflamables... amb d'una escola privada situada a dalt del mateix edifici!. Malgrat tot, els subtítols s'automesuraven: “¿debe una escuela estar situada en un edificio donde se manejan productos inflamables? ¿Responsabilidad Particular? No Es defecto de la sociedad en que vivimos" ${ }^{502}$.

No obstant, la premsa era cada dia més agosarada. Diaris de nova planta com Tele/ eXprés ${ }^{503}$ havien de guanyar-se una quota de mercat i per això van dedicar una especial atenció a la vida local. Això feia que altres diaris més antics com podien ser El Diario de Barcelona, La Vanguardia, El Noticiero Universal, El Correo Catalán, haguessin de fer-ne també referència malgrat la línia conservadora que imperava

501Una referència força contemporània als fets la podem trobar a Gonzalo Dueñas: La Ley de prensa de Manuel Fraga, Ruedo Ibérico, París?, 1969. Veure també les referències a la Llei de Premsa de 1966 a Carme Molinero i Pere Ysàs: El règim franquista..., p. 35 i La anatomía del franquismo..., p. 88-93.

502 Solidaridad Nacional, 19-4-1970.

503Aparegut a l'any 1964, Tele/ eXpres era el primer nou diari aparegut a Barcelona des de el final de la Guerra Civil. Anys després destacaria el cas del rotatiu Mundo Diario, publicat a Catalunya entre 1974 i 1980. Dirigit per Sebastià Auger, va tenir una línia força progressista propera al PSUC i amb un especial interès pel moviment veïnal. Veure també Joan B. Culla i Clarà i Pierre Vilar: Història de Catalunya. Volum 7. El franquisme i la transició democràtica, 1939-1988, Edicions 62, Barcelona, 1994. 
en general. I aquest fet va ajudar no només a la conscienciació de la que estem parlant- si no també a erosionar el poder franquista local que reaccionava nerviós davant aquesta nova premsa ${ }^{504}$. Ja hem vist, en aquest sentit, la resposta de l'Alcaldia de Badalona davant la denúncia de irregularitats als Plans Parcials de Llefià i Caritg ${ }^{505}$. Un altre exemple d'aquest "nerviosisme" de les autoritats municipals el podem trobar en la rèplica que va dirigir el mateix Alcalde de Sant Adrià de Besòs a una carta apareguda a La Vanguardia, arran la mort d'un nen per un lleó d'un circ instal-lat irregularment al Barri del Besòs-Cobasa ${ }^{506}$. El mateix Alcalde de Badalona, Felipe Antoja Vigo, felicitava efusivament al seu "col·lega" per la resposta:

\begin{abstract}
"Te felicito por dicha respuesta, que viene a salir al paso de noticias o informaciones periodísticas que desgraciadamente están en la actualidad proliferando y que solo tienden al desprestigio de las autoridades, sin ninguna labor constructiva. Como sabes, aquí también estamos acostumbrados a ello, como recientemente ha ocurrido con las lamentables notas del Colegio de Arquitectos de Barcelona. Pero en fin, paciencia, no es cuestión de disgustarse por ello. Nosotros hemos de seguir nuestra labor, siempre con el ánimo bien dispuesto y pensando que hacemos un servicio a nuestras respectivas y queridas poblaciones.
\end{abstract}

Como siempre, un cordial abrazo de tu buen amigo." ${ }^{507}$

Cada vegada seran més freqüents casos com aquests on les autoritats, bé directament, o bé fent servir persones afins ${ }^{508}$ hauran de defensar-se d'acusacions

504Veure de nou Joan B. Culla i Clarà i Pierre Vilar: Història de Catalunya. Volum 7... i Martí Marín: Els Ajuntaments franquistes..., sobretot al capítol III "El tardofranquisme: continuitat, pseudoreformes i transició (1966-1977)", p. 355-455.

505Veure nota 473.

506[Carta de Francisco Roqueta Valls al Director de La Vanguardia] (25-3-1970), ASAB, Hemeroteca, Caixa Recull Premsa 1965-1978. L'alcalde feia referència a un article publicat el mateix dia a l'esmentat diari, titulat "Carta a un Alcalde", feta per un grup de veïns del barri Besòs-COBASA on havien denunciat la passivitat de l'Ajuntament respecte les denúncies fetes al respectiu Circ. La rèplica de l'alcalde va sortir publicada a La Vanguardia el dia 26.

507 [Carta de Felipe Antoja Vigo a Francisco Roqueta Prats], ASAB, Hemeroteca, Caixa Recull Premsa 1965-1978.

508El recurs de fer servir als palmeros és molt vell. Un exemple curiós ho trobem en una carta que van redactar un grup de barraquistes del Parapeto (la part adrianenca del Camp de la Bota) en protesta per un article aparegut al Noticiero Universal el 29 de maig de 1970 (J. J. Sánchez Costa: "Curiosidades Administrativas del Campo de la Bota"), entre ells, un dels patriarques d'un clan gitano amb connexions amb l'administració franquista: Manuel Alunda Bolunda (que havia arribat a ser alcalde de barri i era conegut popularment com el "Tio Manolo"). En aquesta carta es criticava al redactor de l'article i es donava suport a l'alcalde de Sant Adrià, a més d'exigir-se la seva publicació al diari com a rèplica. Manuel Alunda Bolunda, Sebastián Moreno Márquez, Ángel Molina Guerra, Alfredo Castro Vaca, Mario Marín Martínez, Sebastián Platero García, i José 
d'incompetència o desídia pels habitants de nombrosos barris. Aquest fet ens posa de manifest un altre element a tenir en compte en aquest període: el desgast progressiu del règim i la crisi progressiva que patirà a mesura avancin els anys setanta fins arribar a la mort del dictador.

En efecte, des de l'any 1969 i malgrat les proclames triomfalistes del règim després de l'Estat d'Excepció vigent entre els mesos de gener i març, el cert és que l'oposició a la dictadura va anar creixent progressivament. Les mobilitzacions que es van donar contra el Procés de Burgos l'any 1970 n'eren un reflex, per bé que el franquisme aleshores encara es va sentir prou fort per permetre's el "luxe" de commutar les penes de mort:

\begin{abstract}
"La "crisis de diciembre" de 1970 mostró que la dictadura disponía sobremente de los recursos, en especials de los coercitivos, para asegurar su orden, pero también que la falta de legitimidad democrática de la legalidad y de las instituciones del régimen, en un contexto de contestación interior creciente y de progresiva mayor relación con las democracias occidentales, constituía un problema que no paraba de acrecentarse; por ello se acentuó en buena parte de la clase política la convicción de la necesidad de introducir algunos cambios en el ordenamiento franquista." ${ }^{509}$
\end{abstract}

Però la realitat anys posterior era encara més alarmant pel règim. Estudis com els de Pere Ysàs sobre la dissidència en les etapes finals del franquisme ens demostren clarament com aquesta va ser una de les principals preocupacions del règim ${ }^{510}$. Nombrosos informes d'institucions governamentals, d'organismes policials, del Consejo Nacional del Movimiento, etc. informaven de la creixent oposició en diferents sectors de la societat, com els universitaris, els treballadors, els i les intel-lectuals i sectors de l'Església. A aquests es va afegir la constant preocupació de les autoritats per la "subversió" als barris populars de les grans ciutats en la mesura que la protesta creixi significativament durant els primers anys setanta ${ }^{511}$. Crec que és prou simptomàtic que als anys 1974 i 1975 la dictadura

Hernández Rodríguez: “Carta abierta don J .J. Sánchez Costas” (?-maig/juny-1970), ASAB; Hemeroteca, Caixa Recull Premsa 1965-1978.

509Carmen Molinero i Pere Ysàs: La anatomia del franquismo. De la supervivencia a la agonía, 19451977, Crítica, Barcelona, 2008, p. 266.

510 Pere Ysàs: Disidencia y subversión. La lucha del régimen franquista por su supervivencia, 19601975, Crítica, Barcelona, 2004.

511Amb l'exemple del ja esmentat Plan Barrio d'octubre de 1973, o la segona versió, Plan Barrios. Estudio de la Subersión en los barrios de gener de 1975, que analitzarem amb més detall en pàgines posteriors. 
si que portés fins a les darreres conseqüències les diferents condemnes de mort per motius polítics, perquè assetjada per diversos fronts, no podia permetre's signes de "debilitat".

A nivell local aquesta progressiva debilitat del franquisme també es va veure reflectida en la cada vegada major dificultat per controlar unes eleccions que s'havien volgut presentar com "exemple de democràcia orgànica": les municipals del Tercio Familiar ${ }^{512}$. Que les coses estaven canviant i que ja no era tan fàcil manipular les votacions com abans ho posen de manifest diversos documents. Després de l'Estat d'Excepció s'havia decidit ja un primer ajornament de les eleccions municipals al Tercio Familiar. Però al setembre de 1969 el mateix José Solís Ruiz enviava una nota al Ministre de la Governació, Camilo Alonso Vega expressant la seva opinió sobre un possible nou ajornament ${ }^{513}$. En aquesta qüestió si que es van posar d'acord ràpidament la Secretaria General del Movimiento i el Ministeri de la Governació:

\footnotetext{
"Así las cosas, la Secretaría General del Movimiento afirma que ante las intenciones de aplazamiento manifestadas en el mes de Marzo, consideran que no tienen ahora a punto la maquinaria electoral y por lo tanto estiman preferible su aplazamiento.

El Ministerio de la Gobernación considera que esta objeción es muy importante. Estima también que el clima político se ha deteriorado en cierta medida últimamente. Por consiguiente, lo lógico sería volver a pensar en una postergación o aplazamiento de las elecciones, y en este sentido ha redactado un Proyecto de Decreto-ley."514
}

Evidentment, la raó oficial que es va fer servir per fer finalment les eleccions l'any 1970 no va ser aquesta, sinó un "ajustament de calendari” amb les altres eleccions per fer-les coincidir totes (les Municipals, Sindicals, Procuradors a Cortes, etc.) el mateix any, així un nou Decret Llei que permetia també la votació de les dones casades (a més dels ja reconeguts “Cabezas de Familia”). Vam veure com ja al

512De nou remeto a Martí Marín: Els Ajuntaments franquistes... i al seu capítol III "El tardofranquisme: continuitat, pseudoreformes i transició (1966-1977)”, p. 355-455.

513José Solís Ruiz: Observaciones Formuladas por la Secretaria General del Movimiento. [Nota del Ministro Secretario General del Movimiento José Solís al ministre de la Gobernación Camilo Alonso Vega] (10-9-1969), AGA, Fons Ministerio del Interior. Régimen Municipal y Provincial. Elecciones Municipales, Caixa 53/1228, Dossier Elecciones Municipales 1969. Aplazamiento de las mismas.

514 [Ministerio de la Gobernación] (11-9-1969): “Nota sobre las alternativas posibles en materia de las elecciones municipales y provinciales”, AGA, Fons Ministerio del Interior. Regimen Municipal y Provincial. Elecciones Municipales, Caixa 53/1228, Dossier Elecciones Municipales 1969. Aplazamiento de las mismas. 
1966 s'havia previst la possibilitat d'infiltració de candidats opositors i les mesures a prendre al respecte ${ }^{515}$. La novetat serà que en les eleccions de 1970 serà més complicat d'aconseguir totalment aquest objectiu, per molt que es tingués un control exhaustiu dels candidats. Aquests van ser, per exemple els que es van presentar al Barcelonès Nord:

"BADALONA Censo de población: $92.985 \quad$ Vacantes a cubrir: 3

Antonio Solé Alemany, 50 años, casado, industrial, afecto. Juan Munells Sabatés, 30 años, casado, industrial, afecto. Juan F. Enciso García, 28 años, casado, comercio, afecto.

Monserrat Fibla Tura de Walter, 50 años, casada, sus labores, afecta.

José Guillén Clapés, 45 años, casado, industrial, afecto.

Lorenzo Osa García, 54 años, empleado, casado, afecto.

Fco. R. Vallespín Campos, 44 años, casado, mecánico, afecto.

Fernando Ruiz Narbón, 41 años, casado, transportista, afecto.

Mariano Escuedero Mayoral, 40 años, casado, comercio, afecto.

Juana Ma Jordán Romero de Comabella, 29 años, casada, sus labores, afecta.

Cecilia March Blanch, 50 años, casada, sus labores, desafecta. (?)

(...)

SAN ADRIÁN DE BESOS Censo de población: 15.972 Vacantes a cubrir: 2

José Sabadell Piera, 56 años, casado, agricultor, Afiliado.

Angel Guirao Pelegrin, 40 años, casado, comercio, adicto.

Antonio Aragall Agut, 38 años, casado, industrial, adicto.

Rafael Guzman Marquez, 46 años, casado, comercio, indiferente.

Francisco Aliaga Ibáñez, 50 años, casado, comercio, indiferente

Juan S. López Higinia, 52 años, casado, panadero, panadero, indiferente.

Francisco Guerrero Godoy, 41 años, casado, verificador, indiferente.

Agustín Bonet Manich, 54 años, casado, contramaestre téxtil, indiferente.

(..)

SANTA COLOMA DE GRAMANET Censo de población: $32.277 \quad$ Vacantes a cubrir: 2

Jesús Cirprés Orduna, 30 años, casado, comercio, afecto.

Gregorio Génova Egea, 47 años, casado, propietario, afecto.

Gabriel Torralba Vicente, 38 años, casado, auxiliar de farmacia, afecto.

Dionisio Sanz Martín, 47 años, casado, empleado, afecto.

Joaquin Amorós Nofrerias, casado, Delegado local de excombatientes

José Antonio Egea Hidalgo, casado, Guardia de Franco

Amadeo Bernader, Borrell, casado" ${ }^{\prime 516}$

La "novetat" no va ser només la presència d'una candidatura "desafecta" a

515Veure notes 322,323 i 324 .

516Candidatos presentados por el Tercio de Representación Familiar [Tèlex enviat a Gobernació per part del Govern Civil de Barcelona. ], AGA, Fons Ministerio del Interior. Regimen Municipal y Provincial. Elecciones Municipales, Caixa 53/1452, Extracto Elecciones Municipales 1970. Información electoral transmitida por télex por los Gobiernos Civiles (Provincia de Barcelona). 
Badalona, sinó que aquesta resultés ser la guanyadora, com va ser el cas de Cecília March Blanch. També és interessant veure les diferents dades de participació en aquestes eleccions. Destaca les grans diferències entre Badalona i Sant Adrià que registren més participació que Santa Coloma ${ }^{517}$. El fet que en la ciutat més gran del Barcelonès Nord hi hagués una candidatura "alternativa" segurament va tenir alguna cosa a veure, a l'igual que el perfil polític dels altres candidats presentats. A Sant Adrià hi ha un nombre important "d'indiferents" mentre a Santa Coloma estaven més identificats amb el franquisme i això els hi restava simpaties d'una població notablement obrera i que estava adquirint -si no es que tenia ja- una forta consciència antifranquista. A més, a diferència de les eleccions sindicals, la majoria de l'oposició organitzada no havia optat per una tàctica entrista sinó més aviat de boicot respecte aquestes eleccions municipals.

Però la novetat no és només que a Badalona sorgís elegida una candidata "desafecta" (encara que d'un perfil més dissident que no pas opositor, com era el cas de la germana de l'ex-Alcalde Santiago March Blanch), sinó el nivell d'exigència a l'Ajuntament de Badalona que faran els seus votants: un grup de dones enviava una instància a Governació reclamant un càrrec de major responsabilitat a l'Ajuntament de Badalona per Cecília March Blanch, per tal de que la seva elecció no resultés gratuïta -com acabaria passant en un cas similar a Terrassa ${ }^{518}$. A Sant Adrià de Besòs Agustín Bonet Manich, President de l'AVV de La Catalana i candidat

517[Resultats electorals eleccions al Tercio Familiar 1970 en el Barcelonès Nord], AGA, Fons Ministerio del Interior. Regimen Municipal y Provincial. Elecciones Municipales, Caixa 53/1452, Extracto Resultados Obtenidos con expresión de porcentajes (Barcelona, 1970). Cecília March va ser la candidata més votada a Badalona amb 9.713 vots, seguida de José Guillem Clapés (7.433 vots) i Juan Nunells Sabates (5.966 vots). El número d'electors era de 74.902 i van haver-hi 25025 vots vàlids i 359 nuls (participació del 34\%). A Sant Adrià de Besòs van resultar escollits Ángel Guirado Plegrin (1.164 vots) i Rafael Guzmán Márquez (999) vots amb 12.187 / 11.789 electors (no entenc aquesta disparitat, però així figura al document original), 3.331 volts vàlids i 9 nuls (participació del 29\%), tot i que es van haver de repetir les eleccions l'any següent per la impugnació feta, van sortir escollits els mateixos. A Santa Coloma de Gramenet els escollits van ser Gabriel Torralba Vicente (1.945 vots) i Gregorio Genova Egea (1.856 vots) amb 49.648 electors, 3.609 vots vàlids i 9 vots nuls (participació del 7,3 \%).

518[Petició signada per nombroses dones adreçada al Ministerio de la Gobernación exigint un càrrec de major responsabilitat que el de la Delegación de servicios de Mercados, Escuelas y Lucha contra el Analfabetismo atorgat a Cecília March Blanch], (12-2-1971), AGA, Fons Ministerio del Interior. Regimen Municipal y Provincial. Elecciones Municipales, Caixa 53/1284, Carpeta Elecciones Municipales 1970. Extracto Se formula queja en relación con las funciones atribuídas a la Concejal del Ayuntamiento de Badalona (Barcelona) Do Cecília March Blanch. El cas dels dissidents de Terrassa a Martí Marín: Els Ajuntaments franquistes..., p. 385-387 i 395396. 
al Tercio Familiar va interposar un recurs contra les eleccions i aconseguia que es declaressin nul-les per que la Junta Electoral no havia acceptat la seva candidatura $^{519}$. Aquestes es van repetir el 21 de març de 1971 però Agustí Bonet no va aconseguir ser escollit tot i ser el tercer candidat més votat i un segon recurs que va interposar va ser desestimat ${ }^{520}$.

Les autoritats franquistes van prendre nota del que havia passat. El governador civil Pelayo Ros volia aplicar la divisió de la votació per districtes que es feia a Barcelona des de 1961 a altres ciutats de l'àrea metropolitana (una idea apadrinada pel ministre Tomàs Garicano Goñi) ${ }^{521}$. Com que no era una nova llei, el governador va demanar el parer dels diferents alcaldes que van respondre de maneres diferents en funció de les seves necessitats. En Felipe Antoja, que a més d'Alcalde de Badalona era Diputat Provincial per Barcelona i Procurador en Cortes escrivia una carta en resposta suggerint la divisió de la ciutat en diferents districtes electorals, per poder així afavorir la presència de candidats "afectes" de cara a les eleccions al Tercio Familiar que havien de celebrar-se el $1973^{522}$. Recomanació que tal com ja s'ha dit no es va aplicar a tot arreu:

“(...)

Elección por Distritos: Sí, con la sugerencia de que los candidatos estuvieran inscritos en el censo electoral del propio Distrito.

Ventajas:

519[Sentència al recurs interposat per Agustín Bonet Manich (Sant Adrià de Besòs) contra les eleccions Municipals de 1970], (18-1-1971), Fons Ministerio del Interior. Regimen Municipal y Provincial. Elecciones Municipales, Caixa 53/1284. A Santa Coloma de Gramenet Amadeo Bernadas Borrell també va interposar un recurs però va ser desestimat. Veure document al respecte del Ministerio de la Gobernación, SNIACL (Madrid, 2-3-1971) referent als recursos contencioso-administratius interposats contra les eleccions municipals de 1970, AGA, Fons Ministerio del Interior. Régimen Municipal y Provincial. Elecciones Municipales, Caixa 53/1282, Extracto Elecciones Municipales 1970. IV Impugnaciones y recursos.

520 [Carta del Govern Civil de Barcelona al Director General de Administración Local on s'informa de la desestimació del recurs presentat per Agustin Bonet Manich contra la proclamació dels Concejas Electes del Terç Familiar Angel Guireu Pelegrín i Rafael Guzmán Marquez en les Elecciones Complementarias del 5 de març de 1971] (10-8-1971), AGA, Fons Ministerio del Interior. Régimen Municipal y Provincial. Elecciones Municipales, Caixa 53/1284, Carpeta Elecciones Municipales y Otras. Extracto Recursos y reclamaciones pendientes.

521 Martí Marín: Els Ajuntaments franquistes..., p. 393-400.

522 [Carta de Felipe Antoja, Alcalde de Badalona, Procurador en Cortes i Diputado Provincial per Barcelona, suposem que al governador civil] (24-8-1973), AGA, Fons Ministerio del Interior. Régimen Municipal y Provincial. Elecciones Municipales, Caixa 53/1287, Distritos. Proyecto de Orden sobre circunscripciones electorales en los Municipios de la provincia de Barcelona, Carpeta Antecedentes Barcelona. 
- Evitar el peso que en la balanza electoral supuso (en las elecciones de 1970) la fuerte votación de determinados sectores influenciados por ciertas Parroquias y Centros sociales afectos a ellas, cuando por contra se acusó una abstención masiva en otros sectores de la ciudad.

- Mayor participación del electorado si los candidatos residen en el propio Distrito, al ser más conocidos y al mismo tiempo estar ellos mas al corriente de las necesidades y características de su sector.

Inconvenientes:

- Posibilidad de que en algún Distrito salga elegido algún candidato no demasiado conveniente aunque ello sería mejor que no exponerse a la pérdida de la totalidad de las elecciones.

Número de Distritos actualmente: $\quad 9$

Número de Concejalías familiares: $\quad 7$

Número de vacantes familiares: $\quad 4$

Propuesta de Distritos para los próximos comicios:

IV y VI (no fundidos) VII, VIII y IX [aquesta línia del document està tallada i no sé si posa exactament això]

(...)

SANTA COLOMA DE GRAMANET (población de derecho 105.880 habitantes)

Elección por distritos: No.

Inconvenientes:

Se ocasionaría un fraccionamiento de los esfuerzos a realizar para llevar adelante la candidatura única, la cual se estima mas coherente porque en ellas los candidatos se ayudan recíprocamente." 523

Tal com ja va dir Martí Marín a la seva Tesi sobre els Ajuntaments franquistes, tot depenia del que afavoria més a les candidatures oficials promogudes per les autoritats franquistes. D'aquesta manera a Badalona es van fer 7 districtes electorals: "1. Torner. 2. Santa María y San José. 3. Bufala y Morera 4. Canyado y Pomar.5. La Salud y Sistrells. 6. Lloreda. 7. Artigas, Llefia y San Roque"524, mentre a Santa Coloma i Sant Adrià es va mantenir la circumscripció única per que era

523[Conjunt de documentació emesa pel Govern Civil de Barcelona i adreçada al Director General de l'Administració Local (Carta i Annex)] (28-8-1973), AGA, Fons Ministerio del Interior. Régimen Municipal y Provincial. Elecciones Municipales, Caixa 53/1287, Distritos. Proyecto de Orden sobre circunscripciones electorales en los Municipios de la provincia de Barcelona, Carpeta Antecedentes Barcelona.

524 [Document del Ministeri de la Governació sobre la divisió en districtes electorals de diverses ciutats catalanes, entre elles Badalona] (15-9-1973), AGA, Fons Ministerio del Interior. Régimen Municipal y Provincial. Elecciones Municipales, Caixa 53/1287, Carpeta Distritos. Proyecto de Orden sobre circunscripciones electorales en los Municipios de la provincia de Barcelona. 
considerat més convenient. Tot i que en general es considerava que la situació estava força controlada ${ }^{525}$, els documents del Ministeri de la Governació evidencien una major preocupació:

(...)

3‥ CRITERIOS DE ESTRATEGIA ELECTORAL.

a) Criterios a nivel local:

$1^{\circ}$ ) Adelantarse a los acontecimientos y dominarlos, en lugar de ir a remolque de los mismos. A estos efectos, en todos los Ayuntamientos de naturaleza urbana, han quedado los Gobernadores Civiles en presentar ante el Ministerio de la Gobernación en el plazo de 7 días, los resultados electorales ideales, a fin de que los resultados finales reales, de diferencien lo menos posible de dichas previsiones.

(...)

3ํ) Los candidatos deben manifestar y ratificar su adhesión a los Principios Fundamentales del Movimiento y, dentro de este ancho campo, debe darse primacía a la calidad. Especialmente en el tercio familiar, se acordó dar una especial relevancia a la juventud, así como cierta participación a la mujer.

(...)

$7^{\circ}$ ) En caso de presentación de algunas candidaturas, que aunque formalmente acepten los Principios del Movimiento, pero que en el fondo se sepa y conozca su significado contrario, se recomendó beligerancia. En caso de que todos los candidatos sean adictos al Movimiento, se recomendó primar la calidad y que de ninguna manera saliera ningún ganador sin tener algo que agradecer."526

La poca participació també preocupava, així com la dificultat de trobar candidats idonis en determinats ambients urbans ${ }^{527}$. Per això es van intensificar les campanyes per esperonar la participació per intentar aconseguir una façana "de semblança democràtica", ja fos des de Governació o la Secretaria General del Movimiento, fent campanyes de premsa en la ràdio i la televisió ${ }^{528}$, o fins i tot

525Delegación Nacional de Províncias. Resumen de la Circular 7/73. "Informe reservado" (i-i1973) [A la província de Barcelona s'esmenta el cas de Badalona], AGA, Fons Ministerio del Interior. Régimen Municipal y Provincial. Elecciones Municipales, Caixa 53/2963, Carpeta Elecciones Municipales 1973, Subcarpeta Recursos promovidos contra la validez de las elecciones municipales.

526Ministerio de la Gobernación, Dirección General de la Administración Local: "Informe al Comitè Electoral Central", (¿1973), AGA, Fons Ministerio del Interior. Regimen Municipal y Provincial. Elecciones Municipales, Caixa 53/2963, Elecciones Municipales 1973.

527 Ministerio de la Gobernación: "Elecciones Municipales" (1973), AGA, Fons Ministerio del Interior. Regimen Municipal y Provincial. Elecciones Municipales, Caixa 53/1285, Carpeta Miniterio de la Gobernación. Elecciones Municipales. (Boletín).

528“Campañas de prensa y radio en las elecciones municipales para la renovación de los Consejos 
contractant companyies privades de màrqueting i publicitat ${ }^{529}$.

L'estricte control va impedir, per una banda, que es presentés alguna candidatura alternativa com el cas de Juan Cos Arqué a Badalona, com així semblen demostrar diferents telegrames de protesta enviats al President del Govern per part de la ja esmentada Asociación de Cabezas de Família de Alta Badalona, el Centre Social de Sant Roc o l'AVV del Congrés Eucarístic ${ }^{530}$. Però per una altra, no van poder evitar la proclamació com a regidor per Tercio Familiar d'Ernesto Rojo Rombouts (catalogat com a "catalanista") a la Circumscripció primera ${ }^{531}$.

Que el dissentiment era cada vegada major ho proven les darreres reformes del franquisme als anys 1974-1976 com la creació de les denominades "Asociaciones Políticas" dins del Movimiento (a les quals se'ls volia atorgar la possibilitat de proposar candidats al Tercio Familar, ja fos als Ajuntaments o a les

Locales del Movimiento, septiembre-noviembre 1973.", AGA, Fons Ministerio del Interior. Régimen Municipal y Provincial. Elecciones Municipales, Caixa 53/2963, Carpeta Elecciones Municipales 1973; "Anteproyecto de la campaña de promoción en radio y televisión para las elecciones municipales y de consejeros locales del movimiento 1973", AGA, Fons Ministerio del Interior. Regimen Municipal y Provincial. Elecciones Municipales, Caixa 53/2963 [sense carpeta].

529Com va ser la que per exemple es va encarregar a Madrid a l'empresa Tiempo Synergie. Compañía anínoma de Publicidad: "Documentación Campaña de Divulgación Elecciones Municipales" (27-9-2973), AGA, Fons Ministerio del Interior. Regimen Municipal y Provincial. Elecciones Municipales, Caixa 53/2963, Carpeta Elecciones Municipales 1973. Subcarpeta Secretaria General del Movimiento. Informe Político electoral. Noviembre 1973.

530 [Subsecretaria de Presidencia del Gobierno a Ministerio de la Gobernación. Carta i telegrames referents a les queixes de diverses entitats de Badalona adreçades al President del Govern per l'exclusió del candidat JUAN ROS ARQUÉ de les eleccions pel Tercio Familiar] (8-11-1973), AGA, Fons Ministerio del Interior. Régimen Municipal y Provincial. Elecciones Municipales, Caixa 53/2963 Carpeta. Impugnaciones de las elecciones.

531 “Elecciones Municipales de 1973. Tercio de Representación Familiar" [Document que recull les vacants (4), els electors (89.663) i els resultats], AGA, Fons Ministerio del Interior. Régimen Municipal y Provincial. Elecciones Municipales, Caixa 53/963, Carpeta Ayuntamiento de Badalona. Els escollits van ser: per la Circumscripció 1era: Ernesto Rojo Rombouts amb 1.140 vots (7.841 electors, 2.884 vots emesos, participació del 36,39\%); 3era: Juana Maa Jordán Romero amb 880 vots (5.513 electors, 2.203 vots emesos, participació del 39,96\%); 5era: Santiago Molina Alcolea amb 2.961 vots (15.953 electors, 5.111 vots emesos, participació del $32,03 \%$ ); 7 ena: Fulgencio Conesa Castillo amb 4.430 vots (28.587 electors, 7.387 vots emesos, participació del 25,84\%). Ernesto Rojo era considerat "catalanista" i tota la resta eren "afectes". A Sant Adrià ho van ser Adrián Guillemí Ariñó amb 1.839 vots, Félix Mora Martín amb 1.843 vots i Juan Arnau Valero amb 1.543 vots (14.055 electors, 6.308 vots vàlids, 91 nuls o en blanc, 45,52\% de participació). Els dos primers eren Alcaldes de Barri i el segon President de l'AVV de La Mina (tots considerats "afectes"). Pedro Solé Villamitjana, va impugnar la candidatura de Juan Arnau Valero per les nombroses irregularitats comeses en la votació i va aconseguir la seva expulsió, esdevenint ell regidor (veure tota una sèrie de documents al respecte a AGA, Fons Ministerio del Interior. Régimen Municipal y Provincial. Elecciones Municipales, Caixa 53/1283, Carpeta Elecciones Municipales Complementarias, 1974. Extracto Posible inclusión en dichas elecciones de diversos Municipios de la provincia de Barcelona. A Santa Coloma no es van fer eleccions en haver-hi 5 candidats per 5 vacants, tots "afectes". 
Corts), l'ampliació del cos electoral als majors de 18 anys (més enllà de los Cabezas de Familia i les dones casades) i la possibilitat d'elecció de l'Alcalde pels regidors (en comptes de la designació directa pel Governador Civil). Però ja era massa tard.

Recuperant el fil de la construcció del moviment popular de barris, sens dubte, el principal factor que va afavorir la presa de consciencia i la mobilització popular va ser la pròpia constatació de que amb la mobilització s'aconseguien èxits. Això ja s'havia observat durant la dècada dels seixanta dins el moviment obrer i ara tocava posar-ho en pràctica als barris. Ja hem vist com s'iniciaven les primeres mobilitzacions per reivindicar millores en serveis elementals o contra la pujada dels lloguers als barris de l'OSH. Aquestes continuaran a la dècada dels 70 . El mateix any la conflictivitat obrera i la mobilització entorn al procés de Burgos esperonava a l'antifranquisme ${ }^{532}$. Però va ser l'any 1971 quan es va produir un conflicte que al meu parer va ser decisiu pel desenvolupament del moviment veïnal a la Comarca del Barcelonès Nord. M'estic referint a la lluita per l'Ambulatori que es va donar a Santa Coloma de Gramenet.

La precària situació de la sanitat pública colomenca ja havia estat denunciada per un document pioner, en l'elaboració del qual van participar, entre d'altres, un grup de persones totes elles relacionades amb l'incipient moviment veïnal d'aleshores: Eloy Jurado, que serà posteriorment President de l'AVV de Singuerlín; Lluís Hernández, futur Alcalde pel PSUC; Núria Valls, assistenta social també ubicada al Singuerlín; José Maria Martin, Salvador Bolancer i Ramon Escudero, tots tres vinculats o propers a la $\mathrm{JOC}^{533}$. Al fet -ja comentat- de que només existís un

532Un full volant de les Comisiones Obreras de Badalona y Comarca titulat "A la clase obrera" (gener 1971) resumia les principals vagues i conflictes obrers a l'Estat, fent ressò de la vaga de la Maniquinsta Terrestre i Marítima, on treballaven molts badalonins, colomencs i adrianencs. Un segon full també se'n feia ressò amb motiu del 1er de Maig; "Al pueblo de Badalona y su comarca ante el 1o de Mayo" (abril 1970). Un tercer full titulat "A la Comarca de Badalona" (9-91970) denunciava els fets del Procés de Burgos cridant a la defensa dels drets nacionals de Catalunya, Galícia i Euskadi, recordava les diferents lluites obreres, el cas "MATESA", denunciava a diversos jerarques nacionals i locals del franquisme, saludava la creació del Consell de Forces Polítiques de Catalunya i cridava a una setmana de lluita que començava l'onze de setembre. ANC Fons PSUC. 06. Context social i polític del partit. 06.02 Moviment obrer. 06.02.01. Organitzacions de Treballadors. 1567 Comissions obreres (CCOO) Badalona i comarca.

533Trabajadores de Santa Coloma de Gramenet: "Acerca de la Seguridad Social y de como se concreta en Santa Coloma de Gramenet", AHMTB, Donació Marcelo López Ródenas, Caixa 3, Dossier núm. 13, Archivo clandestino Comisiones de los Barrios. Veure també Marcelo Lòpez Ródenas: Historia social de la Santa Coloma moderna..., p. 119. 
únic i atrotinat ambulatori (situat en un vell edifici petit i insuficient, com aviat es demostraria) per una població que tenia ja més de 100.000 habitants, 80.000 dels quals amb dret a atenció mèdica en la Seguretat Social, calia afegir tot un seguit de incompatibilitats i corrupteles de persones vinculades a la sanitat que feien el seu negoci particular. Dos clars exemples denunciats al document esmentat eren el mateix inspector comarcal del SOE, el Dr. Luis Osorio Samaniego, que alhora era un dels principals accionistes de la Mútua del Carmen de Badalona, entitat concertada per el Instituto Nacional de Previsión per prestar serveis sanitaris al Barcelonès Nord, i el farmacèutic Feliciano Palacios Moreno, propietari de l'edifici que es feia servir com ambulatori i que al costat hi tenia una farmàcia de la seva propietat. Ell mateix pressionava per que el futur ambulatori es construís en uns terrenys de la seva propietat on "casualment" també hi havia a prop una altra farmàcia seva. Encara més, el Ministre de Treball Jesús Romero Gorria havia anunciat pomposament a l'any 1969 que s'inauguraria un nou ambulatori el 25 d'octubre de 1970. Però la realitat era que va arribar aquesta data i ni s'havia començat a construir. El document també denunciava una de les "solucions" que s'havien proposat, que era construir l'ambulatori en uns terrenys teòricament reservats per fer una residència d'ancians ${ }^{534}$.

La ja de per si precària situació va empitjorar el 29 de setembre de 1970: un incendi provocat per la caldera deixa inservible l'atrotinat local que es feia servir. La "solució" que se'ls ofereix als habitats de Santa Coloma es desplaçar-se al barri de Sant Andreu Arenal de Barcelona mentre no es concretava la construcció d'un nou ambulatori. La paciència havia arribat a un límit, ja que la ciutat de Santa Coloma aportava una gran quantitat de diners en quotes dels seus afiliats de la Seguretat Social per rebre un pèssim o nul servei. Però no s'entén la reacció posterior si no tenim en compte el procés de conscienciació que es va anar donant als anys seixanta. Crec que les paraules finals del document anteriorment esmentat resumeixen bé la percepció que molta gent tenia ja de la situació:

“Siguen robándonos y lo seguirán haciendo tanto en las fábricas como en los barrios, si no lo impedimos con la fuerza de nuestra unión, que ahora debe servirnos para:

534Trabajadores de Santa Coloma de Gramenet: "Acerca de la Seguridad Social y de como se concreta en Santa Coloma de Gramenet”, AHMTB, Donació Marcelo López Ródenas, Caixa 3, Dossier núm. 13: Archivo clandestino Comisiones de los Barrios, p. 4-5. 
1 INMEDIATA SOLUCIÓN EN SANTA COLOMA EN CUANTO A ASISTENCIA MÉDICA.

2 INMEDIATA READMISIÓN DE LAS ENFERMERAS Y LOS CELADORES.

3 ACLARACIÓN POR PARTE DEL ESTADO DE LA SITUACIÓN DE LOS [848?]

MILLONES.

TRABAJADORES DE SANTA COLOMA DE GAMANET [sic]”535

D'aquesta manera, aviat es van fer vàries reunions on van participar diverses persones i organitzacions polítiques de la ciutat. Els Grupos Obreros Autònomos (GOA), el PSUC, Bandera Roja, la Federació Catalana del PSOE, CCOO, UGT, el PCE(i), Justícia i Pau i persones provinents de l'Església, la JOC... ${ }^{536}$. Els GOA van tenir un protagonisme a Santa Coloma de Gramenet que no van tenir a les altres ciutats del Barcelonès Nord. Segons Isidre Molas eren:

"un col-lectiu marxista revolucionari constituït per un sector dels Círculos de Formación de Cuadros al desembre de 1970, a partir de la vaga de l'empresa HarryWalker. El sector més important fou l'Equip Obrer (José Antonio Díaz i Manuel Murcia) i comptà també amb l'Equip Teòric (Santi Soler) i l'Equip Exterior. Aviat s'allunyà del leninisme inicial per esdevenir un grup consellista de to llibertari. Al desembre de 1971 l'equip teòric i l'equip exterior se separaren i constituïren el Movimiento Ibérico de Liberación (MIL)." ${ }^{537}$

Sorgits a Santa Coloma entre els anys 1969-1970, estaran formats per persones joves, amb gent que havia tingut militància cristiana a la JOC, marxistes i no marxistes, però amb una tendència llibertària cada vedada més preponderant. $\mathrm{A}$ nivell organitzatiu actuaran sobretot al barri del Fondo ${ }^{538}$. Segons el mateix Marcelo López Ródenas, "els GOA van ser la primera organització de barri de caràcter independent respecte els partits polítics que ja començaven a despuntar

535Trabajadores de Santa Coloma de Gramenet: "Acerca de la Seguridad Social y de como se concreta en Santa Coloma de Gramenet", AHMTB, Donació Marcelo López Ródenas, Caixa 3, Dossier núm. 13: Archivo clandestino Comisiones de los Barrios, p. 6.

536Carles Capdevila Llovera: “1971: la lluita per l'ambulatori” dins Grup d'Història José Berruezo: Una ciutat dormitori sota el franquisme..., p. 317.

537Isidre Molas: Diccionari dels Partits Polítics de Catalunya al segle XX. Enciclopèdia Catalana, Barcelona 2000. Més informació sobre els GOA a Carles Capdevila Llovera: "Els "Grupos Obreros Autónomos" (GOA)" dins Grup d'Història José Berruezo: Una ciutat dormitori sota el franquisme..., p. 245-264,

538Carles Capdevila Llovera: "Els "Grupos Obreros Autónomos" (GOA)" dins Grup d'Història José Berruezo: Una ciutat dormitori sota el franquisme..., p. 250. El mateix autor ens comenta que el primer nucli dels GOA va estar format, entre d'altres per militants com Ángel Nogales, Sebastian Puigcerver, Ángel Sody, José-Pepe-Martínez (el Rubio), La Cati, el Eusebio, el Roman... 
fins i tot de la mateixa JOC"539. Aquest grup va tenir enfrontaments ideològics amb el PSUC i el mateix Jaume P. Sayrach, que en una entrevista recent es mostrava més crític amb aquests $^{540}$. Com veurem més endavant, tant Sayrach com membres dels GOA s'atribueixen els mèrits de la fundació del Centre Social Amics del Fondo ${ }^{541}$.

Aviat el PCE(i) (sorgit al 1967 d'una escissió de la secció universitària del PSUC i que seran coneguts més tard com a PTE) s'en va desmarcar d'aquestes reunions per que encara prioritzava la lluita a les fàbriques i no donava tanta importància a la mobilització als barris. Alhora tant els GOA (o Grups Autònoms de Santa Coloma -GA- com van ser coneguts a nivell local) com el PSUC discrepaven sobre quina tàctica fer servir, però finalment es va acceptar la idea dels GA d'impulsar mobilitzacions al carrer per reclamar la construcció d'un centre hospitalari, constituint-se un Comitè Unitari de Lluita on van participar totes les forces polítiques i persones individuals amb l'excepció que ja he comentat ${ }^{542}$.

Es va decidir fer un primer full volant on es reclamava la construcció d'una o més clíniques en comptes d'un simple ambulatori i, el més important, es convocava a una primera concentració pel divendres 23 de febrer a les 20:30 h davant de l'Ajuntament. La fulla aparegué signada com “Trabajadores de Santa Coloma" ${ }^{543}$. Aquesta primera concentració va ser un èxit amb 2.000 persones, que marxaren en manifestació fins a la Plaça del Rellotge (o com va ser coneguda aviat, la "Plaça Roja”) al barri del Fondo, malgrat el fort marcatge policial que van patir. La manifestació va acabar amb una declaració d'intencions "volveremos otro día"544. L'èxit va alarmar a l'Alcalde de Santa Coloma, que escrivia preocupat una carta al Governador Civil i apuntant als -segons ell- culpables:

539Carles Capdevila Llovera: "Els "Grupos Obreros Autónomos" (GOA)" dins Grup d'Història José Berruezo: Una ciutat dormitori sota el franquisme..., p. 249 i Marcelo López Ródenas: Historia social de la Santa Coloma moderna..., p. 120.

540Entrevista amb Jaume P. Sayrach i Fernando Saro, 22-5- 2013.

541Jaume P. Sayrach: En el Fondo. Parroquia de Joan Baptista (Santa Coloma de Gramenet) 19651979. Edicions Fòrum-Grama, 2001, p. 77. Carles Capdevila Llovera: "Els "Grupos Obreros Autónomos" (GOA)" dins Grup d'Història José Berruezo: Una ciutat dormitori sota el franquisme..., p. 255-257.

542Marcelo López Ródenas: Historia Social de la Santa Coloma Moderna, p. 119. L'assemblea constituent de l'esmentat Comitè Unitari va ser el dia 2 de febrer de 1971. Veure Carles Capdevila Llovera: "1971: la lluita per l'ambulatori" dins Grup d'Història José Berruezo: Una ciutat dormitori sota el franquisme..., p. 320.

543 Trabajadores de Santa Coloma: [Full volant sense títol, febrer 1971], AHMTB, Donació Marcelo López Ródenas, Caixa 3, Dossier núm. 13: Archivo clandestino Comisiones en los Barrios.

544 Marcelo López Ródenas: Historia social de la Santa Coloma moderna..., p. 123. 
“Como V.E. bien sabe por otros informes remitidos por esta Alcaldia-Presidencia, es de lamentar que dicha manifestación y otras habidas en su día se inicien en las diferentes parroquias de ésta localidad, únicos lugares en los que hay capacidad suficiente para las reuniones que se vienen sucediendo con alta frecuencia.

Son los principales instigadores de estas reuniones los reverendos D. Juan Morán (Parroquia San Jaime), D. Jaime Cirach [sic] (Parroquia Fondo) y D. Salvador Cabré (Parroquia San Miguel)."545

El mateix Porta Bussoms admetia que no s'havia atrevit a fer cap mesura repressora per que aquestes reunions es feien a les parròquies i això comportava violar el concordat. No obstant, demanava si havia d'emprendre-les o deixar-les a instàncies governatives superiors. Reclamava urgentment la creació d'una comissaria de policia per una ciutat de més de 100.000 habitants mentre no es deia res de les imperioses necessitats sanitàries de la ciutat ${ }^{546}$. Estava prou clar quines eren les prioritats.

Aviat va aparèixer un segon full volant que continuava denunciant les mancances existents i recordava l'èxit de la recent manifestació, així com la possibilitat de noves mobilitzacions. També es feia ressò al manteniment de la unitat de la classe treballadora per aconseguir les reivindicacions proposades:

$$
\text { “iVOLVEREMOS OTRO DÍA!! }
$$

Hemos de seguir juntos porque este es el único método de que disponemos los trabajadores (no solo nosotros, los de Santa Coloma, sino los del resto de España) para que los que nos roban el dinero no tengan otra salida que ceder y volver a ceder, mientras nosotros continuamos avanzando, igual que el martes, paso a paso sin dejar que nos separen ni permitir que la guardia civil ni ningún elemento de la represión se nos lleve a ningún compañero." ${ }^{547}$

No es va detenir ningú el dia 23 de febrer, però uns dies després, repartint l'anterior full volant si que va ser detingut el militant dels GA Francisco Fernández

545Juan Porta Bussoms: [carta-informe al governador civil] (24-2-1971), AHGCB, Gobernadores Civiles, Caixa 184, Ayuntamiento de Santa Coloma de Gramanet 1967-1971, p. 1.

546Juan Porta Bussoms: [carta-informe al governador civil] (24-2-1971), AHGCB, Gobernadores Civiles, Caixa 184, Ayuntamiento de Santa Coloma de Gramanet 1967-1971, p. 1-2. Segons Porta els manifestants eren uns 350-450.

547Trabajadores de Santa Coloma: "Vecinos de Santa Coloma" [full volant, 2-1971], AHMTB, Donació Marcelo López Ródenas, Caixa 3, Dossier núm. 13. Archivo clandestino Comisiones en los Barrios. 
Heredia $^{548}$. Aquest fet va encrespar més els ànims, de manera que aviat apareixia un nou full volant denunciant aquesta detenció i convocant a una nova mobilització pel dimecres 10 de març:

"Por lo que llamamos a toda la población no sólo a hacer acto de presencia, sino que además ya desde ahora mismo vayamos comunicando y organizando a todos los vecinos, es decir, que cada uno de nosotros multiplique el número de asistentes.

Llamamos a todos los trabajadores, a las mujeres, y en especial a los que asististeis a la última manifestación para que seamos entre todos los organizadores en los barrios, calles y escaleras de las protestas y ahora de la marcha hacia la Plaza del Ayuntamiento.

POR: $\quad 1$ ASISTENCIA MEDICA INMEDIATA EN SANTA COLOMA

2 LÍNICA (RESIDENCIA) EN VEZ DE AMBULARORIO

$3^{\circ}$ LIBERTAD PARA EL DETENIDO

Todos el próximo miércoles dia 10 a las 8:30 de la tarde acudamos a la Plaza del Ayuntamiento

Trabajadores de Santa Coloma"

La manifestació va ser massiva, desbordant les previsions de les autoritats i, qui sap, si dels mateixos organitzadors. Aquests estimen la participació en unes 10.000 persones, que en diferents manifestacions procedents dels diferents barris, van confluir a la Plaça de la Vila de Santa Coloma ${ }^{550}$. La policia i la Guàrdia Civil es van veure totalment desbordades per l'elevat nombre de manifestants i pel fet, que quan van intentar reprimir-los, es van trobar que part dels manifestants no s'hi van arronsar i s'hi van enfrontar fent-los recular fins a les portes de l'Ajuntament, fins al punt que es van haver de demanar reforços a les comissaries i casernes de Badalona, La Verneda i Sant Andreu ${ }^{551}$. El mateix Alcalde Porta Bussoms admetia en un nou informe al Governador Civil que es van haver de fer "trets intimidatoris" amb armes de foc (que -per sort- no van provocar la mort de ningú) ${ }^{552}$.

548Marcelo López Ródenas: Historia social de la Santa Coloma moderna..., p. 124.

549Trabajadores de Santa Coloma: "Vecino de Santa Coloma" [full volant 8-3-1971)] AHMTB, Donació Marcelo López Ródenas, Caixa 3, Dossier núm. 13. Archivo clandestino Comisiones en los Barrios.

550Entrevista a Marcelo López Ródenas, 8-4-2013. Ell hi va participar personalment. Les seves paraules, citades a l'inici del present capítol a la nota 447 , son prou significatives.

551Carles Capdevila Llovera: “1971: la lluita per l'ambulatori” dins Grup d'Història José Berruezo: Una ciutat dormitori sota el franquisme..., p. 331.

552Juan Porta Bussoms: [carta-informe al Governador Civil] (11-3-1971), AHGCB, Gobernadores Civiles, Caixa 184, Ayuntamiento de Santa Coloma de Gramanet 1967-1971. Segons Porta els manifestants eren uns 2.000 . 
Posteriorment hi hagueren una trentena detencions ${ }^{553}$, si bé en la majoria dels casos van ser de persones que no tenien res a veure amb els esdeveniments anteriors $^{554}$. A 4 d'elles se'ls hi farà un Consell de Guerra ${ }^{555}$.

El Comitè Unitari va fer una reunió urgent de valoració. Van haver-hi discrepàncies sobre si convocar o no una tercera manifestació. Bandera Roja (organització també sorgida d'una escissió universitària del PSUC i que, a part de ser pionera en teoritzar sobre els moviments als barris tenia una important implantació a la veïna Barcelona) defensava que calia fer-ho mentre que els altres col-lectius apostaven per concentrar-se en la solidaritat amb els detinguts i en deixar passar uns dies -sense excloure futures mesures de força-. Es van fer difusió dels fets amb una nova fulla informativa ${ }^{556}$. Alhora les parròquies de Santa Coloma es posicionaven amb un comunicat de suport a les mobilitzacions i molt crític amb la repressió policial ${ }^{557}$. Però la tensió dintre del Comitè Unitari va esclatar quan es va descobrir que militants de Bandera Roja vinguts de Barcelona -contradient el que s'havia acordat al Comitè Unitari- repartien fulls volants convocant a una tercera manifestació pel dia 24 de març, signats com “Trabajadores de Santa Coloma"558. Els integrants de BR van ser expulsats del Comitè Unitari i aquesta actitud va ser durament criticada en un document posterior que van elaborar els

553Juan Porta Bussoms: "Relación de detenidos con motivo de la manifestación efectuada en el dia de ayer" [documentació adjuntada a la carta-informe al governador civil esmentat a la nota anterior] (11-3-1971), AHGCB, Gobernadores Civiles, Caixa 184, Ayuntamiento de Santa Coloma de Gramanet 1967-1971. En total van haver-hi 34 detinguts pels fets de febrer-març de 1971.

554Entrevista a Marcelo López Ródenas, 8-4-2013. Textualment em va dir: "No detuvieron ni a uno que hubiese participado en la movida".

555Carles Capdevila Llovera: “1971: la lluita per l'ambulatori” dins Grup d'Història José Berruezo: Una ciutat dormitori sota el franquisme..., p. 330. Els quatre colomencs sotmesos al Consell de Guerra del 16-12-1972 van ser Esteban Guerra, Diego Poyatos, Antonio Morales i Francisco Casas. Només aquest darrer va ser condemnat a 6 mesos de presó que ja havia acomplert. Es pot consultar l'escrit de l'advocat Antonio Martín Martín, defensor de un dels detinguts -Diego Poyatos Garcia- sotmès al Consell de Guerra a AHMTB, Donació Marcelo López Ródenas, Caixa 3, Dossier 13: Archivo Clandestino Comisiones de los Barrios. Hi ha també un article publicat a la revista Grama núm. 49 (gener 1973) al respecte: "Por los hechos del ambulatorio. Consejo de Guerra contra cuatro colomenses", p. 21.

556Trabajadores de Santa Coloma: "Vecinos de Santa Coloma" [3-71], AHMTB, Donació Marcelo López Ródenas, Caixa 3, Dossier 13: Archivo Clandestino Comisiones de los Barrios.

557 Los Sacerdotes de Santa Coloma de Gramanet: "Reflexión cristiana a raiz de unos hechos" (març de 1971), AHGCB, Gobernadores Civiles. Caixa 189. Notas sobre situación político-social de Cataluña 1969-1973.

558Trabajadores de Santa Coloma [en realitat es tractava de Bandera Roja i no del Comitè Unitari]: "Vecinos de Santa Coloma" [20-3-1971]. Una segona fulla va aparèixer el dia 22 de març signada també com a "Trabajadores de Santa Coloma" on s'exigia la dimissió de l'Alcalde Pablo Porta i tornava a convocar a la manifestació pel dia 24. AHMTB, Donació Marcelo López Ródenas, Caixa 3, Dossier 13: Archivo Clandestino Comisiones de los Barrios. 
GOA colomencs d'anàlisi de tot el conflicte:

"Lo que no necesitamos es que vengan de fuera grupitos como Bandera Roja a decirnos lo que hemos de hacer, lo que es realmente necesario es QUE CADA POBLACIÓN OBRERA SE CONVIERTA EN UN FOCO DE LUCHA CONTRA LA EXPLOTACIÓN CAPITALISTA" ${ }^{\prime 59}$

El 24 de març la ciutat de Santa Coloma va ser ocupada policialment, amb efectius vinguts fins i tot d'altres províncies. Llevat d'algunes corredisses tindran poca feina per que la convocatòria no va ser gaire secundada per la població (les organitzacions de base local no l'havien convocada i no van fer-ne agitació al respecte). Paral-lelament el mateix mes de març la ja popular revista Grama reproduïa un article d'un col-laborador seu publicat al diari Tele/ Exprés del 20 de març on es recollien totes les mancances sanitàries de la ciutat ${ }^{560}$.

A aquestes accions va seguir una frenètica activitat de l'ajuntament per demostrar que aviat es construiria un ambulatori. El 5 d'abril s'afanyaven a inaugurar un de provisional -que continuava sent insuficient, com denunciava un full volant aparegut al maig ${ }^{561}$ - i prometien tenir el definitiu en 6 mesos. Es més, aquest conflicte va ser fet servir fins i tot en les lluites internes de les camarilles franquistes per desprestigiar a Juan Porta Bussoms ${ }^{562}$

Finalment una clínica-ambulatori va ser inaugurada el 13 d'abril de 1972 amb la presència de totes les autoritats. Però malgrat això, per a gran part de la població colomenca i del Barcelonès Nord dos fets havien quedat de manifest: que

559Grupos Obreros Autónomos de Barrio (Santa Coloma de Gramanet) [abril de 1971]: "La lucha de Santa Coloma", AHMTB, Donació Marcelo López Ródenas, Caixa 3, Dossier 13: Archivo Clandestino Comisiones de los Barrios.

560Javier Caño Tamayo: "Historia de una falta de asistencia”, Grama núm. 27 (març 1971), p. 7 i 8.

561Trabajadores de Santa Coloma (maig 1971): "Vecinos de Santa Coloma", AHMTB, Donació Marcelo López Ródenas, Caixa 3, Dossier 13: Archivo Clandestino Comisiones de los Barrios.

562 El mateix Porta Bussoms informava en una carta al governador civil Tomàs Pelayo Ros el 31 de juliol de 1971 d'un escrit contrari a la seva persona a la que acusava de casos de corrupció com nombrar Tinents d'Alcalde implicats en cobraments il-legals, de nombrar càrrecs de confiança a empleats de la seva pròpia empresa, a un regidor condemnat per un afer tèrbol i per una obscura permuta dels terrenys destinats a una escola a Almacenes Tarragona. S'esmenta també l'ús d'unes pistoles pertanyents a la Guàrdia de Franco Local en un atracament en Barcelona. Tot això fet des de una perspectiva franquista ja que el mateix autor desconegut de l'escrit s'atribueix el mèrit d'haver previngut al consistori de la força de l'oposició antifranquista. Porta refusa les acusacions que li fan o remet la responsabilitat a l'anterior equip, com el cas de la Guardia de Franco de la que arriba a dir que "era un atajo de pistoleros". Veure a [carta de l'Alcalde Juan Porta Bussoms a Tomas Pelayo Ros] (31-7-1971) i [document adjunt], AHGCB, Gobernadores Civiles. Caixa 184. Ayuntamiento de Santa Coloma de Gramanet 1967-1971. 
amb la lluita es podien aconseguir millores pel conjunt de la població i, no menys important, que les autoritats franquistes locals tenien por de la capacitat de mobilització que havia demostrat el poble.

\subsection{Centres Socials, Comissions de Barri, Associacions de Veïns i partits polítics. Tots alhora?}

Els anys posteriors a la lluita per la clínica-ambulatori de Santa Coloma de Gramenet van representar una explosió reivindicativa que aniria "in crescendo" fins a la mort del dictador. Però el que potser no és tan conegut és la diversitat de formes organitzatives que va tenir aquesta. Quan parlem de moviment veïnal tendim a pensar en Associacions de Veïns, que certament, amb la perspectiva, va ser la forma d'organització més reeixida i que més va perdurar. Però no va ser la única manera d'organitzar-se ni va ser la hegemònica en tot el període en tot el Barcelonès Nord, especialment a Santa Coloma. En aquest apartat parlo de les diferents formes d'organització que es van donar: les promogudes per entitats religioses, les impulsades pels diferents grups polítics i les més pròpiament veïnals -fent algun esment, entremig, de les que van intentar fomentar els poders polítics locals-. Tot això al Barcelonès Nord, integrat per tres ciutats similars, però també amb diferències, on veurem característiques comunes, més accentuades en una o altra d'elles en cada cas concret.

Ja havia fet esment del sorgiment dels Centres Socials creats sota l'aixopluc de Càritas o de les parròquies locals durant la dècada dels seixanta. En la primera meitat dels setanta aquests Centres tindran un nou impuls, sobretot per la afluència de gent jove, de militants de diverses formacions polítiques i per una major activitat reivindicativa d'aquells centres on va haver-hi una major politització.

La inexistència de llocs d'oci als barris de les grans ciutats del Barcelonès Nord -a excepció dels bars- juntament amb les activitats que es van intentar desenvolupar en aquests Centres van atreure a un gran nombre de joves i els hi va donar una vitalitat important. L'afluència de gent jove no va estar exempta de 
dificultats. Algunes de les activitats lúdiques que els joves feien van provocar fins $\mathrm{i}$ tot queixes de veïns com he pogut documentar al respecte per exemple l'any 1969 respecte el Centre Social Besòs ${ }^{563}$.

Les activitats que es desenvolupaven als Centres -especialment les d'oci "no polititzat" com els balls- també van atreure a un altre sector del jovent que va resultar potencialment "conflictiu". Diferents "bandes" juvenils d'aleshores com "Los Correas" (anomenats així per que portaven cinturons foradats amb monedes per colpejar amb ells, sent el grup més conegut i nombrós), "Los Pepitos", "Avecrem", "El Pincho", "El Piloto" (per nombrar algunes de les més conegudes a l'àrea) solien freqüentar-los buscant diversió i gresca. S'ha de tenir present el context de marginació social existent en determinats barris que fomentarà la seva proliferació ja en aquesta època, fet que encara anirà a més quan es facin sentir els primers efectes de la crisi econòmica dels 70. Amb notables semblances amb el discurs actual, des de les autoritats en comptes d'analitzar la problemàtica social que afavoria la seva proliferació, s'exigia mà dura i s'estigmatitzava la seva imatge, si bé aleshores les referències a les procedències geogràfiques dels implicats eren menys comuns a les que es solen fer en l'actualitat amb una clara intencionalitat xenòfoba. Un exemple ho podem veure en la revista Gramanet, publicada per l'Ajuntament:

\footnotetext{
"Desde hace meses, venimos observando una serie de jóvenes cuyo aspecto no puede pasar inadvertido para nuestra siempre inquieta ciudad. Los vemos vagando a todas horas sin un lugar propio para calmar sus ideas de inadaptados o incomprendidos. Es difícil catalogar el grado de parásitos al que pertenecen y más difícil todavía es conocer la meta que se han trazado; si es que en su argot existe una definición capaz de esclarecer las aspiraciones a las que todos los humanos tenemos derecho..." ${ }^{\prime 54}$
}

Certament, des dels mateixos Centres Socials, l'apostolat obrer i les organitzacions d'esquerres, ni es va ignorar el tema ni es va fer servir el mateix llenguatge, com ho demostren les següents paraules d'un article pioner en tractar

563 Hi ha un conjunt de documentació al respecte a ASAB, Fons 101 Ajuntament, Caixa 369, Carpeta 43, Expediente "Escrito del Gobierno Civil, interesando informe con relación a molestias producidas por jóvenes que acuden a un Centro Social instalado en c/ Dr. Fleming no 1". Curiosament hi han queixes de l'any 1969 i també de l'any 1977.

564Gramanet (1-8-1972), p. 8. Citat a Marcelo López Ródenas: Historia Social de la Santa Coloma moderna..., p. 145. 
el tema de la delinqüència:

"La ciencia, por su parte, está intentado probar que el delincuente es un enfermo mental, que delinque porque no está sano del cerebro. Pero aunque podamos admitir un cierto número de delincuentes que estuvieran locos (como el "estrangulador de Boston" y similares), no deja de ser muy cómodo considerar a todo delincuente como enfermo mental. Mas bien habrá que admitir que el posible desequilibrio y actuación de los delincuentes son, a su vez, consecuencia de los condicionamientos sociales que les ha tocado vivir. En todo caso si se llegara a probar que toda actividad delictiva es fruto de la enfermedad mental entonces lo correcto seria enviar los delincuentes al hospital psiquiátrico y no a la cárcel.

No pretendo afirmar, sin embargo, que solo las circunstancias de la vida de los delincuentes son las que le llevan a delinquir, pero hay que dejar muy claro que esas circunstancias, esos condicionamientos sociales influyen considerablemente en la creación de delincuentes." ${ }^{565}$.

Es van fer intents de conciliació amb els membres d'aquestes bandes com els que des de el Fondo va promoure J. P. Sayrach o fins i tot des de el Centre Social de Santa Rosa, on es va intentar ensenyar a llegir i a escriure a Lorenzo Martínez Hidalgo, el líder dels Correas més conegut com "el Chino"566. Fins i tot la revista Grama, molt sensibilitzada amb la problemàtica dels joves va recollir les seves opinions en un article titulat "Hablan "los Correas"”567. Però aquest fet no va impedir que els joves més polititzats, militants i veïns s'organitzessin per fer-los-hi front amb les seves mateixes armes quan fracassaven els intents de mediació i integració. El setembre de 1973, a la Plaça del Rellotge de Santa Coloma -coneguda popularment aleshores com la "Plaça roja"- la tensió arribà al màxim amb diversos enfrontaments violents entre Correas i joves del moviment popular de Fondo i de Sistrells. Aquests fets van continuar sent freqüents, encara que amb menor

565 Maria Victoria Aldama: “El delincuente común ¿malvado, enfermo o inadaptado?”, Grama núm. 41 (maig 1972), p. 6.

566 Marcelo López Ródenas: Historia social de la Santa Coloma moderna..., p. 146-147.

567Eugenio Madueño: “Hablan” los Correas"”, Grama núm. 54 (juny 1973), p. 10-11. Altres números i articles de la mateixa revista van continuar tractant de la delinqüència juvenil. J. $P$. Sayrach: "Los Correas todavia. No es problema de una banda, sino de toda la juventud. ¿Qué responsabilidad tenemos cada uno de nosotros?" i Mar Fontcuberta: "Dos solucciones para el delincuente juvenil: Carcel o reformatorio iiVaya soluciones!!", Grama núm. 57 (setembre 1973), p. 7-9. Una altra revista que va dedicar-hi gairebé un monogràfic va ser La Voz de Badalona, que titulava el seu número 76 (22 de setembre de 1973) “¿Por qué golpean los Correas?". 
intensitat, fins ben entrat l'any 1975 quan per exemple va haver-hi assalts als Centres Socials colomencs de Can Mariner i Arrabal-Santa Rosa. En aquest darrer es va produir un front enfrontament on els assaltants van ser repel-lits amb el resultat de fortes contusions ${ }^{568}$.

En tot cas, cal ressaltar la tasca que van fer els Centres Socials per oferir uns espais a la joventut diferents al clàssic oci consumista i que, sens dubte va servir per que els joves es conscienciessin de la seva situació, de la dels seus respectius barris i de les problemàtiques socio-polítiques del moment. Això es va fer, en especial, en aquells que eren regentats per sacerdots crítics que van destacar pel foment de la JOC. Es feien xerrades i activitats on s'analitzava la situació del barri, de la joventut, de diferents aspectes de la societat, analitzant-se el perquè de les injustícies que es trobaven. No serà estrany, aleshores, que els Centres Socials que desenvolupaven majors activitats no estrictament lúdiques fossin considerats un viver per la captació de militància per nombroses organitzacions polítiques antifranquistes.

La ciutat de Santa Coloma de Gramenet va ser la que va destacar en la proliferació d'aquest tipus d'entitats. El motiu va ser sens dubte la seva relació amb les noves parròquies de les quals havíem parlat -que els hi donaven aixopluc legalaixí com també per la participació de nombrosos militants de partits clandestins en aquests. Es va fer servir també la cobertura de Càritas Diocesana per aconseguir un estatus de legalitat per aquest tipus de centres. Els pioners van ser -ja ho hem ditl'Obra Social de Singuerlín, impulsada pel sacerdot Salvador Cabré i materialitzat l'any 1966, i el Centre Social Arrabal de Santa Rosa (impulsat per Mossèn Esquirol, que va elaborar els seus estatuts al 30 de gener de 1967 i va ser legalitzat pel bisbat al novembre de l'any posterior) ${ }^{569}$. L'orientació que es volia donar a aquests Centres es pot intuir mirant els seus Estatuts. Per posar uns exemples els elaborats l'any 1967 pel Centre Social de Santa Rosa deien:

“2. El Centro tiene por fin el Apostolado social y Caritativo para procurar la mejora

568Marcelo López Ródenas: Historia social de la Santa Coloma moderna..., p. 146-147.

569Ídem, p. 134-138. La primera Junta de l'Obra Social Singuerlín va estar formada pels veïns Fabià Torró, Mariano Bascones, Salvador Cabré, Francisco Sagrera i les assistentes socials Maria Dolores Segolá i Rosa Domènech. La primera Junta del Centre Social Arrabal de Santa Rosa estava formada per: President: Miguel Molina Reinoso; Vicepresident: Pedro Rudolfo Paredes; Tresorera: Maria Clara Suchet; Secretaria: Maria del Carmen Esteban. 
moral, material y cultural de todos sus vecinos mediante la acción común de los socios y el empleo de los medios legales a su alcance.

3. Se dedicará especial atención al estudio de las necesidades del barrio, elaborando y desarrollando un plan de acción específico para cada una de ellas. Inicialmente se establecen: servicio de ayuda cultural que montará una biblioteca popular y procurará organizar conferencias y clases especiales; ayuda sanitaria, que coordinará las posibilidades para casos urgentes, orientará para ingresos en clínicas y hospitales y fomentará la mutua responsabilidad de los vecinos; servicio de asistencia social; sección para la juventud, que fomentará las diversiones sanas y la orientación cultural y cívica; sección recreativa para actos sociales y colaboración con la Comisión de Fiestas del barrio. En general se fomentará todo lo que vaya siendo necesario para la vida del Centro, y se colaborará con las obras ya existentes en el barrio."570

\section{O els de l'Obra Social Singuerlín:}

“Art. 3. Tendrá por objeto fomentar el espíritu de justicia, de verdad y fraternidad, organizar toda clase de actividades en torno a esa finalidad."571

El fet que es cerqués l'aixopluc de Càritas Diocesana era degut a la seva protecció com paraigües protector davant unes autoritats sempre vigilants, i, evidentment, per que els promovien capellans. Però això a vegades provocava altres "conflictes", com per quan la mateixa Càritas es queixava de que l'esmentat Centre Arrabal-Santa Rosa es definís com "no exclusivament catòlic", a lo qual des de el Centre es contestava que com que no tots els veïns eren cristians volien remarcar que aquell era un espai obert a tots els veïns ${ }^{572}$.

Apart d'aquests dos centres pioners, posteriorment es van fundar a Santa Coloma els centres socials de Santa Rosa (no confondre amb el Centre Social Arrabal-Santa Rosa), l'anomenat "Amigos del Fondo" l'any 1972 ${ }^{573}$, i també els del

570 “Estatutos del Centro Social del Barrio de Santa Rosa de Santa Coloma de Gramenet" (30-11967), AHMTB, Donació Marcelo López Ródenas, Caixa 2, Carpeta Centro Social Arrabal- Santa Rosa, p. 2.

571 “Estatutos de la Obra Social del Singuerlín”, (19-1-1969), AHMTB, Donació Marcelo López Ródenas, Caixa 3, Dossier núm. 4.

572 Marcelo López Ródenas: Historia social de la Santa Coloma moderna..., p. 136.

573En la fundació d'aquest va tenir un paper destacat el sacerdot Jaume P. Sayrach que regentava la parròquia del barri, juntament amb persones provinents del GOA i que havien participat al Comitè Unitari i en la lluita per l'ambulatori. El centre s'inaugurà el mes de setembre de 1972 al carrer Beethoven. Encara avui en dia hi ha disputes sobre la "paternitat" del Centre Social Amics del Fondo entre Jaume P. Sayrach i membres dels antics GOA. El primer afirma que ell va ser l'impulsor, tant en l'entrevista que li vaig fer al 22-5-2013 com al seu llibre En el Fondo, publicat al 2001 per Fòrum-Grama. Els segons reivindicaven també el seu paper en la seva fundació 
Rio i Can Mariner ${ }^{574}$. A Badalona van existir els de Pomar i Sant Roc ${ }^{575}$, mentre a Sant Adrià va existir els del Camp de la Bota i, més conegut, el del Barri Besòs ${ }^{576}$. Si bé és cert que en molts d'aquests Centres Socials o Juvenils es van posar les bases per la creació de Comissions de Barri i, posteriorment, Associacions de Veïns, cal dir que que això depenia profundament del tarannà de la parròquia que els fomentava com de la participació en ell de militants de les forces polítiques clandestines. Per posar un exemple al barri colomenc de Santa Rosa va existir un Centre, iniciativa del primer mossèn del barri, Joan Mata, que va ser popularment conegut com "el Centro de los bailes"577. La substitució de Mata per un nou

(veure els testimonis d'antics membres dels GOA com Ángel Sody i Àngel Nogales a Carles Capdevila Llovera: "Els Grupos Obreros Autónomos (GOA)", a Grup d'Història José Berruezo: Una ciutat dormitori sota el franquisme..., p. 256). Malgrat les disputes que hi poguessin haver aleshores i en l'actualitat el fet es que ambdues visions van coincidir en el projecte de fer un local social pel barri i aquesta composició diversa es va veure en la seva Junta, composada per: José Maria Martí, J.P. Sayrach, Ángel Nogales, Salvador Bolancer, Ángel Sody, Sebastian Puig, Paco F. Heredia, Angélica Martínez, Jorge Navarro, Ana Saura, Emiliana Salinas, Salvadora Castaño i Roque Ruiz. Veure a Marcelo López Ródenas: Historia social de la Santa Coloma moderna..., p. 141 i Carles Capdevila Llovera: "Els Grupos Obreros Autónomos (GOA)” a Grup d'Història José Berruezo: Una ciutat dormitori sota el franquisme..., p. 256.

574Aquests van comptar amb el suport de Mn. Josep Catà, si bé sembla ser que van ser un grup de joves que abans havien format part d'un centre juvenil els que van donar contingut a aquests projectes. Tot i que desconec la seva data exacta de fundació, del primer (el del "Rio") en tinc constància com a mínim des de novembre de 1974 per l'aparició del primer número del seu butlletí Flumen (AHMTB, Donació Mn. Josep Catà, Caixa 9). Del segon també pel seu butlletí Mariné (AHMTB, Donació Marcelo López Ródenas, Caixa 1).

575Veure notes 448,449 i 451.

$576 \mathrm{El}$ primer va estar profundament lligat a l'obra i treball social que van desenvolupar escolapis com Antoni Botey i Josep Maria Montferrer i Celades. Vaig poder entrevistar al segon tot i que vam destinar més temps a parlar del barri de La Mina. Però per tenir més informació sobre el Camp de la Bota es pot consultar el llibre que va fer ell mateix: El Camp de la Bota. Un espai i una historia, Octaedro Editorial, Barcelona, 2012. A la p. 62 s'esmenta l'existència d'un Centre Social en l'esmentat barri de barraquistes des de 1965. També hi ha referències a aquest a Alfred Matas Pericé: Al Sud-oest del riu Besòs. Deu anys de vida en un barri barceloní, Editorial Pòrtic, Barcelona, 1970, p. 196-198. Pel que fa al Centre Social del Barri Besòs (Sant Adrià), va ser creat al 1967 i va comptar amb la participació de persones provinents d'un Centre juvenil que s'havia creat l'any anterior am el suport del sacerdot Alfred Matas i una assistenta social, Rosa Romeu (veure a la ja esmentada obra Al Sud-Oest del Riu Besòs..., p. 181-195). Aquest Centre va editar un butlletí anomenat El Besòs i ja s'havia convertit en un referent abans d'arribar als anys setanta.

577Malgrat l'existència d'un nucli de la JOC que es reunia als seus locals, el tarannà més conservador de Joan Mata va ser determinant. Alhora aquest es trobava agobiat pel nombrosos deutes contrets per haver hipotecat molts terrenys de l'església, "fruit d'un excessiu afany lucratiu", si fem cas de les afirmacions de Marcelo López Ródenas a Història social de la Santa Coloma moderna..., p. 138-139. L'autor insinua també alguna irregularitat econòmica comesa en el control dels seus comptes. La Junta de l'entitat aleshores estava formada pels germans Miguel i Rafael Güetos, Pedro Montilla, Antonio Cejas, Antonio Hernández, José Navarro, Antonio "el Patillas", Rafael López i Benjamín González. Finalment Mata va vendre el local que havia albergat el Centre Parroquial a una constructora que va pagar al Bisbat 3,9 milions de pessetes. A canvi va prometre un nou local pel Centre més petit, de $90 \mathrm{~m} 2$ que es construirà a principis de 1972 en l'Avinguda Banús Alta. 
sacerdot, José Sánchez Muñoz, ja als anys setanta va ser determinant pel canvi d'orientació del Centre, que va anar molt més enllà d'un simple canvi de local i ubicació $^{578}$.

Els Centres Socials van acabar esdevenint uns llocs importants i de referència en diferents barris del Barcelonès Nord. Per una banda, gràcies al paper que hi van jugar determinats sacerdots en donar-lis una orientació concreta per que no fossin només uns centres d'oci i prou. Aquestes activitats eren prou conegudes per la policia de l'època, com ens ho demostra el següent testimoni:
“Si, per que al Torrella lo tenían bien... Cuando detenían a alguno de Pomar lo hinchaban a palos. Había aquí un tal Chato que tenía un bulto aquí (...) El Comisario
(...) es veu que era una perla... Cada vegada que detenien a uno li deia '¿de donde eres?' 'de Pomar' '¡de Pomar! ¡Hasta el cura es comunista! ¡Las ganas que tengo yo de pillarlo!'”579

Per altra banda, aquests centres en la mesura que desenvolupaven activitats més subversives i tenien una notable afluència de gent jove, van propiciar un altre fenomen: l'interès dels diferents grups i organitzacions clandestines per ser-hi (si no havien estat, en alguns casos com el del Fondo, co-partíceps de la seva creació). Aquests espais eren considerants, per una banda, com una plataforma legal on poder fer arribar les orientacions, propostes i consignes d'organitzacions clandestines como alhora un lloc per fer proselitisme i captar militància jove. Això provocava enfrontaments i tensions entre alguns d'aquests grups polítics i els sacerdots que els regentaven com per exemple ens explicava en Jaume P. Sayrach respecte a l'OICE:

“Però aquí es deien Grupos de Barrio em sembla (...). I llavors jo com que ho havia fundat i anava a les reunions em presento allà i em diu el José Maria: 'No, no, tu no puedes entrar' dic 'i como no' diu 'no porque es de Grupos de Barrio', dic 'però si es mi barrio' 'no, no, no puedes entrar', i ara, que estrany... vaig preguntar a un dels meus

578Marcelo López Ródenas a Història social de la Santa Coloma moderna..., p.138-139. La nova Junta d'aquesta nova etapa estava formada per, entre d'altres: Salvador Bolancer, Manuel Capote Espada, Antonio Iglesias, Eusebio Hidalgo, Román Barrera, Ramón Bueno, Pedro Gómez, Mari Delgado, Marcelo López Ródenas i el mateix José Sánchez Muñoz. Aquest Centre també va acabar editant un butlletí propi amb el nom El Alba i tindrà uns anys de força vitalitat per la gent jove que se'n va fer càrrec. Veure també el testimoni de Salvador Bolancer Dugo a la nota 366.

579Entrevista a Fina Valverde, 14-6-2013. Membre de l'ACO i de la Comunitat Cristiana de Pomar (tot i que residia al veí barri badaloní de La Morera). 
amics i diu 'no, es que ara...' hi havia l'Eugeni i aquests, la Emiliana... diu ' es que això ara estem en una disciplina' dic 'ah!, es Grups de Barri però ja amb cometes (...). Llavors venia el Pájaro i quan havia de venir em venien aquests militants i em deien Jaume (...) 'Jaume, ve el Pájaro, amaga't'. I em feien amagar per que no el veiés amb ell!" 580

La presència i predomini d'uns determinats grups o d'altres als diferents Centres Socials variarà en funció de la ciutat o el barri. Així a Santa Coloma de Gramenet van tenir més pes grups llibertaris i de l'anomenada esquerra radical que a la resta del Barcelonès Nord. D'aquests darrers va destacar l'OICE i també fins i tot l'OCE(BR) tot i tenir una implantació menor ${ }^{581}$. En canvi, en les altres poblacions la correlació de forces estava més clarament decantada a favor del PSUC (la força hegemònica, no ho oblidem) i en alguns casos fins i tot es podien trobar persones socialistes, como era el cas del Centre Social de Pomar (Badalona):

"Aleshores (...) a través de Càritas es van fer aquests Centres Socials i era divertit per que en els Centres Socials de Càritas de l'església hi havien tots els comunistes, els socialistes, hi havien tots...

(...) Si home... aleshores hi havia el Pedro Rueda (...) que aquest era socialista, era dels del Llopis... [riu] Era dels diríem dels històrics. Després hi havia en Valentín, que aquest va ser diputat. Si... Valentín Antón, aquest va arribar a ser diputat en el Congrés... i aquest era socialista... Però aquest...

(...) Si, però en aquesta època diria jo que... per allà, hi havien els del PSUC (...) que hi havia un tal Celestino que después va ser del sector més del PCC... aleshores allà els veïns... Aquests eren una mica (...) eren molt populars però eren gent cultivada aquests dos... eren els clàssics dels socialistes però aleshores hi havia un grup del PSUC que eren gent molt de base, eh? I eren els que pencaven, eh? Els que pencaven..." ${ }^{282}$

580Entrevista amb Jaume P. Sayrach, 22-5-2013. El 'Pájaro' era en Dídac Fábregas, un dirigent de l'OICE molt conegut aleshores que era el màxim responsable del grup de Santa Coloma.

581Al febrer de 1976, en un context polític de grans mobilitzacions es va crear per exemple des de la secció jovenil de l'OCE(BR) una efímera Coordinadora de Joves de Santa Coloma formada pels Grups Juvenils dels Centres de Santa Rosa, Can Mariner, Raval, Singuerlín, de les AVV's del Centre i Riu i de l'Institut d'Ensenyament Secundari Puig Castellar. Veure Coordinadora de Jóvenes: Especial Fiestas [butlletí editat segurament a l'agost-setembre de 1976], AHMTB, Donació Marcelo López Ródenas, Caixa 1.

582Entrevista a Joan Cuadrench, 7-4-2013. Pedro Rueda, de tendència socialista va ser durant molts anys el President del Centre Social. A Pomar existia una cèl-lula del PSUC anomenada "Llibertat" des de feia uns quants anys. Diferents fulls volants trobats tant de CCOO com de l'esmentada cèl-lula del PSUC ho confirmen. Comisiones Obreras de Bdalona y Comarca: [Full volant sense títol i data] ANC, Fons PSUC, 06. Context social i polític del partit, 06.02. Moviment Obrer, 06.02.01. Organitzacions dels Treballadors, 1567, Comissions Obreres (CCO0) de Badalona i comarca; "Informe Asamblea" i “!!VECINOS DE POMAR!!” [fulls volants de 1972], 
En aquest cas concret el Centre Social es va convertir en l'espai de confluència d'aquelles persones que per la seva ideologia i sensibilitat estaven oposades a la Asociación de Cabezas de Família del barri, controlada per persones conservadores i franquistes. Aviat el Centre es va convertir en l'aglutinador de les reivindicacions d'un barri de l'OSH com era Pomar i alhora esdevenia un referent pel teixit associatiu $^{583}$. Va ser des d'aquest mateix Centre Social que es va impulsar l'Associació de Veïns de Pomar, fundada oficialment al 1972 però amb una dinàmica que ja venia d'abans. De fet, el mateix President del Centre Social va esdevenir uns anys després el President de l'Associació de Veïns ${ }^{584}$. És interessant veure les raons que donava Joan Cuadrench per aquest canvi, ja que apunta a una que no havia sortit fins ara, el paper de la mateixa Càritas Diocesana:

\begin{abstract}
"Quan va venir la democràcia, aleshores Càritas va dir 'home, aquests Centres Socials que nosaltres donàvem cobertura legal, ens assembla que ara hi ha llibertat i per tant demanem que doncs una mica, que es dissolguin com a Centres adherits a Càritas i en tot cas...' I vam ser que es va dissoldre i es va fer l'Associació de Veïns amb els mateixos que érem.
\end{abstract}

ANC, 03. Organitzacions de base, 03.01. Organitzacions territorials, 818 Badalona: Cèl·lula Libertad del PSUC (1972).

583Es van produir alguns casos de "trencament generacional" significatius al barri. Per exemple el mateix Joan Cuadrench ens va explicar com Manuel Hurtado era el President de la Asociación de Cabezas de Família, mentre que el seu fill, Antonio Hurtado, militava clandestinament en el PSUC i havia estat un dels principals impulsors del Centre Juvenil, sent posteriorment regidor. La creació del Centre Social de Pomar no va ser vista amb bons ulls per les autoritats com ho posa de manifest una carta del 28 d'abril de l'Alcalde Felipe Antoja al Procurador en Cortes Eduardo Tarragona que feia referència al Centre Social, el qual ja li havia adreçat un llistat de reivindicacions del barri. El comentari d'Antoja al Procurador és revelador: "Ja els hi vaig indicar que és millor que s'inscriguin com afiliats a l'Asociación de Cabezas de Família, on podrien manifestar les seves necessitats i les inquietuds pels cursos legals i perfectament establerts".", Carles Mas: El Pomar (Badalona)..., p. 95-96. En la fundació del Centre Social de Pomar havia tingut també important l'Assistenta Social del barri, Carme Ribas, que va redactar els seus Estatuts amb el suport d'un veí, Florenci Ortovas (veure El Pomar (Badalona)..., p. 96-97). Però apart d'existir un grup de la JOC al barri, des de el Centre es va impulsar també l'anomenat "Moviment Infantil de Pomar" (PIM), un Centre Juvenil, un Grup de Dones i membres del Centre van fer fins i tot una cooperativa de consum anomenada significativament "Convivència Obrera" (sense esmentar el paper de la revista del Centre, Pomar Convivència). Així ens ho va explicar en respectives entrevistes tant Joan Cuadrench, 7-4-2013 i Antonio Jurado, 14-6-2013. Aquest darrer vivia al barri de La Morera, pròxim a Pomar i va esdevenir un membre d'un grup de Cristians de Base arran les seves visites a l'Església i al Centre on hi participava la seva dona Fina Valverde, membre de l'ACO i de la Comunitat Cristiana de Pomar. Jurado va ser membre de l'esmentada cooperativa, de la CNT i posteriorment de l'AVV de La Morera.

584El primer President va ser Antonio López Molina. Veure Carles Mas: El Pomar (Badalona)..., p. 102-103. Però posteriorment segon Juan Cuadrench -entrevistat el 7-4-2013- va ser-ho Pedro Rueda, que ja havia estat President del Centre Social. 


\section{(...)}

Però jo això ho recordo perfectament, no se si va ser en aquest moment o no... o ja en democràcia... que Cáritas va dir 'bueno... la Llei permet, por lo tant, millor que ja...' I vam fer... es va fer una reconversió. Els mateixos que estaven en el Centre Social de la parròquia ja van passar com Associació de Veïns i es reunien a la parròquia." 585

El canvi no deuria ser immediat, però és possible que després de 1975-1977 Càritas volgués desentendre's d'aquests Centres Socials que mai va arribar a controlar totalment i que havien fet servir el seu nom com a façana ${ }^{586}$. Però aquest procés de transformació dels Centres Socials en Associacions de Veïns havia començat molt abans.

Un altre exemple d'aquest fet el podem trobar al Barri Besòs de Sant Adrià on el Centre Social, que també havia encapçalat les reivindicacions del barri, va acabar cedint el protagonisme a una Associació de Veïns tot i que al començament va haver-hi reticències entre totes dues entitats, segurament per la major presència de llibertaris i partits de l'esquerra radical al Centre i del PSUC en l'AVV ${ }^{587}$. Però va ser precisament una de les persones que havia ajudat a la creació del Centre Social anys enrere qui va jugar un paper important en l'entesa de les dues entitats:

“ La Rosa Romeu va fer unes gestions per domiciliar ... [la seu de l'AVV al Centre Social] Jo crec que va ser una doble jugada aquella (...) que la Rosa Romeu estava posada també en el Centre Social. I una manera de [inintel-ligible] el Centre Social era l'Associació de Veïns. En els quals els veïns que anàvem a formar part de l'Associació eren gent que no teníem ni idea de política (...) Potser les persones que tenien ja una mica més de certa consciència feien reunions fora (...) de l'associació. Jo vaig ser la primera Secretària de l'Associació i el primer President va ser aquest senyor, l'Àngel Pardo, bona persona." ${ }^{588}$

585Entrevista amb Joan Cuadrench, 7-4-2013.

586Per les mateixes dates, al 1977 un grup de joves provinents del Centre Juvenil de Pomar impulsaven una nova entitat: l'Ateneu Popular de Pomar. Veure Carles Mas: El Pomar (Badalona)..., p. 98.

587Entrevista a Maria Codina i Cabré, 5-4-2012. Va ser membre de l'AVV i militant del PSUC, regidora a l'Ajuntament de Sant Adrià de Besòs i posteriorment del PCC.

588Entrevista a Maria Codina i Cabré, 5-4-2012. Segurament aquest fet va ser una jugada seva per intentar fer partícep de les reivindicacions veïnals a un sector de gent que escapava de l'estereotip de joves que hi havia al Centre Social, molt polititzats, i alhora fer-los treballar conjuntament. El fet de domiciliar l'AVV al mateix lloc que el Centre Social no devia ser casual. Tot així, segons la mateixa entrevistada les tensions van continuar durant un cert temps, sobretot quan a partir de l'any 1973-74 hi van entrar més gent del PSUC. Durant un temps el Centre Social va continuar existint i sent el referent. Per exemple el seu President, Pedro Rudolfo Paredes enviava una instància dirigida a l'Ajuntament on es recollien les principals 
El procés de creació de Comissions de Barri i d'Associacions de Veïns partit de Centres Socials es va donar també en altres indrets del Barcelonès Nord, com van ser el barri colomenc del Fondo, el Raval, Santa Rosa i Singuerlín ${ }^{589}$. Tot i que la creació d'una AVV no implicava la desaparició instantània del Centre, el cert és que aquests van acabar perdent el seu paper en la mesura que les seves funcions eren assumides per les AVV's en la segona meitat dels setanta o per la marxa -per desenvolupar altres iniciatives o pel desencís- dels joves. Per exemple el Centre Social Arrabal-Santa Rosa (Santa Coloma) tancava el juny de 1977, mentre que una assemblea general de socis de la també colomenca Obra Social del Singuerlín es plantejava, l'any 1979, quines havien de ser les seves perspectives de futur, si cedir tot el local per ampliar l'escola bressol que ja funcionava en una de les seves plantes o si re-impulsar el Centre Juvenil ${ }^{590}$. Només va haver-hi un cas en el Barcelonès Nord on un Centre Social va continuar esdevenint un referent per sobre de l'Associació de Veïns, exemple que també ens serveix per explicar quines van ser les darreres maniobres de l'administració local per intentar no perdre totalment el control. Em refereixo al Centre Social de Sant Roc.

Aquest Centre inicialment s'havia centrat en activitats culturals i d'entreteniment a la joventut per iniciativa del rector de la parròquia del barri, Mn. Amadeu Bassols, que no era precisament un "sacerdot obrer" però si que tenia una certa sensibilitat (el podríem comparar amb el cas de Joan Mata al barri colomenc de Santa Rosa) ${ }^{591}$. Però als anys setanta, el Centre va començar a adquirir un prestigi i protagonisme notori, en especial a través de la seva Vocalia d'habitatge creada l'any $1971^{592}$. Es més, la línia portada a partir d'aquell moment va anar molt

mancances i deficiències del barri en un annex: [instància presentada a l'Ajuntament de Sant Adrià de Besòs recollint les mancances i deficiències del barri, amb signatures] (15-2-1973), ASAB, Fons 101 Ajuntament, Caixa 388. Desconec la data exacta de la desaparició del Centre Social, però el cert és que a partir de 1974 va ser l'Associació de Veïns Besòs-Sant Adrià la que va anar agafant progressivament el protagonisme en les reivindicacions del barri.

589 Marcelo López Ródenas: Història Social de la Santa Coloma moderna..., p. 137-138.

590 [Document convocant l'Assemblea General de Socis] (2-2-1979), AHMTB, Donació Mn. Josep Catà, Caixa 9.

591Segons Juan Jesús Guerrero, entrevistat el 14-6-2013, Amadeu Bassols era un capellà ben connectat amb l'alta burgesia catalana. Havia estat a sud-amèrica i en Sant Roc va impulsar algunes millores com el mateix Centre Social, un Casal i un Centre de Salut al voltant de la parròquia aprofitant les donacions caritatives que recollia.

592Felipe Guerrero: Sant Roc, 25 anys de lluita, Ateneu Popular de Sant Roc, 1991, p. 5 i Joan Tudela: Sant Roc, Badalona (Els Barris d'Adigsa, 37), Generalitat de Catalunya, Departament de Benestar 
més enllà de la caritat, apostant clarament per la justícia social. Va ser el Centre Social, a partir d'aquesta Vocalia, el que va encapçalar les lluites tant per la millora dels habitatges com per la urbanització d'un barri (també de l'OSH) i de la seva dotació de serveis, esdevenint un referent. La Asociación de Cabezas de Familia era vista com una entitat afí als governants franquistes i, a diferència d'altres barris del Barcelonès Nord, l'Associació de Veïns que es va crear al 1976 va estar fomentada per les autoritats locals:

"Mi distinguido amigo y respetado Gobernador:

Te dirijo la presente a fin de rogarte, dada tu probada amabilidad e interés por todos los asuntos que afectan a esta Alcaldía, que pudiera ser autorizada, a la mayor brevedad posible, la Asociación de Vecinos del sector de San Roque, cuyos Estatutos tuvieron entrada en ese Gobierno Civil el 17 de febrero pasado, y a los cuales esta Alcaldía ha cursado un informe favorable.

El motivo de mi interés por la expresada Asociación es el que precisamente la misma se ha promovido a solicitud mía, en un sector muy conflictivo socialmente y con el fin de contrarrestar o atenuar las actividades y aspiraciones de otra Asociación denominada "Centro Social San Roque", radicada en el mismo sector y de ideología muy avanzada." ${ }^{\prime 53}$

Aquesta línia del Centre Social es va veure en un altre episodi com va ser la crítica que es va fer a la construcció d'un Port Esportiu a la ciutat de Badalona. El Centre Social de seguida es va posicionar en contra l'any 1975 ${ }^{594}$, però posteriorment el seu President Francisco Lleal va posicionar-se a favor conjuntament amb el regidor delegat del barri, el Sr. Casado, fet que li va comportar una dura crítica dels seus companys ${ }^{595}$, i la seva posterior dimissió. Va ser Lleal, sota les ordres de Caballeria el que va voler impulsar aquesta nova Associació en contra dels seus antics companys. Anys després incitava als seus veïns a "aixecar-se

Social, 1995, p. 37.

593Isidro Caballeria Pla [alcalde de Badalona aleshores]: [Carta al gobernador civil Salvador Sánchez Teran] (10-7-1976), AHGCB, Gobernadores Civiles, Caixa 357, Ayuntamiento de de Badalona, 1976-1978.

594 "La del Centro Social de San Roque en Badalona. Otra voz en contra el puerto deportivo.", Mundo Diario, 12-2-1975.

595 “En torno al Puerto deportivo. San Roque pide explicaciones a su concejal”, Mundo Diario, 20-41975. Tinc dubtes si el Sr. Juan Casado Reverté era realment el regidor delegat del barri com afirma la notícia (era un regidor procedent del Tercio Sindical), i no Fulgencio Conesa, que ho era de tot el Districte 9. 
contra el Centro Social i contra un tal José Maria Mateu Zamora"596. Pel que es veu, tant en Lleal com el Mateu tenien unes disputes personals que anaven més enllà de qüestions polítiques. Aquests fets, entre d'altres, van impedir la confluència en una AVV potent ${ }^{597}$.

La població de Sant Roc tenia més confiança en el Centre Social que no en una Associació de Veïns que s'havia vist massa vinculada al poder local i amb interessos no gens clars per part dels seus dirigents. Aquests fets es van donar en paral-lel al procés de canvi polític del qual parlaré amb més detall posteriorment. Però veient aquests esdeveniments no es d'estranyar aleshores que quan es va aconseguir -després de nombroses lluites- que el Consell de Ministres aprovés un projecte de reforma integral de tot el barri el 2 de març de 1978, els veïns, en una assemblea multitudinària feta al col-legi l'Estonnac, confiessin el control de les obres a la Vocalia d'habitatge del Centre Social i no a l'Associació de Veïns ${ }^{598}$. Aquest era el context polític on van aparèixer aquestes disputes anteriorment esmentades. Lleal, com a President de l'AVV de Sant Roc, no volia que els seus antics companys exercissin el control sobre les obres de remodelació i intentava -sense èxitatribuir-se els mèrits de l'obtenció d'aquest projecte de reforma. El "problema" era que el Centre Social s'havia guanyat un prestigi impulsant les reivindicacions del barri durant els anys anteriors i l'Associació de Veïns no.

Dins el Centre Social de Sant Roc, al igual que en d'altres es va reproduir la presència de diferents sectors ideològics en considerar-lo un espai important d'actuació. Tot i que, sembla ser que es va preservar una línia independent no subordinada a cap organització:

"Participava tot tipus de gent. Era un Centre en que volíem, com era ja te dic una mica protegit, i mai jo des de que estic aquí mai es va mirar la ideologia. Des de persones de l'església, des de persones de moviments... l'MC, de persones que estaven... Bandera Roja també estaven molt ficats per aquí... Els socialistes havien pocs, com a partit. Havien persones que si que van estar però... I eren persones de barri, persones significatives del barri, o persones lluitadores del barri. Però sense una ideologia dominant. Ja dic, era molt variat. La idea que teníem, que tenim i que sempre hem

596El Besós núm. 6 (5-9-1978): “Asociación de Vecinos Barrio San Roque”, p. 10. Es tracta de la transcripció literal d'un escrit de Francisco Lleal.

597Entrevista a Entrevista a Juan Jesús Guerrero, 14-6-2013. Ell mateix ens comentava que el tal José Maria Mateu havia militat durant un temps a Bandera Roja i al MC. 598Felipe Guerrero: Sant Roc, 25 anys de lluita, p. 19. 
tingut es de fer una política de barri, no una política de partit. La política de partit es fa a la seu del partit. I aquí es venia a fer una política de barri." ${ }^{599}$

Als anys setanta, el Centre Social Sant Roc va ser el que va canalitzar les reivindicacions més esteses al barri i això va ser el que el va convertir en un referent. No està de més recordar que va ser la Vocalia d'Habitatge del Centre la que va fer el llistat i anàlisi de les grans deficiències del barri i els seus habitatges (i de les morts que això havia provocat), el que enviava les reclamacions a les instàncies governamentals i el que impulsava les mobilitzacions ${ }^{600}$. La diferència 0 peculiaritat d'aquest Centre es que no va desaparèixer -com tants altres- sinó que es va reconvertir en una altra entitat anomenada Ateneu Popular de Sant Roc que encara existeix en l'actualitat, dedicada més al món del lleure i l'educació de població amb risc d'exclusió social, però que encara conserva un esperit reivindicatiu i un prestigi notable. En canvi, l'Associació de Veïns va tenir -i té encara avui- "l'estigma" de ser una entitat massa servil amb els interessos del poder polític institucional local.

Però abans de parlar de les Associacions de Veïns que van aparèixer -o reconvertir-se- a la primera meitat dels anys 70, cal que tinguem en compte un altre tipus d'entitat que va coexistir amb Centres Socials i Associacions durant un cert temps, sobretot a la ciutat de Santa Coloma (tot i no ser exclusives d'aquesta ciutat). M'estic referint al les denominades Comissions de Barri que van tenir un protagonisme notable entre els anys 1971-1977.

Cal aclarir primer uns conceptes. Primer, que sota el terme de "Comissions de Barri" es podien incloure tota una serie de tipologies, tal com afirmava el Plan Barrio de l'any 1973:

599Entrevista a Entrevista a Juan Jesús Guerrero, 14-6-2013.

600 Felipe Guerrero: Sant Roc, 25 anys de lluita... Enumero algunes reclamacions que es van fer i que consten al treball mencionat. Una carta del 22 d'octubre de 1971 adreçada al President de la Comissió d'Urbanisme de Barcelona reclamava la reparació dels fanals instal-lats que ràpidament havien deixat de funcionar (p. 6); Una altra carta adreçada al Director Provincial de l'OSH de Barcelona el 15 de febrer de 1976 denunciava la pèssima situació general del barri, la responsabilitat de l'OSH a la qual s'acusava de fer només "un lavado de cara" $\mathrm{i}$ haver provocat diverses morts, exigint reparacions controlades directament pels veïns (p. 7-8); un altre escrit adreçat al Delegat Provincial del Ministerio de la Vivienda el 30 de juny de 1976 tornava a recordar totes les anomalies dels pisos i del barri en general (p. 8-10). El desembre de 1977 es va fer una enquesta als veïns on es recollien els nombrosos defectes i desperfectes existents en els habitatges (p. 12-13). 
"Se adopta el nombre genérico de Comisiones de Barrio (CC. B.) para designar aquellas organizaciones que con distintos nombres (Asociaciones de Vecinos, Comisiones Populares, Grupos de Barrio, Plataformas de Barrio...), han aparecido con la finalidad aparente o real de solucionar los problemas existentes en los barrios." ${ }^{601}$

Com podem veure, en aquest cas es feia servir un nom per simplificar. Però hem d'especificar què van ser les Comissions de Barri de Santa Coloma i què les va fer diferents, ja que aquest nom ja es va fer servir a la ciutat de Barcelona a partir de l'any 1970 i on va arribar a existir una Coordinadora de Barris al setembre de 1971 i una Coordinadora de Comissions de Barri al gener de $1972^{602}$. Sobre aquesta qüestió, Iván Bordetas ens recordava a la seva Tesi Doctoral que:

"La tercera forma organizativa surgida de la experiencia de las CCOO fueron las Comisiones de Barrio (CB), que compartieron con las anteriores esta función de articulación de un discurso identitario y favorable a la acción colectiva, pero que tienen, según la historiografía consultada, un papel fundamental en el nacimiento del movimiento vecinal, especialmente en el área de Barcelona." ${ }^{603}$

Llavors que va fer peculiars a les Comissions de Barri colomenques? Sens dubte, la seva força, la seva durada en el temps, la seva ideologia profundament revolucionaria, apart de la seva heterogènia composició:

“También se afirma su importancia en las poblaciones del área metropolitana de Barcelona que tuvieron recorridos que, aunque similares con Barcelona, guardaron especificidades propias como en el caso de Santa Coloma con unas CB de largo recorrido y muy heterogéneas -desde gente vinculada al mundo católico de las parroquias y Centros Sociales de barrio hasta miembros de distintos partidos de la izquierda antifranquista y de grupos de la autonomía obrera y próximos al mundo libertario-“ ${ }^{404}$

Sens dubte no es pot entendre l'eclosió de les Comissions de Barri a Santa

601"Plan Barrio. Madrid, Octubre 1973", AGA, Fons Cultura. Fons Gabinete de Enlace del Ministerio de Información y Turismo, Caixa 42/08906, Dossier 7 sobre Comités de Barrio.

602 Ídem. El mateix informe en parlava del seu creixement exponencial, sent la ciutat de Barcelona la més destacada en aquest aspecte en tot l'Estat espanyol.

603 Iván Bordetas Jiménez: Nosotros somos los que hemos hecho esta ciudad. Autoorganización y movilización vecinal durante el tardofranquismo y el proceso de cambio político, Tesi Doctoral dirigida per Martí Marín i Corbera i Pere Ysàs Solanés. UAB, Juliol 2012, p. 358. 604 Ídem, p. 360. 
Coloma de Gramenet sense l'experiència del Comitè Unitari forjat en la lluita per la clínica-ambulatori d'inicis de 1971. Totes les experiències i tota la conscienciació que havien culminat en aquesta gran mobilització no podien quedar en el no-res:

"Si, después de lo del ambulatorio, la CUT se disuelve porque ya... y se crea en cada zona, grupos que se les denomina Comisiones de Barrio, de lluita en barris. Y pasan por muchas circunstancias, unos que creen en ellas, otros que quieren que sean vehículo del partit, con el permiso del partit... "605

Així ja el mateix 1971, coincidint amb l'esmentat conflicte ja s'havia donat un cas pioner al barri del Raval, on ja s'havia fet una primera Comissió integrada per membres de CCOO, el PSUC, Bandera Roja, membres de la JOC i persones independents ${ }^{606}$. Aquest tipus d'organització amb voluntat d'incidència en la lluita popular però també de clandestinitat va ser seguit ràpidament en altres barris colomencs durant els anys 1972-1973. D'aquesta manera van existir Comissions de Barri (d'ara en endavant CCBB) en un primer moment als barris de Santa Rosa, Arrabal, Singuerlín i més tard també al Fondo, al Centre i a Les Oliveres ${ }^{607}$, arribant pràcticament a existir en tots els indrets de Santa Coloma com ens ho demostra també l'existència de documents d'aquestes Comissions a Can Mariné i Riu Nord ${ }^{608}$.

En aquestes Comissions de Barri van participar inicialment persones procedents de diferents organitzacions polítiques però a Santa Coloma van tenir un pes molt important persones sense carnet de partit que havien estat als GOA, a la JOC, llibertaris...

"Porque si bien desde un principio son potenciadas por grupos políticos (PSUC, MCE,

BR) de carácter antifascista, es cierto que estos no suelen tener un peso específico en su posterior consolidación. En Singuerlín, Fondo, Santa Rosa, Centro y Las Oliveras existirá una militancia generalmente independiente y del área anticapitalista." ${ }^{609}$

605Entrevista a Marcelo López Ródenas, 9-4-2013. En les seves paraules s'entrevé ja el que serà les disputes de les diferents organitzacions polítiques dintre de les Comissions de Barri.

606Marcelo López Ródenas: Historia social de la Santa Coloma moderna..., p. 149.

607Ídem, p. 148.

608Com es pot veure a AHMTB, Donació Marcelo López Ródenas, Caixa 3, Dossier 5 “Debats Interns CC.BB.".

609Marcelo López Ródenas: Historia social de la Santa Coloma moderna..., p. 149. Cal dir que aquí l'autor fa servir el concepte "anticapitalista" d'una manera restringida i aplicada a uns grups concrets (llibertaris, OICE...). Per que aleshores ni el MCE, ni BR ni el PSUC mateix es declaraven partidaris al capitalisme. 
L'interès dels diferents grups polítics per impulsar algun tipus d'organització als barris és evident, Això contrasta amb la dècada anterior on es prioritzava el moviment sindical. Ara, sense oblidar les lluites obreres, evidentment, la lluita popular als barris es comença a situar al mateix nivell. Un document del Comitè Local del PSUC de Santa Coloma de Gramenet de l'any 1972 ens evidencia aquest procés, ja que si bé continuava afirmant la necessitat d'impulsar la lluita obrera a la comarca i la creació d'una Comissió Obrera de Barri també deia que:

\begin{abstract}
"En Santa Coloma es muy importante, imprescindible, desarrollar un potente movimiento popular de barrios organizado. La combatividad de los vecinos de Santa Coloma ha quedado demostrada en varias ocasiones de las que las más destacables son la lucha por la asistencia médica, la acción por los semáforos en el Arrabal y la lucha por los vecinos de las Oliveras por conseguir la renta limitada para sus viviendas contra la empresa constructora que los ha estafado. La no existencia de un potente movimiento de masas de barrio se debe a la falta de auténticas organizaciones de masas; las actuales Comisiones de Barrio no son tales; son grupos pseudopolíticos, cerrados, clandestinizantes, superpolitizados y alejados de la problemática concreta de los vecinos y, desde luego, incapaces de aportar soluciones a esos problemas. Una estéril postura anti-Partido aún las hace más ineficaces.

Los únicos intentos correctos y ya muy avanzados de auténtica organización de masas los tenemos en la unión de los vecinos de las Oliveras y la de los vecinos afectados por la estafa inmobiliaria Montane, Aloy y Ginart.

La falta de entidades legales que sirvan de plataforma y aglutinante a la hora de plantear las acciones reivindicativas ciudadanas es uno de los problemas con que se encuentra Santa Coloma para poner en marcha un potente movimiento popular de barrios. Por ello, el Partido se tiene que plantear la promoción y creación de las mismas." 610
\end{abstract}

Es curiós que aquest document no citi als Centres Socials, que si eren entitats legals i que estaven ja aglutinant lluites que aquí s'esmenten com per exemple el Centre Social Arrabal-Santa Rosa. Altres organitzacions com els Círculos Obreros Comunistas (que més tard van configurar l'OICE) si que tenien clara la importància

610Comité de Santa Coloma de Gramenet del Partit Socialista Unificat de Catalunya: "Resolución interna del Comité Local del PSUC de Santa Coloma de Gramanet" [1972], AHPCE, Nacionalidades y Regiones, Cataluña. PSUC, Comités Comarcales. Comité Local de Santa Coloma de Gramanet. Caixa 63. Carpeta 14/1. 
que podien tenir aquests Centres Socials. Els seus anàlisis ja havien parlat de la importància del barri com a espai on incidir:

"Por ello la vida en el barrio o en el pueblo es un lugar más donde se desarrolla y se prolonga los mecanismos de explotación capitalista; y a la vez un lugar donde se forja esa conciencia colectiva y social de la clase obrera. El hacer tomar conciencia de esta explotación en el barrio o en el pueblo es una actividad necesaria para poder llegar a dotar a la clase obrera del conocimiento de todos los aspectos bajo los cuales se está manifestando y desarrollando la explotación por la clase dominante y a la vez ampliando los campos en los cuales debe luchar contra la hegemenia [sic] impuesta por la burguesía y su Sociedad de Clases" ${ }^{\prime 611}$

Des de el punt de vista de l'OICE, eren els sectors més conscienciats del Centre Social juntament amb altres persones que estiguessin lluitant als barris les que havien de formar una Comissió Obrera de Barri, que tenia la funció de "llançar, desenvolupar i dirigir la lluita en tots els camps susceptibles de ser mobilitzats per objectius anticapitalistes" ${ }^{\prime 12}$. Aquesta funció de nucli d'avantguarda que agrupava als elements més conscienciats del barri va ser el que feren les CCBB de Santa Coloma.

S'ha de dir que la resolució del PSUC colomenc estava anticipant un debat molt important que es donarà dins les CCBB: la seva funció i la seva relació amb altres entitats legals com les AVV. En tot cas, aquest document és premonitori de l'abandó del PSUC i d'altres forces polítiques (MCE i BR) de les CCBB de Santa Coloma per potenciar la creació de les AVV's als anys 1974-1975613.

Però el cert es que les CCBB van continuar tenint una gran importància a Santa Coloma durant un cert temps, pel fet que en van continuar formant part un gran nombre de persones "independents" (antics membres dels GOA, llibertaris, antics jocistes i persones properes a Comunitats Cristianes de Base) així com militants de diverses forces polítiques. Per exemple hi haurà una destacada

6110rganización de Izquierda Comunista de España [Treball elaborat per un grup amb experiència en un barri de Catalunya] [sense data], CEHI-Pavelló de la República, Fons DDP (Sèrie Documents Partits Polítics), Subsèrie Organización de la Organización de Izquierda Comunista de España, Caixa DDP (OICE) 2. Carpeta 4- Organización de Izquierda Comunista de España. Documents sobre la lluita als barris, p. 7.

612Ídem, p. 16.

613 Marcelo López Ródenas: Historia social de la Santa Coloma moderna..., p. 150. El mateix autor deia que aquest fet "abría por primera vez la posibilidad de incorporar en su seno la discusión y confrontación política." 
presència de membres de l'OICE a les CCBB del Fondo, Singuerlín, Oliveres i Can Mariner (nascuda posteriorment a partir de l'aparició del Centre Juvenil-Social i la mateixa AVV); d'Acción Comunista a la CCBB de Santa Rosa; del Movimiento de Liberación Comunista (MLC) a les de Centre i Riu Nord. En canvi, en els barris de Riu Sud i Llatí (aleshores "Italianos") van existir efímerament i no es van arribar a consolidar, tant per la impossibilitat de tenir un Centre Social estable com per l'abandó de les persones que les van impulsar inicialment. Segons un dels seus membres, les Comissions de Barri van arribar a tenir la respectable xifra de 150 persones organitzades als diferents barris de Santa Coloma ${ }^{614}$. Aquests militants van ser fonamental en l'impuls de les diferents lluites que es van donar a Santa Coloma en un primer moment als anys setanta i que veurem més endavant. Van arribar a constituir una Coordinadora que va editar un butlletí, Barrio Obrero ${ }^{615}$. Fins i tot a l'any 1976 van estar discutint l'elaboració d'un programa polític alternatiu al dels Ajuntaments Democràtics que s'oferia des de les AVV's ${ }^{616}$.

Ja hem vist quina opinió tenia el PSUC de les CCBB colomenques... ara bé, com es definien elles mateixes? Com veien la línia defensada pel PSUC? Quins debats interns van tenir en relació amb la seva forma d'actuar i la seva interacció amb altres plataformes legals de lluita com els Centres Socials i les mateixes Associacions de Veïns? Crec que en aquest debat està -en part- el perquè malgrat el seu relatiu èxit, van acabar desapareixent en el transcurs de l'any 1977 mentre les AVV's encara es van mantenir. Si bé, com veurem, en determinats casos els membres de la CCBB van acabar dirigint Associacions de Veïns concretes.

Les CCBB es caracteritzaven per tenir una ideologia obrerista, revolucionària, contrària al capitalisme i una pràctica interna teòricament assembleària. Així es definien, per exemple, en un dels seus documents interns:

\section{“QUE ES UNA COMISIÓN DE BARRIO}

La comisión es el instrumento de los elementos más conscientes del barrio para hacer tomar conciencia a las masas de sus verdaderos intereses, dirigiéndolas y organizándolas.

614 Marcelo López Ródenas: Historia social de la Santa Coloma moderna..., p. 150.

615Es poden consultar uns quants exemplars a: AHMTB: Fons Marcelo López Ródenas, Caixa 1. Es van editar als anys 1976-1977.

616Comisiones de Barrio de Sta. Coloma (c.b.): "Manifiesto" [9-1976], AHMTB: Donació Marcelo López Ródenas, Caixa 1. 


\section{COMPOSICIÓN DE LA COMISIÓN}

En la comisión pueden estar miembros de las capas populares que integran el barrio, que luchan contra la opresión. Aunque la composición de la c.b. debe garantizar el carácter proletario de la lucha.

\section{OBJETIVOS}

a) A largo plazo: la supresión del sistema capitalista con la revolución socialista.

b) A corto plazo: Consolidar la c.b. a través de la lucha en el barrio, la formación y el perfeccionamiento de la organización (el funcionamiento) y ampliándola con los elementos más combativos del barrio que destaquen en las luchas concretas (ampliándola o creando nuevas comisiones). Denunciar sistemáticamente toda situación opresiva.

(...)

\section{FUNCIONAMIENTO}

-El carácter continuo de la labor de la c.b. Lleva consigo la práctica de la clandestinidad, aunque esta debe servir para preservar a la organización y no al individuo, impidiéndole su vínculo con las masas."617

Amb aquesta definició sembla evident que, si més no, el PSUC tenia raó en una cosa: les CCBB no eren una organització de masses. I alhora, malgrat que des de les CCBB es criticarà durament la política del PSUC, el cert és que en el fons coincidien en que calia una organització "d'avantguarda" que agrupés als elements més conscienciats i impulsés la lluita política, encara que en un cas fos "el partit" i en l'altre la "comissió de barri". El que no estaven d'acord -evidentment- era en qui havia d'acomplir aquest paper i en la manera d'arribar al socialisme, apart de com encarar la lluita, sobretot pel que fa a on calia posar l'accent, si en la lluita clandestina o en la pública.

Dins les CCBB hi haurà tensions i discrepàncies internes, i un element que serà fonamental en aquestes serà el posicionament respecte les AVV's que començaran a aparèixer a partir de 1975 impulsades per altres forces polítiques. A grans trets es pot dir que existirà un bloc que podríem qualificar de més "purista", agrupat en en les Comissions del Centre, Riu Nord i Oliveres (en aquest barri hi van haver dues Comissions de barri amb tendències oposades). Aquests faran una defensa més ferma de la concepció clandestina de la Comissió de Barri. Seran molt

617[Criterios Internos CCBB]: "Sobre las Comisiones de Barrio" [1974], AHMTB, Donació Marcelo López Ródenas, Caixa 3, Dossier 5: Debats interns CC.BB., p. 1. 
crítiques amb determinades forces polítiques que -al seu parer- s'oposaven a fer una política favorable a la classe obrera i a les quals qualificava de "reformistes" -en especial a totes les que estaven apostant per la creació d'Associacions de Veïns. I per "reformistes" no entenien només al PSUC, sinó també al PTE i MCE!- a les que acusaven de "arrastrar a las c.b. a los cauces de la política conciliadora burguesa" 618. També es faran acusacions des de la CCBB del Centre a determinades forces polítiques -MCE i PC (PSUC, suposem)- de crear "comissions fantasma" al Centre o de voler copar altres de ja existents com la de Santa Rosa ${ }^{619}$. Però el debat de fons girava també al voltant del paper de les Associacions de Veïns, ja que la irrupció d'aquest tipus d'associació impulsada per les forces polítiques acusades de "reformisme" estava alterant la correlació de forces als barris colomencs i entre aquests i l'Ajuntament, en un context com el procés de canvi polític on tot s'estava accelerant:

\begin{abstract}
"Esta debilidad en la consolidación e incidencia de las c.b. junto con la irrupción de las Asociaciones de Vecinos crea una nueva situación mucho más favorable al desarrollo de la política reformista, capaz de poner en crisis la política de clase desarrollada hasta ahora por las c.b. en la dirección de las luchas reivindicativas y amenazando su propia existencia como organización de clase"620
\end{abstract}

Aquests fets demostren l'existència de debats interns molt profunds dintre de les mateixes CCBB respecte l'aparició de les Associacions de Veïns. Un grup d'aquestes considerava aquesta aparició negativa, i que no calia implicar-si per que ja existien organismes legals per fer aquest tipus de tasques com els Centres Socials i Juvenils, tot i que encara no eren considerats com organitzacions "de masses":

"La c.b. se considera organización de clase, que partiendo de los frentes concretos, barrio y fábrica, lucha por los objetivos revolucionarios de la clase obrera: la implantación del socialismo (...)

La c.b. no se considera organización de masas, ya que esta organización no puede ser clandestina, por su bajo nivel, que solamente es reivindicativo.

Creemos que actualmente por cuestiones de represión, las organizaciones de masas no

618Comisión de Barrio Centro: “Propuesta de discusión de la C.B.C. Al resto de CC.BB." (6-1975), AHMTB: Donació Marcelo López Ródenas, Caixa 3, Dossier 5: Debats interns CC.BB, p. 1. El document qualifica textualment de reformistes a aquestes tres forces polítiques. 619Ídem. 620Ídem, p. 2. 
existen en España; los centros sociales y asociaciones de vecinos no llegan a este nivel. ${ }^{\prime 621}$

Però existirà un altre bloc de Comissions de Barri, sobretot les del Fondo, Can Mariner, Singuerlín i Santa Rosa (precisament aquelles en les que hi havia una major presència de militants de l'OICE, si bé la de Santa Rosa anava més pel seu compte) amb unes visions enfrontades en part amb les de l'anterior grup esmentat pel que feia a quina actitud prendre davant l'aparició de les Associacions de Veïns . No es que aquest grup renunciés a una concepció avantguardista i clandestina de les CCBB. En això podien coincidir. Per exemple, un document de la Comissió de Barri de Santa Rosa parlava dels criteris per formar-ne part, remarcant la obligatorietat d'assistir a les reunions sota pena d'expulsió davant tres faltes sense justificar ${ }^{622}$. Però pel que fa a les AVV's, no es tancaven a utilitzar-les tàcticament tal i com s'havia venint fent amb els Centres Socials. En el fons de tot hi havia una qüestió que ja avançava la Comissió de Barri de Singuerlín en un document crític amb els postulats de la Comissió de Barri del Centre:

\footnotetext{
"Combatimos a la A. de V. en la medida que pretende presentarse al barrio como la vanguardia y órgano de lucha de los vecinos, ¿pero nuestra práctica como c.b. respalda esta crítica? ¿ciertamente los vecinos ven en la c.b. su órgano de lucha?, o por el contrario no ven nada pues la c.b. se dedica a la práctica de vanguardia que llevan el resto de grupos organizados." ${ }^{623}$
}

La qüestió de fons era que, independentment de la major o menor voluntat revolucionària que poguessin tenir les $\mathrm{CCBB}$, la participació o us de les AVV's els hi oferia una major possibilitat de connectar amb sectors amplis de població. En canvi, un excessiu avantguardisme i clandestinitat les aïllava de les "masses" susceptibles d'escoltar els seus postulats. Va ser aquest fet el que a la llarga va decantar la balança a favor de les AVV's, sumat a les disputes internes que es van donar dins les mateixes CCBB colomenques. En el transcurs de 1976 es van fer

621Comisión de Barrio Centro: "Criterios de Militancia y puntos de actuación", AHMTB, Donació Marcelo López Ródenas, Caixa 3, Dossier 5: Debats interns CC.BB, p. 1 i Marcelo López Ródenas: Historia social de la Santa Coloma moderna..., p. 210.

622 Comisión de Barrio de Santa Rosa: "Criterios y bases de militancia en la Comisión de Barrio de Santa Rosa”, AHMTB: Donació Marcelo López Ródenas, Caixa 3, Dossier 5 “Debats interns CC.BB. 623[Comisión de Barrio de Singuerlín]: "Respuesta a la crítica”, AHMTB: Donació Marcelo López Ródenas, Caixa 3, Dossier 5: Debats interns CC.BB, p. 3. 
dues assemblees on es va discutir l'elaboració d'un programa alternatiu propi en base a un document presentat per la CCBB de Santa Rosa ${ }^{624}$. En la primera, feta al mes de maig, van participar les CCBB més properes a l'OICE (Singuerlín, Fondo i Les Oliveres) més Santa Rosa. En la segona, al mes de juny també van participar representants de l'altre sector (Centre, Riu Nord i Les Oliveres bis) ${ }^{625}$. Malgrat tot el sector més "purista" se'n va desmarcar i va fer el seu propi Manifiesto, que encara era molt crític amb l'us que "els reformistes" volien donar a les AVV's per "enganyar a la classe obrera i desviar-la dels seus objectius de classe pactant amb la burgesia", (si bé reconeixia que es podien fer servir tàcticament en determinats $\operatorname{casos}^{626}$ ). Hi haurà CCBB que participaran en les AVV's, repetint-se pràcticament les persones a les Juntes. Així passarà per exemple en Santa Rosa, en Singuerlín i pel que es veu també en Les Oliveres, si bé aquí es donarà el cas curiós que de les dues Comissions de Barri existents una es posicionarà a favor i l'altra en contra de participar a l'AVV. Al barri del Centre en canvi la CCBB, tot i no oposar-se finalment a la seva creació de l'Associació, els seus membres no acceptaran ocupar càrrecs a la Junta ${ }^{627}$. I segons un altre testimoni, això també va passar inicialment al barri del Fondo (tot i que després rectificaran) ${ }^{628}$.

Va ser, en definitiva un període de confrontació ideològica per les organitzacions polítiques com ens recordava un dels protagonistes dels fets: PSUC, PTE i MCE optaven clarament per les AVV's mentre Acción Comunista, Grupos Autònomos (de tendència llibertària) i d'altres en canvi no. També ens va fer constatar que en els barris on les noves AVV's solien tenir poca força eren aquells on la gent que participava en la Comissió de Barri no s'involucrava o on si la tenien era on es donava el fet contrari ${ }^{629}$. Les Comissions de Barri, a la llarga, no van

624Comisión de Barrio de Santa Rosa: “La Comisión de Barrio ante la alternativa de AD” (?-1976), AHMTB, Donació Marcelo López Ródenas, Caixa 3, Dossier 5: Debats interns CC. BB.

625 Marcelo López Ródenas: Historia social de la Santa Coloma moderna..., p. 215-216. Algunes de les actes d'aquestes assemblees així com els documents de discussió es poden trobar a AHMTB, Donació Marcelo López Ródenas, Caixa 3, Dossier 5: Debats interns CC. BB. Segons el mateix autor en aquestes dues reunions van participar una seixantena de persones.

626"Manifiesto Comisiones de Barrio de Sta. Coloma" (Setembre de 1976), AHMTB, Donació Marcelo López Ródenas, Caixa 1.

627 Marcelo López Ródenas: Historia social de la Santa Coloma moderna..., p. 210.

628Entrevista amb Eloy Jurado Cubera, 12-11-2013. Va ser membre de la Comissió de Barri de Singuerlín, de l'AVV de Singuerlín i del PSUC, esdevenint regidor d'Urbanisme a l'Ajuntament de Santa Coloma entre 1983-1991.

629Entrevista amb Salvador Bolancer Dugo, 8-5-2013. 
adaptar-se al nou context polític, ja fos per aquest debat o per altres diferències internes existents, com per exemple en la concepció interna que es tenia de l'assemblearisme en el funcionament de la Coordinadora ${ }^{630}$. De manera que van desaparèixer pràcticament durant l'any 1977, si bé, això no va significar que tots els seus membres marxessin a casa.

Malgrat les reticències existents respecte les AVV's o a implicar-se en les seves Juntes, a vegades els esdeveniments van portar a que es rectifiqués aquesta línia. A Santa Rosa, per exemple va passar això segons el testimoni de Salvador Bolancer, la mateixa persona que ens feia les afirmacions anteriors i que les va viure en primera persona. És una cita llarga però crec que molt significativa:

“Si, si. Ahí estaba... hubo ese debate. Muy fuerte... los diferentes debates en diferentes (...) Y en muchos barrios pues adoptamos... mira, continua la Comisión de Barrio haciendo ese tipo de trabajo ideológico y de... y se promociona la Asociación de Vecinos como un grupo de gente que están más ahí en la sociedad y que sean ellos quien lo lleven (...). Yo lo se porque incluso la Asociación de Vecinos nuestra la primera Junta rectora y todo esto eran gente del barrio de Santa Rosa. Y no quisimos entrar ninguno de la Comisión de Barrio [a la Junta], la apoyábamos pero sin estar en los cargos directivos... Dijimos: que los cargos directivos los lleven gente del barrio y nosotros ya trabajaremos para que sea posible.

Y bueno, y lo intentamos y se hizo asín pero no funcionó. No funcionó porque a la gente en el momento que se le plantea un problema de tipo más ideológico y más de enfrentarse como fue la cuando la reivindicación del Motocros, algunos se echaron pa atrás... 'ostia no porque esto, la policía...' la familia le presionaba, 'yo bueno quiero ser socio pero ser Presidente de una Asociación con tanto problema...' (...). Y entonces al final no teníamos más remedio... y entonces los grupos que de alguna manera estaban detrás de quedarse con los cargos de la... ya fueron a la carga y entonces fue cuando ya tuvimos que decir: 'oye, no valen inventos, lo haremos mixto' gente en la Asociación [Comissió] de Barrio de la Junta de la Asociación de Vecinos diríamos y empiecen a trabajar conjuntamente, porque si no esto no tira... Y entonces asín fue (...) Y a partir de ahí con el tiempo y la dinámica diaria la Comisión de Barrio se fue relegando y ya dijimos, 'mira, los partidos políticos que hagan lo que tengan que hacer y el que quiera que trabaje en la Asociación de Vecinos y el que no que haga lo que quiera'. Y entonces

630Els representants de les CCBB de Centro, Oliveres (una de les dues) i Riu Nord per exemple creien que a les plenàries de les CCBB de Santa Coloma s'havia d'assistir per delegació, mentre que les de Can Mariner, Santa Rosa i Fondo (amb més pes de l'OICE, curiosament) eren partidàries de que en aquestes s'assistís de manera individual. Veure per exemple: "Los militantes de las c.b. De C., O. y R.N. , ante el pleno propuesto por las c.b. De C.M. S.R. Y F." [51976], AHMTB, Donació Marcelo López Ródenas, Caixa 3, Dossier 5: "Debats interns CC.BB". 
crearon dos cosas paralelas y (...) asín la Coordinadora de Asociaciones de Barrios pasó a ser la Coordinadora de Asociaciones de Vecinos... vestido de alguna manera más legal pero haciendo las mismas cosas. Y hasta ahí llegamos hasta constituir digamos, casi todos los barrios hicieron Asociaciones de Vecinos, especialmente todos los barrios que teníamos Comisión de Barrio. Después los que no tenían posteriormente se fueron engrescando más tarde. Hicieron Asociación de Vecinos en los diferentes barrios que no había Comisiones de Barrio. Que fueron el Barrio Latino, La Guinardera, el Río, que no había Comisión de Barrio... en el Río Sur si había Comisión de Barrio, pero se hicieron ya Asociaciones de Vecinos diferentes en todos los barrios prácticamente a partir de una época determinada, a partir de los años 74 por ahí ya... $75(\ldots) \cdot{ }^{631}$

Aquestes Associacions de Veïns on hi haurà implicació de gent provinent de les Comissions de Barri tindran un discurs de classe molt accentuat i malgrat els formalismes que imposava la legalitat vigent, com triar una Junta, President, etc., continuaran aplicant pràctiques assembleàries en la seva organització interna i, ara també externes (fent assemblees de barri). Algunes d'elles, com veurem més endavant, seran les que continuaran actives durant la dècada dels vuitanta ja que la presència del PSUC no era majoritària i no van estar afectades per la "fuita de càrrecs" cap a l'Ajuntament democràtic després de les eleccions municipals de 1979.

Durant la primera meitat dels anys 70 al Barcelonès Nord hi haurà partits polítics -PSUC, PTE, MCE, sobretot, amb una implantació més gran el primer tot i que la dels altres dos també tenia una certa rellevància- que optaran per l'impuls de les AVV's com hem vist. Bandera Roja no tenia aquí la important presència i implantació que si tenia a Barcelona ciutat, on va ser precursora:

"A nivel concreto creemos que hay que desarrollar, ahora, los esfuerzos en:

Empresas: Organizar una verdadera campaña de explicación y discusión de masas en torno las próximas elecciones sindicales, preparándolas ya desde ahora. Centrar especial atención en la conexión de enlaces y jurados que, sin estar en CCOO ni en su esfera de influencia, participan de alguna manera, en la lucha reivindicativa.

Barrios: Utilización más amplia de las Aso. de Vecinos incorporando a su actividad reivindicaciones culturales, recreativas, deportivas, etc., Coordinar de este modo desde la Asociación a otras instituciones del barrio: centros deportivos, peñas. etc.

631Entrevista amb Salvador Bolancer Dugo, 8-5-2013. 
Revitalizar las condiciones de A.V. en torno a iniciativas generales (precios). Proseguir en dónde no las haya la lucha por el reconocimiento de la Aso. de Vecinos y centros sociales. Plantear al menos en Barcelona, la utilización de las Juntas Municipales de Distrito. Utilización que no puede consistir en la infiltración de ellas de unos hombres más o menos representativos del barrio sino que debe plantearse desde una verdadera campaña democrática: Reunión de todos, o la mayoría, de las instituciones legales del barrio y lucha por la elección, desde ellas, de representantes que asistan a las Juntas. Este es un tema de discusión que el estudio concreto de las posibilidades de estas Juntas, y, a la vez, la realización de las primeras experiencias, que podría ser en Distrito IX, debe concretar." ${ }^{\prime 632}$

Aquest fet es concretarà en dues línies tàctiques. Una va ser l'entrisme en Associacions ja existents però controlades per les persones franquistes i conservadores. No era una pràctica nova, ja ho havien fet les CCOO amb el sindicat vertical amb un notable èxit. A Badalona i Sant Adrià, on les Comissions de Barri no van tenir la força i la importància assolides a Santa Coloma de Gramenet ${ }^{633}$ (més endavant analitzarem el perquè), aquesta línia va ser posada en pràctica. Aquest fet es donarà en Associacions de Veïns ja existents com la de Juan Valera (Badalona) i La Mina (Sant Adrià) -per posar dos exemples- que van passar a ser controlades per persones del PSUC o properes. Alguns testimonis així ens ho expliquen:

\footnotetext{
"Me dice el partido a mi (...) tendrías que ir a echarle una mano al camarada Juan Palencia, que allí hay movimiento quiere meterse en la Asociación (...) [referint-se a la de Juan Valera] y darle la vuelta a eso"634
}

"Allí [referint-se a la mateixa associació anterior] tenemos al Vallespir, al Lloreta,

6320CE(BR): "Circular no 3 Cté de Cataluña. La inmediata prespectiva [sic] de lucha política de masas. Organizar el movimiento democrático.", Centre de Recursos per a l'Aprenentatge i la Investigació (CRAI)-Pavelló de la República, Fons DDP. Subsèrie Organización Comunista de España (Bandera Roja), Caixa DDP (OCE(Br)).1, Carpeta 7- OCE(BR). Documents interns línia minoritària contrària a la integració al PSUC (donació Jordi Borja), p. 4-5.

633Vaig trobar alguns fulls volants que en feien alguna referència, però res més. Els testimonis que he entrevistat no m'han aportat cap data significativa de la seva existència. Veure: Comisión de Barrio (Centro Badalona):[Declaració de la Comissió de Barri del centre de Badalona davant el Primer de maig], (4-1974); Comisiones de Barrio de San Roque, Santo Cristo y Lloreda: [Octaveta de les Comissions de Barri de Sant Roc, Sant Crist i Lloreda] [1973-74?], AHGCB, Gobernadores Civiles. Caixa 289. Actividades Contra el Régimen 1973-1975 i Barrios en Lucha. Órgano de expresión de la comisión anticapitalista del barrio de Buenavista, núm. 1 (juliol 1976), Universitat Autònoma de Barcelona, Fons DDD, https://ddd.uab.cat/record/56071?ln=ca. 634Entrevista a Àngel Navarro Rubio, 21-7-2009. 
tenemos una seria de gente que son franquistas (...) allí hay jóvenes que seguro son de tu línea" ${ }^{\prime 35}$

I d'aquesta manera es va aconseguir forçar unes eleccions a Junta el 24 d'abril de 1976 on el militant del PSUC -i posterior regidor a l'Ajuntament- Manuel Armentero sortirà elegit President, relegant als vells jerarques franquistes a càrrecs simbòlics. A l'Associació de Veïns de La Mina, es va donar un cas similar, tot i que aquesta inicialment va estar presidida per un independent, José Buenafuente Iglesias, des de l'any 1974:

\begin{abstract}
"Això va passar al 73-74. Hi ha un canvi pràcticament del que era una associació de veïns model franquista al que ja és un associació de veïns pràcticament dominada per Comissions, Comissions i el PSUC, bàsicament els elements més comunistes. El que passa és que aquí com en altres barris, i això va ser un element molt comú, ens afegíem tota la gent de bona voluntat que ja ens agradava tot aquest tema, alguns polítics i altres no polítics, i elements d'església. Aquí l'església era una mica més esquerranosa i més progressista, més del concili, bé, aquella que va donar suport a l'alternativa política d'alguna manera (...) aquí hi havien sis comunitats religioses i a més implicadíssims" ${ }^{\prime \prime 36}$
\end{abstract}

En segon lloc es van crear noves Associacions de Veïns fomentades pels Centres Socials existents com ja he explicat. Així va passar, per exemple, amb l'AVV de Pomar (Badalona, 1972). Hem vist també el procés de sorgiment de l'AVV del Barri del Besòs de Sant Adrià, en part vinculat a l'existència del Centre Social del Barri (1973-1974). En llocs on no existien AVV's prèvies també se'n van crear de noves com a La Salut Alta (Badalona 1972). En canvi, el cas de l'Associació de Sant Mori de Llefià, també de Badalona i legalitzada l'any 1976, va ser un procés diferent. Un grup de veïns, independents i militants d'organitzacions polítiques d'esquerres com el PSUC i el PTE van intentar infiltrar-se a una Associació ja existent, la de Sant Antoni de Llefià ja des de $1974^{637}$. Allà, els vells dirigents

635Entrevista amb Manuel Armentero Molina, 10-4-2010. José Miguel Cuesta Gómez: El moviment veïnal a Llefià (Badalona), p. 211.

636Entrevista amb Josep Maria Montferrer, 20-3-2012. Escolapi al Camp de La Bota, va anar a viure a La Mina on va ser mestre durant molts anys i va formar part de l'AVV. Actualment continua a la Plataforma d'Entitats del Barri i és el President de l'Arxiu Històric de La Mina.

637Entrevista amb Pedro Jesús Fernàndez, 26-4-2009. Primer president de l'AVV de Sant Mori de Llefià, posterior militant del PSUC i regidor a l'Ajuntament durant 1979-1983. José Miguel Cuesta Gómez: El moviment veïnal a Llefià (Badalona), p. 200. 
franquistes com Fulgencio Conesa que encara era Alcalde de Barri van arribar a prohibir l'entrada de més socis amb arguments surrealistes ${ }^{638}$ i fins i tot a expulsarlos físicament amb la policia:

"La asociación de vecinos no nos dejó nunca entrar. Queríamos hacer las reuniones en el local y nos echaban fuera, llamaban a la Policía a la Guardia Urbana y nos echaban a la calle"639

Davant aquest fet van decidir promoure una associació nova en paral·lel, que va ser la que va impulsar les primeres mobilitzacions al barri. Aquesta associació va comptar amb moltes traves administratives i va trigar gairebé 2 anys en ser legalitzada. Tot el contrari que l'AVV de Sant Roc (1976), pels motius ja esmentats. Altres associacions que es van legalitzar a Badalona van ser les de Verge de la Salut (1976, a la urbanització coneguda popularment com "el hoyo" per on estava situada) i Morera (1977). A Sant Adrià de Besòs, apart de les ja esmentades del Besòs i La Mina, l'any 1976 es van legalitzar dels de Sant Adrià Nord (al nucli antic, tenint una composició més diversa i interclassista) i la de Sant Joan Baptista.

A Santa Coloma de Gramenet, finalment, va ser durant l'any 1975 quan es van fer les primeres legalitzacions d'Associacions de Veïns, les del Centre, Singuerlín, Guinardera, Santa Rosa, Raval, Oliveres i Fondo, si bé la majoria ja funcionaven des de l'any anterior o fins i des de feia 3 anys com les de Les Oliveres i La Guinardera $^{640}$ (l'oposició de Juan Porta Bussoms i del Govern Civil va endarrerir els tràmits). En alguns casos també sota l'auspici dels Centres Socials. Més endavant es legalitzaran també les de Riu Nord, Riera Alta, Safaretjos i Barri Llatí641.

638Primer es va al-legar que era una associació de propietaris i no de veïns. Després que l'aforament del local impedia l'accés de més socis. Que els nous socis "volien fer política" i eren uns "revolucionaris, alteradors de l'ordre i perillosos" i fins i tot que existia un deute de 3,8 milions de pessetes contret per l'Associació amb l'Ajuntament "per culpa d'uns veïns morosos" per les obres fetes en la dècada anterior... i que mentre l'Associació no els pagués al Consistori no admetria més socis!. Com que el mateix Conesa, apart de Alcalde de Barri era regidor pel Tercio Familiar, la gent sospitava amb raó que jugava a dues bandes i es lucrava personalment. Veure: Emma Plana Alsinas i Pedro Jesús Fernàndez: Història d'un barri. Història d'una associació. Sant Mori de Llefià (1974-1987) [estudi inèdit], p. 11; i Marta Puertolas: "Sant Antonio de Llefià. Una asociación de vecinos vetada", Revista de Badalona (29-9-1976). Segons l'autora Fulgencio Conesa estava vetant l'entrada a 150 persones.

639Entrevista amb Maria Relles Bellido, 25-4-2006. Militant del PTE aleshores, va ser la primera Secretària de l'AVV de Sant Mori de Llefià i posteriorment Presidenta. Més endavant va ser regidora per IC.

640Marcelo López Ródenas: Historia social de la Santa Coloma moderna..., p. 211.

641Emili Ferrando Puig i Juan Rico Màrquez: Les Comissions Obreres en el franquisme..., p. 509. 
Recapitulant, doncs, varen ser les condicions polítiques dels barris i les experiències organitzatives prèvies -fossin catòliques, partidistes o purament veïnals- les que varen condicionar el sorgiment i evolució de les associacions de veïns als diferents barris del Barcelonès Nord i no l'estructura d'oportunitats generada per la legislació associativa franquista de 1964, Aquesta legislació va ser només el marc legal en el que es varen haver d'inserir: un marc legal que no havia estat dissenyat per a facilitar el seu sorgiment sinó més aviat per al contrari.

Fins aquí he explicat com van sorgir i evolucionar diferents formes d'organització del moviment veïnal, que a més van coincidir les unes amb les altres durant un temps concret. La forma que finalment es va acabar imposant a la segona meitat dels anys setanta va ser la de les Associacions de Veïns tal i com avui les coneixem. Però això no ens ha de fer oblidar o menysvalorar la importància dels Centres Socials o de les Comissions de Barri com hem vist. També he analitzat quina va ser la participació i preferències de les diferents organitzacions polítiques (partits o no) en aquest tipus d'entitats veïnals. Un esment apart mereix el cas de les organitzacions socialistes predecessores al PSC-PSOE (ens referim bàsicament a Convergència Socialista de Catalunya i a la Federació Catalana del PSOE). Tradicionalment s'ha afirmat que aquestes organitzacions no van tenir un pes rellevant en el moviment veïnal, llevat d'alguna militància individual. Les entrevistes personals que vaig fer semblen confirmar aquesta qüestió, fins i tot quan he preguntat a antics a militants socialistes:

"Si si, havia gent de la Convergència Socialista que estava a les Associacions de Veïns, a la Junta... Sí, hi havia gent (...) Era poca, era poca... però ara no recordo quina era (....) Si, en aquella època el que dominava era el PSUC (...) Qui tallava el bacallà era el PSUC. Els socialistes teníem poca presència... si si..." ${ }^{642}$

El fet es que -en contra del que es sol pensar- aquestes organitzacions si havien manifestat un cert interès pels processos que s'estaven donant a les grans ciutats catalanes:

"El capitalisme exerceix la seva explotació fonamental a l'àmbit de l'empresa però també projecta aquesta explotació fonamental a l'àmbit de l'empresa però també

642Entrevista a Manuel Galgo Iserte, 4-7-2013. Antic militant de Convergència Socialista de Catalunya, del PSC-PSOE (va ser Secretari d'Organització a Santa Coloma) i del Centre Excursionista del Puig Castellar de Santa Coloma de Gramenet. 
projecta aquesta explotació a tots els vessants de la vida social i, particularment, a l'organització i gestió de la ciutat i el territori.

La situació d'explotació dels treballadors en el marc urbà i comarcal constitueix un dels elements principals de sensibilització i mobilització de les classes populars. Per als socialistes és un front d'acció important que ha viscut un increment considerable a aquests darrers anys i que cal situar dins el marc de la lluita de classes, per una nova societat socialista autogestionaria" ${ }^{143}$

Els seus documents, en concret els de Convergència Socialista de Catalunya reflecteixen una voluntat d'actuació als barris, impulsant tant les Associacions de Veïns com unes Assemblees Democràtiques. Les primeres havien de treballar les necessitats materials del barri i les segones impulsar les reivindicacions de l'Assemblea de Catalunya $^{644}$. Però la realitat va ser que mai van tenir suficient militància per acomplir els seus objectius, com ens posa de manifest una nota manuscrita sobre un Cercle (una mena de cèl-lula) de La Mina-Besòs (Sant Adrià):

"La Mina-Besòs.

Aquest Cercle encara està en formació. Hi ha dos militants i tres simpatitzants. Mentrestant ens reunim amb altres militants del cercle Verneda-La Pau amb els quals hem repartit responsabilitats: encarregat de formació, de propaganda, de cotització.

Es treballa a l'Associació de Veïns de La Mina i al Centre Social Besòs però encara amb poca incidència en front de altres forces (PSUC y [sic] UCL)

Ara mateix no hi ha ningú en cap altre front.

Tampoc, de moment, els militants disposen de temps per a dedicació a feines derivades de la coordinació del sector." ${ }^{\prime \prime 45}$

Per tant, en el moment crucial de produir-se la mort de Franco i engegar-se l'ofensiva cívico-política que havia d'emportar-se per davant la dictadura, en l'àmbit del moviment popular urbà, la presència dels socialistes -pocs anys després hegemònics en els governs municipals- era menor, no ja que la del PSUC, sinó que

643Centre d'Estudis Socialistes: "Lluita Urbana i Comarcal" [sense data], Fundació Rafael Campalans (FRC), Fons Organitzacions. Fons CES (Centre d'Estudis Socialistes), Caixa 119 A.004.14.01.05, p. 1.

644Convergència Socialista de Catalunya: [Sense títol. Document de CSC sobre la lluita als barris, 12 p.], "Aportació dels Cercles per a una línia d'acció a barris no 2. Notes sobre el document d'Aportació no1" [sense data, 3 p.]; "Aportació d'un Cercle par a la línia d'acció a barris no3. Notes sobre els documents 1 i 2" [sense data, 2 p.], FRC, Fons Jordi Font (FJF), Caixa 100, Carpeta P5,A005.02 Front Barris.

645CSC: [2 Notes manuscrites sobre la I 100, Carpeta P 5, A005.02 Front Barris - Notes i Apunts CB. 
es trobava per sota de la d'altres grups polítics als que s'ha titllat -sovint encertadament tot i que a vegades també pejorativament- de grups minoritaris. Un fenomen que, sens dubte, necessita explicació.

Però deixant de banda el posicionament de les organitzacions polítiques concretes, és interessant veure com s'articulava la ideologia i el discurs des de els mateixos organismes del moviment popular en la dècada dels setanta, quan adquiriran una força i presència pública innegables. Això ens permetrà veure, entre d'altres coses, el sistema de valors i creences que s'estava socialitzant. D'això en parlaré al proper capítol.

\subsection{Molt més que unes simples demandes de serveis: model de societat $\mathbf{i}$ referents culturals. Consciència de classe, anticapitalisme i democràcia.}

En aquest capítol analitzo el discurs que es feia des de el moviment veïnal (en les seves diferents expressions i formes organitzatives), sobretot a nivell extern, de cara a enfora, analitzant els documents, publicacions, etc. amb la intenció de veure la ideologia i els valors que s'intentaven socialitzar des d'aquest moviment popular.

Malgrat que a nivell general s'ha insistit que el moviment veïnal té un caràcter interclassista, també és cert que en els seus primers moments i en determinats barris, va tenir un component de classe molt important ${ }^{646}$. En el Barcelonès Nord el moviment popular va aparèixer inicialment en els barris de població nouvinguda d'extracció treballadora, i amb majors mancances urbanístiques i de serveis. La consciència obrera es reflectia en les primeres publicacions i fulls volants que es van editar. Deixant de banda les publicacions més pròpies d'organitzacions polítiques clandestines, aquesta tasca va ser iniciada als anys seixanta per les CCOO de Badalona "i la seva comarca" amb la impressió sobretot de fulls volants. El mateix exemple va ser seguit per les COJ. Tot i que és evident que no es pot fer un tall entre aquestes experiències i l'aparició de les reivindicacions als barris -ja que estan molt relacionades- em centro més en el discurs "de classe" que van començar a fer pròpiament les organitzacions dels barris i la relació sobre les seves 646Iván Bordetas Jiménez: Nosotros somos los que hemos hecho esta ciudad..., p. 43. 
problemàtiques. Un discurs que a nivell de moviment popular, van començar a encetar les ja esmentades Comissions Obreres de Barri o els primers Centres Socials. Per exemple el número 2 del Boletín de la Comisión Obrera de Barrio del Sector Besós deia:

\begin{abstract}
"NUESTRAS CASAS tienen constante humedad, por esta razón el barrio en que vivimos es considerado "inhabitable"; si añadimos a esto los materiales de baja calidad empleadas por las constructoras privadas y estatales para la construcción de nuestras viviendas, vemos que somos de nuevo nosotros, la CLASE OBRERA, los que hemos de soportar la injusticia y las incomodidas [sic] a que nos tiene sujeto el capitalismo como clase oprimida, en todos los aspectos de nuestra vida y como aquí vemos en nuestros barrios y dentro de nuestras casas." ${ }^{647}$
\end{abstract}

Un llenguatge certament més explícit que el que es feia servir en els primers moments d'alguns butlletins dels Centres Socials ${ }^{648}$, però que ja havia manifestat, encara que fos amb un to més moderat, un nivell de consciència obrera. Aquest nivell de consciència anirà fent-se cada cop més evident, i el que és més, vinculantse a la pertinença a uns determinats barris. Consciència de classe i de barri anaven doncs cada cop més de la ma i alhora van esdevenir progressivament més crítiques amb les condicions de vida i treball imperants per la majoria de la població. En la revista Pomar Convivència, la ja esmentada publicació del Centre Social de Pomar, s'afirmava a finals de 1971:

"Problemas del barrio

Los problemas del barrio, los tenemos que solucionar nosotros los que habitamos en el barrio.

Todos sabemos el poco tiempo libre que tenemos los obreros, a la mayoría no nos queda tiempo para nada, porque nuestra rutina es del trabajo a casa y de casa al trabajo, y las jornadas de trabajo de 10 a 12 horas y hasta 14 horas diarias de trabajo, después de esto, poco tiempo nos queda libre; esto se podría solucionar con una jornada de 8 horas suficiente para poder vivir. Pero como decía antes, los problemas nos los hemos de solucionar nosotros y en nuestro barrio hay muchos."649

647 “Boletín de la Comisión Obrera del Barrio Besós” núm. 2 (setembre-octubre 1968), AHPCE, Publicaciones periódicas. Carpeta 64/23, p. 2. El subratllat és de l'original. 648Veure nota 450.

649José Delgado: "Los problemas del barrio", Pomar Convivència, núm. 23 (octubre-novembre 1971), MB-Hemeroteca, Caixa 21-1-6, p. 2-3. 
El text continuava enumerant els nombrosos problemes existents: la incomunicació i manca de transports, el proper abocador d'escombraries, la falta de serveis i equipaments... Però sembla evident la relació que s'estableix entre consciència de barri, consciència obrera, i les mancances d'aquest, apart d'una voluntat d'autogestió. Certament no es fa amb un llenguatge tant explícit como el de les publicacions clandestines. Recordem com s'analitzaven els dèficits de la sanitat pública en un document contemporani a la lluita per l'ambulatori ${ }^{650}$. 0 el llenguatge que feien servir els GOA o el PSUC, per posar dos exemples de dos grups que estaven relativament distanciats però que tenien implantació als diferents barris del Barcelonès Nord:

"En una sociedad capitalista los trabajadores solo servimos para burros de carga. Las decisiones las toman los burgueses a nuestras espaldas y el muerto lo cargamos los obreros. En España, desde 1939, en que fueron destruidas y aniquiladas todas nuestras organizaciones de clase fuimos privados de las libertades más elementales (asociación, reunión, prensa, etc.), los patronos y los terratenientes han podido exprimirnos a sus anchas amparados en unas leyes hechas para defender sus privilegios y que se aplican mediante el terror de su estado fascista bendecido por los obispos." ${ }^{\prime 651}$

“Todos vamos viendo cómo suben cada día los artículos de primera necesidad: pan, carne, calzado, ropa, transportes, escuelas... El régimen dice que va aponer severas medidas de control, pero para quienes són [sic] esas medidas es para todo el pueblo, escepto [sic] la clase capitalista.

Cada día nos resulta más difícil nuestra vida después de agotadoras jornadas de 10 o 12 horas de trabajo para medio poder vivir, y largos desplazamientos en condiciones poco higiénicas e inseguras a nuestros lugares de trabajo.

Cada nos va expoliando y destruyendo la clase capitalista, pero a ellos poco les importa como vivimos la clase trabajadora." ${ }^{652}$

Fins i tot els grups socialistes antecessors del PSC-PSOE d'aleshores feien

650Trabajadores de Santa Coloma de Gramenet: "Acerca de la Seguridad Social y como se concreta en Santa Coloma de Gramanet", AHMTB, Donació Marcelo López Ródenas, Caixa 3, Dossier 14 "Informes. Archivo Bibliográfico Clandestino".

651Grupos Autónomos de Barrio (Santa Coloma de Gramanet): "La lucha de Santa Coloma" [maig 1971], AHMTB, Donació Marcelo López Ródenas, Caixa 3, Dossier 14: Informes. Archivo Bibliográfico Clandestino, p. 1.

652Célula Horizonte del PSUC de Badalona: “!!A los ciudadanos de Badalona!!” (24-2-1973) [full volant], ANC, 03. Organitzacions de Base, 03.01. Organitzacions territorials, 817 Cèl-lula Horizonte del PSUC. [Aquesta cèl-lula estava situada al barri de Llefià de Badalona]. 
servir aquest llenguatge -com hem vist anteriorment- fet que contrasta enormement amb la seva evolució posterior cap a posicions interclassistes i "d'elogi" de les capes mitjanes de la población ${ }^{653}$.

Però com es podia fer servir aquest discurs tan explícit en els àmbits considerats de masses o en els "espais legals"? Per que aquest discurs tan clar, fet per organitzacions il·legals, tenia una difusió limitada. Aquí s'establirà una relació dialèctica entre la línia ideològica d'aquestes organitzacions i com fer arribar un discurs de classe a sectors amplis de població. Tant partits polítics marxistes como els mateixos GOA en tenien una condició avantguardista de com s'havia organitzar la lluita, amb la importància d'un nucli polític més conscienciat -que podia ser un partit polític concret o la Comissió de Barri- que donés consignes, participés i orientés en els moviments de masses. Un exemple d'aquesta mateixa concepció ho podem veure en Bandera Roja, organització que va destacar als anys setanta per la implicació que va tenir en el moviment veïnal, sobretot a Barcelona ciutat:

"Los comunistas trabajaremos siempre por una lucha política de masas, porque las masas obreras y populares sean el protagonista directo de la lucha política bajo la dirección del proletariado; en todas las fases y periodos del proceso revolucionario. $\underline{\text { Por eso defendemos que las organizaciones de masas deben hacer política. La política }}$ que corresponde a sus intereses objetivos de clase. (...). Las organizaciones de masas no son ni deben ser partidos políticos. La elaboración de una política proletaria, revolucionaria, corresponde a la organización revolucionaria de los trabajadores, a la organización comunista, capaz de precisar una estrategia, una táctica y una dirección que una la actual lucha con la conquista y construcción del socialismo, objetivo político de los trabajadores y de amplios sectores populares. A la organización comunista corresponde sobre todo, la formación política e ideológica de las masas en lucha.

A las organizaciones de masas corresponde sobre todo unir la lucha de los sectores que representa, crear las condiciones para pasar del nivel de conciencia individual a la conciencia colectiva de la situación y problemática de las masas. Precisar los objetivos inmediatos económicos, sociales y políticos que deben arrancarse, crear las bases de una movilización general que convierta a las masas en protagonistas de la historia y la lucha, que convierta a sus organizaciones propias en un modelo de democrácia [sic], en escuelas de socialismo. Y deben impulsar, defender y representar aquellos objetivos políticos unitarios de las masas explicitados en su propia lucha." ${ }^{654}$

653 Veure nota 643.

654[Document intern de la Organización Comunista de España-Bandera Roja]: "III 2ª parte. La 
Seguint orientacions com aquestes diferents grups polítics van tractar de tenir una major incidència en els Centres Socials. Això va provocar lluites dintre d'aquests per obtenir el seu control per fer proselitisme polític, i aquest fet va provocar la crisi i inacció d'alguns Centres davant la incomprensió de la resta de persones no militants d'organitzacions clandestines davant tant enfrontament ${ }^{655}$. Però això també va fer que el discurs que es feia des de les publicacions de determinats Centres fos cada vegada més explícit pel que feia a un contingut de classe crític amb el sistema capitalista i no només contra la dictadura. Així es pot observar una evolució en el llenguatge utilitzat, per exemple, al Centre Social Arrabal de Santa Rosa. El seu primer Butlletí Arrabal informava encara amb un llenguatge moderat de quina era la funció del Centre Social:

"El Centro Social es un intento de encuentro y diálogo sobre la vida en nuestro barrio. Un instrumento para todos aquellos que quieren mejorar la situación de las personas y la población. Es también un medio de encuentro para dar a conocer y despertar en nosotros, todo lo que interesa al bien común.

Se intenta conocer las realidades, sobre toda clase de situaciones, (vida de los niños, jóvenes, problemas de los padres, servicios que no son comunes, como escuelas, calles, parques infantiles...etc.) la verdad al ser conocida, muchas veces no gusta, e incluso incomoda, pero nos puede impulsar a transformarla mejorándola"656.

El mateix butlletí afirmava dos números més tard en un article referent a la joventut:

“MUCHO ANTES DE OBTENER EL DERECHO AL VOTO, LOS JÓVENES RECIBEN EL PODER DE COMPRAR.

Una afirmación que en España encuentra su máxima expresión; estudiando un poco en la postura del joven obrero español, se encuentra que la máxima necesidad que siente es la búsqueda de la "Felicidad Material" que lógicamente encontrará a través de una

organización del movimiento obrero y popular" [data indeterminada], CRAI-Pabelló de la República, Fons DDP (sèrie documents partits polítics), subsèrie Organización Comunista de España (Bandera Roja), Caixa DPP (OCE(Br)). 1, Carpeta 1-OCE(BR). Documents interns ([s.d.]), p. 12.

655OICE: "Historia movimientos populares en Barcelona. 9 Barrios" [1977], CEHI-Biblioteca Pavelló de la República, Fons DDP (Sèrie Documents Partits Polítics), Subsèrie Organización de Izquierda Comunista de España, Carpeta 3- Organización de Izquierda Comunista de España. Conferència Regional de Catalunya (1977), p. 1.

656 "Editorial" Arrabal. Boletín del Centro Social Arrabal de Santa Rosa núm. 1 (novembre 1972), AHMTB, Donació Marcelo López Ródenas, Caixa 3, Dossier 4: Centres Socials Singuerlín, Arrabal de Santa Rosa, p. 2. 
serie de caminos hechos y creados para ello, cuales son por ejemplo: el pluriempleo, horas extras, trabajo a destajos, etc. Pero cabe preguntarse ¿como encuentra el joven la felicidad a través de todas esas razones anteriores? Existe una sola explicación: consumiendo. Para poder consumir (tener felicidad material) el joven español sacrifica toda una serie de caminos que le conducirían al bienestar espiritual, como por ejemplo estar y convivir más con la familia, la adquisición de una mejor cultura o la participación en las tareas sociales y políticas auténticas." ${ }^{\text {"57 }}$

La crítica al sistema capitalista -encara velada- s'anirà fent més explícita en números posteriors. Segurament gràcies a la major implicació de persones conscienciades que estaven organitzades en les CCBB. Un altre exemple ho podem veure en un article que parla sobre les vacances -i no deu ser casual- després d'informar del conflicte obrer existent a Casadeport (una de les majors empreses tèxtils de Santa Coloma aleshores):

\footnotetext{
“Todo trabajador, después de ser explotado, durante todo el año necesita un poco de reposo, reunirse con la familia un corto tiempo y disfrutar con ella, aunque algunas familias no pueden ir fuera y se tienen que quedar en sus barrios.

Esto es debido a que durante todo el año no hay [sic] podido ahorrar una peseta por los horribles salarios que nos dan en las fábricas con los cuales no se puede mantener todo el año, por eso se pasan todos los dias haciendo horas extras e incluso hay personas que trabajan los domingos y aún así solo pueden ir 15 días de vacaciones." ${ }^{\prime 658}$
}

Tant important era aquesta configuració d'un "nosaltres", per la configuració d'una identitat pròpia en base a una consciència de classe -treballadora- i de barri -treballador-, com la d'un "ells", els que creaven aquestes condicions. Així mentre es fa ressò de les lluites i reivindicacions dels barris, s'assenyala als culpables. Un exemple ho tenim en un article de la mateixa publicació que analitza els mitjans de comunicació on apuntava clarament cap als "burgesos"659. Tot i que discrepo amb la famosa cita "una imatge val més que mil paraules", la portada de la primera publicació del Centre Social de Singuerlín també es prou explícita al respecte en

657E. Bayo: "La Juventud en nuestra sociedad", Arrabal. Boletín núm. 3 (gener-febrer 1973), AHMTB, Donació Marcelo López Ródenas, Caixa 2, Carpeta Centre Social Arrabal-Santa Rosa. 658 “Las Vaciones", Boletín Arrabal núm. 3 (setembre 1974) [es tracta d'una nova publicació, diferent de l'esmentada en notes anteriors tot i elaborar-se al mateix Centre Social], AHMTB, Donació Marcelo López Ródenas, Caixa 2, Carpeta Centre Social Arrabal-Santa Rosa. 659[Resum d'un cicle de xerrades sobre els mitjans de comunicació celebrat al Centre Social Arrabal-Santa Rosa], Boletín Centro Social Arrabal de Santa Rosa núm. 5 (novembre 1974), AHMTB, Donació Marcelo López Ródenas, Caixa 2, Carpeta Centre Social Arrabal-Santa Rosa, p. 5. 
identificar al empresari-capitalista com l'enemic:

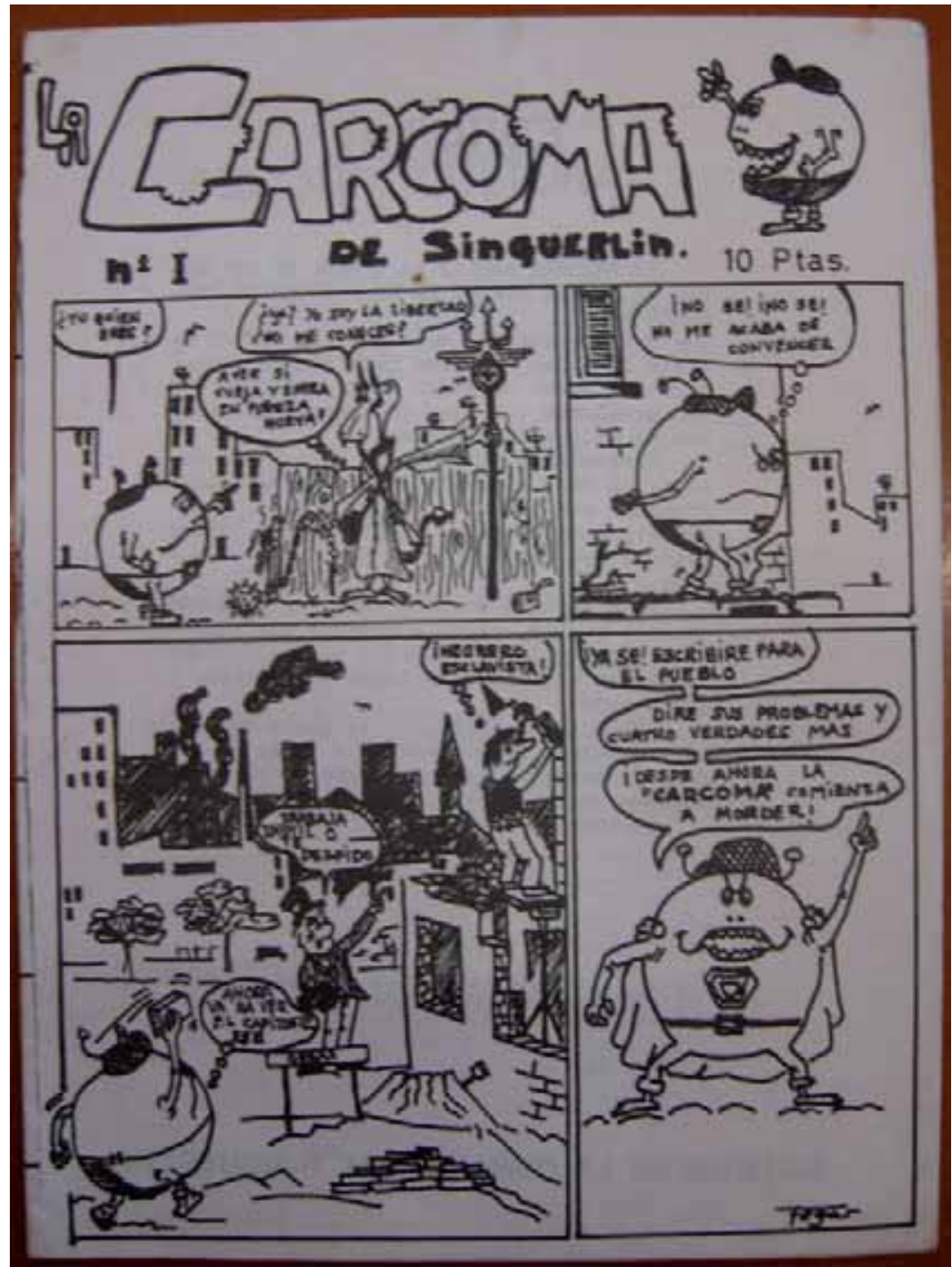

La Carcoma del Singuerlín núm. 1 [publicació de l'Obra Social del Singuerlín] [novembre-desembre? 1976], AHMTB, Donació Marcelo López Ródenas, Caixa 1.

I si podia quedar algun dubte, un article del mateix número acabava de recordar de quin tipus de barri era el que habitaven i la seva relació directa amb els problemes existents:

“En nuestro barrio de Singuerlín, al igual que en todos los barrios obreros, tenemos una serie de problemas que solamente se ven en esta clase de barrios"660

Per a continuació fer un llistat dels problemes i mancances més habituals existents: falta d'urbanització, d'asfaltat, d'enllumenat, d'escoles, de mercat, de zones verdes, d'equipaments socials i culturals... Es clar, que en aquest any, 1976,

660 “Barrio", La Carcoma del Singuerlín núm. 1 [publicació de l'Obra Social del Singuerlín] [novembre-desembre? 1976], AHMTB, Donació Marcelo López Ródenas, Caixa 1, p. 7-8. 
aquest llenguatge havia esdevingut l'hegemònic en uns Centres Socials de Santa Coloma amb una forta presència de les CCBB.

Les mateixes CCBB havien fet servir un llenguatge molt explícit sobre aquesta qüestió en la seva agitació. Ja havia existit el precedent de la lluita per l'ambulatori i l'experiència de la Comissió Unitària. Un document -ja esmentat- que analitzava la situació sanitària de Santa Coloma estava carregat d'un discurs de classe evident ${ }^{661}$. I malgrat que les fulles volants editades al voltant del conflicte intentaven centrarse en el cas concret de l'ambulatori, les mencions a la classe treballadora no faltaven:

"Hemos de seguir juntos porque este es el único método de que disponemos los trabajadores (No solo nosotros, los de Santa Coloma, sino los del resto de España) para los que nos roban el dinero no tengan otra salida que ceder y ceder y volver a ceder, mientras nosotros continuamos avanzando, igual que el martes, paso a paso sin dejar que nos separen, sin permitir que la guardia civil ni ningún otro elemento de la represión se lleve a ningún compañero."662

Aquest discurs serà més evident a les fulles volants fetes per les diferents CCBB implicades en les diferents lluites de Santa Coloma:

"En esta lucha participamos una gran parte de los trabajadores de Santa Coloma, demostrando una vez más la fuerza que tenemos cuando nos unimos. Nuestra unión es peligrosa para los intereses de los capitalistas, que viven de nuestro trabajo, por este motivo nos mandan a sus perros guardianes -la policia- para reprimir nuestra lucha y deshacer nuestra unidad, no lográndolo y viéndose obligados a "prometer" públicamente la ampliación de la carretera en el plazo de 5 a 6 meses." ${ }^{663}$

"En nuestra lucha contra los capitalistas -la clase que vive de nuestro trabajo- no hay lugar para las promesas y buenas "palabras". TODO LO QUE LES ARRANQUEMOS VA EN BENEFICIO NUESTRO Y EN PERJUICIO DE SUS INTERESES. Por lo tanto sólo con nuestra unión, que es nuestra fuerza, conseguiremos nuestras reivindicaciones y la

661Trabajadores de Santa Coloma de Gramanet: "Acerca de la Seguridad Social y de como se concreta en Santa Coloma de Gramanet" [desembre 1970-gener 1971?], AHMTB, Donació Marcelo López Ródenas, Caixa 3, Dossier 13 "Archivo Clandestino Comisiones en los Barrios".

662Trabajadores de Santa Coloma: "Vecinos de Santa Coloma", [full volant, febrer 1971], AHMTB, Donació Marcelo López Ródenas, Caixa 3, Dossier 13 "Archivo Clandestino Comisiones en los Barrios".

663Comisiones de barrio de Santa Coloma (C.B.): "A la clase obrera y al pueblo trabajador" [full volant] (desembre 1974), AHMTB, Donació Marcelo López Ródenas, Caixa 3, Dossier 3. 
victoria final contra la minoria explotadora." ${ }^{364}$

Aquestes van treure a partir de setembre de 1976 la seva pròpia publicació, Barrio Obrero, on el missatge revolucionari i favorable a la classe obrera impregnava tot el seu contingut i que es podia resumir amb una frase-eslògan: "Barrio Obrero: Una prensa de los obreros para los obreros" ${ }^{665}$. Més endavant analitzarem la postura d'aquesta publicació davant els esdeveniments de la transició, on va ser molt crítica. Però abans veurem també com va penetrar aquest discurs basat en una consciència de classe i de barri en les publicacions de les Associacions de Veïns.

En efecte, ens podria semblar en un primer moment que aquest llenguatge només era utilitzat en aquells espais on hi havia una presència de minories molt militants. Però amb l'aparició de unes Associacions de Veïns molt combatives i el fet d'estar legalitzades -com els Centres Socials-, ens permet també observar quin era el llenguatge que es feia servir en les seves publicacions. Pel que fa al discurs centrat en la classe treballadora i el barri (treballador) podem comprovar que aquest també existeix. L'entrada de gent jove en antigues Associacions o la creació d'altres de noves els hi van donar un nou impuls, una nova orientació, una nova voluntat de recollir la participació i la sensibilitat de la població dels barris on estaven situades. I aquests barris pioners van ser generalment els poblats per la classe treballadora i altres capes populars. Així per exemple es manifestava la publicació El Rollo Despertador, el primer número del butlletí de l'AVV Congrés (Badalona), la qual encetava la nova etapa:

“Una asociación de vecinos no es algo separado sino que debe ser EL VECINDARIO MISMO, por lo que los problemas del vecindario son los de la Asociación de Vecinos. Cuando un problema corre de boca en boca, de vecino a vecino, tiene que ser la asociación de vecinos quien lo resuelva. Asociación que organiza a través de la ASOCIACIÓN DE VECINOS debe defender su barrio con uñas y dientes, defenderlo de la polución, de la falta de escuelas y como en el caso del domingo 18, de la suciedad."666

664Comisiones de Barrios de Santa Coloma (C.B.): "Preparémonos para la Lucha" [full volant] (gener 1975), AHMTB, Donació Marcelo López Ródenas, Caixa 3, Dossier 3.

665Barrio Obrero, [publicació de les CCBB de Santa Coloma] núm. 2 (desembre 1976), AHMTB, Donació Marcelo López Ródenas, Caixa 1, p. 3.

666El Rollo Despertador. Boletín de la Asociación de Vecinos del Congreso, (juny 1975), AHMTB, Donació Marcelo López Ródenas, Caixa 1, p. 6. El president d'aquesta associació, Miguel Ordoñez, era aleshores militant del Bandra Roja, si bé als anys 80 es va acostar al PSC. Veure "Miguel 
La mateixa publicació afirmava, unes pàgines més endavant al voltant de la polèmica del port esportiu que alguns volien construir aleshores a Badalona i que va generar una forta oposició social:

\begin{abstract}
"Por lo que se ve, nuestra ciudad ya puede darse por satisfecha, pues posee numerosas escuelas, un sin número de parques y zonas verdes. En todos los barrios hay "hogares del Jubilado", brotan por doquier. Y no hablemos ya de las calles, que están todas asfaltadas y limpias. Además como en nuestros Barrios no hay enfermos ni niños pequeños, no son necesarios ni los hospitales ni las guarderias.

Y viendo así que todas nuestras necesidades están ya cubiertas, lo único que ahora nos falta es un puerto Deportivo, el más grande y esplendoroso de toda esta zona costera. Por lo tanto, solo nos queda comprarnos un yate y seremos completamente felices." ${ }^{667}$
\end{abstract}

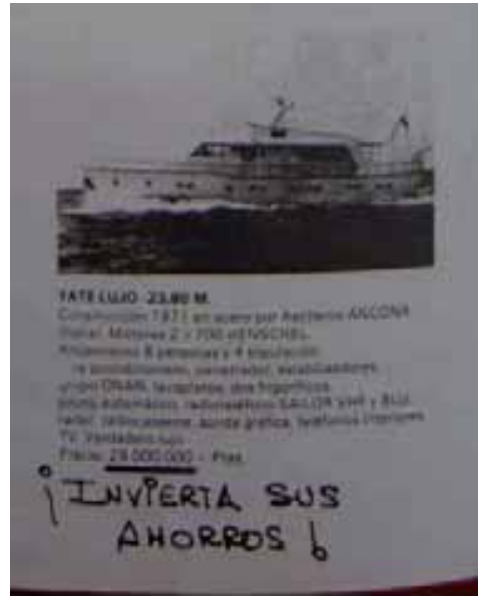

Les contínues referències al "barri obrer" són una constant en aquest tipus de premsa que apareix amb força al Barcelonès Nord als anys 1975-1976. Poso només alguns exemples més per que podria continuar fins a l'infinit. Però queda força clar que el moviment veïnal va tenir en els seus orígens un fort component obrerista en determinats barris i ciutats:

"Todos los "optimismos oficiales" caen por su propia base, cuando un visitante llega a nuestro barrio por primera vez. El abandono en que se encuentra la zona de Oliveras explica con toda claridad la afirmación que hacemos: ratas, basura, carencia de zonas verdes, bloques amontonados de viviendas, calles sin asfaltar...

Ordónez: El del Congreso", Eco Badalonés (18-11-1983), p. 26-27.

667Ídem, p. 12. La foto pertany al mateix article. Crec que és molt expressiu posar-la, tant com era en el mateix article original. Per fer-nos una idea i amb el risc de generalitzar massa, pensem que un habitatge d'aleshores al voltant dels $60 \mathrm{~m} 2$ en un barri obrer encara no superava el milió de pessetes i que la majoria de la gent ho pagava en lletres bancàries en uns 15-20 anys. 
Es el nuestro un barrio obrero, abandonado por la administración pública, pero lleno de ilusiones y esperanzas que los vecinos -con su esfuerzo y preocupación- saben mantener a toda costa.

Nosotros también somos ciudad y no nos resignamos al silencio. Es una lástima que en los barrios obreros siempre se caractericen por sus déficits en toda clase de servicios y equipamientos. En consecuencia, la lucha de clases no es un invento de seres resentidos, sino una realidad que se impone y que está ahí a la vista."668

"Teniendo en cuenta de que nuestra barriada hoy por hoy carece de casi todo (por no decir de todo) es necesario de que los vecinos tengan en su mano un instrumento ágil y hábil para agruparse en torno a él, para potenciarlo, para presionar en la solución de este o aquel problema que pueda agravar la buena habitabilidad a que toda persona tiene derecho.

Nos hacemos cargo que por ser un barrio obrero, los vecinos apenas tienen tiempo para poder preocuparnos por los problemas que más nos conciernen, por que nos vamos a las tantas de la mañana a trabajar y venimos a las tantas de la noche, sin tener apenas un hueco que nos permita convivir con el resto de los vecinos. Pero a pesar de esto y si nos queremos llamar personas tenemos que hacer por vencer estas dificultades, para ponernos al corriente de las cosas que pasan por delante de nosotros y que sabemos que si no las arreglamos entre todos no vendrá una mano todopoderosa y buena a arreglarlas." ${ }^{\prime 69}$

Des d'aquestes identitats de barri tant marcades, es va anar forjant, amb les lluites i amb el temps una identitat de ciutat -si bé això és un procés que s'inicia en aquest període i continua durant els anys següents-. A aquest fet van contribuir sens dubte la revista ja esmentada Grama, tractant les problemàtiques globals de la ciutat de Santa Coloma, també des de un punt de vista de classe i des de els barris més desfavorits, i on no s'escatimava el suport a les AVV's ${ }^{670}$. Aquest exemple va ser

668“Un barrio obrero: Oliveras”, La Oliva Indigesta núm. 42 [octubre? 1976], AHMTB, Donació Josep Mo Catà, Caixa 8, p. 5 .

669 “Para qué sirve la As.Ve.”, Ojo. Asociación de Vecinos Juan Valera núm. 1, Biblioteca de Ciències de la Comunicació de l'UAB, Dipòsit, RC 467.1/50, p. 3.

670Ja vam veure alguns dels primers articles de Grama dedicats als barris colomencs, així com el tractament de les problemàtiques i dèficits globals de la ciutat en el famós número 43-44 (juliol-agost 1972) "Santa Coloma en Peligro". El número següent (setembre 1972) l'article de F. Teixidor "Las Asociaciones de Vecinos" (p.15) esdevenia pioner en defensar la seva creació i en criticar les traves que es trobaven. Destacat va ser també l'article de José Olives "Movimientos reivindicativos en los barrios de Santa Coloma" al núm. 50 (febrer 1973) recollint les principals lluites d'aleshores. Les traves a la legalització de les AVV's colomenques van tornar a ser denunciades en J. Tudela "El difícil parto de nueve asociaciones" Grama núm. 73 (gener 1975, p. 9) i a l'editorial "Por fin Asociaciones de Vecinos" del núm. 76 (març 1975, p. 3). 
imitat al 1976 per una altra revista que no tant afortunada -no va arribar a l'any de vida- Comarca Exprés ${ }^{671}$.

En tots els exemples anteriors la crítica al sistema socio-econòmic vigent sembla evident, feta això si, amb un llenguatge més entenedor i accessible que el de les publicacions clandestines. Vull remarcar això per recordar que des de el moviment veïnal es va fer una profunda crítica al sistema capitalista i als valors que aquest fomentava, de manera que la qüestió "dels drets i del deute social esdevindria un argument bàsic per raonar la justícia de les reivindicacions del moviment veïnal", tal com ja va afirmar Ricard Martínez i Muntada ${ }^{672}$. En relació directa amb aquest fet la imatge de l'empresari en aquell període estava fortament qüestionada. Com ja s'ha comentat en pàgines anteriors, la identificació d'un enemic, un "ells", els responsables de la dura situació en que es vivia també era fonamental per forjar la pròpia identitat. En una època com l'actual on es parla sense embuts de "foment de l'emprenedoria" i "d'emprenedors" associats a valors "positius" ens pot sorprendre com eren de valorats negativament els empresaris aleshores. Aquesta idea ja havia estat expressada en treballs que remarcaven la complicitat evident de l'empresariat català amb el franquisme en tant havien estat els grans beneficiaris d'una dictadura que sempre havia tingut un clar component de classe ${ }^{673}$. I aquest fet era tan obvi i evident que la deslegitimació del franquisme dins les classes populars també era reflex d'aquesta percepció de la dictadura com, -entre d'altres coses- un instrument dels interessos empresarials ${ }^{674}$. Tot això es pot observar en la imatge de l'empresari reflectida en la premsa veïnal d'aleshores:

671Van editar-se només 14 números entre desembre de 1976 i juny de 1977, que es poden consultar a MB, Hemeroteca, Comarca Expres, Volums 21-7-4 i 21-7-5.

672Ricard Martínez i Muntada:"IV. Construint futurs. La dimensió anticapitalista del moviment veïnal" a Carme Molinero i Pere Ysàs: Construint la ciutat democràtica..., p. 267. Un article més recent sobre la mateixa qüestió és: "Movimiento vecinal, antifranquismo y anticapitalismo", Historia, Trabajo y Sociedad, núm. 2 (2011), p. 63-69. També cal destacar obres anteriors on ja va tractar aquesta qüestió: "Capítol III. El moviment veïnal en el tardofranquisme i la transició: conflicte, identitat obrera i valors alternatius" dins Enric Prat (coord.), Els moviments socials a la Catalunya contemporània, Publicacions i edicions de la Universitat de Barcelona, 2004 i en el seu treball de Programa de Doctorat El moviment veïnal a l'àrea metropolitana de Barcelona durant el tardofranquisme i la transició: el cas de Sabadell (1966-1976), Institut Universitari Vivens Vives de la Universitat Pompeu Fabra, Barcelona, juny de 1999.

673Veure per exemple Carme Molinero i Pere Ysàs: Els industrials catalans durant el franquisme, Eumo, Vic, 1991.

674Ricard Martínez i Muntada:"IV. Construint futurs. La dimensió anticapitalista del moviment veïnal” a Carme Molinero i Pere Ysàs: Construint la ciutat democràtica..., p. 280. 


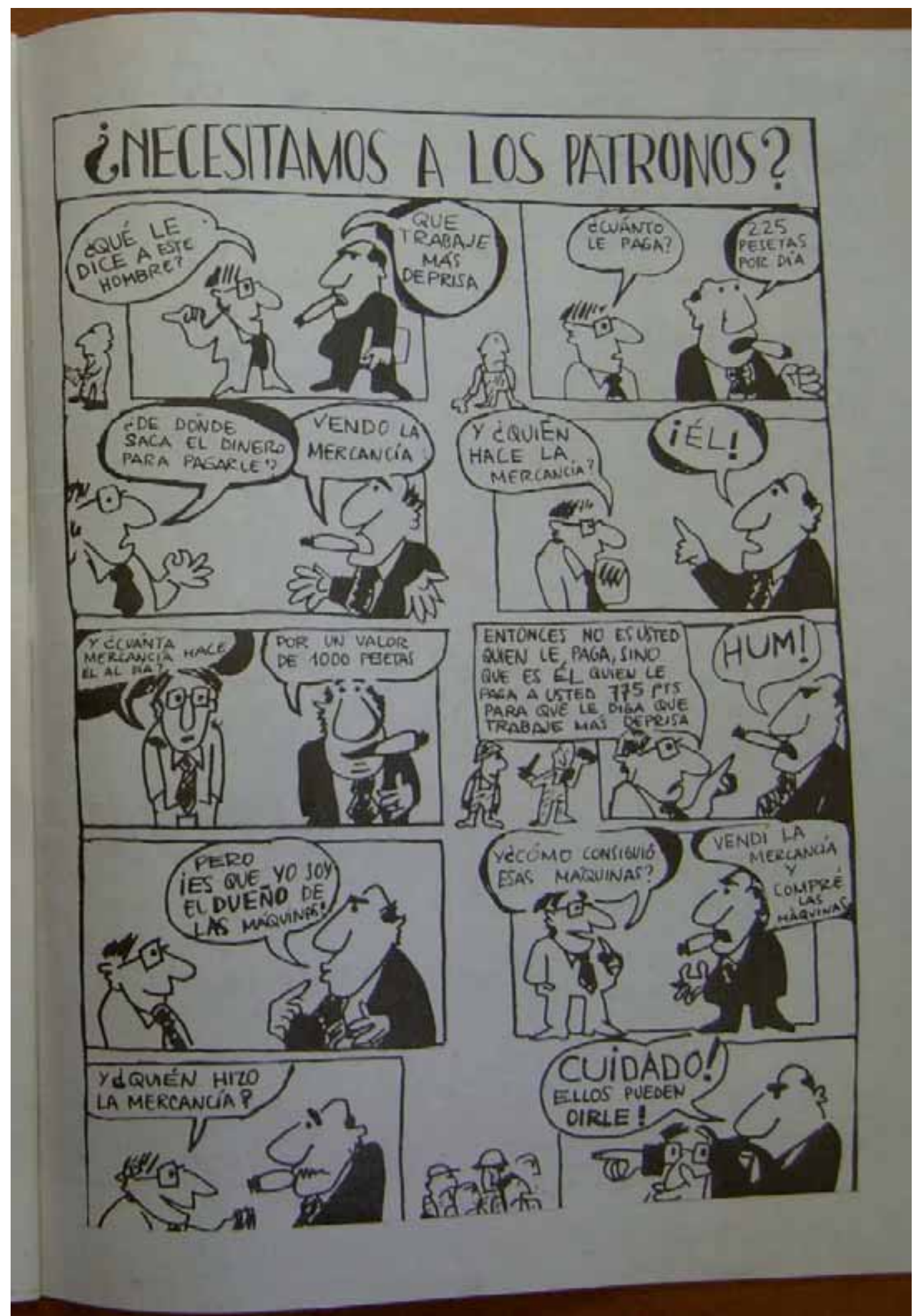

La Voz del Arrabal. Boletín de la Asociación de Vecinos de Arrabal, (març 1976), p. 12, AHMTB, Donació Josep Ma Catà, Caixa 2., p. 14. Aquesta Associació tenia una presència important de militants del MC, entre ells Josep Pitarque (el qual protagonitzarà un episodi important als anys 80 ).

Altra qüestió era si aquests valors eren assumits per totes les persones que es mobilitzaven, ja que aquesta mateixa població estava bombardejada per tota una altra sèrie de valors individualistes fomentats tant per la dictadura com pel sistema 
econòmic capitalista. Però el discurs que es feia servir en les publicacions era molt evident, en especial des de 1975 en endavant, quan el franquisme estava ja en una crisi evident i la contestació social estava molt estesa.

I aleshores, quina visió es transmetia del franquisme pel moviment veïnal? Hem de tenir present que en aquest període encara era perillós expressar públicament les opinions al respecte, i més des d'una entitat que no era clandestina. Així que les primeres manifestacions explícites en aquest sentit provindran d'organitzacions i organismes clandestins, ja fossin plataformes de masses o partits polítics:

“En los últimos tiempos estamos viviendo un poderoso movimiento de oposición al régimen que ha tomado cuerpo con fuerza insospechada, apoyado por el clamor popular de las capas trabajadoras, estudiantes, mujeres, sacerdotes e intelectuales.

Al frente de nuestro pueblo, en lucha por el restablecimiento de sus libertades y la democracia, estamos los trabajadores abriendo brechas con ejemplar batalla. (...) Las COMISIONES OBRERAS DE BADALONA I COMARCA, llaman a todo el pueblo a participar para que sea realidad la acción coordinada que nos permita ir a una HUELGA GENERAL que dé fin a la opresión y ponga en libertad a todos los españoles que hoy sufren prisión por el único delito de haberse alzado con fuerza para defender los intereses de sus compañeros y hermanos de clase, por su lucha por la democracia." ${ }^{675}$

La mateixa entitat deia posteriorment als fets del "Procés de Burgos":

"Una batalla ha sido ganada a la Dictadura Capitalista dominante representada por Franco. En esta batalla la clase obrera y todas las fuerzas democráticas del país han cercado al régimen, éste se ha visto obligado a anular las 9 penas de muerte que pesaban contra los seis luchadores vascos." ${ }^{\text {676 }}$

De fet, en la majoria de casos les fulles volants de les CCOO acabaven denunciant el context dictatorial existent, encara que el text en qüestió fes

675Comisiones Obreras de Badalona y Comarca: "Al pueblo de Badalona y su comarca ante el 1o de Mayo" (abril 1970) [full volant], ANC, Fons PSUC, 06. Context social i polític del partit, 06.02. Moviment Obrer, 06.02.01. Organitzacions de Treballadors, 1567 Comissions Obreres (CCOO) Badalona i comarca.

676Comisiones Obreras de Badalona y Comarca: "Trabajadores, pueblo de Badalona y Santa Coloma" (2 gener 1971) [full volant], ANC, Fons PSUC, 06. Context social i polític del partit, 06.02. Moviment obrer, 06.02.01. Organitzacions de Treballadors, 1567 Comissions Obreres (CCOO) Badalona i comarca. 
referència a un conflicte obrer o veïnal concret:

"Denunciamos la dictadura de Franco y Juan-Carlos como responsables de todos los males que aquejan a nuestro país, incluida dicha Ley, pagada por el Banco Mundial que controlan los americanos y que es la plataforma para colonizar técnicamente a España. Terminar con la dictadura fascista es acabar con todo ello."677

A mesura que s'acosti la fi de la dictadura i s'accentuï la seva crisi, les referències seran encara més directes, com les d'un full volant d'agost de 1974 titulat significativament "!No a la dictadura! !Ni Franco ni Juan Carlos!”"678.

Que feien organitzacions polítiques com el PSUC? Doncs per exemple, aprofitar conflictes veïnals per introduir el mateix missatge. Un full volant repartit al barri de Pomar en relació amb el conflicte dels lloguers dels habitatges de l'OSH establia el nexe entre les mancances del barri i la dictadura, així com la necessitat de revocar-la:

“Compañeros, el régimen de ladrones que está en el gobierno no sólo nos explota en nuestro trabajo diario sino que además nos estafa por medio de la Organización Sindical del Hogar hasta en nuestras propias casas.

Para acabar de una vez con la explotación de que somos objeto por parte del régimen de la dictadura es preciso defender todos unidos las reivindicaciones del barrio, las reivindicaciones de todos los trabajadores, así como la necesidad de imponer un Gobierno Provisional de amplia coalición que devuelva la palabra al pueblo como señala la Asamblea de Catalunya" ${ }^{\prime 679}$

Els mateixos GOA feien al·lusió a les llibertats perdudes per la instauració de la dictadura. Però no seran tan explícits com el PSUC en la reivindicació d'un govern provisional. Ells estaven més per iniciar un procés revolucionari que anés més enllà del que conceptuaven com a meres llibertats formals:

677Comisiones Obreras de Badalona y Comarca: “!!Los estudiantes contra la Ley de Educación!!” (febrer 1972) [full volant], ANC, Fons PSUC, 06. Context social i polític del partit, 06.02. Moviment obrer, 06.02.01. Organitzacions de Treballadors, 1567 Comissions Obreres (CCOO) Badalona i comarca.

678Comisiones Obreras de Badalona y Comarca: "INo a la dictadura! !Ni Franco ni Juan Carlos!" (agost 1974) [full volant], ANC, Fons PSUC, 06. Context social i polític del partit, 06.02. Moviment obrer, 06.02.01. Organitzacions de Treballadors, 1567 Comissions Obreres (CCOO) Badalona i comarca.

679 [Cel-lula Llibertat del PSUC (barri Pomar)]: “!!Vecinos de Pomar!!” [full volant de 1972], ANC, Fons PSUC, 03. Organitzacions de Base, 03.01. Organitzacions territorials, 818 Badalona: Cèl-lula Libertad del PSUC. 


\begin{abstract}
"En una sociedad capitalista los trabajadores solo salimos para burros de carga. Las decisiones las toman los burgueses a nuestras espaldas y el muerto lo cargamos los obreros. En España, desde 1939, en que fueran destruidas y aniquiladas todas nuestras organizaciones de clase y fuimos privados de las libertades más elementales (asociación, reunión, prensa, etc.), los patronos y los terratenientes han podido exprimirnos a sus anchas amparados en unas leyes para defender sus privilegios y aplican mediante el terror de su estado fascista bendecido por los obispos." ${ }^{\prime \prime 80}$
\end{abstract}

Els Centres Socials, en els seus inicis no podien ser tant explícits sense arriscar-se a la repressió. Per tant les crítiques al franquisme i les reivindicacions democràtiques hauran d'esperar cap els darrers anys. Serà en 1976, encara en dictadura però en un context molt diferent quan trobarem un discurs més clar des dels butlletins dels Centres Socials existents. Es poden veure recollides notícies d'actualitat com per exemple la manifestació per l'Amnistia Celebrada en Badalona el 29 de febrer ${ }^{681}$ (autoritzada pel Govern Civil, en contrast amb la prohibició i dura repressió de les fetes anteriorment a Barcelona els dies 1 i 8 de febrer i també amb la feta a Santa Coloma el dia 28 de març sense permís ${ }^{682}$ ). És a la ciutat colomenca -recordem la presència de sectors joves en aquests Centres Socials, que a Santa Coloma podien estar militant alhora en les CCBB- on trobarem les anàlisis més clarament crítiques amb el present polític, destacant, per exemple, les postures respecte el Referèndum per la Reforma Política, la impunitat dels atemptats feixistes...

"De nuevo se ha demostrado quienes son los verdaderos enemigos de la democracia y

la libertad: los fascistas y quienes permiten que sigan actuando impunemente." ${ }^{683}$

El Centre social de Can Mariner també expressava a través de la seva publicació els seus dubtes sobre el model de democràcia que s'estava propugnant des del reformisme franquista:

680 Grupos Autónomos de Barrio (Sta Coloma de Gramanet). "La lucha de Santa Coloma" [abrilmaig? 1971], AHMTB, Donació Marcelo López Ródenas, Caixa 3, Dossier 13 "Archivo Clandestino Comisiones de los Barrios (CC.BB.)", p. 2.

681“Badalona ¡Por la Amnistia!”, Pomar Convivència, núm. 14 (gener-febrer 1976), MBHemeroteca, Caixa 21-1-6, Carpeta "Pomar Convivència", p. 4 (contraportada).

682"Mas de 3.000 personas en la manifestación no autorizada”, Grama núm. 87 (abril 1976), p. 7.

683 “Editorial”, La Carcoma del Singuerlín núm. 2, [gener? 1977], AHMTB, Donació Marcelo López Ródenas, Caixa 1, p. 2. En el mateix número l'article "Ocurre" (p. 4-5) analitzava els esdeveniments més recents. 


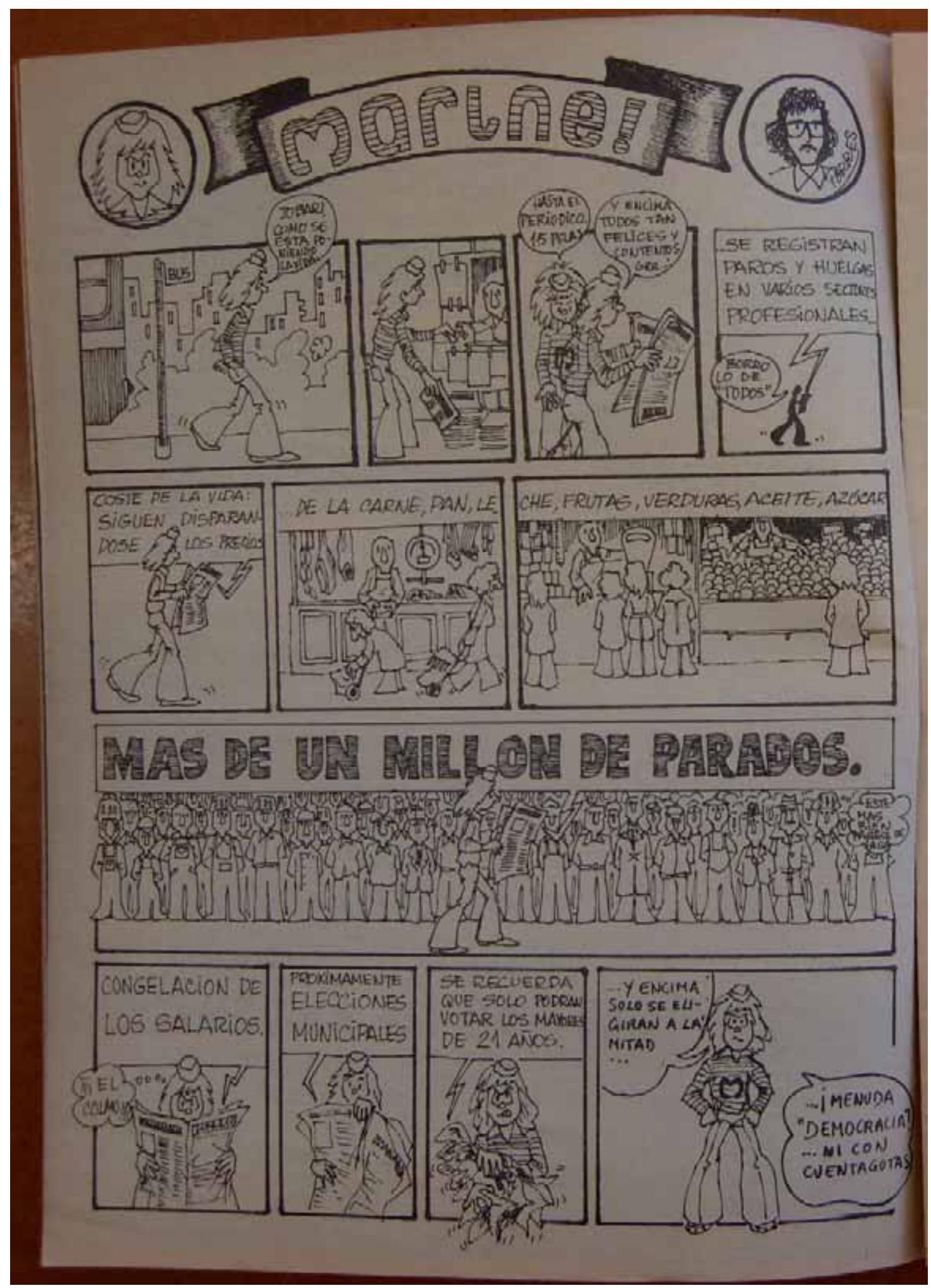

Marine. Can Mariner [número sense identificar estiu o tardor de 1976], AHMTB, Donació Marcelo López Ródenas, Caixa 1, p. 8.

El cas més evident el trobem en el butlletí del Centre Social Santa Rosa on ja es critica obertament l'entesa de sectors de l'oposició amb el govern de Suárez per 
acceptar uns mínims, un cop aquest va aconseguir la iniciativa política ${ }^{684}$ :

"Actualmente, con la democracia burguesa que nos ha dado el gobierno, son muchos los partidos de izquierdas que luchan primero la legalización; y en segundo el poder ganar votos; para tener más representantes en el Senado y las Cortes o Congreso; todos sus lemas de que la Clase Obrera es a la que representan y dan el oro y el moro, si los obreros votan a su partido, incluso partidos tan franquistas como Alianza Popular, van diciendo que defienden a los obreros, prometiendo toda clase de ayudas." ${ }^{\prime 65}$

1977 va representar el "cant del cigne" per les CCBB de Santa Coloma. Però abans havien expressat la seva opinió pels canals clandestins -certament més restringits-. Malgrat que, com en la lluita de l'Ambulatori, la seva propaganda intentava destacar els fets i lluites concretes. La crítica contra el capitalisme anava implícita... I contra la dictadura? El cert és que si ens guiéssim per la seva propaganda, pot semblar que facin més crítiques al capitalisme que no pas a aquesta. El fet que les CCBB propugnessin un canvi de model social d'una manera més intensa segurament ens podria donar aquesta impressió. Però això no volia dir -òbviament- que no es critiqués a la dictadura:

"Los capitalistas y su estado franquista no tienen suficiente con explotarnos en las fábricas, en los lugares de trabajo, sino que necesitan robarnos en el barrio también $(\ldots)^{686}$.

"Estamos en unos momentos en que el pueblo trabajador de toda España estamos demostrando con nuestras luchas que estamos hartos de la explotación a las que nos

684Més detalls sobre el procés de canvi polític a Carme Molinero (ed.): La Transición, treinta años después. De la dictadura a la instauración de la democracia, Península, Barcelona, 2006; Nicolás Sartorius i Alberto Sabio: El final de la dictadura. La conquista de la democracia en España, noviembre de 1975-junio de 1977, Temas de Hoy, Madrid, 2007; Pelai Pagès i Blanch: La Transició democràtica als Països Catalans : història i memòria, Universitat de València, València, 2005; Actes del Congrés la transició de la dictadura franquista a la democràcia, Barcelona, 20, 21 i 22 d'octubre de 2005, Centre d'Estudis sobre les Èpoques Franquista i Democràtica, Bellaterra, 2005 , Pere Ysàs (ed.): La Transició a Catalunya i Espanya, Fundació Doctor Lluís Vila d'Abadal, Barcelona, 1997. Al Capítol Primer cito més obres sobre el procés de canvi polític.

685 “Se lucha por la clase obrera?”, El Alba. Centro Santa Rosa núm. 8 [abril-maig-juny? 1977], AHMTB, Donació Marcelo López Ródenas, Caixa 1., p. 4. L'article acabava amb un efusiu “¡Viva la clase obrera!" en lletres grans. El mateix butlletí recollia en la seva portada i editorial les jornades de lluita per l'Amnistia a Euskadi, violentament reprimides. La facturació del butlletí és molt rudimentària i de baixa qualitat.

686Comisiones de barrio de Sta. Coloma [gener 1975]: "A todo el pueblo de Santa Coloma" [full volant], AHMTB, Donació Marcelo López Rodenas, Caixa 3, Dossier 3. 
someten los capitalistas hemos dicho basta a la falta de libertad (...)"687

"Nuestra lucha no es aislada, cientos de trabajadores han sido despedidos por mejoras [sic] un salario que se queda cada día más corto por las continuas subidas de precios, por exigir una auténtica representatividad obrera frente a la patronal y frente al sindicato fascista por exigir la liberta [sic] para el pueblo." ${ }^{.68}$

El mateix franquisme va ser analitzat dins dels seus documents interns de formació ${ }^{689}$. Ara bé, el que és evident és que la concepció de democràcia que tenien les CCBB no era la d'una democràcia liberal similar a la dels altres estats d'Europa Occidental, sinó una democràcia socialista o "obrera" (però sense estar inspirada en els estats de l'Europa Oriental, règims també molt criticats). Aquest fet es va posar més de rellevància l'any 1976, quan tot es va accelerar. El documentprograma del sector més "purista" de les CCBB colomenques era molt crític no només amb els "reformistes" provinents del franquisme, sinó amb altres sectors de l'oposició democràtica:

"Coinciden en aspectos de los que hemos tratado anteriormente, pero hay una diferencia fundamental, no parten de los intereses de clase del proletariado. Hablan de democracia, y están pensando en otros países capitalistas más avanzados. Hablan de libertad, y olvidan que la libertad los trabajadores la queremos para algo, propugnan ayuntamientos y gobiernos democráticos y se tapan los oídos cuando se habla de poder obrero, democracia obrera de las masas y sus organizaciones, independientes del capital, etc. Se escabuyen con argumentos "esto no lo entienden las masas" "esto no es política..." como si los trabajadores entendieran la alta política de pactos, concesiones y burocratismo que practican."${ }^{1690}$

Per això, seran extremadament crítiques amb la proposta dels Ajuntaments Democràtics que ja s'havia plantejat aleshores des d'altres sectors i les mateixes AVV's en el document “Salvemos Sta. Coloma! Manifiesto ciudadano de los 51”:

"Por tanto, ¿podremos considerar que la lucha por unos A.D. Está en la línea de esa

687 Comisiones de barrio de Sta. Coloma: "A la clase obrera y al pueblo trabajador de Santa Coloma" (gener 1975) [full volant], AHMTB, Donació Marcelo López Rodenas, Caixa 3, Dossier 3. 688Comisión de Barrio Centro: "A la clase obrera y al pueblo trabajador de Santa Coloma" (març 1975) [full volant], AHMTB, Donació Marcelo López Rodenas, Caixa 3, Dossier 3.

689CCBB: "El franquismo" (1976), AHMTB, Donació Marcelo López Ródenas, Caixa 3, Dossier 6, 690Comisiones de Barrio de Santa Coloma (c.b.): "Manifiesto" (setembre 1976), AHMTB, Donació Marcelo López Ródenas, Caixa 1, p. 3-4. (apartat "Sobre la política "democrática" de los reformistas"). 
conclusión?, es decir, ¿luchar por unos A.D. es dotar a los trabajadores de formas organizativas que permiten alcanzar nuestros objetivos? Rotundamente NO, porque antes que poner en duda el carácter democrático o antidemocrático de un órgano de poder como es el ayuntamiento habremos de poner en duda el carácter de clase de ese órgano de poder. Y sobre esto no hay confusiones, un ayuntamiento en el capitalismo por más democrático que sea es un ayuntamiento burgues [sic], es decir sirve a los intereses de la clase dominante, se doblega a sus directrices, independientemente de los "personajes" que en ese momento lleven la gestión burocrática de ese órgano.

Por todo ello valoramos que los trabajadores como explotados no tenemos ningún papel en esos A.D., los únicos beneficiados serán los que buscan algún modo de pactar con la burguesiía [sic] y aunque digan que estarían por satisfacer las reivindicaciones de los trabajadores se quedarán en eso; en las reivindicaciones que permite el marco del capitalismo.

Estamos en contra por lo tanto con la participación en las elecciones municipales que prepara el gobierno y las cuales hemos de propugnar el BOICOT TOTAL." ${ }^{691}$

No obstant, existien matisos fets des l'altre sector de les CCBB colomenques. Santa Rosa, per exemple, havia fet anteriorment un document per a debatre i elaborar una alternativa des de les CCBB a l'aparició de la reivindicació dels Ajuntaments Democràtics. En aquest no es parlava explícitament de boicot a unes eleccions municipals. Si que en canvi s'apostava pel socialisme, per una democràcia radical, basada en els barris, en l'assemblearisme i en la revocabilitat dels càrrecs, lligada a un programa de reivindicacions concretes que poguessin ser assumits per sectors amplis de població a les quals s'havia de conscienciar de que l'Ajuntament Democràtic, per si sol, no podria resoldre la majoria dels seus problemes en una societat capitalista. El llenguatge que es feia servir era menys "sectari" i el nivell de concreció de les reivindicacions concretes fins i tot major ${ }^{692}$.

En contrast en aquest període -1975 i sobretot 1976- moltes AVV's faran campanya per uns Ajuntaments Democràtics. Com s'havia arribat fins aquí? Les Associacions de Veïns que van agafar un tarannà reivindicatiu i que s'estaven foguejant en nombroses lluites al carrer, no van trigar gaire a relacionar els dèficits dels barris amb l'existència d'un règim dictatorial. Internament això estava 691Comisiones de Barrio de Santa Coloma (c.b.): “Manifiesto" (setembre 1976), AHMTB, Donació Marcelo López Ródenas, Caixa 1, p. 4-5.

692Comisión de Barrio de Santa Rosa: "La Comisión de Barrio ante la Altenativa de AD" [data desconeguda, segurament de 1976], AHMTB, Donació Mn. Josep Catà, Caixa 2. 
clarament assumit des de feia molt de temps i més pels grups de persones més polititzades. Però en un context dictatorial on les crítiques al règim estaven severament sancionades, era més arriscat expressar aquestes opinions en butlletins i revistes públiques. Els segrestos i sancions de mitjans de comunicació tan comuns en aquell període en són un clar exemple. Tanmateix, ben aviat la dinàmica de la lluita va superar aquestes restriccions legals i repressives. A Santa Coloma de Gramenet les crítiques a l'administració franquista i a la seva expressió local van ser cada vegada més evidents. El butlletí La Voz del Arrabal ja ho anticipava el mes d'octubre de 1975, amb el dictador encara -per poc- viu:

"Muy claro tenemos hoy los vecinos del Arrabal que los graves problemas que tiene Santa Coloma no serán solucionados por aquellos que no necesitan del voto del pueblo para llegar a cargos municipales." ${ }^{693}$

La plasmació de la reivindicació dels Ajuntaments Democràtics va ser el document “¡Salvemos Sta. Coloma! Manifiesto Ciudadano de los 51”, elaborat per un conjunt d'entitats colomenques -on destacaven les AVV's- el mes de novembre de 1975:

"El divorcio entre el Ayuntamiento y el pueblo en Sta. Coloma es la causa de la acumulación de problemas y de la tendencia a agravarse.

En efecto: la especulación del suelo, la acción de las grandes compañías inmobiliarias han hecho en Sta. Coloma esta monstruosa ciudad dormitorio. Esto ha sido posible por la complicidad de una serie de consistorios que se han inhibido del proceso, que no han sabido preveer las necesidades, que no han tenido la suficiente fuerza para oponerse a los intereses privados. En efecto, un Ayuntamiento que no ha sido elegido por el pueblo, que depende de los que le han nombrado solo representa los intereses de una minoria. Solamente un AYUNTAMIENTO DEMOCRÁTICO que haya de responder de su actuación ante la población responderá a los intereses generales de la población, y podrá con esa autoridad popular enfrentarse a los intereses creados." ${ }^{694}$

693 La Voz del Arrabal. Boletín Informativo de la Asociación de Vecinos de Arrabal (octubre 1975). "Editorial: Ayuntamientos Democráticos", AHMTB, Donació Mn. Josep Catà, Caixa 2, p. 2.

694 “Salvemos Sta. Coloma! Manifiesto Ciudadano de los 51”, ANC, Fons PSUC, 2392, Santa Coloma de Gramenet, 1970-1975, p. 7. El nom prové de que va ser signat per 51 persones representatives de nombroses entitats: els Presidents de les AVV's d'Arrabal, Santa Rosa, Centre, Oliveres, Riu i Singuerlín; dels Centres Socials Arrabal i Amigos del Fondo; de les AMPAS del col-legi Joan XXIII, del Centre Preescolar Santa Rosa; pels President/a de l'Escola Activa de Pares i de l'Associació de Mestresses de Casa del Singuerlín; per varis professors de l'Institut Puig Castellar; pel Director i redactors de Grama; pel President de la Unión Deportiva Obreros; pel President i Vicepresident de la UTT del Sindicat Mixt de Santa Coloma i el President de l'Agrupació Elèctrica Comarcal; per diversos professionals, comerciants, sacerdots, llibreters, 
Aquesta reivindicació va ser recollida per la popular revista Grama, en el mateix número on un Editorial parlava clarament de l'Amnistia i el restabliment de les llibertats més elementals ${ }^{695}$. Ara bé, la concepció de "Ajuntament Democràtic" podia anar molt més enllà d'un simple consistori escollit per sufragi universal, en el plantejament d'alguns col-lectius, com ens ho demostren aquestes paraules de l'AVV Santa Rosa davant la pantomima "d'eleccions" a alcalde que es van fer al Gener de 1976, en el marc de la "reforma Fraga"696.

"Ya dentro de las elecciones, bien de concejales o de alcaldes, se haría necesario un control directo de los vecinos de las votaciones. También como contrapartida a los lugares y maneras de votar; en los barrios con las Asociaciones, y haciendo asambleas de vecinos, debíamos efectuar nuestra elección de candidatos. Aquí no se correría el peligro de no conocerlos. Debemos pensar también que los elegidos siempre sean revocables, pues los resultados de su trabajo son los que le afincarían en el cargo. Y por supuesto, que este no fuera perenne." ${ }^{\prime 67}$

Les semblances entre aquestes afirmacions fetes per l'Associació de Veïns i les expressades per la Comissió de Barri de Santa Rosa no eren pas casuals, car els membres de la CCBB hi participaven en la primera entitat. En altres Associacions en canvi aquestes referències no seran tant explícites, si és que realment pensaven el mateix:

"Lo malo del caso es que seguiremos con este estado de cosas mientras el pueblo con la papeleta en la mano no pueda votar a sus verdaderos representantes, que cuenten siempre con la decisión de sus representados en todo lo que pueda repercutir en el futuro de nuestra ciudad." ${ }^{698}$

mestres... inclús per un ex-regidor i un ex-tinent d'alcalde de l'ajuntament colomenc. Es va editar també una edició més resumida que es pot veure a AHMTB, Donació Mn. Josep Catà, Caixa 2.

695 Mariano Álvarez: "Al no de los 11 contestan los 51" Grama núm. 84 (desembre 1975), p. 14. L'Editorial del mateix número tenia el clarificador títol "El futuro que queremos".

696Més informació sobre els intents de reforma de l'administració local a les darreries de la dictadura a Martí Marín: Els Ajuntaments franquistes a Catalunya, p. 416-423.

697 “Elecciones a Alcalde: CACA”, Pimienta. Boletín de la Asociación de Vecinos de Santa Rosa , núm. 3 [gener? 1976], AHMTB, Donació Marcelo López Ródenas, Caixa 1, p. 6-7.

698 “Editorial. Ayuntamientos democráticos", Ojo, Asociación de Vecinos Juan Valera. Barrio de La Salud. Badalona, núm. 2 [febrer o març? De 1976], Biblioteca de Ciències de la Comunicació de l'UAB, Dipòsit, RC 467.1/50, p. 2. El subratllat és original. Aquesta associació estava més controlada per militants del PSUC, com el seu president i futur regidor, Manuel Armentero. 
En el que si que van coincidir més clarament tant AVV's com CCBB's (sense oblidar que van ser les primeres les que es van acabar imposant al 1975-77) és en un punt que anava lligat a la crítica de la dictadura: la reivindicació de l'Amnistia pels presos polítics. Les referències a aquesta reivindicació tan elemental seran constants, i més quan entre dels detinguts hi hagi sovint membres d'aquest tipus d'entitats, que a la vegada havien participat en les convocatòries fetes al respecte, ja fossin fetes al marge de la legalitat i reprimides, legalitzades o "tolerades". Un exemple del seu reflex a la premsa veïnal serà l'editorial de La Voz del Arrabal del mes de juliol de 1976 amb l'expressiu títol “Clamor de Amnistia”. 699

Fins el moment he tractat uns temes que -paral-lelament a les mobilitzacions i les lluites- he considerat fonamentals pel desenvolupament del moviment veïnal: la consciència de barri, de classe (i posteriorment de ciutat), l'antifranquisme i la reivindicació de la democràcia, del socialisme i l'amnistia. Aquests es continuaran treballant en l'etapa posterior però ja eren ben visibles a la mort del dictador. No obstant, no volia deixar d'esmentar uns altres temes també molt importants i que es van començar a projectar dins el moviment popular en aquest període, malgrat que el seu desenvolupament més intens fos en gran part ja durant el procés de canvi polític.

Un serà el paper de la dona dins la societat, que començarà a ser treballat dins el moviment veïnal, precedint l'esclat del moviment feminista. La qüestió de la problemàtica de la discriminació de la dona s'havia començat a plantejar tímidament als anys seixanta a revistes com Albada $^{700}$, o fins i tot en la JOC. El protagonisme femení en les primeres mobilitzacions que es van donar en aquesta dècada va ser certament notable. La divisió sexual del treball i l'assignació a les dones del treball domèstic i de cura i recuperació "de la força productiva" va fer que les dones estiguessin més temps en aquells barris mancats de tots els serveis. Però poc a poc es van anar produint canvis, ja fos per la participació de dones més

699 “Clamor de Amnistia”, La Voz del Arrabal, (juliol 1976), AHMTB, Donació Mn. Josep Catà, Caixa 2, p. 2.

700 Albada núm. 2 (III època), (15-11-1961). Aquest número era un monogràfic dedicat a la dona arran la promulgació de la nova "Ley sobre los derechos políticos, profesionales y de trabajo de la mujer" ("Ley 22 de julio num. 56/61 de la Jefatura del Estado") . Tot i ser una publicació del Círculo Católico de Badalona, diversos articles critiquen obertament la visió masclista de la societat i la subordinació de la dona a l'home. Veure a MB-Hemeroteca, Caixa 21-1-1, Carpeta "Revista Albada. Anys 1961,1962,1963,1964,1966". 
conscienciades dels barris -militants de partits polítics o no- o de les que no ho estaven tant mitjançant la lluita. És cert que inicialment els rols assignats a cada gènere es solien repetir fins $\mathrm{i}$ tot en les mobilitzacions veïnals quan per exemple eren les dones les que es mobilitzaven per mercats, parcs infantils i escoles o quan se les feia servir per fer determinades accions -com per exemple el segrest d'autobusos o algunes manifestacions- esperant que obtindrien algun avantatge del fet de ser dones.

Als primers Centres Socials ja es van promoure grups de dones. Un exemple va ser la "Sección de Señoras" del Centre Social de Pomar (Badalona). També des del Centro Social Santa Rosa es feien crides a les dones a participar, si bé inicialment es queia en la repetició de rols tradicionals per intentar atreure's a les dones menys polititzades i més alienades:

“El Centro Social también está para tí. No solo es para la juventud, o para los hombres, sinó también para tí. A trabés [sic] de él podéis adquirir nuevos conocimientos de cosas que os interesan: vuestros hijos, el hogar, etc. Podríamos juntas hablar de aquellas cosas que os preocupan y a través de aquí encontrarás nuevos caminos, nuevas cosas que realizar en el Centro y que estuvieran dedicadas a vosotras. Por ejemplo: clases de hogar, puericultura, etc."701

Certament el nivell de masclisme que impregnava la societat era encara molt gran, com ens ho mostra aquest exemple explicat per una militant veïnal d'aleshores:

“Dons jo recordo... clar, a la hora que jo anava a cobrar la quota era a partir de les 6 de la tarda (...). Pues moltes vegades anaves a cobrar la quota i sortia la dona i 'no, no, esto es cosa de mi marido' (...). Tu anaves repartint fulls pel barri pues explicant... que es fes una escola o una propaganda com Associació de Veïns, anaves a un matrimoni i anaves a donar-li un full a la dona que a lo millor era per invitar-la a una xerrada i l'altre deia 'no, no, que l'agafi el meu marit'."702

Però en pocs anys el debat al voltant sobre la discriminació de la dona es va accentuar. Així, per exemple, el butlletí del Centre Social Can Mariner dedicava una

701 “Editorial: Para ti mujer”, Arrabal, núm. 3 (gener-febrer 1973), AHMTB, Donació Marcelo López Ródenas, Caixa 2, Carpeta Centro Social Arrabal-Santa Rosa.

702Entrevista a Ma Elvira Ruiz García, 7-6-2013. Mestra al Camp de la Bota, militant del MC, de l'AVV del Raval i fundadora del Casal de la Dona a Santa Coloma. 
enquesta a la discriminació de la dona jove i mencionava dos temes tabú fins aleshores: els anticonceptius i l'avortament ${ }^{703}$.

Per la seva banda, les CCBB no van destacar als seus inicis per tractar aquest tema en la seva agitació. En canvi si ho va fer en la seva formació interna en períodes posteriors com ho demostra el document "La emancipación de la mujer" de l'any 1976:

\begin{abstract}
"Teniendo en cuenta que en la mujer concurre una doble alienación: como persona situada en una sociedad alienadora y como mujer utilizada como objeto por el hombre, su incorporación al trabajo solo puede liberarla de la alienación que le es propia como mujer, al equipararse al hombre en la participación económica y superar la tutela proteccionista de este, pero la mujer no puede, como no puede el hombre, librarse mediante el trabajo de su total alienación. La liberación total no va por otro camino que el de la superación de la sociedad clasista, que por clasista es alienadora." 704
\end{abstract}

\title{
A les Associacions de Veïns van existir les Vocalies de Dones ${ }^{705}$ (o de
} mestresses de casa). Aquestes van encetar la tasca d'implicar les dones en les reivindicacions als barris:

“(...) lo que fue muy importante fue la incorporación de la mujer, que hasta entonces había muy poca participación de la mujer, de la mujer más sencilla, no te hablo de la mujer politizada sino de las mujeres sencillas del barrio, que eran la esposa del currante, que solo trabajaba en casa o que como mucho salían a hacer faenas. Esa mujer tomó conciencia de que era importante también su participación, sobretodo en el tema de las escuelas, y fuimos capaces de sacar a las mujeres de su casa, a manifestaciones con las mujeres por la mañana"706

Com als Centres, inicialment es va recórrer als temes tradicionalment considerats "de dones" per atreure-les i mobilitzar-les: la carestia de la vida, les

703“Discriminación y emancipación de la mujer joven. Encuesta”, Marine núm. 5 (desembre 1976), AHMTB, Donació Marcelo López Ródenas, Caixa 1, p. 5-6.

704Equipo de coloquios CCBB. Grupo Juventud C.b.C. [1976]: "La emancipación de la mujer", AHMTB, Donació Marcelo López Ródenas, Caixa 3, p. 3.

705Veure l'estudi al respecte de Eva Fernàndez Lamelas: Vocalies de Dones de Barcelona a la Transició Democràtica: una experiència emancipadora. Tesina de doctorado. Universitat Autònoma de Barcelona, Cerdanyola del Vallès, 2009. Actualment té una Tesi Doctoral en curs titulada El feminisme de les classes populars als barris. Vocalies i grups de dones (1975-1990).

706Entrevista a Ma Reyes Bellido Jaime, 24-5-2006. José Miguel Cuesta Gómez: El moviment veïnal a Llefià..., p. 174-175. 
escoles, els mercats... Però aviat el discurs es va anar fent més crític i reivindicatiu davant la discriminació de la dona. Amb l'excusa de que l'any 1975 va ser proclamant "any de la dona" per l'ONU, de seguida van proliferar articles que denunciaven aquesta situació. El butlletí Pimienta, de l'AVV de Santa Rosa al seu primer número ja afirmava:

"Las mujeres hemos sido educadas, no como elementos activos que han de desarrollar un trabajo social, sino como "mujeres", en el sentido parcial de la palabra, no nos es nada fácil la convivencia en nuestra sociedad por la cantidad de marginaciones a las que somos sometidas; sin embargo, tenemos que hacer todo lo que esté en nuestras manos para no sentirnos al margen del desarrollo y la evolución de la sociedad."707

Dos números més endavant, al mateix butlletí l'article "Mujer y Trabajo" criticava obertament la discriminació laboral de la dona i demanava la seva supressió $^{708}$ i tres números més tard tractaven sobre els anticonceptius ${ }^{709}$. Ben aviat van aparèixer seccions a les revistes de les AVV's, com l'anomenada "Las Leyes discriminan a la Mujer" del butlletí La Voz del Arrabal, que s'encarregava de recordar les discriminacions vigents en la legislació d'aleshores en temes com la pàtria potestat o l'existència dels "delictes de la dona" com l'adulteri ${ }^{710}$. L'existència de casos reals i punyents com el de Maa Ángeles Muñoz del Barri Besòs de Sant Adrià -denunciada al 1976 a l'empara d'aquest precepte legal- van ser tractats i denunciats des d'aquesta sección ${ }^{711}$. L'eclosió de les reivindicacions feministes i el seu nou espai dins el moviment veïnal es va accentuar amb les I

707 “Tribuna libre-cartas a la redacción. La educación de la mujer en España”, Pimienta. Boletín de la Asociación de Vecinos de Santa Rosa núm. 1 (juny-juliol 1975), AHMTB, Donació Marcelo López Ródenas, Caixa 1, p. 10.

708 “Mujer y Trabajo", Pimienta. Boletín de la Asociación de Vecinos de Santa Rosa núm. 3 [setembreoctubre? 1975], AHMTB, Donació Marcelo López Ródenas, Caixa 1, p. 10.

709 “Anticonceptivos", Pimienta. Notícias internas de la Asociación de Vecinos de Santa Rosa núm. 6 [desembre? 1976], AHMTB, Donació Marcelo López Ródenas, Caixa 1, p. 6-7.

710 “Las Leyes Discriminan a la Mujer”, La Voz del Arrabal. Boletín informativo de la Asociación de Vecinos del Arrabal , (octubre 1976), AHMTB, Dona ció Mn. Josep Catà, Caixa 2, p. 7.

711 “Las Leyes Discriminan a la Mujer", La Voz del Arrabal. Boletín informativo de la Asociación de Vecinos del Arrabal, (desembre 1976), AHMTB, Donació Marcelo López Ródenas, Caixa 1. El cas de $M^{a}$ Angeles Muñoz va ser molt conegut aleshores i va comportar nombroses mobilitzacions. Es tractava d'una dona que havia estat abandonada pel seu marit quan s'havia quedat embarassada. Anys després aquest la va denunciar per adulteri pel fet de tenir relacions amb un altre home i volia treure-li la custòdia de la filla (amb l'excusa de la Pàtria potestat) però no per fer-se'n càrrec ell, sinó per entregar-la als seus pares. Mํㅡㄹ Angeles es va negar a entregar-li la filla a un pare que no s'havia preocupat per ella durant anys i des de les Vocalies de les AVV's i altres grups feministes es van iniciar unes mobilitzacions en el seu suport i per denunciar la discriminació legal de la dona. 
Jornades Catalanes de la Dona celebrades els dies 27 al 30 de maig de 1976, que van suposar un autèntic revulsiu per a moltes joves militants:

"Vaig anar a les Jornades i les que van anar van ser 'això és lo meu, eh?, això és lo meu'. Jo estigué pensant en l'antifranquisme que la classe obrera no se què i tal... però jo no sóc classe obrera però si que soc una dona, surt allà lo de la opressió de la dona... Carai! Eso és lo que jo sé, jo que jo estic vivint, no? I vaig tenir la sort de la direcció del MC en general però en Catalunya hi havia dones molt potents, com l'Empar Pineda, com Marisol, com (...) algunes dones potents que de seguida....'això, tenim que crear com una estructura de dones'. Es que al marge del que seria l'estructura regular, de cèl-lules, comitè i tal. Una estructura de... això va ser, ja havia mort Franco, no calia aquella estanqueidad en cèl·lules (...) I vam crear una estructura de dones. Vam veure que era important que les dones estiguessin soles sense homes per discutir com veien la opressió de la dona... Pues es van fer des de Assemblees de territori petit hasta Assemblees Generals de totes les dones de Catalunya... es veien un dissabte al matí per discutir o per parlar de tot. Des de com havien viscut la sexualitat a com pensaven fer tenir les relacions amb els companys de partit, si el partit havia fet discriminació a les dones... Totes això va ser tot un procés molt interessant de concienciación y valoración de les dones. I yo creo que eso hace que tot el partit en el seu conjunt, sobretot totes les dones, evolucionessin de manera uniforme. Cosa que en els altres partits, era una cosa a títol individual.

Por ejemplo la Alicia [Alicia Ruzafa, presidenta de l'Associació de Mestresses de Casa del Singuerlín i del PSUC] va anar a les Jornades Catalanes de la Dona i l'Alicia va tenir molt clar que s'havien de canviar el nom de 'Amas de casa' i passar-se a dir... però el PSUC no ho veia així... La Montserrat Roig tenia claríssim el tema de les dones, però no el PSUC. Va costar uns anys el que els partits assumissin el tema de la dona. Primer havia aquesta idea de que les reivindicacions de dones eren reivindicacions burgeses, que lo prioritario era acabar con el fascismo... la típica història que ha passat sempre, no? Que això és important però 'primero haremos la revolución socialista y después (...) podremos soluccionar la contradicción hombre-mujer'. (...) No, no... nosaltres ho volem fer ara, no volem esperar (...). Volem reivindicar la democràcia però també el aborto (...)." ${ }^{\prime 12}$

712Entrevista a Mํㅡㄹ Elvira Ruiz, 7-6-2013. 


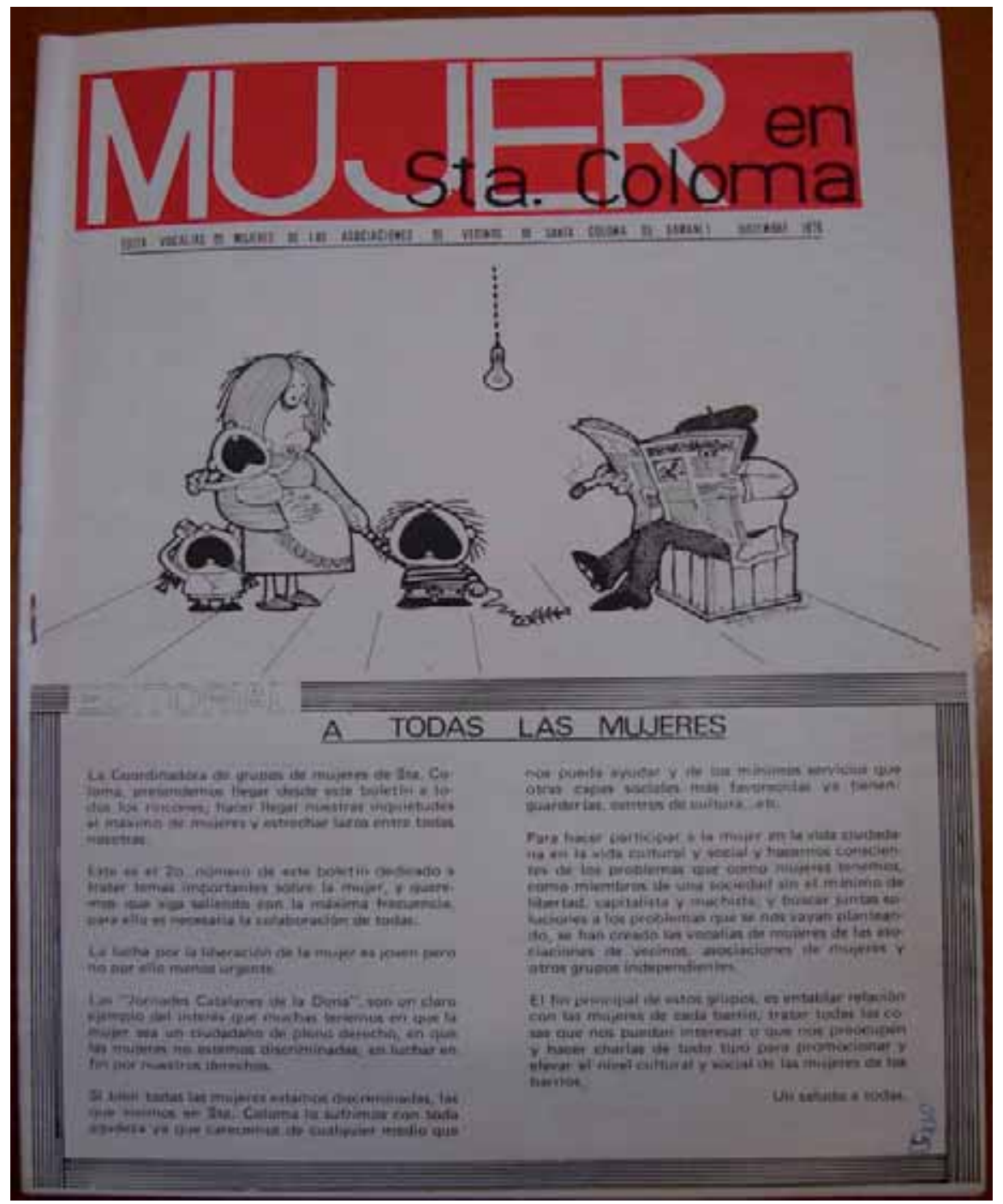

Mujer en Santa Coloma núm. 1, AHMTB, Donació Mn. Josep Catà, Caixa 2.

Així a Santa Coloma s'editava un monogràfic sobre la dona a càrrec de les Vocalies de Dones de les AVV"s i l'Associació de Mestresses de Casa de Singuerlín ${ }^{713}$, i poc després les mateixes editaven la revista Mujer en Santa Coloma. Anys després i fruit d'intensos debats les militants feministes més conscienciades crearien el Casal de la Dona a Santa Coloma. Mentrestant revistes tant conegudes com Butifarra! també editaven monogràfics sobre la discriminació de la dona amb uns còmics que seran àmpliament reproduïts per la premsa veïnal ${ }^{714}$. La revista

713 [Vocalies de dones de les AVV's i Asociación de Mestresses de Casa del Singuerlín]: Mujer en Santa Coloma. (1976), AHMTB, Donació Marcelo López Ródenas, Caixa 1. L'Associació de Mestresses de Casa de Singuerlín va ser una organització potent on va destacar una militant del PSUC, Alicia Ruzafa, companya d'un altre històric del barri: Eloy Jurado.

714Butifarra! [monogràfic dedicat a la dona, 1976], AHMTB, Donació Mn. Josep Catà, Caixa 2. Aquesta publicació satírica de còmics es va iniciar al juny de 1975 sota l'empara del col-lectiu 
Grama també va tractar aquesta qüestió en nombrosos articles ${ }^{715}$. No es pot entendre l'eclosió del moviment feminista posterior sense aquesta primera fase desenvolupada dins el moviment popular ciutadà.

De fet, els temes que van ser tractats des de la perspectiva veïnal son molts i variats. Alguns podien ser molt evidents com a conseqüència de les mateixes lluites que es van desenvolupar. Uns exemples serien tots els temes relacionats amb la carestia de la vida -davant el continu augment de preus i els minsos salaris existents- i l'ensenyament. De la reivindicació elemental de la construcció d'escoles, tema que va ser una constant dins el moviment veïnal es va passar al debat sobre els models educatius i pedagògics ja des de ben aviat:

"Al contrario de lo que podríamos creer, la educación no es un obsequio que el Gobierno entrega a sus súbditos, sino que, en la forma que hoy la recibimos es el resultado de los intereses y las contradicciones de los capitalistas. Como muestra de ello hemos analizado la "educación" que el Estado nos proporciona. Toda esta enseñanza tiene como fin sacar de nosotros, los obreros, el máximo beneficio para sus negocios y, especialmente, crear una ideología y una conciencia a medida de sus intereses, es decir que no ponga en duda la validez del sistema opresor.

La educación verdadera ha de estar encaminada a desarrollar distintas capacidades que todo ser humano posee. Esto es imposible en una forma de organización social que sólo persigue que unos pocos acumulen dinero y comodidades a costa del trabajo y del sacrificio de los demás." ${ }^{716}$.

ANCHE (Asociación Nacional de la Comunicación Humana y la Ecologia) i es va fer ressò de les lluites veïnals.

715 La popular revista colomenca Grama també va dedicar nombrosos articles a la situació de la dona i la seva opressió. Cito uns quants publicats entre els anys 1971 i inicis de 1977: Hilda Abeleira: “Empleadas del hogar..." Grama núm. 32-33 (estiu 1971), p. 9-10;L. Tarasón: “La mujer, ¿que papel juega en nuestra sociedad? Grama núm. 37 (gener 1972), p. 10-11; Jose Antonio Martínez i M. Victoria Aldana: "Machismo: queremos tener a alguien a quien dominar y lo pagamos con quien creemos más débil: la mujer" Grama núm. 42 (juny 1972), p. 10-11; Serafín Bravo i J. P. Sayrach: "El pan nuestro de cada mes. Una profesión para la mujer: enfermera" Grama núm. 50 (febrer 1973), p. 10-11; Antonio Màrquez: "El pan nuestro de cada mes. Academias de Corte y Confección. Casadas y solteras a por el título" Grama 51 (març 1973), p. 19; Antonio Márquez: "El pan nuestro de cada mes. Las empleadas del Hogar" Grama num. 61 (gener 1974), p. 9; Alfonso: "De profesión: sus labores" [còmic] Grama núm. 63 (març 1974), p. 22; Agustina Rico: "La Mujer: una mayoría olvidada que empieza a despertar" Grama núm. 76 (abril 1975); "Las mujeres quieren liberarse" [article sobre les I Jornades Catalanes de la Dona] Grama núm. 89 (juny 1976), p. 16-17; "Jornades Catalanes de la Dona. Unidas, a por la igualdad" Grama 90/91 (juliol-agost 1976), p. 13; Agustina Rico i Gabriela Serra: "Las mujeres saltan al "ring"' Grama núm. 96 (gener 1977) p. 13; Mar Fontcuberta: "Ser mujer tampoco es una ganga" Grama núm. 97 (febrer 1977), p. 13.

716 "Comité Unitario de Trabajadores de Santa Coloma de Gramanet" (un organisme precursor de les CCBB) titulat "17.500 niños sin escuela en Santa Coloma", AHMTB, Donació Marcelo López Ródenas, Dossier 1 "Ensenyament local". Grama també va dedicar-ne nombrosos articles i 
De manera similar des de la reivindicació d'espais pels ancians als barris es va qüestionar el paper que el sistema capitalista atorgava a les persones un cop ja no estaven en edat de "produir"717. Cal mencionar també que la premsa veïnal dedicarà una especial atenció a tot el món laboral, tant en la vessant de la intensa conflictivitat obrera existent -en molts casos eren els mateixos protagonistes- com en l'aspecte jurídic i d'assessoria. Ja hem vist com les lluites obreres havien estat publicitades als fulls volants des de els anys seixanta per la majoria d'organitzacions antifranquistes d'esquerres. Amb la proliferació de les AVV's seran freqüents les notícies sobre el món del treball als diferents butlletins ${ }^{718}$.

Però és que fins i tot debats que podrien semblar "allunyats" d'uns barris amb una població majoritàriament immigrada van tenir el seu reflex en la premsa veïnal, com podia ser el cas de les reivindicacions nacionals catalanes, el català, el

dossiers. Per exemple ja el núm. 29 de maig de 1971 havia publicat l'article "Por una escuela popular. Educación y sociedad. Enseñanza viva, antiautoritaria y crítica", p. 11-12 i a l'estiu apareixia "Educación en Santa Coloma" al núm. 32/33, p. 20-21; el núm. 55-56 (juliol-agost 1973) tenia un dossier dedicat a l'estat de l'educació (p. 3-25) i a la portada s'afirmava "Más de 8.000 niños no pueden ir al colegio"; altres articles: Paulo Freire: "La educación como práctica de la libertad" Grama núm. 67-68 (juliol-agost 1974), p. 25; F. J. Suárez: "Enseñanza, todo sigue igual" Grama núm. 74 (febrer 1975), p. 13 i "Barrcones por escuelas" Grama núm. 83 (novembre 1975), p. 13. Molts mestres van ser militants de partits polítics clandestins, CCBB's i AVV"s, trobant-se en experiències pedagògiques com les del Campt de la Bota (Sant Adrià), col-legis i instituts concrets com el Lluís Millet de Les Oliveres, l'Institut Puig Castellar (Santa Coloma) el Antoni Botey de Llefià o l'Institut Eugeni d'Ors de Sant Roc (Badalona), només per posar uns exemples (eren llocs estigmatitzats on altres mestres no hi volien anar). Anys després a la mateixa Santa Coloma es va crear el "Casal del Mestre" per treballar en la renovació pedagògica. Unes altres entitats molt importants van ser les associacions de pares de disminuïts psíquics com ASPANIN (Badalona), ASPANIDE (Santa Coloma) i ASSA (Sant Adrià), que també van protagonitzar nombroses mobilitzacions. Menció apart mereixent també les Escoles d'Adults que van crear-se als barris per alfabetitzar totes aquelles persones que havien tingut una escolarització precària o nul·la.

717 Cito només alguns exemples: "Un tema candente. Nuestros ancianos" El Rollo Despertador, núm. (juny 1975), p. 4; “¿Qué hacer con los ancianos?” Ojo. Asociación de Vecinos Juan Valera núm. 1 [gener? 1976], p. 14-15; "Herencia Ràfols: un asunto sucio", "La medicina de los ancianos", "La tercera edad", articles dins un dossier "Nuestros ancianos" de El pino seco. Boletín informativo de la A. de V. del Centro-Santa Coloma [gener-febrer? 1976], p. 8-13; "La Nueva lucha de lso Jubilados" La Voz del Arrabal (octubre 1976), p. 15. Grama també va dedicar-hi articles com "Los ancianos: ¿una carga social?" i Eugenio Madueño "Ancianos" Grama núm. $32-33$ (estiu 1971), p. 13 i 15 respectivament; J. M. Diez de Ulzurrún "Protagonistas: los Ancianos. La nueva residencia ¿es suficiente? i E. M.: "En Rambla San Sebastián se construirá un "Hogar de Ancianos" Grama núm. 60 (desembre 1973), p. 7; Humberto Roma: "La Jubilación" Grama núm. 70 (octubre 1974), p. 10-13. El mateix número incloïa un còmic sobre la qüestió a la p. 14.

718En alguns casos amb seccions fixes com "Nuestro mundo laboral" de Pimienta (revista de l'AVV de Santa Rosa-Santa Coloma), o temes recurrents en seccions com "El abogado" de Fondo (publicació de l'AVV de Fondo-Santa Coloma), només per posar dos exemples. Totes dues a AHMTB, Donació Marcelo López Ródenas, Caixa 1. 
lerrouxisme, l'autodeterminació, el debat a l'entorn de l'Estatut, etc. ${ }^{719}$. És cert que les CCBB no van treballar gaire aquesta qüestió, tot i que finalment, amb més o menys reserves, sembla que van assumir la reivindicació de l'autodeterminació de Catalunya $^{720}$.

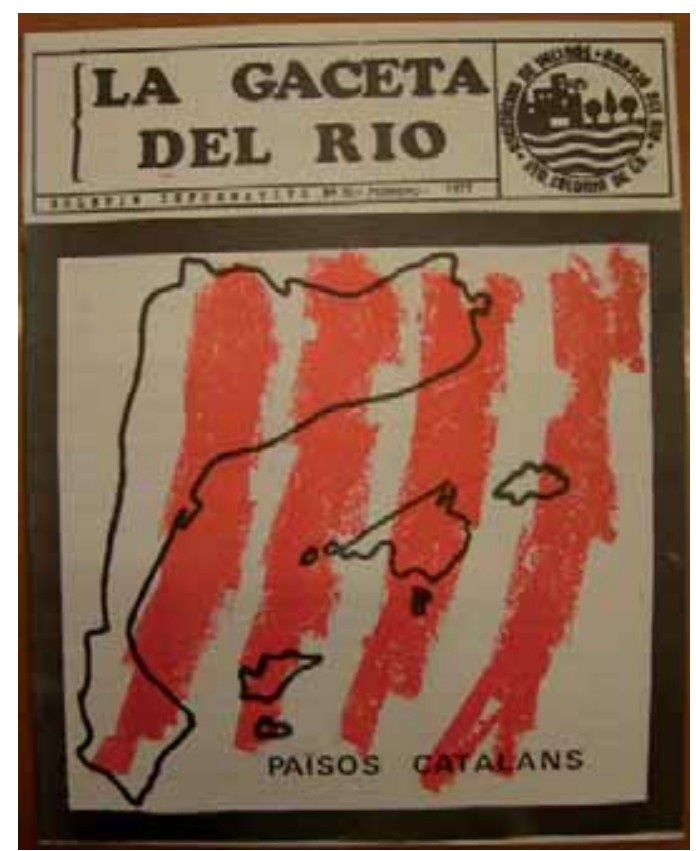

La Gaceta del Rio núm. 10 (febrer 1977), MTB, Fons Marcelo López Ródenas, Caixa 1.

719Sobre la qüestió nacional catalana l'octubre de 1976 la Voz del Arrabal deia textualment en l'article "11 de Setiembre. Diada nacional de Catalunya" a la p. 3: "Doscientos sesenta y dos años después de que Felipe $\mathrm{V}$ conquistara Barcelona y con ello perdiera el pueblo catalán su independencia como nación”; Altres articles sobre la qüestió: "Volem l'Estatut” La Gaceta del Río num. 11 (març 1977). El mateix butlletí publicava un monogràfic "Nacionalismo y regionalismo" en el seu núm. 12 (abril 1977) on s'explicava la història de les reivindicacions nacionals p. 8-19. Sobre el lerrouxisme i els intents que es van fer de manipular a la població catalana d'orígen andalús la premsa veïnal colomenca també va dedicar un especial interès: "Andalucismo en Catalunya” La Gaceta del Río núm. 7 (novembre 1976), p. 5; “iiCuidado!! La casa de Andalucia” Fondo núm. 3 (novembre-desembre 1976), p. 6. Grama també va tractar aquesta qüestió al núm. 92 (juny 1976): José Tordera: “Una "Casa regional" para 50.000 andaluces". També cal destacar la Editorial "Quienes son (y quienes no son) catalanes" del núm. 93 (octubre 1976), p. 3. Ja al 1977 la revista Comarca Expres núm. 8 (2ona quinzena de març) va publicar un article de Pedro José Blanco i Enric Juliana amb l'eloqüent títol "No nos dividiran" a les pàgines 4-5 (que a més era el tema de la portada). De la llengua catalana se'n parla en l'editorial del Grama núm. 93 citat anteriorment on es critica el surrealista l'eslògan que van fer servir -sembla ser- alguns grups polítics de que el català "era la llengua de la burgesia i el castellà el de la classe treballadora". La demanda d'ensenyament del català va comportar importants mobilitzacions. Ara, bé, el que no m'esperava era trobar una publicació d'una AVV a Santa Coloma amb una portada amb l'expressió "Països Catalans" com La Gaceta del Rio núm. 10 (febrer 1977), MTB, Fons Marcelo López Ródenas, Caixa 1.

720"Resumen general de las distintas asambleas de CCBB" [en llapis posa: "Sector OICE", enumerant a continuació: "Santa Rosa, Fondo (Sector OICE), Oliveras (Sector OICE), Can Mariner (“ ") i Singuerlín (“" "), [juny 1976], AHMTB, Donació Marcelo López Ródenas, Caixa 3, Dossier 5 "Debats interns CC. BB.". En aquest document, al Punt 5 "Programa de las Comisiones de Barrio" hi diu "Autodeterminación para el pueblo de Catalunya", però està significativament subratllat i amb una anotació al costat que diu "se debe discutir en distintas c.b.s.". 
Tot i l'evidència d'aquests exemples, cal tenir sempre present que aquests discursos que es feien des de les publicacions veïnals no va ser assumits sempre en la seva totalitat pel conjunt de les classes populars, que estaven influenciades també pels discursos de caire conservador i individualista que es difonien des de les esferes del poder del mateix capitalisme. Com ens recordava Javier Tébar, en el procés de conscienciació de classe que es va donar als diferents barris durant els anys 60-70 també van haver-hi actituds que eren contràries o matisaven aquella voluntat col-lectiva:

\footnotetext{
"A menudo se manifestaban desconfianzas, por ejemplo entre los obreros cualificados y no cualificados, entre los mayores y los aprendices, predominando el individualismo y manifestándose una oscilación de las actitudes de la población obrera entre la pasividad y la rebeldía, cuando no, insisto, en el arraigo del fatalismo."721
}

Totes aquestes temàtiques van tindre una gran efervescència al període posterior, fins les primeres eleccions municipals. Però no hem d'oblidar pas que va ser la mateixa lluita per aconseguir la millora dels diferents barris i ciutats del Barcelonès Nord la que va anar impulsant aquest procés de presa de consciència política i també de ciutat i que es comencessin a tractar altres temes tenint en compte també el context de crisi de la dictadura que s'estava vivint. D'aquestes lluites en pararé a continuació.

\subsection{Les principals lluites veïnals fins la mort de Franco.}

Tot i que generalment es considera que va ser durant el procés de canvi polític fins les primeres eleccions municipals de 1979, quan hi va haver més mobilitzacions veïnals, el cert és que des d'inicis de la dècada dels 70 ja s'havia

721Javier Tébar Hurtado: "La clase trabajadora en la "Gran Barcelona”", dins Javier Tébar Hurtado (dir.), El movimiento obrero en la gran ciudad. De la movilización sociopolítica a la crisis económica, El Viejo Topo, [Barcelona], 2011. El mateix autor, referenciava en una nota (núm. 168) d'aquest mateix fragment, els estudis de Margarita Bedos: La asistente social ante los problemas que plantean los horarios de trabajo en un barrio de nueva creación "Les Termes", Biblioteca Miquel Carreras (Sabadell), 1964; Remedios Bona Puigvert; Descripción general de la vivienda y problemas de convivencia que de ella se derivan en la barriada de Torre Romeu, Bibioteca Miquel Carreras (Sabadell), 1970. J. M. Martínez-Martí Odena: La immigració a Barcelona, Rafael Dalmau, Barcelona, 1964, p. 300-303. Pel barri del Poble Nou de Barcelona esmentava a Pedro Negre: El obrero y la ciudad, Ariel, Barcelona, 1968, p. 15-16. 
iniciat una dinàmica que aniria "in crescendo" en els següents anys. D'aquesta manera quan va morir el dictador, al Barcelonès Nord el moviment veïnal ja era una realitat ben present als barris i ciutats en major o menor mesura.

Segurament va ser a la ciutat de Santa Coloma de Gramenet on abans es va iniciar aquest procés. El mateix any 1971 al barri del Raval es produïen unes mobilitzacions per la millora de l'aleshores "Avenida del Caudillo" (avui de la Generalitat). Aquesta era una carretera que comunicava Santa Coloma amb Badalona i Sant Adrià de Besòs i on l'elevat transit de vehicles juntament amb l'absència de semàfors i el seu pas per un barri popular produïa un elevat nombre d'accidents. El més de gener, abans inclús que es fessin les massives manifestacions per l'ambulatori, des de el Centre Social Arrabal de Santa Rosa s'entregava una instància a l'Alcalde signada pel seu president, Ezequiel Sánchez Alonso i per un grup de veïns del barri denunciant la situació existent, exigint semàfors i que mentre aquests no s'instal·lessin dos guàrdies urbans en regulessin el trànsit en les hores més conflictives ${ }^{722}$. L'Ajuntament accedí a col·locar només un guàrdia però davant la pobre resposta el 20 de març 150 persones, dones i nens en la seva majoria feren el primer tall de trànsit. Amb la presència de la Guàrdia Civil es van dissoldre pacíficament, tot advertint que tornarien si no es responien les seves demandes ${ }^{723}$. I en efecte, el 28 de març els veïns del barri en un nombre superior a les 500 persones van sortir al carrer al crit de "Fets si, paraules no!" i van tornar tallar el trànsit. La Guàrdia Civil va intervenir dispersant els concentrats ${ }^{724}$. Finalment el 3 de juny del 1972 l'Ajuntament va iniciar els tràmits per instal·lar semàfors.

Aquest exemple va ser seguit aviat en altres indrets de la ciutat, de manera que el 30 de gener de 1973 un grup de dones tallava la circulació entre els carrers Mestre J. Martorell i Avinguda Baró també per reivindicar semàfors (era un altre "punt negre" on hi havia hagut nombrosos atropellaments). L'acció es va repetir diàriament fins el dia 7 de febrer on va tornar a intervindre la Guàrdia Civil amb la 722 Marcelo López Ródenas: Historia social de la Santa Coloma moderna..., p. 172. Una còpia de la instància feta el 15-1-1971 es pot veure a AHMTB Donació Marcelo López Ródenas, Caixa 3, Dossier 4.

723Dirección General de la Guardia Civil: Nota Informativa: Manifestación en Santa Coloma de Gramanet" (21-3-1972), AHGCB, Gobernadores Civiles, Caixa 140, Actividades Contra el Régimen (III) 1971.

724Marcelo López Ródenas: Historia social de la Santa Coloma moderna..., p., p. 173. 
policia municipal aquesta vegada, provocant vàries persones contusionades i detingudes, que van ser alliberades posteriorment sense cap càrrec gràcies -en part- a la pressió d'altres veïns concentrats en la Plaça de la Vila. Poc temps després, el 12 de març de 1973 l'Ajuntament aprovava de nou la instal·lació de semàfors en el lloc demanat.

El mateix 1973 el barri del Raval va ser protagonista d'unes altres mobilitzacions importants. La manca de llum era un altre dels problemes més greus existents. El Centre Social Arrabal-Santa Rosa va dur a terme una campanya per recollir els principals problemes del barri i reivindicar a les autoritats la seva solució (uns dèficits quantificats en gairebé 2,6 milions d'euros, 432 milions de pessetes d'aleshores). El febrer de 1973 es feia arribar un document on s'enumeraven els carrers sense asfaltar del barri així com els que tenien una deficient il-luminació, fent-se constar, a més, les llums existents i les considerades necessàries ${ }^{725}$. Aviat es va imposar la necessitat de la mobilització, conjuntament amb els veïns del barri veí de Santa Rosa que patien mancances similars. El 17 de maig es va fer una manifestació amb espelmes ${ }^{726}$-un fet que serà imitat en reivindicacions posteriors en altres barris del Barcelonès Nord. Aviat la van seguir dues mes, una el 24 de maig ${ }^{727}$ i la darrera el 14 de juny amb la participació també de veïns del barri de Santa Rosa i que va acabar amb enfrontaments amb la Guàrdia Civil i amb contusionats. En les dues primeres havien participat, respectivament, unes 500 persones i en la darrera al voltant de $1.000^{728}$. La Comissió de Barri de l'Arrabal es van fer ressò d'aquesta lluita en la seva propaganda clandestina. Un full volant recordava el perquè de la mobilització i el desenvolupament de la mateixa per acabar dient:

\footnotetext{
"Ni nos van a frenar ni lograron asustarnos, cada día somos más fuertes porque nuestra unidad crece y vamos aprendiendo que uniéndonos y organizándonos conseguiremos todo lo que nuestro barrio necesita, pero los problemas de los otros barrios son los mismos que los nuestros si todos nos vamos juntando haremos mas
}

725 [Document del Centre Social Arrabal Santa Rosa sense títol, febrer 1973], AHMTB, Donació Marcelo López Ródenas, Caixa 3, Dossier 2 "Reivindicaciones vecinales". Aquest document va ser recollit per la revista Grama al núm. 52 (abril 1973), en concret a l'article "Arrabal: un barrio que carece de casi todo", p. 13-15.

726“Queremos luces”, Tele/ eXprés, 18-5-1973.

727 “Santa Coloma de Gramanet: Nueva manifestación con velas”, El Correo Catalán, 25-5-1973. La notícia parla de "nueva manifestación", per tant, aquesta no era la primera que es produïa. 728Marcelo López Ródenas: Historia social de la Santa Coloma moderna..., p. 181. 
fuerza para que no solo el Arrabal tenga luces, sino todo Santa Coloma.

¡iLUCES PARA TODOS LOS BARRIOS!! ¡iLUCHEMOS HASTA CONSEGUIR LAS LUCES!! ${ }^{29}$

L'Ajuntament colomenc finalment s'avindrà a les reivindicacions veïnals i cap a finals de 1973 van començar les obres d'infraestructura per poder acollir un nou enllumenat pels principals carrers del Raval i Santa Rosa. La mobilització, un cop més, aconseguia resultats malgrat la repressió patida.

En aquests anys va iniciar-se també una lluita en un barri situat a l'altre extrem de Santa Coloma: Les Oliveres. Edificat d'una manera inversemblant a les faldes de la muntanya, en una zona que havia d'haver estat parc forestal, aquest barri s'havia començat a construir l'any 1968. L'any següent ja era habitat per algunes famílies però no va ser fins a finals de 1972 que el barri va estar acabat i habitat pràcticament en la seva totalitat. La major part, 27 edificis, varen ser construïts per la immobiliària ALBICA S.A. Altres 10 blocs eren propietat del Patronat Municipal de l'Habitatge i 10 més ho eren sota un règim de Cooperativa d'habitatges. Aïllat de la resta de Santa Coloma, mancat de transports i dels serveis més elementals, els veïns han de suportar la manca d'urbanització del barri i els nombrosos defectes dels habitatges construïts, producte de la mala qualitat dels materials que es van fer servir. Però la guspira que va encetar la lluita veïnal va ser la estafa immobiliària de l'empresa ALBICA. Aquesta havia promocionat els seus pisos sota el paraigües de la Renda Limitada. Però com el barri no acomplia les condicions establertes pel Ministerio de la Vivienda per acollir-se a aquesta bonificació, finalment li va ser denegada:

"La denegación de la renta limitada conllevaba un incremento del precio de los pisos.

El precio inicial, de 366.000 pesetas, aumentaba 30.000 pesetas del Ministerio, 25.000 pesetas de notaría, 4.000 pesetas de registro, 80.000 pesetas de contribución urbana y 40.000 pesetas de derechos reales. En total, unas 194.000 pesetas más, pasando el coste del piso de 360.000 pesetas a 550.000 pesetas, mientras que la empresa constructora obtenía beneficios: mejor servicio de materiales, exención de pago de impuestos al Ayuntamiento, reducción del 10 por ciento durante 20 años de la contribución territorial, facilidades para adquirir préstamos en entidades de crédito,

729Comisión de Barrio del Arrabal: "A todos los trabajadores y pueblo de Santa Coloma” [full volant] (15-6-1973), AHMTB, Donació Marcelo López Ródenas, Caixa 3, Dossier 2 "Reivindicaciones vecinales". 
además de 30.000 pesetas por cada vivienda edificada." ${ }^{730}$

Els principals responsables d'aquesta situació van ser els germans Rafael i Manel Guitart Soler Vicens, els propietaris de l'empresa immobiliària. Davant el malestar i reclamacions dels veïns, ALBICA només va oferir una compensació de 30.000 pessetes (10.000 destinades a la urgent remodelació dels edificis) i la possibilitat d'aconseguir a les escriptures de propietat ${ }^{731}$. Massa poc. La indignació augmentà. L'1 de novembre aparegué un full volant pel barri, signat com a "Vecinos de Las Oliveras" (primer nom sota el qual actuava la CCBB), denunciant aquesta situació i desestimant aquesta oferta de l'empresa. Finalitzava fent una crida:

“Qué debemos hacer ahora? En este momento lo más importante es que este mes DEJEMOS DE PAGAR TODOS

Para ello es necesario que estemos todos unidos: los que desde el principio no hemos colaborado, los que hemos dejado de hacerlo después y los que hemos seguido hasta ahora."732

La immobiliària va prometre arreglar les deficiències, però els veïns desconfiaven. Al mes de novembre es produïren quatre manifestacions al barri. El dia 21 una vuitantena de dones tallaven el trànsit a la carretera de La Roca durant una hora i apart dels temes esmentats, reclamaren autobusos i enllumenat pel barri, que les autoritats prometeren portar en 8 dies. El dia 25 hi hagué una nova mobilització. A les 17 h una manifestació de 400 persones aproximadament va recórrer el barri i després va enfilar cap a les oficines d'ALBICA situada a l'altra punta de Santa Coloma. S'afegiren més persones a la manifestació arribant-se a 800. La Guàrdia Civil intentà aturar-la però per dues vegades es va trencar la

730Fernando Saro: Les Oliveres. Sabor a barrio 1970-1980, Edicions Fórum Grama, 2012, p. 20.

731 Marcelo López Ródenas: Història social a la Santa Coloma moderna..., p. 175. Els propietaris dels terrenys on es va edificar aquest barri els havien venut al procurador de la propietat Agustín González Mozo, represenant a Barcelona de l'antic president de les Corts franquistes, José Rodríguez de Valcárcel, amic personal de Franco. A més va comprar la muntanya on està situat aquest barri i el de Can Franquesa per un preu irrisori ja que era zona forestal (així ho havia previst el Pla Comarcal de 1953). El posterior Pla Parcial del Sector Nord-est havia transformat la zona en edificable. Això va multiplicar el valor dels terrenys. El negoci urbanístic ja estava fet. Per la seva banda la immobiliària ALBICA S.A. es presentava amb la disfressa de 4 empreses per esquivar determinades disposicions legals: el mateix d'ALBICA, S.A., ASTARTE S.A., Construcciones GUITART i ACORTERRES, S.A.

732Vecinos de Oliveras: "Vecinos de las Oliveras" [full volant] (novembre 1972). AHMTB, Donació Marcelo López Ródenas, Caixa 3, Dossier 2 "Reivindicaciones vecinales". 
barrera policial. Hi hagué algun incident i intent de detenció, però es va aconseguir arribar a les oficines i posteriorment la manifestació es va dissoldre sense més incidents $^{733}$. El dia 28 hi hagué una tercera mobilització. Més de 700 persones es manifesten pel barri i són dissoltes per les forces d'ordre públic, Policia Municipal i Guàrdia Civil a l'alçada de l'Avinguda Anselmo de Riu amb la Carretera de La Roca. En el transcurs d'aquesta manifestació tres agents vestits de paisà agredeixen al sacerdot Lluís Hernàndez ${ }^{734}$. El Cap de la Policia Urbana va ser còmplice, ja que va ser ell el que el va requerir per parlar, aïllant-lo de la manifestació. Més endavant es tornaran a trobar, en una situació molt diferent, a l'Ajuntament. El mateix Lluís Hernàndez ens recordava els esdeveniments:

"La Guàrdia Civil d'incògnit (...). Em van fer una emboscada (...) Vestits de paisà. (...).

Vine que 'tenemos que decirle una cosa'... Em van treure de la manifestació llavors van començar insults i cops, em van tirar a terra, em van donar patades i em van deixar allà. I jo cridant demanant auxili. Van venir unes veïnes que estaven allà, eren del Patronat (...) i van venir i aleshores aquests em van deixar, varen fugir."735

La indignació es va estendre pel barri i dos dies després unes 200 dones recorrien de nou el barri en solidaritat amb l'agredit. Van ser les dones les que van tenir un protagonisme destacat en aquestes mobilitzacions, tal com reconeixia un document repartit que resumia la lluita duta fins al moment pel barri ${ }^{736}$.

Durant els mesos següents ALBICA va fer algunes reparacions als blocs d'habitatges i semblava albirar-se l'esperança d'aconseguir la Renda Limitada ${ }^{737}$. Es va aconseguir l'arribada de l'autobús 203 al barri, alguns fanals i una cabina telefònica. Però en no fer-se res més el malestar tornà al barri. Després d'una infructuosa entrevista dels veïns amb l'Alcalde Porta, aquest va prometre una imminent urbanització de la via principal, la carretera que portava a la Font de

733Marcelo López Ródenas: Història social a la Santa Coloma moderna..., p. 176.

$734 \mathrm{El}$ mateix full mencionat a les notes anteriors fa esment a aquests esdeveniments. Una altra fulla volant signada per les Comisiones de Barrio de Santa Coloma titulada "Hoja Informativa no 2. Sobre la lucha de los trabajadores de Las Oliveras" (novembre 1972) també explicava els fets, AHMTB, Donació Marcelo López Ródenas, Caixa 3, Dossier 2 "Reivindicaciones vecinales".

735Entrevista amb Lluís Hernàndez Alcàsser, 5-6-2013. Aleshores sacerdot i membre d'una Comunistat Cristiana de Base a Les Oliveres, va ser posteriorment militant del PSUC i Alcalde de Santa Coloma de Gramenet entre els anys 1979-1991.

736Vecinos de Oliveras "Solidaridad con la lucha de Oliveras" [full volant A4 a doble cara, novembre 1972], AHMTB, Donació Marcelo López Ródenas, Caixa 3, Dossier 2 “Reivindicaciones vecinales". 737Marcelo López Ródenas: Història social a la Santa Coloma moderna..., p. 177. 
l'Alzina. Però no es va fer res al respecte i al juny de 1973 la CB de Oliveres torna a posar sobre la taula les reivindicacions del barri:

"A todos los vecinos de Las Oliveras:

LA CARRETERA FUENTE DE LA ENCINA SIGUE SIN URBANIZARSE.

EL CAMPO DE FUTBOL ESTÁ ABANDONADO.

LA CARRETERA DE LA ROCA CONTINUA SIN LUCES NI ACERAS.

EL ALCALDE NO HA CUMPLIDO SU PALABARA.

LOS VECINOS DEL BARRIO HEMOS SIDO ENGAÑADOS."738

Al juliol tornaren a convocar-se mobilitzacions. Un nou full volant signat per "Vecinos de las Oliveras" instava a la mobilització, recordant, entre d'altres motius, com la manca d'urbanització podia afectar a l'assoliment de la Renda Limitada:

"Sobretodo porque de no estar pronto urbanizada perderemos los beneficios de la Renta Limitada, que supondría tener que desembolsar mucho dinero: unas 150.000 pesetas por familia.

Por eso salimos otra vez a la calle. Somos un barrio unido que luchará por defender sus derechos. No pedimos la luna: pedimos cosas bien concretas y necesarias. Estamos hartos de promesas y constatar que las cosas se arreglan muy lentamente.

!!!OLIVERAS VENCERÁ!!!

!!PROMESAS NO-REALIDADES SI!!

!!! QUEREMOS UN BARRIO EN CONDICIONES!!!"739

El 16 de desembre una assemblea de 200 veïns acordava una nova manifestació, tal com deia un nou full volant que recordava alhora les principals reivindicacions pendents ${ }^{740}$. I, mentrestant, es mantenia el boicot d'unes 450 famílies al pagament del lloguer a la immobiliària ALBICA. Finalment l'abril de 1975 es va concedir la Renda Limitada a les famílies de 7 blocs i al maig de 1976 uns altres 20 blocs adquirien el mateix estatus ${ }^{741}$. El 14 de novembre del mateix any també es va resoldre la demanda que havien interposat contra el Patronat Municipal pel mal estat dels habitatges. Aquest va ser condemnat a una multa 738Comisión de Barrio "Las Oliveras": "A todos los vecinos de Las Oliveras" [full volant] (juny 1973), AHMTB, Donació Marcelo López Ródenas, Caixa 3, Dossier 2 “Reivindicaciones vecinales”. 739Vecinos de Oliveras: "¿Por qué los vecinos de Oliveras salimos otra vez a la calle? [full volant] (juliol 1973), AHMTB, Donació Marcelo López Ródenas, Caixa 3, Dossier 2 "Reivindicaciones vecinales".

740 Comisión Obrera de las Oliveras: “Oliveras vencerá” (desembre 1973), AHMTB, Donació Marcelo López Ródenas, Caixa 3, Dossier 2 "Reivindicaciones vecinales". 741Marcelo López Ródenas: Història social a la Santa Coloma moderna..., p. 178. 
irrisòria de 10.000 pessetes i a executar la reparació dels pisos en un termini de tres mesos ${ }^{742}$. No obstant, el mal estat dels habitatges d'ALBICA, que només es podia solucionar amb una forta inversió de diners -tal com va avalar un informe del Col-legi d'Aparelladors i Arquitectes tècnics de Catalunya- i altres dèficits existents al barri van fer que les mobilitzacions continuessin en anys posteriors, ja encapçalades per l'Associació de Veïns. Però en aquestes primeres lluites, va ser la Comissió de Barri la que va destacar. Un dels seus integrants ens recorda qui en va formar part aleshores:

"La Comisión de barrio empezó a funcionar en el año 1971 y estaba formada por un grupo reducido de personas, la mayoría pertenecientes al PSUC, OIC y al MC, como Matías Álvarez, Tomàs Lorenzo, Lluís Herández, Fernando Saro, Ferran López, Rodolfo del Hoyo, Luís Martínez, José Herrera, -más conocido como León- y algunos como Rogelio Ventura, Carmeta Ots, Jerónimo Serrano, Antonio González, Juan Antonio Madueño y otros, que no estaban afiliados a ningún partido político. Puerto Moreno y alguna otra compañera del grupo de monjas también participaban en la Comisión de Barrio.".743

A més altura de l'anterior barri, a 300 metres sobre el nivell del mar mirant cap a la muntanya de Sant Mateu s'havia construït el barri de Can Franquesa. Era un nucli de 22 blocs amb sis plantes, construït pel Patronato Municipal de la Vivienda en la seva majoria i que també contemplava els beneficis de la Renda Limitada. Però aquest barri estava encara més aïllat que l'anterior i patia els habituals dèficits d'equipaments: manca d'escoles, de transport públic, d'urbanització...

El 5 de juliol de 1973100 dones dels blocs més alts tallaven els accessos al barri per reivindicar l'arribada dels autobusos de l'empresa TUSA que recentment s'havien aconseguit a Les Oliveres. Aviat tornaren a mobilitzar-se i el 2 d'agost protagonitzaren un acte que esdevingué molt comú en la lluita pel transport públic: van segrestar l'autobús TUSA que arribava fins Les Oliveres i el van fer pujar a Can Franquesa. La Guàrdia Civil en va detindre a 8 dones, si bé van ser posades en llibertat aviat ${ }^{744}$. A partir de 1975 la conflictivitat es revifà al barri, quan al mes de

742 Marcelo López Ródenas: Història social a la Santa Coloma moderna..., p. 178-179.

743Fernando Saro: Les Oliveres. Sabor a Barrio..., p. 32-33.

744 Marcelo López Ródenas: Historia Social de la Santa Coloma moderna..., p. 182-183. Segons aquest el 2 de març de 1974 les veïnes van ser jutjades i condemnades a pagar una multa de 
febrer 700 veïns signaren dues instàncies dirigides al director general de Transportes Urbanos de Barcelona i al Ministerio de Educación y Ciencia en demanda de transports i escoles.

Al juny de nou es van manifestar 100 veïnes fins el proper barri del Singuerlín reivindicant escoles i l'allargament de la línia 203 fins al barri, a més d'altres millores urbanístiques com la reparació dels murs de contenció. El setembre de 1975 el Ple municipal va aprovar la construcció de la tant demandada escola, però fins febrer del 1976 no hi hagué dotació pressupostària. La demanda de transports continuà encara sense solució i aquest fet provocà unes protestes els anys posteriors -en concret l'any 1977, ja mort del dictador- que tingueren molta rellevància ${ }^{745}$.

Al costat d'aquest barri n'existia un altre anomenat "La Guinardera", també situat a dalt de la muntanya. Allà una Cooperativa d'Habitatge anomenada VIPES havia edificat un polígon a partir de la compra d'uns terrenys l'any 1965 pels quals es va demanar als socis un avançament de 45.000 pessetes $^{746}$. En general aquesta Cooperativa va tenir una gestió gens transparent i amb moltes irregularitats:

El Francisco Fernández comenta: “Aquí hi ha gent que tenen pisos i no eren socis, eh! Al Gimeno, li donaves deu mil peles i... a qui més diners li donava, li donava, a la millor, una terrassa. Però com que això ho portaven ells, tu no podies dir amb documents: això no és així!". Els papers corroboren la corrupció. Jaime Mensa, soci fundador de la Vipes, resident a Barcelona, i amb recursos més que suficients, compra un pis a la Guinardera, on viurà un noi jove, i ell els caps de setmana. El mateix president GilOrtega, soci número 2.765, un dels més alts del polígon, hi col·loca un familiar també amb el seu número personal. I el vigilant de les obres és comminat a marxar pels socis perquè ell, de soci, no n'és. Però s'hi quedarà sense problemes."747

150 pessetes i els costos del judici, en total, unes 394 pessetes cadascuna.

745 El 6 de juny de 1977 es tornen a segrestar autobusos obligant-los a pujar al barri. Els dies 7 i 8 intervé la policia amb una gran brutalitat: hi han vàries persones contusionades, entre ells una dona en estat de gestació i una criatura de 8 anys amb dues costelles trencades (veure Tele Exprés 8-6-1977 i 9-6-1977). Amb els ànims molt encesos pels esdeveniments recents l'Alcalde Blas Muñoz va visitar el barri i va haver de fugir per que els veïns el van rebre a pedrades. Veure Tele Exprés 10-6-1977: "A pedradas con el Alcalde". Ben aviat es van posar el servei d'autobusos reclamat, tot i que encara quedaven nombroses reivindicacions per resoldre. Veure Tele/ eXprés 11-6-1977: "Las pedradas aceleraron la gestión."

746Jordi Rovira Sánchez: La Guinardera, A.V. La Guinardera, Ajuntament de Santa Coloma de Grament, amb la col·laboració del la Direcció General d'Acció Cívica del Departament de Benestar i Família de la Generalitat de Catalunya, 2002, p. 23.

747Jordi Rovira Sánchez: La Guinardera..., p. 29. 
El barri va tenir les mancances habituals. Però al 1971 la Cooperativa, va deixar de pagar a la companyia elèctrica i els veïns van quedar a les fosques. Aleshores, el 21 de març, els presidents dels 21 blocs d'habitatges del barri van presentar una instància a l'Ajuntament exigint una solució. Aquest va ser l'embrió de la futura Associació de Veïns del barri, que tot i funcionar des de el 18 d'agost de 1972, no va ser legalitzada fins tres anys després i tenint com a principals càrrecs de la Junta a persones conservadores fins que va haver-hi un canvi posterior ${ }^{748}$. Durant aquest temps VIPES, per problemes econòmics havia venut una part del terreny a un altre constructor, José Castro, que tenia la intenció d'acabar les obres que la Cooperativa no havia enllestit per falta de liquiditat. Això va provocar la protesta veïnal per impedir més edificacions quan al barri faltaven equipaments i zones verdes. La constructora volia acabar dos edificis que havien quedat a mig fer i que ja havien provocat molt malestar per ser un pou d'infeccions. L'Ajuntament, per la pressió veïnal havia declarat il·legals les obres, però la constructora les continuava fent d'amagat, per la qual cosa els veïns es dedicaven a destruir el que els obrers aixecaven. Finalment es van sortir amb la seva tot i que altres problemes com els deutes arrossegats per la Cooperativa VIPES no es van solucionar fins la liquidació de la Cooperativa l'any 1985. Per la seva banda, habitants del barri van participar a les mobilitzacions dels veïns barris de Singuerlín, Can Franquesa... En aquest barri darrer coincidien un nucli de població catalana d'origen amb persones arribades d'altres indrets. Aviat també es va reivindicar l'us del català tot i que aquest fet no va estar exempt de tensions, com va succeir en la crisi que l'Associació de Veïns va tenir l'any $1980^{749}$.

Al barri del Singuerlín, situat a prop dels esmentats anteriorment va haver-hi durant aquests anys també una explosió reivindicativa on sovint hi participaven

748El president serà un ex-guàrdia civil, Francisco Villegas, el vicepresident l'Antonio Sánchez, el secretari el Lucas Lomero i el tresorer el Luís Jurado. Una Junta qualificada com "apolítica", però que ja comptarà amb tres persones d'esquerres com a vocals: Jordii Rovira, Serafín Hernández i Purificación Jiménez. Un any després aquesta Junta es va veure desplaçada per l'acció d'un grup de militants del PSUC que va fer servir la ja esmentada tàctica de l'entrisme. Així els militants Antonio Portero i José Manzanedo van ocupar el càrrec de President i Vicepresident. Jordi Rovira Sánchez: La Guinardera..., p. 36-37.

749Jordi Rovira Sánchez: La Guinardera..., p. 46. Segons el seu autor el 1980 es va dissoldre la Vocalia de Joves entre d'altres motius per conflictes lingüístics i en una conflictiva assemblea del mateix any un grup de veïns va arribar a boicotejar la participació de Miquel Hernàndez, el Vocal de Joventut perquè feia servir el català. 
habitants dels barris propers, ja que era el nucli de població més gran d'aquella zona de Santa Coloma. La reivindicació d'un mercat per al barri va ser la guspira que va activar nombroses lluites.

Ja havia esmentat l'existència d'una parròquia molt sensibilitzada al barri (amb la presència de Salvador Cabré) i la creació de l'Obra Social Singuerlín. Va ser aquest Centre Social el que va recuperar un antic projecte de la Comissió d'Urbanisme Local fet l'any 1964 i que no s'havia portat a terme: la construcció d'un mercat per la zona. L'Obra Social del Singuerlín va recollir 1.620 signatures que es van entregar a l'Alcalde Juan Porta Bussoms. Aquest arribà a prometre que en tres mesos hi hauria alguna resposta, però com solia passar, les paraules se les va emportar el vent ${ }^{750}$. Així que al novembre de 1973 i després d'una crida a la protesta feta pel Centre Social i la Comissió de Barri del Singuerlín, es produí una primera manifestació el dissabte 23 de novembre pel barri que serà dissolta per la intervenció policial ${ }^{751}$. La Comissió de Barri va repartir un full volant denunciant la repressió:

"Cuando habíamos recorrido algunas calles se presento la policía (3 jeep, 1 autocar, un tanque de agua y varios 091).- QUEDO BIEN CLARO EL PAPEL DE LA POLICIA, bajaron como "bestias", porras en mano y golpearon sin consideración a nuestras mujeres y niños.

¿Quién mandó que vinieran aquellos "perros rabiosos"?, el ayuntamiento nos dio la respuesta otra vez, la misma respuesta que el pueblo recibe cada vez que reclama sus derechos: ¡La represión brutal!" ${ }^{752}$

En aquestes primeres mobilitzacions, el protagonisme del centre social i sobretot de la Comissió de Barri del Singuerlín va ser molt important:

"Jo crec que va ser la única que era totalment independent de qualsevol organització política (...) la del barrio del Singuerlín (...). Jo encara no estava organitzat enlloc. El PSUC va tenir jo crec un error. Potser per la seva història de sempre, però que mai es va arribar a organitzar a fons en els moviments socials. Es van retirar de seguida [de les CCBB] (...). Potser per que es dedicaven o pensaven que s'havien de dedicar més a tota la qüestió del moviment obrer, Comissions Obreres, sindicats, etc. Per lo que sigui

750Marcelo López Ródenas: Historia Social de la Santa Coloma moderna..., p. 185.

751 Ídem, p. 185.

752Comisión del Barrio Singuerlín: "VECINOS: iiMERCADOS SI-POLICIAS NO!!" [full volant, desembre 1973], AHMTB, Donació Marcelo López Ródenas, Caixa 3, Dossier 2 "Reivindicaciones vecinales". 
el PSUC en aquella època no va incidir a les Comissions de Barri o va incidir molt poc. Va començar a incidir quan ja era Associació de Veïns (...)

Aquí la Comissió de Barri l'únic partit que tenia 2 persones dintre de la Comissió de Barri era el PT que hi havia la Fina que era una persona excel-lent, una mestra (...). Però aquí la gent que hi havia... potser fora de l'Enric que mai ho hem sapigut per que era un tio molt clandestí però que venia potser del moviment anarquista. El Quimi que també hi havia per qui i també va ser un bon company que mai va intentar portar res enlloc... Jo tampoc, encara que tothom em deia que jo era "el enviado de la iglesia" per que estava vinculat a l'església d'alguna manera."753

Però la protesta continua. L'1 de desembre un grup de 200 dones es van desplaçar al mercat del Fondo en manifestació, portant cistells de la compra amb uns cartells on deia "Mercado para Singuerlín"754. A aquesta reivindicació s'hi van sumar més persones a la Plaça de la Vila així com la popular revista Grama. De nou la $\mathrm{CB}$ es feia ressò d'aquesta mobilització i de la seva importància:

"Sabemos de sobra que el Ayuntamiento solo se mueve cuando lo obligamos, por eso es necesario que seamos el mayor número posible de vecinos que exijamos nuestro mercado, si no, no nos lo harán.

Además, en un barrio como el nuestro de 30.000 habitantes podemos y tenemos el derecho a exigir que el mercado se empiece a construir de inmediato., ${ }^{755}$

Arran de tota aquesta pressió l'Ajuntament (la Comissió Municipal Permanent) el juliol de 1974 aprovà el projecte urbanístic pertinent dels carrers Aragó, Singuerlín i Avinguda Catalunya, contemplant un espai pel mercat. No obstant, aquest no s'acabarà fent fins la dècada dels vuitanta.

A inicis de l'any 1975 van començar també les mobilitzacions per la urbanització del Passeig de la Salzareda, al barri del Riu Sud. Existia aquí una zona sense urbanitzar al costat del riu Besòs. L'abril de 1974 en commemoració del "dia mundial forestal" el municipi havia organitzat una plantada d'arbres a càrrec de 308 Alcaldes de poblacions catalanes -sens dubte per rentar la seva ja perjudicada imatge. Però els veïns eren ben conscients de la passivitat de les autoritats locals i

753Entrevista a Eloy Jurado Cubero, 12-12-2013. Va estar vinculat a la parròquia de Singuerlín, membre de la Comissió de Barri, President de la AVV de Singuerlín, i posteriorment regidor pel PSUC.

754Eugenio Madueño: ·"Manifestación silenciosa de unas 200 mujeres", Tele/ eXprés, 3-12-1973. 755Comisión de Barrio Singuerlín: "Vecinos del Singuerlín" (desembre 1973) [full volant], AHMTB, Donació Marcelo López Ródenas, Caixa 3, Dossier 2 "Reivindicaciones vecinales”. 
el que és més: si bé el Pla Comarcal de 1953 havia contemplat aquesta zona com un parc urbà, la revisió feta el 1974 pretenia construir una via ràpida que paral·lela al riu Besòs enllacés Montcada i el Vallés amb l'autopista de Mataró.

Així el 27 de febrer es va organitzar el primer acte popular dels veïns per reivindicar que es fes un passeig i no una via ràpida. Va ser un festival infantil amb la participació de 300 nens i es va desplegar una pancarta on es reivindicava el passeig com a zona verda ${ }^{756}$. També en aquest cas les primeres accions van ser impulsades per la Comissió de Barri. Al setembre un full volant elaborat per aquesta circulava pel barri, amb el seu habitual llenguatge:

“COMPAÑEROS! EL BARRIO ESTÁ A PUNTO DE PERDER EL ÚNICO LUGAR DONDE PODRÍAMOS TENER UN PARQUE PARA NUESTROS HIJOS: EL PASEO ALAMEDA, ALLÍ DONDE LOS NIÑOS HAN JUGADO TANTAS VECES CON SUS AMIGOS.

(...)

NUESTRO BARRIO NECESITA UN PARQUE. CON 200.000 PERSONAS QUE SANTA COLOMA CUENTA, NO TENEMOS NI UN SOLO PARQUE. ¿QUÉ HARÁN NUESTROS HIJOS?, ¿DÓNDE PODRÁN JUGAR?. LA BURGUESIA NO VENDRÁ A SOLUCCIONARNOS EL PROBLEMA; SUS HIJOS YA TIENEN PARQUES Y RESIDENCIAS... ¡SOLO NOSOTROS PODEMOS DEDICIR SOBRE EL FUTURO RECREO DE NUESTROS HIJOS! ¿COMO?. HACIENDO VER LA NECESIDAD A TODOS LOS VECINOS, HABLANDO CON ELLOS EN LOS BARES, EN LAS TIENDAS, EN LAS PUERTAS DE LOS COLEGIOS, EN EL AUTOBÚS... DISCUTIENDO Y DEFENDIENDO ESTA CONSIGNA: iiVAYAMOS CON NUESTROS HIJOS AL PASEO ALAMEDA!!"757

Aquesta lluita va ser continuada per l'AVV del Rio a partir de la seva legalització l'octubre de 1975. La lluita es perllongà durant els anys següents amb talls de trànsit fets l'any 1977. Però no serà fins la dècada dels 80 que s'urbanitzà definitivament el passeig.

Apart d'aquestes lluites més localitzades, a Santa Coloma es van donar uns altres conflictes que van adquirir proporció "de ciutat" durant aquest període. Un cas va ser la lluita contra la carestia de la vida, que aviat es va relacionar amb la millora del transport públic: en contra de la pujada del preu de l'autobús, per l'ampliació de la "carretera de los cuarteles" i per l'arribada del Metro a la ciutat.

756Marcelo López Ródenas: Historia Social de la Santa Coloma moderna..., p. 224-225. 757Comisión de Barrio del Rio: "A todos los trabajadores del barrio" (setembre 1975) [full volant], AHMTB, Donació Marcelo López Ródenas, Caixa 3, Dossier 2 “Reivindicaciones vecinales”. 
A començaments de març del 1974 l'Empresa Municipal de Transports va decidir pujar el preu de bitllet de 5 a 6 pessetes. Per una població que feia servir l'autobús habitualment per traslladar-se al seu lloc de treball vàries vegades al dia, en no pocs casos agafant vàries combinacions conjuntament amb el metro, aquest fet va ser molt mal rebut (i a més, la tarifa als dies festius pujava a 7 pessetes). El malestar popular va ser canalitzat per diversos Centres Socials i per les Comissions de Barri, que van cridar al boicot i a la millora del transport públic existent en nombrosos fulls volants -fins a més de vint de diferents tipus! ${ }^{758}$ - com el següent:

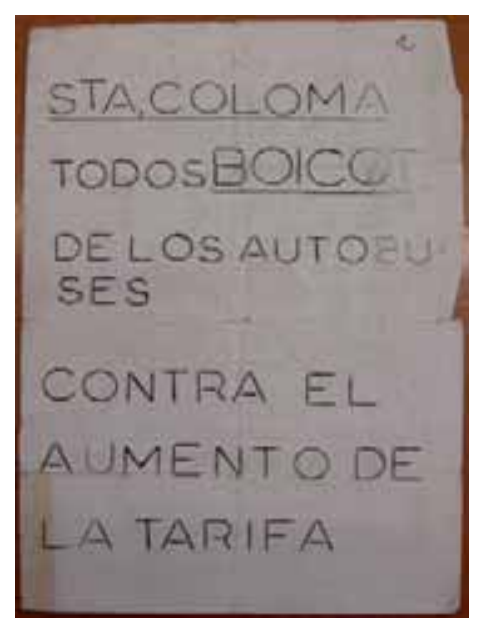

El boicot va començar el 12 de març. A les sis del matí grups de militants clandestins van començar a repartir fulles clandestines exhortant al boicot. A la tornada de la feina, cap a les $19 \mathrm{~h}$ s'organitzaren manifestacions cap al centre de la ciutat. El fet més visible va ser la riuada humana que es materialitzava sobre la "carretera de los cuarteles", quan els treballadors i treballadores colomencs tornaven des del metro de Torres i Bages caminant, fet que es va repetir els dies següents, al igual que l'apedregament d'alguns autobusos. Les forces policials intentaren reprimir la protesta. Es van fer diverses detencions -unes 12-, entre elles la de diversos militants de les CCBB, de Bandera Roja i veïns "sense carnet de partit", si bé van ser alliberats en 72 hores. Entre ells va ser detingut el sacerdot del Fondo Jaume P. Sayrach ${ }^{759}$. Aquest ja havia estat assenyalat anteriorment com a un dels instigadors de les protestes i de la redacció de propagada "subversiva" ${ }^{760}$. El 25

758Uns quants es poden consultar a AHMTB, Donació Marcelo López Ródenas, Caixa 3, Dossier 3. 759Marcelo López Ródenas: Historia Social de la Santa Coloma moderna..., p. 188. Segons aquest llibre Jaume P. Sayrach va se condemnat a una multa de 50.000 ptes. que mai va arribar a pagar. 760Veure per exemple: [Carta de Juan Porta Bussoms al governador civil] (5-2-1972), AHGCB, Caixa 
de març les CCBB tornaven a insistir en el boicot ${ }^{761}$. El 28 va ser incendiat un autobús de la línia SC (Santa Coloma-Trafalgar-Barcelona) de la companyia URBAS que també havia apujat 1 pesseta el preu del bitllet. El 5 d'abril un nou autobús va ser obligat a aturar-se i evacuar-se, per tot seguit punxar les seves rodes i calar-li foc. Al mes d'abril el boicot es començà a desinflar i la segona setmana del mes, després de la crema del darrer autobús, es tornarà a la normalitat després de tres setmanes de lluita. El preu es mantingué en 6 ptes. Però al poc temps es va marcar un carril només pel bus a la "carretera de los cuarteles" i es va fer una millora notòria a les freqüències de les línies 103, 203 i SC, les més utilitzades pels treballadors de Santa Coloma. Les converses entre l'Alcalde colomenc Porta Bussoms i el barceloní Enric Masó van obrir la possibilitat d'iniciar les obres d'ampliació de la carretera que comunicava les dues ciutats en un lapse de sis $\operatorname{mesos}^{762}$. Durant tot aquest període les CCBB van tenir una gran presència (i també altres grups polítics) si bé la seva actuació no va estar exempta de conflictes interns i acusacions entre les diferents CCBB's i els grups polítics de no estar a l'alçada dels fets -en alguns casos producte de les diferents concepcions que es donaven a les CCBB com a organismes de classe o de masses ja esmentades anteriorment barrejades amb acusacions de major o menor "reformisme"-, a més d'una profunda autocrítica per no poder mantenir la intensitat del conflicte, de no dotar-lo de contingut polític, de voler allargar-ho artificialment, de manca de coordinació o de voluntarisme segons les diferents postures. Fins i tot hi havia diferents comissions desdoblades al mateix barri -com al Fondo i Singuerlín, si fem cas d'algun document- amb visions enfrontades!! $!^{763}$.

185, Ayuntamiento de Santa Coloma de Gramanet 1972-1974. Aquí se l'acusava de ser redactor i impulsor d'uns fulls volants. Posteriorment un informe del "Servicio de Información de la Jefatura Provincial del Movimiento" tornà a acusar a Sayrach [el document l'anomena Xirach] de ser un dels principals instigadors de les protestes i grups opositors. Veure "Santa Coloma de Gramenet. Informe socio-político" (gener 1975), AHGCB, Caixa 205 Ayuntamiento de Santa Coloma de Gramanet 1974-1975.

761Comisiones de Barrio de Santa Coloma (C.B.): “iBOICOT!! A todos los trabajadores de Santa Coloma”, (març 1974) [full volant], AHMTB, Donació Marcelo López Ródenas, Caixa 3, Dossier 3. 762 Marcelo López Ródenas: Historia Social de la Santa Coloma moderna..., p. 189.

$763 \mathrm{Hi}$ ha diversos documents d'anàlisi i valoració de la lluita fets per diverses CCBB's. Si fem cas d'aquests sembla ser que la lluita va ser iniciada per dos CCBB's a la qual es van afegir després la resta i diversos grups polítics que estaven aleshores preparant accions pel primer aniversari de la mort de Manuel Fernández Márquez, l'obrer de la tèrmica del Besòs assassinat el 3 d'abril de 1973. De fet les divergències van provocar que diferents CCBB actuessin al marge d'una incipient Coordinadora existent. [CCBB, any 1974]: "Valoración lucha boicot bus (Días: del 12-31974 al 5-4-1974"; [Coordinadora de CCBB "Valoración alternativa a la lucha contra aumento 
Relacionat amb el conflicte anterior, la "carretera de los cuarteles" va esdevenir el següent focus de mobilització. A aquesta esmentada carretera, que comunicava Santa Coloma amb Barcelona passant per sobre del riu Besòs, que només tenia un carril de circulació per cada sentit es formaven uns embussos formidables els dies laborables. Amb 1.200 metres de llargada i 8 d'amplada la carretera suportava un volum de 27.000 vehicles al dia l'any 1971, xifra que augmentà a 40.000 quatre anys més tard. Per fer un trajecte de 10 minuts fins al metro de Torras i Bages es trigaven 45 minuts $^{764}$. El 3 'octubre s'acabava el termini de 6 mesos que havien donat les autoritats municipals de Barcelona i Santa Coloma per començar les obres de millora. El descontent per aquesta problemàtica continuava sent tant gran que fins i tot circulava aquesta cançó pels Centres Socials amb la música d'una altra melodia de Manolo Escobar ("la niña del rio"):

\begin{tabular}{|c|c|}
\hline $\begin{array}{l}\text { “La otra tarde pasé por el puente } \\
\text { por el puente de Santa Coloma }\end{array}$ & $\begin{array}{l}\text { Mi corazón solo piensa en la caravana } \\
\text { mi corazón no descansa ni estando en la cama }\end{array}$ \\
\hline Y pensaba muy seriamente & mi corazón sería feliz cada mañana \\
\hline Lo de Santa Coloma debe ser broma & si para ir a trabajar \\
\hline pues no creo que haya Santas & no tuviera que hacer "caranava"765 \\
\hline \multicolumn{2}{|l|}{ que tengan tan mala "leche" } \\
\hline que a nosotros se nos pone & \\
\hline Iando cruzamos el puente & \\
\hline
\end{tabular}

Així al desembre de 1975 les CCBB colomenques retornaren a la lluita. Van aparèixer noves fulles volants amb les següents reivindicacions:

“AMPLIACIÓN INMEDIATA DE LA CARRETERA
METRO A SANTA COLOMA
LINEA DE AUTOBUSES A TODOS LOS BARRIOS
NO MÁS SUBIDA DE PRECIOS
CARRIL “SOLO BUS" HASTA EL METRO
MARQUESINAS EN TODAS LAS PARADAS
BILLETES DE IDA Y VUELTA EN TODOS LOS AUTOBUSES"766

BUS] (finals abril 1974): "Sta. Coloma: La lucha contra el aumento del precio del autobús y por unos mejores accesos"; C.b de C. [Comissió de Barri del Centre]: "Informe de la lucha de los autobuses” (gener 1975). Tots a AHMTB, Donació Marcelo López Ródenas, Caixa 3, Dossier 6.

764 Marcelo López Ródenas: Historia Social de la Santa Coloma moderna..., p. 190.

765 Ídem, p. 190.

766Comisiones de Barrio de Santa Coloma (C.B.): "A la clase obrera y al pueblo trabajador" (desembre 1974), AHMTB, Donació Marcelo López Ródenas, Caixa 3, Dossier 3. Es van fer quatre models de full volant amb reivindicacions similars que es poden consultar a la mateixa 
$\mathrm{Al}$ gener es tornava a insistir des de les CCBB en les mateixes reivindicacions de nou en fulles volants similars ${ }^{767}$. Però aviat s'afegiren a aquesta reivindicació diferents grups polítics com el PSUC, el MCE i Bandera Roja. Es van fer diverses reunions i assemblees al voltant d'una "taula de partits i organitzacions de barri" i fins i tot els presidents d'entitats legals com els Centres Socials, les Parròquies i les Juntes Gestores de les AVV's en tràmit van enviar una carta a l'Ajuntament denunciant el problema ${ }^{768}$. El dia 5 es va fer una primera mobilització a la "carretera de los cuarteles" després d'una intensa campanya d'agitació feta els dos mesos anteriors ${ }^{769}$. Al 12 de febrer les CCBB van fer una crida a un nou boicot als autobusos els dies 18 i 19 del mateix amb un full volant ${ }^{770}$, al igual que el PSUC ${ }^{771}$. Hi participaran nombroses persones, malgrat la repressió policial amb càrregues i dos detinguts, però sense assolir el nivell aconseguit al boicot de l'any anterior ${ }^{772}$.

El 26 de març va haver-hi una nova pujada del preu del bitllet d'autobús: una pesseta els dies laborables i dos els festius. Les CCBB cridaren a un nou boicot a partir de l'1 d'abril (la pujada s'havia fet enmig Setmana Santa, per apaivagar possibles protestes) $)^{773}$. El dia 2 la Coordinadora de CCBB acordava prorrogar la jornada de boicot fins el dia 4. Però el dia 3 un fet va enterbolir els esdeveniments. Un grup va assaltar i incendiar un autobús al Passeig de Santa Coloma. El vehicle

referència.

767Es poden veure a AHMTB, Donació Marcelo López Ródenas, Caixa 3, Dossier 3.

768 "Ilmo. Señor Alcalde de Santa Coloma de Gramenet", [carta enviada la primavera de 1975],AHMTB, Donació Marcelo López Ródenas, Caixa 3, Dossier 3. Apart de els reivindicacions del transport públic, es feien altres de tipus social de suport als aturats i contra la pujada del cost de la vida.

769Comisiones de Barrio de Santa Coloma (C.B.) [full volant sense títol] (febrer 1975), AHMTB, Donació Marcelo López Ródenas, Caixa 3, Dossier 3.

770 Comisiones de Barrio de Santa Coloma (C.B.): “Todos al boicot a los autobuses los dias 18 y 19 !! Por la ampliación de las carreteras!!” [full volant, febrer 1975], AHMTB, Donació Marcelo López Ródenas, Caixa 3, Dossier 3.

771 Partit Socialista Unificat de Catalunya, Comité de Santa Coloma de Gramanet: "Todos al boicot de autobuses el martes dia 18” (febrer 1975), AHMTB, Donació Marcelo López Ródenas, Caixa 3, Dossier 3.

772 Marcelo López Ródenas: Historia Social de la Santa Coloma moderna..., p. 192.

773De nou van haver-hi vàries fulles volants convocant a la mobilització: Comisiones de Barrio de Santa Coloma (C.B.): "A la clase obrera y al pueblo trabajador: Por la ampliación inmediata de la carretera” [1 març 1975]; [sense signar]: “iiNo a la subida de precio de los autobuses!!” [26-31975]; Comisión de Barrio del Centro: "A la clase obrera y al pueblo trabajador de Santa Coloma" (març 1975); Comisiones de Barrio de Santa Coloma (C.B.): "Nueva victoria del pueblo de Santa Coloma" (abril 1975); Comisiones de Barrio de Sta. Coloma (C.B.): “Contra la subida de tarifas. Boicot bus!!”, totes a AHMTB, Donació Marcelo López Ródenas, Caixa 3, Dossier 3. 
esclatà en flames davant de molts veïns que fugiren espantats. Aquest fet va implicar la fi de les protestes i una dura crítica de les CCBB en un full volant:

"Las c.b. no somos contrarias a la acción de quemar un autobús siempre y cuando esa acción sea un modo de extender y aumentar la participación de las masas en la lucha. Estamos totalmente en contra de esas acciones cuando expresan la impotencia de la vanguardia en atraerse a las masas o producen el efecto de liquidar una lucha. Por eso las c.b. Denunciamos a las organizaciones FRAP, LCR-ETA VI como:

-liquidacionistas: pues su acción provocó tal dispersión que impidió, junto a la inmediata acción de la policía, realizar la marcha a Santa Coloma, manifestarnos y crear las condiciones adecuadas para finalizar con éxito la lucha el día 4.

-oportunistas: pues sin haber realizado ninguna labor en toda la lucha, pretenden ser la vanguardia quemando un autobús"774.

No obstant a l'abril de 1975 van començar les obres d'ampliació de la “carretera de los cuarteles", que no es van finalitzar fins març de 1977. El metro encara va trigar molt més i no va arribar a Santa Coloma fins 1983.

Mentrestant, el 29 d'abril de 1974 la "Comissión de Urbanismo y Servicios Comunes de Barcelona y otros municipios" aprovà un nou Pla Comarcal. Malgrat aquest era un intent de crear un ordenament més racional del territori i durant un any es van suspendre les llicències d'obres, pel que fa a Santa Coloma de Gramenet va generar una forta oposició ja que, per una banda, es proposava la creació de zones verdes en terrenys ja edificats -amb la subsegüent expulsió dels seus habitants- mentre contradictòriament no contemplava la conservació de grans solars que encara no estaven edificats (com els terrenys de Can Zam, el Motocross, la Bastida, les Vinyes...) per aquesta funció. Alhora projectava uns grans eixos viaris (2on Cinturó, autovia del Besòs, ampliació de la Rambla Sant Sebastià i del Carrer Irlanda amb un túnel que enllaçaria amb Badalona...) que també afectaven a domicilis particulars i espais que es reivindicaven com zona verda (per exemple, el Passeig de la Salzareda...). Aquest fet va comportar una nombrosa mobilització popular en Centres Socials i parròquies, que van promoure una impugnació al Pla, no com un refús frontal si no més amb la idea d'elaborar un altre més d'acord amb

774Comisiones de Barrio de Santa Coloma (C.B.): "Las Comisiones de Barrio de Santa Coloma denunciamos a las organizaciones F.R.A.P. Y L.C.R.-E.T.A. VI, por su actuación en la lucha de los autobuses" Abril 1975. AHMTB, Donació Marcelo López Ródenas, Caixa 3, Dossier 3. El subratllat és de l'original. 
la realitat local i que es recollissin les reivindicacions del moviment popular a la ciutat. En aquestes impugnacions es contemplaven l'ampliació del transport públic, de la "carretera de los cuarteles" i l'arribada del metro; el refús a totes les obres de vies ràpides; el respecte als habitatges particulars afectats i en cas ineludible d'afectació el control de les obres pels veïns; la reivindicació dels grans solars no edificats -ja esmentats- i d'altres més petits als diferents barris per parcs urbans i equipaments; el refús frontal a les contribucions especials; reivindicacions específiques de determinats barris així com la denúncia de la manca d'un procés participatiu de la població en l'elaboració de l'esmentat $\mathrm{Pla}^{775}$. En contrast, el consistori colomenc, per boca del seu assessor d'urbanisme Ramón Rovira Vilamitjana $^{776}$, no hi posava objeccions ja que no contravenia els principals projectes municipals existents.

Es van fer 35.000 al-legacions al Pla i la Comissió d'Urbanisme davant tanta oposició va suavitzar-lo i el novembre va reconsiderar les expropiacions de zones ja edificades. Posteriorment la Corporació Metropolitana de Barcelona, entitat que va substituir a l'anterior va decidir revisar-lo i fer-ne un de nou, que va sortir publicat al febrer de 1976. Tot i ser millor que el seu predecessor, encara no va ser ben vist per les entitats veïnals per que no es recollien totes les seves propostes, en especial pel que fa a la conservació íntegra per zones verdes i equipaments com per exemple Can Zam. Per això les mobilitzacions no es van aturar, ara encapçalades pels Centres, les AVV's i el nou Casal de Cultura. El fruit d'aquestes lluites va esdevenir el "Estudio sobre la situación social y urbana de Santa Coloma de Gramenet y propuesta para un plan de alternativas" o, com va ser altrament denominat, el "Pla Popular", del qual parlaré més endavant ${ }^{777}$.

Durant aquest període també van ser prou importants diferents lluites per la conservació de determinats solars per zones verdes o equipaments. Si bé el Pla

775 Marcelo López Ródenas: Historia Social de la Santa Coloma moderna..., p. 228. Ja en aquestes primeres impugnacions es van destacar tècnics que assessoraven al moviment popular com Xavier Valls, del qual tornarem a parlar en l'elaboració del posterior Pla Popular.

776Aquest assessor urbanístic era alhora també assessor de diverses empreses constructores privades. Aquest fet va ser denunciat per entitats populars i per la revista Grama al seu núm. 79-80 (juliol- 1975), en concret a l'article de Marta Badosa i Humbert Roma: "Santa Coloma: un gran tablero de ajedrez". Membre de "Planificaciones Urbanísticas", que havia redactat els projectes municipals de Can Zam i el Motocros, al seu despatx s'havia negociat la compra de terrenys de Cam Zam per la constructora Construcciones Gumi, S.A.

777 Marcelo López Ródenas: Historia Social de la Santa Coloma moderna..., p. 229. 
Comarcal de 1953 havia previst tres grans parcs forestals (un a la muntanya de San Mateu, un altre al sector Cementiri Vell/Riera Alta, i el tercer a tocar de Badalona) i quatre parcs urbans que superaven les 8 Ha (i també més zones amb edificacions de poca alçada, en concret 128 Ha de "ciutat jardí"), els plans parcials posteriors van destruir aquesta planificació en benefici del negoci i l'especulación ${ }^{778}$.

Pel que fa a un d'aquests terrenys, els que envoltaven la Masia de Can Zam, les immobiliàries havien comprat els terrenys quan encara eren zona agrícola a 20 ptes. el pam. El Pla Parcial del Sector Nord-est de 1964 va canviar la qualificació a zona urbana i el preu va pujar a 150 ptes. el pam. El negoci era evident tot i que la urbanització es va ajornar, fins que al 1972 l'Ajuntament va concretar com seria la urbanització de la zona: habitatges per unes 10.000 persones i una zona comercial i industrial. Si sumem les instal-lacions de l'Institut Puig Castellar, un poliesportiu i l'autopista que devia anar paral-lela a l'Av. Pallaresa, només quedaven $46.250 \mathrm{~m} 2$ per fer un parc urbà. La revista Grama va denunciar el negoci que s'amagava darrera de l'operació ${ }^{779}$. La suspicàcia de la gent es va transformar en indignació i ira quan un Ple celebrat el dia 10 d'octubre de 1975 refusava una proposta veïnal de dedicar tot el terreny a equipaments col-lectius ${ }^{780}$. Les reivindicacions per aquest espai -com veurem- s'allargaren durant molt temps arribant fins avui en dia.

Un cas similar va ser el dels terrenys del Motocross, situats al barri de Santa Rosa tocant a Badalona (Llefià). Aquest terreny, de 8,4 Ha, no havia estat protegit pel Pla Comarcal de 1953, que només contemplava 1 Ha com a parc urbà comarcal. En aquest descampat situat dalt la serralada d'en Mena s'havien celebrat

778Ídem, p. 230. L'autor parla de més de 300.000 Ha perdudes de zona verda entre els anys seixanta i setanta

779Marta Badosa i Humbert Roma: "Santa Coloma: un gran tablero de ajedrez" Grama núm. 79-80 (juliol-agost 1975), p. 27-31. En aquest article s'analitzaven els diferents "pilotassos" urbanístics de la ciutat, així com els principals beneficiats, particulars, empreses i Ajuntament.

780Van votar en contra de la proposta l'Alcalde Blas Muñoz Blaya, Juan Aloy Casellas, Juan Pérez Terol, Francisco Jesús Esteban, Juan Aloy Pina, Fernando Pérez Jerez, Gabriel Torralba, Manuel Robles, Jorge Antolín y José Blanchart (12 en total). En canvi, sis van posicionar-se a favor de la proposta veïnal: Juan de Dios López del Moral, Julo Baena Moreno, Gregorio Génova, Manuel Matés, José Rosset Bugía y Salvador Callejón. Grama es fer ressò en el seu núm. 83 (novembre 1975) amb una portada prou explícita: les fotografies dels 12 regidors del NO i la llegenda "CAN ZAM, el pueblo que si, ellos que no...". Les Parròquies de la ciutat també van emetre un document crític al respecte adreçat a l'Alcalde (veure AHMTB, Donació Mn. Josep Catà, Caixa 3). Però sens dubte la reacció més clara va ser el document “iiSalvem Santa Coloma!! Manifiesto Ciudadano de los 51" anteriorment esmentat. Aquest fet també va ser prou resseguit en la premsa diària, en alguns casos amb titulars tan explícits com "El Ayuntamiento, totalmente de espaldas a la población" a Tele/ eXpres, 20-10-1975. 
competicions internacionals de "motocross" (d'aquí el nom) durant els anys seixanta. Al 13 de juliol de 1973 es feia un Pla Parcial que contemplava la construcció de polígons d'habitatges de 9, 11 i 15 pisos d'alçada (que implicaven un augment de població de 7.600 habitants) sense preveure tots els equipaments necessaris per aquests. El projecte havia estat realitzat per la firma Promociones Sociales S.A. on també figurava com assessor l'arquitecte municipal Ramon Rovira Vilamitjana (repetint una operació similar a la de Can Zam).

Des de feia temps els Centres Socials d'Arrabal i Santa Rosa, la Comissió de Barri i les Comunitats Cristianes venien reclamant la totalitat d'aquest espai per zones verdes i equipaments. El 27 de novembre de 1973 es va intentar fer una primera reunió informativa a la parròquia de Sant Jaume del Raval amb la presència d'un tècnic del Col-legi Oficial d'Arquitectes. La reunió va ser avortada per la presència policial amb l'argument que era il·legal. Al 6 de desembre es repetí -ara si- amb permís governatiu i dos tècnics de l'esmentat Col-legi van poder explicar el que pretenia el Pla Parcial ${ }^{781}$. Aviat va començar una campanya d'oposició a aquest, que va culminar amb més de 1.000 impugnacions i amb el suport del Col·legi de d'Arquitectes de Catalunya i Balears mentre paral-lelament es convocaven actes reivindicatius als terrenys implicats com va ser per exemple una "tortillada popular" el dia 21 de febrer de 1974 o una festa infantil el 13 de maig de 1974 ${ }^{782}$. El 24 d'octubre de 1974 va saltar l'alarma: unes excavadores van començar a treballar rebaixant els terrenys. La protesta veïnal aconsegueix que s'aturin les obres que es feien sense permís ${ }^{783}$. Però el dia 27 la policia reprimí violentament un festival popular organitzat al Motocross pels Centres Socials d'Arrabal i Santa Rosa. Aquest fet va ser denunciat en una carta enviada per aquests a diferents mitjans -apart d'explicar el per què es reivindicava l'esmentat terreny-:

“(...) 4o El domingo día 27 durante la celebración de uno de estos actos y concretamente en el momento en que los niños realizaban el juego de "romper la olla", intervino, con el correspondiente asombro de todos los allí presentes la fuerza pública, desalojando a todos los vecinos que nos encontrábamos allí."784

781 Marcelo López Ródenas: Historia Social de la Santa Coloma moderna..., p. 232-233.

782Eugenio Madueño: "Una "tortillada" muy significativa" i "Masiva fiesta infantil en el Motrocross de Santa Coloma", Tele/ eXpres, 22-2-1974 i 14-5-1974

783 “Suspendidos los trabajos en los terrenos del Motocross", Diario de Barcelona, 25-10-1974.

784 Miguel Molina Reinoso [president del Centro Social Arrabal-Santa Rosa]: "Reivindicación de los terrenos del Motocross", Diario de Barcelona, 30-10-1974. 
En aquesta carta es denunciava també el paper jugat per l'arquitecte Ramon Rovira Vilamitjana, el qual es defensava de les acusacions en un escrit de rèplica publicat el 5 de novembre, on negava que fes assessoria jurídica de cap entitat que tingués interessos en el Motocross i que les obres que s'estaven fent allà no eren d'urbanització sinó per proveir de sorra la construcció d'una planta de CAMPSA a Badalona $^{785}$. Davant aquest fet el President del Centre Social Arrabal-Santa Rosa li responia de nou que ell mateix s'havia atribuït l'autoria del Pla Parcial del Motocross en articles apareguts a la premsa anteriorment ${ }^{786}$ i que aquest havia estat fet per una empresa privada -Promociones Sociales S.A.- en la qual constava com advocat-urbanista de l'equip planificador, i que per tant estava mentint ${ }^{787}$. Aquest afer va enterbolir més la ja greu crisi existent al Consistori Colomenc que va acabar -mesos més tard- amb la dimissió de l'alcalde Juan Porta Bussoms.

La reivindicació del Motocross continuà fins al punt que el 9 de març de 1975 es celebrà una reunió impensable uns quants mesos abans: una assemblea al carrer de 400 veïns amb el nou alcalde Blas Muñoz i el "procurador en Cortes" Eduardo Tarragona Corbella, amb la presència d'un tècnic urbanista i diversos regidors, i, per descomptat, del delegat governatiu. L'arquitecte va exposar les peticions dels veïns: un parc de $2 \mathrm{Ha}$, un grup escolar d'EGB, 2 escoles bressol, 1 residència d'avis, 1 ambulatori, 1 centre social i un Institut ${ }^{788}$. Eduardo Tarragona portà la reivindicació a les Cortes mentre l'Ajuntament canviava de postura i s'oposava ara a la construcció dels blocs d'habitatges. El Centre Social d'Arrabal-Santa Rosa havia encapçalat la lluita veïnal ${ }^{789}$ ) i ara celebrava la seva victòria exposant una maqueta del projecte veïnal al juliol de 1975 al seu local social, tot i que aquest encara trigaria a materialitzar-se $\mathrm{e}^{790}$.

785Ramón Rovira Vilamitjana: "Revindicación de los terrenos del Motocross de Santa Colo", Diario de Barcelona, 5-11-1974.

786Com per exemple: Alfonso Anguera Sampere i Ramón Rovira Vilamitjana: "El Plan Parcial del Motocross en Santa Coloma de Gramanet, no modifica el Plan Comarcal” al Correo Catalán 2012-1973.

787Miguel Molina Reinoso, Presidente del Centreo Social Arrabal-Santa Rosa: [Carta publicada a Diario de Barcelona, 12-11-1974].

788Marcelo López Ródenas: Historia Social de la Santa Coloma moderna..., p. 233-234.

789El Centre Social Arrabal-Santa Rosa va arribar a fer un número especial del seu butlletí: Boletín extra Motocros recollint les notícies aparegudes a la premsa, les cartes, etc., AHMTB, Donació Marcelo López Ródenas, Caixa 3, Dossier 9.

790 Marcelo López Ródenas: Historia Social de la Santa Coloma moderna..., p. 234. 
Unes altres lluites que van adquirir un volum important a Santa Coloma de Gramenet van ser les derivades de la sanitat, l'ensenyament i la pujada del cost de la vida. Pel que fa al primer dels dos aspectes, la lluita de 1971 ja havia demostrat la seva importància. No obstant, la construcció del nou ambulatori havia estat un pedaç del tot insuficient. La ciutat es trobava molt per sota dels estàndards de l'Organització Mundial de la Salut, que recomanava l'existència de 1.500-2.000 llits hospitalaris (n'hi havien 40 de la clínica maternal); 300-400 metges amb dedicació complerta i 900-1000 assistents tècnics sanitaris, també a temps complert. Però fins i tot incomplia la pròpia legislació franquista al respecte existint només 87 facultatius i especialistes quan en teoria segons aquesta llei n'hi haurien d'haver $141^{791}$.

Als 10 mesos de la inauguració del nou ambulatori, el 3 de febrer de 1973, va morir una dona a la clínica maternal i la gent, malgrat les justificacions mèdiques, aviat va sospitar que la causa real havia estat una negligència mèdica relacionada amb les insuficiències del centre, que no disposava de sang per fer transfusions ${ }^{792}$. Setmanes abans havia esclatat un conflicte laboral del personal dels centres hospitalaris de Barcelona al qual es va sumar el personal sanitari colomenc exigint una millora del servei, amb una vaga dels dies 11 a 15 de gener i un enfrontament del personal del centre amb la direcció del mateix.

El 13 de juny una altra mare donava a llum però amb complicacions. Davant la manca de sang a l'hospital el seu marit va anar a cercar-la a l'Hospital de la Vall de Hebrón a Barcelona on li va ser negada per la manca d'un volant d'autorització. El mateix dia la dona moria. El mes de juliol va morir també un recent nascut i una altra dona va estar-hi a punt. El 4 d'octubre de 1974 ho feia una dona embarassada de 4 mesos i el 8 del mateix mes moria una altra amb complicacions en el seu embaràs. Fets com aquest van provocar les nombroses denúncies de grups polítics locals, les CCBB així com la revista local Grama ${ }^{793}$. No va ser fins el 1er d'abril de 1975 quan es va inaugurar un altre ambulatori -en unes instal-lacions del tot inadequades- al carrer Irlanda. Poc després ho feien uns altres al Barri Llatí i al

791Veure l'article "Así es el ambulatorio" a Grama núm. 69 (setembre 1974), p. 9-11. 792Grama núm. 50, (febrer 1973).

793 Les CCBB van editar diversos fulls volants al respecte que es poden consultar a AHMTB, Donació Marcelo López Ródenas, Caixa 3, Dossier 11 “Temes varis locals: Sanitat, carestia de la vida, 1er de maig...". 
Singuerlín, però l'atenció sanitària encara estava lluny de ser satisfactòria.

El segon dels temes era el de l'ensenyança. Ja he esmentat anteriorment com el mateix any 1971 el mateix Comitè Unitari que havia encapçalat la lluita per l'ambulatori havia fet reivindicacions per cobrir l'alarmant dèficit escolar existent, agreujat progressivament pel "baby-boom" i l'escassa inversió feta en els anys anteriors $^{794}$. Des de 1972 es van continuar denunciat els dèficits en aquest àmbit i el contrast entre la teoria -la nova llei d'educació de 1970- i la pràctica, a més de fer esment a les necessitats especials de determinats col-lectius, com els deficients mentals (on va destacar l'entitat colomenca ASPANIDE ${ }^{795}$ ). Les mateixes CCBB havien analitzat en un document intern les primeres lluites que s'havien donat en aquest sentit ${ }^{796}$.

El mateix número especial de Grama de juliol-agost de 1972 reconeixia un dèficit de 8.148 places escolars d'EGB ${ }^{797}$. El mateix setembre de 1974 s'inicià, al barri de Les Oliveres, un conflicte pel retard en l'obertura del col-legi públic Lluis Millet. Els pares i altres persones van ocupar el centre i van impartir classes fins que el Ministeri no va dotar al centre dels mestres necessaris ${ }^{798}$. Malgrat la inauguració d'alguns centres, la situació va continuar sent molt deficitària, no només per la falta de places sinó per que moltes eren d'escoles privades que feien les classes en els locals més inversemblants com ara baixos d'edificis i d'altres que no reunien les mínimes condicions humanes ni pedagògiques, en amuntegar-se 50 o més alumnes per classe (fet que també passava l'escola pública). Les lluites per les escoles van ser una constant dins el moviment veïnal en la segona meitat dels 70 i fins i tot als 80 com veurem més endavant.

Pel que fa a la carestia de la vida, serà un tema transversal que es farà servir en altres ocasions, sobretot quan les pujades afectaven els productes essencials de la cistella de la compra i es combinaven amb la progressiva congelació salarial i

794Veure el document "17.500 niños sin escuela", ja esmentat, AHMTB, Donació Marcelo López Ródenas, Caixa 3, Dossier 1.

795Es poden consultar diversos números de la revista Aspanide a AHMTB, Donació Marcelo López Ródenas, Caixa 1.

796[Comisión de Barrio de Singuerlín?] [Anàlisis-situación primeros mov. Lucha enseñanza] [el títol està posat a mà, probablement en un moment posterior a l'elaboració del document datat també a mà en la primavera de 1972], AHMTB, Donació Marcelo López Ródenas, Caixa 3, Dossier 5.

797“Hacen falta más escuelas”, Grama núm. 43-44 (juliol-agost 1972), p. 14.

798 Fernando Saro: Les Oliveres. Sabor a barrio 1970-1980, Edicions Fòrum Grama, 2012, p. 48. 
atur creixent quan els efectes de la crisi econòmica mundial es van començar a fer notar. Les CCBB havien treballat aviat aquesta qüestió com posa de manifest l'existència de fulls volants en dates tan primerenques com les darreries de $1971^{799}$, fet que tindrà continuïtat als anys posteriors ${ }^{800}$. Posteriorment les AVV's continuaren aquesta tasca.

També cal fe esment, ni que sigui breument per que aquest treball no està centrat en el moviment obrer, a la creixent conflictivitat obrera i els seus nexes amb el moviment veïnal. Tot i que un nombre important de colomencs i colomenques treballaven fora de la ciutat, no s'ha de menystenir la importància d'un sector com el tèxtil dins la mateixa ciutat que vindria a matisar, si més no, la clàssica concepció de Santa Coloma com a "ciutat dormitori" ${ }^{801}$. Conflictes com el desenvolupat a Casadeport durant l'estiu de 1974 (del qual les CCBB també es van fer ressò) van tenir la seva influència dins el moviment popular als barris, ja fos per la solidaritat despertada com per que en no pocs casos es tractava dels mateixos protagonistes $^{802}$.

Hi ha un fet cabdal, doncs, que no se'ns pot escapar. A la ciutat de Santa Coloma el moviment veïnal havia esdevingut un problema per les autoritats locals ja abans de la mort del dictador. L'Alcalde Juan Porta Bussoms estava molt desgastat per aquesta conflictivitat que es traslladava als plens municipals, pels nombrosos casos de corrupció -que eren realment escandalosos- i per l'oposició de les capelletes locals que ambicionaven el seu càrrec ${ }^{803}$. No va poder evitar la seva

799Comisiones de Barrio [finals del 1971]: “Comañeros y compañeras de Santa Coloma” [full volant denunciant la pujada de preus i relaccionant-los amb reivindicacions laborals i l'habitual crítica al sistema capitalista], AHMTB, Donació Marcelo López Ródenas, Caixa 3, Dossier 11 “Temes varis locals: Sanitat, carestia de la vida, $1 \mathrm{er}$ de maig...."

800 He trobat més fulles volants de les CCBB al respecte els anys 1972, 1974 i 1976. També un document de formcaió interna: C.B Barrio Centro: "La carestia de la vida" (febrer 1974), AHMTB, Donació Marcelo López Ródenas, Caixa 3, Dossier 6.

801Veure el treball de Lola Carrión: La conflictivitat laboral en Santa Coloma de Gramenet des de 1968 a 1978. Treball de Màster, Universitat de Barcelona, 2008.

802El cas més paradigmàtic pot ser el de Emiliana Salinas, una de les líders obreres a Casadeport (a Plataformes Anticapitalistes) i activista veïnal al barri del Fondo (on posteriorment va arribar a presidir l'AVV) i Alicia Ruzafa, també obrera a Casadeport, militant del PSUC i presidenta de l'Associació de Mestresses de Casa al Singuerlín. Apart del treball esmenat a la nota anterior sobre el conflicte de Casadeport es pot consultar els articles de David Monsergas Ferrer: "La vaga de Casadeport" i Juan José Gallardo Romero "Aportacions a la vaga de Casadeport" dins Grup d'Historia José Berruezo: Una ciutat dormitori sota el franquisme..., p. 343-367 i p. 369379 , respectivament.

803 Un "Informe Anónimo y Reservado. Situación del Municipio de Santa Coloma de Gramanet" [de data desconeguda, però deu ser de finals de 1974] i un altre document reservat anomenat 
substitució al capdavant de l'alcaldia per un dels seus màxims rivals, Blas Muñoz Blaya, el mes de febrer de 1975. El nou Alcalde coincidia amb l'anterior en l'habilitat d'enriquir-se ràpidament i fraudulentament, igual que la majoria de les elits locals que havien copat els càrrecs a l'Ajuntament durant el franquisme:

\begin{abstract}
"Al señor Muñoz se le atribuyen durante su actuación como corresponsal de la banca numerosos negocios de usura, procedimiento por el cual se apropió de gran número de terrenos y fincas que luego ha ido edificando, los unos a través de una Constructora que manejan sus hermanos, Manuel y Juan. Asimismo, y con motivo de la venta de unos puestos del Mercado Nuevo, obtuvo a bajo precio uno que figura a nombre de su hermana Josefina Muñoz en el mercado de Hondo [sic]. Parece que fue procesado por delito de fraude y contrabando, en el Tribunal de la Delegación de Hacienda de Barcelona, por el cual fue multado.

Lo que llama poderosamente la atención es que en pocos años haya podido amasar la fortuna de que dispone, lo que parece confirmar sus actividades de usura y otros negocios poco claros" ${ }^{\prime 804}$
\end{abstract}

Però Blas Muñoz, tot i que va intentar donar un tarannà més dialogant molt aviat va haver d'enfrontar-se amb els mateixos problemes que el seu antecessor fins al punt que ja aviat l'oposició veïnal exigia la seva dimissió abans d'acabar l'any després de l'afer de Can Zam, i anys després fins i tot va rebre alguna pedrada de part dels veïns de Can Franquesa. La seva no va ser, precisament, una alcaldia plàcida.

Pel que fa la ciutat més gran del Barcelonès Nord, Badalona, tot i ser una ciutat més gran que Santa Coloma de Gramenet, durant aquests primers anys setanta fins la mort de Franco va experimentar una conflictivitat menor que la seva

"Situación del Municipio de Santa Coloma de Gramanet" (novembre de 1974) enumeraven les nombroses irregularitats comeses per Porta i els seus regidors afins, que anaven de l'enriquiment personal desviant diners del cobrament d'impostos sobre les escombraries, del mateix Frente de Juventudes o del Patronato Municipal de la Vivienda, a més de tenir vincles directes amb empreses que tenien interessos en Can Zam (en una promotora d'obres) i el Motocros (Banca Catalana) o negocis il-legals com les rifes de determinats bars.

804[Jefatura Provincial del Movimiento]: "Santa Coloma de Gramanet.-Informe socio-político (gener 1975), AHGCB, Caixa 295 [millorar referència], p. 4. Blas Muñoz va comptar, no obstant, amb el suport del nou governador civil Rodolfo Martin Villa, com es pot comprova a la carta enviada per Rodolfo Martin Villa al vicepresident primer i ministre de la Governació José Garcia Hernández (30-4-1975), AHGCB, Gobernadores Civiles. Caja 205. Ayuntamiento de Santa Coloma de Gramanet 1974-1975. En aquesta mateixa carta es comentava com altres candidats "més preparats" havien refusat l'oferiment entre d'altres motius, per la força del moviment popular reivindicatiu. 
veïna. Sobre els motius que van portar a això hi reflexionaré al darrer apartat del present capítol. Però això no vol dir que no hi haguessin lluites veïnals. Aquestes van existir, tot i que inicialment es van concentrar més en els seus barris perifèrics, que eren els que havien rebut més població nouvinguda i els que experimentaven els majors dèficits de tot tipus. Dos dels seus barris que aviat van destacar per la seva conflictivitat van ser dos dels construïts per l'Obra Sindical del Hogar: Pomar i Sant Roc.

De la conflictivitat en el barri de Pomar ja havia parlat anteriorment, per que ja va començar a finals dels anys seixanta amb la primera vaga de lloguers ${ }^{805}$. La conflictivitat va anar creixent ja que a aquesta qüestió s'hi van sumar uns altres temes pendents (equipaments, serveis, transports, etc.) i a la presència molt pròxima de l'abocador d'escombraries. Inicialment les reivindicacions van ser canalitzades pel Centre Social de Pomar. Ja el 22 d'Octubre de 1971 la "Sección de Señoras" de l'esmentat Centre s'havia adreçat a l'empresa TUSA per notificar les deficiències del servei d'autobusos en Pomar en horaris, a més de:

“2/ Petición de que el T.P. LLEGUE HASTA EL FINAL DEL SERVICIO TUSA Y LA INSTALACIÓN DE UNAS MARQUESINAS a fin de no mojarse los días de lluvia (solicitud hecha ya hace algún tiempo al Ayuntamiento. Nos contestó que el permiso dependía del Ayuntamiento y de Obras Públicas, pero que éstas estaban supeditadas al Ayuntamiento, en fin, que era el Ayuntamiento de Badalona el que tenía que dar el permiso.

Las señoras hicieron el propósito de insistir periódicamente al Ayuntamiento y presentar la petición en el próximo pleno." ${ }^{\text {806 }}$

Va ser a l'any 1972 que es va reprendre amb força la lluita al barri. I amb unes formes molt més contundents. Davant d'una pujada tarifària dels autobusos que es va fer a partir de l'onze de juliol, on els autobusos BS i TP van passar de 8 a 9,5 pessetes $^{807}$, un grup de persones van assaltar i cremar el 4 de juliol un autobús al carrer Tiana del barri de Pomar $^{808}$, amb el suport de 150 persones que van cridar 805Carles Mas: El Pomar - Badalona, p. 52-53.

806Pomar Convivència núm. 23 (octubre-novembre 1971), MB, Hemeroteca, Caixa 21-1-6, Carpeta Pomar Convivència, p. 5.

807Un full volant del Comitè Local del PSUC n'informava: "Al Pueblo de Badalona" [juny 1972], ANC,

Fons PSUC, 03. Organitzacions de Base, 03.01. Organitzacions territorials, 819 Badalona: Comitè Local del PSUC (1967-1977).

808Dirección General de la Guardia Civil: "Nota Informativa: 155. De arrojar un coctel molotov. Dos 
consignes i llençar fulls volants contra la pujada de les tarifes que concloïen de la següent manera:

"Para hacer frente a esta nueva explotación a la clase obrera ya que esta es la que más utiliza estos medios de transporte, organicémonos en nuestros centros de trabajo. Hagamos asambleas, marchas a pie, manifestaciones. Organicémonos en nuestros barrios, asociaciones de vecinos y en todos los centros.

NO A LA SUBIDA DE AUTOBUSES

NO A LA SUBIDA DE PRECIOS

LIBERTAD A LOS DETENIDOS!!!"809

El mateix any 1972 es va fundar, partint del Centre Social adherit a Càritas l'Associació de Veïns de Pomar (si bé encara durant uns anys el Centre Social va continuar existint). En aquell moment ja es començava a fer una coordinació amb els barris de l'OSH d'altres ciutats catalanes, ja que solien tenir les mateixes problemàtiques fins a constituir-se formalment una Coordinadora de Barris de l'OSH $^{810}$. I d'aquesta manera es va reactivar la lluita. El 7 d'agost es va fer una assemblea a la parròquia de Sant Sebastià, amb la presència d'Eduardo Tarragona (procurador per Tercio Familiar a les Corts franquistes ja esmentat anteriorment), no sense dificultats, com ens recorda un dels protagonistes d'aleshores, el sacerdot Joan Cuadrench:

"Hi va haver una... Totes les reunions dels pisos es feien a l'església (...). I s'omplia eh? Vull dir tot el barri (...). I aleshores jo recordo una que va venir el Tarragona, que era el... [procurador en Cortes] Això ja era el 73 potser.. no sé. [es possible, cal contrastarho amb la premsa] Aleshores hi va haver un... això deuria ser al 72 o $71 . .$. eh... I va ser sonat per que un seminarista que [al 72] (...) Màrius Casador, era professor de la Minguella i del Badalonès (...). I aleshores va demanar a en els grans de batxillerat si els volia ajudar a repartir octavetes per la convocatòria d'aquesta assemblea de veïns per lo dels pisos, no? I que havien convidat a en el Tarragona. I els van enganxar la Guàrdia Civil (...) I aleshores els hi van agafar les octavetes i van dir que els seus pares anessin a l'endemà a la Guàrdia Civil. I l'endemà vam anar el Pedro Rueda i jo... per que el rector estava fora. Jo no sé... cada vegada que hi havia un merder, el Torrella era fora

desconocidos. Manifestandose y repartiendo propaganda clandesina" (5-7-1972), AHCGB, Gobernadores Civiles, Caixa 140, Actividades Contra el Régimen (III) 1971. Es tracta d'un informe fet per la comandància de la Guàrdia Civil de Manresa adreçat al Govern Civil.

809Comités de Estudiantes, Comisiones de Barrios, Conmisiones Obreras: "Trabajadores, estudiantes, pueblo de Badalona", [juliol 1972], AHCGB, Gobernadores Civiles, Caixa 140, Actividades Contra el Régimen (III) 1971.

810Carles Mas: El Pomar - Badalona, p. 53. 
i em tocava en a mi arreglar... [riu] (...)

Bueno, total que aleshores a l'endemà anem a la Guàrdia Civil. I... 'Carnet de identitat!' Jo clar, com el carnet de identitat dura varios anys, encara posava 'estudiante' i...'¿ ¿Usted es el sacerdote?'... 'Si', 'Oh, pero aquí pone...', 'es que és d'abans. Però ara... ja soc capellà', 'Ah, pues no le conocíamos', 'Oh, no deben venir a misa a Pomar, sinó ya me conocerían...' Bueno, va ser un diàleg d'aquells de besugos, no? I jo 'pero si es una cosa de los pisos, no es nada político' i tal i qual, no?... 'I más, si quieren venir pues vengan a la asamblea y ya veran que no...' (...) i llavors dic 'Bueno, nos devolveran las octavillas?', 'Ah, pues las debe de haber tirado la señora de la limpieza', 'Pues escuche... esta señora es peligrosa, eh? Para ustedes..' hi havia tot d'arxius tot de... 'Un dia les tira alguna cosa de compromiso y potser tienen que mirar esta señora...' Tot va anar aixins... vull dir [riu] ... Però bé... Diríem pobres guàrdies civils molts eren... que anaven a missa i tot (...)."111

Finalment l'assemblea es va fer amb presència policial. Tres arquitectes havien fet el mateix any una taxació dels 3 habitatges tipus del barri, resultant un preu mitjà de 277.000 pessetes, notablement inferior a les 500.000 ptes. que volia cobrar en aquell moment l'OSH. Així es va acordar reprendre la vaga de lloguers i deixar pendents els rebuts durant tres mesos com a mesura de pressió per si s'atenien les reivindicacions dels habitants de Pomar $^{812}$. Tres mesos més tard, el 26 de novembre es feia una altra assemblea veïnal al barri, amb la presència de representants d'altres barris de l'OSH com la Trinitat Nova (Barcelona), Arrahona (Sabadell), Cinc Roses (Sant Baudili) i La Pau (Barcelona) que van remarcar la necessitat d'actuar units i de continuar sense pagar fins que no s'arreglessin els pisos, se'ls oferís un contracte de propietat i una quantitat a pagar inferior a la demanada per l'OSH. I així es va acordar ${ }^{813}$. És interessant veure quin va ser el paper dels militants del PSUC (que disposaven d'una cèl-lula al barri anomenada “Libertad"), en l'esmentada assemblea:

"Nuestra participación fue el estar distribuidos por la sala y contribuir al caldeamiento del ambiente unas veces con aportaciones, otras con aplausos o comentarios con nuestros vecinos. A la salida hubo que dispersarse debido a un grupo de sociales que

811Entrevista amb Joan Cuadrench, 7-4-2013.

812Carles Mas: El Pomar - Badalona, p. 53 i p. 128.

813 [Cèl-lula Libertad del PSUC del barri de Pomar]: "Informe Asamblea" [full volant, novembredesembre? 1972], ANC, Fons PSUC, Organizacions de Base, 03.01. Organitzacions territorials, 818 Badalona: Cèl·lula Llibertat del PSUC. 
corría por las inmediaciones"\$14

La presència policial va fer que tant l'Alcalde com el Governador Civil estiguessin aviat informats dels acords presos, igual que el Jefe Provincial de la Obra Sindical del Hogar ${ }^{815}$. Aquest afirmava clarament que:

“Tal conducta es consecuente con la línea de actuación seguida, desde hace unos cinco años aproximadamente, por un sector en el que se integran, según nuestras noticias, como elementos más activos, el cura titular de la Parroquia secundado por personas pertenecientes a Cáritas, y de otro lado, por miembros de las denominadas Comisiones Obreras. En ese sentido, es copiosa la propaganda que a lo largo de estos años se ha hecho circular tanto en las calles e interior de los buzones del citado Grupo, como en los Centros de trabajo y en general por toda la ciudad de Badalona.."16

Motius tenien per estar preocupats, ja que al barri es va desenvolupar tot un teixit social alternatiu que va superar durant aquests anys a l'Asociación de Cabezas de Familia. Al voltant de la parròquia i el Centre Social es van anar configurant el PIM o moviment infantil, una Cooperativa anomenada "Convivència Obrera" i la mateixa AVV. El mateix 7 de febrer una manifestació de veïns del barri anava cap a l'Ajuntament reclamant el tancament del molest abocador d'escombraries. L'alcalde va prometre una solució en breu ${ }^{817}$. L'abocament d'escombraries va semblar aturarse el maig de 1973, però un any més tard, els veïns van veure consternats com aquest reprenia la seva activitat. El mateix barri poc després va ser pres policialment arran de l'enterrament al proper cementiri de l'obrer assassinat per la

814 [Cèl-lula Libertad del PSUC del barri de Pomar]: "Informe Asamblea" [full volant, novembredesembre? 1972], ANC, Fons PSUC, Organitzacions de Base, 03.01. Organitzacions territorials, 818 Badalona: Cèl-lula Llibertat del PSUC. Poc van trigar els militants del PSUC en editar una altra full volant cridant a secundar l'acord pres a l'assemblea de no pagar: [Cèl-lula Libertad del PSUC]: “!!Vecinos de Pomar!!” (4-12- 1972) (consultable a la mateixa referència que l'anterior).

815Tot un conjunt de cartes creuades entre l'Alcalde de Badalona Felipe Antoja Vigo, el Governador Civil de Barcelona Tomàs Pelayo Ros i el Director Provincial de l'OSH José Luis Mas Garcia a partir del 5 de desembre de 1972 i que s'allarga fins febrer de 1973 ens ho demostren. Destaca el fet que segons l'alcalde badaloní només un $10 \%$ de la població de Pomar secundava la vaga de lloguers. AHGCB, Gobernadores Civiles, Caixa 182. Jefatura Provincial de la Obra Sindical del Hogar 1970-1974.

816[Carta del Director Provincial de l'OSH, José Luis Mas al Governador Civil Tomàs Pelayo] (22-21973), AHGCB, Gobernadores Civiles, Caixa 182. Jefatura Provincial de la Obra Sindical del Hogar 1970-1974. El sacerdot titular era el conegut Joan Torrella (al qual ajudava Joan Cuarench). Importants van ser també l'Assistenta Social Carme Ribas. Els membres de CCOO eren pràcticament els de la cèl·lula Libertad del PSUC.

817Carles Mas: El Pomar - Badalona, p. 129. 
policia a la Central Tèrmica del Besòs, en Manuel Fernandez Marquez, com ens ho recordava de nou en Joan Cuadrench:

"La més grossa (...) va ser quan van matar aquell (...) el de la tèrmica. Que aquell dia, aleshores ens van demanar 'de hacer un funeral' . I vam dir 'home, un funeral no però bueno, podemos hacer un acto'. I aleshores es va fer en l'església, es va fer un acte... vam dir una pregària, però bueno... una pregària mig laica, no? I després es va anar cap el cementiri. Aleshores jo vaig fer la missa i el meu company se'n va anar amb la gent. Tots amb braçalets negres... una quantitat... Molta gent... l'església pleníssima... hi podien haver 1.000 persones... jo no ho sé... eh? (...) I aleshores jo després de la missa me'n vaig cap amunt cap el cementiri. I em vaig trobar a la policia muntada amb una metralleta d'aquelles amb trípode allí enmig de la carretera i... amb un megàfon. I aleshores... encara me'n recordo... '¡Sabemos sus intenciones! ¡Dispérsense inmediatamente, sinó actuaremos!'. I aleshores es clar la gent baixava del cementiri i aleshores (...) com que coneixien els camins... hi havia per la riera... molts van baixar i bueno... anaves sentint per darrera que '¡este es el cura!' i jo 'no em deixeu!' I bueno... tothom dispersi general... hi vam haver de córrer... “818

Uns fets similars van passar al barri un any després, quan la policia va tornar a carregar contra els assistents al funeral de les obreres mortes en l'incendi de la fàbrica HAISSA del 17de maig de 1974, fet a l'Església de Sant Sebastià de Pomar ${ }^{819}$. Malgrat que al juliol d'aquest any es van fer algunes obres de millora al barri ${ }^{820}$ i es va aconseguir el compromís del nou director de l'OSH, Aníbal Rodríguez, de que no es faria fora a ningú del seu pis ${ }^{821}$, la lluita per la reforma dels blocs d'habitatges i per l'adquisició en condicions dels pisos va allargar-se fins molts anys després de la mort del dictador. Ara bé, tal i com hem vist a Santa Coloma, quan aquest agonitzava el barri de Pomar ja tenia un teixit social reivindicatiu ben present.

L'altre barri de l'OSH que aviat va ser un maldecap per les autoritats va ser el de Sant Roc. Ja hem vist que al igual que a Pomar a finals dels anys seixanta s'havia creat un Centre Social. També, arran d'un incendi en un edifici industrial amb materials inflamables que alhora tenia unes escoles privades en els seus pisos superiors el PSUC havia repartit el 1970 uns fulls volants criticant a la dictadura, a

818Entrevista amb Joan Cuadrench, 7-4-2013.

819Carles Mas: El Pomar - Badalona, p. 129.

820Manuel Armengol: "En Pomar (Badalona) siguen con el verdetero de basuras", Tele/ eXpres 9-31974.

821 “No se echará a nadie por falta de pago”, Tele/ eXpres 12-8-1974. 
l'Alcalde Antoja Vigo i reivindicant unes escoles dignes ${ }^{822}$. Però va ser a partir de 1971 quan la Vocalia d'habitatge del Centre Social va engegar una veritable dinàmica reivindicativa. Ja les primeres pressions al respecte havien aconseguit que l'OSH dediqués una magra partida de 15 milions de pessetes per unes primeres reparacions i pintura dels blocs, tan minsa que no es van cobrir ni la meitat d'aquests. Amb aquestes condicions i el lamentable estat dels pisos i del barri en general, els seus habitants també van refusar l'oferta de l'OSH d'adquirir els pisos en propietat, ja que això els hauria obligat a assumir totes les despeses de les reparacions. ${ }^{823}$.

Així, que com a mesura de força, els veïns van començar a fer el que s'estava fent en altres barris: no pagar el lloguer. Això i entrevistes amb delegats de l'OSH i escrits adreçats a diferents organismes oficials. Un primer escrit, redactat el 22 d'octubre de 1971 i adreçat al president de la Comissió Provincial d'Urbanisme reclamava la restitució de l'enllumenat públic del barri, ja que la majoria ja no funcionava ${ }^{824}$.

De fet, la premsa de l'època ja es feia ressò del lamentable estat del barri:

\footnotetext{
"Las casi veinte mil personas que habitan el barrio de Sant Roque, padecen una serie de problemas relacionados con los servicios públicos que son vitales para el desarrollo de una comunidad de vecinos." ${ }^{825}$
}

En efecte, apart dels defectes dels pisos i d'urbanització, mancaven escoles, ambulatoris i en general qualsevol tipus d'equipament públic.

Aquestes primeres reivindicacions aviat van adquirir un tint més dramàtic pels nombrosos accidents producte de la mala urbanització i la pèssima qualitat dels materials fets servir. Ja l'any 1972 un nen havia mort atropellat al costat d'un col·legi on no hi havia ni semàfor ni pas de vianants. Els atropellaments van ser una cosa ben habitual en els carrers amb més tràfic del barri, sobretot a les

822 [Carta de l'Alcalde de Badalona Felipe Antoja Vigo al Governador Civil] (25-5-1970), en la qual s'expliquen els fets i s'adjunta la fulla repartida: Comité Local del Partit Socialista Unificat de Catalunya: "!!Lo que no dice la prensa legal!!!" (30-4-1970) [es tracta d'un full A4], AHGCB, Gobernadores Civiles, Caixa 285, Ayuntamiento de Badalona, 1969, 1970, 1971, Alcalde Presidente Iltmo. Sr. Felipe Antoja Vigo.

823Felipe Guerreo: Sant Roc 25 anys de lluita, Ateneu de Sant Roc, 1991, p. 5.

824Ídem, p. 6.

825 “Badalona. El barrio de San Roque no tiene suficientes servicios públicos”, Tele/ eXpres, 19-21972. 
Avingudes d'Alfons XIII i Marqués de Montroig. I aquest fet va desencadenar protestes veïnals. El dia 8 de novembre un miler de veïns indignats pel darrer atropellament d'un nen de 8 anys el dia anterior que havia resultat greument ferit, feien una "sentada" i tallaven el trànsit durant una hora a l'Avinguda Marquès de Montroig reclamant un semàfor per la proximitat d'una escola a aquell punt de tant trànsit rodat i on s'havien produït varis accidents, fins l'arribada d'un tinent d'alcalde i de diversos cotxes de la policia municipal ${ }^{826}$.

Ja el mateix mes de març any 1973 des del Centre Social s'havia fet arribar un informe a la Dirección Provincial de la OSH avalat per dos arquitectes i el Col·legi d'Arquitectes de Barcelona on es denunciava el lamentable estat del barri com a producte de la mala qualitat dels materials fets servir ales obres, la falta de serveis de conservació, i la necessitat d'una reparació integral del barri, no de solucions parcials. Només per posar un exemple recollint una enquesta que es va fer entre els seus habitants en un $52 \%$ dels habitatges hi entrava l'aigua de pluja de l'exterior; en un $81 \%$ hi havien humitats; un 59\% tenia desperfectes als banys; un $59 \%$ els terres aixecats; un $59 \%$ desperfectes a les finestres; un $30 \%$ estaven mal orientades respecte el sol; un $37 \%$ tenia esquerdes exteriors i un $43 \%$ desperfectes a les canonades ${ }^{827}$. S'afirmava també, qüestió molt important, ja que el barri estava patint un procés d'estigmatització tant d'ell com dels seus habitants (una part d'ells eren d'ètnia gitana), que:

\footnotetext{
"La mayoría de los desperfectos son imputables a los promotores del barrio, pues son desperfectos de origen por lo que no son imputables a un uso incorrecto de los vecinos." $^{828}$
}

Però no es podia argumentar cap "us incorrecte" al fet que el 6 d'octubre de 1973 es desprengués una cornisa i matés a una dona de 23 anys d'edat. Tampoc a que el mes d'agost de 1974 un nen morís al caure d'un balcó on s'havia després la barana protectora -baranes ja de per si baixes i poc segures, com un servidor va poder observar personalment durant anys a casa dels seus avis, un 12è pis!-.

826 "Badalona: "Sentada" de vecinos del barrio de San Roque para pedir semáforos", La Vanguardia Española, 9-11-1973.

827 Carles Arcas: “Siete años sin resolver el problema de sus viviendas”, Tele/ eXpres, 4-4-1974.

828 [Carta al Director Provincial de l'OSH de Barcelona enviada pel Centre Social de Sant Roc] (15-21976), reproduïda a Felipe Guerrero: Sant Roc 25 anys de lluita..., p. 7-8. En aquesta carta es feia un repàs a les accions i gestions infructuoses fetes anteriorment. 
Al 31 de març de 1974 hi havia hagut una altra assemblea veïnal al Centre Social amb la presencia del Regidor pel Tercio Familiar Fulgencio Conesa (ja n'hem parlat d'aquesta persona que exercia la presidència de l'AVV de Sant Antoni de Llefià), el qual va adreçar-se d'una manera prou peculiar als veïns:

\footnotetext{
"Prosiguió el Concejal y Procurador en Cortes con un discurso que imagino que dejaría más que sorprendidos a los vecinos de San Roque. El señor Conesa, dejando bien claro que a partir de ahora se hacía cargo de la difícil papeleta de solucionar los problemas del barrio: Yo con mi vara dirigiré este asunto, dijo, haciendo una comparación entre la comisión creada y una banda de músicos, hizo una verdadera declaración de principios: "católico, amante del orden" apeló a la "buena gente trabajadora" del barrio "alejada de los conflictos, agitaciones y tonterías de esas" y atacó a los "agitadores profesionales, pagados por quien sea, que se aprovechan de esta buena gente". El concejal remarcó la importancia del orden, la disciplina y el respeto." 829
}

La paciència dels veïns ja estava a punt d'esgotar-se, i més d'un veí va manifestar que el que s'havia de fer era no pagar, cosa amb la qual fins i tot Conesa es va mostrar aparentment d'acord, sempre i quan es tornessin els endarreriments un cop solucionats els problemes. Però les continues promeses quedaven desmentides pels fets. Poc després, a l'agost de 1974 un nen moria en desprendre's els barrots d'una barana d'un balcó del bloc 103 i precipitar-se al buit ${ }^{830}$.

El mes de febrer de 1975 veïns de Sant Roc manifestaven la urgent necessitat d'un ambulatori al barri ${ }^{831}$. Però el primer de maig de nou un atropellament acaba amb la vida d'un nen davant l'Institut Eugeni d'Ors. Una gran manifestació de protesta per exigir semàfors va aplegar un miler de veïns, la majoria dones i nens el dissabte 4 a l'Avinguda Marquès de Montroig i va ser violentament reprimida per la Policia Armada amb el resultat de varis veïns ferits i contusionats ${ }^{832}$. A partir de febrer de 1976 es van intensificar més les mobilitzacions arran una nova mort d'un nen en cedir -novament- la barana d'un balcó. La mort de criatures s'estava convertint tràgicament en un fet comú al barri ja que al març tornà a caure un altre nen i un tercer moria electrocutat per tocar un cable de l'enllumenat sense

829Carles Arcas: "Siete años sin resolver el problema de sus viviendas”, Tele/ eXpres, 4-4-1974. 830Felipe Guerrero: Sant Roc 25 anys de lluita..., p. 14.

831Juan Cairat: "Los vecinos de San Roque solicitan un ambulatorio de la Seguridad Social", La Vanguardia, 22-5-1975.

832Felipe Guerrero: Sant Roc 25 anys de lluita..., p. 14. Veure també Carles Arcas: "Manifestación pidiendo semáforos", Tele/ eXpres, 5-5-1975. 
protecció. La dinàmica de mobilitzacions esperonades per la Vocalia d'Habitatge del Centre Social ja no es va aturar fins aconseguir -com veurem més endavant- un Pla de Reforma Integral del Barri aprovat pel Ministerio de la Vivienda i sota el control veïnal l'any 1978. De res van servir les maniobres de l'alcalde i de Governació per crear una Associació de Veïns afí. ${ }^{833}$.

A inicis dels anys setanta es van crear només dues Associacions de Veïns l'any 1972: la de Pomar, i la de La Salut Alta, en una zona on encara hi havia importants bosses de barraquisme i habitatge precari (a vegades ocult a simple vista, ja que estava situat en patis interiors). En aquest barri tinc constància d'una protesta veïnal feta per dones del barri el 18 d'octubre de l'any 1971:

\footnotetext{
"Saludamos la valiente y combativa actitud de las mujeres de esta barriada que el lunes, dia 18, hartas de los abusos que se ejerce sobre la clase obrera, se organizan y unidas deciden manifestarse, protestando de la arbitrariedad cometida por la empresa de electricidad ENHER (empresa del Estado), cobrando unos precios desorbitados por los contadores de electricidad, y por el tipo de corriente eléctrica."${ }^{1834}$
}

No tinc molta informació d'aquesta associació en concret. En canvi, al mateix barri però a la part baixa i més a prop de Llefià, existia una altra Associació des de l'any 1969, la de Juan Valera, però aquesta havia passat força desapercebuda per la majoria dels veïns, segurament per que en estar controlada per persones franquistes no es fa preocupar gaire per promoure accions reivindicatives. Ara bé, l'any 1975, cap a l'estiu, va haver-hi un canvi molt important. Va haver-hi una entrada nova de gent, molts d'ells joves i entre ells persones militants del PSUC ${ }^{835}$. Un d'ells, aprofitant que estava "d'excedència forçosa" per un conflicte laboral a la seva empresa, la Olivetti, va acabar esdevenint el nou president: Manuel Armentero. L'Associació iniciarà així, sobretot a partir de 1976 una dinàmica molt 833 Veure nota 593.

834Comité Local de Badalona del PSUC: “Vecinos del Barrio "Nuestra Sra. De la Salud"” (21-101971), AHGCB, Gobernadores Civiles. Caixa 285, Ayuntamiento de Badalona, 1969, 1970, 1971. Alcalde Presidente: Iltmo. Sr. D. Felipe Antoja Vigo.

835 “Breve historia de la Asociación”, Ojo. Asociación de Vecinos Juan Valera núm. 1 (febrer 1976), Biblioteca de Ciències de la Comunicació, UAB, P-3 Dipòsit, RC(467.1)/50, p. 5 . Evidentment, en aquest article no s'especificava que hi havia militants del PSUC entre la nova gent jove de l'Associació. Però si di que es passa de 200 socis a 500 en dos mesos i que es creen grups de treball. Poc després, el 24 d'abril de 1976 es feien unes eleccions a la Junta de l'Associació i Manuel Armentero era el candidat que n'obtenia més vots (uns 90), esdevenint així el nou President. Veure a "Las elecciones fueron..." Ojo. Asociación de Vecinos Juan Valera núm. 3 (abril 1976), Biblioteca de Ciències de la Comunicació, UAB, P-3 Dipòsit, RC(467.1)/50, p. 4. 
reivindicativa i de lluita de la qual en parlaré més endavant, si bé sembla ser que ja abans els seus membres més actius havien participat a les reivindicacions del barri veí.

Al barri de Llefià ${ }^{836}$, hi havia, des de feia any i mig, una forta mobilització impulsada per un grup de veïns que havia decidit fundar una nova Associació. Als anys setanta un petit grup de persones molt sensibilitzades va intentar, en un primer moment, entrar dintre l'Associació de Veïns de Sant Antoni de Llefià per intentar canviar la seva dinàmica. Aquesta estava controlada per un ja vell conegut nostre: Fulgencio Conesa, regidor a l'Ajuntament pel "Tercio Familiar" i "Procurador en Cortes" pel "Tercio Sindical del Trigo" i tal com ja vaig explicar, no els va deixar entrar a l'Associación ${ }^{837}$. Davant d'aquesta situació, es va decidir crear una Comissió amb la intenció de fer una nova associació veïnal. En aquesta hi havia tres militants del PSUC, (Àngel Navarro, Juan Amor i Salvadora Castaño), cosa que no ens hauria d'estranyar la que disposaven d'una potent cèl-lula al barri anomenada "Ferrol". Però també tres del Partido del Trabajo de España (PTE) (Mạ Reyes Bellido, Paco Muñoz i Francisco Macareno) que també hi tenia una forta implantació. A més hi havia persones no militants però amb sensibilitat d'esquerres: Maria Soledad Leiva, Sebastián Ardilla, Sebastián Henche, Francisco Amador i Pedro Jesús Fernàndez ${ }^{838}$. Aquest darrer va ser el primer president de la nova Associació de Veïns de Sant Mori de Llefià (que va trigar dos anys en ser legalitzada per les traves que es posaven des de el Govern Civil a una entitat que es presumia seria "problemàtica") i va formar part del primer Ajuntament anant com a independent a les llistes del PSUC, partit on acabarà militant. Fins que no van trobar un local es reunien en bars del barri o en l'escola Babar, privada aleshores, però $a m b$ un bon nombre de mestres progressistes. I des de l'any 1974 van impulsar una tasca de conscienciació important amb visites i xerrades amb els

836El "barri" de Llefià administrativament son tres barris: Sant Antoni de Llefià, Sant Joan de Llefià i Sant Mori de Llefià. Però la gent no en feia (ni en fa encara en l'actualitat) gaires distincions i es refereix al seu conjunt com "barri de Llefià".

837Entrevista a Ma Reyes Bellido, 24-5-2006 dins José Miguel Cuesta Gómez: El moviment veïnal a Llefià (Badalona), p. 200 i Marta Puertolas: "San Antonio de Llefià. Una asociación de vecinos vetada", Reforma de Badalona (Revista) núm. 6 (29-6-1976).

838Tot això segons ens va explicar el mateix Pedro Jesús Fernández en dues entrevistes realitzades el 26-4-2009 i el 24-5-2009 i ja ressenyades a José Miguel Cuesta Gómez: El moviment veïnal a Llefià (Badalona), p. 200-201. 
veïns

A Llefià existia una part més antiga que havia tingut una població considerable des dels anys trenta. La població havia crescut sense aturador des de el final de la Guerra Civil i al 1967 ja es va fer un primer Pla Parcial, que si ja era del tot insuficient, les constructores privades ni el van respectar. Ja el 1970 el Col-legi d'Arquitectes de Catalunya i Balears havia denunciat irregularitats en els Plans Parcials de Llefià i del Caritg (aquest darrer, al costat de la zona militar), protagonitzant una notable polèmica amb l'Ajuntament de Badalona ${ }^{839}$. Aquesta consistia en permetre la construcció de més habitatges dels previstos per la Llei del Sol vigent, fet que es traduïa en unes edificacions amb més alçada -i més habitatges- de la que teòricament estava permesa. El Col·legi va arribar a interposar dos recursos d'interposició i un contenciós administratiu l'any $1974^{840}$.

Les primeres accions veïnals van començar al mes d'octubre de 1974 quan el grup que estava impulsant la creació de la nova AVV de Sant Mori de Llefià va començar una recollida de signatures denunciant totes les mancances existents -especialment a la zona de l'Avinguda Marqués de Sant Mori, on s'havien fet recentment molts blocs de pisos nous però amb les mancances habitualsreclamant la seva urbanització i neteja, així com la preservació d'espais per parcs i equipaments com ara escoles, molt necessàries a un barri amb una elevada població en edat escolar ${ }^{841}$. Seguint exemples d'altres indrets es van fer manifestacions amb espelmes, fent visible la falta d'enllumenat públic al barri. La primera va ser el 23 de gener de 1975 i com recollia la premsa, els fets ja venien de lluny:

"Hace más de cuatro años fueron instaladas dichas farolas y hasta el momento no han entrado en funcionamiento, por lo que la zona está sumida en la más absoluta oscuridad." ${ }^{342}$

839Veure "Construcción ilegal de 35 edificios en Badalona", El Correo Catalán 30-1-1970 i "Las construcciones en los sectores de Caritg i Llefià, de Badalona" La Vanguardia 9-2-1970.

840"Recurso del Colegio de Arquitectos al proyecto de ordenación por manzanas de Llefià. Ya había provocado una fuerte polémica entre el Ayuntamiento de Badalona y el Colegio", El Correo Catalán, 3-5-1974.

841Segons El Correo Catalán de el 27-10-1974 es van recollir 580 signatures ("Seiscientos vecinos denuncian las deficiencias de su barrio") La xifra que ens donava Pedro Jesús Fernández en l'entrevista que li vaig fer el 24-5-2009 era notablement superior, d'un miler.

842 "Manifestación de mujeres pidiendo luz", Tele/ eXpres 24-1-1975. En canvi Juan Rico Màrquez, al seu llibre Llefià, de la Barraca a la dignidad... (p. 172-173) situa aquesta primera manifestació el dia 25 de gener. 
En aquesta primera manifestació hi van participar al voltant d'un centenar de persones, en la seva majoria dones i nens. I aviat es va repetir el dia 30 de gener, ara ja amb mig miler de participants ${ }^{843}$, i quan es va fer una tercera el dia 1 de febrer el nombre de manifestants ja era de dos milers. Davant aquesta pressió l'Alcalde Isidro Caballeria va rebre una comissió de veïns i es va començar a instal-lar un enllumenat provisional mentre no s'aconseguia la solució definitiva, que no era altra que la urbanització completa d'aquell sector. De nou la premsa se'n feia ressò d'una manera prou clara i reveladora:

\footnotetext{
"Fueron, pues, más eficaces las reiteradas manifestaciones callejeras (...) que los años de palabras entre el Ayuntamiento badalonés y las juntas directivas de dos asociaciones que, como explicaremos más adelante, prácticamente carecen de toda participación por parte de los ciudadanos de Llefià.

(...)

$\mathrm{Si}$, las dos asociaciones de Llefià -la de Sant Antoni y la de Sant Joan- constituyen un problema, porque no cumplen el que, a nuestro entender, es su cometido porque apenas fomentan actividades entre los vecinos. Con decir que el presidente de la primera es al mismo tiempo concejal del distrito y el de la segunda, el alcalde de barrio, ya está todo dicho." ${ }^{844}$
}

El diumenge 23 de febrer es feia una assemblea veïnal a la parròquia del barri amb la participació d'unes 350 persones després de diversos intents frustrats de reunió amb el regidor del districte Fulgencio Conesa. En aquesta assemblea es va fer una crítica general a l'estat del barri, a l'actitud de Conesa tant en la seva condició de regidor (no es va presentar a la reunió) com de President de l'AVV de Sant Antoni (on recordem que no deixava entrar-hi més socis). També al fet que des de l'Ajuntament s'haguessin enviat uns rebuts de contribucions especials per l'enllumenat amb uns imports molt elevats (i més tenint en compte que fins al moment aquest enllumenat havia brillat per la seva absència o precarietat). L'assemblea va acabar amb una manifestació cap el domicili de l'esmentat regidor

843“Segunda manifestación con velas”, Mundo Diario 1-2-1975.

844Joan Tudela: "Tras las tres manifestaciones con velas... Ya hay alumbrado, pero aun queda mucho por lograr", Mundo Diario, 20-2-1975. La noticia esmenta a Fulgencio Conesa, el president de Sant Antoni de Llefià i alhora regidor del Districte i també a Ramon Arjona, President de la de Sant Joan de Llefià -si bé no estic segur que fos Alcalde de Barri en aquells moments-. 
on no el van trobar ${ }^{845}$. Després d'una nova entrevista amb l'Alcalde Caballeria el 3 de maig i una reunió -ara si- amb Conesa el dia 5, aquest els hi va confirmar que no s'hauria de pagar cap contribució especial per les obres de millora del barri ${ }^{846}$.

Finalment el mes de maig començaven les obres d'urbanització (asfaltat, enllumenat, clavegueram...) de la zona de Sant Mori sense que el veïnat hagués d'assumir les despeses amb contribucions especials, si bé en un primer moment aquestes es van enviar "per error" i de nou per la pressió de la Comissió Gestora de l'AVV de Sant Mori es van haver de retirar. La lentitud de les obres va fer que les mobilitzacions continuessin. En una d'aquestes mobilitzacions es va trencar el mur que envoltava la finca de l'antiga casa Torre Mena (que era reivindicada com a equipament cultural del barri) i va acabar amb la repressió policial i la detenció de Francisco Muñoz, membre del PTE i de la Comissió Gestora. La solidaritat i el desplaçament d'un grup de persones a Madrid -on estava detingut- va aconseguir el seu alliberament en pocs dies ${ }^{847}$. Les obres d'urbanització d'aquesta zona de Llefià no es van acabar fins l'any 1976 però sens dubte aquesta va ser una primera gran victòria que va ajudar a esperonar altres lluites. Com veurem més endavant, en aquest any, el 1976, les mobilitzacions es multiplicaran, ja fossin per reivindicacions urbanístiques (equipaments, brutícia, etc.) com també polítiques (Ajuntaments democràtics).

Al mateix any 1975, a la part alta del barri, la situada a la Serra d'en Mena i en concret a l'actual Sant Joan de Llefià s'estava desenvolupant un altre conflicte important. Al juliol un grup de veïns es va començar a mobilitzar per preservar l'únic solar que encara no havia estat edificat per aconseguir un parc: els terrenys anomenats del "Gran Sol". Curiosament aquest estava tipificat com a zona verda o d'equipaments en la revisió del Pla Comarcal de l'any 1974, però paradoxalment una immobiliària ja havia començat les obres per construir habitatges amb permís municipal i ja havia enllestit dos blocs. El 5 de juliol dos centenars de veïns i veïnes

845"Badalona: Protestas del vecindario de Llefià", Tele/ eXpres, 25-2-1975 i "Los vecinos del barrio de Llefià celebraron asamblea en la calle", Diario de Barcelona, 27-2-1975.

846Manuel Armengol: "Badalona: Ha comenzado la urbanización de la calle Sant Mori en Llefià", La Vanguardia, 10-5-1975.

847El mateix Martin Villa adreçava una carta a Fulgencio Conesa el 20-5-1975 informant dels fets i dels antecedents polítics i militants de Francisco Muñoz, que era membre de la Comissió Gestora de l'AVV de Sant Mori de Llefià, AHGCB, Gobernadores Civiles, Caixa 198, Ayuntamiento de Badalona 1974-1975. 
es reunien i prenien la decisió de lluitar per aquest espai ${ }^{848}$. El 25 es produïa una manifestació de 300 persones que ocupaven el solar i posaven plantes metre tallaven el carrer Juan Valera. Per la tarda van repetir la manifestació un grup de 100 persones que repetia els actes del matí, però que a més, enderrocava la tanca que encerclava el solar i muntava una barricada a la confluència entre l'Av. Àfrica i Joan Valera mentre començava la manifestació. Es va produir una càrrega de la Guàrdia Civil que es va saldar amb tres detencions, dues dones i un home, Manuel Armengol, periodista redactor de La Hoja del Lunes i corresponsal a Badalona de La Vanguardia Española. Sobre aquest darrer la Direcció de la Guàrdia Civil deia en el seu informe:

“(...) desde hace algún tiempo viene exagerando -al publicarlas- las incidencias que se suscitan en aquella localidad siempre que tengan un carácter oposicionista." ${ }^{849}$

En protesta per aquests fets el dia següent, el diumenge 26 per la tarda es produí una tercera manifestació, que també va acabar amb el trencament de part de la tanca que encara aguantava del dia anterior i d'una caseta de l'obra. Hi va haver un nou detingut ${ }^{850}$. Aquesta lluita, com tantes altres, es va perllongar durant els anys següents. De fet, no va ser fins l'elaboració del PERI de Llefià, l'any 1978, que es va aconseguir la preservació dels espais que encara quedaven sense urbanitzar per equipaments i zones verdes.

El mateix any 1974 es van reactivar altres AVV's existents, també per l'entrada de gent jove i militants polítics en una estratègia planificada. En aquest mateix any per exemple, va haver-hi un canvi de Junta a una de les Associacions més antigues existents a Badalona: la de Sistrells. Va esdevenir President un militant del PSUC, Alfredo Amestoy, que juntament amb la gent jove que anys abans ja havien format d'una Vocalia de Joventut, li donaren un aire més reivindicatiu a una Associació que havia estat en hores molt baixes i que havia acabant portant a Judici a dos dels antics membres d'una Junta. Un cop resolt aquest litigi es va

848“El último solar libre, a punto de desaparecer", Mundo Diario 20-7-1975.

849Dirección General de la Guardia Civil: "Manifestaciones en Badalona" (1-8-1975), AHGCB, Gobernadores Civiles, Caixa 200, Dirección General de la Guardia Civil, 1975.

850 Ídem. Veure també "Cuatrocientos vecinos reivindican una zona verde en Badalona" i "Los vecinos de Llefià insisten sobre la única zona verde posible para su barrio", Tele/ eXpres, 27-71975 i 28-7-1975; "Badalona: Manifestación de los vecinos del barrio de Llefià", La Vanguardia 27-7-1975. 
convocar una assemblea el 12 de maig de 1974 i va sortir escollit uns nous càrrecs ${ }^{851}$. La deficient situació d'aquest barri ja havia estat tractada a la premsa al $1971^{852}$. Fins i tot el mateix any les Joventuts Comunistes l'havien denunciada en un full volant, que malgrat tot, encara reflectia molts prejudicis del moment:

"De lo que si nos hacen estar orgullosos es de la cantidad de bares que tenemos (sobrepasan los 30) pero sobretodo por el llamado LAS MAÑICAS, frecuentado por homosexuales y prostitutas.

¿Qué educación pueden adquirir los jóvenes que a él asisten? Recogen los estímulos del vicio, corrupción, drogas y demás. Claro! que esto viene que ni pintado a este gobierno fascista, hacer que los jóvenes se degeneren, para que no piensen en sus propios problemas, para que no se preocupen en estudiar, para que su conciencia quede tan baja, que la puedan pisar con sus propios pies." ${ }^{853}$

El nou tarannà de l'Associació es va poder comprovar quan el mateix Alfredo Amestoy adreçava una carta al director de la SEAT en solidaritat amb els treballadors de l'empresa i les seves reivindicacions, argumentant que molts eren veïns del barri i socis de l'Associació ${ }^{854}$. Aviat es va reivindicar una bústia de correu, cabines de telèfons i un semàfor a l'encreuament entre General Weyler i Baldomer Solà. Al mateix article reblava:

"De las 16 calles de la barriada, solamente 4 están asfaltadas, y de estas 2 fueron costeadas por la asociación de vecinos. Pero este capitulo dados los precedentes enumerados, parece que deberá costar muchas más visitas y muchos más despachos que los realizados para conseguir (si se hace realidad) unas papeleras y un buzón ¿Será que el aparato burocrático municipal, a fin de resultar eficaz y ágil, estima más oportuno dejar sin buzón de correos a Sistrells, ante el temor de verse desbordado por

851Les persones que van ser portades a Judici per un deute pendent amb l'Associació van ser [buscar nom] Castro i Juan Teruel. La nova Junta va estar composada per President: Alfredo Amestoy Sanz (militant del PSUC i abans del PCE); Vicepresident: Manuel Cabaco García; Secretari: Laureano Rodríguez Tomás; Tresorer: Marcelino Barambio del Barco; Vice-Tresorer: Víctor Torres Antequera; Vice-Secretari: Salvador Márquez Garcia; Vocals: Ramón Vergara Aira, Nicolás Campayo Medina, Juan Marín Sánchez, Agustin Martínez Guirso; Francisco Juárez Navarro; Felipe Castillo i Luís Pérez Quevedo. Veure Miguel López Parra: Historial Barrio Sistrells 1924-1960. Asociación de Vecinos 1960-1974, [estudi inèdit], 1976, p. 78.

852"Sistrells, un barrio medio incomunicado en medio de Badalona”, Tele/ eXprés 22-10-1971.

853Juventudes Comunistas de Badalona: "Vecinos del barrio de Sistrells" (setembre 1971), AHCGB, Gobernadores Civiles, Caixa 285, Ayuntamiento de Badalona, 1969,1979,1971, Alcalde Presidente Iltmo. Sr. Don Felipe Antoja Vigo.

854Alfredo Amestoy Sanz: [carta al director de SEAT] (10-1-1975), ANC, Fons PSUC, 06. Context social i polític del partit, 06.07. Moviment veïnal, 2351 Badalona. 
las cartas de 10.000 vecinos, planteando al Ayuntamiento sus problemas?"855

A tot això s'afegia que al barri hi havia encara un elevat nombre d'infrahabitatges, uns 58, encara sense aigua corrent ni clavegueram ${ }^{856}$. Alhora, una de les primeres lluites d'aquesta nova etapa de l'Associació va ser aconseguir una escola, conjuntament amb les Associacions de la Immaculada i Lloreda en uns terrenys que el Pla Caritg als anys seixanta ja havia catalogat com escolars. El 17 de maig havien presentat una instància, si bé a inicis de 1976 la construcció encara estava paralitzada ${ }^{857}$

El maig de 1975 va esclatar la polèmica al barri Sistrells quan una immobiliària, Plusrenta, es va apropiar, sense demanar cap permís, d'un antic col-lector sufragat pels veïns als anys seixanta per fer-lo servir pels nous 600 habitatges que n'havia construït ${ }^{858}$. Va ser a l'any 1976 quan es produïren les mobilitzacions més importants a Sistrells fins al punt que les autoritats municipals d'aleshores van acceptar la tria de l'Alcalde de Barri pels mateixos veïns.

Altres Associacions es van sumar al carro reivindicatiu en aquests anys 19741975. La del Congrés Eucarístic, situada en un polígon d'habitatges amb el mateix nom ja existia des de 1969, però va ser a partir de 1974 que també va assumir una nova dinàmica. Tot i que no en disposo de molta informació em consta que des de 1975 en endavant el seu President era Miguel Ordóñez, militant de Bandera Roja i Desiderio León, posterior regidor pel PSC-PSOE, també en formava part ${ }^{859}$. Però la prova de que ja al febrer 1974 la dinàmica de l'Associació havia canviat -segurament per l'entrada de gent nova a la seva Junta- van ser les primeres reivindicacions fetes a l'Ajuntament mitjançant cartes i reunions per la millora dels serveis del barri, així com la instal·lació de semàfors a l'Av. Marqués de Montroig

855“Diez mil vecinos quieren un buzón de correos", Tele/ eXpres 13-7-1974.

856J. Tudela: "Más de veinte años de barraquismo", Mundo Diario, 6-3-1975.

857 “Una escuela para tres barrios de Badalona”, Tele/ eXpres 21-7-1975 i "Primer aniversario de una reivindicación", Mundo Diario 24-2-1976.

858J. Tudela: “Una inmobiliaria va y se apropia del colector", Mundo Diario, 21-5-1975.

859Joaquima Utrera: “Miguel Ordóñez. "El del Congreso"”, Eco Badalonès (18-11-1983), p. 26-27. Pel que es desprèn d'aquest article, als anys 80 s'havia situat en l'òrbita del PSC. Sobre la pertinença de Desiderio León a aquesta associació em va informar Alfredo Amestoy en l'entrevista que li vaig fer el 3-7-2013. A nivell de curiositat es pot veure també la publicitat de la Sastreria que tenia el mateix Desiderio León al carrer Tortosa en la publicació El Rollo Despertador. Boletín de la Asociación de Vecinos del Congreso, (octubre 1976), Biblioteca Ciències de la Comunicació de l'UAB - Hemeroteca, signatura RC(467.1)/512, p. 3 
(on ja s'havien donat vàries morts per atropellaments a prop d'una escola). De seguida es van reclamar bústies de correus, escoles, així com una millor neteja del barri $^{860}$. La mateixa AVV va sofrir un atemptat al seu local, on van ser llançats còctels molotov per algun grup d'extrema dreta el mes d'octubre de $1974^{861}$. L'any següent la polèmica va esclatar quan des de l'Associació es va organitzar una “jornada de neteja popular" pel dia 18 de maig, com anunciava un cartell:

"iVecina!! ¡Vecino!Se hace saber a todos los habitantes de este "lindo y bello" barrio (claro, no tanto como el de Pedralbes), que el próximo día 18 de mayo a las 11 horas se os convoca a la 1a Bienal Local de la Limpieza en el local de la ass. de vecinos, donde el cortejo limpiador iniciara el "paseillo". Se recomienda traer los instrumentos de trabajo (cubo, escoba, guantes, etc...). ii Premios a la cantidad y calidad ${ }_{\mathrm{ii}}$ Si Dios quiere las Autoridades lo permiten y el tiempo no lo impide, a las 6 de la tarde fiesta y gran chocolatada con entrega de premios en la asociación". ${ }^{862}$.

La Policia Armada va fer avortar la operació, amb gran indignació dels presents, quan un cop recollida la brossa després d'una manifestació de 50 joves feta pel barri, es disposaven a concentrar-la i denunciar a l'empresa concessionària del servei, SERCONSA ${ }^{863}$. La importància de l'element jove en aquesta mobilització i en la nova orientació presa per l'associació quedava de manifest en el primer butlletí editat per aquesta: El Rollo Despertador, on es recriminava la poca participació de determinada gent en aquesta iniciativa on havien destacat els joves i els jubilats ${ }^{864}$. Els mesos i anys següents aquesta Associació va continuar una dinàmica reivindicativa on va destacar, apart de les demandes habituals, la lluita per la recuperació dels terrenys de l'antiga fàbrica "La Regaliz" per equipaments pel barri en contra de la pretensió dels propietaris de fer més habitatges.

Una altra associació que va iniciar una dinàmica nova va ser la de Bufalà. Controlada anteriorment per persones conservadores, va canviar totalment amb

860 “Aventuras y desventuras de una Asociación de Vecinos", Tele/ eXpres, 7-5-1974.

861"Puntualizaciones de la Asociación de Vecinos del Congreso Eucarístico", Tele/ eXpres, 19-101974.

862 [AVV Congrés Eucarístic]: [cartell convocat als veïns a la "Ia Bienal de la limpieza", maig 1975], AHGCB, Gobernadores Civiles, Caixa 198, Ayuntamiento de Badalona, 1974-1975.

863“"'Operación limpieza”, frustrada”, Mundo Diario, 21-5-1975.

864“'iSe prohibe limpiar el barrio!”, El Rollo Despertador. Boletín de la Asociación de Vecinos del Congreso núm. 1 (juny 1975), MTB, Fons Marcelo López Ródenas, Caixa 1, p. 5-6. 
l'entrada de gent jove procedent del PSUC i de la CNT el mateix any $1975^{865}$. També va ser important la tasca d'un nou capellà, el pare Braulio Arraiza arribat l'any 1973 amb un caràcter molt progressista. De fet es pot dir que el Casal de Joves de la parròquia va ser el lloc on es van forjar futurs militants del PSUC i segurament també de la CNT. Van haver de conviure durant un temps amb els sectors més conservadors dins l'entitat. Però ni aquests van poder evitar que sobretot a l'any 1976 s'iniciés una dinàmica reivindicativa i un nivell important de lluita per la millora del barri amb un gran protagonisme de els vocalies de cultura i urbanisme, controlades pels joves del PSUC i la CNT ${ }^{866}$. La combativitat dels veïns, en especial els del sector de El Bruc (un polígon d'habitatges de l'Obra Sindical del Hogar) no va decréixer, sinó tot just el contrari.

Sense arribar al mateix nivell de Santa Coloma, la conflictivitat veïnal existent a Badalona no era gens menyspreable. I a partir de 1976 va anar a més, equiparantse amb la de la seva ciutat veïna. Abans, no obstant, van existir alguns conflictes que se'ns dubte ja es podien catalogar "de ciutat". Un d'aquests va ser el de Montigalà. L'Ajuntament badaloní havia planificat el 1967 la construcció d'una "ciutat satèl-lit" que hauria d'albergar prop de 60.000 habitants ${ }^{867}$. Aquest projecte es va vendre com un "model d'urbanisme", amb tots els equipaments necessaris, comparant-lo, fins i tot, amb una ciutat finlandesa considerada un model al respecte: Tapiola. La realitat molt diferent, ja que la ciutat finesa ocupava un espai superior (250 Ha font les 195,5 Ha de Montigalà-Batllòria), amb una població de 10.000 habitants enfront els 60.000 que preveia el projecte badaloní (amb unes densitats de població de 65 habitants per Ha enfront 230 habitants per $\mathrm{Ha}^{868}$ ). La

865Marc Andreu i Acebal: El Bruc-Bufalà... p. 32.

866Ídem, p. 90-96.

867Javier Alsina: "Badalona: Un importante y ejemplar Plan Parcial de ordenación urbana: el de "Montigalà-Batllória", Tele/ eXpres 14-3-1967; "Badalona: Un importante y ejemplar Plan Parcial de ordenación urbana: el de "Batllória-Montigalà", El Correo Catalán, 14-3-1967; "Badalona: Importate y ejemplar Plan de Ordenación Urbana de los polígonos Batllèria [sic]-Montigalà", El Noticiero Universal, 14-3-1967 i Javier Alsina: "Badalona: Un importante y ejemplar Plan Parcial de ordenación urbana: el de "Batllória-Montigalà", La Vanguardia Española, 14-3-1967, entre d'altres. El tema encara va estar candent anys posteriors: "Se creará una ciudad satélite para sesenta mil personas", Diario de Barcelona 5-10-1974. Uns quants anys després la revista quinzenal Comarca Exprés, al seu número 1 publicava un article d'Enric Juliana molt crític sobre el projecte, titulat "Urbanización Montigalà-Batllòria: Un "satélite" peligroso", MB-Hemeroteca, Volum 21-7-4, p. 10-11.

868Enric Juliana:" Urbanización Montigalà-Batllòria: Un "satélite peligroso", Comarca Exprés num. 1 (1 al 15 desembre 1975), MB-Hemeroteca, Volum 21-7-4, p. 10-11. 
mitjana de zona verda per habitant al projecte badaloní era de 2,18 metres per habitant, una quantitat ridícula.

El projecte del Pla Parcial de Montigalà-Batllòria va ser una aposta forta del consistori de Felipe Antoja Vigo. La "Comisión de Urbanismo y Servicios Comunes de Barcelona" va elaborar l'esmentat pla parcial, comptant amb unes "Asociaciones Mixtas de Compensación" que estaven presidides pel mateix alcalde i on també participaven els propietaris dels terrenys afectats, de manera que tothom en sortia prou beneficiat, al igual que l'empresa constructora CALPISA ("Compañia Alicantina de Promociones Inmobiliarias, S.A. ${ }^{869}$. El que no es mencionava era que el projecte amenaçava a gran part del patrimoni històric i natural de la comarca. Diferents monuments van arribar a estar-hi en perill com una masia fortificada del segle XVI, Can Butinyà, que va estar a punt de ser enderrocada, o el Monestir de Sant Jeroni de la Murtra del segle XV que estava en un estat de conservació deplorable. A més, el projecte afectava a una zona que molta gent de Badalona i Santa Coloma feien servir com a zona d'esbarjo on sortien a passejar i gaudir d'un dels pocs espais no urbanitzats que existia en una zona de gran densitat de població. No s'entenia com davant les evidents mancances d'equipaments i serveis de la ciutat, s'apostava per un projecte que faria incrementar notablement la seva població. D'aquesta manera, el projecte va tenir de seguida opositors. I si bé inicialment van ser els habitants de Santa Coloma els que més es van oposar, posteriorment es van afegir les entitats veïnals badalonines i el litigi es va allargar durant els anys 70-80 870 .

Però abans de la mort del dictador si que es va iniciar amb força un conflicte que va servir per vehicular un cert "sentiment de ciutat" i alhora una campanya comuna de diferents AVV's (que sens dubte va influir en la creació posterior de la FAVB) i altres entitats: el projecte del Port Esportiu, del qual l'any 1969 l'Ajuntament va encarregar el primer avantprojecte. El redactat definitiu va enllestir-se entre el gener-juliol de 1971 per l'enginyer J. Vilalta González. L'any 1972 va ser posat a "exposició pública" i al 1973 enviat a Madrid per que fos aprovat en un Consell de Ministres. Mort Antoja Vigo l'any 1974, el projecte va ser

869Ídem, p. 10.

870 Ja la revista Grama havia denunciat el projecte en l'any 1972: Jaume P. Sayrach: "Sant Gerónimo de la Murtra: Un parque que todos debemos salvar”, Grama núm. 42 (juny 1972), p. 12-13. 
continuat pel seu successor, Isidre Caballeria Pla. Va comptar inicialment amb el suport entusiasta de les elits polítiques i socials del moment, així com de diversos mitjans de comunicació, que intentaren justificar la construcció d'aquest port en la suposada necessitat que en tenien els pescadors de la ciutat, en l'impuls econòmic que li donaria a Badalona o fins i tot arguments més increïbles com el següent:

“(...) Otra de las ventajas que nos traerá la construcción de este puerto badalonés es la limpieza de las aguas marítimas en algunas zonas, facilitándolas para el uso del baño." ${ }^{\prime 87}$

Però molt aviat van aparèixer altres veus crítiques amb el projecte també reflectides als mitjans de comunicació ${ }^{872}$, tot just el mateix any -1974- on l'Ajuntament havia accelerat els tràmits per la seva construcció. El sorprenent va ser que en dos anys el cost estimat del projecte es multipliqués un $200 \%$, passant dels inicials 192 milions de pessetes al 1972 a 590 milions l'any 1974 ${ }^{873}$. Per comparar xifres només al 1973 el pressupost per renovar la xarxa de clavegueram era de 900 milions i des del consistori ja s'havia manifestat la seva dificultat per cobrir-lo. I més encara quan l'any 1975 tot el pressupost de l'Ajuntament ascendia a sis-cent milions de pessetes ${ }^{874}$. Amb una ciutat amb tant dèficits en els serveis elementals i en la urbanització del molts barris, la majoria de gent no entenia que es contemplés aquesta despesa que beneficiava a molt poca gent, de classe benestant i resident majoritàriament fora de la ciutat, i que a sobre amenaçava amb destruir la millor zona de la ja de per si contaminada platja de Badalona. De seguida sectors amplis de població van percebre el negoci que hi havia al darrera i que el benefici d'uns pocs seria en perjudici de molts ${ }^{875}$.

871C. Dunyo: "El puerto de Badalona, una realidad a corto plazo", El Correo Catalán 15-1-1974, p. 6. Un altre article favorable al projecte era el de Maria Teresa Ribó: "Hacia la construcción del puerto deportivo-pesquero", El Noticiero Universal, 24-1-1974.

872Articles de periodistes d'esquerres com Manuel Armengol: "Badalona: Los 591 millones del puerto hipotecan la solución de muchos déficits", El Correo Catalán, 1-6-1974 o Enric Giralt: "Casi nadie quiere un puerto deportivo en Badalona", El Correo Catalán, 8-12-1974.

873Manuel Armengol: "Badalona: Los 591 millones del puerto hipotecan la solución de muchos déficits", El Correo Catalán, 1-6-1974.

874Ruiz: "El presupuesto municipal para el año 1975 asciende a más de seiscientos millones de pesetas", El Noticiero Universal, 31-12-1974.

875Articles com "El gran negocio de los puertos deportivos" publicat a El Noticiero Universal 3-91974 eren molt clars en aquest sentit. El subtítol deia així "Si usted tiene 40 millones no lo dude: construya uno. Las trabas legales son mínimas". Fins i tot la notícia animava a fer-ne impugnacions al projecte. 
L'Ajuntament continuava endavant amb el projecte, demanant al novembre de 1974 un préstec al Banc de Crèdit Local de 310 milions. Mentrestant la polèmica es va traslladar també a la premsa local. El 21 de desembre de 1974 apareixia a Revista de Badalona un escrit del patró de la Confraria de Pescadors, Joaquim Costa Durich, posicionant-se a favor del port. La resposta va ser un escrit adreçat a l'Ajuntament i signat per 1.354 persones i 17 entitats de la ciutat oposant-s'hi pels motius ja abans esmentats i detallant les urgències existents a la ciutat en matèria d'urbanisme, sanitat, educació, etc ${ }^{876}$. S'ha de dir que no existia una oposició a que es fes un petit port pesquer pels pescadors de la ciutat. El que no es volia era un port que tothom sabia que seria majoritàriament esportiu com ho demostrava el fet que el projecte parlés d'una capacitat de 600 o 700 embarcacions esportives i només de 50 de pesca ${ }^{877}$.

El fet insòlit es que per primera vegada en molt temps s'estava donant un debat ciutadà públic sobre aquesta qüestió, fins al punt que la mateixa Radio Barcelona ho va tractar al programa "Directo" del 5 de març ${ }^{878}$. La Jove Cambra de Badalona va enviar un escrit a l'Ajuntament -signat també pels presidents dels Centres Socials de Pomar i Sant Roc, de l'AVV de Sistrells i de l'ACF de Sant Crist on es demanava una nova exposició pública dels detalls del projecte ${ }^{879}$. Poc després un grup d'entitats feia una petició de cara al proper ple del 3 d'abril on s'havia de dirimir la qüestió:

“Los abajo firmantes, representantes de asociaciones de vecinos y otras entidades de
Badalona se dirigen a ustedes, concejales del Ayuntamiento de Badalona, y
especialmente a los concejales Cecilia March Blanch, José Guillén, Juan Munells,
Ernesto Rojo, Juana Jordán de Comabella, Santiago Molina y José Conesa, elegidos por
el Tercio Familiar, para solicitarles su voto negativo al dictamen sobre la construcción

876"Mil quinientos badaloneses contra el puerto deportivo", Tele/ eXpres, 2-1-1975 i Juan Cairat: "BADALONA: 17 Asociaciones de Vecinos se oponen a la construcción del puerto deportivopesquero", La Vanguardia 16-1-1975. Aquest darrer rotatiu informava de 17 AVV's signants tot i que no les esmenta. Penso que es tracta d'entitats diverses, no només de veïnals. La revista Grama, com no podia ser d'una altra manera, també se'n va fer ressò de manera crítica del projecte al núm. 74 (febrer 1975) amb l'article de Dionis Orrit: "Cuando la pesca es solo un pretexto. Mil millones y medio puede costar el puerto de Badalona”, p. 7. (també hi havia un requadre amb un breu escrit per Jaume P. Sayrach amb el títol “Casi nadie lo quiere”).

877C Dunyo: "El puerto de Badalona, una realidad a corto plazo" i Manuel Armengol: "Los 591 millones para el puerto hipotecan la solución de muchos déficits”, El Correo Catalán, 15-1-1974 i 1-6-1974, respectivament.

878J. Tudela: “Opiniones dispares sobre el puerto”, Mundo Diario, 7-3-1975.

879“Nueva exposición pública del proyecto del puerto”, Mundo Diario, 2-3-1975. 
del puerto deportivo-pesquero."${ }^{\text {880 }}$

El ple va ser molt tens, amb presencia de públic, i es va allargar durant dos dies més, en el transcurs dels quals va aparèixer un article signat per l'Alcalde Isidro Caballeria als principals diaris (Tele/ eXprés, Mundo Diario, Diario de Barcelona, La Vanguardia, El Noticiero Universal, entre d'altres ${ }^{881}$ ), fet que encara va encrespar més els ànims. Finalment, el 5 d'abril el projecte va ser aprovat amb 17 vots a favor i tres en contra (Cecilia March, Ernest Rojo i el tinent d'alcalde d'Esports, Vicent Marquès). Tal com va recollir una fulla volant repartida dies posteriors:

“(...) els regidors del "si" van ser acollits per l'esbronc de centenars de persones que els hi cridaven: Fora! Dimissió! Esperant que sortís el batlles es van cantar cançons al-lusives al port i a les necessitats de Badalona, l'arribada de la Guàrdia Civil i la Policia només servir [sic] per que es cridés més fort: "Haveu enganyat als pescadors"!

“Dimissió"! Més escoles"!

Van seguir més reaccions. La Jove Cambra va demanar explicacions a dos regidors per les seves opinions i vots ${ }^{883}$. De nou un conjunt d'entitats de la ciutat van adreçar una carta a l'Ajuntament per que no es construís el port esportiu ${ }^{884}$. La qüestió va crear polèmica dins de les mateixes entitats com ja vaig explicar en el cas de l'Ateneu de Sant Roc pel "canvi de jaqueta" del seu President Francisco Leal i la seva desautorització per la resta de socis. Al maig s'intensificaren les protestes. Es convocaren dues concentracions i manifestacions festives a la platja els

880 “Contra el puerto", Mundo Diario, 3-4-1975. Les entitats eren AVV Sistrells, AVV Congrés Eucarístic, ACF Sant Crist, CS Pomar, Centre d'Influència Catòlica, AMPA Institut Albéniz, Jove Cambra de Badalona, Cine Club Studio i el Grup Cristià de Defensa i Promoció dels Drets Humans.

881L'esmentat article es titulava "La Alcaldia de Badalona razona la construcción del puerto deportivo-pesquero".

882 [Full volant sense signar, potser del PSUC?] (7-8-1975): "Badalona: Crits de "Dimissió"! Despres de l'aprovació del port dels "mil milions"”, ANC, Fons PSUC, Context social i polític del Partit, 06.07. Moviment veïnal, 2351 Badalona. Els mateixos fets van ser recollits a la premsa com per exemple Tele/ eXpres (7-4-1975). Es parla de 250 persones increpant als regidors.

883 “La Joven Cámara pide explicaciones a dos concejales", Mundo Diario 14-4-1975. Els regidors esmentats eren Diego Garcia Rodríguez i Fulgencio Conesa Castillo (un "vell conegut"). Aquests havien manifestat que només votarien a favor del port a condició que es ressolessin les mancances de la ciutat. Però a l'hora de la veritat van votar afirmativament sense cap problema.

884 "Escrito contra el puerto deportivo-pesquero de Barcelona", Diario de Barcelona, 17-4-1975. Les entitats signants segons aquest diari eren les mateixes nombrades a la nota 914 a més de la Mancomunitat Lloreda, el Centre Social Sindical Pomar, A. E. Escalem (parròquia Sta. Maria) i altres més que no nombra. 
diumenges 4 i 18 de maig amb notable èxit ${ }^{885}$. Caballeria, alarmat, enviava cartes al Gobernador Civil Martín Villa informant de les activitats de la Jove Cambra en relació amb la seva participació en les protestes així com les advertències que els havia fet al respecte. L'informe adjuntava també unes fulles volants amb cançons populars adaptades al tema del port on es denunciava el classisme del projecte i la complicitat dels 17 regidors i l'Alcalde, i també cançons com l'Estaca o aquesta que reivindicava directament els Ajuntaments democràtics:

\author{
"VOLEM AJUNTAMENTS CATALANS I DEMOCRÀTICS \\ Volem ajuntaments catalans i democràtics (2 vegades) \\ i que l'alcalde, i que l'alcalde, i que l'alcalde foti el camp. \\ Volem que Guillen se l'emportin al Sahara (2 vegades) \\ per que faci, per que faci, el camel amb el Lleal. \\ Que n'estem farts de camells i somia truites (2 vegades) \\ volem consellers, volem consellers, volem consellers de veritat." ${ }^{\prime 86}$
}

Per una altra banda dues persones, el farmacèutic Josep Maria Peras Guense i l'aleshores militant clandestí del PSUC i futur Alcalde badaloní Màrius Díaz Bielsa van presentar un recurs contenciós-administratiu contra el projecte argumentant que vulnerava la "Ley Orgánica del Estado" ${ }^{887}$. Diverses entitats acceptaren el repte llançat pel Tinent Alcalde de Cultura José Parra Estévez i el convocaren a un debat públic $^{888}$. Tres centes mares enviaren una carta al Governador Civil Martín Villa demanant la suspensió del projecte ${ }^{889}$. Abans d'acabar el mes de juny aparegué un

885 “Badalona: no al puerto", Diario de Barcelona, 6-5-1975 i Manuel Armengol: "Badalona: Nuevas manifestaciones contra el puerto deportivo", La Vanguardia, 20-5-1975. Aquest darrer diari parlava de l'assistència d'unes 800 persones a la segona concentració, de la qual es pot consultar un cartell de convocatòria: "Atención!! Domingo dia 18. Gran fiesta en defensa de la playa”, ANC, Fons PSUC, Context social i polític del Partit, 06.07. Moviment veïnal, 2351 Badalona.

886[Cartes de l'Alcalde de Badalona Isidro Caballeria al Governador Civil Rodolfo Martín Villa, on s'adjunta també fulles volants de propaganda i amb la lletra de cançons.] (20-5-1975), AHGCB, Gobernadores Civiles. Caixa 198, Ayuntamiento de Badalona, 1974-1975. Entre les cançons populars adaptades hi havien: “No, no ,no lo construiran”, “Cielito lindo", "Matarile”, el "Porrompompero"...

887 Manuel Armengol: "Badalona: El acuerdo municipal sobre el puerto deportivo-perquero debe ser revocado", La Vanguardia 27-5-1975 i Maria Teresa Ribó: “Escrito de alegación contra el proyecto del puerto", El Noticiero Universal, 5-6-1975.

888 “Convocan al teniente de alcalde de Cultura para que explique su sí al puerto”, Tele/ eXpres, 14-61975. Les entitats van ser les AVV Congrés Eucarístic, AVV Sistrells, la Mancomunitat de Propietaris de Lloreda, Veïns de la Immaculada, els Centres Socials de Pomar i Sant Roc i el Centre Parroquial de "La Balsa". Es va fer el 10 de juliol al Museu de Badalona.

889 Manuel Armengol: "Badalona: Más de 300 madres de família, en contra el puerto", La 
escrit titulat "Reflexió cristiana davant un greu fet ciutadà" signat pels sacerdots de diferents parròquies badalonines destacades per donar suport a la lluita contra la dictadura: Sant Sebastià (Pomar), Sta. Clara (La Morera), Ntra. Senyora del Rosari (Lloreda-"La Balsa"), Sant Antoni (Llefià) i Sant Roc, juntament amb Comunitats Cristianes de Base d'aquests barris i el Grup Cristià de Promoció i Defensa dels Drets Humans" i també per la parròquia de Sant Joan de Montgat ${ }^{890}$. Aquest fet va ser analitzat per l'aparell repressiu del franquisme:

"Figura como principal instigador el párroco de la iglesia de San Sebastián D. José María TORRELLA GIRALT, secundado por los sacerdotes del templo de San Roque D. Amadeo BASSOLS LLOPARTS; de San Antonio de Llefià, D. Antonio SOLE DUCH y de Nuestra Señora del Rosario, D. Rafael ANGELATS PUIG." ${ }^{891}$

Els partidaris del port, encapçalats per la Confraria de Pescadors van fer una campanya de recollida de signatures, rebent el suport d'antics alcaldes, personalitats, entitats bancàries i fins i tot del Club Joventut de Badalona. Entremig de tot aquest afer a l'estiu van aparèixer cartes de diversos metges desaconsellant el bany a Badalona per la gran contaminació de les seves aigües ${ }^{892}$. Malgrat els rumors d'un immediat començament de les obres, el cert es que aquestes no es van iniciar. L'Ajuntament necessitava un crèdit per fer-ho i en comptes d'això va rebre un nou cop quan a l'abril el Governador Civil, Salvador Sánchez Terán admetia el recurs presentat feia gairebé un any abans contra el port badaloní per la via del contenciós-administratiu ${ }^{893}$, i més si es tenia en compte que a l'octubre s'acabava la

Vanguardia, 19-6-1975 i “Trescientas madres contra el puerto”, Mundo Diario 20-6-1975.

890El mencionat document va tenir un gran ressò en la premsa: Hoja del Lunes, 23-6-1975; Tele/ eXpres, 24-6-1975 i Mundo Diario, 26-6-1975.

891[Nota adjuntada a una carta del Vicepresident Primer del Govern José Garcia Hernàndez adreçada a Rodolfo Martin Villa, Governador Civil de Barcelona] (1-7-1975). Existeixen vàris documents al respecte: Nota Informativa de la Dirección General de la Guàrdia Civil (27-61975), correspondència del Gobernador Civil cap el Cap Superior de Policia de Barcelona (22-71975) i la Nota Informativa emesa per la Jefatura Superior de Policia de Barcelona, (5-9-1975), analitzant la mobilització. Totes a AHGCB, Gobernadores Civiles, Caixa 198, Ayuntamiento de Badalona, 1974-1975. En alguns d'aquests hi sortia també el nom del periodista Manuel Armengol, corresponsal de La Vanguardia Española que poc després serà detingut en una protesta veïnal a Llefià.

892 “Los médicos desaconsejan el bañarse en la playa de Badalona”, Tele/ eXpres, 5-8-1975. L'Alcalde accidental, Alfonso Ramos, va replicar d'una manera desafortunada en un article titulat, seguint les seves afirmacions, "La playa de Badalona, tan limpia como las otras”, Tele/ eXprés, 8-8-1975. Certament si un mirava cap a Sant Adrià o cap a Barcelona ciutat, l'afirmació no era gaire tranquilitzadora.

893 “Luz verde al recurso contra el puerto de Badalona”, Tele/ eXpres 22-4-1976 i Maria Teresa Ribó: "S'accepta el recurs contra el port", Avui 23-4-1976. 
concessió del Ministeri d'Obres Públiques per construir-lo. Les tensions dintre del consistori entre els sectors més ultres i els més "aperturistes", en un context de creixent contestació i mobilització tampoc van ajudar ${ }^{894}$. La mateixa Assemblea Democràtica de Badalona es posicionava en contra del port el mes de maig, i forces polítiques com el PSUC i el PSOE, encara il·legals, també manifestaven públicament el seu rebuig al juliol (també ho tornava a fer la Jove Cambra). Per si no estava prou clar, l'Assemblea Democràtica al seu "Manifest de Badalona” (on exigia Ajuntaments Democràtics) ho tornava a afirmar. De res van servir les pressions del regidor i cap local del Movimiento Mariano Escudero ni de la Confraria de Pescadors, o fins i tot les amenaces que va rebre el periodista Manuel Bazataqui per fer-ne un article crític amb el projecte ${ }^{895}$. La progressiva feblesa de l'Ajuntament els anys posteriors fins arribar al 1979 i el context de creixent crisi econòmica van acabar de rematarho. El port va haver d'esperar per veure la llum -amb un nou projecte que també va ser polèmic- al segle XXI.

Sant Adrià de Besòs no podia comparar-se en població ni en volum de conflictivitat global amb les seves dues veïnes del Barcelonès Nord, però si que abans del decés de Franco hagueren uns barris, els situats al marge dret del Besòs si mirem al mar, que ja feia temps havien engegat una dinàmica reivindicativa comparable amb la d'altres barris badalonins i colomencs. Tot i això va ser el sacerdot de l'Església de Sant Adrià, situada al centre antic del poble, a l'actual barri de Sant Adrià Nord, el que va engegar una primera campanya de recollida de signatures per aconseguir la instal-lació d'un semàfor a un punt perillós de la carretera que anava cap a Santa Coloma ${ }^{896}$. Davant la nul.la resposta es va fer una concentració de 800 persones als trams dels carrers conflictius al febrer de 1973

894Per exemple el Tinent Alcalde de Gobernació, José Mateu Cunillé va dimitir el 3 de maig de 1976 per la pressió dels sectors "ultres" que criticaven la seva política "tova" amb l'oposició antifranquista. Veure "Dimiten dos concejales de Mataró y un teniente de alcalde en Badalona", Tele/ eXpres, 4-5-1976.

895Article en qüestió es deia "Tortugueando" i va ser publicat a Revista de Badalona (any 1976, número desconegut). Denunciava la connexió entre el patró de la Confraria de Pescadors i el projecte d'un complex hoteler situat a la platja, al costat del futur port. L'articulista va denunciar haver rebut dos anònims i una trucada telefònica advertint-lo de la conveniència "de escribir en favor del proyecto del puerto, a la vez que se le amenazaba sobre su seguridad personal", "Amenazas contra un periodista", Mundo Diario, 12-9-1976.

896[Instància al respecte presentada pel sacerdot Emili Vives Gimó, amb 14 fulles de signatures], ASAB, Fons 101 Ajuntament, Caixa 352, Carpeta 34. 
tallant el trànsit. Posteriorment el semàfor va ser instal $\cdot$ lat $^{897}$.

Tant l'AVV Besòs-Sant Adrià com la AVV La Catalana van mostrar una especial preocupació per un projecte de construcció d'una incineradora al costat dels seus respectius barris. Fins i tot l'AVV La Catalana i el seu President, que fins al moment havien estat considerat persones "d'ordre" (Agustín Bonet Manich estava catalogat com a "indiferent" respecte el règim) van viure durant aquests anys un cert procés de "radicalització" en veure que no es donaven solucions a les greus mancances del barri. Una carta publicada per La Vanguardia el 10 d'Agost de 1972 escrita pel mateix Agustín Bonet ens pot donar pistes del perquè d'aquest procés:

“A) El día 9 de agosto de 1971 se publicó un edicto referente a la incineradora de basuras. Dicho Edicto fue impugnado a su debido tiempo por la Asociación Vecinos, impugnación que no fue considerada. ¿Por qué?... Si estamos en Zona Verde por Ley de 3 de noviembre de 1953, que declara no poderse edificar en dicha zona ¿por qué se aprobó en un Pleno dicha incineradora? ... ¿O es que solamente existe zona verde para los propietarios de "La Catalana" que hace 18 años estamos en esta situación? ¿Por qué...?"898

El barri de La Catalana vivia pendent, sobretot, de la regularització dels seus habitatges. No obstant, el pla parcial del sector que s'havia aprovat al 1968, finalment va ser retornat a l'Ajuntament de Sant Adrià per la Direcció General de Urbanisme $^{899}$. Aquest afer, les obres de canalització del riu Besòs que van afectar a un grup de veïns del barri ${ }^{900}$, el polèmic Pla Cantallops (que volia traslladar a la població de La Catalana) i d'altres qüestions -com per exemple tota la polèmica al voltant de les Eleccions al Tercio Familiar- van fer que un president aparentment "indiferent" estigués cada vegada més enfrontat amb les autoritats municipals.

897 González Hergueta: "San Adrián: Un peligroso tramo para peatones en la carretera de La Roca" i "San Adrián del Besós: "Sentada" de 800 vecinos en un tramo de la carretera de la Roca", La Vanguardia 25-1-1973 i 24-2-1973, respectivament.

898Agustín Bonet Manich, President de l'AVV i Centro Cultural La Catalana: "Tres preguntas a un Alcalde", La Vanguardia, 10-8-1972. Anteriorment també havia denunciat les obres de construcció de la Central Tèrmica del Besòs sense el permís municipal corresponent. Veure La Vanguardia, 19-9-1971.

899Arumi: "Se devuelve al Ayuntamiento el Plan Parcial de La Catalana", Diario de Barcelona, 11-11973.

900González Hergueta: "San Adrián del Besós: Viviendas afectadas por el encauzamiento del Besós", La Vanguardia, 23-5-1973. Aquest fet va provocar gran malestar en l'AVV de La Catalana, ja que el curs del riu s'havia modificat artificialment per fer-ne anteriorment unes instal-lacions esportives municipals i per culpa d'això ara hi havia un grup d'habitatges afectats. 
Alguna maniobra es va fer per que al 1976 aquest presentés la seva dimissió i assumís la presidència un antic Alcalde de Barri, Alfonso Chaos Campo, tot i que el president dimissionari, Agustín Bonet, es va negar a reconèixer la validesa de l'Assemblea on es va triar la nova junta i també a entregar la documentació i claus del local al seu successor, fent-ho, finalment, a l'Ajuntament de Sant Adrià ${ }^{901}$.

Al gener de 1973 a tot el sector del Besòs es va engegar una campanya per la higiene pública, de manera coordinada per les AVV's La Pau, Maresma, La Catalana i el Centre Social Besòs i amb la participació de professionals i tècnics (metges, urbanistes, ecologistes, sociòlegs, etc.). Es tenia la voluntat d'aconseguir unes millores molt necessàries per cada barri i pel conjunt del sector. Un full volant recollia les accions que es farien al barri Besòs de Sant Adrià:

“CO.BA.S.A.: Estudio a través de los Presidentes de Escalera, de todas las necesidades y deficiencias urbanísticas y de construcción de las viviendas, así como de las higienes y servicios comunes." ${ }^{\prime 92}$

Així al febrer 1973 el Centre Social Besòs havia realitzat una enquesta entre els veïns -escala per escala- per denunciar les principals mancances del barri. Els resultats d'aquesta havia estat remesos a les autoritats municipals ${ }^{903}$. Les conclusions eren demolidores: servei de recollida d'escombraries totalment ineficient i inadequat (es demanà la millora del servei, que es fes amb camions especialitzats i per les nits); nombroses deficiències urbanístiques, en especial en el clavegueram, que ocasionà nombroses inundacions i molèsties. A més, la deficient urbanització feia que quan plovia l'aigua s'acumulés en determinades zones, fet agreujat per existir encara nombrosos espais sense asfaltar. Es feien constar la falta de parcs, zones infantils, el perill que representava el despreniment de recobriments de les façanes així com una especial preocupació pel projecte de la

901És interessant veure les cartes creuades entre el nou President i l'antic, que es poden trobar a ASAB, Fons 101 Ajuntament, Caixa 388, Carpeta Associació de Veïns de La Catalana.

902Asociaciones de Vecinos de: La Maresma-La Paz-La Catalana y Centro Social Besós: “iHigiene Pública! [full volant A4 doble cara] (gener 1973), ANC, Fons PSUC, 06. Context Social i polític del partit, 06.07. Moviment veïnal, 2354 Barcelona i Sant Adrià de Besòs: Barris del Besòs, Maresme, La Catalana, La Mina i La Pau, 1972-1976.

903Centro Social Besòs: [Instància i annex] (15-2-1973), ASAB, Fons 101 Ajuntament, Caixa 388. La notícia també es recull a la premsa en un article de González Hergueta "San Adrián de Besós: el barrio "Besós", en lamentable estado de abandono municipal" publicat a La Vanguardia, 15-31973 . 
incineradora de La Catalana.

Però no van rebre cap resposta de l'Ajuntament adrianenc ${ }^{904}$. Abans, al febrer s'havia produït la dimissió de l'alcalde Francisco Roqueta, al·legant motius de salut però se sabia que havia patit un fort desgast per projectes fallits com el del pàrquing municipal de la Plaça -aleshores- de Calvo Sotelo, que un cop construït va patir nombroses inundacions. Així com per altres projectes polèmics com el nou Ajuntament, la piscina municipal, -quan part de la població valorava que hi havia altres necessitats més urgents ${ }^{905}$ - o tot el que va envoltar el pla parcial de La Catalana, sense esmentar les diferències amb membres del seu consistori. També al mes d'abril s'havien produït els fets de la Tèrmica del Besòs, amb l'assassinat de Manuel Fernàndez Màrquez per trets de la policia ${ }^{906}$. No va ser fins el 16 de setembre que el nou Alcalde Juan Oller Valls va prendre possessió.

Al barri Besòs es desconfiava de les autoritats municipals. Al Gener l'AVV Besòs-Sant Adrià (legalitzada l'any anterior) va tenir una primera reunió amb el nou alcalde per exposar els problemes del barri, de la qual no van extreure tot el que volien, com ens ho demostra l'acta de l'Assemblea Extraordinària de l'AVV del 4 de març de 1974:

"Al hablar de higiene pública la Asamblea se muestra muy preocupada, puesto que no ha mejorado en absoluto la recogida de basuras, así como la limpieza del Barrio, si bien en las diversas entrevistas con el Sr. Alcalde se ha prometido una mejora en el sentido y una desratización intensa." ${ }^{907}$

El mes d'abril es va engegar una campanya de recollida de signatures per aconseguir les millores pendents, ja que no es confiava gaire en les autoritats locals. Aquest fet fins i tot quedava recollit a les actes:

"El Barrio se manifiesta disconforme con las razones y promesas que le ha hecho el Ayuntamiento y no se cree ni confía en dichas promesas." ${ }^{908}$

904González Herguesta: "San Adrián de Besós. Silencio Municipal entorno las deficiencias del barrio Besòs, sector “Cobasa”", La Vanguardia Española, 21-7-1973.

905González Hergueta: "San Adrián del Besós: Manifesta precisión de un nuevo ambulatorio de la Seguridad Social", La Vanguardia Española 28-6-1973. L'article recordava la imperiosa necessitat d'un nou ambulatori. El vell local, atrotinat, rebia el despectiu nom de "La Cuadra". 906Més informació sobre aquest esdeveniment a Emili Ferrando Puig i Juan Rico Màrquez: Les Comisions Obreres en el franquisme. Barcelonès Nord (1964-1977), p. 326-356.

907 [Acta de la Assemblea Extraordinària de l'AVV Besòs-Sant Adrià] (4-3-1974), ASAB, Fons 101 Ajuntament, Caixa 389.

908[Acta de la Assemblea Extraordinària de l'AVV Besòs-Sant Adrià] (24-5-1974), ASAB, Fons 101 
Malgrat millores puntuals en alguns serveis com la recollida d'escombraries i alguna campanya de desratització, quedaven moltes mancances per resoldre. El mes de desembre, els dies 21 i 22 es va fer un festival organitzat per l'AVV i el Centre Social en uns terrenys reivindicats com a parc. Apart d'un concurs de dibuix infantil i recollida de signatures per les habituals reivindicacions d'urbanització, de neteja, de serveis bàsics... fins i tot es va organitzar un "safari" de cacera de rates pel barri el dia 21 a les 20 h, fet que havia estat publicitat com una “Gimkama”909.

Al febrer es reprenien les reivindicacions al barri. L'AVV tornava a adreçar-se a l'Ajuntament exigint les solucions als greus problemes que no s'acaben de resoldre per molt que recentment s'hagués aprovat el pla parcial Marina-Besòs ${ }^{910}$. Un nou cop pels barris del marge dret del riu serà l'autorització per part del Ministeri d'Indústria de la incineradora del Besòs un cop aquesta ja s'estava acabant de construir, fet que va provocar una gran indignació popular en un sector ja greument afectat per la crema d'escombraries ${ }^{911}$. Mentrestant l'AVV Besòs-Sant Adrià havia engegat una campanya de xerrades informatives sobre temes com la carestia de la vida, la sanitat al barri i d'altres similars ${ }^{912}$. Al setembre l'Associació va triar una nova Junta ${ }^{913}$, i demanava permís per fer un gran festival infantil al carrer el dia 18 d'octubre ${ }^{914}$. Però al desembre, quan es va intentar repetir el festival infantil de l'any anterior el dia 14, el Govern Civil prohibia l'acte

Ajuntament, Caixa 389

909[Instància de sol-licitud signada per Guillermo Casado Olmedo, President de L'AVV Besòs-Sant Adrià] (9-12-1974), ASAB, Fons 101 Ajuntament, Caixa 389. Veure també La Vanguardia Española, 28-12-1974.

910Arumi: "Aprobado el Plan "Marina-Besòs"”, "Más de dos mil viviendas en el Plan "MarinaBesós"” , "El barrio del Besós pide solución a los problemas de equipamiento", Diario de Barcelona, 9, 12 i 15-2-1975, respectivament.

911Eduardo Cortés: "Industria autoriza la incineradora cuando está terminándose de construir", Diario de Barcelona, 19-4-1975.

912Es poden consultar els tràmits de petició dels actes així com les autoritzacions de les autoritats locals (amb la presencia del "delegado gubernativo") en ASAB, Fons 101 Ajuntament, Caixa 389.

913AVV Besòs-Sant Adrià: "Asamblea Extraordinaria del dia veintisieis de septiembre de mil novencientos setenta y cinco" (26-9-1975), ASAB, Fons 101 Ajuntament, Caixa 389. La nova Junta estava composada per: President: Guillermo Casado; Vice-Presidenta: Maria Codina; Tresorer. José Romero; Secretària: Milagros Delgado; Vocals: Cultural: Maribel Barba, Urbanisme: Ramon Quer, Sanitat: Arturo Lahoz, Carestia Vida: Cristina Manso, Recreativa: Ramón Subirana, Propaganda: Àngel Delgado. El President i la Vice-Presidenta eren militants del PSUC (i potser també algú més, però no ho sé del cert).

914[Instància de Guillermo Casado Olmedo, President de l'AVV Besòs-Sant Adrià] (26-11-1975), ASAB, Fons 01 Ajuntament, Caixa 388. 
argumentant que aquest es podia fer en un espai tancat ${ }^{915}$.

Aquest fet va encrespar més els ànims de manera que al 1976 es van intensificar les mobilitzacions de l'AVV Besòs, que va començar a coordinar-se amb la de La Mina. El 7 de gener s'havia fet una entrega de signatures per la reivindicació d'un solar per a parc infantil. El 24 els mateixos veïns el van netejar i el 25 es feia una concentració al barri per reivindicar-lo. En el dia 30 una assemblea veïnal reclamava la construcció d'un ambulatori al barri. El dia 5 la AVV del Besòs, juntament amb la de La Mina i diferents càrrecs sindicals exigien la dimissió de l'Ajuntament, mentre una manifestació de veïns del Besòs marxava cap a l'Ajuntament per assistir al ple per protestar, entre d'altres coses, per la continua negació del Govern Civil a la realització del Festival Infantil a l'aire lliure ${ }^{916}$. El dia 15 una nova manifestació dels veïns del Besòs exigia un ambulatori pel barri. S'havia iniciat ja una dinàmica que continuà durant els següents anys.

Per la seva banda el barri de La Mina es va construir en aquests anys i, com era habitual aleshores, es va començar a poblar abans de que s'enllestissin les obres. La Mina va ser un polígon creat en base a un acord de l'Ajuntament de Barcelona i el Ministerio de la Vivienda el 18 de maig de 1970, per acabar d'eradicar el barraquisme a Barcelona, i en ell es van concentrar a habitants procedents del Camp de La Bota, Can Tunis, l'Hospital de Sant Pau i La Perona ${ }^{917}$. La "primera pedra" del nou complex de 2.152 habitatges es va col-locar el 16 de desembre de $1971^{918}$. En ell tots els habituals defectes es van multiplicar per la manera com es va construir i per l'elevat nombre de població que es va concentrar sense els serveis més elementals. A més es va donar la paradoxa de ser un barri situat a Sant Adrià però depenent del Patronato Municipal de la Vivienda de

915Gobierno Civil de Barcelona [Carta del Gobernador Civil a l'Alcalde de Sant Adrià de Besòs] (312-1975), ASAB, Fons 01 Ajuntament, Caixa 389.

916“En Sant Adrián piden la dimisión del consistorio”, El Correo Catalán, 5-2-1976 i "Que dimita el consistorio", Mundo Diario 5-2-1976. Al mateix es temps es reivindicaven uns Ajuntaments democràtics. Finalment el festival el van fer a inicis del mes d'abril, farts d'esperar ja qualsevol tipus de permís.

917 “Convenio entre el Ministerio de la Vivienda y el Ayuntamiento para liquidar el chabolismo", La Vanguardia Española, 19-5-1970.

918Cal dir, que abans d'aquest es va fer un primer polígon de 600 habitatges però amb unes característiques molt diferents, ja que van ser 12 blocs amb només 5 pisos d'alçada i els seus habitants, tot i provenir de les barraques, tenien un perfil menys "marginal". Es la part del barri que es coneix com "Mina vella". La població estimada del barri, un cop terminat el trasllat dels habitants de diferents barris barraquistes, s'estimava a prop de 14.000 persones. 
Barcelona, fet que va comportar que les administracions es passessin mútuament la pilota sense resoldre les problemàtiques del barri. La Mina va ser l'exemple més clar del que molts van anomenar "barraquisme vertical", tal com recollia la premsa amb motiu de la visita del "Ministro de la Vivienda" Rodríguez de Miguel al l'esmentat barri el 23 de febrer de $1974^{919}$. Poc després un full informatiu del SECOD (Secretariat de Coordinació pel Desenvolupament, depenent de "Justícia i Pau") descrivia aquestes previsibles mancances quan iniciava un estudi sobre el barri $^{920}$, al igual que feia la revista Oriflama en un dossier especial dedicat a La Mina $^{921}$. Un article del conegut periodista Josep Ma Huertas Claveria denunciava el mateix $^{922}$. La situació era tant greu que fins i tot es van detectar casos de poliomielitis al barri ${ }^{923}$. A més, la primera Associació de Veïns que es va legalitzar l'any 1973 estava controlada per persones conservadores i franquistes, com el seu primer President Juan Arnau Valero. Però aviat l'entrada de gent nova va canviar aquesta situació ${ }^{924}$.

D'aquesta manera, a l'any 1975 Juan Arnau Valero va ser substituït en la Presidència i l'AVV canvià de tarannà, fent-se molt més reivindicativa. En especial amb la presidència de Juan Ponce, militant del PSUC aleshores i del qual tornarem a parlar més endavant. Es va iniciar una campanya de xerrades sobre la situació del barri ${ }^{925}$, i també de pressió de cara al "Patronato Municipal de la Vivienda", no sense dificultats com ens demostra aquest escrit del Govern Civil denegat la celebració d'una xerrada sobre urbanisme amb la presència d'un arquitecte, amb l'excusa que s'havia anunciat com un acte exclusiu pels socis i en canvi la propaganda convidava a vindre al veïnat en general:

"Significo a esa presidencia, que en lo sucesivo la propaganda de los actos que esa Asociación pretenda celebrar, ha de ser consecuente con la petición de permiso gubernativo, a fin de evitar confusionismo y situaciones enojosas como la planteada en

919Teresa Rubio: “El polígono de la Mina: Barraquismo vertical”, Mundo Diario, 23-2-1974.

920SECOD: "Full informatiu núm. 6" (agost-setembre-octubre 1974), Arxiu Històric de La Mina (AHLM), Caixa C.1-C1.3 La Mina anys 70, Carpeta Prensa Años 70.

921 Ma Àngels Alcàzar: "La Mina. Un triomfalisme sense límits", Oriflama núm. 146 (novembre 1974), AHLM, Caixa C.1-C1.3 La Mina anys 70, Carpeta Prensa Años 70., p. 16-21.

922 Josep Mo Huertas Claveria: “La Mina, recién nacida y casi abandonada", Tele/ eXpres 24-5-1974. 923 “Tres casos de polio en La Mina”, Tele/ eXpres, 13-8-1974.

924Entrevista a Josep Maria Montferrer, 20-3-2012. Veure cita nota 636.

925Es poden trobar les instàncies que es feien a l'Ajuntament i Governació per fer-les a ASAB, Fons

01 Ajuntament, Caixa 387. 
el presente caso, y que solo puede ser imputable a negligencia o quizá a la deliberada intencionalidad de todos o algunos de sus dirigentes."${ }^{{ }^{926}}$

De la mateixa manera durant 1975 van ser constants les denúncies per la situació de brutícia existent al barri, en especial als mesos de febrer i d'agost (en aquest darrer cas agreujat per la presència d'una fàbrica de plàstics al barri) ${ }^{927}$. El setembre la mateixa AVV de La Mina enviava un escrit denunciant aquesta greu situació al delegat de Sanitat i alhora criticant durament a l'Inspector Mèdic del Departament d'Epidemiologia, Francisco Zanuy, el qual culpava als habitants del barri i en especial als gitanos de la situació de brutícia existent ${ }^{928}$. Davant la manca de respostes per part de les autoritats, l'AVV va adoptar la mesura de dir als veïns que no paguessin els rebuts corresponents a la quota de recollida d'escombraries per la nul.la eficàcia del servei ${ }^{929}$. El 21 de gener el President de l'AVV de La Mina adreçava una carta a la premsa denunciant el greu estat del polígon i acusant al $\mathrm{PMV}^{930}$. Al febrer l'AVV de la Mina i la del Besòs Sant Adrià (i diversos càrrecs sindicals) demanaven la dimissió del consistori i reclamaven un Ajuntament democràtic. Com veurem més endavant, l'any 1976 va ser un any de mobilitzacions al barri que va anar radicalitzant les postures de l'Associació i de la població davant la manca de respostes de les autoritats, fins que varen arribar a la vaga de lloguers, una mesura semblant a la que feien els polígons de l'OSH ${ }^{931} \mathrm{i}$, ja al març de 1977, a

926[Carta de la Secretaria del Gobern Civil de Barcelona a l'Alcalde de Sant Adrià de Besòs] (25-101975), ASAB, Fons 01 Ajuntament, Caixa 387.

927 Arumi: "Alarmante suciedad en el polígono de La Mina" i "En La Mina se quejan de una fábrica de plásticos", Diario de Barcelona, 14-2-1975 i 21-8-1975. L'Ajuntament de Sant Adrià no volia fer-se càrrec del polígon abans que el PMV no l'acondicionés. Fins i tot es va aprovar atorgar provisionalment el servei de neteja a Manuel Alunda Bolunda (més conegut com el "Tio Manolo"), un patriarca gitano amb els quals les autoritats franquistes ja havien tingut contactes des de el Camp de La Bota i al qual li reconeixien l'autoritat (fins i tot la primera AVV va fer un escrit per que se'l considerés com a persona de referència pel que feia a assumptes dels gitanos del barri). Com veurem més endavant, serà un personatge polèmic i serà detingut als anys 80 acusat de tràfic de drogues i vehicles. Al més d'agost els mateixos veïns, impulsats per l'AVV van col-locar pancartes de denúncia de la brutícia als seus balcons. Veure Asociación de Vecinos La Mina. Hoja Informativa (8? -1975), AHLM, Caixa C.1-C1.3 La Mina anys 70, Carpeta Associació de Veïns Anys 70. Transcrits o escanejats.

928“"'La Mina” se dirige al delegado de Sanidad”, Diario de Barcelona, 27-9-1975.

929“San Adrián del Besós: Los vecinos de La Mina ya estan cansados”, La Vanguardia, 18-1-1976.

930“El polígono de La Mina, de Sant Adrià, acumula deficiencias”, Diario de Barcelona, 21-1-1976.

931 “San Adrián de Besós: Los vecinos de La Mina deciden no pagar los alquileres", La Vanguardia Española, 21-5-1976. Una assemblea amb la presència de 300 veïns va decidir deixar de pagar els rebuts a partir del mes de juny. En la Mina teòricament els habitatges estaven en un règim de propietat diferida similar al dels polígons de l'OSH. En teoria els pisos no es podien revendre però van existir un gran nombre d'irregularitats en aquest aspecte. 
una Vaga General en tot el barri per la reivindicació d'un ambulatori que feia anys que s'esperava. Paral-lelament, també va haver una campanya de dignificació del barri i de denúncia de la seva estigmatització, com la que van fer un grup de veïns contra el rodatge de la pel·lícula "Perros Callejeros" 932 . Tal com afirmava un grup de mestres de l'USO en una carta:

\begin{abstract}
"La película que se está filmando nos presentará aventuras de estos muchachos con alardes de denuncia social, pero no nos dirá nada sobre las causas reales que originan estos hechos. Incluso servirá como tranquilizador de conciencias para algunos espectadores que creerán así resuelto el problema de la delincuencia y la marginación. Todo esto, por supuesto, a 100 pesetas la entrada." ${ }^{933}$
\end{abstract}

Van existir a Sant Adrià de Besòs conflictes que ajudessin a configurar un sentiment de ciutat com van existir a Santa Coloma i Badalona? La divisió geogràfica del riu Besòs va ser un obstacle físic (a més de psicològic) molt important, i certament en aquest període els barris situats a la riba dreta (el Besòs i La Mina), que són els que abans van engegar una dinàmica de lluita veïnal, van estar més relacionats amb Barcelona que no amb Sant Adrià. No obstant, si que van donar-se alguns fets que van erosionar a les autoritats locals ajudant a estendre una consciència crítica i alguna reivindicació, com la de l'ambulatori, que va ser un element aglutinador dels diferents barris.

Al 8 de setembre de 1970 es posava la primera pedra del nou Ajuntament, un edifici que no es va enllestir fins 1974 i que va ser criticat per ser massa car i sumptuós ${ }^{934}$. Igual o més polèmic va ser el projecte d'aparcament subterrani de la Plaça -aleshores- de Calvo Sotelo. L'aparcament va ser inaugurat amb tota la pompa el 8 de juliol de 1971, dins els actes de commemoració del 18 de juliol, però aviat va quedar parcialment inutilitzat per les filtracions que van inundar diverses plantes $^{935}$. Un altre fiasco va ser el d'unes instal-lacions esportives fetes al costat del

932J. González Hergueta: "San Adrián de Besós: Jóvenes de La Mina contra filmación de "Perros callejeros"” i "Nota del M.I.J.A.C. de Barcelona sobre la película "Perros Callejeros"”' La Vanguardia Española, 8-12-1976 i 23-12-1976, respectivament.

933 [Carta enviada per un grup de Mestres de l'USO de Besòs-La Mina] La Vanguardia, 29-12-1976. 934“San Adrián del Besós: Inauguración del grupo escolar "José Aguilera”"La Vanguardia, 12-91970. La mateixa notícia informava de la col-locació de la primera pedra del nou Ajuntament. 935“El gobernador civil inauguró diversas obras municipales en San Adriánd el Besós”, La Vanguardia Española, 9-7-1971. Fins a l'any 1974 no es van subsanar les deficiències permetien la filtració d'aigües freàtiques. Veure Arumi: "Ya funciona el "parking" municipal subterraneo", Diario de Barcelona 20-7-1974. 
Besòs, que inaugurades al mes de juliol, van quedar molt malmeses per la riada del 20 de setembre de de $1971^{936}$. També el cas de la de la Piscina Municipal, que al poc temps de ser inaugurada va esdevenir inservible per les nombroses deficiències de la seva construcció ${ }^{937}$. Tots aquests fets van minar l'autoritat de l'Alcalde Francisco Roqueta fins que va dimitir i va ser substituït per Francesc Oller Valls com a Alcalde i Cap del Movimiento.

Però va ser la lamentable situació de l'ambulatori municipal, la que va provocar una de les primeres reivindicacions "de ciutat". Ja la premsa va començar a fer-se ressò de les mancances de l'antic local que es feia servir -"La Quadra"- l'any 1973 ${ }^{938}$. I si bé en un Ple de febrer de 1974 es va aprovar la cessió d'un solar per la seva construcció, les obres no van començar immediatament per l'oposició de la CMB. La reivindicació de l'ambulatori va ser una de les mobilitzacions més importants durant els anys 1976 i sobretot 1977, assumida en conjunt per les AVV's. Cal tenir present que en 1976 també es legalitzaran les AVV's de Sant Adrià Nord i de Sant Joan Baptista, de les quals parlaré més endavant. Un fet que també va ser rellevant a Sant Adrià va serla suspensió d'un recital de Lluís Llach i Quico Pi de la Serra que s'havia de celebrar el dia 15 al poliesportiu de Sant Adrià per ordre del Govern Civil $^{939}$.

Durant aquest temps el Comitè Local del PSUC va fer propaganda denunciant casos com el de l'ambulatori i la falta d'un Institut d'ensenyament mitjà a la ciutat, a més de denunciar el caràcter dictatorial del franquisme ${ }^{940}$. Però a Sant Adrià les mobilitzacions "de ciutat" amb un cert relleu van produir-se un cop mort el dictador, sense que això desmereixi la dinàmica iniciada als barris de la dreta del Besòs on si que els membres del PSUC, i d'altres partits en menor mesura, van tenir una presència més activa.

936“En San Adrián de Besós”, Diario de Barcelona i "Han sido arrasadas las instalaciones deportivas en San Adrián del Besós", El Correo Catalán, 21-9-1971.

937 Arumi: "La piscina municipal, una instalación deficitaria", Diario de Barcelona, 23-7-1974.

938González Hergueta: "San Adrián de Besós: Manifesta precisión de un nuevo ambulatorio de la Seguridad Social", La Vanguardia Española, 28-6-1973.

939Jordi Garcia Soler: "Llach i Pi de la Serra no cantaron en Sant Adrià", Diario de Barcelona, 19-111974.

940Exemples d'aquests fulls volants es poden trobar en ANC, Fons PSUC, 03.01. Organitzacions territorials, 929 Sant Adrià de Besòs i Comitè Local del PSUC, 1972,1980. 


\subsection{Badalona, Santa Coloma de Gramenet i Sant Adrià de Besòs: un procés similar?}

Abans de donar per acabar aquest extens tercer capítol, vull fer algunes reflexions a l'entorn del desenvolupament del moviment veïnal a les tres ciutats del Barcelonès Nord, observant similituds i diferències. Si bé és innegable que van haver-hi unes característiques similars en el desenvolupament del moviment popular ciutadà, de seguida salta a la vista que van haver-hi dinàmiques particulars en les tres ciutats, i fins i tot en diferents barris d'aquestes.

Un fet important a destacar és per exemple la importància que va tenir a Badalona l'existència d'un primer associacionisme veïnal desenvolupat ja a finals dels anys cinquanta i als seixanta, fet que no es va donar amb la mateixa intensitat a les altres dues ciutats. Aquestes entitats van sortir en els barris perifèrics de Badalona, en aquells que estaven mancats de les infraestructures més elementals. Per entendre el perquè d'això crec que cal tenir en compte la dialèctica entre el paper jugat per unes autoritats locals badalonines que van jugar a fomentar aquest associacionisme per estendre el seu control a unes zones de Badalona que podien ser potencialment molt conflictives, com alhora al paper que van jugat algunes persones d'aquests barris per intentar autoorganitzar-se d'alguna manera per donar resposta a les necessitats més immediates o fins i tot en alguns casos com en el barri badaloní de Lloreda, evitar perdre la casa que amb tant esforç s'havien fet ells mateixos. Aquest fet és cabdal per que demostra una major estabilitat del poblament. Quan es donaven aquests processos es demostrava que el suburbi ja no era "provisional" i que hi havia una voluntat dels seus pobladors de millorar un hàbitat que consideraven estable. D'aquí el renovat interès de les autoritats franquistes per ser-hi en uns barris que fins al moment havien escapat al seu control:

“Es generalitzaren a poc a poc els alcaldes de barri, ja presents en la postguerra en els nuclis urbans tradicionals, i es feren alguns esforços per fomentar l'associacionisme esportiu (...). La construcció de veïns al voltant de l'alcalde de barri fou més conflictiva, car massa sovint acabà per actuar de para-xocs de les autoritats en comptes 
d'esdevenir portaveu del veïnat."1941

Abans de començar aquesta investigació tendia a creure que la majoria d'aquestes entitats veïnals havien estat creades d'una manera molt teledirigida pel poder franquista local. Però quan he avançat el meu treball he constatat que els fets son més complexos i que, en determinades associacions d'aquest tipus, es van donar processos d'infiltració de persones amb antecedents polítics antifranquistes força notables. La importància d'aquest procés fins i tot ha estat argumentada per un dels meus entrevistats per "justificar" que a Badalona no hi haguessin unes CCBB tant potents com a la veïna Santa Coloma de Gramenet ${ }^{942}$.

En canvi, a Santa Coloma de Gramenet aquest procés no va acabar de reeixir amb tanta força tot i que hi havia una situació urbanística més greu fins i tot que a Badalona. Només vaig poder documentar dues entitats veïnals fundades abans dels anys 70 malgrat que es van fer intents ja al $1958^{943}$. Per què? Potser per que les autoritats locals franquistes colomenques no van posar el mateix empeny que a Badalona en fomentar aquest tipus d'associacions? Tot i que la ciutat estava creixent vertiginosament als anys seixanta, es possible que encara conservessin una mentalitat més "de poble" que la dels seus veïns badalonins. 0 potser per que les barriades de Santa Coloma eren de més nova creació i van tenir un creixement més accelerat que va fer -en un primer moment- més difícil la creació d'aquest tipus d'entitats? Aquest segon factor sens dubte va tenir la seva importància ${ }^{944}$. Cal recordar que aquestes no van sorgir de la nit al dia i en determinats casos ho van fer en uns barris on ja havien existit nuclis de població -encara que fossin més reduïts- des de els anys 20, 30 o 40 o fins i tot 50 del segle XX, com per exemple va passar a Lloreda, Sistrells i Llefià. I més si tenim en compte que els intents d'associació que es van intentar fer "tutelats" a Santa Coloma van ser al Fondo i

941 Martí Marín (dir.): Memòries del viatge [1940-1975], Museu d'Història de la Immigració de Catalunya i Ajuntament de Sant Adrià de Besòs, Sant Adrià de Besòs, 2009, p. 143.

942Entrevista a Diego Guerrero, 20-11-2013.

943Recordem el cas de la fulla volant convocant a una reunió al barri del Singuerlín l'any 1958. Veure nota 317.

944 La importància d'aquesta qüestió ja havia sigut destacada per Martí Marín i Corbera a "La fàbrica, el barri, la ciutat, el país. La integració dels immigrants a la Catalunya sota el franquisme" dins Jordi Font i Agulló (dir.): Història i memòria: el franquisme i el seus efectes als Països Catalans, Publicacions de la Universitat de València, Sueca, 2007, p. 261-282 i a "Epíleg: de suburbis a barris..." a Martí Marín (dir.): Memòries del viatge [1940-1975], p. 136-148. 
Sistrells (uns barris ja poblats als anys 40 i 50), i que a Sant Adrià de Besòs si que va existir l'AVV de La Catalana, fundada al l'any 1968 molt condicionada per la problemàtica especial d'un barri que datava dels anys vint. La major antiguitat del nucli urbà afavoria que s'haguessin produït unes relacions de veïnatge que podien afavorir el nou procés (i en alguns casos fins i tot existia la memòria de l'existència d'entitats precursores als anys 30, com va ser per exemple l'Associació de Propetaris i Veïns de Llefià-Puigfred). En canvi, en uns barris amb una immigració més recent i més elevada proporcionalment, com els colomencs, va haver de passar un major temps per que hi haguessin uns processos de socialització que en no pocs casos van passar en un primer moment per les noves parròquies:

\footnotetext{
"Per tant, cal pensar que calia un cert arrelament en el lloc de residència abans de pensar en termes de barri: de comunitat de veïns. Fins i tot quan la residència es convertí en estable, la cohesió veïnal podia trigar a arribar. Així, per exemple, la quotidianitat del treball en comú per a fer obres públiques que no proveïa el municipi -documentades a Cerdanyola de Mataró, a Ca n'Oriac de Sabadell, al Verdum de Barcelona, etc.- podia afavorir l'acció veïnal, de la mateixa maner que un actiu centre parroquial podia facilitar-ho." ${ }^{945}$
}

Santa Coloma va tenir la peculiaritat de tenir un moviment cristià de base molt desenvolupat, amb la importància que va representar l'arribada a mitjans dels seixanta d'un grup de nous sacerdots joves amb unes idees progressistes i renovadores. L'impuls que van donar als locals socials com els Centres (que van ser un espai de socialització important) així com a la JOC i a les Comunitats Cristianes de base va ser un fet que la va diferenciar de les seves veïnes (i la JOC va ser posteriorment una cantera de militància política per l'esquerra revolucionària molt important). A Badalona no va existir aquest moviment amb tanta força, si exceptuem les parròquies de determinats barris perifèrics com per exemple Pomar, Llefià o Sant Roc, on si que les diferents esglésies, els Centres Socials i/o entitats coma la HOAC, l'ACO i la JOC van tenir un paper important. A Sant Adrià només al barri de Besòs-COBASA havia existit un fet similars amb la importància del Centre Social Besòs i la parròquia (encara que aquesta estava situada a Barcelona ciutat i donava "cobertura" als diferents barris del "Sector Besòs"). També va passar, si bé 945 Martí Marín i Corbera: “La ciutat, el barri...” a Jordi Font i Agulló (dir.): Història i memòria: el franquisme i el seus efectes als Països Catalans, p. 279. 
amb unes peculiaritats diferents, al Camp de la Bota amb la implicació dels sacerdots escolapis com Antoni Botey i d'altres.

Però sens dubte s'hi hi ha un fet peculiar en aquests primers anys setanta al Barcelonès Nord, és la força que va tenir el moviment popular i en concret les CCBB a la ciutat de Santa Coloma de Gramenet. Per què es va donar aquest fet en aquesta ciutat i no en les altres? Alguns dels nostres entrevistats ens donaven la seva opinió:

"Entonces las Comisiones de Barrio ya fueron de una manera más clandestina, más organizada, más... con una Coordinadora por ejemplo que hacía campañas conjuntas. Y entonces a partir de ahí diríamos empieza un poco la organización de lo que fue el movimiento social de Santa Coloma.

Paralelamente a eso están las Comisiones Obreras, pero Comisiones Obreras más se dedica a la cuestión laboral (...) que a la cuestión social. Entonces en Badalona que tienen fábricas y todo eso evoluciona diríamos todo el movimiento de Comisiones Obreras y tira para adelante por su cuenta. Pero (...) en algunos barrios, como era La Balsa [Lloreda], Llefià y algunos sitios, había movida social en torno a las parroquias. Los demás son curas más tradicionales y no permiten que la gente se reúna allí. Y por lo tanto quedan (...) socialmente menos activos. Santa Coloma será socialmente más activa porque los curas que vienen son que quieren participar diríamos en la movida social. Y entonces (...) los que vivíamos en esta época... una diferencia tremenda de los movimientos que se hacen sociales en Santa Coloma de los movimientos sociales que se hacen en Badalona que era mucho más obrero, más diríamos... tenían mucha más capacidad para hacer movimientos que en Santa Coloma como era lógico, porque aquí no había nada. Aquí no había prácticamente ninguna infraestructura y allí si tenían infraestructura. Allí la medicina la tenían más o menos, lo poco que había estaba allí. Nosotros teníamos que ir a los especialistas de Badalona. Los especialistas estaban allí cerca de la vía, en la calle (...) al final de la calle del Mar, allí había unos ambulatorios y allí teníamos que ir al especialista hasta que hicieron el ambulatorio grande esta que hay pegado a la autopista (...). Nos mandaban a ese ambulatorio a los especialistas. Aquí no había más que medicina general y los especialistas allá. Pero como quitaron la medicina general pasó lo que pasó."1946

Aquest testimoni ens posa sobre la taula vàries hipòtesis del perquè les CCBB van tenir més força a Santa Coloma que no a Badalona. Per començar, reforça la imatge de Santa Coloma com a "ciutat dormitori", justificant el fet de que a

946Entrevista a Salvador Bolancer Dugo, 8-5-2013. 
Badalona van tenir més pes les CCOO i a Santa Coloma, en haver menys indústria, les mobilitzacions es van polaritzar més en les millores als barris. Apart de la major presència dels capellans obrers i de la JOC -ja esmentada- remarca un altre argument: la pitjor situació de Santa Coloma de Gramenet respecte la seva veïna pel que fa a urbanització, infraestructures, comunicacions, etc., fet que la faria tenir -aparentment- unes condicions objectives més fàcils per impulsar la lluita i la mobilització respecte una ciutat com Badalona, que si tenia un centre històric més urbanitzat i amb una millor dotació de serveis (no així els seus barris perifèrics).

L'argument de el major pes de Santa Coloma com a ciutat-dormitori ha estat matisat -sense negar-ho- per estudis més recents com el de Lola Carrión, la qual concloïa la seva recerca amb aquestes significatives paraules:

\footnotetext{
“Les meves hipòtesis en quan l'existència d'un teixit industrial de petites i mitjanes empreses, així com que aquest havia estat protagonista d'una conflictivitat laboral a Santa Coloma de Gramenet a mitjans dels anys 1970 queda demostra en el transcurs del treball de la recerca." 947
}

L'etiqueta de "ciutat dormitori" ha estat una teoria recurrent en diverses ocasions (recordem només el títol de l'estudi del Grup colomenc d'Historiadors José Berruezo, referenciat en diverses ocasions en el present treball, Santa Coloma de Gramenet. Una ciutat dormitori sota el franquisme. 1939-1975). Però aquesta explicació per si sola no pot justificar l'auge de les CCBB. No dic que no pogués tenir la seva influència, però en combinació amb altres causes. Crec que s'ha de tenir molt en compte també el pes de la militància d'esquerra revolucionària, en molts casos provinents de sectors i comunitats cristianes de base o de la JOC. A Santa Coloma de Gramenet va haver-hi un major pes de grups llibertaris com els GOA o marxistes revolucionaris com l'OICE, molt implantats en diversos barris (i també d'altres grups com el PTE, AC, l'MCE...). La línia que van seguir els va enfrontar amb el PSUC, primerament als inicis de les CCBB i després, quan el PSUC, PTE i MCE es van retirar d'aquestes i van impulsar més tard les Associacions de Veïns. A Badalona, aquests grups no van tenir tanta força, llevat potser del PTE que

947 Lola Carrión: “La conflictivitat laboral en Santa Coloma de Gramenet des de 1968 a 1978. Treball de Màster, Universitat de Barcelona, 2008, p. 173. 
si va tenir una forta implantació als diferents barris, i, posteriorment, el MC ${ }^{948}$.

El major pes d'aquests grups va fer que les CCBB de Santa Coloma tinguessin una ideologia classista i revolucionària molt marcada. La seva idea no era acabar només amb la dictadura sinó que també lluitaven per implantar el socialisme però amb una tàctica i estratègia diferents a la del PSUC. No obstant, en determinats casos van portar aquesta idea fins a un nivell força "esquerranista". Vull que se m'entengui bé en aquest aspecte. No estic pas dient que tinguessin unes idees equivocades per se o quelcom similar. La principal contradicció que van tenir va ser que en alguns casos van prioritzar tant el treball clandestí i extremadament polititzat que van acabar tancant-se en elles mateixes, aïllant-se de sectors populars que podien ser potencialment receptius als seus missatges. No van saber percebre que el nivell de consciència de la majoria de la població no estava tant "en la seva línia" com alguns volien creure i era més divers i complex. I davant d'això tens dues opcions, continuar tancat en teu món o mirar d'incidir en espais més amplis, on hi són presents més sectors populars. Algunes CCBB i els seus membres van percebre que les Associacions de Veïns els hi permetien arribar a més gent, encara que suposés fer servir els canals legals (però sense renunciar als seus principis). Altres en canvi creien que per això ja estaven els Centres Socials i no van voler-ne saber res de les noves Associacions de Veïns, que identificaven amb l'estratègia "reformista" del PSUC i d'altres organitzacions (PTE, MCE), amb les quals probablement tenien una certa recança a disputar-li espais per por a quedar

948Sobre l'esquerra revolucionària veure Jose Manuel Roca (ed.): El Proyecto radical : auge y declive de la izquierda revolucionaria en España (1964-1992), Los Libros de la Catarata, Madrid, 1994; Consuelo Laiz Castro: La Lucha final: los partidos de la izquierda radical durane la transición española, Los Libros de la Catarata, Madrid, 1995; José Luis Martín Ramos (coord.): Pan, trabajo y libertad. Historia del Partido del Trabajo en España, El Viejo Topo, [Barcelona], 2011; Sergio Rodríguez Tejada: "Nueva izquierda, extrema izquierda: bases intelectuales y pràcticas militantes de las organizaciones revolucionarias al inicio de la transición española" a Quirosa-Cheyrouze, Rafael, Navarro, Luis Carlos y Fernández, Mónica (coords): Las organizaciones políticas. Congreso Internacional Historia de la Transición en España, Universidad de Almería, Almería, Servicio de Publicaciones, 2011, p. 631-648; Joel Sans Molas: "Entre las instituciones y la movilización: la crisis de la izquierda radical durante la Transición" a QuirosaCheyrouze, Rafael, Navarro, Luis Carlos y Fernández, Mónica (coords): Las organizaciones políticas. Congreso Internacional Historia de la Transición en España, Universidad de Almería, Almería Servicio de Publicaciones, 2011, p. 649-666; "L'esquerra revolucionària i el seu paper en la mobilització social i el canvi polític dels anys 70: estat de la qüestió i alguns apunts per al seu estudi", a IV Encuentro de Jóvenes Investigadores en Historia Contemporánea, Universitat de València, 10-13 de setembre de 2013 i també en la seva Tesi Doctoral en procés d'elaboració L'esquerra radical durant la transició: el cas de l'Organització d'Esquerra Comunista (1974-1979). 
en minoria. El mateix Marcelo López Ródenas avançava aquests fets en un article que analitzava el paper de les CCBB a Santa Coloma, just quan estaven ja en el seu moment de crisi final:

"La represión ejercida durante la etapa franquista, exigía para la supervivencia como organización de luchadores, unas medidas de clandestinidad muy estrictas. Esta situación dificultaba enormemente la necesaria unidad política y organizativa y la estrecha unión con las masas trabajadoras de nuestra ciudad. Progresivamente fueron cayendo en una práctica vanguardista, aislada del trabajo real entre el vecindario y con una manifiesta incapacidad de integrar en su seno a los vecinos más decididos surgidos de la lucha.

Por otra parte, la falta de un mínimo proyecto político común, convertía al movimiento de Comisiones en un fraccionamiento grupuscular, convirtiendo de hecho su actividad en un sindicalismo meramente reivindicativo, poniendo el acento en los métodos más radicales de lucha.

La misma capacidad de dar una respuesta política, junto a una política vanguardista, es lo que explica, para los miembros de la organización, el auge de otras tendencias políticas en los últimos años en nuestra ciudad."'949

I aquestes divisions internes juntament amb el canvi de conjuntura i la força emergent de les AVV's les va acabar fent desaparèixer malgrat els darrers intents de coordinació i d'oferir una alternativa política comuna al programa dels Ajuntaments Democràtics que oferien altres sectors opositors. El Manifest que es va editar al setembre de 1976 no recollia totes les sensibilitats i estava polaritzat més clarament cap al cantó més recelós respecte les noves AVV's, (les CCBB del Centre, Riu Nord, i una de les dues existents al barri de Les Oliveres).

Però malgrat això, s'ha de reconèixer el paper que van tenir les CCBB pel desenvolupament del moviment veïnal a Santa Coloma de Gramenet. Després de la lluita de l'ambulatori van ser elles les que van impulsar les lluites als barris en un primer moment i van ser els llocs on es van iniciar en la militància posteriors membres de diverses Associacions de Veïns. Sense elles no es pot entendre la ràpida importància que el moviment popular va adquirir a Santa Coloma en relació amb les seves veïnes:

“Más allá de la defensa de los problemas concretos, las comisiones de barrio

949Marcelo López Ródenas. "Comisiones de Barrio: seis años en la brecha”, Grama núm. 96 (gener 1977), p. 15. 
constituyeron una importante oposición política al franquismo y a la institución municipal, que lo representaba. En Santa Coloma de Gramenet durante varios años las comisiones de barrio fueron casi el único referente de organización vecinal. No obstante, el papel destacado, organizativo y dirigente de las comisiones de barrio en las luchas vecinales no ha sido aún suficientemente estudiado y reconocido.

Las comisiones de barrio prepararon, en el año 1975, la legalización de las famosas asociaciones de vecinos, no sin divergencias internas, ya que algunos preferían seguir como comisiones de barrio. Pero poco a poco, las asociaciones de vecinos fueron superando el papel de las comisiones de barrio, ya que la precaria legalidad de la que disponían significó una apertura mayor hacia los vecinos y la posibilidad de utilizar formas de convocatoria más amplias y abiertas." ${ }^{950}$

Pel que fa a l'altre argument, les pitjors condicions en que estava Santa Coloma, certament podria semblar lògic. Però per si sol és insuficient. Ja hem vist com unes condicions més dures no són sinònim per se de mobilitzacions. Calen més factors com l'arrelament i la conscienciació. El desencadenant de la primera mobilització veritablement de masses va ser la reivindicació de l'ambulatori, una necessitat bàsica que pot semblar elemental però que molta de la població colomenca no havia conegut als seus llocs d'origen. La voluntat d'arrelament en el seu nou lloc de residència, la tasca de conscienciació feta per parròquies progressistes, partits i altres organitzacions, agreujada per l'incendi del vell local que era a l'any 1971 l'únic servei d'assistència sanitària pública de la ciutat van ser claus per l'esclat reivindicatiu. La ciutat havia experimentat també un creixement més ràpid i massificat, amb una major arribada de població d'origen immigrant que les seves veïnes (que també en van rebre molta població, no ho oblidem). El pes proporcional d'aquesta serà major a la ciutat de Santa Coloma que a Badalona o Sant Adrià. Aquest major creixement proporcional de població va "afavorir", en certa mesura, un major creixement especulatiu per la major possibilitat de negoci existent. La tolerància -quan no complicitat- municipal davant les barrabassades urbanístiques van fer que les mancances urbanístiques i d'equipaments bàsics fossin més greus a la ciutat colomenca. Tots aquests condicionants van influir també a que les lluites "de ciutat" adquirissin un major i primerenc protagonisme a Santa Coloma. No es pot obviar tampoc el paper que va tenir la revista Grama pel 950Fernando Saro: Les Oliveres. Sabor a barrio 1970-1980, p. 34. 
que fa a l'adquisició d'una consciència col·lectiva i dels problemes més greus de la ciutat.

De tota manera, els darrers anys de vida del dictador la situació va tendir a igualar-se. Per una banda, a Badalona, i en especial al seus barris perifèrics, les Associacions de Veïns van experimentar un important impuls als anys 1974 i 1975, justament en el mateix moment que van començar a adquirir força a Santa Coloma -en competència amb les CCBB- i també als barris del marge dret del Besòs a Sant Adrià. Sens dubte va haver-hi una estratègia premeditada de diversos grups polítics per impulsar aquests tipus d'entitats, dels quals destacaria el PSUC (sense menystenir el paper d'altres com el PTE i el MCE). En aquest sentit, la situació va ser similar, si bé a Santa Coloma amb dues peculiaritats: les CCBB es van mantenir encara un temps i les AVV's van aparèixer pràcticament a tots els barris als anys 1974-1975, mentre que a Badalona i Sant Adrià ho van fer primer als barris perifèrics, aquells que havien rebut més immigració, i no sempre van ser entitats de nova creació. En determinats casos es van prendre el control de les Juntes d'entitats veïnals que abans havien estat controlades per persones conservadores. Aquest fet no es va poder produir a Santa Coloma per que als anys anteriors pràcticament només s'havien creat dues entitats "veïnals" que havien quedat feia temps desbordades pels esdeveniments i les Associacions de Veïns es van crear de nou cuny o van ser impulsades des de algunes Comissions de Barri i Centres Socials.

Les lluites van ser en molts casos per motius similars. Pels serveis elementals i la urbanització dels barris i les respectives ciutats, si bé cada ciutat va tenir-ne algunes de més específiques atesa les diferents característiques. Però de manera progressiva les mobilitzacions es van anar polititzant, en el sentit de reivindicar uns Ajuntaments que estiguessin realment al servei del poble o que, com a mínim, els seus representats fossin triats lliurement. Aquest procés estava relativament madur al 1975 tant a Santa Coloma com a Badalona, on ja diferents mobilitzacions plantejaven obertament la dimissió de tot el consistori i la necessitat d'uns Ajuntaments Democràtics.

El que si que podem dir amb rotunditat és que al Barcelonès Nord les entitats veïnals que es van crear en els primers moments van tenir un component de classe 
molt destacat que es veu reflectit en el seu discurs, tot i que en el cas de les AVV's potser no fos tan explícit com el que es va donar a les CCBB i estigués major o menor mesurat en funció de la composició de les respectives AVV's. Amb això no vull negar el component interclassista que va tenir el moviment veïnal en determinats barris i ciutats. Però crec que és important reconèixer que en un primer moment, al Barcelonès Nord (i a d'altres grans ciutats catalanes), aquest moviment va tenir una forta consciència obrera sense que això vulgui dir, tal com afirmava Manuel Castells en els seus estudis més recents -no en els contemporanis dels anys 70- que no s'hagin de contemplar altres variables -apart de les de classeper analitzar el moviment veïnal. El mateix autor remarcava un fet que jo crec que resumeix a la perfecció el perquè de la importància del moviment veïnal:

"Por otra parte, la movilización de los barrios no fue simplemente obra de una vanguardia activista y políticamente aislada. A pesar del radicalismo ideológico que por lo general caracterizaba a sus dirigentes, las asociaciones de vecinos gozaban de la simpatía y el apoyo de la mayoría de los sectores de la sociedad, sobre todo en los grupos profesionales y, de manera más destacada, los arquitectos y abogados." ${ }^{951}$

El que és innegable és que a la mort del dictador, s'havia engegat una mobilització veïnal molt important que anava ja més enllà d'aquestes avantguardes militants i era capaç de mobilitzar a centenars i milers de persones al Barcelonès Nord. Primer i amb major volum a Santa Coloma però aviat també a Badalona, en especial als seus barris perifèrics i a Sant Adrià, als barris de la dreta del Besòs. Aquesta mobilització va créixer en els dos anys posteriors, en intensitat, en freqüència i fins i tot arribant a barris amb un perfil més interclassista on abans no s'havien donat fets similars, com al Centre de Badalona o a Sant Adrià Nord. Semblava que en aquests moments el moviment veïnal era imparable i que gaudia d'una bona salut, demostrant la capacitat de posar contra les cordes a les autoritats franquistes locals. Però mentre aparentment el moviment popular ciutadà semblava gaudir de la serva major força, s'estaven posant les bases per la seva futura crisi posterior. De tot això en parlaré al proper capítol.

951 Manuel Castells: La ciudad y las masas. Sociología de los movimientos sociales urbanos, Alianza, Madrid, 1986, p. 299. 


\title{
IV. El moviment veïnal durant la primera part de la transició: el seu moment culminant.
}

\begin{abstract}
"La participación llegaba a tal extremo que dos o tres vecinos nos juntábamos en medio de la calle Sant Mori sin asfaltar ni iluminar (...) dos palmadas y un megáfono: vecinos, hemos de salir a la calle y conseguir que asfalten la calle, comerciantes, cerrar las tiendas... todo el mundo respondía... inmediatamente te encontrabas con unas trescientas personas y los comercios cerrados." 952
\end{abstract}

\begin{abstract}
“Les Associacions de Veïns i les entitats ciutadanes són avui una altra forma mitjançant la qual es manifesta la nostra vitalitat democràtica. Però no són els organismes específics del canvi democràtic. Tenen funcions delimitades i també estan destinades a desenvolupar-se en un marc democràtic, no pel fet de ser institucions de base de l'administració i organitzacions del poder popular, sinó per actuar com organitzacions representatives dels ciutadans i com a agents de democratització municipal. És a dir, les Associacions són avui i han de ser demà un mitjà de vida social i un instrument de participació política a nivell local." 953
\end{abstract}

\begin{abstract}
"Per tant jo penso que aquest procés, el procés dramàtic, en Santa Coloma és precisament quan després de les primeres eleccions. Que això si és el moment on aquest conglomerat que havia aconseguit el moviment popular, el moviment d'Associacions de Veïns, de Centres Socials... es comença a trencar i comencen a haverhi problemes interns. Per què? Per què és el moment on el PSUC fa l'escombrada tremenda a l'àrea metropolitana. A Santa Coloma és tremenda i a on obertament el Luís Hernàndez diu 'ara, torneu a casa... dediqueu-vos a fer cultura, a fer altres coses per que ara ja estem nosaltres'..'954
\end{abstract}

\subsection{La crisi del franquisme i el paper de l'oposició antifranquista. “¿Atado y bien atado?"}

El franquisme a la dècada dels setanta, i especialment en els seus darrers anys, el 1974 i 1975, estava en una profunda crisi, malgrat que alguns sociòlegs i

952Entrevista amb Pedro Jesús Fernàndez, 26-4-2009.

953Jordi Borja: “Les associacions avui i demà", Arreu núm. 1, (25-31 d'octubre de 1976), p. 32-33.

954Entrevista amb Gabriela Serra Freidiani, 10-7-2013. Antiga militant de l'OIC, el MC i Presidenta de l'AVV de Singuerlín. 
politòlegs -com Cayo Sastre o Juan José Linz tal qual vaig dir al primer capítol d'aquesta investigació ${ }^{955}$ - sostenen tesis contràries a aquesta interpretació. Uns altres investigadors apuntaven als canvis socio-econòmics i a la "modernització" produïda a partir dels anys seixanta per explicar els esdeveniments posteriors, reconeixent l'existència d'una certa crisi institucional i política, però negant o minimitzant l'existència d'una forta conflictivitat socio-polìtica que estava minant profundament la dictadura ${ }^{956}$.

Pel que fa a la crisi institucional i política, es pot parlar d'una pugna que ja venia de lluny, però que es va accentuar en un context creixent de conflictivitat social. Durant la dècada anterior, sobretot entre 1957-1969 s'havia intentat institucionalitzar d'una manera més clara el règim. Un procés que havia començat amb els intents -infructuosos- de Arrese d'aprovar tres lleis fonamentals al $1957^{957}$, que havia continuat amb l'aprovació, el 17 de maig de 1958, dels Principios Fundamentales del Movimiento Nacional $^{958}$ i que va continuar amb el debat a l'entorn de l'associacionisme "familiar", com ja vam veure al capítol 2.

L'enfrontament entre els sectors partidaris de potenciar la Secretaria General del Movimiento, adaptant-se als nous canvis socials que s'estaven produint i els

955Cayo Sastre: Transición y desmovilización política en España (1975-1978), Universidad de Valladolid, Valladolid, 1998. Juan J. Linz: "La transición a la democracia en España en perspectiva comparada" en R. Cotarelo (comp.): Transición Política y Consolidación Democrática, España (1975-1986), Centro de Investigaciones Sociológicas, Madrid, 1992, p. 435-436.

956Entre d'altres, recordo les obres ja citades de: Santos Julià: "Obreros y sacerdotes: cultura democrática y movimientos sociales de oposición" en Javier Tusell, Alicia Alted i Abdon Mateos (coords.): La oposición al régimen de Franco. Vol. II, UNED, Madrid, 1990, p. 147-159 i “Orígenes sociales de la democracia en España", Ayer núm. 15 (1994), p. 165-188; amb José Carlos Mainer: El aprendizaje de la libertad. Madrid, Alianza, 2000; Víctor Pérez Díaz: La primacía de la sociedad civil. El proceso de formación de la España democrática, Alianza, Madrid, 1993;Robert Fishman: Organización obrera y retorno a la democracia en España, Siglo XXI, Madrid, Centro de Investigaciones Sociológicas, 1990; Jorge Benedicto Millán: "Sistemas de valores y pautes de cultura predominantes en la sociedad;Álvaro Soto: ¿Atado y bién atado?. Institucionalización y crisis del franquismo, Biblioteca Nueva, Madrid, 2005; José Félix Tezanos: "La crisis del franquismo y la transición democrática" en José. F. Tezanos, Ramón Cotarelo i Andrés de Blas (eds.): La transición democrática española, Sistema, Madrid, 1989.

957“Ley de Principios Fundamentales del Movimiento, Ley Orgánica del Movimiento i Ley de Ordenación de la Jefatura del Estado". Carme Molinero i Pere Ysàs: La anatomía del franquismo. De la supervivencia a la agonía, 1945-1977, Crítica, Barcelona, 2008, p. 30.

958De fet, aquests van ser una actualització dels vint-i-sis punts de FET-JONS, ara reduïts a 12 i $\mathrm{amb}$ un llenguatge més adient als temps. Però amb un fet molt important que es sol passar per alt. Que en aquell moment els "Principios Fundamentales del Movimiento" es transformaven en una Llei de major rang que totes les existents, ja que no es podia aprovar cap llei que vulnerés els seus continguts (article 3 ) i el que era encara més significatiu: s'establia que aquests eren permanents i inalterables (article 1). Carme Molinero i Pere Ysàs: Anatomía del franquismo, p. 38-39. 
tecnòcrates de l'Opus Dei i també Carrero Blanco que no volien cedir poder en la seva pugna per controlar Governació i Presidència es va fer patent al llarg de tota aquesta dècada dels seixanta. Els primers van apostar clarament per l'impuls de l'Associacionisme familiar i veïnal -com ja vam veure- i per la revitalització de l'OSE, fet que es va plasmar sobretot a les eleccions sindicals de 1966. També per la potenciació del Consejo Nacional del Movimiento, que tot i tenir funcions consultives i deliberatives no vinculants- va adquirir una renovada vitalitat als anys 60 al voltant de tots els debats legislatius que es van donar durant aquests anys ${ }^{959}$. Aquest fet posa en qüestió, com a mínim, aquelles visions que ens volen presentar un partit únic sense vitalitat, com una closca buida, totalment instrumentalitzada per l'aparell de l'Estat ${ }^{960}$.

Els segons, defensaven la primacia del Governació i Presidència en el control d'aquest Movimiento. La seva idea per assegurar el futur del règim era la "eficiència econòmica" i l'aparent despolitització i moderació de sectors amplis de població que relacionaven amb uns majors nivells de consum i renda ${ }^{961}$.

Ara bé, malgrat el seu enfrontament cal deixar clar que:

“Contra lo que la publicística y algunos historiadores señalan, la línea de separación entre falangistas y tecnócratas no pasaba por la distinción entre inmovilistas y aperturistas; a mitad de los años sesenta ambas corrientes pueden considerarse como "aperturistas" e "inmobilistas" al mismo tiempo; aperturistas porque casi todos compartían la necesidad de introducir cambios en el orden franquista para adecuarlo a las transformaciones que estaba viviendo la sociedad pero, a la vez, inmobilistas porque rechazaban cualquier cambio que implicara acercar el régimen a las democracias liberales, lo que era descalificado como una inaceptable desnaturalización." 962

959Com van ser tots els que es van donar al voltant de la Llei d'Associacions de 1964, la llei de Premsa de 1966 (Fraga), la Ley Orgánica del Estado (22-11-1967). Va ser en aquesta llei on es va introduir la figura del "Procurador familiar", és a dir, la tria de 108 procuradors a les Corts orgàniques pel sufragi dels caps de família i les dones casades, tal com ja es feia als ajuntaments. Continuaven sent una minoria enfront els membres del Consejo Nacional del Movimiento, els presidents de les més importants institucions de l'Estat, els representants de l'OSE, de diputacions i ajuntaments, rectors universitaris, col-legis i associacions professionals, que també composaven aquestes Corts. Carme Molinero i Pere Ysàs: La anatomía del franquismo, p. 77.

960Sobre l'aparell de propaganda que va desenvolupar la sens dubte més important organització del Movimiento, la OSE, veure Alex Amaya Quer: El acelerón sindicalista. El aparato de propaganda de la Organización Sindical Española entre 1957 y 1959, Centro de Estudios Políticos y Sociales, [Madrid?], 2013.

961 Carme Molinero i Pere Ysàs: La anatomía del franquismo, p. 60.

962 Ídem, p. 61-62. 
Tot i que a mi personalment m'agrada més el terme "reformistes" que no pas el "d'aperturistes", sobretot per la interpretació autojustificadora que alguns van donar a la seva participació activa a la dictadura emparats en aquest concepte i en una suposada e inexistent "voluntat democratitzadora", el terme aperturisme, per tant, es pot utilitzar sempre que es faci notar el seu origen històric i el seu contingut propagandístic i no literal.

Tots aquests enfrontaments van confluir en la crisi de govern de 1969 on Carrero Blanco finalment va aconseguir que Franco prescindís de Manuel Fraga i José Solís al mes d'octubre. Semblava que el sector liderat per Carrero i López Rodó havien guanyat la partida, però això no és del tot cert. Des de les seves posicions els partidaris de l'enfortiment de la Secretaria General del Movimiento va continuar defensant les seves posiciones en un ambient cada cop més difícil per la creixent oposició al franquisme. Els fets al voltant del Consell de Burgos van ser el detonant que van posar sobre la taula de nou el debat sobre "l'actualització" del règim, o també els debats al voltant de la nova Llei Sindical de 1971 i el pendent sobre "l'associacionisme polític". La decrepitud progressiva del Caudillo va accentuar aquestes pugnes, amb l'afegit d'un sector d'ultres que com a única solució reclamaven el retorn a les "essències" del règim ${ }^{963}$.

No es aquest el lloc per relatar amb detall la crisi profunda que va viure el franquisme dintre de les seves institucions els darrers anys, sobretot arran la mort de Carrero Blanco al desembre de 1973 just quan feia sis mesos que havia estat nomenat President de Govern ${ }^{964}$. El nou govern d'Árias Navarro va fracassar en el seu intent de fer un cert reformisme (l'anomenat "esperit del 12 de febrer") per que va decidir que havia de continuar aplicant la mà dura per impedir que la situació es desbordés. L'execució de Puig Antich i Heinz Chez al març de 1974 va demostrar els límits del reformisme. I per si això fos poc, la Revolució dels Clavells portuguesa va produir una profunda preocupació, fet que va esperonar als ultres

963Veure Carme Moliinero i Pere Ysàs: “3. Alarma, confusión e incertidumbre”, dins La anatomía del franquismo, p. 142-181.

964Per veure el procés amb detall es pot consultar l'obra ja citada sovint en aquest capítol de Carme Molinero i Pere Isàs: Anatomia del franquisme. També la de Álvaro Soto, ¿Atado y bien atado?, si bé les dues discrepen en el paper que va tenir la mobilització antifranquista durant tot aquest període. 
com José Antonio Girón ${ }^{965}$. Aquestes pressions van aconseguir la dimissió del ministre més "reformista", Pio Cabanillas, i, fet insòlit, la dimissió del Ministre d'Hisenda Barrera de Irimo i diversos alts càrrecs, en protesta per aquesta destitució ${ }^{966}$.

I en aquest context es va reprendre el debat sobre l'associacionisme polític en el si del Consejo Nacional del Movimiento, car havia estat una promesa d'Árias Navarro en el seu discurs del 12 de febrer el reprendre aquesta qüestió. Finalment al desembre de 1974 es va promulgar el "Estatuto de Asociaciones Políticas", que havien de constituir-se dintre del Movimiento i amb fidelitat absoluta als Principios Fundamentales. D'entrada, ja era el Consejo Nacional del Movimiento el que determinava el seu reconeixement, suspensió o dissolució, però per si això no fos poc, alhora s'establien unes condicions molt difícils per poder-les constituir formalment. Només cal veure alguns dels seus requisits:

“13. PARA QUE SE RECONOZCA UNA ASOCIACIÓN POLÍTICA, ESTA HABRÁ DE CONTAR, ALMENOS CON 25.000 AFILIADOS DISTRIBUIDOS CON LA PROPORCIÓN ADECUADA EN 15 PROVÍNCIAS ESPAÑOLAS, CON ARREGLO A LA SIGUIENTE ESCALA A) PROVINCIAS CUYO CENSO DE POBLACIÓN SEA INFERIOR A $\underline{500.000}$ HABITANTES: UN NÚMERO DE ASOCIADOS QUE NO PODRÁ SER INFERIOR AL CINCO POR MIL DE DICHO CENSO.

B) PROVINCIAS CUYO CENSO DE POBLACIÓN OSCILE ENTRE $\underline{500.001}$ Y $\underline{1.000 .000}$ DE HABITANTES: UN NÚMERO DE ASOCIADOS QUE NO PODRÁ SER INFERIOR AL CUATRO POR MIL DE DICHO CENSO.

C) PROVINCIAS CUYO CENSO DE POBLACIÓN SEA SUPERIOR A $\underline{1.000 .000}$ DE HABITANTES POR UN NÚMERO DE ASOCIADOS QUE NO PODRÁ SER INFERIOR AL TRES MIL KIL DE DICHO CENSO." ${ }^{967}$

Per fer-nos una idea, a la província de Barcelona calia acreditar 11.787 persones, fet ja difícil de per si però que no servia de res si no s'aconseguien els

965Aquest va publicar un incendiari article amb el títol “Declaración política de José Antonio Girón” al diari Arriba el 28-4-1974, popularment conegut com el "gironazo".

966 En concret, entre d'altres, Marcelino Oreja, Ricardo de la Cierva, Fernando Castedo i posteriorment Francisco Fernández Ordóñez (aquest darrer a l'INI), Carme Molinero i Pere Ysàs: La anatomía del franquismo..., p. 202. Álvaro Soto destaca a ¿Atado y bien atado?, p. 182183, les dimissions del darrer així com les de Juan José Rosón a TVE, o Miguel Boyer com a cap d'estudis de l'INI.

967 [Teletip de l'Agència Logos]: "Anteproyecto del Estatuto de Asociaciones Políticas" (2-121974), AGA, Fons Cultura. Gabinete de Enlace del Ministerio de Información y Turismo, Caixa 42/09155, Dossier 3, Documentación relativa al Asociacionismo Político. 
mínims establerts en 14 províncies més (penalitzant clarament les més poblades). Això sense parlar de les sancions previstes, que podien ser: molt greus si feien "peligrar la seguridad del estado, la paz de la nación, o que lleve consigo una alteración del orden público", amb sancions com la suspensió de l'associació durant 6 mesos; greus quan "cometan alguna acción o adopten una postura contraria a las Leyes Fundamentales, produzcan alteraciones del orden público, infrinjan la moral pública o se excedan de los fines asociativos en actos financieros o económicos", amb sancions de mig milió a cinc milions de pessetes d'aleshores o la suspensió si existia reincidència. Per les sancions "lleus" s'establien multes de deu mil a mig milió de pessetes ${ }^{968}$. Es contemplava una remota possibilitat de concórrer a processos electorals.

El projecte aprovat era tant restringit que fins i tot dirigents que havien promogut les associacions en el passat, com Manuel Fraga, se'n van desmarcar i els sectors ultres tampoc van quedar contents. L'any 1975 va haver-hi una nova crisi de govern al voltant d'una possible regulació -amb moltes restriccions- del dret de vaga just en un moment que aquestes eren molt freqüents malgrat la seva prohibició. El Ministre Licinio de la Fuente, defensor d'aquesta regulació, va acabar dimitint per l'oposició que va trobar tot i que finalment el seu successor va aconseguir que s'aprovés un decret que regulava la vaga però amb tantes restriccions que era pràcticament impossible fer-la de manera legal. Árias havia aprofitat per fer fora als seus ministres més ultres: el secretari general del Movimiento José Utrera Molina i el ministre de Justícia Francisco Ruiz Jarabo ${ }^{969}$. La Secretaria General del Movimiento va ser ocupada fugaçment per Fernando Herrero Tejedor i la vicepresidència per Adolfo Suárez. Ambdós van intentar promocionar aquest model tant limitat d'associacionisme amb la creació de la Unión del Pueblo Español (UDPE), única associació que havia aconseguit els requisits necessaris per constituir-se, tot i que la mort d'Herrero Tejedor, substituït per José Solís Ruiz, va suposar un cop per l'impuls que es volia donar a aquesta darrera reforma. De poc o res va servir que en els mesos posteriors s'aprovés una

968 [Teletip d'Europa Press]: "Síntesis del Anteproyecto de Bases sobre los criterios públicos del estatuto jurídico del derecho de asociación política” (2-12-1974), AGA, Fons Cultura. Gabinete de Enlace del Ministerio de Información y Turismo, Caixa 42/09155, Dossier 3, Documentación relativa al Asociacionismo Político.

969 Carme Molinero i Pere Ysàs: La anatomía del franquismo..., p. 216. 
nova Llei de Règim Local que obria la porta a "l'elecció" d'alcaldes i presidents de Diputacions Provincials (amb un sistema molt restringit, evidentment) i a la participació de les Associacions Polítiques en el procés electoral, sense eliminar, però, la representació per terços.

L'amenaça de les continues mobilitzacions i de l'oposició política (amb la creació de la Junta Democrática de España (juliol 1974) i la Plataforma de Convergencia Democrática (juny 1975), impulsades pel PCE i el PSOE respectivament havia derivat en un major enduriment repressiu. Si el 25 d'abril s'havia declarat l'estat d'excepció a Biscaia i Guipúscoa, el 24 d'agost s'aprovava un nou decret-llei anomenat "antiterrorista" on eren qualificades de "terroristes" totes les opcions polítiques que s'oposaven a la dictadura, fos quina fos la seva ideologia o fessin o no lluita armada. $\mathrm{Al} 27$ de setembre es van produir les execucions de tres presos del FRAP i dos de ETA malgrat la campanya que es va fer per impedir-ho, tant a dintre de l'estat com a fora, on es van produir nombroses condemnes internacionals. La resposta del règim va ser similar a la de 1946. L'1 d'octubre es va celebrar una concentració multitudinària a la Plaza de Oriente "braç en alt" amb la presència de Franco i el príncep Juan $\operatorname{Carlos}^{970}$. Poc després el Caudillo queia malalt i ja no es recuperaria.

Aquesta crisi dins l'aparell polític del franquisme no es pot entendre de cap de les maneres sense l'existència d'uns esdeveniments que van agreujar aquests fets: la cada cop més gran conflictivitat social i política que havia arribat, a l'any 1975, a nivells gairebé insostenibles per la dictadura malgrat l'eficàcia del seu aparell repressiu. Va ser aquest fet el que va condicionar tots els altres, així com l'extensió del dissentiment i la protesta en els àmbits universitari i laboral -sobretot- i també en menor mesura, en sectors de l'església catòlica i dels intel-lectuals ${ }^{971}$. De poc van servir els darrers intents que es van fer per intentar

970 Nicolás Sartorius i Alberto Sabio: El final de la dictadura. La conquista de la democracia en España (noviembre 1975-junio de 1977), Temas de Hoy, Madrid, 2007, p. 258-259.

971 Per l'estudi de la contestació política al franquisme en els diferents àmbits de la societat, és imprescindible la consulta de l'obra de Pere Ysàs: Disidencia y subversión. La lucha del régimen franquista por su supervivencia, 1960-1975, Crítica, Barcelona, 2005 i també del mateix autor "Conflictividad social, oposición política i crisi de la dictadura" a Jordi Font Agulló: Història i memòria: El franquisme i els seus efectes als Països Catalans, Universitat de València, València, 2007. Sobre els nivells de conflictivitat obrera veure Carme Molinero i Pere Ysàs: Productores disciplinados y minorías subversivas. Clase obrera y conflictividad laboral en la España franquista, Siglo XXI, Madrid, 1998. Per Barcelona i la seva àrea metropolitana veure Sebastian 
crear una base popular pel règim. Uns intents que van estar sempre condicionats per la por a perdre el control de la situació.

L'altre àmbit on l'antifranquisme va tenir una força evident va ser el del moviment veïnal. No entraré a detallar aquí les lluites veïnals que es van donar ni al Principat, ni als Països Catalans ni a l'Estat espanyol, per que seria impossible. No obstant, alguns exemples gràfics poden servir per reflectir l'escalada de la conflictivitat:

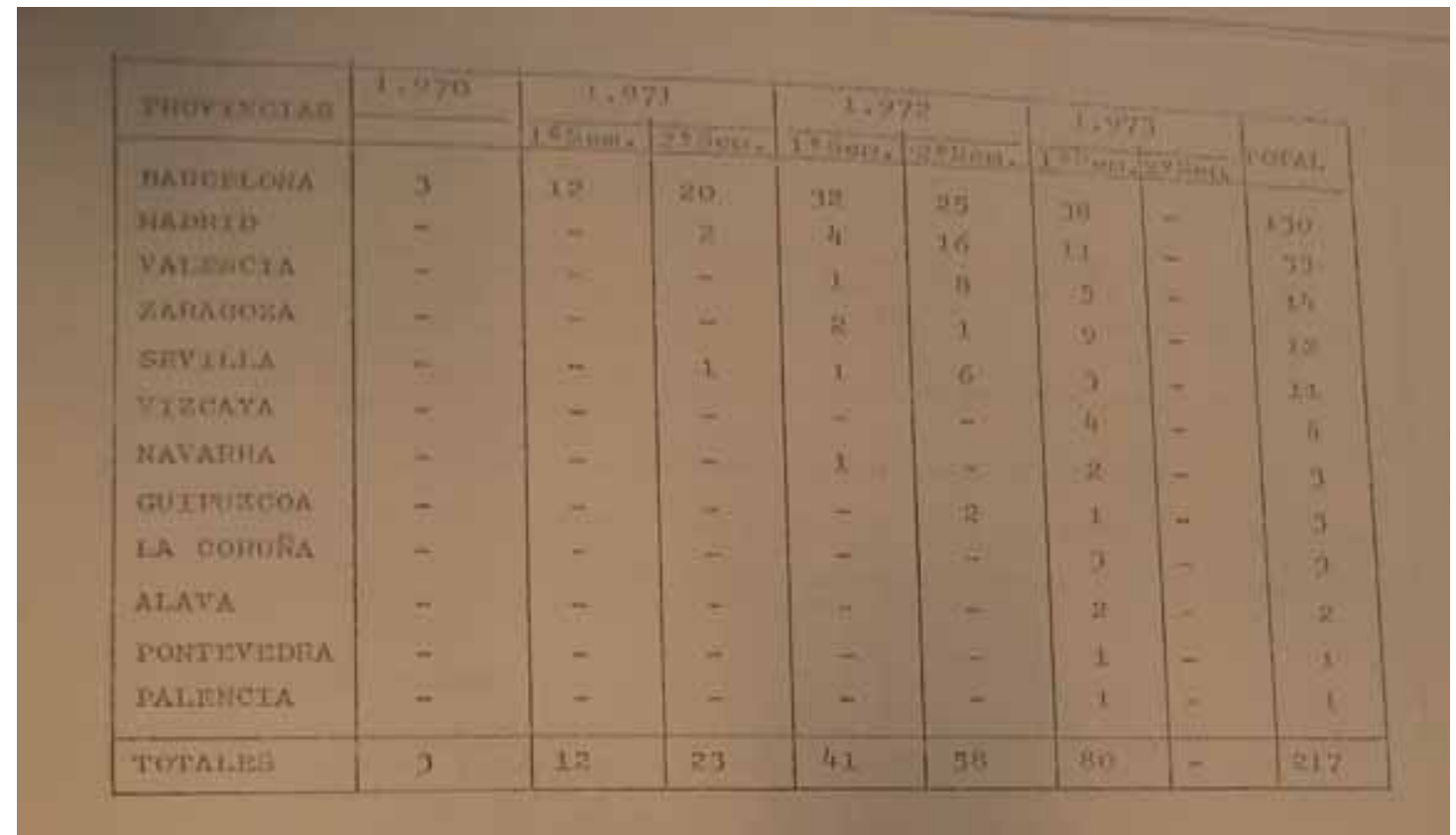

Taula que fa referència a la propaganda incautada a les Comissions de Barri (aquí s'inclouen AVV's i altres entitats similars). Veure "Plan Barrio", (Madrid, octubre 1973), AGA, Fondo Gabinete de Enlace del Ministerio de Gobernación, caixa 42/8906, Dossier 7 sobre Comités de Barrio.

A primera vista destaca el paper de la província de Barcelona en aquest àmbit. El mateix document afirmava que:

"Las organizaciones subversivas tomando como piloto a Barcelona pusieron en marcha las CC.B en el año 1970, comprobada su utilidad para la subversión iniciaron a partir de 1972 su expansión a otras provincias (...)

1- Se puede considerar que a inicio de 1974 se habrá detectado la presencia de CC.B.

Balfour: La dictadura, los trabajadores y la ciudad. El movimiento obrero en el área metropolitana de Barcelona (1939-1988), Edicions Alfons el Magnànim, València, 1994. Pel cas del Barcelonès Nord imprescindible la ja citada obra d'Emili Ferrando Puig i Juan Rico Màrquez: Les Comissions Obreres en el Barcelonès Nord (1964-1977), Publicacions de l'Abadia de Montserrat, Barcelona, 2005. Pel que fa a Comissions Obreres mateixes veure David Ruiz (dir.): Historia de Comisiones Obreras (1958-1988), Siglo XXI, Madrid, 1993. I a Catalunya veure Pere Gabriel (coord.) i Carme Molinero (et. al.): Comissions Obreres de Catalunya: (una aportació a la història del moviment obrer), CERES, Barcelona-Empúries, 1989 i Carles Sagués i Baixeres: Història abreujada de les Comissions Obreres a Catalunya, Germania, [Alzira]. 
como mínimo en 20 provincias que serán las de mayor concentración demográfica y las más industrializadas, por consiguiente, las más conflictivas”972

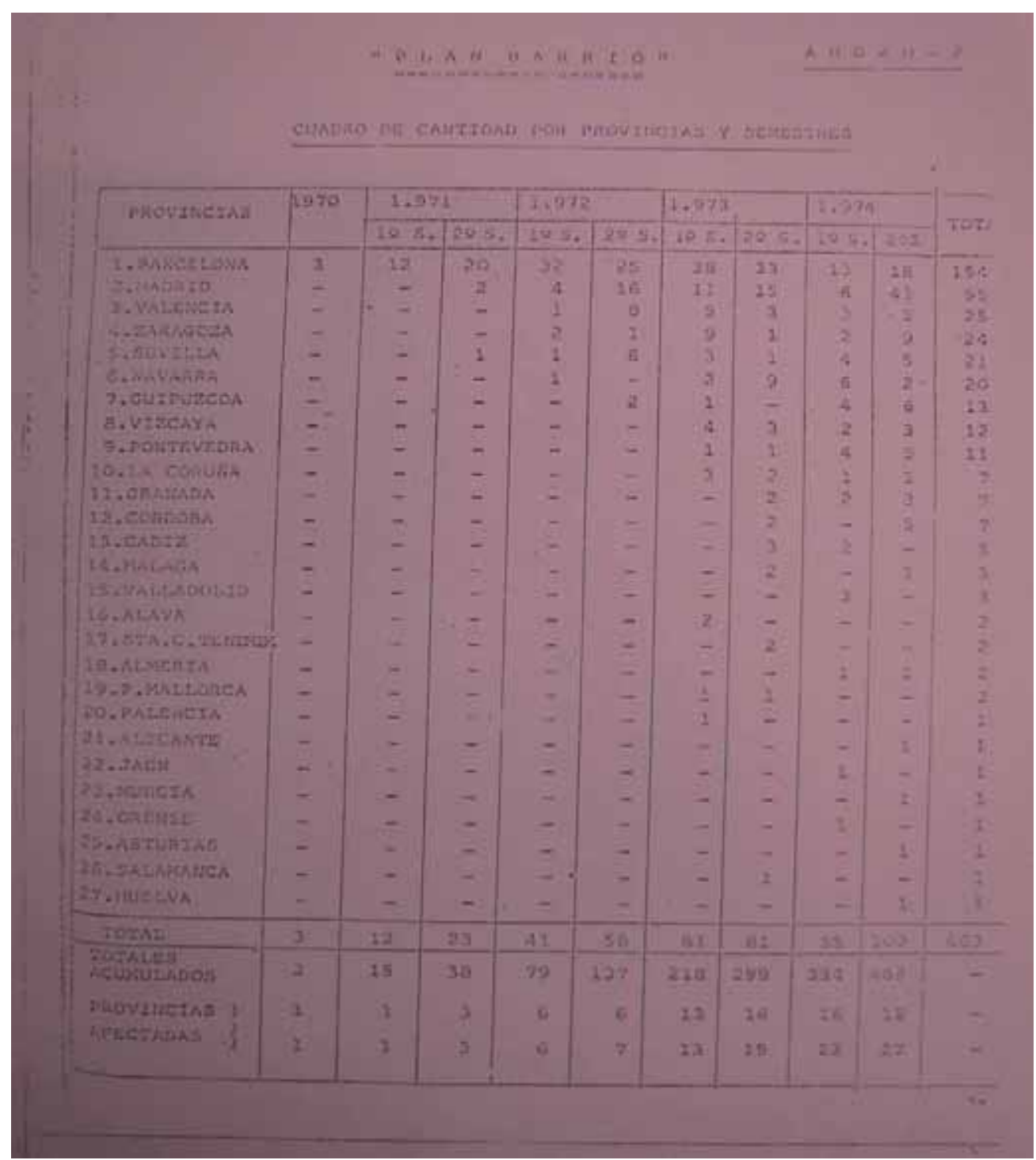

Taula que fa referència a la propaganda incautada a les Comissions de Barri (aquí s'inclouen AVV's i altres entitats similars). Veure "Plan Barrio. Estudio sobre la subversión en los barrios" (gener 1975), Fundació Utopia d'Estudis Socials del Baix Llobregat, Fondo García-Nieto, no 5110 . He d'agrair profundament a Iván Bordetas Jiménez que em facilités la consulta d'aquest document.

I en efecte, així va ser com ens ho demostra el document anterior. Més endavant analitzaré el paper d'aquesta mobilització veïnal en la crisi del franquisme, sobretot de les seves administracions locals. Abans, però, he de fer un breu esment al paper de l'oposició antifranquista en la crisi del règim. Per començar, he de dir que en moltes d'aquestes lluites esmentades van tenir un

972“Plan Barrio”, (Madrid, octubre 1973), AGA, Fondo Gabinete de Enlace del Ministerio de Gobernación, Caixa 42/8906, Dossier 7 sobre Comités de Barrio, p. 10. 
paper important els militants d'organitzacions polítiques clandestines, sobretot per garantir unes estructures més estables per organitzar la protesta. Aquest fet ha de ser valorat en la seva justa mesura ja que, evidentment, això no volia dir que tota persona que es signifiqués contra la dictadura o que es mobilitzés en un conflicte obrer o veïnal fos automàticament un militant d'un partit polític clandestí. Però això tampoc volia dir que l'oposició antifranquista fos tant dèbil com ens vol argumentar Álvaro Soto, o que:

"El antifranquismo obrero y universitario, y más tarde el movimiento popular urbano, fue un movimiento de amplias vanguardias que no consiguió transformarse en un gran movimiento de masas."${ }^{\prime 973}$

Em sembla evident que en els àmbits obrer, estudiantil i posteriorment veïnal si que es va arribar a articular moviments de masses que anaven molt més enllà de les avantguardes militants per molt àmplies que fossin. Que això no fos suficient per provocar el derrocament de la dictadura en vida de Franco no ens ha d'impedir veure que sí van impossibilitar la seva perpetuació posterior, deixant de banda la qüestió de si va haver-hi trencament o no o si els membres de la dictadura van sortir-ne impunes. Pel que fa a la divisió de l'oposició, un dels altres arguments esgrimits, certament existien un gran nombre de grups però a efectes pràctics la majoria no deixaven de ser molt petits, en alguns casos "de notables". En contrast, per exemple el PSUC va arribar a tenir 2.000 militants al 1970 i 5.000 al novembre de $1975^{974}$. Això sense comptar el nombre de simpatitzants o persones properes als seus postulats, que a Catalunya va arribar a un nivell molt important ${ }^{975}$. Els altres partits de l'esquerra comunista revolucionària no van arribar al seu nivell tot i que no s'ha de menystenir la implantació que van tenir en diversos territoris i sectors $^{976}$.

973Álvaro Soto Carmona: ¿Atado y bien atado?, p. 271.

974Giaime Pala: "El PSUC hacia dentro. La estructura del Partido, los militantes y el significado de la política" a VVAA: El PSU de Catalunya. 70 anys de lluita pel socialisme, Ediciones de Invervención Cultural i Associació Catalana de Investigadors Marxistes, [Barcelona], 2008, p. 183.

975Un anàlisi en aquest sentit a Carme Molinero i Pere Ysàs: Els anys del PSUC. El partit de l'antifranquisme (1956-1981), L'Avenç, Barcelona, 2010. També a Guiame Pala: El PSUC. L'antifranquisme i la política d'aliances a Catalunya (1956-1977), Editorial Base, Barcelona, 2011.

976Per més informació de l'esquerra revolucionària veure José Manuel Roca (ed.): El proyecto radical. Auge i declive de la izquierda revolucionaria en España (1964-1992), Los Libros de la Catarata, Madrid, 1994. Un cas d'una organització concreta el podem veure a José Luis Martín 
En canvi el socialisme estava fragmentat i dividit, i malgrat la renovació que va suposar el Congrés de Suresnes del 11-13 d'octubre de 1974, havien de passar uns anys per que el PSOE en el cas de l'Estat espanyol (i el PSC-PSOE a nivell català, després de la unificació dels diferents grups que conformaven el socialisme català) adquirís un nivell de força i militància considerable, fet també impossible sense l'ajuda exterior de la socialdemocràcia europea, la Fundació Friedich Ebert Stiftung de l'SPD, i segons alguns autors més agosarats, la mateixa CIA o el SECED franquista, tots preocupats per impedir una hegemonia d'un PCE "a la italiana"977.

De tota manera, aquesta desunió de l'oposició té molts matisos. Al Principat, si més no, van existir uns precedents en la creació d'instàncies unitàries que no es va donar a l'Estat fins anys després. La creació de la Taula Rodona al 1966, de la Comissió Coordinadora de Forces Polítiques el 1969, i sobretot la creació de l'Assemblea de Catalunya al 1971 així com la seva extensió territorial en son un bon exemple. A nivell de l'Estat no va ser fins juliol que es va crear la Junta Democrática de España i un any després la Plataforma Convergencia Democrática, que no es van fusionar fins març de 1976.

I al Barcelonès Nord, quina situació es va donar els darrers anys del franquisme? Pel que fa a moviments d'oposició al franquisme trobem unes certes similituds. És evident que a nivell universitari no podem trobar protestes i mobilitzacions al Barcelonès Nord, però si que van tenir importància, per exemple, les mobilitzacions dels PNN i en l'ensenyament secundari, que sovint anaven relacionades. Per exemple la vaga de PNN's de l'any 1972 va comptar amb el suport d'una manifestació d'alumnes de l'Institut Albéniz de Badalona violentament reprimida. Les paraules de l'Alcalde Antoja Vigo eren prou esclaridores:

\footnotetext{
“Esta alcaldía lamenta profundamente en primer lugar que durante dicho día se produjeran en ese Centro alteraciones en el ritmo de clases y concentraciones de diversos tipos que ni los padres de alumnos, ni el profesorado, lograron evitar, dando lugar a una manifestación de más de trescientos y que circularan por las calles de la
}

Ramos (coord.): Pan, trabajo y libertad. Historia del Partido del Trabajo en España, El Viejo Topo, [Barcelona], 2011.

977Alfredo Grimaldos: La CIA en España: espionaje, intrigas y política al servicio de Washington, Debate, Barcelona, 2006, en especial el capítol “La CIA y la refundación del PSOE”. El mateix autor ha publicat recentment un assaig sobre el procés de canvi polític també molt crític: Claves de la Transición 1973-1986 (para adultos). De la muerte de Carrero Blanco al referéndum de la OTAN, Península, Barcelona, 2013. Més endavant faré algun comentari respecte les teories defensades en aquestes publicacions. 
ciudad, entorpeciendo los cruces normales del tránsito denso y del paso de peatones que a esas horas inundan las calles céntricas. Esta concentración masiva, ya de por si prohibida y de alteración manifiesta dio lugar a que elementos en ella integrados lanzaran gritos subversivos y de ofensa e insulto a los agentes de la Autoridad, que motivó el que en evitación de males mayores, siempre imprevisibles, la fuerza pública, aun lamentándolo, no tuviera más remedio que actuar para disolverlos en el lugar en que la alteración empezaba a tomar cuerpo, por los únicos medios que en tales casos pueden emplearse (...) Lamenta finalmente que con estas actitudes se haya ofendido e insultado de forma tan inconsciente a la fuerza pública, que durante tantos años ha mantenido y mantendrá con toda clase de riesgos personales un orden y una paz que nos es necesaria e imprescindible para la debida convivencia y que tanto nos costó conseguir con el sacrificio de nuestros mejores para que tuvieran una España mejor de la que nosotros encontramos. ${ }^{978}$

A aquests es van afegir a inicis del curs de 1973 els alumnes de l'institut badaloní Eugeni d'Ors duent la protesta al carrer per la manca de professors, protestes que es van repetir a l'any 1975 davant la detenció d'un mestre i dos alumnes acusats de difondre propaganda socialista ${ }^{979}$.

Santa Coloma també van tenir cada cop més importància la mobilització dels estudiants de l'Institut d'Ensenyament Secundari Puig Castellar, que per exemple van fer vaga el febrer de 1975 també per la manca de professors. No entro aquí ja a parlar de les lluites dins l'ensenyament primari que van estar molt vinculades amb el moviment veïnal i que seran molt intenses en aquests anys i en els posteriors.

Pel que fa a les lluites obreres, ja vaig parlar del sorgiment de les CCOO al Barcelonès Nord, sobretot a Badalona, Però als anys setanta també va augmentar la conflictivitat a les empreses de la sub-comarca. Fins i tot el sector tèxtil, que s'havia mantingut passiu fins aleshores, es va reactivar ${ }^{980}$. A l'any 1971 es mobilitzaren FECSA i ESESA (la seva filial) pels seus convenis. Important va ser el mateix any i

978Emili Ferrando Puig i Juan Rico Màrquez: Les Comissions Obreres en el franquisme..., p. 388. 979Ídem, p. 390. En concret es tractaven del professor Manuel Escudero (anys després militant conegut del PSOE), Aida Esparcia, menor aleshores i l'ex-alumne Xavier Soto, militant de la JSC i posteriorment diputat al Parlament de Catalunya. Un cop mort el seu nom va ser adoptat per la biblioteca de Llefià inaugurada l'any 2002. Existeix també un fons amb el seu nom a l'Arxiu de la Fundació Rafael Campalans del PSC-PSOE.

980Ídem, p. 318. En concret ambdós citen, pel que fa al Barcelonès Nord, les empreses tèxtils Eurostil, Casadesport, Casademont, Camisería Covisa, Sedería Polaris (Santa Coloma); Superpantalón, Petronio, Stilok, Belcor, Nerva, Nic, Cuyàs, Montalfita, Cordereria Ribó (Badalona) i Baurrier (Sant Adrià). 
els posteriors les lluites a l'empresa de Sant Adrià CEMOTO (que fabricava les motocicletes Bultaco), on fins i tot els treballadors constituïts en assemblea actuaven al marge del sindicat vertical. Les mobilitzacions laborals també es fan en un sector com el de les arts gràfiques, on predominava la petita empresa, amb un major control del treballador. En el sector de la construcció també van donar-se conflictes aquells anys, però sens dubte, el més conegut va ser la vaga dels obrers que construïen la Central Tèrmica de Sant Adrià de Besòs, al costat de Badalona, i els durs enfrontaments que es van produir el 3 d'abril amb la policia:

\footnotetext{
“Una vez se alejó el tren hubo más idas y venidas entre policías y trabajadores hasta que la llegada de una carga de la policía se respondió con una lluvia de piedras. Y se empezaron a oír los primeros disparos. Hubieron dos heridos de bala y numerosas quemaduras de ropa, entre ellos Manuel Fernández Márquez, que si bien no era de la Comisión, sí estuvo en la primera línea. Los dos heridos de bala se recogieron en un coche y se les llevó al dispensario. Manuel Fernández Márquez ya estaba muerto."981
}

Aquests fets van tenir molta repercussió en el conjunt de l'Estat, però a la comarca cal destacar els que es van donar al seu enterrament a Pomar (que ja vaig comentar), o fins i tot la manifestació de protesta "llampec" que es va muntar al Barri Besòs per la Comissió Obrera del Barri ${ }^{982}$. Sense esmentar les nombroses aturades i mobilitzacions de protesta que es van donar en nombroses empreses del Barcelonès i les comarques limítrofs (destacant les vagues de solidaritat de Cerdanyola i Ripollet) i les condemnes que es van fer per part de totes les organitzacions polítiques i sindicals clandestines, capellans obrers o fins i tot col·legis professionals ${ }^{983}$. Els fets no van terminar aquí ja que la vaga encara va continuar un temps, fins que al final els obrers van haver de reintegrar-se a la feina esgotada la caixa de resistència. Però no van aturar la seva lluita fins que el seu cas va arribar a Magistratura de Treball, on van aconseguir una resolució favorable malgrat que allà mateix van ser detinguts els principals líders de la Comissió

981Testimoni de Manuel Pérez Ezquerra, líder de la Comisión Obrera, citat a Emili Ferrando Puig i Juan Rico Marquez: Les Comissions Obreres en el franquisme..., p. 335-336.

982 Per aquest cas concret del Barri Besòs, és interessant el testimoni d'un tal "Gil", recolllit a Emili Ferrando Puig i Juan Rico Màrquez: Les Comissions Obreres en el franquisme..., p. 340-341.

983Uns obrers d'ESESA, filial de FECSA en parlaven de la solidaritat en una entrevista feta a Adelante. Órgano del comité de Badalona del Partit Socialista Unificat de Catalunya, núm. 12 (especial) de juny de 1973, Veure Ciències de la Comunicació-CEDOC (UAB), Dipòsit 21 Signatura 4019, p. 4-5. 
Obrera i jutjats en un consell de guerra ${ }^{984}$.

A l'any 1974 es van donar altres mobilitzacions importants. No puc recollirles totes en aquestes línies, però després d'un conflicte obrer a l'empresa SERCONSA, concessionària de la neteja de l'Ajuntament de Santa Coloma, un succés va marcar la mobilització obrera al Barcelonès Nord: l'incendi de la fàbrica tèxtil HAISSA de Badalona el 17 de maig i la mort de cinc joves obreres (entre 14 i 21 anys) així com la d'un treballador. Aquest fet va posar de manifest les pèssimes, per no dir nul·les, condicions de seguretat existents així com l'explotació laboral que es feia. I malgrat que des de el sindical vertical es van tramitar indemnitzacions i prestacions d'atur, es produiren protestes -atiades en part pels joves de l'Institut Albéniz molt proper a la fàbrica- fins i tot en actes oficials que acabaran amb càrregues policials i detencions, entre elles el germà d'una de les noies mortes ${ }^{985}$.

El mateix any 1974 es va donar a Santa Coloma un altre conflicte obrer que va tenir molta rellevància: la vaga de Casadeport ${ }^{986}$. Era una gran empresa tèxtil, la segona més gran en nombre de treballadores a Santa Coloma (al voltant d'unes 400) on existia una mena de Comissió clandestina que amb diverses mobilitzacions havia aconseguit aquest anys totes les demandes plantejades:

"De ahí, pasamos a todas las otras reivindicaciones. 25 días de vacaciones seguidos cuando nadie tenía... más que 18 y 5 cuando la empresa quisiera... Pasamos a conseguir el $100 \%$ en caso de jubilación y accidente (...) ya teníamos reconocido lo de la hoja de salario, la prima, la jornada de 40 horas (...) cuando éramos la segunda empresa de España [en aconseguir-la], la primera era la Renault de Valladolid... y era

984Emili Ferrando Puig i Juan Rico Màrquez: Les Comissions Obreres en el franquisme..., p. 351-356. En concret el Consell de Guerra es va fer el 7 de febrer de 1974 i hi van ser jutjats Manuel Pérez Ezquerra, Leonardo Farrero Rodes, José Moreno Rides i Fernando Lozano Revuelto, que van ser condemnats a quatre anys de presó el primer i un per als altres tres, a la "pèrdua de drets públics" (com si es respectessin gaire) i a pagar una multa a l'estament militar de 2.241,10 pessetes.

985Ídem p. 356-358. Veure també la publicació d'Emili Ferrando Puig: Haissa. Història d'una tragèdia obrera en el tardofranquisme, Ediciones Carena, Barcelona, 2009.

986Sobre aquesta vaga veure Emili Ferrando Puig i Juan Rico Marquez: Les Comissions Obreres en el franquisme..., p. 359-367; David Monsergas: "La Huelga de Casadeport" a Ágora núm. 1 (1995); Juan José Gallardo Romero: "Aportaciones a la huelga de Casadeport" en Ágora núm. 2 (desembre 1995), p. 103-116; ambdós articles van ser recollits i traduïts al català a la publicació del Grup d'Història José Berruezo: Una ciutat dormitori sota el franquisme. Santa Coloma de Gramenet 1939-1975, Ediciones Carena, Barcelona, 2006, a les pàgines 343-367 i 369-379. També a Marcelo López Ródenas: Historia social de la Santa Coloma moderna 1954-1979, Ajuntament de Sant Coloma, 1982, p. 199-202. I a Lola Carrión: La conflictivitat laboral en Santa Coloma de Gramenet des de 1968 a 1978. Treball de Màster, Universitat de Barcelona, 2008, p. 132-136. També he trobat documentació al respecte (fulls volants) a AHMTB, Donació Marcelo López Ródenas, Caixa 3, Dossier núm. 7. 
del Metal. La primera de Confección. Teníamos el sueldo más alto de Confección en España, la jornada de 40 horas, 25 días de vacaciones cuando el convenio de Confección decía 18 y 5 cuando la empresa quisiera (...) 25 seguidos... Bueno... todo lo que he dicho antes, todas las mejoras que el Convenio nos diera, batas, uniformes (...) las tijeras, nos daban dos pares de tijeras también, unas más pequeñas, otras más grandes, pa lo duro, pa lo blando... todo eso a nivel de empresa, todas las pequeñas cosas...."987

Totes aquestes victòries havien contribuït a que entre les treballadores hi hagués una gran unitat i conscienciació, que es posà a prova en el conflicte d'agost de $1974^{988}$. L'empresa decidí fer un pols a les seves treballadores i en tornar de les vacances acomiadà a un jove, Antonio Pérez Sánchez, que era un dels pocs afiliats al PSUC i CCOO i l'únic home que pertanyia a la Comissió Amplia i que feia d'enllaç dels homes amb la majoria de les seccions de la fàbrica, on treballaven les dones. La resposta va ser la vaga, decidida en una assemblea el 20 d'agost. L'empresa va optar per la línia dura, probablement per provocar el conflicte per tenir l'excusa per acomiadar personal. La policia va ocupar la factoria i impedí l'accés a les treballadores vaguistes que provaren d'accedir cada dia, mentre començaven a arribar les cartes d'acomiadament que a finals d'agost arriben a les 194. Mentrestant les treballadores es dividiren en un sector format per membres de Plataformes Anticapitalistes, partidari de no fer servir les vies legals (encapçalat per Emiliana Salinas, Maruja Saez i Isabel Hurtado) i un altre més proper al PSUC (Alicia Ruzafa, Elen Martínez, Ángeles Pérez i Antonio Pérez, -el primer acomiadat- $)^{989}$, que no descartava anar a Magistratura. Les diferències ja venien de lluny, tal com explicava la mateixa Alicia Ruzafa:

"Cuando yo les digo que quiero entrar en la comisión me dan los estatutos de las Plataformas Anticapitalistas, las personas que estaban organizadas allí pertenecían a las Plataformas, y entonces teníamos que aceptar aquello, no eran unos estatutos elaborados por la Comisión de Empresa, eran los de las Plataformas. No había ningún sindicato en la Fábrica. La única persona que era del PSUC y de CC.OO. Toni el despedido, vivía en Barcelona, y no se donde estaba organizado supongo que como era

987Entrevista a Emiliana Salinas, 28-5-2013. Militant de la JOC, de la OICE, Plataformes Anticapitalistes, líder obrera de Casadesport i posterior presidenta de l'AVV del Fondo. 988Veure el testimoni d'altres tres treballadores: Elen Martínez, Ángeles Pérez i Alicia Ruzafa. Emili Ferrando Puig i Juan Rico Màrquez: Les Comissions Obreres en el franquisme..., p. 361. 989Emili Ferrando Puig i Juan Rico Marquez: Les Comissions Obreres en el franquisme..., p. 362-363. 
de Barcelona seria en su zona, pero no en la fábrica ni en Santa Coloma. Mi experiencia era en las Comisiones de Barrio. Nos juntamos una cuantas que queríamos hacer cosas, pero que no compartíamos las formas de hacer de la Comisión, pero que siempre respetamos las decisiones de la asamblea."${ }^{990}$

No obstant, al final si que van poder formar-ne part. No em puc estendre gaire amb els detalls d'aquest conflicte, que va tenir un ampli ressò a la ciutat colomenca i d'altres on es van produir diverses accions de solidaritat ${ }^{991}$. Més interessant d'analitzar es la divisió que va haver-hi a la Comissió de Fàbrica. El mateix primer acomiadat va decidir acudir a Magistratura pel seu compte, mentre després de diversos estires i arronses -entre ells una infructuosa assemblea al Centre Social de Pomar de Badalona- una assemblea posterior decidí fer una tancada a l'església de Santa Rosa, acte que sembla que no va ser secundat per una part de la mateixa Comissió, i finalment, la majoria de treballadores va decidir anar a Magistratura. No obstant, les coses eren més complicades del que semblava, tal com recull el testimoni de la mateixa Emiliana Salinas:

“Hubo dos partes, una parte que quería negociar, yo represento a los que no quería negociar, la otra parte quería ir a Magistratura. Al final se decide ir a Magistratura. Se planteaba la lucha radical hasta no ir a Magistratura, yo entonces ya estaba en la OIC y me criticaron por aceptar ir a Magistratura, pero después de 40 días, la gente ya se había jugado el puesto de trabajo, ya no se les podía pedir más, algo tenían que sacar de toda la lucha, y me echaron de la OIC por aceptar.

...La otra parte estaba representada por Alicia Ruzafa, que tenía influencia del PSUC, lo mismo que el chico despedido, pero las propuestas que planteaba Alicia, como la del encierro en la iglesia de Santa Rosa, no llegaron a tener el seguimiento mayoritario de la gente. No tenía la fuerza que tenía yo, pero también era lógico, ella llevaba muy poco tiempo en la empresa, y yo llevaba muchos años, y habíamos ganado muchos

990Testimoni de Alicia Ruzafa, que va ser membre de la JOC, del Centre Social i de la Comissió de Barri del Singuerlín. Treballadora de Casadesport i membre de la Comissió de fàbrica. Va ser una de les fundadores de l'Associació de Mestresses de Casa (posteriorment de Dones) del Singuerlín. Era -i és en l'actualitat- la companya d'un altre conegut activista veïnal i posteriorment militant del PSUC i regidor: Eloy Jurado. Veure Lola Carrión: La conflictivitat laboral en Santa Coloma..., p. 135.

991Per exemple es van donar vagues de solidaritat a Eurostil (on es van sancionar a 22 treballadors) i a Nespral (on s'acomiaden a 26 obreres i es sancionen a unes altres), totes dues empreses també colomenques. Algunes altres empreses van fer accions de solidaritat i les vaguistes van rebre el suport de les Comissions de Barri, Grama i les parròquies de la ciutat. Veure Emili Ferrando Puig i Juan Rico Màrquez: Les Comissions Obreres en el franquisme..., p. 363. 
conflictos. ...Sí, también puede ser que fuera una estrategia de la empresa, el socio capitalista de América había retirado su capital dos años antes, coincidiendo con otro conflicto, vino y dijo que nuestras luchas eran muy radicales y que la dirección no lograría controlarlas." ${ }^{\prime 99}$

Finalment Magistratura va fallar a favor de l'empresa i 200 treballadores van ser acomiadades amb l'excusa de l'aplicació de l'article 103 del "Código de Procedimiento Laboral", que facultava a una empresa acomiadar als treballadors sense indemnització si s'aturava totalment la producció més de tres dies -si bé l'empresa al final els va facilitar els tràmits per que poguessin acollir-se al subsidi d'atur-. Tot i la derrota, va ser la mobilització obrera més important de Santa Coloma fins aleshores. Les divisions existents dins el moviment obrer i les CCOO van tenir una major importància a Santa Coloma i Sant Adrià, on les Plataformes Anticapitalistes i altres grups i escissions de CCOO tindran més força que a Badalona, on les CCOO més majoritàries i més controlades pel PSUC no veuran tant disputada la seva hegemonia ${ }^{993}$.

La següent mobilització obrera important a la comarca va ser la vaga de la FECSA que es va produir al novembre de 1974. Les reivindicacions de millores laborals i salarials ja venien d'anys enrere, però davant les diverses negatives, dues instal-lacions, la Tèrmica del Besòs (Sant Adrià-Badalona) i una altra central situada al Carrer Mata de Barcelona comencen una vaga el 18 de desembre. En aquests centres existia també una divisió entre les Comissions Obreres i el Sindicat Unitari (una fracció sorgida de les mateixes Comissions), si bé a Sant AdriàBadalona tenien més pes les CCOO. Es van ocupar els centres de treball i davant l'amenaça d'intervenció policial va haver-hi també una divisió de postures sobre si resistir o desallotjar els centres i continuar la lluita amb altres mètodes:

"Los compañeros de trabajo estaban por las azoteas, por las escaleras, por las naves altas, por todas partes y no querían ser desalojados de ninguna de las maneras (...) Y nosotros los sindicalistas tratando de negociar una salida no violenta. Pero todo se hacía de una forma atropellada agotando hasta el último momento (...). Al final hubo avenencia en medio de aquel barullo, la cosa se destensó y los compañeros depusieron

992Entrevista a Emiliana Salinas recolllida a Lola Carrión: La conflictivitat laboral en Santa Coloma..., p. 134. 993Emili Ferrando Puig i Juan Rico Márquez: Les Comissions Obreres en el franquisme..., p. 307. 
su actitud saliendo del centro de trabajo comprendiendo que no había otro camino y así se efectuó el desalojo (...) Los jóvenes trotskistas no estaban ni por el desalojo ni por parar la acción. La resistencia más bien estuvo en los compañeros de la LOC (Liga Obrera Comunista) que de ninguna manera estaban dispuesto a que aquello acabara aquí. Tenían otros planteamientos y no coincidían con nosotros en la exposición de los objetivos." 994

Però malgrat el desallotjament, els treballadors es van sortir amb la seva ja que l'empresa va concedir un augment lineal de 6.000 pessetes i l'obertura de negociacions pel Conveni Col-lectiu que van ser acceptats.

El mateix mes de desembre un altre conflicte laboral era protagonitzat per la filial ESESA (el seu accionista majoritari era Juan March, conegut banquer mallorquí amb una carrera fosca ja des de abans de la guerra civil). La qüestió també venia de lluny, per que s'havia declarat un Conflicte Col-lectiu al mes de juliol. Al setembre els treballadors havien fet una plataforma reivindicativa on es demanava un augment lineal de 12.000 pessetes, la supressió de l'article 103 i el dret de vaga. Després de diversos estires i arronses en la negociació del nou conveni, entre el 7 i l'11 de novembre diversos centres de l'empresa es posen en vaga, que durarà 25 dies fins que s'arriba a un acord per tornar a la feina el 2 de gener de 1975. Com solia passar aleshores, a tot conflicte econòmic se l'intentava contextualitzar políticament:

"Para que la huelga no decayera era imprescindible una buena dosis de información, la cual había que elaborar diariamente. Hacíamos discusiones fortísimas sobre lo que pasaba en todo el mundo y en especial nos metíamos con la dictadura que secuestraba nuestras libertades democráticas y consentía la sinrazón de la empresa."995

L'èxit de les candidatures opositores a les eleccions sindicals de 1975 també es va veure reflectit al Barcelonès Nord, tot i que les maniobres fetes per l'OSE van impedir un resultat més clar. En aquest any abunden els conflictes. Al març es fan aturades a Jumberca (Badalona) contra la discriminació salarial de les dones. També hi ha aturades a la banca i protestes al ram del gas, aigua i electricitat. A

994Entrevista a Miguel Guerrero, membre de CCOO de la filial de FECSA, ESESA. Veure Emili Ferrando Puig i Juan Rico Márquez: Les Comissions Obreres en el franquisme..., p. 369. 995 Ídem, p. 378. 
l'abril hi ha vaga dels treballadors de la construcció que estan fent la ciutat sanitària de Can Ruti on va haver-hi 70 acomiadats -si bé després del judici la majoria foren readmesos a excepció de tres molt significats: Alfonso Moya, José Parrilla i Emilio Torres-. Al juny s'impugna les eleccions sindicals a les empreses VADATOLRA i PIHER per manipulació de les urnes. Al juliol demanaren vaga (amb la nova legislació) les empreses Caldereria Industrial i Tecnomecànica. Els mestres entraren també en vaga després d'una assemblea. Al novembre tancà l'empresa Filcor i Cortex i s'intentà fer un festival de solidaritat amb Ramon Muntaner, Quico Pi de la Serra i Ovidi Montllor. L'empresa adrianenca CELO expedientava i reprimia a 12 càrrecs sindicals. El desembre tornà a haver vaga a la construcció i s'aturaven obres a diferents barris badalonins com Llefià, Pomar i Lloreda mentre una manifestació de 500 obrers marxava cap a l'Ajuntament. En aquesta darrera mobilització van ser detinguts Francisco Téllez Luna, Alfonso Moya Cachinero, Alejo Castellanos Blánquez i Emilio Contreras Fernández, que van ser torturats per la Guàrdia Civil, tots militants de CCOO i del PSUC, a excepció de Alfonso Moya que era del $\mathrm{PTE}^{996}$. Les tortures que van patir a la caserna de la Guàrdia Civil de Badalona, en especial el primer, van genera una onada de indignació i protestes populars:

"Al llegar al cuartel de la guardia civil de Badalona, un cabo primero me preguntó por la Coordinadora de Comisiones Obreras de la comarca de Badalona. Respondí que no sabía nada de lo que me estaba hablando y me respondió dándome seis o siete "guantadas" y un rodillazo en el estómago. A los cinco o diez minutos me tendieron encima de una mesa y durante una hora me estuvieron pegando siete u ocho guardias civiles (continuaba con las manos esposadas): me daban puñetazos en el estómago y me golpeaban con gomas de butano y de manguera en los pies, en las manos, en los dedos y en las piernas. Me desnudaron de medio cuerpo para abajo, me amarraron a un "catre" y sin colchón que había en una pieza contigua y me colocaron durante un cuarto de hora aproximadamente, una vela encendida debajo de los "huevos". A continuación me dejaron solo con uno que me incitaba a "hablar" amenazándome. Me decía "mira, que si me voy van a venir otros y va a ser peor", y "si no hablas, voy a ir a por la pistola y te voy a pegar dos tiros". Como yo no decía nada, me volvieron a tender encima de la mesa y me estuvieron pegando como antes durante otra media hora. Me sacaron de la mesa y continuaron haciéndome preguntas."997

996Emili Ferrando Puig i Juan Rico Màrquez: Les Comissions Obreres en el franquisme..., p. 385. 997Testimoni de Francisco Téllez recollit a Emili Ferrando Puig i Juan Rico Márquez: Les Comissions 
En capítols anteriors ja vaig parlar del dissentiment de determinats capellans i parròquies del Barcelonès Nord, destacant la seva implicació en les lluites veïnals i en especial el cas de Santa Coloma. Sobre l'oposició de sectors intel-lectuals, culturals i professionals ja vaig comentar com Badalona ja va ser pionera durant els anys seixanta. I sobre les mobilitzacions veïnals ja vaig fer una enumeració detallada al capítol anterior. Ara bé, la situació de crisi del franquisme mencionada al present apartat es pot aplicar al món local? I si fos així, quin seria el causant principal d'aquesta?

$\mathrm{Si}$ analitzem les estructures de poder franquistes a nivell local veurem, grosso modo, que durant els darrers anys del franquisme estaven sent també fortament qüestionades. A Badalona Felipe Antoja Vigo havia dirigit amb ma de ferro el consistori local, exercint alhora com cap local del Movimiento i promovent una política "d'engrandir Badalona” molt còmplice amb el creixement especulatiu, amb projectes polèmics com el port esportiu, el polígon Montigalà-Batllòria, la construcció d'un nou Ajuntament o, el que finalment es va fer sota el seu mandat, l'adquisició de la finca de Can Ruti per la posterior construcció de l'Hospital, on es veu que va obtenir un lucre personal ${ }^{998}$. L'única escletxa que es va obrir en aquells anys al consistori va ser via eleccions al Tercio Familiar amb la candidatura de Cecília March al 1970 i la d'Ernesto Rojo al 1973. Però la seva mort al febrer de 1974 va fer que fos substituït provisionalment pel primer tinent d'Alcalde, Josep Guillén Clapés i definitivament, a partir del 12 de juny de 1974 per Isidre Caballeria Pla. Aquest va intentar seguir la línia del seu predecessor, però es va trobar ja una

Obreres en el franquisme..., p. 424-425. A les p. 423-432 els diferents detinguts donen testimoni de les tortures que van sofrir.

998La revista Adelante núm. 7 (juliol 1972), òrgan del Comitè de Badalona del PSUC ja va denunciar aquest asumpte en un article titulat "Can Ruti y los oscuros negocios de Antoja Vigo". Veure Ciències de la Comunicació-CEDOC (UAB), Dipòsit 21 Signatura 4019, p. 3. Anys després es publicava un interessant article d'Enric Juliana, titulat "Ayuntamiento en el Juzgado" a Comarca Exprés núm. 11 (primera quinzena de maig de 1977), p. 4-5, incloïa una entrevista amb un antic regidor pel tercio sindical, Eduardo Vinyas, que va denunciar les arbitrarietats del procés arribant a demanar la dimissió de Felipe Antoja Vigo per l'operació especulativa que es va fer amb els terrenys a l'Instituto Nacional de Previsión per la construcció del futura ciutat sanitària. L'Ajuntament havia adquirit uns terrenys al gener de 1972 pel preu de 92 o 95 milions per cedidr-los a l'INP. La compra la va fer a la societat Instalaciones Urbanísticas S.A., participada en la seva majoria per l'industrial badalonés Santiago Schilt, que havia adquirit els terrenys l'any 1968 per només 12 milions. Uns terrenys, que segons el propi arquitecte municipal , eren poc aptes per construir la ciutat sanitària. Pel que es veu, l'Alcalde Antoja Vigo es va emportar una sucosa comissió en tot l'assumpte. 
oposició molt més organitzada, com vam veure al capítol anterior amb el tema del port esportiu i l'emergent moviment veïnal als barris.

A Santa Coloma de Gramenet l'alcaldia de Juan Porta Bussoms va haver de fer front de seguida a la major mobilització ciutadana viscuda fins aleshores: la lluita per l'ambulatori. Progressivament es va anar trobant amb una major contestació, tant dels Centres Socials, les CCBB i finalment les AVV's, a la legalització de les quals va posar totes les traves possibles. Apart dels nombrosos afers de corrupció, no s'ha de menystenir el desgast que va patir per les nombroses mobilitzacions veïnals per que finalment fos cessat i substituït per Blas Muñoz. I a Sant Adrià de Besòs vam veure com també l'Alcalde Francisco Roqueta Prat va ser substituït per Juan Oller Valls l'any 1973 entremig de diversos escàndols i fiascos municipals.

Però el que per mi és rellevant és que en l'àmbit local del Barcelonès Nord -com a d'altres zones urbanes- va ser el moviment veïnal el que va aconseguir un elevat grau d'erosió del poder franquista local. Van existir nombroses protestes obreres, com he ressenyat, però van ser les mobilitzacions als barris les que van posar més en qüestió a les autoritats locals franquistes, a les quals culpaven de les mancances existents. Si bé inicialment les mobilitzacions amb més èxit solien ser les articulades arran una mancança o reivindicació concreta, aquestes ràpidament es polititzaven. I no s'ha de menystenir la presència de mobilitzacions explícitament per motius polítics, com la que per exemple es va donar a la Plaça Trafalgar de Llefià on 1.500 persones es manifesten el 6 de març contra l'execució de Puig Antich ${ }^{999}$. Les Comissions de Barri ja havien fet una tasca important de contextualitzar les reivindicacions veïnals dins les polítiques (en especial en la crítica al sistema econòmic capitalista). I l'any 1975, com vam veure, en les mobilitzacions contra el port esportiu a Badalona i per la preservació de Can Zam a Santa Coloma es reclamaren obertament uns Ajuntaments Democràtics des de les Associacions de Veïns, sectors de l'església i els mateixos partits polítics clandestins, si bé el procés de construcció de plataformes unitàries va trigar una mica més ja que les filials badalonesa, colomenca i adrianenca de l'Assemblea de Catalunya no es van constituir fins 1976 (a Badalona, però, si que s'havia fet un primer intent amb la creació al novembre de 1971 de la Comissió Democràtica de 999“Manifestación en Badalona”, Diario de Barcelona, 7-3-1974. 
Badalona en una reunió celebrada a l'Institut Albéniz ${ }^{1000}$ ) . Aquest procés d'erosió i qüestionament del poder franquista a nivell local va continuar els anys posteriors, arribant a quotes molt elevades que van desbordar a les autoritats locals franquistes. D'això en parlaré tot seguit.

\subsection{El procés de canvi polític. Quin paper va jugar el moviment veïnal?}

La mort del dictador es va produir just en aquest moment de conflictivitat creixent i, malgrat el discurs del atado y bien atado, s'obria un període d'incertesa on, tot i els discursos que alguns han fet posteriorment -sobretot en el famós "relat canònic de la transició" ja esmentat al capítol primer- no tot estava predeterminat $^{1001}$. Ni el Rei, ni Torcuato Fernàndez-Miranda, ni Suárez ni Fraga tenien un pla preconcebut per portar una democràcia parlamentària ni els movia un ingenu altruisme. Tots van anar actuant condicionats per altres fets que interactuaven amb el seu propi interès personal. El projecte reformista del primer govern de la monarquia va fracassar per les seves pròpies limitacions i contradiccions, però sobretot per la gran l'oposició popular que es va trobar ${ }^{1002}$.

1000Joan Villarroya (dir.): Història de Badalona, Museu de Badalona, Badalona, 1999, p. 225.

1001 Pere Ysàs: "La crisis de la dictadura franquista", a Carme Molinero (ed.), La Transición, treinta años después. De la dictadura a la instauración y consolidación de la democracia, Península, Barcelona, 2006, p. 58. En un sentit oposat al "relat canònic" però seguint aquesta línia "determinista" trobem les afirmacions del periodista Alfredo Grimaldos, que en les obres citades a la nota 1071 ve a dir que el resultat del procés de canvi polític estava ja determinat i dissenyat per la CIA. Sense negar el paper i la influència que l'agència nord-americana pogués desenvolupar (que segur és més important del que creiem), em sembla també una explicació massa simplista.

1002Sociòlegs com Cayo Sastre han minimitzar aquest aspecte a obres com Transición y desmovilización política en España (1975-1978), Secretariado de Publicaciones e Intercambio Científico, Universidad de Valladolid, Valladolid, 1997. Molt diferent ha estat la interpretació d'obres ja citades de Pere Ysàs: Disidencia y subversión..., "La crisis de la dictadura franquista" dins Carme Molinero (ed.): La Transición, treinta años después. De la dictadura a la instauración y consolidación de la democracia, Península, Barcelona, p. 27-58; Carme Molinero i Pere Ysàs: Anatomia del franquismo... i Productores disciplinados y minorías subversivas...; Sebastian Balfour: La dictadura, los trabajadores y la ciudad...; Nicolás Sartorius i Alberto Sabio: El final de la dictadura..., a les quals podríem afegir en l'ambit laboral l'obra de José Babiano: Emigrantes, cronómetros y huelgas: un estudio sobre el trabajo y los trabajadores durante el franquismo, Madrid, 1951-1977, Siglo XXI i Fundación 1o de Mayo, Madrid, 1995. El mateix autor ha editat un estudi de diversos autors sobre la dona treballadora durant el franquisme: José Babiano (ed.): Del hogar a la huelga: trabajo, género y movimiento obrero durante el franquismo, Los Libros de la Catarata, Madrid, 2007. 


\begin{tabular}{lcc}
\hline & $\begin{array}{c}\text { PERIODE ARIAS } \\
\text { (1ER SEMESTRE DE 1976) }\end{array}$ & $\begin{array}{c}\text { PERIODE SUÁREZ } \\
\text { (20N SEMESTRE DE 1976) }\end{array}$ \\
\hline Atemptats & 270 & 250 \\
Detencions per & & 2.769 \\
motius polítics & 1.619 & 474 \\
Tancades & 451 & 1.733 \\
Manifestacions* & 2.317 & 15.490 \\
Aturades laborals & 18.977 & 265 \\
Heridos FOP & 262 & 260 \\
\hline
\end{tabular}

Font: Gabinete Técnico del Ministerio de la Gobenación. Aquesta gràfica és una traducció al català de la que figura a la p. 279 de Nicolás Sartorius i Alberto Sabio: El final de la dictadura...

Ara bé, l'esclat de conflictivitat no va ser un fet exclusiu del moviment obrer. A les diferents localitats, els conflictes veïnals també van accentuar-se, col·locant a les autoritats locals franquistes en una situació molt delicada. I el que segurament és més important: van tenir cada vegada unes reivindicacions polítiques més concretes. La gent ja no es mobilitzava només per a tal o qual millora urbanística, per defensar un espai de l'especulació, per les escoles, els serveis bàsics, etc. Ara també ho farà per reivindicacions amb un major calat polític. Una d'aquestes serà la lluita per l'amnistia, una reivindicació clarament política, ja que:

\footnotetext{
"Para la oposición y para buena parte de la sociedad española, la amnistía comportaba no solamente la libertad de los presos políticos y el libre retorno de los exiliados, sinó también el reconocimiento del carácter ilegitimo de la legalidad franquista, lo que obligaba a su inmediata derogación; de ahí la radical negativa del gobierno ante dicha demanda." ${ }^{1003}$
}

Així per exemple va ser la Federació d'Associacions de Veïns de Barcelona la que va convocar les dues manifestacions dels dies 1 i 8 de febrer per l'amnistia, que van comptar amb una gran participació, i també una gran repressió. Les imatges dels grisos carregant contra la gent van donar la volta al món, gràcies, entre d'altres, al fotoperiodista Manuel Armengol.

Però tant o més important que aquest fet va ser la tasca que van fer les AVV's en la difusió, propagació i assumpció dels valors democràtics de sectors amplis de les classes populars. En contra de les tesis mecanicistes que associen el desenvolupament de "valors democràtics" a un determinat nivell de 
desenvolupament socio-econòmic ${ }^{1004}$, sembla evident que l'adquisició d'uns valors contraris a la dictadura es van fer per uns altres canals, com van ser per exemple la participació dins el moviment veïnal, en assemblees participatives, en la tria lliure de les Juntes veïnals, etc. Altres autors han parlat de que va ser la "societat civil" la que va adquirir aquests valors democràtics que van afavorir el canvi polític, però no ofereixen -al meu parer- una explicació convincent de com van fer aquest procés i tornen a caure en un cert mecanicisme ${ }^{1005}$, sense esmentar els prejudicis ideològics que demostren afirmacions com aquesta:

“Así, en España, dos clases de ideologías tuvieron que desaparecer previamente: por parte de la derecha, el nacionalcatolicismo y, por parte de la izquierda, el radicalismo social. Ambas habían generado en los años treinta un modo de hacer política, militante y polarizado, que se puede llamar 'política absoluta', incompatible con el nuevo régimen." ${ }^{1006}$

Ja vaig dir que en general aquestes visions minimitzen les mobilitzacions que es van donar durant aquest període, i a més, les solen relacionar amb reivindicacions "poc polítitzades" (en el sentit de reivindicacions polítiques concretes). Però si analitzem les mobilitzacions veïnals d'aquest període, la realitat és ben diferent:

“(...) el moviment veïnal es va convertir en un dels principals espais de participació política de les classes populars, especialment important per aquells sectors que no podien intervenir directament en la resta de moviments socials que operaven en aquelles dates." ${ }^{1007}$

És a dir, que el moviment veïnal era el lloc on podien intervindre sectors de població que no ho podien fer en altres lluites, ja fos per que eren molt sectorials no tant per la temàtica sinó per la seva composició (el moviment estudiantil universitari) o estiguessin molt masculinitzades (el moviment obrer). Al moviment popular ciutadà hi podien confluir els diferents habitants d'un barri, sense diferència de gènere, edat, ocupació... Si bé, com ja he dit, aquest moviment si que

1004Veure les notes 25 i 26 del Capítol 1.

1005 Álvaro Soto: ¿Atado y bien atado?... i Víctor Pérez Díaz: La primacía de la sociedad civil: el proceso de formación de la España democrática, Alianza, Madrid, 1993.

1006Víctor Pérez Díaz: La primacía de la sociedad civil..., p. 20.

1007Iván Bordetas i Anna Sánchez: "III. El moviment veïnal en (la) Transició, 1974-1979" a Carme Molinero i Pere Ysàs: Construint la ciutat democràtica..., p. 163. 
va sorgir en una primera instància en barris de composició obrera.

I a més, aquest moviment veïnal de seguida va adquirir unes reivindicacions que anaven més enllà de les mancances materials existents. Ben aviat es va relacionar les deficients condicions de vida als barris populars amb la situació política existent, així que les crítiques a la dictadura i les reivindicacions d'uns Ajuntaments democràtics van ser fonamentals per l'erosió del primer govern de la monarquia. Això ja havia passat amb el dictador viu -recordem les mobilitzacions contra el port esportiu de Badalona o el colomenc Manifest dels 51-. Però amb la mort de Franco això es va accentuar. La revista Grama, considerada per molts la “portaveu no oficial” del moviment veïnal colomenc era prou explícita en el seu editorial de desembre de 1975:

“(...) No se puede hablar, pues, de amnistía real si la liberación de los presos no va acompañada de un pleno reconocimiento de las libertades y los derechos fundamentales, sin el auténtico ejercicio de las libertades democráticas.

La conquista, pues de este pleno ejercicio de las libertades de expresión, reunión y asociación está unida íntimamente a la aspiración general por la amnistía, y no es posible la una sin la otra. Dentro de estas libertades nos parecen especialmente importante en el seno del Estado español la aspiración de los distintos pueblos que lo componen a decidir sus propios destinos. El respeto a su personalidad histórica es un sentimiento ámpliamente arraigado en cada uno de ellos."1008

Un altre magnífic exemple gràfic d'aquesta situació a nivell local ho podem trobar durant les "eleccions" a Alcaldes que es van fer al gener de 1976 amb la nova Llei de Règim Local, que permetia la seva tria entre els regidors en comptes del procediment anterior de designació a dit pels Governadors Civils. La premsa recollia aquests fets succeïts a Badalona:

"Una hora después de finalizar las votaciones, varios centenares de personas se concentraron frente al Ayuntamiento, marchando silenciosamente hacia el Paseo del Caudillo una de las principales vías de la ciudad, donde realizaron una votación simbólica en una urna en la que se pedían elecciones democráticas y la dimisión del consistorio. Seguidamente se desplegaron dos pancartas, una de las cuales iba firmada por los trabajadores del ramo del Metal, que hacían referencia a "un Ajuntament català i democràtic", y empezaron a ondear banderas catalanas. De allí la manifestación se encaminó otra vez a la "plaça de la vila” para entregar la urna “democrática”, “¡Batlle

1008“Editorial. El futuro que queremos”, Grama núm. 84 (desembre 1975), p. 3. 
dimissió!”, “Amnistia i llibertat” y “ ¡Estatut d'autonomia!” hasta llegar frente al edificio del Ayuntamiento donde entregaron a los funcionarios que se encontraban allí en aquellos momentos, la urna que contenía las papeletas pidiendo la dimisión del Consistorio." ${ }^{1009}$

Mentrestant a Santa Coloma també es produïa la dissolució per part de forces policials a un grup de persones que protestaven pel mateix motiu ${ }^{1010}$.

Les manifestacions per l'Amnistia es van donar també a nivell local, si bé amb una disparitat de criteris de les autoritats respecte aquestes. A Badalona es va fer la primera manifestació per l'Amnistia autoritzada del Principat (i de l'Estat), el dia 29 de febrer de 1976. En canvi, a Santa Coloma de Gramenet una manifestació similar convocada per l'Assemblea Democràtica no era autoritzada, encara que es va realitzar igualment el dia 28 de març amb una forta presència policial, i que tot i la tensió viscuda, va acabar sense enfrontaments greus ${ }^{1011}$.

Poc abans, el 26 de març s'havien fusionat a l'Estat espanyol la Junta Democràtica i la Plataforma Convergència Democràtica. Dintre del mateix aparell de l'Estat i del Movimiento hi havia una oposició al projecte reformista de Fraga dins la "Comisión Mixta Gobierno-Consejo Nacional", que havia sigut creada a proposta d'Adolfo Suárez, que en aquell moment no propugnava precisament cap reformisme ${ }^{1012}$. El govern havia presentat una proposta que assumia la majoria de les propostes defensades per Fraga. Però dins el Consejo Nacional del Movimiento es van donar posicions enfrontades a aquesta proposta ja que l'entenien com un qüestionament a la legitimitat del "18 de juliol", al mateix Movimiento Nacional i a los "Principios Fundamentales". Així la primera ponència de debat per reformar les Cortes i les "Leyes Fundamentales" va quedar aturat. Una posterior segona ponència, més conservadora -ja que remarcava la vigència dels "Principios Fundamentales", del Movimiento i la continuitat del Consejo Nacional dins el Senats'estava debatent quan va ser cessat al juliol Carlos Arias, i el posterior govern va cancel-lar el projecte.

1009“Badalona: el caso de la urna democrática”, Mundo Diario, 27-1-1976.

1010 Tele/ eXpres, 26-1-1976.

1011Eugenio Madueño: “Tres mil personas participan en una manifestación no autorizada", Diario de Barcelona, 30-3-1976.

1012Carme Molinero i Pere Ysàs: Anatomia del franquisme, p. 237. 
El que si es va aprovar el 9 de juny va ser la Llei d'Associació Política, que permetia crear associacions al marge del Movimiento (derogant-se així la legislació aprovada al desembre de 1974). Governació tindria les competències per legalitzar les associacions i no el Consejo Nacional. El mateix Suárez va defensar la proposta i tot i l'oposició de determinades figures, finalment va ser aprovada per 337 vots a favor, 92 negatius i 25 abstencions ${ }^{1013}$. Però malgrat aquest fet, no es va reformar el Reglament Penal a fons per l'oposició d'aquests sectors, de manera que es va aprovar només un text on es restringia molt la legalitat d'aquestes associacions, que no podien atemptar contra "la moral pública", el sistema socioeconòmic vigent, la unitat de l'Estat espanyol o les "sotmeses a una disciplina internacional que vulguin implantar un sistema totalitari".

Les mobilitzacions populars havien forçat la paràlisi del govern Árias, que alhora es va veure qüestionat per la facció ultra. La seva destitució i el nomenament de Suárez s'ha d'entendre com un intent de reconduir una situació que amenaçava amb desbordar-se. El monarca va tornar a actuar aquí en funció de la conservació dels seus interessos i no per cap pla preestablert o "voluntat democratitzadora" (o si més no, exempta de la conservació de la Corona). El mateix criteri es pot aplicar a Suárez i al seu equip, i bé per tractar aquest tema caldria un altre treball d'investigació.

És en aquest sentit que s'ha d'entendre la reforma promulgada pel nou govern de Suárez. A més es va trobar amb que els principals pesos pesats "reformistes" del franquisme (Fraga, Areilza...), que van rebre amb igual desconcert que la resta el seu nomenament, no li podien fer ombra "des de dintre" al no formar part del govern, on si van participar en canvi els anteriors ministres militars i alguns altres membres civils ${ }^{1014}$. El nou govern va fer us de l'aparell propagandístic

1013Carme Molinero i Pere Ysàs: Anatomia del franquisme, p. 247. El projecte va tenir tres esmenes a la totalitat defensades per Raimundo Fernández Cuesta, Joaquín Gías Jové i José Maria Fernández de la Vega, en base a la vulneració del principio VIII del Movimiento i que segons la Llei Orgànica vigent per aquest Movimiento havia de passar tota la vida política. Els sectors més conservadors i ultres van ser els que van votar negativament.

1014En concret de l'antic gabinet hi havien Alfonso Osorio (va continuar a Presidència però com a vicepresident segon), Rodolfo Martín Villa (a l'important ministeri de Gobernació) i Leopoldo Calvo Sotelo (nou al ministeri d'Obres Públiques). Els nous ministres tenien també un perfil "reformista" i provenien de l'ACNP i del "Grup Tácito": Marcelino Oreja (Asuntos Exteriores), Landelino Lavilla (Justícia). Altres nous nomenaments van ser Enrique de la Mata (Relaciones Sindicales) i Ignacio García López (Secretaría General del Movimiento). Carme Molinero i Pere Ysàs: Anatomía del franquismo, p. 250. 
per excel·lència d'aleshores, la televisió, per fer difusió de les seves aspiracions, que malgrat les proclames oficials, no era establir un joc polític obert a tothom.

Les mobilitzacions per l'Amnistia continuaven en el conjunt de l'Estat, i això va forçar la concessió d'una amnistia limitada pel nou govern (30 de juliol), que també va concedir la modificació de la legislació penal per permetre la legalització d'associacions polítiques -a excepció de aquells partits "que sometidos a una disciplina internacional pretendan instaurar un régimen totalitario"1015, eufemisme fet servir per referir-se ales organitzacions comunistes, que eren considerades "totalitàries" curiosament pels membres d'un règim que al menys al meu parer correspondria a aquesta definició.

Suárez va aconseguir amb gran habilitat l'aprovació de la Llei Para la Reforma Política el 18 de novembre de 1976 amb 425 vots a favor, 59 en contra i 13 abstencions. Com va aconseguir que les Corts Franquistes l'aprovessin? Cal tenir en compte que aquesta Llei per si mateixa no pressuposava l'establiment de cap democràcia, sinó la tria de les Corts per sufragi universal en un moment que no se sabia si tots els partits polítics serien legalitzats i que a més disposava de diversos mecanismes correctors ${ }^{1016}$. Aquest fet, la fidelitat dels procuradors a l'aparell de l'Estat que els garantia el seu càrrec, juntament amb tota classe de maniobres que es van fer des del mateix govern per comprar voluntats va donar com a resultat que s'aconseguissin els $2 / 3$ de vots necessaris ${ }^{1017}$.

Al Barcelonès Nord aquest va ser també un període d'intenses mobilitzacions. Amb Árias a la Presidència ja s'havien fet reivindicacions més clarament polítiques, a favor de l'amnistia i els ajuntaments democràtics -sense esmentar les contínues mobilitzacions veïnals, de les quals parlaré amb més detall en un capítol posterior, que també estaven profundament polititzades-. Les connexions entre les diferents mobilitzacions eren evidents. Per posar només un exemple, hi ha una fotografia de

1015Carme Molinero i Pere Ysàs: Anatomía del franquismo, p., p. 250 i 296 (nota 50). La reforma del Codi Penal va obtenir 245 vots a favor, 175 en contra i 57 abstencions.

1016Es preveia un mínim de sufragis per accedir al Congrés, la circumscripció electoral provincial penalitzava les províncies més urbanitzades, en el Senat $1 / 5$ part era de designació reial i el mateix monarca podia convocar referèndums sense l'aprovació de les Corts (a més de que la intenció inicial no era legalitzar a totes les forces polítiques, sent clarament excloses les comunistes, "separatistes" i republicanes).

1017 “Menos acostarnos con ellos, hicimos de todo", recordava Martín Villa respecte les maniobres per garantir el vot favorable dels procuradors a VV.AA: Memoria de la transición. Del asesinato de Carrero a la integración en Europa, El País, Madrid, 1996, p. 102. 
la manifestació del dia 29 per l'Amnistia a Badalona a la Rambla de la ciutat, i a la capçalera es pot veure una pancarta amb el lema "Los vecinos de Llefià por la Amnistia"1018. Cal esmentar que a Badalona el 6 d'abril es va constituir una "Associació pro amnistia de Badalona" amb 19 membres fundadors, mentre que a Sant Adrià de Besòs el 23 de juliol també es produïa una manifestació reclamant l'amnistia general i l'amnistia laboral amb autorització, al contrari del succeït a Santa Coloma el 28 de març ${ }^{1019}$.

Ja he parlat de la constitució d'organismes locals de l'Assemblea Democràtica, constituïdes formalment a Badalona el 27 de maig, a Santa Coloma el 12 de juny i a Sant Adrià també al voltant d'aquestes dates, si bé en el cas de les dos poblacions més grans del Barcelonès Nord existien Grups Promotors des de feia un cert temps ${ }^{1020}$. En el cas Badaloní ja vaig comentar que s'havia creat al 1971 una Comissió Democràtica que no va acabar de reeixir, si bé a inicis de 1976 s'havia reactivat un Grup Promotor de l'Assemblea Democràtica de Badalona que poc després va participar en la manifestació per l'Amnistia del dia 29 de febrer. Al juliol les AVV's més reivindicatives conjuntament amb altres entitats de la ciutat van presentar el "Manifest de Badalona" on es recollia la demanda d'Ajuntaments Democràtics i les línies d'actuació que aquest hauria de seguir a Badalona ${ }^{1021}$. A Santa Coloma des de l'elaboració del "Manifiesto Ciudadano de los 51" al 27 de setembre de 1975 de fet diverses reunions entre forces polítiques, que no van

1018Una reproducció de l'esmentada foto es pot veure a Joan Villarroya (dir.): Història de Badalona, p. 226.

1019Els fundadors de l'entitat badalonina van ser Fernando Celma Diez (president), Manuel Mateu Rotger (secretari), Joan Zabalza Martí, Adoni González Mateos, Pere Joan Calicia, Josep Gual Llorens, Joan Soler i Amigó, Alfredo Amestoy Sáez, Franciso Gené Anglés, Josep Maria Boada, Fermín Vila Velázquez, Manuel Fernández Moreno, Rafael Calderón Martín, Fernando Lloveta Aznar, Carmen Márquez Corominas, Blas Zamora Martínez, Francisco Rafael Vallespín, Mariano Batlle Vilaseca i Francesc Celma Belmonte. Aquesta associació va intentar fer un acte al 10 de juliol de 1976 al pavelló d'esports de la Plana que va acabar suspès per incidents amb membres de la CNT. Veure Emili Ferrando Puig i Juan Rico Márquez: Les Comissions Obreres en el franquisme..., p. 524 i “Incidentes en el mitin de Badalona”, Mundo Diario, 14-7-1976.

1020 “Constitución de l'Assemblea Democràtica de Badalona”, Mundo Diario, 29-5-1976 i "Constitución de la Assemblea Democràtica de Santa Coloma", Tele/ eXpres, 15-6-1976. En el cas colomenc es pot consultar una "Proposta de declaració de l'Assemblea Democràtica de Santa Coloma de Gramenet" a AHMTB, Donació Marcelo López Ródenas, Caixa 3, Dossier 10.

1021En concret ho van signar les AVV's de Sistrells, Juan Valera, Sant Crist, Lloreda, Puigfred, Bufalà, Sant Mori de Llefià i Morera; els Centres Socials de Pomar i Sant Roc; i les entitats Jove Cambra, Grup Cristià de Defensa i Promoció dels Drets Humans, Xarxa de Comunitats Cristianes, CIC i Cine Club Studio. "Una alternativa democràtica per la ciutat", Mundo Diario, 18-7-1976. 
cristal-litzar fins la primavera de 1976. Demostrant de nou les connexions entre les reivindicacions veïnals i les polítiques, era el butlletí Arrabal de l"AVV colomenca del mateix barri la que informava d'aquest procés:

\begin{abstract}
"Después de más de un año de intentos repetidos y sin frutos, la oposición democrática de Santa Coloma parece unirse definitivamente con la creación de la Asamblea de Catalunya y en torno a sus mismos objetivos políticos. Fue a raíz de la crisis del NO de los once concejales de Can Zam para equipamientos, y la consiguiente aparición del Manifiesto de los 51 en el que se pedía un Ayuntamiento Democrático, un ayuntamiento elegido por el pueblo, cuando empezó a tomar cuerpo la creación de un movimiento democrático integrado por todos los demócratas de la ciudad. En una reunión celebrada en Marzo a la que asistieron un centenar de personas representativas de nuestra ciudad se aprobó la propuesta de declaración de la Asamblea Democrática, propuesta que será leída próximamente en una amplia Asamblea de constitución." ${ }^{1022}$
\end{abstract}

Com ja vaig explicar, les CCBB colomenques van polemitzar amb aquest sector amb el qual discrepaven profundament i van intentar fer el seu propi programa alternatiu.

En canvi a Sant Adrià de Besòs el procés va ser més tardà, si bé segurament va accelerar-se quan al mes de febrer diverses AVV's (La Mina i Besòs i el grup promotor de la de Sant Adrià Nord) i càrrecs sindicals havien entregat una carta exigint la dimissió del consistori i uns Ajuntaments democràtics ${ }^{1023}$. A totes tres ciutats les respectives Assemblees Democràtiques no van tenir una gran capacitat mobilitzadora, a excepció dels seus primers moments. Les dinàmiques polítiques que van començar a gestar-se a la tardor de 1976 van esquarterar la precària unitat aconseguida i la perspectiva d'unes futures eleccions va fer que alguns tinguessin més interès en mirar de concórrer amb avantatge que en preservar un espai unitari.

El mes d'abril els dos regidors badalonins d'oposició moderada (Cecília March i Ernesto Rojo) s'havien sumat a una petició de diversos regidors de diferents Ajuntaments catalans que demanaven eleccions democràtiques a

1022 La Voz del Arrabal (maig 1976), citat a Emili Ferrando Puig i Juan Rico Márquez: Les Comissions Obreres durant el franquisme..., p. 517-518. 1023 “Que dimita el consistorio", Mundo Diario, 5-2-1976. 
l'aleshores Ministre de la Gobernació Manuel Fraga ${ }^{1024}$. Altres mobilitzacions amb un contingut clarament polític van ser per exemple l'anomenada Marxa per la Llibertat que es va organitzar a tot Catalunya i que va ser fortament reprimida a Badalona com en altres llocs quan va arribar el dia 29 de juliol:

\begin{abstract}
"Quan la Marxa de la Llibertat va arribar a Badalona els estudiants dels instituts van ser una mica els protagonistes de la mobilització al fer de marxaires i ens vam concentrar en la Plaça de la Vila on es feia un acte per l'amnistia. Va venir un "mogollón" de jeeps de la Guàrdia Civil, van començar a repartir cops de culata i a quatre, cinc o sis ens van detenir i ens van portar cap a la caserna de la Guàrdia Civil. Personalment em van posar una pistola sobre la taula i... sempre el guàrdia bo i el dolent, com a les pel·lícules. I això és veritat, ho he viscut. Un primer, en una habitació a cops de puny i a potades et tirava per terra i et llançava un gos perquè et mossegués. Anaven a destrossar-te moralment, o sigui, a trencar totes les defenses. L'altre et deia: "no siguis tonto, tu pensa que els de l'Assemblea Democràtica, què us penseu, que governareu mai? Sou uns desgraciats, sou uns 200 com a molt a Badalona. Arribarà un dia que us aplicarem la llei de fugues com hem fet a Vitòria, i no us detindrem, us fotrem quatre trets directament. Tu digues qui ha fet aquell paper i no t'amoïnis home, ells no se n'enteraran. Tu te n'aniràs a casa tranquil, ja no et passarà mai més res."'1025
\end{abstract}

Altres mobilitzacions van ser les que es feren aquest any i el següent al voltant del Congrés de Cultura Catalana, amb festes populars com les de Can Solei el 30 de maig de $1976^{1026}$ (més endavant parlaré de tot l'afer al voltant del monòlit del Parc de Can Solei de Badalona). També tingueren una importància molt rellevant les que es feren contra la revisió del Pla Comarcal de 1976, en especial a l'àmbit veïnal ${ }^{1027}$.

Però de nou la conflictivitat obrera va ser, en sintonia amb la dinàmica general, la que va agafar un cert protagonisme en un context on els efectes de la

1024A la petició s'hi van sumar, apart dels regidors badalonins, altres regidors dels ajuntaments de Mataró, Vilafranca del Penedès, Sant Vicens de Montal, Sant Sadurní de Noia, Codinas, Canovelles i Granollers. Un total de 25. Veure "Petición de elecciones democráticas", Solidaridad Nacional, 22-4-1976.

1025Entrevista a Francesc Alfambra, recollida a Emili Ferrando Puig i Juan Rico Màrquez: Les Comissions Obreres en el franquisme..., p. 527-528.

1026 "Massiva festa democràtica a Badalona", Mundo Diario 3-6-1976.

1027Sobre aquestes mobilitzacions en parlaré més detalladament al capítol dedicat a les lluites veïnals. Però tinc que dir que fins i tot altre tipus d'entitats que no eren AVV's van posicionarse en contra. Un exemple va ser la Jove Cambra de Badalona, sobretot per la part que contemplava la construcció del Port. "La "Jove Cambra" contra el plan comarcal", Mundo Diario, 25-3-1976. 
crisi econòmica ja es feien notar amb més força amb el tancament d'empreses i l'augment de l'atur, començant, per exemple, pel tancament dels treballadors de l'empresa colomenca Radiotronic a l'església de San Joan Baptista del barri del Fondo en protesta pel seu acomiadament la setmana del 12 al 18 de gener de $1976^{1028}$. Durant els primers mesos d'aquest any va haver-hi moltes mobilitzacions en el context de negociació del conveni del metall, amb sancions i acomiadaments de represàlia a tot el Barcelonès Nord en un sector que mantindrà un alt nivell de conflictivitat fins novembre, en sintonia amb el que s'estava donant a altres empreses i localitats (Motor Ibèrica, Sabadell). La mort d'un obrer a les obres de construcció de l'Hospital de Can Ruti el mes de febrer va tornar a impulsar la mobilització d'aquest sector, juntament amb la detenció de dos treballadors. Importants van ser també les lluites el mes de febrer a TUSA, l'empresa més important de transport en autobús a la sub-comarca on Comissions Obreres tenia molta implantació. Al febrer i març aquesta conflictivitat es va estendre a altres empreses ${ }^{1029}$. Significatives van ser les mobilitzacions al sector dels forners, on es va exigit la dimissió d'un vell conegut nostre, Fulgencio Conesa, que era procurador en Corts i president nacional de cereals (apart de regidor municipal), un conflicte que es va tornar a revifar el mes d'octubre. Però sens dubte, la vaga més important aleshores va ser la que van protagonitzar els treballadors de l'Òptica Hispano de Badalona, que iniciada el 10 de març va durar 70 dies per impedir l'acomiadament de sis companys, mesura repressiva amb la que l'empresa havia reaccionat davant una demanda de millores salarials i de condicions de treball.

El mes d'abril es va celebrar un acte d'homenatge a Manuel Fernàndez Màrquez al cementiri de Pomar, amb la intervenció de Manuel Pérez Ezquerra, recent sortit de la presó pels mateixos esdeveniments, sense intervenció policial. La conflictivitat en aquest mes es va concentrar en alguna empresa tèxtil (Lowry's),

1028 "Finaliza el encierro de trabajadores en Santa Coloma", Tele/ eXpres, 19-1-1976. La policia va envoltar la parròquia amb un fort dispositiu policial arribant a impedir fins i tot l'entrada del Vicari Episcopal per assumptes obrers, Mn. Joan Carrera i Planes el dia 15. Veure "Se le impidió entrar al Vicario Episcopal en una iglesia de Santa Coloma", Diario de Barcelona, 16-1-1976.

1029En concret a Duñó i Filco en el tèxtil, Filcar i Midsa al ram del metall i a d'altres empreses com Eaton Livia, Ollearis, Bomba Bloch, Gelpha, Óptica Hispano, Vidad, Cros, Artrs Gràfiques i també a les benzineres. Inclús hi ha una manifestació a Badalona en protesta per l'assassinat dels obrers de Gasteiz. Emili Ferrando Puig i Juan Rico Márquez: Les Comissions Obreres en el franquisme..., p. 533. 
al gremi dels fusters, del suro i, sobretot, al metall per la reivindicació del conveni esmentada anteriorment. Va destacar, sobretot, la vaga iniciada el dia 5 a l'empresa CEMOTO (Bultaco) en defensa del conveni del Metall i on van ser acomiadats tots els seus treballadors com a primera resposta de l'empresa (que després va rebaixar a un número de 30 i 12 per mirar de trencar la unitat obrera, sense èxit). En aquest conflicte va ser molt important la solidaritat rebuda per l'AVV de La Mina, posant de manifest de nou les connexions entre moviment obrer i veïnal ${ }^{1030}$.

La conflictivitat laboral va continuar els mesos següents en sectors com el tèxtil (vagues a Eurostil, Jovers, Balismo, Tello, Casademont i Vicente Ferrer), el sanitari (vaga de 5 dies dels treballadors de l'Hospital Esperit Sant), el metall a Sant Adrià (amb mobilitzacions i 18 detencions de membres de piquets), de nou els flequers, els carters... Es va fer una manifestació el 30 d'abril a Badalona en vigílies del 1er de maig i al mes de setembre l'empresa de la mateixa localitat del sector tèxtil Filcor i Còrtex van entrar en un conflicte amb els seus treballadors quan tancà les portes devent als seus operaris dos mesos de salari. Els obrers colomencs de Creaciones Ponz iniciaren una vaga el dia 5 d'octubre en demanda d'una pujada de sou i continuaren amb jornades de baix rendiment. L'empresari en resposta tancà l'empresa i desaparegué deixant-los en l'estacada. A l'octubre els dies 7 i 8 hi ha aturades de nou al sector del metall on participen 34 empreses i 4.000 treballadors. També hi ha conflictes a la sanitat, en concret al sector dels MIR. Cal esmentar que durant aquest any també es van començar a mobilitzar col·lectius de població molt concrets, com els jubilats que a Badalona van crear la seva pròpia associació després d'una assemblea de 200 persones $^{1031}$

La repressió també va continuar a nivell local malgrat les proclames "reformistes" del Govern Suárez i dels Ajuntaments locals. A l'octubre va haver-hi diverses detencions, com per exemple la del periodista badaloní Enric Giralt, a Llefià, processat pels seus escrits punyents i de denúncia a El Correo Catalán, i en concret per un que denunciava el maltractament policial a dos detinguts

1030 Emili Ferrando Puig i Juan Rico Màrquez: Les Comissions Obreres en el franquisme..., p. 537-539. 1031 “Los jubilados asociados”, Mundo Diario, 31-3-1976. Es pot trobar nombrosa documentació de l'Associació de Jubilats i Pensionistes de Badalona (i d'una anomenada Coordinadora Reivindicativa de Jubilats i Pensionistes de Badalona formada per aquesta entitat i els diferents sindicats de la ciutat) a MB-AHCB, Fons personals i professionals, Caixa C350 (Matias González Garcia) i en l'Hemeroteca, Gent Jove d'Ahir, Llibre 21-8-1 i Carpeta 21-9-21. 
erròniament acusats d'un atemptat contra un policia local ${ }^{1032}$. Uns 15 joves van ser detinguts a la sortida d'una missa a l'església de La Salut (Badalona) en memòria d'un estudiant, Carlos González, assassinat a Madrid, tot això sense esmentar les detencions relacionades amb les protestes veïnals -que tractaré posteriorment amb més detall- com per exemple, la irrupció policial en un acte organitzat per les diferents vocalies de dones de Santa Coloma el 8 de febrer a la parròquia de Can Mariner o les detencions que es van fer de membres de l'AVV del Rio de Santa Coloma quan netejaven un solar que reivindicaven ${ }^{1033}$. En una manifestació posterior de protesta per aquests fets es van donar 7 noves detencions ${ }^{1034}$. Durant tot aquest any van proliferar també les prohibicions d'actes dels partits comunistes, de Comissions Obreres o de les diferents seccions de l'Assemblea Democràtica. Mentrestant altres partits polítics com els socialistes o Convergència es movien amb una gran tolerància de les autoritats ${ }^{1035}$. Però sens dubte, va haverhi una actuació repressiva que va generar una gran indignació a Badalona i a les altres poblacions. Em refereixo a l'actuació policial i de la Guàrdia Civil durant una manifestació de més de 2.000 persones que es va concentrar a la Plaça de la Vila de Badalona en demanda d'escoles el 18 de setembre de 1976, que no va tenir cap escrúpol en carregar violentament ferint fins i tot a nens, fet que va provocar que

1032 “Detención de nuestro corresponsal en Badalona”, El Correo Catalán, 7-10-1976. La notícia informava sobre aquesta detenció. L'escrit que es va presentar com a "causa" per la detenció havia estat publicat al mateix diari el dia 2 d'octubre.

1033En concret van ser detinguts el seu President Ricardo Bonet i dos persones més, un matrimoni de veïns del barri, que van ser processats. Veure "Procesados varios vecinos de Santa Coloma de Gramenet", Tele/ expres, 14-6-1976.

1034Van ser detinguts i detingudes Josep Maria Martí, Alfoso Gómez, Pepe Sánchez, Jaume P. Sayrach, Motserrat Cascante, José Maria Ballesteros i Hernán Freire després d'una manifestació de 400 veïns. Van ser alliberats el dia 9 on també es va produir una manifestació d'un miler de persones. Veure "Graves incidentes en Santa Coloma de Gramenet" i "En libertad los siete detenidos el jueves en Santa Coloma de Gramenet", Tele/ eXpres, 9-7-1976 i 10-7-1976.

$1035 \mathrm{~A}$ Badalona es va prohibir una manifestació per l'amnistia laboral i un acte convocats per CCOO el juliol de 1976 (Mundo Diario, 28-7-1976). A Santa Coloma de Gramenet el 4-3-1976 es van suspendre unes jornades sobre les forces polítiques de Catalunya que s'havia de fer organitzada per l'Escola Social de Santa Coloma de Gramenet; El 27-3-1976 es prohibeix un acte de Pere Ardiaca (PSUC) en Santa Coloma (Tele/ eXpres, 29-3-1976); 1'11-7-1976 es va fer un acte de presentació al carrer del PSUC davant la prohibició de fer servir Can Sisteré (Tele/ eXpres, 12-7). A Sant Adrià el Govern Civil el 27-3-1976 prohibeix una assemblea de l'UTT del Metall que s'havia de fer al local de l'AVV La Mina; i al 26-11-1976 es va prohibir la presentació del PTE a l'Ateneu Adrianenc (al qual s'havien pogt presentar UDC i CDC sense cap problema. També al mes de setembre l'UGT local havia fet un acte públic sense cap impediment). Tot i que a finals de juny s'havia "tolerat" un acte del PSUC a nivell comarcal fet a Badalona a la muntanya a prop de Can Ruti a finals de juny, El 5-10-1976 el Govern Civil va prohibir la presentació de les CCOO del Barcelonès Nord. 
les AVV's i l'Assemblea Democràtica exigissin la dimissió de tot el consistori ${ }^{1036}$. Tot això sense esmentar les contínues amenaces i accions de membres de l'extrema dreta contra sectors d'esquerres practicades amb la total indiferència i complicitat de l'aparell policial de l'estat ${ }^{1037}$. També és important recordar que va ser durant aquest any 1976 quan es va constituir la Federació d'Associacions de Veïns de Badalona i la Coordinadora d'Associació de Veïns de Santa Coloma ${ }^{1038}$. Com es pot observar, ens trobem amb una situació local amb una oposició i mobilització molt activa, i això que no he entrat a detallar les mobilitzacions veïnals -molt freqüentsque hi va haver als diferents barris (cosa que faré en un apartat concret més endavant).

A nivell estatal, la tardor de 1976 va representar un moment polític crucial. Per una banda, passat un cert moment de desconcert de l'empresariat davant tanta mobilització popular, es va engegar un nou pols al moviment obrer. Un exemple molt conegut d'això és la resposta que va donar la patronal sabadellenca davant la vaga del Metall de l'octubre: un lock-out salvatge, arribant-se a 200 empreses tancades Amb el suport governamental la vaga, malgrat la força que va tenir, va acabar derrotada ${ }^{1039}$. En aquells moments s'estava entrant en un nou pols entre el govern Suárez i l'oposició, que es veurà plasmant en dos moments concrets: la vaga del 12 de novembre i el referèndum per l'aprovació de la Llei per la Reforma Política del 15 de desembre. En aquell moment, el PSUC de Badalona encara afirmava:

"Lluitar per restabliment de la democràcia, tal com venim fent des de l'any 1939, que la política reformista en la nova versió de Suarez, no fa més que ajornar i limitar perillosament, comprometent el trànsit pacífic vers la mateixa. Restabliment de la

1036Joan Villarrolla (dir.): Història de Badalona, p. 228-229. Veure també Mundo Diario, 22-9-1976, 23-9-1976 i 25-9-1976.

1037A Badalona ja vam comentar l'atemptat contra el local de l'AVV Congrés l'any 1975. A Santa Coloma el 1976 van rebre amenaces telefòniques els presidents de les AVV's d'Arrabal i Singuerlín, també els redactors de Grama i diferents personalitats d'esquerres de la ciutat. Veure "Nuevas amenazas telefónicas en Santa Coloma" i "Amenazas de muerte a "Grama" corresponsales y entidades", Diario de Barcelona, 29-2-1976, 7-3-1976 i "Santa Coloma: "sentencias de muerte" de la ultraderecha", Mundo Diario, 11-3-1976.

1038 “Las asociaciones se federan", Mundo Diario, 15-5-1976.

1039Una empresa -Massey-Ferguson- va arribar a remetre 1.800 cartes d'acomiadament davant en represàlia als seus treballadors que protestaven per l'acomiadament inicial de tres companys. Nicolás Sartorius i Alberto Sabio: El final de la dictadura... p. 114. Més informació sobre la vaga del metall a Sabadell a Xavier Domènech: Quan el carrer va deixar de ser seu. Moviment Obrer, societat civil i canvi polític. Sabadell (1966-1976), Publicacions de l'Abadia de Montserrat, Barcelona, 2002, p. 301-335. 
llibertat, que en la nostra opinió passa indefectiblement pels següents punts: Govern provisional d'ampla coal-lició [sic] i sense signe constitucional, Aministia total, reconeixement de totes les llibertats polítiques i sindicals, sense condicions ni restriccions, llibertat per a tots els partits polítics, Reposició dels Estatuts d'Autonomia de Catalunya, Euzkadi i Galicia i la possibilitat de què tots els pobles i regions puguin pronunciar-se sobre la seva voluntat autonòmica.

Reafirmar-nos una vegada més en la idea de què la lluita per defensar els interessos de Catalunya, pel restabliment de les institucions i principis configurats a l'Estatut d'Autonomia del 1932 i la posterior autodeterminació, està indissolublement unida amb la consecució de la ruptura a nivell de tot l'Estat i en conseqüència amb la coordinació i acord entre les forces de l'oposició i les instàncies unitàries de tots els pobles d'Espanya." ${ }^{1040}$

Però com hem vist, el govern Suárez estava recobrant la iniciativa i davant la continua protesta va optar per la clàssica política del tupí i el bastó. Oferir algunes propostes de reforma com l'esmentada Llei para la Reforma Política però continuar amb una forta repressió vers les forces comunistes mentre amb socialistes i altres partits moderats o de dretes es mantenia una política benevolent. Mentrestant antics dirigents franquistes, davant l'avenç del projecte reformista governamental i la possibilitat d'unes futures eleccions, van constituir l'anomenada Alianza Popular ${ }^{1041}$, un partit que, en contra del que es sol dir, podia ser catalogat aleshores com d'extrema dreta ${ }^{1042}$. En aquest context el Consell de ministres del 8 d'octubre suspenia l'article 35 de la Llei de Relacions Laborals d'abril, que obligava a la readmissió d'un treballador per qualsevol empresa si un acomiadament era considerant improcedent i establia que podia pagar-li una indemnització sense readmetre-ho (a la pràctica, un acomiadament lliure amb compensació econòmica). El refús a aquesta mesura i a d'altres com la que per exemple reduïen

1040 “Resolució del IV Ple de l'Organització de Badalona del P.S.U.C” (10-10-1976), ANC, Fons PSUC, 03.Organitzacions de Base, 03.01. Organitzacions Territorials, 819 Badalona: Comitè Local del PSUC (1967-1977), p. 1-2.

1041 Alianza Popular va aparèixer l'octubre de 1976. L'integraven Reforma Democràtica (Fraga), associacions polítiques del Movimiento constituides amb la llei de 1974 (UDPE i UNE) i grups de nova formació com Democracia Social (Licinio de la Fuente) o Acción Regional (Laureano López Rodó). 183 procuradors en Corts es van inscriure en AP. Carme Molinero i Pere Ysàs: La anatomía del franquismo..., p. 259.

1042Sobre aquest tema imprescindible la consulta de la Tesi Doctoral de Miguel Ángel del Río Morillas: De la extrema derecha neofranquista a la derecha conservadora: los orígenes de Alianza Popular (1973-1979), UAB, 2013. 
la prestació de l'atur, els sindicats, encara il·legals i agrupats en la Coordinadora de Organizaciones Sindicales (COS) van convocar a la vaga general el dia 12 de novembre. Però es podia intuir que en aquesta mobilització es dirimia quelcom més que una qüestió purament econòmica. I el mateix govern, conscient d'això, va aplicar tota la seva capacitat repressora i coercitiva per evitar l'èxit de la convocatòria.

Sobre el resultat d'aquesta mobilització s'han dit moltes coses, però el que sembla evident és que va ser una mobilització prou important, ateses les circumstàncies repressives en les quals es va dur a terme:

\footnotetext{
"Es verdad que el proyecto de paralizar el país desde la calle con un paro general fracasó, o por lo menos se quedó a medias, pero de ahí se ha deducido de forma automática que la presión de al calle tuvo escasa importancia en el proceso político de la Transición y que al final, con Suárez a la cabeza, todos aceptaron implícitamente que la única vía razonable a la democracia era a través de la legalidad, como si en los meses anteriores no hubiese sido preciso "forzar" esa legalidad y destejer la red para que la caída de Arias careciese de reposición. (...)

El paro no fue ni suficientemente fuerte para ganarle el pulso a Suárez ni tan débil como para que éste no se diese cuenta de que no podía hacer lo que le viniese en gana. A pesar de no "detener el país", Martín Arce ha calificado a este 12 de noviembre como "la jornada de lucha más importante que conoció el país en cuarenta años"”1043
}

Jo no sé si qualificaria la jornada del $12 \mathrm{~N}$ com un fracàs quan en les condicions existents es va aconseguir implicar més de 2 milions de treballadors en la vaga. En tot cas, potser els objectius eren massa ambiciosos i més tenint tot l'aparell de l'estat en contra. No es va aconseguir que el govern es fes enrere amb les mesures que havia aprovat. Però aquesta jornada va ser, al meu parer, el que més es va acostar a la famosa "Vaga General Política" propugnada pel PCE-PSUC que havia de fer caure la dictadura, encara que fos insuficient.

Al Barcelonès Nord l'impacte d'aquesta vaga va ser notable. A Badalona l'activitat pràcticament es va paralitzar per l'acció dels piquets malgrat la repressió policial que va detenir a una trentena de persones que finalment van ser alliberades el mateix dia. A Santa Coloma també les principals empreses van fer

1043Nicolás Sartorius i Alberto Sabio: El final de la dictadura..., p. 117. Veure també l'obra de l'autor mencionat, J. M. Martín Arce: "La COS. Una experiencia de unidad de acción sindical durante la Transición”, en Espacio, tiempo y forma. Historia Contemporánea, núm. 9, p. 295-313. 
vaga i es van produir també detencions i alliberaments el mateix dia, i, segons Grama, un $80 \%$ dels treballadors la van secundar ${ }^{1044}$. A Sant Adrià també va tenir un impacte notable. L'OSE de Badalona afirmava que havien secundat la vaga el $24,6 \%$ dels assalariats badalonins. Segons la CONC 500.000 treballadors havien secundat la vaga a Catalunya ${ }^{1045}$.

El següent pols entre govern i oposició democràtica va ser el Referèndum per la Reforma Política que s'havia de fer el 15 de desembre de 1976. La postura de l'oposició va ser la de propugnar l'abstenció en tant no estaven reconegudes les llibertats fonamentals i aquest referèndum es feia sense garanties democràtiques. En efecte, de nou l'aparell de l'Estat es va posar en marxa per garantir la victòria del si amb tots els seus mecanismes a l'abast, incloent la repressió. Es van tancar les escoles i es van atorgar permisos de 4 hores retribuïdes per que els treballadors poguessin votar. No van poder votar els menors de 21 anys. No es va poder fer campanya per l'abstenció pels mitjans de comunicació de masses, que, controlats pel govern, van fer una propaganda massiva a favor del si amb eslògans tan coneguts -i cínics- com el de "habla pueblo habla" o "si quieres la democracia vota", tot i que, al Barcelonès Nord com a tants altres llocs, des dels partits polítics, les Associacions de Veïns i les Comissions de Barri (aquestes darreres a Santa Coloma) es va intentar difondre l'opció de l'abstenció des de la seva limitada capacitat. Els motius per abstenir-se es recollien a les pàgines de Grama:

\footnotetext{
“"Informate y vota dice uno de los slogans del gobierno. Pero informarse quiere decir conocer todas las opciones sobre el referéndum. Y esto es imposible, dado que la única opinión que podrá expresarse será la de aquellos que están a favor del referéndum. No es, pues, una consulta democrática. Y; además, no se celebra en unas condiciones democráticas.

No hay democracia formal de verdad porque no están garantizadas las libertades de reunión, de asociación y de expresión. Porque no hay libertad sindical. Porque no se ha concedido una amnistía total.

Porque los distintos pueblos del Estado español -como nosotros, el pueblo catalán- no pueden decidir libremente su futuro, es decir, no pueden ejercer el derecho a la autodeterminación. La libertad debe ser sin exclusiones. La democracia es para todos o no es para nadie. Todos los partidos, si hubiera realmente democracia, deberían
}

1044Grama núm. 95 (desembre 1976). Veure article "12 de noviembre huelga. La ciudad paralizada", p. 21-23.

1045Emili Ferrando Puig i Juan Rico Márquez: Les Comissions Obreres en el franquisme..., p. 541-543. 
estar legalizados, incluidos, claro está, los socialistas, comunistas y nacionalistas." ${ }^{1046}$

Les Comissions de Barri i la seva incipient Coordinadora, van fer servir el seu discurs de classe per cridar al boicot:

"Esto es lo que pretenden: ENGAÑAR AL PUEBLO CON LA FALSA PARTICIPACIÓN PARA QUE EL PUEBLO DEJE DE LUCHAR. Y más adelante con las elecciones, con el pacto que ya están intentando con parte de la oposición, como los trabajadores ya tendremos a nuestros "representantes" en el parlamento, ya no será necesario preocuparnos de ningún problema, puesto que ellos lo harán por nosotros. (...)

Desde el punto de de vista nuestra clase, vemos que no podemos coincidir nunca con el de nuestros explotadores. Vemos también que desde unos aparatos y una gente que durante 40 años ha servido en el franquismo no se puede hacer ahora la pantomima de la democracia." ${ }^{1047}$

Va ser un referèndum semblant als celebrats en vida del dictador, cosa que caldria recordar, amb una certa coacció per participar-hi. Seria interessant poder investigar quin grau de transparència va tenir el recompte de vots, un tema sobre el que ningú sembla preguntar-se. Per tots aquests motius, era difícil per l'oposició aconseguir un elevat grau d'abstenció. A nivell de l'Estat les dades oficials parlen d'una participació del 77,7 \% del cens electoral, dels quals el el 94,1 \% va donar el seu vot afirmatiu. A Catalunya el resultat va ser pràcticament igual. Només a Barcelona va haver-hi una mica menys de participació, amb el $72 \%$, mentre que al País Valencià la participació era del 85,2\% i a les Illes del 82,6 \% ${ }^{1048}$. Al País Basc en canvi l'abstenció va tenir una força notable ja que la participació va ser només del 54 \% (a Guipúscoa va ser del 44,9 \%!!). A les principals ciutats del Barcelonès Nord es van donar els següents resultats:

1046"Referéndum: ni "si," ni "no": nada”, Grama núm. 95 (desembre 1976), p. 5.

1047 "Referéndum: el gran engaño democrático", Barrio Obrero núm. 2 (desembre 1976), AHMTB, Donació Marcelo López Ródenas, Caixa 1, p. 6.

1048La Vanguardia Española, 17-12-1976 i Martí Marín i Corbera: Història del franquisme a Catalunya, Eumo Editorial/Pagès Editors, Lleida, 2005, p. 343. 
REFERÈNDUM DE LA LLEI PER LA REFORMA POLÍTICA AL BARCELONÈS NORD

\begin{tabular}{|c|c|c|c|}
\hline & BADALONA & SANTA COLOMA & SANT ADRIÀ \\
\hline Cens & 129.895 & 82.583 & 22.524 \\
\hline Vots & $96.441 \quad(74,24 \%)$ & $62.288(75,42 \%)$ & $17.509(77,43 \%)$ \\
\hline Abstenció & $33.454(25,75 \%)$ & $20.295(24,57 \%)$ & $5.015 \quad(22,26 \%)$ \\
\hline Si & $88.814 \quad(92,09 \%)$ & $57.470 \quad(92,26 \%)$ & $16.318(93,14 \%)$ \\
\hline No & $1.950 \quad(2,02 \%)$ & $1.058 \quad(1,69 \%)$ & $383 \quad(2,18 \%)$ \\
\hline En Blanc & $4.599 \quad(4,77 \%)$ & - & $(4,32 \%)$ \\
\hline Nuls & $349 \quad(0,36 \%)$ & - & $(0,28 \%)$ \\
\hline
\end{tabular}

Font: Elaboració pròpia a partir de les dades de Comarca Exprés núm. 2 (15/30 desembre 1976) i Grama núm. 96 (gener 1977).

Com es pot observar, no hi ha diferències apreciables entre les diferents poblacions que estan al voltant de la mitjana de la província de Barcelona. Només a Sant Adrià es pot observar un percentatge una mica més alt de participació. Un periodista molt significat políticament, Enric Juliana, resumia l'esdeveniment amb aquestes paraules:

"Malgrat la imaginació, el voluntarisme, i el gran esforç polític realitzat per l'oposició, i
que també es personalitza en el treball fet per les Assemblees Democràtiques en
difondre la propaganda de l'Assemblea de Catalunya; han guanyat com diuen en el
futbol, l'equip de casa, el "propietario del terreno de juego", en el llenguatge televisiu.
"Ens han menjat el coco", en el de la progresía. Aviat podran dir que els de l'oposició no
son tan demòcrates com ells. Aviat les eleccions. Bon vent i barca nova."1049

El govern Suárez es podia apuntar una victòria amb el referèndum (una victòria aconseguida amb coaccions i no democràticament). Tot i que això no significava exactament que tingués les mans lliures per poder fer lo que li vingués en gana, ja que l'oposició tenia la capacitat encara per convocar mobilitzacions importants. Es va produir, en certa mesura, una mena "d'empat tècnic", com ja va afirmar en el seu moment l'historiador Xavier Domènech ${ }^{1050}$ : al llarg de 1976 l'oposició, malgrat la seva capacitat de mobilització, no va aconseguir fer una vaga general que impliqués una ruptura clara, ni la reivindicació d'un Govern Provisional amb la participació de totes les forces polítiques amb l'encàrrec d'engegar un procés constituent. Els governs franquistes, sobretot el d'Arias en un primer moment, malgrat tenir un important poder coercitiu (en gran mesura

1049Enric Juliana: “Ha guanyat l'equip de casa”, Comarca Exprés, núm. 2 (15/30 desembre 1976), p. 9.

1050Xavier Domènech Sampere: Quan el carrer va deixar de ser seu. Moviment obrer, societat civil i canvi polític. Sabadell (1966-1976), Publicacions de l'Abadia de Montserrat, Barcelona, 2002. 
responsable de les limitacions de l'oposició) tampoc va poder articular una alternativa política que normalitzés la vida política del país i impedís totalment les continues i massives mobilitzacions. El govern Suárez, s'avingué a negociar amb l'oposició per intentar dividir-la i recuperar la iniciativa, conscient que la situació tal com estava no es podia perllongar en el temps. Davant d'això, quina va ser la resposta de l'oposició?

“En aquest context, l'oposició s'avingué a negociar i alguns sectors del règim acceptaren, una mica sense saber cap a on anaven, el procés que portà al canvi polític. En el camí, l'oposició deixà moltes reivindicacions, bàsicament les de caràcter social i la depuració de cossos de l'estat, i la monarquia, única font de legitimitat d'on podia sorgir aquest poder autònom, quedà reforçada com a principal protagonista de la transició."1051

Afegiria jo que es van deixar pel camí, apart d'aquestes reivindicacions esmentades, la del model de l'estat (és a dir, el qüestionament de la monarquia mateixa) i -en determinats casos- les nacionals (la renúncia a defensar el dret d'autodeterminació dels pobles i nacions existents dins l'estat espanyol, defensada aleshores fins i tot pel PSOE). Ara bé, era aquesta la única opció possible?

Tot i que per ser honest he de reconèixer que estic fortament influenciat per una tradició política que ha parlat -i parla- de la "traïció dels líders", sempre he pensat que les coses són més complexes. Des de sectors de l'esquerra revolucionària s'ha parlat molt d'aquesta qüestió, de com uns líders haurien "venut" les aspiracions de les masses en una situació potencialment revolucionària. Sent honest he de dir que per mi és una explicació massa simplista, tot i que pot tenir una part de raó, en el sentit que determinats líders polítics i partits es van desdir de les seves tesis i formulacions anteriors, en especial el PCE-PSUC i el PSOE $^{1052}$ (que van renunciar a la república, a l'autodeterminació i en el cas del PSOE al mateix marxisme) com veurem amb més detall al següent apartat del present capítol, ja fos per una qüestió d'oportunisme polític, por a quedar marginats o per que en el fons mai se les havien cregut. El govern Suárez aquí va mostrar una major

1051Xavier Domènech Sampere: Quan el carrer va deixar de ser seu..., p. 337.

1052 Pel canvi ideològic experimentat pel PCE i el PSOE veure Juan Antonio Andrade Blanco: El PCE y el PSOE en (la) transición. La evolución ideológica de la izquierda durante el proceso de cambio político, Siglo XXI, Madrid, 2012. Més endavant tornaré a citar aquesta obra. 
habilitat que l'anterior en buscar la divisió de l'oposició i en mirar de marginar als comunistes, i cal dir que molts sectors d'aquesta s'hi van avindre, sempre recelosos de l'hegemonia que havien tingut els primers, en ser partidaris d'uns canvis democràtics, si, però no de profundes transformacions socials ${ }^{1053}$.

Malgrat que a Catalunya segurament la situació socio-política estava molt més a prop d'una veritable ruptura, no era així en el conjunt de l'estat (o si més no, no s'estava tant a prop d'un trencament revolucionari com alguns volien creure), per que si això fos així, tampoc s'explicaria la "facilitat" amb la qual es va arribar al pacte amb els sectors reformistes del mateix règim. Ara bé, això tampoc vol dir que l'única opció possible per l'oposició, i en especial pel PSUC-PCE fos la que van triar. Un pot tenir la percepció que encara no es compta amb la força suficient per canviar la situació socio-política i davant això es poden seguir diverses opcions. I una podia haver estat treballar per aconseguir un veritable contrapoder popular, amb l'impuls i suport dels moviments socials de masses. Però aquesta no va ser l'opció escollida, sinó la de mirar de pactar uns mínims, que reconeguessin els més elementals drets democràtics, però que alhora implicava no traspassar determinades línies vermelles, si més no a curt termini: la monarquia, la unitat de l'estat espanyol i el sistema socio-econòmic vigent, és a dir, el capitalisme.

Per què es va fer això? Alguns per que hi creien fortament:

\begin{abstract}
"Miquel Sellarès, representant de CDC a l'Assemblea de Catalunya, ho descrivia amb total sinceritat: "De cara al demà, tot allò que quedi fora del marc dels partits polítics $\mathrm{i}$ les organitzacions sindicals, tot allò que representi una extensió del "poder popular" des de baix, sense sufragi universal, és preocupant.”. Es tractava així que el procés d'institucionalització política de la democràcia comportés, a la vegada, la pèrdua del poder polític que les organitzacions populars havien guanyat durant el franquisme."1054
\end{abstract}

I en conseqüència, determinades forces polítiques van jugar la seva pròpia carta, trencant la política d'unitat que s'havia seguit en instàncies com l'Assemblea de Catalunya o el Consell de Forces Polítiques de Catalunya:

1053Ja vaig criticar anteriorment totes les postures que parlaven de la transició com un procés on no va existir una important mobilització popular, o com un procés dirigit pel monarca o les elits provinents del franquisme. Ara bé, tot i la simpatia política que hi pugui sentir, també se'm fan massa simplistes determinades interpretacions com les que fa Alfredo Grimaldos a Claves de la Transicion... de que tot el procés estava teledirigit per la CIA i l'aparell franquista, sense negar que, efectivament, van mirar de jugar les seves cartes.

1054Xavier Domènech i Sampere: Quan el carrer va deixar de ser seu..., p. 341. 
"Amb la perspectiva oberta de reforma o de canvi de règim, un seguit de formacions amb un paper molt limitat o fins i tot nul en els moviments socials, i amb ideologies $i$ interessos més conservadors, pugnaven per situar-se en la millor posició de cara a un futur previsiblement democràtic i per limitar el paper de l'esquerra política i dels moviments socials." ${ }^{1055}$

En el cas dels socialistes, segurament s'hi van avindre ràpid a aquesta línia per que malgrat el seu radicalisme verbal -que és molt dubtós que els seus dirigents es creguessin realment en vista dels esdeveniments posteriors- n'era perfectament conscient de la feblesa que tenia dins els moviments de masses. Aleshores per què el PCE i el PSUC van acabar cedint? Deixant de banda els interessos personals que poguessin tenir -o no- els seus dirigents, el cert és que calia tenir en compte que la situació que vivia aquest partit i els situats a la seva esquerra no era la mateixa que els altres, car com ja he dit abans, era durament perseguit i reprimit en un context de violència policial i d'impunitat d'atemptats de membres de l'extrema dreta, amb la complicitat, quan no directa implicació, del Ministeri de Governació1056. Mentrestant amb les altres forces -els socialistes malgrat ser il-legals van poder celebrar un Congrés a principis de novembre amb total normalitat- es practicava una política de tolerància, en una clara voluntat de dividir la oposició i controlar el procés de canvi polític.

VÍCTIMES DE LA VIOLÈNCIA POLÍTICA D'ORÍGEN INSTITUCIONAL

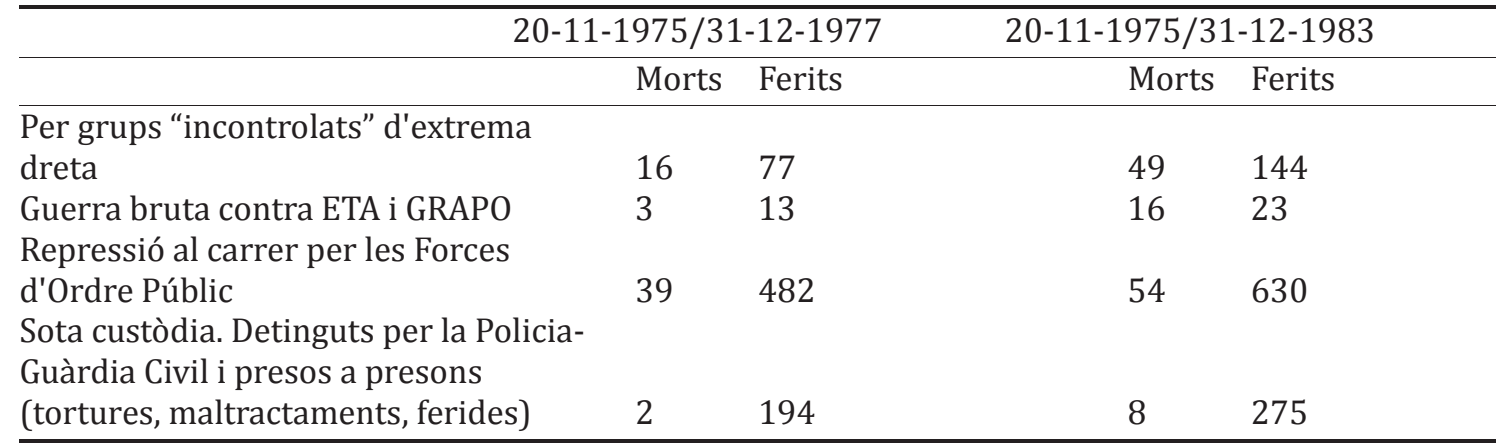

Font: Elaboració pròpia a partir de les taules existents a Mariano Sánchez Soler: La Transición Sangrienta..., p. 304 i 312.

La por a quedar aïllats i marginats d'un procés electoral que es preveia

1055Carme Molinero i Pere Ysàs: Els anys del PSUC..., p. 213.

1056Per un anàlisi sobre la violència durant el procés de canvi polític, veure Mariano Sánchez Soler: La transición sangrienta. Una historia violenta del proceso democrático en España (1975-1983), Península, Barcelona, 2010. 
proper i el paper central que es donava a la presència en aquestes processos electorals -pròpia de l'eurocomunisme-, sens dubte van ser un factor que va condicionar la seva decisió final, de canviar la ruptura democràtica per la reforma pactada. Una decisió, que com veurem més endavant, no va ser ben païda del tot per les bases. Aquest canvi de tendència es pot observar també en els documents del PSUC al Barcelonès Nord. Així un Ple de la secció del PSUC del Centre de Badalona deia al desembre de 1976:

"Un repas a la situació política actual ha de recollir evidentment la qüestió del referèndum, no tant des de la perspectiva d'una valoració de resultats com des del seu significat en relació per un costat a la política del règim i per l'altre en relació a la de la oposició.

La situació del país, i d'això el govern n'és conscient, fa totalment necessària una democràcia estable, i l'elevat \% de vots afirmatius així ho confirmen. En base a aquesta necessitat Suárez ofereix a certs sectors de l'oposició la possibilitat d'arribar a aquesta democràcia estable a partir de la reforma (l'oferta queda però en part desvirtuada per qüestions com, les declaracions de Martin Villa o pel mateix planteig formal del referèndum).

Amb tot està clar que un dels seus objectius -el de dividir l'oposició- l'ha aconseguit en bona part. Les forces de dretes s'han avingut a que la direcció del procés cap a la democràcia la porti el govern, mentre que es preparen per ser hegemòniques després (atenció centrada ja en les eleccions). Per altre cantó ha aconseguit enfrentar [sic] el partit comunista amb les forces de dretes i al mateix tempo distanciar-ho de les forces d'extrema esquerra amb una repressió discriminada i espectacular d'aquestes."1057

El document contrasta notablement amb l'emès el 10 d'octubre pel PSUC badaloní. A més, deixa entreveure una altra debilitat en una altra part titulada significativament "Crida a la militància activa":

"Aquests elements ens ajuden a revisar, el que és avui la nostra presència en la vida política de la ciutat i el nostre grau de militància en el PSUC, que relaxat per una mala comprensió del que és un partit de masses o del que és la flexibilitat dins l'organització podem afirmar que en general és baix (l'assistència de 22 militants a aquesta reunió n'és una prova)." ${ }^{1058}$

1057“Ple de la secció centre del PSUC de Badalona (19-12-1976), ANC, Fons PSUC, 03. Organitzacions de Base, 03.01. Organitzacions territorials, 820, Badalona: Secció Centre del PSUC, p. 1.

1058Ídem, p. 3. 
Tot i que no sabem si això és aplicable a tot el Barcelonès Nord, s'entreveu que no tota la militància del PSUC tenia la mateixa dedicació i compromís necessaris per mantenir una estratègia de lluita i confrontació en un període sostingut. Sigui com sigui el cas es que l'estratègia del PCE-PSUC va canviar, enfocant-se ja no a aconseguir la ruptura democràtica amb la mobilització sinó a forçar al govern de Suárez a pactar uns mínims que incloguessin la seva legalització i participació per no quedar aïllats de la resta de l'oposició, amb gestos com la presència i detenció del mateix Carrillo el 22 de desembre de 1976. Poc després començaven les negociacions entre la restringida "Comissió dels Nou" i el govern, en un context de gran inestabilitat i tensió (segrestos del GRAPO, matança d'Atocha, actuacions de les FOP... ${ }^{1059}$ ). Finalment la Comissió dels Nou va posar uns mínims per participar en les eleccions promogudes pel govern, que no es van acomplir totalment però si en aspectes prou importants ${ }^{1060}$.

NÚMERO DE DETENCIONS PER MOTIUS “POLÍTICO-SOCIALS”, MARÇ-JUNY DE 1977

\begin{tabular}{llll}
\hline Març & 846 & Maig & 862 \\
Abril & 894 & Juny & $232^{*}$ \\
\hline
\end{tabular}

Font: Ministerio de la Gobernación. Boletines de Información reservada.

PROPAGANDA INCAUTADA ENTRE MARÇ-JUNY DE 1976 I MARÇ-JUNY DE 1977

\begin{tabular}{lll}
\hline & 1976 & 1977 \\
\hline Març & 405.915 & 238.445 \\
Abril & 285.409 & 448.763 \\
Maig & 293.935 & 293.281 \\
Juny & 410.044 & $112.565^{*}$ \\
\hline
\end{tabular}

Font: Ministerio de la Gobernación. Boletines de Información reservada. Aquestes gràfiques són una reproducció traduïda al català de les existents a Nicolás Sartorius i Alberto Sabio: El final de la dictadura..., p. 330 i 331, respectivament.

(*) Només fins el 15 de juny.

1059 Més detalls sobre aquest tipus de fets a Mariano Sánchez Soler: La Transición sangrienta : una historia violenta del proceso democrático en España (1975-1983), Península, Barcelona, 2010.

1060En concret les condicions van ser: 1-Reconeixement de tots els partits polítics i sindicats; 2Reconeixement i protecció de les llibertats polítiques i sindicals; 3- Dissolució de l'aparell del Movimiento Nacional i neutralitat política de l'Administració; 4-Amnistía política; 5-Utilització equitativa dels mitjans de comunicació; 6-Negociació de les normes i procediments de les eleccions; 7-Reconeixement de la necessitat d'institucionalitzar políticament els països i regions que integren l'Estat espanyol. Veure Carme Molinero i Pere Ysàs: Els anys del PSUC..., p. 245-246. Va ser molt important, sens dubte, la desarticulació del Movimiento (Llei de l'1 d'abril de 1976) i la legalització de la majoria de partits i sindicats, inclosos el PCE (9 d'abril) i el PSUC ( 3 de maig). Però d'altres condicions no s'havien acomplert el 15 de juny com per exemple la legalització de tots els partits polítics (encara que van poder presentar-se sota l'eufemisme "d'agrupacions d'electors"), l'amnistia o la neutralitat política de l'administració, sense comptar que tampoc estaven del tot reconegudes les llibertats polítiques i sindicals. Només calia veure com encara actuaven les FOP. 
La normativa electoral aprovada el 18 de marc per les eleccions al Congrés i al Senat del 15 de juny va perjudicar clarament a les esquerres en sobrerepresentar les zones rurals, sense comptar que l'UCD va tenir tot l'aparell de l'estat i l'administració al seu favor. El no aconseguir una majoria absoluta i els bons resultats obtinguts per altres forces com el PSOE, va fer que Suárez i els seus haguessin de pactar amb l'oposició un procés constituent que d'entrada no estava previst.

ELS RESULTATS DE LES ELECCIONS GENERALS EL 15 DE JUNY DE 1977

\begin{tabular}{lllll}
\hline & Catalunya & País Valencià & Illes Balears i Pitiüses & Estat espanyol \\
\hline Participació & $79,3 \%$ & $80,6 \%$ & $80,9 \%$ & \\
\hline PSC-PSOE* & $15(28,4 \%)$ & $11(36,2 \%)$ & $2(22,7 \%)$ & $118(28 \%)$ \\
\hline PSUC-PCE & $8(18,2 \%)$ & $2(9,6 \%)$ & $-(4,3 \%)$ & $20(9 \%)$ \\
\hline PDC & $11(16,8 \%)$ & - & - & - \\
\hline UCD & $9(16,8 \%)$ & $13(32,7 \%)$ & $4(49,8 \%)$ & $166(34 \%)$ \\
\hline UD-CC & $2(5,6 \%)$ & - & - & - \\
\hline EC & $1(4,5 \%)$ & - & - & - \\
\hline AP-CC/AP- CD & $1(3,5 \%)$ & $1(5,9 \%)$ & $-(8,6 \%)$ & $-(4,6 \%)$ \\
\hline PSP-US & - & $-(4,6 \%)$ & \\
\hline UDPV & $-(2,6 \%)$ & $-(10,0 \%)$ & \\
\hline PSPV & $-(2,4 \%)$ & & \\
\hline Altres & $-(6 \%)$ & & \\
\hline
\end{tabular}

*El PSC no estava encara unificat amb el PSOE (de fet era el PSC-C, ja que el PSC-R va anar a la coalició PDC. A Catalunya PSC-C i PSOE es van presentar en la coalició "Socialistes de Catalunya".

Font: Elaboració pròpia a partir de fonts diverses: Martí Marín i Corbera: Història del franquisme a Catalunya, p. 345 i Borja de Riquer i Permanyer (dir.): Història, Política, Societat i Cultura dels Països Catalans. Volum 11. De la dictadura a la democràcia 1960-1980, Enciclopèdia Catalana, Barcelona, 1998, p. 280 i 293.

RESULTATS DE LES ELECCIONS GENERALS DEL 15 DE JUNY AL BARCELONÈS NORD

\begin{tabular}{llcl}
\hline & Badalona & Santa Coloma de Gramenet & Sant Adrià de Besòs \\
\hline Participació & $85,7 \%$ & $84 \%$ & $81,9 \%$ \\
\hline PSC-PSOE* & $35,9 \%$ & $45 \%$ & $35,90 \%$ \\
\hline PSUC & $29 \%$ & $31,3 \%$ & $29,58 \%$ \\
\hline PDC & $10,7 \%$ & $3,4 \%$ & $4,45 \%$ \\
\hline UCD-CC & $9,4 \%$ & $10,4 \%$ & $14,94 \%$ \\
\hline UD-CC & & $2,42 \%$ \\
\hline EC & $1,3 \%$ & $2,8 \%$ & $2,65 \%$ \\
\hline AP-CC & & \\
\hline FUT & $1,02 \%$ & $1,43 \%$ \\
\hline CUPS & $0,32 \%$ & $1,41 \%$ \\
\hline CE-CC & & $3,54 \%$ \\
\hline PSP-US & & \\
\hline Altres & & \\
\hline
\end{tabular}

*El PSC no estava encara unificat amb el PSOE (de fet era el PSC-C, ja que el PSC-R va anar a la coalició PDC. A Catalunya PSC-C i PSOE es van presentar en la coalició "Socialistes de Catalunya". 
Elaboració pròpia amb fonts diverses (Comarca Expres núm. 14 (2ona quinzena juny 1977), Grama núm. 102-103 (juliol-agost 1977) i altres). Tot i així, em continuen faltant dades.

Els resultats catalans havien estat notablement diferents als de la resta de l'Estat. Fet que alguns van qualificar com de "ruptura catalana"1061. Sense esmentar que al Barcelonès Nord el biaix cap a l'esquerra és encara més notable. Sens dubte va ser aquest resultat diferent el que va permetre que fos a Catalunya l'únic lloc on es donés el restabliment d'una institució que enllaçava amb la legalitat republicana anterior al cop d'estat del juliol de 1936: la Generalitat i el retorn de Tarradellas, si bé també el govern de l'Estat i altres forces polítiques van jugar aquí a fer aquesta maniobra per minimitzar el poder del PSUC aprofitant-se del mateix anticomunisme del vell president de la Generalitat a l'exili ${ }^{1062}$. Tot fos per que a Catalunya no es formés un govern d'unitat amb una hegemonia clara de les esquerres $^{1063}$.

Els esdeveniments se succeïren amb una certa rapidesa, amb els Pactes de la Moncloa l'octubre de 1977 on els partits d'esquerres van cedir a un "pacte social" que posava sota les esquenes de la classe treballadora els esforços per superar la situació de crisi econòmica a canvi d'unes promeses de reformes socioeconòmiques mai acomplertes en la seva totalitat ${ }^{1064}$. Posteriorment es va iniciar el procés d'elaboració de la nova Constitució, on encara que alguns investigadors han afirmat que es va poder parlar lliurement de $\operatorname{tot}^{1065}$, no es pot obviar que els poders

1061 Andreu Mayayo i Artal: La Ruptura catalana : les eleccions del 15-J del 1977, Catarroja, Afers, Barcelona, 2002.

1062 La restauració de la Generalitat Provisional seria conseqüència d'una negociació a tres bandes entre el govern Suárez, el mateix Tarradellas i l'oposició antifranquista. Un decret Llei de 29 de setembre va restaurar provisionalment la Generalitat, derogant la llei franquista de 1938 però sense restaurar automàticament l'Estatut de 1932. Alhora el 17 d'octubre Tarradellas era nomenat President de la Generalitat Provisional i de la Diputació de Barcelona. Tarradellas per exemple no va voler reconèixer a l'Assemblea Provisional de Parlamentaris Catalans que s'havia constituït després del $15-\mathrm{N}$, tot i que finalment, en substitució d'aquesta, es crearà un Consell Consultiu amb la presència de les forces polítiques principals. Veure Carme Molinero i Pere Ysàs: Els anys del PSUC..., p. 278 i 281-282.

1063 Nicolás Sartorius i Alberto Sabio: El final de la dictadura..., p. 728.

1064Es va decidir mantenir l'augment dels salaris per sota de la inflacció i això va ocasionar la pèrdua d'un $7 \%$ del poder adquisitiu de la classe treballadora. Sebastian Balfour: La dictadura, los trabajadores y la ciudad..., p. 252.

1065Pere Ysàs: "Ni modèlica ni immodèlica. La transició des de la historiografia", Franquisme \& Transició. Revista d'història i cultura núm. 1 (2013), p. 286. L'autor afirma que es va poder parlar de tot en els debats constituents: de república, d'autodeterminació, de "nacionalitats" (significatiu que no es digui "nacions") de franquisme i antifranquisme.... Però una cosa és el que es parli en un cercle reduït i una altra molt diferent el que es deixa expressar-se en un debat públic al conjunt de la societat. La persecució de símbols independentistes i republicans 
fàctics no estaven disposat a acceptar-ho tot, que l'exèrcit va imposar l'article segon on es remarcava la "indissolubilitat de la nació espanyola", que havien unes línies vermelles, ja esmentades (monarquia, unitat de l'estat i model capitalista) que no es podien traspassar, i, que mentre uns parlaven "lliurement", altres, els que no van acceptar el "consens", van ser durament reprimits, fessin o no lluita armada, en un context on les bandes ultradretanes i la violència policial continuaven operant amb total impunitat ${ }^{1066}$.

No puc entrar aquí en un debat amb profunditat sobre com va ser el procés constituent i de les renúncies i canvis que van tenir els partits majoritaris d'esquerres (d'això si que en parlaré -parcialment- al proper apartat), però si que es pot observar com les delegacions locals d'aquests partits van fer seves les consignes que arribaven "de dalt", no sense debat i crítica, per bé que la disciplina de partit s'acabava imposant. Per una banda es donaven visions massa optimistes de la nova constitució mentre que alhora es matisava:

\begin{abstract}
"Una de las tareas más importantes que tenemos en estos momentos es el estudio de la Constitución, para tener claro lo que representa no solo de ruptura con las leyes franquistas y su propio Estado dictatorial y centralista sino también los aspectos positivos, incluso progresistas, que en ella se contemplan, su carácter abierto incluso a ciertas transformaciones en lo económico, la defensa de los derechos humanos y la juventud, el reconocimiento de la mayoría de edad a los 18 años, el carácter plurarista de España, con el reconocimiento nacional de Cataluña, Euzkadi i Galicia.

Pero aun siendo una Constitución abierta y democrática hemos de explicar a la población los aspectos negativos ayudando a que se comprenda que no es la Constitución de los Comunistas sino la acordada, por todas las fuerzas políticas parlamentarias en una correlación de fuerzas determinada." ${ }^{1067}$
\end{abstract}

El contrast de com s'estava duent el procés de canvi polític en la realitat respecte al predicat en anys anteriors serà un dels factors -entre d'altres- causants del que es va anomenar posteriorment el desencanto. D'aquest en parlaré més endavant, però no puc concloure aquest apartat sense esmentar el paper que va

en l'espai públic n'és un exemple de com hi havia temes que no es podien tractar públicament amb llibertat fora d'aquests espais restringits. I, repeteixo, una cosa es poder-ne parlar de determinats temes i altra cosa que el poder et reconegui la possibilitat real d'aplicar alguna de les propostes de les que es parla.

1066De nou em remeto a l'estudi de Mariano Sánchez Soler: La Transición Sangrienta... 1067"A todas las agrupaciones del PSUC de Sta. Coloma” (28-10-1978), ANC, Fons PSUC, 03.01.937. Santa Coloma de Gramenet. Comitè Local del PSUC, 1970-1988. 
tenir el moviment veïnal en tot aquest procés. Va ser a nivell local on les nombroses mobilitzacions que es van produir en aquest període, ja fossin per demandes més polititzades o per reivindicacions més del dia a dia van deixar astorades les autoritats franquistes dels diferents municipis. Amb la seva pràctica diària de lluita i de denúncia havien fet molt per l'extensió d'uns valors democràtics i també d'uns altres crítics amb el sistema econòmic vigent, que qüestionaven fortament el capitalisme i la figura dels empresaris. No s'ha de menystenir tampoc l'extensió dels valors feministes en les classes populars fetes a través de les Vocalies de dones i Associacions de dones, malgrat que la crisi de les AVV's també les va afectar en un primer moment ${ }^{1068}$. Va ser certament el moviment veïnal -i no el moviment obrerel que va posar en més dificultats a les autoritats franquistes locals del Barcelonès Nord durant el procés de canvi polític. Només cal veure uns quants exemples: després de les eleccions del 15-J, el 31 d'agost es feia una reunió entre el Governador Civil José Maria Belloch i els alcaldes “cabezas de partido judicial”, i parlant de qüestions d'ordre públic, l'alcalde de Sabadell no podia ser més explícit:

"El Alcalde de Sabadell piensa que no conviene cargar en exceso a los Alcaldes la responsabilidad de las actuaciones de la FOP por razón de vulnerabilidad de la figura de los mismos; los Alcaldes son reiteradamente atacados por la mayoría de sus actuaciones, si, además, se añade la de las actuaciones de orden público, su figura saldrá más deteriorada, añade es preferible que la responsabilidad última de las acciones la asuma el Gobernador. ${ }^{1069}$

No és per casualitat que les eleccions municipals no es fessin fins l'abril de 1979, ja que el govern de Suárez era conscient de la seva feblesa en aquest àmbit $\mathrm{i}$ de l'hegemonia que podien tenir les esquerres. Malgrat l'inici d'una certa crisi dins

1068Un exemple d'això es pot veure en un informe fet per una militant del PSUC de Santa Coloma de Gramenet, Anna González, fet el març de 1978, al voltant de la situació de les dones del partit i en les organitzacions de masses. En aquest segon cas s'esmenta l'abandó de les dones del partit de les vocalies de dones de les AVV's durant la crisi d'aquestes així com la desaparició de la Coordinadora de Vocalies de Dones justament a l'estiu de 1977. Veure "Santa Coloma de Gramenet", (3-5-1978), ANC, Fons PSUC, 03.03.937. Santa Coloma de Gramenet: Comitè Local del PSUC, 1970-1988. També és imprescindible en aquest aspecte la recerca, ja citada, d'Eva Fernàndez Lamelas: Vocalies de Dones de Barcelona a la Transició Democràtica: una experiència emancipadora. Tesina de doctorat. Cerdanyola del Vallès: Universitat Autònoma de Barcelona, 2009 i la Tesi Doctoral en curs titulada El feminisme de les classes populars als barris. Vocalies i grups de dones (1975-1990).

1069 “Reunión con Alcaldes de poblaciones Cabezas de Partido Judicial” (31-8-1977), AHGCB, Fons Gobernadores Civiles, Caixa 444, p. 2. 
el moviment veïnal un cop es van legalitzar els partits polítics el cert és que les mobilitzacions continuaren. Només cal veure un exemple de les que es van produir a Badalona durant aquell mateix estiu: entre l'1 de juliol i el 29 de setembre de 1977 es van produir més de 30 mobilitzacions veïnals en els diferents barris de la ciutat $^{1070}$. Els Alcaldes es van veure desbordats i no ens hauria d'estranyar que poc després enviessin una carta al Governador Civil on denunciaven el seu "abandonament".

“(...) y desde el 15 de junio pdo. la situación de Alcaldes y Consistorios creemos resumirla en cuatro palabras: total soledad y total olvido; soledad y olvido por parte del Gobierno, diríamos más: una inaceptable despreocupación que no solo no ha apoyado nuestra delicada situación, sino que no ha roto ninguna lanza contra quienes -y son cuantos quieren- intentan con su proceder responsabilizar a los Ayuntamientos actuales del resultado de una gestión política que ha durado 40 años. Numerosos grupos de los más extremistas carismas lo materializan con el ataque a la persona de los Alcaldes y a la de los miembros de la Corporación." ${ }^{1071}$

Això sense comptar diversos intents de dimissió de determinats consistoris, com va ser per exemple el cas de Badalona ${ }^{1072}$. Van ser significatius els assumptes que els mateixos Alcaldes denunciaven: unes mobilitzacions molt freqüents on les autoritats municipals eren denunciades i "insultades i humiliades" (en les seves paraules) en una situació on l'ordre públic es trobava en crisi, amb continus atacs de la premsa, amb uns funcionaris municipals també agitats i sindicant-se, amb un conjunt de la població que els exigia solucions per als seus problemes agreujats amb la crisi econòmica amb l'afegit del total desconeixement de quan es celebrarien unes futures eleccions municipals. Pel que fa a la seva relació amb els partits polítics i les associacions de veïns, són rellevants aquestes paraules:

“5‥- Los representantes de los partidos políticos, ganadores de las últimas elecciones, imponen su presencia en los Ayuntamientos en forma de comisiones informativas de control, con el consiguiente condicionamiento de nuestra actuación.

1070Dirección General de la Guardia Civil: [Informe remés al Governador Civil sobre les mobilitzacions veïnals de la ciutat] (26-9-1977), AHGCB, Fons Gobernadores Civiles, Caixa 357, Ayuntamiento de Badalona, 1976-1978.

1071[Carta adreçada per diversos Alcaldes al Governador Civil] (10-10-1977), AHGCB, Fons Gobernadores Civiles, Caixa 328, p. 1.

1072Veure Enric Giralt: "Badalona: els partits amb el governador" i "El governador no accepta les dimissions de Badalona", Avui, 1-7-1977 i 7-7-1977. 
60.- Las Asociaciones de vecinos -y totalmente al margen de los partidos políticos- no sólo quieren imponer comisiones de control si no que pretenden que por parte de las actuales corporaciones, aquellas sean institucionalizadas." ${ }^{1073}$

Sobre aquest fet, la relació que tenien els diferents partits polítics amb el moviment veïnal i com concebien aquest en parlaré tot seguit -abans de fer un recordatori de les lluites més importants- ja que va ser una qüestió que va condicionar, juntament amb altres motius, l'evolució posterior del moviment popular ciutadà.

\subsection{Les organitzacions polítiques i la seva visió del moviment veïnal. Gèrmens de la futura crisi? La demanda d'ajuntaments democràtics i poder popular.}

En efecte, ja determinades organitzacions polítiques havien fet les seves primeres valoracions sobre com s'havia de treballar als barris als anys seixanta, tal com hem vist en capítols anteriors, però sens dubte va ser durant els anys setanta quan es van fer les anàlisis i teoritzacions més destacades sobre aquest tema. Lògic, tenint en compte que serà ara quan determinades organitzacions polítiques reconegueren la importància d'aquest àmbit d'actuació i el situaren en un nivell comparable al d'altres moviments com l'obrer o l'estudiantil. Així, en funció del paper que atorgaven les diferents organitzacions polítiques a les lluites de masses o moviments socials (i la funció que havien de tenir en el seu model de societat) serà la implicació i valoració -durant aquest període- respecte el moviment veïnal. Ara bé, aquest fet tindrà diferents gradacions i una gran complexitat, ja que per exemple, alguns autors matisen que les diferents organitzacions polítiques tinguessin una visió clara del paper a jugar pel moviment popular, apart de la seva instrumentalització:

"La importancia y oportunidad del movimiento vecinal de los setenta no supone que las diferentes corrientes de izquierda tuvieran una percepción clara de cual debería

1073[Carta adreçada per diversos Alcaldes al Governador Civil] (10-10-1977), AHGCB, Fons Gobernadores Civiles, Caixa 328, p. 2. 
ser su papel en una estrategia de transformación. En muchos casos predominaba una visión instrumental del mismo nuevo espacio de intervención con cobertura legal y agitación para ampliar las contradicciones y conflictos que pudieran llevar a la ruptura democrática o a la revolución socialista (según el radicalismo de los diversos partidos políticos), pero faltaba en muchos casos una reflexión profunda de su papel en un proceso democratizador real." ${ }^{1074}$

També cal estar atent a les evolucions internes de les diferents forces, ja que hi haurà canvis de tàctica que es traslladaran directa o indirectament a l'espai veïnal, juntament amb el fet que alguns dels seus militants no seguiran al peu de la lletra les consignes fetes per les direccions.

En aquest apartat em centraré sobretot en el període que va des de l'any 1976 fins l'any 1979, quan es van fer les primeres eleccions municipals democràtiques després de la dictadura. Crec que és molt important l'anàlisi i valoració de la visió de les diferents organitzacions polítiques respecte al moviment veïnal i al paper que havien de jugar en el nou context polític, ja que al meu parer això és un dels motius que va condicionar la crisi del moviment veïnal que ja es va intuir en aquest període, amb una, diguem-li, "pre-crisi" a partir de l'any 1977. Cal dir, però, que aquest no va ser l'únic motiu que va provocar la davallada del moviment popular ciutadà, com tindrem temps de veure. Tot això ens permetrà valorar des de una altra perspectiva quin va ser el pes dels partits polítics i dels seus militants dins el moviment veïnal.

Sens dubte, qualsevol anàlisi que es faci ha de comptar amb el paper i visió del moviment veïnal que va tenir el principal partit de l'antifranquisme català: el PSUC. De fet ja vam veure com ja als anys seixanta va fer les seves primeres valoracions respecte del moviment als barris. Però com la majoria, va ser als setanta quan va engegar les seves accions més decisives, en un primer moment dins les Comissions de Barri però finalment apostant d'una manera més clara per les Associacions de Veïns. Pel que fa al Barcelonès Nord aquest fet s'havia fet més evident sobretot a partir de 1974 i 1975. Quin havia de ser el paper del moviment veïnal en la futura democràcia segons el PSUC? En principi, les AVV's eren

1074Albert Recio i Andrés Naya: "Movimiento vecinal: claroscuros de una lucha necesaria", Mientras Tanto núm. 91-92 (estiu-hivern 2004), p. 65. 
considerades una peça important per l'assoliment d'aquesta en l'àmbit local, sintetitzada en la demanda d'ajuntaments democràtics que va ser una de les reivindicacions del mateix moviment. Ara bé, fins i tot abans de la rectificació de la línia de ruptura democràtica del PSUC feta a l'hivern de 1976-1977 i l'acceptació de la reforma pactada des d'un dels ideòlegs del PSUC ja es van deixar clars quins eren els límits de les seves propostes ${ }^{1075}$. En cap cas les AVV's eren considerades els organismes de canvi democràtic i no havien de ser uns organismes de contrapoder popular que poguessin condicionar el poder polític de l'administració local. Els seus més importants teòrics al respecte, reconeixien que serien un important instrument de promoció democràtica i de mediació amb el poder polític local, i que tindrien continuïtat en el nou context polític:

“El papel del movimiento popular ciudadano no se agota con el cambio democrático.

No se trata que después desaparezca porque ya habrá ayuntamientos democráticos y partidos políticos. Todo lo contrario, debe continuar para profundizar la democracia, para articular la democracia representativa con la base."1076

Però al mateix temps hi reflectien els seus límits i pors:

“Las organizaciones populares deberán reconstruir su espacio propio y no suplantar a los partidos (algunos hablan incluso de presentar candidatos a las elecciones municipales, lo que significaría una crisis irreversible para muchas Asociaciones). Es evidente que el protagonismo que tenían hasta ahora ya no podrá darse. Pero también se corre el riesgo de que los Ayuntamientos elegidos y los partidos políticos dilapiden un capital democrático con el que se ha llegado y hecho posible la democracia."1077

Aquestes pors i, fins i tot en alguns casos, contradiccions, no es poden desvincular, al meu parer, de l'evolució que va anar seguint el PSUC en el transcurs del procés de canvi polític. El més important va ser, sens dubte, l'avinentesa a negociar la reforma pactada amb el govern Suárez seguint la línia del PCE, que va renunciar a aconseguir la ruptura democràtica -que implicava la instauració d'un govern provisional encarregat de l'articulació d'un nou model d'estat democràticquan va veure que aquesta era una opció molt més difícil d'aconseguir del que es

1075 La cita de Jordi Borja referenciada a l'inici d'aquest capítol és prou significativa: "Les associacions avui i demà", Arreu núm. 1 (25-26 d'octubre de 1976), p. 32-33. Veure nota 953. 1076Marçal Tarragó, Ricard Boix i Jordi Borja: Por una política municipal democrática, Centre d'Estudis d'Urbanisme-Avance, Barcelona, 1977, p. 141. 1077 Ídem. 
pensaven (sobretot a partir de la jornada de vaga del 12 de novembre de $1976 \mathrm{i}$ dels resultats del referèndum de desembre) ${ }^{1078}$. També hi ha una altra opció que cal tenir en compte, que era el pes prioritari que es donava a la lluita institucional en les formulacions de l'eurocomunisme. Ja sabem que al PSUC va ser un dels llocs on finalment aquesta concepció va acabar tenint més contestació fins arribar al Vè Congrés de 1981, però això va ser un procés progressiu, en la mesura que va anar creixent el descontent de la militància per la deriva de pactes i renúncies que es van fer en el procés de canvi polític en un context d'una dura crisi econòmica que va colpejar durament les seves bases militants. Tal com afirma Juan Antonio Andrade pel cas del PCE:

\begin{abstract}
"Para una parte importante de los militantes se trató de cesiones digeribles tomadas una a una en su momento, pero insoportables vistas en su conjunto después de cinco años (...). Además un problema añadido, si acaso no superior, fue el de cómo se promocionó por parte de la dirección esta política, el de cómo fue justificada o más bien racionalizada. Lejos de presentar algunas de estas cesiones como repliegues impuestos por la adversidad de las circunstancias, como derrotas en última instancia, el PCE hizo de la necesidad virtud, y las presentó como decisiones positivas perfectamente coherentes con la estrategia y los valores del partido, lo cual al final las hizo más insufribles para unos y otros."1079
\end{abstract}

Però abans d'avançar esdeveniments, és interessant anar a la font primària, al que deien al respecte els mateixos documents del PSUC. Al Juliol, la Comissió del Moviment Popular i Política Municipal del Comitè Central, encapçalada per Jordi Borja (antic membre de Bandera Roja i teòric dels moviments populars urbans) elaborava un document titulat "Política municipal i moviment popular", que va ser discutida a la reunió del Comitè Central dels dies 30 i 31 de juliol de 1977, setmanes després de que les eleccions haguessin deixat al PCE en un discret tercer lloc -i una mica millor al PSUC en el context català. En aquesta s'intentava clarificar les diferents funcions que havien de tenir els partits polítics i les associacions de veïns en el nou context obert:

“Primer, la construcció de la democràcia cal fer-la sobre la base d'eleccions, partits

1078Juan Antonio Andrade Blanco: El PCE i el PSOE en (la) transición. La evolución ideológica de la izquierda durante el proceso de cambio político, Siglo XXI, Madrid, 2012, p. 67. 1079Juan Antonio Andrade Blanco: El PCE i el PSOE en (la) transición..., p. 373-374. 
polítics i llibertats públiques. És a dir, no creant situacions que de fet no corresponen a una relació de forces real i que poden desestabilitzar la situació i afavorir els sectors més reaccionaris. En la perspectiva de les eleccions el protagonisme dels partits polítics passa a primer pla i cal, doncs, desenvolupar al màxim la presència i la iniciativa del PSUC a nivell municipal." ${ }^{1080}$

Aquesta importància donada als partits polítics es significativa en un context d'ofensiva contra els Ajuntaments franquistes. Si bé no es va demanar des de el PSUC la seva dimissió immediata ni la creació de Comissions Gestores fins les primeres eleccions municipals, sinó la creació d'una mena de Comissions de Partits per actuar en l'àmbit Municipal on, i això crec que és significatiu, s'afirmava que les Associacions de Veïns no hi haurien de participar, tot i que no s'excloïa que tinguin relacions o fins $\mathrm{i}$ tot puguin enviar delegats en les reunions que aquestes Comissions de partits tinguessin amb les autoritats municipals. Es reiterà que la funció de les AVV's era presentar les reivindicacions col-lectives dels barris i destacava el fet que partits i associacions havien de convergir en uns elements comuns en aquest període i no enfrontar-se mútuament. Però no només això. A continuació s'afirmava què:

"Avui hi ha el perill que les associacions de veïns no siguin cada cop més instrumentalitzades per grups que pretenguin d'aquesta manera intentar compensar la seva escassa incidència política. Hom parla fins i tot que determinades federacions 0 associacions de veïns presentin candidats propis a les eleccions municipals. El mètode més adequat per superar aquestes situacions és que els partits majoritaris, especialment els d'esquerra, estiguin presents a les associacions de veïns. El PSUC, que ha tingut un paper fonamental en el desenvolupament del moviment popular i ciutadà, avui ha de multiplicar la seva presència a les associacions i entitats ciutadanes.

També cal establir formes de cooperació que facin impossible la demagògia fàcil que vol oposar associacions de veïns i partits polítics. Tant pel que fa referència a les tasques de les Comissions Municipals com respecte als criteris de la Llei Electoral Municipal és important aconseguir que les associacions de veïns i entitats n'estiguin assabentades i trobar punts de coincidència. I encara més respecte als problemes urbans i socials locals." ${ }^{1081}$

1080PSUC: “Política municipal i moviment popular” (juliol 1977), CEDOC-UAB, FO 10/033, p. 1-2. 1081Ídem, p. 7-8, Dins el subapartat "Relació amb les entitats ciutadanes i les associacions de veïns". 
Aquí s'entreveu la por a que formacions situades a la seva esquerra, de les quals parlaré posteriorment, poguessin -després del seu fracàs electoral- fer servir les associacions per impulsar polítiques diferents a les seves o per crear algun tipus de poder polític que competís amb el dels recentment legalitzats partits. Però en el fons, el que quedava implícit era -tal com havia dit el mateix Jordi Borja a l'octubre de 1976- que no es volia que les AVV's poguessin constituir una mena de contrapoder popular a nivell local que pogués competir amb el dels partits polítics i les institucions locals en un model molt centrat, com en la democràcia formal que s'estava construint aleshores, en els partits.

No obstant, això no significava que es volgués que aquest tipus d'entitats deixessin d'existir, sinó que tinguessin una funció molt concreta, que poguessin interactuar amb els partits polítics i amb el futur Ajuntament democràtic i fins i tot que poguessin fer les seves reivindicacions, però això si, sempre i quant no qüestionessin l'organització concreta del poder polític local que s'estava configurant aleshores. El mateix document reconeixia l'existència d'una crisi dins el moviment veïnal, causat per una preeminència dels partits polítics que havia causat l'abandó del moviment popular per part dels militants, un aspecte que també vaig trobar en documents locals del Barcelonès Nord ${ }^{1082}$. Per això es feia un esforç de justificació del paper i la importància que encara podien desenvolupar les AVV's -amb les limitacions abans exposades- en el nou context polític local:

"Cal dir, en segon lloc, que moltes de les associacions i organitzacions populars, de caràcter pluralista i reivindicatiu, són avui tan o més indispensables que ahir. Per exemple, l'existència de partits polítics i aviat d'Ajuntaments democràtics no exclou, ans al contrari, l'existència de les associacions de veïns com a organitzacions de base, de caràcter reivindicatiu i socio-cultural especialment, interlocutors principals de l'Administració local. No s'ha d'abandonar aquest espai a la passivitat ni a l'esquerranisme. Les entitats ciutadanes i les associacions de barri no es confonen amb els partits polítics (que tenen propostes globals i opten, mitjançant les eleccions, a la presència en la direcció de les institucions polítiques), i no poden ser mai una caixa de ressonància de cap d'ells". ${ }^{1083}$

1082 Anna González: "Santa Coloma de Garmanet [sic]" (3 maig 1978), ANC, Fons PSUC, 03.01.937. Santa Coloma de Gramenet: Comitè Local del PSUC, 1970-1988. Es tracta d'un informe sobre la situació del moviment de la dona a Santa Coloma. Quan parla de les vocalies existents en els diferents barris colomencs, diu textualment: "Les dones del P. Les varen abandonar en el moment de la crisis de les AA.VV.".

1083PSUC: "Política municipal i moviment popular" (juliol 1977), CEDOC, FO 10/033, p. 9-10, dins 
I alhora es feia una exhortació a no abandonar les AVV's i potenciar-les. Però malgrat que en el text es parla sovint de la independència que han de tenir aquest tipus d'associacions, el PSUC no tenia problemes en exposar el que no havien de fer fent referència a uns esdeveniments succeïts al Barcelonès Nord:

"El PSUC té avui una doble responsabilitat: contribuir a crear institucions democràtiques, buscant la màxima cooperació entre totes les forces polítiques, i posarse al capdavant de les lluites reivindicatives de les classes populars. Aquesta funció no la podem defugir en cap moment, ja que correspon al caràcter de classe del Partit, a la seva base social. A més, si no ho féssim, esclatarien igualment lluites, més minoritàries, menys dirigides, que poden caure fàcilment en la provocació. El clima de violència que ja s'ha creat en alguns moments al voltant de determinats conflictes laborals i urbans (per exemple, a Santa Coloma) és un exemple del perill que comporten situacions conflictives que no tenen al capdavant forces responsables." ${ }^{1084}$

La necessitat de l'existència de les AVV's, la delimitació de funcions de partits polítics i aquestes, així com la voluntat d'evitar que militància i simpatitzants pensessin que els partits les havien de suplantar, seran unes idees en les que insistirà el mateix Jordi Borja en altres documents ${ }^{1085}$. Igual que la independència que havien de tenir les entitats veïnals respecte els partits, fins i tot quan els membres del PSUC participessin a les Juntes o en fossin Presidents. Una proclama fàcil de fer però no tan senzilla de respectar en la seva totalitat.

Arribem així al IV Congrés del PSUC, celebrat entre el 29 d'octubre i l'1 de novembre de 1977. És a dir, passades les eleccions a generals i amb els Pactes de la Moncloa recentment signats, seguint la tàctica de moderació i pacte social imposada per Santiago Carrillo al PCE. Pel que fa als documents referents sobre el moviment popular ciutadà, podem veure com es recullen idees expressades en els textos anteriors. És interessant veure en aquest sentit la proposta de ponència "Política del Partit davant del treball organitzat dels ciutadans en les associacions i entitats":

l'apartat "El PSUC i el moviment popular". 1084Ídem, p. 13-14, dins l'apartat "El PSUC i el moviment popular". 1085 Jordi Borja: "Comissions de partits i associacions de veïns", Treball núm. 493 (11-9-1977), p. 11; Francisco Herrera i Víctor Claudín: Socialistas y comunistas ante las elecciones municipales, Zero Zyx, Bilbao/Madrid, 1978 (hi ha una entrevista a Jordi Borja a les p. 67-87). 


\begin{abstract}
"Per això les entitats han de trencar amb la seva tradicional, sota la dictadura, actuació sustitutòria [sic] dels partits polítics i reconquerir el seu espai específic delimitat pels objectius que a cada una la defineixin. Sols una recuperació dels propis objectius permetrà a les entitats que fins ara han jugat a altres papers el que apareguin dins la vida popular i ciutadana amb la seva veritable faceta." ${ }^{1086}$
\end{abstract}

Tanta insistència en la separació de funcions es simptomàtica -al meu parerde la voluntat clara ja esmentada de no constituir cap doble poder o un poder popular que li pogués fer ombra. Un altre paràgraf significatiu és aquest, que incideix en un aspecte ja comentat: l'abandó dels militants dels partits polítics de les AVV's per dedicar-se a altres tasques, com per exemple, les campanyes electorals:

\begin{abstract}
“Agreujant les consideracions ja fetes, en moltes entitats s'ha donat l'absència en els darrers mesos dels militants de les organitzacions polítiques que hi participaven. Aquest ha estat un error que hem d'aconseguir esmenar no sols els militants del nostre partit, sinó en general els militants de tots els partits democràtics. A les entitats els hi cal l'alicient que representa el debat des de les diferents òptiques polítiques dels seus propis problemes i totes elles es beneficiaran de la incorporació de socis que ajudin a conscienciar al reste d'associats en funció de les implicacions polítiques dels objectius polítics de l'entitat."1087
\end{abstract}

I per això es tornava a demanar la incorporació dels militants del PSUC a les associacions -això si- adequant els objectius d'aquestes a la nova situació política i a com la interpretava aquest partit.

Existeix un altre document interessant al respecte dintre de la documentació del IV Congrés: la "Ponencia de la Comisión Política Municipal y Movimiento Popular del Comité Central". Apart de parlar del paper que han de tenir els nous Ajuntaments Democràtics, dedica una especial atenció a parlar dels moviments populars de barris, ciutats i comarques recollint les mateixes aportacions ja

1086"Política del Partit davant del treball organitzat dels ciutadans en les associacions i entitats (Proposta de ponència pel IV Congrés)" (29 d'octubre de 1977], CRAI-Pabelló de la República, Fons DDP (Sèrie Documents Partits Polítics, Subsèrie PSUC, Caixa DDP (PSUC). 2, Carpeta 1Partit Socialista Unificat de Catalunya. Congrés (4art. : 1977: Barcelona), p. 1.

1087“Política del Partit davant del treball organitzat dels ciutadans en les associacions i entitats (Proposta de ponència pel IV Congrés)" [1977], CRAI-Pabelló de la República, Fons DDP (Sèrie Documents Partits Polítics, Subsèrie PSUC, Caixa DDP (PSUC). 2, Carpeta 1-Partit Socialista Unificat de Catalunya. Congrés (4art. : 1977: Barcelona), p. 2. 
esmentades. És a dir, la necessitat de que continuïn existint en el nou context polític delimitant clarament les seves funcions. Es recull també que la importància que tenien aquests moviments en si com a moviments reivindicatius però també es feia una reflexió en la importància que tenien en un context de lluita de classes:

\begin{abstract}
"En segundo lugar, cometeríamos los comunistas un grave error si no diéramos la importancia que tienen a estos movimientos y organizaciones populares, porque abandonaríamos un terreno de la lucha de clases, terreno en el que la clase obrera y el conjunto de clases populares también se organizan y luchan por sus intereses inmediatos y en el que se pueden desarrollar una política y unos valores socialistas." ${ }^{1088}$
\end{abstract}

S'insistia de nou en la complementarietat que havien de tenir els moviments populars amb els ajuntaments democràtics governats per l'esquerra:

\footnotetext{
"Por otra parte, de poco nos serviría, a nosotros y al conjunto de la izquierda, pretender ocupar la dirección de las instituciones locales si no lo hacíamos apoyados en vastos movimientos populares que nos ayuden a precisar los objetivos y las prioridades de la política municipal y proporcionen además una base de apoyo social sólida para llevar a cabo una política renovadora." ${ }^{1089}$
}

Així que es tornava a repetir que els militants i simpatitzants no abandonessin les associacions, si no que tinguessin una presència activa dins el moviment popular, en les seves paraules "no per donar-li una direcció de partit, sinó per desenvolupar-lo en un sentit unitari"1090. Però seguint la concepció que el PSUC creia que havien de tenir, és a dir, que fossin veritables moviments de masses amb un funcionament democràtic, que tinguessin uns fins específics, és a dir, pel que fa a les AVV's que recollissin les reivindicacions dels barris plantejant els problemes amb realisme polític, i que reconeguessin la legitimitat de principi de la nova administració local democràtica. Segons aquest paràmetre qualsevol reivindicació i mobilització que fes el moviment popular havia de cenyir-se a unes normes concretes que, -es pressuposa- no havien de ser les mateixes que s'havien

1088“Ponencia de la Comisión política municipal y movimiento popular del Comitè Central” [1977], CRAI-Pabelló de la República, Fons DDP (Sèrie Documents Partits Polítics, Subsèrie PSUC, Caixa DDP (PSUC). 2, Carpeta 1-Partit Socialista Unificat de Catalunya. Congrés (4art. : 1977: Barcelona), p. 3.

1089Ídem.

1090 Ibídem. 
fet servir en el passat contra els Ajuntaments franquistes:

“(...) Un Ayuntamiento democrático y un movimiento popular democrático y un movimiento popular organizado deben exigirse mutuamente diálogo, negociación y cooperación, salvaguardando la independencia de cada uno, lo cual representa un cambio muy importante para los hábitos de los unos y de los otros." ${ }^{1091}$

El document continuava amb un apartat dedicat a la "democràcia de base i el desenvolupament socialista de la democràcia política". Però pel que fa a la democràcia de base, tot i reconèixer la importància de l'existència d'interlocutors socials múltiples i autònoms, el foment i la promoció dels moviments populars i la interacció dels partits i institucions amb aquests, no es preserven espais de decisió política, de gestió o cogestió per aquests el el model que es defensa:

“(...) 4. Consideramos indispensable desarrollar la democracia de base articulada con las instituciones del Estado; ni integradas en ellas ni con pretensiones de "doble poder", sino como interlocutores autónomos y representativos de los diferentes grupos sociales y de todo tipo."1092

Però s'ha de dir que tot i això, el mateix Jordi Borja havia parlat l'any 1978 d'admetre alguna possibilitat de que les AVV's poguessin gestionar determinats serveis $^{1093}$. L'any següent, en la Conferència de Barcelona de Movimiento Popular i Política Municipal feta pel PSUC, el document "Asociaciones de Vecinos y Entidades de Barrio", torna a admetre aquesta possibilitat, si bé no immediata:

"A largo plazo, si consideramos las AA.VV. como las organizaciones con más voluntad de representación en los barrios, si realmente en la práctica logran desarrollar esta función, convirtiéndose en el motor de la coordinación de las distintas organizaciones populares del barrio, se puede prever como perspectiva de trabajo unas nuevas características para dichas asociaciones.

Podrían asumir el papel de lo que en el documento de esta Conferencia denominamos Consells de Barri. Es decir, serian las AA.VV., órganos en los que podrían converger las organizaciones populares, con la finalidad de defender los intereses del barrio y ser

1091“Ponencia de la Comisión política municipal y movimiento popular del Comitè Central” [1977], CRAI-Pabelló de la República, Fons DDP (Sèrie Documents Partits Polítics, Subsèrie PSUC, Caixa DDP (PSUC). 2, Carpeta 1-Partit Socialista Unificat de Catalunya. Congrés (4art. : 1977: Barcelona), p. 4.

1092 Ídem.

1093 Entrevista a Jordi Borja en Francisco Herrera i Víctor Claudín: Socialistas y comunistas ante las elecciones municipales... p. 74-79. 
los interlocutores válidos de la población ante el Ayuntamiento, asumiendo progresivamente la gestión de servicios descentralizados, aumentado su participación y control en la política municipal.

Siendo financiados su infraestructura material y medios de trabajo por el Ayuntamiento, -como equipamiento público- podrían dejar de vivir con las cuotas de los socios que desaparecerían como tales siendo substituidos por el conjunto de los vecinos del barrio quienes eligirían democráticamente a sus representantes en las juntas de dichas asociaciones."1094

No obstant, com veurem amb posterioritat al Barcelonès Nord, aquestes declaracions d'intencions genèriques fetes per Barcelona no es van acabar acomplint en altres municipis. Aquesta limitació serà, com veurem més endavant, una de les principals crítiques que es faran des de sectors del moviment popular passades les eleccions municipals d'abril de 1979. Es més, pel que fa al darrer argument de que les AVV's siguin finançades pels Ajuntaments, en tant aquestes no van ser reconegudes al final com entitats d'interès públic i no hi havia una obligació ni una normativa clara al respecte, es va donar una gran arbitrarietat o es va fer sevir el mecanisme de la subvenció i el manteniment de locals per comprar voluntats.

És interessant veure també la Reunió del Comitè Central. 21 i 22 d'Octubre de 1979 i en concret les aportacions de l'informe la Comissió de Moviment Popular i Política Municipal presentat per Jordi Borja un cop passades les eleccions municipals. Les resolucions del Comitè Central continuaven cridant a la participació dels militants dins els moviments populars respectant la seva independència. Però l'interessant es veure les aportacions de l'informe esmentat. Apart de prevenir una deriva institucionalista dels militants escollits als municipis que tendien a aillar-se d'altres estructures del partit i contra les diferències salarials exagerades dins el PSUC, s'afirmava respecte les AVV's:

"S'ha parlat de crisi, però hi ha una crisi quant a la militància dels membres de partits polítics dins les AA.VV., però com a fenomen associatiu s'ha estès. [...] En tot cas el

1094 “Asociaciones de Vecinos y Entidades de Barrio." (1978), CRAI-Pavelló de la República, Fons DDP (Sèrie Documents Partits Polítics, Subsèrie PSUC, Caixa DDP (PSUC). 2, Carpeta 4-Partit Socialista Unificat de Catalunya. Conferencia de Barcelona de Movimiento Popular y Política Municipal (1978: Barcelona), 3-Ponències, p. 5. 
problema amb les AA.VV. en aquests moments no és tant la seva existència quantitativa, sinó un cert abandó per part dels grups polítics, i dels seus militants inclosos els nostres; però no tant un abandó de persones que ja no hi van, sinó d'una diversificació de la perspectiva on se situen els uns i els altres. És a dir els partits polítics hem tendit, inclosos nosaltres, a uns plantejaments institucionals, a uns plantejaments d'objectius polítics que eren absolutament necessaris en aquesta etapa, però que quedaven allunyats del que eren les possibilitats d'intervenció pràctica de la població. La Constitució, les eleccions, l'Estatut, que eren importants i s'havien de fer, però era un discurs que en part quedava per sobre el cap de la gent. Les Associacions han tendit, i el seu allunyament de la campanya de l'Estatut no deixa de ser significatiu i no pas positiu, aleshores a centrar-se en una problemàtica cada vegada més local, més especial, sovint radical, en les demandes que expressaven, radical, fins i tot, contra els partits polítics, contra els Ajuntaments d'esquerra etc., que té un aspecte, en part, positiu, quant a l'existència d'organitzacions voluntàries de base, que plantegen problemes i necessitats reals de la població, però que, és clar, pot portar a un corporativisme, fins i tot, amb un discurs d'esquerres, per exemple, al voltant dels problemes de l'urbanisme, com ocupacions de vivendes, oposicions a certes actuacions, etc., és a dir, els pot portar a no veuri [sic] més enllà que l'interès més localista, d'uns quants usuaris o d'uns quants afectats sense tenir en compte els interessos generals, una política general per a tot un barri o per a tota la ciutat, o el mecanisme democràtic per assignar determinats béns, com poden ser les vivendes, i a través de l’ocupació s'està forçant una assignació que no necessàriament és la justa. Tenim un patrimoni associatiu important a les AA.VV., que ens pot ser molt útil. Però en certs moments pot, fins i tot, servir per uns plantejaments, per a unes actituds, per a unes reaccions socials de caràcter corporatiu. I ens podem trobar amb AA.VV. que acabin col-locant-se al front de lluites importants contra els Ajuntaments d'esquerra. No ens han de fer por els conflictes entre Ajuntaments i determinats moviments o Associacions, però el que sí, és un fet negatiu és que les AA.VV. agafin una dinàmica de caràcter radical localista enfrontats als Ajutaments d'esquerra". ${ }^{1095}$

Per una banda continua vigent la por de que les AVV's s'enfrontessin als nous ajuntaments d'esquerres. Però és important veure que sí que es va decidir apostar per la via institucional i per uns objectius polítics que tenien molt a veure amb la línia eurocomunista i pactista impulsada pel PCE-PSUC en el context de la Transició a partir sobretot del 1977, i que això va comportar conseqüències per al moviment

1095PSUC, "Reunió del Comitè Central. 21 i 22 d’Octubre de 1979. Moviment Popular i Política Municipal”, "Informe del Comitè Executiu presentat pel company Jordi Borja”, p. 21-22. [CEDOC, FO 24/017] 
veïnal, per molt que Jordi Borja intenta remarcar que no va ser una decisió conscient:

"És a dir que nosaltres no hem donat una orientació que sacrifiqués el moviment popular concientment [sic], però sí que ha calgut fer unes opcions polítiques, establir unes prioritats polítiques que deixaven en segon terme la intervenció del partit en el moviment popular. I això em sembla que ho hem d'assumir perquè no és cap autocrítica que hem de fer com a partit sinó que han estat opcions donades per les condicions en què s'ha fet el canvi d'aquest procés polític."1096

En aquest sentit, unes paraules de Manuel Vázquez Montalbán al respecte ens deien com a dintre del PSUC va acabar imposant-se una vessant institucionalista respecte als partidaris de mantenir-se actius als moviments de base, tot i les declaracions oficials:

“Bé, jo puc aportar la batalla interna al PSUC entre institucionalistes i 'basistes', per dir-ho d'alguna manera, de la qual s'havia de trobar un equilibri, però no es va trobar, perquè van guanyar els institucionalistes, això va significar desfer els moviments socials, no d'una manera sistemàtica, però si amb l'abandó de la direcció, deixant que allò es podrís una mica, mobilitzant efectius cap a altres coses, integrant dintre dels aparells de gestió gent molt capaç que hauria portat un treball de base" ${ }^{1097}$

Quina opinió tenien al respecte els partits situats a l'esquerra del PSUC? Tot i que no van poder competir en nombre de militància amb aquest partit, seria injust no reconèixer que nombroses formacions polítiques de l'anomenada "esquerra radical" van tenir també un paper important en el moviment popular. Aquestes, van veure com en aquests anys (1975-1979) malgrat el seu relatiu auge, no s'acomplien les seves expectatives revolucionàries i la majoria acabaven entrant en una profunda crisi que farà desaparèixer els anys posteriors ${ }^{1098}$.

1096PSUC, "Reunió del Comitè Central. 21 i 22 d'Octubre de 1979. Moviment Popular i Política Municipal", "Informe del Comitè Executiu presentat pel company Jordi Borja", [CEDOC-UAB, FO 24/017], p. 27.

1097Eduard Moreno i Manuel Vázquez Montalbán: Democracia y movimientos sociales, Fòrum d'Acció Cultural de l'Ateneu Popular de Nou Barris, Barcelona, 1995.

1098Torno a remetre a l'obra de Jose Manuel Roca (ed.): El proyecto radical... ja citada per un estudi més acurat de les formacions d'aquest espectre polític. Afegeixo l'existència d'un Dossier titulat "L'extrema esquerra espanyola durant la transició" publicat a L'Avenç núm. 207 (octubre 1996) i en cas d'una formació política concreta, a la molt més recent obra de José Luis Martin Ramos (Coord.): Pan, trabajo y libertad. Historia del Partido del Trabajo en España, El Viejo Topo, [Barcelona], 2011. 
Ja vam veure com Bandera Roja va ser una de les organitzacions pioneres en aquest sentit. Havien apostat també clarament per impulsar els moviments als barris ja des de la seva creació al 1968 treballant en els Centres Socials, les Comissions de Barri i posteriorment en les les AVV's ${ }^{1099}$ (poc abans del reingrés d'una part dels seus militants al PSUC, entre ells Jordi Borja, un dels que més havia teoritzat al respecte), arribant fins i tot a plantejar-se i finalment donar suport a candidats democràtics a les eleccions al Tercio Familiar de Barcelona ${ }^{1100}$. Malauradament, no he pogut trobar molta documentació del període posterior que fes referència al moviment veïnal -la marxa dels principals teòrics d'aquest partit cap al PSUC juntament amb altres militants va deixar molt debilitada la organització-, només un butlletí amb un esquema de les ponències del III Congrés de 1978 amb una dedicada al "Movimiento popular" on per exemple s'afirma que:

"3.1.1. el movimiento popular genera las bases para una alternativa revolucionaria a la administración burguesa. La autonomía popular proletaria base de un nuevo poder."1101

És una llàstima no haver trobat el contingut desenvolupat d'aquest esquema de dues pàgines. Per sort, si que he trobat més documentació d'altres formacions polítiques. Per exemple, de la OICE (organització provinent dels Circulos Obreros Comunistas), que va tenir, com hem vist una important presència a Santa Coloma.

1099En aquest sentit veure els documents següents, alguns ja citats: [OCE-BR]: "Tareas políticas del barrio. De la revista marxista independiente "Bandera Roja" no 1 nov. 1968", CRAI-Pavelló de la República, Fons DDP. Subsèrie Organización Comunista de España (Bandera Roja), Caixa DDP (OCE(Br)) 1, Carpeta 2-OCE (BR). Documents Interns (1968); [OCE-BR]: "El trabajo entre las masas de la organización comunista" [S.I.n.d.], CRAI-Pavelló de la República, Fons DDP. Subsèrie Organización Comunista de España (Bandera Roja), Caixa DDP (OCE(Br)) 1, Carpeta 1OCE(BR). Documents interns ([s.d.]); OCE(BR): "La Organización del movimiento obrero y popular" [s.l.] [1974], CRAI-Pabelló de la República, Fons DDP. Subsèrie Organización Comunista de España (Bandera Roja), Caixa DDP (OCE(Br)) 1, Carpeta 7-Documents interns línia minoritària contrària a la integració en el PSUC (Donació Jordi Borja) i OCE(BR): “Circular no 3: la inmediata perspectiva de lucha política de masas, organizar el movimiento democrático" [Catalunya], 1974, CRAI-Pavelló de la República, Fons DDP. Subsèrie Organización Comunista de España (Bandera Roja), Caixa DDP (OCE(Br)) 1, Carpeta 7-Documents interns línia minoritària contrària a la integració en el PSUC (Donació Jordi Borja).

1100 Això es pot observar en: "Circular del Comité de Barcelona no 1" i "Circular del comité de Barcleona OC(BR) no 2", CRAI-Pavelló de la República, Fons DDP. Subsèrie Organización Comunista de España (Bandera Roja), Caixa DDP (OCE(Br)) 2, Carpeta 5-OCE(BR). El suport a candidats al Tercio Familiar es va constatar amb la candidatura de Rodríguez Ocaña a Barcelona. Veure Martí Marín: Els Ajuntaments franquistes a Catalunya..., p. 404-406.

1101 “Boletín III Congreso n. 2", CRAI-Pavelló de la República, Fons DDP. Subsèrie Organización Comunista de España (Bandera Roja), Caixa DDP (OCE(Br)) 1, Carpeta 11-OCE(BR). Congresos, p. 14 . 
Un document del segon congrés de l'OICE -fet l'agost del 1977 al País Basc- titulat "Las tareas democráticas en la construcción del BHAR" (Bloc HistòricRevolucionari) ens ofereix un primer anàlisi sobre com s'estava desenvolupant el procés de canvi polític fins aleshores. Es fa una certa autocrítica en reconèixer que no s'ha pogut fer la ruptura per que les condicions del capitalisme a l'Europa occidental són més complexes. S'afirma que no té sentit aïllar-se en un "purisme revolucionari" i en aquest sentit s'intenta justificar una línia tàctica concreta:

"Cuando para nosotros esto se ha hecho evidente con la reforma política que sufre hoy el país, es necesario sacar en consecuencia, profundas líneas de trabajo político. Y a partir de aquí hemos tenido que desarrollar la táctica sobre todo en el aspecto que contempla la reforma de las reformas y la profundización democrática, en el aspecto de la necesaria reorganización (acumulación de fuerzas) del movimiento popular para que realmente se estructure como tal y avance en la línea de construcción como movimiento de unidad popular y alternativa de gobierno." ${ }^{1102}$

Aquest fet no implicava, segons el mateix document, renunciar a una presa revolucionària -insurreccional i armada- del poder, però alhora afirmava:

“(...) que es el movimiento de masas el agente principal de los cambios democráticos y revolucionarios que necesita nuestro país, que frente al papel de "comparsa" de tales cambios actuales que tanto el bloque dominante como los partidos reformistas han dado al movimiento popular, la tarea consustancial de hoy a la izquierda revolucionaria es dinamizar tal movimiento popular para que éste reencuentre su protagonismo de lucha y combate sopena [sic] de quedar reducido a su tipo de prácticas espontaneas y dispersas que para nada incidan en las actuales coordenadas históricas"1103

Malgrat aquest discurs, la tàctica de la reforma de les reformes i l'aprofundiment democràtic requeria també la participació en les eleccions, i en especial a les municipals, ja que no es renunciava la intervenció "en las estructuras del aparato de estado burgués"1104. El mateix document concloïa amb un programa polític, que incloïa un apartat dedicat a "les necessitats ciutadanes i municipals".

1102 OICE: "Ponencia no 3. Las tareas democrátias en la construcción del BHAR" [Congrés OICE , agost 1977 al País Basc] , CRAI-Pavelló de la República, Fons DDP. Subsèrie Organización de Izquierda Comunista de España, Caixa DDP (OICE). 1, Carpeta 2-OICE. Congressos, p. 7. La cursiva és meva.

1103Ídem.

1104Ibídem, p. 8. 
Destaco els següents punts:

"-Por un Ayuntamiento Democrático elegido por sufragio universal directo y secreto desde los 18 años. Debe contemplarse la posibilidad de revocación de cargos.

-Reforma municipal a fondo y nueva ley de Régimen local. Capacidad de las organizaciones de vecinos y populares de participar en su elaboración y de controlar ampliamente la actividad municipal.

(...)

-Dichos Ayuntamientos se han de dotar de un inmediato plan de urgencia que de resolución a las actuales necesidades más concretas del pueblo en la perspectiva de realizar profundas transformaciones en la estructura de nuestras ciudades y pueblos $(\ldots . .)^{1105}$

La OICE si tenia una experiència en el treball en barris de grans ciutats. Ja fos participant als Centres Socials, o impulsant Comissions Obreres de Barri, Comissions de Barri, o Comissions Anticapitalistes de barri (es feien amb els militants més conscienciats dels Centres i dels barris, tenien una funció més d'avantguarda política i havien d'operar en la clandestinitat ${ }^{1106}$. Tot això sense excloure la utilització d'altres entitats legals com les AVV's, sempre i quan servissin per fomentar una consciència de classe i accions de masses ${ }^{1107}$, i es vinculessin a una lluita anticapitalista ${ }^{1108}$.

1105 OICE: "Ponencia no 3. Las tareas democrátias en la construcción del BHAR" [Congrés OICE , agost 1977 al País Basc] , CRAI-Pavelló de la República, Fons DDP. Subsèrie Organización de Izquierda Comunista de España, Caixa DDP (OICE). 1, Carpeta 2-OICE. Congressos, p. 9-10.

1106En aquest sentit és interessant veure els següents documents de l'OICE: [Treball elaborat per un grup amb experiència en un barri de Catalunya] [s.d.]; "Criterios políticos para la comisión anticapitalista de barrio" [S.l.n.d.]; CRAI-Pavelló de la República, Fons DDP. Subsèrie Organización de Izquierda Comunista de España, Caixa DDP (OICE) 2, Carpeta 4-OICE. Documents sobre la lluita als barris.

1107 És interessant al respecte veure un document d'una pàgina titulat "Esquema de discusión sobre nuestra valoración política de las A.V." [S.I.n.d.], CRAI-Pavelló de la República, Fons DDP. Subsèrie Organización de Izquierda Comunista de España, Caixa DDP (OICE) 2, Carpeta 4-OICE. Documents sobre la lluita als barris. Els punts principals esmentats eren: "1. Criterios políticos generales sobre el uso o no de la legalidad burguesa y su aplicación a las A.V."; "2. Las A.V. Como exigencia de vida humana y social del barrio (...) 3. Las A.V. Como organizaciones de un primer nivel de conciencia (...) 4. Las A.V. Como instrumentos políticos de lucha". En aquest darrer apartat es parlava de contrarestar la "política burguesa" i la "política reformista" amb una "política de ruptura" fent servir les AVV's com a mitjà de propaganda, d'agitació i en l'organització i direcció de les lluites. Un altre document, també sense data, ens explica quin hauria de ser el funcionament de l'estructura interna d'una AVV. Veure OICE: "Sobre la estructura interna de las A.V." [S.I.n.d.], CRAI-Pavelló de la República, Fons DDP. Subsèrie Organización de Izquierda Comunista de España, Caixa DDP (OICE) 2, Carpeta 4-OICE. Documents sobre la lluita als barris.

1108Un altre document sense data titulat significativament "'A) Lucha anticapitalista" insistia en la complementarietat les Comissions Anticapitalistes de Barri i les Associacions de Veïns, sempre 
Però en l'any 1977 la situació ja s'entrevia que no es desenvolupava com s'havia previst. Centres Socials i Comissions de Barri havien perdut la força d'abans i en la majoria dels casos estan a punt de desaparèixer. De manera que ara les AVV's havien de ser el lloc preferent d'actuació en tant que:

“(...) la AV. Cumple este primer papel, de facilitar el encuentro de los vecinos para hablar y discutir juntos: desde organizar una verbena hasta luchar por un problema de sanidad o enseñanza.

(...)

-Si damos un vistazo a la historia de las AA.VV. que tenemos por aquí, podemos ver que han sido un instrumento de lucha de los vecinos, que han servido de cauce para expresar los legítimos deseos de luchar por mejorar nuestros barrios, que se ha demostrado eficaz, al desbordar el carácter "legal" que en un principio tenían, superando los estrechos márgenes que la burguesía había establecido. Un ejemplo es que antes se convocaban asambleas de socios. Hoy se convocan a todos los vecinos, sean socios o no. La Asamblea de barrio es superior a la asamblea de socios. Aunque después, es positivo, que al finalizar las luchas, los vecinos más conscientes se afilien a la $\mathrm{AV}$, como demostración de que han visto la necesidad de estabilizar y continuar su lucha." ${ }^{\prime 109}$

De manera que, tot i que formalment encara es parlava de las $C A B$, era evident l'aposta per la participació dins les AVV's:

"Consideramos, pues, y defendemos como tales, a las A.V. Como el centro unificador orgánico del barrio y la sede de los órganos de democracia directa y del futuro poder popular en los Barrios. Esto supone lograr un funcionamiento de Asambleas realmente de masas en cada Barrio (hoy por hoy son todavía de vanguardia muy amplia), lo cual exige estructural modelos asambleísticos y de representación por escalera, calle, zona, etc." ${ }^{1110}$

des d'aquesta òptica. CRAI-Pavelló de la República, Fons DDP. Subsèrie Organización de Izquierda Comunista de España, Caixa DDP (OICE) 2, Carpeta 4-OICE. Documents sobre la lluita als barris.

11090ICE: “Presente y futuro de las asociaciones de vecinos" [S.l.nd.], CRAI-Pavelló de la República, Fons DDP. Subsèrie Organización de Izquierda Comunista de España, Caixa DDP (OICE) 2, Carpeta 4-OICE. Documents sobre la lluita als barris, p. 1. Un altre document similar al respecte és "Algunos aspectos a considerar hoy respecto a las Asociaciones de Vecinos" [S.l.n.d.] (es pot trobar a la mateixa referència que l'anterior). I un tercer, també interessant, és el titulat "Historia de los movimientos populares en Barcelona. 9 Barrios", que fa una anàlisi del moviment popular i les AVV's de l'esmentat zona de Barcelona, veure a CRAI-Pavelló de la República, Fons DDP. Subsèrie Organización de Izquierda Comunista de España, Caixa DDP (OICE) 1, Carpeta 3-OICE. Conferència Regional de Catalunya (1977).

1110 OICE: "Plan de Intervención y trabajo para el frente de barrios" [S.l.n.d.], CRAI-Pavelló de la República, Fons DDP. Subsèrie Organización de Izquierda Comunista de España, Caixa DDP 
Aquest fet no obviava la possibilitat de participar en les eleccions municipals. Els Ajuntaments, tot i ser considerats "aparells de dominació de l'estat burgés" així com altres institucions no eren exclosos de l'acció política:

"Para nosotros, participar en las instituciones legales solo tiene sentido si nos apoyamos en la lucha de masas y además contribuimos con ello a su desarrollo. La conquista de nuestras reivindicaciones, la defensa de programas que mejoren nuestras condiciones de vida, solo es posible con movilizaciones de masas." ${ }^{1111}$

Aquesta tàctica s'englobava dins l'objectiu més ambiciós d'articular un ampli moviment de masses -"d'unitat popular"- que es pogués transformar posteriorment en forces polítiques capaces d'enfrontar-se al "poder burgés" i lluitar pel socialisme. Pel que feia al cas concret dels Ajuntaments, s'anava més enllà de la estesa reivindicació dels ajuntaments democràtics, assumida pel conjunt del moviment veïnal:

"Hemos de luchar por un Ayuntamiento que asegure la participación directa y el control popular sobre las instituciones locales, sometiendo todo tipo de decisión importante del municipio a la consideración de las Asociaciones de Vecinos y a la aprovación [sic] en Asambleas de vecinos." ${ }^{.112}$

La por a quedar exclosos i marginats i el fet de reconèixer, que malgrat la limitació del poder dels ajuntaments, hi havia un cert marge de maniobra per fer millores amb el seu control (tot i que al seu parer no anaven a solucionar l'arrel dels problemes), els va impulsar a defensar la participació en les eleccions municipals, si be algunes de les seves "condicions indispensables" per fer-ho no es van acabar acomplint, com era la demanda de llistes obertes ${ }^{1113}$. El boicot es va finalment desestimar, reconeixent que en aquell moment no existia una alternativa

(OICE) 2, Carpeta 4-OICE. Documents sobre la lluita als barris, p. 6. Aquest mateix document feia una anàlisi crític de les diferents forces polítiques i la seva actuació al "Front de Barris". (en especial al PSUC, MC i PTE). Només es salvaven BR i el POUM, amb els que es destacaven les coincidències en la línia d'actuació.

11110ICE: "Las elecciones municipales: una próxima batalla para la que nos tenemos que preparar [S.I.], [1978], CRAI-Pavelló de la República, Fons DDP. Subsèrie Organización de Izquierda Comunista de España, Caixa DDP (OICE) 2, Carpeta 4-OICE. Documents sobre la lluita als barris, p. 2.

1112 Ídem, p. 3.

11130ICE: "Ante la cuestión del Ayuntamiento" [S.l.] [1978], CRAI-Pavelló de la República, Fons DDP. Subsèrie Organización de Izquierda Comunista de España, Caixa DDP (OICE) 2, Carpeta 4OICE. Documents sobre la lluita als barris. 
viable ${ }^{1114}$, encara que anteriorment s'hagués explicitat la voluntat de treballar per aconseguir articular un poder popular als Barris com aquesta alternativa al "Ajuntament burgés"1115. Una proposta que si va tenir més èxit -i que va ser compartida amb altres organitzacions polítiques- va ser la d'Elaboració de Plans Populars per barris i ciutats -fets pel veïnat- amb la voluntat de que fossin executats pels Ajuntaments democràtics ${ }^{1116}$. Malgrat tot, aquesta organització va entrar en una crisi a partir sobretot de la segona meitat de $1977^{1117}$ amb debats interns i escissions al qual no eren aliens els debats sobre qüestions veïnals $\mathrm{i}$ municipals (així com els pobres resultats del 15-J) com reflecteixen les següents paraules:

"Profundizando en esta propuesta táctica vemos que la dirección de las transformaciones está en manos del ayuntamiento (partidos políticos) y que las autoorganizaciones no son un contrapoderpopular [sic], sinó órganos para democratizar y apoyar a estos ayuntamientos (partidos). Curiosamente en la propuesta, se le olvida mencionar el papel de las AAVV después de las elecciones municipales." ${ }^{1118}$

11140ICE: "Discusión de nuestra táctica ante la democratización del Ayuntamiento" [S.I.] [1978], CRAI-Pavelló de la República, Fons DDP. Subsèrie Organización de Izquierda Comunista de España, Caixa DDP (OICE) 2, Carpeta 4-OICE. Documents sobre la lluita als barris.

11150ICE: "Ejes de nuestra táctica hoy en barrios" [S.l.n.d.], CRAI-Pavelló de la República, Fons DDP. Subsèrie Organización de Izquierda Comunista de España, Caixa DDP (OICE) 2, Carpeta 4-OICE. Documents sobre la lluita als barris.

1116OICE: "Pro-grama [sic] de Transición (P.T.) para Catalunya", CRAI-Pavelló de la República, Fons DDP. Subsèrie Organización de Izquierda Comunista de España, Caixa DDP (OICE) 1, Carpeta 3OICE. Conferencia Regional de Catalunya (1977), p. 2 i OICE: "El Plan Comarcal y los intereses populares" [S.I.] [1979], CRAI-Pavelló de la República, Fons DDP. Subsèrie Organización de Izquierda Comunista de España, Caixa DDP (OICE) 2, Carpeta 4-OICE. Documents sobre la lluita als barris.

1117Un document seu admet una crisi general de l'esquerra revolucionària i de la mateixa OIC, amb un enfrontament intern dels mateixos redactors del document amb la direcció per les diferents postures a prendre veient l'evolució de la conjuntura política. Veure TENDÈNCIA OIC: "Una propuesta para el debate democrático en la OIC" [S.l.] [1977], CRAI-Pavelló de la República, Fons DDP. Subsèrie Organización de Izquierda Comunista de España, Caixa DDP (OICE) 2, Carpeta 7-Tendència OIC (Futurs CUM). Documents interns diversos.

1118 Ídem, p. 4. Es curiós observar que aquest sector crític en concret argumenta -entre d'altres coses- que la direcció està portant una línia molt semblant a l'exposada abans per Jordi Borja dins el PSUC pel que fa a les AVV's i l'Ajuntament democràtic. Aquesta sector crític va arribar a elaborar el seu propi programa alternatiu de política urbana i municipal on es feia aquesta aposta clara per unes AVV's amb molt poder de control del consistori responent a aquesta voluntat de autoorganització popular. Veure Tendència OIC (CUM): "Las posiciones de la tendencia" [S.l.], [1977], CRAI-Pavelló de la República, Fons DDP. Subsèrie Organización de Izquierda Comunista de España, Caixa DDP (OICE) 2, Carpeta 7-Tendència OIC (Futurs CUM). Documents interns diversos. 
Fins que al febrer de 1979 va acabar fusionant-se amb l'MC (totes dues formacions havien perdut la "E" pel camí després de debatre el fet nacional), en un procés que més que una fusió va ser una absorció.

Que deia l'MC respecte del moviment veïnal? En general, unes postures molt coincidents amb les expressades anteriorment. Valoraven positivament les lluites populars en barris i ciutats, en un sentit ampli:

\begin{abstract}
"Si bien la lucha urbana -lucha en torno a la vivienda, equipamientos, zonas verdes, planes parciales y generales de urbanismo, ... -ha constituido el terreno más peculiar del Movimiento Ciudadano, este engloba también otros campos de trabajo en el marco del pueblo y la ciudad. Entre ellos está la defensa del medio ambiente, la actividad cultural, la lucha de la juventud y los jubilados, la lucha de la mujer contra la opresión que sufre, la problemática del paro y de la carestía de la vida, ...

Junto a todo ello el Movimiento Popular ha jugado un importante papel en la lucha antifranquista y por la democracia y que tenía su expresión más particular en la exigencia de unos Ayuntamientos Democráticos elegidos por los vecinos, junto a la más amplia democracia municipal frente a los ayuntamientos de corte franquista." ${ }^{1119}$
\end{abstract}

Es coincideix en la potenciació de les AVV's com a mitjà per crear un potent moviment de masses i contrapoder als barris i ciutats. Es més, s'argumentava que la seva gran implantació i prestigi, el seu caràcter unitari, els hàbits democràtics i participatius que fomentaven així com la presència -relativament important- dels propis militants de l'esquerra revolucionària com a elements que ho feien un objectiu assolible. Malgrat tot, no es negava l'existència d'una certa crisi al moviment veïnal ja al 1977 del qual acusa al PSUC per fomentar la via institucional i a "congelar l'activitat de les AVV's i a l'abandó d'aquestes per part de militants i quadres"1120. La participació a les eleccions i als Ajuntaments es va contemplar com una opció instrumental, tàctica, per que eren conscients que des de aquests es podien aconseguir millores, tot i fer una crítica als posicionaments del PSUC:

"Para los eurocomunistas la "transformación democrática" de los ayuntamientos es un elemento básico para la transformación del Estado y una gestión municipal "eficaz" el medio de "convencer" a la población e ir así "haciendo socialismo" bajo el capitalismo.

1119 [MC]: "Notas sobre nuestro trabajo en el movimiento ciudadano" [S.l.n.d.], CRAI-Pavelló de la República, Fons DDP. Subsèrie Moviment Comunista, Caixa DDP (MC) 1, Carpeta 2-Moviment Comunista. Documents interns ([s.d.]), p. 1.

1120 Ídem, p. 5. 
Desde este punto de vista el eje de su actividad municipal lo sitúan en el trabajo institucional relegando el movimiento popular al papel de elemento depresión y de apoyo a sus pretensiones de "conquista" del ayuntamiento. Por ello se plantean un movimiento de masas controlado en función de la "relación de fuerzas" que se de, no en los barrios, sino en el seno de los ayuntamientos, unas "movilizaciones responsables" que les permitan mejorar sus posiciones en el aprato [sic] administrativo local. La consecuencia de ello es un movimiento limitado y supeditado totalmente a sus intereses institucionales."1121

Fins i tot el MC va arribar a elaborar una proposta de Llei Electoral Municipal el 5 d'octubre de 1977 que preveia -per exemple- l'elecció per llistes tancades amb vot preferencial als municipis majors de 15.000 habitants i l'elecció per llistes obertes als municipis amb menor població ${ }^{1122}$. No es feien massa il·lusions sobre els resultats que podien treure en aquestes. Així ho manifestava un document intern, que en tot cas valorava el fet de que havien de servir per impulsar el treball en el moviment popular ${ }^{1123}$. En les resolucions i documents aprovats al II Congrés del Moviment Comunista fet l'abril de 1978 es reafirma aquesta voluntat d'impulsar els moviments de masses com a forma d'aconseguir una acumulació de forces, necessària, al seu parer per revertir una situació que no s'havia desenvolupat com preveien els diferents partits de l'esquerra revolucionària. Entre aquests moviments es contemplava òbviament el veïnal però també es feia esment als "nous" moviments -ja vaig comentar que molts d'aquests no eren tant recents-, fent un especial esment al feminista. Dintre d'aquest procés també es contemplava en determinats casos i amb determinades condicions, arribar a pactes d'unitat amb la que anomenaven "esquerra reformista"1124. Els resultats electorals a les municipals van ser modestos malgrat la recent fusió amb l'OIC, de manera que el

1121 [MC]: "Notas sobre nuestro trabajo en el movimiento ciudadano" [S.l.n.d.], CRAI-Pavelló de la República, Fons DDP. Subsèrie Moviment Comunista, Caixa DDP (MC) 1, Carpeta 2-Moviment Comunista. Documents interns ([s.d.]), p. 3.

1122 MCC: "Projecte de Llei Electoral Municipal presentat pel Moviment Comunista" [Catalunya], octubre 1977, CRAI-Pavelló de la República, Fons DDP. Subsèrie Moviment Comunista, Caixa DDP (MC) 1, Carpeta 6-Moviment Comunista. Documents interns (1977).

1123[MCE]: "Algunas notas sobre elecciones municipales" [S.l.], [1977], CRAI-Pavelló de la República, Fons DDP. Subsèrie Moviment Comunista, Caixa DDP (MC) 1, Carpeta 6-Moviment Comunista. Documents interns (1977).

1124MC: "10 años de lucha por el socialismo. Resoluciones y documentos del II Congreso, Abril 1978 (Bilbao), CRAI-Pavelló de la República, Fons DDP. Subsèrie Moviment Comunista, Caixa DDP (MC) 2, Carpeta 2-Moviment Comunista. Congressos. Subcarpeta b. Movimiento Comunista. Congrés (2on. :1978 març: Bilbao), p. 45-50. 
seu treball va continuar centrant-se en l'impuls del moviment popular de base $\mathrm{e}^{1125}$. Una altra força que va comptar amb una important implantació en el moviment veïnal va ser el PTE. Ja quan encara es deia PCE(i) havia mostrat un cert interès per aquest front d'actuació, un cop superada la visió -comuna pràcticament a totes les forces- que prioritzava gairebé exclusivament l'acció al moviment sindical. Una publicació seva ja havia afirmat l'any 1972:

\begin{abstract}
"Es necesario que los militantes del Partido, todos los comunistas, se liguen estrechamente a todos los problemas inmediatos que existen en los barrios y a través de ellos ir incorporando a la lucha a miles y miles de amas de casa, impulsando la creación de organizaciones de mujeres al calor de estas luchas y, apoyándose en el ascenso espontáneo del amplio movimiento de masas que se está desarrollando, promover, consolidar o desarrollar comisiones de barrio para ir presentando batalla organizada en todos los frentes contra el fascismo"1126
\end{abstract}

No obstant, i com a exemple que encara s'arrossegaven velles dinàmiques, al Congrés de Constitució del PCE(i) d'abril de 1973 no es va dedicar una especial atenció al moviment veïnal o ciutadà, fins al punt de no sortir referenciat a les ponències $\mathrm{i}$ resolucions malgrat que ja hi havia militants treballant ${ }^{1127}$. Pràcticament la única referència és la que fa Joaquin Badia quan parla de la situació a Catalunya. Després de posar com exemple la lluita del boicot dels autobusos a Santa Coloma, afirma:

"Pero esto es muy poco, estamos tratando de dar pasos prácticos en este sentido, para relacionar la lucha popular en los barrios con la lucha reivindicativa de las fábricas, obras, etc, para desarrollar un amplio movimiento de masas." ${ }^{1128}$

El març de 1975 el partit canviava el nom i passava a dir-se Partido del

1125MC: "Tras las elecciones municipales" [S.l.] (abril 1979), CRAI-Pavelló de la República, Fons DDP. Subsèrie Moviment Comunista, Caixa DDP (MC) 2, Carpeta 1-Movimiento Comunista. Documents relacionats amb eleccions, subcarpeta b. Eleccions municipals (1979).

1126"La lucha de masas en los barrios", Mundo Obrero Rojo (agost 1972). Cita extreta de Manuel Gracia Luño: "Capítulo II. La refundación del partido: estrategia, táctica y línea de masas" dins José Luis Martín Ramos (Coord.): Pan, Trabajo y Libertad. Historia del Partido del Trabajo de España, El Viejo Topo, Barcelona, 2011, p. 87-88.

1127Ídem, p. 99.

1128“Pasajes de la intervención de Joaquin badia sobre la situación en Cataluña”, dins PCE(I): "Hacia el socialismo. Documentos del Tercer Pleno del Comité Central de Nuestro Partido", Archivo Digital PTE JGRE [http://www.pte-jgre.com/archivo/archivodocumentos.html], p. 31. La línia de crear un potent moviment de masses era considerada imprescindible per portar endavant la seva línia tàctica de Front Popular. Però es dedicava una gran atenció a treballar el moviment obrer i camperol com es pot observar al mateix document. 
Trabajo de España. Per aquella data militants seus ja estaven implicats també en el moviment veïnal al Barcelonès Nord. La frustració de les expectatives de ruptura i, sobretot, el fracàs electoral de la coalició Esquerra de Catalunya (amb ERC, que va ser la beneficiada amb 1 escó per Heribert Barrera), van fer que el partit es moderés molt arribant fins i tot a donar suport al text Constitucional a tot l'estat (en contrast amb les opcions per l'abstenció o el "no" partits de l'esquerra revolucionària o radical), a excepció -curiosament- del País Basc ${ }^{1129}$. En l'àmbit veïnal, apart de la participació en les AVV's havia potenciat les Associacions de Mestresses de Casa per intentar implicar a les dones en les lluites ${ }^{1130}$.

Al 1977 el PTE va tenir, al igual que altres forces del seu espectre polític, una crisi important si bé en el seu cas aquesta es va centrar a Catalunya, on segurament tenia la seva major implantación ${ }^{1131}$. En el fons estava el debat sobre si el PTE havia de tenir una estructura federal o centralista, seguint el model que es propugnava per l'Estat. I malgrat que en un primer moment els federalistes van ser expulsats $^{1132}$, posteriorment es va adoptar la línia que havien defensat. D'aquí el nom del Partit del Treball a Catalunya. Els fracassos electorals i els modestos resultats extrets a les municipals van impulsar la fusió amb l'ORT ${ }^{1133}$, un procés que no acabarà de reeixir i que acabarà amb la seva autodissolució l'any 1980.

No es troben molts documents en aquest període que parlin del moviment

1129Un exemple d'això és l'opuscle “¿Qué es la Constitución?” editat pel Partit del Treball de Catalunya, que es pot consultar a: Archivo Digital PCE JGRE [http://www.ptejgre.com/archivo/archivodocumentos.html].

1130 Recordem l'entrevista a Maria Relles Bellido, militant del PTE i de l'AVV de Sant Mori de Llefià, que també va impulsar una potent Asociació de Mestresses de casa vinculada a aquesta darrera. Veure notes 609 i 706.

1131Segons Ramón Franquesa Artés, el PTE disposava a Catalunya d'uns 2.400 militants. I estava present a moltes localitats. Disposava d'una seu central, de 8 seus en Barcelona ciudat, 3 en Hospitalet, 4 en el Vallés Occidental, 1 en el Vallés Oriental, 2 en Badalona, 2 en Tarragona i una a Sta. Coloma, Baix Llobregat, Lleida, Universitat i Professionals. Veure Ramón Franquesa Artés: "Capítulo IV. Estabilización del nuevo régimen y autodisolución (1977-1980)" a José Luis Martín Ramos (Coord.): Pan Trabajo y Libertad..., p. 278-279. Un altre informe de Sebastián Arroyo: Informe de la secretaria de organización al CE del CNC" [Comitè Executiu del Comitè Nacional de Catalunya] (21 de febrer de 1978). Arxiu Personal de Manuel Gracia, ens diu que al desembre de 1977 a Badalona hi havia uns 80 militants i que de les dues seus, una estava al centre i l'altra al barri de Llefià (pendent d'obrir-se). Per Santa Coloma el mateix informe esmenta 31 militants. Agraeixo a l'investigador Joel Sans que em facilités aquesta informació.

1132Es pot consultar un comunicat de premsa dels represaliats per la direcció al ja esmentat Archivo Digital PTE_JGRE [http://www.pte-jgre.com/archivo/archivodocumentos.html].

1133Ramon Franquesa Artés: “Capítulo IV. Estabilización del nuevo régimen y autodisolución 19771980” a José Luis Martín Ramos (Coord.): Pan, Trabajo y Libertad..., p. 300-301. 
veïnal ${ }^{1134}$. Però hi ha un document interessant, de finals de 1979, on s'analitza la situació del moment i la política que hauria de seguir el PTC pel que fa a l'àmbit del que anomenen "moviment ciutadà". Per una banda es critica que els nous Ajuntaments no han fomentat la participació directa ${ }^{135}$, així com la política del PSOE i del PSUC. Als primers per no impulsar i menysprear al moviment ciutadà, en el qual segons l'informe tenen una escassa presència, i als segons per instrumentalitzar-lo en el seu benefici i transformar-lo en un mers ens col-laborador dels ajuntaments ${ }^{1136}$. Es feia una certa autocrítica afirmant que s'havia abandonat el treball en aquest àmbit i que no hi havia discussió ni consignes clares sobre el treball que s'havia de fer al respecte. La resposta va ser apostar per que el partit tornés a treballar amb força dins aquests àmbits. Un document titulat "Radicalismo una fuerza para una nueva civilización (Propuesta para un debate)" de principis de 1980 recollia uns anàlisis més complexos de la societat capitalista i la importància del potencial revolucionari que podien tenir els "nous" moviments socials.

“(...) Pero el principal límite del documento estaba en su parte propositiva. En síntesis se planteaba implícitamente transformar el partido en un movimiento que combinado las tareas tradicionales de apoyo a las reivindicaciones obreras, se asumiera la defensa de planteamientos feministas, ecologistas, homosexuales, de minorías, etc. De hecho la propuesta se lanzaba en los últimos párrafos, sin una clara justificación, ya que no hay concatenación lógica entre el análisis más abierto que se hace de la realidad en la primera parte del documento y la propuesta de confederación de organizaciones que se hace al final. Se trataba en la práctica de un salto en el vacío, que supondría el golpe final desde el propio Secretario General."1137

Tot això va quedar en el no-res per la crisi i dissolució del PTC poc després.

Tancant l'anàlisi del que deien els partits de l'esquerra revolucionària o

1134Una excepció és la referència que fa el secretari general Eladio García Castro en un "Informe sobre las tareas del Partido" (12-5-1978), on es fa un petit esment al treball en les "Masas ciudadas" (p. 12-13). Es tracta d'un informe presentat al I Congrés del PTE (febrer 1978). Veure al Archivo Digital PTE_JGRE [http://www.ptejgre.com/archivo/archivodocumentos.html].

1135Luis Álvarez-Ude: "Informe sobre movimiento ciudadanom, política municipal y ordenación del territorio" (10-12-1979), Archivo Digital PTE_JGRE [http://www.ptejgre.com/archivo/archivodocumentos.html], p. 6-7.

1136Íldem, p. 12-13.

1137 Ramon Franquesa Artés: “Capítulo IV. Estabilización del nuevo régiment y autodisolución 1977-1980" a José Luis Martín Ramos (Coord.): Pan, Trabajo y Libertad..., p. 306. 
radical que van tenir una certa implantació al Barcelonès Nord, hem de fer un esment a la Lliga Comunista Revolucionària, de la qual he trobat molta documentació. Si bé la seva implantació en aquests moments no era molt gran, va ser, com veurem, una de les poques organitzacions que com l'MCC va subsistir durant els anys vuitanta ${ }^{1138}$.

La LCR ja al 1971 havia parlat de la feina que es podia desenvolupar als barris tant fent tasques de sensibilització i prospecció en les entitats legals com en campanyes per reivindicacions concretes relacionades amb les mancances existents, relacionant-les amb l'opressió en el món del treball per donar-lis també una perspectiva de classe ${ }^{1139}$. En línies generals se seguí una estratègia similar a la d'altres forces polítiques semblants, però limitada per la seva menor implantació. El procés de canvi polític també va fer tornar a analitzar la qüestió. Per una banda es va denunciar l'actitud de determinats partits polítics dins el moviment veïnal. Al PSUC, força de la qual es reconeixia la seva hegemonia, es deia:

"La política del PSUC no ha sido otra que la de plasmar en el mov.. de barrios su pacto por la libertad y la ruptura pactada de los últimos tiempos. Este tipo de política se basa en recoger las [sic] masificación de los vecinos, dotándoles de una dinámica desmovilizadora, de presión testimonial y de diálogo con las autoridades ciudadanas.. Para ello han aprovechado las Juntas de AAVV, copándolas y asegurándose así un control ante cualquier intento movilizador de los vecinos, tratando de despolitizar las cuestiones y diciendo que la política correspondía a los partidos, una vez legalizados..”1140

El mateix document deia que BR tot i impulsar l'autoorganització veïnal i els Plans Populars, no atacava l'arrel dels problemes i era sectària. De l'OIC es reconeixia el seu pes en els barris obrers, però se l'acusava d'esquerranisme. De les

1138Un document intern de novembre de 1979 parla de 10 militants al Barcelonès (Barcelona i Hospitalet són comptats apart, pel qual posem suposar que es refereix al Barcelonès Nord). LCR. Secretaria d'Organització de Catalunya: "Primer informe organización Noviembre 1979", [Catalunya], (novembre 1979), CRAI-Pavelló de la República, Fons DDP. Subsèrie Lliga Comunista Revolucionària, Caixa DDP (LCR-Arx.2) 8, Carpeta 1-LCR. Catalunya. Documents sobre organització", p. 1.

1139 [PROLETARIO] "Barrios" [S.I.], [1971], CRAI-Pavelló de la República, Fons DDP. Subsèrie Lliga Comunista Revolucionària, Caixa DDP (LCR-Arx.2) 3, Carpeta 9-LCR. Documents sobre les relacions entre la LCR i altres grups (Assemblea de Catalunya, CJR, ex-BR, MC, "Mientras tanto", P, PSUC,“La Razón”- PSOE).

1140 LCR: "Sobre AAVV i treball de barris." [S.l.], (novembre 1977), CRAI-Pavelló de la República, Fons DDP. Subsèrie Lliga Comunista Revolucionària, Caixa DDP (LCR-Arx.2) 9, Carpeta 1- LCR. Catalunya. Documents sobre associacions de veïns i barris, p. 3-4. 
altres forces s'esmenta la seva escassa incidència -a Barcelona ciutat-. La LCR reconeixia l'existència d'una crisi del moviment veïnal ja en aquell moment, a la qual culpava a les polítiques del PSC i del PSUC així com a les seves pròpies mancances $^{1141}$. Tanmateix reconeixia el paper de "nous" moviments i formes d'organització (ecologisme, ateneus). Una característica de les consignes de la LCR respecte el moviment veïnal era també la següent reflexió:

"El movimiento de barrios tiene una naturaleza interclasista: hay que luchar por la hegemonía de la clase obrera en su interior. Esta lucha exige conseguir la relación más estrecha entre las organizaciones obreras (particularmente las centrales sindicales, pero también los consejos de fábrica que existan en cada zona) y las organizaciones populares de los barrios. Por otra parte, las organizaciones de vecinos no son un producto natural de la situación social; sin el eje vertebrador de las organizaciones obreras, tienden a ocupar un lugar de auxiliares del ayuntamiento, incapaces de defender consecuentemente su existencia autónoma."1142

Malgrat que intenta explicat aquest fet fent referència a la "composició reformista" de la majoria d'AVV's, s'entreveu una certa subordinació del moviment veïnal a l'obrer que fa recordar vells esquemes. Si bé és cert que poc després del V Congrés de la LCR (que alhora va suposar la unificació amb la Lliga Comunista), es van fer unes crítiques que en el cas del PSOE van ser "profètiques" als anys posteriors. En concret s'avisava que aquest partit reforçaria la seva presència als moviments urbans aprofitant la seva presència institucional. El mateix document s'insistia en que la crisi del moviment veïnal era una "crisi de direcció" pel paper del PCE-PSUC en tenir un moviment popular subordinat a l'Ajuntament ${ }^{1143}$. De manera que si bé es reconeixia que el moviment havia de ser autònom, també hi havia un cert interès en dirigir-lo.

1141 LCR: [Enmienda a la totalidad del apartado "La recomposición del movimiento ciudadano ...]. [Catalunya], [s.d.], CRAI-Pavelló de la República, Fons DDP. Subsèrie Lliga Comunista Revolucionària, Caixa DDP (LCR-Arx.2) 9, Carpeta 1- LCR. Catalunya. Documents sobre associacions de veïns i barris, p. 1-2.

1142 LCR: "Para vencer a Suárez: por una mayoría obrera en las municipales" [sense data], CRAIPavelló de la República, Fons DDP. Subsèrie Lliga Comunista Revolucionària, Caixa DDP (LCRArx.2) 5, Carpeta 6- LCR. Documents sobre les eleccions municipals d'abril 1979, p. 3.

1143[Annex a les "Resoluciones del Vo Congreso reunificaión LCR-LC]: "Las tareas de los revolucionarios ante la crisis de la ciudad capitalista. Anexo. Resolución adoptada en el Comitè Central de la Liga Comunista Revolucionária. 10-12-78", CRAI-Pavelló de la República, Fons DDP. Subsèrie Lliga Comunista Revolucionària, Caixa DDP (LCR-Arx.2) 4, Carpeta 5- LCR. Congrés d'unificació LCR-LC (5è. : 1978 octubre-novembre), p. 56-57. 
De la mateixa manera, la LCR va manifestar un interès per les eleccions municipals. D'una manera -al meu parer- contradictòria s'insistia en el caràcter instrumental d'aquestes eleccions, però alhora es defensava públicament una candidatura obrera encapçalada conjuntament pel PSUC-PSC (o PCE-PSOE) ${ }^{1144}$. Malgrat això, la LCR va presentar candidatures pròpies amb escassos resultats ${ }^{1145}$ (així ho va fer a Badalona i Santa Coloma, mentre que a Sant Adrià no es va presentar). Abans de les eleccions ja es van avançar propostes en la línia de que les AVV's poguessin participar -juntament amb altres entitats- en la planificació general de les ciutats, als consells escolars mentre es demanava una nova Llei de Règim Local que les dotés de més poder alhora que es reclamaven unes Juntes de Districte escollides per sufragi universal i uns alcaldes amb pocs poders respecte el Ple i revocables ${ }^{1146}$. Després de les eleccions va continuar en aquesta línia d'empoderar les AVV's i fomentar la participació ciutadana:

\footnotetext{
"Las AVV deben de abordar toda la problemática participativa, como una forma de avanzar en la resolución de los problemas de los barrios y los pueblos de Catalunya, garantizando progresivamente, en este proceso, el caracter [sic] de control de la gestión municipal, que debe de tener la participación de las AAVV en la vida municipal"1147
}

D'aquesta manera, s'insistia en la declaració de les AVV's com entitats d'interès públic, en el seu dret a veu -però sense vot- als plens municipals, al dret a vet "popular" sobre determinades decisions dels plens, al dret a referèndum i al dret a proposta que podia fer-se a petició de l'1\% del cens electoral ${ }^{1148}$. Paral-lelament la LCR també va demostrar un especial interès pels anomenats 1144Aquesta línia va ser criticada a un document posterior a les eleccions: LCR: "Balance de la campaña electoral(borrador para el Comité Central)”. [S.l.], 1979, CRAI-Pavelló de la República, Fons DDP. Subsèrie Lliga Comunista Revolucionària, Caixa DDP (LCR-Arx.2) 1, Carpeta 3-LCR. Projectes, etc. dirigits al Comitè Central.

1145 A nivell de curiositat, un grup anomenat "La Razón", que estava en procés d'unificació amb la LCR va criticar la campanya electoral d'aquesta per, entre d'altres motius, primar a les seves candidatures membres de les AVV's i posar a pocs "obrers". Veure en "Las elecciones municipales y nuestras diferencias con la LCR" (un document adjuntat amb el referenciat a la nota anterior).

1146LCR: "Dossier municipales. "[S.I.], [1979], CRAI-Pavelló de la República, Fons DDP. Subsèrie Lliga Comunista Revolucionària, Caixa DólDP (LCR-Arx.2) 2, Carpeta 3- LCR. Documents sobre política municipal, p. 5, 23 i 28-29.

1147 LCR: “AAVV y participación ciudadana.”[Barcelona], [198-],RAI-Pavelló de la República, Fons DDP. Subsèrie Lliga Comunista Revolucionària, Caixa DDP (LCR-Arx.2) 9, Carpeta 1- LCR. Catalunya. Documents sobre associacions de veïns i barris, p. 2.

1148Ídem, p. 2-3. 
"nous"moviments socials ${ }^{1149}$.

Quina visió tenien del moviment veïnal les organitzacions socialistes? Tot i la seva menor implicació dins el moviment veïnal -fet àmpliament reconegut- el cert és que, en contra del que s'ha pensat, si que van demostrar tenir-ne un cert interès, en especial les organitzacions que en els anys setanta encara es consideraven marxistes i parlaven de lluitar per aconseguir un "socialisme autogestionari". Els anys de 1975 a 1979 van ser un període de creixement i clarificació de l'espai socialista, i també d'un procés de canvi i moderació ideològica que va culminar amb la renúncia al marxisme l'any $1979^{1150}$.

Poc abans, el 1974, Convergència de Socialista de Catalunya afirmava en un document intern que:

"El front sindical, ja analitzat, és el front econòmic on es controla i dirigeix la producció, i és, per tant, el més important dels fronts de masses. L'altre front de masses és el barris/comarques on es tracta de la lluita a nivell de consum i inversions col-lectives, és a dir, també, en general dels mecanismes de reproducció de la mà d'obra per mitjà de serveis elementals i influències ideològiques (concepció de la vida comunitària, la diversió, l'ús del temps lliure, etc.)."1151

Tot i aquesta primacia donada al moviment obrer, es reconeixia la importància de l'actuació als barris així com l'existència de les AVV's i les Comissions de Barri, fins al punt que aviat van fer documents específics sobre el tema, amb un discurs que avui ens pot sobtar per la seva radicalitat en parlar de

1149Això es pot observar a diversos documents:LCR: [Enmienda a la totalidad del apartado "La recomposición del movimiento ciudadano ...]. [Catalunya], [s.d.], CRAI-Pavelló de la República, Fons DDP. Subsèrie Lliga Comunista Revolucionària, Caixa DDP (LCR-Arx.2) 9, Carpeta 1- LCR. Catalunya. Documents sobre associacions de veïns i barris, p. 1-2. Un altre document parlava dels "Ateneos Populares", [Barcelona] (juny 1978), [mateixa referència que l'anterior]. A l'article "La situación del movimiento ciudadano y nuestros objetivos centrales", publicat a Boletín de Debate $n^{0}$ 5. VI Congreso de la LCR (desembre 1980) també es feia esment als nous moviments de joves i a l'antinuclear. Veure: "La situación del movimiento ciudadano y nuestros objetivos centrales (Secretaria Municipal de Cataluña)". Boletín de debate no 5C, VI Congreso de la LCR (diciembre 1980), CRAI-Pavelló de la República, Fons DDP. Subsèrie Lliga Comunista Revolucionària, Caixa DDP (LCR-Arx.2) 4, Carpeta 6-LCR. Congrés estatal (6è. : 1980), p. 20-21.

1150 Per a un millor estudi d'aquesta qüestió de nou remeto a l'obra de Juan Antonio Andrade Blanco: El PCE y el PSOE en (la) transició...

1151 Convergència Socialista. Per la unitat dels socialistes de Catalunya: "Deu notes de treball per a una discussió col-lectiva sobre la situació política actual” (novembre 1974), Fundació Rafael Campalans-Arxiu Històric del Socialisme Català, Fons Jordi Font (FJF), Caixa 100, Carpeta P 1, A001(01-02), p. 8. 
continguts revolucionaris i alternatives socialistes al capitalisme ${ }^{1152}$. De la mateixa manera s'insistia en la creació de "Cercles de Barri" per treballar arrelats a aquest àmbit ${ }^{1153}$, que havien de estar cohesionats en una Coordinadora de Barri. No obstant, com ja vam veure, la feblesa militant i manca d'efectius va limitar molt aquesta actuació als barris ${ }^{1154}$, com de fet reconeixien poc després ells mateixos durant el procés de creació del PSC-Congrés:

"A todo lo dicho hemos de añadir que es preciso constatar una situación, cuya gravedad en el Partido como organismo global reviste en Barrios caracteres alarmantes: se trata de la falta de base e incidencia obrera. El PSC adolece intensamente de una amplia base obrera, y a nivel de barrios su implantación en las zonas obreras es mínima, cuando no inexistente en muchísimos sectores."1155

A nivell teòric s'havia fet algun esment a la qüestió del moviment popular als barris. Un Manifest-Programa elaborat per CSC l'any 1975 reconeixia l'explotació dels treballadors per la burgesia en altres espais fora del lloc de treball: els barris $^{1156}$. Poc després un altre document ens recordava l'impuls dels moviments

1152 [Sense títol ni data. Document de CSC sobre la lluita als barris], Fundació Rafael CampalansArxiu Històric del Socialisme Català (FRC-AHSC), Fons Jordi Font (FJF), Caixa 100, Carpeta P 5, A005.02 Front Barris. A aquest primer document sense títol s'afegeixen uns altres (que estan agrupats) amb els títols "Aportació dels Cercles per una línia d'acció a barris no 1"; "Aportació dels Cercles per a una línia d'acció a barris no2"; "Sogeriments per a un seminari sobre "la ciutat" (on es donen referències d'escrits de Pascual Maragall i Narcís Serra, però també de Lefevre, Tompson i Castells, entre d'altres); "Seminari: La ciutat capitalista" (a 9 Barris, també amb part dels autors anteriors); "Informe sobre la sessió extraordinària de la Coordinadora de Barris. Tema monogràfic: El cercle de barri" i "№ 3 Notes sobre els documents 1 i 2". En aquests escrits document es parla -entre d'altres coses- de la creació d'organismes de gestió popular i d'una alternativa socialista de ruptura democràtica. Apart de fomentar la participació en les AVV's, també s'insisteix en la creació d'Assemblees Democràtiques de Barri, que serien una representació local de l'Assemblea de Catalunya.

1153 Veure el document Informe sobre la sessió extraordinària de la Coordinadora de Barris. Tema monogràficf: El cercle de barri", esmentat anteriorment.

1154Veure [Diverses notes manuscrites sobre la captació de militants. [ [197?], FRC-AHSC, Fons Jordi Font (FJF), Caixa 100, Carpeta P 5, A005.02 Front Barris - Documents manuscrits sense títol però que parlen de captació de militants. És un document ja esmentat a la nota 645, on es constata la limitada implantació del CSC al Barcelonès Nord. Segons aquest hi havia alguns militants i simpatitzants a La Mina (Sant Adrià) treballant a l'AVV d'allà i al Centre Social del Besòs, entre els un tal Paco "jesuita" i textualment un "marit gitana";, a les Vivendes Congrés de Badalona (s'esmenta a Miguel Ángel, el President de l'AVV, a l'antic president Madueño i a "un grup de gent de l'AV") i alguna persona de Santa Coloma al Centre i als barris d'Arrabal i Santa Rosa (de noms apareixen Miguel Angel, Julio (textualment "de Bp (anarcos de Sta. Rosa")), Paco de Haro, Juanjo "Cojo" (ex OIC) i un tal "Topo".

1155 “Circular Frente de Barrios" [agost 1976], FRC-AHSC, Fons Jordi Font (FJF), Caixa 100, Carpeta P 5, A005.04 Cercles, p. 2.

1156"Projecte de Manifest-Programa" [1975], FRC-AHSC, Fons Jordi Font (FJF), Caixa 100, Carpeta P 6, A006, 1976 - A007, 1975, p. 8. 
de masses en la línia d'un Front dels Treballadors, entès com

“(...) una àmplia aliança de tots els partits, forces polítiques i organitzacions dels treballadors que propugnen, mitjançant una política d'unitat popular o de front socialista, un programa comú capaç de guanyar la voluntat de la gran majoria del poble, iniciant les transformacions -impossibles sense la més àmplia i constant mobilització de les masses que hauran de portar cap el socialisme. Aquesta aliança àmplia ha d'estendre's al màxim i, sense perdre de vista els objectius fonamentals, arribar des de l'esquerra socialdemòcrata i la cristiana fins l'esquerra comunista i la llibertària."1157

Així s'insistia en els documents aprovats en el Congrés Constituent del PSC de novembre de 1976 on s'apostava per la municipalització del sol, la nacionalització de la banca i sectors estratègics industrials, la defensa de la república i l'autodeterminació, a més de fer esment dels Països Catalans ${ }^{1158}$. Idees que es continuaran mantenint al II Congrés fet al desembre de $1977^{1159}$. No obstant en els documents aprovats hi ha un dedicat especialment a la lluita urbana i comarcal, on s'enunciaven els mals provocats pel model de ciutat capitalista i s'insistia en dos eixos del model socialista d'organització de l'espai: la planificació democràtica de l'economia i de l'ordenament del territori i l'autogestió dels treballadors i les classes populars en aquest procés, en la seva decisió i en la seva realitzación ${ }^{1160}$. De manera que nominalment s'apostava per l'acció dels militants i la participació popular a les AVV's i altres associacions (feministes, joves, pensionistes, medi ambient, culturals, etc.) i s'exigia l'abolició de la Llei d'Associacions de 1964, que havia de ser reemplaçada per una nova llei feta per la Generalitat. Es reclamava també unes ràpides eleccions municipals i una nova Llei de Règim Local. La importància donada al front municipal i a la preparació de les futures eleccions

1157"Pel socialisme. L'alternativa actual de la Convergència Socialista. Document aprovat per la IIo Assemblea de delegats", (setembre 1975), FRC-AHSC, Fons Antonio Canals (FAC), Caixa 263, Carpeta P 2.2 CSC, II a Assemblea de Delegats, p. 6. La cursiva és de l'original.

1158 “Documents aprovats en el congrés constituent del P.S.C. ", "Bases per un Manifest Programa" i "Línia Política" (1 de novembre de 1976), FRC-AHSC, Fons Antonio Canals (FAC), Caixa 263, Carpeta P 4 C001.01.03-04, 1976, p. 13-31 i 33-44.

1159 "Manifest-Programa del Partit Socialista de Catalunya" dins "2on Congrés per la unitat de tots els socialistes de Catalunya. Ponències aprovades" (desembre 1977), FRC-AHSC, Fons Antonio Canals (FAC), Caixa 263, Carpeta P 4, C001.02, 1977, p. 31-94.

1160 “I. La lluita urbana i comarcal”; "II. Política Municipal” i "III. Recomanació: Orientacions per a la llei de règim local de Catalunya." dins 2on Congrés per la unitat de tots els socialistes de Catalunya. Ponències aprovades" (desembre 1977), FRC-AHSC, Fons Antonio Canals (FAC), Caixa 263, Carpeta P 4, C001.02, 1977, p. 97-124. 
quedava també de manifest en un document fet per la Federació Catalana del PSOE en el seu XVII Congrés ${ }^{1161}$, poc abans de la unificació socialista.

En aquests anys -la segona meitat dels setanta- s'ha de reconèixer el pes que els militants polítics havien adquirit en el si del moviment veïnal. Cal recordar que si bé inicialment les organitzacions antifranquistes havien prioritzat altres moviments com l'obrer i l'estudiantil, als anys setanta va haver-hi un canvi quan es va veure el potencial que tenia la lluita als barris. Això no vol dir que totes les persones activistes del moviment veïnal fossin militants de partits polítics, però és indubtable el pes que van tenir les persones més polititzades en el si de les Juntes de les associacions. Quan parlo de persones polititzades em refereixo a les que tenien una pràctica activista desenvolupada. Per descomptat que el moviment veïnal va implicar en les seves mobilitzacions a sectors amplis de població que sortien d'aquest perfil, ja que si no no hauria esdevingut un moviment de masses ni hagués tingut la capacitat d'incidència que van demostrar sobretot als anys setanta. Ara bé, el dotar a aquest moviment d'una estructura estable, d'una organització i d'una constància era una tasca on solien destacar les persones més polititzades -amb carnet o no- sense la presència de les quals segurament hagués estat un procés més difícil. Amb les entrevistes que he pogut fer en la majoria dels casos es constata la presència d'aquest tipus de persones a les Juntes, sense que això vulgui dir que totes les persones que hi formaven part responguin a aquest perfil.

Això ens torna a remetre al debat sobre el major o menor pes dels partits polítics i dels seus militants dins el moviment veïnal. En aquest sentit em reafirmo en que van tenir un paper molt important juntament amb altres agents conscienciadors (com les parròquies obreres). Però cal recordar que durant els anys seixanta i fins i tot 50 ja s'havien produït protestes espontànies i alguns intents d'autoorganizació, a més de l'existència d'unes xarxes als barris -en especial els d'autoconstrucció- que s'havia forjat amb la lluita diària per la supervivència en tan dures condicions. I sobre això van actuar les parròquies, les persones més conscienciades i els militants d'organitzacions clandestines ${ }^{1162}$. Pel que fa a aquests

1161Federació Socialista de Catalunya (PSOE): "Memoria de Gestión de la Comisión Ejecutiva. Informe de la Comisión Ejecutiva al Congreso Extraordinario de la FSC (PSOE). Municipal." (Juliol 1978), FRC-AHSC, Fons Federació Socialista de Catalunya Caixa 86, pos 5, Carpeta A018, 1978.

1162 Iván Bordetas Jiménez: “De la supervivència a la resistència: La gestació del moviment veïnal 
últims vull apuntar que a vegades tinc la sensació que se'ls tracta com si fossin unes persones "alienes" als barris. És cert que determinats partits polítics van fer una política de "proletarització" forçosa de la seva militància, quan aquesta estava formada gairebé per universitaris de capes intermèdies o benestants -que eren enviats a viure i treballar a barris obrers- però aquest fet no ens pot fer obviar que la majoria la militància residia en els mateixos barris i que no en pocs casos s'implicaven en entitats i associacions del barri sense esperar la consigna del partit, amb una notable autonomia que a vegades topava amb les pròpies orientacions de les direccions:

“L'Associació de Mestresses de casa de Singuerlín.

La presidenta és una camarada. Té més de 200 socies [sic]. Va ser creada a iniciativa de dones independents i de camarades. Hi han problemes amb la companya que la dirigeix doncs fa una total dicotomia entre la vida de l'Associació i la vida del Partit."1163

És sobretot a finals de la dictadura -com he dit abans- quan hi ha una voluntat més explícita de les forces polítiques d'incidir en el moviment veïnal als barris. A més hi haurà una aposta decidida per potenciar les Associacions de Veïns legals en detriment de les clandestines Comissions de Barri -malgrat que en el Barcelonès Nord vam veure com a Santa Coloma aquestes van tenir una major vida $\mathrm{i}$ prolongació en el temps-.

Ara bé també es constata el fet de que a partir de la legalització dels partits i les eleccions del 15J de 1977, hi ha un descens de l'activitat de determinats persones militants de partits polítics per que es prioritza la feina de donar a conèixer els partits i preparar les campanyes electorals, ja sigui per directrius de les mateixes direccions o per sobrecàrrega de feines. En aquest sentit Josep Martí ja havia parlat d'aquest punt d'inflexió:

"els partits amb més grau de participació, sobretot el PSUC [...] comencen a ampliar el seu camp d'acció pública, tot obrint locals en diferents indrets, i deixant els seus militants de participar tant activament com ho havien fet fins aleshores. Això creà un

al a Catalunya franquista" dins Carme Molinero i Pere Ysàs (coords.): Construint la ciutat democràtica..., p. 111-112.

1163 Anna González: "Santa Coloma de Garmanet [sic]" [informe sobre el moviment de dones a Santa Coloma] (3-5-1978), ANC, Fons PSUC, 03.01.937. Santa Coloma de Gramenet: Comitè Local del PSUC, 1970-1988, p. 1. 
buit que es manifestà, sobretot durant l'any 1977. D'entrada per a preparar-se envers les primeres eleccions legislatives i després per pair-ne els resultats."1164

I no va ser pas l'únic. La revista Grama, en el seu primer número després de les eleccions del 15-J també parlava de l'existència d'una crisi a les AVV's des de feia un cert temps $i$, en aquest aspecte, entre d'altres coses, havia dit arguments semblants als exposats pel testimoni anterior:

“(...) Varias son las razones que podemos aducir. Los Partidos Políticos -ante la nueva situación creada- iniciaron su ofensiva de aparecer públicamente a la superficie. Así, los militantes políticos, que hasta entonces habían dedicado bastante atención a las Asociaciones, al abandonar su clandestinidad se vieron pronto sobrecargados por otras responsabilidades que les atraían más y poco a poco, se fueron desentendiendo de las tareas asociativas. Esta actitud llegó a extremos alarmantes en la campaña electoral. Las Asociaciones estuvieron casi desiertas y sus actividades -donde las hubiera- reducidas al mínimo. La política competitiva de las urnas lo absorbía todo. Además, el desmoronamiento de la dictadura suprimía los resortes que daba la cohesión a muchas actividades que las Asociaciones realizaban."1165

Aquest fet, com hem pogut veure, era reconegut pel mateix Jordi Borja que alertava sobre l'abandó de militants de les Associacions de veïns i reclamava el seu retorn, però per impedir que fossin utilitzades per partits situats a la seva esquerra. La relació del PSUC amb els partits de l'anomenada esquerra radical havia estat tibant i havia sigut focus de conflicte dins les mateixes AVV's, però la crítica del PSUC a aquestes formacions no es pot justificar només per aquest fet de voler hegemonitzar les Associacions, ja que tots els partits van jugar a tenir un major pes a les AVV's en determinats moments. En el fons, el que hi ha, és una diferent concepció del que havien de ser les AVV's en el nou context democràtic i de quin poder en podien tenir.

Pel PSUC i PSC-PSOE (les seves direccions sobretot) estava clar que, conseqüents amb el foment de la via institucional que havien fet des de els seus

1164 Josep Martí: Relació entre associacions de veïns i partits polítics. Barcelona 1970-1980. Citat a Iván Bordetas i Anna Sánchez: "El moviment veïnal en (la) Transició, 1974-1979" dins Carme Molinero i Pere Ysàs: onstruint la ciutat democràtica..., p. 249.

1165 “Asociaciones. Futuro incierto" [editorial], Grama núm. 102-103 (juliol-agost 1977), p. 3. De fet, al juny de 1977, al número 101, ja havia aparegut un breu amb un títol tan explícit com "Asociaciones en crisis" amb motiu del tancament del Centre Social Arrabal-Santa Rosa. 
respectius postulats polítics -eurocomunisme i social-democràcia- de prioritzar la via institucional i legalista, no estaven gents interessats en el foment d'un poder popular encapçalat per unes Associacions de Veïns que poguessin qüestionar el poder que albiraven obtenir passades les eleccions municipals. Malgrat els discursos retòrics i la crida a la participació popular, a efectes pràctics a les AVV's se'ls hi oferia poc poder real de decisió i gestió dins el món local. En contrast amb aquest discurs, els membres de l'esquerra radical apostaven per un moviment veïnal de masses amb capacitat de qüestionar el poder polític local i amb unes atribucions més àmplies i participatives. Un altre debat és si això ho van fer per convicció o per que van constatar la seva escassa força electoral, si bé aquest argument és reversible i es pot aplicar en el sentit contrari. Vull dir que algú també podria pensar que determinats partits, veient la seva força electoral, creguessin que ja no era tant necessària la existència d'un moviment veïnal potent i reivindicatiu que pogués qüestionar el poder que aspiraven a tenir controlant els Ajuntaments. 0 que fins i tot pensessin sincerament que el moviment veïnal ja no era tant necessari per que l'Ajuntament ja es faria càrrec de tots els problemes. En aquest sentit el testimoni d'un líder veïnal del PSUC i president de l'AVV de Juan Valera (Badalona), es significatiu:

"La mayoría de los líderes del movimiento popular (...) fuimos al ayuntamiento (...). Dimití como presidente de la AVV (...) Las reivindicaciones que nosotros llevábamos des de la AVV luego ya empezaban a ser asumidas por el propio ayuntamiento"1166.

En la línia oposada tenim els testimonis de persones que van continuar militant al moviment veïnal, com el cas de la Presidenta aleshores de l'AVV del Fondo (Santa Coloma):

"Resulta de que en el momento que se legalizan los partidos políticos, toda la gente política que había estado dentro de las Asociaciones empieza a desvalorar la Asociación de Vecinos como núcleo organizativo a nivel del barrio y a llevar la gente a la sede del partido. Eso no era válido... a desvalorizar completamente (...) porque ahora las cosas se tendrían que hacer de otra manera y ya había legalidad para hacerlas y esto había que hacerlo des de la sede de los partidos. Entonces toda la gente

1166Entrevista a Manuel Armentero, 10- 4- 2010. President de l'AVV Juan Valera i militant del PSUC. Va formar part de la candidatura del PSUC per Badalona i va ocupar posteriorment la Regidoria de Participació Ciutadana entre 1979 i 1983. 
tendencia política pues claro... cada uno procuró arrimarse al partido que había votado o con el que se identificara. Y pasó una cosa, que la Asociación de Vecinos, había una gente que aunque habíamos militao en partidos de izquierda, pero creíamos que la lucha popular y la lucha reivindicativa y la lucha social tenía que ver con la política, por aquello de que tenemos que tener interpretación de hacia donde vamos, toda esta cosa ¿no? Pero que no.... 'yo ahora soy de este partido, yo ahora soy de este otro, yo ahora soy de este otro...' y ¿entonces lo del barrio?."1167

De manera que podem afirmar que en els anys 1977-1979 s'estaven dirimint aquestes qüestions i en aquest context s'ha d'entendre aquesta primera crisi del moviment veïnal, crisi que s'accentuarà al 1979 un cop passades les eleccions però que com veurem, tindrà matisos i excepcions i unes causes més complexes, on no s'ha de menystenir l'impacte de la crisi econòmica, fet del qual parlaré més endavant. Però vull constatar que la demanda d'un major poder i participació per part del moviment veïnal no va ser una reivindicació reduïda als militants dels partits d'extrema esquerra, sinó que en gran mesura va ser assumida pel mateix moviment com ho demostren les propostes recollides al respecte en la I Assemblea d'Associacions de Veïns catalanes fetes a la ciutat de Manresa el 2 de desembre de 1979, on Federacions d'associacions de veïns i Coordinadores (en concret les de la FAVB de Barcelona, la Coordinadora d'AVV's de Santa Coloma de Gramenet i les AVV's de Tarragona) van presentar propostes que anaven més enllà del limitat espai que s'oferia a les AVV's en el nou context democràtic ${ }^{1168}$. Tot i que no tothom va estar-hi d'acord, es van recollir moltes de les seves aportacions en la línia de que les AVV's fossin reconegudes entitats d'interès públic, amb dret a veu als Plens; com a entitats de control de la gestió municipals i garants de la participació ciutadana; amb capacitat de gestionar serveis socials i culturals dels barris i

1167Entrevista a Emiliana Salinas, 28-5- 2013. Va ser miliant de la JOC, l'OIC, de Plataformes Anticapitalistes durant la lluita a Casadeport i posteriorment Presidenta de l'AVV del Fondo.

1168En concret eren les aportacions fetes per la Coordiandora d'AVV's de Santa Coloma de Gramenet: "La Participación de las AA.VV. y sus campos de intervención"; per la Federació d'Associacions de Veïns de Barcelona: "Aportacions AA.VV. y participación ciudadana"; i AVV's de Tarragona: "Texto de las impugnaciones al proyecto de Juntas de Barrio del Ayuntamiento de Tarragona". En contrast, la Coordinadora d'AVV's de Manresa va presentar un escrit amb reivindicacions més moderades: "Criteris sobre participació ciutadana a Manresa". Tot això a Desenvolupament, conclusions i cens. I Assemblea de les associacions de veïns de Catalunya. (Manresa, diumenge 2 de desembre, 1979), ANC, Fons PSUC, 2350. Activitat de diverses entitats i moviments ciutadans reivindicatius. 1970-1979, p. 8-16. 
municipis; amb poder de convocar a tots els veïns i no només als seus socis; amb capacitat de fer propostes a l'Ajuntament i ser consultades per aquest en aquells aspectes que afectaven els seus àmbits d'actuació. I fins i tot es va proposar la celebració de referèndums municipals en temes d'especial interès ciutadà ${ }^{1169}$.

No obstant, com es pot constatar en el document que recull el debat fet al voltant d'aquestes qüestions, els primers mesos d'Ajuntaments democràtics no van acomplir les expectatives:

“(...) hi havia en la majoria de delegats una gran preocupació, ja que l'actuació dels nous ajuntaments democràtics, pel que fa a la referència a la participació, cal valorar-la com negativa.

• Els Ajuntaments on s'ha aprovat un reglament de descentralització i participació s'ha marginat a les AA.VV. en la seva elaboració. Això es considera greu, ja que hi havia coses que aportar.

- A la majoria de reglaments no es reconeix el dret a veu en els plens, en els consells de Barri o Districte. I en aquells en els quals es reconeix, en general és a través de fórmules restrictives. Per un altre cantó, hi ha alguns casos en els quals el Reglament aprovat tenia en compte els nostres drets, i aquest Reglament ha estat vetat per l'actual Generalitat provisional, cosa evidentment molt greu."

•Hi ha Ajuntaments que no reconeixen les AA.VV. com organització del veïnat, com a entitats de participació ciutadana i els drets de consulta, referèndum, proposta, en general no han estat portats a la pràctica.

- També s'ha constatat la falta d'informació per part dels Ajuntaments: els ordres del dia, les actes de les sessions no es faciliten a les entitats, i no s'ha aconseguit d'establir uns canals que permetin al ciutadà mig d'assabentar-se del que passa a dintre dels Ajuntaments." ${ }^{1170}$

Més endavant analitzaré amb més detall el paper que van jugar els primers Ajuntaments democràtics i la seva relació amb el moviment veïnal. Abans veurem quines van ser les principals lluites veïnals al Barcelonès Nord des de 1976 a 1979.

1169Veure "Anexe: propuesta de Articulado de participación ciudadana" dins la "Ponència. La participació de les AA.VV. en els Ajuntaments." Desenvolupament, conclusions i cens. I Assemblea de les associacions de veïns de Catalunya. (Manresa, diumenge 2 de desembre, 1979), ANC, Fons PSUC, 2350. Activitat de diverses entitats i moviments ciutadans reivindicatius. 1970-1979, p. 15-16.

1170 "Debat de la Ponència" dins "Ponència. La participació de les AA.VV. en els Ajuntaments." Desenvolupament, conclusions i cens. I Assemblea de les associacions de veïns de Catalunya. (Manresa, diumenge 2 de desembre, 1979), ANC, Fons PSUC, 2350. Activitat de diverses entitats i moviments ciutadans reivindicatius. 1970-1979, p 15. 


\subsection{Lluites veïnals i reivindicacions polítiques al Barcelonès Nord: el franquisme local desbordat.}

El període que va de 1976 a 1979 va ser sens dubte el moment on es van donar mes lluites i mobilitzacions veïnals al Barcelonès Nord. Va ser un moment on el poder franquista local es va veure totalment desbordat, a més d'estar en un període especial de "provisionalitat" a partir del 15 de juny de 1977, fet que el posava en una situació molt vulnerable. Aquesta constant pressió i mobilització en el món urbà va condicionar molt el procés de canvi polític, si bé per si sol va ser insuficient per aconseguir la ruptura. Grosso modo podem distingir dues etapes, separades per les primeres eleccions pluripartidistes que es van donar des de la instauració de la dictadura. Quan va morir Franco ja hi havia una important dinàmica engegada que no va trobar pas aturador, ans al contrari, va anar in crescendo.

A Badalona l'any 1976 ja va començar agitat. Primer, des de les Associacions de veïns es va veure amb escepticisme els "intents d'acostament" que va fer l'Ajuntament, conscient de la força que tenien aquestes entitats. Una reunió feta a inicis d'any amb diverses associacions ja va posar aquest fet de manifest quan tot $\mathrm{i}$ ser convocada per l'Ajuntament, cap autoritat digna de menció va fer acte de presència -només membres del Gabinet d'Estudis Econòmico-Socials i les assistentes socials. No va sorprendre que la majoria d'associacions -aquelles que escapaven al control de persones conservadores- sortissin defraudades i expressessin clarament la necessitat d'un consistori democràtic ${ }^{1171}$. Per tant, era d'esperar que fossin especialment crítiques amb les "eleccions" a Alcalde entre Isidre Caballaria Pla i José Guillem Clapés celebrades el 25 de gener de 1976, que

1171 Manuel Armengol: "Badalona: La actitud de los vecinos respecto el Ayuntamiento es de escepticismo. Consideran que la elección democrática del Consistorio es la única garantia para resolver sus problemas y necesidades", La Vanguardia Española, 13-10-1976 i també Manuel Armengol: "Badalona: El interés por las elecciones prácticamente nulo. Las dos candidaturas presentadas no ofrecen perspectivas de cambio y son sobradamente conocidas", La Vanguardia Española, 23-1-1976. En canvi, altres AVV's, les controlades per persones conservadores van donar suport a Isidre Caballeria Pla. Es tractaven de les de Sant Antoni de Llefià, Sant Juan de Llefià, Bufalà, Bonavista, Immaculada, Lloreda, Sant Crist i la ACF de Sant Roc. Veure "Algunas entidades de Badalona apoyan al alcalde en su gestión", Tele/ eXprés, 22-11976. 
van provocar una forta contestació a la ciutat amb reivindicacions per poder triar aquesta figura democràticament ${ }^{1172}$.

De nou les mobilitzacions veïnals van ser les que van marcar el pas aprofitant el nou context d'oportunitats polítiques que s'obria un cop mort el dictador -si bé la dinàmica mobilitzadora ja venia de molt abans-. El barri de Llefià va ser un dels que més va destacar en aquests anys a Badalona ${ }^{1173}$. Ja en aquest mes de gener es va tancar un conflicte que havia començat un mes abans amb l'expulsió de tres mestres del Col-legi privat Nuestra Señora de la Esperanza, que van haver de ser readmesos per la pressió veïnal ${ }^{1174}$. El mateix dia 25 s'havia celebrat una assemblea on els veïns havien denunciat les greus mancances del barri i exigit la dimissió del regidor Fulgencio Conesa ${ }^{1175}$, que era el President de l'AVV de Sant Antoni de Llefià que havia vetat l'entrada de més socis.

A la part baixa del barri, havíem vist les intenses mobilitzacions de l'any 1975 exigint la urbanització del barri i la dotació de serveis. Per fi, a l'any 1976 s'inaugurava una part de l'enllumenat de la zona de Sant Mori i per celebrar-lo, veïnes i veïns impulsats per l'AVV de Sant Mori -que encara estava en tràmit de legalització i funcionava oficialment com "Comissió Gestora”1176- van organitzar una festa popular ${ }^{1177}$. També, finalment, l'Avinguda Marqués de Sant Mori va ser asfaltada i urbanitzada. Els mateixos veïns, esperonats per l'AVV Sant Mori es van encarregar de plantar arbres en tot el carrer en l'anomenada "Setmana Verda". El dijous 18 de març s'inaugurava el primer parc infantil en tot el barri, el Parc de Les

1172 Veure nota 1009 i Manuel Armengol: "Badalona: Manifestaciones contra las elecciones. Quinientas personas pidieron la dimisión del consistorio", La Vanguardia Española, 27-1-1976.

1173Per una anàlisi més detallada d'aquest barri veure la meva Tesina El moviment veïnal a Llefià (Badalona), ja citada i l'obra de Juan Rico Márquez: Llefià. De la barraca a la dignidad, Autoeditat, Badalona, 2010.

1174 Manuel Armengol: "Badalona: El conflicto del Colegio de Nuestra Señora de la Esperanza en vias de solución. Los tres profesores despedidos ya han sido readmitidos", La Vanguardia Española, 14-1-1976. Veure més informació també a "Comenzaron los problemas", Ojo. Asociación de Vecinos Juan Valera núm. 1 [gener 1976], p. 8-11, on s'explica aquest conflicte i una assemblea feta al local de l'Associació amb la presència del Tinent Alcalde de Cultura (Sr. Parra), el Regidor Delegat (Sr. Molina), una comissió de professors, 500 pares d'alumnes i el president de l'AVV (Sr. Vallespin, aleshores), a més del director de l'escola, el popularment conegut al barri com "Sr. Juan".

1175 “Gestiones de las asociaciones de vecinos de Badalona para crear una federación”, Tele/ eXprés, 30-1-1976.

1176“Varias asociaciones de vecinos de Badalona esperan ser legalizadas”,Tele/ eXprés, 9-3-1976.

1177Emma Alsina Planas i Pedro Jesús Fernàndez: Història d'un barri. Història d'una associació. Sant Moni de Llefià (1974-1987) [estudi inèdit], p. 23. 
Palmeres, amb presència fins i tot de l'Alcalde Caballeria, que va haver d'escoltar les paraules dels membres de l'AVV que van llegir públicament les reivindicacions del barri:

\begin{abstract}
"Ante la inesperada situación, el "batlle" de Badalona se limitó a prometer que se haría lo posible para remediar los déficits de la barriada expuestos de una forma exhaustiva por los miembros de la Asociación en el documento que recogía en definitiva lo que la especulación de las inmobiliarias y la falta de planificación no han creado: mejores transportes, asistencia sanitaria, escuela profesional, guarderias, enseñanza gratuita... y algo menos urbanístico: "una convivencia democrática en el barrio"."1178
\end{abstract}

En aquest moment la majoria de la gent del barri, es mobilitzés o no, començava a ser conscient que gràcies a les lluites i mobilitzacions s'aconseguien millores. Com que la situació de brutícia que es patia era molt greu, fins al punt que les rates proliferaven i es reproduïen en unes faixes de construcció amb moltes cavitats fetes per edificar uns blocs en la part alta del barri -no es van fer de formigó "per estalviar"-, el 8 de maig una nombrosa manifestació de 2.000 persones va recórrer el barri des de la part alta de Llefià fins el recent inaugurat Parc de Les Palmeres. A les reivindicacions per la brutícia es van sumar les protestes per la tardança en la legalització de l'Associació, endarrerida per les autoritats franquistes conscients de que no era "de les seves" ${ }^{1179}$. En aquest mateix moment s'inicien els tràmits per fer una nova AVV en Sant Joan de Llefià, a la part alta del barri, davant la inoperància de l'altra associació existent i del regidor Ramón Arjona ${ }^{1180}$.

A la part alta de Llefià un conjunt d'empreses relacionades amb la immobiliària Ibusa (Vensade, Villes, Visepol i Ibume) de l'empresari Eduardo Bueno Ferrer estaven edificant un espai situat entre l'Avinguda Amèrica, el carrers Sant Bartomeu, Atlàntida i l'Avinguda Dr. Bassols. Però ho estaven fent tant malament i amb tants defectes (esquerdes, humitats...) i amb una manca d'urbanització dels carrers que les protestes van esclatar aviat. De seguida van

1178“Inauguración popular en un parque de Badalona”, Tele/ eXpres, 23-3-1976.

1179“Invadidos por las ratas", Mundo Diario, 8-5-1976; "Badalona: denuncian la invasión de ratas en Sant Joan de Llefià", Tele/ eXprés, 10-5-1976 i "Las barriadas de Llefià y Bufalà vuelven otra vez a la calle con sus reivindicacones", Diario de Barcelona, 13-5-1976.

1180 Manuel Armengol: "Badalona: Los vecinos de San Juan de Llefià en busca del tiempo perdido", La Vanguardia Española, 14-4-1976. 
proliferar les pancartes de denúncia posades pel mateix veïnat al les seves balconades ${ }^{1181}$. De fet, fins i tot l'Ajuntament de Badalona va paralitzar durant dos mesos les obres d'urbanització d'aquestes empreses per les irregularitats flagrants que estaven fent ${ }^{1182}$. S'iniciaren converses entre immobiliària i veïns, a les quals s'afegiren els residents dels blocs del Patronato Municipal de la Vivienda de la Ronda de Sant Antoni, unificant les demandes de millora i urbanització que també es feien des d'aquest sector ${ }^{1183}$.

Del 8 al 13 de juny l'AVV de Sant Mori havia organitzat una "Setmana de la Enseñanza" amb nombroses xerrades i actes al recentment inaugurat Parc de Les Palmeres i als locals de la Parròquia de Sant Antoni de Llefià ${ }^{1184}$. La manca d'escoles serà una constant preocupació al barri i un motiu constant de mobilització, però aquest tema el tractaré més endavant de manera transversal.

Finalment, a l'agost de 1976 es va legalitzar l'AVV de Sant Mori de Llefià, després d'una intensa campanya i d'haver d'esperar més d'un any i mig. Les reivindicacions encapçalades per aquesta entitat van continuar. El dijous 9 de setembre una manifestació de 300 persones recorria aquesta part baixa del barri fins acabar al mur de la finca de Torre Mena (una antiga casa senyorial construïda al segle XIX). Es van fer les tradicionals reivindicacions de millora de l'estat del barri, però també es van cridar consignes a favor de la dimissió del Consistori i exigint Ajuntaments democràtics ${ }^{1185}$.

A finals de l'any 1976 el barri de Llefià era un reguitzell de conflictes ${ }^{1186}$. A la

1181Enric Juliana: "Badalona: Pancartas en Sant Juan de Llefià contra las irreguladidades urbanísticas”, Tele/ eXprés, 14-6-1976.

1182 “El Ayuntamiento de Badalona paraliza las polémicas obras de Sant Joan de Llefià”, Tele/ eXprés, 27-5-1976; "Badalona: El alcalde decreta la paralización de varias obras en el barrio de Llefià", La Vanguardia Española, 2-6-1976 i “El ayuntamiento paraliza las obras”, Mundo Diario, 4-61976. De fet un estudi posterior fet per la Comissió Tècnica de Urbanisme de la "Asociación Nacional de Ingenieros Industriales" demostrava com s'havien fet greus irregularitats i com per exemple s'havien edificat 200 habitatges més dels previstos inicialment. Veure "Badalona: Graves irregularidades en una urbanización de Llefià”, La Vanguardia Española, 8-10-1976.

1183 “Badalona: Nueva protesta de los vecinos de Sant Joan de Llefià”, Tele/ eXprés, 1-9-1976. En aquestes lluites es gestarà també la futura Associació de Veïns de la Ronda de Sant Antoni.

1184 “Badalona: Clausura de la Primera Semana de la Enseñanza en Llefià”, Tele/ eXpres, 15-6-1976. Un cartell d'aquesta jornada es pot veure a la meva Tesina de Doctorat El moviment veïnal a Llefià (Badalona), p. 228 i a l'Arxiu Històric de Llefià: http://www.llefia.org/gallery/main.php? g2 itemId=33373.

1185 “Manifestación en Badalona por el mal estado de las calles”, Tele/ eXprés, 11-9-1976 i "Badalona:La Masia de “Can Bofí Vell” serà remozada”, La Vanguardia Española, 12-9-1976.

1186 Part d'aquests van ser recollits a la revista d'efímera duració Comarca Exprés, en concret als núms. 1 (1/15-12-1976): "Más apoyo a Llefià", p. 8 i al núm. 2(15/30-12-1976): "Vecinos 
part alta del barri s'estava donant els relacionats amb els pisos d'Ibusa i el del Parc del Gran Sol (que havia començat l'any 1975 i encara continuava). Baixant una mica hi havia conflictes també entre els veïns i la empresa Inmobilar vinculada a "Gallina Blanca", mentre que a la part plana del barri l'AVV de Sant Mori continuava mobilitzant al veïnat i reivindicant ajuntaments democràtics. Mentrestant es donaven continues reivindicacions en demanda d'escoles que eren transversals a tots els barris. Amb aquest ambient no és d'estranyar que el cap de setmana del $4 \mathrm{i}$ 5 de desembre es fessin dues manifestacions amb la participació de cinc-centes persones $^{1187}$.

1977 començava amb la mateixa tònica. El cap de setmana del 18 i 19 de gener va haver-hi assemblees dels veïns dels blocs del "Patronato Municipal de la Vivienda" demanant la urbanització i el proveïment d'escoles, locals socials i altres equipaments. Per la seva banda, a Sant Joan de Llefià el veïnat dels pisos construïts per Inmobilar (Gallina Blanca) es reunien al local de l'Associació de Sant Joan de Llefià Alt (existent des de 1963, controlada per gent conservadora però que ara es veurà desbordada pels esdeveniments) i reclamaven també millores d'urbanització ${ }^{1188}$. Els diferents afectats es van anar coordinant de manera que el 23 de gener es produïa una nova manifestació protagonitzada per 1.500 persones dels blocs d'Ibusa, el Patronat Municipal i d'Inmobilar. Es va caçar una rata que va ser llançada al domicili particular de Fulgencio Conesa ${ }^{1189}$. Les mobilitzacions van sortir el seu efecte. Ibusa es comprometia públicament a reparar els desperfectes de les seves edificacions i començava les obres per fer-ho ${ }^{1190}$.

Malgrat al mes de febrer en un Ple de l'Ajuntament s'havien tractat específicament els problemes i reivindicacions de Llefià, discutint-se possibles solucions i permutes de terrenys amb la $\mathrm{CMB}$, el cert és que la conflictivitat va augmentar. La construcció d'un supermercat de la multinacional italiana Catalsa en

contra inmobiliarias", p. 8 i "Sant Mori Impuestos ¿otra vez?", p. 6.

1187 “Persiste el conflicto en San Juan de Llefià de Badalona”, Tele/ eXpres, 7-12-1976.

1188Maurici: "Los vecinos de Llefià se mobilizan. Dignificar el barrio y viviendas", Mundo Diario, 20-1-1977.

1189"Badalona: Mil quinientos vecinos del barrio de Llefià se manifestaron por las calles del barrio", La Vanguardia Española, 25-1-1977 i “Los vecinos de Llefià, unidos”, Mundo Diario, 251-1977.

1190“Badalona: Acuerdo entre promotores y vecinos del barrio de Llefià”, La Vanguardia Española, 4-2-1977. 
un pati interior d'una illa d'edificis (situada als carrers Andrés Segovia, Sagrada Família, Carretera Antiga de València i Alfons XIII) per la immobiliària Puger S.A. -vinculada a l'empresari Mestre Ferrer- va engegar un nou conflicte, ja que al veïnat se l'havia promès un pati interior enjardinat ${ }^{1191}$. Es van fer diverses mobilitzacions que van incloure l'ocupació durant 30 hores de l'Ajuntament des de el dilluns 2 de maig per un centenar de persones davant la incompareixença de Mestre Ferrer a una reunió que s'havia de fer al mateix consistori. Finalment l'empresari va comparèixer i va donar la raó als veïns, comprometent-se a enderrocar el construït per fer la zona enjardinada i pagar una indemnització al veïnat de 750.000 pessetes $^{1192}$.

La construcció del Mercat de Llefià va generar un altre conflicte. Aquest s'havia de construir en una zona ja "calenta" del barri pel les lluites veïnals contra la immobiliària Ibusa. En teoria al costat del mercat hi havia d'anar una zona verda però el veïnat es va adonar que el mercat estava ocupant gran part d'aquest espai i van començar a protestar amb pancartes contra Benito Solans, propietari de la constructora que estava fent les obres. Aquest per la seva banda va denunciar als veïns, encrespant més els ànims. Després d'algun intent de conciliació fallit i mobilitzacions com la que es va fer davant l'Ajuntament el 31 de març, Benito Solans va haver de retirar la denúncia i pagar una indemnització de 750.000 pessetes $^{1193}$. Però el conflicte estava lluny de solucionar-se completament pels incompliments de l'acordat per l'empresari i per la proximitat del conflicte per l'espai del Gran Sol (que ja venia d'abans) on es continuava edificant. El 6 de maig després d'una assemblea en aquest espai un grup va assaltar i destrossar les oficines de la immobiliària "Promotores Corsa" i van haver-hi 5 detinguts per la

1191 Miquel Font: "Badalona: pisos en disputa”, El Correo Catalán, 18-2-1977 i Maurici: “Encierro en el Ayuntamiento", Mundo Diario, 4-5-1977.

1192 “Badalona: Cien vecinos se encierran en la Casa Consistorial”, La Prensa, 3-5-1977; "Badalona: Al final, se llegó a un acuerdo en el barrio de Llefià", La Vanguardia Española, 4-5-1977; “Tancada dels veïns de Llefià", Avui , 4-5-1977; "Encierro en el Ayuntamiento", Mundo Diario 45-1977 i "Los vecinos de Llefià ocupan el Ayuntamiento durante 28 horas", Diario de Barcelona, 4-5-1977.

1193 “Veïns contra el mercat" i “50 veïns de Llefià al jutjat”, Avui, 25-3-1977 i 27-3-1977; "Denuncian a los vecinos por los textos de unas pancartas reivindicativas", Tele/ eXprés, 26-31977; "Se construye en zona verde" i "Llefià gana una batalla" Mundo Diario, 25-3-1977 i 3-41977; "Badalona: Protestas por las deficiencias urbanísticas de las zonas de Llefià y Lloreda", La Prensa, 1-4-1977. 
policia ${ }^{1194}$. Benito Solans s'havia compromès a cedir $4.000 \mathrm{~m} 2$ per equipaments en compensació per la construcció del Mercat, però com que no es trobaven aquests espais el veïnat va proposar que s'agafessin del Gran Sol. El constructor també havia ofert una compensació econòmica ${ }^{1195}$. Però tot això no es va solucionar fins l'aprovació del PERI de Llefià-La Salut en anys posteriors.

Tanmateix també va haver-hi mobilitzacions al barri per protestar contra les molèsties que provocaven les indústries contaminants Rovira Bachs i Cruz Verde. Al març s'havia fet una assemblea de tres cents veïns on es va decidir recollir signatures i al maig n'havien recollit unes dos mil ${ }^{1196}$.

Significativament, la CMB decidia el 24 de març suspendre durant un any les llicències d'obres a Llefià, argumentant l'existència d'una "gran massa d'edificacions en el sector"1197, decisió que no s'entén sense la gran conflictivitat existent en el barri. L'entitat es comprometia a fer un Pla Especial de Reforma Interior del barri i a permutar solars amb Cerdanyola del Vallés per aconseguir espais per equipaments -definitivament, el 20 de juliol ${ }^{1198}{ }_{-}$. Però pel seu compte, les AVV's de Sant Mori i Juan Valera es van posar en contacte mitjançant l'advocat Francesc Arnau amb el Secretariat de Coordinació per al Desenvolupament (SECOD), una organització de cristians de base i amb l'ajunt dels seus tècnics van fer el seu propi estudi sobre les necessitats del barri entre abril i agost de 1977. I aquest estudi va ser la base del PERI de Llefià i La Salut ${ }^{1199}$.

Finalment, el canvi va arribar també a l'AVV de Sant Antoni de Llefià malgrat la dura oposició de Fulgencio Conesa. A l'abril de 1977 una nova junta se'n feia càrrec de l'entitat, presidida per un aleshores desconegut militant de l'OIC -i posteriorment del MC- Antonio Agudo Tuñón ${ }^{1200}$. Ell mateix ens ho resumia amb les

1194"Badalona: Nueva incomparecencia de la empresa constructora del mercado de Llefià", La Vanguardia Española, 8-5-1977; “Tot Llefià contra el mercat”, Avui, 8-5-1977; "Destrozos en una oficina inmobiliaria", Diario de Barcelona, 8-5-1977.

1195“Llefià: cinc milions per als veïns”, Avui, 16-9-1977.

1196"Protestas por la contaminación", La Prensa, 11-3-1977 i "Badalona: El Ayuntamiento desestima las alegaciones contra el proyecto Montigala-Batlloria”, La Vanguardia Española, 75-1977.

1197 “Badalona: la cesión de un terreno de 19 hectáreas acaloró el pleno municipal” i "Badalona: La Corporación Metropolitana suspende la concesión de licencias en Llefià”, La Vanguardia Española, 16-4-1977 i 22-4-1977.

1198La Vanguardia Española, 3-6-1977, 15-6-1977.

1199Marta Puertolas: "Plan urbanístico para Llefià", Diario de Barcelona, 2-8-1977 i Juan Carlos Pasamontes: “Badalona: Plan de equipamientos en Llefià”, La Vanguardia Española, 7-8-1977. 1200Aquesta nova Junta estava formada -apart de l'esmentat Antonio Agudo- per Juan Fernández 
següents paraules:

"El fet que jo entrés de President no ho van veure malament per que no tenien clar que jo era d'un partit polític d'esquerres per que no estava vivint al barri (...) aquí va entrar tota una sèrie de gent que si eren del barri però que tampoc eren una gent molt vinculada a nivell social (...) després tota la gent de la generació del Conesa es va desvincular bastant, com si ja veiessin que allà no tenien res a fer. El que [es] va conservar allà com a tresorer va ser el Silvino Velasco (...) de la vieja guardia del Conesa... aquest es va quedar com a controlador allà però mica en mica el vam deixar de banda i el contacte que ells tenien amb l'associació va desaparèixer (...) va ser una sortida (...) com si veiessin que això s'acabava (...) i que no tenien possibilitats de fer res... com si veiessin que allò de la època de Franco ja (...) quan veus que hi ha una perspectiva de canvi important en totes les qüestions polítiques d'un puesto i dius bueno... lo millor serà que em vagi apartant (...) es van marxar i va haver una lluita per intentar recuperar l'activitat dintre de l'associació." ${ }^{1201}$

A cavall entre el barri de Llefià i La Salut estava l'Associació de Veïns de Juan Valera. Aquesta va ser una entitat "infiltrada" per militants d'esquerres fins al punt que al 24 d'abril de 1976 es van fer unes eleccions a Junta que van portar a la Presidència a un militant del PSUC, Manuel Armentero ${ }^{1202}$, culminant un procés que s'havia engegat a l'estiu de 1975. L'entitat va col-laborar en les mobilitzacions que s'estaven fent aleshores a Sant Mori de Llefià, però aviat va destacar per les seves reivindicacions pròpies. Les immobiliàries Norma i Novohogar estaven urbanitzant uns espais que els veïns reclamaven com a parcs i espais públics en ser els darrers que quedaven. Un nombrós grup de veïns, la majoria dones, van començar el 13 d'octubre l'ocupació d'un d'aquests solars situat al costat del carrer Juan Valera, posant plantes com a manera de reivindicar un $\operatorname{parc}^{1203}$. Es va iniciar així un estira i arronsa entre veïns, immobiliària i forces repressives. Les obres van ser

Hilarí, Bernardo Pérez Hernández, Llorens Castells Peris, Silvino Velasco Quintanos, Miguel Ochoa Robledo, Pedro Rodríguez Rodríguez, Inocencio Cordovila Puerto, Lorenzo Cuñado Manero, Blas Gómez Torres, Mercedes Domingo Ramírez, Javier Sánchez Pretel, Eustaquio Granado de Sanbe i Angel Martínez Martín. Veure [Acta de l'Assemblea General Ordinària de l'AVV de Sant Antoni de Llefià], (2-4-1977), Arxiu Històric de Llefià, Fons Entitats, AVV Sant Antoni de Llefià, Actes [enllaç: http://www.llefia.org/gallery/main.php?g2_itemId=33918]. Segons el mateix Antonio Agudo Bernardo Pérez i Eustaquio Granado eren simpatitzants del PSUC i Llorens Castells de la CNT. Entrevista a Antonio Agudo Tuñón, 21-6-2010.

1201Entrevista a Antonio Agudo Tuñón, 21-6-2010.

1202“Las elecciones fueron...”. Ojo. Asociación de Vecinos Juan Valera. Barrio La Salud, núm. 3 (maig? 1976), p. 4-5.

1203“!!Pisos no, Parque si $i[$ [sic]”, Ojo. Asociación de Vecinos Juan Valera. Barrio La Salud (octubrenovembre? 1976) núm. 4, p. 9 i Avui, 20-10-1976 i Tele/ eXprés, 25-10-1976 i 26-11-1976. 
custodiades per números de la Guàrdia Civil i allà van produir-se diversos enfrontaments:

"Allí hubo una lucha muy fuerte allí hubo palos con la Guardia Civil (...) la Guardia Civil estuvo las 24 horas del día custodiando el terreno para que se pudiera construir." ${ }^{204}$

La reacció veïnal va ser també immediata quan va aparèixer una excavadora dins el solar, si bé aquesta va ser una mica "accidentada":

"Yo no he conducido nunca una excavadora, pero si alguien la arranca yo la saco (...) un vecino (...) cogió y le hizo el puente y la arrancó. Yo la saqué (...) hay que llevarla abajo (...) la excavadora era muy lenta (...) le meto la tercera (...) esa excavadora para andar rápida le tienes que plegar la retro y la pala (...) porque si no se desequilibra. Como yo no lo sabía hacer (...) las ruedas pequeñas se levantaron y me quedé sin dirección (...) fue una especie de ping-pong: iba de una acera, rompía un coche, iba a la otra (...) hasta que quedé abajo empotrado en un camión."1205

L'Associació va fer una col·lecta per reparar els vehicles fets malbé i no es va produir cap denúncia per aquest fet. L'empresa Novogar finalment s'avingué a negociar a principis de 1977 una permuta de terrenys per cedir al veïnat el solar ocupat. Al 8 de febrer es celebrava una assemblea als Cines de La Salut convocada per les AVV's de Sant Mori de Llefià, Sant Antoni de Llefià i Juan Valera, amb la participació de sis-centes persones. Es van valorar la oferta de Novogar així com de les reivindicacions pendents que s'havien de parlar amb l'Alcalde ${ }^{1206}$. Un acord entre aquesta empresa i la Corporació Metropolitana de Barcelona va garantir la conservació d'aquest espai i un altre proper on s'havia de construir un "mercadillo", que reberen, significativament, els noms de Parc Salvador Allende i Plaça de la Dona. I no només això, també s'arrencà el compromís d'uns locals per la mateixa AVV i pels jubilats del barri ${ }^{1207}$.

Aquesta Associació havia fet una Setmana de la Juventut del 27 de setembre al 3 d'octubre de $1976^{1208}$. També havia denunciat els nombrosos defectes urbanístics del barri, que provocaven constants inundacions quan plovia pel

1204 Entrevista a Manuel Armentero, 10-4-2010.

1205Ídem.

1206 Miquel Font: “Las AA.VV. de La Salud y Llefià se entrevistaron con el alcalde”, El Correo Catalán, 1-2-1977.

1207 Entrevista amb Manuel Armentero, 10-4-2010.

12080jo. Asociación de Vecinos Juan Valera. Barrio La Salud, núm. 4, p. 4 i 5. 
deficient i insuficient clavegueram. Alhora, hi havien carrers com Nàpols, Quevedo i Floridablanca que van ser edificats sense existir xarxa de clavegueram i vessaven les seves aigües residuals a fosses sèptiques d'un pati interior que va demostrar ser un cau de problemes per la seva saturació i els olors fètids que desprenien ${ }^{1209}$. Les inundacions eren doncs constants per defectes del terrat o dels baixos -on també es filtraven les aigües residuals a les finques dels carrers esmentats més el de Juan Valera $^{1210}$. Aquest darrer fet era recollit amb ironia per la premsa del barri:

"Nosotros sugeririamos [sic] que, envez [sic] de construir el tan rechazado "Puerto deportivo" en la playa lo construyeran en nuestro barrio; seria más necesario y quizá tuviera más aceptación." ${ }^{1211}$

Finalment l'empresari Pablo Porta, propietari de la immobiliària La Salud que havia edificat en aquesta zona, va pactar amb l'Ajuntament la construcció de foses parcials connectades amb el clavegueram general solucionant-se el problema dels olors, una de les principals reivindicacions del veïnat ${ }^{1212}$.

Com tantes altres l'AVV de Juan Valera havia donar suport a la jornada de vaga del 12 de novembre de 1976 i va haver de patir dues detencions ${ }^{1213}$, demostrant, de nou, que les reivindicacions anaven més enllà de l'estricta demanda de millores materials per al barri. Alhora, -com ja he dit- l'AVV de Juan Valera va col-laborar amb Sant Mori i el SECOD en l'elaboració del PERI de Llefià i La Salut l'any 1977.

Al barri de La Salut van existir dues Associacions de Veïns més, la de La Salut Alta, legalitzada en 1972 i la de Verge de la Salut, la Comissió Gestora de la qual es va constituir al desembre de $1976^{1214}$. En el cas d'aquesta darrera associació es corresponia a les necessitats especials dels habitatges d'un grup d'habitatges construïts en un sot envoltat de turons, conegut popularment com "el Hoyo". Tot i

1209 “Polémica en torno a una fosa séptica en el barrio de La Salud de Badalona”, Tele/ eXprés, 12-61976.

1210 “Inundadiones i desagües”, Ojo. Asociación de Vecinos Juan Valera. Barrio La Salud, núm. 2 (març-abril? 1976), p. 9-11.

1211 Ídem, p. 11.

1212 "Ya no apestará", Ojo. Asociación de Vecinos Juan Valera. Barrio La Salud, núm. 5, p. 16.

1213“Dia 12", Ojo. Asociación de Vecinos Juan Valera. Barrio La Salud, núm. 5, p. 8 i 9. Un dels detinguts era el Vicepresident de l'entitat.

1214"Nueva asociación de vecinos en Badalona", Tele/ eXpres, 27-12-1976 i "El "Hoyo" quiere asociación de vecinos", Mundo Diario, 30-12-1976. 
això, no he trobat gaire més informació sobre l'activitat d'aquestes entitats.

Al barri de Sant Roc, com he explicat anteriorment, les mobilitzacions van estar encapçalades no per l'Associació de Veïns -creada a instàncies de l'alcalde i formada per gent conservadora- sinó del Centre Social de Sant Roc i en especial la seva Vocalia d'Habitatge. El 6 de febrer de 1976 tornava a morir un nen en caure d'un balcó amb la barana defectuosa. Aquest fet va desencadenar, per una banda, la redacció d'un nou i dur escrit al director de l'OSH de Barcelona:

"Y así llegamos al 6 de febrero, día fatal en que muere un niño de 3 años al caer desde el balcón del $2^{o}$ piso del bloque 153 porque la baranda está en mal estado. Curiosamente la O.S.H. Daba el bloque por reparado.

Este accidente es el más reciente y el que, en parte motiva este escrito pero no es el único. Recordamos el verano del 74 con un accidente parecido. También un niño muere al caer del 3er. Piso del bloque 103 por una baranda rota. Y anteriormente ya había otras víctimas. Una mujer muerta por el impacto de una parte de la cornisa del bloque 80 que se desprendió. Y un niño electrocutado por tocar un farol que no tenía tapa.

¿Qué ha hecho y que hace la O.S.H. para evitar tantas muertes causadas por el mal estado de conservación del barrio y de las viviendas? ¡iNADA!!

Por todo ello,

DECLARAMOS culpable a la O.S.H. de todas estas muertes producidas por su negligencia en reparar bien nuestras casas y

EXIGIMOS reparaciones generales bien hechas y controladas directamente por los vecinos, tal como pedíamos en el escrito que entregamos a D. Aníbal Rodríguez en enero del 75 junto con otros diez barrios de Barcelona y Provincia.

Pues aunque la O.S.H. en su respuesta a dicho escrito nos llamó "personas ajenas", no lo somos ya que somos los "directamente afectados". ¿O no queda claro que quienes han muerto son hijos de los vecinos y no de los dirigentes de la O.S.H.?"1215

Per una altra banda, una multitudinària manifestació el dia 9 de febrer mobilitza 1.500 veïns farts de les morts que provocaven la mala construcció dels seus habitatges ${ }^{1216}$. Malauradament, el 16 de març queia un altre nen per la cessió

1215 [Carta a] "Excmo. Sr. Director Provincial de la Obra Sindical del Hogar y Arquitectura de Barcelona" (15-2-1976), publicada a Felipe Guerrero: Sant Roc. 25 anys de lluita, Ateneu Popular de Sant Roc, 1991, p. 7 i 8. Veure també Joan Tudela: Sant Roc. Badalona Col·lecció els Barris d'Adigsa núm. 37, Departament de Benestar Social de la Generalitat de Catalunya i ADIGSA, Barcelona. 1995, p. 40.

1216"Quinto accidente mortal por mala construcción”, i “Manifestación en San Roque por el accidente mortal”, Mundo Diario, 10-2-1976. 
de les baranes -baixes i dèbils- d'unes escales d'una altre bloc d'habitatges. Per sort no va perdre la vida ${ }^{1217}$. Però poc després un altre nen moria electrocutat en tocar un cable sense protección ${ }^{1218}$. Tot això sense comptar els nombroses defectes existents tant en els edificis com en la dotació dels serveis més elementals pel barri (zones verdes, equipaments escolars, sanitaris, esportius, culturals, etc.), que ja havien estat de nou denunciades en una assemblea el 15 de febrer al Centre Social que reclamava la urgent construcció d'un Centre de Formació Professional, un mercat, un ambulatori, escoles i una local per jubilats ${ }^{1219}$. Un altre problema molt greu era falta total de neteja existent:

“Una memorable manifestación en el año 1976 llevó hasta la plaza de la Vila a mucha gente del barrio con bolsas llenas de basura que se depositaron en la puerta del Ayuntamiento y esparcieron por la calle del Mar."1220

Al mes de febrer es van recollir signatures al barri i 469 veïns i veïnes van adreçar un escrit a l'Alcalde reclamant un mercat ${ }^{1221}$. Un procediment similar es va fer als mesos d'abril i maig quan 792 persones van adreçar un nou escrit per reclamar un ambulatori ${ }^{1222}$.

Ja amb anterioritat s'havia plantejat a Sant Roc la possibilitat de fer una vaga de lloguers davant l'OSH fins que no arreglés els nombrosos defectes dels habitatges i del barri. Una assemblea celebrada al Centre Social amb la participació d'un miler de veïns celebrada el mes de maig va reafirmar-se en aquesta posició de no pagar fins que l'OSH assumís les seves responsabilitats ni en acceptar un contracte pel seu habitatge fins que aquests no fossin arreglats. També es van manifestar gens satisfets amb la possibilitat de que el "Instituto Municipal de la

1217 “Grave accidente en el barrio de Sant Roc de Badalona”, Tele/ eXprés, 17-3-1976.

1218Felipe Guerrero: Sant Roc. 25 anys de lluita, p. 15.

1219 Manuel Armengol: "Quieren ambulatorios, escuelas-hogares para ancianos y no quieren el puerto", Hoja del Lunes, 16-2-1976. En la mateixa assemblea es va ratificar la postura del veïnat en contra del port i es van denunciar les maniobres de l'ajuntament per dividir-los, ja fos cooptant a determinats líders (com vam veure anteriorment en el cas del president del mateix Centre Social Francisco Lleal), o amb la potenciació de l'Associació de "Cabezas de Familia" o l'AVV de Sant Roque, promoguda per l'Ajuntament per contrarestar al Centre Social (veure nota 593).

1220Felipe Guerrero: Sant Roc. 25 anys de lluita, p. 17

1221Enric Giralt: "Los vecino [sic] de Sant Roque quieren un mercado", El Correo Catalán, 11-21976 i "Badalona: Los vecinos de San Roque reclaman la construcción del mercado municipal de abastos", La Vanguardia Española, 11-2-1976.

1222 "Badalona: Vecinos de San Roque reivindican un ambulatorio", La Vanguardia Española, 4-51976. 
Vivienda" assumís la gestió dels polígons de l'OSH, ja que per ells el prioritari era la solució dels greus problemes que patien ${ }^{1223}$. L'OSH va continuar reclamant el pagament de les quotes i davant aquest fet, se li va enviar una nova carta a finals de juny on es recollien els motius pels quals no s'amortitzaven els rebuts: la llista interminable de deficiències, avaries i defectes dels habitatges del barri i tornaven a exigir la seva reparación ${ }^{1224}$.

Les mobilitzacions, no obstant, van continuar i per exemple el 4 de novembre unes 300 persones es manifestaven amb espelmes i llanternes per Sant Roc reclamant l'enllumenat del barri, en la pràctica inexistent pels defectes de funcionament dels fanals. Aquest fet provocava una gran foscor que afavoria els robatoris i agressions ${ }^{1225}$. Al desembre un article publicat a la nova revista Comarca Exprés denunciava les precàries condicions del barri ${ }^{1226}$.

L'any 1977 va iniciar-se amb la mateixa dinàmica. Al febrer apareixia un colpidor estudi sobre les condicions sanitàries de Sant Roc, on apart de denunciar la falta d'un ambulatori pel barri, s'esmentaven les greus condicions sociosanitàries existents que agreujaven el problema:

"Las enfermedades provocadas por la humedad, la existencia de 22 bares y bodegas de un total de 62 comercios con el consiguiente número elevado de alcohólicos, las infecciones provocadas por la poca salubridad del barrio repleto de ratas, gusanos y mosquitos que acuden a los desperdicios que echan algunos carniceros de Sant Adrià bajo el puente de la autopista, la falta de higiene y limpieza por parte de los barrenderos del Ayuntamiento que hacen peligroso [sic] los juegos de los niños, las rejas oxidadas de los balcones que han causado ya algún muerto, son problemas de difícil solución.

Seria necesario arreglar unos pisos que ya no tienen arreglo, urbanizar una zona completamente descuidada y abandonada a unos vecinos que están empezando a darse cuenta de lo que les puede venir encima." ${ }^{1227}$

1223“Badalona: "Primero que arreglen las casas y después hablaremos del contrato"', La Vanguardia Española, 19-5-1976.

1224[Carta al Delegat Provincial del Ministerio de la Vivienda de Barcelona] (30-6-1976), reproduïda a Felipe Guerrero: Sant Roc. 25 anys de lluita, p. 8-10.

1225 "Manifestación con velas y linternas”, Mundo Diario, 9-11-1976.

1226 “Sant Roc: ratas grandes como conejos", Comarca Exprés núm. 2 (15-30 de desembre de 1976), p. 5.

1227Veure Vladimir de Semir: "El barrio de Sant Roc: un ejemplo de como pueden vivir 17.000 personas sin asistencia”, La Vanguardia Española, 26-1-1977 i 8-2-1977 (és un article publicat en dues parts). També a Miquel Font: "Sant Roc: 17.000 vecinos sin un ambulatorio del SOE", El Correo Catalán, 12-2-1977. L'estudi al qual feia referència aquests articles es titulava "Aproximación a la salud del barrio de Sant Roc" i havia estat realitzat pel Departamant d'Acció 
Les deficiències del barri eren tantes que fins i tot l'Associació de Veïns promoguda per les autoritats es veia en obligació d'exigir la neteja urgent del barri $^{1228}$. Va ser la pressió veïnal sens dubte la que va aconseguir, després de diverses mobilitzacions, que el Ministerio de la Vivienda, que s'havia fet responsable dels polígons de la OSH, afirmés a l'abril de 1977 que encarregaria un projecte de reparació general del barri del qual parlaré més endavant ${ }^{1229}$. A finals de maig una nova manifestació recorria el barri reclamant de nou l'enllumenat i -sembla ser- en ella van coincidir tant el Centre Social com l'AVV, malgrat estar fortament distanciades ${ }^{1230}$.

Pomar, a l'altre extrem de la ciutat era un polígon de la OSH de dimensions similars que també feia sentir les seves reivindicacions. El 8 de febrer de 1976 es feia una assemblea veïnal al local provisional del Centre Social -situat a la parròquia- per discutir com estava la situació dels habitatges ${ }^{1231}$-recordem que ja s'havia iniciat una vaga de lloguers en 1972. Teòricament s'havia aprovat una partida econòmica per arreglar el barri però no s'havia fet encara res. En aquesta assemblea es va acordar crear una Comissió de Control per vigilar el correcte desenvolupament de les obres a les quals s'havia compromès el Ministerio de la Vivienda:

“Desde nuestra hoja informativa os invitamos a apuntaros a la Comisión de Control

Social de Càritas Diocesana, amb la col-laboració de la Vocalia de Sanitat del Centre Social de Sant Roc. Més en concret havia estat dirigit per Haydée López (doctora en medicina social a Xile) i amb la participació de Vicente Herrera (metge responsable del Centre Mèdic del Centre Social Sant Roc), Pilar Maya (encarregada del Departament d'Acció Social de Càritas), Joan Costa (sociòleg), Carmen Pérez (ATS del Centre Mêdic del Centre Social Sant Roc), Ma Ángeles Fabra (biòloga del Centre Mèdic del Centre Social Sant Roc), Ma ${ }^{a}$ Claustre Massana (estudiant d'Assistenta Social) i dos redactors (Nuria Buesa i Rafael Martín). Les conclusions de l'estudi eren demolidores i sens dubte va ser el diari Tele/ eXprés en la seva edició del 3 de febrer el que en una frase ho va resumir millor: "Las condiciones de vida de San Roque son similares a las del Tercer Mundo".

1228 Maurici: "Ultimátum de los vecinos", Mundo Diario, 8-3-1977. S'ha de dir, però, que aquesta Associació també acusava a part del veïnat d'aquesta brutícia i de cuinar en ple carrer a altes hores de la nit. Veure "Badalona: Grupos ambulantes ensucian San Roque", La Vanguardia Española, 8-3-1977; J. Carlos Pasamantes: "En San Roque guisan y hacen fuego en la calle", El Noticiero Universal , 11-3-1977 i Ruiz: "San Roque: La suciedad crea conflictos”, Hoja del Lunes, 14-3-1977.

1229Felipe Guerrero: Sant Roc. 25 anys de lluita, p. 18.

1230 Miquel Font: "Badalona: Exigen luz para la barriada de San Roque", El Correo Catalán, 1-61977.

1231 Pomar Convivència núm. 13 [Nova Sèrie] (gener-febrer 1976), MB-Hemeroteca, Caixa 21-1-6, p. 1. 
¡Vecinos del ramo de la Construcción animaros! ¡Vigilad las reparaciones de vuestras viviendas! ¡Os esperamos! Controlad si la calidad de los materiales son buenos. Si los 70 millones dedicados a Pomar se invierten en nuestro barrio." ${ }^{1232}$

En aquest sentit es van reafirmar en una segona assemblea feta el 4 d'abril, ja que desconfiaven profundament del Ministeri i creien -amb raó- que les reparacions serien només "de façana"1233. No va ser fins l' 1 de desembre del mateix any que el Ministeri va adjudicar una partida més important -de 441 milions de pessetes- per reparacions al polígon de Pomar ${ }^{1234}$.

El barri tenia a més altres problemes: un transport públic que no arribava al conjunt dels seus habitants, mancances en l'atenció sanitària i en la neteja -l'ambulatori més proper estava al barri de Bufalà i per arribar havien d'agafar dos autobusos, a més d'una plaga de rates ${ }^{1235}$. La solució definitiva encara trigaria a arribar.

Existia un tercer polígon de la OSH -de menors dimensions que els anteriorsal barri de Bufalà. En l'l'AVV del barri a l'any 1975 havia entrat gent jove vinculada al PSUC i a la CNT i com era d'esperar, això li va donar un caràcter més reivindicatiu, tot i que l'antic President Joan Garcia va romandre al càrrec fins l'any $1979^{1236}$. Això es va poder observar per exemple en les queixes sobre l'estat dels seus habitatges i del barri en general que els seus habitants van elevar al responsable provincial de la $\mathrm{OSH}^{1237}$, i, també, a la festa popular que es va realitzar el 9 de maig al solar situat entre els carrers Independència i Sardana que el veïnat reclamava com a plaça pública, reivindicació a la qual es va sumar la d'un local per als jubilats, un altre per l'associació, escoles i unes millors comunicacions amb els barris propers ${ }^{1238}$. No obstant, la indignació es va apoderar del barri quan el 17 de

1232 Pomar Convivència núm. 14 [Nova Sèrie] [març 1976?], MB-Hemeroteca, Caixa 21-1-6, p. 1.

1233 "Badalona: Los vecinos del polígono de Pomar velan por sus viviendas", La Vanguardia Española, 8-4-1976; "Los vecinos quieren controlar las reformas de la OSH, en Badalona", Tele/ eXpres, 8-4-1976 i “Fiscalización popular", Mundo Diario, 9-4-1976.

1234 “Lluvia de millones para reparaciones", Mundo Diario, 28-12-1976.

1235 "Badalona: siguen las dificultades de los vecinos de Pomar para acudir al ambulatorio", La Vanguardia Española, 22-10-1976.

1236Marc Andreu i Acebal: El Bruc Bufalà -Badalona-. Els Barris d'Adigsa núm. 7, Departament de Benestar Social de la Generalitat de Catalunya-ADIGSA, Barcelona, 1995, p. 95.

1237 “Badalona: También en el barrio de Bufalà hay deficiencias en las viviendas", La Vanguardia Española, 6-5-1976.

1238 Marc Andreu i Acebal: El Bruc Bufalà..., p. 121. Veure també "Badalona: Los vecinos de Bufalà han abandonado el camino de las gestiones", La Vanguardia Española, 12-5-1976 i "Bufalà- 
maig de 1976 van morir dos nens en incendiar-se una caseta de mostra de la immobiliària CONBASA en la qual jugaven ${ }^{1239}$. L'Associació de Veïns, que havia denunciat vàries vegades el perill d'aquell edifici semi-abandonat, va atribuir el fet a la falta d'espais públics d'esbarjo per la canalla. Una altra lluita important va ser la que es va mantenir per aconseguir l'obertura de l'escola pública que s'estava construint a Can Ruti ${ }^{1240}$.

Tornant a la qüestió de l'OSH, l'1 de desembre de 1976 el ministre de l'habitatge, Vicente Lozano, havia anunciat que es destinarien 813 milions de pessetes a obres de rehabilitació als polígons de Sant Roc i Pomar, però no es va incloure l'existent a Bufalà ${ }^{1241}$. Aquest fet posava de nou de manifest que eren més efectives les mobilitzacions que les instàncies legals. I els veïns de Bufalà van prendre bona nota i durant l'any 1977 van impulsar primer una tasca de conscienciació. A l'estiu es va passar a a fer una intensa campanya de premsa explicant la situació del barri per passar a les mobilitzacions al mes de setembre -que van ser molt sonades- a les quals faré esment posteriorment $\mathrm{t}^{1242}$.

Altres barris badalonins van protagonitzar mobilitzacions en aquest període. Al barri del Congrés va destacar la lluita veïnal per recuperar pel barri l'antic espai de la fàbrica "La Regaliz" així com per la construcció d'una escola pública i contra la delinqüència ${ }^{1243}$. Totes aquestes reivindicacions ja havien estat exposades a les autoritats locals als mitjans de comunicació a principis de $\operatorname{març}^{1244}$. Però com era habitual, van ser necessàries les mobilitzacions per aconseguir-les. L'esmentada fàbrica va ser ocupada pel veïnat en una jornada festivo-reivindicativa feta a finals de juny on es reclamava la compra d'aquesta per l'Ajuntament i la seva posterior conversió en espai verd pel barri, així com alhora es demanava la tan anhelada

Morera-Pomar. Todo lejos" a Comarca Exprés núm. 2 (15-30 desembre 1976).

1239Marc Andreu i Acebal: El Bruc Bufalà..., p. 121. Veure també Enric Giralt: "Sepelio de los dos niños muertos en Bufalà", El Correo Catalán, 23-5-1976; "Un accidente mortal pone en evidencia la falta de zonas de esparcimiento en Badalona", Tele/ eXpres, 24-5-1976 i "Badalona: los vecinos de Bufala denuncian, una vez mas, la falta de atención del barrio”, La Vanguardia, 26-5-1976.

1240 Marc Andreu i Acebal: El Bruc Bufalà..., p. 32-34.

1241 Ídem, p. 37-38

1242 Ídem, p. 38.

1243El Rollo Despertador. Boletín de la Asociación de Vecinos del Congreso, (desembre 1976), Biblioteca Ciències de la Comunicació de l'UAB - Hemeroteca, signatura RC(467.1)/512. Com explicaré més endavant, la lluita pel col-legi públic va ser molt important.

1244Veure "Piden más equipamientos para Viviendas del Congreso en Badalona”, Tele/ eXpres, 4-31976 i “Acumulación de deficiencias”, Mundo Diario, 20-3-1976. 
escola $^{1245}$.

La mateixa associació denunciava pel mes de juliol com s'havia dut a terme una altra reivindicació del barri: la construcció d'un local per jubilats. Aquest havia estat, després de diverses gestions, construït per una entitat d'estalvis que restringia el seu us als seus impositors i el gestionava sense comptar amb l'AVV, provocant la lògica protesta d'aquesta entitat que volia un local obert a qualsevol jubilat $^{1246}$. Però aquesta consciència reivindicativa també tenia els seus entrebancs. Un exemple són els repetits assalts vandàlics a l'escola provisional existent en uns barracots provisionals o fins i tot als locals de la mateixa associación ${ }^{1247}$.

Al barri de Sistrells, la nova Junta de l'Associació de Veïns va impulsar un nou tarannà reivindicatiu. Una assemblea feta el 22 de febrer recollia signatures per donar suport a les principals reivindicacions del barri:

“(...) la construcción de una escuela de EGB, local social para los jóvenes y la Asociación, una guarderia infantil municipal, un dispensario, la normalización de las señalizaciones de tráfico, la regularización del alcantarillado, la eliminación práctica del barraquismo que aún subsiste en algunas zonas, y el aprovechamiento de varios terrenos para equipamientos sociales..." ${ }^{1248}$

L'Alcalde Caballeria es va comprometre a donar-hi solucions i també a una cosa insòlita fins aleshores, a la tria de l'Alcalde de Barri per sufragi universal dels veïns de Sistrells ${ }^{1249}$. Una nova assemblea de 300 veïns al mes d'abril va tornar a tractat totes aquestes reivindicacions i la proposta de tria d'aquesta figura ${ }^{1250}$. Al maig l'Associació de Veïns es va anotar una important victòria en un vell litigi que mantenia amb una immobiliària que havia connectat el clavegueram de dos edificis sense demanar cap permís ni abonar cap quantitat a un col-lector que anys abans havia construït i sufragat la mateixa $\mathrm{AVV}^{1251}$. Al mes de juny l'AVV organitzava les

1245“Los vecinos de Viviendas del Congreso ocupan un solar en Badalona”, Tele/ eXprés, 29-6-1976 i “Los vecinos ocupan la "fábrica de Regaliz"”, Mundo Diario, 1-7-1976. Com veurem més endavant, la demanda de l'escola va comportar una dura repressió policial.

1246"Problemas con un hojar del jubilado en Viviendas del Congreso en Badalona", Tele/ eXprés, 97-1976.

1247 “Asalto a una escuela en Badalona”, Tele/ eXprés, 25-8-1976. El 23 de gener el Club Juvenil de l'AVV havia estat assaltat i destrossat. Veure La Vanguardia Española, 25-1-1976.

1248“Recogida masiva de firmas en la barriada de Sistrells, Badalona”, Tele/ eXprés, 23-2-1976.

1249 “Badalona: Habrá elecciones de alcalde de barrio en Sistrells", Tele/ eXprés, 7-4-1976.

1250“En Sistrells de Badalona se trató de la elección del alcalde de barrio”, Tele/ eXprés, 27-4-1976.

1251 Manuel Armengol: "Badalona: La Asociación de Vecinos de Sistrells gana el pleito a una inmobiliaria”, La Vanguardia Española, 16-5-1976. 
festes del barri i els hi donava un clar caliu reivindicatiu ${ }^{1252}$ :

"Una semana de fiestas donde se une lo reivindicativo con lo popular, con lo tal... Donde hacemos participar a un montón de gente de del barrio, de comerciantes (...) que si la caja, que si los feriantes, el Ayuntamiento subvencionando... organizamos una fiesta interesantísima donde allí yo me acuerdo... tengo una intervención muy interesante para lo que era la época... Hacemos un baile de sardanas... y bueno, muy bien y no tenemos absolutamente ningún tipo de represión ni de nada..."1253

La entrada de gent jove militant i conscienciada (amb sensibilitat comunista o anarquista), així com la seva presidència per un militant del PSUC havien estat factors decisius per l'impuls d'aquesta nova etapa. Les millores, no obstant, encara trigarien a arribar.

Fins aquest moment al barri del Centre, no s'havia donat una mobilització veïnal important tot i que si havia destacat anteriorment per portar a terme iniciatives culturals amb un tarannà antifranquista. Pel que es veu dues persones militants del PSUC, Josep Lluís González i Jordi Rius van reunir-se amb Jaume Solà i li van proposar la necessitat de crear aquesta entitat un dia de març de 1976. De seguida van arreplegar a un equip de gent per tirar endavant la iniciativa ${ }^{1254}$. Així ens ho relatava el que va ser posteriorment alcalde de Badalona pel PSUC, Màrius Díaz:

“Fixa't, ja hi havia moviments però que no s'havia fundat una Associació de Veïns del Centre (...)

Però bueno, la reunió va ser a la nit, jo havia arribat de Cuba feia tres dies i vam fundar l'Associació de Veïns els onze que érem o dotze. I vaig començar a parlar de Cuba i a les 4 del matí ens vam anar a casa i no havíem parlat ni una lletra de l'Associació de Veïns, vam quedar per la setmana següent... I a la setmana següent ens vam tornar a reunir i ja pràcticament vam fundar l'Associació de Veïns. El Jaume Solà i jo vam ser els encarregats de redactar els Estatuts. Vam tenir un mes, els vam donar als companys i al cap d'un mes no ens en sortira tot. Vam anar a Sabadell i vam copiar pràcticament els Estatuts d'una Associació de Veïns de Sabadell del Centre (...) I es va crear el dia

1252“Fiestas populares en el barrio badalonés de Sistrells", Tele/ eXprés, 1-7-1976

1253Entrevista a Alfredo Amestoy Saenz, 3-7-2013. Militant del PSUC, President de l'AVV Sistrells i posteriorment regidor de l'Ajuntament de Badalona.

1254Jaume Solà: "Vint anys d'Associació de Veïns del Centre", El Badiu (febrer 1997) i també a Revista de Badalona, núm. 10 IV Època (maig 2012), p. 24-25. En concret es refereix a, apart dels ja esmentats, Cisco Padrós, Núria Orriols, Pep Zamora, Jordi Rosell, Roser Padrós, Màrius Díaz, Antoni Ariño, els Josep Lluís Gonzàlez (pare i fill), Marissa Mas, Joan Josep Rotger, Ramón Sagués i l'Antoni Serra. 
aquest..." ${ }^{1255}$

Els estatuts es van presentar al Govern Civil el 17 de setembre de 1976 i la seva presentació pública va ser amb una festa feta a la Rambla de Badalona (el passeig marítim) el dia 8 de desembre de 1976 ${ }^{1256}$. L'AVV del Centre va desenvolupar una important activitat en defensa de la cultura popular i del patrimoni històric, però si va haver una lluita en la qual va destacar -apart de la del port- sobretot durant la primera meitat de l'any 1977, va ser la del monòlit del Parc de Can Solei. L'Ajuntament havia adquirit al novembre de 1974 la finca d'aquest mateix nom amb la intenció de convertir-la en parc públic. L'Alcalde Isidro Caballeria va proposar que el nou parc dugué el nom de l'anterior Alcalde -Felipe Antoja- que havia mort recentment. Aquesta proposta va generar un fort rebuig en la població ${ }^{1257}$. Des de feia anys es feia en aquest espai l'anomenada Festa del Badiu, que havia començat com unes activitats lúdiques d'uns agrupaments escoltes però que progressivament s'havia anat obrint a una participació popular. A l'any 1977 el Congrés de Cultura Catalana es va implicar en aquesta celebració i amb la participació també de l'AVV del Centre es va fer un monòlit de formigó amb el nom de "parc de Can Solei" i les quatre barres. Un grup de persones el va col-locar per la nit per que l'endemà, el diumenge 15 de maig es pogués descobrir a la Festa del Badiu $^{1258}$. La resposta de l'Ajuntament va ser enviar una excavadora i dos operaris el dia següent a treure el monòlit, fet que provocà una gran indignació popular. $\mathrm{Al}$ juliol el mateix Congrés de Cultura Catalana expulsava a l'Ajuntament badaloní que

1255Entrevista a Màrius Díaz Bielsa, 28-6-2013. Militant del PSUC, membre de l'AVV del Centre i posteriorment Alcalde de Badalona (1979-1983). Ell mateix ens deia que la composició d'aquesta entitat va ser primerament de gent del PSUC, independents i membres de Cristians pel Socialisme com Josep Solé i Amigó. Posteriorment si que hi participarà algun militant socialista i Convergent. Segons Jaume Solà les següents persones van ser les que van constituir la Comissió Gestora

1256Jaume Solà: "Vint anys d'Associació de Veïns del Centre", Revista de Badalona, núm. 10 IV Època (maig 2012), p. 25.

1257Joan Mayné: "El monòlit de Can Solei: símbol d'una conquesta veïnal”, Revista de Badalona, núm. 10 IV Època (maig 2012), p. 27. Mayné és el soci núm. 20 de l'AVV del Centre i actualment Director del Museu de Badalona.

1258Entre les persones que van participar en aquesta operació hi estaven en Francesc Mayolas (va dissenyar i fer el bloc de formigó), el mateix Joan Mayné (va fer la placa amb el nom i les quatre barres), Màrius Díaz (el trasllat del monòlit es va fer amb el seu cotxe), Sisco Padrós, Enric Farreras, Carles Serracant, Jodri Borràs, Abílio Campos, Josep Guardiola, Jordi Font i Carme Gratacòs. Veure Joan Mayné: "El monòlit de Can Solei: símbol d'una conquesta veïnal", Revista de Badalona, núm. 10 IV Època (maig 2012), p. 32. 
s'havia adherit anteriorment. Es va fer una manifestació el 22 del mateix mes que acabava a la plaça de la Vila i amb la substitució d'una placa commemorativa de la victòria franquista per una que retornava a la plaça el seu nom popular: Plaça de la Vila. Poc després la mateixa família del difunt Felipe Antoja expressava la seva voluntat de renunciar al nom del parc i el Ple de l'agost de 1977 deixava sense validesa l'acord anterior i acceptava el nou nom i restituir el monòlit. No obstant, aquest va estar "perdut" al magatzem municipal i no va poder ser restablert fins el nou Ajuntament democràtic ${ }^{1259}$.

És pràcticament impossible recollir al detall totes les mobilitzacions que es van fer als diferents barris de Badalona durant aquest període. Esmentar que, entre d'altres, també es van fer accions com la retolació dels carrers del seu barri feta pel veïnat de Morera ${ }^{1260}$, talls de trànsit per aconseguir millores urbanístiques al barri d'Artigues $^{1261}$, les mobilitzacions per aconseguir la urbanització del barri de Bonavista $^{1262}$ o les que es van donar al barri de Dalt de la Vila per conservar el seu important patrimoni històric ${ }^{1263}$.

Però si va haver-hi una mobilització realment transversal a la majoria dels barris va ser la lluita per l'educació, en especial per les escoles públiques. L'estat en el que es trobava l'ensenyament a Badalona, en especial pel que feia a pre-escolar i a l'E.G.B. d'aleshores, era lamentable:

“El censo de niños en edad de EGB es según los propios enseñantes de 28.274, existiendo tan solo por el momento siete colegios nacionales que albergan a 6.785 , lo cual representa tan solo algo más del 24 por ciento." 1264

Les places públiques eren totalment insuficients, mentre que les escoles privades, en la majoria dels casos, no tenien les condicions mínimes necessàries

1259Joan Mayné: "El monòlit de Can Solei: símbol d'una conquesta veïnal", Revista de Badalona, núm. 10 IV Època (maig 2012), p. 35-36.

1260 “Badalona: Los vecinos de Morera rotulan sus calles", La Vanguardia Española, 15-6-1976.

1261 “Badalona: Barricadas contra las ratas y el barro", Tele/ Exprés, 3-6-1977.

1262 "Badalona: El barrio de Buenavista firmó el armisticio con el Ayuntamiento", La Vanguardia Española, 23-6-1977. Aquest era un antic barri d'autoconstrucció situat a prop del també antic barri de Lloreda.

1263"Badalona: Los vecinos de "Dalt de la Vila" piden un plan de ordenación y la congelación de licencias" i J. Carlos Pasamontes: "Badalona: El Ayuntamiento pide sugerencias para mejorar el casco antiguo", La Vanguardia Española, 4 i 11-3-1977. No va ser fins 1979 que es va fundar una AVV en aquest barri.

1264“Difícil futuro para la enseñanza en Badalona”, Tele/ eXprés, 28-6-1976. 
per desenvolupar correctament la seva activitat. A això calia sumar el fet de la massificació d'alumnes per aula o les difícils i precàries condicions de molts mestres, situació que els va dur en molts casos al conflicte laboral com per exemple la vaga de febrer de 1976 a la província de Barcelona que va tenir un notable impacte a Badalona ${ }^{1265}$. Una altra qüestió era el tema de les permanències, , la lluita contra les quals va servir per establir punts de contacte entre mestres progressistes i les AVV's en la lluita contra aquestes taxes ${ }^{1266}$.

D'aquesta manera, la reivindicació d'escoles públiques va ser una constant en totes les mobilitzacions veïnals, ja fos en manifestacions, concentracions o Jornades públiques per l'ensenyament com les que es van fer a Llefià i La Salut. La manca d'escoles era denunciada també per barris com Lloreda, Sistrells, Puigfred, Bufalà, Sant Roc, Pomar... en la pràctica per gairebé tots els barris que s'havien poblat intensivament els darrers anys ${ }^{1267}$.

Es va prometre la construcció de nous centres públics i certament, van iniciar-se les obres de nous col-legis però que eren totalment insuficients. Per això i pels motius anteriorment esmentats les protestes veïnals van continuar. Al barri del Congrés, per exemple, a l'estiu de 1976 es van donar vàries mobilitzacions importants, ja que feia set anys que esperaven la construcció d'una escola en uns terrenys on s'havien posat uns barracots "provisionals"1268. El 8 de juliol una manifestació d'aquesta associació que reivindicava la construcció d'aquesta escola d'una vegada per totes va ser violentament reprimida per la Guàrdia Civil ${ }^{1269}$. Però sens dubte el fet més greu va ser dura repressió de la manifestació per

1265 "Los maestros de numersas poblaciones de la provincia se suman a la huelga", Tele/ eXprés, 112-1976.

1266 Un exemple en aquest sentit ens el va donar el testimoni d'un mestre i alhora militant veïnal al barri de Llefià, Pedro Jesús Fernàndez en dos entrevistes fetes ja fa uns anys, al 26 d'abril i el 24 de maig de 2009. Per altra banda, la postura de les AVV's es pot veure reflectida en un article d'Enric Juliana: "Las asociaciones de vecinos de Badalona denuncian el problema de las permanencias", Tele/ eXprés, 3-6-1976. Veure també "Badalona: Escrito de denuncia por la obligatoriedad de las "permanencias" en muchas escuelas", La Vanguardia Española del 9-61976, on es parla d'un escrit de denúncia per l'obligatorietat d'aquestes permanències -que es cobraven- en moltes escoles.

1267Aquest problema s'evidenciava més als inicis de curs, és a dir, al setembre. "1.600 niños sin escuela", Mundo Diario del 19-9-1976.

1268 "Siete años sin escuela en el barrio del Congreso Eucarístico de Badalona”, Tele/ eXprés, 25-61976 i "Siete años tras una esculea", Mundo Diario, 27-6-1976.

1269“Pedían escuelas... y fueron disueltos”, Mundo Diario, 10-7-1976; Manuel Armengol: "Badalona: Manifestaciones en reivindicación de una escuela" i "Badalona: Diversos contusionados en una manifestación disuelta por la fuerza pública", La Vanguardia Española, 9-7-1976 i 11-7-1976. 
l'ensenyament públic que es va fer el dia 18 de setembre de 1976. Diferents columnes van arribar a la Plaça de la Vila procedent dels diferents barris reivindicant places escolars -milers de persones segons la mateixa Federació d'AVV's de Badalona, amb la participació de moltes criatures- però la "benemérita" no va tenir cap problema per carregar brutalment. La resposta de les AVV's, l'Assemblea Democràtica i les diferents organitzacions polítiques -encara clandestines- va ser demanar la dimissió de tot el consistori ${ }^{1270}$.

El mateix any 1976 una altra important lluita de ciutat, la protagonitzada contra la construcció del port esportiu continuava i el projecte -com ja he ditentrava en un punt mort per l'oposició ciutadana i la falta de finançament del qual no es refaria. Paral-lelament continuaven també les crítiques al projecte d'urbanització dels terrenys de Montigalà-Batllòria ${ }^{1271}$. En aquest any també s'havia creat una Associació Pro Amnistia i presentat públicament l'Assemblea Democràtica de Badalona el 27 de juny a l'Institut Albéniz i posteriorment, el 30 de maig al parc de Can Solei ${ }^{1272}$. Aviat també va aparèixer un manifest públic signat per Associacions de Veïns i entitats ciutadanes, l'anomenat "Manifest de Badalona" on es reclamava una alternativa democràtica per la ciutat a més de tot un conjunt de mesures urgents en els àmbits de l'economia, l'educació, la sanitat, l'urbanisme, l'atur... ${ }^{1273}$. La "Marxa per la Llibertat" també va passar per Badalona i s'havien organitzat actes al juny i el 29 de juliol unes 200 persones van rebre els marxaires a la Rambla, reclamant llibertat i amnistia. La intervenció repressiva de la Guàrdia Civil es va saldar amb vàries detencions ${ }^{1274}$.

1270 “Continuas peticiones de dimisión del consistotio de Badalona”, Tele/ eXprés, 21-9-1976, "Que dimita el Consistorio", i "Entrevista Alcalde-Asamblea", Mundo Diario, 22 i 23-9-1976 i "Badalona: Fue disuelta una manifestación de protesta por los problemas de la enseñanza", "Badalona: Malestar por los incidentes ocurridos en la manifestación del pasado sábado", "Badalona: La actual situación escolar es el resultado de muchas promesas incumplidas", La Vanguardia Española, 21, 22 i 23-9-1976. El mateix Ajuntament va admetre reunir-se amb l'Assemblea Democràtica de Badalona per mirar de rebaixar la tensió i desvincular-se del fet repressiu. I la aleshores regidora de cultura -i opositora moderada- Cecília March Blanch va presentar la dimissió en protesta.

1271Enric Juliana: "Urbanización Montigalà-Batllòria: un "satélite" peligroso", Comarca Exprés, núm. 1 (1-15 desembre 1976), p. 10-11.

1272 Emili Ferrando Puig i Juan Rico Màrquez: Les Comissions Obreres en el franquisme..., p. 524-525 i "Constitución de L'Assemblea Democràtica de Badalona", "Massiva festa democràtica a Badalona", Mundo Diario, 29-5-1976 i 3-6-1976.

1273 “Una alternativa democràtica per la ciutat”, Mundo Diario, 18-7-1976.

1274 “La Marxa arriba a Badalona”, Avui, 30-7-1976 i Joan Villarrolla (dir.): Història de Badalona, p. 227. 
Per altra banda i com també ja he esmentat, totes aquestes lluites van ajudar al procés de gestació de la Federació d'Associacions de Veïns de Badalona que va començar ja al mateix mes de gener de $1976^{1275}$. Aquesta entitat havia presentat públicament els seus estatuts al maig de 1976 tot i estar encara en tràmit l'aprovació pel Govern Civil ${ }^{1276}$. Aquest disposava d'informes policials sobre la composició dels seus membres. Un exemple d'això és un document referent a la participació de la Federació respecte la vaga general del 12 de novembre de 1976, on es cita a Miguel Ordóñez Ortega (President de l'AVV del Congrés), Manuel Armenteros Molina (President de l'AVV Juan Valera i de la FAV de Badalona), Marciano Iglesias Pizarro (Secretari de l'AVV Juan Valera) i Alfredo Amestoy Sáenz (President de l'AVV Sistrells):

"A la vista de lo expuesto, se deduce claramente, en opinión del Oficial informante, que los requeridos individuos desarrollan una actividad que lejos de la finalidad social que señalan las Asociaciones de Vecinos, se convierte en una de marcado carácter político al servicio muy especialmente del Partido Socialista Unificado de Cataluña, ya que todos los citados, según la información obtenida forman parte del Comité Local de dicho partido en Badalona.

(...) Por todo ello, es parecer del oficial informante, que las actividades desarrolladas por estos elementos, es totalmente perniciosa para el normal desenvolvimiento de la ciudad de Badalona, y muy especialmente en lo que representa a los barrios periféricos y obreros de aquella localidad, cuya población es muy asequible alas ideas comunistas de los reseñados; no obstante, V.E., con su superior parecer, resolverá."1277

L'auge de l'associacionisme no només veïnal queda reflectit en que fins i tot els Jubilats i Pensionistes constituïen una associació el mes de març de $1976^{1278}$. I el que era més greu per les autoritats locals, és que aquestes noves entitats tenien en la majoria dels casos uns posicionaments clarament reivindicatius i

1275“Gestiones de las Asociaciones de Vecinos para crear una federación”, Tele/ eXprés, 30-1-1976. 1276Jacinto De Miguel Díaz (Tinent de la Guàrdia Civil): "Diligencia información relativa a las actividades desarrolladas por los dirigentes de la llamada Federación de Asociaciones de Vecinos de Badalona, ante la huelga general del 12 de noviembre de 1976", AHGCB, Fons Subgobernadores Civiles, Caixa 592, D. Ramón Soldevila Tomasa, caixa número 6. Comandancia de la Guardia Civil, 1973-1977.

1277 Jacinto de Miguel Díaz, Teniente de la Guàrdia Civil: "Diligencia de Información relativa a las actividades desarrolladas por los dirigentes de la llamada Federación de Asociaciones de Vecinos de Badalona, ante la huelga general de 12 de noviembre de 1976. Diligencias de Informe i parecer." (26-11-1976), AHGCB, Fons Subgovernadores Civiles, Caixa 592, D. Ramón Soldevila Tomasa, caixaa número 6. Comandancia de la Guardia Civil, 1973-1977, p. 2.

1278“Los jubilados asociados”, Mundo Diario, 31-3-1976. 
antifranquistes. I tot això en un context que encara era profundament repressiu amb prohibicions, sancions, detencions i càrregues policials, en especial respecte les organitzacions comunistes i anarquistes. No obstant, això no les va impedir fer cada cop més actes públics desafiant la legalitat com va ser per exemple la celebració del 40è aniversari del PSUC el 17 de juny de 1976 a la pineda de Can Ruti que va aplegar a un miler de persones ${ }^{1279}$.

Per molt que l'Ajuntament intentés maniobrar per crear i mantenir associacions afins que li donessin suport ${ }^{1280}$, l'administració franquista local es va veure desbordada. Conscients de que hi havia una etapa de provisionalitat, i temerosos de que es repetís la imatge de les mobilitzacions de febrer de 1976 a Barcelona, el Consistori havia fet alguna concessió com aprovar en un Ple la petició d'Amnistia ${ }^{1281}$, i la tolerància de la manifestació del 29 de febrer de 1976. A això es va afegir una progressiva i creixent tensió interna per les rivalitats personals i casos de corrupció que van esquitxar l'administració local, per bé que durant 1976 i part de 1977 Isidre Caballeria encara va ser capaç de maniobrar i mantenir un cert ordre dintre del consistori ${ }^{1282}$.

1279Joan Villarrolla (dir.), Història de Badalona, p. 229.

1280Exemples d'això van ser per exemple l'adhesió de set AVV's "oficialistes" a la candidatura de Isidro Caballeria a les "eleccions" municipals de Gener de 1976 -on destacaven la de Sant Antoni de Llefià i la de Bonavista, per que les altres tenien escassos socis- Manuel Armengol: "Badalona: El interés por las elecciones, pràcticamente nulo", La Vanguardia Española, 23-11976. Un altre cas va ser un manifest públic de les Asociaciones de Cabezas de Família-entre elles les Badalonines de Sant Roc, Sant Jaume i Sant crist- a la monarquia i al projecte "reformista" de Árias Navarro, "Las Asociaciones de Cabezas de Familia, preocupadas por el actual momento político", La Vanguardia Española, 3-3-1976. Un tercer exemple va ser la intervenció de l'Ajuntament de Badalona en la creació de l'AVV de Sant Roc per contrarestar el Centre Social del mateix barri, que ja vaig esmentar.

1281Tele/ eXprés, 13-2-1976. La proposta va ser feta pels regidors d'oposició moderada Cecília March Blanch i Ernesto Rojo Rombouts, en una sessió amb un gran nombre de públic jove omplint la sala de plens i amb més gent concentrada també en la Plaça de la Vila, fet que va influir segurament en l'aprovació de la proposta.

1282 El regidor José Guillen Clapés intentava qüestionar-lo i va provocar alguna crisi com la del març de 1976 quan va aconseguir el suport de deu regidors per fer un Ple extraordinari per que l'Alcalde Caballeria respongués una sèrie de preguntes amb acusacions velades de corrupció. Caballeria el va rebatre afirmant que no tindria cap problema en que es fes una auditoria de tots els departaments, tornant-li la pilota així a Guillen Clapés havia estat tinent d'Alcalde d'Urbanisme amb Antoja Vigo. L'Alcalde va respondre a les preguntes en aquest Ple extraordinari però sense concedir la paraula als regidors, fet que va provocar encara més malestar. Veure "Badalona: Diez concejales piden la convocatoria de un pleno municipal extraordinario", "Badalona: Hoy pleno municipal con auspicios de crisis", "Badalona: el alcalde ha devuelto el balón al concejal Guillen" i "Badalona: En el último pleno municipal varios ediles aldieron a las incidencias de la sesión anterior", La Vanguardia Española, 9, 12 i 13-3-1976 i 34-1976. 
Al mes de maig el tinent d'Alcalde de Gobernació, José Mateu Cunillé presentava la seva dimissió al-legant motius personals però s'especulava que aquest fet hagués estat per la pressió dels "ultres" del consistori davant la política -al seu parer "tova"- que s'havia fet amb l'oposició antifranquista així com els enfrontaments interns que hi havia dins l'Ajuntament ${ }^{1283}$. L'afer del port esportiu va ser també un motiu de tensió per la pressió que feien regidors més "pro-port" contra un consistori que començava a dubtar -ni que fos tímidament- davant l'oposició popular i la manca de pressupost ${ }^{1284}$.

La repressió de la manifestació del dia 18 de setembre encara va encrespar més els ànims. L'Ajuntament volia intentar oferir una imatge "aperturista", que li era difícilment creïble quan intentava promoure misses dedicades a Franco en acostar-se el primer aniversari del seu decés, fet que va ser refusat per la majoria de les parròquies Badalonines ${ }^{1285}$.

Al febrer de 1977 el primer tinent d'Alcalde Alfonso Ramos Cruz es va prendre unes "llargues vacances" després d'una forta discussió amb José Guillen arran l'impost de radicació que la Unió d'Empresaris de Badalona volia rebaixar ${ }^{1286}$. Però aviat va haver d'assumir la mateixa Alcaldia el 22 d'abril quan Isidre Caballeria va presentar la seva dimissió per poder anar a les llistes d'Alianza Popular a les eleccions del 15 de juny. Alfonso Ramos Cruz era un metge format en el Frente de Juventudes, del qual havia estat delegat local i seguidor de Felipe Antoja que l'havia triat pel Terç Corporatiu. Ramos Cruz va haver d'assumir el nou càrrec i fer el paper de "suport extern" de la UCD en els conflictius anys d'ofensiva de l'oposició democràtica amb la qual no va tenir més remei que tractar -en especial després de les eleccions del 15 de juny de 1977 fins al punt que un informe del Govern Civil del 18 de gener de 1979 el va arribar a anomenar "el

1283 “Badalona: Posible crisis en el seno del consistorio municipal”, La Vanguardia Española, 5-51976.

1284"Badalona: Fuertes presiones para que se construya el controvertido puerto deportivopesquero" i "Badalona: La polémica sobre el puerto deportivo se extiende", La Vanguardia Española, 15 i 17-7-1976.

1285 “Las parroquias se niegan a celebrar misas”, Mundo Diario, 18-11-1976. Només es fa fer una missa a l'Església del barri de Canyet.

1286 “Mar de fondo en el Ayuntamiento", Tele/ eXprés, 7-2-1977. A tall de curiositat al Ple que es va tractar l'assumpte la majoria de regidors va haver d'absentar-se momentàniament per "incompatibilitat amb el que es votava", ja que molts dels regidors eren també empresaris. Veure "Badalona: Las incompatibilidades dejaron casi vacíos los sillones del pleno municipal", La Vanguardia Española, 17-3-1977. 
Suárez de Badalona"1287.

En aquest context van arribar les eleccions del 15 de juny de 1977. A les ciutats del Barcelonès Nord les esquerres van obtenir un triomf clar $^{1288}$. Aquest fet va col-locar en una situació de debilitat extrema a les autoritats municipals locals. Un exemple d'això és la dimissió presentada pels membres del Consistori Badaloní -a excepció de dos, els opositors Cecília March i Ernesto Rojo- que no va ser acceptada pel Governador Civil José Maria Belloch Ruiz ${ }^{1289}$. Aquests, com la majoria dels partits polítics, no volien una dimissió que provoqués un "buit de poder" sinó la creació d'unes "Comissions de Control" formades pels partits polítics fins que es celebressin unes eleccions municipals. La participació de les AVV's en aquestes no va ser contemplada seriosament, i, curiosament, aquest fet també era propugnat pel mateix Governador Civil:

"El Gobernador afirma que pueden admitirse la participación de los Partidos siempre que sean todos; no uno o unos solamente. Respecto a las Asociaciones de Vecinos, la respuesta es negativa: si no puede evitarse rotundamente, hay que procurar que conecten con los partidos. La intervención de unos y otras debe ser únicamente informativa. No se pueden adminir "Ayuntamientos paralelos". ${ }^{1290}$

Ja vam veure el document on els Alcaldes de localitats "Caps de Partit Judicial" expressaven la serva preocupació per que des del Govern Civil se'ls volgués atorgar massa responsabilitats en qüestió d'ordre públic per la feblesa en que havien quedat. Per que, en comptes del que podríem pensar, les eleccions del 15J no van aturar les mobilitzacions, si més no les veïnals. Si bé vam parlar de com aquest fet havia incidit en una certa crisi de les Associacions Veïnals, el cert és que això no es va traslladar immediatament en una desmobilització veïnal. De fet, els

1287 Martí Marín i Corbera: Els Ajuntaments franquistes de Catalunya..., p. 469 i 498.

1288Veure Taula de la p. 412. No es van produir incidents importants, però en destaco dos de significatiu van estar protagonitzats per militants d'AP, que van actuar com el que eren, una organització d'extrema dreta. El primer es va donar a la pre-campanya, quan en un acte fet al Pavelló de la Plana el servei d'ordre va agredir amb bales de fogueig, porres i aerosols als concentrats a fora de l'espai quan cantaven els segadors i reclamaven l'Estatut. Un segon incident és un possible intent d'assalt de militants d'AP al local del PSC Badaloní en conèixer els resultats. Veure "Balas de fogueo y porras en el miting de" Alianza"” i "Mayoría de izquierdas", Mundo Diario, 11 i 17-6-1977.

1289Enric Giralt: "Badalona: control, no dimissions" i "El governador no accepta les dimissions de Badalona", Avui, 1 i 7-7-1977.

1290"Reunión con Alcaldes de poblaciones Cabezas de Partido Judicial” (31-8-1977), AHGCB, Fons Gobernadores Civiles, Caixa 444, p. 5. 
primers mesos posteriors a les eleccions es va donar el fenomen contrari: les mobilitzacions es van accentuar. A Badalona des del 1 de juliol al 26 de setembre van haver-hi aproximadament unes trenta dues mobilitzacions veïnals: onze al barri de la Immaculada (en l'actualitat La Pau); nou a Llefià i La Salut; cinc a Bufalà i Bonavista; quatre al Congrés; dos a Sistrells i una a Lloreda ${ }^{1291}$. Si bé la majoria de mobilitzacions per separat no solien comportar la participació de més de cinccentes persones, en conjunt és una xifra notable, i més quan moltes d'elles es feien simultàniament en barris diferents.

En aquestes mobilitzacions va irrompre amb força el barri anomenat aleshores "La Immaculada". Aquest era un barri situat en plena Serra d'en Mena, tocant amb Santa Coloma, amb els dèficits habituals d'equipaments i urbanització però amb l'agreujant de que el barraquisme i l'infrahabitatge encara era una realitat ben vigent encara a l'any $1977^{1292}$. De manera que no es d'estranyar que es donés una lluita molt intensa per conservar un dels gairebé únics solars que no estava edificat entre els carrers Listz, Wagner i Mozart (d'aquí que fos popularment conegut com el solar "dels músics"). La lluita va començar amb intensitat el dia 4 d'agost de 1977 amb la concentració de 100 persones en l'esmentat solar on estava previst fer habitatges. Les concentracions van continuar els dies següents, el 5 i el 6. Va ser en aquest darrer dia quan es va produir un greu incident. Quatre-centes persones es trobaven tallant el trànsit a la cantonada del carrer Listz amb Mozart a les $20 \mathrm{~h}$ quan un conductor va voler passar atropellant a tres persones. La gent, indignada va intentar agredir als ocupants que van ser defensats per un Inspector de Policia que va arribar a fer trets a l'aire, aconseguint fugir. El vehicle va ser portat al solar reivindicat i incendiat. Posteriorment la policia va acudir a dissoldre els concentrats i es van produir enfrontaments fins les 23:30 h de la nit ${ }^{1293}$. Les

1291 “Informe de la Dirección General de la Guardia Civil” enviat al Governador Civil Sánchez Teran, AHGCB, Fons Gobernadores Civiles, Caixa 357, Ayuntamiento de Badalona 1976-1978. L'esmentat informe té un error greu. Atribueix moltes mobilitzacions al barri de Bufalà quan ho són de la Immaculada. Ho he pogut deduir pel noms dels carrers esmentats. Veure també Martí Marín i Corbera: Els Ajuntaments franquistes..., p. 470.

1292 De fet, el barraquisme en aquest barri va anar molt més enllà. Es podria dir que fins i tot en l'actualitat hi ha restes d'infrahabitatge. Un servidor va viure any i mig en una antiga barraca d'un pati interior "rehabilitada" per una immobiliària que havia comprat tota la finca.

1293 “Informe de la Dirección General de la Guardia Civil” enviat al Governador Civil Sánchez Teran, AHGCB, Fons Gobernadores Civiles, Caixa 357, Ayuntamiento de Badalona 1976-1978, p. 1. Veure també Joaquim Roglán: "Badalona estuvo al borde de la tragedia, por un solar", Tele/ eXprés, 11-8-1977; “"La Immaculada” clama al cielo", Mundo Diario, 13-8-1977 i 
mobilitzacions però van continuar els dies 7, 8, 9, 18 i 23 d'agost i el 6, 12 i 15 de setembre $^{1294}$. La ocupació del solar es va fer amb mètodes expeditius, com es queixava la Promotora "Plus Renta” propietària dels terrenys:

“(...) los vecinos del barrio procedieron a la ocupación del solar con ánimo de establecer en el una zona verde. Con la ocupación se causaron destrozos en las obras de cimentación y en los materiales y maquinaria existente. Fue destruida una excavadora, quemadas las maderas de las obras y se rellenaron de basuras y escombros los cementos, además fue rota la valla que rodea el solar y se efectuaren diversas pintadas, algunas alusivas a nuestra Sociedad. Posteriormente se produjeron amenazas a los trabajadores creando así un clima de total inseguridad que obligó a la paralización de los trabajos." ${ }^{1295}$

Les mobilitzacions van continuar a la tardor. El 14 d'octubre de 1977 una manifestació del veïnat de la Immaculada d'un centenar de persones marxa per la nacional II fins arribar a la Plaça de la Vila, forcen l'entrada a l'Ajuntament i ocupen el saló de Plens que no abandonen fins les 17 h un cop aconseguit un compromís per que uns locals comercials situats al costat del solar esmentat es transformin provisionalment en escoles per cobrir la gran demanda del barri ${ }^{1296}$. La intensitat d'aquest conflicte -a primers de desembre hi haurà una nova irrupció de veïns d'aquest barri al ple ${ }^{1297}$ - mereixerà, per una banda, que el solar fos citat en un document de la "Asociación de Promotores de constructores de edificios", on es queixaven de l'ocupació veïnal dels solars ${ }^{1298}$, així com d'un nou informe de la Guàrdia Civil. En aquest darrer s'apuntava al conflicte existent del solar al qual s'havia afegit l'ocupació dels locals comercials adjacents i l'establiment d'una escola gestionada pels propis veïns (també es demanava una llar d'infants i de

"Badalona: El barrio de La Immaculda reivindica un solar para zona verde", La Vanguardia Española, 27-8-1977.

1294 “Informe de la Dirección General de la Guardia Civil” enviat al governador civil Sánchez Teran, AHGCB, Fons Gobernadores Civiles, Caixa 357, Ayuntamiento de Badalona 1976-1978, p. 2 i 3.

1295 [Informe sobre el solar "Músicos" la Societat Plus Renta] (12-9-1977), AHGCB, Fons Gobernadores Civiles, Caixa 357, CG 39. Ayuntamiento de Badalona, 1976,1977,1978, p. 3.

1296 Dirección General de la Guardia Civil: [Informe] "Manifestación y ocupación del Ayuntamiento de Badalona" (22-10-1977), AHGCB, Fons Gobernadores Civiles, Caixa 357, Ayuntamiento de Badalona, 1976-1978.

1297 Mario Martínez Abellán: “Badalona: El público impidió que el pleno municipal pudiese acabar", La Vanguardia Española, 3-12-1977.

1298Asociación de Promotores Constructores de Edificios: "Ocupación ilegal de solares" (2-111977), AHGCB, Fons Gobernadores Civiles, Caixa 382. CG: 7. III Ministerio Interior. Antecedentes desde el 5.7.1977, otros antecedentes del Ministerio de la Gobernación desde el 4/77; Sr. Sánchez Terán, Ortiz Sánchez y Belloch Ruiz, p. 1 de l'Annex. 
jubilats), apart de senyalar amb noms i cognoms als principals líders de l'AVV ${ }^{1299}$. Després d'uns mesos de treva, les mobilitzacions van tornar al mes de març amb manifestacions i talls a la Plaça de la Vila els dies 1, 2 (coincidint amb el Ple) i 9 de març, dia en que van ser dissolts per la intervenció policial ${ }^{1300}$. Les reivindicacions del barri encara van trigar en ser ateses.

A Llefià van continuar els conflictes que existien anteriorment i es van donar alguns de nous com els de la tardor-hivern de 1977 que van tenir els veïns del carrer Londres de Sant Antoni de Llefià amb el constructor Garcia Navalón, amb alguna tancada a l'Ajuntament dels veïns afectats. Igual va passar amb els veïns del Carrer Antiga de València enfrontats amb la immobiliària Salvorpi, S. A. fins que al novembre, Pablo Porta (germà de Juan Porta Bussoms que havia estat Alcalde de Santa Coloma) es va avindre a negociar i solucionar les deficiències dels habitatges. O el que va tenir una Associació de Mestresses de Casa amb un forn de pa pel frau en el pes ${ }^{1301}$. Alguns d'antics es revifaren com el cas de Mestre Ferrer i el pati interior de la Carretera Antiga de València ${ }^{1302}$. La majoria dels conflictes que venien d'anys anteriors van quedar en una situació de treva mentre des de la CMB s'estaven fent diferents Plans Especials de Reforma -entre ells el de Llefià i La Salut-.

Finalment el 13 de gener de 1978 la CMB va aprovar provisionalment el PERI Llefià-La Salut, recollint les aportacions que havien fet les mateixes AVV's en col-laboració amb el SECOD. El Pla certament cobria moltes de les necessitats del barri $^{1303}$, tot i que va trigar molt en ser aprovat pel litigi entre l'Ajuntament i la CMB

1299 Comandancia General de la Guardia Civil [Informe]: "Movilización de un barrio de Badalona en reivindicación de equipamientos sociales" (12-12-1977), AHGCB, Fons Gobernadores Civiles, Caixa 357, Ayuntamiento de Badalona, 1976-1978. En aquest informe s'apuntava com a principals instigadors de les protestes a Juan Moreno Sancho, Secretari de l'AVV, el qual era qualificat com "home de palla d'elements del PCE(i) de Santa Coloma" i a Maria Ladevesa Pombo, de la qual es remarca el seu paper capdavanter a les mobilitzacions i, textualment: "por su actitud incitadora a la provocación". Sobre la reivindicació de l'escola veure tambéMario Martínez Abellán: "Badalona: Los vecinos de "La Immaculada" quieren una escuela en el barrio", La Vanguardia Española, 24-11-1977

1300Enric Giralt: "Cortarán el tráfico hasta conseguir escuelas", "Los vecinos de La Immaculdad cumplieron su palabra", "Pleno con manifestación" i "Disueltos los vecinos", Mundo Diario, 2, 3, 4 i 10-3-1978.

1301 “Tancada de veïns a l'Ajuntament", "L'Alcalde de Badalona va fer venir a Pau Porta” i "Pau Porta promet complir el pacte", Avui, 24-9-1977, 22 i 23-11-1977; Maurici: "Al pan le falta peso" i "El pan a juicio", Mundo Diario, 11 i 26-11-1977.

1302“Badalona: M. Ferrer cabalga de nuevo", Tele/ eXprés, 16-12-1977.

1303 Mario Martínez Abellán: "Aprovado el plan parcial Llefià-La Salud", La Vanguardia Española, 
sobre com s'havien de cobrir les seves despeses. Finalment, al novembre del mateix any s'aprovava definitivament el PERI per la Corporació ${ }^{1304}$. Aquest fet va tancar definitivament dos conflictes que s'arrossegaven des de feia anys: el del Parc del Gran Sol (preservat pel PERI) i el del Mercat de Llefià. No obstant, va haver-n'hi altres de nous, com per exemple el dels veïns dels blocs d'Inmobilar que van fer mobilitzacions al febrer de $1978^{1305}$. Altres conflictes van ser els que van tenir els veïns de Sant Antoni de Llefià amb la immobiliària "Red"1306, els del carrer Carretera Antiga de València cantonada amb Mina de Sant Mori amb una altra constructora $^{1307}$. Tot i que al gener semblava que Ibusa tancava el conflicte obert que havia tingut amb els veïns dels seus habitatges de Sant Antoni de Llefià, a l'abril esclataven nous conflictes amb altres habitants del barri, en concret els del carrer Salou i Dr. Bassols ${ }^{1308}$. Després de protestes i l'ocupació de l'Ajuntament, finalment el constructor Eduardo Bueno Ferrer s'avenia a negociar i atendre les reivindicacions veïnals ${ }^{1309}$. Alhora els veïns dels blocs del Patronat de la Ronda de Sant Antoni van aconseguir també amb mobilitzacions la urbanització i millora del seu sector.

31-1-1978. El Pla contemplava la construcció de tres col-legis d'EGB amb vint i dues unitats cadascun; un centre de Formació Professional; un Institut de Batxillerat, vint i cinc unitats de pre-escolar i escoles bressol, dues zones esportives, dos mercats (un ja gairebé fet, el de Llefià), un ambulatori, una biblioteca, un centre per jubilats i un centre cívic socio-cultural. També preveia el tancament o trasllat de les fàbriques de Cruz Verde i Rovira i Bachs i la instal-lació en els seus terrenys d'escoles amb 24 unitats d'EGB i quatre de pre-escolar, respectivament.

1304 Mario Abellán: "Aprobado el Plan Especial de Reforma Interior de Llefià", La Vanguardia Española, 29-11-1978 i M. Martínez: “Badalona: La reforma del barrio de Llefià, aprovada", El Correo Catalán, 30-11-1978. Del cost total de 1.018 milions de pessetes, 718 eren finançades pels diferents ministeris implicats i 300 per l'Ajuntament de Badalona. Es contemplava també que els veïns assumissin pagar 150 milions en diversos impostos per millores urbanístiques durant 5 anys.

1305 Enric Giralt: "Inmobilar no urbaniza", Mundo Diario, 14-2-1978.

1306 “Ultimátum a una empresa ilegal", Tele/ eXprés, 3-4-1978 i Enric Giralt: "Viviendas de 33 metros", Mundo Diario, 6-4-1978.

1307 Mario Abellán: “Problemas en un edificio de Llefià", La Vanguardia, 24-9-1978.

1308 Mario Martínez Abellán: “Graves irregularidades en tres inmuebles de Llefià", La Vanguardia Española, 26-4-1978; Enric Giralt: "Ibusa, otra vez" i "Han abandonado la ocupación”, Mundo Diario, 13-5-1978 i 18-7-1978; "Querella contra los vecinos de la calle Salou", El Noticiero Universal, 26-7-1978.

1309Enric Giralt: "Encierro en el Ayuntamiento" i Eduardo Bueno Ferrer: "Pisos de la calle Salou", Mundo Diario, 3 i 6-9-1978; "Ibusa pactará con los vecinos", Tele/ eXprés, 6-9-1978; Marta Puértolas: "Una comisión paritaria decidirá en el caso Ibusa", Diario de Barcelona, 7-9-1978 i "Badalona: Solución entre IBUSA y vecinos", El Correo Catalán, 7-9-1978. En aquest conflicte va ser molt important la mediació de partits polítics, sindicats i la FAVB davant el Governador Civil i l'Alcalde. 
Aquesta conflictivitat va esperonar l'aparició de noves AVV's. Els anys 197778 s'havien anat formant diverses comissions de veïns. I d'aquestes van sortir per exemple l'AVV Ronda de Sant Antoni de Llefià $^{1310}$ i la de Sant Joan de Llefià Baix, legalitzades l'any 1978. De la mateixa manera les entitats encara controlades per persones conservadores van passar a estar controlades per noves Juntes amb persones d'esquerres (cas ja vist de l'AVV de Sant Antoni de Llefià i ara de Sant Joan de Llefià Alt). Al 1979, poc abans de les eleccions municipals, esclataven dos conflictes nous: els dels habitatges del carrer Sagrada Família fets per la immobiliària "La Salud", també de Pablo Porta (que es perllongarà un temps i va ser el primer conflicte greu al qual va haver de fer front l'Ajuntament democràtic ${ }^{1311}$ ) i el protagonitzat pels habitats del "gratacels" del carrer Marquès de Sant Mori ${ }^{1312}$.

Al veí barri de la Salut, apart de les lluites per la reparació del col·legi Francisco Franco que s'estava enfonsant tot i ser de molt recent construcció, va haver-hi una campanya contra una possible instal-lació d'un bingo. Alhora es va continuar pressionant per que es fessin les obres d'urbanització del Parc finalment anomenat significativament "Salvador Allende", que tant havia costat d'aconseguir, així com l'acondicionament del pati interior dels carrers Floridablanca, Nàpols i Quevedo, així com per l'asfaltat final de determinats carrers ${ }^{1313}$. També els habitants del polígon "Verge de La Salut" ("el Hoyo") es manifestaren reclamant l'asfaltat del tram de l'Avinguda Marquès de Sant Mori més proper als seus habitatges ${ }^{1314}$.

A Bufalà els veïns del Bruc, sobretot, van iniciar una campanya al mes d'agost per denunciar la lamentable situació en que es trobava el barri ${ }^{1315}$. El dia 10 de setembre els veïns del barri van fer una nombrosa assemblea i van intentar parlar

1310 José Baeza: 25 anys de la nostra història. 1977-2002, Associació de Veïns Ronda de Sant Antoni de Llefià, Barcelona, 2002, p. 32-34. La seva primera gestora va estar formada per Antonio López Prior (President), Antonio Piña Sánchez (Secretari), Mateo Cano Sosa, Jordi Font Artigas, José Romero Sanchez, Manuel Gómez Hernández, Francisco López Barriga, Diego Asensio Morales, Pedro Gea Vidal, Fermín Ramos Santiago, Vicente Zamorano Casas i Jorge Munuera Belmonte.

1311 Mundo Diario, 21 i 27-2-1979, 6 i 14-3-1979 i 6-4-1979); Tele/ eXprés, 20-2-1979, 9 i 12-31979; El Correo Catalán, 22-2-1979, 1, 3, 4 i 18-3-1979; La Vanguardia, 13 i 21-3-1979.

1312 "Deficiencias en un bloque de 15 plantas", La Vanguardia, 13-3-1979 i Marco Domenech: "NOVOGAR, más protestas", El Noticiero Universal, 14-3-1979.

1313 La Vanguardia Española, 13 i 24-7-1977, 5-8-1977, 5-2-1978 , 3 i 5-5-1978 i 20-7-1978.

1314Enric Giralt: "Paro en la escuela "Proa"”, Mundo Diario, 26-1-1978.

1315 Marc Andreu i Acebal: El Bruc Bufalà..., p. 38. Veure també Asociación de Vecinos de Bufalà: "'Viviendes del Bruch", 13 años arrinconadas", Mundo Diario, 18-8-1977 
amb la regidora Juana Jordán. Al dia 11 es va repetir la manifestació i els veïns van baixar pel carrer Independència en direcció a l'Ajuntament, acció que va ser impedida per la Guàrdia Civil. Després d'una breu negociació es va enviar una delegació veïnal a parlar amb l'alcalde sense gaire èxit ${ }^{1316}$. L'assemblea veïnal va decidir llavors emprendre una altra acció: apilar bosses d'escombraries davant el domicili de la regidora Juana Jordán. Aleshores es va produir un incident quan el seu marit, Mateo Comabella -un empresari immobiliàri amb negocis especulatiusva sortir violentament i va colpejar un nen. La resposta fou immediata. Els veïns es van abraonar sobre ell i van entrar al pàrquing, trencant els vidres del vehicle familiar i omplint-lo de bosses d'escombraries. Va haver-hi també una càrrega policial i varis detinguts ${ }^{1317}$. Determinada premsa va intentar criminalitzar l'acció veïnal, dient que s'havia donat una brutal pallissa al marit de la regidora i que s'havia intentat calar foc a la casa o segrestar al fill de la regidora. Però el cert és que Mateo Comabella el dia següent havia anat a treballar -això si- amb uns quants blaus.

Aquest fet, però, va provocar la dimissió de Juana Jordán com a regidora el dia següent i de l'alcalde de barri Manuel Cortés. De fet, Juana Jordan i Mateo Comabella van marxar a Amèrica el juny de 1978 fugint de la justícia per un cas de corrupció i frau empresarial $^{1318}$. El mateix dia 12 de setembre els veïns de Bufalà intentaven entorpir el pas de la Volta ciclista a Catalunya, però l'ampli dispositiu policial els ho va impedir. No obstant, la seva lluita va provocar que el 16 de setembre un Ple extraordinari aprovés un pressupost especial de 52 milions de pessetes per urbanitzar carrers del barri. També es va aconseguir que el MOPU pintés els blocs de l'OSH. Les obres d'urbanització van començar el 8 de febrer de 1978. Uns altres conflictes importants abans del primer Ajuntament democràtic van ser la lluita pels semàfors així com la del transport públic. El 7 de març de 1979, poc abans de les eleccions municipals els veïns van segrestar 4 "tuses"

1316 Marc Andreu i Acebal: El Bruc Bufalà..., p. 38-39. La delegació va estar formada pel President de l'AVV, Joan Garcia i altres membres com José Tarín, Antonio Martínez y José Morales.

1317 Martí Marín i Corbera: Els Ajuntaments franquistes..., p. 471-472; Marc Andreu i Acebal: El Bruc Bufalà..., p. 38-39. Veure també Dirección General de la Guardia Civil: "Manifestaciones en Badalnoa pro-reivindicaciones sociales" (16-9-1977), AHGCB, Fons Gobernadores Civiles, Caixa 357, Ayuntamiento de Badalona, 1976-1978.

1318“Una concejal huye a Sudamerica”, La Vanguardia Española, 7-6-1978. 
(autobusos) amb la complicitat de part dels seus treballadors afiliats a $\mathrm{CCOO}^{1319}$.

Al barri de Sant Roc les mobilitzacions van continuar també durant aquests anys. Al novembre va haver-hi una nova jornada de lluita al barri amb assemblees, manifestacions i talls de trànsit a l'autopista que travessava el barri ${ }^{1320}$. Al desembre es va fer una enquesta als veïns sobre l'estat en que es trobaven els seus habitatges, i el resultat va ser demolidors ${ }^{1321}$. Finalment, fruit d'aquestes lluites el Consell de Ministres va aprovar un pla de reparacions pel barri el 2 de març de $1978^{1322}$. Les mobilitzacions no obstant van continuar i per exemple al maig va haver-hi una altra setmana de lluita per reivindicar un consultori, una llar de jubilats i dues escoles ${ }^{1323}$. Però el moment clau va ser la visita del delegat del Ministerio de la Vivienda, el Sr. Codina, i l'assemblea que es va fer en la seva presència, on malgrat els intents d'aquest i les autoritats el veïnat va votar a favor del control de les obres pel Centre Social i no per l'Associació de Veïns ${ }^{1324}$.

Poc després, el 4 de setembre es produïa un altre fet important: l'ocupació de nombrosos habitatges buits del polígon anomenat Maresme, que tot i estar a Sant Roc era administrat pel PMV ${ }^{1325}$. Aquesta ocupació va coincidir amb altres que es feien al Principat:

"Va ser espontània (...) Jo penso que era espontani per que havien alguns que no tenien. Per que just (...) havia algunes barraques per aquí en l'Avinguda Maresme i (...) jo anava precisament amb una gent d'allà, (...) si feien aquests pisos que eren posteriors (...) doncs ficar-se allà dintre. Però no era una qüestió organitzada, no... (...) inclús l'assistent social que havia de l'Ajuntament (...) venia amb unes mantes."1326

1319Marc Andreu i Acebal: El Bruc Bufalà..., p. 40-41. Veure també Carlos Gómez Acuzar: "Dos líneas de autobuses, secuestradas por los usuarios", La Vanguardia, 10-3-1979.

1320Maurici: "Semana de lucha en Sant Roc", Mundo Diario, 17-11-1977.

1321 Les conclusions de l'enquesta es poden veure a Felipe Guerrero: Sant Roc. 25 anys de lluita, p. 12-13.

1322 Ídem, p. 19.

1323Enric Giralt: "Sant Roc reivindica consultorio y escuelas", Mundo Diario, 6-5-1978. Poc abans, a l'abril mestres i pares havien tancat en protesta el col-legi Bori Fontestà (l'únic públic existent) pel seu mal estat. Veure "Cierre de un colegio por padres y maestros", Mundo Diario, 20-41978.

1324 La maniobra va fracassar per que el prestigi ho tenia el Centre Social i no una AVV massa propera al poder. Veure el que ja vaig comentar al respecte a les p. 257-260.

1325Sobre aquest afer destaco el sensacionalista article que va fer El Besós núm. 7 (12-9-1978): "Los gitanos quieren vivir como los payos.", p. 12 i 13. Apart també hi havia hagut irregularitats en la concessió d'aquestes habitatges. Per exemple, el President de l'AVV Francisco Lleal havia rebut un tot i tenir ja un altre pis per la seva amistat amb Isidre Caballeria i Alfonso Ramos, tal com em va confirmar Juan Jesús Guerrero en l'entrevista que li vaig fer el 14-6-2013.

1326Entrevista amb Juan Jesús Guerrero, 14-6-2013. Membre del Centre Social i actualment Ateneu de Sant Roc. 
Després de diversos moments de tensió es va fer una mena de Comissió Mixta entre entitats ciutadanes, partits polítics i administració per avaluar les necessitats dels ocupants, i llevat de 17 casos, es van concedir les habitatges als nous inquilins $^{1327}$. Les obres de remodelació del barri van començar a finals de 1978, si bé, les comissions de control de les obres van tenir moltes més dificultats per les disputes internes i per les insuficiències i mancances de les reparacions fetes. També van fracassar els intents de fusió entre l'AVV i el Centre Social que es van intentar fer.

Una lluita que va irrompre amb força durant aquests anys va ser la del barri de Sant Crist per aconseguir una escola pública pel barri. El febrer començaven les seves reivindicacions reclamant a la Junta de Compensación de Montigalà-Batllòria la cessió de terrenys per aquesta, sense èxit. L'AVV, ara molt combativa, va responsabilitzar tant als promotors, l'Ajuntament i fins i tot als partits polítics, als que acusaven de no treballar als barris on no tenien "líders polítics"1328. La resposta va ser la ocupació dels baixos de l'Església del barri el dia 22 de juny i la posterior ocupació de l'Ajuntament el 6 de juliol quan havia de celebrar-se el Ple on es tractaria aquesta qüestió, del qual van ser desnonats per la policia ${ }^{1329}$. Alarmats per que el 15 de juliol acabava el termini per presentar al MEC les demandes per noves escoles els veïns tornaven a pressionar a l'Ajuntament i finalment aconseguien la cessió gratuïta dels baixos de la parròquia per fer provisionalment les escoles. L'Ajuntament es comprometia en un Ple extraordinari a adquirir uns locals també per la mateixa funció ${ }^{1330}$.

Al barri de Pomar en aquells anys van continuar les obres de reparació dels pisos de la OSH que avançaven lentament i amb la constant pressió i vigilància del veïnat que no parava de trobar defectes en la seva execució, i també la lluita contra l'abocador d'escombraries (aquesta darrera encara va continuar fins l'Ajuntament

1327Joan Roura: "Adjudicadas las viviendas ocupadas", Mundo Diario, 30-11-1978.

1328Enric Giralt: "Solo faltan los terrenos para tener la escuela", "Pleno con manifestación", "El barrio de Sant Crist puede quedarse sin escuela" i "Discriminación municipal”, Mundo Diario, 12-2-1978, 4, 8 i 31-3-1978.

1329Enric Giralt: "No dejarán los locales hasta que sean suyos", "Ocupan el Ayuntamiento" i "Los vecinos deben avalar los créditos", Mundo Diario,, 6, 7, i 8-7-1978.

1330"Conseguidos los locales para las escuelas" i "Enric Giralt: "Han abandonado la ocupación", Mundo Diario, 15 i 18-7-1977. 
democràtic ${ }^{1331}$. I al barri del Centre, apart de tot l'afer ja explicat del monòlit de Can Solei i accions prou simbòliques com el canvi de la placa de la "Plaza Jose Antonio" per el de Plaça de la Vila ${ }^{1332}$, va protagonitzar una lluita contra la instal-lació d'un Bingo al barri ${ }^{1333}$. També va tenir importància la lluita del veïnat de Dalt de la Vila (inicialment organitzat en una Vocalia depenent de l'AVV del Centre i des de 1979 en una AVV pròpia) per la preservació del barri i contra l'edificació d'un edifici il·legal ${ }^{1334}$. Aquest darrer fet es va transformar en tot un escàndol de ciutat, com veurem tot seguit.

Abans cal esmentar, que davant tota aquesta situació el consistori badaloní es trobava totalment superat. El dilluns 10 d'octubre de 1977 una trentena d'Alcaldes -entre ells els de Badalona i Santa Coloma- es reunien amb el Governador Civil sol-licitat ajuda davant la continua ofensiva veïnal i política, amenaçant amb dimissions si no eren ajudats ${ }^{1335}$. El cas badaloní era especialment greu per la pressió a la que estava sotmès el consistori d'Alfonso Ramos. I aquest encara va complicar les coses quan per exemple es va oposar al PERI de Dalt de La Vila (que contemplava aturar i enderrocar les obres il·legals en curs) en una votació feta l'u de juny de 1978 i la CMB el va desautoritzar el mateix dia 9 aprovant-lo. El Consistori badaloní va tornar a presentar la dimissió malgrat tampoc li va ser $\operatorname{acceptada}^{1336}$.

A nivell de ciutat van ser importants les lluites per preservar Montigalà, que van agafar embranzida l'any $1978^{1337}$. 0 la dels afectats per la immobiliària Patrilar del ja conegut Pablo Porta ${ }^{1338}$. I també, sens dubte, les protagonitzades per la Taula de Sanitat i, en especial, la Taula d'Ensenyament, pel que fa a la contínua 1331Carles Mas: El Pomar..., p. 55-57. Veure també Pomar Convivència. Nueva serie núms. 21 (desembre 1977) i 22 (maig 1978), MB, Fons Hemeroteca, Caixa 21-1-6, Carpeta Pomar Convivència i Asociación de Vecinos. La Voz de Pomar núm. 2 (desembre 1978), MB, Fons Hemeroteca, Caixa 21-1-7, Carpeta AVV Pomar.

1332Enric Giralt: “Manifestacón pro "Parc Can Solei”, Mundo Diario, 24-7-1977.

1333“Oposición a la fiebre del Bingo", Tele/ eXprés, 2-3-1978.

1334"El casco antiguo de Badalona, a salvo", Tele/ eXprés, 13-3-1978.

1335Veure el document al respecte, ja citat presentat pels Alcaldes esmentats a AHGCB, Fons Gobernadores Civiles, Caixa 328. Subsecretaría de la Gobernación (a partir del 5.7 .77 se denomina: Subsecretaría del Interior). 1976-1980, i Mundo Diario, 15-10-1977.

1336Mundo Diario, 14 i 15-6-1978. Curiosament quatre regidors no van presentar aquesta dimissió: Ernest Rojo, Cecília March, Vicente Marquès i Diego Garcia.

$1337 \mathrm{Al} 1978$ es van fer mobilitzacions i festivals a l'aire lliure reivindicant la conservació de l'espai i la no construcció del macropolígon d'habitatges que estava previst. Veure Mundo Diario, 27-1$1978,4,16,19,21$ i $26-2-1978$.

1338Mundo Diario, 15,18,22 i 29-11-1978 i 8,9,10,13 i 16-12-1977. 
reivindicació d'escoles públiques, on el dèficit continuava sent alarmant ${ }^{1339}$, sense oblidar algunes mobilitzacions per la llibertat d'expressió ${ }^{1340}$.

A la segona ciutat del Barcelonès Nord, Santa Coloma de Gramenet, el gener de 1976 ja va començar calent amb una cavalcada de reis reivindicativa que va recórrer la majoria dels barris de la ciutat el matí del diumenge 4 per acabar confluint a l'espai reivindicat de Can Zam ${ }^{1341}$. Així ens ho recordava un dels nostres entrevistats:

"Però és (...) al gener del 76 que es fan manifestacions coordinades ja per les Associacions de Veïns (...). Llavors el dia de la cabalgata dels Reis de gener del 76 es prepara una gran manifestació, una gran cabalgata que surt de tots els barris. Per tant, des de Les Olivers, el Fondo i Raval... I es concentra un diumenge al de matí tots allà, no? Reivindicant Can Zam."1342

Quatre dies després les AVV's de Centre, Raval i Singuerlín enviaven un escrit demanant permís per fer un acte d'homenatge a Francisco Téllez, un dels detinguts el desembre anterior que havia estat brutalment torturat a la caserna de la Guàrdia Civil de Badalona ${ }^{1343}$. Com era d'esperar el permís no va ser concedit, però la concentració de suport es va fer igualment el dia 18 i es van donar enfrontaments amb la policia que va mirar d'impedir-la ${ }^{1344}$. Del 12 al 18 de gener els treballadors de Radiotronic, en conflicte laboral pel seu acomiadament, es tancaven a l'església de Sant Joan Baptista del Fondo, regentada per J. P. Sayrach. Es van viure moments de tensió quan la policia va impedir fins i tot l'entrada del Vicari episcopal d'assumptes obrers, Joan Carrera ${ }^{1345}$.

Igual que va passar a Badalona, les AVV's colomenques van denunciar

1339 Maurici: "La "Taula de Sanitat" elabora el seu Pla local d'Urgències", Mundo Diario, 24-1-1978; Enric Giralt: "La Taula d'Ensenyament elabora un plan completo de actuación", Mundo Diario, 25-4-1978 i Enric Giralt: "A la calle por el plan de urgencias de enseñanza", Mundo Diario, 7-51978.

1340 Mundo Diario, 9-4-1978 i 12-5-1978. Cal recordar que a l'abril es va prohibir una manifestació al respecte i que hi havia un badaloní detingut membre de els Joglars: Andreu Solsona.

1341Eugenio Madueño: "Dos mil personas se congregaron el domingo pidiendo parques y amnistía", Diario de Barcelona, 6-1-1976; Agustina Rico: "Santa Claus y los reyes en Can Sam" El Correo Catalán, 7-1-1976.

1342Entrevista amb Fernando Saro. 22-5-2013. Membre de la Comissió de Barri i AVV de Les Oliveres. Militant de l'OIC, del PSUC i posteriorment regidor a l'Ajuntament per IC.

1343Eugenio Madueño: "Asociaciones de Vecinos piden celebrar un homenaje a Téllez", Diario de Barcelona, 9-1-1976.

1344Tele/ eXprés, 19-1-1976.

1345 Veure Diario de Barcelona, 16 i 18-1-1976 i Tele/ eXprés, 19-1-1976. 
públicament la "farsa" d'eleccions a Alcaldes que va fer l'Ajuntament, mentre reclamaven uns Ajuntaments democràtics. Primer en una roda de premsa i després en una concentració el mateix dia de les eleccions a la Plaça de la Vila del veïnat que fins i tot va arribar a entrar a l'Ajuntament amb una pancarta que deia "el pueblo quiere votar a sus representantes" ${ }^{1346}$. El fet és que malgrat els discursos "reformistes" que feia Blas Muñoz un cop nomenat oficialment Alcalde l'1 de febrer, el tarannà havia variat poc. El dia 7 era detinguda una jove per fer una pintada, mentre que al dia següent la policia interrompia un festival organitzat per les Vocalies de Dones de les AVV's de Arrabal, Santa Rosa, Centre, Rio, Oliveras, Can Mariner, i l'Associació Amas de Casa de Singuerlín, a la parròquia de Can Mariner titulat "Mujer en Santa Coloma" (i això que l'acte comptava teòricament amb permís governatiu) ${ }^{1347}$.

Als barris del Raval i Santa Rosa van continuar les mobilitzacions malgrat les amenaces telefòniques rebia el President de l'AVV del Raval José Maria Ballesteros $^{1348}$. Un tema pendent va ser el dels terrenys Motocross, si bé ja s'havia aconseguit al març de 1975 el suport de l'Ajuntament i que fins i tot la revisió del Pla Comarcal de 1976 reservés els terrenys per equipaments. Al mes de juny la Vocalia de Dones de l'AVV de Santa Rosa, juntament amb la del Raval i les de Riu Nord i Centre s'havien solidaritzat amb un grup de metges que reivindicaven la planificació familiar i la legalització dels anticonceptius ${ }^{1349}$. A Santa Rosa es van produir mobilitzacions veïnals durant el juliol contra els bars on s'exercia la prostitució $^{1350}$. Entre el 3 i el 5 d'agost es va produir vàries detencions al barri: Juan Manzanares i Evencio Juárez, militants de Acción Comunista juntament amb les seves respectives dones. Tots quatre eren membres actius de l'AVV i del Centre Social (la companya de Manzanares, Tere, dibuixava al conegut butlletí de l'AVV

1346"Tellez llegó ayer a su domicilio" i "Nota de la policia sobre el recibimiento a Téllez", Tele/ eXprés, 26-1-1976.

1347El Correo Catalán, 11-2-1976. La noia detinguda, però va ser posada aviat en llibertat sense càrrecs. Pel cas del festival de les Vocalies de dones veure "La policía interrumpió un festival en Santa Coloma de Gramenet", Tele/ eXprés, 10-2-1976.

1348 "Nuevas amenazas telefónicas en Santa Coloma”, Diario de Barcelona, 29-2-1976 i "Amenazas al Presidente de la Asociación", La Voz del Arrabal. Boletín informativo de l'Asociación de Vecinos del Arrabal (març 1976), AHMTB, Donació Mn. Josep Catà, Caixa 2, p. 3.

1349 “Santa Coloma de Gramenet", Avui, 4-6-1976.

1350 "Los ruidos nocturnos, motivo de la campaña contra los bares de camareras en Santa Coloma de Gramenet", Tele/ eXprés, 23-7-1976. 
Pimienta) ${ }^{1351}$. Va ser Juan Manzanares, acusat de l'atracament a una sucursal bancària a Badalona el que va romandre més temps a presó mentre s'engegava una campanya de solidaritat al barri.

Al setembre els veïns de Santa Rosa estaven mobilitzats per la transformació del Solar dels carrers Banús Baixa-Irlanda en un parc i també per la construcció d'una escola un altre solar situat a Banús Alta-Amapolas ${ }^{1352}$. A finals d'octubre eren 200 famílies del barri del Raval les que es mobilitzaven amb el suport de l'AVV (on recordem hi havia coneguts militants del MC com José Maria Ballesteros i Josep Pitarque Narejos ${ }^{1353}$ ) pels defectes de construcció dels seus habitatges situats als carrers Churruca, Parcerises, Elcano i Circumval·lació ${ }^{1354}$. Al mes de novembre una concentració de 200 veïns de Santa Rosa que defensava del solar de Banús-AltaAmapoles per la construcció d'una escola en comptes d'habitatges va ser violentament dissolta per la policia ${ }^{1355}$. El mateix mes s'inaugurava, a un antic local parroquial situat al carrer Banús Baixa, el Casal de Cultura de Santa Coloma de Gramenet, amb la participació de l'AVV de Santa Rosa i entitats culturals de la ciutat $^{1356}$.

El 6 febrer de 1977 el veïnat del Raval iniciava la reivindicació d'un ambulatori $^{1357}$, posant taules informatives -que van recollir 2.200 signatures- $\mathrm{i}$ pancartes en diversos punts. A finals del mateix mes eren els veïns de Santa Rosa els que es tancaven en protesta contra una immobiliària propietària d'uns terrenys on es reivindicava una escola bressol ${ }^{1358}$. El mateix ple municipal del 24 de febrer va aprovar finalment la construcció d'un parc als terrenys de Banús Baixa amb

1351 Marcelo L. Ródenas: "Dos vecinos detenidos", Grama núm. 92 (setembre 1976), p. 11. i Pimienta. Notícias internas de la Asociación de Vecinos de Santa Rosa, núm. 5 [setembreoctubre? 1976], AHMTB, Donació Marcelo López Ródenas, Caixa 1, p. 4.

1352 “Editorial: Batallas pequeñas", Pimienta. Notícias internas de la Asociación de Vecinos de Santa Rosa, núm. 5 [setembre-octubre? 1976], AHMTB, Donació Marcelo López Ródenas, Caixa 1, p. 2

1353 La trajectòria dels dos va ser, no obstant diferent. Mentre Josep Pitarque encara és avui en dia un activista veïnal vinculat a la PAH i a l'ANC, José Maria Ballesteros va passar del MC al PSUC i posteriorment al PSC (segons el primer).

1354 "Doscientas familias protestan por el estado de sus viviendas", Diario de Barcelona, 27-101976 i Inés Izuel: “Los vecinos dijeron ¡Basta!”, Grama núm. 94 (novembre 1976), p. 12.

1355Agustina Rico: "Santa Coloma: Los vecinos reivindican más escuelas", El Correo Catalán, 24-111976 i Román Barrera (President de l'AVV Santa Rosa): “Pedimos colegios y nos mandan a la policia", Grama núm. 95 (desembre 1976), p. 10.

1356Veure documentació al respecte a AHMTB, Donació Mn. Josep Catà, Caixa 3.

1357 El Correo Catalán, 8-2-1977 i Aurora Agustí: “El Raval vol ambulatori”, Avui, 13-2-1977.

1358“Fin de semana movido”, Mundo Diario, 22-2-1977. 
Irlanda, llargament reclamat ${ }^{1359}$. El 27 de febrer, en ple auge del "debat sobre el lerrouxisme" que s'estava donant en clau local -en parlaré una mica més endavantl'AVV del Raval inaugurava la plaça Francesc Macià com a espai verd que havien condicionat ells mateixos després d'hores de treball ${ }^{1360}$. I a l'abril curiosament un centenar de veïns i l'AVV de Santa Rosa denunciaven a la recentment inaugurada "Casa de Andalucia" -que havia tingut un paper en el debat esmentat- per sorolls i molèsties ${ }^{1361}$. El mes de maig van haver-hi protestes veïnals reclamant l'asfaltat del Carrer Circumval-lació -limítrof amb Badalona- ${ }^{1362}$. Poc després, i com a símptoma de l'hegemonia clara que ja havien agafat les AVV's, tancava el vell Centre Social Arrabal de Santa Rosa ${ }^{1363}$. El 13 de juny finalitzava també un tancament d'una 30 de veïns a l'església del barri demanant la llibertat de Juan Manzanares, veí del barri que portava prop d'un any detingut ${ }^{1364}$. Aquest va ser finalment alliberat el 27 del mateix mes després de pagar una fiança ${ }^{1365}$.

Un altre barri que havia protagonitzat importants lluites els anys anteriors havia estat el de Les Oliveres. Durant aquest any de 1976 i la primera meitat de 1977 es va continuar reivindicant, sobretot des de l'AVV els serrells pendents respecte els pisos d'ALBICA i del Patronat. Finalment s'havia aconseguit l'estatus de renda limitada pels primers entre 1975 i 1976 (els darrers 20 blocs el maig de 1976 ${ }^{1366}$. També en aquest any, al novembre, es va resoldre la demanda que havien interposat els veïns dels pisos del Patronat Municipal pel mal estat dels seus habitatges, que tot i que va haver de pagar només una petita multa, si va ser condemnat a reparar els pisos en un termini de tres mesos ${ }^{1367}$. No obstant, les reparacions i la completa urbanització del barri van trigar en materialitzar-se i això va fer que l'AVV hagués d'estar a l'aguait i continuar reivindicant aquestes millores. A aquest fet es va sumar l'aparició de diversos casos de meningitis en nens del

1359Pimienta. Notícias internas de la Asociación de Vecinos de Santa Rosa, núm. Extra, "Especial Plan Popular" [març? 1977], AHMTB, Donació Marcelo López Ródenas, Caixa 1, p. 1-2.

1360 "Santa Coloma: El nom de Macià per a una plaça", Avui, 31-3-1977. Veure també Inés Izuel: "Plaza a Francesc Macià", Grama núm. 98 (març 1977), p. 8.

1361 Aurora Agustí: "La Casa d'Andalusia, denunciada", Avui 15-4-1977.

1362 “Barricadas pro asfalto”, Tele/ eXprés, 6-5-1977.

1363 Grama núm. 101, (juny 1977), p. 10.

1364"La urna te olvida, amnistía”, Tele/ eXprés, 14-6-1977.

1365 “Los cuatro procesados de Acción Comunista, en libertad”, Tele/ eXprés, 28-6-1976. Mentre esperava el judici al mateix barri s'havia fet una manifestació reclamant el seu alliberament. 1366Marcelo López Ródenas: Història social a la Santa Coloma moderna..., p. 178. 1367ídem p. 178-179. 
barri, fet que es relacionava amb la brutícia existent i amb el fet greu que s'abocaven residus sanitaris molt a prop del barri ${ }^{1368}$. Les lluites havien contribuït a crear un esperit i consciència de barri molt fort, fins al punt que fins i tot un dels veïns més populars i membre de l'AVV, conegut com el "Niño de la Pera", havia creat un himne:

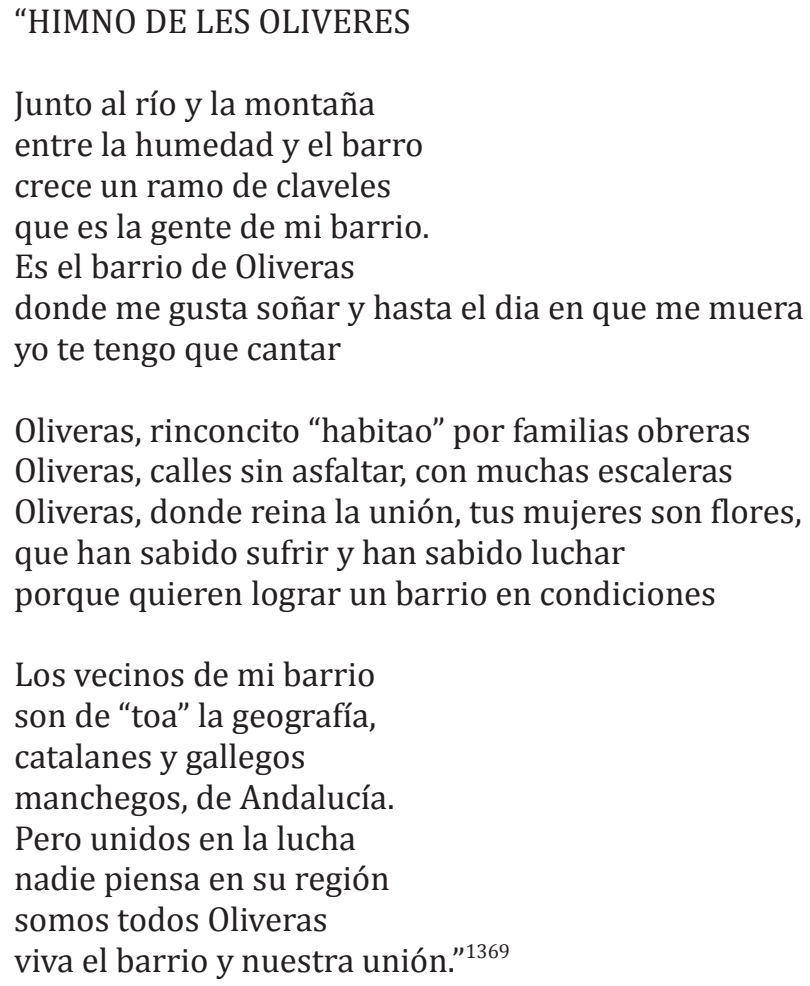

Cal fer esment també al paper que va tenir el col-legi Lluís Millet, on van treballar tot un grapat de mestres progressistes i/o militants de partits polítics clandestins com -entre d'altres- Perico García, Josep Miquel Lacasta, Victòria Marí, Gabriela Serra i Lluís Leal (els tres primers van ser posteriorment regidors), els quals van tenir també un paper rellevant en la creació del Casal del Mestre -juntament amb Elvira Ruiz- que durant uns anys va ser un referent en la innovació

1368“Escombros sanitarios en el barrio "Les Oliveres"”, Tele/ eXprés, 22-3-1977 i "Dos casos de meningitis", Mundo Diario, 20-4-1977.

1369 La Oliva Indigesta. Boletín de la Asociación de Vecinos de Las Oliveras (desembre 1982), AHMTB, Donació Mn. Josep Catà, Caixa 8, p. 4; El “Niño de la Pera” era el veí Antonio González Vela, el qual va fer tot un repertori de cançons reivindicatives com "La Caravana" (referent a la situació de la carretera "de los cuarteles"), "La enseñanza" (sobre la falta d'escoles, etc.), "El Plan Comarcal", "Murga del carnaval" (dedicada al paper de les dones en les lluites del barri) "El Vito" (dedicada a la reivindicació de Can Zam) i "La Banda de los pelmazos" (dedicada als veïns i les reivindicacions del barri). Veure a Fernando Saro: Les Oliveres. Sabor a barrio 1970$1980 \ldots$, p. $174-184$. 
pedagògica ${ }^{1370}$. La mateixa Gabriela Serra ens recordava com va ser el treball en l'escola i les dures condicions que patien els nens del barri:

"Per això jo me'n recordo, a nosaltres ens sobtava molt, que els nens 'los niños de la llave' que en deien. Nens que venien al Lluís Millet, eren de Les Oliveres i Can Franquesa, i venien amb la clau del pis penjada al coll del gran. I el gran quan acabava les classes agafava els tres o quatre [petits] i s'anava a casa a obrir... Que va ser aquella època on contínuament hi havia a la premsa, me'n recordo... que és la època on sortiran Tele-eXpres, Mundo Diario... niño quemado, niño tal, niño se le cae el potaje encima, niño se quema con estufa... Per que eren aquestes criatures quedaven sols per que el pare i la mare estaven treballant.

Doncs quan això va començar, aleshores vam fer... que va ser impressionant, ya no había llave... i enconces salían a la mañana amb uns entrepans aixíns... Jo mai a la vida havia vist entrepà de cocido...Un entrepà de cocido! Dins l'entrepà hi havia cigrons amb morcilla (...). I es quedaven al pati, a les afores de l'escola, menjant l'entrepà! Hivern, estiu (...). Fins que el menjador va començar a funcionar (...) i fins que bueno... Però aquest pas d'aquestes pobres famílies... El trauma que van haver de passar, de passar d'un món més rural, més petit, a aquest món urbà destartalat, descompensat, aïllat, on no coneixes a ningú [i en unes condicions laborals extremes i precàries...] (...) A mi em fa molta gràcia quan diuen que 'oh, es que els nivells de violència aquí van reduir-se...' Van augmentar! Clar que van augmentar, aquesta mare, que arribava a casa, o pare... el pare no?... el pare sempre té la mà més llarga... Que arribava a casa després de treballar 12 hores... limpiant merda o lo que fos, es trobava 4 o 3 criatures allà tancats en un pis que no sabien jugar... tancats en un pis! Per que jugar és un procés d'aprenentatge... No sabien jugar dintre del pis! (...). Jo me'n recordo tenir nens que arribaven amb una cara aixís... '¿que te ha pasao?' 'No, que mi papa me ha pegao' '¿Y por qué te ha pedado el papa?' 'Porque manché el sofá' ... Havien comprat el sofà i aquell noi el tacava (...) Vull dir que el canvi que va suposar per totes les pautes de vida va ser duríssim! Duríssim per aquestes famílies!"1371

Al veí barri La Guinardera van continuar les protestes per solucionar els problemes relacionats amb les irregularitats de la cooperativa d'habitatges VIPES i l'11 de febrer es va fer un judici contra varis dels seus membres, sent condemnats l'ex-president Mariano Gimeno Vinaja i el secretari Francisco Serrano Palasí a dos

1370Entrevista a Eloy Jurado Cubero, 12-12-2013. Membre de la CCBB del Singuerlín, de l'AVV i militant del PSUC. Va ser també regidor d'Urbanisme l'Ajuntament entre 1983-1991.

1371Entrevista amb Gabriela Serra Freidiani, 10-7-2013. Mestra al Lluís Millet i antiga militant de l'OIC, MCC i Presidenta de l'AVV de Singuerlín. 
anys, quatre mesos i un dia de presó per cadascú i a pagar una multa de 20.000 pessetes $^{1372}$. El litigi no es va tancar definitivament fins l'any 1985 quan es va liquidar el patrimoni de la cooperativa $\mathrm{i}$ el deute amb els creditors $^{1373}$. Els problemes urbanístics i amb les edificacions van continuar com ho posava de manifest les queixes del veïnat del barri per la situació de 25 famílies del carrer Eixemenis que no disposaven encara ni de clavegueram, ni d'aigua potable ni d'un servei de recollida d'escombreries ${ }^{1374}$.

A Can Franquesa les lluites per una escola pel barri i pel transport públic van intensificar-se en aquest període. La lluita ja venia de molt abans, però es va reactivar a partir del dia 6 quan es van tornar a segrestar tres autobusos de la línia 203 per fer-los pujar al barri on no arribaven i eren molt reclamats. La resposta va ser una violenta repressió policial per part de la Policia Armada auxiliada per la Policia Municipal ${ }^{1375}$. Però aquest fet no va impedir nous segrestos el dia 7 , on es van "requisar" 9 autobusos i es van fer manifestacions. La intervenció policial va ser molt dura fins al punt que va provocar nombrosos ferits, entre ells un nen de 10 anys que haver de ser ingressat a l'Hospital amb dues costelles trencades ${ }^{1376}$, o fins i tot una dona embarassada. La indignació del veïnat va ser enorme, així no és d'estranyar que quan Blas Muñoz va pujar el dia 9 al barri hagués de fugir corrents, sent el seu cotxe apedregat ${ }^{1377}$. Finalment, el dia 11 s'aconseguia que arribés la línia d'autobús. La pressió popular havia forçat a que Blas Muñoz i Socies Humbert, president aleshores de l'Entitat Municipal Metropolitana signessin un acord al respecte $^{1378}$.

Al barri del Singuerlín es va continuar reivindicant el mercat, ja que malgrat al juliol de 1974 s'havia aprovat un projecte urbanístic que li reservava un espai, no es va acabar construint definitivament fins els anys 80. Des de el mes de març de 1976 es van fer accions com la de muntar un mercat propi:

1372 "Vista del juicio contra varios ex-miembros de la junta de VIPES", Tele/ eXprés, 16-2-1976 i Grama núm. 86 (febrer 1976), p. 9.

1373Veure a Jordi Rovira Sánchez: La Guinardera, A.V. La Guinardera, Ajuntament de Santa Coloma de Grament, amb la col-laboració del la Direcció General d'Acció Cívica del Departament de Benestar i Família de la Generalitat de Catalunya, 2002, p. 33.

1374 “Sin cloacas ni agua potable”, Mundo Diario, 16-4-1977.

1375 “Secuestros de autobuses para lograr que lleguen al barrio”, Tele/ eXprés, 8-6-1977.

1376“Continuan secuestrando autobuses en Santa Coloma", Tele/ eXprés, 9-6-1977.

1377Eugenio Madueño: "A pedradas con el Alcalde", Tele/ eXprés, 10-6-1977.

1378“Acaba la lluita dels autobusos", Avui, 12-6-1977. 


\begin{abstract}
"Per que ens anàvem els dissabtes amb l'Eloy, amb el Fernando Saro, amb tots aquests, i amb un cotxe allà al born, a comprar fruita a majorista per portar a... fèiem un mercat alternatiu allà en medio de nada, que portaven les caixes allà i en medio de nada per a vendre i per la gent se'n dongués compte de que calia un mercat allà i que no se què i no se quantos Bueno... era unos madrugones que no veas... però bueno... allà està el mercat, no? ${ }^{\prime 1379}$
\end{abstract}

Aquesta associació ja s'havia destacat per la seva capacitat reivindicativa i el seu President, Eloy Jurado, militant del PSUC, havia rebut també amenaces ${ }^{1380}$. Amb la seva presidència l'Associació es va significar en reivindicacions més polítiques com per exemple va ser un document escrit conjuntament amb altres AVV's (Singuerlín, Raval, Oliveres, Centre i Santa Rosa) en solidaritat amb els obrers represaliats a Gasteiz ${ }^{1381}$. El mateix Eloy Jurado es va adherir a l'Assemblea Democràtica a nivell personal tot i que l'Associació no ho va fer ${ }^{1382}$. També es van fer reivindicacions per l'amnistia ${ }^{1383}$. Tot això sense menystenir les demandes de millores urbanístiques, arribant a fer accions més expeditives:

"A Can Calvet hi havia un jardí en un pati interior de blocs. Això que estava ple d'escombraries ho vam transformar en un jardí. Robant totxanes (...) Robant totxanes de les obres dels col·legis (...) anàvem amb un camió, carregaven totxanes un dissabte a la nit i el diumenge es posaven les totxanes, no?"1384

Al barri més poblat de Santa Coloma, el Fondo, també es van continuar reivindicant les imprescindibles millores urbanístiques. Al gener de 1976 s'havia legalitzat -finalment- l'AVV que portava ja un temps funcionant ${ }^{1385}$. El 26 de maig de 1976 el veïnat va ocupar un solar abandonat i el va netejar, reivindicant-lo com zona verda celebrant un festival el dia següent ${ }^{1386}$. De fet, al Fondo la reivindicació

1379Entrevista a Gabriela Serra Freidiani, 10-7-2013. L'Eloy Jurado Cubero ens va explicar el mateix en una altra entrevista feta el 12-12-2013. També es poden trobar referències a la publicació de l'AVV del Singuerlín, Las Viñas, en concret al núm. 2, AHMTB, Donació Marcelo López Ródenas, Caixa núm. 1.

1380“Nuevas amenazas telefónicas en Santa Coloma”, Diario de Barcelona, 29-2-1976.

1381 Tele/ eXprés, 12-3-1976.

1382Eloy Jurado Cubero: "Puntualización sobre la Asamblea Democrática de Santa Coloma de Gramenet”, Tele/ eXprés, 19-6-1976.

1383“Destituido el comisario jefe de Policía”, Mundo Diario, 22-7-1977.

1384Entrevista a Eloy Jurado Cubero, 12-12-2013.

1385 “Dos nuevas asociaciones de vecinos”, Tele/ eXprés, 21-1-1976. També es va legalitzar al mateix mes l'AVV del Barri Llatí.

1386“Santa Coloma de Gramenet”, Avui, 2-6-1976. 
de preservar els espais no edificats per zones verdes i equipaments pel barri -en lo que va ser popularment conegut com la "Via Cívica"- va ser molt intensa ${ }^{1387}$. Es van fer continues manifestacions públiques, festes i jornades de treball convocades per la Associació per netejar i condicionar solars. Un exemple van ser les que es van realitzar al febrer de $1977^{1388}$. Aquesta activitat no estava exempta de riscos, no tan sols per l'actuació de les forces policials. Per exemple, el dia el dissabte 7 de maig l'AVV havia convocat una jornada per netejar el solar conegut com "de Molero", i va ser el seu propietari, el Sr. Molero el qui va escometre amb el seu cotxe al veïnat congregat allí provocant varis ferits. Com era d'esperar la reacció de la gent va ser envoltar i colpejar el cotxe, podent-se escapolir a dures penes el seu propietari ${ }^{1389}$.

Com no podia ser d'una altra manera, l'AVV també va assumir reivindicacions polítiques, criticant, per exemple la dura repressió policial durant la jornada de vaga del 12 de novembre de $1976^{1390}$. Les reivindicacions per uns Ajuntaments Democràtics o per l'Amnistia van ser-hi presents. Així com quina havia de ser la postura respecte les eleccions del 15-J. Dins l'AVV del Fondo existia aleshores una postura minoritària que defensava l'abstenció i una majoritària que defensava una participació possibilista sempre que es votés a partits d'esquerra. El que si que tenien clar era sobre el caràcter d'aquestes eleccions:

“Ninguno de los que estábamos allí pudo salir engañado: se dijo bien claro una y otra vez: "esas elecciones, por importantes que sean, no van a ser auténticamente democráticas". Y no lo son porque no se ha concedido la necesaria amnistía total, ni se han legalizado todos los partidos, ni todos los que concurren lo hacen gozan con las mismas oportunidades. Hasta las mismas leyes electorales favorecen a las derechas."1391

Van haver-hi més mobilitzacions en altres barris. Al barri del Riu el 9 de maig

1387Un plànol amb els solars reivindicats es pot veure a Fondo. As. de Vecinos "Barrio del Fondo" de Santa Coloma núm. 3 (novembre-desembre 1976), AHTMB, Donació Marcelo López Ródenas, Caixa 1, p. 8-9. Més informació sobre la Via Cívica es pot trobar al núm. 5 (febrer-març 1977), AHMTB, Donació Mn. Josep Catá, Caixa 6, p. 4-5.

1388 Fondo. As. de Vecinos “Barrio del Fondo" de Santa Coloma núm. 7 (maig 1977), AHTMB, Donació Marcelo López Ródenas, Caixa 1, p. 6-7.

1389Fondo. As. de Vecinos "Barrio del Fondo" de Santa Coloma núm. 8 (juny 1977), AHTMB, Donació Marcelo López Ródenas, Caixa 1, p. 6-7.

1390El Correo Catalán, 20-11-1976.

1391“Las elecciones ya!! 1-La Asociación y las elecciones", Fondo. As. de Vecinos “Barrio del Fondo" de Santa Coloma núm. 8 (juny 1977), AHTMB, Donació Marcelo López Ródenas, Caixa 1, p. 3. 
de 1976 un grup de veïns netejaven un solar per acondicionar-lo com a espai verd. Es va produir una intervenció policial que es va saldar amb la detenció del President de l'AVV del Rio, Ricardo Bonet i dos veïns més, que van haver de comparèixer als jutjats l'onze de juliol ${ }^{1392}$. L'acusació es va estendre al conjunt de l'AVV i a una de les persones detingudes, una dona, se la volia posar sota jurisdicció militar. Aquest fet va desencadenar una onada de protestes que va culminar amb una manifestació de quatre-cents veïns el 8 de juliol, que també va ser violentament reprimida i on es detingueren a 7 persones que van ser alliberades al dia següent ${ }^{1393}$. El judici a l'Associació s'havia de fer el 9 de juliol però va ser ajornat al 24 de setembre i després de nou al 12 de novembre ${ }^{1394}$, justament el dia de la vaga general.

Aquesta associació va fer també una tasca important reivindicant el patrimoni històric, en especial per la restauració i conservació de la Torre Balldovina. Però sens dubte, la seva principal lluita i reivindicació va ser la urbanització del passeig de la Salzareda. Després d'uns anys de reivindicacions la paciència del veïnat va acabar per esgotar-se i la setmana del del 18 al 24 de juny, just passades les eleccions, començaven unes mobilitzacions veïnals amb talls de trànsit periòdics a l'alçada dels carrers Francesc Moragues i aleshores Garcia Morato per reivindicar l'asfaltat i urbanització d'una vegada per totes de l'esmentat carrer $^{1395}$.

L'AVV del Centre havia entregat un escrit a l'Ajuntament el 19 de maig de 1976 amb les principals reivindicacions del barri ${ }^{1396}$. Aquesta associació havia participat conjuntament amb altres AVV's colomenques en altres mobilitzacions. Mentrestant, encara hi havia altres associacions que no havien estat legalitzades

1392 "Procesados varios vecinos de Santa Coloma de Gramenet", Tele/ eXprés, 14-6-1976. Veure també el full volant editat per l'AVV del Rio "La Asociación Procesada", AHMTB, Donació Mn. Josep Catà, Caixa 2. També La Gaceta del Rio. Asociación de Vecinos "Barrio del Rio" núm. 5 (juny 1976), AHMTB, Donació Marcelo López Ródenas, Caixa , p. 2-3 i núm. 6 (juliol-agost 1976), AHMTB, Donació Mn. Josep Catà, Caixa 9, p. 2-3,

1393Les persones detingudes van ser: Josep Maria Martí, Alfonso Gómez, Pepe Sánchez, Jaume P. Sayrach, Montserrat Cascante, José Maria Ballesteros i Hernán Freire. Veure "Graves incidentes en Santa Coloma de Gramenet" i "El libertad los siete detenidos el jueves en Santa Coloma de Gramenet", Tele/ eXprés, 9 i 10-7-1976.

1394“No se celebró el juicio del Río", Tele/ eXprés, 27-9-1976.

1395 “Cuarto día de barricadas" i “"Al a guerra” por un paseo", Tele/ eXprés, 22 i 25-6-1977.

1396“El barrio del Centro denuncia sus deficiencias", Tele/ eXprés, 21-5-1976. 
(Can Mariner, Italians i Cementiri Vell) ${ }^{1397}$. Una altra lluita important va ser la protagonitzada pels veïns el mes de març per aconseguir uns semàfors a la cruïlla dels carrers Camí del Fondo i Jacinto Verdaguer (on hi havia una escola on s'havien produït ja alguns accidents), que van arribar gairebé a paralitzar la ciutat amb els talls de trànsit ${ }^{1398}$.

Tal com he dit en el cas de Badalona, és impossible fer constar aquí la totalitat de lluites i mobilitzacions. No obstant, van haver-hi algunes que van ser comunes a les diferents AVV's i barris. La reivindicació de Can Zam com espai públic n'és un clar exemple. Un altre cas molt evident va ser tota la lluita contra el Pla Comarcal (al febrer de 1976 s'havia fet una revisió del Pla de 1974, que ja havia tingut una forta oposició), que es va estendre a tots els barris i va provocar tota una onada d'impugnacions que van ajudar després a l'elaboració del Pla Popular al 1978. No era per menys ja que aquest Pla, tot i no ser tant agressiu com el de 1974 i preservava espais com el Motocross i Les Vinyes, encara contemplava la urbanització amb habitatges i indústries d'una part de Can Zam, la conversió del Passeig de la Salzareda en una autovia i la divisió de Santa Coloma per l'autopista que passaria per l'Avinguda Pallaresa (la que després es coneixerà per B-20 i que d'entrada no havia de ser soterrada) ${ }^{1399}$. També van ser importants les mobilitzacions que es van fer a partir de 22 d'abril de 1977 contra l'anomenat "decret del santoral" fet pel govern, que preveia només admetre noms de sants per les AVV's i que no es poguessin identificar amb la totalitat d'un barri ${ }^{1400}$.

Però com a tant altres ciutats, la lluita per l'ensenyament públic i les escoles va ser un element comú a tots els barris de Santa Coloma. El 16 de febrer de 1976 unes 5.000 persones es van manifestar en demanda d'escoles i d'un ensenyament gratuït, coincidint, precisament, amb una vaga de mestres que es feia a les escoles estatals i privades ${ }^{1401}$. Es van entregar les reivindicacions per escrit a l'Ajuntament

1397 “Tres Asociaciones de Vecinos pendientes de legalización, en Santa Coloma de Gramenet”, Tele/ eXprés, 15-2-1977.

1398Grama núm. 87 (abril 1976), p. 8.

1399Ma José Olivé: “El nuevo Plan Comarcal: olvidadas las alegaciones populares", Grama núm. 88 (març 1976), p. 21-23.

1400Veure Federació d'Associacions de Veïns de Barcelona (FAVB): "Per la llibertat d'Associació. Defensem la unitat de les A.A. de V.V.", [1977], ANC, Fons PSUC. 2353. Barcelona: Federació d'Associacions de Veïns de Barcelona (FAVB). 1973-1980.

1401“Mañana vuelven a clase los maestros privados”EL Correo Catalán, 15-2-1976. 
colomenc.. Al mes de març es va fer una nova manifestació que va arrencar la promesa de Blas Muñoz de que per al proper curs hi haurien places escolars suficients, a més de la creació de dues escoles bressol municipals i un centre de formació professional ${ }^{1402}$. Però malgrat les promeses per al curs 1976/77s'estimava que hi haurien 10.000 nens sense plaça escolar o escolaritzats precàriament, sense unes condicions mínimes ${ }^{1403}$.

Dintre d'aquest àmbit hi havia un sector encara més vulnerable. El dels nens amb disminucions psíquiques. ASPANIDE havia engegat una campanya per fer visible la seva problemàtica. El dissabte 24 d'abril havien recollit 10.000 signatures i el 25 feien una manifestació amb més de 500 persones. L'associació xifrava el nombre de pares de nens amb aquesta minusvalidesa en un 2.000 i l'escola que gestionaven només podia atendre a uns $80^{1404}$. El 3 de juny un Ple de l'Ajuntament cedia uns terrenys a Can Calvet per la construcció d'una escola especial per ASPANIDE $^{1405}$.

Als mesos de maig i de juny, com a tants altres llocs es van organitzar "setmanes per l'ensenyament" per les AVV's de Fondo, Singuerlín, Centro i Can Mariné i les AMPES on en general es promovien les següents reivindicacions: la no pujada de quotes, l'escolarització realment gratuïta (llibres inclosos), llocs suficients i gratuïts de formació professional, construcció d'escoles bressol i parvularis, manteniment de les escoles estatals i la supressió de les permanències ${ }^{1406}$. D'aquesta manera el mes de setembre es presentava força conflictiu i van proliferar les protestes com la de donar classes en solars reivindicats com escoles davant la manca d'aquestes o les irregularitats dels centres privats. Un exemple d'això ens ho donava una de les nostres entrevistades:

"Si... no però, per exemple, tant com això hi ha una lluita molt bonica amb

l'ensenyament (...) l'escola de Les Vinyes (...), que això va ser també una experiència

1402 Marcelo López Ródenas: Historia social de la Santa Coloma moderna..., p. 197.

1403 Ídem, p. 197 i Maria José Olivé: “10.000 niños sin escuela. El déficit se salvará por los pelos”, Grama núm. 92 (setembre 1976), p. 15-16.

1404 Marcelo López Ródenas: Historia social de la Santa Coloma moderna..., p. 197. i Tele/ eXprés, 264-1976. Per més informació es pot consultar la revista de la pròpia associació: Aspanide de juliol de 1976, que incloia un ampli reportatge de les mobilitzacions d'abril. AHMTB, Donació Marcelo López Ródenas, Caixa 1.

1405 "El Ayuntamiento de Santa Coloma cede terrenos para un centro de educación especial”, Tele/ eXprés, 4-6-1976.

1406Marcelo López Ródenas: Historia social de la Santa Coloma moderna..., p. 197. Tele/ Exprés, 215-1976. 
única. Que va ser quan van muntar, nosaltres nos tomamos la escuela. Nosaltres teníem un problema a dalt, una escola que hi havia al carrer Aragó, que era una escola privada que els pares estaven molt enfadats, pagaven molt i era una mala escola... Van començar a reivindicar l'escola a Les Vinyes (...) i amb aquests van fer una acampada a Les Vinyes i davant d'ells van fer una letrina. Doncs cada dia baixaven i jo vaig buscar uns quants mestres que no tenien escola encara... Baixaven els nens (...) d'aquesta acadèmia amb les cadires i fèiem classe allà a Les Vinyes. Els pares van fer una letrina, com les velles letrines, per que els nens poguessin... Era molt divertit per que a mig matí baixaven les mares amb els termos a donar d'esmorzar als profes i als nens. Però clar, estàvem allà (...) I vam estar un temps. I quan es va acabar de construir [l'escola de...] Les Vinyes... ja estava construïda però no la volien inaugurar per que havia de venir no se qui i no sé quantos... I un dia vam dir (...) Nos tomamos la escuela i la vam gestionar nosaltres... (...) I quan van venir a inaugurar l'escola nosaltres ja estàvem a dintre... Amb el Blas Muñoz (....)"1407

Al setembre, com era d'esperar, hi va haver noves mobilitzacions. A mitjans de mes una manifestació de 3.000 persones va arrencar el compromís de que es construïssin el més aviat possible 96 barracots en solars com Can Peixauet, les Vinyes, la Bastida i d'altres. Aquest fet va produir la denúncia d'un propietari d'un solar al carrer Beethoven contra l'Ajuntament per haver instal-lat els barracots sense el seu permís ${ }^{1408}$. Important va ser també l'entrada en funcionament del Casal de Cultura en uns antics locals parroquials del barri de Santa Rosa, on per exemple es va fer una primera escola d'adults ${ }^{1409}$. Al novembre van haver-hi ocupacions de solars i enfrontaments amb la policia al barri de Santa Rosa i la notícia de que l'Ajuntament va comprar finalment uns terrenys a les zones de "La Bastida” i “Les Vinyes” per la construcció de les tant necessitades escoles ${ }^{1410}$.

Al febrer de 19776.000 colomencs es manifestaven exigint un institut i l'obertura de l'escola de formació professional ${ }^{1411}$. Al març la corresponsal de El Correo Catalán i Grama Agustina Rico va ser processada per les denúncies del

1407Entrevista a Gabriela Serra Freidiani, 10-7-2013.

1408 M. Castellón: "Santa Coloma de Gramanet: el exceso de celo pone en aprietos al Alcalde", La Vanguardia Española, 16-10-1976. Finalment els terrenys van ser expropiats per l'Ajuntament al gener de 1977, veure Eugenio Madueño: "Los que denunciaron a Blas Muñoz, serán expropiados forzosamente", Tele/ eXprés, 21-1-1977.

1409Marcelo López Ródenas: Historia social de la Santa Coloma moderna..., p. 197.

1410 "Santa Coloma de Gramenet: Más de 26 hectáreas para equipamientos escolares", La Vanguardia Española, 25-11-1976.

1411Marcelo López Ródenas: Historia social de la Santa Coloma moderna..., p. 198. 
director de l'acadèmia Jacint Verdaguer, un conegut ultradretà que ja havia tingut enfrontaments amb els pares dels seus alumnes ${ }^{1412}$. Les agressions contra persones que protestaven per falta d'escoles encara podien anar a més:

“Un dels membres de l'Associació de Pares d'Alumnes del Centre pre-escolar Santa Rosa ha estat objecte d'una agressió per part de quatre desconeguts que van colpejarli el cap i diferents parts del cos mentre li deien que es deixés de manifestacions i que no es fiqués en embolics." ${ }^{1413}$

No obstant, les deficiències van trigar molts anys en solucionar-se com demostra el fet que la situació escolar al curs 1977-78 encara estava de la següent manera:

\section{L'ESCOLARITZACIÓ A SANTA COLOMA DE GRAMENET}

\begin{tabular}{lllll}
\hline & Anys & Població escolar & Escolaritzats & Sense Plaça \\
\hline Llar d'infants & $(0 / 1)$ & 7.967 & -- & 7.967 \\
Escola bressol & $(2 / 3)$ & 7.638 & 420 & 7.218 \\
Pre-escolar & $(4 / 5)$ & 7.082 & 3.698 & 3.348 \\
EGB & $(6 / 13)$ & 23.100 & 22.959 & 141 \\
Institut, F.P. & $(14 / 17)$ & 8.495 & 1.400 & 7.095 \\
\hline
\end{tabular}

Font: Marcelo López Ródenas: Historia social de la Santa Coloma moderna, p. 198. (traduït del castellà)

Les lluites per l'educació i les escoles, per tant, van continuar amb una important implicació veïnal.

Alhora a Santa Coloma ja al 1976 s'havia constituït una assemblea d'aturats davant els cada cop més evidents símptomes de la crisi i augment de l'atur ${ }^{1414}$. I aviat també es va constituir l'Assemblea Democràtica de la ciutat (fet que va provocar un debat dins les CCBB per l'alternativa a oferir a aquesta). El dia 28 aquesta havia convocat a una manifestació que es va fer sense permís tot i que va ser tolerada (malgrat moments de tensió amb la Policia que la vigilava estretament). Van participar unes 3.000 persones que van marxar cap a la Plaça de la Vila exigint canvis democràtics, l'amnistia i solidaritat amb els obrers de

1412 "Auto de procesamiento contra una corresponsal de prensa", Tele/ eXprés, 3-3-1977. El director de l'Academia Verdaguer es deia Jesús Velázquez Álvarez.

1413Aurora Agustí: "Ensenyament: protestes a dojo", Avui 31-1-1977. L'article parlava de l'existència de nombroses protestes en aquell moment a Santa Coloma i en concret de la de dues escoles bressol i una de pre-escolar, aquest situat al barri de Santa Rosa (on es va produir l'agressió). Un altre article publicat a Tele/ eXprés el 9-4-1977 tractava sobre les mancances i deficiències de les escoles bressol a Santa Coloma.

1414 “Reunión de parados en Santa Coloma”, Tele/ eXprés, 29-3-1976 i “Exigir puestos de trabajo”, El Correo Catalán, 8-4-1976. 
Gasteiz $^{1415}$. No sempre va existir la mateixa "tolerància" i per exemple, ja amb el govern Suárez, el govern civil va prohibir un acte d'aquesta el 6 de novembre de 1976. Les detencions i repressió policial van ser una constant encara en aquest període $^{1416}$. A començaments de l'any 1977 es va fer una manifestació de 500 persones en contra dels assassinats d'Atocha ${ }^{1417}$. Al llarg d'aquest any l'Assemblea Democràtica va anar caient progressivament en la paràlisi a mesura que s'acostaven les eleccions i es desfermava la lluita partidista per aconseguir el màxim de quotes de poder possible. Un altre fet que també va ser relativament important va ser els actes que es van fer relacionats amb Congrés de Cultura Catalana durant els anys 1976-1977, que com veurem, causarà tensions dintre del mateix consistori.

En efecte, la situació de l'Ajuntament colomenc distava molt de ser una bassa d'oli. Les "eleccions municipals" de 1976, tot i la victòria de Blas Muñoz, havien posat de manifest que hi havia un sector que no li donava un suport incondicional. Els mateixos sis regidors que s'havien oposat a ell al famós ple de Can Zam, van proposar que el consistori colomenc s'adherís a una petició d'Amnistia ${ }^{1418}$. De fet, poc després es va crear una Comissió Pro-Amnistia i malgrat es va expulsar a una regidora de la Secció Femenina que havia signat un manifest en aquest sentit, l'Ajuntament, un cop passades les "eleccions" es va adherir oficialment a la petició d'amnistia al Ple del 20 de febrer de $1976^{1419}$. Però aquest fet no podia amagar les

1415“Tres mil personas participan en una manifestación no autorizada”, Diario de Barcelona, 30-31976 i Grama núm. 87 (abril 1976), p. 7.

1416Apart dels casos ja esmentats, cal recordar la detenció d'una jove el 7-2-1976 a fer una pintada (El Correo Catalán 11-2-1976); la suspensió d'unes jornades sobre les forces polítiques de Catalunya que s'havia de fer el 4-3-1976 organitzada per l'Escola Social de Santa Coloma de Gramenet; les Amenaces de l'ultradreta contra personalitats d'esquerres de Gramenet (Mundo Diario 11-3-1976); La repressió policial durant la vaga comarcal del metall (març-abril de 1976); la prohibició d'un acte de presentació del PSUC a Can Sisteré que al final es va fer a l'aire lliure el 11-7-1976 amb la presència de 2.500 persones (Tele/ eXprés, 12-7-1976); la supressió el 5-10-197 la presentació de les CCOO del Barcelonès Nord per negativa governamental (Tele/ eXprés, 6-10-1976); la detenció de 7 persones durant la Vaga General del 12 de novembre (Avui, 13-11-1976); la detenció de dos joves del MC quan encartellaven propaganda a favor de l'abstenció del Referèndum per la Reforma Política (Tele/ eXprés 10-121976); el 26 i 27 de febrer són detingudes 4 persones per la Guàrdia Civil quan participaven en actes per l'Aministia impulsats per les AVV's (Tele/ eXprés, 28-2-1977); el 2-3-1977 es detenen dos militants del PTE acusats de robatori (Mundo Diario, 5-3-1977); el 10-4-1977 un taxista és detingut i agredit per la policia municipal de Santa Coloma. (Tele/ eXprés, 12-4-1977) i la repressió dels actes del 1 de maig.

1417Josep Tordera: “Piden banderas a media asta”, Mundo Diario, 27-1-1977.

1418 "Seis concejales de Santa Coloma solicitan un pleno extraordinario", Tele/ eXprés, 10-1-1976.

1419“El Ayuntamiento de Santa Coloma se adhiere a la petición de amnistía”, Tele/ eXprés, 23-2- 
profundes tensions internes que existien entre els mateixos regidors. Al Ple del dia 26 de febrer ja es van donar diversos incidents i intercanvis d'acusacions mentre una delegació d'una concentració veïnal i de pares entrava a l'Ajuntament per fer entrega de les seves demandes ${ }^{1420}$. Les interrupcions i presències dels veïns als Plens van esdevenir un fet habitual, reflectint la gran mobilització existent aleshores, però va ser un fet també va fer créixer els enfrontaments entre els regidors. Blas Muñoz, conscient dels nous temps que corrien va intentar mantenir un tarannà més dialogant que Juan Porta. Del 3 al 6 de setembre per exemple va consentir una major implicació veïnal en l'organització de les festes majors de la ciutat $^{1421}$. No obstant, aquesta política no era del gust de tothom i dies després van dimitir dos coneguts tinents d'alcalde immobilistes de l'Ajuntament ${ }^{1422}$. Aquest fet va permetre alhora una remodelació de govern on Blas Muñoz va donar més pes als regidors crítics.

A finals d'Octubre s'inaugurava la "Casa d'Andalucia". Aquest fet va revifar un intens debat públic. Diverses persones sospitaven -amb raó- de les maniobres de persones properes a AP per instrumentalitzar el vot d'origen immigrant recuperant part dels discursos lerrouxistes en la seva vessant centralista (cal tenir en compte que Santa Coloma de Gramanet era una de les ciutats que tenia més població provinent d'Andalusia de tot Catalunya). Veient quin eren els fundadors de la Casa d'Andalusia i quines van ser les seves primeres actuacions, algunes alarmes van començar a saltar entre els sectors d'esquerres de la ciutat ${ }^{1423}$.

Al mes de desembre, mentre es donava un conflicte laboral a l'empresa TUSA

1976.

1420 "Santa Coloma de Gramanet: El último pleno municipal, un espectáculo bochornoso", La Vanguardia Española, 28-2-1976 i "Enfrentamiento verbal entre alcalde y concejal en Santa Coloma”, Tele/ eXprés, 1-3-1976. Un dels incidents va estar protagonitzat per regidor José Matés, un "joseantoniano" molt crític amb la gestió de Blas Muñoz i que ja s'havia significat anteriorment per exemple donant suport a les reivindicacions veïnals sobre Can Zam.

1421 “La Festa Major, massivament popular”, Diario de Barcelona, 12-9-1976. Veure també Jaume P. Sayrach: “Pitos y palmas a la “Festa Major"”, Grama núm. 93 (octubre 1976), p. 18-21.

1422Es tractava de Juan Perez Terol (Tinent d'Alcalde d'Urbanisme) i Juan Aloy Pina (Tinent d'Alcalde d'Ensenyament). Veure "Dimiten de sus cargos dos tenientes de alcalde de Santa Coloma", Tele/ eXprés, 13-9-1976.

1423El seu President era López del Moral, que també era regidor a l'Ajuntament de Santa Coloma. La presència de Juan de Dios Ramírez Heredia (colaborador aleshores de TVE) i altres persones properes a "Reforma Democrática", juntament amb el discurs que es va fer, va donar molt per pensar. Veure Josep Tordera: "Ramirez Heredia: "Andalucía es lo que debe importarnos", Mundo Diario, 26-10-1976. Veure també E. Madueño: "La Casa de Andalucía dice no ser política", Grama núm. 94 (novembre 1976), p. 6. 
que regentava la majoria d'autobusos del Barcelonès Nord, es constituïa el Secretariat Local colomenc del Congrés de Cultura Catalana ${ }^{1424}$. Al gener el regidor Rosset va proposar l'adhesió de l'Ajuntament a aquest, però l'oposició del regidor "ultra" Callejón, contrari a que es fes servir el terme "nació catalana", ho va aturar temporalment i com a conseqüència el Secretariat local del CCC va demanar la dimissió del consistori ${ }^{1425}$. Paral-lelament, mentre s'estava revifant el debat sobre el paper de les Cases Regionals ${ }^{1426}$, el membre del Partido Socialista Andaluz, José Acosta Sánchez, publicava un article a La Vanguardia Española criticant unes manifestacions aparegudes al llibre de Jordi Pujol La immigració, problema i esperança de Catalunya ${ }^{1427}$. Certament en aquest recopilatori de vells escrits hi havia algunes expressions desafortunades, però aquestes van ser magnificades i tretes de context per atiar un discurs que dividia a la classe treballadora catalana en funció del seu origen. El que ens interessa aquí es veure com l'Ajuntament Colomenc, a proposta del regidor Matés, va aprovar una reprovació a l'obra de Pujol en un Ple del 22 de febrer de 1977 que va generar una forta polèmica amb les entitats de la ciutat ${ }^{1428}$. Partits com el PSUC, i nombroses AVV's havien fet un discurs integrador i antilerrouxista per evitar la divisió de les classes treballadores i populars per motius d'origen, així que la contestació no es va fer esperar ${ }^{1429}$. Fins i 1424“Intensa activitat del Congrés en Santa Coloma de Gramenet”, Tele/ eXprés, 17-12-1976. 1425 “Dimisión del Consistorio", Mundo Diario, 16-2-1977.

1426Amb l'aparició, per exemple d'un article de Jordi Borja “Casas regionales y política cultural en Cataluña" a Tele/ eXprés, 1-2-1977, i també del President de la Casa de Andalusia,: Article de Juan de Dios Ramírez Heredia: “Por quien votaremos los immigrantes? a La Vanguardia Española, 10-2-1977.

1427José Acosta Sánchez: "En torno al problema de la emigración en Cataluña”, La Vanguardia Española, 22-2-1977; Jordi Pujol va contestar amb l'article "La immigración, problema y esperanza de Catalunya" a La Vanguardia Española, 1-3-1977; Les tesis de Acosta van ser exposades al diari del PSA, Tierras del Sur núms. 33 (27-12-1976), 37 (24-1-1977), 42 (28-21977), 43 (7-3-1977), 46 (28-3-1977), 49 (18-4-1977), 55 (30-5-1977) i 56 (6-6-1977), significativament a la pàgina anomenada Novena Província. El curiós del cas és que posteriorment José Acosta es va integrar a la candidatura del Pacte Democràtic encapçalada pel mateix Jordi Pujol. Altres polítics que van intervindre en aquest debat van ser Josep Benet i Joan Raventós amb articles publicats també a La Vanguardia Española com "Doctrina catalana sobre el tema” (15-4-1977) i “¿Integración? ¿Lerrouxismo?: socialismo” (8/9-4-1977). No puc entrar a fons ara a recollir més articles publicats sobre aquesta qüestió que si vaig desenvolupar una mica més a la meva Tesina de Doctorat: El moviment veïnal a Llefià (Badalona), p. 27-29.

1428“Concejal con pasado azul logra un voto de censura contra Jordi Pujol”, Tele/ eXprés 26-2-1977. Paral-lelament quedava en l'aire la subvenció de l'Ajuntament al CCC davant les protestes de "grups d'andalusos" que demanaven també una subvenció per la seva cultura si s'aprovava aquesta.

1429En aquest sentit és interessant veure el discurs anti-lerrouxista de la premsa veïnal. Començant pel mateix Grama, en especial el seu número 77(març 1977), amb una eloqüent 
tot el propi José Acosta es va veure interpel·lat pels representats de les AVV's quan van acudir a una conferència seva feta el mes de març a la Casa d'Andalusia ${ }^{1430}$. Gairebé al mateix temps un article del diari Avui recollia l'opinió de diversos líders veïnals com Jaume P. Sayrach (sacerdot al Fondo), Salvador Cabré (sacerdot al Singuerlín), Consol Sánchez (de la Vocalia cultural de l'AVV de Santa Rosa) i Alfonso Barreras (President aleshores de l'AVV del Fondo) ${ }^{1431}$. Per si això no fos prou, el dia 13 de març les parròquies de Santa Coloma repartien un escrit amb el significatiu títol de "Un sol poble" criticant la campanya neo-lerrouxista, mentre al mateix moment es feia un acte de suport a l'Estatut al barri de la Guinardera ${ }^{1432}$. Per la seva banda el PSC (Congrés) de Gramenet també iniciava una campanya antilerrouxista ${ }^{1433}$.

La polèmica va continuar quan des de la Casa d'Andalusia es va vetar la presència de Fernando Soto, membre del Partit Comunista d'Andalusia, per fer una conferència al mateix centre el mes de març, posant-se en evidència quin era el seu tarannà ideològic ${ }^{1434}$. Per intentar millorar la seva imatge la Casa d'Andalusia va adherir-se finalment al CCC $^{1435}$. Tots aquests fets es van desenvolupar en un ambient cada cop més condicionat per la proximitat de les eleccions del 15 de juny.

Passades aquestes, uns barris que van continuar sent molt reivindicatius van ser els d'Arrabal, Safaretjos i Santa Rosa, amb les seves respectives AVV's. L'Associació d'aquest darrer barri ja havia denunciat al setembre de 1977 la il·legalitat de les obres del Carrer Circumval·lació núm. 107 de l'empresa

portada on es veia una maleta en una via de tren i que de deia textualment "Catalanes y andaluces. Quieren que nos peleemos" i l'article "Catalunya y los inmigrantes" (p. 26-27). Altres exemples similars a Comarca Exprés núm. 8 (2ona quinzena de març de 1977) amb una portada amb el títol "Andaluces i Catalanes. No nos dividirán" i una foto d'una manifestació; i tornant a Santa Coloma a Fondo. Asociacion de Vecinos "Barrio del Fondo" (abril 1977), AHMTB, Donació Mn. Josep Catà, Caixa 6, p. 5, a un article titulat "Andaluces y catalanes: quieren dividirnos!!".

1430 “Conferencia de Acosta Sánchez (PSA) sobre el problema de los inmigrados”, Tele/ eXprés, 7-31977.

1431 “Opinió que mereixen els fets i l'ajuntament”, Avui, 8-3-1977.

1432 "La única división es la que se da entre explotadores y explotados", Tele/ Exprés 15-3-1977 i "Santa Coloma: campaña pro-Estatut", Mundo Diario, 15-3-1977.

1433 "Campaña "antilerrouxista" del PSC (C) en Santa Coloma de Gramanet", La Vanguardia Española, 15-3-1977.

1434 “Andalucismo", Tele/ eXprés, 25-3-1977.

1435 "La Casa de Andalucía de Santa Coloma de Gramanet se adhiere al "Congrés de Cultura Catalana”, La Vanguardia Española, 28-4-1977 i "La Casa de Andalucía se adhiere al Congrés", Tele/ eXprés, 31-5-1977. 
Construccions Hispano ${ }^{1436}$. Però sens dubte la lluita que va destacar aleshores va ser la que va emprendre aquesta AVV contra la proliferació de bars on s'exercia la prostitució o que eren molestos, campanya que va començar a l'octubre de 1977 contra el bar "Mini" i que es va perllongar al llarg de tot el 1978 afegint-se la crítica a d'altres locals similars ${ }^{1437}$. Una altra lluita va ser la que va encapçalar sobretot l'AVV del Raval (amb suport també de les AVV's dels veïns barris de Safaretjos i Santa Rosa) per aconseguir un ambulatori pel barri. Ja al 21 de febrer s'havia fet una assemblea al local de l'AVV de Safaretjos conjuntament amb la del Raval. Però va ser el dia 11 de febrer quan un grup de 50 veïns van començar un tancament en uns baixos que reclamaven que es fessin servir com ambulatori ${ }^{1438}$. El 5 de març veïns del Raval feien una manifestació que acabà amb un grup encadenant-se a les portes de l'Ajuntament. La resposta fou una violenta intervenció policial que va acabar amb dos detencions, un ferit de consideració i diversos contusionats ${ }^{1439}$.

"La Asociación de Vecinos Arrabal-Lavaderos denuncia la actitud del Ayuntamiento de no escuchar la reivindicación constante de AMBULATORIO PARA ARRABAL; y además mandar a la Fuerza Pública que ha actuado violentamente contra los vecinos encadenados en la Plaza de la Vila, golpeando al vice-presidente de la Asociación de Vecinos (Miguel Molina), hiriendo a un compañero con bola de goma, deteniendo a dos vecinos (posteriormente puestos en libertad) y obligando al resto de los vecinos a desalojar la Plaza, cuando -pacíficamente- pedían que fueran escuchadas sus peticiones $(. . .)^{\prime 1440}$

La lluita veïnal va continuar amb talls de trànsit diàries des del dia 10 $\mathrm{d}^{\prime}$ abril $^{1441}$. Poc després el mateix president José Maria Ballesteros feia unes declaracions criticant la possibilitat de que es construís un centre penitenciari a

1436“De como una rampa permite aumentar la edificación", Tele/ eXprés, 27-9-1977 i també AVV de Santa Rosa: "Vecinos C/ Circumvalación. Estafa sin precedentes. Todos contra Construcciones Hispano" [butlletí especial sobre aquesta lluita], AHMTB, Donació Marcelo López Ródenas, Caixa 1.

1437 Josep Tordera: “Contra los bares de camareras", Mundo Diario, 12-10-1977 i "En Santa Coloma no gustan los bares de "alterne", Tele/ eXprés, 14-10-1977.

1438 "Noche de encierros en Santa Coloma de Gramenet", Tele/ eXprés, 13-2-1978.

1439 “Arrabal: Encadenados por el ambulatorio", Tele/ eXprés, 6-3-1978 i Josep Tordera: "La Policía cargó contra los vecinos de Arrabal", Mundo Diario, 7-3-1978. Veure també Josep Tordera: "A los del Arrabal los dejaron moraos", Grama núm. 111 (abril 1978), p. 32-33.

1440Asociación de Vecinos Arrabal-Lavaderos: [Comunicat en full volant] (5-3-1978), AHMTB, Donació Mn. Catà, Caixa 2.

1441Josep Tordera: “Cortan el tráfico todo el día”, Mundo Diario, 15-4-1978. 
Santa Coloma mentre hi existien tants dèficits en equipaments i servis ${ }^{1442}$. També a l'abril l'AVV del Raval aconseguia la paralització d'unes obres irregulars ${ }^{1443}$. El 30 de juny es va produir un judici contra la mateixa Associació per l'ocupació d'un solar que van acondicionar com a parc als carrers Àngel Guimerà i Monturiol ${ }^{1444}$. Ara bé, si cal destacar un fet sobre els altres aquest seria la presentació del Pla Popular fet el 4 de novembre als locals del Casal de Cultura i de l'AVV de Santa Rosa ${ }^{1445}$, del qual en parlaré després.

Al Barri del Riu des de juny de 1977 els veïns reclamaven amb talls de trànsit la urbanització del que serà molts anys després el Passeig de la Salzareda. Al setembre encara es continuaven fent, mentre que aquest mateix mes els veïns del barri es van mobilitzar també per la instal·lació de semàfors a l'Avinguda Baró, lloc on s'havien donat varis accidents. Finalment a octubre l'Ajuntament s'hi va comprometre a fer-ho ${ }^{1446}$. A finals de mes també es va comprometre a l'asfaltat del Passeig de la Salzareda. La mobilització va decaure però davant la passivitat de les autoritats l'AVV va organitzar a l'abril de 1978 una "olimpíada popular" on es va tornar a reivindicar el passeig, però la urbanització completa, no es va fer fins els anys vuitanta ${ }^{1447}$. Una altra lluita va ser la que van sostenir els veïns contra un pub musical, el OVNI 3, per les contínues molèsties que ocasionava. L'esmentat local era propietat d'un conegut regidor "ultra", Castejón. Aquesta lluita contra locals molestos no va ser exclusiva només d'aquest barri. Els veïns van tancar-se fins i tot a l'Ajuntament el 7 d'octubre de 1978 d'on van ser violentament desnonats per la policia que va causar vuit ferits. Finalment la pressió veïnal va aconseguir el seu tancament ${ }^{1448}$.

1442 Josep Tordera: "Nadie quiere la cárcel”, Mundo Diario, 22-3-1978.

1443Tele/ eXprés, 6-4-1978. Veure també Angeles Gallardo: “Arrabal. Manzanas con gusano”, Grama núm. 112, p. 9.

1444 “Guarderías para compensar”, Tele/ eXprés, 29-6-1978.

1445 David Marín: "Salvar la ciudad costará diez mil millones", Mundo Diario , 5-11-1978, Antonio Cerrillo: "Santa Coloma salvada con diez mil millones", Tele/ eXprés, 6-11-1978 i, sobretot, "Hacia una ciudad donde poder vivir", Grama núm. 117 (11-1978), p. 27-55 [es tracta d'un resum del Pla Popular].

1446Josep Tordera: "Los vecinos cortan de nuevo el tráfico" i "Dos millones para semáforos", Mundo Diario, 28-9-1977, 11-10-1977 i Tele/ eXprés, 11-10-1977.

1447Josep Tordera: “Olimpiada popular", Mundo Diario, 3-3-1978.

1448 "CNT se manifestó contra Ovni 3", "Ovni 3 carece de permiso de apertura”, "Golpes y carreras por Ovni 3", "Santa Coloma escribe al Rey" i "Sala de fiestas clausurada”, Tele/ eXprés, 8-9-1978, 4, 9, 13 i 19-10-1978. Veure també Antonio Cerrillo: "Nadie quiere ver a OVNI", Grama núm. 116 (9-1978), p. 6-9 i Antonio Cerrillo: "Los locales molestos bajaron la persiana" i José Tordera: “Callejón se ha ido de Santa Coloma”, Grama núm. 117 (11-1978), p. 13-14. 
Al barri del Fondo les reivindicacions van continuar girant a l'entorn de l'anomenada Via Cívica, i també com a Santa Rosa, contra locals molestos com el Bar Kayuga i per això també van participar al tancament anteriorment esmentat. Un fet molt protestat va ser el desnonament d'una parella d'ancians que regentava un quiosc en un solar propietat de l'empresari Luis Molero Sujar ${ }^{1449}$. El barri del Centre per si mateix sembla que no va tenir tantes mobilitzacions com els altres tot i que per exemple l'11 de febrer de 1978 una seixantena de joves es tancaven als locals parroquials de l'entitat Foc Nou per exigir la majoria d'edat als 18 anys ${ }^{1450}$.

Al barri Llatí l'AVV va mantenir diverses lluites per conservar solars per parcs i equipaments. Es va ocupar un solar del C/ Nàpols al novembre de 1977 i com a conseqüència d'això el seu president va ser detingut ${ }^{1451}$. Al febrer de 1978 es reprenien les mobilitzacions i del 22 al 25 se succeiran manifestacions diàries amb la participació de 400 persones. Es van ocupar, netejar i acondicionar com a parcs infantils dos solars... i de nou va ser detingut el President de l'AVV, Sandalio Pizarro. Al 4 de març una manifestació de 1.000 veïns recorria el barri per enfilar després cap a la Plaça de la Vila per entregar les signatures recollides amb les seves reclamacions $^{1452}$.

Al barri de Les Oliveres va ser coneguda a l'any 1978 la reivindicació de l'AVV de que l'Ajuntament oferís ajuda a una família gitana d'onze membres que malvivia en un barracot sense les mínimes condicions d'habitabilitat. El mateix barri va celebrar les seves festes escollint una data emblemàtica de les lluites passades: l'onze de novembre, i tornava a mobilitzar-se al març de 1979 contra les molèsties que ocasionaven les aigües sense depurar d'una piscina privada ${ }^{1453}$. A Can Franquesa l'AVV feia conèixer també la precària situació de dues famílies desnonades sense habitatge -un fet que cada vegada serà més freqüent com a conseqüència de la crisi econòmica i l'augment de l'atur ${ }^{1454}$. Al Singuerlín l'AVV

1449“Dos vendedores de pipas, deshauciados", Tele/ eXprés, 14-3-1978.

1450 “Noche de encierros en Santa Coloma de Gramenet", Tele/ eXprés, 13-2-1978 i Grama núm. 110 (3-1978), p. 9.

1451 “Vecino retenido por ocupación de un solar", Tele/ Exprés, 25-11-1977.

1452 "Cada dia a la calle para, tener asfalto y parques", Tele/ eXprés, 2-3-1978 i Paco Torres: "El barrio italiano, cada dia en la calle", Grama núm. 111 (abril 1978), p. 9.

1453 “Once personas viven en una sola habitación", Tele/ eXprés, 8-7-1978 i Ángeles Gallardo: "Los gitanos de Oliveras no encuentran casa", Grama núm. 116 (9-1978), p. 9. Sobre la piscina veure "Manifestación con agua sucia en Santa Coloma", Tele/ eXprés, 28-3-1979.

1454“Dos famílias sin casa recurren a Belloch”, Tele/ eXprés, 27-11-1978. 
s'havia mobilitzat a inicis de 1979 contra la instal·lació d'un centre d'hemodiàlisis en un baixos que no requeria les mínimes condicions ${ }^{1455}$.

Pel que fa al transport públic i coincidint amb un nou conflicte a l'empresa TUSA, els veïns d'Oliveres, Singuerlín i Can Franquesa van segrestar tres autobusos a partir del 5 de març de 1979 per dotar d'aquest servei al barri i els van fer funcionar de manera autònoma ${ }^{1456}$. Cal esmentar també la lluita dels afectats per l'estafa del Patronato Municipal de la Vivienda als habitatges de Can Calvet, ja que van pagar per uns pisos sobre plànol que mai es van acabar de fer ${ }^{1457}$.

L'existència de la Coordinadora d'AVV's de Santa Coloma va servir per aglutinar i coordinar les lluites que s'estaven fent als diferents barris, malgrat que havien de vèncer moltes dificultats, des de les traves administratives com a la pressió i intimidació policial. Així quan van voler entregar un escrit reivindicatiu amb les demandes més importants van trobar-se com la policia i el Govern Civil els marejaven sense donar-lis resposta, els expulsaven de les seves dependències o s'intimidava telefònicament a l'advocat Francesc Arnau, el despatx del qual portava moltes de les denúncies veïnals ${ }^{1458}$. No obstant, les AVV's van tenir una victòria quan la Corporació Metropolitana va suspendre les llicències de construcció de Can Zam el 14 de setembre de $1977^{1459}$. En canvi un nou boicot que es va intentar promoure contra una nova pujada del bitllet d'autobús no va tenir gaire èxit ${ }^{1460}$.

Com a Badalona, també va haver-hi lluites que van tenir a Santa Coloma un impacte "de ciutat". A nivell laboral -per exemple- la lluita de les treballadores d'Eurostil, que davant l'acomiadament de la patronal es van tancar a l'empresa i la van mantenir funcionant uns mesos fins que al final, mancades de suport i

1455 “Los vecinos logran frenar un centro de hemodiálisis", Tele/ eXprés, 19-2-1979 i Antonio Cerrillo: "Los vecinos no quieren riñones artificiales", Grama núm. 122 (24/31-3-1979), p. 14.

1456 "Secuestro de tres "tusas"” i "Primera semana del transporte autónomo", Tele/ eXprés, 6 i 13-31979 i "La TUSA, de los vecinos", Grama núm. 122 (24/31-3-1979), p. 15.

1457 Ángeles Gallardeo: "Muerto el Patronato se acabó la rabia”, Grama núm. 113-114 (7/8 1978), p. 14-15.

1458Veure [Instància presentada al Govern Civil per AVV's de Badalona i Santa Colooma] (27-121977) i Coordinadora de Asociaciones de Vecinos de Santa Coloma: "A todos los vecinos de Santa Coloma" (1-1978), on es denunciaven aquests fets. AHGCB, Fondo Gobernadores Civiles, Caixa 338. Jefatura Superior de Policía. Años: 1977-1978. Aquests documents estaven adjuntats a un informe policial sobre els fets.

1459 Mario Sasot: "'Can Zam" será del pueblo", Tele/ eXprés, 19-9-1977.

1460 "Falla el boicot al transporte" i "Faltaron rubias en la subida de metro y bus", Tele/ eXprés, 2 i 3 11-1978. Va haver-hi una detenció d'una jove militant de l'OCE-BR. 
finançament, van haver de desistir ${ }^{1461}$. Una altra lluita va ser la del català a l'escola. Els professors de català van deixar de cobrar d'Òmnium Cultural i de seguida va començar una intensa campanya pel català a l'escola amb el suport de les AVV's, conscients de lo necessària que era aquesta assignatura en una ciutat amb una població majoritàriament castellanoparlant ${ }^{1462}$.

De fet, la lluita per les escoles va ser un dels conflictes "de ciutat" que va perdurar en donar-se pràcticament a tots els barris, en tant les mancances encara existien $^{1463}$. Tant de places necessàries com de les condicions materials i pedagògiques. Per tant no es d'estranyar que les mobilitzacions continuessin com per exemple les que es van donar als col-legis Virgen Immaculada, Sagrado Corazón, Lourdes, Fernando de Segarra, Wagner i Juan XXIII que amenaçaven d'anar a la vaga a inicis de 1978 si no es solucionaven les greus deficiències que patien $^{1464}$. La lluita es va estendre també als instituts amb marxes i vagues dels professors del Puig Castellar, mentre que el 17 de febrer de 1978 es va fer una gran manifestació per més escoles i instituts a Santa Coloma de Gramenet ${ }^{1465}$. Però la situació estava lluny de ser resolta:

“Durante el curso 78/79 la situación escolar no mejora, se hace público la existencia de 7.000 niños sin plaza escolar de EGB., a la que se incorpora la incertidumbre y problemática que asola a las guarderias de Santa Rosa, San Miguel y Nazarin. (...). Como es natural, la enseñanza estatal es la más perjudicada. De los 24 centros existentes en la ciudad, sólo 4 presentaban la plantilla de profesores completa (...). La formación profesional sigue sin instalaciones, ello a pesar de las reiteradas promesas hechas desde la administración. Además, 40 nuevas unidades de EGB, prometidas

1461El tancament va iniciar-se el 18 de juny i la fàbrica va mantenir-se funcionant fins el desembre, quan les treballadores finalment van acceptar una indemnització i la prestació d'atur. Entremig també van haver-hi discrepàncies entre les treballadores i algun sindicat com el CSUT,. Veure Mundo Diario, 19-6-1977; Tele/ eXprés, 1, 21-7-1977; Avui, 31-9-1977; Mundo Diario, 18 i 20-10-1977, 16-11-1977 i 28-12-1977. Es pot trobar documentació d'aquest conflicte a AHMTB, Donació Mn. Catà, Caixa 6.

1462 "Perdrem el català?", Avui, 27-10-1977; "Profesores de catalán denuncian al OMNIUM" i "Los emigrantes quieren catalán para sus hijos", Tele/ eXprés, 5 i 30-11-1977 i "Els fills d'obrers, sense català", Mundo Diario, 4-12-1977.

1463En aquest sentit el Casal de Cultura va editar un llibret titulat "La Enseñanza en Santa Coloma” sobre la situació escolar al febrer de 1978 on s'analitzava la situació barri per barri. Veure AHMTB, Donació Marcelo López Ródenas, Caixa 1.

1464 "No hay otoño caliente en muchas escuelas", "Ambiente caldeado por falta de estufas" i "Se avecina un invierno caliente en los colegios", Tele/ eXprés, 7, 10 i 22-12-1977.

1465Veure "Una manifestación como las de antes", Grama núm. 110 (3-1978), p. 21. Es parla e la participació de 6.000 persones a la manifestació del dia 17 . 
tiempo atrás, siguen sin construir." ${ }^{1466}$

Una lluita més va ser la que es va donar contra la possibilitat de que es fes un centre penitenciari a Santa Coloma ${ }^{1467}$, així com la que es va dur des de l'entitat "Grup d'Amics de la Ciutat" per conservar el patrimoni històric que encara no havia estat destruït per les immobiliàries, en especial la Torre Balldovina i la Torre Pallaresa. Aquesta entitat va elaborar tot un catàleg del patrimoni arquitectònic a conservar $^{1468}$. Ja vaig esmentar també les mobilitzacions veïnals contra els locals molestos que finalment van aconseguir el tancament de diversos establiments d'aquests tipus que existien a la ciutat.

Cal destacar en aquest període, sens dubte, l'elaboració del Pla Popular de Santa Coloma de Gramenet ${ }^{1469}$. Sota la direcció de Xavier Valls es van recollir les aportacions populars fetes des de les AVV's sobre les demandes i necessitats de cada barri i es va elaborar un estudi sobre les millores que caldria fer per tota Santa Coloma, amb un nivell de concreció i detall molt alt. Un resum del Pla va ser recollit al número 117 de la revista Grama, que en contrast amb aquell altre famós número de 1972 on apareixia King Kong destruint la ciutat, estava significativament titulat "Hacia una ciudad donde poder vivir"1470. El Pla va ser presentat a l'AVV de Santa Rosa al novembre de $1978^{1471}$, i va ser assumit posteriorment per la majoria de forces polítiques d'esquerres de les ciutats en els seus programes municipals. No obstant, les AVV's, on els partits de l'esquerra radical i altres sectors tenien un major pes, van presentar posteriorment un document anomenat "Plan de Urgències" on ja no hi van estar tant d'acord forces com el PSUC i el PSC-PSOE, sobretot en els terminis d'execució ${ }^{1472}$.

1466 Marcelo López Ródenas: Història social de la Santa Coloma moderna..., p. 198. Veient aquesta situació, no és estrany que les mobilitzacions continuessin, si bé canalitzades a partir d'ara en la Comissió d'Ensenyança formada per diverses persones i entitats i que era la que havia convocat a la manifestació del dia 17.

1467 “Santa Coloma no tendrá la Modelo", Tele/ eXprés, 19-4-1978. Veure també “iSolo nos falta la Modelo!", Grama, núm. 111 (4-1978), p. 4-5.

1468 "Quieren salvar edificios del siglo XVII" i "Tratan de salvar la prehistoria colomense", Tele/ eXprés, 10-6-1978 i 18-7-1978.

1469Xavier Valls i M ${ }^{\underline{a}}$ José Olivè (amb la col-laboració de Jose $M^{\underline{a}}$ Faundez i Alfredo Pastor): "Estudio sobre la situación social y urbana de Santa Coloma de Gramenet y propuestas para un plan de Alternativas.", AHMTB, Donació Marcelo López Ródenas, Caixa 2.

1470Grama núm. 117 (11-1978), p. 27-55.

1471Tele/ eXprés, 6-11-1978.

1472David Marín: “Partidos y asociaciones. Les divide el Plan de Urgencias”, Gramanúm. 119 (1- 
Tots aquests esdeveniments van desbordar encara més l'Ajuntament de Santa Coloma de Gramenet. Però a diferència de Badalona, Blas Muñoz no va fer amenaces serioses de dimitir tot i la seva assistència a la reunió d'octubre de 1977 amb el Governador Civil. No obstant, va haver de fer front a una creixent oposició dels regidors del seu Ajuntament, que van fer maniobres contra ell com la del setembre de $1977^{1473}$, o van dimitir, com el regidor Rosset. Més endavant comentaré la situació que van viure els consistoris fins les primeres eleccions democràtiques.

A Sant Adrià feia temps que el barri de La Mina estava en "peu de guerra" i aquest fet es va intensificar aprofitant el nou context polític. L'AVV de La Mina adreçava una carta a la premsa explicant la dura situació en la qual s'encontrava el polígon i acusant d'això al PMV de Barcelona ${ }^{1474}$. A partir del 17 de gener el veïnat, incentivat per una AVV combativa es negaven a pagar la taxa de recollida d'escombraries per la nul·la eficiència d'aquest servei en el barri ${ }^{1475}$. Poc després la mateixa Associació, juntament amb la del Besòs i càrrecs sindicals van demanar la dimissió de tot el consistori ${ }^{1476}$. Del 5 al 8 d'abril l'AVV va fer una Setmana Cultural en memòria de Manuel Fernàndez Màrquez, l'obrer mort per la policia a la Tèrmica del Besòs el $1973^{1477}$. Finalment, farts de la seva situació, una assemblea veïnal de 300 persones feta a mitjans maig de 1976 decideix fer una mesura de força que ja s'estava fent en altres llocs: no pagar al PMV i retenir les quotes ${ }^{1478}$ :

"Aquí una cosa que també es va organitzar també és el no pagar, la campanya de no pagar: no ens tracten bé, no ens arreglen les coses, no paguem eh? no paguem. Clar, llavors de seguida... si no pagueu us fotran una patada al cul, ho hem de posar en una llibreta per si algun dia passa alguna cosa, nosaltres estem disposats a pagar. Què va

1979), p. 11.

$1473 \mathrm{Al}$ setembre de 1977 un grup de regidors van votar a favor de taxar més les propietats immobiliàries i no pujar la taxa d'escombraries, contrariant la voluntat de Blas Muñoz, un dels més grans propietaris immobiliaris de la ciutat. Veure Tele/ eXprés, 1-9-1977; La Vanguardia, 89-1977 i Mundo Diario, 9-91977.

1474 “El polígono de La Mina, en Sant Adrià, acumula deficiencias", Diario de Barcelona, 21-1-1976. Un exemplar d'aquesta carta es pot consultar a l'Arxiu Històric de La Mina (AHLM), Caixa C1.3. Associació de Veïns anys 70, Carpeta Comunicats de Premsa.

1475González Hergueta: "San Adrián del Besós: Los vecinos de La Mina ya están cansados", La Vanguardia Española, 18-1-1976.

1476González Hergueta: "San Adrián de Besós:Los vecinos piden la dimisión del alcalde y todos los concejales", La Vanguardia Española, 5-2-1976.

1477“San Adrián del Besós: Celebración de la Semana de Cultura en memoria de Manuel Fernández", La Vanguardia Española, 8-4-1976.

1478“En La Mina, deciden retener las cuotas del PMV”, Tele/ eXprés, 20-5-1976. 
passar? Que quan el Patronat anava i perseguia cada més per cobrar la quota que havíem de pagar... aquella pressió mensual feia que la gent ho tingués mínimament present (...) [però] va haver una gran quantitat de gent que va quedar amb el cul a l'aire amb aquesta política que es va acabar girant en contra i això ho va utilitzar també el Patronat per donar a base de facilitar o donar la patadeta a cert tipus de gent (...) la lluita era totalment raonable però el propi poder la girava en contra dels veïns." ${ }^{1479}$

L'Associació també es va mobilitzar al novembre conjuntament amb altres entitats veïnals (Besòs, Sant Adrià Nord, Sant Joan Baptista, Escola Activa de Pares, Escola d'Adults Manuel Fernàndez Màrquez, entre d'altres) contra uns cartells editats per l'Ajuntament en commemoració de la mort de Franco ${ }^{1480}$. Al desembre uns joves del MIJAC van engegar una campanya contra el rodatge de la pel-lícula "Perros Callejeros" que el director José Antonio de La Loma estava rodant a La Mina, ja que consideraven que s'estava estigmatitzant la imatge del barri ${ }^{1481}$. Es van arribar a fer manifestacions com la del dia 11 de desembre amb la participació de 200 veïns ${ }^{1482}$. La pressió va fer que les referències al barri desapareguessin de la pel-lícula ${ }^{1483}$ i que aquesta acabés de rodar-se en altres indrets, com el barri de Pomar badaloní.

Una altra reivindicació que va demostrar la capacitat de lluita del barri va ser la de l'ambulatori. S'havia construït un edifici però aquest no entrava en funcionament. El 28 de febrer de 1977 els veïns de La Mina l'ocupen per reclamar

1479Entrevista a Josep Ma Montferrer i Celades, 20-3-2012. Antic escolapi i mestre al Camp de la Bota i La Mina. Actualment President de l'Arxiu Històric de La Mina.

1480 Tele/ eXprés, 27-11-1976.

1481 Van proliferar els articles a la premsa sobre aquesta qüestió. Per citar uns quants: La Vanguardia Española, 1-12-1976; 8-12-1976; 18-12-1976 (aquest era una carta al director del mateix De la Loma defensant-se de les acusacions que se li feien); 23-12-1976 (nota del MIJAC denunciant els motius pels quals s'oposaven al rodatge) i 29-12-1976 (nota similar de la USO). Veure també Tele/eXprés, 1-12-1976, un article del mateix Josep Ma Huertas Claveria entrevistant a De la Loma, el 9-12-1976 i un nou article el 14-12-1976 on s'explicava com el veïnat continuava protestant contra la pel-lícula. En aquest cas l'AVV no es va implicar gaire per no tenir una consideració tant negativa de la pel-lícula. Veure Asociación de Vecinos del Polígono La Mina San Adrián de Besós: "Comunicado oficial de la Asociación de Vecinos del Polígono La Mina" (25-2-1977), AHLM, Caixa C-1.3. Associacions de Veïns anys 70, Carpeta Comunicats de premsa.

1482 “La Mina es manifesta contra De la Loma”, Avui, 14-12-1976.

1483 El mateix De la Loma afirmava: "Si viven en La Mina esos delincuentes no puedo ponerlos en otro barrio. Ahora, creo que solo salía una vez el nombre, pero ni esa va a salir...." Veure J. M. Huertas Clavería: “De a Loma no contrató nunca a “El Vaquilla””, Tele/ eXprés, 9-12-1976. 
que sigui operatiu d'una vegada per totes ${ }^{1484}$. Finalitzen la seva acció el dia 4 de març amb la promesa del propi Governador Civil Sánchez Terán de que entrarà en funcionament el dia 15. Aquest dia, veient que la promesa -una més- no havia estat acomplerta, una assemblea veïnal massiva de 1.500 veïns aprovava una vaga general al barri per al dia 22 de $\operatorname{març}^{1485}$. La jornada va ser tot un èxit gràcies al suport dels comerciants del barri que van baixar persianes i dels mestres de les escoles que van tancar ${ }^{1486}$. De la intensitat amb la qual es va viure aquesta jornada ens informava una de les persones del barri:

"El merder fort fort fort va ser al 77 (...) És excepcional, és una experiència que en la meva vida és única (...) algú diu que és la primera Vaga General d'un barri que es dona a tota Espanya. Però és que a més hi havia consciència de què ens prenien el pel i que si no lluitaven junts... escolta, no calia amenaçar... des de les escoles fèiem uns panfletos... no calia amenaçar ni fer piquets. Els bars tancaven i es negociava... els autobusos no entraven, arribaven aquí i donaven mitja volta. Inclús algú tant curt de gambals que va haver-hi un petit incendi i van venir els bomberos i no els volien deixar passar $(\ldots)^{\prime 1487}$

La lluita per millorar el barri no es va acabar aquí. Després d'una reunió a finals de març amb el Gobernador Civil Sánchez Terán que va assegurar que aviat es farien les reformes pendents, el 31 de maig es va realitzar una assemblea i una manifestació de 2.500 persones per reclamar que s'executessin les obres de millora. També es va aprovar concentrar-se a partir del dia següent a les oficines del Patronat. Al 3 de juny la pressió veïnal de 100 persones del barri davant les oficines de Barcelona del PMV aconseguia també que uns pisos que encara estaven buits fossin assignats a diverses famílies ${ }^{1488}$. Però les lluites encara van continuar després de les eleccions.

L'altre barri que tenia ja una dinàmica de lluita era l'anomenat Besòs-

1484J. González Hergueta: "San Adrián del Besós: Los vecinos acudiran al pleno municipal a pedir explicaciones", La Vanguardia Española, 1-3-1977.

1485 Es poden trobar escrits referents a aquesta convocatòria a AHLM, Caixa C-1.3. Associació de Veïns anys 70, Carpeta AVV Anys 70.

1486Així ho va recollir la premsa: Ana Galcerán: "El barrio de La Mina lucha para conseguir lo prometido", El Correo Catalán, 23-3-1977; "La Mina paralizada", El Noticiero Universal, 23-31977; La "Jornada de protesta en La Mina", Vanguardia Española, 23-3-1977.

1487Entrevista a Josep Maㅡ Montferrer i Celades, 20-3-2012.

1488“...Y La Mina a la lucha”Mundo Diario, 1-6-1977; "Cien vecinos de La Mina pasaron la noche en Lesseps", El Correo Catalán, 1-6-1977 i "Los vecinos de La Mina levantaron la sentada", Tele/ eXprés, 3-6-1977. 
COBASA, també situat a la riba dreta -mirant al mar- del riu Besòs. Aquesta entitat duia des de feia un any una intensa activitat organitzant un gran nombre de xarrades sobre questions socio-polítiques que va continuar fent-se al llarg de $1976^{1489}$. El mateix 24 de gener els veïns netejaven un solar on es concentraven el dia següent per exigir a l'Ajuntament que el transformés en un parc (abans havien recollit 400 signatures ${ }^{1490}$. Una assemblea feta pocs dies després, el dia 30, reclamava per al barri un consultori, una llar d'avis i dos parcs ${ }^{1491}$. Després d'exigir la dimissió de l'Ajuntament amb altres entitats -com ja he comentat- el dia 5 es va marxar en manifestació cap a l'Ajuntament, assistint al Ple i entrevistant-se amb l'Alcalde per demanar explicacions sobre la situació del barri i també sobre la polèmica prohibició pel Govern Civil d'un festival infantil que s'havia de fer a l'aire lliure $^{1492}$ (aquest festival finalment es va fer el 4 d'abril $^{1493}$ ). El dia 15 unes 300 persones es manifestaven pel barri reivindicant l'ambulatori ${ }^{1494}$. Poc després en una roda de premsa la mateixa Associació exposava públicament els problemes del barri: totes les deficiències urbanístiques i manca de serveis, a més del proper abocador d'escombraries ${ }^{1495}$. La que va ser presidenta durant part d'aquells anys ens recordava aquelles lluites:

"Una altra lluita que vam muntar va ser la de les places, parcs infantils que aleshores no ho eren. Llavors els escombràvem, els netejàvem (...) muntàvem una sardinada, un concurs de truites... i la Guàrdia Urbana de Sant Adrià els teníem avorrits per que també ens volien enganxar... la gent s'hi oposava, es posava davant del President que llavors era un altre xicot... després pedíem un ambulatori, fèiem excursions... vam fer un sopar al carrer (...) Vam fer una ocupació (...) a l'Ajuntament”"1496

1489Així es pot observar a ASAB, Fons 101 Ajuntament, Caixa 388 (on es pot trobar molta documentació referent a les instàncies presentades per celebrar actes i xerrades per aquesta associació).

1490 J. González Hergueta: “San Adrián de Besós: Un grupo de vecinos se congregó para pedir un parque infantil", La Vanguardia Española, 28-1-1976.

1491González Hergueta: Deficiencias en el servicio asistencial del barrio Besós", La Vanguardia Española, 3-2-1976.

1492J. González Hergueta: "San Adrián de Besós: Fueron al pleno municipal a pedir un consultorio", La Vanguardia Española, 10-2-1976.

1493[Instància de Maria Codina Cabré, Presidenta de l'AVV Besòs-Sant Adrià] (25-3-1976), ASAB, Fons 01 Ajuntament, Caixa 388.

1494J. González Hergueta: "San Adrián de Besós: El I.N.P. Considera muy urgente la construcción de un ambulatorio", La Vanguardia Española, 18-2-1976.

1495J. González Hergueta: "San Adrián de Besós: Penosa situación del sector Cobasa-Barrio Besós", La Vanguardia Española, 3-4-1976.

1496Entrevista amb Maria Codina Cabré, 5-4-2012. Aleshores va ser Presidenta de l'AVV BesòsCobasa i també militant del PSUC. Posteriorment va ser regidora a l'Ajuntament i també 
L'AVV del Barri Besòs va participar també en les protestes contra l'aniversari que volia fer l'Ajuntament de la mort de Franco. Al gener de 1977 es reunien al barri Besòs diferents entitats -entre elles també l'AD- que reivindicaven un ambulatori general per la ciutat, sense que per això l'AVV deixés de reivindicar la construcció d'un altre ambulatori al seu barri ${ }^{1497}$. A inicis de febrer els veïns del Besòs es desplaçaven fins i tot al mateix Ministerio de Sanidad a reclamar-lo ${ }^{1498}$. Però alhora es va continuar participant en les mobilitzacions per l'Ambulatori per tot Sant Adrià que explicaré més endavant.

El barri de la Catalana continuava amb la seva problemàtica particular per estar construït en la seva totalitat als anys 20-30 en uns terrenys que posteriorment el Pla Comarcal de 1953 va qualificar como zona verda. El veïnat va assistir al Ple del 18 de març de 1976 on es parlava de la revisió del Pla Comarcal per reivindicar el canvi de qualificació dels terrenys que ocupaven, on de paraula van obtenir el suport de l'Ajuntament ${ }^{1499}$. Certament, les peculiaritats d'aquest barri i de l'AVV, on en aquells moments hi havia una conflicte intern que va acabar amb la presa de possessió d'un nou President en substitució de l'històric Agustí Bonet ${ }^{1500}$, va fer que l'entitat no estigués implicada en la resta de lluites de la ciutat. Bonet es va oposar a entregar la documentació al nou president, fins al punt que fins el 19 d'octubre de 1976 en una trobada feta a l'Ajuntament no va rebre Alfonso Chaos Campo -l'antic Alcalde de Barri- la documentació, claus etc. de l'esmentada associación $^{1501}$. Per la seva banda el nou President acusava a l'antic d'irregularitats

militant del PCC.

1497J. González Hergueta: "San Adrián de Besós: Injustificable demora en la construcción del ambulatorio", La Vanguardia Española, 30-1-1977.

1498J. González Hergueta: "San Adrián de Besós: A pesar de todo, los vecinos del sector Cobasa no se desaniman", La Vanguardia Española, 16-2-1977.

1499“El Ayuntamiento opta por favorecer a los propietarios de La Catalana”, Diario de Barcelona, 20-3-1976. El Ple va aprovar que la zona de La Catalana es catalogués com zona 13b en la revisió del Pla Comarcal.

1500 L'antic President Agustín Bonet Manich havia estat substituït en un procés conflictiu i no gaire net per l'antic Alcalde de Barri, Alfonso Chaos Campo, que va assumir la Presidència. Veure $p$. 372 i nota 898.

1501[Acta de compareixença de Alfonso Chaos Campo i Germinal Bonet Mena, en representació del seu pare Agustín Bonet Manich] [19-10-1976], ASAB, Fons 101 Ajuntament, Caixa 388. La nova Junta estava composada per: President: Alfonso Chaos Campo; Vice-President: Bibiano López García; Secretari: Juan M. Pedreño González; Vice-Secretari: Jaime Romero Verde; Tresorer: Ángel López Fernández; Contador: Francisco Mingotes Joven; Vocal Primero: Leonardo Valverde Mellado. Veure "Acta de la Asociación de Vecinos i Centro Cultural de La Catalana" 
en la tramitació de les al·legacions al Pla Comarcal ${ }^{1502}$. Però del que no hi ha dubte és del tarannà "col-laboracionista" que tenia -en principi- la nova Junta veient aquestes paraules:

"Antes de iniciar la sesión el Sr. Presidente ruega un minuto de silencia a la [faltan paraules]bles, por las causas anormales opuestas a la democratización del país, demostrando el más firme deseo y lealtad a S.M. el Rey y el Gobierno y a cuantas personas trabajan por este menester. La Asamblea conmovida guardó silencio."1503

Sigui com sigui, els veïns de La Catalana no estaven d'acord amb l'aplicació del Pla que s'havia d'aplicar al barri, conegut com a Pla Llansó, per ser aquest el propietari de terrenys que encara restaven sense edificar. Fins al moment allà no es podia construir per ser zona verda, situació que canviaria amb aquest pla que obligaria a marxar als habitants del barri de les seves cases d'autoconstrucció per anar a viure als blocs de pisos que es farien en aquests terrenys un cop requalificats. D'aquí l'oposició del veïnat, fins al punt que van acudir al Ple per pressionar en aquest sentit. Curiosament l'AVV que s'havia mostrat "col-laboracionista" fins aleshores va recórrer a la manifestació i l'Assemblea, arribant fins i tot a fer una vaga de comerços i reclamar la dimissió de l'Alcalde i del Tinent d'Alcalde ${ }^{1504}$. La situació va arribar fins al punt que Juan Matacàs Alcaraz -l'esmentat 1er Tinent d'Alcalde- va dimitir ${ }^{1505}$.

El dia 25 de febrer de 1976 es van presentar al Govern Civil els Estatus de noves Associacions: La de Sant Adrià Nord i la de Sant Joan Baptista. La primera d'aquestes dues comprenia la zona del vell poble. Aquesta tenia en el seu si una major diversitat, comptant entre els seus membres fins i tot alguna persona propera a Unió Democràtica (i posteriorment a Convergència Democràtica):

(16-10-1976), ASAB, Fons 101 Ajuntament, Caixa 388.

1502 [Asociación de Vecinos i Centro Cultural de La Catalana], “Acta” (29-12-1976), ASAB, Fons 101 Ajuntament, Caixa 388.

1503[Acta de l'Assemblea General Extraordinària de AVV La Catalana] (29-1-1977), ASAB, Fons 101 Ajuntament, Caixa 388.

1504J. Dellunder: "El barrio de La Catalana està sentenciado a muerte" i "Sant Adrià: Cierran todas las tiendas de La Catalana", El Correo Catalán, 27 i 29-5-1977 i F. Arnau: "Siguen las dimisiones, ahora a causa del Pla Llansó", Tele/ eXprés, 1-6-1977. Cal tenir en compte que en aquell moment les ocupacions del consistori i les manifestacions eren molt freqüents, per tant, potser no és tant estrany que adaptessin els mateixos mètodes.

1505J. Dellunder: “Sant Adrià: Un concejal ha presentado su dimisión”, El Correo Catalán, 1-6-1977. Veure també per més informació sobre el Pla Llansó a Marta Puértolas: "Sant Adrià: La Catalana no debe ser calificada como zona verde", Diario De Barcelona, 2-6-1977. 
"Jo vaig començar a militar... a tenir relacions amb els Amics de les Nacions Unides a Barcelona, quan encara aquí no es movia res, devia ser l'any 65-75. Me'n recordo que el President (...) era un militant molt conegut d'Unió Democràtica. Em va dir 'apuntate... però ens fotran a la presó... no, a nosaltres ens toleren... ah pos fes-me'n' (...) Després (...) a Sant Adrià d'Unió no hi havia ningú. Els de Convergència si (...) [i es va fer de Convergència més tard] Es van emprenyar una mica els d'Unió (...) als seixanta, 75-76 (...) més o menys. Era més progre Convergència que no Unió."1506

Una altra mostra de la pluralitat d'aquesta Associació ens la mostra el testimoni d'un altre dels seus membres:

“(...) A l'Associació de Veïns teníem el Fraga (...) n'hi havien dos del PSUC, de Convergència [Democràtica de Catalunya] hi havia la meva dona, els socialistes eren tres o quatre, no me'n recordo de més (...) Era diversa. No la controlava cap partit. (...) [però] Tenia més pes el PSC segur (...) del PSOE no hi havia cap." ${ }^{1507}$

Aquesta associació, juntament amb l'Assemblea Democràtica de Sant Adrià (on militaven uns quants dels seus membres) van denunciar al setembre l'existència d'uns gasos tòxics -TCDD, similar al que havia produït una catàstrofe a la ciutat italiana de Seveso- en una fàbrica propera ${ }^{1508}$. Al més següent la mateixa associació reclamava més seguretat per al barri ${ }^{1509}$. Al desembre participava també amb altres entitats en la protesta contra la commemoració de l'Ajuntament del 20$\mathrm{N}$, i com veurem posteriorment, també ho farà a les mobilitzacions per l'ambulatori de ciutat.

L'AVV de Sant Adrià Nord va participar també en actes culturals de reivindicació de la cultura catalana, fet comprensible tenint en compte que era present al barri amb major percentatge de població catalanoparlant. Però la lluita més important que es va donar en aquest barri va ser el que van protagonitzar els veïns del Carrer Maragall. Aquests van protagonitzar un intens conflicte amb l'Ajuntament durant pràcticament tot el mes de maig. El veïnat d'aquest carrer

1506Entrevista a Jaume Vallés Muntades, 26-10-12, 6-11-12 i 29-11-12. Militant d'UDC, de CDC, membre de l'AVV Sant Adrià Nord i regidor a l'Ajuntament per CDC. Als anys 90 va ser Alcalde durant un breu període de temps, després de la moció de censura feta a Antoni Messeger, que havia estat Alcalde pel PSC-PSOE des de 1979.

1507Entrevista a Agustí Gallart, 17-1-2013. Membre de l'AVV Sant Adrià Nord i militant del PSC-C i del PSC-PSOE fins 1979. Posteriorment militarà a CDC.

1508“Denuncia la existencia de gas mortal”, Mundo Diario, 11-9-1976.

1509J. González Hergueta: "San Adrián de Besós: Los vecinos del Sector Norte piden más vigilancia al Ayuntamiento", La Vanguardia Española, 19-11-1976. 
protestava contra unes obres il-legals que estava fent una constructora propietat . El dia 4 es van tancar una cinquantena a l'Ajuntament fins que van ser desnonats per la Guàrdia Civil el dia següent ${ }^{1510}$. Van haver-hi enfrontaments al barri amb la policia que els hi va retirar les pancartes. Entremig l'Alcalde Francisco Oller dimitia i era substituït per Miguel Blasco -que posteriorment anirà a les llistes de CDC a les municipals de 1979-. Els veïns tornen a ocupar l'Ajuntament el dia 11 però van ser de nou expulsats, tancant-se aleshores a la parròquia i continuant les mobilitzacions per pressionar a l'Ajuntament amb el suport de l'advocat Francesc Arnau. Entremig van haver-hi detencions i manifestacions ${ }^{1511}$. La tancada a la parròquia va durar fins el dia 27 coincidint $\mathrm{amb}$ un mes de maig ple de mobilitzacions veïnals. Malgrat que la polèmica obra es va aturar, el conflicte es va allargar durant un temps per la negativa del propietari de la constructora a pagar unes indemnitzacions per desperfectes que havia causat.

Pel que fa a l'altra Associació, la de Sant Joan Baptista he trobat documents de que van fer la primera reunió el dia 4 d'abril i que primerament es va dir "Asociación Cultural y Recreativa Grupo Juventud"1512, canviant posteriorment el seu nom. No he trobat gaire més documentació d'aquesta associació però si un testimoni interessant d'un dels seus membres:

"Aquí a Sant Joan se va crear l'Associació de Veïns entre un company de la CELO muy activo, Miguel Puelma Adalid (...) era delegado sindical. Un dels companys més importants en el movimiento vecinal de Sant Adrian (...) fue concejal en la primera legislatura conmigo. (...) El Puelma hizo un trabajo extraordinario, era un hombre que tenía unas cualidades estupendas para abrirse, para dialogar, para llevar, para ofrecer (...) y el era la pieza, fue la pieza clave en la fundación de la Asociación de Vecinos de San Juan Bautista, igual que fue también (...) muy importante para la construcción aquí del colegio de San Juan Bautista."1513

Van existir altres associacions com la de Montsolís o la de la Via Trajana, a la

1510“Encierro de vecinos en el Ayuntamiento", J. Dellunder: "Sant Adrià: Los concentrados invitados a salir de la sala" i "Sant Adrià: Desalojo de los vecinos encerrados", El Correo Catalán, 5, 6 i 7-5-1977.

1511El Correo Catalán, 12, 14, 15, 18, 24 i 27-5-1977.

1512Veure [Acta de constitució de la "Asociación Cultural y Recretaiva Grupo Juventud"] (4-41976), ASAB, Fons 101 Ajuntament, Caixa 387.

1513Entrevista a Juan José Castro Castillo, 20-12-12 i 21-1-13 . Militant del PSUC, de l'AVV Sant Joan Baptista, regidor a l'Ajuntament i militant del PCC. 
part propera a La Verneda, però no he trobat gaire documentació sobre elles. Si que he pogut trobar referències a l'existència d'una Coordinadora d'AVV's que es va constituir com a tal el 19 de maig de $1977^{1514}$. Però per arribar fins aquí es van donar unes lluites a nivell de ciutat que van fer confluir les diferents AVV's e inclús altres entitats, i d'aquestes, va destacar sens dubte la lluita per l'ambulatori.

Sant Adrià de Besòs disposava en aquell moment només d'un únic ambulatori en un edifici atrotinat que era anomenat despectivament "la quadra". Aquest edifici no només havia de donar servei a tota la població de Sant Adrià, sinó també als barris propers de Badalona. De manera que no va ser estrany que després de les mobilitzacions als diferents barris l'any 1976, a inicis de 1977 les diferents AVV's i altres entitats com l'Assemblea Democràtica, es reunissin al barri Besòs per coordinar-se i reclamar la construcció d'un nou ambulatori per la ciutat ${ }^{1515}$. Un mes més tard, cap a finals de febrer es va fer una assemblea a l'Ateneu Adrianenc de diferents AVV's i la mateixa Assemblea Democràtica on es va decidir portar la reclamació de l'ambulatori al proper Ple ${ }^{1516}$. I en efecte, així va ser. El 3 de març unes 300 persones van entrar al saló de Plens i van fer una assemblea davant l'alcalde i els regidors. La mesura de pressió va semblar reeixir quan el 11 del mateix mes el propietari d'un solar reivindicat per aquesta funció va decidir cedirlo a l'Ajuntament per que construís el tan anhelat ambulatori. El 14 de març es feia una assemblea feta a l'Ateneu Adrianenc per explicar els acords presos al respecte, però també per continuar impulsant les mobilitzacions i denunciar les mancances i irregularitats existents en el servei que es donava al vell ambulatori ${ }^{1517}$.

El dia 24 es produeix una gran manifestació amb la participació d'un miler de persones per reclamar l'inici de les obres de l'ambulatori. La manifestació va recórrer gran part de Sant Adrià per finalitzar a la Plaça de l'Església, on es trobava el vell ambulatori i on es va informar que es farien manifestacions cada dissabte fins que no hi hagués una data d'inici de les obres i s'emplaçava a la propera

1514Marta Puértolas: "Sant Adrià ya tiene una Coordinadora de Vecinos", Diario de Barcelona, 21-51977.

1515 La Vanguardia Española, 30-1-1977.

1516 La Vanguardia Española, 1-3-1977.

1517J. González Hergueta: "San Adrián de Besós: El pleno municipal abocó en una asamblea de vecinos" i "San Adrián de Besós: El solar para el nuevo ambulatorio ya es de propiedad municipal", La Vanguardia Española, 6 i 16-3-1977. 
mobilització pel dia $30^{1518}$. I així va ser. De nou i més de tres-centes persones es van manifestar aquest dia, on de nou es va fer un emplaçament per dintre d'una setmana al qual es va afegir la reivindicació per l'Estatut d'Autonomia ${ }^{1519}$. Pel que es veu les manifestacions es van anar succeint fins arribar a la del dia 21 de maig, on van haver-hi alguns incidents ${ }^{1520}$. No obstant, la construcció de l'ambulatori encara trigaria en començar.

A Sant Adrià de Besòs també va tenir una certa importància l'Assemblea Democràtica en aquestes mobilitzacions. Va existir també una secció local del Congrés de Cultura Catalana que es va donar als anys 1976 i 1977. Però també va haver una altra entitat que va destacar en aquells anys: l'Ateneu Adrianenc, que es va obrir als nous temps. En ell es van poder fer assemblees veïnals, reivindicatives, de l'Assemblea Democràtica... Inclús va iniciar un cicle de presentacions de forces polítiques i sindicals. Al setembre de 1976 s'havia presentat públicament la UGT, a l'octubre el Centre Catala, al novembre UDC i CDC (amb la presència de Miquel Roca i Junyent) ${ }^{1521}$. Però aquest cicle es va tallar arran la prohibició que va fer el Govern Civil el 26 de novembre de la presentació que havia de fer el PTE, demostrant una vegada més, que no tots els partits eren tractats de la mateixa manera $^{1522}$.

A Sant Adrià de Besòs també van continuar les protestes veïnals un cop passat el 15-J. El protagonisme el va tenir sobretot el barri de La Mina. Apart del litigi continuat amb el Patronato Municipal de la Vivienda de Barcelona, hi van haver altres mobilitzacions. A finals d'octubre i principis de novembre el veïnat protestava per trasllat o acomiadament de part del personal de l'ambulatori ${ }^{1523}$. El

1518J. González Hergueta: "San Adrián de Besós: Un millar de personas reivindican el ambulatorio", La Vanguardia Española, 26-4-1977.

1519J. Dellunder: "Los vecinos de Sant Adrià reivindican el ambulatorio", El Correo Catalán, 3-51977.

1520“Provocadores en S. Adrià”, Tele/ eXprés, 23-5-1977.

1521J. González Hergueta:"San Adrián de Besós: Presentación de la U.G.T", La Vanguardia Española, 16-9-1976; "Presentació d'UDC a Sant Adrià", Avui, 6-11-1976 i J. González Hergueta:"San Adrián de Besós: Roca i Junyent defendió el salario social”, La Vanguardia Española, 23-111976.

1522J. González Hergueta: "San Adrián de Besós: Prohibida la presentación del Partido del Trabajo", La Vanguardia Española, 28-11-1976.

1523 “Vecinos de La Mina esperan la readmisión de personal del ambulatorio", La Vanguardia Española, 2-11-1977. Es poden trobar escrits i comunicats de l'Associació protestant per l'acomiadament de 3 celadors a AHLM, Caixa C-1.3 Associació de Veïns anys 70, Carpeta AVV anys 70 . 
10 de novembre de 1977 la mateixa AVV convocava a una "Jornada d'Alerta" per reivindicar una vigilància del barri "educativa i no repressiva"1524. Al maig de 1978 es donarà una mobilització de 400 veïns, que sortiren en manifestació el dia 19 cap a l'Ajuntament per reivindicar tot un conjunt de millores per el barri i després de moments de tensió amb les FOP i d'una breu entrevista amb les autoritats municipals, decideixen repetir la manifestació el diumenge 21 i acampar just al costat de l'Ajuntament. Entre les demandes d'acondicionament general del barri destacaven la reivindicació d'un local per pensionistes, el ple funcionament de l'ambulatori, la construcció de parcs i zones verdes, locals pels joves i una vigilància del barri educativa i no repressiva ${ }^{1525}$. Es van tenir diverses entrevistes amb l'Alcalde i el subgovernador Civil, fins que finalment es va decidir aixecar l'acampada i portar la protesta a organismes de Madrid $^{1526}$. Tot i això, el veïnat aviat es va haver de tornar a mobilitzar per preservar l'Escola d'Artesania i Formació Profesional existent al barri ${ }^{1527}$. La manca de solució dels greus problemes del barri, sumat als estralls que a nivell social estava provocant la crisi econòmica, així com l'estigmatització que s'estava fent, faran que La Mina encara doni molt per parlar els anys posteriors.

Al Barri Besòs-Sant Adrià la lluita en aquest període es va centrar en la reivindicació d'una escola professional pel barri. Es va fer una tancada el 20 de desembre de 1977 al mateix Ajuntament i es va tenir una entrevista amb el President de la CMB Socias Humbert ${ }^{1528}$. No obstant, aquests objectius encara no es van aconseguir a inicis de 1978 com ens ho reflecteix una acta de la seva assemblea

1524“”Jornada de alerta” en La Mina”, El Correo Catalán, 10-11-1977.

1525J. González Hergueta: "Vecinos de La Mina piden soluciones al Ayuntamiento", La Vanguardia Española, 21-5-1978 i J. Dellunder: "Sant Adrià: Los vecinos de La Mina acampan junto el Ayuntamiento", El Correo Catalán, 23-5-1978.

1526J. Dellunder: "Los vecinos de La Mina en el Gobierno Civil" i "Sant Adrià: Vecinos de La Mina levantan sus tiendas", El Correo Catalan, 25-5-1978 i 3-6-1978. A La Vanguardia Española es fa un recull de les infraestructures existents i necessàries pel barri en uns articles de Carlos $\mathrm{M} \stackrel{\text { a }}{\text {. }}$ López titulats significativament "En la mina se lo han hecho todo ellos" (2-6-1978) i "Calcuta es poco comparada con La Mina" (4-6-1978).

1527 “La Escuela de Artesanía y Formación Profesional de La Mina, en peligro", La Vanguardia Española, 25-7-1978. Finalment l'AVV de La Mina havia renunciat anteriorment al seu espai reservat al Centre Cívic en favor d'aquesta escola. Veure document al respecte: Asociación de Vecinos del Polígono de La Mina Sant Adrián de Besós: [Carta al Sr. Fernando Aramburu, Gerent del PMV de Barcelona] (30-11-1977), AHLM, Caixa Caixa C-1.3 Associació de Veïns anys 70, Carpeta A.VV. Anys 70. Diferents escrits.

1528 “La escuela profesional del barrio Besós, en vías de solución”, La Vanguardia Española, 29-121977. 
general. En aquesta també s'insistia en la reivindicacions pendents del barri per que fa a urbanisme, escoles i altres equipaments ${ }^{1529}$.

A La Catalana tot va continuar girant al voltant de com quedava qualificat finalment el barri. Al mes de març va haver-hi una assemblea de veïns a l'Ajuntament on es va exposar la demanda de que la qualificació passés a 13b (construcció semi-intensiva, que permetria conservar els habitatges als veïns) en comptes de la qualificació que estava contemplada (14a, que no ho garantia). Hi van intervindre membres de la Coordinadora d'AVV's, del PSC i del PSUC ${ }^{1530}$. Poc després els veïns de La Catalana es reunien amb la CMB i mostraven el seu desacord amb la possibilitat d'expropiació de 7,8 Ha de terrenys del barri per fer equipaments, per que afectaven a 20 famílies. Fins i tot van aconseguir el suport del Ple Municipal el 1 de juny. Tot depenia de la resolució del Recurs ContenciósAdministratiu que s'havia presentat contra la $\mathrm{CMB}^{1531}$.

Al barri de Sant Joan Baptista la conflictivitat va estar molt centrada al voltant de la fàbrica INBESA. Ja el veïnat havia alertat de la seva perillositat i una explosió d'un gasòmetre va afectar a immobles veïns ${ }^{1532}$. Al setembre protestes veïnals reclamaven el trasllat de la fàbrica, que alhora es va veure afectada per un conflicte laboral per uns acomiadaments dels obrers més combatius. Aquests van ocupar la factoria mentre rebien el suport en forma de diverses manifestacions com la del dia 10 d'octubre de 1977 tot i que les negociacions al Govern Civil van acabar sense $\operatorname{acord}^{1533}$.

Mentrestant, al nucli antic del poble, a Sant Adrià Nord l'AVV era legalitzada formalment a finals de gener de 1978. Al març va intentar oposar-se -sense èxit- a l'autorització d'un bingo a l'Ateneu Adrianenc ${ }^{1534}$. Altres lluites de l'AVV van ser per la minimització de l'impacte de les obres del metro al barri o contra algun local

1529“Acta de la Asamblea Ordinaria de la Asociación de Vecinos "Besós-San Adrián celebrada el dia 31 de marzo de 1978", ASAB, Fons 101 Ajuntament, Caixa 388.

1530J. González Hergueta: “La Catalana, un barrio marginado", La Vanguardia Española, 17-3-1978.

1531J. Dellunder: "Sant Adrià: Inquietud en el barrio de La Catalana" i "S. Adrià: Vecinos de La Mina levantan sus tiendas", El Correo Catalán, 26-4-1978 i 3-6-1978.

1532J. P. Ayza: “Explosió d'un gasómetre a Sant Adrià", Avui, 7-8-1977.

1533 “Indústrias del Besós, S.A." i “Conflicto en "Indústrias del Besós, S.A.", La Vanguardia Española, 6 i $12-10-1977$.

1534J. González Hergueta: "Legalizada la Asociación de Vecinos "Sant Adrià Nord"” i "Luz verde para el bingo del Ateneo", La Vanguardia Española, 28-1-1978 i 8-3-1978. 
molest com el bar "La Tasqueta"1535. També, des de l'AVV de Sant Adrià Nord es va tenir un important paper en la lluita per l'ambulatori de ciutat i al novembre de 1978 reclamava que aquest fos un hospital ${ }^{1536}$.

A nivell de ciutat les reivindicacions més importants van continuar lligades a la sanitat. A la tardor-hivern es denunciava per una banda la precària existència de serveis sanitaris municipals (es va adquirir una ambulància que només funcionava els caps de setmana per falta de personal). Mentrestant la Coordinadora de l'AVV continuava pressionant per l'ambulatori i criticava que el mateix alcalde no els acompanyés a una reunió amb el director de l'Instituto Nacional de Previsión que abans s'havia negat a rebre'ls ${ }^{1537}$. A principis de 1979 les AVV's, partits i entitats tornaven a denunciar l'endarreriment de les obres de l'ambulatori, que no serà plenament operatiu fins als anys vuitanta ${ }^{1538}$.

La Coordinadora d'AVV's va denunciar durant aquest temps les mancances escolars, posant un especial accent en la cessió d'uns terrenys parroquials per poder-los destinar a una escola especial per disminuïts psíquics ${ }^{1539}$. Anteriorment va haver-hi crítiques de la comissió organitzadora de l'onze de setembre de 1978 a l'Ajuntament per la seva poca col-laboración ${ }^{1540}$. De fet, pel que fa a l'Ajuntament adrianenc, després de la substitució de Francisco Oller per Miguel Blasco, malgrat la conflictivitat veïnal existent, va tenir un major nivell d'estabilitat que els de Badalona i Santa Coloma tot i existir alguns conflictes amb els partits polítics que participaven a les Comissions de Treball, fins al punt que, com veurem, CDC va proposar com a cap de llista a les eleccions municipals d'abril de 1979 al mateix Miguel Blasco.

Malgrat que hem pogut veure anteriorment elements que avançaven una certa crisi del moviment veïnal, encara es va mantenir una conflictivitat

1535J. González Hergueta: "Preocupan las obras del metro" i "Un bar escandaliza a los vecinos", La Vanguardia Española, 14-6-1978 i 4-7-1978.

1536J. González Hergueta: “Hospital en vez de ambulatorio", La Vanguardia, 7-11-1978.

1537J. Dellunder: "Sant Adrià: Sin ambulancia ni servicios municipales", El Correo Catalán, 28-91977 i J. González Hergueta: "Critican la falta de colaboración del alcalde" i "Sant Adrià de Besós: No hay personal suficiente para atender el servicio de ambulancia", La Vanguardia Española, 30-9-1977 i 9-11-1977.

1538 La Vanguardia, 13-2-1979.

1539González Hergueta:"La Coordinadora de Vecinos acuerda solicitar la expropiación de un terreno parroquial", La Vanguardia, 18-10-1978

1540J. González Hergueta: “El Ayuntamiento no dio facilidades en la "Diada”", La Vanguardia, 13-91978. 
relativament alta fins arribar a les eleccions municipals de 1979, desmentint -o matisant- que després de les eleccions del 15J hi hagués una gran desmobilització, que d'existir va ser més gradual. El que si que havia variat era el context polític, i ara, les reivindicacions eren més per qüestions urbanístiques o per demanda de serveis. Tot i això ja van començar a sorgir elements de tensió sobre el paper que tindrien les AVV's amb els futurs Ajuntaments democràtics.

\subsection{Els primers ajuntaments democràtics i el paper del moviment veïnal.}

Des del 15 de juny de 1977 els ajuntaments franquistes del Barcelonès Nord, havien quedat en una situació molt fràgil per que apart de la mobilització existent, la UCD havia tinguts uns resultats pobres i per la clara hegemonia dels partits d'esquerres. Ja vaig explicar a l'anterior apartat els intents de dimissió de l'Alcalde i molts regidors de Badalona així com les queixes que van manifestar aquests i d'altres sobre la seva situació i manca de suport de les autoritats centrals. De manera que Alfonso Ramos Cruz i la resta de regidors van haver d'acceptar una mena de supervisió i "control" per part de la Taula de Partits de Badalona, integrada pels que havien aconseguit els millors resultats: PSC-C i PSOE (que havien presentat la coalició "Socialistes de Catalunya"), PSUC, Convergència Democràtica, PSC-R (que havien fet la coalició "Pacte Democràtic" amb Esquerra Democràtica de Catalunya), PTE i ERC (que havien fet la coalició "Esquerra de Catalunya -Front Electoral Democràtic" amb Estat Català i que encara no havien estat legalitzats $)^{1541}$.

La tensió existent dintre del mateix consistori davant una situació d'impotència i que escapava al seu control es podia veure reflectida per exemple quan el 26 de setembre de 1977 el regidor de cultura José Parra, fortament qüestionat per les manifestacions en demanda d'escoles que s'havien produït al setembre, va perdre els papers en ser interpel·lat molt durament per Cecília March sobre la situació escolar i va intentar agredir físicament a l'esmentada regidora ${ }^{1542}$.

1541Joan Villarroya (dir.): Història de Badalona, p. 229.

1542 “Comissió política a Badalona", Avui 28-9-1977 i Maurici: "Los partidos se reúnen solos en el Ayuntamiento", Mundo Diario, 8-10-1977. 
Poc després l'Ajuntament acceptava reunir-se amb la Taula de Partits i assumia fins i tot que els mateixos fessin servir el consistori per fer les seves reunions, cosa que va succeir a altres municipis i que com hem vist responia, en part, a una consigna superior del Govern Civil, i sempre i quan es limités efectivament la participació directa de les AVV's ${ }^{1543}$. Tot i així a l'octubre va haver-hi la reunió de molts alcaldes de Barcelona i rodalies per mirar de reconduir una situació que se'ls escapava de les mans. Finalment a Badalona a finals de 1977 es va arribar a una sèrie d'acords entre l'Ajuntament i la Taula de Partits mentre no es fessin les eleccions municipals. El PSUC va proposar també a la resta de forces i a l'Ajuntament fer un "Pla d'Urgències" fins els propers comicis locals, donada la greu situació de la ciutat. Recollint aquesta proposta, diferents organismes que s'havien creat en anys anteriors, com la Taula de Sanitat o la Taula d'Ensenyament elaboraren treballs i estudis d'urgència per actuar en aquests àmbits de la ciutat. L'Ajuntament badaloní, desbordat i pressionat pels partits polítics va haver d'anar acceptant, en major o menor mesura, aquests plantejaments al llarg de l'any $1978^{1544}$.

Ja vam veure que no tot van ser punts de trobada. Malgrat existir un acord entre l'Ajuntament i la Tala de Partits, el PERI de Dalt de la Vila i la desautorització que va fer la CMB de l'Ajuntament badaloní que havia votat en contra d'aquest va provocar una altra crisi política. El mateix Governador Civil Josep M. Belloch es reunia amb els representants de la Taula de Partits i els membres del consistori, que en sentir-se desautoritzats van presentar una nova de dimissió el 13 de juny que tampoc va ser acceptada ${ }^{1545}$. La crisi va ser superada amb una reestructuració del cartipàs aprofitant algun dels no dimissionaris. Cecília March i Ernest Rojo, aleshores ja militants de Convergència assolien les Tinències d'Alcaldia de Cultura/Esports i Serveis Municipals (sense el consentiment explícit del seu partit,

1543Veure el document ja esmentat a la nota 1494: "Reunión con Alcaldes de poblaciones Cabezas de Partido Judicial” (31-8-1977), AHGCB, Fons Gobernadores Civiles, Caixa 444, p. 5.

1544Enric Giralt: "Dos turnos diarios en las escuelas", Mundo Diario, 14-5-1978. En un subtítol s'afirmava "El Ayuntamiento acepta el Plan de Urgencias".

1545Enric Giralt: "Abandono masivo del consistorio" i "El Dalt la Vila, en manos de la Corporación Metropolitana", Mundo Diario, 14 i 15-6-1978. Martí Marín explicava en el context català les mesures que el Governador Civil José Maria Belloch (pare del posterior ministre del PSOE i alcalde de Saragossa, Juan Alberto Belloch), per, malgrat la voluntat de no acceptar dimissions, intentar resoldre el problema de l'absentisme de determinats regidors que impedien el funcionament dels Plens l'alguns municipis, Els Ajuntaments franquistes a Catalunya..., p. 468. 
fet que va provocar l'abandó d'aquest per part dels dos regidors i que March arribés a presentar una candidatura independent a les eleccions municipals de 1979). Un altre vell conegut nostre, Fulgencio Conesa, esdevenia primer tinent d'alcalde ${ }^{1546}$.

Com era de preveure, la Taula de Partits va considerar aquesta mesura insuficient i va llançar la proposta de que tot el consistori dimitís i es creés una Gestora controlada per aquests. Aquesta proposta no era ben vista des de el propi Ajuntament Badaloní, com reflectia un informe destinat al Governador Civil:

"El hecho de pensar en una Gestora solo sería paralizar el Ayuntamiento, su vida administrativa que, en una ciudad del volumen de Badalona es grave y que piensen que esta decisión es propia de los Partidos Políticos y más difícil que el resto de Fuerzas estén conformes con esta propuesta, pero que ellos tienen la responsabilidad y la representación necesaria para tomar esta decisión."1547

Fins i tot es va arribar a proposar el nom d'un alcalde "provisional", Josep Arpí i Sabater, membre d'ERC. Però com era previsible aquestes propostes no van ser acceptades pel Govern Civil. Aquest, com a molt, acceptava la presència de "regidors gestors" que fossin membres de partits polítics ${ }^{1548}$. Les negociacions es van allargar durant la tardor i van aparèixer discrepàncies dins la mateixa Taula de Partits. Mentre CDC i ERC eren més propers a les postures del Govern Civil, PSCPSOE, PSUC i PTE es mostraven més distants i defensaven la proposta de fer una "Gestora"1549.

Finalment es va arribar a un acord. La Taula de Partits renunciava a crear una Comissió Gestora a canvi de que l'Ajuntament acceptés un "Pla d'Urgències" que entregarien al consistori, juntament amb el compromís de que membres dels partits polítics assumissin càrrecs de responsabilitat ${ }^{1550}$. Mentre es feien aquestes negociacions i el mateix referèndum Constitucional, es va produir un intent de fer fora al mateix Alfonso Ramos Cruz de l'Alcaldia de Badalona per part d'uns quants

1546"Han cambiado todos los tenientes de alcalde", Mundo Diario, 27-6-1978.

1547 "Nota para el Señor Gobernador: entrevista mantenida esta mañana con los representantes de los partidos políticos de PSUC, PSC y CDC, de Badalona", AHGCB, Gobernadores Civiles. Caixa 357. Ayuntamiento de Badalona, 1976-1978.

1548Enric Giralt: "Puede haber un alcalde gestor" i “Hoy, cónclave municipal”, Mundo Diario, 31-81978 i $i-10-1978$.

1549Joan Roura: "Aplazadas las negociaciones", Mundo Diario, 15-10-1978.

1550 Joan Roura: "Pacto municipal de urgencia”, Mundo Diario, 12-11-1978. 
regidors del mateix Ajuntament (es va parlar de la implicació aleshores de Diego Garcia, Mauricio Utset i Luís Rosanas, encapçalats per José Guillen Clapés en l'anomenada "Operació Simbiosi") que van ser identificats com "el bunker de Badalona". En contrast, a finals de setembre es consumava l'entrada dels membres dels partits polítics a l'Ajuntament, assumint una part de les Tinències d'Alcaldia: Enric Flo (PSC-PSOE) s'encarregava d'Hisenda; Mireia Garcia Miró (PSUC) de Cultura; Eduard Vilalta (CDC) de Sanitat; Benet Cerdan (ERC) d'Estadística; José Manuel Ordás (PTC) d'Urbanisme (cal remarcar que dels nombrats només els membres del PSUC i del PTC vivien a Badalona). De la mateixa manera es va crear una Comissió Política integrada per Joan Blanch (PSC-PSOE), Alfredo Amestoy (PSUC), Juan Mondejar (CDC), Juan Martínez (ERC) i Francisco Muñoz (PTC) ${ }^{1551}$. Però tot i aquest acord, la dinàmica dels esdeveniments feia temps que estava condicionada per la convocatòria d'eleccions municipals que s'havien de fer el 3 d'abril de 1979.

A Santa Coloma de Gramenet també va haver-hi tensions internes. L'Ajuntament havia acceptat les "Comissions de Control" però els partits no van acceptar inicialment la composició proposada. Al setembre de 1977 s'havia donat una maniobra del sector més "ultra” contra el propi Blas Muñoz. El conegut regidor Salvador Callejón (el propietari de OVNI 3, un bar musical que havia generat motes protestes veïnals) va aconseguir que 13 regidors signessin un document on es demanava la dimissió de l'alcalde, tot i que després cinc d'aquests es van desdir de la proposta ${ }^{1552}$. Havien argumentat la "falta d'autoritat" davant fets com l'ocupació del consistori després d'una manifestació de suport a les treballadores d'Eurostil.

Per altra banda l'autoritat municipal també es va veure deslegitimada per decisions de la CMB com la suspensió de les llicències de construcció de Can Zam. Un altre focus de tensió interna van ser els regidors adscrits a Reforma Social Catalana, que havien participat en l'intent anterior i que també van participar en la "conxorxa" contra Blas Muñoz per fer pujar els impostos sobre la propietat

1551 “La izquierda asume cargos", Mundo Diario, 22-12-1978; "Primer Ayuntamiento democrático", Tele/ eXprés, 22-12-1978 i F. Ruiz: "Los partidos entran en el Consistorio" Hoja del Lunes, 2512-1978.

1552 "Quieren "cargarse" al Alcalde de Santa Coloma”, Tele/ eXprés, 1-9-1977; M. Castellón:"Santa Coloma de Gramenet: Cinco concejales se retractan de la petición de cese del alcalde", La Vanguardia Española, 8-9-1977 i “Los concejales asisten a un pleno”, Mundo Diario, 9-9-1977. 
immobiliària en comptes de pujar taxes com la de recollida d'escombraries ${ }^{1553}$. Sigui com sigui, el cas es que l'Ajuntament colomenc es trobava en una situació de fallida econòmica ${ }^{1554}$. A finals de novembre el Ple no va aprovar les obres de reforma del Passeig de la Salzareda -una de les reivindicacions veïnals més fortes d'aleshores- i això va fer que els membres dels partits polítics es retiressin de les Comissions de Control en senyal de protesta ${ }^{1555}$. Aquests partits polítics s'havien agrupat d'una manera similar a la Taula de Partits badalonina, en la denominada “Comisión Municipal de Partidos"1556.

El 31 de desembre de 1977 s'havia dissolt el Patronato Municipal de la Vivienda de Santa Coloma. Al 28 de febrer del 1978 el Ple estava discutint sobre aquest fet i va descobrir-se l'existència d'un superàvit en el PMV de 53 milions, donant-se un enfrontament entre diversos regidors, ja que davant les reivindicacions veïnals com la dels veïns de Can Franquesa el Patronat sempre s'havia declarat deficitari per no haver-les d'assumir ${ }^{1557}$. Davant d'aquests esdeveniments no es d'estranyar que la Comissió de Partits fes públic un document on s'exigia la celebració d'eleccions municipals d'una vegada per totes:

"La CMPP de Sta. Coloma consciente de la delicada situación del país, agravada por la crisis económica, y del deterioro de las condiciones de vida en nuestra ciudad, exige la inmediata convocatoria de elecciones municipales que abran los Ayuntamientos al aire renovador y democrático que el pueblo expresó el 15 de junio."1558

Uns mesos després la mateixa Comissió de Partits es reunia amb Blas Muñoz

1553“RSC defiende a concejales con pasado franquista”, Tele/ eXprés, 11-10-1977; Josep Tordera: "Reforma Social defiende a sus concejales", Mundo Diario, 11-10-1977 i “Triunfó la demagógia en el Pleno Municipal, Tele/ eXprés 18-10-1977. És molt interessant veure un opuscle editat per Reforma Social Catalana de quatre pàgines on surt tot aquest assumpte i carrega apart de contra Blas Muñoz, contra PSC i PSUC per "protegir-lo". Veure [RSC]: ¿Qué pasa en Santa Coloma?, AHMTB, Donació Mn. Josep Catà, Caixa 1. Reforma Social Catalana era la sucursal de Reforma Social Española, partit polític fundat al 1976 per l'antic dirigent franquista Manuel Cantarero del Castillo. Després del fracàs electoral de juny de 1977 es va acabar dissolent a l'octubre de 1977. Els regidors colomencs esmentats eren el Sr. Torralba, pel Tercio Familiar i els Srs. Pérez Terol i Pérez Jerez pel Tercio Sindical.

1554 Les dificultats financeres van ser comunes a tots els municipis de la Catalunya urbana. Veure Martí Marín: Els Ajuntaments franquistes a Catalunya..., p. 462-467.

1555 "Santa Coloma pierde el derecho a tener un paseo" i "La comisión, pesadilla de los concejales", Tele/ eXprés, 25 i 29-11-1977.

1556Marcelo López Ródenas: Historia social de la Santa Coloma Moderna..., p. 261.

1557“A causa del superávit suspenden el pleno”, Tele/ eXprés, 1-3-1978.

1558Comisión Municipal de Partidos Políticos de Santa Coloma de Gramanet: PSC-PSOE-PSUCMCC-OIC-PTE-CDC-ER: "Por la convocatoria immediata de elecciones municipales", AHMTB, Donació Marcelo López Ródenas, Caixa 3. 
per exigir-li entrar a la Comissió Municipal Permanent, petició que, com era previsible, no va ser satisfeta ${ }^{1559}$. Al 13 de juliol l'Ajuntament aconseguia aprovar un pressupost ordinari de 565 milions de pessetes. Al mes d'octubre, després de diversos intents dimitia el regidor Rosset que sustentava la Tinència de Cultura, que de fet ja havia presentat dos altres intents de dimissió als mesos de juny i juliol $^{1560}$. El substituïa el polèmic regidor Manuel Matés (que tot i declarar-se "joseantonià" havia fet una política d'oposició populista dins l'ajuntament durant els darrers anys de la dictadura), però no va arribar a ostentar el càrrec ni 3 setmanes ja que va dimitir abans d'acabar el mes de novembre ${ }^{1561}$. Cap altre regidor va voler assumir aquesta responsabilitat, segurament per que això implicava haver de fer front a la potent Comissió d'Ensenyança formada per AVV's. AMPES, partits polítics i altres entitats. Al desembre dos tècnics municipals van ser apartats dels seus llocs de treball per corrupción ${ }^{1562}$. Amb l'any nou l'ambient ja estava impregnat de les properes eleccions municipals.

A Sant Adrià de Besòs la situació dins el consistori va ser, com ja he dit, menys convulsa que a les seves veïnes. Des de juliol de 1977 els representants del PSC, del PSOE, del PSUC i de CDC participaven a les Comissions de Treball de l'Ajuntament ${ }^{1563}$. Al mes de setembre començava a funcionar una Comissió de Control i Informació Municipal amb la participació dels diferents partits polítics ${ }^{1564}$. Aquesta Comissió va anar fent, però al mes de març va haver una greu crisi quan els partits socialistes (PSC-C i PSOE encara estaven en el procés de confluència) van decidir suspendre la seva participació criticant tota una sèrie de mancances: que no havia pogut participar en els òrgans de decisió de l'Ajuntament (permanents i plens), que la revisió del cens electoral s'estava fent al marge de la Comissió, que les propostes de la Comissió no havien estat tingudes en compte, que l'Ajuntament

1559“La comisión de partidos exige poder decisorio”, Tele/ eXprés, 20-5-1978.

1560 “Santa Coloma, sin ponente de Cultura”, Tele/ eXprés, 6-10-1978.

1561 "Matés acepta la ponencia de Cultura" i "En Santa Coloma faltan tenientes de alcalde", Tele/ eXprés, 3 i 21-11-1978.

1562Els sancionats eren Antonio Maria Puente i Blas Puig Salvat, "Dos técnicos municipales, "apartados" en Santa Coloma", Tele/ eXprés, 16-12-1978.

1563J. González Hergueta: "Sant Adrià de Besós: Representantes de PSC-PSOE, PSUC y UDC participarán en las comisiones de trabajo del Ayuntamiento", La Vanguardia Española, 22-71977.

1564J. González Hergueta: “Inicia su actividad la Comisión de Control”, La Vanguardia Española, 119-1977. 
havia aprovat la presència en el consistori d'un grup feixista (el Circulo de Acción Hispánica) i, que en el fons, s'estaven prenent les decisions importants al marge d'aquesta Comissión ${ }^{1565}$. No he pogut trobar més detalls sobre el funcionament d'aquesta, però pel que fa Sant Adrià de Besòs crec que es significatiu que el darrer Alcalde del franquisme en comptes d'anar a la llista d'UCD, fos el cap de llista de CiU a les municipals de 1979. En les poblacions més petites no pocs membres dels consistoris franquistes van passar a militar a aquesta formació política.

La proximitat de les eleccions municipals va marcar, sens dubte, el tempo polític a nivell local apart d'altres temes que s'estaven dirimint a nivell d'estat com era el de la Constitució. El govern de la UCD, conscient que eren les eleccions més difícils pel seu partit i on podrien exercir menys influència des de tot l'aparell de l'Estat, va anar-les retardant progressivament. Alhora, els mateixos partits polítics d'esquerres eren conscients de que era on podien obtindre els millors resultats, i per això, malgrat la participació en Comissions de Control, van fer una política d'assetjament de les Corporacions Locals, donant suport a les mobilitzacions veïnals o demostrant un renovat interès per ser present de nou en aquestes entitats si bé aquest podria respondre als motius que ja havia exposat Jordi Borja. Un document del Govern Civil apunta en aquesta direcció:

"Se ha tenido conocimiento en círculos políticos y económicos que las Asociaciones de Vecinos van a ser potenciadas por el PCE, lo que se interpreta en los medios consultados como un amplio giro en la política que dicho Partido venía propugnando respecto a las asociaciones ciudadanas.

El anuncio de dicho proyecto se incluye en un amplio informe político que el PCE ha difundido últimamente entre las bases de su organización, en que analiza asimismo, aunque someramente, temas como la situación política del país, las próximas elecciones sindicales, las relaciones partido-sindicato y las tareas a desempeñar por el partido frente a las elecciones municipales.

En principio, diversos portavoces comunistas habrían manifestado que las Asociaciones de vecinos deben quedar configuradas como meramente reivindicativas y no gestoras, labor que se dejaría a los entes del gobierno que se crearan."

1565J. González Hergueta: "Crisis en la Comisión de Control Municipal”, La Vanguardia Española, 29-3-1978.

1566 Gobierno Civil de Barcelona: "Informe político del Partido Comunista de España", AHGCB, Fons Gobernadores Civiles, Caixa 408, CG 194. III Asociacionismo y partidos políticos 1978-1980, p. 1. 
Sigui com sigui, el cert és que els partits polítics d'esquerres van dedicar molts esforços a les eleccions municipals. I en aquest esforç es van veure implicats molts líders veïnals que tenien militància política, ja fos per que eren de determinats partits o per que se sentien propers. Com veurem a continuació trobarem sovint líders veïnals en les llistes electorals.

A Badalona el PSUC havia tingut una gran implantació dins el moviment veïnal, per tant, no es d'estranyar que a la seva candidatura estigués farcida de militants veïnals. Començant pel mateix Màrius Díaz, el cap de llista, que s'havia significat a l'AVV del Centre. Però era en els barris perifèrics, els que havien estats pioners en el moviment veïnal on es veia més clarament aquest fet. Alfredo Amestoy, que havia militat activament a l'AVV de Sistrells ocupava el segon lloc i Manuel Armentero, President fins aleshores de l'AVV Juan Valera era el tercer. Pedro Jesús Fernàndez, President de l'AVV de Sant Mori de Llefià ocupava el setè lloc com a independent, Julio Molina, de l'AVV de la Immaculada ocupava el novè, Jaume Solà, de l'AVV Centre el desè i Ángel Navarro, veterà militant del PSUC que havia participat també a l'AVV Juan Valera n'ocupava el 13è. El pes de la gent que militava al "front de barris" era més que evident, tal com ens ho recordava el propi Màrius Díaz:

"Tot, tot era moviment veïnal (...) La feina que feien... Jo per que estava al Centre però l'Amestoy, l'Armentero, el Pedro Jesús, el Juan Cabello, el Gómez Alba... tots estaven... i vam primar la gent que estava més en contacte amb el moviment veïnal"1567

Ell mateix ens explicava com van ser precisament dos dels líders veïnals del PSUC els que li van venir a proposar que encapçalés la candidatura del PSUC:

"I no se qui ho va proposar però em van venir a mi a veure a casa recordo que va venir l'Alfredo Amestoy, el Manolo Armentero i no recordo qui més (...) Van triar l'Alcalde, el que seria candidat. Em van venir a proposar-lo i jo però si jo estava treballant de 'representant del capitalisme'!... si treballava en una empresa capitalista que era el director! No, no no... però al final la Teresa, que també va col·laborar amb ells, pues em va... [convèncer]. Si, però bueno, no guanyarem (...) Bueno, m'ho van proposar i si, vaig acceptar. Aleshores bueno, van confeccionar la llista entre tots, va haver-hi una certa discussió en l'ordre, el primer, el segon... com es feia, si aquest si i aquest no (...) Bueno vaig acceptar i vam muntar la llista de candidatura, vam fer la llista tenint en compte

1567Entrevista amb Màrius Díaz Bielsa, 28-6-2013. 
totes les persones que més o menys crèiem que eren les idònies per estar allà, es va aprovar en assemblees, en reunions, en... i bueno, va quedar una llista que va ser aquesta, si, si... (....)"1568

Altres candidatures badalonines també van tenir una notable presència de persones que havien destacat en el moviment veïnal. Per exemple, el PTC, els seus números 1 i 2, Francisco Muñoz Morilla i Francisco Macareno Ruiz s'havien significat notablement a Llefià i a l'AVV de Sant Mori, igual que la número quatre, Maria Relles Bellido Jaime (que alhora estava casada amb Francisco Macareno). A la llista del PSC-PSOE també hi havien els pocs socialistes que s'havien destacat dins algunes AVV's com Desiderio León al quart lloc (AVV del Congrés) o la futura alcaldessa Maite Arqué al setè (AVV del Centre). A la llista del MCC-OEC hi destacaven també l'advocat Francesc Arnau Arias en segon lloc (com a independent i que era molt conegut per haver defensat a moltes AVV's en judicis) i Antoni Agudo Tuñón en el cinquè (President de l'AVV Sant Antoni de Llefià). A la llista de la LCR destacava el segon lloc de Jordi Dauder Guardiola (que posteriorment serà un actor conegut), el tercer d'Enrique José Elejalde de Poncorvo i el 13è de Maria Estela Fernández Morán (tots dos eren mestres i havien destacat, com Jordi Dauder, en les lluites per aconseguir l'Escola Llibertat, on van participar molts veïns de Sant Crist i Bufalà). Per últim, la llista de "Comunistes de Catalunya" era encapçalada per Miguel Ordoñez Ortega, militant de l'OCE-BR i President de l'AVV del Congrés ${ }^{1569}$.

Aquest fet el trobem també a les llistes electorals de Santa Coloma de Gramenet. Començant per la del PSUC, on el seu cap de llista, el sacerdot Lluís Hernàndez ja s'havia guanyat un nom per la seva militància veïnal al barri de Les Oliveres. Aquest ens explicava com va decidir-se per la militància en el PSUC i el paper que va jugar un dels promotors de "Cristians pel Socialisme":

"Doncs escolta, jo em vaig trobar amb mans d'aquesta gent sense adonar-me'n, per que jo els tenia confiança per que ells me'n donaven de confiança fins que un dia vaig descobrir que eren del PSUC. I ells m'ho van confessar. I jo vaig dir 'expliqueu-me que és això del PSUC...' I m'ho van explicar i em va agradar. I em van dir 'tu també hi

1568Entrevista amb Màrius Díaz Bielsa, 28-6-2013.

1569Les llistes electorals es poden consultar a AHMB, Fons Col-leccions Factícies, Caixa C20, Carpeta Eleccions Municipals 1979. Paperetes. 
podries ser-hi, eh?', 'jo?, m'acceptaríeu a mi?... bueno pues vinga, feu-me!'. Em van donar la fitxa i em van fer omplir la fitxa i ja està, inscrit al PSUC. (...)

Com que jo tenia recels i tenia por, vaig dir 'ells m'han acceptat però no m'acabo de fiar...' I vaig anar al [Alfonso Carlos] Comín i vaig dir 'Comín, passa això...'. El Comín em va explicar tota la nova apertura del Partit Comunista (...) em va parlar de l'eurocomunisme, em va parlar de que el partit havia de ser democràtic i que ells no renunciaven per res a la democràcia, ni un pas enrere. La democràcia era un dels objectius (...). Llibertat, amnistia i Estatut d'Autonomia... Després tota la lluita popular a Barcelona es va concentrar en aquestes..." ${ }^{1570}$

De fet, la idea original del PSUC colomenc era que el cap de llista fos el Xavier Valls, que havia tingut un paper destacat en la confecció del Pla Popular:

"Al Lluís [Hernández] quan el PSUC li proposa... el Xavier Valls renuncia a ser candidat, llavors el Chema [Corral] i el Comitè Local li proposen al Lluís... en Lluís ve a la comunitat cristiana i ho planteja... I la comunitat cristiana li dona el vist-i-blau, només faltaria. Però fa una proposta... 'mira, m'han proposat això ho tinc que acceptar o no?' Es discuteix a la comunitat de base (...). Per tant, hi havia aquesta influència del pensament cristià i humanista... I això s'ha notat molt molt (....."1571

A la mateix a llista, com a independent, ocupava el lloc novè Jaume P. Sayrach, sacerdot del Fondo i que havia estat molt implicat en les lluites veïnals i en la creació de Grama, així com moltes persones conegudes dels diferents barris de la ciutat, com Antonio Titos al lloc cinquè (havia estat vinculat a l'AVV del Rio), Francisco Téllez al 17è (AVV Centre), Matías Álvarez al 23è (AVV Les Oliveres) o Epifania Roman Rodríguez al 27è (vinculada al barri Llatí) ${ }^{1572}$.

A la llista del PSC-PSOE destacava el número 3 de Ricard Bonet, President de l'AVV del Rio. Associació que també va ajudar a fundar Antoni Antonijuan, exsacerdot que anava al 13è lloc i que també havia participat en la fundació de Grama. Entremig hi havia Pilar Puig al cinquè lloc, que havia contribuït a fundar el Centre Social del Singuerlín. I Joan Carles Mas, al setè, que també havia col·laborat

1570Entrevista a Lluís Hernàndez i Alcasser, 5-6-2013.

1571Entrevista a Fernando Saro, 22-5-2013.

1572 Veure Llista electoral del PSUC a les eleccions municipals de Santa Coloma de Gramenet de1979, AHMTB, Donació Mn. Josep Catà, Caixa 3. Sóc conscient que em deixo noms d'aquesta llista que també podien estar vinculats a AVV's, però no he pogut contrastar la informació sobre tots. 
amb Grama fins l'any $1975^{1573}$.

Al PTC hi figurava al segon lloc de la llista Pedro Rodulfo Paredes, un dels fundadors i president del Centre Social Arrabal de Santa Rosa. A la llista del MCCOEC hi havia també persones molt actives dintre de les AVV's d'aleshores. Començant per la cap de llista Gabriela Serra, que havia estat Presidenta de l'AVV de Singuerlín, o José Pitarque i Maㅡ Elvira Ruiz, als llocs cinquè i sisè (vinculats l'AVV del Raval) ${ }^{1574}$. També existien persones vinculades a les AVV's a la llista de “Comunistes de Catalunya (OCE-BR) com el cap de llista Eugenio Gómez Serrano, que tenia relació amb l'AVV del Fondo ${ }^{1575}$.

Per últim, a Sant Adrià de Besòs també trobarem persones procedents del moviment veïnal en les llistes de diferents partits polítics. A la del PSC-PSOE el seu número 1, Agustí Gallart, havia participat destacadament a l'AVV de Sant Adrià Nord. La llista de CiU comptava també amb dos persones d'aquesta associació als llocs segon i tercer: Jaume Vallés i Ma del Carme Violant. Però era sens dubte la llista presentada pel PSUC la que tenia més persones que haguessin estat vinculades amb el moviment popular ciutadà. La número dos, Maria Codina, estava a l'AVV del Besòs. El tercer era Juan Ponce, de l'AVV La Mina (fixem-nos que al segon i tercer lloc hi ha membres de les AVV's més potents de Sant Adrià). Al sisè lloc estava Miguel Puerma, de l'AVV Sant Joan Baptista. Al desè Vicente Ponz, de l'AVV La Mina. A l'onzè Maria Tortajada, de l'AVV Sant Joan Baptista. El 17è era Gabriel Manzaneda, de l'AVV Sant Joan Baptista. Un cas apart -si més no pel seu "currículum" és el d'Alfonso Chaos, antic Alcalde de Barri i President de l'AVV de La Catalana, que anava de número ú a la llista de Coalició Democràtica com a militant $\mathrm{d}^{\prime} \mathrm{AP}^{1576}$.

1573 “Quieren una ciudad libre, próspera, y sin clases”, Grama núm. 121 (març 1979), p. 35.

1574Veure Llista electoral MCC-OEC a les eleccions municipals de 1979 a Santa Coloma de Gramenet, AHMTB, Donació Mn. Josep Catà, Caixa 3. Com he dit abans, no he pogut tenir dades de tots els noms de la llista.

1575 Grama núm. 121 (març 1979), p. 13 i Boletín Oficial de la Província (B.O.P.) núm. 55 (5-3-1979), p. 17.

1576Veure les diferents llistes electorals municipals de Sant Adrià de Besòs per l'any 1979 a ASAB, també a Fons Collecció Factícia, Caixa 3. Partits polítics i també a BOP, núm. 55, p. 16. Insisteixo que nombro les persones que he pogut confirmar i que no s'ha de descartar més gent de les llistes que estigués vinculada al moviment veïnal. 


\begin{tabular}{|c|c|c|c|c|c|c|}
\hline & \multicolumn{2}{|l|}{ Badalona } & \multicolumn{2}{|l|}{ Santa Coloma de G. } & \multicolumn{2}{|l|}{ Sant Adrià de B. } \\
\hline & Vots & Regidors & Vots & $\operatorname{Req}$ & Sots & Regidors \\
\hline PSUC & $29.989(34,89 \%)$ & 12 & $26.035(45,31 \%)$ & 13 & $5.276(35,69 \%)$ & 8 \\
\hline PSC-PSOE & $26.623(31,05 \%)$ & 10 & $20.810(36,16 \%)$ & 11 & $5.389(36,46 \%)$ & 9 \\
\hline $\mathrm{CiU}$ & $9.222(10,72 \%)$ & 3 & $3.828(6,65 \%)$ & 2 & $1.716(11,61 \%)$ & 2 \\
\hline CC (UCD) & $7.391(8,64 \%)$ & 2 & $3.226(5,61 \%)$ & 1 & $1.288(8,71 \%)$ & 2 \\
\hline $\mathrm{CD}$ & & & & & $704(4,76 \%)$ & \\
\hline UC* & $3.152(3,44 \%)$ & & & & & \\
\hline PTC & $2.937(3,42 \%)$ & & $1.104(1,92 \%)$ & & $364(2,46 \%)$ & \\
\hline $\mathrm{EI}^{* *}$ & $2.132(2,69 \%)$ & & & & & \\
\hline ERC & $1.536(1,85 \%)$ & & & & & \\
\hline CC (OCE- BR) & $1.536(1,89 \%)$ & & $1.068(1,86 \%)$ & & & \\
\hline MCC-OEC & $638(0,74 \%)$ & & $1.158(2,01 \%)$ & & & \\
\hline LCR & $404(0,47 \%)$ & & $163(0,28 \%)$ & & & \\
\hline Blancs & $263(0,30 \%)$ & & $119(0,21 \%)$ & & $45(0,30 \%)$ & \\
\hline Nuls & $447(0,52 \%)$ & & $187(0,32 \%)$ & & $113(0,76 \%)$ & \\
\hline Electors & 145.369 & & 93.258 & & 25.851 & \\
\hline Participació & $86.359(59,40 \%)$ & & $57.719(61,89 \%)$ & & $14.895(57,62 \%)$ & \\
\hline Abstenció & $59.013(40,60 \%)$ & & $35.539(38,11 \%)$ & & $10.956(42,38 \%)$ & \\
\hline
\end{tabular}

Elaboració pròpia amb fonts diverses.

* Unión de Ciudadanos de Badalona (candidatura promoguda per antics membres de l'Ajuntament franquista encapçalada per Vicente Marqués)

** Entesa d'Independents per Badalona (candidatura encapçalada pel matrimoni Josep Serra Aloy i Cecília March).

Els resultats electorals de les eleccions municipals al Barcelonès Nord van ser una "sorpresa relativa". Poc abans, el 3 de març, s'havien fet les segones eleccions legislatives al Congrés i al Senat -on ara si podien participar formacions que al juny de 1977 encara eren il·legals- i els socialistes van ser la força més votada a les tres poblacions. D'alguna manera, s'extrapolava que el resultat a les municipals podria ser similar, però en aquestes eleccions el vot al PSUC va experimentar un notable augment que li va fer ser la llista més votada a Badalona i Santa Coloma de Gramenet, mentre que a Sant Adrià de Besòs el PSC-PSOE mantenia -per poc- el primer lloc.

Apart d'això, si observem els resultats de les tres ciutats es pot contemplar la força que tenen les forces d'esquerres i els minsos resultats de les dretes, en unes poblacions on les classes treballadores i populars eren una immensa majoria. A tall d'exemple, a Badalona i Santa Coloma no es van poder presentar llistes de Coalició Democràtica. Un segon element a contemplar és l'elevada abstenció, al voltant del $40 \%$. Tot i que es difícil d'interpretar el fet abstencionista, segurament es van combinar diversos factors ${ }^{1577}$.

Un altre fet a valorar és que els resultats dels partits de l'esquerra

1577Una anàlisi d'aquest fenomen a Manuel Justel: La Abstención electoral en España. 1977-1993, Centro de Investigaciones Sociológicas, Madrid, 1995. 
revolucionària no van ser en la majoria dels casos els que s'esperaven els seus membres i que no era proporcional al que consideraven la seva feina militant. Així ens ho reconeixia un dels seus protagonistes:

"Una altra cosa són les eleccions municipals, que jo estant allà currant molt, ella al Fondo i ell a Santa Rosa, vam presentar una llista que va muntar l'MC i al meu barri ens van votar el meu pare, la meva mare, l'Elvira i jo [riu]"1578

Però el cert és que si formacions com el PTC, el MCC, la OCE-BR o la LCR haguessin fet llistes conjuntes, haurien obtingut representació. A Badalona totes aquestes forces sumaven el 6,52 \% dels vots i Santa Coloma de Gramenet el 6,07 \% (per obtenir algun regidor calia arribar al 5 \%). Però les diferències entre elles i els sectarismes existents els van impedir fer-ho. Poc després algunes d'aquestes organitzacions desapareixien, amb dos notables excepcions: MCC i LCR, que encara existiren durant els anys 80 i -la primera sobretot- encara tindran un cert protagonisme en el moviment veïnal. Dit això, faig un esment als primers anys dels Ajuntaments democràtics de les tres ciutats del Barcelonès Nord, sense poder entrar massa en detall. Però trobo que és necessari per contextualitzar els canvis que es van donar al moviment veïnal i la relació que aquest va tenir amb el poder local des d'abril de 1979.

A Badalona, com a la majoria de grans urbs catalanes, el nou Ajuntament democràtic va començar amb l'anomenat "Pacte de Progrés", formalitzat el 19 d'abril de 1979 entre PSUC, PSC-PSOE i CiU. Màrius Díaz esdevenia el primer alcalde comunista, mentre les primeres tinences d'alcaldia eren assumides per Joan Blanch (PSC-PSOE), Alfredo Amestoy (PSUC) i Pere Sió (CiU) ${ }^{1579}$. El primer Ple es va fer el dia 27 al pavelló municipal de La Plana ple de gom a gom. Els nous membres de l'Ajuntament es van trobar amb una situació força complicada.

1578Entrevista a Josep Pitarque Narejos, 12-3-2013 (feta col-lectivament amb Marcelo Lólpez Ródenas, Salvador Bolancer Dugo i Emiliana Salinas). Pitarque va ser President de l'AVV del Raval i militant del MCC.

1579Les Tinències d'Alcaldia corresponien a Joan Blanch (PSC-PSOE), Alfredo Amestoy (PSUC) i Pere Sió (CiU). El cartipàs quedava així: Urbanisme: Jaume Solà (PSUC); Ensenyament: Joan Soler i Amigó (PSUC); Hisenda: Enric Flo (PSC-PSOE); Règim Interior: Juan Felipe Ruiz (PSCPSOE); Serveis Municipals: Justo Pageo (PSC-PSOE); Ecologia i Medi Ambient: Toni Barberà (PSUC); Sanitat: Joan Monés (CiU); Descentralització i Participació Ciutadana: Manuel Armentero (PSUC); Treball i Foment: Cipriano López (PSC-PSOE); Joventut i Esplai: Julio Molina (PSUC) i Esports: Desiderio León (PSC-PSOE. Veure "Repartidas las competencias en el Ayuntamiento", Solidaridad Nacional, 26-4-1979. 
L'Ajuntament va haver d'intentar solucionar o si més no pal-liar problemes molt greus existents en àmbits tant importants com l'educació, la sanitat, l'urbanisme, la greu contaminació, les precàries finances locals (condicionades per la legislació local franquista que era molt restrictiva pel que feia a on i com es podien gastar els diners, vigent fins 1986) i la profunda crisi econòmica que estava fent créixer l'atur d'una manera alarmant.

Algunes de les seves primeres actuacions van ser, si es vol, simbòliques, però amb un significat molt especial després de tants anys de dictadura. El 27 d'abril s'aprovava un nou nomenclàtor de carrers. Al cementiri s'eliminava el "Panteón de los Caídos" i es convertia en un lloc per a tots els morts de la guerra civil. També s'enderrocava el mur que separava als no catòlics de la resta dels morts. Aviat es va recuperar el monòlit de Can Solei ${ }^{1580}$. El 3 de desembre es demolia el "Monumento a los Caídos" que existia a l'actual plaça de La Plana ${ }^{1581}$. Aquest fet, juntament amb la seva militància comunista va fer que l'alcalde rebés nombroses amenaces de grups d'extrema dreta i que en vàries ocasions s'atemptés contra el seu domicili amb artefactes incendiaris, com ens ho recordava ell mateix:

\footnotetext{
"Però bueno, unes vegades hi van calar foc i... (...) No recordo exactament... Una vegada van calar foc a la porta i els vidres, teníem una vidriera així de colors... es van agrietar però no va entrar foc a dintre, per que va donar la puta casualitat que va passar un tio que era de la UGT, com es deia? si... va veure això i va treure els papers a fora i no va calar foc a dintre. No se qui, no ho podíem saber..." ${ }^{m 52}$
}

Pel que fa l'educació, la manca de places escolars era molt greu a tota la ciutat. Des de l'Ajuntament es va pressionar al Ministeri d'Educació i Ciència per que construís les escoles que feien falta i les dotés del personal docent i auxiliar necessari. Es va haver d'anar diverses vegades a Madrid a negociar ${ }^{1583}$, però també es van convocar des de l'Ajuntament manifestacions com la que es va fer el dia 26 de maig i que va aplegar sis mil persones ${ }^{1584}$. Es feien per pressionar i/o davant les visites d'alguna autoritat governamental, aprofitant els contactes que encara es

1580Joan Roura: “Can Solei recupera su monolito", Mundo Diario, 8-5-1979.

1581Joan Villarroya (dir.): Història de Badalona, p. 233.

1582Entrevista amb Màrius Díaz Bielsa, 28-6-2013.

1583 Carlos Gómez Alcozar: "Que el Ministerio construya las escuelas pendientes", La Vanguardia, 10-6-1979.

1584Joan Roura: “Seis mil personas por la escuela gratuita”, Mundo Diario, 29-5-1979. 
tenien els antics líders veïnals ara membres del consistori:

"Home, jo recordo amb la lluita de l'hospital, dels col·legis i tal los mariachis... 'Manolo, los mariachis!' Manolo Armentero en la Salut. Manolo en 5 minuts et treia 4.000 persones al carrer. Anava allà i 'eh, compañero! i tal i qual ', el coneixia tothom. Òstia, la Salut! Llavors el Juan Cabello, el que vulguis! Al barri eren líders veïnals. Estaven a les Associacions de Veïns, són els que aixecaven la ma... i a vegades feien demagògicament segons quines coses però les tenien que fer també. I la gent els seguia! 'Manolo los mariachis' per l'hospital vam fer-lo unes quatre o cinc vegades. Una vegada el Ministre a l'autopista van entrar per Sant Roc i van entrar per el Centre, i vam baixar al Ministre i vam dir que potser no podia pujar per que no podia entrar ni per aquí ni per allà... Bueno, vale, i va parlar, amb els veïns... I el Mario immediatament cap allà!, En moto o en lo que fos! Ummm! Immediatament cap allà! Anava en moto o en el que fos (...) no m'agraden cotxes oficials ni òsties d'aquestes... vale?"1585

Fins i tot els membres del consistori van arribar a fer tancades dins les dependències municipals com a signe de protesta per demanar la dimissió del Ministre d'Educació ${ }^{1586}$. En la manifestació unitària que culminava la campanya feta a Barcelona van ser detinguts 14 mestres i el regidor d'ensenyament badaloní, que no era un altre que Pedro Jesús Fernàndez (l'antic president de l'AVV de Sant Mori), va ser agredit i colpejat per la policia ${ }^{1587}$. Tot i les dificultats, en els anys d'aquest primer consistori es van inaugurar moltes escoles i parvularis de manera que, si més no pel que fa a l'ensenyament primari obligatori d'aleshores (l'EGB), el dèficit de places escolars es va anar solucionant de manera progressiva (mentre que en altres franges d'edat la situació encara va estar lluny d'estar resolta). Per ajudar en aquesta tasca el mateix Ajuntament va crear l'Institut Municipal d'Educació $(\mathrm{IME})^{1588}$.

Les places hospitalàries per una ciutat de més de 220.000 habitants eren ridícules i faltaven Centres d'Assistència Primària en condicions a molts barris. Les dificultats pressupostàries i legals eren enormes. Els Ajuntaments -i Badalona no era una excepció- tenien uns pressupostos molt migrats i hipotecats pel deute acumulat d'etapes anteriors. Sense comptar que la legislació vigent d'aleshores no

1585Entrevista amb Màrius Díaz Bielsa, 28-6-2013.

1586“Diversos encierros por el tema de los maestros”, El Correo Catalán, 7-9-1979

1587 Pol Ferrán: “Una manifestación colapsa la autopista de Mataró" i "Catorce maestros detenidos durante una manifestación”, El Correo Catalán, 18-9-1979 i 7-10-1979. 1588Joan Villarroya (dir.): Història de Badalona, p. 236. 
atorgava massa competències als Ajuntaments. No es podien obtenir nous préstecs del Banco de Crédito Local i els recursos de la Diputació estaven centrats aleshores en sostenir les finances de la Generalitat provisional. La mateixa Diputació no va començar a actuar seriosament en aquest àmbit fins 1981 mentre que, la nova llei de règim local i el nou finançament no van arribar fins $1986^{1589}$. Tot i això es van aconseguir algunes millores. Es va crear una àrea específica de Sanitat per fer front al problema. L'Hospital Municipal, que estava en una situació lamentable, va tenir importants canvis. D'entrada el seu administrador va ser cessat de manera fulminant a finals del mateix mes d'abril ${ }^{1590}$. Més complicat va ser aconseguir que es posés en marxa el gran hospital que s'estava construint des de els anys setanta als terrenys on estava l'antiga masia de Can Ruti. Aquesta obra faraònica heretada dels Ajuntaments franquistes havia generat molta polèmica en el seu moment com ja vaig mencionar. Però encara va ser motiu de tensió fins entrat als anys vuitanta. La seva ubicació en una zona de muntanya allunyada de la ciutat va ser un problema afegit per les dificultats d'accés que presentava. L'Ajuntament reclamava al Ministeri sense gaire èxit, però la situació no es va començar a solucionar fins que no es va aplicar una mesura de força:

"I ve un dia el Perdigó i ... 'Màrius, he trobat unes coses però amb la llei aquesta de no se què no se quantos (...)'. Se'n va l'home -era el meu Secretari particular, eh?- Se'n va a l'Esteve Gaixa i baixen al cap de mitja hora tots dos... 'Senyor Díaz, ja ho tenim, miri!. La cessió de no sé quants, la llei de no se quantos... miri. (...) Textual i senyalat en el llibre 'Si transcurridos diez años desde la donación no está en pleno funcionamiento lo donado (...) revertirà al donante con sus pertenencias y accesiones'. Això se'm va quedar gravat al cul, eh? 'Con sus pertenencias y acesiones'. Això vol dir... Exactament! Quants anys? Deu anys, havien passat onze i mig que havíem fet la cessió. Va documents! Comprovat. Si, si... buscant tota la documentació antiga, de l'Antoja i tal... estava el mateix Secretari (...). Fecha tal, transcurridos once y medio. Nuestro! Qué mas? 'Revierte automáticamente en (...)'. Tot això que es refereix a lleis vam estar mirant i pam, pam, pam... 'revierten al donante...' I el donante qui és? L'Ajuntament, Felipe Antoja Vigo, l'Alcalde.

Escric una carta a Madrid... se'ns pixen... No ens diuen res. Lo que ens diuen que butifarra. Senyor Gaixa, Perdigó, companys, què podem fer? Nos lo quedamos, lo

1589 Informació subministrada pel meu director Martí Marín en el seu treball inèdit sobre la Diputació de Barcelona 1977-1987.

1590“Cessat l'administrador de l'hospital de Badalona”, Avui, 1-5-1979. 
tomamos. Qué hay que hacer? Vamos a tomar posesión. 0 sigui, no tenien cap intenció d'obrir-lo. Agafem un dia... demà passat a les 11 , les 9, les 10, la màquina excavadora, el Secretari... jo ho feia molt per que amb el bingo que vam tancar portava la Secretària de l'Ajuntament, el Secretari de l'Ajuntament, la meva Secretària particular i els dos assessors meus i el Perdigó. Ens en vam anar a Can Ruti l'arquitecte municipal, el cap de la Brigada, la màquina excavadora, una retro d'aquelles..., el camió, es va anar a dalt...

Què tenim que fer? Lo primer de tot... la Irene, la Secretària... 'El senyor Alcalde ha de dir 'abran la puerta". 'Abran la puerta!'. No hi havia ningú... 'Nadie abre la puerta'. Nadie abre la puerta... 'El señor Alcalde procede por segunda vez, por tercera vez. Ha llamado tres veces y no responde nadie...'. El senyor Alcalde que ha de fer... 'cridar al cap de la Brigada, no al Arquitecto...'. 'Señor arquitecto municipal, procedan al derribo de la puerta por cuanto....'. Bueno tal i cual (...). 'Señor jefe de la Brigada, proceda al derribo de la puerta'. El señor jefe de la Brigada al maquinista... 'Señor maquinista, derribe la puerta!. Bruummm!! La porta avall!. 'En este momento tomamos posesión de ...' I ho comuniquem al Ministeri. Òstia! Ja estava fet!! Propietat de l'Ajuntament, con sus pertenencias y accesiones, tot! Els llits amuntegats sense desplegar... (...) tot lo que hi havia, tot propietat... Això no ha sortit mai, ni ho saben els que estan allà, ho sabia el primer director que hi va haver, però ja... bueno..."1591

La sanitat estava traspassant-se a la Generalitat. Això va ser aprofitat per l'Alcalde badaloní per negociar amb Jordi Pujol per que aquesta institució adquirís i administrés l'Hospital, al qual va batejar, no sense intenció “Germans Tries i Pujol” (uns metges badalonins dels anys 20-30 que eren família de Ramon Trias Fargas). Finalment l'Hospital Germans Tries i Pujol va ser inaugurat parcialment l'abril de 1983, si bé encara va haver de passar uns anys per que funcionés de manera plenament operativa i tingués tot els seus accessos en condicions ${ }^{1592}$. En un altre àmbit també relacionat amb la sanitat, a finals de maig, una visita per sorpresa de l'Alcalde a l'escorxador municipal posava en evidència les greus irregularitats que allà existien amb el registre de la carn dels animals i en les seves condicions higièniques $^{1593}$.

1591Entrevista amb Màrius Díaz Bielsa, 28-6-2013.

1592 “Pujol i Laporte van inaugurar ahir la residència de Can Ruti”, Avui, 15-4-1983. El nom, però no va fer fortuna i l'Hospital sempre ha sigut conegut popularment com "Can Ruti", fins al punt que si una persona pregunta a algun badaloní o badalonina per l'Hospital Germans Tries i Pujol, hi ha possibilitats que li diguin que no coneixen aquest hospital.

1593Joan Roura: "El matadero almacena corrupción", Mundo Diario, 24-5-1979; Carlos Gómez Alcózar: "El matadero adolece de control sanitario y administrativo", La Vanguardia, 25-5- 
La preservació del medi ambient i la lluita contra la contaminació va ser un tema molt important al qual va haver de fer front el nou Ajuntament. L'elevat número d'indústries existents feia que l'atmosfera de la ciutat tingués uns grans índexs de contaminació fins al punt que la ciutat va ser declarada "zona contaminada" al febrer de 1980 i que les platges estiguessin en tal mal estat que s'havia prohibit el bany. Es va crear la regidoria de Medi Ambient, la qual va haver de litigar amb les nombroses indústries contaminants existents a la ciutat (destacant la CAMPSA, que tenia uns dipòsits i un pantalà de descàrrega de vaixells a la platja i la CROS, S.A.). Es van iniciar les gestions per crear un futur parc forestal a l'entorn del monestir de Sant Jeroni de la Murtra ${ }^{1594}$. Es van començar les obres del Col-lector de Llevant, que havien de portar les aigües residuals que fins aleshores s'abocaven directament al mar, cap a la futura Depuradora del Besòs.

L'urbanisme era un altre dels dèficits més importants, en especial a les barriades perifèriques. Es va fer un gran esforç, tot i la migradesa del pressupost, en arranjar les deficiències que tantes protestes havien provocat els anys anteriors $^{1595}$. Es va intentar dotar als barris dels equipaments que eren tant necessaris i fins i tot en alguns casos l'Ajuntament va intervenir per solucionar els conflictes amb les immobiliàries. La conflictivitat veïnal va disminuir notablement. Però no va desaparèixer totalment i van existir alguns conflictes que van desgastar al consistori, com va ser el que va enfrontar al "Patronato Municipal de la Vivienda" amb un grup de veïns del barri de Sant Roc -en concret del polígon del Maresmeque havien protagonitzat ocupacions d'habitatges a finals dels setanta i que mantenien una vaga de lloguers. Fins i tot un inquilí amenaçat de desnonament va morir d'un atac de cor quan va rebre la notificació al respecte (al final l'Ajuntament va acabar tirant-se enrere) ${ }^{1596}$. També va existir un conflicte similar a Llefià amb

1979 i entrevista amb Màrius Díaz Bielsa, 28-6-2013.

1594Carlos Gómez Alcózar: "Trámites para constituir un gran parque forestal”, La Vanguardia, 7-81979.

1595Joan Villarroya (dir.): Història de Badalona, p. 234.

1596Enric Giralt: "Sepelio del badalonés que murió del disgusto ante un desahucio", El Periódico de Catalunya, 5-10-1982. L'Ajuntament de Badalona va haver d'administrar un PMV en números vermells i va interposar una denúncia contra els seus antics administradors. Veure "Querella de D. Mario Diaz Bielsa, Alcalde-Presidente de Badalona, contra D. José Guillen Clapés y otros, por delitos de estafa, apropiación indebida y malversación de fondos públicos" (7-4-1981), AHGCB, Gobernadores Civiles. Caja 665. CG: 39. Ayuntamiento de Badalona 1979-1982. El document està adjuntat a una carta adreçada al Gobernador Civil pel Diputat Provincial Ferran Foix i Carbó. 
uns edificis del Patronat però en aquest cas es va arribar més fàcilment a una entesa.

Un cas molt emblemàtic va ser l'enderrocament d'un edifici situat a Dalt de la Vila, a l'actual plaça Font i Cussó, que havia estat declarat il·legal pel Tribunal Suprem i finalment demolit als mesos de novembre i desembre de 1981. També va ser molt comentat en el seu moment la clausura d'un bingo al carrer Alfons XIII declarat il-legal el 3 de maig de 1982 i que tenia connexions amb el Club Juventut de Badalona. Va haver-hi un greu litigi amb els seus propietaris i amb els treballadors d'aquest que van fer mobilitzacions fins al punt que van ser denunciats pel mateix alcalde per no permetre "el lliure accés a l'Ajuntament" ${ }^{1597}$. La urbanització il·legal de "La Vallensana", situada entre els termes de Badalona i Montcada i Reixac va esdevenir una font de conflictes, ja que mentre no es va arribar a un acord al març de 1983 de suspendre el litigi durant 75 anys els seus habitants van protagonitzar manifestacions a la ciutat ${ }^{1598}$. La futura construcció i ubicació del Mercat de La Salut també va provocar un enfrontament entre l'Ajuntament i els paradistes de l'antic "mercadillo" de La Salut que havien de beneficiar-se de la nova instal-lació. Les diferències sobre l'import que havien de pagar aquests i d'altres disputes van provocar tensions i fins i tot incidents en un Ple Municipal ${ }^{1599}$.

A nivell urbanístic va ser important el futur de Montigalà, on des de finals dels seixanta existia un projecte de construir una "ciutat satèl·lit" de més de 50.000 habitants. Les mobilitzacions per preservar aquest espai havien començat a la segona meitat dels setanta amb el lema "Montigalà per al poble". L'Ajuntament democràtic va manifestar la voluntat d'alterar aquest projecte, iniciant negociacions amb l'empresa propietària dels terrenys, la CMB i al Generalitat. Finalment el 13 de juliol de 1979 es va signar un acord que contemplava la divisió de les $195 \mathrm{Ha}$ dels terrenys en habitatges (23,80 Ha), indústria (31,66 Ha), equipaments $(47,06 \mathrm{Ha})$, parc forestal $(14,58 \mathrm{Ha})$, zona verda urbana $(33,02 \mathrm{Ha})$, segon cinturó $(13,62 \mathrm{Ha})$ i sector viari $(37,25 \mathrm{Ha})$. Pel mig va esclatar la crisi de

1597 “L'alcalde denuncia als que van manifestar-se", Avui, 2-11-1982 i Joan Vila: "L'afer del bingo s'enverina amb acusacions polítiques" Grama, 2-11-1982, p. 4.

1598El Periódico de Catalunya, 1-12-1982 i El Noticiero Universal, 11-3-1983. 1599 Revista de Badalona, 15-4-1982. 
Banca Catalana, que tenia el $45 \%$ de l'empresa privada Montigalà-Batllòria ${ }^{1600}$. En canvi, per altres persones $\mathrm{i}$ associacions que havien participat en les mobilitzacions, aquest acord era insuficient per que volien la preservació de tot l'espai ${ }^{1601}$.

Les fiances municipals van ser una gran dificultat. S'havien heretat greus problemes del període anterior i una crònica falta de recursos ocasionades en gran part per la mateixa legislació franquista, encara vigent ${ }^{1602}$. Això va provocar tensions entre el consistori i altres institucions, com quan per exemple La Caixa de Pensions es va negar inicialment a concedir un crèdit a l'Ajuntament però al final va canviar d'opinió i va acceptar a fer-ho davant una possible campanya de boicot contra l'entitat ${ }^{1603}$. Notori va ser també el conflicte amb empresaris i comerciants per la pujada d'uns impostos municipals (sobre les escombraries i els guals) que els tribunals van revocar finalment l'any 1983 després d'un llarg litigi ${ }^{1604}$.

No es pot oblidar tampoc la tasca de recuperació del patrimoni històric que es va fer en aquests anys. El 1980 es va aprovar el Catàleg de Patrimoni i es van rehabilitar dues masies de propietat municipal: Can Cabanyes i Can Miravitges. Es va potenciar el Museu Municipal aprofitant i recuperant importants restes ibèriques, com l'estela de Can Peixau o obres romanes que havien estat espoliades al 1940 com la Tabula Hospitalaris, les pollegueres de la porta d'entrada a la ciutat romana i l'estàtua anomenada "la Venus de Badalona"1605. També es va excavar per primera vegada en molt temps el poblat ibèric de Can Buscà i es va començar a recuperar l'important patrimoni romà de la ciutat, com les famoses termes.

Alguns conflictes d'aquells anys van acabar fins i tot amb membres del consistori a la presó. L'enfrontament de l'Ajuntament amb l'empresa TUSA per una pujada de preu del bitllet va acabar amb l'empresonament de la regidora de

1600Màrius Díaz: “El Polígono Montigalà-Batllòria”, El Periódico de Catalunya, 31-7-1982. Veure també El Periódico de Catalunya, 11-11-1982 i El País, 11-11-1982.

1601Colectivo DALP [Despatx d'Assessorament Laboral Popular, on hi participaven un conjunt d'advocats d'esquerres entre ells el ja mencionat Francesc Arnau]: "El Polígono MontigalàBatllòria", El País, 11-11-1982.

1602 Veure nota 1554.

1603 "Roce entre el alcalde de Badalona i "La Caixa"” i "'La Caixa" dice que hay crédito para Badalona", El Periódico de Catalunya, 19 i 20-4-1980.

1604Jordi Martí: "El Ayuntamiento de Badalona debe retornar 150 millones", El Periódico de Catalunya, 14-1-1983.

1605Joan Villarroya (dir.): Història de Badalona, p. 236. 
transports del PSUC Luisa Longas el mes d'agost de 1981 quan va impedir la sortida d'aquests amb la nova tarifa ${ }^{1606}$. Malgrat tot la Generalitat va donar la raó a l'Ajuntament i TUSA es va veure obligada a tornar a les tarifes anteriors. Però el cas més greu va arribar al voltant d'un tema aparentment banal com eren els mitjans de comunicació municipals. El 7 de juliol de 1981 començava les seves emissions Radio Ciutat de Badalona, la primera ràdio municipal. Però la posada en marxa de la Televisió de Badalona -Canal 21- de manera experimental el 26 de maig de 1982 va acabar amb la detenció de l'Alcalde i quatre regidors més quan el Govern Civil va ordenar la seva clausura el mateix dia $27^{1607}$. El govern de la UCD actuava amb els representants de les administracions locals escollits democràticament com una mena de subordinats que -com amb la dictadura- haguessin de tenir una obediència absoluta a les autoritats superiors. Les designades per l'administració central de l'Estat com els esmentats Governadors Civils. De fet s'aprofitaven que continuava vigent la Llei de Règim Local franquista on aquesta subordinació dels alcaldes estava establerta.

Tanmateix va haver-hi innovacions dins l'organigrama municipal, que almenys en teoria volia preveure uns certs mecanismes de participació veïnal per mediar en els possibles conflictes. Es va crear la Conselleria de Descentralització, Participació i Promoció Ciutadana (dirigida per l'antic líder veïnal Manuel Armentero), l'Institut Municipal de Serveis Socials i la primera Oficina del Consumidor creada a l'Estat espanyol ${ }^{1608}$. Més endavant veurem fins a quin punt es va fomentar una veritable participació ciutadana.

Com es pot observar, aquesta primera legislatura no va estar exempta de tensions i conflictes que van afectar als partits polítics i a les relacions entre ells, tot i ser un fet normal en el nou context democràtic. Al març de 1980 Alfredo Amestoy del PSUC dimitia del seu càrrec per ocupar un escó al Parlament de Catalunya. Dos més ho van fer per "assumptes personals" el mateix any (Justo Pageo, del PSC-PSOE per discrepàncies amb el seu partit que va abandonar i Julio Molina, del PSUC, per fer el servei militar). Poc després van haver-hi discrepàncies

1606“El Ayuntamiento demanda a TUSA por desacato a la autoridad”, La Vanguardia, 12-8-1981.

1607Joan Villarroya (dir.): Història de Badalona, p. 236 i Enric Giralt: "Conmoción en Badalona al ser detenido el alcalde", El Periódico de Catalunya, 28-5-1982.

1608Joan Villarroya (dir.): Història de Badalona, p. 236. No obstant, caldria contrastar aquesta informació. 
entre els membres del govern municipal davant la possibilitat de construir un port pesquer. CiU se'n va desmarcar de la proposta per divergències sobre el seu lloc d'ubicació i el pressupost de l'obra ${ }^{1609}$. Més sonada va ser la dimissió del regidor de Cultura Joan Soler i Amigó (que havia anat d'independent a les llistes del PSUC) per les seves discrepàncies en com s'havia fet el nomenament del nou director del Museu de Badalona després de la dimissió del seu antecessor.

El juny de 1981 es trencava el "Pacte de Progrés" i CiU passava a l'oposició quan es va negar a votar els pressupostos municipals. Ja existia una tensió entre aquesta formació i les altres per discrepàncies ideològiques importants. Per posar un exemple CiU va criticar que des de l'Ajuntament s'aprovés una moció en favor de la despenalització de l'avortament. Però va ser sobretot per fets polítics que superaven l'àmbit municipal els que havien condicionat aquesta decisió. El pacte CiU-ERC a la Generalitat sens dubte va influir en que es donés la consigna de trencar els pactes municipals amb socialistes i comunistes. A Badalona l'àrea de cultura va passar a mans del PSUC, Sanitat al PSC-PSOE i s'eliminava la Conselleria de Patrimoni, dividint-se les seves funcions entre Urbanisme i Cultura.

L'escissió del PSUC - de la qual tornaré a parlar- va afectar al consistori badaloní amb la dimissió del regidor de Medi Ambient Toni Barberà i el cessament de dos mes: Juan Gómez i Miguel Guerrero ${ }^{1610}$. El naixement del PCC serà un procés molt tens i conflictiu que va enfrontar a ex-camarades i va deixar moltes ferides obertes.

Finalment, les relacions entre el PSUC i el PSC-PSOE malgrat el pacte de govern van ser complexes i es van anar deteriorant a mesura que s'acostaven les pròximes eleccions. El darrer any de mandat va ser especialment conflictiu i per exemple el mateix Tinent d'Alcalde Joan Blanch va arribar a fer unes declaracions molt crítiques amb el PSUC en un acte electoral de les eleccions al Congrés d'octubre de 1982 afirmant que eren els socialistes "els que estaven governant realment la ciutat" ${ }^{1611}$.

La marxa de dirigents veïnals que hi va haver en aquest període a ocupar

1609Pol Ferran: "El emplazamiento del nuevo puerto pesquero, motivo de tensiones", El Correo Catalán, 28-3-1980.

1610 Revista de Badalona, 30-12-1981; 2, 6/9, 20, 23, 27-1-1982; 6-2-1982; 24-3-1982 i 21-4-1982. 1611 “Obiols participa a un mitin en Lloreda”, Grama (IIona època), 20-10-1982. 
càrrecs de responsabilitat en el nou consistori, convençuts en la majoria dels casos que de la prioritat del treball en les institucions, va afectar profundament al moviment associatiu Badaloní. Això i la convicció de que des de el moviment veïnal no s'havia de qüestionar el poder polític de l'Ajuntament. Però tot això no ens pot fer obviar que ja van produir-se topades entre algunes AVV's i l'Ajuntament, en especial aquelles on militaven gent de partits com l'MCC o d'altres. Un testimoni d'un militant o simpatitzant seu d'aleshores (de la MJCC) és prou significatiu per veure les diferències existents:

"A mi la única vegada que m'han fet fora de l'Ajuntament en una ocupació i he cobrat per això físicament parlant ha sigut en un Ajuntament del PSUC, governat pel PSUC (...) estàvem ocupant el saló de Plens de l'Ajuntament i ens va fotre fora la Guàrdia Urbana i ho va fer el PSUC, no el PSC ni el PP (...) qui va donar l'ordre va ser l'Alcalde el Sr. Màrius Díaz." 1612

A Santa Coloma de Gramenet es va constituir també un "Pacte de Progrés" entre el PSUC, el PSC-PSOE i CiU, si bé eren els dos primers els que tallaven el bacallà. Lluís Hernàndez, sacerdot que havia participat al moviment veïnal al barri de Les Oliveres, esdevenia el primer alcalde comunista de la ciutat ${ }^{1613}$. No era pas l'únic sacerdot en el govern municipal, ja que Jaume P. Sayrach també hi era com a independent en una àrea tant important com Urbanisme. Com a Badalona també es va fer un primer Ple multitudinari al Poliesportiu de Can Sisteré el 27 d'abril de 1979 on Blas Muñoz, el darrer Alcalde franquista, va ser fortament increpat i va haver de sortir protegit per la resta de regidors ${ }^{1614}$.

El nou govern també va actuar contra els símbols del franquisme i va impulsar la retirada del "monument dels caiguts" i un nou nomenclàtor dels

1612Entrevista a Antonio Flores Fernàndez, 6-5-2010. Militant del MCC als anys 80 i posterior President de l'AVV Sant Antoni de Llefià. Li vaig preguntar sobre aquest fet a Màrius Díaz quan el vaig entrevistar i em va afirmar que no recordava aquest incident.

1613 Les diferents àrees del Consistori quedaven així: per al PSUC, apart de l'Alcalde, la Segona Tinència d'Alcaldia (José Manuel Corral); Governació (Enrique Bellette); Joventut (Ramona Oltra); Treball (Rafael Parra); Urbanisme (Jaume P. Sayrach); Ensenyament (Pedro García); Informació i relacions (Carlos Grande); Esports (Máximo Luna). Pel PSC-PSOE quedaven la Primera Tinència d'Alcaldia (Jesús Vicente); Hisenda (Antonio Ortiz); Sanitat (Joan Carles Mas); Cultura (Ricardo Bonet); Serveis Municipals (Anastasio Sánchez)i Habitatge (Camilo Rueda). Per CiU quedava Transports i Circulació (Josep Martinell). Jordi Corachán: “Reparto de carteras con discrepancias entre socialistas y PSUC", El Correo Catalán, 25-4-1979.

1614Jordi Corachán: “El ex-alcalde Blas Muñoz salió llorando y escoltado”, El Correo Catalán, 29-41979; M. Castellón: “Dos mil personas en el primer pleno del ayuntamiento", La Vanguardia 29-4-1979 i “El primer pleno acabó en baile”, El Periódico de Catalunya, 29-4-1979. 
carrers, retolats en català. I ho va fer amb una oposició de grups d'extrema dreta com Fuerza Nueva que tenien una certa implantació en la ciutat. Aquests grups es dedicaven a trencar les noves plaques i van protagonitzar un greu incident quan al 7 de novembre de 1979 es van presentar un grup armat per retre homenatge al monument desaparegut en el que va ser conegut aleshores com la "Marxa Blava". Grups d'esquerra revolucionària els estaven esperant i es van produir enfrontaments on els ultradretans van fer servir armes blanques i de foc i els antifeixistes pedres i còctels molotov. Va haver-hi 5 ferits -entre ells, dos policiesdels quals dos de bala, entre ells Miquel González "Miki", conegut militant de la MJCC. L'Ajuntament i altres forces polítiques van demanar la dimissió del Governador Civil per haver permès aquesta marxa ultradretana i una concentració posterior al fets de partits i grups d'esquerra revolucionària va ser violentament reprimida per la policia ${ }^{1615}$.

Les provocacions de l'extrema dreta no van acabar aquí. El local del PSUC va ser assaltat, Lluís Hernàndez rebia amenaces de mort i el seu cotxe va ser cremat i fins i tot el 23-F va haver-hi un ametrallament amb arma de foc al Consistori quan la situació del cop a Madrid encara era incerta ${ }^{1616}$. Entremig va haver-hi un episodi polèmic -a l'octubre de 1980- de falsa amenaça de bomba contra Lluís Hernàndez ${ }^{1617}$, com ens ho explicava ell mateix:

LLUíS: (...) això s'ha de portar a la policia. Es va portar a la policia i la policia el va examinar i va dir 'si esto es peligroso'. La policia va mirar d'explosionar-lo. L'explosió que va fer el paquet en ser explosionat per la policia nosaltres vàrem creure que era per que contenia un explosiu. I la policia ens va deixar que mantinguéssim l'engany i no va sortir de seguida a dir 'no, això no...no es que el paquet portés explosiu, això es per que nosaltres l'hem explosionat'. Aquesta explicació no ens la va donar la policia.

1615Jordi Corachán: "La marcha azul de los falangistas acaba a tiros", "El PSC pide que dimita el gobernador civil", "Duras críticas a la policia por los hechos del domingo", "Interpelación del PSC por los hechos de Santa Coloma" i "El hombre de la pistola formava parte del grupo de falangistas", El Correo Catalán, 9, 10 i 11-10-1979; "Batalla en Santa Coloma entre falangistas e izquierdistas", "Belloch tocado por los hechos de Santa Coloma" i "Los falangistas detenidos en Santa Coloma, en libertad", El Periódico de Catalunya, 9, 10 i 11-10-1979; M. Castellón: "Cuatro heridos y cuatro detenidos en la "Marcha Azul"', La Vanguardia 9-10-1979. Veure també el reportatge especial publicat a Grama núm. 148 (15/20-10-1979), p. 3-10.

1616J. Corachán: "Asaltan los locales del PSUC" i "Queman el coche del alcalde”, La El Correo Catalán, 30-1-1980, 13-2-1980 i "Ametrallado el ayuntamiento de Santa Coloma”, La Vanguardia, 25-21981.

1617Jordi Corachán: "Desactivan un paquete bomba dirigido al alcalde de Santa Coloma de Gramenet" i "La "bomba" contra el alcalde era un ramo de flores", El Correo Catalán, 18 i 23-101980. 
Nosaltres vàrem creure que... i vàrem fer articles i (...) i al final ens vàrem adonar i la policia ens ho va confirmar de que allò no era cap bomba. (...) Era un paquet que jo rebia (...)

FERNANDO: De sudamèrica...

LLUÍS: M'enviava unes flors de paper per que les posés a la tomba de la meva mare...

FERNANDO: [riu]

JAUME: Unes varilles de ferro...

LLUÍS: Si... Les flors tenien les varilles de ferro i això vist amb raigs $\mathrm{X}$ era metàl-lic i 'uns cables'...

[Insisteixo si això es va saber abans de que es fes l'acte de suport a l'Alcalde...]

FERNANDO: De seguida el partit va convocar una concentració. Van haver-hi més de 5.000 persones a la Plaça de la Vila. En paral·lel arriba que s'ha explosionat. I havia aquella confusió...

[torno a insistir si es sabia ja que no era una bomba] Ho sabia algú però no tothom (...) [torno a insistir per que van haver-hi acusacions de que s'havia aprofitat això per enganyar a la gent] No era un engany conscient per que això ho sabia molt poca gent. Hi havia confusió per que es va explosionar i al explosionar va haver-hi una detonació... [comento si podia ser que la mateixa policia els enganyés...]

LLUÍS: Jo crec que la policia ens va enganyar (...)

FERNANDO: Quan vam cridar a la concentració ja teníem el comunicat...

LLUÍS: Vam fer el ridícul... ${ }^{1618}$

No obstant, un altre regidor del PSUC d'aleshores, Enrique Bellette, matisava -i molt- aquests fets:

“(...) Y entonces el subcomisario me llama aparte y me dice: -"Oiga usted, mire... -y me llamó y me dice-. A ver ¿usted no sabe la verdad?"-.

-”¡Yo no!. ¿La verdad?. ¿La verdad es lo de la bomba? (ríe), le digo, ¿sabes?”-.

Dice: -" ¡No, no! (susurra) -dice-. Es que... ¡Eso de la bomba...!. No ha existido bomba"-.

Digo:- “¿Cómo que no ha existido?”-.

Y yo me quedé... ¡En aquel momento me quedé!... Y yo dije: -"¿Cómo que no?”-.

-” ¡Hombre, hasta el alcalde lo sabe!. Esta mañana el comisario ha estado hablando con él. Han estado tomando un café juntos y se lo ha explicado y tal..."-. [aquí cal dir que això es va fer el mateix dia que estava convocat un acte públic de rebuig al pressumpte intent d'atemptat]

Y yo, todo negro. ¡Ya...! ¡Ya encendido!. Digo: “------” -(ríe). Fui al despacho de Luis y

1618Entrevista amb Lluís Hernàndez, Fernando Saro i Jaume P. Sayrach, 5-6-2013. La polèmica va venir per que el PSUC va convocar a un acte públic i es van fer acusacions, per part dels socialistes, de mantenir-lo quan ja sabien que havia estat una falsa alarma. 
digo: "Oye Luis... ¡Hombre, me han dicho esto!!-.

- "Bueno -hace así-. ¡Perdona!. ¡Es que, que...! ¡Es que claro, estoy tan preocupado!.

Perdona que..."-.

- "Pero, pero... ¡Pero Luis como te voy a perdonar!. ¿Pero tú sabes lo que estás haciendo?. ¡Engañar a la gente que está ahí en la Plaza de la Vila!- digo-. Tu ahora sales al balcón (rie) y dices lo que te ha dicho el comisario"-.

- “iHombre!. A ver, que venga el Carlos y que vengan todos”-.

Y empiezan a hablar allí todos y... -”¡No, no!. ¡ No podemos decir eso!. Nosotros tenemos que seguir con..."-.

- ¡Y yo cabreado!. Digo: "Lo siento mucho compañeros, pero yo por aquí no paso -digo-. Yo no puedo engañar, ni puedo decir mentiras -digo-. jAllá vuestra conciencia!"-. Y claro, me subí para arriba. Me tomaría una cerveza. ¡Estaba supercabreado!. ¡Me fumé un paquete de tabaco negro!. ¡Echaba chispas por todos los lados y me encontré a un periodista que era amigo mío: el Jordi Corachán!. El tío me vió asustado y dice: "Enrique, ique te pasa?"-.

Digo: -" ¡Me cago en la madre que parió a ----! -le digo-. ¡Ven, ven!. ¡Ven a mi despacho!. Vamos a fumar un cigarro"-. ¡Y se lo conté!!"1619

El nou consistori va haver de fer front al desastre urbanístic de la ciutat amb escassos recursos. Davant d'això en determinats casos es va impulsar la col-laboració amb algunes AVV's per que posessin ells la mà d'obra i l'Ajuntament els materials per acondicionar determinats espais i solars com per exemple a La Bastida, Can Franquesa o el Singuerlín ${ }^{1620}$. Es va negociar amb altres administracions com el MOPU i la Generalitat per solucionar les greus deficiències de determinats polígons d'habitatges heretades del passat com el cas dels pisos d'Albica de Les Oliveres o els de la cooperativa VIPES fins aconseguir que es comprometessin a la seva reparació ${ }^{1621}$. Es va municipalitzar el servei d'enllumenat ${ }^{1622}$ i també es va iniciat una política de compra i salvaguarda de

1619Arxiu Històric de CCOO de Catalunya, Col-lecció Història Oral i militància sindical. Biografies Obreres. Entrevista a Enrique Bellete Sosa, 17-3-2002 a 22-7-2002. Entrevistador José Manuel Hidalgo Ramírez, p. 141.

1620Jordi Corachán: "Los vecinos construyen su propio campo de fútbol", "Vecinos de Singuerlín limpian un solar", "El Correo Catalán, 25-5-1979 i 13-11-1980.

1621Jordi Corachán: "Les Oliveres: Reparaciones a cargo de las inmobiliarias”, “ Guinardera: Vecinos contra una sentencia judicial", "Los vecinos consiguen 16 millones a Obras Públicas" i "Los vecinos de La Guinardera quieren romper el aislamiento del barrio", El Correo Catalán, 12-31980, 8 i 25-5-1980, 26-10-1980.

1622 M. Castellón: "Municipalización del servicio de alumbrado público", La Vanguardia, 19-101979 i Jordi Corachán: "El servicio de alumbrado, municipalizado", El Correo Catalán, 20-10- 
patrimoni urbà amb l'adquisició i inici re restauració de la Torre Balldovina (per a Museu per la ciutat), de Can Mariner (per a Casal de Barri); Can Franquesa o el Masfonollar, que després de moltes dificultats va ser convertit en Casal de Joventut. Alhora es va engegar una campanya de plantament d'arbres per la ciutat. Pel que fa a l'ensenyament es van fer constants reivindicacions al Ministeri per dotar de més escoles a Santa Coloma, amb manifestacions convocades pel propi Ajuntament com les que es van fer els mesos de juny i setembre de $1979^{1623}$. Cal recordar també que Santa Coloma va ser pionera en aplicar la immersió en català a les escoles. I pel que fa a la sanitat es van donar els primers passos per intentar instaurar ambulatoris als diferents barris i per recuperar el Sanatori de l'Esperit Sant per que fos un Hospital per la ciutat ${ }^{1624}$. També va engegar una política -menys populard'erradicació d'horts "il·legals" que molta gent havia fet a espais com la conca del Besòs que estava profundament contaminada ${ }^{1625}$.

No obstant, van haver-hi diversos temes on el nou Ajuntament va ser fortament criticat. El primer, la forta pujada de taxes i impostos municipals, que va despertar de seguida una forta oposició de la Coordinadora d'AVV's de Santa Coloma on tenien molta presència forces de l'esquerra radical com el MCC i d'altres (en menor mesura encara l'OCE-BR):

“El Ayuntamiento ha caído en la trampa de la burguesía. En una situación como la actual donde los salarios decrecen, donde cada día todo aumenta de precio (la leche, la gasolina...) donde cada vez nos empobrecemos más, no podemos aceptar que desde el Ayuntamiento se apruebe aumentar unos impuestos que revierten en los bolsillos de todos. Nuestro nivel de vida decrecen, y ya nos quitan desde otras fuentes, en el trabajo, en la compra... Sinceramente, esto no puede ser. La medida del Ayuntamiento ha caído mal en las asociaciones y esto lo queremos plasmar y defender." ${ }^{1626}$

1979.

1623“Esta tarde, manifestación por la enseñanza” i Jordi Corachán: "El Consistorio y seis mil personas piden más escuelas", El Correo Catalán, 12 i 13-6-1979; "Barcelona: Conflictivo inicio del curso escolar" i El Correo Catalán, 18-9-1979 i "La enseñanza estatal, prácticamente paralizada en Barcelona-província”, La Vanguardia 18-9-1979.

1624J. Corachán: "Santa Coloma: Un sanatorio se convertirá en hospital”, El Correo Catalán, 15-61982.

1625 Jordi Corachán: "El Ayuntamiento clausura los huertos ante un nuevo caso de colera", El Correo Catalán, 21-9-1979.

1626 “Las Asociaciones acusan de "seguidismo". Los impuestos que los pague la UCD”, [entrevista a diferents líders veïnals: Roberto Rubio (Singuerlín), Rafael Lorenzo (Riu), Ferran López (Les Oliveres) i Emiliana Salinas (Fondo), Grama núm. 138 (14/21-7-1979), p. 6-7. 
Les associacions esmentades afirmaven que el que havia de fer l'Ajuntament davant la manca de pressupost era encapçalar les mobilitzacions contra el govern de la UCD. Havien presentat un Pla d'Urgències amb 40 mesures i exigien que es posessin en marxa el més aviat possible. Però l'Ajuntament, desbordat pel dèficit i pres de la voluntat de donar una imatge de "responsabilitat", va optar per l'apujada d'impostos que en alguns casos va ser molt important ${ }^{1627}$. Carlos Grande, ex militant del MCC i aleshores militant del PSUC i a l'Ajuntament, intentava justificar aquestes contribucions:

\begin{abstract}
"Luego entonces, no es justo que el coste íntegro de las obras lo paguemos todos los vecinos, o sea, el Ayuntamiento. Los vecinos especialmente beneficiados han de pagar una parte: una contribución especial. Porque de lo contrario el arreglo de una calle lo pagarían igual los vecinos de la misma que los de la más alejada, cuando no tienen el mismo beneficio."1628
\end{abstract}

Un argument molt feble, que a més a la gent li recordava les mateixes excuses que donaven els Ajuntaments franquistes per cobrament d'aquestes taxes, agreujat pel fet que els que aleshores s'oposaven, ara, a l'Ajuntament, havien canviat d'opinió. Certament des des de l'Ajuntament es va intentar negociar millores de finançament amb altres administracions. Però en aquest cas, en contrast amb el tema escolar, no va impulsar ni encapçalar una mobilització popular. El tinent d'alcalde socialista del moment, Jesús Vicente, resumia la mentalitat imperant amb aquestes significatives paraules:

"Los manifestantes no aceptan que la culpa de que su problema no se solucione la tenga tal o cual ministerio y en el caso (raro) de que lo comprendan, le piden al alcalde y demás políticos que encabecen la manifestación para dirigirse a la delegación respectiva.

Si se hiciera esto, los políticos del cinturón rojo, en lugar de entrar en los ayuntamientos haríamos la vida en las puertas de las delegaciones de los ministerios."1629

1627J. Corachán: “El ayuntamiento pide apoyo por la subida de impuestos”, El Correo Catalán, 27-61979.

1628Carlos Grande (Regidor membre de la Comissió d'Hisenda): “Contribuciones especiales, si o no?, Grama núm. 179, p. 8. Les escombraries pujaven un $200 \%$ i el clavegueram un $30 \%$.

1629Jesús Vicente Iglesias (Primer Tinent d'Alcalde de Santa Coloma de Gramenet pel PSC-PSOE): "Administradores de la pobreza", El Periódico de Catalunya, 14-12-1979. 
El tema dels impostos -en aquest cas el de radicació- també va enfrontar a l'Ajuntament amb sectors i associacions del comerciants i empresaris, fet que algunes forces polítiques van intentar instrumentalitzar en el seu profit, des de Fuerza Nueva, la UCD o fins i tot $\mathrm{CiU}^{1630}$. Els pressupostos municipals van ser una altra font de conflicte entre Ajuntament i AVV's, ja que alguns dels seus membres, tot i reconèixer que l'Ajuntament no disposava de fons per culpa de la herència franquista i les altres administracions de l'Estat, demanaven la realització de mobilitzacions i d'un pressupost amb la participació popular ${ }^{1631}$.

Un altre tema molt important al meu parer on van topar Ajuntament democràtic i AVV's (si més no unes quantes, on l'esquerra revolucionària tenia una major presència) va ser tot el relacionat amb la participació ciutadana. Des de la Coordinadora d'AVV's de Santa Coloma s'havien fet demandes molt específiques en aquest aspecte: es demanava el dret de la Coordinadora a participar en els Plens, en les diferents Comissions de treball i altres organismes regulats per la Llei de Règim Local, el poder participar en l'elaboració de la Carta Municipal, el dret a una informació real de les AVV's -és a dir- que tinguessin accés a les actes, expedients municipals i a tot tipus de facilitats per conèixer l'ordre del dia dels plens i de les diferents reunions de l'Ajuntament... Afegint el dret a ser consultats abans de que l'Ajuntament emprengués una acció determinada, a poder presentar propostes que havien de ser contestades per l'Ajuntament als Plens públics, i a poder gestionar o co-gestionar determinats equipaments i serveis socials i culturals. Sense oblidar el dret a referèndum sobre temes importants ${ }^{1632}$. Però aquestes demandes topaven amb una certa resistència dels nous governants municipals, que no volien veure qüestionat el seu poder o legitimitat:

"Hay que distinguir entre la participación ciudadana, que ha de ejercerse siempre, y el gobierno de la ciudad, que se ejerce durante cuatro años y se legitima mediante el sufragio universal. No se trata de contraponer estas dos vías, sino de conjugarlas.

1630 Jordi Corachán: "Los comerciantes piden que no se cobre la radicación", El Correo Catalán, 252-1981.

1631Un exemple va ser l'article crític de Gabriela Serra Freidiani: "Presupuesto de 1980. ¿Nueva agresión a los intereses populares?”, Grama núm. 163 (27-1-1980), p. 13.

1632A. Morillo: "Las asociaciones piden un Ayuntamiento que luche", Grama núm. 133 (9/16-61979), p. 4. Són unes demandes que trobarem recollides en document de la Coordinadora de Asociaciones de Vecinos: "Plan de Urgencias. Santa Coloma de Gramenet", AHMTB, Donació Marcelo López Ródenas, Caixa 3, Dossier 10, p. 5-7. També les trobarem a la I Trobada d'AVV's feta el mateix any a Manresa. 
Situar cada cosa en su sitio engarzando las opiniones y propuestas de los vecinos con el equipo que ellos han elegido para cuatro años, combinar la democracia directa con la institucional."1633

El cas es que finalment es va aprovar un reglament de participació ciutadana. Aquest confirmava la creació del Departament d'Informació i Participació Ciutadana, la creació de Consells de diferents sectors (Ensenyament, Sanitat, etc.) on estaven representades les entitats però on les AVV's hi figurarien com una més (sense tenir-hi més pes). Els Consells municipals podien demanar explicacions sobre actuacions municipals i també ho podien fer ciutadans recollint 750 signatures. En els Plens es contemplava que les AVV's poguessin expressar la seva opinió sobre temes que els afectessin, i que ho poguessin fer també persones amb un mínim de 150 signatures. L'Ajuntament es comprometia a mantenir un diàleg i informació constant de les seves actuacions ${ }^{1634}$. Com es pot observar, no es van recollir totes les peticions que es van fer, i en opinió dels membres de les AVV's més combatives aleshores, el reglament aprovat es quedava molt curt i va ser una decepció:

"Bueno... pero es que tampoco nos daban participación. Ellos tomaban las decisiones. O sea, el Plan Popular lo habíamos hecho entre todos, pero a la hora de decidir (...) nos dejaban fuera de todo. Nos dejaban fuera... Si para participar en un Pleno nos exigieron... [li demano més sobre mecanismes de participació veïnal] El Pleno. La Asociación de Vecinos quería exponer algo, tenía que demanar la palabra en Pleno. Los primeros Plenos nos exigían 750 firmas. Entonces que pasa... pues que empezamos a criticar el Reglamento de Participación Ciudadana... 'esto no vale pa na, esto es una mier...' Empezamos a venir a los Plenos... derecho a voz pero no a réplica. ¿Pero que es esto? 0 sea, 'ya lo has dicho... pasemos al punto siguiente... ¡Pero oye! ¡Qué te calles que ya no tienes la palabra!... ¡Pero!' Derecho a exponerlo pero no a réplica. Te dejaban exponer lo que decías pero ese punto no era tratado ahí. No era discutido. Hasta el extremo que hemos traído cosas a plantear, las has expuesto, te han dejado hablar, y después enseguida pasemos al punto siguiente. ¿Pero bueno, entonces a que hemos venido aquí? Y cuando intentabas to mar la palabra por tu cuenta, no hay palabra. No, no y no y no... Era un cabreo tremendo. Llegar al gobierno... entonces ¿pa que nos

1633Carlos Grande (Regidor d'Informació i Promició Ciutadana): “La participación ciudadana en la gestión municipal", Grama núm. 133 (9/16-6-1979), p. 13.

1634A. Morillo: "Regulada la parcitipación ciudadana. Se necesitaran firmas para hablar en los plenos", Grama núm. 134 (16/23-6-1979), p. 6. 
sirve?"1635

Aquest fet va ser una font de conflictes entre algunes AVV's i l'Ajuntament i també d'altres col-lectius més radicalitzats com una Assemblea d'Aturats existent. Va haver-hi diverses ocupacions dels Plens on es feien arribar les protestes, part de les quals tenien a veure amb la qüestió dels pressupostos i la participació. Al proper capítol, centrat en els anys 80 , aprofundiré més sobre aquest tema i de la concepció que es tenia des de els Ajuntaments de les AVV's. Ara també he de fer un breu esment a les lluites internes que va haver dins el consistori colomenc, protagonitzades sobretot entre PSUC i PSC-PSOE i també en el si dels respectius partits.

El "Pacte de Progrés" va ser més conflictiu a Santa Coloma que no pas a Badalona. Ja aviat van sorgir disputes entre comunistes i socialistes, com al juny de 1979 per unes contractacions fetes per la Brigada Municpal on els socialistes acusaven a Rafael Parra de prioritzar als afiliats a CCOO davant altres treballadors, arribant a demanar-ne fins i tot la dimissión ${ }^{1636}$. A l'octubre de nou des del PSC-PSOE acusaven al PSUC de la "inoperància" del consistori ${ }^{1637}$. Els enfrontaments i tensions es traslladaven als mateixos plens on eren freqüents els insults i desqualificacions ${ }^{1638}$. Una possible subvenció a la revista Grama va ser un important conflicte en un Ple. De fet fins i tot una campanya de replantació d'arbres va enfrontar PSC-PSOE i PSUC, ja que els primers acusaven als segons d'utilitzar-la de manera electoralista ${ }^{1639}$ (tot això mentre Convergència es desmarcava aviat del Pacte). Important va ser el conflicte que els socialistes van tenir amb el cap de la Guàrdia Urbana, militant de CCOO, acusant al PSUC de fer-li un "concurs a mida"1640. De fet, això no té res d'excepcional en un context de forta competència electoral 1635Entrevista a Emiliana Salinas, 8-5-2013.

1636Jordi Corachán: "Crisis municipal por las divergencias PSC-PSUC" i "La UGT pide la dimisión del concejal de trabajo", El Correo Catalán, 19 i 20-6-1979.

1637 M. Castellón:“Crisis del pacto de progreso municipal”, La Vanguardia, 2-11-1979.

1638Fins i tot la portada del Grama núm. 173 (9 d'abril de 1980) s'en feia ressò amb un fotomontatge més propi de la premsa sensacionalista on Jesús Vicente (PSC-PSOE) deia “¡Iros a la mierda!” al qual Chema Corral (PSUC) responia “¡Tu delante para que no me pierda!”.

1639Jordi Corachán: "Comunistas y socialistas se enfrentan en el pleno" i "La "campaña verde" enfrenta a socialistas y comunistas”, El Correo Catalán, 1-11-1979 i 26-1-1980. Sobre l'afer de la subvenció a Grama veure el editorial del número 151 (10-11-1976), titulat significativament “El PSC nos agradece los servicios prestados", p. 4-5.

1640 Jordi Corachán: "Protesta socialista por un concurso de la Guardia Urbana”, El Correo Catalán, 4-2-1981. 
-com van ser els anys entre 1979-1983- entre aquestes dues forces polítiques que intentaven hegemonitzar i fidelitzar un electorat majoritari d'esquerres. Lluita que es va traslladar a altres espais com el sindical on la UGT intentava disputar l'hegemonia de CCOO mentre altres opcions sindicals de diferents tendències van quedar progressivament minoritzades o van desaparèixer ${ }^{1641}$.

Les crítiques dels socialistes es van aguditzar arran la crisi interna del PSUC i alhora es van tenir discrepàncies importants com en l'afer de la instal-lació d'un bingo on el PSC es va manifestar a favor mentre el PSUC volia organitzar un referèndum entre els veïns afectats ${ }^{1642}$. La que serà futura alcaldessa pel PSC-PSOE -a més de diputada al Congrés i també al Parlament català- Manuela de Madre criticava durament des de la seva àrea de Benestar Social al responsable d'urbanisme, Jaume P. Sayrach ${ }^{1643}$. Les contínues disputes van impedir l'aprovació momentània dels pressupostos $\mathrm{i}$ els socialistes van arribar a abandonar temporalment el pacte tot i que al final es va aconseguir reconduir la situació ${ }^{1644}$. No obstant els enfrontaments PSUC-PSC-PSOE van continuar ja fossin per un vídeo municipal o pel contingut de les emissions de ràdio municipal ${ }^{1645}$, ja que s'apreciaven les intencions dels segons de donar el sorpasso electoral als primers.

La crisi i escissió del PSUC va afectar molt a la situació interna del PSUC colomenc $^{1646}$. Al Vè congrés la representació colomenca va ser copada pels sectors crítics amb l'eurocomunisme aprofitant la seva superioritat numèrica. La situació posterior a la celebració del Congrés es va enrarir molt ja que el Comitè Local estava controlat pels sectors no "eurocomunistes" que volien incidir en la política municipal que s'estava portant, fins al punt que va dimitir el regidor eurocomunista Enrique Bellete, fet que va provocar la dimissió de 4 regidors més

1641Per veure l'evolució del sindicalisme promogut per l'esquerra revolucionària veure Jose M. Roca: "Sindicalismo y revolución" a J.M. Roca (ed.): El proyecto radical..., p. 155-202.

1642 Jordi Corachán: "El PSC, a favor de la instalación de un bingo", El Correo Catalán, 5-5-1981.

1643Jordi Corachán: "Acusan al Consistorio de falta de sensibilidad con los disminuidos físicos", El Correo Catalán, 15-5-1981.

1644Jordi Corachán: "Los socialistas abandonan el gobierno municipal" i "Conversaciones entre el PSUC i el PSC para superar la crisis municipal”, El Correo Catalán, 7 i 10-7-1981.

1645Jordi Corachán: "Santa Coloma: Un "video" para la Fiesta Mayor enfrenta a los concejales" i "Santa Coloma: el PSC acusa de manipulación a Radio Gramenet", El Correo Catalán, 6-9-1981 i 14-4-1983.

$1646 \mathrm{Al}$ capítol següent hi entro amb més detall. Sobre la crisi del PSUC veure Carme Molinero i Pere Ysàs: Els anys del PSUC. El partit de l'antifranquisme (1956-1981), Avenç, Barcelona, 2010. En especial el capítol “Del IV al V Congrés”, p. 305-342. 
en una greu crisi que només va ser aturada per la intervenció directa de Francisco Frutos $^{1647}$. Davant les crítiques públiques al Vè Congrés que van fer dirigents com Antonio Gutiérrez Díaz i Gregorio López Raimundo ${ }^{1648}$ aprofitant l'accés que tenien a uns mitjans de comunicació àvids de desprestigiar un PSUC que amenaçava els interessos de les classes més benestants, va haver-hi agrupacions del partit a Santa Coloma que demanaren l'expulsió momentània de tots dos i també de Jordi Borja $^{1649}$. Entremig va esclatar el conflicte amb les treballadores de l'empresa de neteja LIMASA, que demanaven la municipalització d'aquesta i van ocupar diverses vegades l'Ajuntament. El CL va donar suport a la petició mentre que l'Alcalde i quatre regidors s'hi van oposar. La situació va arribar a tal extrem que fins i tot Lluís Hernàndez va dimitir i va convocar una assemblea a l'Església de Singuerlín el 17 d'octubre per explicar la seva postura en un ambient de molta tensión ${ }^{1650}$. Davant d'això els partidaris del Vè congrés van fer-se enrere en la seva proposta de municipalització de LIMASA. Poc després la truita es va girar i davant la rectificació dels fets del Vè congrés i l'expulsió dels seus defensors, van ser els regidors partidaris d'Ardiaca els que van ser expulsats ${ }^{1651}$.

El PSC-PSOE també va tenir disputes internes (que reflectien les que es donaven a nivell nacional al partit) per la progressiva hegemonia del sector

1647 El Correo Catalán, 27-1-1981, 5, 6 i 13-2-1981. Francisco Frutos era el secretari general escollit al Vè Congrés de l'anomenat sector "leninista". Els altres regidors que van voler dimitir van ser Jaume P. Sayrach, Carlos Grande, Remedios Martínez i Pedro Garcia. Veure document Lluís Hernández: "Propuestas que el camarada Luís Hernández, alcalde comunista de Sta. Coloma de Gramanet hace al Comité Local para encontrar vías de solucción al conflicto surgido en el Grupo de concejales comunistas y en las relaciones de este con la dirección de nuestro partido.", AHMTB Donació Mn. Josep Catà, Caixa 1.

1648Antoni Gutiérrez Díaz havia deixat la secretaria seneral del PSUC en desacord amb els resultats del Vè Congrés, al igual que l'històric dirigent Gregorio López Raimundo havia deixat la presidència. Més informació a Carme Molinero i Pere Ysàs, Els anys del PSUC..., p. 334.

1649Jordi Corachán: "Sectores del PSUC piden la exclusión del "euro" Jordi Borja", El Correo Catalán, 16-5-1981. Van ser les agrupacions de Santa Rosa, Fondo, Barri Llatí i Arraban les que ho van demanar mentre Centre i Singuerlín no ho van fer. El motiu era que l'històric militant del PSUC i Bandera Roja havia subscrit un document juntament amb Joan Busquets, Jordi Cunill, Domènech Martínez, Josep Maria Riera, Jordi Sole Tura i Maties Vives molt crític amb les resolucions del Vè Congrés. Veure Carme Molinero i Pere Ysàs, Els anys del PSUC..., p. 335.

1650Jordi Corachán: "Sanción de "advertencia" contra el alcalde y cuatro concejales" i "Dimite el alcalde de Santa Coloma de Gramenet", El Correo Catalán, 16-6-1981 i 13-10-1981. Es pot veure el full volant de l'Ajuntament convocant a l'esmentada assemblea: "Por qué el Alcalde ha presentado la dimisión” [10-1981], AHMTB, Donació Mn.Josep Catà, Caixa 1.

1651Com per exemple Jose Maria 'Chema' Corral. Veure Jordi Corachán: "Santa Coloma: Incidente en un pleno municipal", El Correo Catalán, 27-2-1982 i "Se suspende el pleno en Santa Coloma de Gramenet", Diario de Barcelona, 28-2-1982. 
provinent de la Federació Catalana del PSOE sobre sectors "obiolistes" ${ }^{1652}$. Fruit d'aquestes tensions van presentar la dimissió a Santa Coloma el responsable de Premsa Josep Tordera i el d'Organització Manuel Galgo. Aquest darrer ens donava la seva versió d'aquestes lluites internes, que ja venien dels temps del procés de confluència dels diferents grups socialistes:

"Va llavors aquí (...) això és molt difícil d'explicar... però aquí va ser duríssima la fusió (...). Per què, jo penso (...) aquí teníem com si diguéssim, unaaa.... els dirigents que tenien aquí... tenien alguns dirigents que eren molt poc socialistes, eh? Hi havia un grup de la UGT... tu no sé si coneixes la història de los descamisados del peronisme argentí, el sindicat peronista (...) era una cosa... eh? Me'n recordo que dèiem 'collons, això semblen els descamisados' molt demagògics, saps? I no entenien gens el tema català (...). A mi em preguntaven, amb bona fe algun... 'Manel, ¿eso de la autodeterminación qué es? No lo entiendo esto' (...) I llavors jo els hi explicava. Però els sectors aquests t'enviaven a l'Assemblea un tio que amb un paper 'accidentes laborales mortales en los últimos años en Cataluña. Andaluces 32, extremeños, 30, tal tal tal , catalanes $2^{\prime}$... així anaven, lerrouxisme total.

(...)

fins l'any $80 . .$. fins que això que t'he dit d'aquest merder d'aquesta gent que tenien algun tipus de relació que mai vaig sapiguer quina era amb aquests del [Alberto] Royuela al camping... Llavors jo vaig parlar amb el Raventós, l'Obiols i el Viladamat i... el Higini Clotes, eh? Quan ja van liquidar... però va continuar... vaig dimitir a llavorens... (...) estava cansat ja..."1653

El mateix cap de llista, Jesús Vicente també va tenir conflictes amb la resta de

1652 Els "obiolistes" eren, com es pot deduir pel nom, els partidaris de Raimon Obiols que solien provindre del PSC-Congrés i també eren catalogats com "catalanistes". Els procedents de la Federació Catalana del PSOE eren qualificats també com "obreristes" pel seu major pes a l'UGT. Sobre el PSC-PSOE veure Josep Lluís Martín Ramos: Historia del socialismo español, (5 volums dirigida per Manuel Tuñón de Lara), Conjunto editorial, Barcelona, 1989; José Luís Martín Ramos, Isidre Molas, ...[et al.]: 20 anys d'història del PSC, Fundació Rafael Campalans, Barcelona, 1998; [sense autor] PSC : 30 anys de socialisme català, Fundació Rafael Campalans, Barcelona, 2008.

1653 Entrevista a Manuel Galgo Iserte, 4-7-2013.Antic militant del PSC-C i del PSC-PSOE, on va ser responsable d'organització de l'agrupació local de Santa Coloma de Gramenet. El tal Alberto Royuela que esmenta era un conegut "ultra" barceloní que havia estat Secretari General de la Hermandad Nacional de la Guardia de Franco en els vuitantes, detingut en diverses ocasions (El País, 28-11-1981), implicat en activitats mafioses (El País, 29-7-2003) i que havia fracassat el 1970 en voler ser regidor del Districte I de Barcelona (Martí Marín: Els Ajuntaments franquistes..., p. 382-383 i 392). Més tard, en democràcia, optaria sense èxit a la presidència del R.C.D. Espanyol . El seus fills van seguir la tradició "ultra" familiar: Santiago Royuela va ser detingut per un atemptat al barri barceloní de Sants (ABC, 4-3-2001), mentre que Alberto Royuela milità a "Estado Nacional Europeo". 
l'aparell del PSC-PSOE per que era una persona força independent que va acabar dimitint com a Primer Tinent d'Alcalde i de l'executiva del partit juntament amb cinc persones més ${ }^{1654}$. Fins i tot va arribar a signar el "Manifiesto de los 2.300" promogut per Federico Jiménez Losantos (que treballava de professor a la ciutat) -amb algun altre socialista- provocant més tensions internes a nivell local ${ }^{1655}$. Finalment Joan Carles Mas va esdevenir primer Tinent d'Alcalde en substitució de Rafael Hidalgo, que al seu torn havia suplit a Jesús Vicente ${ }^{1656}$.

A Sant Adrià de Besòs els primers anys d'Ajuntament democràtic també van ser intensos i convulsos. Per començar ja ho va ser la mateixa nit electoral. Les tensions entre els sectors provinents del PSC-C i de la Federació Catalana del PSOE eren molt forts. El testimoni del primer cap de llista del PSC-PSOE per Sant Adrià és impagable:

"Bueno total, com que ells no tenien programa (...) m'escolleixen primer de llista. Fem la campanya electoral, i la guanyem. Bueno guanyem (...) fem una festa popular a la Plaça de la Vila amb música i tot i jo faig un primer parlament (...) i me'n recordo d'aquell personatge, en Francisco Franco (...) em diu 'quiero hablar contigo'. I em diu, 'mira, es que... yo te tengo que ser sincero. Yo a los catalanistas no os puedo ver' va treure un sac d'odi contra tot lo que era Catalunya immens, immens immens (...) a mi em veien massa decantat cap el catalanisme polític. I a més a més, com que la meva dona era de Convergència això ... 'esta està fent el joc per Convergència'. I era mentida, jo no feia el joc a Convergència (...).

A llavorens decidim un dia abans de la presa de possessió del 'Ajuntament jo me'n vaig a redactar i a consensuar el discurs que faria en la presa de possessió (...). Llavorens 'previo a esto, tienes que poner tu firma en estos papeles'. I em porten dos papers en blanc per que els firmés... en blanc! I això que ès? 'Tu pones tu cargo a disposición del PSOE'. 'Jo no posaré el meu càrrec a disposició del PSOE ni borratxo!, en tot cas, vaig a buscar a en Joan Reventós i parlem-ne'. A llavorens fixa't el que fan. Era un local planta baixa, amb una persiana metàl-lica d'aquelles que s'enrotllen amunt, baixen la persiana i em segresten. No em deixen ni sortir (...).

1654Jordi Corachán: "Tensión en el PSC: Dimiten once miembros de la ejecutiva" i "Los obiolistas quedan fuera de la ejecutiva local del PSC", El Correo Catalán 6-5-1980 i 13-5-1980. Els altres dimissionaris de l'executiva local eren Chema Vizray (Primer Secretari Local), Manuel Tirado (Organizació), Roser Portas (Ensenyament), Prudencio Martín (Finances) i Manuel Sánchez.

1655Jordi Corachán: "Manifiesto: Medidas contra los socialistas que firmaron", "El PSC no sancionará a los firmantes del "Manifiesto"” i "Debate sobre el "Manifiesto lingüístico", El Correo Catalán, 7, 9 i 26-4-1981 i Fins i tot la revista "El treinta y cinco" va organitzar un debat sobre l'esmentat manifest a la Cooperativa La Colmena.

1656Jordi Corachán: "Dimiten dos tenientes de alcalde del PSUC y del PSC" i "Santa Coloma: Mas substituye a Hidalgo", El Correo Catalán, 30-10-1981 i 11-11-1981. 
Allà hi havien companys del PSC i els hi dic 'neu a buscar al Raventòs i expliqueu-li el que estan intentant fer aquesta gent, per que això no...' No van anar a buscar al Raventòs, van pactar amb els del PSOE els càrrecs de l'Ajuntament... Jo era la nosa, jo sé que soc molt radical en el tema nacionalista però jo no feia formulacions independentistes, en aquell moment no se'n feien. Els que la feien... eren el Front d'Alliberament (...) el PSAN (...) tota aquesta gent. (...)"1657

D'aquesta manera el cap de llista del PSC-PSOE va ser vetat i va esdevenir alcalde Joan Vilanova Vila, el segon de la llista. Davant aquests fets Agustí Gallart es va donar de baixa (més tard s'afiliarà a CiU). No obstant, aquest tampoc va acabar la legislatura i va acabar dimitint al juny de $1981^{1658}$. Els motius d'aquesta dimissió són poc coneguts però presumiblement es devien a pugnes de poder internes. Finalment Antoni Messeguer Mateo, que havia anat de número 4 a la llista d'abril de 1979, va esdevenir Alcalde ${ }^{1659}$.

Com a les altres localitats del Barcelonès Nord inicialment es va fer el "Pacte de Progrés" entre PSC,PSUC i CiU, si bé inicialment a aquesta darrera formació no se li va concedir cap regidoria ${ }^{1660}$. Posteriorment Agustí Gallart, membre de CiU i de l'AVV Sant Adrià Nord va rebre l'àrea de Trànsit, transports i comunicació ${ }^{1661}$. Malgrat això, les pugnes i diferències dins el "Pacte de Progrés van ser cada cop més evidents, sobretot entre el PSC-PSOE i el PSUC. Ja aviat l'afer del vell ambulatori havia enfrontat a les dues forces amb acusacions creuades de com s'estava gestionant el trànsit cap el nou projecte i alhora amb un conflicte laboral dels treballadors de "La Quadra"1662. Una altra disputa va sorgir en la votació del programa municipal de Sanitat on el PSUC va votar en contra i CiU s'abstingué per que el PSC feia servir el terme "centre de salut" en comptes de "ambulatori" (la

1657Entrevista a Agustí Gallart Teixidó, 17-1-2013. Militant del PSC-C-, PSC-PSOE (on va ser el candidat a l'Alcaldia el 1979) i posteriorment de CiU. Membre de l'AVV Sant Adrià Nord 1658“Ha dimitit el batlle de Sant Adrià", Avui, 19-6-1981.

1659 “Antoni Messeguer, nuevo alcalde de Sant Adrià”, El Periódico de Catalunya, 21-6-1981. Deu anys després aquest tenia la gosadia de dir en una publicació de 1991 feta pel propi Ajuntament que la diferència entre la ciutat d'aleshores i la de 1979 era que en aquell any la ciutat no funcionava i ningú no protestava d'aquest mal funcionament. Veure Sant Adrià: 12 anys de democràcia municipal, Ajuntament de Sant Adrià de Besòs , Sant Adrià de Besòs, 1991, p. 19.

1660 Margarida Coromines: "Convergència protesta al quedarse sin cartera", Mundo Diario, 1-51979.

1661 “CiU ha entrat al cartipàs de Sant Adrià", Avui, 29-5-1979.

1662 Joaquim Delllunder: "La izquierda enfrentada por el ambulatoriio" i El Correo Catalán, 11-71979 i M. Coromines: "Sanidad divide a la izquierda" Mundo Diario, 6-7-1979. 
lluita per l'ambulatori havia estat una de les lluites més importants a nivell de ciutat $)^{1663}$. Fins i tot la localització del futur Casal de Cultura els enfrontava. La cosa va arribar fins a tal punt que a l'octubre de 1979 cada grup es va centrar exclusivament al treball en les seves àrees de manera autònoma ${ }^{1664}$.

Però ni això va evitar les disputes. Al novembre i desembre les discussions anaven al voltant de la inclusió dins els Plens dels debats a l'entorn de l'Estatut del Treballador així com per les contractacions dins la Brigada Municipal ${ }^{1665}$. L'aprovació del Pla Marina-Besòs, que també afectava La Catalana, va ser una altra font de discussió ja que el PSUC va acusar al PSC-PSOE d'haver portat unilateralment el tema ${ }^{1666}$. Al juliol CiU va eixir del "Pacte de Progrés" i va passar a l'oposició, protagonitzant polèmiques amb l'Alcalde per temes com la petició de posar a un carrer de Sant Adrià el nom de Dr. Obiols, on Convergència va arribar fins i tot a proposar un referèndum ${ }^{1667}$. Finalment el PSC-PSOE va decidir trencar el pacte amb el PSUC a finals d'octubre de 1980 posant com excusa uns incidents que hi havia hagut en una assemblea veïnal de La Mina entre militants del PSUC i del PSC-PSOE (un presumpte intent d'agressió). La resposta del PSUC va ser decidir absentar els seus 8 regidors dels plens per impedir els acords per falta de quòrum, tot i que després de diverses negociacions on va intervenir fins i tot la Generalitat van acabar tornant ${ }^{1668}$. Van haver-hi negociacions no del tot reeixides per refer el "Pacte de Progrés" i poc després es produïa la dimissió de Josep Vilanova i l'ascens d'Antoni Messeguer. Un altre escàndol del moment va ser la dimissió el 5 de novembre del cap de la policia local acusat d'investigar els antecedents d'un

1663 Margarida Corominas: “La Sanidad dió tensión al Pleno”, Mundo Diario, 2-8-1979.

1664 Joaquim Dellunder: "Enfrentamientos y tensión en el pleno de noviembre", El Correo Catalán, 2-10-1979 i Agustí Gallart: "Consumada la crisis del pacto municipal”, La Vanguardia, 30-101979.

1665Agustí Gallart: “El Ayuntamiento pide la dimisión del gobernador civil”, La Vanguardia, 2-121979; Margarida Corominas: "Que dimita el gobernador", Mundo Diario, 5-12-1979 i "Nou treballadors de Sant Adrià de Besòs acomiadats", Avui. 18-12-1979.

1666Joaquim Dellunder: “El Ayuntamiento compra terrenos para 600 pisos", El Correo Catalán, 1412-1979 i "Sant Adrià de Besós recupera catorce hectáreas para equipamientos" La Vanguardia, 14-12-1979.

1667Joaquim Dellunder. "CiU presenta la dimisión de todas sus carteras", El Correo Catalán, 1-71980; "CiU de Sant Adrià deixa les comissions informatives", Avui, 2-7-1979 i Joaquim Dellunder: "El pleno decide no dedicar una calle al doctor Obiols", El Correo Catalán, 1-101980.

1668El Correo Catalán, 30-10-1980; La Vanguardia, 8, 18 i 21-12-1980; El Correo Catalán, 8 i 14-11981; La Vanguardia, 17-1-1981 i El Correo Catalán, 24-1-1981 i 3-2-1981. 
regidor del PSUC seguint ordres del nou alcalde ${ }^{1669}$.

Però aleshores va esclatar la crisi interna del PSUC. A Sant Adrià de Besòs la gran majoria de la militància eren defensors del Vè Congrés. Així que quan es va produir la "rectificació" i el pacte entre "eurocomunistes" i "leninistes" de seguida van arribar les represàlies. La primera va ser la destitució del cap del Grup Municipal Juan José Castro. Davant el suport que obtingué dels seus companys el Comitè Central del PSUC va suspendre a tot el Comitè Local de Sant Adrià. Poc abans s'havien entregat no menys de 156 carnets $^{1670}$. I que va passar amb els regidors? Ens ho va explicar el mateix Juan José Castro:

\footnotetext{
“'Aquí todos los concejales que éramos seis, del PSUC y dos independientes, los seis éramos prosoviéticos por decirlo de alguna manera. Los seis éramos contestatarios a la dirección y los seis votamos en contra en el Congreso, los delegados que fuimos, y a los seis nos expulsaron de concejal. Entonces vino la debacle del partido aquí por la actitud de la dirección de no aceptar lo que había elegido una mayoría del Congreso...." ${ }^{m 671}$
}

Si bé al Barcelonès Nord la majoria de la militància va passar al PCC, a Sant Adrià va ser on aquesta hegemonia va ser més clara ja que a Badalona i Santa Coloma els "eurocomunistes" i "leninistes" van mantenir-se a les institucions i als càrrecs municipals, com tindrem ocasió de veure més endavant. S'ha de dir, no obstant, que malgrat aquest panorama polític turbulent des de l'Ajuntament de Sant Adrià es van fer millores. Es va aconseguir, amb molt retard, que s'iniciessin les obres de l'esperat ambulatori, la creació de noves escoles i que es fessin PERIS de determinats barris com Sant Adrià Nord ${ }^{1672}$. Menys entesa va haver-hi amb els paradistes dels "encants" de la ciutat, que van protagonitzar un sonor conflicte amb l'Ajuntament per la proposta de trasllat de la seva ubicación ${ }^{1673}$.

Tampoc es va tenir una actuació totalment exitosa en altres barris, en especial

1669Joaquin Dellunder: “Dimite el jefe de la policía municipal", El Correo Catalán, 6-11-1981.

1670“Baix Llobregat i Vallés, las zonas más afectadas", El Correo Catalán, 9-2-1982; "Els escindits del PSUC han lliurat 156 carnets" i "Vuit regidors del PSUC volen dimitir a Sant Adrià", Avui, 17 i 23-2-1982.

1671Entrevista a Juan José Castro Castillo, 20-12-2012 i 21-1-2013. Militant i regidor pel PSUC i posteriorment pel PCC.

1672 Joaquim Dellunder: "Inician el plan de reforma especial de San Olegario", El Correo Catalán, 76-1980.

1673Joaquim Dellunder: “Casi 6 millones de pesetas para trasladar los encantes”, El Correo Catalán, 30-3-1980. 
en La Mina, que encara depenia del Patronat, on es va intentar que altres administracions com l'esmentat PMV, la CMB i la Generalitat invertissin en la regeneració d'un barri que havia estat abandonat per totes les administracions. Finalment es va aconseguir que tant el Patronat com la Generalitat es comprometessin a invertir diners per regenerar el barri i s'aprovés l'anomenat "Pla Interdepartamental"1674.

Les AVV's més potents de Sant Adrià havien estat les de La Mina i el Besòs. Inicialment part dels seus dirigents van marxar a l'Ajuntament, com Juan Ponce i Vicente Ponz de La Mina i Maria Codina del Besòs. Però aviat alguns es van desencantar del que es feia a l'Ajuntament i van retornar al seu barri. Va ser el cas de Juan Ponce (amb el suport d'altres militants com Vicente Ponz i Agustín Cortés) que alhora va protagonitzar una dura pugna amb un altre sector de persones provinents de sectors de l'Església i militants o simpatitzants socialistes com Garcia de Haro i Josep Maria Montferrer:

\footnotetext{
"La Junta acusa a Juan Ponce y colaborades de estar utilizando un problema que ellos mismos crearon desde esta A.A.V.V. para derrocar la actual Junta, de destruir el trabajo que hasta ahora ha venido realizando, de querer politizar con signo claro del P.S.U.C. las asociaciones de vecinos ya que los nuevos electos son todos de dicho partido, de estar creando la desunión del barrio y un evidente confusionismo con las tácticas y las formas que están empleando. Por último la Junta sugiere a Juan Ponce y los demás "electos" formar una A.A.V.V. paralela desde el partido y en sus propios locales (...) ya que disponen de ellos para si aunar esfuerzos en pro del barrio."1675
}

La cosa havia arribat fins al punt que es van produir insults i intents d'agressió en una tensa assemblea veïnal el 30 d'abril de $1980^{1676}$. Durant un moment van coexistir dues Juntes fins que una ajustada votació el 3 de juny davant un delegat governatiu la Junta encapçalada per Ponce va guanyar per 156 vots

1674La Vanguardia, 3-6-1982; El Correo Catalán, 20-7-1982 i 16-3-1983. La inversió de la Generalitat, aprovada al 1983, havia de ser de 250 milions. Però això no es va plasmar en la realitat, i en gran part va ser paper mullat.

1675 Acta de la Junta de l'AVV de La Mina (4-5-1980) [Llibre d'Actes], AHLM, Caixa C1.4.- Associació de Veïns anys 80, Carpeta Llibre d'Actes [primer], p. 50-51. de És interessant seguir les diferents actes de l'AVV per veure com es va anar covant aquest conflicte, la guspira del qual va ser la negociació amb el PMV de Barcelona.

1676Joaquim Dellunder: "Agresiones en una asamblea de vecinos de La Mina”, El Correo Catalán, 45-1980. 
contra $141^{1677}$. Enmig aquest conflicte els partidaris de Ponce van convocar una manifestació el dia 22 de maig cap a l'Ajuntament per protestar per la situació del barri que va ser molt tensa per la presència d'antidisturbis. L'AVV de La Mina va demanar la dimissió de l'Alcalde per aquest fet ${ }^{1678}$, i van continuar les protestes:

\begin{abstract}
"Por último, la Asociación de vecinos manifiesta que no está dispuesta a continuar por más tiempo en esta situación de marginación a la que el barrio de La Mina está sometido, y en vista de que el diálogo con la Administración no da ningún resultado, hacemos un llamamiento a la responsabilidad de los vecinos y del Consistorio para recurrir, si es necesario a la movilización popular"1679
\end{abstract}

S'ha de dir, però, que barrejades amb les enemistats polítiques i personals, n'hi havien també de religioses, ja que l'esmentat Juan Ponce era pastor protestant i això el podia haver enemistat amb eclesiàstics catòlics com Garcia de Haro. Malauradament aquests conflictes van afeblir molt l'AVV durant els anys 80 i va perdre gran part de la seva força.

Al barri del Besòs aleshores no es van donar tants conflictes, tot i que encara hi havien moltes necessitats i perills, com ho posa de manifest l'agressió que va patir un militant del PSUC al juliol del $1979^{1680}$. També el tancament d'una Llar d'Infants, la coneguda "Cascabel" va tenir una certa oposició. Els veïns del barri -juntament amb els de La Mina i els del Poblenou de Barcelona- també van protestar contra la supressió de l'autobús $41^{1681}$. De cara als vuitanta, molts dels militants del PSUC que havien participat a l'Associació es van passar al PCC -com el seu President Rafael Caballero- i van tornar a donar-li un caire reivindicatiu durant els anys 80 .

A La Catalana ja havíem vist com l'AVV havia estat controlada per persones conservadores com Alfonso Chaos, que va militar a AP. La majoria de les reivindicacions van continuar girant al voltant de la qualificació urbanística del

1677Joaquim Dellunder. "Los miembros de la Asociación de vecinos contra la junta oficial" i "La Mina: Fin del conflicto entre vecinos", El Correo Catalán, 8-5-1980 i 5-6-1980.

1678Joaquim Delunder: "La Mina: Manifestación de trescientos vecinos" i "Vecinos de La Mina piden la dimisión del alcalde", El Correo Catalán, 24-5-1980 i 13-6-1980.

1679Asociación de Vecinos del Polígono La Mina de Sant Adrián del Besós: "Comunicado de Prensa" (25-10-1980), AHLM, Caixa C-1.3. Associació de Veïns anys 70, Carpeta Comunicats de Premsa. 1680Margarida Corominas: "Agresión a un comunista", Mundo Diario, 6-7-1979.

1681 "Cancel-lat el servei de menjador a Cascabel" i "La guarderia Cascabel tanca les portes", Avui, 3 i 11-9-1982 i Vecinos del Poble Nou, Mina i Besós: “La línea 41”, El Correo Catalán, 18-1-1983. 
barri i la crítica al Pla Marina-Besòs. Va haver-hi negociacions entre Ajuntament, partits, veïns i CMB i es va fer una Comissió d'Urbanisme del barri. Finalment semblava la situació semblava definir-se amb la redacció d'un PERI i un Pla Especial d'Atenció Urbanística que preveia la reparació dels degradats 502 habitatges existents, la construcció de 330 nous i l'expropiació d'altres terrenys ${ }^{1682}$. Altres temes recurrents van ser les demandes d'una major vigilància contra la delinqüència existent. Però la situació urbanística del barri va continuar sent una font de conflicte els anys posteriors.

Al barri de Sant Juan Baptista el veïnat va estar pendent del Pla Marina-Besòs que contemplava la construcció de nous blocs d'habitatges, així com de la problemàtica que ocasionaven les industries properes, algunes de perilloses com INBESA on va haver-hi un greu accident amb dos obrers morts i dos ferits el juny de $1980^{1683}$. L'AVV esperonava als seus associats a fer pressió a l'Ajuntament per aconseguir millores pel barri ${ }^{1684}$.

Per últim, l'AVV de Sant Adrià Nord va mantenir una certa activitat per la presència a la seva Junta de persones com Agustí Gallart i d'altres persones militants o properes a CiU (com la seva dona o l'esmentat Jaume Vallés) i al PSUC. Van fer campanyes per la nova retolació de carrers, per la seguretat ciutadana, per l'enllumenat públic, contra l'elevat trànsit de vehicles, per la sanitat, el medi ambient o contra l'obertura d'una sala de festes ${ }^{1685}$. També va patir algun assalt com el del maig de 1982, segurament fet per membres d'extrema dreta ${ }^{1686}$. Les seves relacions amb l'Ajuntament van ser tenses en aquest període.

Finalment es va constituir una coordinadora d'AVV's que segons un dels nostres entrevistats, va ser operativa durant un període de 10 anys ${ }^{1687}$. Però les relacions amb l'Ajuntament socialista van ser complicades per que aquest no ho va posar fàcil per unes entitats que no solien ser -encara- totalment de la seva corda. En aquest sentit, el regidor i membre de l'AVV de Sant Adrià nord es queixava en

1682“Sant Adrià: Reformarán el polígono de La Catalana”, El Correo Catalán, 15-5-1982. 1683Joaquim Dellunder: "Denuncian un accidente en INBESA", El Correo Catalán, 6-6-1980. 1684Joaquim Dellunder: "Sant Joan quiere mejoras en el barrio", El Correo Catalán, 4/5-4-1980. 1685 La Vanguardia, 18 i 25-8-1979; Mundo Diario, 31-8-1979; La Vanguardia, 14-2-1980; El Correo Catalán, 22-2-1980, 23-3-1980, 15-5-1980; La Vanguardia, 13-9-1980; El Correo Catalán, 152-1981 i 18-3-1981.

1686Agustí Gallart: "Senyeres fetes malbé en un assalt a la seu de l'Associació", Avui, 5-5-1982. 1687Entrevista a Juan José Castro Castillo, 20-12-2012 i 21-1-2013. 
una carta enviada a La Vanguardia:

\begin{abstract}
“Durante estos tres años, una de las vertientes que más me ha impresionado ha sido el olvido en que ha quedado la "participación ciudadana" por parte de la mayoría de grupos de gobierno municipal (...) ha sido frecuente que, cuando des de las entidades cívicas o desde los grupos de la oposición municipal, se requería a estas mayorías de gobierno local efectuar alguna consulta ciudadana respecto a impuestos, contribuciones especiales o bien a la confección de planes de reforma urbanísticos, se cerraban en la más estricta de las normativas legales vigentes (...) dejando de lado la opinión de los vecinos afectados."1688
\end{abstract}

Com hem pogut apreciar, la situació als primers ajuntaments democràtics al Barcelonès Nord va ser similar a la que es va donar en altres consistoris de la Catalunya urbana, si bé amb peculiaritats pròpies com podrem veure quan analitzem el diferent comportament electoral durant les eleccions municipals de 1983. Van ser uns anys intensos per l'adaptació i la lluita de les diferents formacions polítiques per l'espai electoral després de molts anys on aquesta via estava totalment vetada. Des de aquests nous ajuntaments, malgrat que no tot van ser flors i violes com he pogut explicar en les pàgines anteriors, es va dur una important tasca per redreçar el desgavell urbanístic provocat per la dictadura franquista i les seves administracions locals. Malgrat les queixes i la oposició dels sectors encara més militants que van romandre en les AVV's, el cert és que durant aquests primers anys la percepció de la majoria de la població sobre la tasca feta va ser -en general- positiva. I més tenint en compte un context on les arques municipals no solien estar plenes i amb una dura crisi econòmica.

No obstant, encara que fos des de sectors més minoritaris va existir una certa crítica a les noves autoritats municipals. Certament una part d'aquesta provenia de sectors que havien estat derrotats electoralment, però que propugnaven -como vam veure- uns models de gestió municipal més oberts i participatius i que van tenir un protagonisme notable en determinades associacions encara durant gran part dels anys vuitanta. I malgrat que en general la percepció positiva de la gestió municipal que he esmentat anteriorment podia ser un fre a les mobilitzacions juntament amb altres factors com la crisi econòmica o la major influència de valors

1688Jaume Vallés i Muntades, regidor de l'Ajuntament de Sant Adrià de Besòs [CiU]; “Las elecciones municipales hay que ganarlas día a día", La Vanguardia, 16-4-1982. 
conservadors i dretans, aixo no va significar la fi de les lluites i les mobilitzacions veïnals com tindrem ocasió de veure en el capítol següent. 


\title{
V. El moviment veïnal als anys vuitanta: una crisi real però magnificada.
}

"Enseguida van fer cridar la Policia Nacional i van venir a carregar. Van començar a repartir òsties... a l'Agustín i a mi... '¡A este y este!'. Suposo que ja ens tenien vistos (...) ens tenien molt clixats per que després a un altre que li van fer molt mal també va ser a un mestre que treballava allà al carrer Piferrer, a l'escola d'allà, que tenia tot el cabell blanc. I un dia van venir en plan de todo per que ... '¡Al del pelo blanco!' I li van donar amb la porra a la cara i li van destrossar un ull saps... vull dir que ... Es van ensanyar.... Això va ser va al final que ja veien que la moguda no parava, no parava.." ${ }^{1689}$

\begin{abstract}
"Una gent compra, el pis, van pagant el pis, el tio hipoteca el pis, no paga la hipoteca, els veïns no se n'assabenten, subhasten el pis... la gent que ja hi vivia allà i els volen fer fora. (...). El vam recolzar, al barri apareixen unes octavetes i pancartes que deien 'cuervo subhastero, no nos echarás a la calle' 'fuera cuervo subhastero' (...) I llavors agafa el Sánchez Esteller aquest (...), i em va fer una demanda per injúries, a la revista Grama, a la Associació de Veïns del Barri i al veí.

(...) vam anar a judici aquí a Santa Coloma i Santa Coloma diu que en fin, que ni injúries ni res. Desestimen el cas, acaben el cas. El tio fa un recurs a Barcelona. Al judici a Barcelona anem tots, van tindre que canviar la sala per que no hi cabíem a dins. Vam omplir la sala aquella de gent, va vindre també el Lluís Hernàndez aquell dia (...) i desestimen, diuen que no, que ja.... causa per injúries ni per res d'això. I el Sánchez Esteller fa un recurs a Madrid i el Tribunal Suprem de Madrid, sense conèixer ni saber de que anava el tema, anul·la la sentència i fa la sentència de desterrament d'un any a 100 quilòmetros de Santa Coloma. També per mi es demanava vint milions de pessetes de l'època (...) que diu aquest tio! ${ }^{1690}$
\end{abstract}

"Descubrimos que lo que estaban haciendo es... nos estaban puenteando... el técnico del Ayuntamiento, que además pregunté que había trabajado muy bien en la clandestinidad y en ciertas experiencias pedagógicas interesantísimas... y en aquel momento nos estaba puenteando junto con el Ayuntamiento de Sant Adrià porque el verdadero plan que llevaban era: tirar a la gente fuera, tirar toda esta parte del barrio (...) [es refereix a La Mina] esplícitamente está documentado. Duramos tres meses." 1691

1689Entrevista a Francisco Domínguez García “Curro”, 19-6-2013. Membre de l'AVV Sant Antoni de Llefià (Badalona).

1690Entrevista a Josep Pitarque Narejos, 12-3-2013 (amb Emiliana Salinas i Salvador Bolancer). Membre de l'AVV del Raval (Santa Coloma) i militant del MCC.

1691Entrevista a José Francisco Marín Rodríguez, 14-2-2013. Membre de l'AVV La Mina, de l'Assamblea de Barri i de la Plataforma de Veïns (totes de La Mina, a Sant Adrià de Besòs). 


\subsection{L'Impacte de la crisi econòmica: atur i delinqüència. Crisi de valors. Consciència de classe contra consumisme $\mathrm{i}$ individualisme?}

Qualsevol estudi que vulgui aprofundir en la situació del moviment veïnal durant els anys vuitanta no pot passar per alt un fet molt important que va condicionar gran part dels esdeveniments d'aleshores: la crisi econòmica. En el moment d'escriure aquestes línies estem immersos encara en la greu crisi que va començar al 2007 i 2008, i de manera semblant en aquells anys, finals dels setanta i gran part dels vuitanta, la població va sofrir els efectes colpidors d'una crisi econòmica tant dura -si més no- com l'actual. Els efectes van arribar a l'Estat espanyol amb una mica de retard -com a economia més perifèrica- $\mathrm{i}$ també per que el franquisme que estava en fase terminal va intentar "camuflar" o "dissimular" el seu impacte per no afegir més benzina a una conflictivitat social que el desbordava. Però durant la segona meitat dels setanta els efectes d'aquesta crisi van ser ja impossibles d'ocultar i va esclatar amb tota la seva duresa. No va ser fins que la situació política va estar més clarificada, després de les eleccions del 15-J i de que el resultat d'aquestes precipités un procés constituent que en un principi no estava previst, que es van començar a prendre les primeres mesures per fer front a la nova situació econòmica:

“Els pactes de la Moncloa incloïen dos tipus de mesures, unes de caràcter conjuntural que implicaven un pla d'ajust econòmic, i un segon grup amb propostes de reforma. Aquestes van ser presentades en part com a contrapartida de les primeres i en part com a l'inici del projecte de democràcia socialment avançada que reclamava la ciutadania.

L'element central del programa d'ajust contra la inflació feia referència a la política salarial. De fet, aquests pactes condicionaven totalment la negociació dels convenis col·lectius de 1978, els primers que tingueren lloc en una situació política plenament democràtica. Els pactes de al Moncloa fixaren un límit als augments salarials de l'any següent, de manera que els impedí de recuperar la pèrdua del poder adquisitiu provocada per la inflació de l'any 1977. Amb això es confiava trencar amb l'espiral inflacionària (augments consecutius de preus i salaris). També s'hi incorporà, de manera parcial, la fixació d'augments salarials proporcionals (el mateix percentatge d'augment per totes les categories laborals) en lloc dels increments lineals (una mateixa quantitat de pessetes per totes les categories), que havien estat usuals els 
anys anteriors, a causa de les concepcions igualitàries del moviment obrer. Aquesta reducció de salari real vingué acompanyada de l'assumpció per part del pressupost públic d'una part de les aportacions a la Seguretat Social, per tal de frenar el creixement dels costos salarials indirectes. L'acord també incorporava una sèrie de mesures de vigilància dels preus de determinats productes, amb l'objectiu d'evitar un descontrol que hauria minat la credibilitat de la política salarial. També es preveien mesures monetàries i de fre al creixement de la despesa pública, justificades des d'una perspectiva de control de la inflació." ${ }^{1692}$

Els “Pactes de la Moncloa”, en propugnar la moderació salarial i de la despesa pública, van iniciar la tendència -que va tenir un major èxit les dècades posteriorsde fer revertir les mesures contra la crisi econòmica sobre el poder adquisitiu de la classe treballadora:

"En los Pactos de la Moncloa, firmados por ocho representantes de la nueva configuración de fuerzas políticas, entre ellos Santiago Carrillo por los comunistas y Felipe González por el PSOE, se acordó mantener el aumento de los salarios por debajo del nivel de inflación, lo que supuso un recorte del $7 \%$ del nivel de vida de los asalariados. A cambio se prometieron algunas reformas sociales y económicas. Unos años después, todavía seguían en el tintero."1693

És cert que no totes les culpes es poden atribuir només als Pactes en si. Primer, per que els acords allà signats tenien -en principi- una aplicació limitada en el temps pel que fa a la qüestió salarial a l'any 1978. I segon, per que també teòricament s'havien introduït una sèrie de mesures que havien de compensar aquesta moderació: la reforma fiscal, la regulació dels drets laborals així com altres polítiques més vagues en matèria educativa i industrial ${ }^{1694}$. Però apart de la reforma fiscal que es va fer l'any 1978 amb la creació de l'Impost de la Renda sobre les Persones Físiques i de l'Impost de Patrimoni, el cert és que aquestes altres mesures van ser reiteradament no acomplertes en la seva totalitat -quan no directament boicotejades- per part de la CEOE, la UGT i el PSOE ${ }^{1695}$. Com hem pogut

1692 Albert Recio: "Crisi i reconversió econòmica" dins Borja de Riquer (dir.): Història, política, societat i cultura dels Països Catalans. Volum XI. De la dictadura a la democràcia (1960-1980), p. 316-317.

1693Sebastian Balfour: La dictadura, los trabajadores y la ciudad..., p. 252.

1694 Albert Recio: "Crisi i reconversió econòmica" dins Borja de Riquer (dir.): Història, política, societat i cultura dels Països Catalans... p. 317.

1695 José Maria Marín Arce: Los sindicatos y la reconversión industrial durante la transición, Consejo 
veure al capítol anterior les mobilitzacions per reivindicar les tant necessàries escoles, i també el cas dels dèficits sanitaris van ser especialment intenses durant els primers anys dels ajuntaments democràtics, i eren -en gran part- una conseqüència dels incompliments d'aquests compromisos per part del govern central. De fet, la mateixa conflictivitat obrera de l'any 1979, que va ser superior a la de 1976 en el conjunt de l'Estat si ens fixem en les dades sobre vaguistes i hores no treballades, desmuntant el tòpic de que els Pactes de La Moncloa van implicar la desmobilització immediata dels treballadors, si bé, al contrari que en altres períodes, aquestes van ser preeminentment defensives ${ }^{1696}$.

CONFLICTIVITAT LABORAL 1976-1980

\begin{tabular}{lll}
\hline Any & Vaguistes & Hores no treballades \\
\hline 1976 & 3.638 .957 & 110.016 .240 \\
1977 & 2.317 .026 & 92.572 .050 \\
1978 & 3.633 .004 & 128.738 .478 \\
1979 & 5.752 .304 & 171.067 .662 \\
1980 & 2.461 .061 & 108.625 .662 \\
\hline
\end{tabular}

Font: J. A Sagordoy i D. León Blanco, El poder sindical en España, Barcelona, 1982 [Tabla reproduïda de Pere Ysàs: "Movilización y desmovilización obrera...” a a Javier Tébar Hurtado (ed.): El movimiento obrero en la gran ciudad..., p. 292.]

Segurament van ser tant o més importants per la crisi i relativa desmobilització dels vuitanta la constatació de la divisió sindical i la política de concertació amb la patronal CEOE impulsada inicialment pel sindicat UGT amb el "Acuerdo Básico Interconfederal" (juliol 1979) i el "Acuerdo Marco Interconfederal" (gener 1980), així com el seu suport al "Estatuto de los Trabajadores" en el context de la seva lluita enconada contra l'hegemonia sindical de CCOO, tema que també donaria per una tesi sencera.

Económico y Social, Madrid, 1997. Veure també del mateix autor "Condicionantes económicos y sociales de la transición" a Carme Molinero (ed.): La Transición treinta años después, Península, Barcelona, 2006, p. 81-116. De fet, encara que pugui sobtar a les persones de tradició militant d'esquerres -entre les que m'incloc- la CEOE, encapçalada per Carlos Ferrer Salat es va oposar durament a aquests pactes i les seves pressions van forçar la dimissió de Enrique Fuentes Quintana al cap del gabinet econòmic. Aquesta qüestió està sent tractada en una tesi doctoral en curs de Guillermo García Crespo amb el títol -provisional- "Els empresaris davant la incorporació a la Comunitat Europea (1962-1986)".

1696Pere Ysàs: "Movilización y desmovilización obrera. Del franquismo a la democracia" a Javier Tébar Hurtado (ed.): El movimiento obrero en la gran ciudad. De la movilización sociopolítica a la crisis económica, El Viejo Topo, [Barcelona], 2011, p. 273-297. 


\begin{tabular}{lll}
\hline & 1979 & 1983 \\
\hline PAÏSOS CATALANS & & \\
Catalunya & 8,90 & 19,30 \\
País Valencià & 8,30 & 17,00 \\
Illes Balears i Pitiüses & 6,70 & 11,60 \\
RESTA DE L'ESTAT & & \\
Andalusia & 14,50 & 23,50 \\
Aragó & 7,00 & 14,10 \\
Astúries & 7,90 & 13,50 \\
Canaries & 12,00 & 20,70 \\
Cantàbria & 5,50 & 12,20 \\
Castella-La Manxa & 8,50 & 15,40 \\
Castella-Lleó & 7,30 & 13,50 \\
Extremadura & 15,50 & 20,30 \\
Galícia & 4,30 & 9,00 \\
Madrid & 11,10 & 17,60 \\
Múrcia & 9,10 & 14,50 \\
Navarra & 9,20 & 14,60 \\
País Basc & 10,70 & 20,00 \\
La Rioja & 4,10 & 10,00 \\
Total Estat espanyol & 9,50 & 17,30 \\
\hline
\end{tabular}

Fuente: Martín Rodríguez, M., en Garcia Delgado, J. L., España: Economía, de. Espasa Calpe, Madrid, 1989, pàg. 725 [Tabla reproduïda a Ma del Carmen Hurtado Martínez: La inseguridad ciudadana de la transcición española a una sociedad democrática (1977-1989), Tesi Doctoral, Ediciones de la Universidad de Castilla La Mancha, 1999.

Una de les conseqüències d'aquesta crisi va ser la destrucció de molts llocs de treball al sector secundari. Això va afectar a les poblacions del Barcelonès Nord més eminentment industrials, com eren Badalona i Sant Adrià de Besòs. A Badalona aquest fet es va notar i molt, ja que era una ciutat on predominava la petita i mitjana empresa, a priori més vulnerable. Si al 1973 la ciutat comptava amb 2.324 indústries que donaven feina a 26.678 treballadors, al 1981 restaven 1.213 indústries i al 1986 només 892, que donaven feina a 13.536 treballadores i treballadors. El descens havia estat molt notable, del $61,6 \%{ }^{1697}$. Els sectors més afectats van ser el tèxtil, la química i la metal-lúrgia. El primer ja havia tingut un cert estancament als anys seixanta però amb la crisi una part molt considerable de la seva producció va passar a realitzar-se en l'anomenada "economia submergida". La caiguda de poder adquisitiu i de retruc de la compra de bens va afectar greument a la indústria metal·lúrgica, mentre la construcció va patir també una forta recessió.

1697Joan Villarroya (dir.): Història de Badalona, p. 262. 


\begin{tabular}{lll}
\hline Any & Total d'habitatges & Llicències \\
\hline 1973 & 5.187 & - \\
1974 & 5.001 & - \\
1975 & 2.575 & 165 \\
1976 & 2.242 & 197 \\
1977 & 159 & 61 \\
1978 & 152 & 53 \\
1979 & 203 & 50 \\
1980 & 120 & 37 \\
1981 & 120 & 35 \\
1982 & 261 & 40 \\
1983 & 235 & 59 \\
1984 & 316 & 60 \\
1985 & 443 & 77 \\
\hline
\end{tabular}

Font: Joan Villarroya (dir.): Història de Badalona, p. 264.

A mitjans dels anys setanta l'arribada d'immigrants es va aturar i això, juntament amb la crisi econòmica va frenar molt l'activitat constructora que havia estat frenètica els anys anteriors. La ciutat de Badalona, de la qual les autoritats locals franquistes havien presumit de ser la primera en tot l'estat en diversitat industrial, estava en un estat de shock. La situació es va anar deteriorant progressivament en la mesura que avançava el procés de canvi polític, i com hem vist, al final dels anys setanta va haver-hi una gran conflictivitat motivada pels cada vegada més nombroses expedients de crisi i reconversió. L'escassetat dels resultats positius que es van obtenir van ser un factor molt greu -juntament amb altres esmentats anteriorment- per l'erosió dels sindicats recentment legalitzats, i, sens dubte, va ser un factor més a tenir en compte per l'aparició del "desencanto" i la posterior davallada de conflictivitat ja durant els vuitanta. Com va dir encertadament l'historiador Xavier Domènech:

"Tot un model de creixement econòmic i social, gestat durant la Segona Guerra Mundial, finia i s'iniciava un nou món. Les formes tradicionals de vida de les classes populars fins llavors patien un canvi radical. La fàbrica i el treball perdien la centralitat que les havia caracteritzades. La classe obrera se segmentava generacionalment, entre unes generacions que continuaven vivint en el món de la fàbrica i unes altres que començaven a viure en el món de la precarietat laboral en els primers moments de la seva trajectòria laboral. La socialització tradicional en el món laboral, la transmissió de sabers pràctics i polítics que no s'havien interromput dins de la classe -no desapareixent completament ni durant els moments més durs del franquisme-, ara 
s'esvaïa." ${ }^{1698}$

Amb aquestes perspectives l'atur es va disparar al Barcelonès Nord, arribant a taxes de més del 25 \% de la població. Al 1981 a Badalona estaven registrades oficialment 22.268 persones aturades (un 26\% de la població activa) però al 1986 la xifra pujava ja a 27.000 persones (un 31,3 \% de població activa!) ${ }^{1699}$. La ciutat va passar de ser una urbs preeminentment industrial a una on el sector Terciari adquiria la preeminència. No es d'estranyar la llarga llista de tancaments d'empreses industrials que van cessar la seva activitat als anys vuitanta per la crisi econòmica. Per citar només els casos més importants, en el tèxtil van tancar les fàbriques de Salvador Casacuberta, Indústria del teixit Cuyàs, Industrial Montalfita, Manufactures NIC i Antoni Solé "Elos". Indústries "tradicionals" com les corderies van desaparèixer, mentre que en el sector que més havia crescut als anys seixanta, la metal-lúrgia, van tancar Bomba Prat, Bomba Bloch, Aerosoles Schilt, G. De Andreis Metalgraf (la Llauna), Motoplat, Rivière, Trigamo, Gelpha, Bacàs i Talleres Blanch. Les químiques no es van quedar enrere: Nerca, SA Cros i el CACI també es van acabar tancant. En el sector dels assaonaments tancaven les empreses de Carlos Csonka, Lluís Ysamat i Charles Le Boeuf. Notori va ser també el tancament de l'empresa electrònica Piher, després d'un llarg conflicte ${ }^{1700}$. No hem d'oblidar que en tot aquest procés un gran nombre de mitjanes i petites empreses -menys conegudes i que eren les que predominaven a la ciutat- van acabar desapareixent i que altres empreses que van continuar subsistint també van acomiadar a molt de personal.

En altres casos les empreses es traslladaven a altres municipis que disposaven de sol industrial a un preu més barat, tot i que el sector secundari no va desaparèixer del tot i per exemple a finals dels anys noranta encara ocupava a un 31,7 \% de la població activa. S'estava seguint un procés similar al del Principat, on cada vegada serà més fort el sector Terciari i comercial, però amb uns costos socials enormes i un creixent atur que només va començar a remetre tímidament a

1698Xavier Domènech Sampere: Temps d'interseccions. La Joventut Comunista de Catalunya (19701980), Fundació Francesc Ferrer i Guàrdia, Sabadell, 2008, p. 166-167.

1699Joan Villarroya (dir.): Història de Badalona, p. 267.

1700 Ídem, p. 263. 
partir de l'any 1985-1986 a costa de la major precarització i temporalitat del treball, sobretot de segments de la població com joves i dones ${ }^{1701}$. Tot i això, no tothom va patir aquestes dures condicions ${ }^{1702}$, ja que vist així podria semblar que la situació social era més greu que durant el franquisme i el cert és que també van ser uns anys on es van millorar els serveis públics com l'educació i la sanitat. Va ser a la dècada dels 70 i 80 va ser quan la classe treballadora de l'Estat espanyol va entrar clarament dins la cultura del consum de masses ${ }^{1703}$, amb tot el potencial alienador i carregat de valors individualistes que comportava. Paral-lelament la millora de les prestacions socials en concepte d'atur van atenuar una part de l'impacte de la crisi, al igual que el creixement de l'economia submergida. Però s'havia creat una divisió i una escletxa dins la classe treballadora que serà aprofitada en els anys posteriors per afeblir-la fins a extrems insospitats. Per primera vegada l'atur es va convertir en un fenomen estructural -en especial en els joves- i aquest fet va condicionar molt les formes d'encarar les relacions laborals durant la dècada dels vuitanta per la por, coacció i xantatge a perdre la feina. Això juntament amb uns sindicats que van renunciar -de grat o per força- a tenir un major poder de decisió dins el procés productiu dins les empreses i que van centrar-se en defensar als seus afiliats en un context extremadament hostil, va trencar amb tota una tendència on la lluita obrera i sindical havia aconseguit millores en les condicions de vida de la classe treballadora. Aquest fet va allunyar a questes noves generacions instal-lades en la precarietat de la cultura sindical i va ser un factor que va incidir en l'afebliment dels sindicats per les mancances d'afiliació i relleu generacional. De retruc ho va fer també de la classe treballadora en introduir una important divisió que afeblia els tradicionals vincles de solidaritat de classe.

1701Albert Recio: "Els efectes socials de l'atur", dins Borja de Riquer (dir.): Història, política, societat i cultura dels Països Catalans... p. 324-325. Sobre aquesta mateixa qüestió veure també Xavier Domènech i Sampere:Temps d'interseccions..., p. 170-173.

$1702 \mathrm{~A}$ l'article anterior Albert Recio esmentava com aquesta concentració de l'atur en determinats col-lectius va atenuar els efectes de la crisi (només un $25 \%$ de l'atur va afectar a la persona que aportava els principals ingressos a la unitat familiar).

1703Xavier Domènech: "La otra cara del milagro español. Clase obrera y movimiento obrero en los años del desarrollismo", Historia Contemporánea, núm. 26 (2003), p. 91-112. 
POBLACIÓ OCUPADA PER SECTORS. ANY 1981 EN \%

\begin{tabular}{llllll}
\hline & AGRICULTURA & $\begin{array}{l}\text { ENERGIA } \\
\text { I AIGUA }\end{array}$ & INDÚSTRIA & CONSTRUCCIÓ & SERVEIS \\
\hline BADALONA & 0,8 & 1,6 & 49,8 & 7,8 & 40,0 \\
STA. COLOMA & 0,3 & 1,5 & 48,8 & 9,7 & 37,8 \\
SANT ADRIÀ & 1,5 & 1,7 & 42,8 & 5,8 & 48,1 \\
BARCELONA & 0,5 & 1,6 & 34,1 & 3,6 & 60,3 \\
CATALUNYA & 2,2 & 1,3 & 44,0 & 6,1 & 46,4 \\
\hline
\end{tabular}

Font: Just Casas i Soriano i Manuel Màrquez i Berrocal: Història social de Sant Adrià de Besòs. Vol. I. La Població: segles XVIII-XX, Hacer Editorial, [Barcelona], 1996.

Sant Adrià de Besòs, ciutat que també tenia una indústria important i gran part de població que treballava en ella, va patir un procés similar al de Badalona. Moltes fàbriques es van veure afectades per la crisi. Grans empreses com Bultaco, (en el cas d'aquesta també després d'un intens conflicte ${ }^{1704}$ ), INBESA, CELO (també amb conflictivitat, ja que els antidisturbis van arribar a intervindre contra els treballadors que retenien a directius ${ }^{1705}$ ) van haver de tancar. Això sense comptar els acomiadaments de les empreses que no tancaven però que aplicaven expedients de regulació de personal. Les taxes d'atur a Sant Adrià de Besòs s'enfilaven al 37 \% l'any $1987^{1706}$. I en alguns dels seus barris -com La Mina- encara superaven el $50 \% !^{1707}$.

Santa Coloma de Gramenet també es va veure afectada per la crisi industrial. Molta de la seva població treballava en el sector secundari en altres poblacions dels voltants (com Badalona, Sant Adrià i Barcelona, sobretot). Però fins i tot en l'existent indústria de la ciutat la crisi va tenir els seus efectes. Ja als anys setanta

1704Joaquim Dellunder: "Fin del encierro de los trabajadores de Bultaco", El Correo Catalán, 13-91979; Margarita Corominas: "Bultaco, a la expectativa" i "Encierro indefinido en Bultaco", Mundo Diario, 14 i 21-9-1979, respectivament; "Bultaco: Cierre patronal hasta que acabe su crisis", "Bultaco: Trabajadores y empresa en la Generalitat" i Joaquim Dellunder: "Trabajadores de Bultaco, encerrados”, El Correo Catalán, 8, 11 i 31-1-1980, respectivament; "San Adrián: Trabajadores de Bultaco se encadenan", El Noticiero Universal, 23-1-1980; Joaquim Dellunder: "La policía intenta desalojar a los trabajadores de Bultaco", "Quejas en un expediente de regulación de empleo", i "Bultaco: Los trabajadores apuestan por la normalidad”, El Correo Catalán, 14-3-1980, 23-5-1980 i 8-6-1980, respectivament.

1705 Margarida Coromines: "Sant Adrià lucha por no perder otros 300 empleos", El Periódico de Catalunya, 16-7-1985.

1706"Sant Adrià, vila en complex de marginació", Avui, 21-2-1987.

1707Un estudi de finals dels vuitanta parlava d'una taxa d'atur del 54,73\% (Homes 52,90 \% i Dones 58,32 \%). Veure Fundació Família i Benestar Social: Proposta de Treball Comunitari per al Barri de La Mina. Sant Adrià de Besòs [1988-89?], AHLM, Caixa C-1 L-1.4 La Mina anys 80, Carpeta Anys 80. Fundació Família i Benestar Social p. 26 . En els anys més durs de la crisi econòmica, segons alguna premsa fins i tot arribava al 70 \%!!. Veure Joaquim Roglán: "La Mina, cada vez peor porque ya no hay ni plan de urgencia" i "El Síndic de Greujes oye con angustia las quejas de La Mina”, El Periódico de Catalunya, 20-4-1986 i 8-10-1986, respectivament. 
van tancar Casadeport, Confecciones Ponz, Eurostil i d'altres de les empreses tèxtils més grans de la ciutat, desplaçant-se aquesta activitat a l'economia submergida:

"En un porcentaje muy alto las trabajadoras de la empresa se pusieron a trabajar en la economía sumergida, trabajando sin ningunas condiciones, en sótanos, mal pagadas, sin cotizar y además llevando sus casas, yo conozco antiguas compañeras de mi edad que todavía están en esas condiciones."1708

També van tancar empreses del ram del metall i l'electrònica com RKG i Mecanizados Haro, o del sector de les químiques com Vilaseca. Aquesta darrera va aprofitar les molèsties que ocasionava en el veïnat com excusa per tancar. D'altres faran servir la crisi per traslladar les seves empreses a zones menys conflictives i amb mà d'obra més barata ${ }^{1709}$. El poc teixit industrial colomenc va quedar molt ressentit i l'economia submergida va florir, en especial al sector del tèxtil i la confecció. La proliferació de tallers il-legals i clandestins, que treballaven en no pocs casos amb la maquinària de les antigues fàbriques i amb el control dels antics caps de les empreses tancades, va ser una realitat molt present i coneguda molt abans de l'arribada de la immigració xinesa a la qual s'ha volgut -en l'actualitatresponsabilitzar erròniament de la proliferació d'aquest tipus d'economia.

Aquest anàlisi de la crisi industrial quedaria del tot incomplet sense tenir present que al Barcelonès Nord un nombre important de persones es desplaçaven a les indústries existents a Barcelona ciutat que també van patir els efectes de la crisi amb molts tancaments, que van afectar molt, per exemple, a la zona industrial del Poblenou on van desaparèixer moltes fàbriques.

Tots aquests fets van afectar més intensament als barris de classe treballadora i en el cas del Barcelonès Nord a aquells on s'havia assentat la població provinent d'altres indrets de l'Estat espanyol. En aquest context tant difícil molta gent, en quedar-se sense feina, no va poder fer front -tal com passa en el moment d'escriure aquestes línies- a les seves hipoteques i lloguers i van perdre

1708Veure Lola Carrión: La conflictivitat laboral en Santa Coloma de Gramenet des de 1968 a 1978. Treball de Màster, Universitat de Barcelona, 2008. Entrevista a Fidela Gutiérrez Camacho, treballadora d'Eurostil, p. 162.

1709Lola Carrión: La conflictivitat laboral en Santa Coloma de Gramenet des de 1968 a 1978..., p. 165-166. 
els seus habitatges.

"En el 81 estábamos... vivíamos en el trabajo la crisis aquella fuerte que hubo, que además había desahucios lo mismo que ahora, no tan fuerte como ahora (...). Fue dura y la gente... Lo único que pasa es que yo era como dice él... mucho más organizao. Los barrios tenían una organización potente todavía en el año ochenta y dos y... (...). Entonces resulta de que en esos años la... los años ochenta todavía había un tejido social en el movimiento asociativo suficientemente fuerte para poder de alguna manera tratar cualquier problema des de el barrio mismo. No como ahora que tienen que venir todos aquí a la PAH y en el barrio ni se enteran, y la Asociación de Vecinos ni se entera ni le interesa." ${ }^{1710}$

La premsa de l'època es va fer ressò d'aquest fet que ja va adquirir unes proporcions alarmants aleshores i que va forçar a nombroses famílies a viure de nou en barraques i tendes de campanya. A Badalona per exemple l'Ajuntament va haver d'allotjar una cinquantena de famílies en dependències municipals com regidories del districte, locals de la Brigada d'obres o fins i tot a dins del mateix Ajuntament ${ }^{1711}$. A l'any següent dues centes famílies desnonades de la mateixa ciutat amenaçaven amb una vaga de fam si no es solucionava la seva situación ${ }^{1712}$. A Santa Coloma la situació no era pas millor:

"Un reciente estudio del departamento de Servicios Sociales del Ayuntamiento de Santa Coloma de Gramenet ha revelado que en 1981 se produjeron 94 casos de deshaucio. Los barrios más afectados por este orden son Singuerlín, con 24; Santa Rosa, 16; Arrabal, 14; Italianos, 11; Fondo, 10; Centro, 9 y Can Mariné, 4." ${ }^{m 113}$

Però la situació, lluny de millorar, va anar a pitjor fins a mitjans dels anys vuitanta:

"Mas de doscientas demandas de desahucio, lo que equivale a una denuncia por día, han sido contabilizadas en los juzgados de Santa Coloma durante los siete primeros meses de este año. El mismo número de familias ha solicitado ayuda a los servicios sociales municipales para poder afrontar el alquiler de su vivienda." ${ }^{{ }^{1714}}$

1710Entrevista a Salvador Bolancer Dugo, 12-3-2013.

1711E. Giralt: "Badalona: en 42 metros vive una familia de 25 miembros", El Periódico de Catalunya, 17-4-1980.

1712Enric Giralt: "Badalona: 200 familias irán a la huelga de hambre”, El Periódico de Catalunya, 298-1981.

1713Jordi Corachán: "Los deshaucios en el cinturón barcelones, especialmente graves en Santa Coloma", El Correo Catalán, 7-10-1982.

1714 “Cada dia desahucian a una persona en Santa Coloma”, El Periódico de Catalunya, ?-11-1983. 
Dintre dels afectats pels mateixos desnonaments hi havia inquilins de pisos propietats de l'antic alcalde de Santa Coloma, Blas Muñoz, que era un dels principals propietaris de finques immobiliàries de la ciutat ${ }^{1715}$. La difícil situació no es limitava a la gent que no podia pagar la hipoteca o el lloguer del pis en que habitava. Un estudi municipal de l'any 1983 afirmava que el $20 \%$ dels habitants de la ciutat colomenca vivia en barraques o habitatges poc saludables ${ }^{1716}$.

Els efectes de la crisi econòmica es van fer sentir en les classes més modestes. No es cap misteri que el nivell de salut o l'esperança de vida té molta relació amb el nivell de renta de les persones. Així que no ens hauria d'estranyar que en períodes de recessió econòmica les diferències entre les zones més riques i les més pobres s'ampliessin, malgrat que comparat amb períodes anteriors no gaire llunyans les condicions encara fossin globalment millors:

"Los médicos han apreciado, a través de otras estadísticas, que en el Barcelonès Nord el periodo de cicatrización de las úlceras es más largo que cualquier otra zona de Catalunya." 1717

Si la situació en les tres ciutats del Barcelonès Nord -i en especial en els barris obrers- ja era prou alarmant, encara hi haurà situacions concretes que per les seves característiques "especials" encara seran més difícils. M'estic referint a casos com el dels barris de Sant Roc a Badalona i al de La Mina de Sant Adrià de Besòs. En aquest darrer barri, sobretot, s'estaven evidenciant els errors que es van cometre en la seva concepció, que pràcticament va consistir en concentrar en aquest polígon (en especial a la seva segona fase o "Mina nova") als habitants de diferents nuclis de barraquistes de la ciutat de Barcelona, on hi havia sectors de població en una situació d'exclusió social molt greu. Amb l'agreujant que, com solia passar en aquests casos, el barri es va construir amb moltes mancances en els equipaments

Veure també Eduard Blaus: "Oleadas de desahucios por mes en el Barcelonès Nord en los últimos años”, Grama (II època), 14-10-1982, p. 6-7.

1715Aurora Sánchez: "Orden de desalojo contra una familia de Santa Coloma” i "La Generalitat pagarà el alquiler de su casa a un parado", El Periódico de Catalunya, 10 i 11-10-1986.

1716“El 20 por ciento de los colomenses vive en barracas”, El Periódico de Catalunya, 21-11-1983. Malauradament no he pogut trobar l'estudi original.

1717 “Las úlceras del estómago de los pobres tardan más en cicatrizar”, El Periódico de Catalunya, 24-10-1986. Així ho afirmaven constatar els metges de l'Hospital Badaloní Germans Tries i Pujol (Can Ruti). 
socials mínims, sense suficients escoles, centres culturals, de salut ni zones verdes. Es van fer blocs d'habitatges de 8, 10 i 12 pisos i per tant la població del barri era molt elevada, al voltant de 15.000 persones, i es donaven densitats de 884 habitants per Hectàrea (superior a la del casc antic de Barcelona, de 531 hab/Ha i a la mitjana del Barcelonès de 221 hab./Ha). A això s'havia d'afegir el problema de la contaminació, molt elevada en el Barcelonès Nord i agreujada a La Mina per la proximitat de la Tèrmica del Besòs ${ }^{1718}$.

Tots aquests condicionants van convertir aquest barri en un lloc on es concentraven elevats índexs de marginació social. Els i les assistentes socials del barri ja als anys setanta havien denunciat aquesta problemàtica i com aquesta afectava a un sector especialment vulnerable com la població infantil:

\footnotetext{
“Durante los años en que el servicio social de La Mina ha funcionado se han visto con mucha frecuencia casos de niños con problemas y dificultades diversas. Estos casos unas veces se han podido resolver y otras veces han creado una angustia a los trabajadores al ver que no podía hacerse nada al ser los recursos sociales limitados y insuficientes.

En los dos últimos años, estos casos de "niños problema" han aumentado considerablemente; los asistentes sociales, con un conocimiento del barrio más profundo, han comprobado que las características de estos problemas eran cada vez más graves y complicadas. Esto puede significar que estamos ante unos problemas que tienen su raíz en una situación colectiva y que es urgente encontrar una alternativa para su solución."1719
}

No és aquest el lloc per fer un estudi socio-econòmic acurat d'aquest barri, però si que podem mostrar unes pinzellades gràfiques extretes de treballs ja realitzats que ens poden ajudar a entendre en quina situació es trobava La Mina en relació amb la resta de Sant Adrià. Aquestes dues gràfiques que adjunto a continuació, tal i com figuren en l'original, són una mostra molt interessant per veure quina era la situació dels diferents barris de Sant Adrià de Besòs en dos aspectes tan crucials com el nivell de formació acadèmica i l'atur. El primer ens

1718Daniela Gutiérrez i Tiña Ureña: Polígono La Mina (juny 1980). [Treball de 1er d'Assistents Socials, Curs 79/80], AHLM, Caixa C-1 C-1.4 La Mina anys 80, Carpeta Estudis sobre La Mina anys 80 , p. 4-5.

1719Montserrat Colomer Salmons, Montserrat Flaquer Badell i Maria Teresa Massons Rabasa, Asistentes Sociales del Patronato Municipal de la Vivienda de Barcelona en el barrio de La Mina: Informe sobre la problemática infantil en el barrio de La Mina (juliol 1978), AHLM, Caixa C-1 C-1.3. La Mina anys 70, Carpeta Estudis sobre La Mina Anys 70, p. 3. 
permet fer una extrapolació amb els nivells de renda existents, ja que generalment sol passar que a major nivell adquisitiu hi ha un major nivell de formació acadèmica. I tot i que en general al Barcelonès Nord tenia un predomini de classe treballadora amb una formació més aviat pobre, es poden observar gradacions segons els barris i el sexe dels habitants. Amb l'atur també podem observar que, tot i l'afectació general, també es dona un fenomen similar i existeixen uns barris més afectats que uns altres.

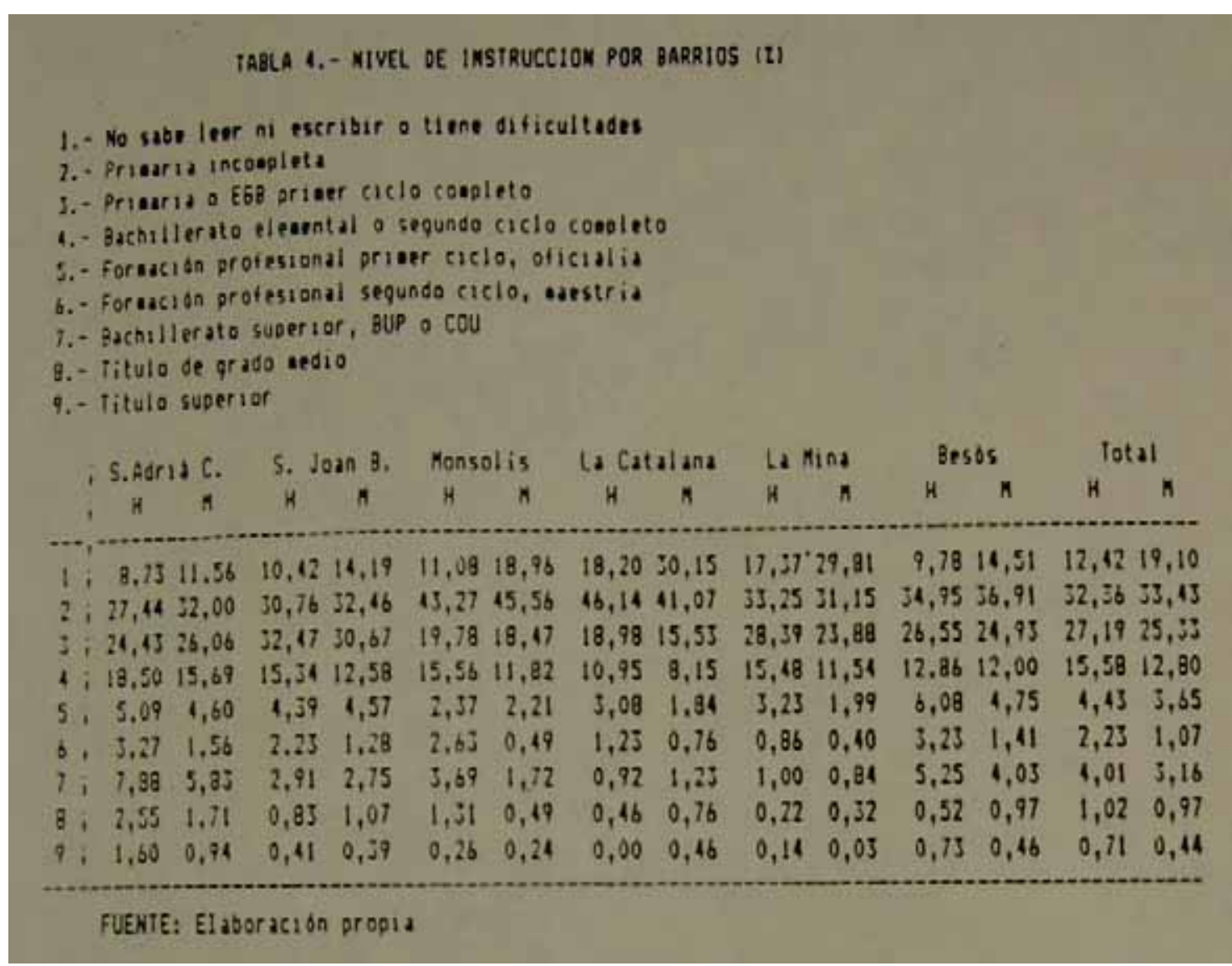

Font: Fundació Família i Benestar Social: Proposta de Treball Comunitari per al Barri de La Mina. Sant Adrià de Besòs [1988-89?], AHLM, Caixa C-1 L-1.4 La Mina anys 80, Carpeta Anys 80. Fundació Família i Benestar Social p. 37-38. 


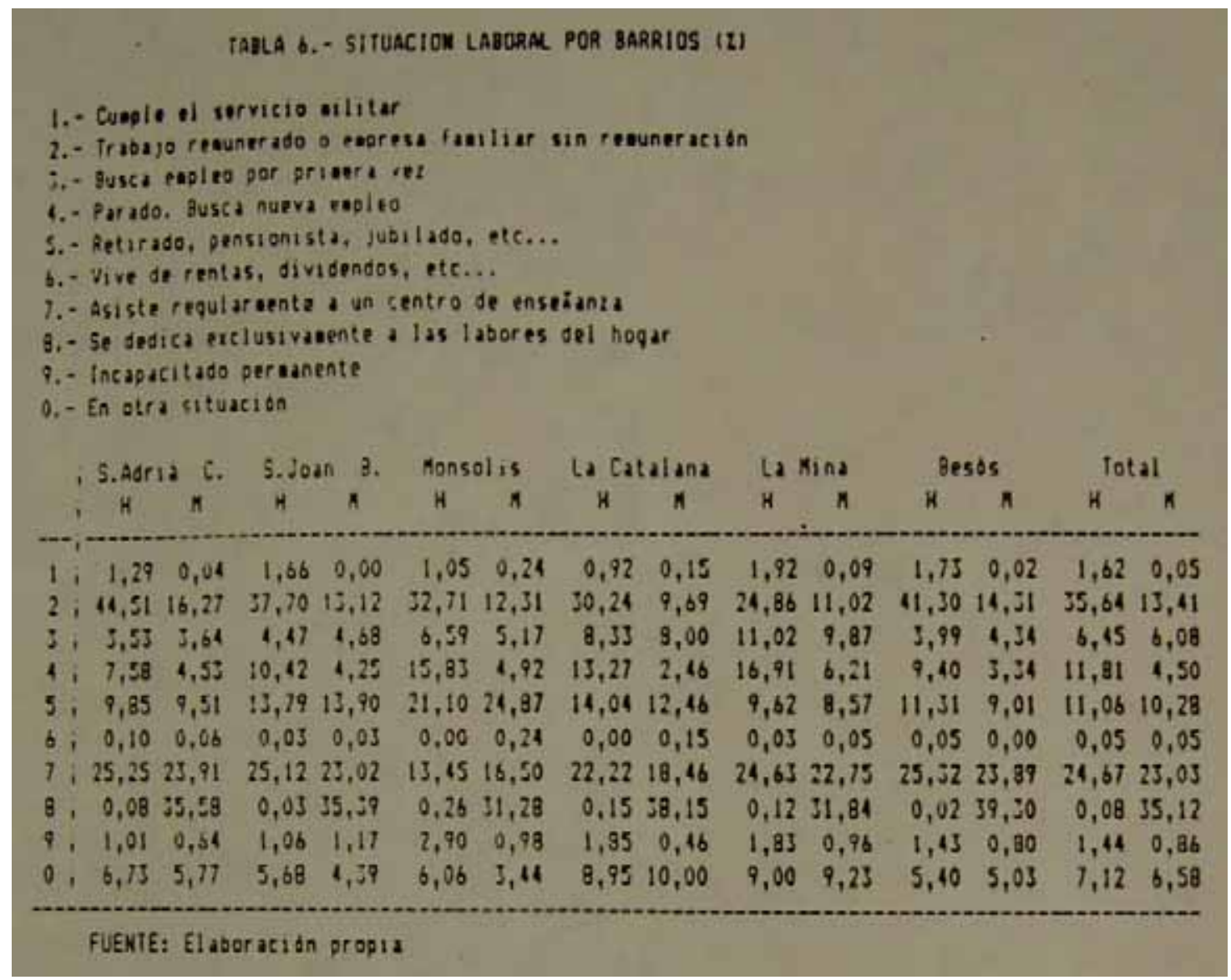

Font: Fundació Família i Benestar Social: Proposta de Treball Comunitari per al Barri de La Mina. Sant Adrià de Besòs [1988-89?], AHLM, Caixa C-1 L-1.4 La Mina anys 80, Carpeta Anys 80. Fundació Família i Benestar Social p. 37-38.

Tots aquests factors van incidir en dos fenòmens que van tenir una certa importància i que van ser en gran part conseqüència de la crisi econòmica: la qüestió de la delinqüència, en especial la juvenil, així com l'impacte del consum de drogues. No obstant, com veurem, aquests fets van ser magnificats i utilitzats políticament per les dretes per recuperar una hegemonia política, social i cultural que havia estat molt qüestionada els anys anteriors.

L'augment de la delinqüència protagonitzada pels sectors més desafavorits socialment va ser un fet constatable si més no a nivell provincial:

EVOLUCIÓ GENERAL DEL DELICTE A LA PROVÍNCIA DE BARCLEONA (denúncies) (1979-1982)

\begin{tabular}{|c|c|c|c|c|c|c|c|c|c|c|}
\hline & 1979 & 1980 & IN. & $\mathrm{I} \%$ & 1981 & IN & $\mathrm{I} \%$ & 1982 & IN & $\mathrm{I} \%$ \\
\hline Barcelona & 145.173 & 147.016 & 1.843 & 1,3 & 134.427 & -12.589 & $-8,6$ & 130.756 & -3.662 & $-2,7$ \\
\hline
\end{tabular}


EVOLUCIÓ GENERAL DEL DELICTE A LA PROVÍNCIA DE BARCELONA (sentències fermes) (1979-1982)

\begin{tabular}{|c|c|c|c|c|c|c|c|c|c|c|}
\hline & 1979 & 1980 & IN. & $\mathrm{I} \%$ & 1981 & IN & $\mathrm{I} \%$ & 1982 & IN & $\mathrm{I} \%$ \\
\hline Barcelona & 4.525 & 5.331 & 806 & 17,9 & 6.109 & 778 & 14,6 & 5.593 & -516 & $-8,4$ \\
\hline
\end{tabular}

IN: Increment numèric

I\%: Incrementopercentual

Font: Elaboració a partir de Mํㅡㄹ del Carmen Hurtado Martínez: La inseguridad ciudadana..., p.231-232 [segons dades de la Memòria del Fiscal General de l'Estat]

EVOLUCIÓ GENERAL DEL DELICTE A LA PROVÍNCIA DE BARCELONA (il-lícits penals) (1982-1984)

\begin{tabular}{llllllll}
\hline & 1982 & 1983 & IN & I\% & 1984 & IN & I\% \\
\hline Barcelona & 130.765 & 163.159 & 32.394 & 24,8 & 224.453 & 61.294 & 37,6 \\
\hline
\end{tabular}

IN: Increment numèric

I\%: Increment percentual

Font: Elaboració a partir de Ma del Carmen Hurtado Martínez: La inseguridad ciudadana..., p. 397-400, [segons dades de la Memòria del Fiscal General de l'Estat]

EVOLUCIÓ GENERAL DEL DELICTE A LA PROVÍNCIA DE BARCELONA (sentències fermes) (1982-1984)

\begin{tabular}{llllllll}
\hline & 1982 & 1983 & IN & I\% & 1984 & IN & I\% \\
\hline Barcelona & 5.593 & 5.410 & -183 & $-3,3$ & 5.380 & -30 & $-0,5$ \\
\hline
\end{tabular}

IN: Increment numèric

I\%: Increment percentual

Font: Elaboració a partir de Mํㅡㄹ del Carmen Hurtado Martínez: La inseguridad ciudadana..., p. 401-404, [segons dades de les Estadístiques Jucicials de l'INE].

EVOLUCIÓ GENERAL DEL DELICTE A LA PROVÍNCIA DE BARCELONA (Il·lícits penals) (1984-1986)

\begin{tabular}{llllllll}
\hline & 1984 & 1985 & IN & I\% & 1986 & IN & I\% \\
\hline Barcelona & 224.453 & 300.962 & 76.509 & 34,1 & 360.572 & 59.610 & 19,8 \\
\hline
\end{tabular}

IN: Increment numèric

I\%: Increment percentual

Font: Elaboració pròpia, a partir de Ma del Carmen Hurtado Martínez: La inseguridad ciudadana..., p. 477-478, [segons dades de la Memòria del Fiscal General de l'Estat]

EVOLUCIÓ GENERAL DEL DELICTE A LA PROVÍNCIA DE BARCELONA (sentències fermes) (1984-1986)

\begin{tabular}{llllllll}
\hline & 1984 & 1985 & IN & I\% & 1986 & IN & I\% \\
\hline Barcelona & 5.380 & 4.243 & -1.137 & $-21,1$ & 4.005 & -238 & $-5,6$ \\
\hline
\end{tabular}

IN: Incremento numèric

I\%: Incremento percentual

Font: Elaboració a partir de Ma del Carmen Hurtado Martínez: La inseguridad ciudadana..., p. 479-482, [segons dades de les Estadístiques Jucicials de l'INE].

EVOLUCIÓ GENERAL DEL DELICTE A LA PROVÍNCIA DE BARCELONA (Il-lícits penals) (1986-1989)

\begin{tabular}{lllllllllll}
\hline & 1986 & 1987 & IN & I\% & 1988 & IN & I\% & 1989 & IN & I\% \\
\hline Barcelona & 360.572 & 411.556 & 50.984 & 14,1 & 414.556 & 3.000 & 0,7 & - & - & - \\
\hline
\end{tabular}

(1) Les xifres totals dels anys 1987,1988 i 1989 així com els increments numèrics són aproximatius, al no tenir algunes províncies dades per aquells anys [això consta a la gràfica original on estat totes les províncies de l'estat espanyol]

IN: Increment numèric

I\%: Increment percentual

Font: Elaboració a partir de Ma del Carmen Hurtado Martínez: La inseguridad ciudadana..., p. 562-563, [segons dades de la Memòria del Fiscal General de l'Estat] 
Cal dir que la immensa majoria dels delictes són contra la propietat, sent més minoritaris els delictes contra les persones ${ }^{1720}$. L'augment, tot i que notable en determinats anys, no sembla exagerat (de fet hi ha anys que els delictes fins i tot semblen disminuir). Alhora s'observa una notable diferència entre els delictes denunciats i els que realment van tenir una sentència judicial ferma.

Malauradament, no he trobat cap estudi amb sèries de dades centrat exclusivament en el Barcelonès Nord i per acostar-me a el possible impacte del fenomen de la delinqüència he hagut de fer servir tant la premsa com la font oral. Aquest fet em permet tractar, més que les dades reals, la visió que transmetien els mitjans de comunicació i la percepció que tenia la gent del que estava passant. No és pas un tema banal, i si no només cal que extrapolem algun exemple de les anomenades "llegendes urbanes" que corren actualment amb el tema de la immigració, com les famoses històries "dels cotxets per als fills dels immigrants" les suposades "exempcions d'impostos" o "incompliment d'horaris comercials" i d'altres de similars, que no se sustenten en la realitat per bé que molta gent hi creu cegament que són veritat encara que en molts casos siguin històries que han sentit, els hi han explicat, però que no han vist amb els seus ulls, amb l'excepció potser de les botigues d'alimentació obertes moltes hores del dia, cosa que permet la llei quan l'establiment no supera un número determinat de metres quadrats i que tampoc és un fenomen nou dons ja abans havien existit les bodegues on es podia comprar productes alimentaris en horaris diferents dels habituals.

Aquest treball no pot analitzar amb profunditat la relació existent entre marginalitat, exclusió social, i l'augment d'aquesta tipologia de fets delictius, en especial els protagonitzats per sectors de la població molt joves, però la relació sembla lògica. Aquest fet ja existia abans de la crisi econòmica -vam veure l'exemple del cas dels "Correas"- si bé ara la seva percepció va ser superior. Un àmbit on diverses persones militants si van percebre un canvi notable a finals dels setanta i durant els vuitanta va ser en l'augment del consum de drogues dures, en especial l'heroïna, amb efectes devastadors. A La Mina, per exemple, va fer estralls socialment, tot i que, paradoxalment, el negoci de la droga també va ser per a molts

1720Veure a M ${ }^{a}$ del Carmen Hurtado Martínez: La inseguridad ciudadana de la transcición española... p. 239-240, 293-294, 410-412, 440-441, 570-571 i 605-606. 
"l'alternativa" a la crisi econòmica:

"Jo tinc més de quaranta alumnes meus morts per la droga (...) Van ser uns anys espantosos (...) Els nanos que (...) van ser protagonistes d'alguna acció social molt poquets es van enganxar, molts d'aquests han acabat estudiant i quan han pogut han fugit del barri i això també és una de les malediccions del barri. És a dir, la gent que pot una miqueta més se'n va (...)

Molta 'solució' de la crisi va ser per tot el tema del diner que portava la droga, objectes robats, el món de la marginalització del barri. A finals dels setanta, quan comença la crisi, als vuitanta, va ser un barri molt aïllat, i a demés amb una crisi econòmica brutal i solventada tota mirant l'administració cap un altre costat, sense això no hagués pogut degradar-se tant amb tot el tema de la màfia de la droga." ${ }^{1721}$

Un altre testimoni referent a La Mina ens tornava a recordar la duresa de situacions que es van donar:

"Precisament a una persona que teníem treballant a l'escola se li van morir quatre fills de la droga (...) i molts dels nens que havia tingut a l'escola bressol han mort de la droga (...) a mi em va afectar moltíssim. Recordo que hi havia una nena (...) que li deien Pitusa, era molt espavilada, era com un gínjol. Jo tenia una nena de la mateixa edat (...) i es va fer molt amiga de la Pitusa, que era una nena gitana. I aquesta nena gitana tenia el seu pare a la presó (...) quan arribava el cap de setmana a mi em feia pena i li demanava a l'àvia si me la podia endur (...) Aquesta nena estava prima i escanyolida i la vaig portar a un metge, que era el metge que tenia el Joan Raventós (...) li van fer un tractament i la nena va fer un canvi espectacular (...) quan veníem cap aquí a La Mina alguna vegada agafàvem un taxi (...) i venia amb les dos nenes i ella em deia: 'yo quando sea mayor voy a ser abogado... por qué quieres ser abogado? Por mi padre que está en la cárcel total por chorrar unos hierros' (...) Aquesta nena és morta, va morir a conseqüència de la droga per que quan el seu pare va sortir de la presó, va venir a la guarderia per donar-me les gràcies pel que havia fet per la seva filla (...) al cap de dos anys la va posar a l'escala per controlar la gent que venia per la droga i al final la nena va acabar drogada (...) va morir de la droga. I com aquesta moltíssimes." ${ }^{1722}$

L'impacte de la droga es va donar en altres indrets del Barcelonès Nord -si fem cas d'altres testimonis- en especial a les barriades obreres on la heroïna va tenir un consum més elevat, en un moment en que la cocaïna era més cara i per

1721Entrevista a Josep Maria Monferrer, 23-3-2012.

1722 Entrevista a Ma Àngels Rosell, 21-3-2012. Va se mestra i educadora amb els Escolapis al Camp de La Bota, a la Llar d'Infants Belendai i també posteriorment a La Mina.. Va militar posteriorment al PSC-PSOE i va ser regidora de Serveis Socials a partir de 1983. 
tant encara era més percebuda com una "droga de rics". Un destacat membre del Centre Social i Ateneu de Sant Roc ens recordava el paper que va tenir l'heroïna en el seu barri:

"Aquí la crisis més gran que hi va haver, que vam tenir... l'època més dura i més difícil... va ser la època dels 80 pel tema de droga. L'heroïna sobretot va fer estragos aquí a molta gent, al barri i tal, no? (...)

Va ser molt dur (...) i va coincidir a nivell de famílies d'aquí, de famílies que venien de fora... A nivell de botigues que tancaven per que no podien venir.. els repartidors es negaven a entrar aquí per que els robaven... 0 aquí en el Centre mateix [es refereix al Centre Social/Ateneu de Sant Roc] ens robaven pues cada dos per tres (...). I va ser dur i inclús a les pròpies famílies. Tu saps que una persona que està enganxada a la pròpia família... jo conec moltes famílies d'aquí per que hem estat treballant en aquest tema... pues va ser dur. “1723

\section{Testimonis similars trobem pel barri de Llefià:}

"En estos años aumentan las familias en las que algunos de sus miembros son devorados por la droga. Sus pequeños negocios se arruinan, sus casas son asaltadas por sus propios hijos, el "caballo" galopa por el barrio a ritmo de vértigo. El bloque de la calle San Cipriano № 2, es abandonado paulatinamente por sus dueños y vecinos, de forma continua se convierte en una mezcla de hotel de los líos y redadas. Pequeños delincuentes, drogadictos y amigos de lo ajeno toman posición de él por muchos años"1724

La premsa d'aleshores es feia ressò també de l'existència d'uns 20.000 alcohòlics en una ciutat com Santa Coloma de Gramenet, una xifra realment molt elevada, i que caldria contrastar amb un estudi més acurat del tema ${ }^{1725}$. 0 també de l'us d'altres substàncies legals como la cola de fuster, que es feia servir, sobretot per sectors marginals de la població infantil i juvenil com a substància barata per

1723Entrevista amb Juan Jesus Guerrero, 14-6-2013.

1724Juan Rico Márquez: Llefià. De la barraca a la dignidad, p. 222.

1725Jordi Corachán: "Vente mil alcohólicos en una ciudad llena de bares", El Correo Catalán, 1-41980. L'article feia esment a un altre publicat a Grama núm. 172 (2-4-1980), escrit per Tomás Román: "Santa Coloma, ¿un colectivo de enfermos alcohólicos?", p. 18-19. La portada del mateix número feia la afirmació "Tenemos un bar por 221 habitantes. Santa Coloma: 20.000 alcohólicos". L'alcoholisme ja havia sigut tractat anteriorment en aquesta mateixa revista, als núm. 99 (abril 1977) i 170 (19-3-1980), entre d'altres. He pogut constatar l'existència d'un Centre per Tractament d'Alcohòlics a Santa Coloma així com l'anomenada Associació d'Alcohòlics Reabilitats de Santa Rosa. Veure AHMTB, Donació Mn. Catà, Caixes 9 i 12. 
“col·locar-se"1726. Més interessant és valorar l'impacte que va tenir la droga -en especial l'heroïna- en desfer i trencar teixits i xarxes socials establertes després de molts anys de treball:

"Aleshores va començar el problema de la droga (...) deu m'hi do els que jo he enterrat! (...) Hi va haver un dia que un dels monitors de l'esplai va dir: mira, tots els meus amics, tots els meus companys, tots han passat per la presó. L'únic que no he estat he sigut jo (...) si jo no hagués estat a l'esplai ja hagués estat a la presó ara (...) tota la meva colla ja hi ha passat." ${ }^{1727}$

La premsa va fer-se ressò del fenomen de la delinqüència i la drogadicció, però com veurem, no ho va fer, generalment, en termes "neutres" o "asèptics", sobretot quan es va començar a fer servir la qüestió de la "seguretat ciutadana" com una arma política o per guanyar diners. Sigui com sigui, El Correo Catalán publicava un article al 31 de juliol de 1979 -referint-se a Badalona- amb el titular "La tercera ciudad española en índice de criminalidad"1728. En aquest s'especificaven els delictes suposadament comesos a la ciutat més gran del Barcelonès Nord en els primers sis mesos de l'any: un homicidi, 22 atracaments amb armes de foc, 98 robatoris amb intimidació, 190 amb força, 22 “con escalo" (?), 7 pel procediment de l'estrebada, 128 furts a l'interior de vehicles, 713 robatoris de vehicles, 2 violacions, un cas d'abusos deshonestos i 3 de tràfic de drogues.

Els atracaments a sucursal bancàries i d'altres comerços van ser també un altre fet recollit habitualment pels mitjans, tal com ja vaig comentar a la meva Tesina doctoral centrada en el barri badaloní de Llefià ${ }^{1729}$. Però pel que es veu la cosa va arribar a tal punt que a Santa Coloma la notícia no eren els atracaments -fet ja habitual- sinó precisament, l'absència d'aquests:

"Un solo atraco se registró en esta ciudad durante todo el mes de marzo, frente a los trece registrados el mes anterior. La reducción de estos hechos delictivos, según

1726Tomás Román: "Escolares de Santa Coloma "compran mercancía” en las droguerias. La cola también "coloca”", Grama núm. 168 (5-3-1980), p. 18-19. Anteriorment la mateixa revista havia tractat el tema de la delinqüència infantil a Antonio Cerrillo: "Santa Coloma es cuna de niños delincuentes", Grama núm. 132 (2/9-6-1979), p. 10-11.

1727 Entrevista amb Joan Cuadrench, 17-6-2006.

1728Pol Ferran: "La tercera ciudad española en índice de criminalidad", El Correo Catalán, 31-71979.

1729José Miguel Cuesta Gómez: El moviment veïnal a Llefià (Badalona), p. 260-261. Per veure els efectes de la delinqüència al mateix barri veure "Capítulo IX: los años de Plomo" dins Juan Rico Márquez: Llefià. De la barraca a la dignidad, p. 208-222. 
fuentes dignas de crédito, está directamente relacionado con la desarticulación de una banda de atracadores, autores de la mayoría de los delitos acaecidos en la ciudad"1730

En algunes ocasions -certament- es podien arribar a donar situacions extremes, com podien ser els "ajustos de comptes" entre diferents persones o bandes si bé cal dir que això no era un fet habitual. Un cas conegut a finals dels anys setanta va ser l'assassinat del "Clemen de Llefià" i altres dos persones més en uns fets relacionats per unes disputes sorgides arran l'atracament a una joieria ${ }^{1731}$. I als anys vuitanta, al mateix barri, es van donar fets semblants:

\footnotetext{
"El "15 de octubre de 1983, miembros de la banda llegan al Bar Sótano, calle Pérez Galdós. Dos componentes de la banda, Álvarez y Bueno con pelucas, se hacen pasar por policías. Sacan al "Andresín" y lo introducen en un coche, para los clientes y parroquianos es una detención legal. El coche coge la autopista y se encamina hacia el Maresme, llegan a un paraje cercano a Orrius, cerca de Mataró. Durante el trayecto manifiestan que no son policías, se identifican con sus nombres, Rafael Bueno Latorre le dispara dos veces en la cabeza y lo entierran." ${ }^{1732}$
}

Un altre fet freqüent recollit per la premsa d'aleshores van ser els continus assalts vandàlics a instal-lacions escolars. Nombrosos col-legis i acadèmies van ser assaltades, i no sembre amb una evident motivació econòmica sinó a vegades simplement pel fet d'entrar i destrossar-ho tot. El perquè d'aquests fets -sobretot els darrers- és difícil d'explicar, però es possible que hi pogués haver un cert sentiment "de revenja" contra una institució, l'escola, que alguns no percebien bé. La marginació social i la creació de sectors molt exclosos -el que en terminologia marxista clàssica es coneixia com a "lumpen"- crea situacions paradoxals com aquestes: que determinats sectors marginats focalitzin el seu odi contra una de les poques institucions que podia ajudar -limitadament, això si, i sempre en funció del model pedagògic que s'apliqués- a sortir de l'exclusió social i que havia estat una font de reivindicacions i lluites populars ${ }^{1733}$.

1730“Un solo atraco en el mes de marzo”, El Correo Catalán, 16-4-1981.

1731Ricard Pallejà: "Dos asesinatos por el reparto de 75 millones", Mundo Diario, 18-10-1979.

1732Juan Rico Márquez: Llefià. De la barraca a la dignidad, p. 221.

1733 Els titulars als diaris sobre aquests fets són molt nombrosos.. Poso només alguns exemples de Badalona: Mario Abellán: "Parvulario destruido por vándalos", La Vanguardia, 14-2-1979 i "Cinco escuelas asaltadas durante el fin de semana", La Vanguardia. 20-3-1980; Santa Coloma: Jordi Corachán: "Un incendio provocado por unos jóvenes destruye todo un colegio", El Correo Catalán, 16-10-1979 o "Varias aulas del Juan XXIII destruidas en un asalto", El Correo Catalán, 
Però sens dubte el que més impacte i ressò va tenir davant capes àmplies de població van ser els atracaments als petits comerços i a persones dels barris populars, o si més la percepció que tenien d'aquests fets els seus habitants. No es difícil trobar testimonis en primera persona que expliquin vivències en aquest sentit. Una persona que regentava un comerç del barri Besòs ens ho recordava així:

“Jo personalment pensa que a mi m'havien atracat no sé... vint vegades. Jo tinc una amistat molt maca amb la Guàrdia Urbana de Sant Adrià solo per les vegades que havien vingut a La Botigueta quan jo trucava que m'havien atracat. Amb pistola, amb escopeta de canyons recortats, amb el cotxe el 124 Sport a l'estilo americano, bueno... I es clar, això ja ha sigut la dècada de los setanta-vuitanta (...) Torete, Vaquilla, tot això...i la gent quan parlaves de La Mina... s'esgarrifava." ${ }^{1734}$

En algunes ocasions, aquests atracaments van provocar algunes morts de petits comerciants, o de persones a peu de carrer. Numèricament van ser pocs casos, però el ressò que van tenir va ser molt ampli, per que apart de donar-se en barris populars, determinada premsa i mitjans de comunicació van donar-lis molta cobertura i seguiment, contribuint així a crear un clima "d'alarma social” que va ser aprofitat políticament per les dretes per aconseguir un enduriment de les lleis i del codi penal. Sembla evident que l'activitat delictiva va augmentar, i en determinats barris es va fer sentir més que en d'altres, al igual que en determinats sectors de població. Però aquest augment no va ser ni de lluny el que semblaven reflectir determinats mitjans de comunicació, ja que el clima creat va aconseguir que fins i tot persones que no havien patit mai cap delicte o que vivien en barris de capes mitjanes o benestants acabessin tenint aquesta percepció. Una tesi doctoral feta sobre la "seguretat ciutadana" durant la transició afirmava el següent:

“"Es esta sociedad desigualitaria la que ve aflorar, como se verá, un periodo de transición hacia la democracia en el que, el gobierno, preocupado por consolidar el sistema democrático, concentra sus esfuerzos en el afianzamiento del mismo, dejando para mejor ocasión problemas -como el paro, la marginación y el desarrollo de políticas sociales que ayuden a la integración de los más necesitados a fin de lograr

7-4-1981. Grama també se'n va fer ressó: “Continuan los asaltos” (núm. 100, 5-1977, p. 13) o "Quinta salvajada” (núm. 167, 27-2-1980, p. 26). No tots els assalts es produïen a escoles, com es pot observar en aquest exemple de Sant Adrià: Joaquin Dellunder: "Vandálicos asaltos a tres centros sociales", El Correo Catalán, 2-4-1981.

1734Entrevista amb Marisol Abril, 23-1-2013. Va ser membre de l'AVV Besòs i també Presidenta de l'Associació de Comerciants del Besòs. Regentava un petit comerç al barri. 
una sociedad más igualitaria-, esenciales junto con la libertad del sistema democrático.

Problemas estos que, dando lugar a situaciones delictivas, serán utilizados políticamente por partidos y medios de comunicación conservadores, en los que el temor, la angustia, y la inseguridad ciudadana, pueden ser provocados y amplificados, convertidos en histerias colectivas, con fines políticos;"1735

És interessant veure una darrera aportació en aquest aspecte de l'esmentat l'estudi de Maㅡ Carmen Hurtado:

PREOCUPACIONS DELS HABITANTS DE L'ESTAT ESPANYOL (ANY 1986)*

\begin{tabular}{lllllll}
\hline & Molta & Força & Gens & Res & NS & NS \\
\hline Moralitat costums & 16 & 31 & 32 & 7 & 13 & 1 \\
$\begin{array}{l}\text { Atur } \\
\text { Seguretat social }\end{array}$ & 72 & 21 & 1 & - & 5 & 1 \\
$\begin{array}{l}\text { Relaciones Estat } \\
\text { espanyol altres països }\end{array}$ & 30 & 35 & 5 & 1 & 7 & 1 \\
$\begin{array}{l}\text { Crisis econòmica } \\
\text { Preus }\end{array}$ & 60 & 40 & 16 & 1 & 11 & 2 \\
$\begin{array}{l}\text { Ordre públic i } \\
\text { seguretat ciutadana }\end{array}$ & 62 & 29 & 3 & - & 7 & 1 \\
$\begin{array}{l}\text { Desigualtats socials } \\
\text { Terrorisme }\end{array}$ & 40 & 29 & 2 & - & 5 & 2 \\
$\begin{array}{l}\text { Autonomies } \\
\text { regionals }\end{array}$ & 64 & 33 & 5 & 1 & 6 & 1 \\
\hline
\end{tabular}

*Tinc profundes reserves sobre alguns dels conceptes que fa servir aquesta enquesta, però em limito a posar els ítems tal qual consten a la font original(traduïts al català, això si).

Font: Mํㅡㄹ del Carmen Hurtado Martínez: La inseguridad ciudadana..., p.536, extret de CIS. Estudio 1.564. Diciembre 1986.

La "seguretat ciutadana" era al 1986 un tema que preocupava a sectors amplis de població. Els exemples que he posat anteriorment demostren que si bé no podem saber del cert en quin percentatge van augmentar els delictes al Barcelonès Nord durant els anys de la crisi econòmica, la percepció de que la delinqüència estava incrementant de manera "alarmant" estava popularment estesa. Fins a quin punt aquest fet es devia al paper que havia jugat una premsa sensacionalista i escabrosa?

Les vegades que els mitjans de comunicació parlaven sobre un determinat barri havia estat contemplat per alguns dels estudis que he mencionat

1735 Ma del Carmen Hurtado Martínez: La inseguridad ciudadana de la transcición española a una sociedad democrática (1977-1989), Tesi Doctoral, Ediciones de la Universidad de Castilla La Mancha, 1999, p. 37. 
anteriorment sobre el barri de La Mina ${ }^{1736}$. Però que millor que posar uns exemples concrets per veure quina era la imatge que es projectava de determinats mèdia. La Vanguardia publicava un article el 21 de novembre de 1980 amb el significatiu títol de "El barrio de La Mina, "paraiso" de "sisleros" i "xorones"”, fent servir el característic argot de l'època. Però deixant de banda aquest recurs periodístic per cridar l'atenció, és important veure el seu contingut:

"Dos grandes grupos engloban la mayoría de jóvenes delincuentes: los "sisleros", especializados en cometer pequeños hurtos, a veces acompañados de violencia, como es el caso de la gran cantidad de atracos perpetrados a la salida de escuelas tanto a niños como a maestros, sin desdeñar el robo a transeúntes, el asalto a dependencias municipales, cívicas o particulares; y los "xorones", que ponen sus ansias en el robo de coches, muchas veces con el único propósito de pasárselo bien y "molar" ante sus compañeros. Los personajes de la película "Perros Callejeros", filmada en el polígono de La mina, son el mejor exponente de este tipo de delincuentes." ${ }^{1737}$

El fragment esmentava la famosa pel-lícula de José Antonio de La Loma, que juntament $\mathrm{amb}$ altres directors com Eloy de la Iglesia van ser els màxims representants del que es va anomenar aleshores cine quinqui ${ }^{1738}$, que va servir també per estendre una imatge alarmista sobre les "bandes juvenils" -un altra qüestió que ens pot sonar molt actual, però amb altres "protagonistes". La psicosi va arribar a tal punt que els membres de les AVV's es queixaven a les pàgines de Grama:

"Los que tenéis hijos sabréis comprender mejor la gran problemática que tienen hoy en día nuestros jóvenes. Los medios de difusión, el cine, las revistas, etc. se han encargado de deformar nuestras cabezas y así, en cuanto vemos a un grupo de jóvenes juntos, pensamos que son una "banda" y que solo son capaces de hacer fechorías. No somos capaces de pensar por qué hay tantos jóvenes por nuestras calles, sin trabajo, sin ilusión ninguna ante la vida, etc." ${ }^{1739}$

1736Daniela Gutiérrez y Tiña Ureña: Polígono La Mina (juny 1980). [Treball de 1er d'Assistents Socials, Curs 79/80], AHLM, Caixa C-1 C-1.4 La Mina anys 80, Carpeta Estudis sobre La Mina anys 80. En concret l'apartat "Aportaciones de la prensa recogidos 1965-1979", p. 67-69.

1737 “El barrio de La Mina, "paraiso" de "sisleros" i "xorones"”,La Vanguardia, 21-11-1980.

1738Les pel-lícules més conegudes de José Antonio de La Loma van ser: Perros Callejeros (1977), Perros Callejeros II. Busca i captura (1979), Los últimos golpes del Torete (1980), Yo "el vaquilla" (1985), Perras Callejeras (1985). D'Eloy de la Iglesia van destacar: Navajeros (1980), Colegas (1982), El pico (1983), El Pico II (1984), La estanquera de Vallecas (1987).

1739Francisco Orellana (membre de l'Associació de Veïns) [segurament de la de Santa Rosa, per un carrer que esmenta a l'article]: "Carta a los vecinos. No todo son "bandas"', Grama núm. 154 (30-11-1979), p. 18. 
A priori podria semblar que aquesta tasca de crear una "alarma social" va ser una feina on els mitjans de tendències dretanes tenien una major predisposició. I certament així va ser. Però els fets ens demostraven com fins i tot mitjans anomenats "progressistes" (un "progressisme" amb molts límits) queien en aquests paranys. Un exemple el podem observar amb el titular que va fer El Periódico de Catalunya el 10 de gener de 1985 "Pujol abre un local de CDC en el barrio del Vaquilla", fet que va ser criticat poc després per diferents membres de CDC, en diverses cartes al director ${ }^{1740}$.

Els titulars de la premsa eren més o menys sensacionalistes. Però la cosa podia ser més greu. Un suposat "periodisme d'investigació" encara contribuí a estigmatitzar la imatge de barris com el de La Mina. La revista Garbo, publicava un article amb el ja pejoratiu títol "Lugar maldito, cuna de delincuentes y atracadores. Así sobreviven en "La Mina", barrio de armas tomar" que incloïa perles com aquesta:

“Desde muy pequeños los muchachos del barrio viven de la delincuencia. La mayoría de sus habitantes han pasado por el "maco" -la cárcel- y ese ambiente es normal para ellos. Aquí es difícil hablar de esperanza." ${ }^{1741}$

Per molt elevats que poguessin ser els índexs de delinqüència al barri, no se m'acudeix una manera millor de criminalitzar a tota una generació i una població que fer aquestes afirmacions tan gratuïtes. Dubto molt que la majoria dels seus 15.000 habitants hagués passat per la presó i que tota la població jove del barri visqués del delicte o anés predestinada cap a ell. Però per si hi havia algun dubte en aquest darrer aspecte, l'article encara queia més baix en intentar remarcar aquesta qüestió:

$1740 \mathrm{El}$ contingut de l'article estava més ponderat i informava d'una dada interessant sobre la qual hi tornarem a parlar més endavant. L'existència de 20 militants i la intervenció activa de CDC al barri de La Mina. Pel que fa a les crítiques al titular de l'article veure les cartes al Director: Cipriano Panadero [cito textualment]: "en nombre de la juventud del barrio de la Mina apoyada por CDC": "La Mina no es sinónimo de delincuencia”, El Periódico de Catalunya, 12-101985 i Joan Oller i Jaume Vallés (regidors a l'Ajuntament de Sant Adrià per CDC): "El barrio de La Mina", i també un altre escrit de protesta signat per Antonio Díaz Pascual, El Periódico de Catalunya, 16-1-1985.

1741Choni Rodríguez: "Lugar maldito, cuna de delincuentes y atracadores. Así sobreviven en "La Mina", barrio de armas tomar", Garbo (12-1985), p. 77, (el text citat es tracta d'un peu de foto on es veuen uns joves i nens). 
"Un gitanillo que no levanta cuatro palmos del suelo empuña una metralleta de juguete: “EEr borzo! ¡Dame er borzo!”. Es un crío regordete y precioso, con dos mofletes que apetece comer a besos, a pesar de los regueros sucios que lo acompañan. Los ojos son dos luceros brillantes y negros, de mirada acusadora y profunda. Inmensamente profunda y terriblemente acusadora.

- ¡Er borzo!

- ¿Pero qué dices tú, chiquitín? ¿Cómo te llamas...?

Su hermana, riéndose, nos explica que pide el chiquillo es "el bolso". Y otra hermana (o prima, o vecina, o lo que le "toque") más mayor, viene y se lo lleva a rastras por un brazo. No les gusta a los de La Mina que los forasteros vallamos allí "a mirar solamente lo malo" ${ }^{1742}$

Tot l'article està impregnat d'aquest discurs sensacionalista, que es pretén justificar sota l'excusa d'una suposada crítica social que a pocs pot enganyar.

Malauradament, en algunes ocasions es van donar successos que aquest tipus de premsa (i determinades formacions polítiques) van saber aprofitar molt bé per creant més alarmisme i per vendre més. Per exemple, a Badalona el 26 de desembre de 1983 una noia, Núria Cardona, va morir al Parc de Les Palmeres de Llefià d'una ganivetada que li va donar un menor d'entre 10 i 13 anys quan juntament amb un grup de set o vuit nens va intentar atracar-la quan anava acompanyada de dues amigues ${ }^{1743}$. El Correo Catalán es va cobrir de glòria amb un article titulat "Navajas y tijeras son los juguetes de los niños de Llefià" (3-1-1984) del qual reprodueixo algun fragment:

"Le preguntamos [a Jordi Font, President de de l'AVV de Sant Antoni de Llefià, arran la mort de Núria Cardona i d'altres fets] si en el vecindario existe psicosis ante estos acontecimientos. “ ¿Miedo? -responde- No, terror. A las ocho de la noche ya no se transita por algunas zonas de Llefià". Los vecinos han pensado formar piquetes, que todavía se discute si este será un buen camino.

Entre tanto, los niños siguen en la calle. En el mismo parque de Las Palmeras se pueden ver grupitos, que se reúnen en corro en unas esquinas, mientras en el centro los padres llevan a otros adolescentes a que jueguen. En San Roque, se sientan en las

1742Choni Rodríguez: "Lugar maldito, cuna de delincuentes y atracadores. Así sobreviven en "La Mina", barrio de armas tomar", Garbo (12-1985), p. 77-78.

1743 T. Cirbián: “Un niño de diez años mata a una joven en una plaza de Badalona", El Periódico de Catalunya, 28-12-1983; Santiago Torres Peldró: "Un niño de 10 años mata a una joven de 24 porque no le quiso dar un duro", "Los vecinos de la joven asesinada en Badalona piden más vigilancia nocturna" i "La banda de niños de Badalona, atrapada por la policía, había inhalado cola antes del asesinato de Núria”, El Correo Catalán, 28, 29 i 30-12-1983, respectivament. 
aceras, delante de los bares. Con ellos siempre viajan armas blancas: navajas, tijeras rotas e incluso limpiaparabrisas arrancados de los coches." ${ }^{1744}$

Aquest tipus de llenguatge que criminalitzava determinades persones, col·lectius o fins i tot barris sencers pot produir una certa sensació de dejà vu en l'actualitat ${ }^{1745}$. Per posar un exemple podem llegir aquest fragment d'un article publicat al diari Avui:

"Galiano, policia de carrer que viu dia a dia la realitat de la delinqüència assegura que "les grans ciutats proporcionen l'anonimat i les situacions fàcils per a realitzar delictes". L'inspector va lligar, a partir de l'experiència del seu grup i de les estadístiques, la desorganització urbanística amb l'augment i gènesi de bona part de la delinqüència juvenil. "La gran massa d'immigrants que va arribar a les ciutats de Catalunya durant els anys cinquanta tenia molt poc poder adquisitiu i es va veure obligada a anar a viure a ciutats dormitori i a treballar tots els membres de la família. Els fills d'aquesta immigració s'han trobat en molts casos mancats d'un ambient familiar -tota la família treballava- i en barris on només hi havia pisos i res més. Tot plegat ha generat insatisfacció i violència en l'individu. Per altra banda, en molts casos, s'ha passat del barraquisme horitzontal al barraquisme vertical en grans blocs de ciment. Es calcula que a tot l'Estat espanyol hi ha encara un milió i mig de barraques". Davant d'aquesta situació angoixant, creada en gran part per l'estructura urbanística de la zona, han aparegut a Catalunya diversos punts en els quals es genera la major part de la delinqüència juvenil, i que són els barris i zones esmentades en el quadre adjunt." $^{1746}$

1744S.T.: "Navajas y tijeras son los juguetes de los niños de Llefià", El Correo Catalán, 3-1-1984. La persona esmentada, Jordi Font, President aleshores de l'AVV Ronda de Sant Antoni de Llefià, algunes persones m'han comentat que era proper al PSC-PSOE. Tal com vaig comentar a la Tesina de Doctorat, un servidor va jugar gran part de la seva infància en l'esmentat parc i no ho feia pas amb navalles i tisores. José Miguel Cuesta: El moviment veïnal a Llefià (Badalona), p. 260.

1745 Només fa falta veure els discursos que fan avui formacions polítiques xenòfobes com Plataforma per Catalunya o el PP badaloní (i que cada cop adopten més -amb major o menor edulcoració- altres formacions polítiques per por a perdre vots, sense parlar ja del racisme institucional existent) i comparar-los amb els que es feien aleshores. Veurem que en determinades ocasions hi ha semblances preocupants, a excepció, es clar, del col·lectiu a criminalitzar que no podia ser, per raons òbvies, el mateix per la diferent procedència geogràfica.

1746 “Els delinqüents es formen als suburbis però actuen al centre. Llista dels barris més conflictius de Catalunya", Avui, 7-10-1983. 

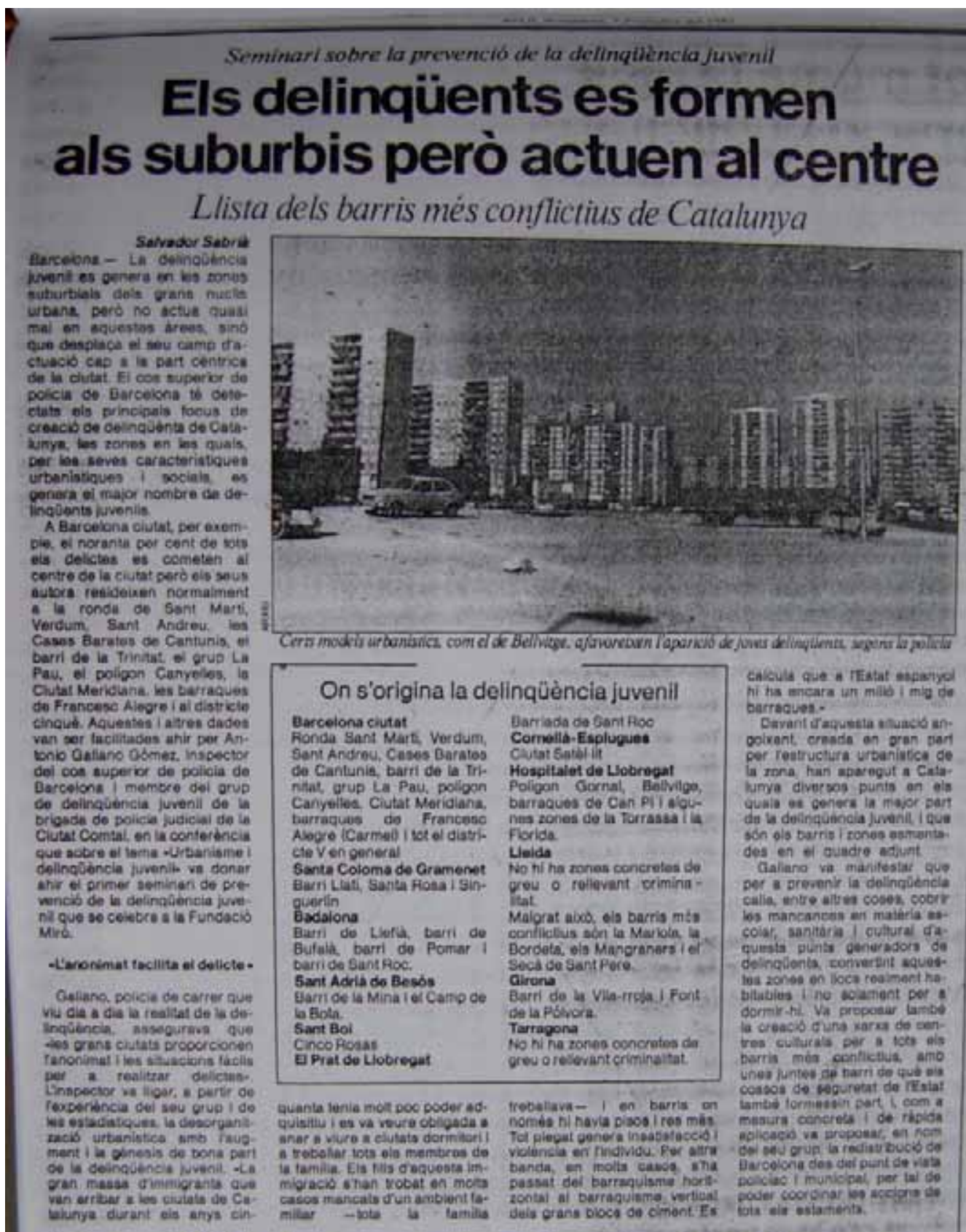

Un milió de nens volen fugir de casa

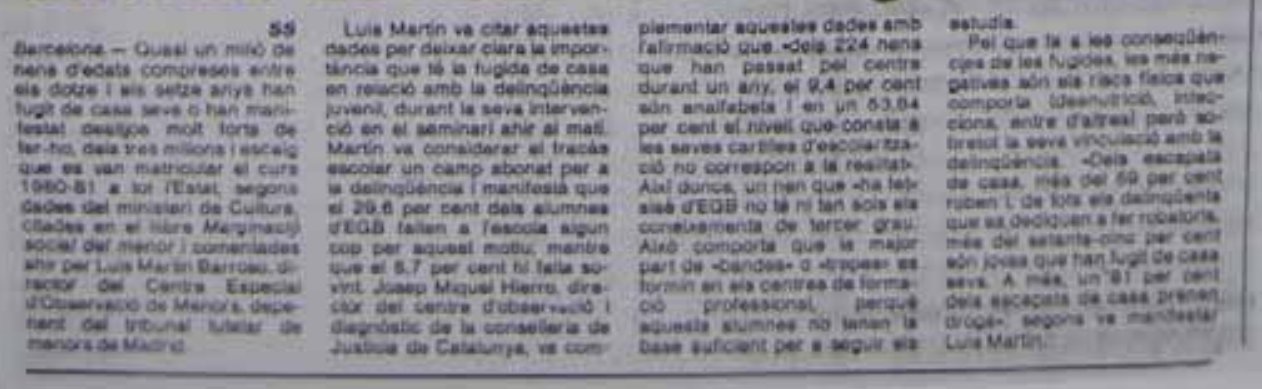

Avui, 7-10-1983. A destacar el quadre central on s'indiquen els barris "perillosos" de les ciutats catalanes. Impactant també el titular de sota. 
Per si no havia quedat clar amb el títol, el subtítol i el contingut, l'article adjunta un requadre central amb un llistat dels barris "més conflictius de Catalunya".

Poc abans del decés de Núria Cardona, la mort d'un comerciant en un atracament el juny de 1983 a Santa Coloma de Gramenet ja havia provocat un cert malestar entre els botiguers ${ }^{1747}$. El el 6 de febrer de 1984 un adroguer va morir d'una ganivetada en un nou assalt a Badalona ${ }^{1748}$. Aquest fet va ser el desencadenant d'un locaut dels comerços badalonins fet el dia 20 de febrer amb notable èxit ${ }^{1749}$. La pressió mediàtica va afavorir la ràpida detenció de tres persones, que van ser jutjades en un procés amb irregularitats que va fer que dos anys després fossin alliberades per manca de proves ${ }^{1750}$.

No podem obviar un altre fet molt important. Els efectes de la crisi econòmica i de canvi de model productiu i del discurs sensacionalista i criminalitzador que es va donar en gran part dels mitjans de comunicació de masses, va anar acompanyat d'un fort rearmament ideològic de la dreta i del seu discurs ideològic. El període de finals dels seixanta i de la dècada dels setanta havia estat, en gran part, una "època daurada" pel discurs d'esquerres i marxista, on va adquirir una notable hegemonia en determinats àmbits socials i disciplines científiques. Això, com he volgut mostrar en aquest treball, es va traslladar als moviments populars d'aleshores, entre ells el veïnal.

Ara bé, també cal tenir en compte que aquest discurs d'esquerres va haver de competir sempre amb el discurs conservador i dretà, que era el difós pels mitjans de comunicació de masses controlats per les elits i en els àmbits polítics i econòmics. Cometríem un error si penséssim que el discurs que vam veure reflectit per exemple en les publicacions de les AVV's havia estat assumit per tota la

1747 Amadau Clavé: "Santa Coloma: El asesinato de un comerciante incrementa la venta de armas", El Correo Catalán, 17-6-1983.

1748Jordi Martí: “Un droguero muere de una puñalada en Badalona”, El Periódico de Catalunya, 7-21984 i "Tres jóvenes asesinan de una puñalada a un droguero de Badalona porque se resistió a un atraco", El Correo Catalán, 7-2-1984.

1749 “Els comerços de Badalona van protestar per la inseguretat”, Avui, 21-2-1984.

1750J. Martí: "Joven detenido en Badalona por matar a un droguero", El Periódico de Catalunya, 7-21984; "A mi hijo le han hecho reconocer un asesinato que nunca cometió", El Noticiero Universal, ?-2-1984; Sergi L. Egea: "Juzgados tres jóvenes que mataron a un droguero en Badalona", El Periódico de Catalunya, 13-9-1985 i Domingo Marchena: "Revocan la condena a tres acusados de matar un droguero en Badalona", La Vanguardia, 29-4-1987. 
població, si bé segur que la consciència de classe estava més estesa que en períodes més recents ${ }^{1751}$.

Les lluites i mobilitzacions populars i les millores que es van aconseguir van ajudar a revertir i matisar aquests discursos de individualisme, consumisme i passivitat que es fomentava des de el poder. Però quan la crisi econòmica va irrompre amb tota la seva força destruint llocs de treball aquesta discurs "positiu" es va veure alterat. A això hem de sumar l'important paper que va tenir una nova ofensiva ideològica neo-conservadora que es va produir ja en la segona meitat dels setanta i que es va accentuar sobretot als vuitanta ${ }^{1752}$. Són els anys de l'arribada al poder de Margaret Tatcher i Ronald Reagan, de la propagació del discurs neoliberal i individualista, que ja va començar en aquesta etapa i no amb la fi de la URSS l'any 1991. Aquest discurs afirmava sense escrúpols que la "societat civil" no existia i que l'important era l'individu:

\begin{abstract}
"Si Tatcher tenía un objetivo, era evitar que pensáramos en términos de clase. "La clase es un concepto comunista", escribiría más tarde. "Agrupa las personas en bloques y las enfrenta entre si". Quería acabar con la idea de que la gente podía mejorar su vida mediante la acción colectiva más que por el enriquecimiento personal: es decir, "saliendo adelante por su propio esfuerzo". Apenas unos meses después de su victoria electoral de 1979, se había propuesto explicárselo al país en términos crudos.

"La moral es personal. No existe la conciencia colectiva, la bondad colectiva, la consideración colectiva", planeaba decir. "Hablar de justicia social, de responsabilidad social o de un nuevo orden puede que sea fácil y nos haga sentir bien, pero no nos exime a cada uno de nosotros de responsabilidad personal". Era claramente demasiado para sus redactores de discursos, y no fue la versión final. Sin embargo, no pudieron impedir que hiciera su infausta declaración siete años después: "No existe una cosa llamada sociedad. Hay hombres y mujeres individuales, y hay familias."”1753
\end{abstract}

Són els mateixos anys on les receptes dels "Chicago Boys" s'estaven aplicant a les dictadures de sud-Amèrica i que es van aplicar també al Regne Unit i als Estats Units per trencar el poder -limitat- que tenien els sindicats. Aquest discurs emfatitzava que tothom podia "triomfar" a la vida i que si no et feies ric era per que

1751 Veure nota 721.

1752 Veure al respecte David Harvey: Breve historia del neoliberalismo, Akal, Madrid, 2009. Una altre anàlisi interessant de l'auge del discurs neoliberal des de una perspectiva interessant a Owen Jones: Chavs, la demonización de la clase obrera, Capitán Swing, Madrid, 2011.

17530wen Jones: Chavs, la demonización de la clase obrera, p. 65. 
no volies, i que els exclosos i marginats socials estaven així per les seves "pròpies limitacions" i no per que hi hagués una societat desigual i classista que condicionava les oportunitats que podia tenir cadascú en funció de la classe social. Crec que no es pot menystenir la importància d'aquest missatge en trencar i erosionar aquesta consciència de classe i de barri que s'havia anat forjant a base de lluites. Com ens recordava un dels nostres entrevistats, als anys setanta, per exemple, les lluites veïnals havien contribuït a generar un esperit molt diferent:

"Quan hi ha una sèrie de manifestacions aquí a l'Arxiu Històric tenim unes fotos d'aquestes manifestacions $\mathrm{i}$ hi ha una que és una preciositat per que hi ha una pancarta que porta una persona molt concreta i no cal dir el nom que diu, una diu: "Mercè Sala (que era en aquell moment la responsable del Patronat Municipal de l'Habitatge) Mercè Sala La Mina no te traga" i una altra al costat que diu "En La Mina no hay payos ni gitanos, solo vecinos" (...) per que ja des de l'administració ja enverinaven, la estava prou emmerdat, a enfrontar per evitar... (...) tot això avui en dia hem fets uns passos enrere brutals"1754

Però la ideologia i discurs dretà i neoliberal va trobar unes condicions favorables per la seva difusió no només per la crisi econòmica, sinó també per la crisi ideològica de les esquerres. Per una banda les renúncies que van fer els partits majoritaris d'aquest àmbit en pro del "consens" o el tacticisme els va desarmar ideològicament en un moment on es feien cada cop més visibles els estralls provocats per aquesta mateixa crisi. Tant PSUC/PCE com el PSC-PSOE van optar per una tàctica de moderació pensant que així atraurien a més sectors de població. I si bé a alguns -el PSOE- això els hi va funcionar a curt termini, al PSUC aquesta línia li va acabar provocant una forta crítica interna que va esclatar amb el Vè Congrés. Per altra banda, els partits de l'esquerra revolucionària que no havien participat del "consens" van demostrar ser incapaços d'adaptar-se al nou context polític -adaptació que no tenia per que ser sinònim de moderació política- i van entrar en una profunda crisi que els va fer desaparèixer o quedar reduïts a forces testimonials, llevat d'alguna excepció que va aconseguir, si més no, tenir una certa presència en determinats moviments socials. D'això en parlaré tot seguit.

1754Entrevista amb Josep Maria Monferrer, 20-3-2012. 


\subsection{El paper dels partits polítics al Barcelonès Nord. La crisi de l'esquerra revolucionària i l'escissió del PSUC. Els "altres" protagonistes: PSC-PSOE i CiU.}

Entre els anys 1975 i 1979 ja les diferents forces de l'esquerra revolucionària havien tingut ja un primera constatació de que els esdeveniments no es desenvolupaven tal com la majoria d'elles havien previst. Si bé és cert que la majoria van patir una major repressió a partir de l'any 1977 en quedar excloses -o autoexcloses- del consens, el cert es que també van tenir unes dificultats pròpies per adaptar-se als canvis que s'estaven donant. Totes les expectatives que havien posat en que s'engegués un procés revolucionari amb la fi del franquisme no s'estaven donant com ells havien pensat. Un document intern del PTC de l'any 1980 en feia una anàlisi autocrítica d'aquests fets:

"El triunfo de la vía reformista sobre la ruptura propuesta por el PTE no tuvo lugar en ningún momento una valoración crítica del análisis hecho anteriormente ni de la sobre-valoración que habían hecho de la capacidad revolucionaria de las masas y se intentó justificar única y exclusivamente con la posición claudicante de las fuerzas de izquierda, sin parar atención en que nuestras alternativas no habían estado asumidas con plenitud por el pueblo para obligar a cambiar la actitud política de las fuerzas mencionadas.

Este error político (sobrevalorar la capacidad del P. para obligar a las fuerzas democráticas en el camino de la ruptura) se repite continuamente a lo largo de nuestra trayectoria, las campañas electorales llevan a profundos desengaños debido a una sobrevaloración de las posibilidades, los movimientos de masas lanzados no llegan a conseguirse siempre plenamente.

En conjunto, se pone de relieve que los planteamientos responden cada vez más a un análisis realizado partiendo de los deseos de unos sectores de vanguardia y no del conjunto de las masas"1755

Sense esmentar que les forces de l'esquerra revolucionària tampoc van ser capaces de llimar moltes diferències entre elles mateixes malgrat que es van engegar alguns processos de fusió (o més ben dit, en no pocs casos, d'absorció d'unes forces per unes altres). Si haguessin aconseguit crear una organització que

1755Esteve Borrell, Josep Dapenz, Xavier Diego, Josep Maㅡ Gordillo, Manuel Gracia, Ramon Pascual, Agustí Villarroya i Xavier Vitoria: "Presentación" [Informe de M. Gracia, Maig 1980], Archivo Digital PTE JGRE [http://www.pte-jgre.com/archivo/archivodocumentos.html], Partido de los Trabajadores de España - Catalunya, p. 3-4. 
agrupés les diferents tendències sens dubte haurien pogut tenir més incidència, fins i tot electoral.

Per exemple, la Unión Comunista de Liberación (que havia tingut una certa implantació a La Mina) ${ }^{1756}$, es va fusionar amb altres grups per crear el Movimiento de Liberación Comunista (MLC) que finalment es va dissoldre el 1978. El PTE va integrar diferents grupuscles i també finalment a una altra organització que havia tingut una certa força, la ORT, al 1979. D'una manera semblant el MCC s'havia unificat amb l'OIC, si bé els testimonis de l'època ens afirmes que va ser més un procés d'absorció del primer sobre el segon. Per la seva part dintre de l'espai trotsquista la LCR havia rebut a una part de la LC i també a la Liga Socialista Revolucionaria (LST), tot i que aquesta darrera aviat es va escindir per formar el Partido Socialista de los Trabajadores (PST) també l'any 1979.

La llista no s'acabaria aquí, però estic fent només esment als grups que van tenir una certa implantació al Barcelonès Nord ${ }^{1757}$, als quals caldria afegir, sobretot en el cas de Santa Coloma, a la gent dels GOA que va anar cap a la CNT o va impulsar també un Ateneu Llibertari. Al capítol quart ja vaig exposar quines havien sigut les principals visions i valoracions d'aquestes forces al respecte del moviment veïnal fins les eleccions d'abril de 1979. L'últim intent va ser al 1980 la candidatura Unitat Pel Socialisme que es va presentar a les eleccions del parlament autonòmic de Catalunya. No obstant, aquest darrer intent es va saldar amb un altre fracàs electoral, entre d'altres motius, per que es va fer massa tard:

“La coalición Unitat pel Socialisme obtuvo en la provincia de Barcelona 28.499 votos, solo el 1,37 \% (el PSUC obtuvo el 20,95\%), en el resto de Cataluña recogió otros 4.587 votos. Fue la constatación de que no solo el PT, sino toda la extrema izquierda había quedado fuera de juego" ${ }^{\prime 1758}$

Davant els reptes que el context polític oferia, quines van ser les opcions que van triar aquestes forces polítiques per intentar adaptar-se a la nova realitat que

1756CSC: [2 Notes manuscrites sobre la Ia Assemblea de Barris] [197?], Fons Jordi Font (FJF), Caixa 100, Carpeta P 5, A005.02 Front Barris - Notes i Apunts CB.

1757 Veure Jose Manuel Roca: "Reconstrucción histórica del nacimiento, evolución y declive de la izquierda comunista revolucionaria en España, 1964-1992", dins Jose Manuel Roca (ed.): El Proyecto radical..., p. 69-89.

1758Ramón Franquesa Artés: “Capítulo IV. Estabilización del nuevo régimen y autodisolución (1977-1980)" a José Luis Martín Ramos (Coord.): Pan, Trabajo y Libertad. Historia del Partido del Trabajo en España, El Viejo Topo, 2011, p. 307. 
estava trastocant gran part de les seves anàlisis? Ernesto Portuondo ho resumia en tres opcions:

"Fugida cap endavant i posterior atrinxerament o "bunquerització": PCE(m-l)

(...)

Fracàs de la integració en el sistema polític i dissolució: PTE i ORT.

(...)

Després del fracàs de la ruptura, el resistencialisme pragmàtic: MC i LCR."1759

La primera feia referència a la intransigència o el sectarisme ideològic. Quan els fets no s'ajustaven als anàlisis previs, en comptes de posar en revisió aquests es produïa l'efecte contrari: mantenir-se en postures més dogmàtiques. L'autor abans mencionat parlava del $\operatorname{PCE}(\mathrm{m}-\mathrm{l})$ com a paradigma d'aquesta opció. El partit va continuar existint gràcies al suport de l'Albània d'Enver Hoxa, i aquesta dependència va macar el seu final. No obstant, aquest grup no va tenir gaire incidència ni presència ni en el moviment veïnal ni menys encara al Barcelonès Nord, llevat potser del cas puntual al barri de Santa Rosa de Santa Coloma ${ }^{1760}$.

La segona opció va consistir en un intent de integrar-se al sistema polític que s'estava gestant, moderant les seves postures. Ja vam parlar de com el PTE, per exemple, havia demanat finalment el vot afirmatiu a la Constitució quan poc abans l'havia criticat durament. El PTE havia intentat competir amb el PSUC dintre del seu camp i, certament, era un partit que al Barcelonès Nord havia aconseguit una implantació notable i que tenia gran força dins el moviment veïnal. No obstant, va patir una desfeta interna a partir de l'any 1980, sobretot a partir de l'elaboració del document "“Radicalismo una fuerza para una nueva civilización (Propuesta para un debate)" per Eladio Garcia Castro i Enrique Palazuelos ${ }^{1761}$. En línies generals el document aportava elements d'anàlisi molt interessants i més propers a la realitat que moltes altres anàlisis fetes anteriorment, com per exemple la ofensiva ideològica conservadora que he esmentat en l'anterior apartat:

1759Ernesto Portuondo: "Transició Política i crisi de militància a l'esquerra revolucionària (19741982" dins el dossier "L'extrema esquerra espanyola durant la transició", L'Avenç, núm. 207 (octubre 1996), p. 28-29.

1760 Veure l'entrevista a Cristóbal Garcia Gil, militant del MC i sindicalista de CCOO a Santa Coloma a l'Arxiu Històric de CCOO a Catalunya, Col-lecció Història Oral i militància sindical. Biografies Obreres, p. 64.

1761 Ramon Franquesa Artés: “Capítulo IV. Estabilización del nuevo régiment y autodisolución 1977-1980” a José Luis Martín Ramos (Coord.): Pan, Trabajo y Libertad..., p. 261-321. 


\begin{abstract}
"Uno de los resultados o efectos del desarrollo del capitalismo actual es la fuerte penetración en los trabajadores de la cultura o ideología capitalista: individualismo, espíritu despilfarrador, subalterno o pasivo, rutinario (no creativo)... a través de una multiplicidad de mecanismos y de la complejidad anteriormente señalada., [sic] como la estructura y patrones de consumo y la inducción a la privatización del individuo, el enorme desarrollo de los medios de información, TV, cine; el papel de la educación; la utilización del tiempo libre en actividades pasivas (nunca creativas) y controladas; la utilización de la informática para un exhaustivo control del individuo; los métodos sicológicos [sic] derivados de la "estratégia de la tensión"... todo ello actua como un poderoso obstáculo para la toma de conciencia revolucionaria, aún en el seno de una crisis profunda como la actual."1762
\end{abstract}

Però alhora aquest document estava qüestionant profundament la necessitat d'un partit revolucionari tal qual s'havia concebut fins al moment. Al final de l'esmentat document es proposava crear una mena de força o moviment polític que havia de recollir les diferents sensibilitats existents dins els diferents partits de l'esquerra revolucionària així com els "nous" moviments socials (al document s'esmenta l'ecologista, el feminista, el "nacionalista radical"... però significativament no es fa esment al moviment veïnal) ${ }^{1763}$. Aquesta proposta estava fet de manera poc concreta, i en un moment de crisi interna del partit encara va provocar més perplexitat, crítica i confusió.

A aquests motius de caire ideològic, calia afegir altres com els econòmics, ja que:

“Tal como reconoce el mismo Garcia Castro [va ser secretari general] (...) , a nivel central se iban cada mes muchos millones de pesetas. Una vez se fracasa en las últimas elecciones, sin poder recuperar lo gastado, con un partido fracturado por una unificación hecha en malas condiciones y con pésimas relaciones personales, el proyecto fue a la quiebra de forma abrupta no solo por las dificultades a nivel político, sino por razones económicas. La enorme deuda, que la estructura del PT, tal como estaba modelada, generaba de forma inevitable cada mes, impidió una reflexión colectiva y forzó una bancarrota orgánica." ${ }^{1764}$

1762 Eladio Garcia Castro i Enrique Palazuelo Manso: "Una fuerza para una nueva civilización. Propuesta para un debate" [presentat al CE el 12 de febrer de 1980], Archivo Digital PTE JGRE [http://www.pte-jgre.com/archivo/archivodocumentos.html], Partido de los Trabajadores de España - Organismos centrales, p. 10.

1763 Ídem, p. 21.

1764Ramon Franquesa Artés: “Capítulo IV. Estabilización del nuevo régiment y autodisolución 1977-1980” a José Luis Martín Ramos (Coord.): Pan, Trabajo y Libertad..., p. 313. 
Molts militants van acabar endeutats per haver fet d'avaladors en préstecs que es van fer per poder sustentar les campanyes electorals, les seus del partit, etc. Tots aquests factors van condicionar que antics lluitadors ho deixessin córrer o anessin a engruixir les files d'altres partits com el PSUC o el PSC-PSOE ${ }^{1765}$. Que un partit que havia tingut una notòria base, implantació i participació al moviment veïnal del Barcelonès Nord acabés dissolent-se sens dubte va ser un cop dur per al mateix moviment ${ }^{1766}$. Un procés similar va succeir amb l'organització BR-OCE i alguns dels seus destacats dirigents i líders veïnals, com el badaloní Miguel Ordóñez, van passar al PSC-PSOE ${ }^{1767}$, en un procés que certament no deixa de sobtar veient les crítiques que des d'aquest grup i d'altres similars s'havien dedicat tradicionalment al PSUC per "reformista".

La tercera opció, encapçalada pel MCC i la LCR va ser segurament la més "reeixida" -si més no en comparació amb les altres-, en el sentit que van ser unes organitzacions polítiques que no van desaparèixer i encara van subsistir -tot i que aquest no era el seu objectiu- durant els anys $80 \mathrm{amb}$ una certa presència en determinats àmbits i moviments. Davant els esdeveniments que s'estaven donant amb el procés de canvi polític, el MC va jugar la carta de l'activisme dins els moviments socials, entre ells el veïnal, i mereix una mica més d'atenció en la mesura que va arribar a tenir una presència important en determinades AVV's del Barcelonès Nord, tot i que al 1978, encara reconeixia el paper avantguardista del partit polític revolucionari:

“27- Nuestro Partido, además des ser una fuerza que desarrolla una labor permanente en favor de la unificación de cada movimiento de masas, se esfuerza por configurarse como una fuerza de vanguardia capaz de aglutinar y dirigir al conjunto de movimientos sociales susceptibles de converger en el objetivo del derrocamiento del poder por la burguesía y edificar una sociedad socialista, nueva y libre, para los

1765Aquest va ser per exemple el cas d'una de les nostres entrevistades, Maria Relles Bellido, militant del PT, Secretària i Presidenta de l'AVV de Sant Mori de Llefià, que posteriorment va ser regidora a l'Ajuntament de Badalona per IC.

1766Veure nota 1190 referent a la implantació del PTC a Catalunya i al Barcelonès Nord.

1767Veure Joaquima Utrera: "Miguel Ordoñez. El del Congreso", Eco Badalonés, (18-11-1983), p. 2627. La OCE-BR va quedar reduïda a un nivell testimonial fins que els pocs militants que hi quedaven es van integrar al 1989 al PSUC. Veure Jose Manuel Roca: "Reconstrucción histórica del nacimiento, evolución y declive de la izquierda comunista revolucionaria en España, 19641992" a José Manuel Roca (ed.) El Proyecto radical... p. 69-89. 
diversos sectores de la población víctimas de la explotación capitalista y sometidos a las mil formas de opresión y dominación existentes en la actual sociedad."1768

Encara que a vegades s'ha criticat des d'altres formacions polítiques aquesta tàctica com massa "movimentista" i poc concreta (és a dir, impulsar els moviments socials però sense explicar massa com s'articulava una alternativa global), el cert és que aquesta línia va permetre aquestes organitzacions sobreviure als anys vuitanta mentre tantes altres desapareixien o quedaven reduïdes a nivells testimonials. Un altre fet a tenir en compte, no menys important, és que el MC (i també la LCR), segons alguns testimonis, tenia ja des de feia temps un funcionament intern més democràtic que altres organitzacions de l'esquerra revolucionària:

\footnotetext{
“Entonces yo empiezo a través de mi compañera a conocer el MCE y me gusta como se organiza 0 sea, es una organización abierta, bastante democrática, de discusiones internas, de no imponer y tal. Entonces a mi me iba gustando esa manera de trabajar, incluso la forma de trabajar en el movimiento de masas. A nivel de discusiones en el MCE hay una actitud abierta de... ¡Aunque había, como siempre, una pelea con el PSUC que sin embargo sabía que había muchas cosas positivas!. Y allí, en el MCE se estudiaban todos los documentos del PSUC. 0 sea, era una escuela de aprendizaje del PSUC en muchas cosas. Sobretodo pues el [Jordi] Borja, por ejemplo, en todo el tema municipal y todo esto, pues en aquella época era importantísimo. (...)

Y después una cosa que vi mucho también en el MCE -que en el PCE (m-l) se hacía de alguna manera, pero se hacía de una manera dispersa y muy formal-, que aquello un poco me recordaban las "revisiones de vida" de los cristianos que era la autocrítica, ¿no?. Pero yo la autocrítica la veíamos en grupo, pero nunca la vi en el PCE (m-l) desde la dirección, mientras que en el MCE si que vi autocrítica de la dirección más de una vez, ¡eh!. De cosas erróneas que se habían equivocado y tal. ¡Claro, a mi todo eso me fue dando confianza!."1769
}

Això no vol dir tampoc que tinguessin la força i influència que haurien desitjat, sobretot a nivell electoral on els fracassos van ser més que evidents. Però aquest partit, segons alguns dels nostres entrevistats del Barcelonès Nord que hi

1768MC: "10 Años de lucha por el socialismo: resoluciones y documentos del II Congreso. Resoluciones aprobadas en el II Congreso. Orientación general de nuestra actividad política", (abril 1978), CRAI-Pavelló de la República, Fons DDP. Subsèrie Moviment Comunista, Caixa DDP (MC) 2/2 B(1), p. 49.

1769Entrevista a Cristóbal Garcia Gil, militant del MC i sindicalista de CCOO a Santa Coloma a l'Arxiu Històric de CCOO a Catalunya, Col-lecció Història Oral i militància sindical. Biografies Obreres, p. 65 . 
van militar i alhora van ser líders veïnals, era capaços de plantejar-se competir al carrer amb el PSUC a nivell local durant un temps:

"Jo coneixia a la gent que era de la meva cèl·lula però no coneixia (...) ja quan va sortir a la llum pública, més gent, molta gent. Jo a l'època, als anys 70 fins als 80 , fins a les eleccions municipals amb els del PSUC ens tutejàvem (...) Vull dir que el carrer era tant dels uns com dels altres (...). El PSUC era un partit històric i en aquella època manifestacions, concentracions a les Associacions de Veïns... Havia una... mogudes (...). La militància era jove, era més activa... Una altra cosa era després arribar a les urnes i...."1770

Les urnes, efectivament, no van donar gaires bons resultats per al $\mathrm{MC}^{1771}$. Malgrat això, si que trobarem una presència important de militants d'aquestes organitzacions -en especial del MCC- en entitats veïnals que van mantenir una certa activitat i perfil combatiu durant els anys 80 . He pogut constatar la presència de militants d'aquest partit a l'AVV de Sant Antoni de Llefià, a la de Sant Mori de Llefià, a Fondo-Sistrells, Maresme i a l'Ateneu Popular de Sant Roc a Badalona. A Santa Coloma de Gramenet he constatat la presència important de membres de l'MC a l'AVV del Raval i a Santa Rosa. I en la majoria dels casos no era només com un activista més, sinó que solien ocupar càrrecs de responsabilitat a les Juntes o fins i tot la presidència. Així era per exemple, a l'AVV de Sant Antoni de Llefià amb Antonio Agudo i a l'AVV del Raval amb José Maria Ballesteros i posteriorment, ja als vuitanta, Josep Pitarque (la dona del qual, Elvira Ruiz, també militant, va desenvolupar un important paper a la Vocalia de la Dona i en la creació del Casal de la Dona de Santa Coloma). No cal oblidar que Gabriela Serra, que va entrar al MCC provinent de la OIC havia estat durant una temporada Presidenta de l'AVV de Singuerlín durant els anys setanta. En tot cas, la implantació del MCC dins Santa Coloma podia haver estat fins i tot major, si fem cas del testimoni de Cristóbal

1770 Entrevista a Josep Pitarque Narejos (amb Emiliana Salinas i Salvador Bolancer), 12-3-2013. Segons un altre militant, els militants del MC a Santa Coloma podien haver arribat als $200 \mathrm{i}$ tenia implantació a diferents barris com el Raval i posteriorment a Santa Rosa, Llatí, Singuerlín , Riu Nord i Riu Sud. Veure Cristóbal Garcia Gil, militant del MC i sindicalista de CCOO a Santa Coloma a l'Arxiu Històric de CCOO a Catalunya, Col·lecció Història Oral i militància sindical. Biografies Obreres, p. 71.

1771 Veure la taula de resultats electorals a la p. 536. Destaca els millors resultats obtinguts pel MCC a Santa Coloma de Gramenet que a Badalona (amb gairebé el doble de vots). Curiosament, els resultats del PTC són inversament proporcionals en les dues ciutats. És a dir, el PTC obté millors resultats a Badalona i a Sant Adrià que el MCC. 
Garcia:

“Ten en cuenta que nosotros, el Movimiento, llegó a tener al Presidente del Raval, al Presidente de Santa Rosa que era del Movimiento Cristiano, al Presidente del Río, al... al de Singuerlín... Eso dentro de la Asociación de Vecinos."1772

Aquest activisme no es va limitar només a l'acció dintre de les AVV's que encara van mantenir un perfil actiu i reivindicatiu durant els anys 80 , com veurem més endavant. En el cas badaloní, per exemple, a les eleccions municipals de 1983 es va presentar una candidatura anomenada "Esquerra Unida de Badalona" on van participar activament militants del MCC i també de la LCR, formació amb la qual tenien punts en comú malgrat ser la segona molt inferior al Barcelonès Nord en nombre de militància. Aquesta candidatura es va presentar de la següent manera:

"Ens hem organitzat com a ESQUERRA UNIDA DE BADALONA per tal d'intentar recuperar el moviment popular, enfortint les lluites dels diferents sectors -de barri, laboral, dones, joves, ecologistes... -mitjançant la coordinació de la gent que encara restem amb ganes i il-lusions per a enfrontar-nos radicalment contra el sistema capitalista.

ESQUERRA UNIDA DE BADALONA la formen persones que des de fa anys ens mantenim fidels a les raons més profundes que mantenen viu el moviment popular. Persones amb diverses històries, plantejaments i activitats de lluita, a les que, tanmateix, ens uneix la voluntat de recuperar el moviment popular d'anys enrera [sic]. No estem -ni hem estat fins ara- d'acord amb els pactes amb la burgesia, ja que pensem que els seus interessos i els nostres són radicalment oposats i que sols la lluita pot donar respostes positives a les reivindicacions que com oprimits tenim." ${ }^{\text {1773 }}$

Però malgrat els esforços, aquesta candidatura també va tenir uns resultats electorals discrets, obtenint 1.068 vots a les eleccions municipals de 1983 (un 1.08 \% dels sufragis). Tot i això, la implicació en el moviment veïnal dels militants del MCC va continuar durant tota la dècada dels vuitanta. Al IV Congrés Federal del 29 d'octubre i 1 de novembre de 1983 es va continuar insistint en la participació del MC en els moviments socials tot i que no es fa una menció apart sobre el moviment

1772 Entrevista a Cristóbal Garcia Gil, Arxiu Històric de CCOO a Catalunya, Col·lecció Història Oral i militància sindical. Biografies Obreres, p. 163.

1773Esquerra Unida de Badalona (EUB): "Presentació" a Informes núm. 1 (març 1983). AH-MB, Fons Hemeroteca, Caixa 20-8-4, Carpeta Esquerra Unida de Badalona, p. 1. 
veïnal ${ }^{1774}$. Això és reflex de com aquest havia perdut relativament importància en l'ordre de prioritats dels militants del MC. Un butlletí intern analitzava l'any 1984 el percentatge de militància destinat als diferents fronts de lluita:

"Los porcentajes destinados a cada frente de actividad son los siguientes:
1.ㅇ) Sindical
$29,6 \%$
$2^{\circ}$ ) Feminista
$12,6 \%$
3을 Interno.
$12,3 \%$
$4^{\circ}$ ) Movimiento por la paz, anti-OTAN, anti-militarista.
$10,9 \%$
5으 Municipal, barrios
$10,7 \%$
6ํㅜ) Enseñanza.
$5,8 \%$
7으 Estudiantil.
$4,7 \%$
$8^{\circ}$ ) Ecologista, antinuclear..
$1,6 \%$
9을 Campo
$1,5 \%$
Otros.
$9,3 \%$

El movimiento sindical sigue siendo el que merece un mayor número de efectivos.

El frente feminista, si bien está en segundo lugar de la clasificación federal, si consideramos cada organización en concreto, sólo ocupa esa segunda posición en Madrid. En el resto la situación es variada.

A los movimientos por la paz y antimilitaristas hemos consagrado crecientes esfuerzos en los dos o tres últimos años, como corresponde a su importancia política. Aquí se ha producido un desplazamiento de efectivos desde frentes de menor interés hoy, como es el municipal y el de barrios.

Este último ha pasado ha ser un frente secundario en la mayor parte de las organizaciones, salvo allí donde el movimiento vecinal conserva una cierta vitalidad.

En suma, en el último periodo se ha producido una revisión y una redistribución de los efectivos militantes, de acuerdo con la orientación de centrar nuestras energías en aquello que posee hoy o a largo plazo un mayor interés político. A nivel federal se puede considerar, sin embargo, que el frente ecologista podría merecer una mayor dedicación que la actual." ${ }^{1775}$

Aquest document ens posa de manifest la davallada que va patir el moviment veïnal en el transcurs d'aquells anys, i com fins i tot va caure fins al cinquè lloc on

1774 Movimiento Comunista. IV Contreso Federal: “Una izquierda para la revolución” (29-10 i 1-111983), CRAI-Pavelló de la República, Fons DDP. Subsèrie Moviment Comunista, Caixa DDP (MC)

2, Carpeta 2- Moviment Comunista. Congressos, subcarpeta c. (1), p. 19-44.

1775 MC Boletín núm, 54 (Mig de 1984). “La Situación del Partido y la Afiliación”, CRAI-Pavelló de la República, Fons DDP. Subsèrie Moviment Comunista, Caixa DDPDPP (MC) 3 [Reservat], Carpeta 5- Boletín Interno, p. 9-10. 
els militants del MC -a nivell global- desenvolupaven la seva tasca. Un pas més es va fer al I Congrés del Moviment Comunista de Catalunya celebrat a l'octubrenovembre de 1985, on ja es va acusar a una força política concreta del declivi del moviment veïnal:

\footnotetext{
“Les primeres eleccions municipals, abril del 79, suposen l'abandó per part del PSUC del moviment veïnal. Els moviments reivindicatius i populars del [sic] barris són sacrificats a la institucionalització en els Ajuntaments de la política municipal i als pactes de Govern amb el PSC en les ciutats on el moviment veïnal havia tingut més dinamisme."1776
}

El mateix document, no obstant, reconeixia l'existència d'unes AVV's combatives, per bé que eren una minoria:

\begin{abstract}
"Tanmateix, algunes Associacions de Veïns, especialment aquelles en les quals treballaven nuclis de gent radical, mantenen una vida activa amb una actitud d'exigència i enfrontament amb els "ajuntaments d'esquerres". Les reivindicacions urbanes, sobretot als barris més degradats, i les mobilitzacions contra les contribucions especials han estat, juntament amb les reivindicacions de participació ciutadana, els camps de batalla de les AA.VV. més dinàmiques. Aquestes associacions han anat incorporant a la seva activitat d'altres temes, a més a més dels estrictament urbans, com fou el cas de l'activitat antifeixista de fa uns anys, la creació de vocalies de dones més o menys vinculades a les Associacions de Veïns, la lluita contra la OTAN o contra les centrals nuclears. Això no obstant, tret de l'excepció que suposen les AA.VV. més combatives, la major part del moviment d'associacions de veïns segueix tenint una vida bastant esllanguida i localista."${ }^{1777}$
\end{abstract}

Certament, no es pot negar la crisi que va tenir el moviment veïnal, però també cal reconèixer que aquesta va tenir molts matisos ja que conservava en alguns llocs un cert nivell d'incidència i combativitat. Tindrem temps de veure això.

La LCR, tot i no tenir tanta implantació al Barcelonès Nord com el MCC ${ }^{1778}$, va ser l'altra organització política que va capejar millor la crisi dins l'esquerra

1776 Moviment Comunista de Catalunya: "Revolta i Comunisme.Primer Congrés. Barcelona, octubre 1985”, CRAI-Pavelló de la República, Fons DDP. Subsèrie Moviment Comunista, Caixa DPP (MC). 2, Carpeta 2-Moviment Comunista. Congressos, subcarpeta d., p. 9. 1777 Ídem, p. 44.

1778 La seva implantació va ser sempre reduïda i segons un document intern de novembre de 1979 no disposava de més de 10 persones al Barcelonès Nord. Veure LCR, Secretaria d'Organització de Catalunya: "Primer Informe Organización - Noviembre 1979", CRAI-Pavelló de la República, Fons DDP. Subsèrie Liga Comunista Revolucionaria, Caixa DDP (LCR-Arx2) 8, Carpeta 1- LCR. Catalunya. Documents sobre organització, p. 1. 
revolucionària. Pel que fa a la seva relació amb el moviment popular ciutadà, ja a l'any 1980 havia fet esment a l'accentuació de la davallada del moviment veïnal un cop passades les eleccions municipals. Tot i així, la mateixa organització afirmava que eren les mateixes AVV's les entitats populars que havien resistit millor la crisi fins aleshores pel prestigi que s'havien guanyat durant la lluita contra el franquisme i que per tant, calia participar-hi activament:

\footnotetext{
"Nuestra orientación para el próximo periodo, caracterizado por la inexistencia de marcos claros de actividad en los barrios, pasa por estar atentos a las protestas que puedan producirse y potenciarlas, desarrollando nuestro trabajo fundamentalmente en las AA.VV., en torno a la elaboración de propuestas sobre temas de vivienda y equipamientos sociales, dotándonos a la vez de un conocimiento superior al actual sobre estos temas."1779
}

Això es feia reconeixent que s'estava en un moment difícil, en una etapa defensiva on no hi havia la previsió de recollir, a nivell proselitista per la LCR, els efectes immediats de les tasques que es desenvolupessin a les Associacions. No obstant, tot i que la prioritat estava centrada en la intervenció en els sindicats i el moviment obrer, es preconitzava no abandonar la tasca dins el moviment veïnal ${ }^{1780}$. Per posar un exemple en el Barcelonès Nord el President de l'AVV Baldomero Solà de militava a la LCR, al igual que dos mestres de l'escola Llibertat presents a la llista Esquerra Unida de Badalona ${ }^{1781}$.

Totes dues organitzacions -MCC i LCR- van iniciar un procés d'acostament que va culminar amb la unificació feta l'any 1991, que en comptes de servir per crear una organització més potent, va desencadenar una greu crisi que segurament es venia covant des de feia temps i que va acabar amb la nova organització. Així ens ho recordava un dels nostres entrevistats:

"No hi ha diferències tàctiques però si hi ha diferències d'estil. Si durant molts anys

1779LCR, Secretaria Municipal de Cataluña: "La situación del movimiento ciudadano y nuestros objetivos centrales" Boletín de debate no 5C, VI Congreso de la LCR (diciembre 1980), RAIPavelló de la República, Fons DDP. Subsèrie Liga Comunista Revolucionaria, Caixa DPP (LCRArx.2) 4, Carperta 6- LCR. Congrés estatal (6è. : 1980), p. 21.

1780 Ídem, p. 22.

1781El President de l'AVV Baldomero Solà era Roque Martínez Sánchez (núm. 4 a la llista d'EUB), i els dos professors esmentats eren Estela Fernàndez Moran (núm. 14) i Enrique Elejalde Martínez de Pancorvo (núm. 26). Veure [full volant A4 a doble cara] "E.U.B. Candidatura. Vota", MB-AHCB, Col-leccions Factícies, Caixa C20, Carpeta Eleccions Municipals 1983. Esquerra Unida de Badalona. 
funciones d'una manera i venen uns anys i funciones d'una altra manera... Es fusionen i alhora la cosa no va. I es van fusionar i va petar. Però no crec que va petar per que uns eren de la Lliga i uns altres del MC, no no. Vam [inintel-ligible] passar entre gent de la Lliga, entre del MC... Jo crec que molta gent va aprofitar aquella moguda per petar. Gent, qualsevol militant que va veure que amb aquella moguda això no... 'un altre món és possible, una altra manera de funcionar' i jo crec que molta gent va plegar per això, si $(\ldots.) .{ }^{n 1782}$

Fos com fos, l'impacte que van tenir aquestes forces polítiques durant la dècada dels vuitanta, tot i ser important, va ser limitat. Què hi va passar amb la força que fins aleshores havia tingut una major presència dins el teixit associatiu i que ara també ostentava les alcaldies de Badalona i Santa Coloma? Pel PSUC, la seva situació durant els anys vuitanta va estar condicionada en gran part pels fets del Vè Congrés i de com aquests es van traslladar al Barcelonès Nord. Uns fets que van esdevenir traumàtics.

Els fets que es van donar al Vè Congrés venien covant-se des de feia temps. Les renúncies i canvis tàctics oportunistes que es van anar fent seguint l'estela del PCE ja havien provocat un cert descontent dins les bases del partit. En el PSUC es va desenvolupar avia una corrent crítica amb com s'havia actuat durant el procés de canvi polític. Una primera mostra d'aquest descontent va ser quan el PCE va decidir suprimir el terme "leninisme" de la seva definició al IX Congrés fet a l'abril de 1978. La Conferència Nacional del PSUC posterior va discutir les tesis del IX Congrés i va mostrar-ne algunes discrepàncies, en especial respecte la visió triomfalista que el PCE estava fent de la transició. També es va mostrar contrari a la supressió del terme "leninisme"1783. Aquest fet ja va comportar una primera dimissió temporal d'Antoni Gutiérrez Díaz i Gregorio López Raimundo, a més d'una dura crítica de Santiago Carrillo, que va acusar al PSUC "d'esquerranista". Totes aquestes tensions van esclatar definitivament al Vè Congrés celebrat entre el 2 i el

1782Entrevista amb Josep Pitarque Narejos (amb Emiliana Salinas i Salvador Bolancer), 12-3-2013. 1783Carme Molinero i Pere Ysàs: Els anys del PSUC. El partit de l'antifranquisme (1956-1981), L'Avenç, Barcelona, 2010, p. 316. De fet el mateix PSUC havia reformulat la seva definició "marxista-leninista" poc abans, en el IV Congrés, per una nova fórmula que apel-lava als principis "del marxisme, del leninisme i de totes les altres aportacions de la pràctica i el pensament revolucionari". Veure PSUC: Programa del Partido Socialista Unificado de Catalunya. IV Congreso, Catalana de Publicaciones Reunidas, S.A. [Barcelona], 1977, AHMTB, Fons PSUC, Caixa 5, p. 3. 
8 de gener de 1981, en el qual van participar 879 delegats en representació de 21.807 militants (el partit havia perdut 10.000 militants respecte el IV Congrés):

“(...) molts militants, cercant més els errors propis que no la correlació de forces existent (...), havien interioritzat que s'havia seguit una política innecessàriament moderada mentre que, en un altre pla, rebutjaven el distanciament real i simbòlic de la tradició pròpia. Altres militants i quadres dirigents, però, consideraven que calia accelerar aquest distanciament per poder consolidar i eixamplar el paper i la influència del partit en la línia de l'audàcia política reclamada per Santiago Carrillo."1784

Les mancances i dificultats que estaven donant-se al moviment veïnal arran l'entrada del PSUC als Ajuntaments i la "fuita de dirigents" era reconeguda en el mateix informe del Comitè Central presentat per Antoni Gutiérrez Díaz, així com altres situacions, incloent una crítica velada al paper de l'esquerra revolucionària dins l'esmentat moviment:

"En todas las ciudades de Catalunya, después de la victoria de los partidos de izquierda, el patrimonio del movimiento popular y muchos de sus dirigentes más destacados pasan a formar parte de los consistorios democráticos, en cuyo seno chocan con grandes dificultades para poder hacer posibles aquellas cosas por las que habían estado luchando.

El partido, tanto a nivel central como en las comarcas y localidades se ve absorbido por las nuevas necesidades de definir una política municipal de progreso y hacer frente a las grandes dificultades que encuentran constantemente los alcaldes y concejales comunistas, y se produce un abandono en la elaboración de una línea política de movimiento popular adaptada a la nueva situación.

El movimiento popular quedó afectado, en este periodo, tanto por la dificultad de situarse ante los nuevos Ayuntamientos democráticos -que no daban respuesta urgente a las demandas sociales ni imponían un nuevo estilo participativo de masascomo por el fenómeno más general de la abstención, apareciendo en el seno del movimiento reacciones de corporativismo y radicalismo exasperado." ${ }^{1785}$

El mateix informe del Comitè Central reconeixia l'existència de la difícil

1784Carme Molinero i Pere Ysàs: Els anys del PSUC..., p. 329.

1785“5è Congrés PSUC. Una Catalunya de progrés, una entesa popular, un PSUC més fort. Barcelona 2/6 de enero de 1981. 1. Informe del Comité Central. Intervenciones de los portavoces. Resumen de la discusión" (versió en castellà), MB-AHCB, Col·leccions factícies, Caixa C19, Carpeta PSUC-Congressos, p. 14. 
situació i la crisi existent, finalment va ser aprovat amb 419 vots a favor, 350 en contra i 282 abstencions. En aquest debat, la delegació del Barcelonès Nord, encapçalada pel colomenc Chema Corral, tot i estat d'acord amb els trets generals de l'informe presentant, havia manifestat la següent posició:

\begin{abstract}
"Nuestra delegación es partidaria de evitar las indefiniciones, utilizando formulaciones que no se presten a distintas interpretaciones. Por eso es urgente clarificar.

Debemos reactualizar -en función de la realidad objetiva y de nuestra perspectiva basada en la revolución de la mayoría-, el frente antimonopolista en la alianza de las fuerzas del trabajo y la cultura, en la dirección y hegemonía de la clase obrera en el proceso de la construcción del socialismo. Esto, en el IV Congreso, era nuestra estrategia del socialismo en la democracia, y no de "eurocomunismo", que es una formulación nueva, ambigua y con diferentes interpretaciones que no debemos utilizar y que debemos suprimir por falta de rigurosidad científica." ${ }^{1786}$
\end{abstract}

No eren aquestes les úniques crítiques que es feien. Aquesta delegació recollia en la seva aportació el descontent acumulat per gran part de la militància psuquera amb com s'havien desenvolupat els darrers esdeveniments:

\footnotetext{
"Sobre la transición, los Pactos de la Moncloa, y el Gobierno de la Generalitat provisional la delegación opina que debemos tener una actitud más autocrítica, siendo corresponsables en la medida que no hemos desarrollado una política lo suficientemente transparente y de movilización.

Estamos pagando nuestras posturas de asentimiento ante la reforma cuando esperábamos la ruptura, y lo que nos ha llevado, entre otras cuestiones, al desencanto y la abstención."1787
}

Sigui com sigui, la polèmica va arribar quan es va aprovar una esmena a favor de la supressió del terme "eurocomunisme" per 424 vots a favor, 350 en contra i 21 abstencions. També es van aprovar unes esmenes que suavitzaven les crítiques contra la URSS, però de cap manera es va tornar a un model submís a Moscou i per exemple, es va continuar condemnant la invasió soviètica d'Afganistan i defensant

1786“Delegación Barcelonés Norte y L'Hospitalet. Portavez: Chema Corral”, dins “5è Congrés PSUC. Una Catalunya de progrés, una entesa popular, un PSUC més fort. Barcelona 2/6 de enero de 1981. 1. Informe del Comité Central. Intervenciones de los portavoces. Resumen de la discusión" (versió en castellà), MB-AHCB, Col·leccions factícies, Caixa C19, Carpeta PSUCCongressos, p. 48. 1787 Ídem. 
la línia del "socialisme en llibertat" com es pot comprovar fent una simple ullada a les tesis aprovades ${ }^{1788}$. En canvi, els sectors partidaris de mantenir el concepte "eurocomunisme" no van pair la derrota i aviat van engegar una campanya pública i mediàtica contra el resultat d'aquest. Alguns dels nostres testimonis del Barcelonès Nord partidaris de l'eurocomunisme han volgut argumentar que els resultats contraris a aquest es van produir per que les delegacions que es van enviar havien estat "pre-cuinades" abans i no eren del tot representatives:

“Com es va muntar el Vè Congrés? Aquí no vam anar ni un delegat, els van vetar. Com es van escollir? Es van escollir per consigna total amb tres o quatre tios del Comitè Central aquí i era el que s'havia de votar, i s'ha acabat, eh? No vam anar ni un, al Vè Congrés (...) Qui era, hi era el Parra, el Antonio Jiménez, el Campesino, el Soto, el Rafael Gómez... tots escollits. Era una cosa... Ja sabíem qui guanyava el Vè Congrés. Qui va portar les formes... la votació dels delegats del Vè Congrés. Es va portar directament de Barcelona (...) que no me'n recordo qui era... juntament amb el Serradell (...) l'home del KGB al partit..."1789

No nego que no es poguessin donar pressions en aquest aspecte en els diferents Comitès Locals, però com veurem deprès, el cert és que la majoria de la militància dels barris populars va decantar-se posteriorment pel PCC, si bé no puc assegurar al cent per cent fins a quin punt les delegacions enviades al Vè Congrés eren realment proporcionals respecte les diferents tendències. Fins i tot el mateix Chema Corral havia afirmat al Congrés en la seva valoració respecte l'informe del Comitè Central que:

"Sin embargo, dieciocho camaradas que están de acuerdo con el contenido y con el redactado mantienen la posición de no suprimir el término por las expectativas que ha desatado este Congreso. 64 están de acuerdo con el redactado leído."1790

Fos com fos, l'actitud dels perdedors del Congrés tampoc va ser exemplar. No van acatar-lo i de seguida van aprofitar la seva popularitat per atacar públicament

1788PSUC: "Programa del Partit Socialista Unificat de Catalunya IV Congreso", Catalana de Publicaciones Reunidas, S.A. [Barcleona], 1977. AHMTB, Donació PSUC, Caixa 5.

1789 Entrevista a Eloy Jurado Cubero, President de l'AVV Sistrells, militant del PSUC i posteriorment regidor a l'Ajuntament de Santa Coloma de Gramenet (1983-1991).

1790“Delegación Barcelonés Norte y L'Hospitalet. Portavez: Chema Corral”, dins "5è Congrés PSUC...." (versió en castellà), MB-AHCB, Col-leccions factícies, Caixa C19, Carpeta PSUCCongressos, p. 48. 
el resultat que es va donar. Antoni Gutiérrez i López Raimundo van renunciar als seus càrrecs juntament $\mathrm{amb}$ altres partidaris de mantenir el terme "eurocomunisme". Persones com Jordi Borja, Joan Busquets, Jordi Cunill, Domènec Martínez, Josep Maria Riera, Jordi Sole Tura i Maties Vives fan fer un document molt dur contra els resultats del Congrés:

\begin{abstract}
"Aquest sector no va dubtar, doncs, a presentar-se com a patrimoni propi i exclusiu l'estratègia de la "revolució de la majoria" i el "socialisme en llibertat", que ho era de tot el partit, o si més no de la immensa majoria, i va reclamar immediatament la convocatòria d'un congrés extraordinari, posició que va comptar amb el ple i bel-ligerant suport de la direcció del PCE."1791
\end{abstract}

El curiós és que els partidaris de l'eurocomunisme van acabar practicant els mateixos mètodes que havien acusat de fer servir a l'altre sector. Primer van fer servir els canals que els hi oferia una determinada premsa que estava àvida de qualsevol cosa que pogués desprestigiar al partit comunista que tenia més força dins l'estat espanyol. Ja des de 1977 s'havia iniciat una violenta campanya anticomunista quan s'havia vist la força i implantació en la societat que tenia aquest partit. Ara els antics líders els hi van facilitar la tasca, a la qual també es van afegir els polítics d'altres partits desitjant afeblir el màxim a un dur rival polític. Joan Raventós (PSC-PSOE), Anton Canyelles (UCD-CC), Miquel Roca (CiU) i d'altres van qualificar les resolucions del Vè Congrés com un retrocés democràtic i un retorn al dogmatisme soviètic quan la realitat no era així ${ }^{1792}$. Una honrosa excepció va ser l'editorial del Diario de Barcelona, el vell "Brusi", del dia 8 de gener, que es va atrevir a dir el que molts callaven:

"L'editorial de "Diario 16" diu: "Atención, mucho ojo con los comunistas que han devuelto al PSUC hacia el fascismo moscovita. La lógica de su catecismo totalitario vaticina actuaciones desestabilizadoras y hasta violentas. El Estado debe estar preparado para reprimir implacablemente sus primeros excesos, en el caso que se

1791 Carme Molinero i Pere Ysàs: Els anys del PSUC..., p. 335. El document es titulava "Continuarem lluitant per l'eurocomunisme" i havia estat publicat pel Diario de Barcelona el 9-1-1981. Alguns d'aquests dirigents ja havien aprofitat també els canals que els oferia la premsa per desprestigiar al Vè Congrés $\mathrm{i}$ als seus rivals, que de seguida van ser qualificats amb els pejoratius adjectius de "prosoviètics" i "afgans". Un exemple: Jordi Borja: "PSUC: Ha ganado la derecha", El Periódico de Catalunya, 8-1-1981.

1792Veure "Els PSUC suprimeix el mot eurocomunisme" i "Anton Canyelles critica els acords del congrés del PSUC", Avui, 6 i 8-1-1981 i "Reventós contra el eurocomunismo" i "Primeras reacciones de Convergència i CC-UCD", Diario de Barcelona, 6 i 8-1-1981. 
produzcan." Acompanya l'editorial una opinió de Sergio Vilar d'una línia semblant i que també reprodueix "La Vanguardia”.

En altres paraules, aquest paràgraf vol dir que els defensors del totalitarisme capitalista opinen que només ells tenen dret a fer el que políticament els interessi, i que ningú pot opinar diferent d'ells. La democràcia està al seu servei. Que ningú cregui que es pot dir quelcom més del que ells permetin. Qui no està amb ells és un violent perillós i cal que sigui perseguit implacablement.

Ens sembla que en una situació com l'actual ens hem de definir amb claredat dient que això és la mateixa argumentació que donava l'Estat feixista del general Franco per impedir per la força les llibertats democràtiques." ${ }^{1793}$

Malgrat la tria de Pere Ardiaca com a president i Francisco Frutos com a secretari general, i d'un Comitè Executiu amb una clara preponderància leninista ${ }^{1794}$, el Comitè Central va ser més plural i va mantenir la presència d'una trentena de persones identificades amb "l'eurocomunisme"1795. Els intents de conciliació que van intentar fer persones com Joaquim Sempere i Manuel Vázquez Montalbán no van tenir èxit. Els partidaris de l'eurocomunisme es van mostrar intransigents en no acceptar els resultats del Vè Congrés i amb el suport del PCE de Santiago Carrillo -un fet curiós, ja que els "euromunistes" no havien deixat de acusar als "prosoviètics" de voler que el PSUC deixés de ser un partit de disciplina catalana-, van exercir una pressió constant fins al punt que el Comitè Central els leninistes van canviar d'opinió acabar acceptant una Conferència Nacional al mes de de juliol que va tornar a admetre el terme "eurocomunisme". El president Pere Ardiaca la va desautoritzar reivindicant la legitimitat del Vè Congrés i poc després va ser destituït pel Comitè Central amb 58 vots a favor, 33 en contra i una abstenció). Al 9 de desembre de 1981 finalment van ser expulsats del Comitè Central 12 membres acusats d'activitat fraccional. 14 van ser suspesos de

1793“El davantal del Brusi. No a l'anticomunisme”, Diario de Barcelona, 8-1-1981.

1794Carme Molinero i Pere Ysàs: Els anys del PSUC..., p. 334. Els membres del CE eren Josep M. Rodríguez Rovira, Andreu Claret, Maria Dolors Calvet, Cipriano García, Antoni Lucchetti, José Luis López Bulla, Joan Ramos, Rafael Ribó, Manuel Vázquez Montalbán, Xavier Folch, Sebastià Vives, Albert Coromines, Josep M. Clariana, Josep Salas i Guillem Sánchez. El secretariat del CC estava format per Rodríguez Rovira, Claret, Lucchetti, Ribó, Clariana, Salas i Sánchez.

1795 “El comité central del PSUC se ha renovado en un 6 por ciento", El Noticiero Universal, 7-11981;"El nou secretari general del PSUC F. Frutos crida a la unitat interna", Avui, 7-1-1981; "Estos son los nombres", Diario de Barcelona, 7-1-1981; "La "línea dura" se instala en la dirección del PSUC", El Correo Catalán, 7-1-1981 i "Leninistas se aprovechan de la victoria de los prosoviéticos", El Periódico de Catalunya, 7-1-1981. 
militància duran sis mesos i uns altres durant tres mesos. El mateix Comitè Central va suspendre les activitats dels Comitès Locals del Vallés Occidental, del Baix Llobregat i de la Intercomarcal de Lleida, mentre convocava un congrés extraordinari, el VI, per corregir la línia del partit ${ }^{1796}$. Certament, els que havien acusat als seus rivals de "dogmàtics i estalinistes" havien girat la truita precisament aplicant aquests tipus de mètodes. Durant l'any 1982, els expulsats, juntament amb altres membres sancionats o que també havien fet fora del partit crearan el Partit dels Comunistes de Catalunya. L'escissió s'havia consumat.

Al Barcelonès Nord, com a tot arreu, el procés de trencament va ser especialment dur, virulent i traumàtic. A Badalona, un cop el Comitè Central va decidir revisar els acords del Vè Congrés, el Comitè Local del PSUC va impulsar assemblees a les vuit agrupacions existents aleshores a la ciutat per ratificar aquesta decisió. La participació en aquestes assemblees va ser força baixa en proporció als militants existents si hem de fer cas a les dades proporcionades per un dels futurs membres del PCC: només 70 persones dels 605 militants del PSUC badaloní d'aleshores van donar ple suport a les resolucions del Comitè Central que havia tornat a acceptar "l'eurocomunisme". Així ho explicava Miguel Guerrero, regidor cessat ja al novembre de $1981^{1797}$, després d'unes tenses reunions on fins $\mathrm{i}$ tot arriba a afirmar que els membres del seu sector van ser rebuts per altres camarades "armats amb pals". Aquest testimoni també és interessant per conèixer la implantació del partit als diferents barris badalonins:

"El Comité [sic] local que no reconeixem ha convocat el 605 membres del Partit. Els resultats han estat els següents: A Sant Roc, 103 camarades, varen treure 5 vots; a Llefià, de 136 militants van treure 16 vots; a la Salut, de 62 militants obtingueren 11 vots; a Morera-Pomar, de 63 militants van obtenir 5 vots: a Sant Crist, de 21 militants van obtenir 5 vots; a Bufalà, de 22 militants van obtenir 8 vots; a Cuatro Barrios [segurament deuen ser Lloreda, Nova Lloreda, Sistrells i La Pau], de 118 militants 8 vots obtinguts, i al Centre, de 85 militants varen treure 12 vots. El resultat final fou 70 vots de 605 militants.

Aquesta és la base del Comité [sic] local de Badalona, al qual no reconeixem"1798

1796Carme Molinero i Pere Ysàs: Els anys del PSUC..., p. 337-342. Els 12 membres del CC expulsats van ser Pere Ardiaca, Joaquim Boix, Alfredo Clemente, Chema Corral, Leopoldo Espuny, Fèlix Farré, Juan Muñiz, Marià Pere, Joan Ramos, Celestino Sánchez, Josep Serradell i Francesc Trives.

1797 Miguel Guerrero Sánchez: “El Porque de un cese”, Revista de Badalona, 21-11-1981, p. 8.

1798Jordi Martí: "El PSUC de Badalona s'ha dividit. El Sector prosoviètic ha creat el seu propi 
Però aquestes van ser suficients per que la majoria d'agrupacions, sis, donessin suport a la direcció. Només les agrupacions de Llefià i Sant Roc-Congrés els partidaris d'Ardiaca i els sancionats van ser majoria ${ }^{1799}$. Tot i així, les baixes xifres de participació ens mostren fins a quin punt el desconcert o l'apatia s'havia estès als militants. Paral-lelament un altre grup va constituir un nou Comitè Local Provisional alternatiu en no reconèixer el Comitè Local del Partit, existint, durant un temps, dos Comitès Locals del PSUC. ${ }^{1800}$. Poc després va dimitir el regidor d'Ecologia i Medi Ambient, Antoni Barbarà, que va explicar els seus motius en un escrit molt crític amb el Comitè Local "oficial” a Revista de Badalona, publicació que va recollir l'enfrontament entre les diverses tendències:

“Enmig d'aquest garbuix de sancions, càstigs, propostes d'expulsions i guerra tan oberta com bruta, jo esperava, des de la meva petita responsabilitat municipal, que ningú, cap dels grups, no m'exigís el prendre partit per una o altra fracció, perquè de fraccions va la qüestió des de fa mesos o anys. I cal dir que jo sóc dels de la U d'"Unificat" i de la C de "Catalunya".

No he tingut, tampoc, aquesta sort i el Comitè Local, de majoria oficial "euro", m'ha exigit que em mulli recolzant la seva actitud, que pretén expulsar centenars de militants que considero honestos i vàlids, sota l'acusació de comunistes "ortodoxos", això utilitzant els més sofisticats sistemes de purga, cosa a la qual, naturalment, m'he negat en rodó, no podent, d'altra banda, passar a militar a la fracció dogmàtica per desconèixer-la i per la meva instintiva aversió al treball de grup."1801

De la mateixa manera el 13 de gener Vicente Sánchez (Arturo) publicava un

Comité [sic] local provisional”, Revista de Badalona, 30-12-1981 i 2-1-1982, p. 13.

1799 “Resolució del Comité [sic] local de Badalona sobre la situació interna del P.S.U.C.”, Revista de Badalona, 30-12-1981 i 2-1-1982, p. 15. No obstant, les dades que donen cal pendre-les amb cautela. La mateixa agrupació de "Cuatro Barrios" criticava posteriorment aquestes dades oficials i manifestava que la seva agrupació s'havia manifestat majoritàriament a favor del Vè Congrés. Veure Agrupación Cuatro Barrios: "El respeto que merecen los ciudadanos", Revista de Badalona, 23-1-1982, p. 11.

1800El Comitè Local "alternatiu" estava format per Juan Gómez i Miguel Guerrero (Sant RocCongrés), José Fuente i Manuel Sousa (Llefià); Antonio López (Centre); Vicente Sánchez Arturo i Eloy Collazos (La Salut); Jacinto Toberia, Antonio Rubio i José Ballús (Morera-Pomar); Joanquin González i Juan Mesa ("Cuatro Barrios"); Mariano Muñoz (Bufalà) i Manuel Garcia Carmona (Sant Crist). Veure Jordi Martí: "El PSUC de Badalona s'ha dividit. El Sector prosoviètic ha creat el seuj propi Comité [sic] local provisional”, Revista de Badalona, 30-121981 i 2-1-1982, p. 13.

1801 Antoni Barbarà i Molina: “Justificació del conseller Barberà”, Revista de Badalona, 6 i 9-1-1982, p. 7. 
article on es defensava a ell mateix i a Miguel Guerrero de les acusacions de "treball fraccional" que segons ell li feia la direcció local del PSUC ${ }^{1802}$, mentre que el 20 de gener apareixia una rèplica d'Àngel Navarro replicant a l'escrit que havia fet Antoni Barbarà per justificar la seva dimissió, acusant-lo de "fraccionalista"1803. Mentrestant, Miguel Guerrero era separat de la delegació d'Estadística mentre Juan Gómez era cessat com a cap de la delegació municipal de Neteja pública ${ }^{1804}$. Van aparèixer més escrits dels defensors de les tesis del Vè Congrés com Manuel Sousa Gil, Vicente Sánchez (Arturo), i els mateixos Miguel Guerrero i Juan Gómez ${ }^{1805}$. Per la seva banda, també van aparèixer articles signats per defensors de les tesis "eurocomunistes" com Emili Muñoz (secretari polític local del PSUC) i de l'Agrupació del Centre ${ }^{1806}$. Finalment Miguel Guerrero i Juan Gómez van ser expulsats del PSUC i substituïts en les seves responsabilitats a l'Ajuntament. Poc després participaren en la creació del PCC a Badalona.

Els efectes de l'escissió a la ciutat de Badalona es van traslladar a les agrupacions del PSUC dels diferents barris. La lluita va adquirir una extrema duresa i es barrejaven la disputa ideològica i també la del patrimoni:

"Para la gente que veníamos del mismo proyecto, de la misma idea, que nos habíamos visto en las fábricas, que nos habíamos visto en los barrios, fue dramático porque fue, aparte de una división ideológica (...) hubo incluso enfrentamientos físicos, casi. Porque claro, cuando el partido se divide y ya se forma una nueva formación política (....) entonces aparece la lucha por los locales, (...) en los barrios donde el PCC era más fuerte se quedó el local pero el local central se lo quedó el PSUC."1807

Aquesta crisi es va traslladar al moviment veïnal, en la mesura que encara hi

1802Vicente Sánchez (Arturo): “Si, al partido de la clase obrera”, Revista de Badalona, 13-1-1982, p. 6.

1803 Ángel Navarro Rubio: "Réplica a la justificación de un ex-camarada (carta abierta a Antoni Barbarà)", Revista de Badalona, 20-1-1982, p. 6.

1804“Els comunistes cessen ara a Joan Gómez”, Revista de Badalona, 27-1-1982.

1805 Manuel Sousa Gil [signa com "Miembro del Comité Local del PSUC de Badalona. Defensor del V Congreso"]: "Els comunistes i Badalona”, Revista de Badalona, 27-1-1982, p. 7; Vicente Sánchez (Arturo): "Los eurocomunistas y los comunistas auténticos", Revista de Badalona, 6-2-1982, p. 13 i Miguel Guerrero Sánchez i Juan Gómez Alba: "Algunas aclaraciones sobre las discrepancias del PSUC", 24-3-1982, p. 6.

1806Emili Muñoz, Secretari Polític de Badalona del Partit Socialista Unificat de Catalunya: "PSUC: el futur d'un patrimoni col-lectiu" i Agrupació del Centre de Badalona del Partit Socialista Unificat de Catalunya: "Som un partit nacional i de classe", Revista de Badalona, 30-1-1982, p. 16-17.

1807Entrevista a Manuel Armentero Molina, 10-4-2010. 
havien AVV's on el PSUC tenia una notable influència malgrat la marxa de dirigents veïnals cap el consistori. No pocs militants del PCC, expulsats del consistori i fracassat el seu intent d'entrar al consistori al 1983, tornaren a impulsar determinades AVV's per prendre posicions de força front l'Ajuntament governat pels seus ex-companys -o pel PSC-PSOE en el cas de Sant Adrià-, tal i com havia estat l'opció del MCC i la LCR front el PSUC. Aquest fet va comportar donar-les-hi de nou una major combativitat.

A Santa Coloma de Gramenet la crisi del PSUC també va ser duríssima. Va provocar la divisió de les agrupacions locals i va arribar al punt de que Lluís Hernàndez dimitís provisionalment, tal qual ja he explicat ${ }^{1808}$, i que fins i tot alguns militants de CCOO i -curiosament- la CNT s'enfrontessin físicament amb els eurocomunistes a l'assemblea que va convocar al Singuerlín per explicar la seva decisió (sempre segons El Correo Catalán ${ }^{1809}$, així que cal agafar amb certes reserves aquestes afirmacions d'un diari que tenia un interès evident en desprestigiar les forces d'esquerra). En Jaume Sayrach ens recordava com es van barrejar el debat del Vè Congrés amb qüestions locals com la municipalització de les treballadores de LIMASA:

"Es clar, la gent, el Chema, la gent que marxen del PSUC, són els que volen la municipalització... coincideixen (...) per que va haver un trencament ideològic del partit. No per un problema local. Llavors es visualitza en un problema local que era la municipalització de LIMASA. I el Lluís es planta.

(...) si si, al 81. I llavors es fa una assemblea a l'església de Singuerlín 'si es municipalitza (...) es presenta la dimissió'. I llavors es quan la gent aquesta del Chema tiren enrere. Van veure que anava en serio que dimitia el Lluís..." ${ }^{\text {1810 }}$

També va comportar l'expulsió de Chema Corral del partit i del seu càrrec de regidor poc després, a inicis de 1982, quan els eurocomunistes havien recuperat el control del PSUC. Poc després ja eren 5 els regidors del PSUC expulsats, fet que va comportar fins i tot protestes i incidents als Plens Municipals com els ocorreguts el mes de març ${ }^{1811}$. Paradoxalment, a Santa Coloma fins aleshores la majoria havia

1808Veure p. 557.

1809 “Militantes comunistas intentan agredir al Alcalde”, El Correo Catalán, 20-10-1981.

1810Entrevista a Fernando Saro (amb Lluís Hernàndez i Jaume P. Sayrach), 5-6-2013.

1811Jordi Corachán: "Pancartas y abucheos entre euros y pro soviéticos en un Pleno en Santa Coloma", El Correo Catalán, 17-3-1982. Els expulsats eren apart de Chema Corral, Rafael Parra, 
estat posicionada en la línia del Vè Congrés, com reconeixia fins i tot un "eurocomunista" com Fernando Saro:

"Aquí a Santa Coloma com es va viure això? Doncs majoritàriament, el PSUC, majoritàriament crec que tant la direcció de Sta. Coloma com fins i tot la base, era més aviat prosoviètica. 0 sigui, és curiós! Però no així el grup municipal!, no?. O sigui, el grup municipal que, majoritàriament era més... més Eurocomunista. Per definir-lo d'alguna manera, per no voler (...).

Es clar, havia un Comitè Local en aquells moments que havien 24... 24, em sembla que eren, 24 companys. La direcció en Sta. Coloma era de 24, dels quals 20 o 21 eren de la línia prosoviètica: per començar el Parra, el Chema, no?. L'Adame!. El... La Leo Crespo (...) I només 3 o 4 eren de la línia Eurocomunista, no?. Un que era l'Eloy Jurado, el Lluís i el Carlos Grande. És a dir, els únics que tenien, que defensaven una línia Eurocomunista en la direcció local eren minoria, minoria, minoria." Clar que eren importants perquè un d'ells era l'alcalde del primer Ajuntament democràtic."1812

Però el sector eurocomunista va començar a reunir-se pel seu compte ${ }^{1813}$, i comptant amb el suport de la direcció nacional després del viratge i nou pacte entre "euros" i "leninistes", van aconseguir revertir la situació a nivell local, fent servir les sancions i les expulsions. No va ser una tasca fàcil, ja que de les sis agrupacions existents a Santa Coloma, només dues agrupacions es van mostrar majoritàriament favorables als "eurocomunistes": les del Centre i Singuerlín. Les altres, Fondo, Santa Rosa i el Raval ho van fer majoritàriament amb el Vè Congrés i posteriorment amb el $\mathrm{PCC}^{1814}$. Fins i tot un informe del nou Comitè Local afirmava que:

"Tras producirse la escisión, hecho sumamente grave y que ha conllevado una sustancial baja de militantes en nuestra organización, todas las agrupaciones, excepto la de Singuerlín, han sufrido las consecuencias de manera muy acusada, especialmente las de Santa Rosa y Latino, en donde hemos perdido el $80 \%$ de los militantes." ${ }^{1815}$

Leo Crespo, Máximo Luna i Juan Romera.

1812 Arxiu Històric de CCOO de Catalunya, Col·lecció Història Oral i militància sindical. Biografies Obreres. Entrevista a Fernando Saro Madrilejos, 13-12-01 a 10-05-02, entrevistador i transcriptor: José Manuel Hidalgo Ramírez, p. 176.

1813 Ídem, p. 177. L'entrevistat esmenta reunions amb la presència de Carlos Grande, Perico García, Eloy Jurado, Remei Martínezx, Tomàs Lorenzo, Lluís Hernàndez, José Miguel Lacasta, Vicky Marín i Antoni Hernàndez (apart d'ell mateix, es clar).

1814 Ídem p. 177.

1815 “El PSUC local da por terminada su crisis”, Grama núm. 280 II Època, 18/24-6-1982, p. 9. Cal tenir en compte que després de la legalització el PSUC colomenc va arribar a tenir entre 1.000 i 1.500 militants segons alguns testimonis, si bé segurament per l'any 1981 la xifra devia ser 
Sigui com sigui, aquest enfrontament tant dur va deixar seqüeles durant molts anys, va trencar amistats i, com era previsible, va traslladar-se al mon associatiu veïnal. La mateixa Emiliana Salinas ens recordava com els enfrontaments entre els que es van quedar al PSUC i els que van fer el PCC es traslladaven a les reunions de l'AVV del Fondo:

“¿Y que pasó después? Pues que vienen las escisiones del propio PSUC aquí en Santa Coloma. ¿Qué pasa? Que en nuestra Asociación habían quedao gente de las dos fracciones. Y había unas peleas personales... que no te puedes ni imaginar... Querían llevarse a la gente, pero como tenían otra gente que son la Asociación, pesábamos nosotros y la gente no se iba y mantenía ese contacto, esa vinculación con la Asociación y a la hora de hacer el barrio un tipo de colaboración. Que ahí yo ya digo directamente que yo participé ahí a todas todas... Incluso dos elecciones y la tercera dije 'no me presento' y ya no me presente... Y me votaban todos, pero entre ellos se mataban. Y yo es que digo 'es que esto no es una Asociación de Vecinos'. (...)

¿El conflicto? De llamarse fascistas mutuamente. Porque habían hecho vacaciones juntos, sabían vida y milagros y se tiraban cosas personales en una reunión de Junta, por ejemplo (...)

A la gente, al que no pensaba en plan comunista o el que no pensaba... ya era un traidor. Estas palabras usaban... con los socios (...) entre ellos también (...) eso era mutuo, el amor-odio... Entonces llegó un momento que yo dije, esto no es una Asociación de Vecinos, aquí no estamos para pelearnos... En alguna Junta otra compañera y yo nos levantamos y los dejamos solos... Y en una Junta casi llegaron a las manos, me tuve que meter por el medio..." ${ }^{1816}$

A Sant Adrià de Besòs l'escissió del PSUC va tenir unes característiques més peculiars, com ja vaig explicar, doncs a diferència de Santa Coloma i Sant Adrià la majoria dels regidors -6 de 8- es van decantar pel PSUC ${ }^{1817}$. El seu cap de files, Juan José Castro ens explicava com es va donar la volta a la decisió presa en el Vè Congrés i com van decidir crear el PCC després que van ser expulsats:

“Pero los leninistas y los eurocomunistas votaron juntos las enmiendas en el plenario.

inferior per que ja va haver-hi una primera pèrdua de militància pel "desencanto". Veure Arxiu Històric de CCOO de Catalunya, Col·lecció Història Oral i militància sindical. Biografies Obreres. Entrevista a Fernando Saro Madrilejos, 13-12-01 a 10-05-02, entrevistador i transcriptor: José Manuel Hidalgo Ramírez, p. 95 i entrevista a Rafael Parra Chica 29-9-2001 a 22-12-2001, p. 232.

1816Entrevista a Emiliana Salinas, 28-5-2013.

1817 Així ho he explicat a la pàgina 570 amb el testimoni de Juan José Castro. 
Los prosoviéticos que éramos nosotros ganamos los votos democráticos que hubo. Pero la Comisión de Candidatura que estuvo Frutos y estuve yo, me acuerdo muy bien, luego... hay que ver lo primaveras que fuimos y lo gilipollas que llegamos a ser. Como pudimos sacar un Comité Central de ciento y pico y solo 26 digamos prosoviéticos, solo 26 comunistas (...)

Claro, porque nosotros (...) pensamos que no podíamos quedarnos en la calle sin nada, sin militar, y que lo que teníamos que hacer era que se volviera a cicatrizar la herida y teníamos que seguir militando y organizados. Y nos pareció mejor crear el PCC que (...) irnos a nuestra casa cada uno. Y es lo que hicimos (...)

Cap el PCC, el 90 o 95 \% cap el PCC (...) Aquí majoritàriament, aplastantament (...)”1818

Com van afectar aquests successos a les associacions veïnals on el PSUC havia tingut més força, és a dir, les de La Mina i la del Besòs? Curiosament de manera força diferent. La primera va entrar durant els anys vuitanta en un procés d'estancament i decadència. Però en la segona, la del Besòs, la gran majoria de membres del PSUC que hi participaven van passar cap al PCC, on militava per exemple el seu President Rafael Caballero. Una altra important militant, dirigent veïnal i regidora expulsada d'aleshores, Maria Codina, ens explicava la seva experiència i per què va acabar decantant-se cap el PCC:

"Per que jo veia que les coses que feien (...) Una de les coses que em va fer caure d'allà $i$ decantar-me va ser per que una companya del PSUC em va vindre a buscar i em va dir que si jo em quedava al PSUC a mi em donarien una responsabilitat en el d'allò... (...) era com una cosa comarcal (...) o a la Diputació (...) i jo vaig dir que no, que ho sentia molt però (...) no van fer servir cap raó política, jo només veia que venia a criticar els meus companys de partit (...) que eren més honestos i a més a més els coneixia... i dirme que jo per quedar-me al grup del PSUC jo tindria un lloc a la Corporació..."1819

Durant els anys vuitanta l'AVV del Besòs mantindrà un elevat nivell de combativitat com veurem més endavant en aquest mateix capítol al conflicte que es va donar al gener i febrer 1984. De fet aquest tarannà va arribar encara més enllà, fins a la dècada els noranta, que va començar amb la famosa "Intifada del Besòs" que va començar el 9 d'octubre de $1990^{1820}$.

1818Entrevista a Juan José Castro Castillo, 20-2012-12 i 21-1-2013.

1819Entrevista a Maria Codina Cabré, 5-4-2012.

1820Aquest conflicte es va donar al 1990 quan dins de les operacions al voltant dels jocs olímpics de 1992 es va voler reubicar en aquest barri població provinent de La Mina construint uns habitatges socials en uns terrenys que el veïnat havia reclamat històricament com a zona 
Però a nivell electoral, la crisi interna del PSUC va afectar més a Sant Adrià de Besòs que a les altres dues localitats del Barcelonès Nord. Aquest fet es pot veure clarament amb el resultat de les eleccions municipals de 1983, on, a diferència de 1979, es poden veure diferents tendències en els tres municipis estudiats:

ELECCIONS MUNICIPALS 1983 (EN DESTACAT ELS RESULTATS DEL PSUC I EL PCC)

\begin{tabular}{|c|c|c|c|c|c|c|}
\hline & \multicolumn{2}{|l|}{ Badalona } & \multicolumn{2}{|l|}{ Santa Coloma de G. } & \multicolumn{2}{|l|}{ Sant Adrià de B. } \\
\hline & Vots & Regidors & Vots & Reg & s Vots & Regidors \\
\hline PSC-PSOE & $39.093(39,39 \%)$ & 12 & $23.106(35.89 \%)$ & 12 & $9.276(62,67 \%)$ & 15 \\
\hline PSUC & $35.926(36.20 \%)$ & 11 & $27.443(45,83 \%)$ & 15 & $973(6,57 \%)$ & 1 \\
\hline $\mathrm{CiU}$ & $10118(10,19 \%)$ & 3 & $2.804(4,68 \%)$ & & $1.621(10.95 \%)$ & 2 \\
\hline AP-PDP-UL & $6.208(6,26 \%)$ & 1 & $2.804(4,68 \%)$ & & $1.303(8,80 \%)$ & 2 \\
\hline PCC & $3.947(3,98 \%)$ & & $2.232(3,73 \%)$ & & $899(6,07 \%)$ & 1 \\
\hline ERC & $1.973(1,99 \%)$ & & $449(0,75 \%)$ & & $169(1,14 \%)$ & \\
\hline EUB* & $1.068(1,08 \%)$ & & & & & \\
\hline CDS & & & $317(0,53 \%)$ & & & \\
\hline PST & $645(0,65 \%)$ & & & & $158(1,07 \%)$ & \\
\hline MCC & & & $617(1,03 \%)$ & & & \\
\hline IND** & & & & & $345(2,33 \%)$ & \\
\hline Blancs & $269(0,27 \%)$ & & $1.472(3,80 \%)$ & & $57(0,38 \%)$ & \\
\hline Nuls & $799(0,80 \%)$ & & $503(1,28 \%)$ & & 355 (2,21\%) & \\
\hline Electors & 159.955 & & 95.945 & & 25.323 & \\
\hline Participació & $100.046(62,55 \%$ & & $61.129(63,71 \%)$ & & $15.136(59,77 \%)$ & \\
\hline Abstenció & $59.909(37,45 \%)$ & & $34.816(36,29 \%)$ & & $10.187(40,23 \%)$ & \\
\hline
\end{tabular}

Elaboració pròpia amb fonts diverses.

* Esquerra Unida de Badalona. Candidatura presentada a Badalona impulsada per militants del MCC i l'LCR més independents.

** Independents Per Sant Adrià

La diferència de resultats és notable. Com explicar el perquè d'aquestes diferències, sobretot entre Sant Adrià i les altres dues poblacions? Sens dubte, hi ha un fet que va ser molt important. A Santa Coloma i a Badalona el PSUC va tenir l'Alcaldia, i això li va permetre capitalitzar més electoralment els primers anys d'Ajuntaments democràtics on la situació va millorar notablement respecte els Ajuntaments franquistes. El PSUC a Sant Adrià no va ser la força més votada i a més va ser la localitat on fins i tot la majoria de regidors van ser partidaris del Vè Congrés (i una amplíssima majoria de les bases). Tot i que això no ho explica tot, la majoria dels mitjans de comunicació van tractar molt durament als partidaris del Vè Congrés i al PCC després ${ }^{1821}$. Els que van mantenir-se al PSUC van poder comptar amb el suport de l'aparell del partit i la imatge aconseguida pels primers

verda o d'equipaments i que ja havia provocat uns enfrontaments amb menor intensitat a l'any 1984. Existeix un interessant documental fet pels mateixos veïns titulat "Besos al Besòs" que narra aquest conflicte des de el seu punt de vista.

1821 Un exemple d'això es pot veure a un recull de premsa sobre el Vè Congrés que vaig trobar a l'Arxiu Històric del Museu de Badalona, en concret a la Caixa C19, Carpeta PSUC-Congressos. Veure també Carme Molinero i Pere Ysàs: Els anys del PSUC..., p. 335. 
alcaldes democràtics no només pel seu passat militant, sinó també pels seus primers anys de gestió municipal.

Tot i això, podem veure com entre Santa Coloma i Badalona també hi ha la diferència en que el PSUC a la primera població obté al 1983 la majoria absoluta, mentre que a la segona tot i augmentar els vots rebuts, no pot fer front a un ascens imparable del PSC-PSOE. Si la escissió va ser igual de dura i traumàtica a les dues localitats... per què aquesta diferència?. És difícil avançar una explicació convincent, i caldria fer-ne una millor recerca en aquest aspecte, apuntant al fet que a Santa Coloma de Gramenet el PSC-PSOE també va tenir durant aquells anys disputes internes com ja vaig esmentar en el seu moment i a Badalona aquest partit va mostrar una imatge més compacta.

Quin va ser el paper aleshores de partits que havien tingut una presència testimonial al moviment veïnal del Barcelonès Nord com el PSC-PSOE i CiU? El PSCPSOE va ser la força que a nivell electoral va anar adquirint l'hegemonia durant els anys vuitanta a nivell municipal, i va ser la gran beneficiada de la crisi interna del PSUC. Tot i que també va tenir algun entrebanc intern entre el sector "catalanista" provinent del PSC-C i el que provenia de la Federació Catalana del PSOE -com hem pogut veure- va aconseguir passar pàgina d'una manera més ràpida o menys traumàtica que el seu rival comunista. I, com sembla evident, es va beneficiar de l'aclaparadora victòria del PSOE a les eleccions a Corts del 28 d'octubre de 1982.

Ja vam veure que a la dècada dels 70 els partits que després van configurar el PSC-PSOE si que van manifestar un cert interès per les lluites veïnals. Malgrat això, aquest interès no va suposar que tinguessin un especial protagonisme, en especial per la seva falta de militància llevat d'alguns casos puntuals que van existir al Barcelonès Nord. El creixement del PSC-PSOE que es va donar a finals dels setanta estava més lligat -segurament- a les expectatives que oferia un partit d'èxit i també a l'ajuda econòmica de la socialdemocràcia internacional (sense que aquest darrer fet ho expliqui tot, ja que per exemple AP va tenir grans ajudes econòmiques i el seu èxit electoral va ser limitat fins l'ensulsiada de l'UCD). La majoria de nova militància no van ser activistes veïnals. El que si que es va donar des de inicis dels 80 es l'arribada de gent que havia militat en partits d'esquerra revolucionària, i entre ells, algun líder veïnal. Davant la crisi i desaparició de moltes de les 
organitzacions on aquests havien militat, no pocs d'aquests antics militants van optar per l'opció possibilista d'anar al PSC-PSOE que els oferia majors possibilitats de "tocar poder" i alhora continuar les velles rivalitats amb el PSUC. En aquest aspecte crec que són prou esclaridores les paraules que donava una d'aquestes persones a l'any 1983:

\begin{abstract}
“Desde que dejó de militar en Bandera Roja, de eso hace ya algunos años, no ha vuelto a tener Carnet de ningún Partido, aunque será por poco tiempo según se desprende de opiniones como : "el independiente se aísla. Es necesario tener algún núcleo donde puedas debatir ideas y concretarlas y eso sólo se da en un Partido Político". Lo suyo son los partidos de masas "con la democracia, crepúsculos [sic] como el MC no tienen mucho sentido, se trata de luchar por unas condiciones de vida mejores y ello sólo puede conseguirlo hoy por hoy un partido como el socialista".,1822
\end{abstract}

Quina era la postura del PSC-PSOE durant els anys vuitanta respecte el moviment veïnal? Per sorprenent que pugui semblar, a l'any 1980, després de la renúncia del PSOE al marxisme, el PSC-PSOE encara feia servir un discurs com aquest:

“El capitalisme exerceix la seva explotació fonamental en l'àmbit de l'empresa, però també projecta la dita explotació en els diversos aspectes de la vida social i, particularment, en l'organització i gestió de la ciutat i el territori.

La situació d'explotació dels treballadors en el marc urbà i territorial constitueix un dels principals elements de sensibilització i mobilització de les classes populars. Per als socialistes es tracta d'un front d'acció important que ha de situar-se en el context de la lluita de classes, per una societat socialista i autogestionària." ${ }^{1823}$

Un llenguatge que distava molt de la política que estaven aplicant en la realitat. Tot i així, pel que feia als moviments urbans i a la participació ciutadana i malgrat l'aparent discurs esquerranista anterior, els socialistes demostraren tenir una concepció que no acabava de concordar amb el radicalisme verbal que encara es feia servir per parlar de conceptes més genèrics. Una concepció, que ens pot

1822 Joaquima Utrera: “Miguel Ordóñez. El del Congreso", Eco Badalonés, 18-11-1983, p. 27.

1823PSC-PSOE: "El projecte nacional dels treballadors. II Congrés Socialista. Ponència de política municipal, comarcal y moviment urbà", Fundació Rafael Campalans, Fons Antoni Canals (FAC), Caixa 264, Carpeta P 1, E001.02, 1980, p. 69. Segurament alguna cosa hi va tenir a veure en el manteniment d'aquest discurs la voluntat de captar als antics militants de l'esquerra radical, com hem vist amb l'exemple de la nota anterior. 
recordar a la que havia exposat la feia un temps Jordi Borja en el PSUC:

"La conquesta de la democràcia, amb la legalització dels partits polítics i dels sindicats, i l'adveniment dels Ajuntaments democràtics, ha produit [sic] una profunda crisi en el si d'aquestes associacions amb el transvasament de militants als òrgans institucionals. Aquesta crisi, però, serà sens dubte, de creixement si les associacions del moviment ciutadà saben adequar llurs funcions al nou moment polític i a les exigències que la nova acció ciutadana demana. Una concepció del moviment ciutadà com a contrapoder municipal no faria més que perllongar la seva crisi, amb la conseqüent burocratització i aillament del poble. Resumint, treure el moviment ciutadà de la seva crisi actual significa combatre tant les posicions esquerranistes que veuen les Associacions de Veïns com a contrapoder municipal, així com aquelles posicions que estimen que la participació del ciutadà passa per depositar el seu vot quan s'el [sic] crida a les urnes i que l'únic moviment associatiu ha de ser cultural i recreatiu. No és tampoc acceptable la concepció instrumentalista que pretén usar les entitats com a "corretja de transmissió" de partits polítics, presents o no en el Consistori, frenant així llur acció ciutadana autònoma i justa quan aquesta tendeix a contestar o criticar les seves àrees de poder municipal." ${ }^{1824}$

Cal dir, que aquestes concepcions sobre el que havien de ser les Associacions de Veïns no van ser sempre respectades per ells mateixos. Per molt que posteriorment en el mateix document es fessin afirmacions de que calia fomentar una participació que no es limités a el vot cada quatre anys, i de que els socialistes havien de donar un decisiu impuls al que denominaven "Moviment Ciutadà", que havia de tenir una gran importància dintre de l'anomenat "Front dels Treballadors", en el fons no s'amagava la voluntat de reduir la representativitat i poder que podien tenir les AVV's als barris, tenint en compte que aleshores el PSC-PSOE tenia poca presència en elles:

“Dins, doncs, de l'òptica de potenciar el desenvolupament del nou Moviment Ciutadà que ja s'expressa en la realitat activa de la lluita ciutadana a Catalunya, es inqüestionable que s'han de definir les funcions a les Associacions de Veïns i llur funcionament: les Associacions de Veïns han de deixar d'ésser l'estructura associativa que vol aglutinar tota l'activitat associativa del barri, han de reconèixer la legitimitat de noves formes d'organització i establir-hi relacions d'igualtat sense errònies

1824PSC-PSOE: "El projecte nacional dels treballadors. II Congrés Socialista. Ponència de política municipal, comarcal y moviment urbà", "5.Moviments Urbans i Participació Ciutadana , Fundació Rafael Campalans, Fons Antoni Canals (FAC), Caixa 264, Carpeta P 1, E001.02, 1980, p. 90 . 
atribucions de prepotència."1825

El cert es que aquesta concepció es farà servir posteriorment per laminar el poder de les AVV's als Consells de Districte, per exemple. Es curiós veure como aleshores defensaven que en la futura remodelació de la Llei de Règim Local es triessin els seus representants també per sufragi universal ${ }^{1826}$. Cosa que després, va semblar caure en l'oblit.

Al Barcelonès Nord, durant la primera legislatura, els socialistes, que formaven part del govern de les tres ciutats del Barcelonès Nord, no van semblar tenir un gran interès en potenciar les AVV's. No obstant, algun testimoni -no neutre, certament- ens va avisar com en aquell moment ja s'estaven donant alguns primers intents de posar un peu en unes entitats on fins ara havien tingut presències puntuals, de cara a fer precisament una de les coses que denunciava el document anterior:

\footnotetext{
"Yo fui concejal de participación ciudadana y como concejal de participación ciudadana cada mes yo hacía una asamblea, el alcalde, el concejal de hacienda y yo mismo en los barrios para informar (...) y cada mes se hacía una asamblea en un barrio distinto, algunas asambleas fueron muy duras porque el Partido Socialista la verdad es que aprovechó (...) nosotros llevábamos el peso de dar la cara y ellos procuraban..." ${ }^{1827}$
}

Però serà des del poder local que progressivament el PSC-PSOE mirarà d'intervenir en el teixit associatiu per contrarestar el pes que tenien allà altres forces polítiques que els hi podien fer oposició i nosa. Aquest fenomen es donarà sobretot primer a Badalona amb l'arribada a l'Alcaldia de Joan Blanch al 1983. A Santa Coloma de Gramenet va ser un fet més tardà mentre que a Sant Adrià de Besòs vam veure com també va haver-hi una pugna entre socialistes i comunistes pel control de l'AVV de La Mina. Posteriorment van continuar aquests intents de fer servir el moviment veïnal des de l'Ajuntament socialista encapçalat per Antoni

1825PSC-PSOE: “El projecte nacional dels treballadors. II Congrés Socialista. Ponència de política municipal, comarcal y moviment urbà", "5.Moviments Urbans i Participació Ciutadana, Fundació Rafael Campalans, Fons Antoni Canals (FAC), Caixa 264, Carpeta P 1, E001.02, 1980, p. 94.

1826 Ídem, p. 96.

1827Entrevista a Manuel Armentero Molina, 10-4-2010. Recordem que era militant del PSUC i havia estat president de l'AVV de Juan Valera. 
Messeguer.

Un altre actor poc estudiat en relació al moviment veïnal és CiU. Certament, abans de la constitució dels Ajuntaments democràtics la coalició, junta o per separat, no havia destacat gaire per la seva participació en el moviment popular ciutadà, si bé hi havia casos puntuals com ja vam veure en l'AVV de Sant Adrià Nord. En aquesta associació, que es corresponia amb la zona de l'antic poble, es va donar una important presència de convergents com Jaume Vallés, Agustí Gallart (que abans havia estat del PSC) i la dona d'aquest, Consol Violant. Ella mateixa ens explicava això com un fet normal i les confrontacions que tenien amb la gent del PSUC:

“(...) Què passava. Que com que la gent de Convergència, com nosaltres, tota la vida treballant i sent... (...) els van posar una etiqueta. No es que haguéssim fet... és que si et fiquen una etiqueta és molt difícil treure't allò. I una mica a la gent de Convergència que volia treballar als barris (...) 'Oh! que estos son de Convergencia' (...). Jo tenia claríssim que s'havia d'anar als barris. (...) La gent de Convergència una mica es va quedar encongida, per que tenien moltes provocacions. (...). Sobretot la gent del PSUC, que en això era molt maniàtica i molt dogmàtica. Jo sempre els vaig dir i em discutia amb el Castro. Sou com l'Església (...) els hi deia (...) tenia molta il·lusió de que entrés al seu partit."1828

Però als anys vuitanta la poca implicació de CiU al moviment veïnal es va ressentir de la crisi del moviment i també per que un cop assolida la Generalitat, CiU va desenvolupar una altra manera de ser present a uns barris que eren considerats feus del PSC-PSOE i del PSUC, sobretot en matèria electoral. Des de la Generalitat es va impulsar una forta campanya amb visites de Jordi Pujol, de captació de líders locals i de fundació de seus a barris com La Mina o Llefià ${ }^{1829}$. També es va tenir un especial contacte amb les associacions de comerciants que hi havia al Barcelonès Nord com l'Associació de Comerciants del Baix Besòs i d'altres, on es va fer una forta campanya per col-locar a persones de la seva corda i fer fora persones d'ultradreta com a Francisco Villora. L'últim engranatge que es va fer

1828Testimoni de Consol Violant, membre de l'AVV Sant Adrià Nord i de CiU (durant l'entrevista a Agustí Gallart,), 17-1-2013.

1829 Ja vam veure el cas de la inauguració de la seu de CDC a La Mina a El Periódico de Catalunya, 10-1-1985 (i la polèmica que va generar pel seu titular, veure nota 1786). A Llefià tenim constància d'una visita de Jordi Pujol per inaugurar una seu de CDC a Revista de Badalona, 2611-1985. 
servir per augmentar la seva capacitat d'influència va ser quan l'empresa pública ADIGSA es va fe càrrec, a partir de l'any 1985 sobretot, dels antics barris dependents de l'OSH com els badalonins de Sant Roc i Pomar. Però fins i tot es podien fer servir mètodes encara mes sibil-lins:

“Este local [es refereix al de l'AVV Besòs] no estaba así ni mucho menos. Hay unos sótanos ilegales (...) Bueno pues al Ayuntamiento, a la Generalitat... habíamos ido a todos los sitios para que nos los arreglaran. (...)

Vino un día uno de la Generalitat. No, de una empresa de la Generalitat (...) no nada, ustedes no se preocupen...(...) No teníamos ni zorra idea de lo que iban a hacer, pero bueno, si esto lo arreglan... Ni tuvimos que hacer escritos, ni tuvimos que hacer nada, nada de nada... [es refereix, em sembla, al local de l'Associació] Habían unas próximas elecciones (...)A los dos años así de tenerlo hecho nos viene una factura que teníamos que firmar, ya estaba la cosa más apaciguada, estábamos en el Ayuntamiento. Hicimos una candidatura indepenciente [es refereix a "La Palmera"] y bueno (...) fuimos tan torpes (...) pues cogen y (...) vamos a que nos orienten porque este coste de obra... ¡13 millones!"1830

En definitiva, durant els anys vuitanta va haver-hi una pugna dels diferents partits polítics per estendre la seva influència pels diferents barris del Barcelonès Nord de cara a millorar els seus rèdits electorals o objectius polítics. I això incloïa, fins i tot en un context de crisi del moviment veïnal, la voluntat d'incidir en aquest. No ho podia resumir millor Faustino Miguélez Lobo amb les següents paraules:

“Mi impresión es que si en los años 70 había un movimiento vecinal fortísimo, no solamente en Barcelona sino también en Badalona y Santa Coloma. En el Besós había una asociación de vecinos fortísima, reivindicativa, potente, etc. Todo el ámbito metropolitano tenía una red de asociaciones vecinales muy fuerte y que en parte, creo que, explica el triunfo de la izquierda en las primeras elecciones municipales etc, en este momeno yo diría que han tenido lugar dos tipos de fenómenos, por un lado los partidos de izquierdas han ido abandonando las asociaciones o bien burocratizándolas en el sentido de convertirlas en mediadoras burocráticas del Ayuntamiento, es decir algunas son gestoras de los ayuntamientos en el barrio, esto ha disminuido la afiliación a las asociaciones y por otro lado se ha dado la vuelta, en este caso la ida, a las asociaciones de un tipo de fuerzas políticas y gente que no había, que es de Convergencia, no en todas pero en bastantes: se han dado cuenta de que realmente

1830Entrevista a Rafael Caballero Úbeda, 29-1-2013. Militant del PSUC, del PCC i President de l'AVV Besòs. 
esto es un potencial importante y encuentras muchas asociaciones que parte de la dirección es de Convergencia y donde el tipo de cosas que se hacen, cada vez son más cercanas a la forma de actuar del partido que gobierna." ${ }^{1831}$

\subsection{Associacions autònomes $i$ actives o dependents $i$ sumisses. La pugna política pel control de les associacions.}

Com hem pogut veure, les diferents forces polítiques solien parlar gairebé sempre de la independència que havien de continuar gaudint les AVV's un cop constituïts els Ajuntaments democràtics després de les eleccions de 1979. Però el cert és que en major o menor mesura les diferents organitzacions van intentar tenir influència dins el moviment veïnal, per diferents motius i també cal dir-ho, amb diferents gradacions.

A Santa Coloma de Gramenet les AVV's tenien -en el moment de constituir-se els primers Ajuntaments democràtics- un notable presència de membres de partits de l'esquerra radical així com de persones independents a les seves juntes. Aquest fet va fer que, d'entrada a algunes d'aquestes entitats no els afectés tant la marxa de líders veïnals cap a l'Ajuntament, com si que va passar amb més intensitat a Badalona o Sant Adrià. Ja hem vist les primeres topades que van haver-hi entre elles i l'Ajuntament colomenc en temes com el "Pla d'Urgències" o la participació ciutadana. Entremig aquestes disputes hi havia qüestions més de fons. Una mostra del debat anterior sobre el major o menor control de les AVV's ho podem veure en aquest article d'Eugenio Madueño publicat en Grama arran -segons ell- la poca implicació de les AVV's en les festes populars de setembre de 1979:

"Sin embargo, y en el trasfondo de esta discusión que a simple vista pudiera parecer pueril hay un contenido político que es el que raramente aparece suficientemente explicado. Se trata de la no disposición de las asociaciones en las que actualmente solo trabajan miembros de los llamados partidos políticos sin representación parlamentaria, en colaborar con un Ayuntamiento en el que predominan los socialista [sic] y los comunista [sic]. Los extraparlamentarios saben que si contribuyen en hacer de la Festa un éxito, el tanto político se lo va a apuntar el Ayuntamiento. Por su parte,

1831 Marco Marchinoni (et al.): Análisis de un conflicto urbano: el caso de Sant Adrià de Besòs: el corporativismo territorial, Institut d'Estudis Metropolitans de Barcelona, 1991, p. 71. 
los partidos en el poder municipal solo pueden llegar al pueblo a través de las entidades que lo representan (las asociaciones) que si bien esa representación seria muy discutible, también es verdad que es la única que hoy por hoy existe. Conclusión: o el Ayuntamiento se crea otros canales para llegar al pueblo -lo que es imposible-, o anima a sus militantes a meterse de lleno en las asociaciones de vecino [sic] para hacer que estas crezcan por la base y sean una representación real de los barrios; u opta por pactar el programa político que propugnan los partidos con incidencia en las asociaciones de vecinos que supondría, básicamente, el acceso al control municipal directo y la atribución de unas potestades que no pudieron conseguir en la lucha electoral." ${ }^{1832}$

Aquest testimoni ens confirma -si més no parcialment a Santa Coloma- que l'abandó de les AVV's pels militants del PSUC en optar per la via institucional va ser un fet malgrat les crides d'alguns dels seus dirigents més importants com Jordi Borja a no fer-ho. Un article de rèplica de la Coordinadora d'AVV's de Santa Coloma ho tornava a recordar:

"Tampoco nos parece justo que el redactor de GRAMA emita valoraciones personales sobre la composición de las AA.VV. y sus objetivos ante el Ayuntamiento sin estar informado o consultar a sus miembros sobre todo ello y sabiendo como sabe, que las AA. de VV. han sido, son y serán entidades abiertas a todos los hombres y mujeres, sea cual sea su parecer o ideología, mientras estén al servicio del pueblo, también que todos los partidos de izquierda que hoy están representados en el consistorio han abogado hasta ahora por la defensa y la potenciación de las AA.VV. Y que si actualmente sus militantes es tan más o menos presentes en las AA.VV. es por causas ajenas a nuestra voluntad. En lo que si que estamos de acuerdo con Eugenio Madueño es, que hoy por hoy la presencia de estos militantes en las AA.VV. es escasa, y nos alegraríamos de que siguieran su consejo y acudieran masivamente a trabajar en las AA.VV. de sus barrios, porque es cierto que gente con ganas de trabajar nunca sobra." ${ }^{1833}$

De fet, fins i tot gent que va militar al PSUC i que posteriorment va tenir responsabilitats a l'Ajuntament reconeixia aquest fet:

"I en el tema de l'inici dels l'Ajuntaments democràtics, clar, va haver-hi un gran

1832Eugenio Madueño: “Las asociaciones se hicieron el longuis”, Grama núm. 143 (8/15-9-1979), p. 11.

1833 Coordinadora de Asociaciones de Vecinos de Santa Coloma de Gramenet: "La Coordinadora de AA.VV. y la Festa Major", Grama núm 145 (22/29-9-1979), p. 11. 
buidatge de les Associacions de Veïns de la gent del PSUC a l'Ajuntament. El Tomás Lorenzo que era de l'Associació de Veïns, el Eloy Jurado, el Luís també estava a l'Associació de Veïns... els que estaven al Fondo... Sí, els líders més importants del moviment veïnal del PSUC van guanyar les eleccions i van entrar a l'Ajuntament. El Titos que també estava a l'Associació de Veïns del Rio... el Matías que també estava a l'Associació de Veïns de Les Oliveres... Mentre que a les Associacions de Veïns es van quedar més la militància més del MC, eh? Amb la Gabriela que no havia tret cap escó, i el Pitarque que no havia sortit, el Salva (...) la Emiliana també al Fondo..." ${ }^{1834}$

En segon lloc s'havia suggerit en l'esmentat article d'Eugenio Madueño, ni que fos de manera velada, el retorn d'aquests militants a les Associacions per controlar-les en veure que estaven en mans dels militants de l'esquerra radical. Però això era certament així? No podem negar la important presència, sobretot a les Juntes, de persones militants d'aquests partits, aleshores sobretot del MCC ja que el PTC va entrar en crisi. Però també és cert que va existir, a la ciutat colomenca, un nucli important de persones que no tenien un carnet de partit polític (per que no l'havien tingut mai o per que n'havien renunciat o fins i tot les havien expulsat d'alguna organització) però si que podíem qualificar com activistes i que es va mantenir a les Associacions. En molts casos aquestes persones provenien del món cristià de base o havien estat a la JOC. Un dels nostres entrevistats respondria a aquesta descripció, en Salvador Bolancer. Ell mateix ens confirmava l'abandó de militants del PSUC de les associacions, però també reconeixia que hi havia excepcions:

"Y resulta que empieza toda la... todo este momento y entonces claro, la gente del PSUC, la gente del PSOE ya lo sabíamos... pero la gente del PSUC está más por la cuestión de la institución y (...) entonces intentan por todos los medios de hacer que se frene cualquier movimiento. A cualquier movimiento ya no están por la labor. Entonces retiran todos sus militantes de las Asociaciones de Vecinos (...) prácticamente.

[demano si va haver una consigna específica en aquest sentit]

No, a lo mejor no hubo ni consigna pero fue diríamos como una inercia. Y entonces tan solo quedan los que, la gente esa que te digo que era capaz de vislumbrar que era una cosa de la otra... que era la Asociación de Vecinos y que era el partido. Entonces esa gente continua conjuntamente con el resto. Incluso hay hasta la... cuestión de que una

1834Entrevista a Fernando Saro (amb Jaume P. Sayrach), 22-5-2013. 
vez nos encerramos en el Ayuntamiento y había gente del PSUC encerrada en el Ayuntamiento... y el alcalde era del PSUC. (...) Aquella gente que estaba en la Asociación de Vecinos que había decidido eso era capaz de romper, diríamos, la disciplina aquella del partido...

Pero el partido...[decían?] esto des de el Ayuntamiento... las Asociaciones de Vecinos ya no tienen papel... “1835

Aquí estava el quid de la qüestió. El paper que havien de jugar les AVV's en el nou context democràtic. Ja he comentat anteriorment com des dels partits que van obtenir representació als municipis, PSUC i PSOE, no es volia un contrapoder als barris. No hem d'oblidar, que malgrat l'inici del seu declivi les AVV encara eren les entitats que tenien el major nombre de socis (i que aquests no tenien majoritàriament carnet de partit) i conservaven un gran prestigi per haver lluitat contra la dictadura i haver aconseguit moltes millores pels barris i ciutats. En el fons es volia unes associacions que no tinguessin les mateixes funcions que havien desenvolupant lluitant contra els Ajuntaments franquistes. No volien que fos el pol de referència de la població sinó que es diluïssin amb totes unes altres entitats que -sense negar la seva legitimitat- no havien tingut la mateixa importància i representativitat. I en això es va insistir des de l'Ajuntament:

"Per que el debat amb el moviment... aquesta va ser la primera trencada... vull dir... aquí quan hi han los Eloys, los Fernandos Saros i los Luises Hernandez i tota aquesta gent comença a dir que les Associacions han de ser d'un altre tipus (...) culturals i no se què no se quantos... és quan hi ha en el sector dels partits extraparlamenaris (...) i tota aquesta gent... l'Emiliana, el Tosco... (...) aquesta gent sempre ha sigut independent, hi ha un malestar. Per que es volen tancar a dintre de les Associacions de Veïns. I no hem votat per això. Hem votat per tenir una altra manera de governar-nos... Hem lluitat per una altra manera de fer les coses... Que això s'aguditzarà més amb els exemples de Marinaleda. (...).

Aleshores, aquí si que hi ha una primera ruptura... Després va venir el desencant del PSOE... Però el desencant en el PSUC, per part de les vanguàrdies i "la base i peinase"... les masses estaven contentíssimes amb el Luís Hernàndez que plantava arbres i feia coses molt bones, eh? Però la gent organitzada deia 'òstia, no era (...) no era exactament això'..."1836

1835Entrevista a Salvador Bolancer Dugo, 8-5-2013. 1836Entrevista a Gabriela Serra Freidiani, 10-7-2013. 
Les tensions, retrets mutus i malentesos van ser freqüents a la ciutat colomenca durant aquests primers anys d'Ajuntament democràtic. Des de les persones que s'havien incorporat a l'Ajuntament s'acusarà a les que encara romanien al moviment veïnal d'utilitzar aquest per aconseguir el que no havien pogut fer a les eleccions i de ser excessivament durs i bel-ligerants:

\begin{abstract}
"Llavorens, aquestes Associacions de Veïns van ser molt dures amb el primer Ajuntament. O sea... es van quedar a les Associacions de Veïns van ser molt durs per que volien l'aplicació immediata del Pla Popular.. O sigui... nosaltres arribem amb un Pla Popular que havíem lluitat tots i tenien els objectius on volíem anar... Però ens trobem amb un Ajuntament buit... sense res! Per tant, l'aplicació, la concreció de les alternatives del Pla Popular era molt difícil. Luego l'Associació de Veïns redacta un Pla d'Urgències que volia dir 'això es té que fer ja!' (...) I llavors anaven al Jaume que era el Primer Tinent d'Urbanisme i... 'jo tinc quatre duros per plantar quatre arbres i fer una placeta..."'1837
\end{abstract}

Fins i tot persones nominalment independents como Jaume P. Sayrach que van anar a la llista del PSUC i que van tenir responsabilitats importants (en l'àrea d'urbanisme, pel que fa al cas esmentat), fan encara en l'actualitat retrets en aquest sentit:

“El segon es que els que no van poder entrar, que volien entrar, van tornar-se ferotges però contra nosaltres. I van manipular la poca gent que quedava a les Associacions de Veïns per que [inintel-ligible] d'Associació de Veïns van dir 'ara ja tenim el nostre Ajuntament, ja anirem a demanar-s'ho'. I per això les Associacions des de aleshores van anar morint, no feien sentit (...). Però en canvi, els que eren més tipus MC, van ser molt ferotges contra nosaltres, però molt. I llavors agafen els 30 punts o 40 del Pla d'Urgències i demanen coses que són pràcticament el Pla Popular que hem estat (...)."1838

Certament, les limitacions de l'Ajuntament eren moltes, sobretot pel seu pressupost esquifit. Això era reconegut també per les persones que s'havien mantingut en el moviment associatiu. Però el fons de la qüestió no era la capacitat de l'Ajuntament per fer o desfer, sinó la participació que podien tenir les AVV's en els processos de decisió de quines eren les prioritats a escometre en una ciutat

1837Entrevista a Fernando Saro (amb Jaume P. Sayrach), 22-5-2013. 1838Entrevista a Jaume P. Sayrach (amb Fernando Saro), 22-5-2013. 
amb tants dèficits com Santa Coloma:

"I és cert que si ells haguessin sigut capaços d'articular mecanismes de consulta des de el primer moment... m'explico? És possible que aquests 40 punts no fossin possibles (...) Sentem-nos i prioritzem... (...) Ells deien, que jo me'n recordo 'es que no hi han diners' bueno, 'on s'ha d'anar a demanar els diners?, va on hem d'anar, on hem de mobilitzar, dieu-nos...' . Què hem de fer? Una mani en contra de... 'No, per que llavorens....' Això s'ajuntava amb 'Hem de demostrar que sabem gestionar i hem de ser serios'... “1839

Sayrach responia a aquestes acusacions afirmant que ell va ser també blanc de molts atacs personals, i que fins i tot li havien arribat a pintar a la Plaça de la Vila "Sayrach, asesino de árboles", o fins i tot al seu propi domicili:

"I a casa on vivia jo doncs que m'assassinaran, posava... 'Jaime asesino'... A llavorens vaig tenir una reunió amb els veïns, i una veïna em va dir que la reunió que havien convocat era per que marxis del pis, i jo arribo allà i dic 'estoy muy contento de que hagáis esta reunión para darme soporte' i allà tots callats mirant sense atrevir-se ningú a fer-me fora. Doncs això... es diu que vam estar en contra de la participació, quan eren fets naturals que van dissoldre's les associacions que vam marxar no per dominar-les si no per treballar des de dalt i si que ens vam descuidar, per que primer, entusiasmats amb la feina, després per que vam tancar-nos molt a l'Ajuntament, i després per que ens feien molt atac els altres... Tot i aixís jo recordo que vaig muntar unes... un Seminari que ens reuníem cada mes sobre Urbanisme. Hi venien 60 veïns... hi venia a fer classes el Xavier Valls i els seus amics arquitectes. Però això no va ser comú a l'Ajuntament. A l'Ajuntament devem tenir prou feina en defensar-nos dels MC's i fer lo que se'ns encarregava. I a demés no érem savis. Gent que vam pujar a l'Ajuntament no havíem tingut mai cap càrrec d'aquesta categoria... cap!"1840

Aquest testimoni qualificava de "natural" la dissolució de les associacions en tant que entenia que la tasca que feien les AVV's ara la faria el nou Ajuntament democràtic d'esquerres. I de fet, no es pot descartar que hi hagués un nombre considerable de gent que compartís aquesta argumentació. De fet, tal com vaig dir, els primers Ajuntaments democràtics van suposar una major transparència en la gestió de les ciutats respecte els seus antecessors i una millora en la qualitat de vida de les classes populars que els habitaven. I la percepció d'aquest fet és un 
factor que no s'ha de menystenir en el fet que minvés la participació popular a les AVV's de la població menys "polititzada" com ens han assenyalat ja diversos testimonis. De fet, el PSUC al 1983 va tenir majoria absoluta a Santa Coloma de Gramenet.

Però encara que sigui entre línies, Sayrach també està reconeixent que es van tancar massa a l'Ajuntament, retret que també se'ls hi va fer des de les Associacions que van continuar sent actives. I a això caldria afegir una altra, diguem-li "obsessió" per donar una imatge de responsabilitat. No oblidem que durant el franquisme $\mathrm{i}$ també durant el procés de canvi polític va existir una agressiva política anticomunista i que encara s'estava en un context de guerra freda. I d'aquí s'entrevé una certa predisposició a no ser massa agoserats, a donar una imatge de "responsabilitat" per por a espantar a possibles votants d'una societat que semblava -arran els resultats de les eleccions al Congrés favorables a l'UCD i el PSOE- força moderada ${ }^{1841}$. De nou una de les nostres entrevistades posava l'accent en aquest fet:

"Exacte... Per un cantó la inseguretat per que hi ha un coneixement de lo que tens vora... I segona, hi ha aquesta cosa de que hem de demostrar que 'som gent d'ordre, que sabem gestionar (...), ja han passat aquelles èpoques...'. Això és una cosa que els afecta a nivell estatal i a tots els nivells... La domesticació del PSUC i del PCE és molt impressionant, m'explico? La sibilització amb 's'... '¡ya no se puede estar todo el día moviéndose en la calle!' Aquest és un problema.... però si ells s'ho haguessin assentat... (...). Molt bé, prioritzem... Nosaltres sabíem que tot el Pla Popular per exemple era impossible... vale? Doncs fem prioritats (...) Què és prioritari? Aquest parc entre medianeras que es una caca i que tampoc ens treurà de pobres, $\mathrm{o}$ allò.... va allò... Això ajuda a participar i a programar, ajuda a prioritzar, m'explico? I posem-nos d'acord.... Però no, ells havien de poguer fer la consecució de diners amb gestió política, no amb mobilització al carrer. Que la mobilització al carrer era... I això va se lo que va creuar aquest malentès tremendo, no malentès, aquesta contradicció tremenda... De dir 'aquest instrument ja no serveix per que nosaltres ara des de la gestió'..."'1842

El que va ser Alcalde de Badalona ens justificava aquestes postures com a

1841 No obstant, m'agradaria introduir algun matís a aquesta afirmació ja que els programes electorals del PSOE de l'any 1977 i 1979 , sobretot el primer, ens podrien semblar avui en dia "d'esquerra radical", ja que parlaven de la nacionalització de la banca i dels mitjans de producció, de caminar cap a una societat sense classes, del "socialisme autogestionari"...

1842Entrevista a Gabriela Serra Freidiani, 10-7-2013. 
producte de la correlació de forces del moment. Però entre línies es pot percebre també aquesta voluntat de donar una imatge de "responsabilitat":

"Lo que passa és que ens passa una cosa que ens passa a tots. Quan estàs a baix en el tal ho vols tot, quan estàs a dalt lo que no pots fer és incumplir coses que no es pot fer per que ho marca les lleis. Coses que ignores (...) a més estàvem en democràcia teòricament, per lo tant, hem d'anar a complir per que si no ens fotran a la presó. Si fem coses irregulars, de enfrente ens denunciaran i ens guanyaran, per que això teníem els nostres assessors." ${ }^{1843}$

De tota manera, com ens recordava Emiliana Salinas, la percepció de que les Associacions anaven "contra" l'Ajuntament sembla que estava molt integrada dins de persones que en el passat havien participat activament en el moviment veïnal contra la dictadura:

"Porque nos decían los propios militantes del PSUC que no podíamos estar en contra del Ayuntamiento. Y nosotros le decíamos 'en contra no, pero frente si'. No se entendía la crítica, no se entendía... ${ }^{\text {“844 }}$

De manera que els recels, la desconfiança i els retrets es van mantenir entre els nous Ajuntament i les AVV's que continuaven actives. Tres anys després es podien observar en gran part les mateixes diferències a Santa Coloma. Un interessant article publicat a Grama amb el significatiu títol "Las amargas relaciones entre los barrios y el Ayuntamiento" ho tornava a posar de manifest. La qüestió anava al voltant de que diverses associacions com la del Fondo i la del Raval, que s'havien mantingut independents i amb un alt nivell de combativitat ja fos per la presència a les juntes de persones militants de partits com el MCC o d'altres sense carnet de partit però amb una llarga experiència en la lluita als barris, havien protagonitzat diverses mobilitzacions i talls de trànsit per reivindicar millores pendents pels respectius barris (en especial la instal·lació de semàfors i equipaments públics). És interessant veure com des de l'Ajuntament diferents regidors, no només del PSUC, reconeixien fets ja esmentats anteriorment. Així Pilar Puig, regidora pel PSC-PSOE feia unes reflexions interessants:

“Con respecto a las escasa penetración municipal en las bases de la población admite

1843Entrevista a Màrius Díaz Bielsa, 28-6-2013. 1844 Entrevista a Emiliana Salinas, 28-5-2013. 
que "Esto es un handicap muy importante con el que jugamos aquí los partidos mayoritarios. Quizás en las Asociaciones, que son movimientos de base, no tengamos gente afín a nosotros que pueda hacer de amortiguador de críticas y déficits nuestros." $^{1845}$

Cal que retinguem aquesta darrera afirmació que serà clau per poder explicar esdeveniments posteriors que el seu partit -el PSC-PSOE- va emprendre respecte el moviment veïnal al Barcelonès Nord. El cas es que fins i tot la mateixa persona, reconeixia que:

"El papel de las AA.VV. es muy importante y creo que tal vez tengamos la responsabilidad de haber ahogado este movimiento. Esto es una cosa que me preocupa mucho." ${ }^{1846}$

El mateix cap de files del PSC-PSOE colomenc d'aleshores reconeixia en el mateix article els problemes burocràtics que impedien donar respostes ràpides als problemes plantejats pel veïnat, tot i que alhora també acusava a determinades forces polítiques de fer-les servir instrumentalment contra l'Ajuntament. No obstant, trobo significatiu que ell mateix acabés reconeixent que el mateix consistori no s'havia dotat d'uns mecanismes eficients de participació ciutadana:

"Se han creado unos consells municipals que funcionan de manera muy diversa, algunos de ellos dependen en buena parte del concejal responsable. No hay una postura conjunta. Tampoco se han impulsado los consells de distrito, que era la postura de los socialistas: tener tanto consells municipales como territoriales (...) las AA.VV. S son las únicas que existen como representantes del movimiento ciudadano, aparte de otras entidades. Ahora bien, ¿la representatividad del barrio está únicamente en manos de las AA.VV.? En algunos casos lo pondría en duda. También el tema de los casales de barrio es parte del desconcierto de los partidos políticos mayoritarios hacia toda esta cuestión. Pero los socialistas mantenemos que hay más alternativas que los casales y las AA.VV."1847

Em sembla evident la intenció de limitar el poder a les AVV's per que de cap

1845“Reportaje-encuesta Grama tras el ciclo de cortes callejeros. Las amargas relaciones entre los barrios y el Ayuntamiento", Grama núm. 281 II Època (26 juny- 2 juliol 1982), p. 12. [Testimoni 1846Ídem. de la regidora del PSC-PSOE Pilar Puig]. La cursiva es meva.

1847"Reportaje-encuesta Grama tras el ciclo de cortes callejeros. Las amargas relaciones entre los barrios y el Ayuntamiento", Grama núm. 281 II Època (26 juny- 2 juliol 1982), p. 12. [Testimoni del regidor del PSC-PSOE Joan Carles Mas]. 
manera es convertissin en el referent representatiu i de participació dels barris. La voluntat d'equiparar-les amb altres entitats -molt respectables- però que en molts casos no tenien la vocació de representativitat d'una comunitat amplia i diversa com un barri ni de fer un aprofundiment democràtic, era més una maniobra per fer servir quan no es podia assegurar amb la presència pròpia a les AVV's el que havia insinuat la regidora Puig del mateix partit. D'aquesta manera per exemple als Consells de Districte la representació de les Associacions quedava minimitzada. El perquè ara aquest propòsit va tenir un major èxit en contrast amb el fracàs del franquisme caldria analitzar-lo en funció de la valoració en general positiva que van tenir sectors amplis de població -més enllà dels activistes- de la gestió dels primers ajuntaments democràtics.

En tot cas, trobo significatiu que també s'esmenti als anomenats Casals de Barri (avui en diríem Centres Cívics) barrejats amb aquesta qüestió. Algunes AVV's havien desenvolupat també una intensa activitat cultural. I en alguns casos -com comentaré més endavant posant un exemple concret que he conegut de primera mà- havien aconseguir teixir unes complicitats amb altres entitats i formes d'associació que actuaven aixoplugades per la mateixa Associació. D'aquesta manera, es podia dir que hi havia entitats veïnals que eren en si mateixes uns veritables "Casals de Barri”. Quan aquests es van impulsar des de l'Ajuntament, una visió limitada o reticent respecte les AVV's que els hi eren tant crítiques els va portar a fer-ho d'una manera dirigista, fent servir "tècnics" sense pensar en fer servir l'àmplia experiència acumulada per algunes entitats.:

“Clar, estava el PSUC en la primera legistatura. I jo crec que això de... van ver com totes les Associacions de Veïns que portaven fins aquell moment se'n van de les mans. Per que van crear lo de los barrios, las Educadoras de Barrio, estos culturales... los Centros. Van començar a obrir Centros a los barris, frente a les Asociaciones de Veïns.

Es clar, tenien molt més poder econòmic per obrir els Casales de Barrio que li deien, ¿no?. I se van donar el caso que hi havia un Casal de Barri i una Associació de Veïns. I poco a poco (...). Restar peso a las Associacions de Veïns. I es clar, amb tots els mitjans que tenien al su alcance es clar. Totes les Vocalies de les Associacions de Veïns ja se feien des de los Casales de Barrio. Que sentido tenien les Associacions de Veïns?"1848

1848Entrevista a Emiliana Salinas (amb Josep Pitarque Narejos i Salvador Bolacer Dugo), 12-32013. 
Això no vol dir que des de les AVV's no es reivindiquessin determinats espais per que fossin centres culturals pels barris. El problema era més de gestió, ja que algunes entitats aspiraven a tenir un paper més actiu en l'organització d'aquests espais. Però el model proposat des de l'Ajuntament era un altre. Això podia generar situacions curioses, si més no, com ens comentava el que era aleshores president d'una de les AVV's més actives de la Santa Coloma dels vuitanta, en Josep Pitarque:

\begin{abstract}
"Van aparèixer les Animadores Socioculturals. En un moment determinat, jo per exemple vaig a l'Associació de Veïns del Raval i un dia estem allà la Junta de l'Associació que teníem la pròpia dinàmica i tal i una persona que s'assenta allà a la taula. La coneixeu? No. Qui és? 'Hola!, presenteu-vos tots qui sou! Soc una animadora sociocultural de l'Ajuntament. Ah, i a què vens? No jo vinc a animar i a dinamitzar. Bueno, però aquí ja estem animats i dinamitzats! [riuen] No però vindré aquí per si tal i qual...' .Què passa amb això? Amb el pas dels anys van anar agafant responsabilitat d'activitats que abans ho fèiem els propis veïns. Què passava? la dinàmica pròpia de l'entitat baixava i anaven cobrint espais. Fins arribar a jugar el paper del President de l'Associació de Veïns. Vull dir, recolzada per la entitat que era l'Ajuntament, es creava una mica... ha hagut entitats de... Associacions de Veïns que lògicament necessitàvem algú que les dinamitzés però no d'aquesta manera. A llavorens què passava a més a més? Que estaves dins un Centre Social, va acabar sent ella l'Animadora sociocultural, la responsable del Centre Social i tenir que demanar permís per anar-te a reunir amb aquesta persona...
\end{abstract}

Què era premeditat? Aquestes persones, les animadores socioculturals, no... Crec que elles en un principi no per que inclús les van intentar fer fora de l'Ajuntament i vam fer una concentració, no se si us en recordeu, a la Plaça de la Vila per que no les acomiadés l'Ajuntament. En un moment determinat, les vam recolzar nosaltres, des del moviment veïnal. Vull dir, teníem moltes amistats amb aquesta penya, però bueno..."1849

Com reconeix el propi entrevistat, potser no tot estava tant planificat per carregar-se les Associacions. Però sembla evident que estem davant d'unes concepcions molt diferents del paper que podien tenir aquestes entitats en el nou context democràtic. I crec que no està de mes afirmar que en el fons hi havia la diferent concepció que es té del que ha de ser la democràcia: si aquesta s'ha de limitar a qüestions formals i a exercir el vot cada quatre anys o si es tenia una concepció més profunda i participativa del terme, oferint altres canals que 1849Entrevista a Josep Pitarque Narejos (amb Emiliana Salinas i Salvador Bolancer Dugo), 12-32013). 
permetessin una implicació més popular de sectors amplis de població en la gestió i presa de decisió de determinats aspectes -pel que fa a les AVV's en concret- de la gestió municipal. Aquest "debat” es barrejava amb les necessitats reals d'una gestió quotidiana on ningú tenia experiència, fet que es sumava a les limitacions que la pròpia legislació establia per l'administració local. De la mateixa manera es pot afirmar que per determinades entitats veïnals, les que tenien una dinàmica molt activa i reivindicativa, la gestió que va fer el primer Ajuntament democràtic colomenc els hi va suposar una -si més no parcial- decepció:

“Con Blas Muñoz lo tenías claro, allí entrabas al Ayuntamiento a cargártelo, a saco. En cambio habíamos luchado por el nuevo ayuntamiento y había unas expectativas que se fueron deteriorando." ${ }^{1850}$

D'aquesta manera, les AVV's colomenques van reeditar l'any 1982 el Pla d'Urgències que ja s'havia fet al 1979. No només per recordar les actuacions urbanístiques pendents, sinó per tornar a reivindicar aquelles decisions polítiques que feien referència a dotar al moviment veïnal d'una major capacitat de participació en la política municipal i de gestió de diversos serveis i equipaments, a les que s'afegien algunes de més recents com aquesta:

"Revocación de los acuerdos municipales al reglamento de los Casales de Barrio, y elaboración del derecho a gestión por las entidades ciudadanas." ${ }^{1851}$

Malgrat això, les diferències sobre com s'entenia la participació ciutadana van continuar i van ser extensibles a les diferents associacions del Barcelonès Nord que volien mantenir una major pes i capacitat d'incidència. Un darrer exemple pel que fa a la ciutat de Santa Coloma de Gramenet ens ho posa de manifest:

“Tras conceder la palabra a la A.VV. Arrabal, el Ayuntamiento dió [sic] sus razones para

1850“Reportaje-encuesta Grama tras el ciclo de cortes callejeros. Las amargas relaciones entre los barrios y el Ayuntamiento”, Grama núm. 281 II Època (26 juny- 2 juliol 1982), p. 13. [Testimoni de membres de l'AVV del Raval].

1851 Veure p. 553 i nota 1632 per les reivindicacions més importants. La majoria d'aquestes es tornaven a contemplar en l'edició actualitzada de l'any 1982 amb l'afegit citat. Veure Coordinadora Informa. Hoja informativa de la Coordinadora de AA.VV. (març 1982), AHMTB, Donació Mn. Josep Catà, Caixa 2, p. 2. Les AVV's existents a Santa Coloma aleshores eren Raval, Can Franquesa, Can Mariner, Fondo, Riera Alta, Safaretjos, Oliveres, Riu Nord, Riu, Singuerlín, Santa Rosa, Guinardera i Llatí. Veure Coordinadora Informa. Hoja informativa de la Coordinadora de AA.VV. (maig 1981), AHMTB, Donació Mn. Josep Catà, Caixa 2, p. 4. Notis que no s'esmenta a l'AVV del Centre. 
la aplicación de estas contribuciones especiales y a continuación los vecinos intentaron expresar su opinión sobre esas razones expuestas por el Concejal de Hacienda y el propio Alcalde. Sin embargo, el Alcalde denegó la palabra a los vecinos y ordenó al Secretario pasar a otro punto del Orden del Día. Ello, provocó que los vecinos protestaran enérgicamente, negándose a que se pasara a otro punto sin que antes se les concediera el uso de la palabra. El Alcalde resolvió el asunto suspendiendo el Pleno.

Estos, y no otros, son los hechos. Y ante estos hechos, nos vemos en obligación de denunciar la actitud del Alcalde al aplicar de forma estricta y contradictoria el restringido reglamento de Participación Ciudadana (Reglamento que fue elaborado sin la participación de las propias entidades ciudadanas)."1852

L'existència d'unes Associacions crítiques amb els Ajuntaments no va ser patrimoni exclusiu de Santa Coloma de Gramenet, si bé va ser el lloc on inicialment van existir amb més força de la sub-comarca. A Badalona i Sant Adrià també van donar-se casos, si bé al començament van ser més puntuals. A Badalona, malgrat que a inicis dels vuitanta havien aparegut alguna nova AVV's ${ }^{1853}$, el cert és que el major pes del PSUC en aquestes entitats va fer que la marxa de dirigents cap a l'Ajuntament es sentís més. També la desaparició del PTC va afectar notablement a la ciutat més poblada del Barcelonès Nord, per la seva notable implantació en el teixit veïnal. Tot i això, van existir alguns casos d'Associacions que es van mantenir més actives, que solien coincidir amb aquelles on l'hegemonia del PSUC no era clara, o on aquesta es va modificar posteriorment pel trencament intern del partit.

Es pot constatar que va haver-hi topades entre algunes Associacions i l'Ajuntament badaloní. Des d'aquest es tenia una concepció de la participació similar a la del consistori colomenc. I si bé es cert que des de el regidor de Participació Ciutadana, Manuel Armentero, es van impulsar assemblees informatives als barris ${ }^{1854}$, no es van acabar d'articular mecanismes de participació vinculants on les AVV's tinguessin un pes efectiu real. Les Taules d'Ensenyament o Educació per posar dos exemples, que havien tingut una gran força a la darrera

1852 Hoja Informativa de la Coordinadora de AAVV (març de 1983): "El Ayuntamiento nos ha engañado" [full volant A4 a doble cara], AHMTB, Donació Mn. Josep Catà, Caixa 2, p. 1.

1853En concret ho van fer les AVV's del Manresà (1980), del Remei (1980), la d'Iris-Sol-Casagemas (1980), la de Can Claris (1981) i la de Joaquim Ruyra (1982). Veure Josep Baeza: L'associacionisme veïnal a Badalona..., p. 29.

1854Entrevista a Manuel Armentero Molina, 10-4-2010. Veure nota 1868. 
època dels Ajuntaments franquistes, van anar adquirint progressivament amb els Ajuntaments democràtics, una funció merament consultiva a mesura que també disminuïen les mobilitzacions en produir-se també una millora progressiva en aquests àmbits. Això sense comptar les pròpies limitacions de l'administració local. En Pedro Jesús Fernàndez, antic president de l'AVV de Sant Mori de Llefià i des d'abril de 1979 regidor d'Ensenyament ens ho recordava:

\begin{abstract}
"Yo tenía a dos personas. Una que se supone que era la que atendía al público y un abogado que habia entrado hace poco (...) luego hubo una secretaria (...)

La dedicación era total (...) pero lo cierto es que problemas que creíamos que se pueden resolver con prontitud no se resuelven... la burocracia impide dar respuestas a las demandas de la ciudadanía"1855
\end{abstract}

Pel que fa als conflictes amb el nou consistori, en Diego Guerrero, que va participar a la Taula d'Ensenyament ens va explicar alguna topada precisament amb el mateix Pedro Jesús:

“Me'n recordo d'un enfrontament aquí al barri de Nova Lloreda entre el Pedro Jesús i jo. Pedro Jesús, que era el regidor que hi va haver d'ensenyament amb el primer Ajuntament democràtic. Per que a més la seva dona era mestra i en aquell moment era la directora, o tenia que ser la directora, del Llorens Artigues [un col-legi]. Hi va haver una reunió i en aquell moment era una persona amb una actitud totalment autoritària que no admitia cap crítica per que ell era el representant del govern democràtic, diguem (...). No acceptaven la crítica de l'esquerra ni molt menys, i fins i tot feien servir lo que va fer servir Stalin: "tu eres antirevolucinari" (...) públicament, eh?”1856

No sempre les relacions eren tant dolentes. Però aviat les limitacions de l'Ajuntament en donar respostes a determinades reivindicacions veïnals va anar creant malestar. Això, i un cert "retorn" dels militants del PSUC a les associacions, com ens ho posa de manifest un altre testimoni d'un dirigent veïnal que no era

1855Entrevista a Pedro Jesús Fernández, 26-4-2009. Va ser el primer President de l'AVV de Sant Mori de Llefià i posteriorment regidor d'Ensenyament al primer consistori (1979-1983). Independent, va acabar militant al PSUC als anys vuitanta.

1856Entrevista a Diego Guerrero Castaño, 20-11-2013. La comparació amb Stalin pot semblar un pel exagerada. El PSUC Badaloní no va arribar a fer cap "Procés de Moscou" ni va condemnar ningú a mort, tot i que dins el PSUC com vam veure en tot el procés del Vè Congrés si es fessin servir mètodes estalinistes per aconseguir el control del partit i desqualificar al rival. L'entrevistat aquí es refereix una certa tendència existent en el si de les esquerres de qualificar com a "antirevolucionari" a qualsevol persona que discrepi amb determinats dogmes. També cal tenir en compte la militància en la CNT del mateix Diego Guerrero quan es van donar aquests fets així com l'animadversió mútua existent entre aquesta organització i el PSUC. 
d'aquest partit:

"Recordo que a nivell personal hi havia una bona relació [amb el Màrius Díaz] (...) però a l'hora de la veritat de les actuacions concretes de cara al barri (...) passava una mica lo que passava amb l'anterior Ajuntament (...) no es veia una força de volguer fer les coses que demanàvem del moviment veïnal (...) vèiem [des de l'AVV de Sant Antoni de Llefià] que les accions de l'Ajuntament tampoc eren de lo més decantat a arreglar la situació del barri de Llefià que era un dels barris més grans de Badalona i que estava molt descuidat. En la època del PSUC va haver-hi una relació més cordial. També (...) hi havia un interès dels militants del PSUC (...) que en aquells moments van entrar a la nostra associació (...) ficar-se dintre per intentar conquistarla i això no ho van aconseguir."1857

Aquest intent -limitat- de tornar a les AVV's no ens hauria de sorprendre gaire. Apart de les crides que es van fer des de finals dels setanta per revertir l'abandonament d'aquest tipus d'entitats, als anys vuitanta es faran de nou emplaçaments -amb més o menys èxit- per retornar a treballar dins de les entitats veïnals. Planificat o no, el cert es que l'abandó dels militants del PSUC de les entitats veïnals havia estat patent. Per posar un exemple, al VIè Congrés del PSUC, que havia de "rectificar" al Vè, podem veure afirmacions com la següent:

"Penso, per exemple que s'han escrit i s'han provocat bons informes en el Comitè Central sobre el moviment popular, sobre el treball municipal. Però hem de revisar el concret com hem d'aplicar-los en la pràctica, com ha treballat cada comitè de districte, cada comitè de localitat, com s'ha treballat en l'aplicació d'aquesta política, en els moviments de masses, en les organitzacions cíviques que hi ha a cada barriada, a cada poble i com participem. Com es possible que a moltes associacions de veïns resulta que ara les organitzacions polítiques extraparlamentàries tinguen més importància i més implantació que el PSUC mateix?"1858

De manera que oficialment des de el PSUC es cridava a tornar-hi a les Associacions, per contrarestar la presència en moltes d'aquestes de les forces de l'esquerra radical. Tot i així les crides van tenir un seguiment limitat, ja que tres anys després un nou congrés del PSUC, el VIIè, tornava a afirmar que:

1857Entrevista a Antonio Agudo Tuñón, 21-6-2010. President aleshores de l'AVV Sant Antoni de Llefià i Vicepresident de la FAVB (Badalona). Militant del MCC.

1858Viè Congrés [Extraordinari] PSUC, 19,20,21 març 1982: "Per la pau, el treball i les llibertats. Per un partit comunista, una política eurocomunista. 1. Informe del Comitè Central i resum de la discussió", AHMTB, Donació PSUC, Caixa 5, p. 23. 


\begin{abstract}
“D'igual manera no hauria d'haver ni un sol militant comunista que no fos present en algun dels moviments o entitats cívico-socials que avui existeixen a Catalunya. El pluralisme i la multiplicitat de l'associacionisme ens ha de fer pensar en la importància que té avui per a Catalunya l'impuls de la societat civil." ${ }^{1859}$
\end{abstract}

Lligat amb les diferències de concepció política que havien de tenir les AVV's , es donarà un altre enfrontament, on es barrejava també un component generacional. Durant un temps, va haver-hi un nodrit grup de gent jove que es va incorporar a aquest tipus d'entitats i van nodrir les anomenades "Vocalies de Joventut". Aquest fet no era nou i ja s'havia donat als anys seixanta i setanta. I va continuar en part fins i tot als vuitanta en aquelles associacions que van tenir la capacitat d'integrar-los i de continuar tenint una presència activa en la vida del barri, malgrat el context de crisi econòmica que va afectar profundament al jovent els barris obrers del Barcelonès Nord. Aquestes noves fornades a vegades havien adquirit la consciència ja de petit en les lluites als barris dels anys setanta o fins i tot a les escoles gràcies a determinats professors. Així ens ho explicava Antonio Flores, futur president als anys noranta de l'AVV Sant Antoni de Llefià:

"El Pedro Jesús [Fernàndez] intentava que els seus alumnes adquirissin compromís al barri, que participessin en entitats (...) en l'Associació de Veïns. L'ambient que també es vivia al barri era de moltes lluites per aconseguir els col·legis, els equipaments bàsics (...) l'asfaltat dels carrers, els alcantarillats (...) això és un component de formació social que he tingut. De fet estava jugant (...) i de passar de jugar amb la pilota (...) passaves a tallar la carretera més avall per demanar un col-legi... o la batalla de les espelmes... son coses que et van anar formant."1860

L'Antonio Flores va començar a militar l'any 1979 a les joventuts del MCC, les MJCC, i amb un altre grup de joves, que també havien estat alumnes del Pedro Jesús Fernàndez al Col-legi Públic Antoni Botey i posteriorment de l'Institut Eugeni d'Ors, van muntar una potent Vocalia de Joves a l'AVV de Sant Mori de Llefià (on

1859VIIè Congrès: "Carta de Normes. Projecte de Reglament. Projecte de Tesis. Projecte de Modificació d'Estatuts. El combat per l'hegemonia a Catalunya." [“58. Lligam amb els moviment socials"], AHMTB, Donació PSUC, Caixa 5, p. 45.

1860Entrevista a Antonio Flores Fernández de Córdoba, 6-5-2010. Militant del MJCC, de la Vocalia de Joves de l'AVV de Sant Mori de Llefià i posteriorment de la Vocalia de Joves de l'AVV de Sant Antoni de Llefià i del MCC. Fundador de la Colla de Diables Kapaoltis (el nom prové les inicials dels seus fundadors: Carlos, Paco, Olga, Toni i Isabel), de la Ràdio L'Ortiga i ja, durant els anys noranta, president de l'AVV de Sant Antoni de Llefià. 
també hi havia gent del PST). Durant un temps en aquesta associació va ser-hi presidenta Maria Relles Bellido (militant del PTC). També va tenir la Presidència breument un militant de MCC com Rafael Rojano. Aquest fet va provocar enfrontaments i tensions amb els militants del PSUC i sembla que en aquest cas si que es van seguir les consignes de "retornar" a les AVV's, de manera que al 1982 assolia la presidència un militant del PSUC, Àngel Peiró. Els mètodes que es van fer servir no sempre eren els més "nets" del món, en el sentit de que es recorria a la tàctica del "desembarcament a darrera hora" per condicionar les votacions:

“El mes abans de l'Assemblea venen socis nous a apuntar-se (...) cada part organitza les seves forces. Que la gent estigués al corrent de pagament per tindre dret a votar."1861

Les diferències polítiques es barrejaven també amb unes diferències generacionals. El joves de l'AVV de Sant Mori mantenien una actitud més combativa que no pas la Junta de l'Associació, quan aquesta va passar a estar controlada pel PSUC. Per exemple, durant una ocupació de l'Ajuntament (ja democràtic) dels veïns afectats pel mal estat dels habitatges del C/ Salou (immobiliària IBUSA) la Vocalia de Joves va donar suport actiu, tancant-se part dels seus membres també. Això va provocar situacions més conflictives quan per exemple la Guàrdia Urbana va expulsar als ocupants ${ }^{1862}$. 0 per exemple, en la implicació dels Carnestoltes del Barri que es van començar a fer el 1982 (amb un important component reivindicatiu i que perduren fins l'actualitat), on mentre la Vocalia participava en la seva organització conjuntament amb l'AVV de Sant Antoni, l'Associació de Sant Mori no ho feia. Tot això va anar enrarint l'ambient dins l'esmentada associació i creant una creixent suspicàcia "dels grans" respecte "els joves" i viceversa, que alhora coincidia amb un major pes del PSUC en els primers i del MCC i el PST en els segons, ja que pel que sembla, en aquesta associació aleshores l'escissió del PSUC, el PCC no hi va tenir gaire presència (situació que canviarà posteriorment). Els desencadenant del conflicte obert que va acabar amb l'expulsió dels membres més destacats d'aquesta Vocalia de Joves, a part de temes com les festes que feien els

1861Entrevista a Antonio Flores Fernández de Córdoba, 6-5-2010. Evidentment no estic qüestionant el dret a votar de qualsevol soci d'aquesta entitat, només el fet de que només es busquessin socis exclussivament per decantar les votacions cap a un costat o un altre.

1862Veure el testimoni del mateix Antonio Flores a la nota 1614. Quan vaig entrevistar personalment a Màrius Díaz li vaig preguntar per aquest incident, que ell em va negar tot i que va admetre que la memòria ja no era la d'abans i que potser no ho recordava. 
joves, va ser la instal·lació d'un bar que alhora havia d'ocupar un espai propi que tenien els mateixos joves dins de l'Associació per organitzar activitats. Es va produir un "incident" quan dos joves van observar moviment dins l'AVV a la 1:30 de la matinada i van trucar a la Guàrdia Urbana i es van trobar que els que hi eren a l'interior no eren altres que les persones a les quals la Junta de l'Associació els hi havia ofert portat l'esmentat bar.

La resposta va consistir primer en el confinament de la Vocalia en un petit local ja que l'espai més gran que abans ocupaven va ser destinat al bar. Però els conflictes van continuar fins al punt que fins i tot el petit local els va ser vetat:

\footnotetext{
"Un día al ir a abrir nuestro pequeño local encontramos que habían cambiado la cerradura. Fuimos a pedir explicaciones a la Junta, que nos respondió que no se nos devolvería el local hasta que no hubiera un "comportamiento correcto" por parte de los jóvenes. A nosotros y nosotras nos gustaría saber que entienden ellos por un comportamiento "correcto". ¿Será que no estamos de acuerdo en que la Asociación de Vecinos se convierta en un bar y abandone la lucha reivindicativa por solucionar los problemas del barrio en general?. ¡Y luego dicen que estamos tirados en la calle!” 1863
}

Al final tot va acabar amb l'expulsió dels membres de la Vocalia de Joves. Primer a les tres persones més destacades, i posteriorment a gairebé tota la gent que la composava. Però la majoria d'aquests no van deixar el món associatiu, sinó que van ser acollits amb els braços oberts per una altra entitat: l'AVV de Sant Antoni de Llefià. Aquesta entitat havia tingut una evolució molt peculiar. De ser una de les darreres AVV's controlades pels franquistes (fins l'any 1977) ara havia passat a ser una entitat molt diferent. Per començar, estava presidida per un militant del MCC, Antonio Agudo. Però de fet tenia una composició força plural ja que no només participaven membres d'aquest partit, sinó de cristians de base de la parròquia, d'algun membre del PCC -com per exemple Manuel Sousa-, persones sense filiació i inclús algun militant socialista. També hi havia gent del PSUC, com havíem dit abans, però tal com ens recordava el que va ser el seu president:

“Eren gent que tampoc eren molt perillosa (...) eren més aviat treballadors, no tenien massa capacitat per influir en les directrius que fèiem nosaltres del barri [a l'AVV] (...) hi havia una situació de bastant acord amb les coses que fèiem nosaltres."1864

1863Vocalia de Joves Sant Mori de Llefià: “Otra vez en la calle”, Revista de Badalona, 21-2-1984, p. 6. 1864Entrevista a Antonio Agudo Tuñón, 21-6-2010. 
Sobre la tasca que feien els militants del MCC i la concepció que tenien de moviments com el veïnal en són un bon resum aquestes paraules d'un dels seus militants:

“Els moviments socials són els que porten la iniciativa, nosaltres lo que fem és recolzar (...). Nosaltres no intentem controlar els moviments socials (...) el treball que feia la militància del MC era impulsar (...). Una altra cosa es que per la tasca de militants concretes [del MC] (...) tenien que aconseguir el respecte dins d'aquests moviments però no era ho muntem i ho controlem.... t'ho tenies que guanyar."1865

Sigui com sigui, aquesta Associació en concret, la de Sant Antoni, va aconseguir articular un teixit associatiu important al seu voltant molt relacionat amb al seva manera de fer. S'oferia la participació a les Juntes de manera oberta, sense la necessitat de ser soci de l'entitat. De la mateixa manera s'oferien els seus locals per altres entitats del barri, de manera que es creava un important nexe entre aquestes entitats i la mateixa Associació, que gaudia així d'un important prestigi i representativitat. L'AVV de Sant Antoni de Llefià va ser molt receptiva a les noves inquietuds i a les noves formes d'expressió i protesta social protagonitzada pels joves dels anys vuitanta. Van acollir sense cap problema als expulsats de l'AVV de Sant Mori de Llefià i dins seu van sorgir iniciatives com els ja mencionats Diables Kapaoltis, un col-lectiu feminista format per dones joves anomenat L'Estel Lila, una coordinadora antirepressiva que es va fer després de diverses agressions policials protagonitzades per la Guàrdia Urbana anomenada Kolectiu de Joves Agobiats, el KGB o Kol·lectiu Gai de Badalona... així com també de la Ràdio lliure "Radio La Ortiga" (aquesta darrera també havia estat expulsada d'una altra AVV, fet que comentaré més endavant). Fins i tot les primeres reunions de SOS Racisme a Badalona es van començar a fer allà. En definitiva, es tractava d'un model de funcionament força diferent al d'altres entitats veïnals del moment i que li va donar una gran vitalitat, malgrat que no tot eren flors i violes. El president d'aleshores, Antonio Agudo ens recordava que malgrat tenir més de 300 socis, a les assemblees solien venir entre 60 i 70 persones i que:

“El problema a nivell de les AVV's era que... tot i que van haver anys encara que si que

1865Entrevista a Antonio Flores Fernández de Córdoba, 6-5-2010. 
hi havia una afluència de gent (...) pensa que el moviment associatiu ha sigut un tema que (...) han sigut nuclis bastant reduïts de gent que han treballat $\mathrm{i}$ han dedicat temps a fer que el moviment associatiu funcioni "bé", no hi ha hagut una gran quantitat de gent que estigui per la labor." ${ }^{1866}$

Interpreto que el que vol dir el nostre entrevistat és que malgrat les protestes i mobilitzacions podien implicar, encara als 80, a nombres molt elevats de persones, la fenia del dia a dia dins de les associacions era feta per una quantitat de gent molt més restringida. D'aquí la importància d'aconseguir incorporar a noves persones i assegurar un recanvi generacional.

Malauradament, no totes les entitats funcionaven així. Durant als anys vuitanta, sobretot a partir de que els socialistes van arribar a l'Ajuntament de Badalona l'any 1983, va començar una política per part d'aquest partit per intentar controlar en major o menor mesura el teixit associatiu. Ja ho vam veure amb els testimonis dels regidors colomencs a Grama. Per una banda es volia amortiguar críticas i per una altra, qüestionar la representativitat de les Associacions de Veïns ${ }^{1867}$, just en un moment en que el teixit veïnal es reactivava contra les polítiques de l'Ajuntament.

Això es podia fer de determinades maneres. Primer cal recordar que ja alguns líders veïnals s'havien passat al PSC-PSOE després de la crisi dels partits de l'esquerra radical, com el cas del President de l'AVV del Congreso, Miguel Ordóñez. Però aquests no eren suficients per fer front a unes associacions que no estaven totalment controlades. Així que es van fer servir diversos mètodes. Un d'ells va ser el clàssic de la cooptació. Des de l'administració municipal s'oferien prebendes a canvi de complicitats. Així ens ho resumia un dels nostres entrevistats:

"Una forma de crear la fisura interna es buscar aliats, a canvi ha sigut alguna vegada de treball per a fills de dirigents veïnals, a vegades han sigut caramels del tipus t'aconsegueixo aquest local per tu, aquesta plaça de l'arreglo (...) coses d'aquestes"1868

Aquest mètode podia tenir més èxit o no, depenent de la composició de l'AVV.

1866Entrevista a Antonio Agudo Tuñón, 21-6-2010.

1867Veure el testimoni dels regidors socialistes colomencs Pilar Puig i Joan Carles Mas a "Las amargas relaciones entre los barrios y el Ayuntamiento”, Grama núm. 281 II Època (26 juny- 2 juliol 1982), p. 12-13.

1868Entrevista a Antonio Flores Fernández de Córdoba, 6-5-2010. 
En aquelles entitats que eren molt personalistes era més fàcil si s'aconseguia cooptar al líder. Això va funcionar per exemple, segons l'anterior testimoni, amb l'AVV de la Ronda de Sant Antoni i amb el seu President Jordi Font. En canvi, a la seva entitat, l'AVV de Sant Antoni no va funcionar per que els militants del PSC eren només 2, malgrat que durant el conflicte de la Plaça Trafalgar, com veurem més endavant, van intentar posar pals a les rodes des de dins. Quan això no funcionava, sovint s'optava per un mètode que no era patrimoni exclusiu del PSC-PSOE ni molt menys, ja que també l'havien fet servir altres forces polítiques: el ja mencionat "desembarcament". El mètode consistia en fer arribar gent afí al propi corrent polític per fer bascular les entitats cap allà on interessava. Es solia fer quan hi havien assemblees per triar noves Juntes o per prendre decisions importants. Un altre entrevistat ens ho exposava amb tota la seva cruesa:

"I van venir (...) però van posar tota una sèrie de gent que mai havien vingut aquí [es refereix a l'Ateneu de Sant Roc]. 0 alguns que les havien comprat... Alguns elements que havien estat batallant i lluitant molt aquí... Que després les van donar un lloc de treball a l'administració... Després venien i llavors alguns d'ells hi van dir 'Home, es que a mi m'han dit que venga a desfer això...' Si si si... Persones que havien estat lluitant com nosaltres, resulta que com tenien (...) [Demano si eren persones concretes amb noms i cognoms...] Concretes amb noms i cognoms, si...[seria massa demanar els noms?] No (...) [l'entrevistat mostra reticències a dir noms concrets] Però noms i cognoms, eh? I que venien a... i van arribar a dir 'Si ja sabem que es fa aquí, però a mi m'han dit que venga a desfer tot això i vinc, i ja ho se...' per que el seu lloc de treball era el seu lloc de treball, i la seva consciència pues bueno... la van vendre... La seva ètica i el seu d'allò, ho van vendre (...)

[Eren gent, càrrecs de confiança de l'Ajuntament, regidors...?] Bueno... regidors no (...). Havíem tingut concretament dos a l'Associació que s'havien quedat a l'atur per que vegis... per la lluita a la seva empresa (...) que eren reivindicatius i tal (...). I aleshores els van oferir (...) i l'Ajuntament els va donar un lloc de treball (...) No era de confiança [càrrec de...] sinó un lloc de treball però... [amb la condició de...] Exacte... I alguns que després lluitaven en contra de (...)."1869

Aquest mètode més groller va ser usat primer a Badalona, però posteriorment es va estendre a altres indrets del Barcelonès Nord. A Santa Coloma algunes de les persones entrevistades ens han insinuat fets similars, si bé pel cas 
del PSC-PSOE amb una mica més de retard que a Badalona, segurament per que a la ciutat colomenca van trigar uns quants anys més a assolir l'Alcaldia amb Manuela de Madre (que no ho va aconseguir fins 1991). Així ho afirmava Eloy Jurado:

“iHombre! Des de que va entrar la Manuela de Madre i potser des de una mica abans que els socialistes van començar a entrar a les Associacions de Veïns i desfer-les"1870

Els efectes d'aquesta intervenció del PSC ja fos cooptant gent -que no tenia per que fer-se del partit- o aportant militants va tenir diversos efectes. A Badalona per exemple tinc el testimoni de com un canvi de Junta va propiciar -de nou- la marxa o expulsió d'un grup de gent. Em refereixo en aquest cas concret a l'emissora Ràdio L'Ortiga que havien fet un grup de joves a Llefià:

\begin{abstract}
“En un principi estava a l'AVV de Sant Joan Baix-Gran Sol. Patim un sabotatge al cable que va a l'antena (...) També allà hi ha un cop d'estat a la Junta en la qual el Valenzuela, que també havia estat militant del MC se'l treuen fora i se fiquen els Muñoz, la saga Muñoz."1871
\end{abstract}

El resultat va ser de nou la marxa forçada d'un col-lectiu de gent jove amb inquietuds cap a l'Associació que s'estava convertint en la "casa d'acollida" dels repudiats per altres entitats més submises amb el poder local o per "xocs generacionals": l'AVV de Sant Antoni de Llefià. Com veurem posteriorment, aquesta operació per canvia la Junta de l'AVV Sant Joan Baix-Gran Sol es va fer amb una intencionalitat molt concreta, ja que aleshores estava en plena vigència el conflicte de la Plaça Trafalgar que enfrontava a algunes AVV's del barri contra l'Ajuntament. Si anteriorment l'AVV de Sant Joan Baix-Gran Sol s'havia posicionat de manera crítica amb l'Ajuntament amb la nova Junta va passar a donar-li suport pel que feia al projecte de remodelació de l'esmentada plaça, un afer del qual parlaré més endavant car va ser un dels conflictes veïnals més important dels anys vuitanta. Una altre exemple d'Associació badalonina on als anys vuitanta els socialistes van aconseguir la preeminència va ser la de Bufalà, amb el desplaçament dels antics militants del PSUC i la CNT:

“El 1982 va començar una etapa de llanguiment en l'Associació de Veïns. Gent propera

1870Entrevista a Eloy Jurado Cubero, 12-12-2013.

1871Entrevista a Antonio Flores Fernández de Córdoba, 6-5-2010. El nou president de l'entitat va ser un tal Pedro Muñoz, persona molt propera al PSC-PSOE i a Joan Blanch. 
al Partit dels Socialistes de Catalunya va passar a dirigir l'entitat, i es va nomenar president Andrés López, que participava en les activitats de l'Associació des del 1976 i hi va estar actiu fins al 1992."1872

Però si la cooptació de líders o el desembarcament de persones no era encara suficient per desequilibrar la balança, encara quedava una tercera opció. Com hem vist per als socialistes les AVV's no havien de ser les entitats representatives dels barris, ja que segons ells havien de tenir la mateixa importància que altre tipus d'entitats. Així que quan no es podia controlar a una Associació veïnal el que s'optava era per potenciar altres entitats del barri que poguessin ser afins per minimitzar la importància de l'AVV “díscola". Així per exemple, si es feien assemblees públiques o reunions dels Consells Sectorials o de Districte es convidaven a representats de diferents entitats que ajudaven a diluir la importància del moviment veïnal. Aquesta política es va aplicar també al barri de Llefià durant i després del conflicte de la Plaça Trafalgar de l'any 1986:

"L'Ajuntament des de 1986 intenta crear-ne el seu propi teixit associatiu "afi" -Club de Petanca de Sant Antoni, Radio Ona Badal de Torre Mena, li dona un local als de Castilla la Mancha (...) Ferran Bello [regidor del districte aleshores, un dels pocs socialistes que havia participat del moviment veïnal als anys setanta] comença a recollir signatures a Llefià dient que se seva gestió ha sigut perfecta i meravellosa." ${ }^{1873}$

Un altra manera de fer i desfer del PSC-PSOE durant els anys vuitanta la podem trobar a Sant Adrià de Besòs, en concret al barri de la Mina. L'AVV als anys vuitanta va patir de seguida un declivi pels diversos enfrontaments interns que van haver-hi ja de ben antuvi entre socialistes i comunistes. D'aquesta manera a la segona meitat dels vuitanta aquesta entitat havia perdut la força i representativitat que havia tingut als anys setanta. Aleshores es va crear una nova Assemblea i Plataforma Veïnal, que en el dur context dels anys vuitanta al barri i després de diverses frustracions i promeses incompletes per les administracions, va optar per tenir incidència dins el món institucional local:

“(...) en el 87, la Asamblea de Barrio, la Plataforma de Vecinos, en el 87, decide tener

1872 Marc Andreu i Acebal: El Bruc-Bufalà. Badalona. Col·lecció els Barris d'Adigsa núm. 7, Departament de Benestar Social de la Generalitat de Catalunya i ADIGSA, [Barcelona], 1995, p. 96. 1873Entrevista a Antonio Flores Fernández de Córdoba, 6-5-2010. 
una representación en el espacio político. Entonces en asamblea, aquí en el barrio, se busca a alguien que los represente y me tocó a mi representarlos. Entonces nos presentamos... pero esto es mucho más... no es una cuestión política. Era sencillamente porque nosotros habíamos presentado en el año 87 (...) no el 85... no se exactamente el año, tendría que mirarlo, unos planes, para Europa, a la Comunidad Europea para la transformación del barrio en los programas de pobreza. Y cuando (...) se logra que se meta hacia delante supimos que eso iba a través del espacio municipal. Entonces para poder controlar el espacio municipal y esto que habíamos presentado los vecinos... pues pensamos, que coño, hay que estar presentes en el espacio municipal, hay que controlarlo. Entonces hicimos un pacto con los socialistas en aquel momento, en el 87 estoy hablando (...).

Entonces lo que se llega un pacto la Asamblea de Vecinos a través de la Permanente de Vecinos es de acompañarlos en la lista como independiente un vecino para que apoye, si apoyan los planes de transformaciones integrales que nosotros habíamos presentado a Europa (...) nosotros apoyamos en el barrio esta candidatura"1874

Però malauradament, aquests aviat descobriran que el PSC-PSOE els havia manipulat per guanyar vots a les eleccions amb promeses falses, cosa que va comportar l'abandó ràpid de l'entesa que s'havia arribat amb l'esmenat partit. A l'apartat següent del present capítol, centrat en explicar els diferents conflictes i mobilitzacions veïnals durant els anys vuitanta, tindré ocasió d'aprofundir més en aquest cas concret ${ }^{1875}$.

Continuant a Sant Adrià de Besòs, un cas força diferent va ser el d'una entitat que si va mantenir un perfil força actiu i reivindicatiu durant els anys vuitanta: l'AVV del Barri Besòs. Aquesta entitat havia sigut una de les més lluitadores de la ciutat -juntament amb la de La Mina- durant els setanta. Però als vuitanta, a diferència de la seva veïna, no va entrar en un període de declivi tant greu. En part això va ser per que en ella van tenir un especial pes a la seva Junta dirigents veïnals que ja s'havien destacat als anys setanta però que ara ho continuaran fet enquadrats en una nova organització: el PCC.

En efecte, fins ara no hem parlat del paper que va jugar l'escissió del PSUC en el moviment veïnal durant aquest període. Però és innegable que molts dels antics

1874Entrevista a Paco Marín Rodríguez, 14-2-2013.

1875Una de les cites amb les quals inicio aquest Vè capítol fa referència a aquesta qüestió, en concret la de la nota 1691. 
dirigents del PSUC ja fos per que estaven descontents amb com havia anat el procés de canvi polític o per que havien estat derrotats en la lluita interna del partit al Vè Congrés van decidir "retornar" (si es donava el cas que havien marxat) a treballar en les associacions:

“Es que en eso no hubo cambio porque nosotros teníamos la mayoría antes y después continuamos prácticamente lo mismo. El PSUC y el PCC fue la misma continuación. Por eso no hubo ningún problema. Y el movimiento vecinal no lo notó ni se notó en casi ningún sitio." ${ }^{1876}$

Per posar un altre exemple podem veure que afirmava una publicació del PCC badaloní durant la campanya de les municipals de 1983 pel que feia a la participació ciutadana:

\section{“PARTICIPACIÓN}

Es necesario combinar la acción de Gobierno con la movilización popular y formar así un todo inseparable.

Pese a promesas hechas por partidos de la izquierda reformista, la realidad es que esta participación no se ha dado nunca. Nosotros, el PCC, planteamos que es necesario volver a reactivar y potenciar las Asociaciones de Vecinos, la Federación de Asociaciones, las Taulas d'Ensenyament y de Sanitat.

Que las AA.VV. sean oídas en los Plenos Municipales."1877

Tot i que van ser criticats en ocasions per membres d'altres formacions de l'esquerra revolucionària acusant-los de conservar tics autoritaris i estalinistes, no es pot negar que els militants del PCC van ser actius en algunes AVV's que van mantenir una activitat reivindicativa als anys vuitanta. Apart de l'esmentat cas de l'AVV del Besòs, els militants del PCC van tenir també presència per exemple a l'AVV de Pomar durant el conflicte dels autobusos de l'any 1985 i també, tot i que en menor mesura, a la de Sant Antoni de Llefià durant els fets de la Plaça Trafalgar.

Aquestes pugnes entre diferents forces polítiques es van traslladar als organismes de coordinació veïnal, com van ser les federacions. El cas més conegut durant aquells anys seria el de la Federació d'Associació de Veïns de Badalona, que després d'uns anys d'aparent inactivitat -a finals dels setanta i principis dels 1876Entrevista a Juan José Castro Castillo, 20-12-2012 i 21-1-2013.

1877Partit dels Comunistes de Catalunya (PCC): "Participa con nosotros. Fem habitable Badalona" [publicació per les eleccions municipals de 1983], MB, Arxiu J. № Cuyàs i Tolosa, Caixa 131, Carpeta PCC, p. 6. 
vuitanta- va tornar a engegar-se a partir de l'any 1984 gràcies precisament a l'acció de militants del PCC i del MCC, sobretot. Es prou significatiu que el President d'aleshores fos Julio Molina, militant del PCC i destacat dirigent de l'AVV de La Pau, mentre que el Vicepresident era Antonio Agudo, militant del MCC i President de l'AVV de Sant Antoni de Llefià ${ }^{1878}$. Els socialistes van voler posteriorment recuperar el terreny perdut i durant anys va haver-hi una batalla política pel control de la FAVB fins arribar a l'extrem que durant els anys 90 -això ja escapa a l'àmbit cronològic d'aquesta investigació- aquesta es va dividir i durant un temps van existir dos secretariats enfrontats de la FAVB de Badalona ${ }^{1879}$.

A Santa Coloma de Gramenet durant part dels anys vuitanta va subsistir la Coordinadora d'AVV's i no es va constituir una Federació fins més tard. No obstant, alguns militants veïnals del MCC n'eren reticents a la creació d'aquesta segona entitat per diversos motius:

"I nosaltres vam muntar la Coordinadora d'Associacions de Veïns. També nosaltres vam dir que no es muntés la Federació per que la Federació allò s'acabaria burocratitzant com així ha sigut. I clar, la Coordinadora... ens anàvem coordinant en cadascú dels moments (...). Quan es va muntar [es refereix a la Federació] vam dir: munteu-la si vulgueu, però la Federació és una manera de burocratitzar... un Secretari, un President..." ${ }^{1880}$

A Sant Adrià de Besòs també va existir una Coordinadora d'AVV's, però no he trobat referències seves durant els anys vuitanta llevat de la feta per un testimoni que ens va dir que havia funcionat durant uns deu anys ${ }^{1881}$.

Fos com fos, el que queda clar es que durant aquests anys va haver-hi una certa lluita per controlar les AVV's protagonitzada en gran part per membres de diferents partits polítics. Aquest fet ens demostra que, malgrat la crisi que es va

1878José Miguel Cuesta Gómez: El moviment veïnal a Llefià (Badalona), p. 264.

1879Josep Baeza: Associacionisme veïnal a Badalona, p. 30. El punt que va provocar la divisió va ser la campanya contra el recàrrec en el rebut de l'aigua. El sector més proper al PSC-PSOE no volia que es protestés contra l'Ajuntament, mentre els altres si que mantenien que s'havia de protestar contra les tres administracions implicades (Ajuntament, CMB i Generalitat). Finalment l'Ajuntament va cedir i va retirar el cobrament del clavegueram en el rebut de l'aigua.

1880Entrevista a Josep Pitarque Narejos (amb Salvador Bolancer Dugo i Emiliana Salinas, 12-32013.

1881Entrevista a Juan José Castro Castillo, 20-12-2012 i 21-1-2013. La Coordinadora d'AVV's de Sant Adrià de Besòs s'havia creat al maig de 1977. Veure Diario de Barcelona, 21-5-1977. 
donar en el moviment veïnal, aquest encara conservava un prestigi i una capacitat d'incidència notable entre sectors amplis de població. Tot i que a les seves Juntes hem constatat la presència de persones militants de partits polítics i d'activistes sense partit, no hem d'oblidar pas que la majoria dels seus associats eren persones sense carnet i que quan es donaven mobilitzacions populars la majoria de gent que es manifestava eren també aquestes persones. Això no vol dir que fos gent "apolítica", ja que tothom, en siguem més o menys conscients, estem "polititzats" en major o menor mesura.

Però el que sembla evident és que no s'entendria l'interès en estar present dins les AVV's durant els anys 80 si aquestes no conservessin un cert poder d'incidència i capacitat de mobilització. No s'explica que les diferents organitzacions es prenguessin tantes molèsties si no era per que a través del moviment veïnal encara es podien acomplir una part dels objectius que es marcaven. Això si, els motius per ser-hi presents podien ser molt diferents. Algunes forces polítiques, bé per que van veure frustrades les seves expectatives electorals o bé per que tampoc hi confiaven gaire en la via institucional, havien apostat fort per la presència i l'impuls de diferents moviments socials i el veïnal, malgrat la davallada, encara conservava certa força en determinats barris. Altres en canvi van voler incidir-hi per motius oposats: per fer servir aquest teixit associatiu com a coixí que parés o minimitzés les protestes ciutadanes que es poguessin donar contra la seva gestió de les institucions locals. Per que de protestes veïnals hi van haver als anys vuitanta, algunes d'elles amb una magnitud comparable amb les de la dècada anterior com veurem tot seguit.

\subsection{Malgrat tot mobilitzacions: les principals lluites veïnals al Barcelonès Nord als anys vuitanta.}

Que el moviment veïnal va patir un declivi durant els anys vuitanta és un fet constatat. Si mirem les xifres de participació en les tres primeres trobades d'AVV's es pot veure de manera clara. Mentre al desembre de 1979 a la I Trobada d'Associacions de Veïns havien participat 950 persones, a la II Trobada feta a Santa 
Coloma de Gramenet l'any 1981 els participants eren unes 300 persones, i a la III Trobada de Badalona l'any 1982 ja eren menys d'un centenar ${ }^{1882}$. Però dit això, aquest capítol ens servirà per dir que aquesta crisi del moviment no va ser tant gran i ni generalitzada com a vegades s'ha volgut presentar ${ }^{1883}$. Van haver-hi barris $\mathrm{i}$ associacions que van conservar una important capacitat reivindicativa $\mathrm{i}$ combativa. I si bé és cert que, en contrast amb els anys setanta, la majoria de conflictes -per no dir tots- eren defensius i no proposaven una alternativa política concreta o un canvi de sistema, des de el moviment veïnal que encara es va mantenir reivindicatiu es van fer propostes d'aprofundiment democràtic i es propagaven uns valors contraris als de l'ofensiva neoliberal i individualista d'aleshores.

Començant per la ciutat més gran del Barcelonès Nord, Badalona, cal dir que els primers conflictes que es van donar a la dècada els vuitanta solien ser per qüestions heretades de la dècada anterior. Durant aquest primer any d'Ajuntament democràtic van ser molt freqüents les mobilitzacions per les escoles públiques, ja que el dèficit de places escolars encara estava lluny de ser resolt. La diferencia important va ser que aquestes convocatòries comptaren amb el suport, o estaran organitzades directament pel mateix Ajuntament, i en no pocs casos pels mateixos antics dirigents veïnals, fet que va esdevenir, sens dubte, una font de legitimació de les noves administracions ${ }^{1884}$. Però aquestes no van ser les úniques mobilitzacions que es feien per problemes heretats. Hi havia nombroses deficiències i irregularitats urbanístiques pendents de solucionar que van provocar més protestes veïnals.

Un exemple va ser la mobilització engegada pels veïns del carrer Sagrada Família de Llefià pel lamentable estat dels seus edificis que havia començat al 1979 abans de la constitució del primer Ajuntament democràtic després de la dictadura.

1882 AA.DD.: De la protesta... a la proposta. El moviment veïnal a Catalunya, CONFAVC, Barcelona, 2005.

1883 Miquel Domingo i Maria Rosa Bonet: Barcelona i els moviments socials urbans, Mediterrània, Barcelona, 1998 i també "Urbanisme i participació" a Revista Catalana de Sociologia, núm. 7 (71998), p. 73-89.

1884 “El Ayuntamieno convoca al pueblo a una manifestación”, La Vanguardia, 24-5-1979; "Seis mil personas en la manifestación pro maestros", El Correo Catalán, 6-9-1979“Diversos encierros por el problema de los maestros", El Correo Catalán, 7-9-1979; “Una manifestación colapsa la autopista de Mataró", El Correo Catalán, 18-9-1979 i "Catorce maestros detenidos durante una manifestación", El Correo Catalán, 7-10-1979. 
De fet, una de les primeres accions de Màrius Díaz com alcalde va ser reunir-se amb els veïns afectats per mirar de trobar una solució. Amb la mediació de l'Ajuntament i el MOPU es va aconseguir que la immobiliària La Salut es comprometés a reparar els habitatges ${ }^{1885}$. Al mateix barri existia un altre conflicte dels veïns del carrer Salou amb la immobiliària IBUSA per un cobrament de més d'unes quotes que no s'havia tancat i que feia dos anys que durava. Aquest fet va provocar una tancada veïnal a l'Ajuntament com a mesura de pressió al mes de setembre de 1980. Els vells mètodes continuaven practicant-se, fins al punt que el portaveu del grup de CiU a l'Ajuntament badaloní, Pere Sió, es queixava a la premsa local:

“(...) 2-Com a representant de Convergència i Unió en la comissió de govern municipal no puc acceptar la permanent conversió de l'Ajuntament en plataforma reivindicativa, i al mateix temps lamento profundament que els procediments i formes que s'utilitzin siguin: ocupar durant dies el saló de sessions i col-locar pancartes en diversos balcons de l'Ajuntament. Mitjans incorrectes per plantejar qualsevol tipus de reivindicació i per intentar solucionar problemes. (...)

Democràcia no és desori, ni desgovern, sinó equilibri basat en la llibertat en l'ordre i en la responsabilitat de tots els seus ciutadans." ${ }^{1886}$

Els conflictes heretats de la dècada anterior de diversos veïns de Llefià contra immobiliàries com Inmobilar, IBUSA, La Salut (Pablo Porta), Núñez i Navarro i d'altres es van allargar fins als anys 1982-1983 pràcticament ${ }^{1887}$. Va haver-hi un conflicte dels veïns del Carrer Guasch per les obres d'una escola ${ }^{1888}$. També els

1885Veure Carlos Gómez Alcozar: "El nuevo alcalde ya se enfrontó con el primer problema", La Vanguardia, 20-4-1979; Joan Roura: "Nadie ayuda a los desalojados", Mundo Diario, 4-5-1979 i Carlos Gómez Alcozar: "El Ayuntamiento pide ayuda al gobernador" i "La inmobiliaria La Salud se compromete a arreglar un bloque de viviendas", La Vanguardia, 9 i 12-5-1979.

1886 Pere Sió i Puig: "L'ocupació de l'Ajuntament per un grup de veïns d'IBUSA", Revista de Badalona (27-9-1980).

1887 “Protestan porque sus pisos parecen pantanos", El Periódico de Catalunya, 8-5-1982; "Vencinos de Badalona traman un "show" anti Porta en el mundial", El Periódico de Catalunya, 17-5-1982; Jordi Martí: "Uns veïns reclamen 40 milions per uns pisos deficients", Revista de Badalona, 215-1982, p. 15; Jordi Martí: "Els veïns del passatge Sagrada Família tallen el pas a la carretera nacional", Revista de Badalona, 19-6-1982, p. 10; "Núñez y Navarro no cede a los vecinos unos bajos que prometió", El Periódico de Catalunya, 9-12-1982; Angel Marín: "Principio de acuerdo entre vecinos y Núñez y Navarro", Grama, 30-12-1982; "Concentración de vecinos ante la empresa de Nuñez", El Periódico de Catalunya, 5-7-1983. Aquest darrer conflicte enfrontava a un grup de veïns del Carrer Antiga de València contra l'empresari de la construcció i president del F.C. Barcelona.

1888 "Vecinos de Llefià paran las obras de un colegio", El Periódico de Catalunya, 12-8-1982 i "Los vecinos de la calle Guasch, contra el Ayuntamiento", Diario de Barcelona, 14-8-1982. En 
veïns de l'esmentat barri van reivindicar l'adquisició de la Torre Mena, un antiga casa senyorial de la segona meitat del segle XIX que estava semi-abandonada per convertir-la en un local cultural pel barri, fins que finalment el mateix Ajuntament la va expropiar amb aquest objectiu ${ }^{1889}$.

En altres barris com Sant Roc o Pomar també va haver-hi mobilitzacions per acabar de tancar temes pendents de la dècada anterior. En aquest barri per exemple s'estaven duent a terme les obres de remodelació i reparació que havia promès el Ministeri i que en teoria es feien amb un sistema de control popular veïnal amb el suport del Centre Social de Sant Roc. Però les coses no van anar tot el bé que s'esperava. El pressupost inicial es va quedar curt i van caldre noves mobilitzacions per que es destinessin més diners ${ }^{1890}$. A més, va haver-hi topades entre els tècnics del Ministeri, els de l'empresa que feia les obres així com els designats pel veïnat, que provenien del despatx DALP. Però fins i tot va haver-hi diferències entre aquests i els mateixos veïns, fet que va provocar la seva dimissió a finals de l'any $1980^{1891}$. Les obres van continuar sota control veïnal si bé van distar molt d'esser perfectes i van ser necessàries noves reparacions els anys següents.

Al barri de La Pau als inicis dels anys 80 es va continuar reivindicant una escola en condicions pel barri alhora que es feia una escola autogestionada, el "Col-legi Popular Assembleari” en un local ocupat amb els pares, alumnes d'institut o estudiants de magisteri com a mestres i es reclamava el suport a aquesta per part de l'Ajuntament ${ }^{1892}$. Tot això mentre es continuava reivindicant el "solar dels músics" com a zona verda ${ }^{1893}$. Alhora els veïns del barri de Pomar es van tornar a mobilitzar a l'any 1980 per que es continuava fent servir un abocador d'escombraries en les rodalies del seu barri ${ }^{1894}$.

Però sens dubte, el principal conflicte veïnal amb el qual es va trobar el Consistori encapçalat per Màrius Díaz va ser el referent als habitatges del

aquesta ocasió, l'AVV de Sant Antoni de Llefià es va posicionar al costat de l'Ajuntament. 1889 Revista de Badalona, 13-7-1983, p. 8.

1890 Pol Ferran: “Las obras para mejorar Sant Roc, a punto de paralizarse”, El Correo Catalán, 23-21980.

1891Felipe Guerrero: Sant Roc: 25 anys de lluita, p. 20.

1892 M. Castellón: “La Immaculada precisa un colegio en condiciones”, La Vanguardia, 23-4-1980.

1893Pol Ferran: “Inmaculada: Quieren zona verde en el único solar libre”, El Correo Catalán, 3-41980.

1894 Pol Ferran: “Mil toneladas de basura a 200 metros de las viviendas”, El Correo Catalán, 28-21980. 
Patronato Municipal de la Vivienda de Renta Limitada. Aquest organisme estava en fallida econòmica per uns deutes acumulats durant els darrers Ajuntaments franquistes i sobre ell estava l'amenaça d'embargament dels mateixos habitatges. A aquest fet s'afegia el de les ocupacions que van fer nombrosos veïns al barri de Sant Roc d'uns blocs, els del Maresme, que estaven buits i on s'havien comés nombroses irregularitats en la seva concessió. L'actitud de l'Ajuntament va ser, per una banda, denunciar als antics gestors del Patronat, en concret als ex-Alcaldes Alfonso Ramos, Isidro Caballeria, el difunt Felipe Antoja i al regidor Guillen Clapés ${ }^{1895}$. I per altra intentar revertir la situació augmentant les amortitzacions o quotes als inquilins. Això va provocar un important conflicte amb els habitants dels polígons de Sant Antoni de Llefià i del Maresme (Sant Roc) amb amenaces de desnonament incloses, fet que ma motivar protestes veïnals com les que van protagonitzar 700 veïns d'ambdós polígons manifestant-se tallant el trànsit el 6 d'abril de $1981^{1896}$, a més d'un impagament organitzat de quotes. Amb els primers es va arribar a un acord $^{1897}$, però amb els segons el litigi va arribar als tribunals que finalment van fallar a favor dels veïns, si bé el conflicte no es va acabar de tancar del tot ${ }^{1898}$. La situació de la urbanització de La Vallensana a cavall entre Badalona i Montcada també va provocar alguna protesta dels seus habitants per conservar-la en estar situada en uns terrenys de parc forestal ${ }^{1899}$. A tots aquests fets cal sumar, a nivell de ciutat, les mobilitzacions que es van començar a fer per la preservació de l'espai de Montigalà, amenaçat per un projecte d'urbanització que ja venia de lluny ${ }^{1900}$. Finalment l'Ajuntament va signar uns acords amb els propietaris dels terrenys, la

1895Querella de D. Mario Diaz Bielsa, Alcalde-Presidente de Badalona, contra D. José Guillen Clapés y otros, por delitos de estafa, apropiación indebida y malversación de fondos públicos" (7-41981), AHGCB, Gobernadores Civiles. Caja 665. CG: 39. Ayuntamiento de Badalona 1979-1982. Veure nota 1654.

1896 “Protestas contra el Patronato de la Vivienda”, El Periódico de Catalunya, 8-4-1981.

1897"Badalona: 600 viviendas se salvan de un embargo. Acuerdo entre los vecinos de San Antonio y el Patronato de la Vivienda", El Periódico de Catalunya, 4-7-1981.

1898Ja vaig fer un esment d'aquest conflicte a l'apartat 4.5, en concret a la nota 1596. Veure també i "Badalona: no hi hauran desnonaments. Sentencia a favor dels veïns del Maresme", Diario de Barcelona, 16-1-1983.

1899Jordi Martí: “Manifestación por una urbanitzación ilegal a Badalona”, El Periódico de Catalunya, 1-12-1982. Al final però es va arribar a un acord per que els seus habitants utilitzessin els seus habitatges durant 75 anys. Veure "Badalona: acuerdo para la urbanización la Vallensana", El Noticiero Universal, 11-3-1983.

1900 En les primeres mobilitzacions es va comptar fins i tot amb el suport de l'Ajuntament. Veure: Enric Giralt: "El alcalde estuvo en la ocupación de Montigalá", El Periódico de Catalunya, 15-51979. 
Generalitat i la CMB contemplant una densitat d'urbanització molt menor que la inicialment projectada ${ }^{1901}$.

Però els conflictes veïnals més sonats es van donar més endavant, quan ja s'havia produït un canvi polític important a l'Ajuntament. A les eleccions del 8 de maig de 1983 el PSC-PSOE va superar al PSUC en vots a Badalona. Sens dubte es van veure beneficiats pels efectes de la victòria socialista de les eleccions generals d'octubre de 1982, però també pels problemes interns del PSUC -la seva escissió-, fins al punt que els vots del PSUC sumats als del PCC encara superaven per poc als obtinguts pels socialistes ${ }^{1902}$. Tanmateix les relacions entre PSUC i PSC-PSOE s'havien deteriorat molt durant el darrer any de pacte municipal i durant la campanya electoral. De manera que la reedició del "Pacte de Progrés" va ser pràcticament impossible. Des del PSUC es van posar unes condicions molt dures per fer-ho:

"Al principio de las elecciones yo era partidario de pactar con el PS porque habíamos estado gobernando 4 años (...) hubo gente que dijo que no, que había que poner una condición (...) algo que los socialistas no podían aceptar de ninguna manera (...) que el alcalde tenía que seguir siendo Marius." ${ }^{1903}$

El mateix Màrius Díaz em matisava -parcialment- aquesta afirmació:

"Eeehh, en el moment inicial que havia opcions... nosaltres l'Alcaldia, i vosaltres Hisenda, tal tal... o Vosaltres l'Alcaldia i nosaltres Hisenda... Lo que nosaltres us oferim i dieu no, doncs doteu-lo vosaltres i diem si. Aquest és el tema... L'acord... hi han 14 àrees per dir algo. Alcaldia, que és la que tria més... i 7 àrees... quines... estem d'acord? Doncs... de les 7 àrees... tu ja has triat la primera ara trio jo, de les set àrees nosaltres volem aquesta... de dos en dos, de una en una o de tres en tres... com vulguis... I així es fa una negociació, tu tens una cosa, jo tinc una altra... la vols tota? Tant... no, però si tu tens una altra que igual per mi puc dir-te lo mateix (...) vale, jo te la compro... això és una negociació. I no van haver-hi converses pràcticament... O sigui... sense parlant-se... jo no vaig parlar mai amb el Blanch..." 1904

1901En Joan Blanch i Rodríguez, aleshores Primer Tinent d'Alcalde, ho argumentava en un article: "Montigalà-Batllòria y la Badalona nueva", El Periódico de Catalunya, 24-8-1982. L'assumpte es va complicar amb la fallida de Banca Catalana, que era una de les propietàries dels terrenys $\mathrm{i}$ que l'Ajuntament va intentar comprar. Veure Jordi Martí: "Badalona quiere Montigalá-Batlloria para el Municipio", 11-11-1982.

1902 Veure els resultats a la gràfica de la p. 622.

1903Entrevista amb Manuel Armentero Molina, 10-4-2010.

1904Entrevista a Màrius Díaz Bielsa, 28-6-2013. 
Mentre que Joan Blanch, el que va ser Alcalde a partir de maig de 1983 pel PSC-PSOE argumentava que havia estat aquesta intransigència el que havia impedit el pacte:

\begin{abstract}
"Les relacions es van tensionar quan nosaltres vam guanyar (...) no van acceptar la derrota. El PSUC no ho va acceptar. Hi havia dirigents molt tancats a Badalona en aquella època, el mateix Màrius Díaz era un home molt tancat políticament (...) . I van intentar capgirat la derrota que havien tingut." ${ }^{1905}$
\end{abstract}

Però el cert és que el PSC-PSOE també tenia els seus motius. Havia apostat clarament des de feia temps en fer una política de sorpasso al PSUC. Al mateix any 1983 també havia trencat amb el PSUC a la Diputació i poc després hi pactava amb CiU, fet que es repetirà un any després a Badalona. Sigui com sigui, va haver-hi una forta tensió política entre ambdues forces, fins al punt que el dia de la proclamació de Joan Blanch com a Alcalde amb els 12 vots del PSC-PSOE, en sortir al balcó va ser xiulat i increpat per un grup de persones ${ }^{1906}$. Poc després de la presentació del nou cartipàs municipal, el PSUC va fer una nova proposta de pacte municipal amb condicions mes assumibles, però aquesta va ser refusada pels socialistes ${ }^{1907}$. El tarannà del PSC-PSOE es va veure aviat amb la destitució del director de Radio Ciutat de Badalona, Silvestre Ramon i la seva substitució per Paloma Soler. Desiderio León, regidor socialista i president del Consell d'Administració de RCB, va intentar justificar aquest cessament amb arguments tècnics però a ningú se li escapaven que els motius eren polítics ${ }^{1908}$.

Aquells anys l'atur va arribar al les xifres més altes, i aquest fet, juntament amb altres factors, van fer créixer la conflictivitat (si bé cal dir també que durant aquells anys es va anar estenent la prestació per desocupació, una seguretat social universal i una escolarització més efectiva, fets que sens dubte van esmorteir l'impacte de la crisi). Un factor que cal tenir en compte és que diverses formacions

1905Entrevista amb Joan Blanch Rodríguez, 14-7-2010.

1906Sergi L. Egea i Jordi Martí: "Abucheo al alcalde Blanch en Badalona”, El Periódico de Catalunya, 25-45-1983.

1907Joan Villarroya (dir.): Història de Badalona, p. 239.

1908 “Nova etapa a Radio Ciutat de Badalona”, Revista de Badalona, 30-9-1983, p. 16-17. En aquest article s'entrevistava a Silvestre Ramon i a Ferran Bello, que exposaven les seves opinions al respecte. El mateix Silvestre Ramon adreçava un escrit, desmentint les justificacions exposades per Bello i apuntant cap a la motivació política. Revista de Badalona, 14-10-1983, p. 13. 
polítiques van apostar per l'impuls de determinats moviments de protesta contra la gestió de l'Ajuntament socialista. Entre aquestes estaven el MCC i el PCC -que també havien apostat per reactivar el moviment veïnal-. El PSUC, un cop desfetes les possibilitats de pacte amb el PSC-PSOE, van afegir-se a una política de confrontació amb el consistori ${ }^{1909}$. Els primers van donar-se ja a finals de 1983. La instal-lació a Pomar d'un centre comercial de la multinacional Makro va enfrontar a la Unió de Botiguers, CCOO i veïns del barri amb la multinacional i l'Ajuntament, si bé cal tenir en compte que el permís per instal·lar-se l'havia concedit l'anterior govern municipal ${ }^{1910}$. Per altra banda, també es va revifar el conflicte amb els veïns del Polígon del PMV del Maresme que van ocupar el 2 de desembre de 1983 l'ambulatori de Sant Roc, quan es van fer noves demandes de desnonament per part de l'Ajuntament ${ }^{1911}$.

1984 va començar amb mobilitzacions dels comerciants i també veïnals per la qüestió de la inseguretat ciutadana. Recordem la mort de Núria Cardona al Parc de les Palmeres al 27 de desembre de 1983 i el d'un adroguer el 6 de febrer de 1984. Al mes de març veïns de Pep Ventura s'oposaven a la instal·lació d'un jutjats en un entresòl ${ }^{1912}$. A començaments de juny s'aprovava el PERI de Montigalà amb l'abstenció del PSUC, ja que s'havien introduït modificacions respecte els acords dels anys anteriors. Les reivindicacions per conservar Montigalà en la seva totalitat com a zona verda o parc forestal van reactivar-se, impulsades per entitats com la FAVB i partits com el MCC i amb el lema "Montigalà per al poble". El mes de juny va haver-hi algun conflicte laboral amb els ATS dels dispensaris de Sant Roc i Pomar. El mateix mes un grup de joves de la Vocalia de Sant Mori de Llefià denunciava a la Guàrdia Urbana per maltractaments ${ }^{1913}$. La reclamació feta per part de l'Ajuntament

1909Unes interessants reflexions autocrítiques d'un militant del PSUC es poden veure a Enric Giralt: "El PSUC reconeix els seus errors. Emili Muñoz: “S'ha de tornar a la societat i a les fàbriques"”, Revista de Badalona, p. 10-11.

1910Enric Giralt: "Protestes de CCOO i dels veïns de Pomar. L'obertura del Makro pot ser conflictiva", Revista de Badalona, 21-10-1983, p. 3, i del mateix autor "El "Makro ja ha obert", Revista de Badalona, 28-10-1983, p. 5.

1911Jordi Martí: "Ocupación de un ambulatorio por cinco deshaucios", El Periódico de Catalunya, 312-1983.

1912Aquests esdeveniments els vaig comentar a ja l'apartat dedicat a la crisi econòmica i a la delinqüència, així com l'us alarmista i electoralista que es va fer.

1913 Jordi Martí: "Els ATS dels dispensaris de Pomar i Sant Roc enfrontats amb l'Ajuntament", Revista de Badalona, 1-6-1984, p. 4 i "Un grupo de jóvenes denuncian a guardias de Badalona", El Periódico de Catalunya, 15-6-1984. Les denúncies contra l'actitud repressiva de la Guàrdia Urbana s'accentuaran en aquest període i tindran el seu màxim exponent -com 
davant el Govern Central d'incloure Badalona dins de les noves Zones d'Urgent Reindustrialització (ZUR), fet que es va aconseguir el 1985, i la creació al mes d'agost d'un Consell Econòmic i Social a la ciutat no van ajudar a rebaixar la tensió ${ }^{1914}$.

Entretant, també es van produir importants esdeveniments polítics a nivell local. Joan Blanch oferia un pacte municipal tant al PSUC com a CiU, si bé aviat va quedar prou clar que l'oferta es feia sobretot als convergents. L'oferta va ser feta poc abans de les eleccions autonòmiques que van donar la majoria absoluta a CiU al Parlament de Catalunya. Mentre que a nivell català el cas Banca Catalana enfrontava a PSC-PSOE i CiU -un enfrontament que curiosament no els va impedir pactar per governar la Diputació de Barcelona- l'alcalde de Badalona va fer unes manifestacions públiques donant suport a Jordi Pujol ${ }^{1915}$. "Casualment", poc dies abans els socialistes havien perdut una votació a l'Ajuntament quan PSUC i CiU van presentar una moció contra el pregó que va fer Pasqual Maragall a les "Festes de Maig"1916. I també "casualment" poc després de les declaracions de l'Alcalde badaloní CiU votava a favor dels pressupostos municipals -el PSUC votava en contra i l'únic representant d'AP s'abstenia ${ }^{1917}$-. El que estava en boca de tothom, la possibilitat d'un pacte municipal entre PSC-PSOE i CiU es va plasmar definitivament el 28 de novembre amb la signatura oficial d'aquest. Convergència s'incorporava a l'equip de govern assumint dues àrees de nova creació: Cultura, joventut i esports i Programació, estadística i lleves. Alhora Josep Serra Aloy era nomenat tercer Tinent d'Alcalde ${ }^{1918}$. Com era d'esperar, aquest pacte va ser valorat molt negativament per les forces d'esquerra de la ciutat. Dins els plens es van viure moments de molta tensió per l'oposició feta pel PSUC, però va ser al carrer on aquest malestar es va manifestar de manera més viva.

veurem- en els fets de la Plaça Trafalgar.

1914“El Barcelonès Nord reclama reindustrialització urgent”, Avui, 7-7-1984 i Enric Giralt: "El Consell Econòmic i Social de Badalona", Revista de Badalona, 21/24-8-1984, p. 7.

1915“El alcalde socialista de Badalona apoya a Pujol”, El Correo Catalán, 2-7-1984.

1916"Voto municipal contrario a los socialistas de Badalona", El Noticiero Universal, 2-6-1984 i Jordi Martí: "Moción en Badalona contra un pregón que hizo Maragall", El Periódico de Catalunya, 26-1984.

1917Jordi Martí: "Aprovat el Pressupost Ordinari de 1984, amb els vots a favor de socialistes i convergents, el vot en contra dels comunistes i l'abstenció d'Alianza Popular", Revista de Badalona, 10-7-1984, p. 10-11.

1918Joaquima Utrera: "El pacte municipal entre socialistes i convergents és un fet", Revista de Badalona, 30-11-1984, p. 5 i Joan Villarroya (dir.): Història de Badalona, p. 239. 
Sigui com sigui, el moviment veïnal badaloní es va començar a reactivar en aquest període. A la presència de gent provinent del PCC i d'altres partits de l'esquerra radical com el MCC i també en menor mesura la LCR en determinades associacions reivindicatives, ara s'hi sumaran les persones que encara militaven al PSUC. Això, juntament amb la crisi econòmica que estava causant estralls a Badalona amb taxes d'atur superiors al $30 \%$, les polítiques que va implementar l'Ajuntament socialista-convergent i un context propici a les mobilitzacions com va ser la campanya Anti-OTAN que aleshores estava en el seu moment àlgid, posaven els ingredients per uns anys més convulsos socialment.

La FAVB de Badalona des de 1979 havia caigut en una etapa de languidesa fins al punt que a efectes pràctics només existia de nom. Tot i que a inicis dels vuitanta s'havia creat alguna nova associació ${ }^{1919}$, no va ser fins l'any 1984 que la FAVB es va reorganitzar. Ja abans la conflictivitat havia anat creixent. A l'octubre de 1984 es van produir vages a l'empresa TUSA, que ja havia experimentat altres vagues a l'any 1983 i a gener de 1984. Al novembre va haver-hi una manifestació contra l'OTAN i al desembre una altra per l'ensenyament el dia 4 on van participar 5.000 persones.

I en aquesta reorganització o refundació de la FAVB van tenir un especial protagonisme persones provinents del PCC i el MCC fins al punt que tal com ja he dit el President Julio Molina militava al primer partit i a l'AVV La Immaculada-La Pau i el Vicepresident Antonio Agudo ho feia al MCC i a l'AVV Sant Antoni de Llefià. Així, el mes de desembre pràcticament es refundava la FAVB gràcies a l'impuls que havien fet feia mesos les AVV's de La Immaculada (La Pau), Juan Valera, Bonavista, Sant Mori, Pomar i Canyadó i que finalment va agrupar a 21 Associacions de les 34 existents a la ciutat, i que es van inspirar en el model de coordinació que feia temps havien establert les Associacions del barri de Llefià.

El procés es va fer públic el 15 de desembre, juntament amb un pressupost de quatre-centes mil pessetes i un programa de reivindicacions de 44 punts entre els quals destacaven: la demanda de que les AVV's fossin considerades entitats de

1919Veure nota 1853 per les noves AVV's creades a inicis dels 80. Fins a final de la dècada no es van crear de noves com la de Can Solei (1988), Fondo Sistrells (1989) [crec que aquesta ja existia abans per que n'he trobat referències al 1983], Progrés (1990) i Nova Lloreda Nord (1990). Josep Baeza: Associacionisme veïnal a Badalona..., p. 29. 
interès públic i que la Federació tingués dret a paraula als Plens; que l'Ajuntament ajudés a la FAVB per dotar-se d'una infraestructura i mecanismes bàsics pel seu funcionament; que l'Ajuntament demanés un informe a les AVV's abans de l'obertura de qualsevol indústria, establiment o fira; que es potenciés el transport públic amb noves línies, el perllongament de les actuals i la creació d'una xarxa de micobusos i que l'Ajuntament s'oposés a la supressió d'algunes que volia fer l'empresa TUSA. Pel que fa a la sanitat s'exigia l'obertura de nous CAP's a Sant Roc, Pomar i Llefià, així com la construcció d'un centre de Pediatria, d'un Geriàtric així com de nous Centres de Planificació Familiar. A nivell de l'ensenyament es demanava que cap nen quedés sense plaça escolar, la coordinació entre AVV's i AMPES i l'assumpció per part de l'escola pública de la xarxa d'escoles de la CEPEC, així com que les instal-lacions escolars poguessin ser aprofitades per les entitats dels barris i el suport i creació de més Escoles d'Adults. Tanmateix, també s'exigia acabar amb els romanents de barraquisme encara existents així com crear una xarxa anti-desnonaments ${ }^{1920}$. Des d'aquell moment i sobretot del 1985 en endavant la FAVB es va convertir en un dels principals impulsors de reivindicacions a la ciutat.

L'any 1984 va acabar amb un nou acord entre l'Ajuntament, la CMB i al Generalitat sobre la urbanització de Montigalà, per on també havia de passar el segon cinturó de ronda (el que avui és la B-20). El Pla Especial de Montigalà es va ratificar en un ple molt tens el dia 28 de febrer de 1985. De seguida algunes associacions com la de Sant Crist es va posicionar en contra d'aquest i poc després la FAVB, el PSUC, el PCC, el MCC, CCOO i el "Col·lectiu Montigalà" signaven un manifest contra el projecte d'urbanització de Montigalà Batllòria. En aquell moment la societat "Montigalà S.A." comptava amb el $92 \%$ de la propietat del territori i estava participada un $45 \%$ per Banesto i un altre $45 \%$ pel Fons de Garantia de Dipòsits, que havia assumit l'antiga participació de Banca Catalana. Les entitats signats reclamaven que:

"1r.- La paralització de la tramitació i aprovació final del PERI de Montigalà aprovat recentment pel Govern Municipal socialista-convergent amb la finalitat de no

1920 Joaquima Utrera: "La Federació d'Associacions de Veïns o El ressorgir del moviment associatiu a Badalona", Revista de Badalona, 14-2-1984, p. 18-19 i "Veïns de Badalona constitueixen una Federació" Avui, 19-12-1984. 
consolidar uns acords aconseguits en unes circumstàncies completament diferents i menys favorables."

2n.- La negociació amb el Fons de Garantia de Dipòsits de l'adquisició per part de l'Ajuntament de la propietat que fou de Banca Catalana en el mateix.

3r.- El replantejament del Polígon en el seu conjunt en el sentit de millor rendiment públic i social tant per a la Badalona actual com per la del futur." ${ }^{1921}$

Aviat se sumarien els comerciants a aquesta reivindicació, per que s'oposaven a la instal-lació d'hipermercats al mateix polígon ${ }^{1922}$. Però va ser un conflicte amb el transport públic el que va fer posar el nom de Badalona i més en concret el del barri de Pomar, en boques de moltes persones aquest any 1985.

El mes d'abril, per fi, arribava el metro a Badalona, mitjançant un allargament de la Línia 4 després de molts anys d'espera ${ }^{1923}$. Coincidint amb aquest fet es va reestructurar el servei d'autobusos. La línia BS-TP, que unia -amb servei diürn i nocturn- el barri badaloní de Pomar amb el centre de Barcelona (carrer Trafalgar, passant pel Poble Nou on treballava molta població del barri) va ser modificada suprimint la part final del seu recorregut, finalitzant el seu trajecte sense arribar al populós barri badaloní. Aquest tram va ser substituït per un altre autobús que enllaçava Pomar amb la nova línia de metro i Llefià (el "4") i per un altre que anava a Barcelona ("B-25"), però només fins a la plaça de les Glòries. Aquests autobusos només funcionaven en horari diürn. Pomar, com ja hem vist, era un antic barri de l'OSH que encara estava força aïllat i que havia estat protagonista de importants lluites veïnals durant els anys setanta, com va ser l'impagament de les quotes fins que no s'arreglessin les deficiències dels pisos i del barri (de fet, als vuitanta encara no es pagaven les quotes i no va ser fins el mateix any 1985, quan ADIGSA es va fer càrrec del barri, que no es va començar a regularitzar la situació) ${ }^{1924}$. Amb una taxa 1921CCOO, Federació d'Associació de Veïns, PCC, PSUC, MCC i Col·lectiu Montigalà: "Per la recuperació de Montigalà" (20-3-1985), MB-AHCB, Fons Col-leccions Factícies, Caixa C19, Carpeta Comunicats Diversos.

1922 Jordi Martí: “El Plan de Montigalá ya tiene luz verde”, El Periódico de Catalunya, 19-12-1984; "Aprobado el PERI de Montigalà en Badalona", El Noticiero Universal, 15-3-1985; Antoni Castellà: "La Associació de Veïns de Sant Crist, contra l'aprovació del PERI Montigalà-Batllòria", Revista de Badalona, 15-3-1985, p. 4;Toni Soler: "Ple Municipal” Eco Badalonés, 8-3-1985 i “Los comerciantes de Badalona se oponen a la instalación de hipermercados en Montigalà", La Vanguardia, 25-9-1985.

1923Julian Felipo: “Badalona, Sant Adrià i Barcelona ja són unides pel metro”, Revista de Badalona, 23-4-1985, p. 4-5.

1924Carles Mas: El Pomar. Badalona, p. 55-56. L'AVV de Pomar va tenir una important tasca en anar 
d'atur al voltant del $35 \%$ i encara força mancat d'equipaments, una part important de la seva població treballava a Barcelona així que la indignació del barri va ser molt gran ja que per fer el trajecte que abans es feia amb el BS calia agafar ara dos transports i pagar dos bitllets (aleshores s'estava molt lluny de l'existència de "bitllets integrats") a més del perill de quedar aïllats per la nit en no tenir les noves línies un servei nocturn.

L'AVV del barri, havia tingut molt protagonisme als anys 70, amb una important presència d'una potent comunitat cristiana de base i militància del PSUC -i inclús algú del PSC-. Sobre l'any 1983 o abans, segons un dels nostres testimonis, van incorporar-se a la Junta gent provinent del PCC quan es van fer unes eleccions:

“Entonces entremos todos gente del partido. Empezamos trabajando aquí en el barrio y tal. Intentamos alguna lucha más que no dio resultado como por ejemplo cuando nos quitaron el dispensario por la noche intentamos movilizar a la gente porque nos quedábamos sin ningún servicio de urgencias y todo el fin de semana... Y nada, la gente no acudía (...). Sin embargo, cuando pasó lo de los autobuses la gente se volcó cada vez a más, a más, a más y fue una movida impresionante."1925

\begin{abstract}
Això va ser una decisió política conscient:
"Y entonces se dice: bueno, la Junta que hay en la Asociación de Vecinos es poco reivindicativa, es tal y pascual, vamos a intentar... Y como no se podía llegar a acuerdos tampoco con ellos para hacer una... una Junta así amplia y esto... que eran bastante cerraditos por lo que decían, eh? Pues hacemos una lista alternativa y cuando se hace la asamblea general anual o cuando se hiciera (...) pues nos presentamos y la gente nos votó." ${ }^{1926}$
\end{abstract}

Ja abans l'AVV havia intentat mobilitzar, amb menys èxit, a la població per evitar perdre el servei d'urgències existent als horaris nocturn i de cap de setmana.

bloc per bloc explicant el pacte que es va arribar amb ADIGSA per les reparacions i recollint $\mathrm{i}$ presentant tota la documentació pertinent.

1925Entrevista a Maite Torelló Galdón (amb Carmen Díaz Bermejo), 16-12-2013. La primera era veïna, militant del PCC i membre de la Junta de l'AVV de Pomar aleshores. La segona era una veïna sense militància política de carnet però implicada en la lluita dels autobusos. Curiosament, totes dues han seguit un procés invers de despolitització/politització i mentre la primera ara no té una militància activa la segona actualment està a EUiA i al Grup de Dones del barri. En la Junta d'aleshores apart de Maite Torelló, el seu marit José Sánchez també era del PCC, al igual que el President, Jacinto Tobeña, i altres membres com José Banús, Antonio Casas i José Rodríguez (així ens ho va dir ella mateixa).

1926Entrevista a Maite Torelló Galdón (amb Carmen Díaz Bermejo), 16-12-2013. 
Però com deia la mateixa entrevistada, això dels autobusos va ser la gota que va fer vessar el got. Així el dilluns 21 d'abril un nodrit grup de manifestants es concentrava davant de l'Ajuntament exigint el retorn del BS a Pomar i s'entrevistaven amb l'Alcalde Blanch sense treure cap compromís concret. El mateix dia alguns grups de veïns agredien amb pedres diversos dels nous autobusos de TUSA -acció rebutjada per l'AVV de Pomar- i un altre grup retenia dins de les cotxeres de la mateixa empresa una vintena de vehicles. El 24 d'abril les protestes pujaven d'intensitat. Grups de veïns i veïnes van fer nombrosos talls de trànsit mentre grups de dones, recuperant els mètodes de la dècada anterior, es dedicaven a segrestar autobusos de la línia BS-TP i els obligaven a pujar a Pomar $^{1927}$. Les protestes es van estendre a les altres localitats del Barcelonès Nord per que també es van suprimir altres autobusos ${ }^{1928}$. Així ho recordava una de les protagonistes de Pomar:

"MAITE TORELLÓ: Se decide que vayan mujeres para evitar que haya enfrentamientos con la policía (...) tal y cual... Entonces bajamos dos grupos y unas nos quedamos en Pep Ventura que fue donde lo cogí yo. Que yo era la única mujer de la Asociación de Vecinos (...) de la Junta solo estaba yo. Y fui la que le dijo al señor, (...) 'bueno, cuando llegue usted al final, en vez de parar en el final por favor nos sube hasta Pomar que queremos ir hasta Pomar'. Y nos dijo: 'no te preocupes, que yo te subo hasta Pomar!'. Porque los conductores...

CARMEN DÍAZ: ¡Estaban muy cabreados!

MAITE TORELLÓ: ¡Claro! Era su lucha también (...) les reducían a ellos servicios. Y al final salieron perdiendo también porque metieron a la TUBSAL que era privada y cargarse a líneas que eran públicas...."1929

Va haver-hi alguns intents de negociació per solucionar el conflicte i l'Ajuntament va rebaixar les tarifes de les noves línies i va posar un servei provisional nocturn que unia el final de la nova línia BS-TP amb Pomar, però els veïns volien el restabliment de l'antic recorregut i les mobilitzacions no es van aturar. Les manifestacions es produïen de manera diària i els segrests d'autobusos

1927 "Secuestro y apedreamiento de autobuses por la reordenación del transporte de Badalona" i

"Un herido en Badalona durant la protesta por el autobús BS", La Vanguardia, 24 i 25-4-1985;

"Apedreguen els autobusos al barri badaloní de Pomar" i "El barri de Pomar incomunicat des de fa tres dies", Avui, 24 i 25-4-1985.

1928El Periódico de Catalunya, 24 i 25-4-1985.

1929Entrevista a Maite Torelló Galdón i Carmen Díaz Bermejo, 16-12-2013. 
continuaven. Amb la implicació de tanta gent -fins i tot des de l'Escola d'Adults del Barri s'encoratjava a la lluita, ens explicava Carmen Díaz- es va fer necessari crear nous organismes per que la mateixa AVV no donava a l'abast, i també per evitar el perill de que amb tanta gent mobilitzada cadascú hi anés a la seva:

"MAITE TORELLÓ: Al final des de la Asociación de Vecinos tuvimos que hacer una especie de Comité más amplio (...) para mantener unido al barrio.

CARMEN DÍAZ: Porque habían dos o tres (...)

MAITE TORELLÓ: Como convocatorias... a lo mejor ibas tu con la gente que mi marido iba con el coche en cabeza con la megafonía... subías para arriba para manifestarte delante del Ayuntamiento y resulta que pasabas por debajo de la autopista y el grupo del final resulta que decía que: 'ahora vamos a cortar la autopista'. Y se iban un grupo y cortaban la autopista. No te dabas cuenta... Y después venían y los habían ostiao y ¡que malos éramos porque nos habíamos ido!”1930

La situació es va enverinar més quan des de l'Ajuntament intentaren desprestigiar les mobilitzacions populars argumentant, vagament, que no tenien raó de ser. Igualment l'equip de govern municipal va acusar al PSUC i al PCC d'estar manipulant als veïns i d'incitar a actes violents, arribant a fer declaracions com aquesta nota presentada pel Consell de Federació del Barcelonès Nord del PSCPSOE:

“(...) denuncia ante la opinión pública la actuación irresponsable de partidos políticos como el PCC, el PSUC y otros que han tergiversado la realidad y la información dada por las corporaciones municipales (...) en lugar de crear soluciones a los problemas de los vecinos, han procurado agravarlos utilizándolos con fines partidistas, fomentando desórdenes públicos que quieren ser presentados como movilizaciones ciudadanas y confundiendo oposición con terrorismo político."1931

Declaracions d'aquest tipus encrespaven més els ànims de la gent, ja de per si prou caldejats. Finalment també la FAVB de Badalona es sumava a la protesta i va donar suport al veïnat de Pomar. Les mobilitzacions es van intensificar produint-se

1930Entrevista a Maite Torelló Galdón (amb Carmen Díaz Bermejo), 16-12-2013. El testimoni reflecteix que a les manifestacions hi devia participar molta gent.

1931 “Polémica política a Badalona por la supresión de autobuses", El Periódico de Catalunya, 30-41985 i "Los barrios de Badalona enlazados por autobuses", El Correo Catalán, 1-5-1985. En aquest darrer es recollien unes declaracions de l'Alcalde Joan Blanch que s'assemblaven molt a les ciutades o in fins i tot arribava a dir que es coaccionava a la gent per que anés a les manifestacions. 
manifestacions diàries dels habitants del barri. El dos de maig una manifestació de 2.500 persones impulsada per la FAVB arribava a la Plaça de La Vila després de paralitzar tot el Centre de Badalona i intentava entrevistar-se amb l'alcalde sense èxit, i davant d'això, es va envoltar l'Ajuntament i no es va deixar sortir ningú durant una estona. Mentrestant que els segrestos d'autobusos continuaren fins al punt de que a Pomar van estar retinguts i custodiats pels veïns catorze vehicles. Es va establir un servei de vigilància de dia i nit pel veïnat per vigilar que no vinguessin a emportar-se els autobusos i alhora que ningú els fes malbé.:

"Yo me acuerdo tenía dos turnos. Por la mañana me levantaba a las cuatro, y me iba hasta las siete y cuarto o así que me subía a levantar a los niños para llevarlos al colegio. Y llevaba los termos de café con leche. Y luego por la tarde me iba a las seis o así, cuando ya se recogían los niños, dejaba la merienda preparada, dejaba la cena medio organizada... Me bajaba, a las nueve subía, les daba de cenar y me bajaba luego hasta las once [riu] ${ }^{m 932}$

En un barri d'aproximadament deu mil habitats es van recollir cinc mil signatures de suport que intentaren portar a l'Ajuntament i al Governador Civil Ferran Cardenal. 14 entitats culturals i cíviques de Pomar donaven suport a aquesta acció, entre les quals es trobava apart de l'AVV la parròquia de Sant Sebastià de Pomar. Altres parròquies d'altres barris badalonins com Morera, Bufalà, Sant Roc, Lloreda, Sant Antoni de Llefià (el rector d'aquesta Joan Cuadrench, havia estat a Pomar als anys setanta) donaven suport també a les mobilitzacions ${ }^{1933}$.

El dia 2 de maig a la matinada va haver-hi un primer intent per part de la policia de recuperar els autobusos, però la ràpida mobilització veïnal ho va aconseguir impedir:

"Pues la primera vez vinieron y bueno es eso... ya tenías gente vigilando y la megafonía en el coche de mi marido (...) es que además fue algo bestial, porque mi marido salió zumbando con el coche con la megafonía llamando a los vecinos'¡iVecinos, vecinos, que viene la policía a llevarse los coches! (...) La gente corriendo en pijama pa abajo, en

1932Entrevista a Carmen Díaz Bermejo (amb Maite Torelló Galdón), 16-12-2013.

1933 Jordi Martí: "Persiste la lucha en Badalona para recuperar sus autobuses", El Periódico de Catalunya, 3-5-1985; "Los vecinos de Pomar retienen 14 autobuses de la linea de Badalona", El País, 3-5-1985; "Catorze autobusos segrestats pels veïns de Pomar", Avui, 3-5-1985; "Catorze autobuses secuestrados en el barrio de Pomar de Badalona", El Noticiero Universal, 3-5-1985. 
camisón (...) y bueno, en un momento se llenó todo aquello y la policía cuando vio lo que había allí dijeron ehhh vamos." ${ }^{1934}$

La policia va repetir l'operació al dia següent amb un desplegament molt més espectacular. La matinada del 3 de maig uns cinc cents policies assaltaven per sorpresa el barri i malgrat l'alarma que es va fer sonar des del campanar de l'església on es feia la vigilància nocturna aconseguien apoderar-se dels autobusos abans que els veïns poguessin reaccionar. Així ens ho explicaven algunes de les persones que ho van viure:

"Jo la nit aquella... Però es que lo bo del cas, molta gent no ho sap, es que abans de que hi hagués el merder, quan van dir que treien el TP, que era el que pujava, per que el metro arribava a Pep Ventura. Un grup de capellans, de rectors dels barris, vam anar a transports a la Plaça Lesseps, i els hi vam dir que era una animalada, que no ho fessin... 'Que no! (...) Això està planificat, està pensat (...)' Els hi vam dir 'penseu que això, la gent haurà d'agafar dos coses (...) però això els hi vem dir, eh? Els hi vam fer reflexionar a en els responsables de l'Àrea Metropolitana que eren els que portaven això. Els hi vam demanar una entrevista i no ens van fer cas. Després es va armar la que es va armar.

I la nit aquella, la nit que va venir la policia, jo ho vaig intuir. Vaig tenir com una mena de intuició de dir 'avui vindran!'. I jo estava a Llefià, els hi vaig dir a els companys... 'M'emporto un entrepà i no m'espereu per que aquesta nit si hi ha merder jo em quedaré'. I sí, si... aleshores estava ja per allà, amb els que... I va venir una moto, un periodista tu... 'no se que pasa aquí, pero ve una quantitat de policia! Necessito un lloc segur!'. Jo els enviava a tots al campanar. Aleshores la megafonia 'la megafonia, un lloc segur' al campanar! I tots van anar al campanar. Aleshores vaig obrir l'església per si hi havien corredisses que hi hagués un lloc per refugiar-se (...). I si si... Però el que passa és que no els hi va donar temps. Per que aleshores ja van començar a dir 'Veïns, veniu, baixeu, baixeu!'. La policia va arribar abans de que baixés... I es clar, es van posar allà al mig, els anaven agafant i separant... Vull dir que va ser (....."1935

“El Elias [no se segur si diu aquest nom] Trujillo, subió a la torre con el megáfono... ¡Vecinos, que se nos llevan los autobuses! (...) y era la una más o menos de la noche por ahí sería (...) que yo me levanté, salí corriendo y me entré una bata encima del

1934Entrevista a Maite Torelló Galdón (amb Carmen Díaz Bermejo), 16-12-2013

1935Entrevista a Joan Cuadrench, 7-4-2013. Tot i que als anys vuintanta estava adscrit a la parròquia de Sant Antoni de Llefià, durant un temps també va portar la parròquia de Pomar quan el seu vicari ho va deixar. Carrera coneixia el barri de Pomar per que ja hi havia estat a la parròquia de Sant Sebastià als anys $70 \mathrm{amb}$ Josep Torrella. 
camisón, cogí las zapatillas y perdí una por el camino (...) salí corriendo y llegando hacia la iglesia ya juntaban las manos y rompí las manos que casi me caigo de bruces de los policías, o no se habían agarrao todavía, creo que fui la última que pasó de cuando veníamos corriendo. Ya no pasó nadie más." ${ }^{1936}$

El mateix dia 3 en saber-se les notícies persones de Sant Adrià -on hi havia un conflicte similar- segrestaven quatre vehicles que foren conduïts a Pomar "en solidaritat". A continuació, i amb els ànims encrespats, un grup va intentar abocar un dels nous autobusos segrestats per un barranc, fet que al final va ser impedit pels mateixos veïns que van, fins i tot, tornar posteriorment els vehicles a l'empresa davant l'anunci de l'Ajuntament que s'avenia a entrevistar-se amb una comissió veïnal ${ }^{1937}$. S'establia una treva en les mobilitzacions per part de l'Associació de Veïns de Pomar i la FAVB en espera d'aquestes converses. Les negociacions es van iniciar el dia 6 de maig primer amb una comissió de veïns i després i després amb una tensa assemblea al barri on el mateix Joan Blanch va anar a explicar les seves propostes i es va endur un petit ensurt:

"El día de la asamblea aquí, cuando salió que lo tuvieron que sacar entre cuatro, ocho o no se cuantos, con el coche en la puerta de la iglesia... meterle en el coche y levantaron el coche en vilo y lo ponían boca abajo (...) tuvieron que venir a decir 'no tumbéis el coche que os llevarán presos' ipero le tenían en vilo! (...) Entró al coche y los guardaespaldas que llevara, y el coche lo levantaron por la parte esta de fuera, unos por abajo y otros por la parte de arriba y por la parte de la acera... ¡No se los tíos había cogiendo el coche, pero el coche lo levantaron del suelo! [riu]"1938

La solució que es va trobar va ser que un autobús de la TUSA fes el mateix recorregut que l'antiga BS (la nova B-25), amb servei nocturn inclòs, després que la CMB acceptés, també, aquests canvis. Tot i que la proposta no va ser del tot ben

1936Entrevista a Carmen Díaz Bermejo (amb Maite Torelló Galdón), 16-12-2013.

1937 Veure diversos articles: "Unos 400 policías toman Pomar y rescatan los autobuses" i "Tregua en la guerra del 'bus' de Pomar", El Noticiero Universal, 4 i 6-5-1985; Toni Soler: "Cop de ma policial per a rescatar els catorze autobusos segrestats" i "Veïns de Sant Adrià volien estimbar un autubús", Avui, 4 i 5-4-1985; Jordi Martí: "La policía recupera todos los autobuses de Badalona" i "Tregua en Badalona para recuperar el autobús BS", El Periódico de Catalunya, 4 i5-1985; Abel García: "La policía toma el barrio de Pomar para recuperar los autubuses", El Correo Catalán, 4-5-1985 i Joan García Riera: "La policía ocupó Pomar de madrugada y rescató los 14 autobuses retenidos por los vecinos" i Jaume V. Aroca i Jordi García Riera: "Los vecinos de Santa Adrià vuelven a secuestrar autobuses", La Vanguardia, 4 i 5-5-1985.

1938Entrevista a Carmen Díaz Bermejo (amb Maite Torelló Galdón), 16-12-2013. 
vista pel PSUC, que argumentava possibles conflictes amb la CMB i Transports de Barcelona i la debilitat de la TUSA per cobrir aquest servei, al final es va arribar a un acord amb aquesta solució entre l'Ajuntament, la FAVB de Badalona i la CMB el 7 de maig, sent ratificat pels veïns de Pomar el dia 8, posant fi a 18 dies de conflicte $^{1939}$. Els veïns del barri, tal i com havien fet contra l'OSH amb la lluita i la mobilització havien aconseguit una gran victòria, tot i que l'alcalde d'aleshores, en Joan Blanch, ens donava una visió diferent del perquè del conflicte i del seu final:

"El tema clau va ser que la majoria de la gent de Pomar venia de les cases barates del Port (...) hi havia molta gent que tenien relació amb l'origen, sobretot gent gran i aleshores es va produir una bossa de descontentament molt gran a Pomar, durant un temps... aquesta situació no la vam entendre (...) jo no la vaig entendre (...). La majoria d'aquella gent venia d'un puesto de Barcelona amb el que es comunicaven directament amb l'autobús (...). Hi havia una situació de crispació política pel trencament amb el PSUC i el PSUC aprofitava això per llançar-ho a tope, quan jo vaig prendre consciència que hi havia aquest tren de fons jo vaig canviar de criteri (...) aleshores la Mercé [es refereix a la Mercé Sala, Vicepresidenta aleshores de la CMB] no volia per que deia que no era racional (...). El conflicte es va solventar per que vam ocupar la Coorporació."1940

Tanmateix, a diferència del període anterior, aquesta victòria no acabaria tenint conseqüències polítiques en el sentit de debilitar i desprestigiar de manera irreversible el nou govern municipal del PSC i CiU, tal com havia esdevingut en el passat amb fets similars amb la corporació franquista. De fet ni els mateixos grups polítics als quals el consistori havia acusat d'instigar la proposta van treure uns rèdits polítics apreciables, si més no a nivell electoral. Però és important veure també que, de manera un tant paradoxal, una lluita victoriosa en comptes servir per enfortir l'Associació de Veïns sembla que la va acabar afeblint:

"La Asociación de Vecinos un poco se desmanteló, toda la gente que estaba dentro desapareció (...). Supongo que los que habían venido al calor de la lucha pues como ya se había terminado la lucha volvieron a sus cosas... no sé... y en la Asociación de Vecinos hubo gente que se quemó bastante (...) el Tobeña había dimitido, mucha gente estaban cansaos, estaban agotaos, estaban... Mi marido volvió a su tarea principal que

1939Abel Garcia: "Logrado el acuerdo de transporte para el barrio de Pomar" i "Los vecinos de Pomar ratifican el acuerdo", El Correo Catalán, 8 i 9- 5-1985; "Badalona: los vecinos apoyan la oferta municipal de que TUSA realice el trayecto de la línea BS" i "Pomar consiguió recuperar su autobús 18 días después de ser suprimido", La Vanguardia, 8 i 9-5-1985.

1940Entrevista amb Joan Blanch Rodríguez, 14-7-2010. 
era la sindical (...) Total, que me quedé yo con dos viejillos." ${ }^{1941}$

Aquí es deixa veure una de les principals diferències amb les lluites veïnals dels setanta. Si durant la dècada anterior les diferents mobilitzacions, encara que fossin per temes concrets, tenien un objectiu comú que no era un altre que acabar amb la dictadura, als vuitanta aquesta motivació ja no existia. Els conflictes es donaven per casos concrets i això podia passar factura a la mateixa associació quan aquests es tancaven (bé o malament). Aquesta gent que va restar a l'Associació va haver de acabar de resoldre tot el tema pendent dels pisos amb ADIGSA, malgrat que al principi no volien que aquesta es fes càrrec del barri. Volien gestionar les reparacions ells mateixos per por a que es fes clientelisme. Tot i que al final ho van haver d'acceptar, reconeixent que ADIGSA va donar millor resposta que el Ministeri (sense negar que també li van fer molta pressió per que es fessin les reformes).

El mateix any va haver-hi altres conflictes veïnals a la ciutat. A Lloreda s'havien succeït protestes i sabotatges contra la instal-lació d'uns jutjats dins una comunitat de propietaris ${ }^{1942}$, o la mobilització del veïnat d'Artigues i Llefià contra les molèsties de la fàbrica Rovira i Bachs ${ }^{1943}$, però va ser la pujada de l'impost de la Contribució Urbana la que va provocar diferents manifestacions al mes d'octubre i novembre convocades per la FAVB i amb el suport de CCOO, PSUC, PCC, MCC i fins i tot la Unió de Botiguers del Baix Besòs ${ }^{1944}$. Tot això mentre l'Ajuntament decidia augmentar, en alguns casos, fins el $40 \%$ els sous dels alts càrrecs municipals, mentre que als funcionaris i el personal i el personal contractat se'ls pujava el souen comparació- sobre un 6,5 i un $7 \%$ de mitjana ${ }^{1945}$. En un context de crisi 1941Entrevista a Maite Torelló Galdón (amb Carmen Díaz Bermejo), 16-12-2013. La persona que menciona era Jacinto Tobeña, president de l'AVV Pomar i també militant del PCC.

1942 Toni Soler: "Uns veïns inunden els locals que acolliran els nous jutjats" i "Continua la violència contra els nous jutjats", Avui, 14 i 15-6-1985.

1943 "Cortes de tráfico por una fuga en una fábrica de amoniaco", El Periódico de Catalunya, 20-71985; "Badalona: cortan la N-II en protesta por la presencia de una factoría química", La Vanguardia, 22-7-1985.

1944 “Manifestació a Badalona contra la contribució", Avui, 16-10-1985; "Manifestación en Badalona contra la subida de la contribución", El Periódico de Catalunya, 18-10-1985; Joaquima Utrera: "Les Associacions de Veïns es mobilitzen contra la Contribució Urbana (CTU)" i Margarida Ferràs: "L'Ajuntament no vol negociar el tema de la contribució", Revista de Badalona, 22-101985, p. 3 i 5 i Jordi Martí: "La contribució. No s'arriba a acords entre l'Ajuntament i els veïns", Revista de Badalona, 10-12-1985, p. 5.

1945 “El consistorio badalonés concederá elevados aumentos salariales a los cargos de confianza", El País, 31-10-1985 i "Críticas al aumento de un 40 por ciento del sueldo a los altos cargos municipales", La Vanguardia, 1-11-1985. Els directors de les diferents àrees municipals 
econòmica aquesta era una mesura fàcilment criticable per les organitzacions polítiques i socials que s'estaven enfrontant al govern local, i més en un moment on a la majoria de la població se li exigia moderació salarial i "sacrificis". En aquest mateix període es van accentuar les mobilitzacions contra l'OTAN on hi va haver una notable presència veïnal. 500 persones es manifestaven el diumenge 27 de novembre ${ }^{1946}$. La visita que el primer ministre suec Olof Palme va fer a Badalona el 14 de novembre també va transcórrer amb incidents al carrer i dins l'Ajuntament ${ }^{1947}$.

L'any 1986 no podia començar d'una manera més tensa, malgrat l'Ajuntament s'hagués vist beneficiat políticament per la posada en marxa del col-lector de Llevant (fet que va permetre recuperar la platja de Badalona per al bany) i l'enfrontament amb la CAMPSA per una taca de contaminació que havia causat el tancament provisional de les seves instal-lacions de vora el mar i l'abandonament definitiu al gener de $1986^{1948}$. L'Ajuntament s'apuntava també la recuperació per la ciutat d'uns terrenys sota jurisdicció militar situats al turó Caritg (popularment conegut com "los cañones") al març el nou any. Aquests fets, segurament van tenir la seva incidència en l'evolució de l'opinió que tenien els habitants de Badalona respecte l'Ajuntament. Però l'any 1986 va estar protagonitzat per un nou gran conflicte que va enfrontar al consistori socialista-convergent amb una part dels veïns i veïnes de la ciutat: el de la Plaça Trafalgar de Llefià.

El barri de Llefià havia estat un dels que havia tingut un moviment veïnal més fort a Badalona durant la dècada dels setanta. A inicis dels vuitanta havia patit una certa decaiguda, tot i que a inicis d'aquesta dècada s'havia establert una Coordinadora d'Associacions de Veïns de Llefià que posteriorment va servir de

passaren a percebre 223.000 pessetes brutes mensuals (abans alguns d'ells cobraven 154.344 pessetes i aquests eren els casos on la retribució havia pujat més, prop del $44 \%$ ). En altres casos, la pujada era menor, d'un $23 \%$ i d'un $9 \%$ com era el cas del càrrec de confiança que més cobrava del consistori badalonès: el director de serveis d'Urbanisme que va passar a percebre 230.186 pessetes brutes (abans cobrava 210.186). Certament, la mesura suposava posar "ordre" i establir uns sous en funció de categories quan abans sembla que hi havien tants sous com càrrecs. Però com les millores més evidents en els salaris les van tenir els "càrrecs de confiança" (aquells que són designats pels partits polítics del govern municipal), la mesura no deixava de ser polèmica i impopular.

1946Joaquima Utrera: “Crits contra l'OTAN van inaugurar l'hivern a Badalona," Revista de Badalona, 29-10/1-11-1985, p. 3.

1947 “La visita de Olof Palme provoca més tensions a l'Ajuntament”, Avui, 16-11-1985.

1948 “CAMPSA se retira de Badalona y deja la playa para la ciudad”, El Periódico de Catalunya, 15-11986. 
model per la FAVB. Aleshores hi havia entre 5 i 6 associacions veïnals al barri. Aquells anys va haver-hi -com ja he dit- protestes per conflictes urbanístiques heretats dels anys setanta, així com noves protestes com la que es va convocar el 2 de febrer de 1984 contra la inseguretat ciutadana (just un dia abans d'una vaga de comerços pel mateix motiu) on van participar entre 1.500 i 4.000 persones $^{1949}$. El mateix any 1984 s'havia revifat al maig la problemàtica dels blocs de la Sagrada Família i al novembre mestres i alumnes del col·legi "provisional" Rafael Alberti (un barracot mentre no es feia l'edifici definitiu) protestaven pel lamentable estat de la seva escola ${ }^{1950}$.

L'any 1985 es van posar els fonaments pel futur enfrontament al voltant de la urbanització de la Plaça Trafalgar i els terrenys que l'envoltaven. El problema ja venia de lluny ja que la plaça havia estat urbanitzada "provisionalment" pel primer Ajuntament democràtic per les pressions exercides per l'AVV de Sant Antoni de Llefià $^{1951}$, a espera d'un projecte de remodelació definitiu amb les noves possibilitats que oferia l'expropiació de la finca de Torre Mena. Aquest projecte, no obstant, es va endarrerir fins que el conjunt d'obres que s'estaven fent a l'àrea Metropolitana en previsió dels Jocs olímpics de 1992 va propiciar que la CMB aprovés el 18 de juliol de 1985 unes obres d'urbanització de la Plaça Trafalgar ${ }^{1952}$. El nou projecte anava relacionat amb les obres de construcció d'uns vials que havien de comunicar Barcelona amb Santa Coloma i els barris perifèrics de Badalona (l'anomenada per la premsa "Gran Via Nord"), amb la voluntat de descongestionar la vella carretera N-II ${ }^{1953}$. El mateix mes l'Ajuntament de Badalona presentava el projecte d'urbanització de la plaça "per sorpresa" a les diferents Associacions del barri, de la mà dels regidors Desiderio León i Ferran Bello amb

1949 “Llefià cierra comercios”, El Periódico de Catalunya, 3-2-1984 i Coordinadora de Asociaciones de Vecinos de Llefià: "El Señor Juan Felipe no se entera”, Revista de Badalona, 21-2-1984, p. 6. Aquesta darrera era una carta on la Coordinadora criticava les declaracions de Juan Felipe Ruiz que minimitzava el tema de la delinqüència. També exposaven que no només reclamaven una major vigilància, sinó més atenció escolar, un centre de formació professional i mesures contra l'atur.

1950 “Els mestres i alumnes de l'escola "Rafael Alberti" volen un edifici definitiu", Revista de Badalona, 9-11-1984, p. 4.

1951G.M.C.: "El futuro de la plaza Trafalgar”, Revista de Badalona, 4-7-1981, p. 11.

1952 La CMB va fer una subvenció de 123.000 .000 milions pel projecte, on també s'incloïa la urbanització del Motocross a Santa Coloma. Veure Juan Rico Márquez: Llefià. De la barraca a la dignidad, p. 246.

1953 “Badalona i Santa Coloma s'uniran a Barcelona per un vial rodó”, Avui, 13-7-1985 i Revista de Badalona, extra d'estiu de 1985, p. 34. 
una maqueta. El projecte no va agradar, ja que algunes associacions creien que els diferents vials que havien de passar al costat de la plaça amb dos carrils per sentit de la circulació significaven la divisió del barri i un perill per l'elevat trànsit rodat que provocarien. Van valorar també molt negativament que l'Ajuntament presentés un projecte tancat, sense la possibilitat d'introduir modificacions, i que no s'hagués consultat abans a les entitats del barri malgrat els nombrosos requeriments que s'havien fet al respecte:

“Portàvem més d'un any -diu Pedro Rodríguez- demanant al conseller del barri, Ferran Bello, els plànols del que pensaven fer. -I anà donant llargues a l'assumpte fins que es presentà amb la maqueta." ${ }^{1954}$

Per contra, l'opinió de l'alcalde d'aleshores, Joan Blanch era força diferent ja que segons ell el PSUC va estar d'acord amb el procés inicial i no va ser fins que va estar a l'oposició que va posicionar-se en contra:

"Al estar-hi d'acord el PSUC no se'n va ocupar cap associació quan estaven els projectes en exposició pública, (...) vol dir que quan tu comences a fer una obra el projecte està adjudicat (...) tot això és un procés llarguíssim (...) dura dos o tres anys i ningú es va oposar..."1955

Però l'AVV de Sant Antoni, com vam veure, no estava controlada pel PSUC (la de Sant Mori si que ho estava en major mesura). Si que es cert que hi havia una previsió de remodelar la plaça des de 1981 i que tothom estava d'acord amb això. Però aleshores, es va aprovar la remodelació de Plaça pendent de la concreció posterior per part de la $\mathrm{CMB}$, que era qui aportava la majoria dels diners. Com es va fer l'exposició pública i en quins horaris i terminis? No s'entén que l'AVV de Sant Antoni no hagués presentat cap al-legació a no ser que aquesta no fos explícita i concreta del que realment es volia fer a la plaça o es fes en uns locals i horaris menys accessibles pel veïnat.

A més, el projecte d'urbanització de la plaça es va vincular a la construcció d'un Centre d'Atenció Primària, una vella reivindicació del barri, fet que va ser considerat com un xantatge. Les AVV's de Sant Antoni, Sant Mori i Sant Joan Baix

1954 Joan-Anton Coves: "L'Associació de veïns de Sant Antoni de Llefià s'oposa als vials, "Abans de tot reclament la infraestructura necessària, diu el President"'”, Revista de Badalona, 5-11-1985, p. 5.

1955Entrevista amb Joan Blanch Rodríguez, 14-7-2010. 
van emetre un comunicat criticant el projecte i l'actitud de l'Ajuntament, a més de reivindicar la solució dels problemes pendents del barri. Exigien una modificació del projecte de manera que els vials fossin parcialment subterranis per poder obtenir una plaça més gran. Els veïns van fer un projecte alternatiu de plaça amb l'ajuda de tècnics -com en els vells temps-, però sense èxit:

"Lo que van dir era que era un projecte més car que el que ells tenien i no el podien modificar (...) que no era viable." ${ }^{1956}$

\begin{abstract}
"Després també hi havia.... fins i tot hi vam trobar un constructor que estava disposat a fer un aparcament subterrani a fer-ho a canvi de pagar el cost que suposava [soterrar els vials] per que ens van dir 'no! No hi han diners! I això costa molts diners fer-ho soterrani!' . Vam trobar nosaltres, ja et dic, un constructor que estava disposat a fer-ho a canvi de un aparcament també a sota de la plaça (...) i també van dir que no. 0 sigui que d'alternatives ja n'hi vam (...) Però estaven en plan 'això per collons es fa així. Ens han votat, s'ha aprovat en el Ple de l'Ajuntament i (...) no hi ha més discussió possible'. Llavors clar, és quan la gent es va tirar al carrer i òbviament l'Associació de Veïns va convocar i....."1957
\end{abstract}

En la mateixa nota anterior les tres AVV's encoratjaven al veïnat per participar en les assemblees públiques i comissions que s'estaven fent per afrontar el problema ${ }^{1958}$. El regidor del districte, Ferran Bello, responia dient que tot es tractava d'una maniobra política acusant al PCC i el MCC d'estar al darrere. El mateix Joan Blanch, anys després, insistia en les mateixes acusacions, anant fins i tot més enllà:

"Eren ganes de tocar els pebrots i sobretot el PSUC estava al darrera... allà hi havia també el Moviment Comunista, que encara hi és, encara hi són (...) Convergència que estava al govern feia costat al PSUC en aquest tema (...) en tot cas a mi no em va donar gaire de suport. Allò vam tenir que defensar-lo els socialistes sols." ${ }^{1959}$

1956Entrevista amb Antonio Agudo Tuñon, 21-6-2010. Era el president aleshores de l'AVV de Sant Antoni i militant del MCC.

1957 Entrevista a Francisco Domínguez García “Curro", 19-6-2013. Membre de l'AVV Sant Antoni de Llefià (Badalona).

1958Las Asociaciones de Vecinos [Sant Antoni, Sant Mori i Sant Joan Baix de Llefià]: "A todos los vecinos de Llefià", Revista de Badalona, 15-10-1985, p. 8. El document original, datat el 8 d'octubre de 1985, també es pot tobar a l'Arxiu Històric de Llefià, Documents/Entitats/AVV Sant Antoni de Llefià/Convocatòries: http://www.llefia.org/gallery/main.php? g2_itemId=35115.

1959Entrevista amb Joan Blanch Rodríguez, 14-7-2010. 
Llefià es va poblar ràpidament la tardor de 1985 de pancartes reivindicatives en un context badaloní ja prou agitat per les mobilitzacions que ja havia protagonitzat la FAVB i el moviment anti-OTAN ${ }^{1960}$. Dos membres de l'AVV de Sant Antoni van exposar les crítiques a l'Ajuntament per com s'havien fet el projecte a una entrevista feta a Revista de Badalona el 5 de novembre de 1985. En aquesta mateixa ja es veia com no totes les AVV's no tenien la mateixa opinió. Les de la Ronda de Sant Antoni i Sant Joan de Llefià Alt -les que estaven més allunyades de la zona conflictiva- no es van oposar formalment al projecte. Ferran Bello responia a les crítiques en un altre article a Revista de Badalona el dia 22 de novembre, afirmant que ell havia tingut personalment informat als veïns del projecte mentre alhora exposava totes les obres que estava executant l'Ajuntament a Llefià ${ }^{1961}$. La qüestió de la Plaça Trafalgar arribava a un tens Ple fet el 21 de desembre. PSC i CiU van votar a favor de l'inici de les obres mentre el PSUC votava en contra. La tensió i lluita es va traslladar dintre de l'AVV's ja que segons alguns dels protagonistes del conflicte:

"Algunos partidos políticos entran al trapo, la orden a los militantes socialistas de entrar a saco en las juntas de las asociaciones está en boca de todos." ${ }^{1962}$

A Sant Antoni dos integrants d'aquestes membres del PSC van acusar a membres del MCC i del PCC d'intentar fer-los fora de la Junta ${ }^{1963}$. En tot cas, la tria de la nova Junta va ser posposada ${ }^{1964}$. Però la política d'infiltració de persones properes als socialistes va tenir èxit en una altra associació que de donar suport al projecte alternatiu de plaça va passar a alinear-se amb l'Ajuntament, canviant la correlació de forces dins les AVV's del barri:

“En Sant Joan hi havia un senyor baix que ara no recordo com es deia que era del PCC, una persona bellíssima com a persona... I era un home molt conseqüent i molt... Va

1960 “Badalona: oposición de los vecinos a unos viales en la N-II”, La Vanguardia, 14-10-1985; "Oposición a nuevas avenidas en Badalona", El Periódico de Catalunya, 15-10-1985 i "Los vecinos de Llefià, contra una via ràpida en el barrio", El Correo Catalán, 15-10-1985.

1961 Ferran Bello Hernáinz: "Carta abierta a los vecinos de Llefià sobre la supuesta "guerra" no declarada", Revista de Badalona, 22-11-1985, p. 14.

1962 Juan Rico Márquez: Llefià. De la barraca a la dignidad, p. 254.

1963 Jordi Martí: "Enfrontament a la junta de l'Associació de veïns de Sant Antoni de Llefià", Revista de Badalona, 4-2-1986, p. 8.

1964Veure acta de l'Assemblea ordinària anual de l'AVV Sant Antoni de Llefià, 31-1-1986, AHLL, Fons Documents, Entitats, AVV Sant Antoni de Llefià, Llibre d'Actes: p. 39-41 [http://www.llefia.org/gallery/main.php?g2_itemId=34005] 
venir i va dir que per suposat que si. Quan van veure això la gent del PSC va entrar en una assemblea a saco i van agafar majoria i se'n van despenjar de la història... [pregunto si van ser els Muñoz, el Pedro Muñoz] (...) Jo diria que si (...) [es veu que aquest home no tenia el carnet del PSC però estava en la seva línia...] Saps que passa, que hi havia allà molt a prop al voltant la Conselleria que estava el Ferran Bello. El Ferran Bello també tenia molta mà esquerra per saps... d'anar de... en plan (...) 'escolta que et donarem això per l'Associació..."'1965

Al mes de febrer s'iniciaven les obres i al mateix temps les mobilitzacions veïnals. Recordant mètodes de lluita del recent passat, de dia es convocaren manifestacions i concentracions que tractaven d'impedir, o com a mínim entorpir, les obres. El dia 20 el veïnat esborrava les marques de senyalització i impedien la instal-lació d'una barraca d'obres. L'Ajuntament continuava denunciant que tot això responia a una maniobra del PSUC, PCC i MCC ${ }^{1966}$. Certament aquests partits eren presents, sobretot a les AVV's de Sant Mori i de Sant Antoni de Llefià. Però era evident que totes les persones d'aquestes associacions i els centenars que es van mobilitzar no pertanyien en la seva majoria a aquests partits.

El 24 de febrer, en una demostració de força es presentaven a la Plaça Trafalgar l'Alcalde Joan Blanch i diversos regidors socialistes amb nombrosos contingents de la Guàrdia Urbana. Davant la negativa dels veïns a dispersar-se i excusant-se en uns suposats intents d'agressió a l'alcalde, la Guàrdia Urbana va carregar contra el centenar de concentrats amb una gran duresa fen servir material anti-avalots i d'altres no reglats, com porres extensibles i esprais d'autodefensa no reglamentaris. Nombrosos veïns van resultar ferits i contusionats i van interposar denúncies contra la Guàrdia Urbana, entre ells els regidors del PSUC Manuel Armentero i Luisa Longas, que també van ser denunciats per l'Ajuntament ${ }^{1967}$. Joan Blanch, anys després encara volia negar l'evidència:

"L'únic que es va fer es impedir que paralitzessin les obres, de càrrega res (...) una càrrega és una càrrega i altra cosa es mirar de separar la gent que impedeix que es

1965Entrevista a Francisco Domínguez García “Curro”, 19-6-2013.

1966 “Vecinos del barrio badalonés de Llefià, contra el proyecto de un eje viario", La Vanguardia, 212-1986 i Toni Soler: "La Guàrdia Urbana ha de protegir unes obres", Avui, 21-2-1986.

1967 Joan Garcia Riera: "Badalona: carga de la Guardia Urbana contra unos vecinos" i "Los vecinos denuncian a la Guardia Urbana", La Vanguardia, 25 i 27-2-1986; Jordi Martí: "Policias contra vecinos por un nuevo vial", El Periódico de Catalunya, 25-2-1986 i ¡Toni Soler: "La guardia urbana carrega contra els veïns del barri de Llefià", Avui, 25-2-1986. 
facin les obres (...). El que es va fer es impedir que paralitzessin les obres i res més, no es va fer us de la violència amb força, es va separar la gent d'allà, res més." ${ }^{1968}$

La protesta, com no podia ser d'una altra manera, es va radicalitzar. Malgrat que en teoria l'Ajuntament s'havia ofert a introduir petites modificacions per suavitzar l'impacte del trànsit (carrils d'aparcament i semàfors) la violenta càrrega policial havia encrespat els ànims. De dia se succeïen les manifestacions i concentracions per aturar les obres. A les nits, grups més organitzats planificaven i executaven accions de sabotatge:

"Sobretot els nuclis més combatius d'allà vam decidir passar a l'acció..' hem de parar aquestes obres'. Es va crear una sèrie de grups una mica (...) amb coordinació de gent de l'Associació nostra [de Sant Antoni de Llefià], veïns sueltos, gent de la parròquia... que vam plantejar una sèrie d'accions per parar les obres (...) fer accions contra totes les màquines i els camions (...) va ser una lluita bastant forta. El tema dels camions es van fer accions en els punts on estaven els camions per que no poguessin sortir (...) accions de sabotatge, de carregar-se els camions (...) els camions no van poder sortir per que tenien totes les rodes punxades." ${ }^{1969}$

L'Ajuntament va tancar files, destacant, apart de la figura de Joan Blanch, la del primer Tinent d'Alcalde, regidor de Seguretat Ciutadana i cap polític de la Guàrdia Urbana, Juan Felipe Ruiz, per les seves provocatives declaracions ${ }^{1970}$. Alhora s'intentava desprestigiar les alternatives proposades per les AVV's. Apart de l'argumentació del pressupost, es va afirmar que soterrar els vials podia posar en perill els fonaments dels habitatges propers -poc anys després es va foradar tota l'Av. Marqués de Sant Mori per fer pàrquings i no va semblar existir aquest problema-. L'obra era pagada en la seva major part per la CMB i segurament estava condicionada a que s'executés fil per randa. Una altra argumentació que es va fer servir va ser la legitimació dels vots i la defensa de l'interès general ${ }^{1971}$. Certament el

1968Entrevista amb Joan Blanch Rodríguez, 14-7-2010. Els titulars de la premsa generalista, poc sospitosa de "radicalisme", no deixaven dubte de que va haver-hi una dura càrrega policial.

1969Entrevista amb Antonio Agudo Tuñon, 21-6-2010.

1970Juan Felipe Ruiz va ser posteriorment delegat del Govern Central a Menorca i des de l'any 2000 Gerent de la societat pública Marina Badalona que gestiona el port de l'esmentada localitat. Va ser imputat pel jutge Garzón al sumari del cas Pretòria per la compra-venda d'un solar en el port esportiu on van participar diversos intermediaris, entre ells la societat Badalona Building Waterfront de la qual era ell mateix conseller delegat.

1971Entrevista a Joan Blanch Rodríguez, 14-7-2010. Pel que es veu, es consideraven legitimats per defensar aquest interès general a cop de porra... 
PSC-PSOE havia estat el partit més votat, però demostrava tenir una concepció estrictament liberal de que era la democràcia, poc interessada en desenvolupar mecanismes participatius apart de les eleccions municipals. No obstant, molts agents de la Guàrdia Urbana no estaven d'acord en que el cos es fes servir per reprimir el veïnat per diversos motius:

"Lo que no nos esperábamos nadie dentro de la Guardia Urbana es que el Ayuntamiento o la propia jefatura utilizase a la Guardia Urbana como medida represora hacia los vecinos... Ni estábamos preparados nosotros, ni técnicamente ni teníamos las herramientas adecuadas, ni tampoco era, digamos (...) la forma de dar ese cambio de imagen. Porque claro, todo lo que se había trabajado 4 o 5 años con aquella intervención se vino abajo totalmente."1972

Amb l'arribada dels ajuntaments democràtics s'havia fet un esforç per rentarli la cara al cos de policia local i a més havien entrat noves promocions de gent amb una sensibilitat diferent i que van ser pioners del sindicalisme dins la Guàrdia Urbana (fins i tot una antiga dirigent veïnal com Maria Reyes Bellido va ser membre del cos). L'anterior testimoni ens desmenteix les afirmacions que feia Joan Blanch:

\footnotetext{
"Les hicieron montar un servicio que no se había estructurado hasta ese momento, de recoger todas las defensas que se tenían, de gas, eléctricas, y todo tipo de herramientas de trabajo que se podían tener para disolver una manifestación que nosotros no teníamos ni la preparación ni las herramientas adecuadas (...) se hizo montar a la mayoría de plantilla en vehículos de la propia Guardia Urbana y dirigirse hacia la plaza Trafalgar (...) luego se dieron unas consignas de entrar en cuña (...) que nosotros no habíamos practicado nunca (...). Hubo compañeros que se negaron a dar y otros que dieron (...) Se que hay muchos compañeros que vieron aquello una barbaridad, en cambio otros lo vieron normal porque ya tenían costumbre de haberlo hecho en otros momentos." ${ }^{1973}$
}

Els agents contraris a aquesta operació van organitzar una recollida de signatures dintre del propi cos per protestar. Aquest fet va ser ràpidament sufocat per Juan Felipe Ruiz i el cap militar -i mai millor dit- de la Guàrdia Urbana, Gabriel Cardona, que segons el nostre entrevistat va estripar personalment el paper on es

1972Entrevista a José Maria Navarro, Guàrdia urbà destinat a la Plaça Trafalgar, 30-6-2010. 1973 Ídem. 
recollien les signatures quan ja ho havien fet 38 agents $^{1974}$. La repressió dins el cos no es va fer esperar. Els hi van retirar l'arma als agents díscols i els van enviar a custodiar la mateixa plaça de Trafalgar per exposar-los a la ira del veïnat, sense dret a relleu ni a parlar amb els companys. També els van amenaçar amb obrir-lis un expedient de suspensió de feina i sou durant tres anys per haver fet una traïció al cos policial ${ }^{1975}$. No obstant, algú va fer córrer la veu d'aquest fet, de manera que:

"Cuando se van enterando los vecinos que los guardias que estamos allí somos los guardias que hemos firmado contra la carga policial que hubo los propios vecinos fueron bajando a la calle y nos van atendiendo, incluso dando agua o de comer a nosotros... son los propios vecinos los que se dirigen a nosotros para ver como estamos y nos protegen un poco....1976

Els agents sancionats pel seu compte havien aconseguit més signatures i la implicació d'unes 70-80 persones per protestar contra les mesures que s'estaven prenent. L'Ajuntament va intentar aturar-ho amb més sancions però momentàniament no es van atrevir a aplicar-les. Si bé alguns van quedar marcats i per exemple al mes següent dos agents van ser sancionats amb quatre dies de suspensió de sou acusats d'insubordinació i d'incorrecció davant un superior ${ }^{1977}$.

Les accions de protesta i sabotatge diàries van continuar durant el mes de març mentre alhora es donava una guerra d'informació. El 27 de febrer ja havien aparegut uns fulls volants signats per les AVV's de Sant Mori, Sant Antoni, la “Comissió de Veïns de la Plaça”, el "Grup de membres de la parròquia de Llefià", les AMPES dels col-legis "Llefià" i "Rafael Alberti", juntament amb els alumnes de l'Escola d'Adults de Llefià, que explicaven el seu punt de vista i la repressió exercida per l'Ajuntament. Al revers apareixien els dos projectes confrontats: el que proposava l'Ajuntament i l'alternatiu oposat per les AVV's ${ }^{1978}$. Mentrestant l'Ajuntament editava i repartia de forma massiva un full d'informació municipal on explicava els beneficis que -al seu parer- comportava pel barri el seu projecte ${ }^{1979}$. Al

1974Gabriel Cardona, el cap de la Guàrdia Urbana de Badalona havia estat un militar vinculat a la UMD i alhora exercia d'historiador.

1975Entrevista a José Maria Navarro, Guàrdia urbà destinat a la Plaça Trafalgar, 30-6-2010. 1976Ídem.

1977 Antoni Soler: "Guardies urbans de Badalona podrien ser sancionats", Avui, 4-3-1986 i Joaquima Utrera: "Mar de fons a la Guàrdia Urbana", Revista de Badalona, 25/28-3-1986, p. 3. 1978 “Nuestra lucha por la plaza Trafalgar”, 27-2-1986, Arxiu Històric de Llefià [sense catalogar]. 1979Badalona Full Municipal, núm. 11 (21/28-2-1986), MB-AHCB, Fons Hemeroteca, Volum 21-7- 
seu torn, de nou les entitats del barri abans esmentades -excepte les AMPESsignaven una carta escrita pel President de Sant Antoni, Antonio Agudo on denunciaven la tendenciositat d'aquesta campanya i l'autoritarisme de l'Ajuntament ${ }^{1980}$. Les AVV's de Sant Mori i Sant Antoni convocaven concentracions i manifestacions pels matins i per les tardes a partir de les $19 \mathrm{~h}$, mentre en diferents assemblees s'informava dels esdeveniments i es decidien les afirmacions a seguir $^{1981}$.

El 10 de març pel matí, en el transcurs de les mobilitzacions eren detingudes tres persones, entre elles el regidor i cap del PSUC badaloní Manuel Armentero (tot i que van ser alliberats poc després). Aquest fet va fer augmentar la tensió quan -segons la premsa-hi havia hagut alguns intents de negociació. En aquestes les AVV's enfrontades a l'Ajuntament havien proposat fer un referèndum entre els veïns del barri per decidir quin dels dos projectes es feia. No cal dir que la proposta va ser ràpidament rebutjada per l'Ajuntament ${ }^{1982}$. Paral-lelament els veïns denunciaven una campanya de coacció feta per membres de la Guàrdia Urbana contra els veïns del barri. No obstant, el cos policial local no podia controlar la situació i aviat es va cridar a la Policia Nacional:

"La Policia Nacional era una altra història. Estem a l'any 86... havien passat 11 anys però encara hi havia molts mandos que venien de l'etapa franquista, eh? S'havien canviat l'uniforme de color marró... però la mentalitat era la mateixa. Venien al bar aquell de la cantonada, venien allà amb las furgonas, a la cantonada a prendre cubates i quan estaven ben calents ens posaven a dintre de la furgona i..."1983

8.6, p. 5.

1980Asociación V. Sant Antonio, Asociación V. Sant Mori, Comisión Vecinos Pl. Trafalgar, Grupo miembros Parroquia S. Antonio, Fdo. Antonio Agudo Presidente A.V.S. Antonio: "A la opinión pública", (10-3-1986), Arxiu Històric de Llefià [sense catalogar].

1981 AVV Sant Mori i AVV Sant Antoni: "A todos los vecinos en defensa de la Plaza Trafalgar" [sense data], Arxiu històric de Llefià [sense catalogar].

1982 “Un edil de Badalona detenido, por paralizar unas obras”, La Vanguardia, 11-3-1986; Toni Soler: "Regidor del PSUC, detenido porque entorpecía unas obras", Avui, 11-3-1986; Jordi Martí: "La protesta por una plaza acaba con tres detenidos", El Periódico de Catalunya, 11-31986 i Joaquima Utrera: "Tres detinguts a la plaça de Trafalgar", Revista de Badalona, 11-31984, p. 3.

1983Entrevista a Francisco Domínguez García “Curro”, 19-6-2013. 


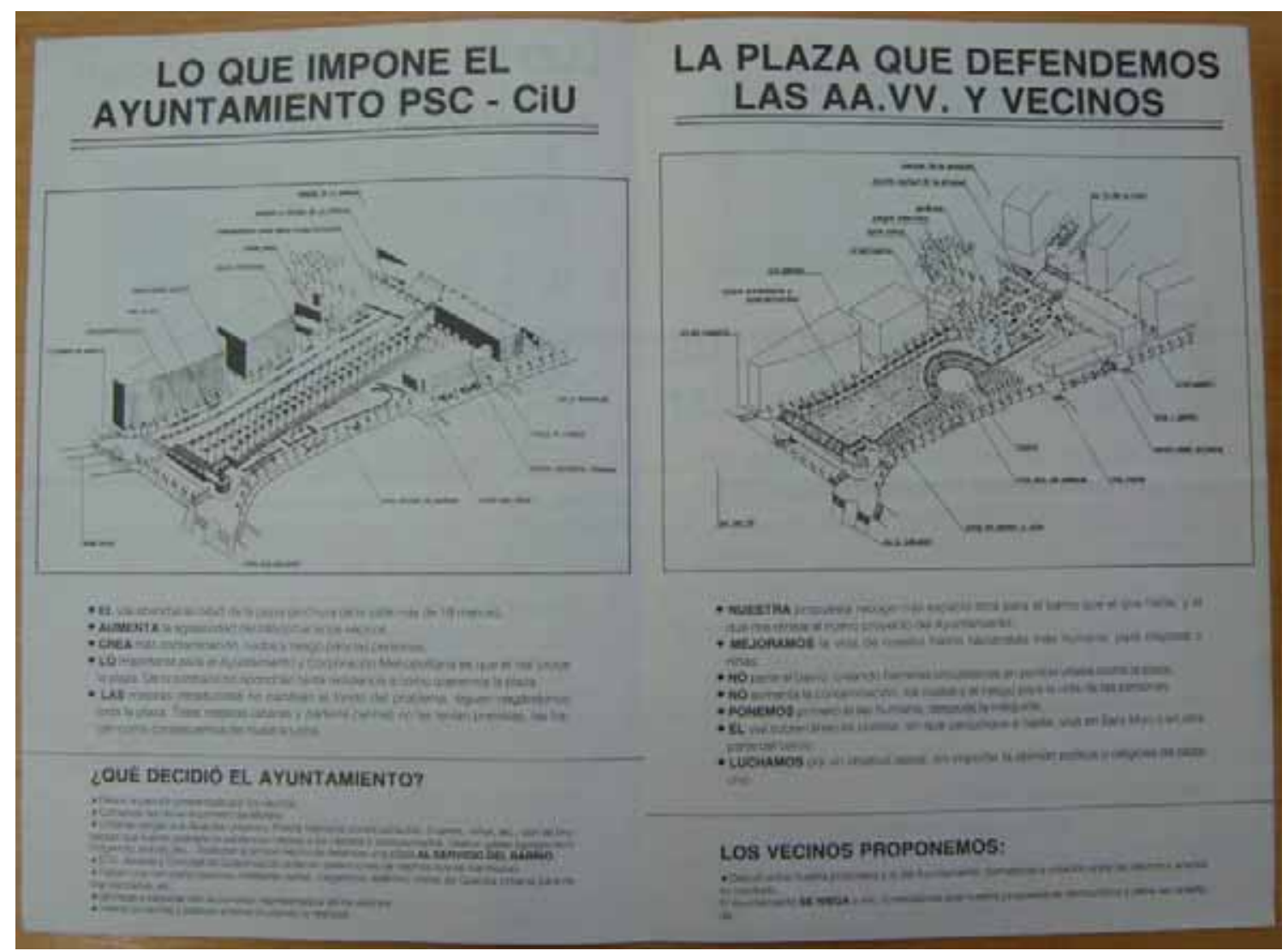

Revers d'un full volant signat per les AVV's de Sant Mori, Sant Antoni, Grup Parroquial i Comissió de Veïns de la Plaça: "Llefià - Plaça Trafalgar. Informamos" (març 1986), AHMB, Col-leccions Factícies, Caixa C19, Carpeta Comunicats Diversos. Es poden veure els projectes confrontats respecte la Plaça Trafalgar.

L'onze de març al vespre es produïen violents enfrontaments entre la Policia Nacional i els concentrats a la plaça. La Guàrdia Urbana denunciava poc després a Antonio Sánchez Illescas, militant del PCC al qual afirmava haver sorprès amb una bossa plena de pedres ${ }^{1984}$. La FAVB es va oferir com mediadora en el conflicte, però havia de ser curosa per que les AVV's del barri estaven dividides: dues s'enfrontaven a l'Ajuntament i tres li donaven suport o no es manifestaven obertament en contra (tot i que a l'inici del conflicte la proporció era de 3 a 2 a la inversa). Però Joan Blanch es va mantenir immutable ${ }^{1985}$.

Els enfrontaments es van agreujar al mes d'abril sense que una reunió de les diferents Associacions amb Ferran Bello servissin per suavitzar les postures. El 3

1984 “El Ayuntamiento de Badalona denuncia a un miembro del PCC”, El Periódico de Catalunya, 133-1986 i "El Ayuntamiento de Badalona denuncia a un militante del PCC", La Vanguardia, 13-31986.

1985Jordi Martí: "La Federació de l'Associació de Veïns s'ofereix com a mediadora en el conflicte de Llefià”, Revista de Badalona, 14-3-1986, p. 11. 
d'abril es produí una nova càrrega policial contra un grup de trenta dones que protestaven al matí. Al dia següent, amb l'excusa que unes persones havien fet caure unes tanques de les obres la Policia Nacional va fer una càrrega molt violenta que va acabar amb diversos ferits i contusionats, un d'ells de gravetat ${ }^{1986}$. Quatre homes i tres dones van ser detinguts, dels quals dos van passar tres dies als calabossos de la Comissaria de la Policia Nacional per ordre del jutge. Un d'ells va ser Francisco Rodríguez "Curro":

"A la tarda quan va arribar tota la gent de treballar i les dones van explicar tot el que havia passat, tota la moguda i que hi havien detinguts, doncs no només això, sinó també altra gent de tota la ciutat, que va córrer de seguida... Doncs va anar tothom en manifestació cap allà, a la comissaria. I llavors van dir... 'Osti, això no són 4 chorizillos...' Aquí hi ha una moguda al darrera i la policia s'ho va mirar més. Vull dir que a l'Agustí el van escalfar abans d'arribar fins allà, vull dir en el cotxe si que li van donar..." ${ }^{1987}$

Els veïns afectats van presentar denúncies als jutjats per aquests fets. El dia 8 la FAVB emetia una nota a l'Associació de Sant Antoni expressant-li el seu suport i solidaritat així com informant de que havia enviat telegrames al Governador Civil i a l'Alcalde de Badalona. Poc després, una nova protesta davant l'esmentada comissaria on continuaven detinguts els veïns del barri va ser dissolta el 9 d'abril per la Policia Nacional i la Guàrdia Urbana. Només el rector de la parròquia Joan Cuadrench i també el propi Manuel Armentero van poder visitar als detinguts, comprovant les deplorables condicions de les dependències policials i instant a que fossin ben tractats.

El dia 11 d'abril el PSUC s'afegia a la proposta feta per les AVV's de Sant Mori i Sant Antoni de fer un referèndum al barri. Mentrestant diverses cartes al director denunciaven en la premsa la brutalitat policial ${ }^{1988}$. A l'abril nous fulls volants denunciaven la violenta repressió exercida a la plaça, amb fotos dels veïns apallissats i convocaven a noves mobilitzacions pel dia 18 a la mateixa plaça ${ }^{1989}$. El

1986Veure al respecte el testimoni sobre la brutalitat policial citat a la nota 1741, p. 598 de Francisco Domínguez García "Curro".

1987Entrevista a Francisco Domínguez García "Curro", 19-6-2013.

1988Toni Soler: "Augmenta la violència al barri de Llefià de Badalona”, Avui, 11-4-1986 i Cartes al director sobre "La "batalla" de Trafalgar" de Ángel Perió (president de l'AVV Sant Mori i militant del PSUC) i Laura Vidal Pons, El Periódico de Catalunya, 12-4-1986.

1989 Comisión AA.VV. S. Antoni de Llefià-AA.VV. S. Mori-Grupo Parroquial y Comisión Vecinos de la Plaza: "Plaza de Trafalgar-Por los espacios libres-Contra la represión [full volant, abril 1986], MB-AHCB, Fons Col-leccions Factícies, Caixa C19, Carperta Comunicats diversos. 
20 d'abril les comunitats parroquials de l'arxiprestat de la perifèria de Badalona denunciaven la falta de diàleg i la repressió policial exercida. Van acusar a l'Ajuntament d'haver actuat amb mètodes poc democràtics i propis d'altres èpoques:

"Lamentamos que no haya suficiente diálogo para resolver el problema democráticamente, además de protestar por la dura represión de que han sido objeto los vecinos por parte de la Guardia Urbana. Consideramos desproporcionado que por tirar al suelo unas vallas metálicas, seis o siete agentes apaleen encarnizadamente a un vecino indefenso, produciéndole lesiones importantes." ${ }^{1990}$

El mateix Joan Cuadrench, rector de Sant Antoni de Llefià aleshores ens donava la seva opinió dels fets:

"Nosaltres ens vam trobar una mica al mig. Hi havia gent de la parròquia que deia: escolta, ens hem de mobilitzar per que ens faran (...) la gent estava molt preocupada, aleshores bueno l'únic que vam fer nosaltres va ser demanar que parlessin (...) més aviat vam estar al costat dels veïns."1991

Al mes de maig la conflictivitat va decaure. La mobilització dels veïns havia aconseguit en moments puntuals paralitzar les obres, però la forta presència policial va acabar donant el seu fruit malgrat l'esforç que s'havia fet durant tres mesos. La repressió soferta i la impotència en veure que no s'aconseguia aturar les obres va fer que progressivament la lluita acabés morint. Joan Blanch, ens tornava a donar la seva peculiar opinió del perquè es van acabar les protestes:

\footnotetext{
"Per tirar-ho endavant es va tenir que fer un pont que permetés que la gent passés (...) va ser una condició que va sortir en les negociacions on es va arribar a un acord amb els que negociaven que si es feia això ho deixaven estar (...). Els que negociaven amb l'Ajuntament (...) els que estaven més en contra es van quedar sols (...) per que veien que l'actitud de dir no a això era dolenta (...) es van retirar de seguida." ${ }^{1992}$
}

Aquesta obra, segons el mateix Joan Blanch, va ser una condició posada per CiU i ja va ser polèmica aleshores. Difícilment podia ser el motiu de la fi de les protestes. La seva inutilitat com a pas de vianants es va posar de manifest els anys

1990 Comunidades parroquiales de Bufalà, Canyet i otras cuatro personas más: "Las parroquias de Badalona" [sembla una carta al Director], El Periódico de Catalunya, 13-6-1986. 1991Entrevista a Joan Cuadrench, 17-6-2006. 1992Entrevista a Joan Blanch Rodríguez, 14-7-2010. 
posteriors quan es va convertir pràcticament en un lloc on els heroïnòmans es punxaven les seves dosis i on altres persones portaven els seus gossos a fer les seves necessitats, en esdevenir un lloc poc freqüentat i apartat. Finalment va ser enderrocat 20 anys després. Al juny una caseta electoral de CiU instal·lada a Llefià va ser destrossada, si bé no sabem si en relació amb el conflicte anterior o pel context d'enfrontament electoral. A finals d'aquest mes encara un antic militant i regidor del PSUC, Àngel Navarro, publicava una carta a El Periódico de Catalunya criticant el paper de l'Ajuntament als esdeveniments recents ${ }^{1993}$. Les obres, però, van continuar inexorablement el seu curs mentre es produïen diversos processos judicials contra les persones denunciades i detingudes en la lluita. Ja el 16 de juliol havia hagut un primer intent de judici, que finalment va ser suspès per unificar totes les causes pendents ${ }^{1994}$. Al novembre es jutjava al militant del PCC i membre de l'AVV de Sant Antoni Manuel Sousa, que havia estat denunciat per Juan Felipe Ruiz per injúries contra la seva persona i contra la Guàrdia Urbana. El fiscal va demanar l'absolució ${ }^{1995}$. El gener de 1987 el jutjat va desestimar la denúncia feta per la Guàrdia Urbana contra els regidors Manuel Armentero i Luisa Longas del PSUC. Poc després també eren absolts els dos veïns que van estar detinguts tres dies a la comissaria de Badalona ${ }^{1996}$.

Finalment el 16 de maig s'inaugurava la Plaça de Trafalgar després de fer una campanya de propaganda amb la presència del president de la CMB i alcalde de Barcelona Pasqual Maragall i l'alcalde Joan Blanch. Grups de veïns van expressar el seu rebuig a les autoritats presents ${ }^{1997}$. La plaça s'havia construït amb algunes modificacions respecte el projecte inicial per suavitzar el trànsit, com era l'eliminació d'un dels dos carrils per sentit que es van transformar en aparcaments i amb la instal-lació d'un parterre i semàfors. La mobilització havia obligat a l'Ajuntament a introduir aquest canvis, però no havia aconseguit que es fes el

1993Ángel Navarro: "Represión municipal en Badalona”, El Periódico de Catalunya, 28-6-1986. 1994Joan Ariza: "Suspès el judici dels veïns de Trafalgar, a Badalona" Avui, 17-7-1986.

1995Jaume V. Aroca: "Judici pels fets de Trafalgar", Revista de Badalona, 25-11-1986 i "El secretario local del PCC, jutjat per un presumpte delicte de injúries", Eco Badalonès, 28-11-1986.

1996 “Un concejal yi dos vecinos de Badalona, absueltos de la acusación de alterar el orden”, El País, 18-3-1987.

1997 Jordi Martí: “Badalona inaugura su plaza más polémica”, El Periódico de Catalunya , 17-5-1987 i Àngel Marín: "Obren la polèmica Plaça de Trafalgar de Badalona" Diario de Barcelona, 17-51987. 
projecte de plaça proposat per les AVV's que havien encapçalat la lluita. No obstant, i al contrari del que va passar a Pomar, aquestes Associacions no van sortir afeblides, en especial la de Sant Antoni de Llefià. Així va acabar la "Batalla de Trafalgar" la mobilització veïnal més important dels anys vuitanta al Barcelonès Nord -pràcticament tres mesos de lluita- amb permís de la "Intifada del Besòs" d'octubre de 1990.

Van produir-se més mobilitzacions a Badalona, com per exemple van ser les que es van fer també en setembre de 1987 de nou a Llefià contra un policia que havia violat a una veïna del barri ${ }^{1998}$, o les que es van fer contra la instal·lació d'un centre comercial a Montigalà durant el mateix l'any (on van tenir un paper important els petits comerciants) arribant la Generalitat a paralitzar temporalment el projecte ${ }^{1999}$. Però finalment el centre comercial Continente s'acabaria inaugurant juntament amb la que va ser coneguda aleshores com "la vila olímpica de Badalona" (tot un conjunt d'habitatges que també van servir en un primer moment per allotjar periodistes i altres professionals en relació amb els Jocs Olímpics del 92).

A Santa Coloma de Gramenet també van existir mobilitzacions veïnals posteriors a la constitució de l'Ajuntament democràtic. Ja a inicis de maig de 1979 per exemple va haver-hi un acte a la Plaça de la Vila reivindicant la municipalització de les quatre escoles bressol laborals existents a la ciutat ${ }^{2000}$. Igual que a Badalona, van haver-hi nombroses manifestacions en demanda d'escoles, amb el suport o convocades fins i tot pel propi Ajuntament. El 12 de juny va haver una manifestació per l'ensenyament amb la participació de 6.000 persones $^{2001}$. Al setembre es van reprendre amb força, coincidint amb l'inici de curs, ja que en comptes de posar més mestres, el MEC en treia ${ }^{2002}$. Però no totes les protestes van

1998Jordi Martí: "Los vecinos de un barrio de Llefià acusan a un policía de haver violado una vecina" i "Ira contra un policia por la violación de una mujer", El Periódico de Catalunya, 10 i 13-9-1987; Toni Soler: "El jutje ordena empresonar el policia que va violar una dona", Avui, 169-1987.

1999Jordi Martí: "Cierre de tiendas en Badalona y Santa Coloma" i "Los comerciantes consiguen frenar el futuro 'hiper' de Badalona, El Periódico de Catalunya, 16 i 23-10-1987; Silvia Soler: "La guerra del hiper de Badalona arriba a la Plaça Sant Jaume" i "Euforia en Badalona per que no hi construiran l'hiper", Avui, 16 i 23-10-1987.

2000 “Masiva participación en un acto sobre guarderías", El Correo Catalán, 8-5-1979.

2001Jordi Corachán: "El Consistorio y seis mil personas piden más escuelas", El Correo Catalán, 136-1979:

2002Jordi Corachán: "Cuarenta y nueve maestros han sido relevados de sus cargos por el 
comptar amb el suport del Consistori. La pujada de taxes municipals no va ser ben vista i va provocar la que la Coordinadora d'AVV's fes públic un comunicat crític ${ }^{2003}$. Aquesta entitat va ser la que va protagonitzar un major enfrontament amb l'Ajuntament durant aquests anys, si bé també des de diferents AVV's es va instar a la lluita contra les Contribucions especials. Així va passar als barris del Centre, al Barri Llatí, el Fondo o al Riu (entre d'altres) ${ }^{2004}$. Recordem també que aquesta Coordinadora havia protagonitzat reivindicacions urbanístiques amb el "Pla d'Urgències" i també havia fet crítiques contra la manera de fer de l'Ajuntament en la qüestió de la participació ciutadana ${ }^{2005}$, encara que des de l'Ajuntament s'haguessin creat diferents Consells sectorials com per exemple el d'Educació i el de la Salut.

Durant aquesta primer mandat es va mantenir un cert nivell de conflictivitat als diferents barris, si bé no es podia comparar amb el de la dècada anterior. Així als barris de l'Arrabal i Santa Rosa, on hi havien unes AVV's amb forta presència d'independents, cristians de base i militants del MCC van continuar les reivindicacions veïnals per la tardança en les millores urbanístiques. Al gener de 1981 el veïnat del Raval es queixaven per la falta de neteja al barri ${ }^{2006}$. L'any següent va haver-hi també mobilitzacions periòdiques al barri amb talls de carrers en reivindicació de millores urbanístiques com el tant necessari asfaltat. No ens hauria d'estranyar quan fins i tot la premsa qualificava a l'AVV del Raval -amb una forta presència a la seva junta de militants del MCC- com una de les més actives de la ciutat aleshores ${ }^{2007}$. Al barri del Fondo es van donar també protestes similars reclamant la ràpida urbanització de l'anomenada "Via Cívica" del Fondo o la

Ministerio", El Correo Catalán, 1-9-1979; "Manifestaciones en Barcelona y comarcas por la falta de maestros", El Correo Catalán, 8-9-1979; "Barcelona: conflictivo inicio del curso escolar", El Correo Catalán, 18-9-1979; "Barcelona: Manifestación y paro pidiendo maestros", El Correo Catalán, 20-9-1979.

2003Jordi Corachán: "Los vecinos, contra el aumento de los impuestos" i "Protesta por los nuevos impuestos", El Correo Catalán, 4-7-1979.

2004Jordi Corachán: “Los vecinos se niegan a pagar las obras del paseo Alameda”, El Correo Catalán, 4-11-1980; "Vecinos de San Ramón contra las contribuciones especiales", El Correo Catalán, 31-3-1981; “Deciden no abonar las contribuciones especiales", El Correo Catalán, 10-6-1981

2005 Veure Coordinadora Informa. Hoja informativa de la Coorinadora de AA.V. (març 1982), AHMTB, Donació Mn. Catà, Caixa 2. Pel que fa a les reivindicacions sobre la participació ciutadana veure l'apartat "Reivindicaciones políticas", p. 2.

2006 “Arrabal: los vecinos se quejan por falta de limpieza", El Correo Catalán, 23-1-1981.

2007 "Las amargas relaciones entre los barrios y el Ayuntamiento", requadre "Los vecinos se explican", Grama, núm. 281, II Època (26-juny-2 juliol 1982), p. 13. Veure també “El Asfalto que no llega", El Correo Catalán, 17-10-1982. 
instal-lació de semàfors en carrers conflictius. L'AVV del barri encara mantenia una certa activitat i esperit reivindicatiu amb la presència de persones independents i amb una llarga trajectòria com Emiliana Salinas ${ }^{2008}$.

Al barri del Riu la urbanització del Passeig de la Salzareda encara va comportar reivindicacions veïnals per la tardança en al seva execució i -tal com he dit abans- per la voluntat del Consistori de cobrar contribucions especials. Per exemple al juliol de 1981 va haver-hi diverses manifestacions i talls de trànsit de l'esmentada avinguda ${ }^{2009}$. Al mateix barri els veïns es van mobilitzar contra la instal-lació d'un bingo al març de 1981 fins al punt de forçar un referèndum municipal sobre aquesta qüestió que van aconseguir guanyar ${ }^{2010}$. A barris com Can Franquesa o Les Oliveres les reivindicacions es van centrar en aconseguir definitivament la reparació i regularització dels seus habitatges ${ }^{2011}$, que s'arrossegaven de molt abans, igual que a La Guinardera amb el contenciós pendent amb VIPES. També es van donar mobilitzacions als barris esmenats per millores d'equipaments o de l'ensenyament, amb la demanda de més mestres de català $^{2012}$. Al barri veí de Singuerlín el veïnat havia col-laborat amb l'Ajuntament i ells mateixos havien netejat un solar i un parc ${ }^{2013}$. Però l'anhelat mercat es va retardar i fins març de 1983 no es presentava el projecte de construcció del mateix $^{2014}$.

2008Veure també la primera referència de la nota anterior.

2009Jordi Corachán: "Piden que se asfalte la Avenida Pallaresa" i "Levantan una barricada como protesta", El Correo Catalán, 1 i 4-7-1981.

2010Jordi Corachán: "Referéndum sobre un bingo" i "La oposición al bingo gana el referéndum municipal”, El Correo Catalán, 7-3-1981 i 1-5-1981

2011“Los vecinos consiguen 16 millones a obras públicas”, El Correo Catalán, 25-5-1980; "Los vecinos de La Guinardera quieren romper el aislamiento del barrio", El Correo Catalán, 26-101980; Jordi Corachán: "El Ministerio de Obras Públicas promete una subvención para reparar los pisos de Las Oliveras", El Correo Catalán 15-2-1981; Jordi Corachán: "Santa Coloma de Gramenet: tras 7 años de conflictos se construyen los pisos de Can Calvet", El Correo Catalán, 14-2-1982; Jordi Corachán: "Inversió de la Generalitat en Les Oliveres de 44 milions", El Correo Catalán, 21-3-1982 i Eva Martínez: "Santa Coloma: La Generalitat da 20 millones para Can Franquesa", El Correo Catalán, 2-12-1982.

2012 "Santa Coloma: los niños de Les Oliveres piden a Pujol más maestros de catalán", El Correo Catalán, 27-4-1982. No tot van ser flors i violes amb la qüestió de la llengua catalana. A l'AVV de la Guinardera les disputes a l'entort de l'us de català havia convocat conflictes interns i la dissolució de la Vocalia de Joves. Veure Jordi Rovira Sánchez: La Guinardera, A.V. La Guinardera, Ajuntament de Santa Coloma de Grament, amb la col-laboració del la Direcció General d'Acció Cívica del Departament de Benestar i Família de la Generalitat de Catalunya, 2002, p. 46.

2013Jordi Corachán: “Vecinos de Singuerlín limpian un solar" i “Vecinos de Singuerlín se construyen su parque", El Correo Catalán, 13-11-1980 i 6-12-1980.

2014Eva Martínez: "Santa Coloma de Gramenet: Presentan el proyecto del Mercado del Singuerlín", 
Per altra banda, el dur impacte que va tenir la crisi econòmica havia fet sorgir una Assemblea d'Aturats que va protagonitzar alguns enfrontaments amb l'Ajuntament ${ }^{2015}$. El greu número de desnonaments a la ciutat havia impulsat la creació d'una "Comisión para la defensa de la Vivienda" impulsada per diferents AVV's que igual que la PAHC en l'actualitat, intentava oposar-se als desnonaments ${ }^{2016}$.

A diferència de Badalona, a Santa Coloma de Gramenet les eleccions municipals del 8 de maig de 1983 no van suposar un canvi polític al Consistori, sinó que el PSUC va obtindre majoria absoluta, cosa que els va permetre governar en solitari sense pactar amb el PSC-PSOE ${ }^{2017}$. Aquest fet ens demostra que l'Ajuntament colomenc havia resistit a les crítiques que se li feien des d'altres grups d'esquerra com a la propi crisi interna del PSUC i comptava amb un ampli suport veïnal. Fou en aquest segon mandat quan les diverses crisis internes dins el grup municipal del PSUC el van anar erosionant, si bé encara lentament. Va haver-hi un enfrontament entre Lluís Hernàndez i Carlos Grande, que va acabar amb la marxa d'aquest del grup municipal del PSUC que va ser seguida aviat per dos regidors més -José Candado i Antonio Gómez- de manera que aquest va perdre la majoria absoluta $^{2018}$. El final de la segona legislatura va estar així marcat per una forta El Correo Catalán, 12-3-1983.

2015“Acto de constitución de la asamblea de parados", El Correo Catalán, 15-6-1980; Jordi Corachán: "Pleno: Concejales y parados se enfrentan" i "Encierro en el Ayuntamiento de Santa Coloma” , El Correo Catalán 2 i 4-7-1980. La creació d'Assemblees d'aturats no va ser un fet exclusiu de Santa Coloma de Gramenet i es va donar també en altres de les principals ciutats catalanes.

2016Eva Martínez: "Santa Coloma: 10 vecinos que se opusieron a su desahucio pueden ser procesados", El Correo Catalán, 20-2-1983; "Un enfermo impide su deshaucio al decir a los policías que tendrían que disparar" i "Las asociaciones de vecinos piden una nueva ley de arrendamientos urbanos", El Correo Catalán, 24-3-1983. La "Comisión para la defensa de la vivienda" estava formada per les AVV's de Italians, Santa Rosa, Raval, Riu Nord, la Coordinadora d'AVV's, PSUC, PSC-PSOE, UGT, CCOO, MCC, Ateneu Llibertari, ERC, PCC, Tinència d'Alcaldia de Sanitat i Serveis Socials, la Regidoria d'Habitatge i els Assistents socials. Es pot trobar alguna documentació seva a AHMTB, Donació Mn. Catà, Caixa 11.

2017Aquest partit, el PSC-PSOE, explicava que les condicions per pactar amb el PSUC eren "inacceptables" en el seu butlletí: "Por que los socialistas no gobernamos en el Ayuntamiento" Grup Municipal Socialista de l'Ajuntament informa, (juliol 1983), AHTMB, Donació Mn. Josep Catà, Caixa 8.

2018Abel García: “Crisis comunista en el consistorio colomense”, El Correo Catalán, 25-5-1985; Abel García: "La crisis municipal en Santa Coloma se complica", El Correo Catalán, 29-5-1985; "Paralizado el nuevo equipo municipal de Santa Coloma", El Correo Catalán, 30-5-1985; "Cesan al portavoz comunista del Ayuntamiento de Santa Coloma", El Periódico de Catalunya, 11-61985; “Un concejal de Santa Coloma se va del PSUC", El Periódico de Catalunya, 28/29-3-1986; "La pérdida de otro concejal pone en peligro la mayoría del PSUC en Santa Coloma", La Vanguardia, 6-5-1986 i "El PSUC pierde la mayoría absoluta en Santa Coloma tras abandonar 
tensió dins l'Ajuntament, tant dins el grup del PSUC com pels enfrontaments d'aquests amb els socialistes per diversos temes, com per exemple va ser la campanya contra l'OTAN. L'Ajuntament de Santa Coloma va fer una apagada de llum el 31 d'octubre de 1984, va fer un referèndum propi el 8 de juny de 1985 (abans de l'oficial de 1986) i va donar diners a la campanya Anti-OTAN ${ }^{2019}$. L'estat de la Hisenda i comptes municipals va ser un dels altres temes de disputa ${ }^{2020}$, i fins i tot també els Jocs Olímpics de Barcelona $92^{2021}$. La cosa arribava a tal extrem que fins i tot en les coses que estaven d'acord el PSUC i PSC-PSOE es barallaven. Així va passar també amb el suport que es va donar a Justo Molinero quan a inicis de 1987 va ser clausurada Radio Tele-Taxi per la Generalitat seguint ordres del Govern Civil $^{2022}$. L'objectiu de desbancar a Lluís Hernàndez i al PSUC de l'Alcaldia de Santa Coloma de Gramenet va ser gairebé una obsessió -lògica, des de el seu punt de vista- pel PSC-PSOE en les municipals de 1987 on no es van escatimar esforços per aconseguir això promocionant la figura de Manuela de Madre i amb la visita constant de dirigents del PSC-PSOE ${ }^{2023}$.

No obstant, la continuïtat de Lluís Hernàndez al consistori en el segon mandat segurament va tenir alguna cosa a veure per que no hi hagués mobilitzacions veïnals de la importància i intensitat que si que va haver-hi a Badalona i Sant Adrià (en referències als casos de Pomar, Llefià i El Besòs). Això no significa que no hi hagués protestes ni mobilitzacions, sinó que aquestes no van

sus filas un tercer concejal", La Vanguardia, 10-5-1986.

2019“Apagón contra la OTAN", El Correo Catalán, 2-11-1984;"Referéndum anti-OTAN en Santa Coloma", El Periódico de Catalunya, 10-6-1985; "Pacifistas apoyan a Luís Hernández", El Periódico de Catalunya, 13-7-1986.

2020 Per exemple, segons el Ajuntament de Santa Coloma hi havia un dèficit de 780 milions de pessetes però una auditoria d'Hisenda comptabilitzava un superàvit de 29 milions. Abel García: "Hacienda y Santa Coloma entran en conflicto", El Correo Catalán, 4-2-1985; Antonio Cerrillo: "El PSC de Santa Coloma acusa a los comunistas de no saber demostrar el déficit municipal existente", La Vanguardia, 5-2-1985; Abel García: "Hacienda autidará otra vez a Santa Coloma”, El Correo Catalán, 14-2-1985; “Otorgados más de 452 millones al Ayuntamiento de Santa Coloma de Gramenet", La Vanguardia, 3-9-1985.

2021Aurora Sánchez: "Los Juegos enfrentan a socialistas y comunistas en Santa Coloma", El Periódico de Catalunya, 2-10-1986.

2022 “PSC i PSUC rivalizan en su apoyo a Radio Tele-Taxi de Santa Coloma”, La Vanguardia, 8-31987.

2023 “El PSC promociona a la candidata a la alcaldía de Santa Coloma”, El Periódico de Catalunya, 33-1987 i "La esposa de Felipe González apadrina a una candidata del PSC", El Periódico de Catalunya, 8-3-1987. Al 1987, poc abans de les eleccions municipals s'editava per part del PSCPSOE el butlletí Línea Directa, per promocionar la figura de Manuela de Madre. AHTMB, Donació PSUC, Caixa 6. 
arribar a tenir la intensitat de les que es van donar a les ciutats veïnes, segurament per que l'Ajuntament colomenc no va engegar una política urbanística amb el nivell d'agressivitat que van demostrar en determinades ocasions els Ajuntaments regentats pel PSC-PSOE. Per exemple, van ser una constant les protestes per la situació escolar, contra la proliferació de barracots provisionals i contra l'estat lamentable de moltes escoles, però això si, dirigides contra la Generalitat que era l'administració que tenia les competències en aquest àmbit ${ }^{2024}$. Els desnonaments $^{2025}$, i les mancances en el transport públic també van ser motius de mobilitzacions. Es van tornar a segrestar autobusos a les Oliveres al desembre de 1983 i a Singuerlín l'abril de 1985, coincidint amb el conflicte badaloní de Pomar $^{2026}$. En tots dos casos també per protestar contra la supressió de línies d'autobús que passaven pel barri, si bé no es va arribar al nivell del barri badaloní. Van haver-hi també reivindicacions puntuals per la conservació d'espais d'us públic també al Singuerlín ${ }^{2027}$. Sembla evident, doncs, que la menor conflictivitat de Santa Coloma té una relació directa amb la permanència del PSUC a l'Ajuntament i a les polítiques que va desenvolupar. Malgrat les dificultats pressupostàries i les crítiques rebudes, el consistori colomenc va desenvolupar durant aquest segon mandat una intensa activitat urbanística de reforma i millora dels barris seguint les directrius del Pla Popular de 1978, si bé sense enllestir-lo en la seva totalitat ${ }^{2028}$. Però si va haver-hi un conflicte a Santa Coloma als anys vuitanta amb una magnitud comparable en mobilització veïnal als casos de Pomar, Llefià, el Besòs i La Mina va ser, sens dubte, l'anomenat "Cas Pitarque", però amb la important diferència de

2024 "Las obras de tres escuelas de Santa Coloma finalizarán entre octubre y enero", El Correo Catalán, 19-9-1984; "Protesta en Santa Coloma en favor de la escuela pública", El Correo Catalán, 14-12-1984; Aurora Sánchez: "Mil niños de Santa Coloma no pueden matricularse aún", El Periódico de Catalunya, 6-6-1984; "Cadena humana en defensa de la pública", El Periódico de Catalunya, 10-5-1985; "Santa Coloma pide aulas en lugar de barracones", El Periódico de Catalunya, 26-9-1985; "Protesta escolar” , El Periódico de Catalunya, 14-12-1985.

2025Així es pot veure per exemple en la crida que es feia des de la "Comisión de Desahuciados de la AVV de Arrabal" en un full volant de 1983 a una concentració el dimecres 27 de juliol per impedir-ne un llançament. AHMTB, Donació Mn. Josep Catà, Caixa 2.

2026Aurora Sánchez: "Cuatro "buses" de Santa Coloma "secuestrados"”, El Periódico de Catalunya, 23-12-1983; "Sigue la guerra de los autobuses", El Periódico de Catalunya, 29-4-1985.

2027“Jardines equipados "a la brava”", El Periódico de Catalunya, 27-5-1986.

2028Un exemple d'aquestes realitzacions es pot veure a Ferran Navarro i Acebes (coord. i comp.): Perifèria o Marginalitat. Tres anys d'urbanisme municipal a Santa Coloma de Gramenet, Servei d'Urbanisme i Habitatge de l'Ajuntament de Santa Coloma de Gramenet, Santa Coloma de Gramenet, 1987. El Tinent d'alcalde d'Urbanisme i Obres Públiques era aleshores Eloy Jurado Cubero, un dels nostres entrevistats, que també em va recordar aquesta tasca. 
que no va ser una protesta dirigida en part o totalment contra el mateix Ajuntament.

Aquest conflicte es va originar per uns fets produïts als anys setanta. En concret, al 1975, quan Manuel Rubio i la seva família va adquirir un immoble al barri del Raval, al carrer San Francesc núm. 19, però l'escriptura de propietat estava en dipòsit del Ginés Romero el constructor, que, endeutat, va hipotecar els pisos sense el coneixement dels compradors ${ }^{2029}$. El mateix Josep Pitarque ens ho explicava:

"És un tio que compra un solar... ven participacions dels pisos que va fer. Una gent compra, el pis, van pagant el pis, el tio hipoteca el pis, no paga la hipoteca, els veïns no se n'assabenten, subhasten el pis... la gent que ja hi vivia allà i els volen fer fora. Llavors el xaval aquest va vindre allà que el recolzessin per que el volien fer fora. El vam recolzar, al barri apareixen unes octavetes i pancartes que deien 'cuervo subhastero, no nos echarás a la calle' 'fuera cuervo subhastero'... Sánchez Esteller i tal i tot això... I llavors agafa el Sánchez Esteller aquest (...)"2030

El cas es que el constructor Ginés Romero no va poder satisfer les hipoteques que havien fet i els pisos van ser subhastats. Un funcionari de l'Ajuntament de Barcelona, José Sánchez Esteller, que tenia vinculació amb el món de les subhastes va adquirir un dels seus immobles. Pel que es veu, al voltant de les subhastes s'havia creat una mena de màfia organitzada per adquirir propietats a baix preu, especular amb elles i enriquir-se, i no només pel que fa als immobles, sinó també a les empreses, com ens recordava un altre testimoni colomenc:

"Como nosotros pasamos de la empresa a cooperativa.... tuvimos que subastar... un follón en Magistratura para subasta. Bueno, los subhasteros que de alguna manera se ... estaban todos relacionados entre ellos (...) y era una mafia pero bien organizada y tal. Entonces los abogados los conocían, conocen todo el tinglado. Entonces se veía claramente. Entonces los tíos en aquella época pues tenían que llevar el dinero, o al menos la entrada del dinero que valía en la subasta en efectivo, porque no admitían cheques no admitían na.... iban con el maletín lleno de cuartos y lo soltaban allí en el... en la Magistratura cuando subastaban. Entonces se veía clarísimo... el abogado

2029L'estafa ja va ser denunciada a "Otra presunta estafa de pisos", La Voz del Arrabal. Boletín informativo de la Asociación de Vecinos del Arrabal (juliol-agost de 1975), AHMTB, Donació Mn. Josep Catà, Caixa 2, p. 8.

2030Entrevista a Josep Pitarque Narejos (amb Emiliana Salinas i Salvador Bolancer Dugo), 13-32013. 
nuestro, el que iba con los trabajadores nos dijo: 'tenéis que ir con una decisión muy clara, no podéis dejarlos entrar. Yo os diré quienes son. Y entonces (...) me dijo a mi 'yo te lo digo a ti y tu [li dius a la resta] conoces a toda la gente. Ese, ese y ese... y no los dejéis entrar. Os ponéis en la puerta, cuando hay subasta, jsubasta pública! Cataplás... ¡Todos los trabajadores allí!' Y no dejáis entrar'. Y dice, en aquella época no había ni escarni ni nada...dice 'y cada uno lleváis una barra de hierro debajo y si el tío pasa lo atravesáis, si es necesario lo atravesáis porque son malos... ¡tú no te puedes imaginar lo malos que son!' Por lo tanto... dice... ninguna compasión (.....”2031

El mencionat Sánchez Esteller va voler revendre els pis a les persones que habitaven la finca que havia adquirit i havien estat pagant les seves quotes i no sabien res d'aquesta operació. Manuel Rubio, no va voler fer-ho i va recórrer a l'AVV del Raval a la recerca d'ajuda. L'Associació es va abocar amb el cas i aviat es van fer mobilitzacions i van aparèixer pel barri pancartes i fulls volants denunciant el cas i titllant a Manuel Sànchez Esteller de "cuervo subhastero":

\footnotetext{
“Tenemos la obligaciòn [sic. En l'original tots els accents són oberts] por ser una asociaciòn que lucha a favor de los vecinos para defenderlos de una lacra de individuos sin escrúpulos, que sòlo buscan su beneficio sin importarles que un obrero pueda quedarse en la calle con sus hijos y su mujer. (...)

Y los que quieren quitarle su casa al vecino Manuel se dedican a comprar en subasta los pisos que por medio de trampa de los constructores pretenden que nos quiten la ley (son los que normalmente llaman cuervos de subastas).

Este individuo es Jose Sancho Esteller que con "manos limpias" quiere que darse [sic] con el piso que tanto sudor costó a nuestro vecino. Nos dice que no quiere negociar, que el piso es suyo porque así lo dice la ley."2032
}

Sancho Esteller va denunciar a l'AVV del Raval, a l'inquilí Manuel Rubio i a Grama per injúries i calumnies. En ser el president aleshores Josep Pitarque, la denuncia a l'AVV va recaure sobre ell. Hi va haver una voluntat clara d'acarnissament per part del denunciant contra un moviment popular que feia

2031Entrevista a Salvador Bolancer Dugo (amb Josep Pitarque Narejos i Emiliana Salinas), 13-32013.

2032 [AVV Raval]: "La AA VV. De Arrabal informa a la opinión pública" [full volant A4 sense data], AHMTB, Donació Mn. Josep Catà, Caixa 2. Posteriorment es va difondre una altra fulla titulada "Luchemos contra la especulación y el fraude en la vivienda. Impidamos el deshaucio" signada per les AVV's Riera Alta, Fondo, Singuerlín, Guinardera, Italians Can Mariner, Riu Nord, Can Franquesa, Santa Rosa, Oliveres, Raval, pel Casal de Cultura, el Casal de la Dona i els partits PCC, MCC, PSC (PSC-PSOE), PSUC, i sindicats CCOO i UGT. Veure AHMTB, Donació Mn. Josep Catà, Caixa 8. 
perillar els interessos especulatius que es movien al voltant d'aquest mon de les subhastes. Només cal veure el que demanava l'acusació particular al respecte dels denunciats:

“(...) pidió que se impusiera al procesado Manuel Rubio Cañadas tres penas de cuatro años de prisión menor y tres multas de noventa mil pesetas, por los tres delitos de calumnias (...) y cinco penas de cuatro meses de arresto mayor y cinco multas de noventa mil pesetas por los cinco delitos de injurias graves por escrito y con publicidad (...) y pago de los costes correspondientes y al procesado José Pitarque Narejos tres penas de cuatro años de prisión menor y tres multas de noventa mil pesetas por los tres delitos de calumnias proferidas por escrito y con publicidad (...) y cuatro penas de cuatro meses de arresto mayor y cuatro multas de noventa mil pesetas por los cuatro delitos de injurias graves, proferidas por escrito y con publicidad (...) y al pago de los costes correspondientes, debiendo indemnizar cada uno de los procesados al querellante en veinte millones de pesetas por los perjuicios morales y materiales irrogados por los delitos (...)"2033

Els denunciats van ser defensats per l'advocat Francesc Arnau, del DALP. Al judici hi va anar una nodrida representació del moviment veïnal i altres persones en solidaritat $\mathrm{amb}$ els processats ${ }^{2034}$. Aquests finalment van ser absolts ${ }^{2035}$. Però el denunciant va recórrer la sentència al Tribunal Suprem, que rebatia la sentència de l'Audiència Provincial de Barcelona i tot i mantenir la absolució de Manuel Rubio Cañadas:

"Asimismo, debemos condenar y condenamos a JOSE PITARQUE NAREJOS, como autor de un delito de injurias graves, sin la concurrencia de circunstancias modificativas de la responsabilidad, a la pena de UN AÑO DE DESTIERRO, a cien kilómetros de Santa Coloma de Gramenet (Barcelona) y MULTA DE CINCUENTA MIL PESETAS, con arresto subsidiario de veinticinco días si no la hiciera efectiva, y a que se indemnice al perjudicado José Sancho Esteller en concepto de daños y perjuicios en la cantidad de trescientas mil pesetas (...."2036

Com era d'esperar, aquesta resolució va provocar una gran indignació a la

2033“Senténcia de la Audiencia Provincial de Barcelona” (17-12-1983), Arxiu Municipal Administratiu de Santa Coloma de Gramenet (ASCG), Caixa Cas Pitarque, p. 6

2034 “Santa Coloma se mobiliza por el juicio a dos vecinos", El Periódico de Catalunya, 15-12-1983. 2035 “Senténcia de la Audiencia Provincial de Barcelona” (17-12-1983), ASCG, Caixa Cas Pitarque, p. 10.

2036"Segunda sentencia" [del Tribunal Suprem de Madrid] (17-3-1986), ASCG, Caixa Cas Pitarque, p. 2. 
ciutat colomenca i en especial a la Coordinadora d'Associacions de Veïns, que no va dubtar en qualificar-la com "una sentència de l'Edat Mitjana però al 1986" 2037. L'Ajuntament colomenc va aprovar una moció de suport a Josep Pitarque i es va fer un recurs però va ser refusat ${ }^{2038}$. Així que es van fer diverses mobilitzacions en solidaritat amb el sentenciat:

\begin{abstract}
“Cada paper que rebíem del Jutge (...) del Procurador vam aprendre molt d'això. Ens deia: 'vostès tenen que vindre a fer qualsevol declaració'. Automàticament tocàvem el pito, es reunia la Coordinadora d'Associació de Veïns i fèiem una reunió, convocàvem els partits, les entitats, sindicats... Fèiem unes assemblees grans de gent... 'bueno, ha vingut aquest paper, què es fa?' Per això dic jo que l'estil Arnau funcionava molt bé. L'endemà quan tenia que anar al Jutge no anava [sol] (...) anava allà un fotiment de gent per una declaració pura i dura. I quan havia que fer alguna cosa que es demanaven els diners o lo altre, muntàvem manifestacions i venia la gent massivament. De la Plaça de la Vila fins al Raval, tots acabàvem... Això es va donar en aquella època i va passar durant aquests anys quatre o cinc vegades (...)."2039
\end{abstract}

Tres persones van ser detingudes i posteriorment alliberades durant una manifestació davant dels jutjats de Santa Coloma de Gramenet ${ }^{2040}$. El 19 de setembre de 1986 centenars de persones sortien al carrer en solidaritat amb Josep Pitarque convocats per la Coordinadora d'AVV's, partits polítics i el propi Ajuntament ${ }^{2041}$. El dia 20 es tornava a fer una nova manifestació amb un miler de persones que va transcórrer pels carrers de Santa Coloma reclamant l'anulació de la sentència ${ }^{2042}$. Anteriorment a aquestes mobilitzacions ja s'havia engegat una campanya per aconseguir l'adhesió de diferents entitats de la ciutat per que no s'executés la injusta sentència ${ }^{2043}$. Mentrestant la ciutat s'omplia de pancartes,

2037 “El Supremo envía a destierro a un líder del movimiento vecinal”, El Periódico de Catalunya, 44-1986.

2038“Moción en el Ayuntamiento contra el destierro de un vecino”, La Vanguardia, 16-4-1986. i "Rechazan el recurso de amparo de un condenado a destierro", El Periódico de Catalunya, 18-61986. La moció que es va aprovar en un Ple extraordinari el 15 d'abril de 1986 es pot consultar a ASCG, Caixa Cas Pitarque.

2039Entrevista amb Josep Pitarque Narejos (amb Salvador Bolancer Dugo i Emiliana Salinas), 12-32013.

2040“Protestas en Santa Coloma por un destierro”, El Periódico de Catalunya, 19-9-1986.

2041 “Rebelión por un destierro”, El Periódico de Catalunya, 19-9-1986.

2042“El destierro de un vecino provoca más protestas”, El Periódico de Catalunya, 21-9-1986 i “Unas mil personas se manifiestan contra el destierro de un vecino de Santa Coloma” , La Vanguardia, 21-9-1986.

2043Veure el document al respecte a ASCG, Caixa Cas Pitarque, 
cartells i fulls volants denunciant el cas, tot i que cal recordar, com ja he dit abans, que "l'enemic" no era en aquest cas l'Ajuntament.

Es va fer un recurs al Tribunal Constitucional i un altre al Tribunal Europeu de Drets Humans, mentre també es feien reclamacions al Síndic de Greuges ${ }^{2044}$. Però aquests procediments legals anaven lents. Així es va donar un pas més quan es va arribar a plantejar la possibilitat de demanar "asil polític" a l'Ajuntament de Santa Coloma de Gramenet. Aquesta opció va ser explorada pels membres del moviment veïnal que van desenvolupar una línia pròpia per pressionar al consistori colomenc per que, tot i el suport d'aquest al mateix Pitarque, s'avingués a fer efectiva aquesta mesura concreta:

"Que también el hecho de que todavía fuera representativa la gente del movimiento popular muchas veces forzó esta perspectiva: 'anem conjuntament'. Forçava una mica a l'Ajuntament, per que jo me'n recordo d'alguna reunió en el Gobierno Civil que decían: 'si, juntos pero no revueltos' . Y llegar al Gobierno Civil separados. Ayuntamiento por un lao y movimiento vecinal por el otro. El día que fuimos con la lista al Alcalde 'como vengar a por el Pitarque la Guardia Civil mira, esta lista...' estábamos la Estela y yo en el despacho del Luís Hernández, 16 nombres (...) 'nosotros vendremos y nos encerraremos aquí en tu despacho y pediremos auxilio social, auxilio político al Alcalde que es el máximo representante. Asilo político. Y nos conoces a todos y venimos aquí'..."2045

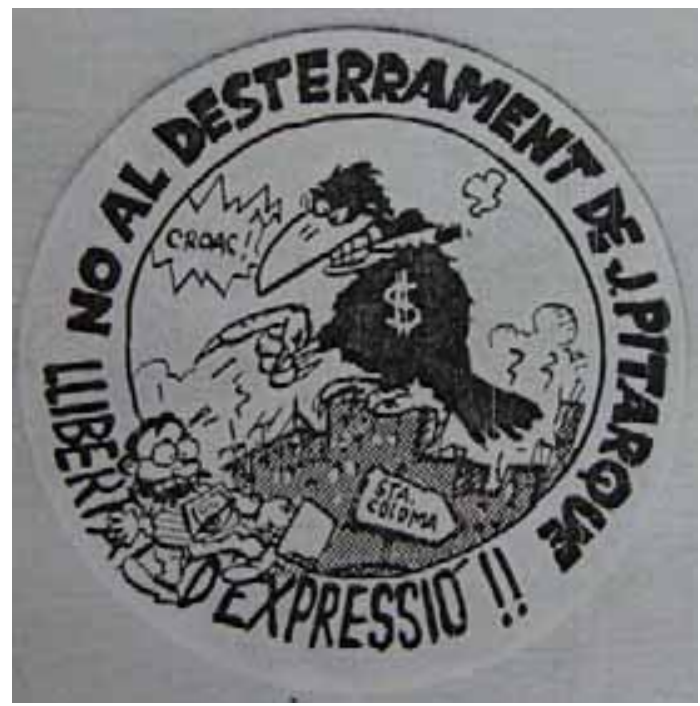

Adhesiu de la campanya de solidaritat amb Josep Pitarque dissenyat pel popular dibuixant de còmics colmenc Carlos Azagra. Font: ASCG, Caixa Cas Pitarque.

2044Tots aquests documents es poden consultar a ASCG, Caixa Cas Pitarque.

2045Entrevista a Emiliana Salinas (amb Josep Pitarque Narejos i Salvador Bolancer Dugo), 12-32013. 
L'Ajuntament colomenc va tenir un comportament digne i va fer una sol-licitud d'indult pel seu compte, conscients de que des de la Coordinadora no ho volien fer per una qüestió de principis, ja que creien que això significava reconèixer que s'havia comés un delicte:

"FERNANDO: (...) Després de fer-se totes les mobilitzacions, els judicis que vam anar com Ajuntament i tal, vam recomanar el indult (...). A llavorens el Pitarque no va acceptar 'jo no he fet cap delicte, jo no vull el indult, llavors jo no el demano'. Però el vam demanar nosaltres en nom d'ell (...) per que ja enteníem que no el volgués demanar (...) el Lluís, l'Ajuntament i també els socialistes, per que llavors estàvem en l'època de Felipe González i estàvem al Congrés, estava la Manuela [era diputada] i per tant també va ajudar a tirar endavant el indult. (...) I van indultar al Pitarque, cosa que ell no havia demanat, però [inintel-ligible].

LLUíS: Jo vaig parlar amb ell i em va dir 'Lluís, tu has d'entendre que jo no vull demanar l'indult per que... no he fet cap delicte, tu saps...' , 'home, jo ja ho se però es per intentar evitar que et trobis així afectat en aquesta ciutat que tu estimes i que' [inintel-ligible] 'No puc fer-ho això'. 'Doncs, i si tu et mantens al marge i deixes que nosaltres fem...', 'Home, si feu això si, acceptaria el resultat' i per tant..."2046

El mateix Ajuntament de Santa Coloma va fer un informe de conducta positiu a requeriment judicial ${ }^{2047}$. L'indult es va concedir finalment amb un reial decret fet pel govern central el mes de març de $1989^{2048}$. Apart de la mobilització popular i el suport de l'Ajuntament colomenc, segurament va pesar la denúncia feta al Tribunal Europeu dels Drets Humans pel mateix Josep Pitarque i la por del Govern espanyol a que el Tribunal Suprem, que encara estava ple de persones que havien "prosperat" a la dictadura -per dir-ho suaument- continués fent el ridícul amb una sentència que a totes llums semblava forassenyada ${ }^{2049}$. Semblava que aquest indult tancava el tema, però no va ser així. Tot i que escapa al àmbit cronològic del present

2046Entrevista a Fernando Saro Madrilejos i Lluís Hernàndez Alcasser (amb Jaume P. Sayrach), 5-62013. La petició d'indult la va signar Lluí s Hernàndez el 2 de desembre de 1987 i es pot consultar a ASCG, Caixa Cas Pitarque.

2047 Ajuntament de Santa Coloma de Gramenet [signat per Lluís Hernàndez]: "Informe de Conducta" (3-1-1989), ACSB, Caixa Cas Pitarque.

2048“REAL DECRETO 268/1989, de 10 de marzo por el que se indulta a José Pitarque Narejos.", BOE núm. 68 (dimarts 21-3-1989), ASCG, Caixa Cas Pitarque.

2049Es interessant veure el document "Observaciones del gobierno español sobre admisibilidad y fundamento de la demanda no 13.420/87, Pitarque contra España” (2-21989), ACSB, Caixa Cas Pitarque. Aquest havia considerat "inadmisible" la demanda presentada a les instàncies europees. No hauria de ser tant inadmissible quan poc després es va concedir l'indult. 
estudi no puc deixar d'esmentar que el litigi encara va continuar durant molts anys. Al 1996 José Sancho Esteller va reclamar judicialment la indemnització monetària de 350.000 pessetes que pel que sembla l'indult no es va molestar en anular. A aquestes el denunciant afegia unes altres 427.221 en concepte d'interessos ${ }^{2050}$. De nou van caldre mobilitzacions ${ }^{2051}$, i l'Ajuntament, aleshores encapçalat per Manuela de Madre del PSC-PSOE, es va comprometre a pagar la sanció ${ }^{2052}$, però al final només va caldre que fes una aportació parcial per completar la quantitat reclamada ja que la FAVGRAM havia recollit pel seu compte gairebé tota la quantitat reclamada (faltaven prop de 55.000 pessetes, que va ser el que va aportar l'Ajuntament) ${ }^{2053}$.

Però per increïble que sembli, la cosa no va acabar aquí. L'any 2002 José Sanchez Esteller va reclamar 2.251,63 euros en concepte de la minuta dels honoraris del seu advocat (les costes del judici). De nou van caldre recursos i tràmits judicials ${ }^{2054}$. El mateix Josep Pitarque afirmava que tot responia a "una venjança contra el moviment associatiu de Santa Coloma” per part dels diferents lobbys immobiliaris i del món de les subhastes ${ }^{2055}$. L'any anterior, la família de Manuel Rubio havia marxat del pis. Finalment sembla ser que es va aconseguir que es donés per prescrit el cas. Però com deia el propi Josep Pitarque, que també lloava el paper que va tenir l'advocat Francesc Arnau en la seva defensa, la intenció havia estat molt clara:

"Això era criminalitzar el moviment veïnal, per que havia defensat un veí! (...) Es com si es volgués criminalitzar la PAHC actual per que la gent no sortís a defensar la gent... $(\ldots)^{\prime 2056}$

2050David Saura: "El desterrament de Josep Pitarque encara cueja vuit anys després de concedir-li l'indult", El Punt, 19-1-1997. El document de reclamació es pot consultar a ASCG, Caixa Cas Pitarque.

2051 La FAVGRAM (Federació d'AVV's de Santa Coloma de Gramenet), entitats de la ciutat i partits polítics com el PSC-PSOE, IC-EV, CDC i sindicats com CCOO i UGT es van tornar a mobilitzar i van impulsar una recollida de diners. Es poden veure documents al respecte a ASCG, Caixa Cas Pitarque.

2052 David Saura: "Manuela de Madre garanteix que l'Ajuntament pagarà la sanció a Pitarque", El Punt, 23-1-1997.

2053En concret l'aportació va ser de 54.789 pessetes. Veure Decret d'Alcaldia (25-11-1997), ASCG, Caixa Cas Pitarque.

2054De nou, tots els documents al respecte es poden consultar en ASCG, Caixa Cas Pitarque.

2055 Carme López: [entrevista a Josep Pitarque Narejos] "Es una venjança dels subhastaires contra el moviment associatiu de Santa Coloma", El Punt, 5-5-2002.

2056Entrevista a Josep Pitarque Narejos (amb Emiliana Salinas i Salvador Bolancer), 12-3-2013. L'entrevistat continua ben actiu sent membre de la PAH de Gramenet, de l'Ateneu Júlia Romera 
A Sant Adrià de Besòs, durant el darrer any dels setanta i inicis dels anys vuitanta va haver-hi també alguna mobilització veïnal com ja vaig explicar al capítol quart ${ }^{2057}$. A les segones eleccions municipals el PSC-PSOE obtenia la majoria absoluta amb quinze regidors. CiU i AP n'obtenien dos respectivament, mentre el PSUC s'esfondrava i, com el PCC, obtenia només un regidor ${ }^{2058}$. La majoria absoluta socialista els hi va permetre governar amb comoditat i, com va denunciar l'oposició, amb prepotència. Fins i tot es va acusar al consistori de restringir la participació als Plens i va dimitir un regidor independent a la llista del PSC-PSOE per una qüestió de censura ${ }^{2059}$. El consistori va tenir conflictes amb comerciants per temes de seguretat ciutadana ${ }^{2060}$, amb el veí Ajuntament Badaloní pel nom d'una parada del nou metro ${ }^{2061}$, o fins i tot amb la pròpia CMB per posar en funcionament el Col-lector de Llevant abans de que funcionés la Depuradora del Besòs, anant a parar així totes les aigües contaminades a la seva platja ${ }^{2062}$.

L'oposició també els va acusar d'irregularitats econòmiques en diversos àmbits, ja fos en la retribució dels regidors, en el Patronat d'Esports Municipal ${ }^{2063}$. Un altre tema recorrent van ser les crítiques per les pujades de sous que solia fer el consistori socialista de l'Alcalde i Tinents d'Alcalde, que en el cas dels segons va arribar al 52 per cent ${ }^{2064}$.

\section{i de l'ANC.}

2057Veure p. 563-566.

2058 Veure gràfica p. 623.

2059 “El Ayuntamiento de Sant Adrià restringe la participación”, El Periódico de Catalunya, 25-71983; "Dimite un concejal por un artículo no publicado", El Periódico de Catalunya, 10-101983. Es tractava de Jaume Casanellas, que denunciava la censura a un article seu a la revista municipal.

2060 “Multan a las paradas del mercado de Sant Adrià por cerrar el 1 de marzo”, El Correo Catalán, 4-3-1985; "Comerciantes de Sant Adrià contra el Ayuntamiento", El Correo Catalán, 7-4-1984. La tancada de l'1 de març era una protesta contra la inseguretat ciutadana feta a nivell de Barcelonès.

2061 "Sant Adrià: sigue la polémica por la estación del metro" i "Acabó la polémica entre Badalona i Sant Adrià por el nombre de la estación de metro limítrofe", La Vanguardia, 5 i 19-1-1985.

2062 Jaume V. Aroca: “El colector de Levante, motivo de preocupación en Sant Adrià”, La Vanguardia, 3-8-1984; Jaume V. Aroca: "La CMB apoya la apertura del colector de Levante", La Vanguardia, 30-9-1984 i Jaume V. Aroca: "Clima de oposición a la Corporación Metropolitana, La Vanguardia, 4-12-1984.

2063Jaume V. Aroca: "Polémica municipal por la manipulación de fondos”, La Vanguardia, 29-11984; Jaume V. Aroca: "CiU denuncia irregularidades en el Patronato de Deportes de San Adrián de Besòs", La Vanguardia, 30-11-1985; Jaume V. Aroca: "La oposición en el Ayuntamiento de Sant Adrià pide una auditoria del Patronat d'Esports", La Vanguardia, 23-11986.

2064 Jaume V. Aroca: “El pleno aumenta el sueldo de los tenientes de alcalde de Sant Adrià un 52 
A nivell de mobilitzacions veïnals, de nou les més destacades van tindre lloc als barris que estaven en pitjor situació, amb un especial protagonisme pel barri del Besòs. En aquest existia des de feia temps un solar que era reivindicat per que es fessin equipaments al barri i que era conegut popularment pel "Solar de la Palmera" per que allà s'havia plantat un arbre d'aquest tipus com a símbol d'aquesta reivindicació. La Generalitat havia aprovat, a través de l'Institut Català del Sol, la construcció d'uns 218 habitatges socials en aquest espai, cosa que va provocar un greu enfrontament amb el veïnat quan aquests van tractar d'impedir que comencessin les obres el 25 de gener de $1984^{2065}$. La policia va reprimir als veïns que intentaven impedir les obres i es van donar diversos enfrontaments durant aquest mes i el següent. El dia 7 de febrer, en un enfrontament particularment greu van ser detinguts el president de l'AVV Besòs, Rafael Caballero i una segona persona ${ }^{2066}$, fet que va provocar noves manifestacions amb la participació de cinc-centes persones ${ }^{2067}$. Els veïns van mantenir la vigilància del solar per impedir que s'edifiqués ${ }^{2068}$. I aquesta obstinada resistència va fer que la Generalitat tirés enrere -provisionalment- aquest projecte. Durant el conflicte, l'Ajuntament adrianenc va inhibir-se i no va donar un suport explícit a la Generalitat.

Però dins la mateixa associació ja va haver-hi discrepàncies d'opinió tot i que en aquesta el PCC era hegemònic. Aquesta divisió es va posar més en evidència durant l'octubre de 1990, quan es va intentar repetir l'operació de construir 196 pisos socials en el mateix espai i es va desencadenar el que popularment va ser conegut com "La Intifada del Besòs".

"Lo que passa és que ja al final, com que ells mateixos es van barallar i en la transició ja es van quedar... la Maria Codina es va barallar amb la Luisa Flores, amb el Rafael Caballero, i claro, això ja (...) ja en els anys 80 avançat eh? (...). L'Associació era molt reivindicativa, però dintre de l'Associació tothom no pensava igual. Eren del mateix partit però tothom no pensava igual. Entonces a llavorens que passava: la Maria

por ciento", La Vanguardia, 7-7-1987.

2065Jaume V. Aroca: "Sant Adrià: los vecinos no quieren que se construyan más viviendas en el barrio del Besòs", La Vanguardia, 30-1-1984.

2066 Jaume V. Aroca: "Sant Adrià: enfrentamiento entre vecinos y policia por la construcción de viviendas", La Vanguardia, 8-2-1984.

2067 “Manifestación en Sant Adrià contra unas viviendas” , El Periódico de Catalunya, 8-2-1984. 2068 “Los vecinos de Cobasa hacen guardia en un solar”, El Periódico de Catalunya, 9-2-1984. 
Codina era com més dialogant i comprenia les coses... com que havia que fer una evolució i tot això... (...)

Doncs per això es van barallar... la Maria Codina deia que tampoc els pisos... que era algo també positivo, per que era gent nova... ho veia d'una altra manera (...) pisos de protecció i que serien per la gent del barri... bueno, tal com ho va vendre l'Ajuntament, no? Que eren per la gent del barri que per qui que per allà. Clar, tot això semblava molt bonic: gent nova pel barri, locals nous, que això activaria el comerç (...). Jo com ja estava a l'Associació de Comerciants anava a les reunions on deien que això activaria més el comerç per que clar quan més gent vinguessin doncs el comerç s'activaria i tot això.

Però després ellos mateixos o concretament Rafael Caballero van filtrar que los pisos no eren perla gent del barri si no per ubicar a la gent que no tenia pis aquí al barri de La Mina. Per que el barri de La Mina estava massificat. Hi havia casos d'un pis on vivien tres, quatre o cinc famílies. I era per quitar la massificació. Es veu que això es va filtrar d'alguna manera de l'Ajuntament i es va enterar l'Associació de Veïns i a partir d'ahí han sigut ja les baralles. I clar, els comerciants no volíem per que vèiem que en compensatòria d'inseguridad amb la gent que venia això no era activar el comerç““2069

Tot i això, les decisions importants es prenien en assemblees públiques amb molta participació, fet que evidenciava la gran preocupació que aquest tema tenia pels habitats del Besòs. La situació va evolucionar fins un veritable aixecament de del barri que es va enfrontar durant dies i setmanes -sobretot des de el 24 al 29 d'octubre- als Mossos d'Esquadra en una batalla campal on es van arribar a llençar des de els balcons i finestres electrodomèstics, bombones de butà i d'altres objectes contundents. Els Mossos havien actuat anteriorment amb gran duresa per desallotjar als veïns que, com al 1984, s'havien interposat al solar el dia 9 d'octubre de 1990 per impedir les obres. Va haver-hi molts ferits i fins i tot un d'ells va perdre un ull per l'impacte d'una pilota de goma. La cosa va arribar a tal punt que fins i tot es va afirmar que s'havien fet servir armes de foc ${ }^{2070}$.

La lluita va impedir aleshores, com al 1984, que les obres es portessin a

2069Entrevista a Marisol Abril, 21-1-2013.

2070Així ho recordava un article de Manuel Delgado: “El odio", El País, 6-11-2005. Van haver-hi 17 ferits (tres policies) i 19 detinguts durant els enfrontaments. Existeix un documental que narra els esdeveniments des de el punt de vista veïnal anomenat "Besos al Besós". Veure també un estudi contemporani als fets ja citat: Marco Marchinoni [et al.]: Análisis de un conflicto urbano: el caso de Sant Adrià del Besòs. El corporativismo territorial, Institut d'Estudis Metropolitans de Barcelona, 1991. 
terme si bé en aquest cas l'Ajuntament i l'alcalde Messeguer va sortir-ne més malparat per que havia donat més suport al projecte d'edificació de la Generalitat. I com al 1984, on també es va fer alguna insinuació, des de les autoritats es va acusar als veïns que protestaven de racisme argumentant que el que no volien era rebre població gitana i obviant el fet que existia una reivindicació de conservar l'espai per equipaments públics ja des dels anys setanta. Tenia algun fonament aquesta acusació? Maria Codina, ens donava la seva opinió sobre aquest assumpte:

"I al cap de poc temps, a l'endemà van vindre a començar a voler a edificar i la gent es va tirar al carrer, però el problema és que no volien les vivendes no per que volien habitatges sinó per que s'havia corregut la veu de que es feien pels habitants de La Mina (...). Per que es començava a parlar d'esponjament de La Mina (...)”2071

Al respecte d'aquest tema el mateix Rafael Caballero ens donava el seu parer: "Algo de cierto, bastante de cierto hay en eso. No fue, una cosa, que fuera generalizado en que había por defender al barrio por equipamientos y por unas mejoras de esto. Eso había unos cuantos de personas, sí. Pero la inmensa mayoría... cuando hacíamos asambleas de cuatro o cinco mil personas, tres o cuatro mil personas y todo eso, era por lo de tal.. (...)

Ya no entraba si con razón ni sin razón. Eso es aparte. Habíamos mucha gente concienciada en que eran los equipamientos y era lo que nos hacía falta. También se salva o nos salvamos, en eso del racismo, en que no se puede decir que muchas personas eran racistas cuando estábamos juntos. Los médicos nosotros los tenemos en La Mina. Y muy buenos médicos. Y además otra cosa. Aquí habemos dos personas que hemos estado desde el principio (...). Y nunca se ha sentido nunca de que haya maltrato (...) ¡nunca! Eso no quiere decir que hubo una época en que había mucho de esto (...) y que a lo mejor... pero nunca, nunca, nunca podemos decir que haya habido personas... (...) 0 sea que lo del racismo es una cosa entre comillas porque por decir... ahora sus maneras de ser todo esto y tal... pues hay quien les guste más, les guste menos... Pero una cosa, si no tienen la torpeza, los bandoleros aquellos de decir que los pisos que se iban a hacer eran solo para los de La Mina. Porque en el 84 no... era diferente. (...)

En el 90 si el Ayuntamiento no son tan torpes y dicen que para el barrio siquiera un 25 $\%$, esto aquí no se consigue [es refereix als equipaments] porque había gente, era era una manifestación al Ayuntamiento cada día a preguntar que si pisos, que si pisos, que si pisos... Algunos querían pisos y claro, como tenían amigos en los partidos y una cosa

2071Entrevista a Maria Codina Cabré, 5-4-2012. 
y la otra iban y machacaban (...). Entonces, cogieron un compromiso muy fuerte que les venían ya debido al 90, que querían meter aquí el segundo Pedralbes, de limpiar todo eso de lanzarlo... empezaron antes a comprar pisos aquí, en la Via Trajana, para irlos pasando, irlos alejando de esta zona. Bueno, pues la gente cuando vio aquí que ellos no iban a tener pisos, no apoyaron. Pero como el día 25 [d'octubre de 1990] nos mandaron 750 policías recién llegados de Alemania (...). Entonces nos apalearon, nos tirotearon, a pequeños, grandes, viejos y todo quisqui. Y cuando los que estaban trabajando venían y no los dejaban entrar en el barrio (...) entonces aquello ya fue la gota que...(.....". 2072

Malauradament, aquest estudi no pot aprofundir en el que va ser sens dubte un dels conflictes veïnals més grans no ja del Barcelonès Nord, sinó de la Catalunya d'aleshores. Al final, malgrat l'ocupació policial per part dels mossos del barri el veïnat es va sortir amb la seva, independentment de les diferents motivacions que tenien els mobilitzats i al lloc reivindicat, el "solar de la Palmera", finalment es van edificar equipaments pel barri. Els més conscienciats tenien clar que lluitaven pels equipaments, sense descartar, però que hi haguessin també persones fora del cercle més activista que es moguessin per motivacions més fosques com podia ser un cert racisme. Arran d'aquesta mobilització va sorgir una candidatura municipal que va arribar a tenir representació municipal amb 4 regidors. El que és innegable és que aquests esdeveniments van marcar profundament la història del barri i han passat a formar part de la seva identitat, fins avui. A la mateixa AVV Besòs encara avui en dia hi ha un mural fet amb pilotes de goma i altres elements antidisturbis que es van fer servir per part dels mossos aleshores.

Íntimament lligada amb aquests fets del Besòs hi havia una operació urbanística especulativa a aquesta zona de la ciutat i a d'altres barris de Barcelona de cara a la celebració dels jocs olímpics de 1992. I això va afectar també al barri veí de La Mina, fins al punt que es va arribar a planificar un enderrocament -total o parcial- d'aquest per que "feia lleig" a la Barcelona "cosmopolita" i "olímpica" que es volia projectar aleshores, com veurem tot seguit.

El barri de La Mina va patir molt durament els efectes de la crisi econòmica i va ser maltractat per les administracions públiques. El Pla Interdepartamental de del Besòs durant els 80 . 
1983 que havia d'implicar a la Generalitat, CMB, Diputació, Ajuntament de Sant Adrià i a l'Ajuntament de Barcelona no es va aplicar per falta de dotació econòmica. Així ho denunciaven els propis veïns ${ }^{2073}$, o fins i tot la que va ser regidora pel PSCPSOE de La Mina i Serveis Socials i que també havia treballat al Camp de la Bota:

"Com que no va haver-hi prou diners, es va començar el Pla i no es va acabar. I llavors que passava, que es creaven unes expectatives i després es quedaven en res."2074

Per molt que el Pla es va revisar al 1986, es va "desbloquejar" al 1987 o fins i tot es va fer un nou Pla al 1988, que com veurem, tenia una vessant oculta ${ }^{2075}$, la percepció a La Mina era que se l'estava perjudicant. Alguns exemples: Al juny de 1984 uns joves monitors de La Mina es queixaven de que l'Ajuntament no els donava la subvenció per les colònies d'estiu ${ }^{2076}$. El barri va perdre també el seu Centre de Planificació Familiar en teoria per que les seves funcions havien de ser assumides per l'ambulatori, però al Centre hi havia tot un equip que portava anys treballant al barri ${ }^{2077}$. Fins i tot les aules d'escolarització especial que existien per alumnes amb problemàtiques greus van ser tancades ${ }^{2078}$. No es estrany llavors que es tingués aquesta percepció de retrocés al barri i que molta gent cerqués una sortida individual intentant marxar de La Mina.

Que havia passat mentrestant a l'AVV del barri? Recordem que a inicis dels vuitanta havia hagut una dura pugna pel control d'aquesta de la qual van sortir guanyant els militants del PSUC. No obstant, aquest procés i la posterior escissió del partit sens dubte van influir en l'afebliment d'aquesta -i segurament els anys més durs de la crisi al barri també van ajudar-. Al Juliol de 1982, si fem cas d'una acta de l'entitat, comptava amb 649 socis dels quals estaven al corrent de pagament 136. Però aquests números ens poden portar a engany, ja que:

2073 Jaume V. Aroca: “Los vecinos de La Mina opinan que el Pla Interdepartamental no funciona”, La Vanguardia, 30-3-1985.

2074Entrevista a Maria Àngels Rosell, 21-3-2012.

2075 Marco Marchinoni [et. al.]: Análisis de un conflicto urbano..., p. 49.

2076“Monitores de La Mina atacan la política juvenil municipal”, El Correo Catalán, 26-6-1984; Margarida Corominas: "Niegan un campamento a jóvenes de La Mina”, El Periódico de Catalunya, 26-6-1984; Jaume V. Aroca: "Los jóvenes de La Mina piden más dinero para las colonias de verano", La Vanguardia, 28-8-1984.

2077 “Inquietud en La Mina por cambios en el centro de "planning”", El Periódico de Catalunya, 1511-1984 i Jaume V. Aroca: "Sant Adrià: La Mina pierde su centro de planificación familiar", La Vanguardia, 19-11-1984.

2078“Cierran la única esculea para chavales difíciles en La Mina”, El Periódico de Catalunya, 10-41986. 


\begin{abstract}
"Se pasa al segundo punto del orden del día "Elección de Junta" no alcanzándose acuerdo en la elección de esta por falta de candidatura. Se acuerda elegir a una comisión gestora que prepare una convocatoria de asamblea a finales de septiembre $(\ldots)^{2079}$
\end{abstract}

De fet si s'observen els llibres d'actes a la Junta anterior al 1980, més propera als socialistes, hi participaven aproximadament unes 18-21 persones. La nova junta de amb Juan Ponce de President tenia una mitjana de 8 persones que va anar disminuint fins trobar-nos amb reunions amb 6 o 5 persones i que en aquesta esmentada reunió no sortís cap candidatura ferma de Junta. La cosa va arribar fins a tal punt que fins i tot l'antic patriarca del Camp de La Bota, el "Tio Manolo" va arribar a fer un "Consejo de Barrio" davant el "buit de poder" existent ${ }^{2080}$. Sembla ser que al final des d'aquesta Comissió Gestora es va anar fent fins que es va poder constituir una Junta més estable. Però l'AVV durant els 80 no va recuperar mai la força que havia tingut als anys $70^{2081}$. De fet més endavant agafarà el protagonisme en les reivindicacions una Assemblea de Barri on participaven altres persones i l'AVV hi era com una entitat més, però no la dinamitzadora.

Per que de protestes si que n'hi van haver. El barri es va mobilitzar al març de 1984 reclamant locals per als joves del barri i altres promeses no acomplertes per les administracions públiques ${ }^{2082}$. El 28 de març de 1985 uns dos cents veïns de La Mina es desplaçaven a la Generalitat per reivindicar la realització del Pla Interdepartamental ${ }^{2083}$. Fins i tot quan es van tancar les aules d'escolarització especial es va fer una vaga a les escoles públiques i es va anar a exposar els problemes del barri al Parlament ${ }^{2084}$. Aquestes mobilitzacions sens dubte van

2079 [Acta de l'AVV de La Mina], (31-7-1982), AHLM, Caixa C1.4. Associació de Veïns Anys 80, Carpeta Llibres d'Actes, [segon llibre p. 17]

2080 [Acta] (5-10-1982], AHLM, Caixa C1.4. Associació de Veïns Anys 80, Carpeta Llibres d'Actes, [segon llibre p.21-22.

2081Si s'observen els llibres d'actes, es pot veure com al desembre de 1982 es constitueix una nova Junta, però no es troben més actes fins novembre de 1986 on consta com a President Agustín Cortés, un antic gitano militant del PCC. Veure AHLM, Caixa C1.4. Associació de Veïns Anys 80, Carpeta Llibres d'Actes, [segon llibre p. 24-25.]

2082 “La Mina reclama locales para atender a jóvenes”, El Periódico de Catalunya, 29-3-1984; Jaume Bertran i Regué: “Plenos Municipales en Sant Adrià", El Correo Catalán, 30-4-1984.

2083 “Vecinos de La Mina, en la Generalitat”, El Periódico de Catalunya, 29-3-1985.

2084 Jaume V. Aroca: "Huelga en las escuelas de La Mina al suprimirse las aulas de escolarización", La Vanguardia, 11-4-1986; "La Mina porta avui el seu problema escolar al Parlament",Avui, 295-1986. 
servir per anar articulant un nou teixit quan es va constatar que l'AVV no tenia la força d'abans. Una nova Assemblea Veïnal va ser la que va aglutinar aquests esforços, arribant a presentar un nou programa de rehabilitació pel barri que va servir de baser per negociar amb el poder polític local, arribant a un acord amb el PSC-PSOE per incloure un independent -Paco Marín- a la seva llista electoral ${ }^{2085}$.

Després de les eleccions municipals de 1987 des de les administracions es va presentar un nou Pla pel barri que havia de superar el mai aplicat Pla Interdepartamental de $1983^{2086}$. Però poc després va esclatar l'escàndol. Es va descobrir que l'empresa pública REGESA, depenent de la CMB, havia fer un document secret on es plantejava l'enderrocament total o parcial de La Mina i la deportació de la seva població, en una operació especulativa relacionada amb la neteja de cara que es volia fer per Barcelona $92 \mathrm{i}$ on es titllava al barri "d'irrecuperable"2087. Les autoritats van intentar negar-ho però en unes posteriors declaracions d'Antoni Messeguer -després desmentides- es tornava a insistir en la idea d'enderroc ${ }^{2088}$. La reacció immediata va ser la dimissió i denúncia pública de Paco Marín, si bé va continuar a l'Ajuntament com a regidor independent:

"Ayer, en la asamblea de vecinos desarrollada en el barrio, Francisco Marín afirmó que "había comunicado al Alcalde para que presentara una querella contra el periodista que había reproducido sus declaraciones, si éstas no eran ciertas. No lo hizo -dijo Marín- lo que significa que son ciertas". El concejal Marín señaló que "antes prefiero morir a participar en la deportación de 15.000 personas como no se hizo ni siquiera en el franquismo."'"2089

Com era d'esperar davant aquesta perspectiva, el barri es va tornar a

2085Entrevista a Paco Marín Rodríguez, 14-12-2013. Veure nota 1874.

2086Es tractava del Pla d'Acció Mina 88, que havia disenyat Josep M. Rueda, l'antic coordinador del Pla Interdepartamental de 1983. Veure Laia Gonzàlez: "Volen "dinamitar" La Mina abans dels Jocs Olímpics de 1992", Avui, 10-1-1988.

2087J. Utrera i F. Valls: "La Mina tiembla ante el gigante olímpico", El País, 16-2-1988; Laia Gonzàlez: "La Mina començarà a ser demolida”, Avui, 16-2-1988. Veure també la cita del mateix Paco Marín a l'inici del present capítol, nota 1743. El pla preveia l'especulació amb el sol que es vendria a la iniciativa privada per costejar l'operació.

2088“El Alcalde de Sant Adrià de Besòs asegura que el Ayuntamiento quiere derribar el barrio de La Mina, La Vanguardia, 18-2-1988; Ángel Marín: "L'Alcalde Messeguer reitera que enderrocarà La Mina", Diario de Barcelona, 26-2-1988.

2089“El anuncio de un posible derribo de La Mina causa una dimisión y distancia a los vecinos del Ayuntamiento", La Vanguardia, 20-2-1988. Paradoxalment i en contra del que afirma aquí Paco Marín, el franquisme si va deportar a 15.000 persones... Si més no aquestes son les xifres que es contemplen en els estudis fets sobre el Pavelló de Misions. Veure Imma Boj i Jaume Vallés: "El Pavelló de les Missions, la repressió de la immigració”, L'Avenç, núm. 298 (2005), p, 38-44. 
mobilitzar. El 22 de febrer s'iniciava tota una setmana de mobilitzacions de protesta que va culminar amb una manifestació el dia 25, amb una participació d'entre 1.000 i 1.500 persones, segons la Guàrdia Urbana ${ }^{2090}$. Finalment, la mobilització juntament amb unes negociacions que es van fer per aconseguir un Pla d'Ajuda europeu per un projecte que s'havia fet anteriorment al barri va fer que ningú s'atrevís a fer l'enderroc total. Les administracions locals, que abans havien fet poc cas de l'esmentat projecte sorgit dels grups que havien treballat amb joves durant molts anys al barri, van avenir-se a parar més atenció a un propi Pla que va fer l'Assemblea Permanent del barri per por a quedar en evidència davant les autoritats europees ${ }^{2091}$. Finalment la Generalitat els Ajuntaments de Sant Adrià de Besòs i Barcelona, juntament amb la Fundació Benestar i Família van comprometre's a finançar un $50 \%$ mentre un altre $50 \%$ ho posava la $\mathrm{CEE}^{2092}$. No obstant, des de la Generalitat i els Ajuntaments implicats si que es va continuar intentant fer alguna maniobra per treure població de La Mina, com la que va acabar desencadenant la Intifada del Besòs abans esmentada.

Fora de La Mina i el Besòs van existir altres protestes veïnals, si bé mai van adquirir la importància que en aquests dos barris. Per exemple, la problemàtica de La Catalana i el PERI que l'afectava, amb l'enderroc d'una gran part del barri i el trasllat de la majoria de la seva població al nou polígon Marina-Besòs fet al veí Sant Joan Baptista no va estar exempt de problemes. Gran part dels veïns es van oposar a l'enderrocament dels seus habitatges per que consideraven que estaven subvalorats i no els compensava anar a viure en un pis que havien de tornar a pagar, si més no parcialment, així que van decidir oposar-se i fer dures crítiques a l'empresa semi-pública MAPSA que estava gestionant tota l'operación ${ }^{2093}$, protagonitzant també protestes al $\mathrm{Ple}^{2094}$. Entremig es van produir diverses

2090“Cierre de comercios y manifestación de vecinos en La Mina en protesta por el posible derribo del barrio", La Vanguardia, 26-2-1988.

2091 Jaume V. Aroca: "La Mina elabora un plan para la rehabilitación del barrio", La Vanguardia, 134-1988.

2092Àngel Marín: “Cinc projectes pretenen tornar l'esperança al barri de La Mina”, Diari de Barcelona, 12-4-1989 i "Acuerdo institucional para aplicar un plan social a La Mina con ayuda de la CE", El País, 12-4-1988.

2093Jaume V. Aroca: "Oposición a la transformación del barrio de La Catalana", La Vanguardia, 9-51985.

2094Jaume V. Aroca: "Sant Adrià: rehabilitación urbanística de una zona del barrio de La Catalana", La Vanguardia 17-7-1985. 
ocupacions de famílies gitanes dels pisos del polígon Marina-Besòs ${ }^{2095}$, i també es van descobrir que els nous habitatges tenien nombroses deficiències, lo qual va provocar més protestes ${ }^{2096}$. De fet, una presumpta irregularitat amb aquests habitatges va fer que el propi Antoni Messeguer anés a judici als anys noranta com ens recordava el testimoni de Jaume Vallés:

\begin{abstract}
“"'Amb el Messeguer va haver-hi un problema que és que a La Catalana hi havia un promotor francès o no se què, que volia fer grans pisos, grans coses i volia comprar tot, què sé jo. I havia tractes amb l'Ajuntament. Hi havia associacions que estaven en contra i deien que si l'Ajuntament s'untava les mans. Nosaltres això no ho vam dir mai però en canvi ha corregut la veu que nosaltres vam denunciar l'alcalde. No és veritat, lo que passa es que crèiem que (...) el promotor d'aquelles cases, d'aquells pisos i d'aquell barri, el promotor aquell no era... en fi, per les nostres informacions era mafiós. I per això dèiem que no, que l'Ajuntament no havia de fer tractes amb ell. (...) Nosaltres vam estar en contra. Inclús el van denunciar associacions i no sé qui cony el van denunciar amb el Messeguer (...) com si s'hagués posat quartos a la butxaca. Nosaltres no ho vam dir mai això, jo no ho vaig dir mai, lo que passa és que estàvem en contra de que pactés amb aquell d'allò. I encara el Messeguer diu que el vam denunciar. No el vam denunciar mai. El que passa és que estàvem en contra i donàvem els arguments que aquell promotor no era cosa legal, diríem. (...) I va anar a judici i va sortir absolt. Nosaltres no vam anar a testificar ni la denúncia la vam fer... no, no, no. Ara, vam dir que el promotor aquell no ens semblava bé (...)."2097
\end{abstract}

Una altra qüestió que va provocar protestes va ser la instal-lació de l'hipermercat PRYCA als terrenys de l'antiga fàbrica CELO. Al igual que va passar a Badalona i Santa Coloma pel fet de la instal-lació del hipermercat Continente al polígon de Montigalà, els comerciants de Sant Adrià van encapçalar diverses protestes contra aquest establiment si bé no van aconseguir impedir la seva obertura $^{2098}$.

2095Jaume V. Aroca: "Más de 50 familias gitanas ocupan los pisos de un nuevo polígono de Sant Adrià", "La policía impide la ocupación de viviendas" i "Más de 30 personas fueron detenidas en el desalojo de los pisos ocupados por los gitanos en Sant Adrià" i "La tensión por la ocupación de viviendas en Sant Adrià acaba en una carga policial" La Vanguardia, 29,30 i 31-81985; "La "mafia" de Sant Adrià podria estar tras la ocupación de pisos" i "Dos detenidos más por la ocupación de viviendas", El Correo Catalán, 30 i 31-8-1985.

2096Jaume V. Aroca: "Aparecen deficiencias en el polígono recien construido en Sant Adrià", La Vanguardia, 22-2-1987 i "Protestan ante el Alcalde de Sant Adrià por unos pisos en mal estado", El Periódico de Catalunya, 3-6-1987.

2097Entrevista amb Jaume Vallés Muntades, 26-10-2012.

2098“Los comerciantes de Sant Adrià suspenden un pleno”, El Periódico de Catalunya, 22-3-1986; Antoni Soler: "Botiguers de Sant Adrià contra un Hipermercat", Avui, 23-3-1986; Jaume V. 
A Sant Adrià, com a les altres ciutats del Barcelonès Nord va haver-hi protestes a l'abril i maig de 1985 quan es va remodelar el transport públic amb l'arribada del metro. En concret per la supressió del bus 43, que també va provocar protestes veïnals fins al punt que es va modificar el recorregut de la línia 44 TC per cobrir gran part del recorregut de l'anterior ${ }^{2099}$. No va ser aquesta la única proposta que es va donar a nivell de Barcelonès Nord. La mobilització contra l'OTAN va tenir també una gran importància en les tres poblacions i va ser una lluita on el moviment veïnal també es va implicar fortament, si més no aquelles associacions que encara tenien una voluntat combativa i havien escapat a l'òrbita del PSC-PSOE. Malgrat la creació de diversos Comitès Locals contra l'OTAN, el suport de l'Ajuntament de Santa Coloma de Gramenet a la campanya pel "NO" i les diverses manifestacions que es van fer ${ }^{2100}$, al referèndum va guanyar el "SI" a les tres poblacions del Barcelonès Nord. Sens dubte el pes de la "campanya de la por" encetada pel PSOE en el sentit d'afirmar que si no entràvem a l'OTAN no se'ns deixaria entrar a la CEE juntament amb altres afirmacions encara més alarmistes va fer el seu efecte. Malgrat tot, a Barcelona ciutat i a Catalunya el NO va guanyar, encara que no fos per molta diferència.

Aroca: "Los comerc iantes de Sant Adrià se oponen al acuerdo municipal de autorizar un hipermercado", La Vanguardia, 24-3-1986; Jaume V. Aroca: "El Ayuntamiento de Sant Adrià aprobó la instalación del hipermercado", La Vanguardia, 17-5-1986; "Incidents en l'acte inaugural de PRYCA a Sant Adrià", Avui, 3-6-1987.

2099“Manifestació en Sant Adrià defensant una línia d'autobús”, Avui, 23-4-1985; "Protestas en Sant Adrià i Badalona por los buses", El Periódico de Catalunya, 24-4-1985; Imma Porta: "La línea 43", La Vanguardia, 30-4-1985; Jaume V. Aroca: "Los vecinos de Sant Adrià vuelven a secuestrar autobuses", La Vanguardia, 5-5-1985; "Acuerdo para variar el recorrido del "bus" 44TC de Sant Adrià", El Periódico de Catalunya, 18-5-1985 i Jaume V. Aroca: "Se ampliará el recorrido del 44-TC de Sant Adrià", La Vanguardia, 20-5-1985.

$2100 \mathrm{He}$ pogut trobar documentació de campanyes contra l'OTAN a Badalona: MB-AHCB, Fons Col-leccions Factícies, Caixa C19, Carpeta Campanya per la pau i Anti-OTAN i a MB-Arxiu Josep Maria Cuyàs i Tolosa, Caixa 153, Carpeta Comitè per la Pau i el desarmament; Pel que fa a Santa Coloma es pot trobar documentació a AHMTB, Donació Mn. Josep Catà, Caixes 8 i 12. Es interessant veure la propaganda i argumentacions del PSOE a l'any 1981 quan s'oposava a l'entrada de l'Estat espanyol en aquesta ("OTAN, de entrada no") i el canvi que va fer de cara al Referèndum de 1986. 


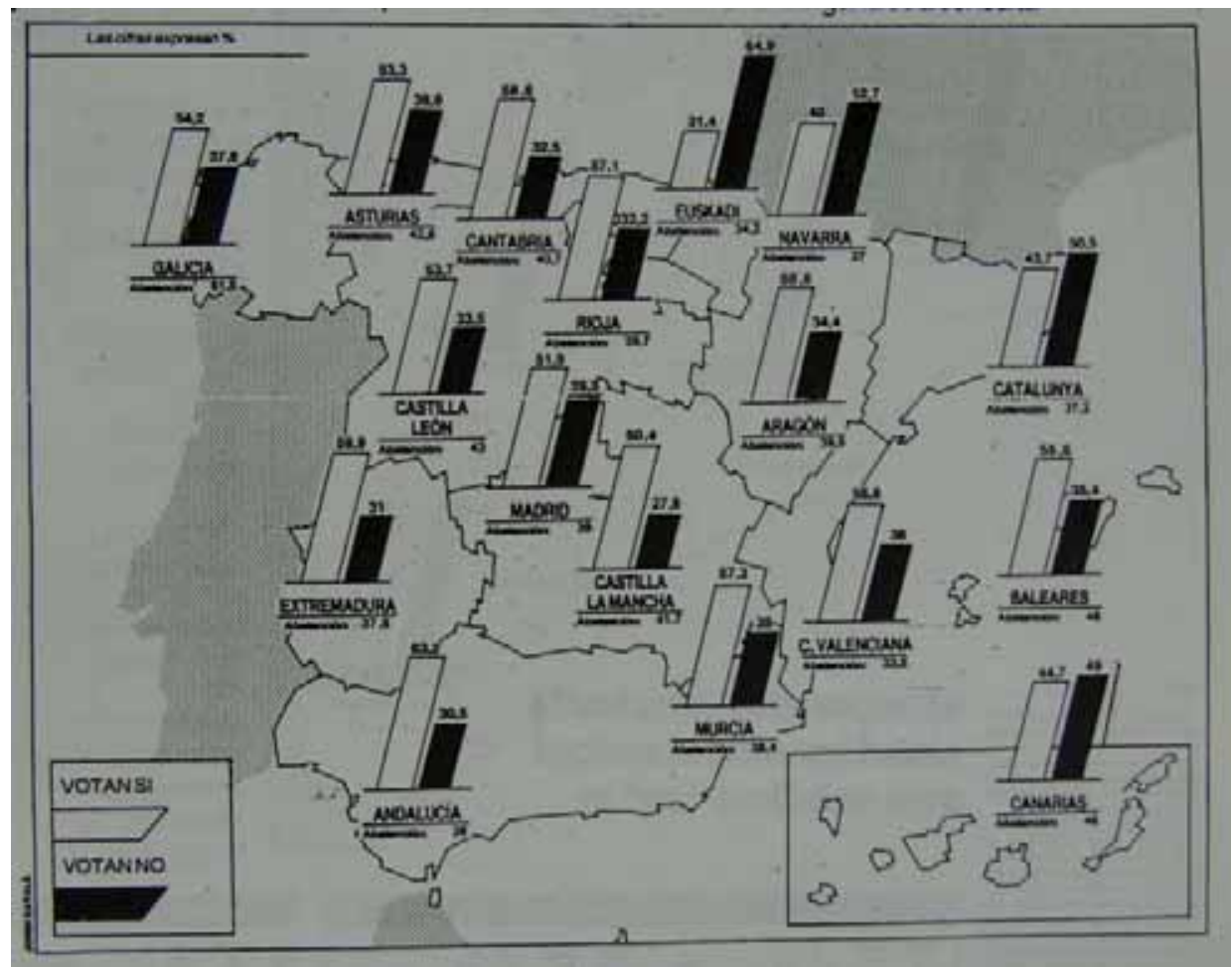

Resultats del referèndum de l'OTAN a l'Estat espanyol (12-3-1986), per Comunitats Autònomes. Font: El Periódico de Catalunya (13-8-1986).

\begin{tabular}{llllll}
\hline & SI & NO & BLANC & NUL & ABSTENCIÓ \\
\hline Badalona & $52,20 \%$ & $48,70 \%$ & $4,5 \%$ & $0,47 \%$ & $34,10 \%$ \\
Santa Coloma de Gramenet & $51,60 \%$ & $45,70 \%$ & $2,0 \%$ & $0,56 \%$ & $32,40 \%$ \\
Sant Adrià de Besòs & $49,10 \%$ & $47,40 \%$ & $3,3 \%$ & $0,57 \%$ & $35,30 \%$ \\
Barcelona & $41,40 \%$ & $52,10 \%$ & $5,6 \%$ & $0,63 \%$ & $31,10 \%$ \\
Catalunya & $43,70 \%$ & $50,50 \%$ & $5,05 \%$ & $0,69 \%$ & $37,20 \%$ \\
País Valencià & $55,80 \%$ & $36,00 \%$ & - & - & $33,50 \%$ \\
Illes Balears i Pitiüses & $55,60 \%$ & $35,40 \%$ & - & - & $48,00 \%$ \\
Estat espanyol & 52,5 & $39,85 \%$ & $6,54 \%$ & $1,11 \%$ & $40,58 \%$ \\
\hline
\end{tabular}

Fonts: El Periódico de Catalunya, 13-8-1986 i Idescat. Falten algunes dades pel que fa a vots en blanc i nuls.

Com hem pogut apreciar en aquest capítol, van existir importants mobilitzacions veïnals en el Barcelonès Nord durant els anys vuitanta, fet que matisa -i molt- la crisi del moviment veïnal. Algunes d'aquestes lluites van ser d'una magnitud comparable a les de la dècada anterior, si més no en la mobilització de gent i en la intensitat de la seva repressió policial. Això si, amb una diferència molt important. Els conflictes responien a problemàtiques molt concretes, fetes des de una òptica defensiva. No es plantejava una alternativa global i coordinada al sistema polític vigent com si es va fer durant la dictadura. Aquestes mobilitzacions 
van estar força focalitzades en barris concrets, allà on van haver-hi problemàtiques greus i complexes $\mathrm{i}$ on les AVV's havien aconseguit conservar una vessant reivindicativa notable, ja fos per que no estaven subordinades a cap partit polític que estigués al govern municipal o per que havien aconseguit conservar un paper de referencialitat i prestigi dins determinats barris. No obstant, aquestes lluites veïnals no es van transformar en canvis en la intenció de vot importants, amb la notable excepció de la "Intifada del Besòs", que va ser capaç d'articular una candidatura independent que va aconseguir 4 regidors l'any 1991 i que es va mantenir al consistori adrianenc per tres mandats (però aquest fet queda ja fora de l'àmbit cronològic del present estudi). Cal destacar que en el cas Badaloní després de 1987 Iniciativa per Catalunya va perdre vots i es va avenir a pactar amb el PSCPSOE i entrar a l'Ajuntament ${ }^{2101}$ (un pacte que es va trencar abans d'acabar la legislatura i que va provocar de retruc un nou trencament entre PSUC i PCC) i que a Santa Coloma de Gramenet IC, amb Lluís Hernàndez encara va resistir l'embat del PSC-PSOE encapçalat per Manuela de Madre l'any 1987, tot i que finalment també van acabar pactant amb els socialistes ${ }^{2102}$.

ELECCIONS MUNICIPALS 1987

\begin{tabular}{|c|c|c|c|c|c|}
\hline \multirow[b]{3}{*}{ PSC-PSOE } & Badalona & \multicolumn{2}{|l|}{ Santa Coloma de G. } & \multirow{2}{*}{ Sant Adrià de B. } & \multirow[b]{2}{*}{ Regidors } \\
\hline & Regidors & Vots & Reg & & \\
\hline & $42.227(42,94 \%) 13$ & $24.965(40,24 \%)$ & 12 & $8.082(58,02 \%)$ & 14 \\
\hline IC & $30.626(31,14 \%) 10$ & $27.610(44,50 \%)$ & 13 & $1.705(12,24 \%)$ & 2 \\
\hline $\mathrm{CiU}$ & $14.297(14,54 \%) 4$ & $4.524(7,29 \%)$ & 2 & $2.502(17,96 \%)$ & 4 \\
\hline AP & $3.563(3,62 \%)$ & $1.537(2,48 \%)$ & & $1.115(8,00 \%)$ & 1 \\
\hline CDS & $3.430(3,49 \%)$ & $1.526(2,46 \%)$ & & & \\
\hline ERC & $1.141(1.16 \%)$ & & & & \\
\hline PTC-UC (1) & $1.050(1,07 \%)$ & $1.103(1,78 \%)$ & & $284(2,04 \%)$ & \\
\hline PH (2) & $581(0,59 \%)$ & $375(0,60 \%)$ & & $95(0,68 \%)$ & \\
\hline POSI (3) & $320(0,33 \%)$ & & & & \\
\hline FE-JONS & $183(0,19 \%)$ & & & & \\
\hline PDP (4) & $0(0,00 \%)$ & & & & \\
\hline Blancs & $930(0,94 \%)$ & $406(0,65 \%)$ & & $146(1,03 \%)$ & \\
\hline Nuls & $795(0,80 \%)$ & $43880,70 \%)$ & & $202(1,43 \%)$ & \\
\hline Electors & 158.305 & 95.026 & & 24.602 & \\
\hline Participació & $99.143(62,63 \%)$ & $62.484(65,75 \%)$ & & $14.131(57,44 \%)$ & \\
\hline Abstenció & $59, .162(37,37 \%)$ & $32.542(34,25 \%)$ & & $10.471(42,56 \%)$ & \\
\hline
\end{tabular}

Elaboració pròpia amb fonts diverses.

(1) Partit dels Treballadors de Catalunya-UC

(2) Partit Humanista

(3) Partit Obrer Socialista Internacionalista

(4)Partido Demócrata Popular

2101 "PSC y Iniciativa pactan finalmente en Badalona”, La Vanguardia, 30-7-1987; "PSC y IC se reparten el cartapacio municipal en Badalona”, El Periódico de Catalunya, 30-7-1987

2102“Socialistas y comunistas pactan en Santa Coloma de Gramenet”, La Vanguardia, 14-7-1987. 
ELECCIONS MUNICIPALS 1991

\begin{tabular}{|c|c|c|c|c|c|c|}
\hline & \multicolumn{2}{|l|}{ Badalona } & \multicolumn{2}{|l|}{ Santa Coloma de G. } & \multicolumn{2}{|l|}{ Sant Adrià de B. } \\
\hline & Vots & Regidors & Vots & & Vots & Regidors \\
\hline PSC-PSOE & $36.228(46,87 \%)$ & 14 & $21.896(43,41 \%)$ & 13 & $5.665(44,62 \%)$ & 10 \\
\hline IC & $17.730(22,94 \%)$ & 7 & $20.396(40,44 \%)$ & 12 & $1.138(8,96 \%)$ & 2 \\
\hline $\mathrm{CiU}$ & $12.560(16,25 \%)$ & 5 & $3.858(7,65 \%)$ & 2 & $2.142(16,87 \%)$ & 4 \\
\hline PP & $4.471(6,13 \%)$ & 1 & $1.527(3,03 \%)$ & & $734(5,78 \%)$ & 1 \\
\hline PEC-PCC (1) & $2.393(3,10 \%)$ & & $992(1,97 \%)$ & & $424(3,64 \%)$ & \\
\hline ERC & $1.278(1,65 \%)$ & & $187(0,37 \%)$ & & $135(1,06 \%)$ & \\
\hline CDS & $966(1,25 \%)$ & & $454(0,90 \%)$ & & $143(1,13 \%)$ & \\
\hline AIB (2) & & & & & $2.257(17,78 \%)$ & 4 \\
\hline PST & $383(0,50 \%)$ & & & & & \\
\hline PED-UC (3) & $186(0,24 \%)$ & & & & & \\
\hline $\operatorname{AR}(4)$ & $125(0,16 \%)$ & & & & & \\
\hline LVLE-H (5) & & & $480(0,95 \%)$ & & & \\
\hline AISC (6) & & & $364(0,72 \%)$ & & & \\
\hline Blancs & $705(0,91 \%)$ & & $285(0,56 \%)$ & & $59(0,46 \%)$ & \\
\hline Nuls & $250(0,32 \%)$ & & $133(0,26 \%)$ & & $63(0,49 \%)$ & \\
\hline Electors & 167.001 & & 102.150 & & 26.249 & \\
\hline Participació & $77.545(46,43 \%)$ & & $50.572(49,51 \%)$ & & $12.760(48,61 \%)$ & \\
\hline Abstenció & $89.456(53,57 \%)$ & & $51.578(50,49 \%)$ & & $13.489(51,39 \%)$ & \\
\hline
\end{tabular}

Elaboració pròpia amb fonts diverses.

(1) Proposta d'Esquerres per Catalunya-Partit dels Comunistes de Catalunya (a Badalona, a la resta només PCC)
(2) Agrupación Independiente del Besòs y de los Barrios de Sant Adrià
(3) PED-Unidad Centrista
(4) Aliança per la República
(5) Los Verdes Lista Ecologista-Humanista
(6) Agrupación Independiente de Santa Coloma 


\section{Conclusions.}

En aquesta investigació he pogut analitzar com es va desenvolupar el moviment veïnal en les tres ciutats del Barcelonès Nord des de els seus orígens fins ben entrat els anys vuitanta, superant, en especial en el seu tram final, les cronologies que, amb contades excepcions, solien aturar-se en el procés de canvi polític. Contemplar aquest marc cronològic ampli ens permetia veure els canvis i continuïtats que es van donar en aquest moviment durant tres dècades.

Però no podríem entendre el sorgiment del moviment veïnal sense analitzar el paper que va tenir la dictadura. Com ja va afirmar Iván Bordetas en la seva investigació cal tenir en compte el model de desenvolupament urbà que va imposar una dictadura feixista i de classe com la franquista ${ }^{2103}$. La gran repressió que va exercir sobre les classes populars va ser un dels motius de que durant els seus primers anys d'existència molta població de les àrees rurals de l'Estat espanyol emigrés cercant un anonimat que només podien trobar a les grans ciutats. I això es va donar malgrat que el règim va fer tot els possibles per impedir-ho durant les dues primeres dècades. La ciutat era roja i subversiva i la població era molt més fàcil de controlar en el món rural.

Però ni les persecucions policials ni els Centres d'Internament de l'època com va ser el Pabelló de Missions de Montjuïc ni les deportacions forçoses cap els seus pobles d'origen van impedir que volums importants de població arribessin al Barcelonès Nord ja des dels anys 40, establint-se en aquells espais no urbanitzats o en aquells que ja ho havien estat, ni que fos de manera precària, els seus predecessors dels anys 20 i 30. En aquests nous llocs de residència van haver de patir la falta dels serveis més elementals començant pel propi habitatge que en no pocs casos es van haver de construir ells mateixos, lluitant, contra la política repressiva de les autoritats franquistes locals o provincials. A això caldria afegir la manca total d'altres equipaments bàsics com l'enllumenat, l'aigua potable, la sanitat, la neteja i higiene, els transports públics, les escoles... D'aquesta manera no es d'estranyar que a les ciutats del Barcelonès Nord, com a tantes altres, existissin

2103Iván Bordetas Jiménez: Nosotros somos los que hemos hecho esta ciudad. Autoorganización y movilización vecinal durante el tardofranquismoy el proceso de cambio político, Tesi Doctoral, UAB, Juliol 2012, p. 582. 
uns elevats nivells de barraquisme o altres formes d'infrahabitatge com coves.

Però paradoxalment, aquestes greus deficiències van ser un factor que va contribuir a la creació d'unes certes xarxes de solidaritat, que primerament van ser familiars i/o de paisanatge. La construcció de l'incipient barraca, de rudimentàries obres de clavegueram, etc. van ser un factor que segurament va ajudar a que s'establís una incipient consciència col-lectiva. Això no vol dir que fos un procés exempte de tensions i excepcions, doncs ja sabem que les situacions extremes també poden generar una competència individualista pels migrats recursos. Però hi havia tasques que no es podien fer individualment i en alguns casos, l'amenaça exterior com podia ser els intents d'una administració local per enderrocar unes edificacions "il·legals" podia fer d'aglutinant d'una incipient autoorganització, com vam poder veure per exemple al barri badaloní de Lloreda ja als anys cinquanta.

A aquest fet caldria sumar l'acció d'organitzacions catòliques d'apostolat obrer que si bé inicialment van intervindre des de una òptica paternalista i assistencial emmarcada en una visió general de les jerarquies eclesiàstiques plenes de prejudicis, molt aviat van desenvolupar un tarannà molt diferent. El contacte amb les dures condicions diàries que es vivien en aquests barris, sumat a una nova fornada de sacerdots joves amb unes mentalitats més obertes juntament amb l'impacte del Concili Vaticà II van ser un factor a tenir en compte i que també va incidir en una progressiva presa de consciència de la població, en especial de les noves generacions que no havien viscut directament la guerra civil.

A finals de la dècada dels cinquanta i inicis dels seixanta es van donar canvis importants en la percepció del règim respecte el fenomen migratori, per una banda, i sobre com s'havia d'actuar en els nous barris d'autoconstrucció. El canvi de política econòmica va fer que es deixessin de reprimir les migracions, ja que ara la mà d'obra era necessària per les empreses dels nuclis industrials del conjunt del territori, alhora que també es mirava de canalitzar una part d'aquesta més enllà de les fronteres de l'Estat espanyol. Però aleshores calia controlar i posar ordre en aquestes barriades obreres de la perifèria de les ciutats que havien estat ignorades fins al moment. Això es va fer, per una banda, recuperant una antiga figura, l'anomenat Alcalde de Barrio, per que fos el representant de les autoritats locals franquistes i que mitjançant ell es canalitzessin determinades gestions. 
Però més important, -si més no pel nostre estudi- va ser l'intent de crear un associacionisme popular franquista per dotar d'una base de suport de masses al règim. Aquesta és una característica netament feixista que es va donar no als anys quaranta, sinó als seixanta i va ser impulsada per la Secretaria General del Movimiento controlada per José Solís Ruiz, conscient, per una banda, de que calia assentar el règim davant els canvis socio-econòmics que s'estaven produint i que alhora, podia augmentar les seves quotes de poder dintre de l'aparell franquista. Aquests plantejaments, juntament amb les polítiques que va desenvolupar durant els mateixos anys al sindicat vertical ens demostrarien que lluny de ser una estructura simbòlica, el partit únic o Movimiento era una organització ben viva i amb una força i poder no menyspreable. I si bé és cert que des d'una part de l'aparell franquista va haver-hi una certa oposició als intents que es van fer per part de la Secretaria General, no ho era tant per una qüestió de si el règim s'havia de dotar d'una base popular o no sinó més aviat per dos factors: per la rivalitat que existia entre diverses faccions en el Consell de Ministres per controlar més quotes de poder dins de l'Estat i per una por -fonamentada, com hem vist- a que aquests nous canals podien fer-se servir per l'oposició antifranquista.

Sigui com sigui, es va establir un cert enfrontament polític i dialèctic entre la necessitat de fer certes reformes per perpetuar el franquisme però sense perdre el control, juntament amb una lluita soterrada en el seu interior. Al final es van fer les reformes legislatives que feien falta per que es poguessin crear aquest tipus d'associacions, com van ser la Llei d'Associacions de 1964 i tota la legislació referent a l'anomenat associacionisme familiar, si bé a aquestes entitats se les va dotar de menys competències de les previstes inicialment per por que escapessin al control del règim. Certament, aquest canvi legislatiu va tenir la seva importància, però per si sol no fou el factor principal pel sorgiment del moviment veïnal. La nova legislació no va ser pensada per oferir espais d'actuació a sectors desafectes sinó precisament per tot el contrari, per intentar dotar d'una base popular al règim franquista per contrarestar aquesta desafecció.

I això es feia en un moment on el franquisme, amb molt endarreriment, engegava una política de promoció d'habitatges per intentar mitigar els efectes de vint anys de inacció en aquest àmbit. Apart d'intentar mitigar una situació 
potencialment explosiva, la Obra social, si se li pot dir així, que es va intentar fer des del règim també es feu servir per omplir de contingut un determinat discurs polític del franquisme com a règim que proveïa de justícia social. Aquest discurs ja s'havia intentat fer en el passat sense gaire èxit per les evidències materials de que la dictadura precisament com a règim classista havia afavorit a les classes privilegiades i perjudicat notablement a les classes populars. A la dècada dels seixanta es va fer un nou intent amb la política d'habitatge i de nou amb els Falangistes com els seus principals valedors, sobretot amb l'anomenada Obra Sindical del Hogar feta des del sindicat vertical en aquest sentit (sense obviar tampoc el paper que van tenir els "Patronatos Municipales de la Vivienda" promogut per les autoritats locals). Però de nou, el classisme evident del règim va llastrar aquestes polítiques en crear-se uns polígons d'habitatges massificats en els llocs més inversemblants ja fossin de nova planta o en els mateixos barris d'autoconstrucció. Generalment van ser edificats en llocs aïllats o mal comunicats, sense els serveis bàsics més elementals i amb una qualitat sovint molt deficient, canviant una situació de barraquisme tradicional pel que molts van anomenar "barraquisme vertical".

Però aquestes polítiques de captació de les masses en general no van assolir l'èxit esperat, per que les mancances estructurals van continuar ben presents en els barris i ciutats del Barcelonès Nord alhora que aquestes noves entitats es mostraven inoperants per transformar-les, encara que es van promoure algunes obres urbanístiques per solventar els dèficits més evidents amb la col·laboració de les autoritats locals. Va ser a Badalona, com a ciutat més antiga i de majors dimensions on aquesta política es va intentar fer més seriosament, promovent entitats d'aquest tipus alhora que es va promocionar als seus "líders" cap al consistori mitjançant el Tercio Familiar, potenciant-se també les eleccions respectives justament també en aquest moment. Va ser de nou a Badalona on les "eleccions" van tenir quotes de participació major a finals dels seixanta i als anys setanta, però segurament perquè, malgrat les irregularitats i manipulacions existents va aconseguir "colar-se" alguna candidatura opositora moderada que va comptar amb el suport d'algunes parròquies. En canvi a Sant Adrià de Besòs i, sobretot, a Santa Coloma de Gramenet, la participació va ser molt menor. No es va 
articular cap candidatura opositora i les vies de protesta inicialment van ser unes altres.

Un altre factor fonamental que va propiciar aquests intents del franquisme i que va ser decisiu per l'adveniment del futur moviment veïnal va ser, tal com he dit, el paper dels cristians de base d'organitzacions com l'HOAC o l'ACO i d'una nova fornada de sacerdots amb una sensibilitat molt diferent a la de la jerarquia d'aleshores. Aquest procés es va fer sentit sobretot a la ciutat de Santa Coloma de Gramenet amb l'arribada d'uns nous capellans destinats als nous barris que estaven creixent de manera caòtica i desordenada als anys seixanta. Des de les seves parròquies es va potenciar la JOC i la demanda i reivindicació d'unes condicions de vida més justes. Van convertir les seves parròquies en espais de llibertat on es podien fer activitats i reunions gràcies, paradoxalment, al Concordat. No van tenir tanta força com a Santa Coloma però també van existir parròquies a determinats barris de Badalona i Sant Adrià que van ser exponenets d'aquesta nova sensibilitat.

En els anys seixanta, paral·lelament, va irrompre amb força el nou moviment obrer de les Comissions Obreres també al Barcelonès Nord, si bé amb unes característiques peculiars que van reforçar el seu nexe amb altres estrats socials organitzats, ja fossin de tipus socio-cultural (a Badalona, sobretot) com amb les noves parròquies que els hi oferien el seu aixopluc per poder-se organitzar i escapar a la repressió policial. El teixit productiu de la sub-comarca, amb un predomini de la petita i mitjana empresa va impedir, com vam veure, les formes d'organització més freqüents de fàbrica o sector productiu. En aquestes Comissions Obreres hi van tenir un gran pes també sectors catòlics de base, però sobretot militants polítics clandestins amb una preponderància del PSUC. I si bé, durant els anys seixanta es va prioritzar la participació en l'organització del moviment obrer, també es van donar uns primers intents de fomentar algun tipus d'organització veïnal.

Així van sorgir les anomenades Comissions Obreres de Barri, que aviat van comprovar com eren les reivindicacions fetes pels barris les que adquirien una major resposta popular. D'aquesta manera, ja durant els anys seixanta van existir unes primeres protestes més espontànies, protagonitzades per dones en no pocs 
casos, davant les mancances més evidents que existien. I aquest fet va provocar que cada vegada més des de les organitzacions polítiques clandestines -que prioritzaven l'actuació dins el moviment sindical- prenguessin consciència de la situació i destinessin més atenció a la potencialitat que podia tenir un moviment popular organitzat als barris. No obstant, no va ser fins els anys setanta quan es va poder observar com les organitzacions antifranquistes feien del moviment veïnal una prioritat.

Una relativa sorpresa que m'ha portat aquesta investigació es veure, com abans d'aquests anys setanta, ja es van produir casos d'infiltració de persones amb un passat antifranquista en les associacions veïnals promogudes per les autoritats locals, ja fossin Associacions de Caps de Família o Associacions de Veïns i/o propietaris, fins i tot en dates tan primerenques com els anys cinquanta. De fet, a Badalona es va constituir una de els AVV's més antigues de tot l'Estat espanyol, la del barri de Lloreda, on es podien trobar algunes persones d'aquesta sensibilitat. Certament aquestes persones van estar molt controlades i des de les administracions locals es va estar ben atents a intervindre quan podien ocupar càrrecs amb determinades responsabilitats i col-locar a persones més dòcils. No obstant, és un factor a tenir en compte i que no ha estat massa estudiat fins el moment veure fins a quin punt aquestes persones van servir de nexe entre antigues i noves generacions que van trobar-se en el Barcelonès Nord.

S'ha debatut i es debat actualment sobre quins van ser els processos d'autoorganització popular que van afavorir el desenvolupament del moviment veïnal i sobre fins a quin punt van estar condicionats, o no, per les organitzacions polítiques clandestines. No és una qüestió fàcil de respondre. Penso que certament, amb anterioritat a la intervenció conscient de les organitzacions polítiques s'havien donat uns certs processos d'organització a determinades barriades, ja fos de forma espontània per resoldre els dèficits més urgents com fomentats per algunes d'aquestes entitats veïnals pioneres, que fins i tot quan estaven controlades per persones conservadores podien, sense haver-s'ho plantejat, fomentar algun tipus de consciència de barri i de grup quan promovien obres veïnals per asfaltar carrers o instal-lar incipients xarxes de clavegueram (o fins i tot organitzant festes populars). Això sense tenir en compte l'existència de militants d'organitzacions 
clandestines que podien actuar als barris pel seu compte sense esperar l'arribada de consignes i també de la mateixa memòria i experiència política que tenien els seus habitants, ja fos per vivència pròpia o per transmissió intergeneracional. $\mathrm{A}$ vegades s'ha volgut tractar a les organitzacions polítiques clandestines com un cos "extern" als barris populars. I sense negar que va haver-hi organitzacions que van practicar la proletarització forçosa i el "paracaigudisme territorial" (enviar gent a barris concrets amb tasques de dinamització político-social), no es pot negar que en no pocs casos les mateixes organitzacions clandestines, en especial les més importants, podien tenir una implantació als barris sense recórrer a aquests mètodes. A més, les persones conscienciades en aquest sentit no tenien per que ser "militants de carnet" -cosa difícil en un ambient de persecució i clandestinitatsinó que podien ser-ne simplement simpatitzants -o no- amb sensibilitat social.

Sigui com sigui, els dèficits i greuges acumulats durant tota la dècada dels seixanta van començar a esclatar a inicis dels setanta. I ho va fer precisament a la ciutat del Barcelonès Nord que havia estat més perjudicada per l'especulació immobiliària i que patia més els dèficits ocupacionals i de serveis més elementals, agreujats encara més pel fer que havia rebut els contingents més elevats -proporcionalment- de població nouvinguda: Santa Coloma de Gramenet. La lluita per l'ambulatori que es va donar a l'any 1971 va ser el primer esclat i mobilització popular amb una participació de masses. I aquí va confluir tot un veritable malestar popular per la falta d'un dels serveis més elementals en una ciutat que havia multiplicat la seva població gairebé per set entre 1950 i 1970. Comptava ja Santa Coloma a inicis dels setanta amb un teixit associatiu als barris fomentat per les parròquies concretat en els anomenats Centres Socials, juntament amb la presència de les organitzacions antifranquistes que van copsar la importància del que allà es covava. La lluita i mobilització que es va donar va, per una banda, desbordar i alarmar a les autoritats franquistes locals i per altra, va posar la base d'un moviment que es va estructurar en un primer moment en les anomenades Comissions de Barri.

Aquestes van tenir una rellevància a Santa Coloma de Gramenet -barri per barri- mentre que a Badalona i Sant Adrià la seva presència va ser més testimonial. Per què aquesta diferència? Segurament gran part es pot explicar per una banda, 
pels majors dèficits existents en la ciutat colomenca, que era la que havia patit un creixement més accelerat i desordenat, i per una altra, per la major importància del teixit associatiu dels cristians de base i dels partits polítics de l'esquerra radical. Alhora, a Santa Coloma de Gramenet hi havia un major procés de terciarització de l'economia i un percentatge major de població es traslladava a treballar fora de la ciutat que a les seves veïnes Badalona i Sant Adrià, que comptaven amb un major teixit industrial. Malgrat això, no hauríem tampoc d'oblidar que a la ciutat colomenca va existir també una certa conflictivitat obrera en un sector fortament minimitzat com era el tèxtil i de la confecció, d'on, precisament, també va sorgir alguna militant veïnal. Per últim, segurament l'existència d'entitats veïnals a Badalona ja en els anys seixanta -encara que un nombre important fossin controlades per persones conservadores- també va ser un factor que limitar l'aparició i proliferació de Comissions de Barri a inicis dels anys setanta.

Aquestes Comissions de Barri colomenques es van caracteritzar per la seva organització totalment clandestina i autònoma. Si bé inicialment en aquestes hi van participar partits com el PSUC aquest aviat se'n va desmarcar per no considerar-les un treball d'espai prioritari per desenvolupar un moviment de masses i van optar per l'impuls de les Associacions de Veïns. De manera que en les CCBB hi van romandre cristians de base, llibertaris i militants de partits de l'esquerra radical que van ser els que van protagonitzar les primeres mobilitzacions als diferents barris. Van destacar per la seva concepció fortament anticapitalista ja que la seva lluita no estava emmarcada només en fer caure la dictadura si no en acabar amb tot un sistema socio-econòmic que consideraven profundament injust. Però quan van començar a aparèixer les noves AVV's es va produir un interessant debat intern sobre quina postura havien de prendre al respecte.

Per una banda, des de les CCBB s'havia limitat la seva actuació en espais "legals" als Centres Socials, que durant els inicis dels anys setanta van ser una font de captació de militants molt important. Així que un sector de les CCBB colomenques van veure amb grans reticències l'aparició de les AVV's que van ser considerades com un instruments fomentats pels que ells anomenaven "reformistes", refusant, d'entrada, la seva participació en aquestes. El sectarisme d'alguns dels seus membres els impedia veure que mantenir una estricta 
clandestinitat i renunciar a fer servir aquest tipus de plataformes els portava aïllarse cada cop més de les masses a les quals volien convèncer per fer la revolució. No tots els seus membres van tenir aquesta concepció ja que una part si van percebre la utilitat que podien tenir les AVV's per arribar a sectors més amplis de la població, sense renunciar però als seus mitjans propis i autònoms d'organització.

Aquesta divisió interna va provocar forts debats mentre que des de les AVV's es presentava una alternativa com els Ajuntaments democràtics que atacava directament les estructures locals de la dictadura. Malgrat que des de les CCBB van intentar presentar també les seves propostes alternatives, el cert és que el procés de canvi polític com les seves divisions i contradiccions internes les van acabar fent desaparèixer a partir de l'any 1977. Però també s'ha de dir que aquesta desaparició va tenir molts matisos, ja que no van ser estranys els casos en que la mateixa gent que havia format part d'algunes Comissions de Barri ocupaven ara les juntes de les Associacions de Veïns. El cert és que van ser les AVV'S les que van aconseguir tenir una projecció i incidència major en sectors més amplis de població.

Mentrestant a Badalona i Sant Adrià no havien proliferat les CCBB, però va començar a donar-se la infiltració de militants de partits d'esquerra o de persones sense carnet però amb sensibilitats socials dins les AVV's que fins al moment havien estat controlades per franquistes. Fins al punt que en molts casos es va aconseguir desbancar les antigues Juntes i donar-lis una nova orientació molt més reivindicativa i amb un clar component antifranquista. Quan la via "entrista" trobava més obstacles dels previstos l'alternativa solia ser la fundació d'una nova associació. Davant això la resposta de les autoritats va ser posar contínues traves administratives, impedint o allargant el màxim possible la legalització d'unes entitats que presumien problemàtiques. Quan malgrat aquestes traves constataven que les entitats veïnals, legalitzades o no, continuaven funcionant, la resposta va ser intentar crear les seves pròpies entitats per si més no esmorteir la influència $\mathrm{i}$ prestigi que estaven aconseguint les AVV's entre els veïns dels barris. Aquest procés es va donar primerament en els barris perifèrics de Badalona i Sant Adrià, aquells que havien crescut per la immigració i tenien els percentatges més elevats de població treballadora.

Certament, en aquestes primeres associacions el component de classe va ser 
primordial, com hem pogut veure analitzant els discursos que es feien en les seves publicacions, on les crítiques al sistema capitalista, la dictadura i als empresaris eren molt freqüents. Així com fins i tot anàlisis i posicionaments sobre la realitat nacional catalana i contra l'intent que es va fer des de els darrers governs de la dictadura de fomentar la divisió de la classe treballadora en funció del seu origen. Les AVV's més primerenques i potents es donaran als barris perifèrics de Badalona i als del marge dret del riu Besòs de Sant Adrià. Posteriorment, ja després de 1975 en una segona tongada apareixeran altres Associacions de Veïns en altres barris més interclassistes com el Centre badaloní o al de Sant Adrià Nord (on estava el nucli de l'antic poble).

En l'aparició del moviment veïnal la dona va adquirir un protagonisme que no havia pogut assolir en altres àmbits, com l'obrer. La divisió del treball existent en funció del gènere encara relegava a les dones a la llar i la reproducció de la força de treball. Paradoxalment això els hi va permetre participar més en les activitats i protestes que es desenvolupaven als barris, sent en molts casos les protagonistes de les primeres mobilitzacions, tot i que en aquestes es continuaven reproduint els rols masclistes de la societat. Poc a poc, en base a anar adquirint un major protagonisme en els espais públics, juntament amb la creació de Vocalies de dones dintre de les AVV's va anar produint un progressiu procés de conscienciació entre la població femenina de la seva situació d'opressió. L'impacte que van tenir les Jornades Catalanes de la Dona al 1976 també es va fer sentir, i malgrat l'existència de moltes contradiccions i entrebancs, provocats en no pocs casos pels membres masculins de les associacions i els partits, el cert és que el moviment veïnal va contribuir notablement a desenvolupar un feminisme de caire popular, creant-se no poques Vocalies i/o grups de Dones en els diferents barris de les ciutats del Barcelonès Nord, que, tot hi haver-hi gradacions, aviat van passar de reivindicar escoles i protestar per la carestia de la vida a reivindicar centres de planificació familiar, l'equiparació en drets i la igualtat real amb els homes.

Com en altres ciutats, el moviment veïnal del Barcelonès Nord va ser capaç de posar en series dificultats i finalment desbordar a les autoritats franquistes locals. Ja abans de la mort de Franco l'alcalde colomenc Juan Porta Bussoms va haver de dimitir per diversos casos de corrupció però també per la intensa pressió que 
estaven exercint les mobilitzacions veïnals en contra de les seves operacions urbanístiques. També un Alcalde adrianenc -Francisco Roqueta- havia dimitit anteriorment després de diversos escàndols municipals. Va ser, sobretot, durant el procés de canvi polític quan les mobilitzacions als barris es van accentuar, percebent clarament que hi havia unes noves possibilitats en "l'estructura d'oportunitats polítiques" per la crisi profunda que estava patint la dictadura. Sense aquestes importants mobilitzacions que van posar en escac les autoritats franquistes locals no es pot entendre els canvis que es van veure forçat a realitzar des de la dictadura per mirar de no perdre el control d'una situació que no havia estat ni planificada ni prevista per les seves autoritats per molt que els relats hagiogràfics de la transició difosos pels mitjans de comunicació de masses ens vulguin fer creure el contrari.

Malgrat l'habilitat del govern Suárez, un cop fracassat Árias Navarro, en recuperar la iniciativa política a l'oposició, que es va avenir, posteriorment, a pactar uns mínims renunciant a part de les seves formulacions anteriors de trencament, el cert és que en l'àmbit local les autoritats van expressar sovint la sensació "d'abandonament" amb la qual es van trobar després de les eleccions del 15-J, criticant fins i tot al govern central i arribant a presentar dimissions com en el cas badaloní. Malgrat que les grans qüestions com la unitat de l'Estat, la monarquia i la vigència del model econòmic capitalista havien quedat assegurades, el cert és que a nivell local la percepció que van tenir els alcaldes i Ajuntaments franquistes durant la segona meitat de 1977 va ser molt diferent quan havien de fer front en determinats moments a mobilitzacions diàries o fins i tot rebre agressions físiques d'uns veïns que encara eren durament reprimits per les forces d'ordre públic.

Alhora que succeïen aquests esdeveniments, el nou context polític que s'estava generant també va provocar canvis dins el moviment veïnal, per què, quina era la funció que tindrien les AVV's un cop assolits els Ajuntaments democràtics?. Determinats partits polítics que havien apostat per impulsar aquest tipus d'associacions durant la clandestinitat, un cop legalitzats i amb perspectiva d'arribar a gestionar les administracions municipals, van moderar una part dels seus plantejaments respecte el moviment veïnal. El PSUC, que era el partit que havia tingut una major implantació, va ser el principal protagonista d'aquest 
procés en apostar fortament per la via institucional. És cert que militants del nivell de Jordi Borja i d'altres van alertar contra l'abandonament de les entitats veïnals, però no per que tinguessin en ment la creació d'una mena d'organismes de contrapoder popular que poguessin fiscalitzar el propi Ajuntament. Precisament era aquesta la perspectiva que els hi provocava recels, per que contemplaven que unes entitats veïnals autònomes i controlades -o no- per partits de l'esquerra radical que els hi podrien fer oposició en el futur.

Els partits de l'anomenada esquerra radical van defensar un moviment autònom, independent $\mathrm{i}$ amb unes importants quotes de poder dins els municipis, ja fos per una qüestió de principis o per que, fracassades les seves temptatives electorals, aquest era un dels pocs espais on podien fer servir la seva incidència. Però indiferentment de si les seves reivindicacions van ser més o menys oportunistes, crec que s'han de tenir en comptes les seves propostes en la mesura que oferien unes posiblitats i un protagonisme a les associacions veïnals que haguessin ajudat, d'haver-se acomplit, a un aprofundiment democràtic més gran de la gestió municipal. Propostes com la creació de consells de districte amb competències significatives i amb un pes gran de les Associacions Veïnals, de referèndums populars vinculants i d'altres per l'estil haurien estat un gran estímul per la participació ciutadana en la gestió de l'administració local. Però una gran part d'aquestes organitzacions d'esquerra radical també van ser víctimes del sectarisme i van ser incapaces de posar-se d'acord entre elles mateixes i d'adaptarse als nous canvis no només polítics, sinó econòmics que s'estaven donant. Només algunes organitzacions van sobreviure a aquest procés de finals dels setanta i inicis dels vuitanta, tenint, alguna d'elles, un important paper durant els anys vuitanta.

Va haver-hi més factors que van incidir en la crisi que es va donar dins el moviment veïnal. Un element que no s'ha valorat potser amb tota la seva importància va ser el dur impacte que va tenir la crisi econòmica, que es va accentuar a finals dels anys setanta i durant gran part dels vuitanta. Les taxes fins aleshores desconegudes d'atur, els desnonaments, la precarietat laboral i l'economia submergida que va créixer de manera desbocada... Tot això va tenir un impacte en unes classes treballadores i populars que fins al moment havien aconseguit millores gràcies a les lluites. Ara van veure com aquestes es limitaren en 
no pocs casos a conservar els llocs de feina, moltes vegades sense èxit, fet que provocà una major desmoralització. A això cal afegir l'impacte que va tenir, sobretot entre els mes joves, el consum massiu de drogues com l'heroïna que va realment desfer no només famílies, sinó també xarxes socials que s'havien anat creant amb molt esforç durant els anys anteriors. Mentrestant, el limitat augment de la delinqüència que es va donar com a conseqüència de la crisi va ser aprofitat ideològicament per les dretes per enfortir el seu discurs.

Als efectes de la crisi econòmica cal afegir els no menys importants de la crisi ideològica de les esquerres que ja va començar als anys vuitanta i a l'auge de la dretana neoliberal. Aquesta va engegar una dura ofensiva per reforçar ideològicament el capitalisme, fortament qüestionat dins les classes populars la dècada anterior. La defensa exacerbada de l'individualisme, del consumisme, de l'ordre econòmic capitalista, la "rehabilitació" de la figura de l'empresari, de les polítiques de mà dura contra la "inseguretat" van ser una constant mentre de manera paral-lela s'iniciava un procés de atac als drets més fonamentals que havien sigut la base de l'anomenat "estat del benestar", que tot i limitats, s'havien aconseguit després de dures lluites. No s'ha de menystenir el pes que aquest discurs va anar guanyant progressivament durant aquests anys vuitanta previs a la crisi ideològica encara major de les esquerres durant els anys noranta.

Però malgrat tot, als anys vuitanta la situació del moviment veïnal no va ser tan negativa com en moltes ocasions ens podia haver semblat. Malgrat l'existència d'una davallada important, no és menys cert que aquesta va tenir molts matisos i en el cas del Barcelonès Nord ens hem trobat encara durant aquests anys amb Associacions molt combatives i també amb determinats conflictes amb una magnitud comparable -i en alguns casos fins i tot superior- als de la dècada anterior. És cert que ara seran conflictes que tindran un caràcter majoritàriament defensiu. Foren respostes contra agressions d'agents privats o de les administracions públiques contra els interessos de determinats barris. Les protestes no cercaren un canvi de règim socio-polític, sense negar, però, que entre els seus protagonistes hi hagi persones que poguessin tenir aquest horitzó en ment. Tot i ser protestes defensives enfront una agressió urbanística (com els casos de la Plaça Trafalgar de Llefià, el solar de la Palmera del Besòs o contra 
l'enderrocament total o parcial del barri de la Mina), una retallada de serveis públics (com el cas dels autobusos de Pomar i d'altres barris), o una agressió contra una persona per haver-se significat dins el moviment veïnal (com el cas Pitarque), el cert és que en aquestes lluites es pot percebre la permanència encara d'una sèrie de valors que entraven en conflicte amb els "oficials".

El respecte a uns drets que eren considerats com bàsics (habitatge, transport, espais públics), la voluntat de tenir una major participació i un major aprofundiment democràtic en la gestió pública del territori, juntament amb una consciència de barri, de ciutat (i segurament encara, de classe) que encara era molt viva en sectors nombrosos de la població del Barcelonès Nord durant els anys vuitanta ens expliquen, en part, que perduressin aquests conflictes. Això i també la presència de persones que van continuar mantenint-se actives en les Associacions de Veïns malgrat els diversos intents que es van fer de controlar-les o domesticarles. Això no era pas nou, ja que als anys setanta ja s'havien donat pugnes internes entre diversos partits polítics, persones i les administracions franquistes pel control d'unes entitats que tenien un gran potencial per mobilitzar sectors amplis de població. La novetat durant els anys vuitanta serà l'aparició de "noves" forces polítiques en aquesta pugna en un context democràtic.

Els socialistes, en general, no havien tingut una força important dins el moviment veïnal, llevat d'excepcions puntuals. Però això no es devia a manca d'interès de ser-hi. La documentació consultada de les diferents organitzacions socialistes catalanes tant d'abans de la unificació com també de després de la creació del PSC-PSOE ens demostren que si que hi havia una voluntat de tenir-hi incidència. Però en un primer moment no van tenir la capacitat per fer-ho, ja fos per que no tenien prou militants o per la força que hi exercien altres forces polítiques o persones independents. La situació, però, va començar a canviar als anys vuitanta, sobretot quan el partit va assolir quotes de poder, ja fos a nivell estatal o, especialment, a nivell local. Sant Adrià de Besòs primer, i Badalona després van passar a ser governades pel PSC-PSOE en solitari o en acord amb CiU. I va ser des de el Ajuntament que, conscient del pes i capacitat d'incidència que encara tenien les AVV's, que es va iniciar una política per "fer-se" amb aquest moviment, o, si més no, limitar-ne la seva capacitat d'oposició a les polítiques que 
es feien des de els consistoris.

És en aquest sentit que hem d'entendre les diferents maniobres que es van dur a terme, que van passar per la cooptació d'antics líders veïnals -que podien ser antics militants de partits d'esquerra radical-, o la tàctica del "desembarcament" per poder-se fer amb el control efectiu de les Juntes. Si això hi sumem l'establiment de tota una xarxa clientelar de favors, subvencions i altra tipus d'ajudes a les Associacions que s'avenien a entrar en aquest joc, podem entendre també per que en determinats llocs el moviment veïnal va patir un daltabaix i es va anar transformant en una cosa inofensiva, que organitzava festes i altre tipus d'activitats que no posaven en dificultats a les autoritats locals. Diversos testimonis ens han explicat la presència d'aquestes pràctiques i hem pogut observa la seva efectivitat en dividir el moviment veïnal en conflictes concrets, on les Associacions es van fracturar entre les que s'oposaven a l'Ajuntament i les que li donaven un suport més o menys explícit. De la mateixa manera, quan aquest recurs fallava, es solien potenciar altre tipus d'entitats per mirar de qüestionar la representativitat que podia tenir en un determinat barri l'Associació de Veïns i Veïnes.

No obstant, no va ser només el PSC-PSOE el que va fer servir aquestes tècniques. CiU també va tenir un especial interès en ser present als barris de les ciutats de l'àrea metropolitana de Barcelona un cop va assolir el govern de la Generalitat. Igual que el PSC-PSOE, abans del 1979 no havia tingut un especial protagonisme dins el moviment veïnal llevat d'algunes excepcions com va ser, per exemple, l'AVV de Sant Adrià Nord. Però als anys vuitanta van demostrar un especial interés en tenir una presència en aquells barris que s'havien creat per l'arribada de població d'altres indrets de l'Estat espanyol i que presumiblement votaven a d'altres opcions polítiques. La creació de locals propis a barris com La Mina o Llefià juntament amb les freqüents visites de Jordi Pujol a aquestes zones ens posen de manifest l'interès existent. Més endavant, amb creació de la Conselleria de Benestar i Família i, en especial de l'empresa pública ADIGSA que es va fer càrrec dels antics polígons de l'Obra Sindical del Hogar es va intentar estendre la seva influència amb més o menys èxit, si bé és cert que en el terreny estrictament urbanístic aquesta empresa va donar un millor servei en la rehabilitació dels barris que totes les anteriors. 
Però per què davant tots aquests reptes i dificultats encara va haver-hi associacions que es van mantenir actives i reivindicatives als anys vuitanta? Una part es pot explicar per la presència encara de persones amb un perfil militant molt actiu. Fossin o no militants de partits d'esquerra radical o de col-lectius cristians de base, el cert es que es pot seguir el rastre d'aquestes persones a les Associacions que es van mantenir actives. En un primer moment aquest fet va ser més constatable a la ciutat de Santa Coloma de Gramenet, on la marxa de militants del PSUC cap a l'Ajuntament va deixar a les Associacions de Veïns pràcticament en mans d'unes persones que es van manifestar molt crítiques amb els dèficits democràtics i de participació del consistori. Tot i així, els principals conflictes veïnals de la dècada dels vuitanta no es van donar a Santa Coloma, sinó a Badalona i Sant Adrià de Besòs, se'ns dubte per la política més agressiva en sentit urbanístic que van dur els ajuntaments governats pel PSC-PSOE.

$\mathrm{Hi}$ ha un altre factor important a tenir en compte per que hi hagués Associacions que es mantinguessin actives davant aquest context hostil: el relleu generacional. Algunes AVV's van demostrar tenir una major sensibilitat i capacitat per atreure's a joves amb inquietuds socials. Uns joves que havien jugat en uns carrers on la presència de manifestacions era un fet habitual. En determinats casos, malgrat l'impacte de la crisi, l'atur i la proliferació de l'heroïna, trobem grups de joves molt actius que van nodrir i protagonitzar part de les lluites i "noves" formes de mobilització i expressió dels anys vuitanta com van ser els moviments antimilitaristes, feministes, d'homosexuals, antirepressius, d'ocupació o fins i tot culturals (les anomenades ràdios lliures). Les Associacions que van ser capaces de atreure'ls van aconseguir mantenir una important vitalitat mentre que les que no ho feien depenien en excés de persones concretes que havien pogut ser molt lluitadores en el seu moment, però que no tenien recanvi. Quan aquesta fallava l'entitat podia desaparèixer o quedar sumida en un període d'hibernació o inactivitat. No totes les Associacions van mostrar les mateixes capacitats en aquest àmbit, ja que es podia donar xocs generacionals que podien ser conflictius i acabar amb la marxa dels joves.

I sens dubte, el model organitzatiu també serà un factor a tenir en compte en la major o menor activitat i longevitat d'una determinada Associació. Aquelles que 
van tenir una major predisposició per un model de gestió més obert, democràtic, amb Juntes obertes o assemblees de barri, fugint d'excessius personalismes, controls partidistes, i integrant en el seu si una major pluralitat van demostrar tenir una major continuïtat en el temps i en el manteniment de la seva vessant reivindicativa. Aquest factor les permetia -fins i tot- gestionar millor les derrotes parcials o victòries pírriques, mentre que d'altres entitats que havien aconseguit uns millors resultats en les lluites veïnals dels anys vuitanta van acabar posteriorment decaient pel cansament, desafecció o falta de relleu dels seus dirigents.

En conclusió, amb aquest estudi he volgut posar de manifest no només la importància que va tenir el moviment veïnal al Barcelonès Nord durant els anys setanta, sinó que aquest encara va mantenir una gran força i capacitat de lluita durant els anys vuitanta, encara que fos en unes condicions difícils i amb una orientació més defensiva. De manera que va ser a la dècada dels noranta quan la crisi del moviment veïnal al Barcelonès Nord va fer-se més evident -i encara amb algun matís com sembla evidenciar els fets de la "Intifada del Besòs" i l'èxit d'una candidatura veïnal independent a Sant Adrià de Besòs-. Però això queda pendent per futures investigacions. 


\section{Bibliografia.}

\section{Llibres i articles especialitzats}

ABRAS, Margarida, CARRERAS, Montserrat, NIETO, Ma Dolors: "Badalona segle XX: els Barris", Carrer dels Arbres, 3era. Època, núm. 11 (desembre 2000), p. 6586.

Tots els carrers de Badalona, Museu de Badalona, 2003.

AA.DD.: "Els barris de Badalona d'avui: Llefià.", Revista de Badalona. Àlbum 1994, 28 de Gener de 1994.

AA.DD.: “La Historia hablada del Barcelonès Nord. Llefià”, Alhora. Àlbum 1995.

AA.DD.: "Districte 1. Canyadó, Casagemes, Centre, Coll i Pujol, Dalt de la Vila, Manresà", Revista de Badalona núm. 3422 [monogràfic, febrer 2011].

AA.DD.: "Districte 2. Nova Lloreda, Sant Crist de Can Cabanyes, Sistrells, Revista de Badalona núm. 3423 [monogràfic, març 2001].

AA.DD.: "Districte 3. Bonavista, Bufalà, Canyet, Guixeres, El Mas Ram, Montigalà, Morera, Pomar, Pomar de Dalt", Revista de Badalona, núm. 3424 [monogràfic, abril 2001].

AA.DD.: "Districte 4. La Salut", Revista de Badalona núm. 3426 [monogràfic, juny 2001]

AA.DD: "Districte 5. Sant Antoni de Llefià, Sant Joan de Llefià, Sant Mori de Llefià" Revista de Badalona núm. 3427 [monogràfic, juliol 2001].

AA.DD.: "Districte 6. Artigues, El Congrés, La Móra, El Remei, Sant Roc", Revista de 
Badalona núm. 3428 [monogràfic, setembre 2001].

AA.DD.: “Districte 7. Can Claris, El Gorg, El Progrés, El Raval”, Revista de Badalona núm. 3429 [monogràfic, octubre 2002].

AA.DD.: "Districte 8. Lloreda, Montigalà, La Pau, El Puigfred”, Revista de Badalona núm. 3430 [monogràfic, novembre 2002].

AA.DD.: Los suburbios 1957. Compendio de las ponencias y coloquios desarrollados durante la Semana del Suburbio, Barcelona, [s.n.], [1957]

AA.DD.: "Los suburbios", Cuadernos de Arquitectura, núms. 60 - 61 (1965), p. 1-47 i $2-46$

AA.DD.: Conversaciones sobre inmigración interior, Ayuntamiento de Barcelona, Patronato Municipal de la Vivienda, [Barcelona], 1966.

AA.DD.: La Immigració a Catalunya, Edició de Materials, Barcelona, 1968.

AA.DD.: “La Gran Barcelona”, CAU núm. 10, novembre-desembre 1971.

AA.DD.: "El área metropolitana de Barcelona", Cuadernos de Arquitectura i Urbanismo, núm. 87 (1972), pp. 3-101.

AA.DD.: "La Obra Sindical del Hogar", Cuadernos de Arquitectura i Urbanismo, núm. 105 (1974), p.34-95.

AA.DD.; La gran Barcelona, Plaza Mayor, Madrid, 1972.

AA.DD.: "La lucha de los barrios de Barcelona, 1969-1975", CAU, núm. 34, 1975, p. 26-120. 
AA.DD.: Els problemes de Sabadell, Jove Cambra de Sabadell, Sabadell, 1976.

ÁGUILA, Rafael del i MONTORO, Ricardo: El discurso político de la transición española, CIS-Siglo XXI, Madrid, 1984.

AGUILAR FERNÁNDEZ, Paloma: Memoria y olvido de la Guerra Civil Española, Alianza Editorial, Madrid, 1996.

AJUNTAMENT DE BADALONA: Población, Vivienda, Transportes, Enseñanza, Economia Pública Local, 1976.

Conèixer Badalona, Conselleria d'Estadística, 1983

Badalona avui. Padró 1986, Àrea de Programació, Població i Estudis, 1987.

AJUNTAMENT DE SANTA COLOMA DE GRAMENET: Introducció a l'estudi de la població de Santa Coloma de Gramenet segons el Padró d'Habitants de 1986. I. Estadístiques poblacionals, Santa Coloma de Gramenet, 1986.

AJUNTAMENT DE SANT ADRIÀ DE BESÒS: Sant Adrià. 12 anys de democràcia municipal, Àrea d'Alcaldia, Sant Adrià de Besòs, 1991.

ALABART, Anna: Els barris de Barcelona i el moviment associatiu veïnal. Tesi Doctoral inèdita, Universitat de Barcelona, 1982.

"Els moviments socials urbans a Catalunya", Revista Catalana de Sociologia, núm. 7 (1998), p. 9-28.

ALBERCH, Ramon (dir.): Els barris de Barcelona, 4 vols., Enciclopèdia Catalana, Barcelona, 1997-2000.

ALIBÉS, Josep M.; MIGUÉLEZ, Faustino; PARDO, Maria José et. al.: "La lucha de los 
barrios de Barcelona, 1969-1975”, CAU, núm. 34, 1975.

ALIBÉS, Josep M; CAMPO VIDAL Manuel J.; GIRAL, Eugeni; HUERTAS CLAVERÍA Josep M.; PRADAS, Rafael; TARRAGÓ, Salvador: La Barcelona de Porcioles, Laia, 1975.

AMAYA QUER, Àlex: Prensa sindical y discurso social: Aproximación al aparato de propaganda de la OSE, 1957-1969, Tesina inèdita de Doctorat, UAB, 2007.

El Acelerón sindicalista: el aparato de propaganda de la Organización Sindical Española entre 1957 y 1969, Asociación de Historia Contemporánea, Centro de Estudios Políticos y Constitucionales, Madrid, 2013

ANDRADE BLANCO, Juan Antonio: El PCE y el PSOE en (la) transición. La evolución ideológica de la izquierda durante el proceso de cambio político, Siglo XXI, Madrid, 2012.

ANDREU I ACEBAL, Marc: El Bruc/ Bufalà. Badalona, Col-lecció Els Barris d'Adigsa, Vol. 7, Generalitat de Catalunya, Departament de Benestar Social, ADIGSA, 1995.

ANGULO URIBARRI, Javier: Cuando los vecinos se unen, PPC, Madrid, 1972.

ARTOUS, Antoine; WILNO, Henri; FORTINO, Sabine i CUPERTY, Patrice: Classe obrera, salariat, lluites de classe, Edicions del 1979, Barcelona, 2012.

ARTURO, Julián (comp.): Pobladores urbanos, TM Editores/Instituto Colombiano de Antropologia-Colcultura, Santa Fe de Bogotá, 1994.

ARRIERO, Francisco: "El movimiento democrático de mujeres: de la lucha antifranquista a la conciencia feminista (1964-1975)" en Actes del Congrés La transició de la dictadura franquista a la democràcia. Barcelona, 20, 21 i 22 
d'octubre de 2005, UAB-CEFID, Barcelona, 2005, p. 253-263.

"El Movimiento Democrático de Mujeres: del antifranquismo a la movilización vecinal y feminista", Historia, Trabajo y Sociedad, 2 (2011), p. 33-62.

ARREY, Francesc; FERRANDO, Emili; OJUEL, Maria: Badalona, un segle de ciutat. La Immigració, Museu de Badalona.

ASSOCIACIÓ DE VEÏNS DEL BARRI DEL MANRESÀ: Història del Barri del Manresà de Badalona, Associació de Veïns del Barri del Manresà, Badalona, 2006.

AVV POMAR: Pomar, 25 años: la nueva Badalona. Pomar: aún una esperanza. 19671992 fiestas conmemorativas del 23 de mayo al 23 de junio, Generalitat de Catalunya, Departament de Benestar Social, [Barcelona?], [1992?]

AYUSO, Luis Manuel: Asociaciones familiares en España. Un estudio sociológico, Tesi Doctoral, Universitat de Granada, 2005.

BABIANO, José: Emigrantes, cronómetros y huelgas: un estudio sobre el trabajo y los trabajadores durante el franquismo, Madrid, 1951-1977, Siglo XXI i Fundación 1ํ de Mayo, 1995.

(ed.): Trabajo, género y movimiento obrero durante el franquismo, Fundación 1ํ de Mayo / Los Libros de la Catarata, Madrid, 2007.

BABIANO, José i FERNÁNDEZ ASPERILLA, Ana: "En manos de los tratantes de seres humanos (notas sobre la emigración irregular durante el franquismo), dins Historia Contemporánea núm. 26, 2003, p. 35-36.

La patria en la maleta: Historia social de la emigración española a Europa, Ediciones GPS, Madrid, 2010. 
BADE, Klaus J.: Europa en movimiento. Las migraciones desde finales del siglo XVIII hasta nuestros dias, Crítica, Barcelona, 2003.

BAEZA, Josep: Associacionisme veïnal a Badalona, FAVB, Badalona, 1998.

25 anys de la nostra història, 1977-2002. Associació de Veïns de Sant Antoni de Llefià i Adjacents, AA. VV. Ronda de Sant Antoni de Llefià, 2002.

BAGUR, Joel i DÍEZ, Xavier (eds.): La gran desil·lusió, El Cep i La Nansa, Vilanova i la Geltrú, 2005.

BALFOUR, Sebastian: La dictadura, los trabajadores y la ciudad. El movimiento obrero en el área metropolitana de Barcelona (1939-1988), Edicions Alfons el Magnànim, València, 1994.

BALFOUR, Sebastián i MARTÍN GARCÍA Óscar J.: “Movimientos sociales y transición a la democracia: el caso español" en Rafael Quirosa-Cheyroze, La sociedad española en la Transición. Los movimientos sociales en el proceso democratizador, Biblioteca Nueva, Madrid, 2011, p. 43-62.

BALLARÍN ELCHANO, César; CASAS I SORIANO, Just; MÁRQUEZ I BERROCAL, Manuel: Ca N'Anglada. Lluita d'un barri. Història social del Ca N'Anglada: El moviment veïnal, 1950-1995, AA. VV. de Ca N’Anglada, 1996.

BALLESTER, David: "Trets a Santa Coloma de Gramenet. El cas de Camilo Rueda i la UGT de Catalunya a les darreries del franquisme", Àgora núm. 7 (març 2002), p. 47-88.

BARBARÀ I MOLINA, Antoni: "Editorial: Implicacions ecològiques del desenvolupament industrial", Carrer dels Arbres, núm. 8 1era època (novembre 1980), p. 1. 
BARCIELA, Carlos: "Franquismo y corrupción económica”, Història Social, núm. 30 (1998), p. 83-96.

(et al.): La España de Franco (1939-1975), Síntesis, Madrid, 2001.

BARRERA I MEYA, Judit: Canyet, un vell poble, Museu de Badalona, 2001.

BARRERA, Carlos: Historia del proceso democrático en España. Tardofranquismo, transición y democracia, Fragua, Madrid, 2002.

BASSÓ, F.; BUXÓ, J. M. i BOHIGAS, Oriol: “Estudio social del problema de la vivienda en relación con las zonas afectadas por el mismo. Concepto humano del problema", Cuadernos de Arquitectura, núms. 15-16 (1953), pp. 2-40.

BENEDICTO MILLÁN, Jorge: "Sistemas de valores y pautas de cultura predominantes en la sociedad española (1976-1985)" en José Félix Tezanos, Ramón Cotarelo i Andrés de Blas (eds.): La transición democrática española, Sistema, Madrid, 1989.

BERRIATÚA, Javier Maria: Las Asociaciones de Vecinos, Instituto de Estudios de Administración Local, Madrid, 1977.

BIER, Alice Gail: Crecimiento urbano y participación vecinal, CIS, Madrid, 1980.

“"Vox Pópuli": el desarrollo de las Asociaciones de Vecinos en España", Papers núm. 11 (1979), p. 169-183.

BOJ, Imma: La represión de inmigración en la Barcelona franquista. El pabellón de las Misiones, Tesina de Màster, Barcelona, 2003.

“El Pavelló de les Missions. La repressió de la immigració”, L'Avenç núm. 298 (2005), p. 38-44. 
BOJ, Imma i V. AROCA, Jaume: “La repressió de la immigració: les contradiccions del franquisme" dins Martí Marín (dir.): Memòries del viatge..., p. 71-86.

BOLÓS, Maria de: “La inmigración en Barcelona en los últimos decenios”, Estudios Geográficos, núm. 75, 1959.

BORDES ROCA, Pedro (dir.): El desarrollo y la población, Consejo Económico Social de Catalunya, Barcelona, 1972.

BORDETAS JIMÉNEZ, Iván: Del suburbio al barrio: los orígenes del movimiento vecinal en Barcelona, Tesina de Doctorat, UAB, Bellaterra, setembre de 2009.

"El viatge: canals d'informació, rutes, condicions i arribada" a MARÍN, Martí (dir.): Memòries del viatge 1940-1975, Ajuntament de Sant Adrià de Besòs, Museu d'Història de la Immigració de Catalunya, 2009, p. 33-50.

"Habitatge i assentaments, de la postguerra a l'estabilització" a MARÍN, Martí (dir.): Memòries del viatge 1940-1975, Ajuntament de Sant Adrià de Besòs, Museu d'Història de la Immigració de Catalunya, 2009, p. 51-69.

"El movimiento vecinal en el tránsito de la resistencia a la construcción de alternativas", Historia del Presente, 16 (2010), p. 43-61.

"De la supervivència a la resistència: la gestació del moviment veïnal a la Catalunya franquista" a MOLINERO, Carme i YSÀS, Pere (coords.): Construint la ciutat democràtica. El moviment veïnal durant el tardofranquisme i la transició, Icària, Barcelona, 2010, p. 35-112.

“'Ni tú ni yo somos nadie si tú y yo no somos nosotros': los orígenes del movimiento vecinal en Catalunya" a BARRIO ALONSO Á.; DE HOYOS PUENTE J. i SAAVEDRA ARIAS, R. (eds.): Nuevos horizontes del pasado: 
culturas políticas, identidades y formas de representación. Santander, Universidad de Cantabria, 2011.

"«Las Asociaciones de Vecinos son la mejor escuela de formación de ciudadanos conscientes». El moviment veïnal durant el tardofranquisme i la transició", Plecs d'Història Local, 141 (abril de 2011), p. 5-7.

"'Las ansias de participación': la ofensiva del movimiento vecinal en el proceso de cambio político en España. Comunicación a Conferência Internacional Greves e Conflitos Sociais no Século XX. Lisboa, FCSH, 10-20 de Março de 2011.

Nosotros somos los que hemos hecho esta ciudad. Autoorganización y movilización vecinal durante el tardofranquismo y el proceso de cambio político, Tesi Doctoral, UAB, Bellaterra, juliol 2012.

BORDETAS, JIMÉNEZ, Ivan i SÁNCHEZ SORRIBES, Anna: "El moviment veïnal en (la) transició, 1974-1979" a MOLINERO, Carme i YSÀS, Pere (coords.): Construint la ciutat democràtica. El moviment veïnal durant el tardofranquisme i la transició, Icària, Barcelona, 2010, p. 159-261.

BORJA, Jordi: "Elementos teóricos para el análisis de los movimientos reivindicativos urbanos", Cuadernos de Arquitectura y Urbanismo, núm. 94 (1973), pp. 57-61.

"Movimientos urbanos de las clases populares: movimiento reivindicativo, movimiento democrático, dualidad de poder", Papers, núm. 3 (1974), pp. 3961.

Movimientos sociales urbanos, Ediciones SIAP, Buenos Aires, 1975.

Qué son las Asociaciones de Vecinos, La Gaya Ciencia, Barcelona, 1977. 
“Crisis del Estado autoritario y sistema de partidos en España”, Papers, núm. 8 (1978), p. 143-172.

Estado y ciudad, PPU, Barcelona, 1988.

BORJA, Jordi; TARRAGÓ, Marçal: "V. La planificación urbana”, CAU núm. 10 (novembre-desembre de 1971), p. 80-91.

BORJA, Jordi; TARRAGÓ, Marçal; LLEIXÀ, Joaquim et al: La Gran Barcelona., A. Corazón, Madrid, 1972.

BOSCH, Esperanza i FERRER, Victoria A.: El model de dona a la Secció Femenina. Implantació a les Illes Balears (1939-1975), Universitat de les Illes Balears, 1997.

BOTEY, Jaume: Cinquanta-quatre relats d'immigració, Diputació de Barcelona i Centre d'Estudis de l'Hospitalet, Barcelona, 1986.

BOU, Luís: El Carmel ignorat. Història d'un barri impossible, Ajuntament de Barcelona, 2007.

BRANDES, Stanley H.: Migrations, Kinship, and Comunity, Tradition and Transition in a Spanish village, Academic Press, Nova York, 1975.

BURILO, Lluís i GRAUPERA, Isabel: Històries de vida. Fonts orals de la lluita obrera i l'antifranquisme al Baix Llobregat. [s.l.], Fundació Utopia Joan N. GarcíaNieto, 2008.

CABRÉ, Anna: “Les Migracions a Catalunya 1900-2000”, Papers de Demografia núm. 38., Centre d'Estudis Demogràfics.

CABRERO, Claudia: “Género, antifranquismo y ciudadanía. Mujeres y movimiento 
vecinal en la Asturias del desarrollismo y el tardofranquismo", Historia del Presente, 16 (2010), p. 9-26.

CAMÓS, Joan: “El mite de la Torrassa”, Plecs d’Història Local/ L’Avenç, 1, febrer 1986.

CANDEL, Francesc: Dónde la ciudad cambia su nombre, José Janés, Barcelona, 1957.

Els altres catalans, Edicions 62, Barcelona, 1962.

“El Amazacotamiento”, Cuadernos de Arquitectura, núm. 60 (2on Trimestre de 1965) (p. 5-8).

Apuntes para una sociología del barrio, Edicions 62, Barcelona, 1972.

CAPDEVILA LLOVERA, Carles: "La lluita per l'ambulatori (1971)", Àgora núm. 5 (març 2000), p. 31-78.

“Els Grupos Obreros Autónomos (GOA)”, Àgora núm. 8 (març 2003), p. 135163.

CARBONELL, Maria Mercè; FABÀ, Albert i ROVIRA, Jordi: Santa Coloma de Gramenet: de poble pagès a ciutat obrera, Ajuntament de Santa Coloma de Gramenet, 1988.

CÀRITAS DIOCESANA: Visión sociográfica de Barcelona, [s.n.], Barcelona, [1965?]

CARR, Raymond i FUSI, Juan Pablo: España de la dictadura a la democracia, Planeta, Barcelona, 1979.

CARRERAS, Carles: Sants. Anàlisi de la producció de l'espai urbà de Barcelona, Serpa, Barcelona, 1980. 
CARRERAS, Francesc i VILAGUT, Josep R.: "La Obra Sindical del Hogar y el Patronato Municipal de la Vivienda: dos ejemplos de ineficacia”, CAU, núm. 52, novembre-desembre 1978, pp. 31-34.

CARRERAS, Montserrat; VALL I SERRA, Núria: La II República a Badalona, 19311936: una població industrial en crisi, Museu de Badalona, Badalona, 1990.

CARRERAS, Montserrat; FERRANDO, Emili; VILLARROYA, Joan: La immigració a Badalona durant el segle XX, Museu de Badalona, 2006.

CARRION, Lola: La conflictivitat laboral en Santa Coloma de Gramenet des de 1968 a 1978. Treball de Màster, Universitat de Barcelona, 2008.

CASALS I CORTÉS, Núria; PADRÓ I WERNER, Jordi: Història Gràfica de Badalona. Volum I (1980-1939), Museu de Badalona, 1994.

Història Gràfica de Badalona. Volum II. (1939-1975), Museu de Badalona, 1993.

CASAÑAS, Joan: El progressisme catòlic a Catalunya (1940-1980), La Llar del Llibre, Barcelona, 1989.

CASTAÑO, Josep: Memòries sobre les JOC a Catalunya, Institut Catòlic d'Estudis Socials a Catalunya, 1974.

CASAS I SORIANO, Just i MÁRQUEZ I BERROCAL, Manuel: Història Social de Sant Adrià de Besòs. Vol I. La Població: segles XVIII-XX, Hacer Editorial, Sant Adrià de Besòs, 1996.

CASTELLS, Andreu: El franquisme i l'oposició sabadellenca, 1939-1976; Sabadell, informe de l'oposició, vol. VI, Edicions Riutort, Sabadell, 1977. 
CASTELLS, Manuel: Luttes urbaines et pouvoir politique, Maspéro, París, 1973.

La cuestión urbana, Siglo XXI, Mèxic D.F., 1974.

Movimientos sociales urbanos, Siglo XXI, Madrid, 1977.

Ciudad Democracia y Socialismo. La experiencia de las asociaciones de vecinos de Madrid, Siglo XXI, Madrid, 1977.

City, Class and Power, MacMillan, Londres, 1978.

Crisis urbana y cambio social, Siglo XXI, Madrid, 1981.

La ciudad y las masas. Sociología de los movimientos sociales urbanos, Alianza Editorial, Madrid, 1986.

CEFID: Catalunya durant el franquisme. Diccionari, Eumo, Vic, 2006.

CHECA, Martí: Bon Pastor: sociabilitats d'un barri, Ajuntament de Barcelona, 2003.

"Forces antifranquistes per un barri: el cas del Bon Pastor (Barcelona)", Actes del Congrés La transició de la dictadura franquista a la democràcia, Barcelona, 20, 21 i 22 d'octubre de 2005. CEFID-UAB, Barcelona, 2005, p. 47-55.

CHULIÁ, Elisa: La evolución silenciosa de las Dictaduras. El régimen de Franco ante la prensa y el periodismo, Instituto Juan March de Estudios e Investigaciones-Centro de Estudios Avanzados en Ciencias Sociales, Madrid, 1997.

CIDUR: Madrid/ Barrios 1975, Ediciones de la Torre, Madrid, 1976. 
Vallecas: las razones de una lucha popular, Mañana, Madrid, 1976.

Las asociaciones de vecinos en la encrucijada: el movimiento ciudadano en 1976-77, Ediciones La Torre, Madrid, 1977.

CÍRCULO DE ECONOMIA: Gestión o caos: el área metropolitana de Barcelona, Ariel, Barcelona, 1973.

CLUSA I ORIACH, Joaquim: Estudio-informe de los barrios de Can Oriach, Plana del Pintor y Torrent del Capellà, Serracanta Copisteria, Sabadell, 1967.

COBO PULIDO, Pedro: "Las asociaciones de cabezas de familia como cauce de participación: un fallido intento de apertura del régimen franquista", Espacio, Tiempo y Forma, Serie V, Historia Contemporánea, núm. 14 (2001), pp. 437-488.

Representación familiar en la época de Franco (1945-1974). Un caso de evolución de un régimer autoritario, Departamento de História Moderna y Contemporánea, Facultad de Filosofia y Letras de la Universidad de Málaga

COMÍN, Alfons C. i GARCIA NIETO, Juan N.: Juventud obrera y conciencia de clase. El proceso inmigratorio y su función innovadora en la sociedad catalana, Cuadernos para el Diálogo (EDICUSA), Madrid, 1974.

COMISIÓN DE URBANISMO Y SERVICIOS COMUNES DE BARCELONA Y OTROS MUNICIPIOS, Estudio sobre necesidades de vivienda en el Área Metropolitana de Barcelona, CINAM, Madrid, 1971.

CONCEJALÍA DE SERVICIOS SOCIALES DEL AYUNTAMIENTO DE SANTA COLOMA: La tercera edad en Santa Coloma, Santa Coloma de Gramenet, 1980.

CORRAL I BELORADO, José Maria: Santa Coloma. La riba esquerra, Edicions 
l'Èsguard, Santa Coloma de Gramenet, 2008.

COSTA, Joan: Dels moviments d'Església a la militància política, Mediterrània, Barcelona, 1997.

COTARELO, Ramón (comp): Transición política y consolidación democrática. España (1975-1986). Centro de Investigaciones Sociológicas, Madrid, 1992.

COTURRELO, Agustín: La política económica de la vivienda en España, CSIC, Madrid, 1960.

CUYÀS I TOLOSA, Josep Maria: Història de Badalona. Vols. VII-VIII, Badalona, 1982.

CUESTA GÓMEZ, José Miguel: “Immigració i moviment veïnal a Llefià: més història de la que us penseu", Carrer dels Arbres, 3era. Època, núm. 19 (desembre 2008), p. 97-108.

El moviment veïnal a Llefià (Badalona). Tesina de Doctorat, UAB, Bellaterra, setembre 2010.

"El papel de las organizaciones políticas en el movimiento vecinal del barrio de Llefià (Badalona)" a QUIROSA-CHEYROUZE, Rafael; NAVARRO, Luis Carlos i FERNÁNDEZ, Mónica (coords): Las organizaciones políticas. Congreso Internacional Historia de la Transición en España. Universidad de Almería, Almería, Servicio de Publicaciones, 2011, p. 57-72.

"El moviment veïnal i la seva capacitat de millorar les condicions de vida col-lectives d'un barri: el cas de Llefià (Badalona)" a ARNABAT MATA, Ramón i SANTESMASES i OLLÉ, Josep (dirs.): 1960-1980. Transicions i canvis a les terres de parla catalana, Actes del VIII Congrés de la CCEPC. Barcelona i Cornellà de Llobregat, 10,11 i 12 de novembre de 2011, Publicacions de la Coordinadora de Centres d'Estudis de Parla Catalana, Institut Ramon 
Muntaner i Cossetània Edicions, Valls, 2012.

"La lluita política dins un moviment popular: les associacions veïnals al Barcelonès Nord durant el tardofranquisme i la transició (1969-1986)" a Congrés Internacional. Societats en Canvi: Espanya i Portugal als anys setanta. 15 i 16 de novembre de 2012.

"La lucha por la hegemonía política en un movimiento popular: las asociaciones de vecinos el el Barcelonès Nord (1969-1986)" a Claves del mundo contemporáneo. Debate e investigación. Actas del XI Congreso de la Asociación de Historia Contemporánea, Editorial Comares S.L., Granada, 2013.

"La conflictividad vecinal en los años ochenta en el Barcelonès Nord. Una gran desconocida" a Maison des Sciences de l'Homme, Dijon: Strikes and social conflicts. II International conference Dijon, 15-16-17 may 2013.

"Equipaments bàsics, llibertats democràtiques i transformació social. El moviment veïnal al Barcelonès Nord a finals de la dictadura" a MOLINERO, Carme i TÉBAR, Javier: VIII Trobada Internacional d'Investigadors del Franquisme. Barcelona 21,22 de novembre de 2013, CEFID-UAB, Fundació Ciprinao García, Red de Archivos Históricos de CCOO i Diputació de Barcelona, 2013.

DE MICHELE, Andrea: "I diversi volti del ruralismo fascista”, Italia contemporanea, núm. 199 Juny 1995.

DELGADO, José Luis García: Reformismo y crisis económica, Saltés, Madrid, 1977.

Franquismo. El juicio de la historia, Temas de Hoy, Madrid, 2000.

DÍAZ, Pilar: "La lucha de las mujeres en el tardofranquismo: los barrios y las 
fábricas", Gerónimo de Uztariz, 21 (2005), p. 39-54.

DOMÈNECH, Xavier: Quan el carrer va deixar de ser seu. Moviment obrer, societat civil i canvi polític. Sabadell (1966-1976), Publicacions de l'Abadia de Montserrat, Barcelona, 2000.

“El cambio político (1962-1976). Materiales para una perspectiva desde abajo", Historia del Presente, núm. 1 (2002), p. 46-67.

"El problema de la conflictividad bajo el franquismo: saliendo del paradigma”, Historia Social, núm. 42 (2002), p. 123-143.

“El cambio político desde abajo (1962-1976). Una perspectiva teórica y metodológica". Comunicació al V Encuentro de Investigadores del Franquismo. Albacete, 13-15 de novembre de 2003.

Pequeños grandes cambios. Movimiento obrero y cambio político en la década de los sesenta. Materiales para una historia desde abajo y una perspectiva desde Catalunya, Tesi Doctoral, UAB, Cerdanyola del Vallès, 2006.

Clase obrera, antifranquismo y cambio político. Pequeños grandes cambios, 1956-1969, Los Libros de la Catarata, Madrid, 2008.

Temps d'interseccions. La Joventut Comunista de Catalunya (1970-1980), Fundació Francesc Ferrer i Guàrdia, Sabadell, 2008.

"Orígenes. En la protohistoria del movimiento vecinal bajo el franquismo", Historia del Presente, 16 (2010), p. 27-41

"La reconstrucció de la raó democràtica. Del suburbi a la ciutat", MOLINERO, Carme i YSÀS, Pere (coords): Construint la ciutat democràtica. El moviment veïnal durant el tardofranquisme i la transició, Icària, Barcelona, 2010, p. 
113-155.

DOMINGO, Miquel i BONET, Maria Rosa: Barcelona i els moviments socials urbans, Mediterrània, Barcelona, 1998.

“Urbanisme i participació”, Revista Catalana de Sociologia, núm. 7, 1998, p. 73-89.

DONATO, José E.: “Barrios Altos de San Andrés", Cuadernos de Arquitectura y Urbanismo, núm. 60, 1965, p. 19-40.

DUOCASTELlA, Rogelio: Planificación de los servicios sociales de la ciudad de Sabadell (Barcelona) (1961-1962), inèdit, Sabadell, 1962.

DURÀ I GUIMERÀ, Antoni: “Moviment urbà, premsa local i canvi en la percepció del paisatge a Santa Coloma de Gramenet", Documents d'Anàlisi Geogràfica, núm. 19-20, 1991-1992, pp. 57-79.

EQUIPÒ DE ESTUDIOS: La lucha de barrios en Barcelona, Elias Querejeta Ediciones, Barcelona, 1976.

FABRÉ, Jaume: Nou Barris: la penúltima Barcelona, Ajuntament de Barcelona, 1991.

FABREGAS, Dídac i GIMÉNEZ, Dionisio: La huelga y la reforma: Sabadell, metal otoño 1976, Ediciones La Torre, Madrid, 1977.

FEBO, Giuliana di: Resistencia y movimiento de mujeres en España 1936-1976, Icaria, Barcelona, 1979.

"Resistencias femeninas al franquismo. Para un estado de la cuestión", Cuadernos de Historia Contemporánea, vol. 28 (2006), p. 153-168. 
FEDERACIÓ D'ASSOCIACIONS DE VEÏNS DE BARCELONA: Barcelona a cops! X Aniversari de la FAVB, FAVB, Barcelona, 1982.

FÉLIX TEZANOS, José: "La crisis del franquismo y la transición democrática”, en José F. Tezanos, Ramón Cotarelo i Andrés de Blas (eds.): La transición democrática española, Sistema, Madrid, 1989.

FERNÁNDEZ ASPERILLA, Ana: “Emigración como exportación de mano de obra: el fenómeno migratorio a Europa durante el franquismo", dins Historia Social núm. 30, 1998, p. 63-81.

FERNÁNDEZ, Pedro Jesús: “Editorial: El recent problema escolar: Caos programat del govern central", Carrer dels Arbres, núm. 5, 1era època (novembre 1979), p. 1.

FERNÁNDEZ SEGURA, José: La participación de los católicos en el movimiento obrero de Barcelona (1946-1978), Tesi Doctoral, 2005.

FERRANDO PUIG, Emili: Cristians i rebles. Història de l'HOAC a Catalunya durant el franquisme (1946-1975), Editorial Mediterrània, Barcelona, 2000.

FERRANDO PUIG, Emili i RICO MÀRQUEZ, Juan: Les Comissions Obreres en el franquisme: Barcelonès Nord 1964-1977, Publicacions de l'Abadia de Montserrat, Barcelona, 2005.

Haissa. Història d'una tragèdia obrera en el tardofranquisme, Ediciones Carena, Barcelona, 2009.

FERRER, Amador: Els polígons de Barcelona. L'habitatge massiu i la formació de l'àrea metropolitana, Edicions UPC, Barcelona, 1996. 
FISHMAN, Robert: Organización obrera y retorno a la democracia en España, Centro de Investigaciones Sociológicas, Madrid, 1990.

FONT, Jordi: ¡Arriba el campo! Primer franquisme i actituds polítiques en l'àmbit rural nord-català, Diputació de Girona, Girona, 2001.

"El régimen franquista frente a la oposición", Documentos de Trabajo. Cuadernos de la España contemporánea, 3 (2007).

FONT AGULLÓ, Jordi (dir.): Història i memòria: el franquisme i els seus efectes als Països Catalans, Publicacions de la Universitat de València / Centre d'Estudis Comarcals de Banyoles, València / Banyoles, 2007.

FONTANA, Josep (ed.): España bajo el franquismo, Crítica, Barcelona, 1986.

FORCADELL, Carlos: "Sobre desiertos y secanos: los movimientos sociales en la historiografia española”, Historia Contemporánea, núm. 7 (1992), pp. 101116.

FOWERAKER, Joe: La democracia española, Arias Montano, Madrid, 1990.

FUSI, Juan Pablo Fusi, VILAR, Sergio Vilar i PRESTON, Paul: De la dictadura a la democracia: desarrollismo, crisis y transición (1959-1977), Información y revistas, Madrid, 1983.

FUSI, Juan Pablo i PALAFOX, Jordi: España 1808-1996. El desafío de la modernidad, Espasa Fórum, Madrid, 1997.

GABRIEL, Pere (coord.): Comissions Obreres de Catalunya 1964-1989 (Una aportació a la història del moviment obrer), Empúries / Centre d'Estudis i Recerca Sindicals de la CONC, Barcelona, 1989. 
GAIL BIER, Alice: Crecimiento urbano y participación vecinal. Madrid: CSIC, 1980 i “«Vox populi»: el desarrollo de las Asociaciones de Vecinos en España”, Papers: Revista de Sociología, núm. 11, 1979, p. 169-183.

GALLARDO GUERRERO, Juan José: “Aportaciones a la huelga de Casadeport. Entrevista con Ángel Nogales”, Àgora núm. 12 (març 1997), p. 105-118.

“Aproximación al estudio de las alcaldías franquistas (1951-1975), Àgora núm. 8 (març 2003), p. 177-223.

GALLEGO, Teresa: Mujer, falange y franquismo, Taurus, Madrid, 1983

GARCÍA BARBANCHO, Alfonso: Las migraciones interiores españolas. Estudio cuantitativo desde 1900, Publicaciones del Instituto de Desarroyo Económico, Madrid, 1967.

Las migraciones interiores españolas de 1961-1970, Instituto de Estudios Económicos, Madrid, 1975.

GARCIA FERNÁNDEZ, Javier i GONZÁLEZ RUIZ, Maria Dolores: Las Asociaciones de Vecinos, Dopesa, Barcelona, 1976.

Presente y futuro de las Asociaciones de Vecinos, Pecosa Editorial, Madrid, 1976.

GARCIA NIETO, Mạ Carmen: "Marginalidad, movimientos sociales, oposición al franquismo. Palomeras, un barrio obrero de Madrid, 1950-1980" en J. Tusell, A. Alted i A. Mateos (coords.), La oposición al régimen de Franco. Tomo II, UNED, Madrid, 1991, p. 269-285.

GIMÉNEZ, Dionisio: Sabadell, el pueblo unido..., Alternativas, L'Hospitalet, 1976. 
GIRALT PAULÍ, Enric: "El nou Ajuntament Democràtic, Carrer dels Arbres, núm. 1, 1era època (maig 1979), p. 9-10.

“La Transició a Badalona 1975-1979”, Carrer dels Arbres, núm. 9, 3era època (desembre 1998), p. 69-80.

GONZÁLEZ MORELL, Constantino: Democracia i barrio. El movimiento vecinal en Valladolid (1964-1986), Universidad de Valladolid, Valladolid.

GRAMSCI, Antonio: Antología. Selección traducción y notas de Manuel Sacristán, Akal, Madrid, 2013.

GRIBAUDI, Maurizio: Mondo operaio e mito operaio. Spazi e percorsi sociali a Torino nel primo novecento, Eianudi, Torí, 1987.

GRIMALDOS, Alfredo: Claves de la Transición 1973-1986 [para adultos]. De la muerte de Carrero Blanco al referéndum de la OTAN, Península, Barcelona, 2013.

GUAITA JIMÉNEZ, Pere: Per les llibertats i la democràcia. La lluita del moviment associatiu a Cornellà de Llobregat.: Ajuntament Cornellà de Llobregat, Cornellà de Llobregat, 2008

HARVEY, David: Urbanismo y desigualdad social, Siglo XXI, Madrid, 1979.

Breve historia del neoliberalismo, Akal, Madrid, 2007.

HERNÁNDEZ ALCÀSSER, Lluís: Escrits, 1980-1992 / Lluís Hernández: l'alcalde de la transformació de Santa Coloma, Associació Edicions Teresa Quintana, 1992.

HUERTAS, Josep M.: “Los nueve barrios (que pronto serán diez)”, CAU, núm. 20 (1973), p. 38-44. 
HUERTAS, Josep M. i FABRÉ, Jaume: Tots els barris. 7 vols., Edicions 62, Barcelona, 1976-1977.

Barcelona, 1888-1988. La construcció d'una ciutat, Plaza\&Janés/Diari de Barcelona/Fira de Barcelona, 1988.

HUERTAS, Josep M. i ANDREU, Marc: Barcelona en lluita. El moviment urbà 19651996, Federació d'Associacions de Veïns de Barcelona, Barcelona, 1996.

HUERTAS, Josep M. i VILASERÓ, Manuel: La premsa de barris a Barcelona (19391982), Diputació i Ajuntament de Barcelona, Barcelona, 1982.

IMBERT, Gérard: Los discursos del cambio. Imágenes e imaginarios sociales en la España de la Transición (1976-1982), Akal, Madrid, 1990.

INSTITUTO NACIONAL DE LA VIVIENDA: Una tierra bajo el techo. Veinticinco años del Instituto Nacional de la Vivienda en Cataluña, Ministerio de la Vivienda, Barcelona, 1964.

J.A.D.: "La construcción de viviendas en España", Cuadernos de Arquitectura i Urbanismo, núm. 96 (1973), p. 19-31.

JÓDAR, Pere; MENDOZA Rocío i SANZ, Gonçal: La Confecció submergida: característiques sòcio-econòmiques del sector de la confecció a Santa Coloma de Gramenet, Ajuntament de Santa Coloma de Gramenet i Eumo, Vic, 1991.

JULIÀ, Santos: “Obreros y sacerdotes: cultura democrática y movimientos sociales de oposición", en TUSELL, Javier; ALTED, Alicia i MATEOS, Abdon (coords.): La oposición al régimen de Franco. Vol. II, UNED, Madrid, 1990, p. 147-159.

“Orígenes sociales de la democrácia en España”, Ayer núm. 15 (1994), pp. 
165-188.

JUTGLAR, Antoni i altres: La immigració a Catalunya, Edició de Materials, Barcelona, 1968.

KANDERMANS, Bert: "La construcción social de la protesta y los campos pluriorganizativos", p. 183-220, a Enrique Laraña i Joseph Gusfield (eds.): Los nuevos movimientos sociales. De la ideologia a la identidad, CIS, Madrid, 1994.

KAPLAN, Temma: "Luchar por la democracia: formas de organización de las mujeres entre los años cincuenta y los años setenta" a AGUADO, Anna (ed.), Mujeres, regulación de conflictos y cultura de la paz, Universitat de València, València, 1999.

KÖHLER, Holm-Detlev: El movimiento sindical en España. Transición democrática. Regionalismo. Modernización económica, Fundamentos, Madrid, 1995.

LARAÑA, Enrique: La construcción de los movimientos sociales, Alianza, Madrid, 1999.

LARAÑA, Enrique i GUSFIELD, Joseph (eds.): Los nuevos movimientos sociales. De la ideologia a la identidad, CIS, Madrid, 1994.

LARROSA Manuel; SABATER, Pere i GIL, Josep M.: Zonas verdes en Sabadell, Joven Cámara de Sabadell, 1975.

LARUMBE, Ma Ángeles: Las que dijeron que no. Palabra y acción del feminismo en la Transición, Prensas Universitarias de Zaragoza, Zaragoza, 2004.

LEFEBVRE, Henri: La revolución urbana, Alianza, Madrid, 1972. 
El derecho a la ciudad, Península, Barcelona, 1978.

LINZ, Juan J.: “Una teoría del régimen autoritario. El caso de España”, dins FRAGA, Manuel; VELARDE, Juan i DEL CAMPO, Salustiano (dir.): La España de los 70, vol. III, "El Estado y la política”, Moneda y Crédito, Madrid, 1970.

"La transición a la democracia en España en perspectiva comparada" a COTARELO R. (comp.): Transición política y Consolidación Democrática, España (1975-1978), Centro de Investigaciones Sociológicas, Madrid, 1992, p. $435-436$.

LOJKINE, Jean: El marxismo, el estado y la cuestión urbana, Siglo XXI, Mèxic D.F., 1979.

LÓPEZ, Manuel: Un periodisme alternatiu i autogestionari. La premsa de barris a Barcelona, 1968-1977, Diputació de Barcelona i Col·legi de Periodistes de Catalunya, Barcelona, 1994.

LÓPEZ CRESPÍ, Miquel: No era això. Memòria política de la Transició, Edicions el Jonc, Lleida, 2001.

LÓPEZ PARRA, Miguel: Historial Barrio Sistrells 1924-1960. Asociación de Vecinos 1960-1974, [1976, inèdit].

LÓPEZ RÓDENAS, Marcelo: Historia social de la Santa Coloma moderna, 1954-1979, Regidoria de cultura de l'Ajuntament de Santa Coloma de Gramenet, Santa Coloma de Gramenet, 1982.

LÓPEZ RODÓ, Laureano: Memorias, 4 vols., Plaza \&Janés i Cambio 16, 1990-1993.

LOWE, Stuart: Urban Socials Movements. The City after Castells, MacMillan, Londres, 1986. 
LLADÓ BLANCH, Francesc: "Places i carrers. Espais de lleure i comunicació per fer ciutat", Carrer dels Arbres, núm. 1, 1era època (maig 1979), p. 17-22.

LLIGADAS, Josep i DE MAYA, Juan Francisco: Cerdanyola, el barri gran de Mataró. 1920-2000, Patronat Municipal de Cultura, Mataró, 2000.

MADUEÑO, Eugenio: Grama: una experiència insòlita de periodisme popular, Diputació de Barcelona i Ajuntament de Santa Coloma de Gramenet i Col·legi de Periodistes de Catalunya, Barcelona, 1988.

MADUEÑO, Eugenio i CATÀ, Joan: Grama; El Maresme: dues revistes heroiques, Diputació de Barcelona i Col·legi de Periodistes de Catalunya, Barcelona, 1988.

MAESTROJUAN, Francisco Javier: "Ni un hogar sin lumbre ni un español sin hogar. José Luis Arrese y el simbolismo ideológico en la política del Ministerio de la Vivienda", Príncipe de Viana, any 58, núm. 210, 1997, p. 171-190.

MAINER, José Carlos i JULIÀ, Santos: El aprendizaje de la libertad, Alianza, Madrid, 2000.

MALGESINI, Graciela (comp.): Cruzando fronteras. Migraciones en el sistema mundial, Fundación Hogar del Empleado, Madrid, 1998.

MANRESA, Kim: Nou Barris, 25 anys, Coordinadora d'Associacions de Veïns i Entitats de Nou Barris, 1997.

MARAVALL, José María: La política de la transición 1975-1980, Taurus, Madrid, 1981.

MARÍN I CORBERA, Martí: Franquisme i poder local. L'Ajuntament de Sabadell, 1939- 
1979, memòria de Doctorat, UAB, 1990.

Política i administració local durant el franquisme. Els ajuntaments de la Catalunya urbana entre 1938 i 1979, Tesi Doctoral, UAB, 1993.

Els Ajuntaments franquistes a Catalunya, Pagès editors, Lleida, 2000.

Catalanisme, clientelisme i franquisme. Josep Maria de Porcioles, Societat Catalana d'Estudis Històrics, Institut d'Estudis Catalans, 2000.

Immigració, suburbialització i dictadura, 1939-1960, III Beca Miquel Carreras. Treball inèdit, Museu d'Història de Sabadell, 2003.

D’immigrants a ciutadans. La immigració a Catalunya del franquisme a la recuperació de la democràcia. Barcelona: Diputació de Barcelona, Ajuntament de Sant Adrià del Besòs, Museu d'Història de la Immigració de Catalunya, 2004.

(Coord.): “Dossier: Immigració a Catalunya. Els anys del franquisme”, L’Avenç núm. 294 (Gener 2005).

"Franquismo e Inmigración interior: el caso de Sabadell (1939-1960)" en Historia Social núm. 56, 2006.

Història del franquisme a Catalunya, Pagès, Eumo, Lleida i Vic, 2006.

"La gestación del Documento Nacional de Indentidad: un proyecto de control totalitario para la España franquista". Comunicació inèdita en Novísima. II Congreso Internacional de Historia de Nuestro Tiempo, Logronyo, 11-13 de setembre de 2008, Universidad de La Rioja.

(dir.): Memòries del viatge 1940-1975, Ajuntament de Sant Adrià de Besòs, 
Museu d'Història de la Immigració de Catalunya, 2009.

MARISTANY, Gerard i MUSSONS, Albert: Del desencant a la contrainformació. La premsa de barris a Barcelona, 1976-2001, Diputació de Barcelona i Col·legi de Periodistes de Catalunya, Barcelona, 2002.

MÁRQUEZ I BERROCAL, Manuel: Història Social de Sant Adrià de Besòs. Vol III. La Transformació del territori: La producció de l'espai urbà a Sant Adrià de Besós, 1910-1940, Hacer Editorial, Sant Adrà de Besòs, 1996.

MARQUEZA, José Manuel: “Desarrollo urbano y nivel de conflictividad en Santa Coloma de Gramenet (1969-1980)", Àgora núm. 8 (març 2003), p. 103-134.

MARTÍ, Ernest [Joaquim Sempere]: “Ciudad y lucha de clases”, CAU, núm. 43, maigjuny 1977, pp. 88-92.

MARTÍ, Francesc i MORENO, Eduard: Barcelona, ¿a dónde vas?, Dirosa, Barcelona, 1974.

MARTÍ, Josep: Relació entre Associacions de Veïns i partits polítics. Barcelona 19701980, Tesina inèdita, 1981.

MARTÍ, Josep i MARCÈ, Josep: Centre Social de Sants. Una experiència associativa, Centre Social de Sants, Barcelona, 1996.

MARTÍ, Pep: "Les associacions de veïns en el moviment associatiu de la Barcelona contemporània", dins ROCA i ALBERT, Joan (coord.): L'articulació social de la Barcelona contemporània, Barcelona, Biblioteca Històrica núm. 4, Institut Municipal d'Història/Institut de Cultura de Barcelona/Proa-GEC, 1997, pp. 329-336.

MARTÍNEZ, Maria Teresa i PAGÈS, Pelai (coords.): Diccionari biogràfic del moviment 
obrer als Països Catalans, Universitat de Barcelona i Publicacions de l'Abadia de Montserrat, 2000.

MARTÍNEZ BARCELÓ, Josep: "Del moviment ciutadà i de la democràcia local. Moviments socials i democràcia local. Pinzellades en tres temps", Revista catalana de sociologia, núm. 7 (1998), p. 29-72.

MARTÍNEZ HOYOS, Francisco: La JOC a Catalunya. Els senyals d'una Església del demà (1947-1975), Mediterrània, Barcelona, 2000.

MARTÍNEZ MUNTADA, Ricard: El moviment veïnal a l'àrea metropolitana de Barcelona durant el tardofranquisme i la transició. El cas de Sabadell, 19661976, Tesina de Doctorat, Universitat Pompeu Fabra, 1999.

"El moviment veïnal a Sabadell durant el tardofranquisme, 1966-1976: Todos los barrios unidos para conseguir sus derechos", Arraona, núms. 24 i $25,2001$.

"El movimiento vecinal en el tardofranquismo: acción colectiva y cultura obrera. Propuestas y problemas de interpretación". Comunicació presentada al IX Congreso de la Asociación de Historia Contemporánea, Múrcia, 2008.

“Construir futurs. La dimensió anticapitalista del moviment veïnal” a MOLINERO, Carme Molinero i YSÀS, Pere (coords.): Construint la ciutat democràtica. El moviment veïnal durant el tardofranquisme i la transició, Icària, Barcelona, 2010, p. 265-317.

“Movimiento vecinal, antifranquismo y anticapitalismo", Historia, trabajo y sociedad, núm. 2 (2011), p. 63-90.

MARTÍNEZ BARCELÓ, Josep: "Del Moviment ciutadà i de la democràcia local. Moviments socials i democràcia local", Revista Catalana de Sociologia núm. 7 
(7-1998), p. 29-72.

MARTORELl, V.; FLORENSA, A.; MARTORELL, V.: Historia del Urbanismo en Barcelona. Del Plan Cerdà al Área Metropolitana, Labor, Barcelona, 1970.

MAS, Carles: El Pomar. Badalona, Col-lecció Els Barris d'Adigsa, Vol. 27, Generalitat de Catalunya, Departament de Benestar Social, ADIGSA, 1995.

MATAS PERICÉ, Alfred: Al sud-oest del riu Besòs. Deu anys de la vida d'un barri barceloní, Pòrtic, Barcelona, 1970.

MATEOS, Abdón i HERRERÍN, Angel (eds.): La España del presente: de la dictadura a la democracia. II Congreso de la Asociación de Historiadores del Presente, Madrid, 2005. Asociación de Historiadores del Presente, Torrecaballeros, 2006.

MAYNÉ AMAT, Joan: "El Monòlit de Can Solei: símbol d'una conquesta veïnal”, Carrer dels Arbres, núm. 22, 3era època (2012), p. 163-173.

McADAM, Doug, McCARTHY, John i ZALD, Mayer N.: Movimientos sociales: perspectivas comparadas, Itsmo, Madrid, 1999.

McKEOWN, Kieran: Marxist Political Economy and Marxist Urban Sociology, MacMillan, Londres, 1987.

MIGUÉLEZ, Faustino: "Sindicalismo y conflicto social en la España de la transición", Mientras Tanto, núm. 24, setembre 1985, pp. 19-44.

MOLINERO, Carme: La captación de masas: política social y propagada en el régimen franquista, Cátedra, Madrid, 2005.

(ed.): La Transición, treinta años después. De la dictadura a la instauración de 
la democracia, Península, Barcelona, 2006.

MOLINERO, Carme i YSÀS, Pere: "Pàtria, justícia y pan": nivell de vida i condicions de treball a Catalunya, 1939-1951, La Magrana, Barcelona, 1985.

“La població catalana a la postguerra: creixement i concentració, 19391950", L'Avenç', núm. 102 (1987), pp. 38-46.

Els industrials catalans sota el franquisme, Eumo, Vic, 1991.

El règim franquista. Feixisme, modernització i consens, Eumo, Vic, 1992.

"Movimientos sociales y actitudes políticas en la crisis del franquismo", Historia Contemporánea núm. 8, 1992, p. 269-279.

"De la fi de la Guerra Civil a la Barcelona actual", III Congrés d'Història de Barcelona. Ponències i Comunicacions, Vol. II, Ajuntament de Barcelona, 1993, p. 509-514.

“Josep M. de Porcioles, un polític de la Dictadura”, suplement Avui-Diumenge, 3 d'octubre de 1993, p. 39.

Productores disciplinados y minorías subversivas. Clase obrera y conflictividad laboral en la España franquista, Siglo XXI, Madrid, 1998.

"La historia social de la época franquista. Una aproximación", Historia Social, núm. 30, 1998, p. 122-154.

"Mujer, franquismo, fascismo. La clausura forzada en un "mundo pequeño", Historia Social, núm. 30, 1998, p. 97-117.

“El malestar popular por las condiciones de vida: ¿un problema político para 
el régimen franquista?", Ayer, núm. 52 (2003), p. 255-282.

"Present i futur de la Historiografia sobre el règim franquista. Balanç sobre algunes línies d'investigació i els seus resultats" en FONT AGULLÓ, Jordi (dir.): Història i memòria: el franquisme i els seus efectes als Països Catalans, Universitat de València, València, 2007, p. 285-302.

La anatomía del franquismo. De la supervivencia a la agonía, 1945-1977, Crítica, Barcelona, 2008.

MOLINERO Carme i YSÀS, Pere (coords.): Construint la ciutat democràtica. El moviment veïnal durant el tardofranquisme i la transició, Icària, Barcelona, 2010.

MOLINERO Carme i DI FEBO, Giuliana (eds.): Nou Estat, nova política i nou ordre social: feixisme i franquisme en una perspectiva comparada, Fundació Carles Pi i Sunyer d'Estudis Autonòmics i Locals -CEFID-UAB, Barcelona, 2005

MONFERRER I CELADES, Josep María: El Camp de la bota. Un espai i una història, Octaedro, Barcelona, 2012.

La història des de Sant Adrià llegida des de la Mina, Octaedro, Barcelona, 2013.

MONSERGAS, David: “La huelga de Casadeport (1974)”, Àgora, núm. 1 (desembre 1995), p. 85-120.

"Las Comisiones de Barrio en Santa Coloma de Gramenet, 1971-1975", Àgora núm. 12 (març 1997).

MORÁN, Gregorio: Adolfo Suárez. Historia de una ambición, Planeta, Barcelona, 1979. 
Miseria y grandeza del Partido Comunista de España, 1939-1985, Planeta, Barcelona, 1986.

El precio de la transición. Una interpretación diferente y radical del proceso que condujo a España de la dictadura a la democracia, Planeta, Barcelona, 1991.

MORELL, Luis: "Movimientos sociales urbanos. Presupuestos para su análisis", Revista de Administraciones Públicas, 84 (1977).

MORENO, Eduard i VÁZQUEZ MONTALBÁN, Manuel: Barcelona, cap on vas?. Llibres de l'Índex, Barcelona, 1991.

NADAL, Jordi; CARRERAS, Albert i SUDRIÀ, Carles (comps.): La economia española en el siglo XX. Una perspectiva histórica, Ariel, Barcelona, 1994.

NADAL, Jordi; MALUQUER, Jordi; SUDRIÀ, Carles i CABANA, Francesc (dirs.): Història econòmica de la Catalunya contemporània, Enciclopèdia Catalana, Barcelona, 1989: 5. Segle XX. Població, agricultura, energia i 6. S. XX. Indústria, finances i turisme.

NASH, Mary: Dones en transició. De la resistència política a la legitimitat feminista: les dones en la Barcelona de la Transició, Ajuntament de Barcelona, Barcelona, 2007.

NAVARRO i ACEBES, Ferran: (coord. i comp.): Perifèria o marginalitat: tres anys d'urbanisme municipal a Santa Coloma de Gramenet, Servei d'Urbanisme i Habitatge, Ajuntament de Santa Coloma de Gramenet, 1987.

NUALART, Jaume: “Concepto de ciudad”, Cuadernos de Arquitectura, núm. 60 (2on Trimestre de 1965), p. 13-16. 
OBRADORS DOMÈNECH, Carme: La integración del suburbio en la comunidad urbana, Nova Terra, Barcelona, 1966.

O'DONELL, Guillermo; SCHMITTER, Philippe C.; WHITELEAD, Lawrence (comp.): Transiciones des de un gobierno autoritario, 4 vols., Paidós, Barcelona, 1994.

OFFE, Claus: Partidos políticos y nuevos movimientos sociales, Sistema, Madrid, 1992.

OLIVÉ, Maria J.: “Santa Coloma de Gramenet. Conflictes i moviments urbans", Serra d'Or, Juny 1975, p. 63-66.

"Santa Coloma de Gramenet. La lógica de un caos", Ciudad y Territorio, 3 (1977), p. 91-96.

OLIVES, Josep: El Movimiento social urbano. Barcelona 1969-1972, Tesi Doctoral inèdita, 1973.

“La conflictualidad urbana”, Papers núm. 3 (1974), pp. 275-323.

ORIOL I SABATER, Montserrat; ROTGER I ESTAPÉ, Cristina; SAGUÉS I BAIXERAS, Ramon: Quaderns d'Història de Badalona. Creixement demogràfic i urbanístic, Institut Municipal d'Educació de Badalona, Ajuntament de Badalona, 1983.

ORTIZ GUITART, Anna: "La construcció quotidiana i col-lectiva del sentit de lloc als barris de Prosperitat, el Verdum i el Raval de Barcelona", Treballs de la Societat Catalana de Geografia, núm. 60 (2005), pp. 87-108.

ORTIZ HERAS, Manuel; CASTELLANOS LÓPEZ, José Antonio i MARTÍN GARCIA, Óscar: "Historia social y política para una transición. El cambio desde abajo y la construcción de una nueva autonomia: Castilla-La Mancha", Historia 
Actual On Line, núm. 14 (Tardor 2007), pp. 115-126.

PADRÓS, Pepita; MONÉS, Jordi; SAGUÉS, Ramon; SURROCA, Josep: "Resum d'Història de Badalona", Quaderns de Cultura Popular núm. 4, Ajuntament de Badalona, 1984.

PAGÈS, Pelai (dir.): Història i memòria: La Transició democràtica als Països Catalans, Universitat de València, València, 2005.

PARRÒQUIA DE SANT ANTONI DE LLEFIÀ: Notes històriques de la Parròquia de Sant Antoni de Pàdua de Llefià (Badalona), 1996

PASTOR, Manuel: “Las postimetrías del franquismo” en COTARELO, Ramon (comp.): Transición política y consolidación democrática en España (1975-1985), Centro de Investigaciones Sociológicas, Madrid, 1992.

PEREMIQUEL PUIG, Francesc: "Montigalà", Carrer dels Arbres núm. 8, 3era època (desembre 1997), p. 67-82.

"L'habitatge popular: Els polígons d'iniciativa pública", Carrer dels Arbres, núm. 10, 3era època (desembre 1999), p. 83-94.

PÉREZ DÍAZ, Víctor: La primacía de la sociedad civil. El proceso de formación de la España democrática, Biblioteca Nueva, Madrid, 2001.

PÉREZ LEDESMA, Manuel: "Viejos y nuevos movimientos sociales en la Transición” en Carme Molinero (ed.): La Transición, treinta años después. De la dictadura a la instauración y consolidación de la democracia, Península, Barcelona, 2006, p. 117-151.

PIZZARONO, Alessandro: “Identidad e interés”, Zona Abierta núm. 69 (1994), p. 135-152. 
PLANAS ALSINA, Emma, FERNANDEZ, Pedro Jesús: Història d'un barri. Història d'una associació. Sant Mori de Llefià (1974-1987). [1988? inèdit].

PORCEL, Pilar: Vint anys d'assistents socials al Vallès Occidental, Editora Pedagògica del Vallès, Terrassa, 1980.

PORCIOLES, José M.: Mis Memorias, Prensa Ibérica, Barcelona, 1994.

POWELL, Charles T.: El piloto del cambio. El rey, la monarquía y la transición a la democracia, Planeta, Barcelona, 1991.

PRAT, Enric (coord.): Els moviments socials a la Catalunya contemporània, Publicacions i Edicions de la Universitat de Barcelona, 2004.

PREGO, Victoria: Así se hizo la transición, Plaza\&Janés, Barcelona, 1996.

PRESTON, Paul: El triunfo de la democracia en España: 1969-1982, Plaza\&Janés, Barcelona, 1982.

PUIG SIÓ, Pere: “Consideracions urbanístiques sobre la problemàtica industrial de Badalona", Carrer dels Arbres, núm. 8, 1era època (febrer 1980), p. 17-24.

PUIG VALLS, Angelina: Naixement i creixement dels barris perifèrics a les ciutats industrials de Catalunya. Història viva de Torre-Romeu, Sabadell, Memòria de doctorat, UAB, 1989.

De Pedro Martínez a Sabadell: l'emigració, una realitat no exclusivament econòmica, 1920-1975, Tesi Doctoral, UAB, 1991.

PUJOL, Jordi: “Integración y urbanismo”, Cuadernos de Arquitectura, núm. 60 (2on Trimestre de 1965), p. 9-12. 
La immigració, problema i esperança de Catalunya, Editorial Nova Terra, Barcelona, 1976.

QUIROSA-CHEYROUZE, Rafael: La sociedad española en la Transición. Los movimientos sociales en el proceso democratizador, Biblioteca Nueva, Madrid, 2011.

RADCLIFF, Pamela: "La construcción de la ciudadanía democrática: las Asociaciones de Vecinos en Madrid en el último franquismo" en Actes del Congrés La transició de la dictadura franquista a la democràcia. Barcelona, 20, 21 i 22 d'octubre de 2005, UAB-CEFID, Barcelona, 2005.

Making democratic citizens in Spain: civil society and the popular origins of the trPansition, 1960-78, Basingstoke, Hampshire [England] ; New York : Palgrave Macmillan, 2011.

REBOLLO, Julián; RODRÍGUEZ, Emilio; SOTOS, Carlos: El Movimiento Ciudadano ante la democracia, Cenit, Madrid, 1977.

RECAÑO VALVERDE, Joaquin: "La Immigració al Baix LLobregat: l'onada migratòria dels anys seixanta", a Papers de demografia núm. 177, Centre d'Estudis Demogràfics, Universitat Autònoma de Barcelona, 2001.

RECIO, Albert i NAYA, Andrés: "Movimiento vecinal: Claroscuros de una lucha necesaria", Mientras Tanto, núm. 91-92 (2004), p. 63-82.

REDERO SAN ROMÁN, Manuel (ed.): La transición a la democracia en España, Marcial Pons, Madrid, 1994.

"Apuntes para una interpretación de la transición política en España", Ayer núm. 36 (1999), p. 261-282. 
REDERO SAN ROMÁN, Manuel; YSÀS, Pere, (et al.): La Transició a Catalunya i Espanya, Fundació Doctor Lluís Vila d'Abadal, Barcelona , 1997.

REDERO SAN ROMÁN, Manuel i DE LA CALLE VELASCO, Ma a Dolores (eds.): Movimientos sociales en la España del siglo XX, Ediciones Universidad de Salamanca, Salamanca, 2008.

RICHMOND, Kathleen: Las mujeres en el fascismo español. La Sección Femenina de la Falange, 1934-1959, Alianza ensayo, Madrid, 2004

RICO MÁRQUEZ, Juan: Llefià. De la barraca a la dignidad, Autoeditat, Badalona, 2010.

RIQUER, Borja de (dir.): Història, política, societat i cultura dels Països Catalans, Enciclopèdia Catalana, Barcelona, 1995-1999: Vol. 10. RIQUER, Borja de (dir.): La llarga postguerra, 1939-1960 i Vol. 11. MOLINERO, Carme i YSÀS, Pere (dirs.): De la dictadura a la democràcia, 1960-1980.

ROCA, Jose Manuel (Ed.) i ARIEL DEL VAL, Fernando (et alii): El proyecto radical. Auge i declive de la izquierda revolucionaria en España (1964-1992), Los Libros de la Catarata, Madrid, 1994.

RÓDENAS, Carmen: Emigración y economía en España (1960-1990), Civitas S.A./ Universidad de Alicante, Madrid, 1994.

RODRÍGUEZ OCAÑA, Fernando: Candidato de los trabajadores, Avance, Barcelona, 1976.

RODRÍGUEZ TEJADA, Sergio: "Nueva izquierda, extrema izquierda: bases intelectuales y pràcticas militantes de las organizaciones revolucionarias al inicio de la transición española" a QUIROSA-CHEYROUZE, Rafael; NAVARRO, 
Luis Carlos i FERNÁNDEZ, Mónica (coords): Las organizaciones políticas. Congreso Internacional Historia de la Transición en España. Almería: Universidad de Almería, Servicio de Publicaciones, 2011, p. 631-648.

ROMAGUERA, Ramón: El área metropolitana de Barcelona: génesis y problemática, Editorial Moneda y Crédito, Madrid, 1972.

ROS VILA, J. M.: "El problema de la vivienda”, Cuadernos de Arquitectura, núms. 1516 (1953). p. 1.

ROTGER ESTAPÉ, Joan Josep: "La festa del Badiu en els anys de la transició", Carrer dels Arbres, núm. 22, 3era època (2012), p. 127-138.

ROVIRA SÁNCHEZ, Jordi: La Guinardera. A.V. La Guinardera, Ajuntament de Santa Coloma, amb la col-laboració de la Direcció General d'Acció Cívica del Departament de Benestar i Família de la Generalitat de Catalunya, 2002.

RUIZ, David (dir.): Historia de Comisiones Obreras (1958-1988), Siglo XXI, Madrid, 1993.

RUIZ CARNICER Miguel Ángel (ed.): Falange. Las culturas políticas del fascismo en la España de Franco (1936-1975), Intitución Fernando el Católico, Zaragoza, 2013.

SABATÉ PUIG, Mạ Dolors: "L'etapa de l'Associació de Veïns del Centre. Primers punts d'aproximació", Carrer dels Arbres núm. 22, 3era Època (2012), p. 145162.

SAGARRA, Ferran (ed.): De les cases barates als grans polígons. El Patronat Municipal de l'Habitatge entre 1929 i 1979, Ajuntament de Barcelona i Patronat, 2003. 
SALA PARRA, Jordi: “Badalona al llindar de la Democràcia, 1975", Carrer dels Arbres, núm. 7, 3era Època (desembre 1996), p. 13-22.

SAMUEL, Raphael (ed.): Historia Popular y teoría socialista, Crítica, Barcelona, 1984.

SÁNCHEZ RECIO, Glicerio i TASCÓN HERNÁNDEZ, Julio (eds.): Los empresarios de Franco: política y economía en España, 1936-1957, Crítica, Barcelona, 2003.

SÁNCHEZ SOLER, Mariano: La Transición sangrienta. Una historia violenta del proceso democrático en España (1975-1983), Ediciones Península, Barcelona, 2010.

SANZ MOLAS, Joel: "Entre las instituciones y la movilización: la crisis de la izquierda radical durante la Transición” a QUIROSA-CHEYROUZE, Rafael, NAVARRO, Luis Carlos i FERNÁNDEZ, Mónica (coords): Las organizaciones políticas. Congreso Internacional Historia de la Transición en España. Universidad de Almería, Almería, Servicio de Publicaciones, 2011, p. 649666.

“L'esquerra revolucionària i el seu paper en la mobilització social i el canvi polític dels anys 70: estat de la qüestió i alguns apunts per al seu estudi", Comunicació presentada a IV Encuentro de Jóvenes Investigadores en Historia Contemporánea, Universitat de València, 10-13 de setembre de 2013.

SARO, Fernando: Les Oliveres. Sabor a barrio 1970-1980, Edicions Fórum Grama, 2012.

SARTORIUS, Nicolás i SABIO, Alberto: El final de la dictadura. La conquista de la democracia en España noviembre de 1975 - junio de 1977, Temas de Hoy, Madrid, 2007. 
SASTRE, Cayo: Transición y desmovilización política en España (1975-1978), Universidad de Valladolid, 1997.

SAYRACH, Jaume P.: "L'Església de Santa Coloma de Gramenet durant el franquisme (1965-1975)", Àgora núm. 12 (març 1997), p. 119-126.

El en Fondo. Parròquia de Sant Joan Baptista (Santa Coloma de Gramenet 1965-1979), Edicions Fòrum-Grama, Santa Coloma de Gramenet, 2001.

L'esperança d'una Església pobra i evangèlica. Santa Coloma de Gramenet 1965-1980, Edicions Fòrum-Grama, Santa Coloma de Gramenet, 2007.

SAZ, Ismael: "Y la sociedad marcó el camino. O sobre el triunfo de la democracia en España (1969-1978)” a QUIROSA-CHEYROUZE, Rafael: La sociedad española en la Transición. Los movimientos sociales en el proceso democratizador, Biblioteca Nueva, Madrid, 2011, p. 29-42.

SECO SERRANO, Carlos: "La Corona en la transición española”, en Javier Tusell i Álvaro Soto (eds.): História de la Transición, 1975-1986, Alianza Editorial, Madrid, 1996, p. 138-158.

SELLÉS I VIDAL, Eleonor: Moviment obrer, canvi polític social i cultural. Comissions Obreres a Catalunya 1964-1978, Tesi Doctoral, Universitat de Barcelona, 2005.

SERRA, Eva: "Memòria històrica", suplement Avui-Diumenge, 7 de novembre de 1993, p. 40.

SERRANO VILLARROYA, Francesc: "Estudi socio-econòmic de Badalona de Josep Angueras i Torrents, Joan B. Casas", Carrer dels Arbres núm. 5, 2ona Època [1988], p. 55-56. 
SHARE, Donald: The Making of Spanish Democracy, Praeger, Nova York, 1986.

SEVILLANO I BUSTINS, Magda: Estudi de l'Evolució Demogràfica de Badalona. 19601980, Ajuntament de Badalona, 1984.

SILLERO PAREJO, Joan: La Salut “El barri”, Ajuntament de Badalona, 1999.

SOBREQUÈS, Jaume (dir.): Història de Barcelona, vol 8, El segle XX. II Del creixement desordenat a la ciutat olímpica, Enciclopèdia Catalana, Barcelona, 1991.

SODY DE RIVAS, Ángel: "Evolución de la prensa en Santa Coloma II (1939-1979)", Àgora núm. 4 (març 1999), p. 45-100.

SOLÉ, Carlota: La integración sociocultural de los inmigrantes en Cataluña, Centro de Investigaciones Sociológicas, Madrid, 1981.

Los inmigrantes en la sociedad y en la cultura catalanas, Península, Barcelona, 1982.

SOLÉ I AMIGÓ, Joan: “Catalunya: immigració i reconstrucció nacional”, Carrer dels Arbres, núm. 7, 1era Època (gener 1980), p. 13-16.

“Salut i treball”, Carrer dels Arbres, núm. 7, 1era Època (gener 1980), p. 1316.

SOTO, Álvaro: ¿Atado y bien atado? Institucionalización y crisis del franquismo, Biblioteca Nueva, Madrid, 2005.

STOVALL, Tyler: "'Friends, Neighbours, and Communists': Community Formation i Suburban Paris during the Early Twenteith Century", Journal of Social History, vol. 22, hivern 1988, p. 237-254. 
SUAREZ SÁNCHEZ, Emilio: Can Clos. Historia de un barrio obrero, CIMS, Barcelona, 1997.

STRUBELL I TRUETA, Miquel: Llengua i població a Catalunya, Edicions La Magrana, 1981.

SUNYOL I SAMPERE, Jaume: Dalt de la Vila, Badalona, Museu de Badalona.

TATJER, Mercè: La Barceloneta: del siglo XVIII al Plan de la Ribera, Barcelona, Saturno, 1973.

TARRAGÓ, Marçal: Política urbana y luchas sociales, Avance, Barcelona, 1976.

TARRAGÓ, Salvador: En defensa de Barcelona, Aedos, Barcelona, 1974.

TARROW, Sidney G.: El poder en movimiento. Los movimientos sociales, la acción colectiva y la política, Alianza, Madrid, 2004.

TÉBAR HURTADO, Javier (ed.): El movimiento obrero en la gran ciudad. De la movilización sociopolítica a la crisis económica, El Viejo Topo, Barcelona, 2011.

TÉBAR HURTADO, Javier: “Immigració i treball a Catalunya, 1939-1975" dins MARTÍ, Marín (dir.): Memòries del viatge..., p. 87-115.

TEZANOS, José Félix, COTARELO, Ramón i BLAS, Andrés de (eds.): La transición democrática española, Sistema, Madrid, 1989.

THOMAS, Joan Maria: Falange, Guerra Civil, Franquismo. F.E.T. i de las J.O.N.S. de Barcelona en els primers anys del règim franquista, Publicacions de l'Abadia de Montserrat, 1992. 
THOMPSON, Edward P.: Tradición, revuelta y conciencia de clase, Crítica, Barcelona, 1984.

La formación de la clase obrera en Inglaterra, Crítica, Barcelona, 1989.

TRIAS, Carlos: La política de la vivienda del Ayuntamiento de Barcelona, Instituto Municipal de la Vivienda, Barcelona, 1947.

TREVES, Anna: Les migrazione interne dell'Italia fascista: politica e realtà demografica. Torí, Einaudi, 1976.

TUDELA, Joan: Sant Roc. Badalona, Col-lecció Els Barris d'Adigsa, Vol. 37, Generalitat de Catalunya, Departament de Benestar Social, ADIGSA, 1995.

TUÑÓN DE LARA, Manuel (dir.): Historia de España, vol. X-2: Transición y democracia (1973-1985), Labor, Barcelona, 1992.

TUSELL, Javier: La transición española a la democràcia, Història 16, Madrid, 1991.

Carrero Blanco. La eminencia gris del régimen de Franco, Temas de Hoy, Madrid, 1994.

"La transición a la democracia en España como fenómeno de Historia política”, Ayer, núm. 15 (1994), p. 55-76.

La Transición a la democracia (España 1975-1982), Espasa Calpe, Madrid, 2007.

TUSELL, Javier; ALED, Alicia i MATEOS, Abdon (coords.): La oposición al régimen de Franco, vol. II, UNED, Madrid, 1990. 
TUSELL, Javier i SOTO, Álvaro (eds.): Historia de la Transición, 1975-1986, Alianza, Madrid, 1996.

URRUTIA, Víctor: El movimiento vecinal en el área metropolitana de Bilbao, Instituto Vasco de Administración Pública, Oñati, 1985.

UTRERA, Joaquima: 30 anys d'ajuntaments democràtics. Crònica d'una transformació. Santa Coloma de Gramenet 1979-2009, Edicions FòrumGrama, 2010.

Lluís Hernàndez. El capellà rebel, Fundació Nous Horitzons, Barcelona, 2011.

VALLS, Maria Carme: L’oposició a Sabadell a partir de la revista "Can Oriach" (19661977), Tesi de Llicenciatura, UAB, 1983.

VARO MORAL, Nàdia: "Mujeres en Huelga, Barcelona metropolitana durante el franquismo" dins BABIANO, José (ed.) i PÉREZ, José Antonio (et. al.): Del hogar a la huelga: trabajo, género y movimiento obrero durante el franquismo, Los Llibros de la Catarata, Madrid, 2007.

VERDUGO MARTÍ, Vicenta: "Organizaciones de mujeres en Valencia durante la transición. Prácticas y formas de acción" en ORTIZ, José María; UGARTE, Javier i RIVERA, Antonio (coords.), Movimientos sociales en la España contemporánea, Abada, Madrid, 2008.

VILA, Marc Aureli: Les migracions i Catalunya, El Llamp, Barcelona, 1984.

VILLARROYA I FONT, Joan: Revolució i Guerra Civil a Badalona, Ajuntament de Badalona, 1986

Història de Badalona, Museu de Badalona, Badalona, 1999. 
VILLASANTE, Tomás R.: Los vecinos en la calle: por una alternativa democrática a la ciudad de los monopolios, Ediciones de la Torre, Madrid, 1976.

Comunidades locales. Análisis, movimientos sociales y alternativas, IEAL, Madrid, 1984.

VILASECA I SEGALÉS, Joan: Historia General de Santa Coloma de Gramenet, Ediciones Metropol, Barcelona, 1985.

VINADER, Xavier i BENAUL, Josep. M.: Sabadell, febrero de 1976: una semana de huelga general política, inèdit, Sabadell, 1976.

VINYES, Ricard: "Un exemple de cultura democràtica i societat urbana a Barcelona (1953-1977)", Revista de Catalunya, núm. 21, juliol-agost 1988, p. 50-60.

YNFANTE, Jesús: Los negocios de Porcioles. Las sagradas familias de Barcelona, Monipodio, Toulouse, 1974.

YSÀS, Pere: Disidencia y subversión. La lucha del régimen franquista por su supervivencia, 1960-1975, Crítica, Barcelona, 2004.

"El régimen franquista frente a la oposición", Documentos de Trabajo. Cuadernos de la España Contemporánea, núm. 3, 2007.

"Conflictivitat social, oposició política i crisi de la dictadura" a FONT AGULLÓ, Jordi (dir.): Història i memòria: el franquisme i els seus efectes als Països Catalans, Publicacions de la Univesitat de València, València, 2007.

"El PSUC durant el franquisme tardà i la transició: de l'hegemonia a la crisi (1970-1981) a PALA, Giaime (ed.): El PSU de Catalunya, 70 anys de lluita pel socialisme. Materials per a la història, Ediciones de Intervención Cultural i Associació Catalana d'Investigacions Marxistes, [Barcelona], 2008. 


\section{Annexos.}

\section{Premsa i revistes consultades}

\section{Generalista}

-Avui

-La Vanguardia

-Tele/ eXprés

-Solidaridad Nacional

-Mundo Diario

-El Correo Catalán

-Diario de Barcelona

-El Noticiero Universal

-El País

-El Periódico de Catalunya

-Hoja del Lunes

-Garbo

-Interviu

-Serra d'Or

\section{Especialitzada}

-Treball

-Cuadernos de Arquitectura

-CAU

-Sal Terrae

-Butifarra

-SECOD Full Informatiu

-Oriflama 


\section{Local}

-Revista Albada

-Comarca Exprés

-Revista de Badalona

-Eco Badalonés

-La Voz de Badalona

-Entre totes. Grup de dones de Badalona

-Gent jove d'ahir. Butlletí de l'Associació de Jubilats i Pensionistes de Badalona

-Pienso. Revista de agria cultura [Badalona]

-El Besós Ia Època i IIa Època.

-Unió i Lluita. Portavoz de la Unió Comarcal de CCOO del Barcelonès Nord

-Santa Coloma Obrera. Portavoz de las CCOO de Santa Coloma de Gramenet

-L'Antena Grama

-Grama I Època i II Època

-Fòrum-Grama

-Gramanet

-Iglesia de Santa Coloma/ Església de Santa Coloma

-Aspanide. Asociación de Padres de niños deficientes

-Junio Negro [Institut Puig Castellar]

-Macondo

-Nocturnidades

-Endavant. Boletín informativo de la Tercera Edad

-Xino-xano

-Mujer en Santa Coloma

-Dona (1983) [Casal de la Dona, Associació Catalana de la Dona, Grup de Dones de Singerlín, Vocalia de Dones de Can Mariner]

-Eina. Casal de Cultura de Santa Coloma de Gramenet

-L'Heura [Butlletí del Centre de Normalització Lingüística de Santa Coloma de Gramenet]

-Cercle

-Besós. Asociación de ex-alumnos del colegio Sagrado Corazón 
-Sant Adrià Mediterrània

-El Carrer dels Arbres

-Àgora

\section{Veïnal}

-Ciutadà. Publicació de la Federació d'Associacions de Veïns de Badalona

-El Badiu. Butlletí de l'Associació de Veïns del Centre de Badalona

-Boletín de Noticias del Barrio, [Llefià]

-La Torre del Huevo

-La Voz de Llefià. Boletín interno de l'AV de Sant Mori

-La Voz de Llefià. Boletín de la Coordinadora de Asociaciones de Vecinos de Llefià

-La Veu de Llefià

-Boletín Informativo Penya Bufalà

-A.A.V.V. Joaquim Ruyra. Boletín Informativo

-Pomar Convivència

-AAVV Pomar Informativa

-La Voz de Pomar

-Canyet. Butlletí Informatiu de l'AA. VV. de Canyet

-Associació de Veïns de Can Cabanyes [Barri Sant Crist]

-Nuestro Barri. Revista del barrio de Sant Crist

-Associació de Veïns Dalt de la Vila. Full Informatiu

-El Rollo Despertador. Boletín de la Asociación de Vecinos del Congreso

-Ojo. Asociación de Vecinos Juan Valera. Boletín Informativo

-La Voz del Arrabal. Boletín informativo de la Asociación de Vecinos del Arrabal

-Asociación de Vecinos "Arrabal" Sector Lavaderos

-La Gaceta del Río. Asociación de Vecinos del "Barrio del Rio"

-El Pino Seco. Boletín Informativo de la A. de V. del Centro Santa Coloma

-Fondo. As. De Vecinos "Barrio del Fondo"

-La Oliva Indigesta. Asociación de Vecinos 'Las Oliveras'

-Rio Norte

-Pimienta. Boletín de la Asociación de Vecinos de Santa Rosa 
-Informativo Santa Rosa

-Las Viñas. Boletín Informativo Interno AA. VV. Singuerlín

-Barrio Obrero. Comisiones de Barrio

-Mariné [publicació del CS Mariner]

-El Alba. Centro Santa Rosa

-La Carcoma [Obra Social Singuerlín]

-Boletín Arrabal. Centro Social Arrabal de Santa Rosa

-Flumen. Boletín del Centro del Río

-La mujer en nuestro barrio. Asociación de Amas de Casa de Singuerlín

-Coordinadora Informa. Hoja informativa de la Coordinadora de AA. VV.

-Asociación de Vecinos La Mina. Hoja Informativa

-Asociación de Vecinos La Mina Informa

\section{Política (local)}

-Adelante, Órgano del Comité de Badalona del PSUC

-Badalona. Boletín de Información Municipal/ Badalona Full Informatiu Municipal/ Badalona Full d'Informació Municpal

-La Colmena Obrera, Órgano de la Federación Local de Sindicatos de Indústria de Santa Coloma

-La Veu Comunista. Órgano del Comitè Local de Badalona [PCC]

-Amb la Ciutat. Agrupació Centre [PSUC Badalona]

-Avant. Mensual de política, cultura i societat [PSUC Badalona]

-Esquerra Unida de Badalona

-Grup Municipal Comunista. Butlletí d'informació dels Consellers del PSUC a l'Ajuntament de Badalona

-Butlletí d'informació d'Inciativa per Catalunya a Badalona

-La Rambla. Informació de Convergència Democràtica de Catalunya [Badalona]

-L'Ajuntament Informa [Santa Coloma de Gramenet]

-Gramanet Socialista

-Tribuna Socialista 
-Camino Abierto. Boletín informativo del Ateneo Libertario [Santa Coloma de Gramenet]

-Barricada Comunista. Órgano del Comitè Provincial de Barcelona del Frente de Barrios de la Organización de Izquierda Comunista de España

-Boletín de información política municipal. OIC-MCC

-PSUC Informa. Santa Coloma de Gramenet

\section{Arxius consultats}

-Archivo Histórico del Gobierno Civil de Barcelona: Fons "Gobernadores Civiles", "Ayuntamiento de Badalona 1974-1975" i “1976-1978” (documentació facilitada per Ivan Bordetas i Anna Sánchez). "Administración local. Relevos de alcaldes 1962-1975", “Administración local. Elecciones municipales, 1967-1976"; "Administración local. Ayuntamientos desde 1939"; “Gobernadores. Gobernadores civiles, 1951-1979"; Gobernadores, "Subgobernadores civiles, 1975"; "Secretaría Política. Relevos de alcaldes, 1951-1963" (documentació facilitada per Martí Marín).

-Arxiu de la Corona d'Aragó: Fons del Govern Civil de Barcelona: "Comisiones Gestoras 1939-1948”, “Elecciones Municipales 1948-1967” i “Constitución de Ayuntamientos, 1939-1965" (documentació facilitada per Martí Marín).

-Archivo General de la Administración (Alcalá de Henares). Fons: Presidencia, Delegación Nacional de Asociaciones del Movimiento, Ministerio de la Gobernación, Ministerio del Interior, Cultura. Gabinete de Enlace del Ministerio de Información y Turismo,

-Archivo històrico del PCE (documentació facilitada per Iván Bordetas). Fons Nacionalidades y Regiones, Cataluña (PSUC).

-Archivo digital del PTE- JGRE: 
http://www.ptejgre.com/archivo/archivodocumentos.html

-Arxiu Històric Fundació Cipriano García (CCOO). Fons Biografies Obreres.

-Arxiu de la Fundació Rafael Campalans (PSC-PSOE). Fons Organitzacions: CES (Centre d'Estudis Socialistes), Federació Socialista de Catalunya. Fons Personals: Xavier Soto, Josep Maria Triginer - Federació Socialista Catalana, Jordi Font, Daniel Font.

-Arxiu Històric Ciutat de Badalona: Recull de Premsa, Col-leccions Factícies, Fons Associacions-Cine Club Studio, Fons Personals i Professionals. (Museu de Badalona)

-Arxiu Josep Maria Cuyàs i Tolosa (Museu de Badalona)

-Arxiu Nacional de Catalunya: Fons PSUC

-Arxiu Històric de Llefià: http://llefia.org/arxiu/ Fons Entitats: AVV Sant Antoni de Llefià i AVV Sant Mori de Llefià; Fons Dades del Barri i Hemeroteca; Fons Publicacions.

-Arxiu Històric Museu Torre Balldovina. Donacions Marcelo López Ródenas, Mn. Josep Catà, Jaume P. Sayrach i PSUC.

-Arxiu Municipal Administratiu de Santa Coloma de Gramenet. Recull de premsa i fons diversos.

-Arxiu Municipal de Sant Adrià de Besòs. Recull de Prema i Fons Ajuntament 101 (diversos)

-Arxiu Històric i Centre de Documentació de La Mina i del Camp de la Bota (Sant Adrià): http://www.desdelamina.net/arxiuhistoric/ Recull de premsa i Fons AVV 
La Mina.

-Centre Documental de la Comunicació (CEDOC-UAB). Fons de Documentació Política Contemporània.

-CEHI-Pavelló de la República. Fons DDP, Subsèries PSUC, MCC, OICE, BR-OCE, LCR. Fons Publicacions Periódiques. Organitzacions Sindicals i Obreres

CEFID, Fons Moviment Veïnal

-Gramenet TV: http://www.gramenet.tv/

\section{Fonts Orals (entrevistes)}

\section{Badalona}

Antonio Agudo Tuñón

Alfredo Amestoy Saenz

Manuel Armentero Molina

Maria Reyes Bellido Jaime

Joan Blanch i Rodríguez

Joan Carrera i Planes

Joan Cuadrench Aragonès

Carmen Díaz Bermejo

Màrius Díaz Bielsa

Francisco José Domínguez García

Antonio Flores Fernàndez de Córdoba

Pedro Jesús Fernàndez

Antonio Jurado

Diego Guerrero Castaño

Juan Jesús Guerrero Robles

Francisco Lillo Titadonis 
Ángel Navarro Rubio

José Maria Navarro

Félix Rizo Bove

Francisco Rodríguez Marco

Maite Torelló Galdón

Fina Valverde

\section{Santa Coloma de Gramenet}

Salvador Bolacer Dugo

Eloy Jurado Cubero

Marcelo López Ródenas

Josep Pitarque Narejos

Emiliana Salinas Navarro

Maria Gabriela Serra Freidiani

Fernando Saro Madrilejos

Jaume P. Sayrach Fatjó dels Xiprers

Lluís Hernàndez Alcàsser

Manel Galgo Iserte

Elvira Ruiz García

\section{Sant Adrià de Besòs}

Marisol Abril Gracia

Juan José Castro Castillo

Maria Codina Cabré

Agustí Gallart Teixidó

Jaume Vallès Muntades

Josep Maria Montferrer i Celades

José Francisco Marín Rodríguez

Ma Àngels Rosell Simplicio

Rafael Caballero Úbeda 


\section{Cronologia Badalona.}

1954: $\quad$ Primers intents d'autoorganització dels veïns de Lloreda davant el perill d'enderrocament del seu barri. Junta de Veïns a Sant Joan de Llefià Alt. Santiago March Blanch (1954-1961) substitueix en l'Alcaldia a Lluís Maristany Polanco.

$\underline{1955-1960}$

1957:

Primer intent -sense èxit- de legalitzar l'AVV de Lloreda.

Comissió de veïns a Sant Antoni de Llefià.

1959: $\quad$ Legalització de l'AVV de Lloreda.

Es forma l'AVV de Sant Antoni de Llefià (no es legalitza fins 1968).

1960: $\quad$ Legalització de l'AVV de Puigfred.

Associació de Propietaris a Sant Joan de Llefià Alt.

$\underline{1961-1965}$

1961:

Legalització de l'AVV de Sistrells.

Joan Carrera Planas arriba a la parròquia de Sant Antoni de Pàdua de Llefià (fins 1968).

"Caiguda del duro". Detenció de nombrosos militants del PSUC al Barcelonès Nord.

1961-1964: José Torras Trias (1961-1964) substitueix a l'Alcaldia a Santiago March Blanch després d'unes irregularitats en les eleccions al Tercio Sindical i Corporatiu.

1963: Legalització de les AVV's de Sant Joan de Llefià Alt, Bachs-Bufalà i Bonavista.

1963-1964: $\quad$ Eleccions al Tercio Familiar i inclusió dels líders veïnals a les candidatures: Ramon Arjona (AVV Sant Joan de Llefià Alt), Fulgencio Conesa (AVV Sant Antoni de Llefià), Antonio Forteza (AVV Bachs-Bufalà) i José Casanellas (AVV Sistrells).

1964: $\quad$ Felipe Antoja Vigo (1964-1974) substitueix a José Torras Trias després que aquest s'enfrontés a Porcioles pel trasllat de barraquistes barcelonins a Badalona.

1965: $\quad$ Legalització de l'AVV de Sant Crist.

2-1965: $\quad$ Canvi de Junta a l'AVV de Sistrells.

$\underline{1966-1970}$

1966:

Creació de les CCOO de Badalona i la seva comarca. Participació a les eleccions sindicals.

10-8-1966: Concentració d'obrers davant l'OSE i entrega d'un escrit de protesta per l'acomiadament d'un obrer de METALGRAF. Al dia següent tornen a repetir la concentració un grup de personalitats badalonines que donen suport als obrers (per desconcert de les autoritats).

8-1966: $\quad$ Presència de Marcelino Camacho en una assemblea de CCOO a la parròquia de Sant Antoni de Llefià. 
9-1966: $\quad$ Manifestació de dones contra el "polsim negre" provocat per la FECSA. Es posa en marxa una Comissió Ciutadana amb CCOO (participades pel PSUC i la FSF), l'Orfeó Badaloní, el Círcol Catòlic, Badalona Sardanista i els grups teatrals del Centre Sant Josep. Posteriorment s'afegiran el Cine Club Studio, les Joventuts Musicals i la Jove Cambra.

9-2-1967: $\quad$ Constitució de la Asociación de Cabezas de Familia de Badalona.

3-1967: $\quad$ Elaboració del Pla Parcial de Montigalà. Es projecta una ciutat-satèlit de 60.000 habitants.

4-1967: $\quad$ Nou canvi de Junta a l'AVV de Sistrells.

1-5-1967: Trobada multitudinària de CCOO a Ca l'Artiller. La policia intenta sense èxit detenir al militant del PSUC Adonio González. Detenció del mateix uns dies després juntament amb Abilio Campos.

6-1967: Concentració de dones de Bufalà davant l'Ajuntament demanant aigua potable pel barri.

7/8-1967: $\quad$ Creació de las COJ.

27-10-1967: Detenció d'una persona en una manifestació davant el sindicat vertical.

1968: $\quad$ Legalització de les AVV de Sant Antoni de Llefià i Artigas.

Creació de la Federació Badalona-Santa Coloma de l'HOAC.

20-1-1968: Legalització de la ACF de Pomar.

3-1968: $\quad$ Creació del Centre Social de Pomar.

5-1968: $\quad$ El Centre Social de Pomar denúncia la lamentable situació del barri.

11-7-1968: $\quad$ Aprovació de l'ACF de "Alta Badalona".

21-9-1968: $\quad$ Aprovació de l'ACF de Sant Roc.

1969: $\quad$ Legalització de les AVV de Congrés Eucarístic i Juan Valera.

Inauguració del Centre Social de Pomar.

Document d'un militant del PSUC on s'afirma que hi ha Comissions Obreres de Barri a Llefià i amb possibilitats de fer-se a Sant Roc i Bufalà (també al barri de Singuerlín de Santa Coloma).

Primer avantprojecte del port esportiu de Badalona.

5-1969: $\quad$ Els veïns del barri de Pomar (OSH) reben la notificació de que se'ls puja la quota.

9-6-1969: Repartiment de les COJ de fulls volants per Pomar amb la consigna de no pagar.

30-6-1969: Carta de resposta del CS Pomar i nombrosos veïns: "no podem pagar".

8-1969: $\quad$ Un 80\% dels veïns de Pomar no paguen a l'OSH.

9-1969: Intent de concentració de dones davant el Centre Social de Pomar.

10-1969: $\quad$ Creació del Centre Social de Sant Roc.

1970: Assemblea de socis de l'AVV de Sistrells. Expulsió del president José Sánchez de 
Castro i del seu delfí, Juan Teruel Tobías (franquistes).

1/2-1970: $\quad$ Polèmica entre el Col-legi d'Arquitectes de Barcelona i l'Ajuntament de Badalona per la denúncia dels primers de diverses irregularitats als Plans Parcials de Llefià i Caritg.

30-4-1970: Una fulla volant del PSUC critica l'Ajuntament arran un incendi d'una fàbrica amb productes inflamables que coexistia al mateix edifici amb una escola.

9-1970: $\quad$ Després d'un simulacre de detenció de Miguel López Parra, l'AVV de Sistrells amb la presència de Cecília March Blanch ratifica l'expulsió dels dos antics dirigents franquistes.

17-11-1970: $\quad$ Eleccions municipals al Tercio Familiar. Entre els escollits hi ha una candidatura “d'oposició moderada”: Cecília March Blanch. Participació del 34\%.

\section{1-1975}

Mobilitzacions a FECSA i ESESA pel seu conveni.

22-10-1971: La "Sección de señoras" del Centre Social de Pomar s'adreça a l'empresa TUSA reclamant millores en el servei d'autobusos, la prolongació d'una línia i la instal·lació de marquesines. Faran aquesta petició també a l'Ajuntament. El Centre Social Sant Roc reivindica en un escrit el restabliment de l'enllumenat del barri.

11-1971: $\quad$ Creació de la Comissió Democràtica de Badalona.

18-11-1971: $\quad$ Protesta de les dones de La Salut alta contra l'abús en les tarifes elèctriques.

10-12-1971: $\quad$ Aprovació de l'ACF Sant Jaume.

1972: $\quad$ Creació de l'AVV de Pomar i de l'AVV de La Salut Alta.

Un nen mor atropellat a Sant Roc.

4-7-1972: $\quad$ Es crema un autobús a Pomar en protesta per la pujada de tarifes.

7-8-1972: $\quad$ Assemblea a la parròquia de Sant Sebastià de Pomar amb la presència del Procurador en Cortes Eduardo Tarragona. Es decideix reprendre la vaga de lloguers.

7-11-1972: Un nen greument ferit en un atropellament a Sant Roc. El dia següent una manifestació d'un miler de veïns tallen el trànsit a l'Avinguda Marquès de Montroig.

26-11-1972: Assemblea veïnal a Pomar amb presència de representants d'altres barris de l'OSH. Es continua no pagant.

1973: Eleccions municipals al Tercio Familiar. Es triat un altre candidat d'oposició moderada: Ernesto Rojo Rombouts.

Arriba el capellà Braulio Arraiza a la parròquia de Bufalà i li dona un nou aire més progressista i reivindicatiu.

S'aprova en un Consell de Ministres el projecte de port esportiu de Badalona.

7-2-1973: $\quad$ Manifestació dels veïns de Pomar cap a l'Ajuntament per reclamar el tancament de l'abocador d'escombraries.

3-1973: $\quad$ El Centre Social de Sant Roc fa arribar un informe a la direcció provincial de l'OSH sobre el lamentable estat del barri amb l'aval de dos arquitectes. 
4-1973: $\quad$ Funeral de Manuel Fernàndez Màrquez a Pomar. Violenta repressió per part de la Guàrdia Civil.

5-1973: $\quad$ Aturada temporal de l'abocador de Pomar (malauradament, es tornarà a fer servir un any més tard).

6-10-1973: $\quad$ Es desprèn una cornisa i mata a una dona a Sant Roc.

1974: $\quad$ Intents infructuosos per entrar a l'AVV Sant Antoni de Llefià per part de persones i militants de forces d'esquerres (vetats per Fulgencio Conesa). Creació de la Gestora de l'AVV Sant Mori de Llefià i inici de la seva tasca al barri.

Entra gent nova a l'AVV Congrés Eucarístic.

31-1-1974: $\quad$ Assemblea veïnal al Centre Social de Pomar amb la presència de Fulgencio Conesa. Alguns veïns manifesten que el que s'ha de fer és no pagar.

6-3-1974: $\quad$ Manifestació de 1.500 persones a Llefià contra l'assassinat de Puig Antich.

7-3-1974: $\quad$ Mor l'Alcalde Felipe Antoja Vigo. El substitueix temporalment José Guillén Clapés.

4/5-1974: Reivindicacions de l'AVV Congrés davant l'Ajuntament per la millora del barri (neteja, escoles, semàfors...)

5-1974: Dos recursos d'interposició i un contenciós administratiu interposats pel Col·legi d'Arquitectes de Catalunya i Balears contra els Plans Parcials de Llefià i Caritg.

12-5-1974: Assemblea a l'AVV de Sistrells i tria d'una nova Junta. Alfredo Amestoy (PSUC) esdevé el nou President. Comença una etapa molt més reivindicativa.

17-5-1974: $\quad$ Incendi de la fàbrica HAISSA (situada al barri de La Morera) on moren 5 dones i un home per la manca de mesures contra incendis. Les FOP carreguen durant el funeral fet a la parròquia de Pomar.

12-6-1974: $\quad$ Aprovació de l'ACF Sant Crist.

Isidre Caballeria Pla, nou Alcalde de Badalona.

7-1974: $\quad$ Es fan algunes obres de millora a Pomar. El nou director de l'OSH, Aníbal Rodríguez, diu que no es farà fora a ningú del seu pis.

8-1974: $\quad$ Un nen mor a Sant Roc en caure des de un balcó on s'havia després la barana.

10-1974: $\quad$ La Comissió Gestora de l'AVV Sant Mori de Llefià engega una recollida de signatures denunciant les mancances del barri.

12/13-10-1974: Assalt i robatori al local de l'AVV del Congrés. Condemna de la FAVB (Badalona).

11-1974: $\quad$ L'Ajuntament demana un préstec al Banco de Crédito Local de 340 milions per la construcció del port esportiu.

Vagues a FECSA i ESESA.

21-12-1974: $\quad$ Escrit del patró de la Confraria de Pescadors a Revista de Badalona a favor de la construcció del port.

1975: $\quad$ Entra gent jove del PSUC i la CNT a l'AVV de Bufalà. 
1-1975: $\quad 1.354$ persones i 17 entitats adrecen un escrit a l'Ajuntament en contra de la construcció del port esportiu.

10-1-1975: $\quad$ Carta del president de l'AVV de Sistrells (A. Amestoy) al director de la SEAT en solidaritat amb els seus treballadors.

23-1-1975: Primera manifestació a Sant Mori de Llefià amb un centenar de veïns amb espelmes reclamant l'enllumenat pel barri.

30-1-1975: $\quad$ Segona manifestació a Sant Mori de Llefià amb 500 persones.

2-1975: $\quad$ Els veïns de Sant Roc es mobilitzen per reclamar un ambulatori.

1-2-1975: $\quad$ Tercera manifestació a Sant Mori de Llefià amb espelmes. Dos milers de persones. Isidre Caballeria rep posteriorment a una comissió de Veïns i es compromet a instal·lar un enllumenat provisional al barri mentre no es fa el definitiu.

23-2-1975: Assemblea veïnal amb la participació de 350 persones a la parròquia de Sant Antoni de Llefià. Crítiques a Fulgencio Conesa (president AVV Sant Mori i regidor del districte a l'Ajuntament), després de diversos intents infructuosos de reunió amb ell. La reunió acaba amb una marxa cap al domicili del regidor. Crítiques per uns rebuts elevats de contribucions especials.

3-1975: $\quad$ Escrit de la Jove Cambra de Badalona signat també pels presidents dels Centres Socials de Pomar i Sant Roc, de l'AVV de Sistrells i de l'ACF de Sant Crist on es demanava una nova exposició pública dels detalls del projecte.

Aturades a l'empresa Jumberca.

4-1975: $\quad$ Vaga dels treballadors de la construcció a Can Ruti.

3-4-1975: $\quad$ Entitats badalonines (AVV Sistrells, AVV Congrés Eucarístic, ACF Sant Crist, CS Pomar, Centre d'Influència Catòlica, AMPA Institut Albéniz, Jove Cambra de Badalona, Cine Club Studio i el Grup Cristià de Defensa i Promoció dels Drets Humans) demanen als regidors que votin contra el projecte del port esportiu.

5-4-1975: $\quad$ S'aprova el projecte del port esportiu amb 17 vots a favor i 3 en contra. Concentració i esbroncada als regidors de l'Ajuntament a la Plaça de la Vila. Nou escrit d'entitats badalonines contra el port.

5-1975: Nou atropellament mortal d'un nen de Sant Roc.

L'AVV de Sistrells reclama una escola pel barri (també per Lloreda i La Pau). Denúncia a una constructora privada que ha fet servir sense permís el col-lector construït per l'associació als anys seixanta.

3-5-1975: $\quad$ Entrevista de veïns de Sant Mori de Llefià amb l'Alcalde Isidro Caballeria.

4-5-1975: $\quad$ Nova manifestació de protesta a Sant Roc exigint semàfors violentament reprimida per la Policia Armada.

4 i 18-5-1975: Concentracions i manifestacions festives contra el port a la rambla i a la platja de Badalona.

Josep Maria Peras Guens i Màrius Díaz Bielsa (futur Alcalde del PSUC de Badalona) presenten un recurs contenciós-administratiu contra el port esportiu.

5-5-1975: Reunió de veïns de Llefià amb Fulgencio Conesa. No es pagaran els rebuts de contribucions especials. 
Comencen les obres d'asfaltat i pavimentació a Sant Mori de Llefià, però de seguida hi ha problemes per la seva lentitud. Una manifestació veïnal intenta trencar el mur de la finca de Torre Mena. Repressió policial i dentenció de Paco Muñoz, de l'AVV Sant Mori i del PTE. És alliberat als pocs dies.

18-5-1975: Jornada de neteja popular per l'AVV Congrés, avortada per la policia. El president és Manuel Ordoñez, militant de OCE-BR (també hi participa Desiderio León, posterior regidor del PSC-PSOE).

6-1975: $\quad$ Tres-centes mares envien una carta al Governador Civil Martín Villa demanant la cancel·lació del projecte.

Escrit de diverses parròquies i grups cristians en contra del port: "Reflexió

cristiana davant un greu fet ciutadà"

5-7-1975: $\quad$ A la part alta de Llefià, els veïns es mobilitzen en una assemblea per conservar l'espai del Gran Sol, on s'estava edificant tot i ser una zona verda o d'equipaments.

25-7-1975: $\quad$ Manifestacions al matí i a la tarda de veïns que ocupen el solar del Gran Sol i enderroquen la tanca de l'obra i munten barricades. Enfrontaments amb la Guàrdia Civil i tres detencions: dos dones i un home, el periodista Manuel Armengol.

26-7-1975: $\quad$ Nova manifestació a la part alta de Llefià en protesta per les detencions del dia 25. Nova ocupació del solar del Gran Sol i enderroc de la tanca i una caseta d'obra.

7/8-1975: $\quad$ Entrada de gent jove i nova a l'AVV Juan Valera.

12-1975: $\quad$ Vaga de la construcció. Manifestació de 500 persones cap a l'Ajuntament. Detenció de Francisco Téllez Luna, Alfonso Moya Cachinero, Alejo Castellanos Blánquez i Emilio Contreras Fernández. Els tres primers, son torturats a la Caserna de la Guàrdia Civil de Badalona. Téllez ha de ser ingressat a l'hospital.

\section{$\underline{1976-1980}$}

1976:

Legalització de l'AVV Verge de La Salut (“El Hoyo”), de l'AVV Sant Roc i l'AVV Sant Mori de Llefià.

Constitució de la Federació d'Associacions de Veïns de Badalona (FAVB).

1-1976:

Reunió de l'Ajuntament amb AVV's. Aquestes li recorden els nombrosos dèficits existents i reclamen eleccions democràtiques.

Tres mestres acomiadats del Col·legi privat "La Esperanza” de Llefià son readmesos per la pressió veïnal.

Es comença a gestar la Federació d'Associacions de Veïns de Badalona. El Ple aprova una petició d'amnistia.

25-1-1976: Protestes i reivindicacions a favor d'Ajuntaments democràtics davant les "eleccions" a Alcalde.

Assemblea veïnal a Llefià on es reclama la dimissió del regidor Fulgencio Conesa.

2-1976: $\quad$ Mor un obrer de la construcció a Can Ruti. Protestes per aquest fet.

Conflicte laboral a TUSA.

Vaga de mestres.

6-2-1976: $\quad$ Nou accident mortal a Sant Roc. Una altra cessió de la barana d'un balcó provoca la caiguda i mort d'un altre nen. Dur escrit de protesta de la Vocalia d'Habitatge del Centre Social Sant Roc al director de l'OSH a Barcelona.

8-2-1976: $\quad$ Assemblea veïnal a Pomar per parlar del dèficits del barri i les reclamacions a 
l'OSH.

9-2-1976: $\quad$ Manifestació de 1.500 persones a Sant Roc en protesta per la situació del barri.

15-2-1976: Assemblea al Centre Social de Sant Roc que reclama la urgent construcció d'un Centre de Formació Professional, un mercat, un ambulatori, escoles i una local per jubilats.

El mateix mes es recullen signatures i s'envien cartes a l'Ajuntament reclamant un mercat.

22-2-1976: Assemblea veïnal a Sistrells per recollir les reivindicacions del barri (i signatures).

29-2-1976: Manifestació pro-amnistia a Badalona (autoritzada pel Govern Civil).

3-1976: $\quad$ Conflictivitat laboral intensa a Badalona.

Es crea la Associació de Jubilats i Pensionistes de Badalona.

Es troben un grup de persones amb la intenció de crear l'AVV del Centre.

Crisi municipal. Enfrontament entre Isidre Caballeria i José Guillen Clapés per unes irregularitats en els comptes municipals.

10-3-1976: Comença la vaga a Òptica Hispano, que durarà 70 dies.

16-3-1976: Cau un altre nen i es fereix greument per la cessió d'una barana a Sant Roc. Poc després mor un nen en tocar un cable d'alta tensió deficientment protegit.

18-3-1976: Inauguració del primer parc infantil a Llefià: El "parc de les palmeres".

4-1976: $\quad$ S'accepta el recurs contenciós administratiu contra el port esportiu.

Cecília March i Ernesto Rojo se sumen a les peticions de diversos regidors

d'ajuntaments catalans que demanen eleccions democràtiques.

Acte d'homenatge a Manuel Fernàndez Màrquez a Pomar.

Isidre Caballeria es compromet a triar l'Alcalde de barri de Sistrells per sufragi universal.

4-4-1976: $\quad$ Nova assemblea veïnal a Pomar.

4/5-1976: Problemes amb foses sèptiques d'uns pisos de Pablo Porta a La Salut. Les crítiques de l'AVV Juan Valera faran que l'empresari s'hagi de comprometre a construir el clavegueram corresponent.

Es recullen signatures i s'envien cartes a l'Ajuntament reclamant un ambulatori per Sant Roc.

6-4-1976: Constitució d'una Associació pro-amnistia a Badalona.

24-4-1976: $\quad$ Eleccions a l'AVV Juan Valera. Manuel Armentero (PSUC) President.

30-4-1976: $\quad$ Manifestació a Badalona pel 1er de maig (no autoritzada).

5-1976: Dimissió del Tinent d'Alcalde de Governació, José Mateu Cunillé.

L'Assemblea Democràtica es posiciona contra el port esportiu.

Assemblea veïnal a Sant Roc. Es reafirmen en no pagar a l'OSH.

Els habitants de Bufalà a través de l'AVV envien queixes sobre l'estat del polígon a l'OSH.

L'AVV de Sistrells guanya el litigi amb la immobiliària que havia fet servir sense permís el seu col-lector.

La FAVB presenta els seus Estatuts. 
8-5-1976: $\quad$ Manifestació de 2.000 persones a Llefià reivindicant millores pel barri i reclamant la legalització de l'AVV de Sant Mori.

S'inicien els tràmits per crear una nova associació a la part alta de Llefià.

17-5-1976: Dos nens moren a Bufalà en incendiar-se el pis de mostra abandonat d'una immobiliària (Conbasa) on jugaven. Protestes de l'AVV que ja havia avisat del perill.

30-5-1976: $\quad$ Festa del CCC a Can Solei i instal-lació del monòlit (que serà retirat més tard per odre de l'Ajuntament.)

6-1976: $\quad$ Pancartes a Llefià contra el constructor Benito Solans que estava edificant el nou mercat del barri ocupant gran part d'una zona verda.

Legalització de l'AVV de Sant Mori de Llefià.

L'AVV de Sistrells organitza les festes del barri.

Els veïns del barri Morera posen nous noms als carrers.

3-6-1976: Les AVV's denuncien les permanències.

Prohibició d'un acte pro-amnistia a Badalona.

17-6-1976: Celebració del 40è Aniversari del PSUC a la Pineda de Can Ruti.

26 i 27-6-1976: Ocupació, neteja i reivindicació del solar de la fàbrica de "La Regaliz" pels veïns del Congrés. Instal·len un columpi.

27-6-1976: $\quad$ Es presenta públicament l'Assemblea Democràtica de Badalona a l'Institut Albèniz. El dia 30 ho torna a fer al parc de Can Solei.

30-6-1976: Carta del Centre Social al Delegat Provincial de l'OSH recordant els nombrosos defectes del barri i reafirmant-se en la decisió de no pagar mentre aquests no es solucionin.

7-1976: $\quad$ PSUC i PSOE manifesten públicament el seu rebuig al port esportiu.

Presentació del "Manifest per Badalona" per part de les AVV's de Sistrells, Juan Valera, Sant Crist, Lloreda, Puigfred, Bufalà, Sant Mori de Llefià i Morera; els Centres Socials de Pomar i Sant Roc; i les entitats Jove Cambra, Grup Cristià de Defensa i Promoció dels Drets Humans, Xarxa de Comunitats Cristianes, CIC i Cine Club Studio.

Reivindicació de l'AVV Congrés d'un local obert a tots els jubilats del barri.

8-7-1976: $\quad$ Manifestació al Congrés reivindicant una escola, violentament reprimida.

9-9-1976: Manifestació de 300 persones a Llefià reclamant millores al barri , la dimissió del consistori i ajuntaments democràtics.

10-1976: $\quad$ Detenció del periodista Enric Giralt acusat d'injúries per un article on denunciava la detenció i maltractament de dues persones acusades d'atemptar contra un policia local.

? Detenció de 15 joves a la sortida d'una missa per un estudiant assassinat a Madrid feta a l'església de La Salut.

10-7-1976: Carta de Isidre Caballeria al Governador Civil Salvador Sánchez Terán demanant la legalització de l'AVV de Sant Roc que l'alcalde Badaloní ha fomentat per contrarestar al Centre Social Sant Roc.

29-7-1976: La "Marxa de la Llibertat" és violentament reprimida al seu pas per Badalona.

9-1976: Amenaces contra el periodista Manuel Bazataqui per haver escrit un article crític 
amb el projecte del port esportiu.

Conflicte laboral a Filcor i Còrtex.

Mobilitzacions als barris exigint escoles.

17-9-1976: $\quad$ Es presenten els Estatuts de l'AVV del Centre al Govern Civil.

18-9-1976: Manifestacions i concentració a la Plaça de la Vila reivindicant escoles, violentament reprimida per la Guàrdia Civil. Les AVV's i l'Assemblea Democràtica demanen la dimissió de tot el consistori.

27-9/3-10-1976: Setmana de la Joventut organitzada per l'AVV Juan Valera.

13-10-1976: Comença la ocupació d'un solar -on la immobiliària Novogar vol construir habitatges- reivindicat com a zona verda per part de membres de l'AVV Juan Valera.

4-11-1976: Manifestació de 300 persones a Sant Roc amb espelmes i llanternes reclamant il·luminació pel barri.

12-11-1976: Vaga General. Fort seguiment a Badalona. 30 persones detingudes.

12-1976: $\quad$ Apareix el primer número de la revista Comarca Exprés.

Mobilitzacions de l'AVV del Congrés Eucarístic per recuperar la fàbrica de "La Regaliz", per la construcció d'una escola pública i contra la delinqüència.

Constitució de la Comissió Gestora de l'AVV Verge de La Salut ("El Hoyo").

1-12-1976: El "Ministro de la Vivienda" anuncia 813 milions per rehabilitar Pomar i Sant Roc (no esmenta Bufalà).

El "Ministerio de la vivienda" destina 441 milions de pessetes a fer reparacions al polígon de Pomar.

4 i 5-12-1976: Dues manifestacions veïnals a Llefià amb la participació de cinc-centes persones.

8-12-1976: Festa a la Rambla per presentar oficialment l'AVV del Centre.

15-12-1976: Referèndum per la reforma política.

1977: $\quad$ Legalització de l'AVV Morera.

1-1977: $\quad$ Reunions i mobilitzacions dels veïns dels blocs de "Gallina Blanca" (Llefià). Novogar s'avé a negociar amb l'AVV Juan Valera i l'Ajuntament. Un acord amb la CMB permet una permuta de terrenys permet conservar el solar per zona verda i un altre proper (futures places Salvador Allende i de la Dona).

18 i 19-1-1977: Assemblees a Llefià dels habitants dels blocs del PMV.

23-1-1977: $\quad$ Manifestació de 1.500 veïns de Ibusa, el Patronat Municipal i d'Inmobilar a Llefià. Acaba amb la cacera d'una rata que és llançada al domicili particular de Fulgencio Conesa.

2-1977: $\quad$ S'inicia un conflicte dels veïns del C/Antiga de València (Llefià) amb el constructor Mestre Ferrer per un pati interior.

Apareix un estudi sobre les deplorables condicions del barri de Sant Roc. El tinent d'alcalde Alfonso Ramos es pren unes "llargues vacances" després d'un enfrontament amb José Guillen pel tema de l'impost de radicació.

3-1977: $\quad$ Mobilitzacions a Dalt de La Vila per conservar el patrimoni històric del barri. 
24-3-1977: La CMB suspèn durant un any les llicències d'obra a tot Llefià.

31-3-1977: Benito Solans es veu obligat a retirar la denúncia contra els veïns de Llefià que protestaven per les irregularitats en la construcció del mercat i també a indemnitzar-los amb 750.000 ptes.

4-1977: Nova junta de caràcter reivindicatiu a l'AVV de Sant Antoni de Llefià. El nou President, Antonio Agudo, és militant de l'OIC (i posteriorment del MCC).

L'OSH es compromet a elaborar un projecte de reparació general del barri de Sant Roc.

22-4-1977: $\quad$ Isidre Caballeria presenta la dimissió per anar a les llistes d'AP. Alfonso Ramos Cruz esdevé el nou alcalde.

4/8-1977: $\quad$ Elaboració per part del SECOD i les AVV's de Sant Mori i Juan Valera d'un Pla Especial de Reforma Interior de Llefià i La Salut.

2-5-1977: $\quad$ Ocupació de l'Ajuntament per part dels veïns afectats per Mestre Ferrer, que no compareix a una reunió amb aquests. Finalment l'empresari dona la raó als veïns i es compromet a indemnitzar-los amb 750.000 pessetes.

14-5-1977: $\quad$ Un grup de persones de l'AVV del Centre col·loca per la nit el monòlit al parc de Can Sole (reivindicant aquest nom i no el de Felipe Antoja), per ser presentat el dia següent a la Festa del Badiu. L'ajuntament el retira posteriorment rebent fortes crítiques.

22-5-1977: $\quad$ Manifestació que acaba a la Plaça de la Vila on es substitueix la placa amb el nom oficial.

31?-5-1977: $\quad$ Manifestació a Sant Roc reclamant l'enllumenat pel barri, convocada tant pel Centre Social com per l'AVV.

6-1977: $\quad$ Veïns de Bonavista arriben a un acord amb l'Ajuntament per l'acondicionament del seu barri després de nombroses protestes.

15-6-1977: $\quad$ Eleccions pluripartidistes al Congrés i al Senat. Victòria clara de les esquerres a Badalona (i a les altres ciutats del Barcelonès Nord).

30-6-1977: Veïns del carrer Mariscal Cabanes del barri d'Artigas munten barricades per protestar per l'estat del seu carrer.

7-1977: Intent de dimissió en bloc del consistori de Badalona (excepte Cecília March i Ernesto Rojo). El Governador Civil no l'accepta.

L'Ajuntament és expulsat del CCC.

1-7-1977: $\quad$ Manifestació de 100 persones pel carrer Juan Valera (Llefià i La Salut) reivindicant parcs i col-legis.

2-7-1977: $\quad 30$ joves del Congrés tallen el trànsit de la N-II protestant per la falta de neteja del barri.

3-7-1977: $\quad$ Manifestació de 200 persones de Sant Mori de Llefià fins la Plaça de La Vila reivindicant col·legis, zones verdes i neteja.

4-7-1977: $\quad$ Tancament de Comarca Expres.

8-1977: $\quad$ El Ple suspèn l'acord de posar el nom de Felipe Antoja al parc de Can Solei i 
restituir el monòlit, cosa que no es fa per estar "desaparegut" a les dependències municipals.

4-8-1977: $\quad$ Concentració d'un centenar Veïns (dones i nens la majoria) de La Pau al carrer Listz reclamant escoles, zones verdes, ambulatori i criticant a l'Ajuntament.

5-8-1977: $\quad$ Nova concentració de 150 persones al carrer Listz.

6-8-1977: $\quad 400$ persones es manifesten al Carrer Listz (La Pau) exigint la construcció d'un parc al solar de "els músics". Incident amb un turisme que intenta travessar el tall de trànsit i atropella a tres persones. El conductor ha de fugir ajudat per un policia i el vehicle és incendiat.

7, 8 i 9-8-1977: Concentracions, talls de trànsit i manifestacions als carrers Listz i Mozart (200500 persones).

18,19 i 23-8-1977: Més manifestacions a La Pau (carrers Listz i Mozart) (300 persones).

6-9-1977: $\quad$ Manifestació des de La Pau fins a l'Ajuntament reivindicant millores pel barri (zones verdes, escoles, etc.).

10 i 11-9-1977: Talls de trànsit fets per veïns de Bufalà i Bonavista per protestar per l'estat dels seus barris (600 persones).

El dia 11 es concentren 200 persones a Bufalà davant de la regidora Juana Jordán, llançant bosses d'escombraries contra la mateixa. En encarar-se el seu marit amb els manifestants i agredir a un nen aquest és agredit pels veïns que trenquen els vidres del seu cotxe i aboquen escombraries al seu interior (la regidora dimitirà posteriorment).

12-9-1977: $\quad$ A La Pau 500 persones tallen el trànsit i pinten passos de vianants.

A Llefià i La Salut 300 persones tallen el trànsit en la N-II exigint zones verdes i neteja als barris.

Assemblea reivindicativa a Bufalà. Veïns del barri intenten entorpir, sense èxit, el pas de la Volta Ciclista a Catalunya.

13 i 14-9-1977:300-400 persones, es manifesten per Llefià reivindicant escoles i zones verdes i tallant la $\mathrm{N}-\mathrm{II}$.

15-9-1977: $\quad$ Nova manifestació a Llefià (400 persones) que enfila cap a l'Ajuntament on conflueix a la Plaça de la Vila amb una altra procedent de La Pau (500 persones), reivindicant escoles públiques.

16-9-1977: $\quad$ Un Ple especial aprova un pressupost especial de 52 milions per urbanitzar el barri de Bufalà.

17-9-1977: Concentració de 150 persones al barri del Congrés reivindicant parcs pel barri.

19-9-1977: $\quad$ Concentració de 150 persones al parc de les Palmeres de Llefià i fan una assemblea per discutir els problemes del barri.

21-9-1977: $\quad$ Manifestació de 500 persones a Llefià i tall de la N-II reivindicant col·legis i parcs. Concentració de 100 veïns del Congrés davant l'Ajuntament i entren a l'edifici reivindicant la construcció d'una escola al barri.

22-9-1977: $\quad$ Manifestació de 500 persones al barri de Llefià que es troba a la N-II amb una altra procedent del barri de Sistrells (400 persones), marxant cap a l'Ajuntament tallant el trànsit. A la Plaça de la Vila 300 nens fan classe a l'aire lliure. Són rebuts per 
l'Alcalde.

El mateix dia una assemblea de 500 persones es reuneix a Llefià per parlar de la manca de col-legis.

Manifestació de 150 veïns pels barris de Sistrells, la Salut i Lloreda, reivindicant un col·legi públic.

26?-9-1977: El regidor de Cultura Parra intenta agredir a Cecília March Blanch quan aquesta el criticava durament (després d'un context de nombroses mobilitzacions veïnals reclamant escoles).

27-9-1977: Primera reunió de la Comissió Política (integrada pels partits polítics) amb l'Ajuntament.

10-1977: $\quad$ Augmenta la tensió entre la Comissió de Partits i l'Ajuntament.

10-10-1977: Reunió d'una trentena d'Alcaldes (entre ells els de Badalona i Santa Coloma) amb el Governador Civil de Barcelona i amenacen amb dimissions si no són ajudats.

11-1977: $\quad$ Mobilitzacions a Llefià contra el frau en el pes del pa.

10-11-1977: Principi d'acord entre partits polítics i Ajuntament. Creació d'una Comissió Informativa.

3-12-1977: $\quad$ Ple suspès per la protesta dels veïns de La Pau.

23?-12-1977: El PSUC proposa un pacte i un pla d'urgències fins les eleccions municipals als altres partits polítics i a l'Ajuntament.

1978: $\quad$ Els legalitzen les AVV's de Ronda de Sant Antoni de Llefià i Sant Joan de Llefià Baix.

1-1978: $\quad$ Els inquilins d'IBUSA (Sant Joan de Llefià) semblen arribar a un acord amb la immobiliària per la reparació dels seus habitatges.

La Taula de Sanitat, recent creada, presenta un pla d'urgències per la ciutat.

1/2-1978: Mobilitzacions en defensa de Montigalà.

13-1-1978: La CMB aprova el PERI de Llefià-La Salut.

2-1978: $\quad$ Mobilitzacions a Llefià contra l'empresa Inmobilar.

Sant Crist reivindica una escola pública pel barri.

2-2-1978: $\quad$ El Ple autoritza l'inici de les obres d'urbanització del Bruc-Bufalà.

19-2-1978: $\quad$ Manifestació a Montigalà de 3000 persones.

2-3-1978: $\quad$ El Consell de Ministres aprova un Pla de Reforma Integral per al barri de Sant Roc.

17?-3-1978: El PSOE es retira de la Comissió Municipal.

4-1978: $\quad$ Mobilitzacions a Sant Antoni de Llefià contra la immobiliària Red.

El pressupost municipal per l'any 1978 és de 928 milions de pessetes.

5?-4-1978: $\quad$ CDC abandona la Comissió Municipal.

4/5-1978: La Taula d'Ensenyament presenta un pla d'actuació i convoca diverses mobilitzacions. L'Ajuntament l'acaba acceptant.

Mobilitzacions per la llibertat d'expressió (el badaloní membre dels Jotglars 
Andreu Solsona havia estat detingut)

4/7-1978: Nous conflictes veïnals amb immobiliàries als carrers Salou i Dr. Bassols (Llefià).

1/7-5-1978: Setmana de lluita a Sant Roc per reivindicar un consultori, una llar de jubilats i dues escoles.

Assemblea veïnal amb la presència del Ministre de l'Habitatge. Els veïns aproven que sigui el Centre Social i no l'AVV qui controli les obres de reparació del barri.

6-5-1978: $\quad 2.000$ persones en una manifestació convocada per la Taula d'Ensenyament.

1-6-1978: $\quad$ El Ple refusa en votació el PERI de Dalt de la Vila.

9-6-1978: $\quad$ La CMB desautoritza a l'Ajuntament de Badalona i aprova el PERI de Dalt de la Vila.

14?-6-1978: $\quad$ El Consistori Badaloní torna a presentar la dimissió a excepció de 4 regidors. No és acceptada. La Taula de Partits l'exigeix.

22-6-1978: Veïns de Sant Crist ocupen els baixos de l'església per fer-los servir com escola.

26?-6-1978: L'Ajuntament solventa la crisi municipal canviant tots els tinents d'Alcalde. Cecília March i Ernesto Rojo accepten Tinències d'Alcaldia desobeint a CDC i acaben abandonant la formació.

La Taula de partits considera un pedaç aquests canvis i reclama una Gestora.

29-6-1978: $\quad$ Reunió entre Ajuntament, partits polítics i AVV's pel tema de les escoles on no s'arriba a cap consens i es demana la dimissió del consistori.

7-1978: Juana Jordán (antiga regidora per Bufalà) i el seu marit Mateo Comabella fugen a Veneçuela per un cas de corrupció i frau empresarial.

6-7-1978: Veïns de Sant Crist ocupen el saló de Plens de l'Ajuntament i son desallotjats per la policia. Posteriorment aconseguiran la cessió provisional del local per fer l'escola mentre l'Ajuntament es comprometia a buscar uns terrenys per construir-ne una de definitiva.

8-1978: $\quad$ Per ordre governativa se suspenen les obres a Dalt de la

31-8-1978: $\quad$ La Taula de Partits proposa un Alcalde Gestor d'ERC.

9-1978: Mobilitzacions dels veïns del Carretera Antiga de València, cantonada Mina (Sant Mori de Llefià) contra una immobiliària.

4-9-1978: $\quad$ Ocupacions de pisos al polígon del Maresme del PMV (a Sant Roc).

10-1978: Continua la crisi municipal. Reunions partits-alcalde. El governador civil no accepta una Comissió Gestora de partits però si regidors gestors que substitueixin als dimissionaris.

CDC i ERC tenen postures més pròximes a l'Ajuntament mentre les més allunyades són les de PSUC, PSC i PTE.

5-10-1978: Manifestació de la Taula d'Ensenyament. Es vol intervenir al Ple però no els deixen llegir un escrit.

30-10-1978: Reunió de la Taula de Sanitat i les AVV's. Es parla de la greu situació de l'Hospital Municipal. 
11-1978: $\quad$ Creació d'una Comissió Mixta per avaluar les ocupacions del polígon Maresme. Es concedeix els habitatges als ocupants llevat de 17 casos.

Els veïns de Sant Crist obtenen 3 Ha per la construcció d'escoles i els de La Pau 1,5 Ha.

1?-11-1978: $\quad$ Roda de premsa del PSUC. Anuncia la seva disponibilitat de formar govern local amb PSC, CDC, ERC i PTC.

11/12-1978: Mobilitzacions dels veïns de la immobiliària Patrilar contra Pablo Porta.

13-11-1978: $\quad$ La Taula de Partits entrega un document amb un Pla d'Urgències a l'Ajuntament. Comencen les obres de reparació a Sant Roc.

22-11-1978: $\quad$ Dimissió del regidor de CDC Ernesto Rojo.

Un Ple Extraordinari aprova el pressupost per la Urbanització de Sant Crist.

24-11-1978: $\quad$ Segons la Taula de Partits l'Alcalde Ramos accepta el "pla de transició", la creació d'un "govern provisional local" i l'aplicació del Pla d'Urgències.

12-1978: $\quad$ L'Ajuntament garanteix la supervivència de l'Hospital Municipal.

6-12-1978: Referèndum constitucional. Queixes per nombroses errades i irregularitats que potser han impedit votar a un $10 \%$ d'electors.

7-12-1978: $\quad$ Ple Municipal. S'absenten els 5 regidors ultres implicats en l'anomenada “Operació Simbiosi" per fer caure l'Alcalde Ramos.

Es suspenen les llicències de construcció per un any al barri de Sant Crist.

13-12-1978: En una roda de premsa els regidors implicats neguen "l'operació Simbiosi".

19?-12-1978: Acord entre Alfonso Ramos i els partits polítics per un govern provisional fins les eleccions. Diferents partits polítics assumiran càrrecs dins l'Ajuntament (PSUC Cultura, PSC Hisenda, CDC Sanitat, ERC Estadística, PTC Urbanisme). Es crea una Comissió Política integrada per representats dels mateixos partits.

16-1-1978: $\quad$ Es fa pública la candidatura de Màrius Díaz com alcaldable del PSUC.

2-1979: $\quad$ Protestes dels veïns del carrer Sagrada Família (Sant Mori de Llefià) contra la immobiliària de Pablo Porta pel deficient estat dels seus habitatges. Acampen tallant el carrer.

Cecília March i Ernesto Rojo es presenten en una candidatura independent. Es presenten les llistes del PTE, ERC i PSC-PSOE.

20-2-1979: 140 famílies del carrer Sagrada Família dormen a l'Ajuntament davant l'aparició de noves esquerdes en els seus habitatges.

24?-2-1979: $\quad$ Manifestació de 1.000 persones protestant per la pèrdua de llits per la Seguretat Social de la Clínica del Carmen en un incompliment de la promesa de la UCD.

3-1979: $\quad$ Protestes dels veïns del "rascacielos" (Sant Mori de Llefià).

3-3-1979: $\quad$ Locaut patronal a TUSA. Vaga dels treballadors a partir del dia 6.

7-3-1979: Veïns de Bufalà segresten quatre autobusos en protesta pel deficient transport públic.

Nova manifestació de 2.000 persones per la greu situació sanitària de Badalona. 
8-3-1979: La FAVB, després d'intentar reunir-se infructuosament amb l'alcalde, emet un comunicat criticant el Locaut de TUSA.

4-1979: $\quad$ Els veïns afectats per la immobiliària La Salut (c/ Sagrada Família) continuen fent talls de trànsit.

3-4-1979: $\quad$ Eleccions Municipals: PSUC 12 regidors; PSC-PSOE 10, CDC 3; UCD 2.

28-4-1979: Multitudinari primer Ple de l'Ajuntament al pavelló de la Plana presidit pel nou alcalde del PSUC, Màrius Díaz.

1-5-1979: $\quad$ Es fa públic el cessament de l'administrador de l'Hospital Municipal.

13-5-1979: $\quad$ Acampada reivindicativa a Montigalà-Batllòria.

22-5-1979: $\quad$ Es fa públic que l'Ajuntament es posiciona en contra de la pujada de la tarifa dels autobusos.

23?-5-1979: $\quad$ L'Ajuntament convoca una manifestació per reivindicar escoles.

24-5-1979: $\quad$ Inspecció sorpresa de l'escorxador municipal feta per l'alcalde, tinents d'alcalde i la Guàrdia Civil que revela nombroses irregularitats.

6-1979: Negociacions de l'Ajuntament amb el Ministeri d'Educació per la construcció oㅡ d'escoles.

Greu estat de contaminació de la platja.

Cessament del director de l'Escorxador municipal.

7-1979: $\quad$ S'atura l'ampliació de les instal·lacions de la CAMPSA a la platja.

L'Ajuntament comunica que contractarà aturats en les obres de millora de la ciutat. 700 milions de pressupost municipal pel segon semestre.

2-7-1979: Debat popular sobre Montigalà-Batllòria convocat per l'Ajuntament (partits, sindicats, empresaris, AVV's...).

8-1979: $\quad$ La xifra d'aturats a Badalona s'acosta a 20.000.

S'instal·len dutxes a la platja de Badalona.

9-1979: $\quad$ S'inicien els tràmits per crear un parc forestal.

Es constata la desaparició d'expedients conflictius d'urbanisme a l'Ajuntament (d'afers aprovats a l'anterior consistori).

1-9-1979: $\quad$ Ple on es vota una resolució a favor del reconeixement del Front d'Alliberament Gai de Catalunya. Es convoca a una manifestació per l'ensenyament el dia 7 en protesta per les retallades ministerials en aquest àmbit.

7-9-1979: $\quad$ Tancada a l'Ajuntament i 6.000 persones en la manifestació a favor de l'ensenyament.

17-9-1979: Més de 3.000 persones tallen l'autopista de Mataró durant dues hores en protesta per la manca d'escoles.

19-9-1979: Màrius Díaz es desplaça Madrid per aconseguir un préstec del Banc de Crèdit Local.

17/21-9-1979: Inspeccions a empreses contaminants fetes pel regidor de medi ambient Toni Barberà. 
6-10-1979: La policia agredeix al regidor d'Ensenyament Pedro Jesús Fernàndez davant la delegació del MEC en una jornada de manifestacions i protestes on 14 mestres son detinguts.

11-1979: $\quad$ Continuen detectant-se irregularitats a l'Hospital de Badalona.

S'aprova crear una Escola de Natura a l'edifici de Can Miravitges.

6?-11-1979: $\quad$ Socialistes i convergents no participen al Ple per estar en desacord en presentar una moció de reprovació al govern de l'UCD sense haver-la discutit abans.

22-11-1979: Funcionaris municipals es concentren davant l'Ajuntament en protesta per les normes de retribució del personal.

27-11-1979: Es tres regidors de CDC fan un balanç negatiu dels primers 6 mesos d'Ajuntament democràtic en una roda de premsa.

28-11-1979: Roda de premsa del PSC-PSOE per manifestar el seu desacord en que Màrius Díaz hagi assumit en persona els treballs de reestructuració de la Hisenda Municipal.

12-1979: Un grup de veïns d'un immoble de Sant Roc s'oposen a que una família gitana accedeixi al pis que l'Ajuntament els hi va concedir.

Es descobreix un abocador il·legal a Pomar.

4-12-1979: Es produeix un atracament d'una sucursal bancària després d'un mes sense cap delicte d'aquest tipus (en concret a una sucursal de la Caixa de Pensions a Llefià).

15-12-1979: Jornada sobre el medi ambient organitzada per la Regidoria d'Ecologia i Medi Ambient.

1-1980: $\quad$ Es fa públic que l'anterior Ajuntament deixa un deute pendent de mil milions de pessetes.

Gestions per permutar el terreny de Torre Mena a Ràdio Miramar i que sigui un equipament pel barri de Llefià.

Un miler de ciutadans es posiciona contra l'Ajuntament per que aquest ha sol-licitat en un ple la despenalització de l'avortament.

Finalitza la discriminació funerària dels no catòlics al cementiri de Badalona.

4-1-1980: $\quad$ Atracament en una joieria al Centre.

31-1-1980: Incidents a Pomar provocat per dos guàrdies urbans en estat d'embriaguesa que arriben a fer servir les seves armes disparant a l'aire.

2-1980: $\quad$ Gestions de l'Ajuntament de Badalona per la construcció del col-lector transversal. L'Ajuntament amenaça amb embargar la residència sanitària (futur hospital Germans Tries i Pujol).

5-2-1980: Suspensió de 4 dies de feina i sou als guàrdies urbans implicats en els fets de Pomar.

16-2-1980: L'aixecament d'acta d'incompliment de contracte al Ministeri de Sanitat al l'Hospital de Can Ruti per part de l'Ajuntament de Badalona.

Badalona és declarada zona contaminada.

19-2-1980: L'empresa Núñez i Navarro es compromet a compensar un grup de veïns per defectes en els seus habitatges (Carretera Antiga de València i Alfons XIII, Sant Mori de Llefià). 
3/4-1980: Es debat sobre la possibilitat de fer un port pesquer (no esportiu), però hi ha discrepàncies entre les diferents forces polítiques (PSUC i CDC, sobretot).

3-1980: $\quad$ Conflicte entre l'Ajuntament i el govern central pels antics locals del Movimiento que no es volen cedir a la ciutat. L'Ajuntament ocupa un en protesta.

Robatoris i destrosses en $5 \mathrm{col} \cdot$ legis públics.

3-3-1980: $\quad$ Uns atracadors fugen amb un cotxe de la Guàrdia Urbana que havien aconseguit a punta de pistola.

14-3-1980: Dur comunicat d'ASPANIN contra el govern d'UCD per la situació de les escoles de disminuïts psíquics.

19-3-1980: Intenten calar foc a la casa de Màrius Díaz.

28-3-1980: Els alumnes de l'Institut de Batxillerat Eugeni d'Ors fan classes al carrer en protesta per lamentable estat del seu edifici.

4-1980: $\quad$ Tensió entre l'Ajuntament i La Caixa de Pensions per la negativa inicial d'aquesta entitat en concedir un crèdit a l'Ajuntament.

El Col-legi Popular Assembleari de La Pau continua reivindicant el solar dels músics (propietat d'una immobiliària).

Enfrontament entre el Joventut i l'Ajuntament per la voluntat d'aquest de recuperar el pavelló de La Plana, construït en terreny municipal.

L'Ajuntament demana a la Generalitat que es prohibeixi el bany a la platja de Badalona per la greu contaminació que tenen les seves aigües.

11-4-1980: $\quad$ El Ple aprova les noves taxes municipals.

19-4-1980: Una representant de l'Associació Catòlica de Pares de Família denúncia a la TV que l'alcalde de Badalona vol educar en el marxisme en les escoles públiques, acusació negada per l'Ajuntament.

27-6-1980: L'empresa TUSA augmenta el preu del bitllet en contra de l'opinió de l'Ajuntament i del mateix Govern Civil.

20-9-1080: Cent veïns afectats per la immobiliària IBUSA del carrer Salou (Llefià) es tanquen a l'Ajuntament.

4-10-1980: $\quad$ Finalitza el tancament dels veïns del carrer Salou en arribar a un acord amb la immobiliària.

28-11-1980: $\quad$ PSUC i PSC-PSOE presenten una moció criticant durament a CDC per les crítiques que es fan del govern municipal al seu butlletí.

17-11-1980: Nou assalt a una escola de Badalona.

9-12-1980: L'Ajuntament de Badalona suspèn unes obres que amenaçaven patrimoni històric romà.

18-12-1980: L'AVV del Congrés reclama la construcció d'un poliesportiu als terrenys de l'antiga fàbrica "La Regaliz" i amenaça amb mobilitzacions si no es fa.

\section{$\underline{1981-1985}$}

24-1-1981: Visita polèmica de Jordi Pujol a Badalona (en concret a Sant Roc) que s'havia 
anunciat com a privada.

21-3-1981: $\quad$ Una sentència ordena l'enderrocament d'un edifici il·legal a Dalt de La Vila.

26-3-1981: Dimissió de Joan Solé i Amigó com a responsable de Cultura per discrepàncies amb el PSUC pel nomenament del nou director del Museu Municipal.

4-1981: $\quad$ Oposició de l'Ajuntament a la construcció d'una presó a Badalona.

6-4-1981: $\quad$ Manifestació i tall de trànsit al carrer Marquès de Montroig de 500 veïns dels polígons del PMV de la Ronda de Sant Antoni de Llefià i del Maresme (Sant Roc). Amenaça d'embargament de 2.750 habitatges del PMV per l'impagament de les hipoteques per part del Banco de Crédito de la Construcción.

12-5-1981: $\quad$ Manifestació i concentració en la Plaça de la Vila d'un centenar d'afectats pel PMV. Son desallotjats per la Policia Nacional.

20-6-1981: C CiU trenca el "Pacte de Progrés" a Badalona i vota en contra dels pressupostos municipals.

6-1981: $\quad$ Enfrontaments intens al PSUC i crítiques de diferents agrupacions locals per tornar a admetre el terme "eurocomunisme".

3-71981: $\quad$ Acord entre els veïns de Ronda de Sant Antoni (Llefià) i el PMV de Badalona. Els afectats podran esdevenir propietaris sense haver de pagar més del ja acordat.

7-7-1981: Ràdio Ciutat de Badalona comença a emetre en període de proves.

10-8-1981: $\quad$ Nou conflicte a TUSA. Davant una nova pujada de bitllet l'Ajuntament de Badalona intenta impedir el servei de l'empresa. La regidora Luisa Longas és detinguda quan intentava impedir la sortida dels autobusos. Finalment la Generalitat dona la raó a l'Ajuntament i l'empresa ha de derogar la pujada de tarifes.

11-8-1981: $\quad$ Nou assalt contra la casa de Màrius Díaz.

29-8-1981: 200 famílies desnonades de Badalona amenacen amb anar a una vaga de fam.

10-1981: $\quad$ L'Ajuntament anuncia la seva voluntat d'eradicar els horts il·legals.

17-11-1981: $\quad$ Enderrocament de l'edifici il·legal de Dalt de la Vila.

23-11-1981: Inicia les seves activitats l'Escola de la Natura (Can Miravitlles).

12-1981: $\quad$ Cessament del regidor Miguel Guerrero (partidari del Vè Congrés) i obertura d'expedient al regidor Juan Gómez, també partidari del Vè Congrés (que serà també expulsat).

Divisió en el PSUC de la ciutat. Existeixen dos Comitès Locals.

7-12-1981: Concentració de mestres d'escoles públiques davant l'Ajuntament per protestar contra la inseguretat i els assalts als col·legis.

9-12-1981: $\quad$ Comencen les obres del col-lector de Llevant.

12/13-12-1981:La regidoria d'Ecologia i Medi ambient organitza unes Jornades a Badalona.

1-1982 Articles creuats en la premsa local (Revista de Badalona) de diferents militants del PSUC de les dues tendències. 
6-1-1982: El regidor Toni Barberà fa públic que dimiteix del seu càrrec criticant al Comitè Local oficial. Posteriorment és cessat Juan Gómez.

20-1-1982: Rèplica d'Àngel Navarro a l'escrit de Toni Barbarà.

21-1-1982: Sessió extraordinària del Ple Municipal.

28-1-1982: Incidents en un Ple extraordinari per l'afer del Mercat de La Salut.

30-1-1982: Tancada d'uns 35 paradistes al nou mercat de La Salut per estar disconformes amb l'Ajuntament. S'inicia un conflicte per aquesta qüestió (estan tot el cap de setmana i el dilluns 1 de febrer es fa una manifestació).

9-2-1982: $\quad$ Aprovació dels nous pressupostos municipals.

4-1982: $\quad$ Acord entre Ajuntament, Generalitat i CMB sobre Montigalà-Batllòria.

5-1982: $\quad$ Clausura per par de l'Ajuntament d'un Bingo.

27-5-1982: Tancament de TV Badalona i detenció per la policia de Màrius Díaz i de quatre regidors més (Jaume Oliveres, Juan Felipe Ruiz, Luisa Longas i Manuel Armentero) per oposar-s'hi.

11-6-1982: L'Ajuntament projecta el programa que no es va deixar emetre amb la clausura de la televisió.

11-8-1982: Veïns del carrer Guasch (Sant Mori de Llefià) s'oposen les obres per construir una escola per que implicarà enderrocar una tanca i un solar que havien arreglat ells mateixos.

26-9-1982: $\quad$ ETA fa esclatar una bomba en una boia del pont del petroli.

2-10-1982: $\quad$ Mor un inquilí dels pisos del Maresme que havia de ser desnonat en sortir del jutjats (d'un atac de cor).

Continua el conflicte amb els inquilins del Polígon Maresme i el PMV.

Comunicat del MCC criticant la política feta per l'Ajuntament en aquest assumpte i per que s'aturi el desnonament de la família del mort. El PMV finalment el suspèn.

5-10-1982: $\quad$ S'inaugura una Oficina de Defensa del Consumidor a Badalona.

10/11-1982: Torna la polèmica pel Bingo clausurat el mes de maig. L'Alcalde es nega a obrir-lo tot i les protestes dels treballadors.

10,11 i 12-11-1982: Jornades sobre "Catalanisme i immigració" organitzades per l'Ajuntament.

16-11-1982: El PMV anuncia que obligarà a pagar a tots els inquilins del polígon del Maresme (Sant Roc) que tinguin prou recursos per fer-ho.

29-11-1982: Manifestació dels habitats de la urbanització "il·legal" de La Vallensana.

1-1983: $\quad$ S'instal-len contenidors per la recollida d'escombraries.

12-1982: L'Ajuntament dona suport al PMVRL amb el conflicte amb els veïns del polígon Maresme de Sant Roc.

30-12-1982: El PSUC anuncia que inclourà a dos independents en la propera candidatura 
municipal.

1-1983: Una sentència judicial fa retornar a l'Ajuntament 150 milions en concepte de pujades d'impostos d'escombraries i guals (el consistori diu que només són 40 milions).

12-1-1983: $\quad$ Comença una vaga a TUSA

15?-1-1983: Primera sentència judicial favorable als inquilins del PMVRL del Maresme.

11-3-1983: $\quad$ Acord entre Ajuntament i habitants de la urbanització La Vallensana. Podran ser-hi durant 75 anys.

14-4-1983: Inauguració oficial de l'Hospital Germans Tries i Pujol (Can Ruti) pel president de la Generalitat tot i que només funciona parcialment.

8-5-1983: $\quad$ Eleccions Municipals: PSC-PSOE 12 regidors; PSUC 11; CIU 3, AP-PDP-UL 1. No hi ha entesa entre PSC-PSOE i PSUC.

24-5-1983: Després de ser enllestit Alcalde, Joan Blanch és xiulat a la Plaça de la Vila.

2-7-1983: Detenció d'Andreu Solsona, ex-membre dels Joglars i d'altres persones de l'LCR, MCC i PCC acusats de ser de Terra Lliure.

5-7-1983: L'empresa Rovira i Bachs accepta traslladar la seva factoria de Llefià (que havia provocat nombroses protestes veïnals per les molèsties que ocasionava).

8-7-1983: $\quad$ Andreu Solsona es posat en llibertat a espera de judici.

20-7-1983: S'inaugura l'accés a l'Hospital de Can Ruti.

9-1983: Destitució del director Silvestre Ramon de RCB. L'afectat diu que ha estat per motius polítics.

10-11-1983: Dimissió de la regidora independent del PSUC Armonía Rodríguez.

2-12-1983: Continua la lluita dels veïns del Maresme per impedir més desnonaments. Uns cinquanta veïns ocupen l'ambulatori de Sant Roc.

Entitats, sindicats i partits de l'oposició donen suport als veïns.

27-12-1983: Una jove de 24 anys, mor per una ganivetada d'un menor al Parc de les Palmeres de Llefià.

3-1-1984: $\quad$ Una sentència dona la raó a l'Ajuntament en el tancament del Bingo.

11-1-1984: $\quad$ Noves vagues intermitents a TUSA per l'acomiadament d'un representant sindical. Continuen fins el dia 26 quan l'empresa readmet a l'acomiadat.

16-1-1984: Manifestació de 1.000 persones a favor dels treballadors de Construcciones Famadas i en protesta per la crisi i els tancaments d'empreses.

2-1984: $\quad$ L'Hospital de Can Ruti encara no és plenament operatiu.

2-2-1984: Tancament de comerços a Llefià denunciant la inseguretat.

6-2-1984: Un adroguer mor en un atracament al barri del Remei.

Psicosi d'inseguretat a Badalona. 
17?-2-1984: Detenció de tres joves acusats de la mort de l'adroguer. La mare d'un defensa la innocència del seu fill.

20/21-2-1984: Tancament dels comerços en protesta per la inseguretat a diverses ciutats de l'Estat.

3-1984: 20 famílies d'un immoble contra la instal-lació d'uns jutjats al seu portal. Actes de sabotatge per impedir-ho.

5-3-1984: $\quad$ Membres de la Comissió d'Aturats de CCOO ocupen un despatx de l'Alcaldia.

10-4-1984: $\quad$ Calen foc a una caseta de CiU.

Joan Blanch ofereix un pacte a CiU i PSUC (en realitat més als primers).

5-1984: $\quad$ Els ATS dels dispensaris de Pomar i Sant Roc enfrontats amb l'Ajuntament.

1-6-1984: $\quad$ El PSC-PSOE perd una moció al votar PSUC, CIU i AP conjuntament una crítica a la tria de Pasqual Maragall com a pregoner de les festes de maig.

3-6-1984: $\quad$ S'aprova el PERI de Montigalà amb l'abstenció del PSUC.

L'MCC exigeix la preservació de tot Montigalà.

14?-6-1984: Un grup de joves denuncia a la Guàrdia Urbana per maltractaments.

24-6-1984: Nou atemptat contra la casa de Màrius Díaz.

7-1984: $\quad$ Es posa en funcionament un tram del col-lector de Llevant.

9-7-1984: $\quad$ S'aproven els pressupostos amb els vots favorables de PSC-PSOE i CiU. PSUC vota en contra i AP s'absté.

8-1984: $\quad$ Constitució del Consell Econòmic i Social de Badalona (òrgan consultiu).

10-1984: $\quad$ Es creen cooperatives de joves en atur amb suport de l'Ajuntament.

Es comença a treballar per refundar la FAVB a Badalona.

4-10-1984: $\quad$ Calen foc un taller mecànic propietat del regidor d'AP.

9-10-1984: $\quad$ Vaga dels treballadors de TUSA per incompliment del conveni.

11-1984: $\quad$ Protesta dels mestres del CEIP Rafael Alberti (Llefià) per que es construeixi un col-legi definitiu en condicions i abandonar els barracots. Talls de trànsit i manifestacions.

9-11-1984: Mil persones es manifesten per la pau i contra l'OTAN.

28-11-1984: $\quad$ Es signa el pacte de govern entre PSC-PSOE i CiU.

29-11-1984: Es desconvoca la vaga de TUSA.

4-12-1984: Protestes escolars a Badalona. 5.000 persones es manifesten a la ciutat en defensa de l'escola pública i criticant la Generalitat. (també hi ha protestes a Santa Coloma).

15-12-1984: Assemblea de refundació de la FAVB.

18-12-1984: Representants de la Generalitat, l'Ajuntament i la Corporació donen llum verda al projecte de Montigalà. 
1-1985: Disputa entre els Ajuntaments de Badalona i Sant Adrià pel nom d'una estació de metro.

23-1-1985: $\quad$ Es presenta el programa d'actuació de l'Assemblea en defensa de l'escola pública de Badalona.

29-1-1985: Quatre-cents alumnes de batxillerat es concentren davant l'Ajuntament de Badalona en protesta per l'estat del seu centre.

2-1985: $\quad$ Comencen les obres de remodelació de l'Hospital Municipal.

28-2-1985: $\quad$ Aprovació definitiva del PERI de Montigalà. El PSUC vota en contra. L'AVV de Sant Crist es posiciona en contra del PERI de Montigalà.

6-3-1985: $\quad$ Ocupació per part d'un centenar de joves d'una oficina del INEM.

2?-4-1985: Sis entitats signen un manifest contra el PERI de Montigalà-Batllòria (PSUC, PCC, MCC, FAVB, CCOO i Col-lectiu Montigalà).

14-4-1985: $\quad$ Acte públic de constitució de la FAVB al poliesportiu de Llefià.

22-4-1985: $\quad$ El metro arriba a Badalona i Sant Adrià.

23-4-1985: $\quad$ Comencen les protestes a Pomar per la supressió del BS-TP. Concentracions, talls de trànsit i segrest d'autobusos. Dos vehicles són apedregats.

24-4-1985: $\quad 1.000$ veïns de Pomar fan talls de trànsit. Un conductor ferit per una pedrada en no voler aturar l'autobús. Continuen els segrestos d'autobusos.

26-4-1985: Se suspèn el Ple en previsió d'incidents amb els manifestants de Pomar.

27-4-1985: Concentració de manifestants de Pomar davant el domicili de Joan Blanch.

28-4-1985: $\quad$ Tres-cents manifestants de Pomar tornen a tallar el trànsit.

El PSC-PSOE acusa a PSUC, PCC i MCC de manipular als veïns i de practicar "mètodes terroristes".

30?-4-1985: L'alcalde Joan Blanch justifica els canvis en les línies d'autobusos i denuncia intents d'agressió contra la seva persona.

5-1985: $\quad$ Badalona obté una Zona d'Urgent Reindustrialització (ZUR).

2-5-1985: $\quad$ Manifestació de 2.000 persones convocada per la FAVB en protesta per la supressió de les línies d'autobusos que arribaven a Pomar. El nombre d'autobusos segrestats és de 14 .

Per la matinada hi ha un primer intent policial de recuperar els autobusos segrestats que és avortat per la ràpida reacció del veïnat.

3-5-1985: $\quad 500$ policies ocupen Pomar de matinada i recuperen els autobusos segrestats. El mateix dia 3 autobusos són segrestats a Sant Adrià i portats a Pomar.

6-5-1985: $\quad$ Es reprenen les negociacions entre els veïns de Pomar i l'Ajuntament. Després d'una tensa assemblea on el cotxe de l'alcalde va ser colpejat s'arriba a un principi d'acord. Una línia de TUSA modificarà el seu recorregut per fer gran part de l'antic trajecte del BS-TP. 
7-5-1985: $\quad$ La FAVB es posiciona a favor de l'acord i de que una línia de TUSA presti el servei.

8-5-1985: $\quad$ Una assemblea veïnal a Pomar ratifica l'acord anterior.

20-6-1985: Badalona aturada per la vaga general.

25-6-1985: $\quad$ Apareix una taca de fuel-oil a la platja de Badalona.

27-6-1985: L'Ajuntament decideix tancar parcialment les instal-lacions de la CAMPSA a causa d'un vessament de fuel-oil al mar.

7-1985: Veïns d'Artigues i Llefià tallen el trànsit en protesta per les molèsties ocasionades per una fàbrica d'amoníac.

8-7-1985: $\quad$ Els regidors del PSUC abandonen el Ple de pressupostos.

15-7-1985: Dos nens es cremen amb residus químics d'una fàbrica.

18-7-1985: La CMB aprova el projecte de remodelació de la Plaça Trafalgar. L'Ajuntament presenta el projecte a les AVV's de Llefià, tres de les quals manifesten el seu desacord.

9-1985: Diferents hipermercats i grans magatzems demostren interès per instal-lar-se a Montigalà. Oposició dels comerciants de Badalona.

12?-9-1985: Jutjats tres joves per l'assassinat d'un adroguer a Badalona.

10-1985: $\quad$ Les AVV's de Sant Antoni, Sant Mori i Sant Joan de Llefià Baix es mostren disconformes amb el projecte de remodelació de la Plaça Trafalgar que inclou una via ràpida. Apareixen pancartes al barri en contra. Ferran Bello, regidor del districte acusa a PCC i MCC d'instrumentalizar la protesta.

Diversos atemptats neofeixistes a Badalona.

Veïns de Bufalà s'oposen a la privatització d'un solar per una immobiliària.

17-10-1985: $\quad$ Manifestació convocada per la FAVB contra la pujada de la contribució urbana. Les protestes continuen durant tot el mes. L'Ajuntament es nega a parlar amb els veïns.

27-10-1985: 500 persones es manifesten contra l'OTAN.

11-1985: $\quad$ Suspensió de pagaments de la Clínica del Carme.

L'Ajuntament crea una societat anomenada Reactivación Badalona S.A.

Opinions creuades entre l'AVV Sant Antoni i el regidor Ferran Bello sobre el projecte de la Plaça Trafalgar.

1-11-1985: Crítiques a les pujades de sou de l'Alcalde i alts càrrecs municipals de confiança (en alguns casos arriben al $40 \%$ ).

5?-11-1985: Dos atracadors a una sucursal bancària de Coll i Pujol amenacen amb una falsa bomba.

12-1985: $\quad$ Proposta dels accionistes de la Piher per salvar l'empresa.

Creació de l'empresa municipal Engestur.

2-12-1985: $\quad$ S'inaugura un centre de desintoxicació d'heroïnòmans.

21-12-1985: Un tens Ple aprova iniciar les obres de la Plaça Trafalgar (Llefià) amb el vot 
favorable de PSC-PSOE i CiU (el PSUC vota en contra)

$\underline{1986-1987}$

15-1-1986: La CAMPSA fa públic que desmantellarà les seves instal·lacions a Badalona.

8-1-1986: $\quad$ Els partits i organitzacions contraris a l'OTAN acusa a l'Ajuntament de tapar murals reivindicatius al respecte.

2-1986: $\quad$ Maniobres del PSC-PSOE per canviar la correlació de forces dins les AVV's del Barri de Llefià. Canvi de Junta a Sant Joan de Llefià i nou posicionament d'aquesta AVV, que abandona la crítica a l'Ajuntament.

1-2-1986: $\quad$ L'Ajuntament de Badalona aprova el Pla Especial del front marítim.

3-2-1986: $\quad$ Tancament patronal de Motoplat.

20-2-1986: Veïns esborren les marques d'obra a la Plaça Trafalgar (Llefià).

24-2-1986: La Guàrdia Urbana carrega contra els manifestants que impedien les obres a la Plaça Trafalgar. Nombrosos ferits i contusionats. Inici de la "Batalla de Trafalgar". Manifestacions diàries i accions de sabotatge.

Divisió de la Guàrdia Urbana davant aquests fets. Gabriel Cardona reprimeix les protestes dels agents disconformes amb la repressió als veïns.

3-1986: $\quad$ L'Ajuntament recupera pel municipi els terrenys militars del Turó Caritg. Continua la lluita a la plaça Trafalgar.

Sancions a dos guàrdies urbans.

10-3-1986: Detenció de tres persones a la Plaça Trafalgar, una d'elles és el regidor del PSUC Manuel Armentero (son posats en llibertat poc després).

La Guàrdia Urbana no pot aturar la protesta. Arriba la Policia Nacional i s'intensifica la repressió.

11-3-1986: Violents enfrontaments entre policia i veïns a la Plaça Trafalgar. La policia denúncia a un militant del PCC per portar pedres.

La FAVB intenta mediar en el conflicte sense èxit.

12-3-1986: $\quad$ Referèndum de l'OTAN.

16-3-1986: Tancament de joves aturats a una oficina de l'INEM.

3-4-1986: $\quad$ Càrrega policial contra un grup de dones que protestaven al matí a la Plaça Trafalgar.

4-4-1986: Intervenció molt violenta de la Policia Nacional a la Plaça Trafalgar. Diversos ferits i contusionats, un d'ells de gravetat. 7 persones detingudes, de les quals dues van passar tres dies als calabossos.

8-4-1986: $\quad$ La FAVB dona suport a l'AVV de Sant Antoni i envia escrits al governador civil i a l'alcalde Joan Blanch.

9-4-1986: Una manifestació als calabossos en solidaritat amb els detinguts de Trafalgar es dissolta violentament per la Policia Nacional i la Guàrdia Urbana.

11-4-1986: $\quad$ El PSUC dona suport a la proposta de les AVV's de Sant Mori i Sant Antoni de fer un referèndum al barri. El PSC-PSOE s'oposa. 
Manifestació dels treballadors de PIHER.

20-4-1986: L'Arxiprestat de la perifèria de Badalona denúncia la falta de diàleg i la repressió policial a la Plaça Trafalgar.

5-1986: $\quad$ La conflictivitat decau a la Plaça Trafalgar. Les obres avancen.

L'empresa PIHER fa suspensió de pagaments.

Tensions entre PSC-PSOE i CiU a l'Ajuntament.

6-1986: $\quad$ Una caseta electoral de CiU és destrossada a Llefià.

4?-6-1986: $\quad$ Nova fuita d'àcid sulfurós a l'empresa CROS.

7-6-1986: $\quad$ Estrena de nous autobusos a les línies TUSA de Badalona que s'han convertit recentment en Societat Anònima Laboral (a la pràctica una empresa controlada per l'UGT i el PSC-PSOE).

21-6-1986. Cinquena fuita de l'empresa CROS.

27-6-1986: $\quad$ Nova fuita de diòxid de sofre a CROS.

28-6-1986: Carta a El Periódico de Catalunya d'Ángel Navarro denunciant els fets i la repressió a la Plaça Trafalgar.

31-7-1986: Comunicat conjunt de PSUC, PCC, ERC, MCC, ENE, CCOO i FAVB en contra del projecte d'urbanització de Montigalà-Batllòria.

27-8-1986: L'Ajuntament anuncia que obrirà un expedient sancionador a l'empresa CROS per les nombroses fuites.

9-1986: $\quad$ Crisi interna a CDC.

10-1986: $\quad$ La FAVB vol ser reconeguda com a entitat d'interès públic. Campanya de la mateixa entitat a favor d'un Reglament de Participació ciutadana.

4-10-1986: $\quad$ Nova fuga de la CROS.

10-10-1986: Manifestació de 3.000 nens en protesta pels escapaments de la CROS.

20-10-1986: Tancada de treballadors de la Clínica del Carme a l'Ajuntament de Barcelona.

23-10-1986: L'Ajuntament li entrega el "premi per la pau” a Olof Palme.

11-1986: Judici i absolució de Manuel Sousa (PCC) que havia estat denunciat per injúries i calumnies per regidor de seguretat ciutadana Juan Felipe Ruiz arran els fets de la "Batalla de Trafalgar".

4-11-1986: $\quad$ El col-legi Dauradell, proper a l'Opus, acomiada a un professor per no fer servir corbata.

5-11-1986: $\quad$ Acomiadament de 5 treballadors de la Clínica del Carme.

6-11-1986: La CMB aprova el PERI de Montigalà-Batllòria.

20-11-1986: Vaga en la Clínica del Carme per la reducció de plantilla que afecta a 55 persones.

27-11-1986: Es fa públic que la FAVB es querellarà contra l'Alcalde per incompliment del 
programa electoral, en especial per no acomplir la promesa de crear un reglament de participació ciutadana.

10-12-1986: Finalitza la vaga en la Clínica del Carme al considerar Magistratura il-legal la reducció de plantilla.

12/13?-12-1986: Detenció de tres persones, una d'elles de Badalona, acusades de pertànyer a ETA. Manifestació a Badalona el dia 13 de dues-centes persones en solidaritat amb el detingut.

1-1987: $\quad$ Es desestima la denúncia presentada per membres de la Guàrdia Urbana contra els regidors del PSUC Manuel Armentero i Luisa Longas.

9-1-1987: $\quad$ Nova fuita de diòxid de sobre de CROS.

18-1-1987: Finalitza el termini concedit per l'Ajuntament a l'empresa CROS per que subsanar les deficiències que provoquen les fuites.

28-1-1987: 300 treballadors de PIHER Badalona es manifesten davant la delegació de Govern.

29-1-1987: Incident entre uns guàrdies urbans i un fill de Màrius Díaz, que és detingut i colpejat.

2-1987: $\quad$ PSUC, ENE i PCC arriben a un acord per presentar-se junts a les properes eleccions municipals.

16-2-1987: Els treballadors de la Clínica del Carmen denuncien greus anomalies que posen en perill la salut dels pacients.

2-1987: Botiguers de Badalona amenacen amb mobilitzacions contra el centre comercial Continente previst a Montigalà.

28-2-1987: Visita sorpresa de Jordi Pujol a Sant Roc i Llefià.

2-3-1987: $\quad$ Presentació d'Inciativa per Catalunya a Badalona.

13-3-1987: Defensors de l'Escola Pública ocupen un solar per reclamar un institut.

16-3-1987: Assemblea de 400 persones de la Unió de Botiguers del Baix Besòs on planifiquen protestes contra el centre comercial Continente de Montigalà.

18-3-1987: Judici i absolució de dos veïns detinguts durant la Batalla de Trafalgar.

27-3-1987: $\quad$ CiU aprova al Parlament la supressió de la CMB.

9-4-1987: $\quad$ Els municipis que formaven part de la CMB creen una Mancomunitat.

26-4-1987: Milers de persones protesten a Montigalà contra la instal-lació d'un Hipermercat Continente.

10-4-1987: Manifestació en protesta pels atemptats i agressions de l'extrema dreta a membres de la Crida i ERC.

29-4-1987: Es revoca la sentència que va condemnar a tres joves a la presó per l'assassinat d'un adroguer per falta de proves (després d'estar tres anys en presó).

30-4-1987: Querella de la Unió de Botiguers del Baix Besòs contra l'alcalde Joan Blanch. 
11-5-1987: Detenció de quatre joves després d'un concert durant les festes de Badalona.

14-5-1987: $\quad$ Compra dels terrenys de la CROS, que marxarà de Badalona.

CiU acusa al PSC-PSOE de fer campanya electoral amb els diners dels contribuents.

16-5-1987: Inauguració de la Plaça Trafalgar amb la presència de Pasqual Maragall.

25-5-1987: $\quad$ La Clínica del Carme tanca definitivament.

10-6-1987: $\quad$ Eleccions municipals: PSC-PSOE 13 regidors, IC 10; CiU 4.

1-7-1987: $\quad$ IC dona suport a la investidura de Joan Blanch com Alcalde.

14-7-1987: $\quad$ Un interventor judicial és segrestat pels treballadors de PIHER.

20-7-1987: $\quad$ Manifestació d'un centenar de treballadors de PIHER.

29?-7-1987: $\quad$ PSC-PSOE i IC formalitzen el seu pacte a l'Ajuntament de Barcelona.

9-9-1987: $\quad$ Un miler de persones es manifesten a Llefià contra la vilolació d'una veïna feta per un Policia Nacional que vivia al mateix immoble que l'agredida. Detenció posterior.

10-1987: $\quad$ La Generalitat paralitza temporalment el projecte d'Hipermercat a Montigalà.

\section{Cronologia Santa Coloma de Gramenet.}

1954:

1955-1960

1958:

1959:

1961-1965

1963:

1965:

\section{$\underline{1966-1970}$}

30-12-1965:

Lluís Mutlló Salgot (1954-1959) substitueix en l'Alcaldia a José Mas Roger.

Un full volant crida als veïns del barri de Singuerlín a una reunió per fer una entitat veïnal al barri.

Víctor Jove Miguillón (1959-1965), substitueix en l'Alcaldia a Lluis Mutlló Salgot.

Eleccions al Tercio Familiar. Candidatura oficial anomenada Barriadas. Inclusió de Albert Perich Dou (un acabalat comerciant, alcalde de barri del Singuerlín i membre del Sometent Armat), Francisco de Miguel Fajardo (president de l'Associació de Veïns de Santa Rosa,) i Victor Ramos Cano, fill d'un guàrdia civil i resident al barri del Fondo.

Antonio Romero Tutusaus (1965-1970) substitueix en l'Alcaldia a Víctor Jove Miguillón.

Arriben a Santa Coloma els sacerdots Joan P. Sayrach (parròquia de Sant Joan Baptista, barri del Fondo), Jaume Cabré (parròquia de Sant Miquel, barri del Singuerlín), Josep Esquirol (parròquia de Sant Jaume del barri del Raval) i Joaquim Trias (parròquia de Sant Josep Oriol al barri de Riu Nord).

Santa Coloma té oficialment 58.165 habitants. 
1-10-1966: Inauguració de l'Obra Social del Singuerlín.

30-11-1966: Un ple de l'Ajuntament aprova la creació del Patronat Municipal de la Vivienda (PMV).

23-2-1967: El Consistori dona el vist i blau al Pla Parcial de la Torre Balldovina i Can Jané.

1968: $\quad$ El Consistori aprova una Disposició de volums d'unes parcel·les propietat del Patronato Municipal de la Vivienda en la zona de Les Oliveres i Can Franquesa.

1-5-1968: Celebració del 1er de Maig en la muntanya pel PSUC per sectors cristians, Comissions Obreres i Can Franquesa.

2-9-1968: Diversos dies de boicot a l'autobús municipal 3.

8-11-1968: Càritas Diocesana aprova els estatuts del Centre Social Arrabal Santa Rosa.

1-1969: $\quad$ Apareix el primer núm. de la revista Grama.

20-1-1969: El Ministerio de la Gobernación aprova legalment el Patronato Municipal de la Vivienda.

9-12-1969: Per decret del Consejo de Ministros es concedeix el títol de Ciutat al poble de Santa Coloma de Gramenet.

8-9-1970: L'industrial Juan Porta Bussoms (germà de Pablo Porta) és nombrat Alcalde de Santa Coloma.

1-11-1970: $\quad$ Es constitueix legalment ASPANIDE.

29-12-1970: Un incendi atura les activitats del Consultori de la Seguretat Social del carrer Dr. Ferran.

30-12-1970: El barri de Singuerlín té un dèficit d'infraestructures de 1.731 milions de pessetes. Santa Coloma té oficialment 105.870 habitants.

$\underline{1971-1975}$

24-2-1971: $\quad 2.000$ veïns exigeixen en manifestació una clínica d'assistència sanitària.

10-3-1971: $\quad 10.000$ veïns tornen a sortir al carrer reivindicant la clínica i una sanitat de qualitat. Enfrontaments amb les Forces d'Ordre Públic.

24-3-1971: $\quad$ Tercera manifestació amb poca participació per la pressió policial i discrepàncies internes en el Comitè Unitari.

3-1971: La immobiliària VIPES, que té paralitzada les seves obres al barri de Singuerlín.

1-4-1971: $\quad$ Entra en servei, provisionalment, un Consultori de la Seguretat Social en la Rambla de Sant Sebastià, núm. 49.

1-6-1971: $\quad$ Es distribueix de manera clandestina l'informe "La Lucha del Ambulatorio", primer document il·legal (segons Marcelo López Ródenas) sobre les lluites reivindicatives del barri.

12-1971: Esclata l'afer de la Immobiliària Aloy-Muntané-Guinart. 
1-1-1972: $\quad$ Inauguració del Centre Social de Santa Rosa.

18-3-1972: $\quad$ Còctel molotov contra la parròquia major de Santa Coloma.

20-3-1972: $\quad$ Manifestació-sentada exigint semàfors en l'encreuament de l'Av. del Generalísimo (actualment Generalitat) amb Monturiol.

26-3-1972: 1.000 manifestants demanen semàfors al barri del Raval.

1-4-1972: $\quad$ Entra en funcionament el nou Ambulatori-Clínica maternal de la Seguretat Social.

5-1972: $\quad 627$ habitatges amb problemes a Les Oliveres.

3-6-1972: $\quad$ L'Ajuntament instal-la finalment els semàfors reivindicats a la manifestació del dia 20-3.

21-6-1972: $\quad$ Segrest del núm. 39-40 (març-abril) de la revista Grama per l'article "Informe sobre la delincuencia: los criminales de guante blanco."

26-6-1972: $\quad$ Promoció municipal de la Reestructuració de l'edificabilitat del polígon de Can Zam i complementació del seu traçat viari.

7-1972: Dèficit de places escolars alarmant a Santa Coloma.

7/8-1972: $\quad$ Número especial de la revista Grama (especial King Kong) on es denuncia que Santa Coloma té un dèficit de 4.561 milions en infraestructures. S'analitzen també pels diferents barris.

18-7-1972: $\quad$ Inauguració parcial del barri de Les Oliveres.

8-1972: $\quad$ Aute de processament contra el director de Grama pel suposat delicte de "propaganda il·legal" per l'article "Informe sobre la delincuencia: los criminales de guante blanco."

9-1972: $\quad$ Inauguració del Centre Social “Amigos del Fondo" (important paper de J. Sayrach i d'altres membres del GOA).

6-9-1972: $\quad$ L'alcalde Pablo Porta diu en una roda de premsa que en dos anys Santa Coloma estarà "urbanitzada".

10-1972: $\quad$ S'instal-len semàfors a la Carretera de Sant Andreu després de vàries protestes veïnals. No obstant, encara no s'han posat a la Carretera de la Roca, objecte de demandes similars.

Dèficit de 2.000 infants sense escolaritzar. El III Plan de Desarrollo preveu la construcció de 172 aules.

Problemes amb els accessos a Santa Coloma (insuficiència de la "carretera de los cuarteles")

25/28-10-1972: Afer de la Immobiliària Montaner, Aloy i Guinart. 1.500 veïns afectats per les irregularitats d'aquesta que va hipotecar els pisos sense coneixement dels compradors a terminis.

29-10-1972: $\quad$ El Ple aprova l'adquisició de la Torre Valldovina.

27-11-1972: Manifestació veïnal a Les Oliveres exigint la qualificació de renda limitada de les edificacions i altres millores pel barri. Hi participen varis centenars de persones. 
28-11-1972: Nova manifestació de veïns de Singuerlin, Les Oliveres i dels pisos de la Muntanya. Agressió a Lluís Hernández (segurament amb complicitat policial). Varis centenars de persones.

12-1972: $\quad$ Pressupost d'onze milions de pessetes per 1973 de l'Ajuntament de Santa Coloma de Gramanet. Increment respecte l'anterior del trenta quatre per cent."

1-1973: $\quad$ Les parròquies de Santa Coloma de Gramenet fan públiques les noves normes per determinades cerimònies religioses dins el context de la celebració d'unes Jornades Pastorals.

El Ministerio de la Vivienda concedirà la renda limitada a Les Oliveres, que estava en entredit per unes irregularitats immobiliàries.

Nova escola per disminuïts psíquics a càrrec d'ASPANIDE.

11-1-1973: Onze dies de vaga del personal sanitari paralitzen les activitats de l'Ambulatori de la seguretat social.

29?-1-1973: Atracament a una sucursal de la Caixa d'Estalvis de Sabadell situada l'Av. Del Baró, on sustreuen 340.000 ptes.

30-1-1973: Manifestació en la Carretera de la Roca exigint semàfors.

2-1973: L'escola activa de pares del Raval elabora un document sobre la situació escolar a Santa Coloma de Gramenet.

Robatori de llibres de temàtica socio-política i fitxers de socis al Centre Social de Santa Rosa i al Centre Juvenil de Foc Nou (el primer ja havia patit diversos assalts.). Multa de 25.000 pessetes a l'antic director de Grama J. P. Sayrach per l'article "Informe sobre la delincuencia: los criminales de guante blanco."

7-2-1973: $\quad$ Manifestació d'un centenar de dones que tallen la Carretera de la Roca a l'alçada del carrer José Martorell. Dissolta per la Policia Municipal. Retenció de 5 dones conduïdes a l'Ajuntament, concentració de suport i identificació de dues més.

20-2-1973: 250 persones es manifesten a la Carretera de la Roca entre Santa Coloma i Sant Adrià demanant un semàfor.

3-1973: $\quad$ Perill d'enderrocament (per runa) d'un monument del segle XI, la Torre Balldovina, que l'Ajuntament havia adquirit fa 4 mesos però en el que no ha fet cap obra de conservació i restauració.

Un estudi quantifica un bar per cada 325 habitants de Santa Coloma de Gramenet. Denúncies a la premsa per la insuficiència de la plantilla del Jutjat Municipal (només hi ha nou funcionaris.

15/18-3-1973: Manifestacions al barri de Santa Rosa per una subvenció a una escola de preescolar gestionada pels propis pares.

22?-3-1973: Un nen de 12 anys és agredit greument per 5-6 joves que li tiren benzina i calen foc.

1-4-1973: $\quad$ El Ple aprova concedir la medalla d'or de la Ciutat a Franco.

4-1973: $\quad$ Articles a la premsa que denuncien les mancances de barris com el Raval (en especial la falta d'enllumenat), del conflicte amb els terrenys de Can Zam i de la falta de mercats (reivindicació d'un al Singuerlín). També de la falta alarmant de centres escolars.

5-1973: Es comença a retirar la línia d'alta tensió que passava pel carrer Jacint Verdaguer. 
Un antic alcalde i tres ex-regidors de l'Ajuntament acusats dels delictes d'estafa i suborn (és una denuncia de 1966).

17-5-1973: $\quad$ Manifestació de 400 veïns del Raval reclamant llums.

20-5-1973: $\quad$ Publicació a La Vanguardia Española de la carta d'un grup de pares denunciant la falta d'informació sobre la matriculació dels nens a les escoles i per la manca de places públiques.

24-5-1973: $\quad 1.000$ veïns es manifesten reivindicant llums pels barris del Raval i Santa Rosa. (amb espelmes).

6-1973: $\quad$ Articles a la premsa sobre la "Cooperativa" VIPES i les seves edificacions a La Guinardera, sobre la delinqüència juvenil i sobre la manca de locals pels jubilats (6.000).

7-6-1973: Manifestació de 600 persones del barri del Raval amb torxes per reclamar llum. Dissolta per la Policia i Guàrdia Civil i detenció d'una persona que va ser posada en llibertat poc després.

7-1973: $\quad$ Es comença a instal·lar enllumenat públic al Raval.

5-7-1973: 100 veïnes del barri de Can Franquesa tallen el trànsit exigint transport públic fins el barri.

11-7-1973: $\quad$ Aturada de 3 hores de les treballadores de Casadeport en demanda de millores salarials, jornada de $40 \mathrm{~h}, 25$ dies de vacances..

13-7-1973: L'Ajuntament aprova el Pla Parcial del Sector Motocross (que tindrà una forta oposició veïnal).

29-7-1973: Visita del governador civil Pelayo Ros a Santa Coloma.

8-1973: $\quad$ Expedient administratiu contra la revista Grama núm. 52 (abril) i el seu director Humberto Roma per dos articles: "Un obrero muerto en San Adrián" i "Las últimas horas del Che".

4-8-1973: $\quad$ Una nena morta per una tromba d'aigua al ensorrar-se un mur.

10-9-1973: Batalla campal a la Plaça del Rellotge entre "Los Correas" i altres joves del moviment popular.

11-9-1973: Continua la tensió a la Plaça del Rellotge. La policia impedeix un nou enfrontament entre joves "procedents d'un Centre Social" i "Los Correas".

19-9-1973: Manifestació contra el cop d'estat a Xile. Varis centenars de persones al barri del Fondo. Subhasta dels blocs de VIPES a La Guinardera.

11-1973: $\quad$ Aprovació en el Ple d'una modificació urbanística per la futura construcció del mercat de Singuerlín i aprovació de la proposta d'un complex poliesportiu a Can Zam.

No hi ha eleccions al Tercio Familiar a Santa Coloma (hi ha tants candidats com places. 4 dels 5 candidats aprovats són Alcaldes de Barri.

12-11-1973: Inauguració de la Residència-llar de jubilats de la Seguretat Social al barri del Singuerlín (av. Ramon Berenguer). 
1-12-1973: $\quad$ Manifestació de 200 dones de Singuerlín que van marxar cap el Fondo reivindicant un Mercat pel barri.

4-12-1973: $\quad$ Atracament a una sucursal de la Caja de Ahorros Layetana.

9-12-1973: Finalitza el tancament de diverses persones i els sacerdots de Santa Coloma fet a l'Església Major.

13-12-1973: El Colegi d'Arquitectes de Catalunya i Balears i Associacions de Veïns impugnen el Pla Parcial del "Motocross". Posteriorment apareixen articles del tècnic i de l'Arquitecte municipal criticant això i contrarèplica d'Eugenio Madueño al Tele/ eXprés 15-12-73.

16-12-1973: Més de 500 veïns de Les Oliveres tallen el trànsit de la Carretera de La Roca durant 15 minuts.

18-12-1973: Detenció de tres homes i una dona per repartir propaganda.

24-12-1973: Es publica a Tele/ eXprés la contrarèplica de Alfonso Anguera Sampera (Arquitecte municipal) i Ramon Rovira Vilamitjana (advocat-urbanista) contra Eugenio Madueño.

25-12-1973: Es publica a La Vanguardia Española "Santa Coloma de Gramanet: Nota aclaratoria del Colegio de Arquitectos sobre el Plan Parcial Sector Motocross". Aclareixen que van fer l'informe a petició de dues entitats de la ciutat i 187 veïns afectats.

1-1974: $\quad 210$ milions de pressupost de l'Ajuntament per 1974.

2-1974: $\quad$ Notícies a la premsa del nyap urbanístic dels "Pisos de la Muntanya” (La Guinardera i Can Franquesa)i del deficient servei de recollida d'escombraries que presta l'empresa concessionària de la neteja.

23-2-1974: Manifestació de 200 persones, dones i nens, al solar “Las Viñas", en Singuerlín, reclamant un Mercat. CC: "Amplio déficit de zonas verdes en Santa Coloma de Gramanet".

3-1974: $\quad$ Un jutge imposa una multa de 394 pessetes per segrestar un autobús a una dona de Can Franquesa que reivindicava l'arribada del transport públic al barri.

12-3-1974: Dotze dies de boicot als autobusos municipals per la pujada de tarifes.

14-3-1974: Grups organitzats de piquets fan buidar els autobusos en arribar a Santa Coloma.

21-3-1974: $\quad$ Detenció del sacerdot Jaume P. Sayrach (posat en llibertat el mateix dia), rector del Fondo, pel tema del boicot als autobusos..

23-3-1974: Manifestació de dones i nens al solar de "Las Viñas", al Singuerlín exigint un Mercat.

25-3-1974: Detenció del vocal de l'AVV del Centre quan posava cartells (Ricardo Guix). Es posat en llibertat el mateix dia.

27?-3-1974: Incendi d'un autobús.

29-3-1974: $\quad$ Nous incidents al passeig Lorenzo Serra (Boicot busos). Detenció de 6 persones.

30-3-1974: 19 dies de boicot als autobusos. 
4-1974: $\quad$ Els veïns disconformes amb les obres del Passeig de la Salzareda.

5-4-1974: $\quad$ Incendi d'un segon bus prop de l'Esperit Sant.

13-4- 1974: 25 dies de boicot als autobusos, que comença a declinar.

25-4-1974: Polèmic ple on es tracta el pla d'urbanització del Passeig de la Salzareda, amb fortes crítiques veïnals de com s'estava fent. Discussió entre Matés i l'alcalde Porta al voltant d'això.

29-4-1974: $\quad$ S'aprova la revisió del projecte urbanístic del Pla Comarcal de 1953.

12?-5-1974: $\quad$ Festa infantil reivindicativa en el Motocross.

28-5-1974: $\quad$ Multa de 50.000 ptes. a Jaumpe P. Sayrach per l'afer del boicots als busos.

27-6-1974: $\quad$ Polèmic Ple on es parla de Can Zam i el regidor Matés denuncia que no s'estan preservant espais verds. S'aprova la urbanització del Passeig de la Salzareda.

8-7-1974: $\quad$ Enderrocament per explosió controlada de la “Casa de Dios", edifici en perill de runa on malvivien nombroses persones.

11 o 13?-7-1974: Reunió de l'Ajuntament amb veïns i veïnes al voltant de la revisió del Pla Comarcal. Els assistents abandonen la reunió indignats amb l'actuació de l'Alcalde Porta.

8-1974: $\quad$ Dimiteix el ponent de Cultura de l'Ajuntament, José Roset Uria. El regidor Matés s'oposa a la recepció d'obres de pavimentació de diversos carrers de Santa Coloma per no estar ben fetes.

20-8-1974: Assemblea de 500 treballadors a Casadeport per la readmissió d'un acomiadat el dia 18 dissolta per la policia. Comença una aturada per la seva readmissió.

26-8-1974: Continua l'aturada a la fàbrica Casadeport (que comportarà l'acomiadament de 220 treballadores).

28-8-1974: $\quad$ Aturades en Eurostil i Nespral en solidaritat amb Casadeport.

30-8-1974: $\quad$ Manifestació en solidaritat amb les treballadores de Casadeport.

3-9-1974: Torna el Boicot als autobusos davant l'incompliment de l'eixamplament de la "carretera de los cuarteles".

4-9-1974: Manifestació exigint l'eixamplament de la “carretera dels cuarteles”.

9-1974: Diferents conflictes laborals existents. 160 treballadors de Serconsa en baix rendiment, 60 acomiadats de Nespral i 280 de Casadeport.

Els veïns de les Olivers demanen escoles al regidor de Cultura de l'Ajuntament, Sr. Toral.

11-9-1974: $\quad$ Manifestació en Les Oliveres per la mort d'una dona atesa en l'ambulatori.

13/14-9-1974: Concentracions de treballadores davant de Casadeport (13) i tancament dels mateixos a l'església de Santa Rosa (14).

13-9-1974: $\quad$ Manifestació contra la mort d'una dona a l'ambulatori i en solidaritat amb les treballadores de Casadeport al Fondo. 
26-9-1974: Nou enfrontament al ple entre l'lcalde Porta i el regidor Matés per l'afer de la revisió del Pla Comarcal i pel dèficit escolar. Dimissions de Matés i Blas Muñoz en ser-lis atorgats "càrrecs cerimonials" en el nou cartipàs.

10-1974: Veïns de Santa Rosa impugnen el Plan Comarcal”.

Acord en Casadeport en un acte de conciliació fet abans del judici.

Veïns de Singuerlín també presenten alegacions al Pla Comarcal.

Crisi municipal. Rumors sobre la possible dimissió de l'Alcalde.

7/9-10-1974: Intervencions policials contra els obrers concentrats davant de Casadeport on continua el conflicte per un obrer acomiadat.

11-1974: $\quad$ S'ultimen les obres de canalització del riu Besòs.

Condemna d'un policia municipal pel delicte de lesions.

27-10-1974: Varis centenars de veïns reclamen el Motocross com a zona verda i d'equipaments, denunciant el fet que ja hi havia excavadores treballant. També han fet

impugnacions al Pla Comarcal. Intervenció de la força pública que desallotja als concentrats.

30-10-1974: $\quad$ Carta del Centre Social de Santa Rosa al Diario de Barcelona on es denuncia l'actuació de la força pública al Motocross.

31-10-1974: Tens Ple a l'Ajuntament que acaba suspès sense tractar-se tots els punts. Es reprèn el 6 de novembre sense finalitzar-se de nou.

11-1974: $\quad$ Campanyes públiques per defensar el Motocross i Can Zam com espais públics per construir zones verdes i/o equipaments.

Articles creuats a la premsa entre Miguel Molina Reinoso, President del Centre Social Arrabal-Santa Rosa i l'advocat assessor d'urbanisme de l'Ajuntament Ramon Rovira Vilamitjana per l'afer del Motocros (s'acusa al segon de assessorar a privats amb interessos al Motocross i alhora haver fet el Pla Parcial).

Denuncia per una construcció il-legal un pati interior a un regidor pel Tercio Coorporativo de l'Ajuntament, Juan Pérez Terol, presiden del Sindicat Local de la Construcció.

16-11-1974: Judici de faltes contra el director de Grama per uns articles referents a la mort de 6 treballadores de Haissa, sobre la pena de mort a un acusat d'un homicidi en Santa Coloma. Absolució.

28-11-1974: Intens Ple on entre d'altres aspectes es debat el Pla Parcial de Can Zam, aprovat amb 14 vots a favor i 4 en contra. Es desallotjada la sala.

1/3/4/5-12-1974: Entrevistes al Diario de Barcelona a tres dels quatre regidors que voten no al Pla Parcial. Respectivament: Rosset, Juan de Dios López del Moral, Matés i Génova.

3-12-1974: Reunió dels obrers acomiadats de “Cumbre” en l'església de Singuerlín.

7-12-1974: Roda de premsa al Centre Social del Singuerlín on es denuncia l'obstruccionisme del Govern Civil davant la legalització de nombroses AVV's que teòricament compleixen tots els requisits.

28-12-1974: Nou desallotjament del públic al Ple Municipal. Porta manifesta la intenció de dimitir.

Atracament d'una sucursal de Caja Laietana al Singuerlín. 
31?-12-1974: $\quad$ Escàndol per uns permisos a feriants expedits a mà per un regidor sense la signatura de l'alcalde ni del secretari de la Corporació.

Recurs del fiscal a l'absolució del director de Grama Humberto Roma.

1975: Legalització de les AVV's de Centre, Singuerlín, Guinardera, Santa Rosa, Raval, Oliveres i Fondo. Més tard es legalitzaran les AVV's de Riu Nord, Riera Alta,

Safaretjos i Barri Llatí.

1-1975: $\quad$ S'accepta la dimissió de l'alcalde Juan Porta.

Creació d'una Comissió Pro Amnistia (AVV's, càrrecs sindicals, familiars presos, comunitats cristianes).

Absolució del director i redactors de la revista Grama.

No s'accepta la dimissió del recaptador municipal fins que no s'aclareixen els comptes.

reunió feta en el CS Arrabal-Santa Rosa per parlar dels problemes del transport

públic.

5-1-1975: Les AVV's organitzen una "rebuda reivindicativa als reis mags". Participació de 2.000 persones demanant parcs i amnistia en una comitiva que des de diferents barris arriba a Can Zam.

20-1-1975: Roda de premsa al CS Arrabal-Santa Rosa per denunciar la manca de transports públics.

30-1-1975: $\quad$ Darrer Ple presidit per Porta Bussons.

2-1975: $\quad$ Pacte entre empresa i els treballadors en s'empresa de sanejament que té la concessió de neteja de Santa Coloma.

El 80 \% del Motocross serà destinat a serveis a instàncies del procurador Eduardo Tarragona. (els veïns reclamen el 100 \%).

11-2-1975: $\quad$ El Govern Civil comunica a la Corporació de Santa Coloma la tria de Blas Muñoz com alcalde.

15-2-1975: Reunió entre veïns del Raval i Santa Rosa amb Transports de Barcelona per demanar millors comunicacions i transports públics.

Legalització AVV Centre.

20-2-1975: $\quad$ Torna el boicot als autobusos pel retard en l'eixamplament de la "carretera de los cuarteles".

27-2-1975: Manifestació de més d'un centenar de persones en el barri del Raval exigint transports públics per al barri (on no arriben els busos).

3-1975: $\quad$ Autoritzades les AVV's de Oliveres i Singuerlín.

1-3-1975: $\quad$ Article a Tele/ eXprés sobre l'estafa immobiliària feta per un regidor de l'Ajuntament, actualment fugit de la justícia (Rosell).

4-3-1975: $\quad$ Demanda per usura contra Blas Muñoz. Presa de possessió d'aquest de l'alcaldia de Santa Coloma amb la presència del Governador Civil Martin Villa.

9-3-1975: $\quad$ Assemblea popular de més de 600 persones al Motocross. Apart del president del Centre Social, destaca la presència de l'Alcalde Blas Muñoz i el Procurador en Cortes Eduardo Tarragona. Les autoritats es comprometen a escoltar les demandes populars. 
18-3-1975: $\quad$ Enterrament d'un nen mort per un atropellament en la Carretera de la Roca. (el 14) Malestar per un article aparegut en una revista municipal Gramanet on es criticava a les mares que deixen els nens als carrers.

25-3-1975: $\quad 80$ persones en representació de AVV's i altres entitats entreguen una escrit signat per 1.461 persones a Blas Muñoz amb els principals problemes de Santa Coloma i amb les seves principals reivindicacions.

26-3-1975: $\quad$ Es puja el bitllet de l'autobús 1 pesseta. Nou boicot als busos.

2-4-1975: $\quad$ Es crema un Autobús de la línia 103 (en protesta per les pujades de tarifes).

4-4-1975: Comencen les obres a "la carretera de los cuarteles".

4-4-1975: $\quad$ Ple municipal que dona via lliure al projecte de Can Zam.

6-4-1975: $\quad$ Assemblea constitutiva de l'AVV Centre amb la presència de Blas Muñoz.

8-4-1975: Detenció de dos membres de l'AVV de Singuerlín a la sortida d'un banc on havien anat a demanar subvencions.

16-4-1975: Nou atropellament d'un nen a Les Oliveres.

20-4-1975: Assemblea constitutiva de l'AVV Les Oliveres.

22-4-1975: Tres atracaments en poques hores a Santa Coloma (dos benzineres i un garatge) Es torna a deixar de publicar la revista de l'Ajuntament Gramenet.

25-4-1975: Les AVV's del Raval i el CS Santa Rosa demanen la incompatibilitat de l'assessor jurídic d'urbanisme Ramon Rovira Vilamitjana per l'afer del Motocross al Procurador Eduardo Tarragona. Exigeixen també l'acompliment dels acords de l'Assemblea del mes passat.

27-4-1975: Festival infantil organitzat al Paseo de la Alameda.. Reivindicació del passeig com Zona Verda. Assemblea Constitutiva de l'AVV Santa Rosa.

5-1975: $\quad 400$ veïns de Les Oliveres porten 20 mesos negant-se a pagar fins que els seus pisos no es declarin de renda limitada.

1-5-1975: Dos ferits de bala per un policia quan intentaven impedir la detenció d'un tercer que repartia propaganda.

6-5-1975: Les AVV's Centro, Santa Rosa i Raval, més el CS Arrabal-Santa Rosa fan arribar un escrit al Governador Civil de queixa per la detenció i ferides a dos habitants de la ciutat (els anterior esmentats).

7-5-1975: $\quad$ Reunió dels aturats a l'edifici sindical per fer sentir les seves reivindicacions.

15-5-1975 : $\quad$ Situació molt delicada del PMV de Santa Coloma

Ple extraordinari on van assistir nombrosos veïns portant pancartes i adhesius reivindicatius de Can Zam, el Motocross i Les Vinyes. Les AVV's amenacen amb demanar la dimissió de l'Alcalde si són declarades zones edificables.

17-5-1975: 5 presidents d'AVV's demanen a Blas Muñoz que exposi al proper Ple la situació de Can Zam.

21/22?-5-1975: Un grup de 50 dones segresten unes màquines que estaven fent obres i exigeixen 
que aplanin una zona per fer jocs infantils. Les màquines i els obrers son "rescatats" per la policia.

29-5-1975: $\quad$ Es fa pública la pròxima creació d'una casa regional andalusa i esmenta que a Santa Coloma hi ha 40.000 andalusos.

29-30?-5-1975: Ple on es parla de la rehabilitació de la Torre Valldovina.

6-1975: La AVV de Singuerlín demana millors transports a l'Ajuntament i a Transportes de Barcelona, S. A.

Aprovació del Pla Parcial Especial Torre Valldovina per l'Entitat Municipal Metropolitanta de Barcelona a proposta de l'Ajuntament, que en teoria ha de servir per preservar l'edifici.

1-6-1975: $\quad$ Concurs de Paelles reivindicatiu al Motocross (AVV's Raval i Santa Rosa).

6-6-1975: Manifestació d'una cinquantena de dones pel barri del Singuerlín demanant murs de contenció, escoles i que arribin els autobusos.

20-6-1975: $\quad$ Sentència que condemna les vulneracions que va fer el Pla Parcial sector Noreste al Pla Comarcal de 1953 fetes pel consistori de Porta.

22-6-1975: $\quad$ Taula rodona a l'institut Puig Castellar organitzada per les AVV's per parlar de les necessitats d'equipaments de la ciutat.

24-6-1975: $\quad$ Entrevista a Diario de Barcelona als presidents de l'AVV Raval (José Maria Ballesteros) i Singuerlín (Eloy Jurado) on detallen la situació pèssima de la ciutat, dels seus barris així com les seves opinions respecte el consistori (demandes democràtiques).

27-6-1975: $\quad$ Polèmic ple on l'alcalde i la majoria de regidors es neguen a votar una moció que vol preservar els espais majors no edificats majors de $500 \mathrm{~m} 2$ (7 en contra, 5 a favor i 1 abandona el Ple).

Taula rodona-col·loqui sobre el Pla Parcial de Can Zam, suspès en la seva segona part pel delegat governatiu.

7-1975: $\quad$ Escrit de l'AVV de Santa Rosa contra els bars on s'exerceix la prostitució.

3-7-1975: $\quad$ Cessament del regidor Matés com a quart Tinent d'Alcalde i president de la Comissió Informativa de Treball Comunitari, Patrimoni Municipal i Parcs i jardins. Serà substituït per López del Moral.

8-7-1975: $\quad$ Ajornament fins el febrer del judici a VIPES, (que afecta als veïns de diversos habitatges de La Guinardera).

12 i 13-7-1975: Veïns de Santa Rosa netegen i acondicionen un solar entre els carrers Banús Alta e Irlanda i fan un parc infantil.

19-7-1975: $\quad$ Escrit de solidaritat de l'AVV de Singuerlín amb la de Sant Andreu (que ha sofrit un atemptat).

14 al 20-7-1975: Setmana d'urbanisme al CS Santa Rosa. Presentació d'un Pla Popular alternatiu al Pla Comarcal i al Motocross.

18-8-1975: Carta de l'AVV del Raval a l'Ajuntament reclamant transports públics pel barri.

23-8-1975: $\quad$ Acte de les AVV's dins la campanya “Can Zam per al Poble”. 
24-9-1975: Aprovació de l'AVV del barri del Riu, que fa la seva assemblea constituent el dia 25).

25-9-1975: Ple Municipal ple de gom a gom per membres de les AVV's. Al final s'aplaça la votació sobre Can Zam. Es rescindeix l'acord de neteja amb Serconsa.

27-9-1975: Es fa públic el "Manifest dels 51", un document alternatiu a la gestió municipal i on es demana un Ajuntament democràtic.

30-9-1975: Detenció de tres treballadors colomencs (José Marin, Andrés Pérez Ezquerra i Juan Moreno Rider).

10-1975: L'AVV de Singuerlín demana més transports públics.

14-10-1975: Dimiteix Ramon Rovira, assessor urbanístic de l'Ajuntament implicat en l'afer de Can Zam.

16-10-1975: 10 regidors i l'alcalde voten al Ple en contra de la proposta veïnal de destinar el $100 \%$ dels terrenys de Can Zam per equipaments diversos. Tampoc prospera una moció sobre els Equipaments presentada per tres regidors (Matés, Rosses i Callejón), que només obté 6 vots favorables i 11 voten en contra.

Pocs dies després es fa una carta de protesta per aquest fet al Consistori per part de les AVV's (Centre, Raval, Singuerlín i Oliveres).

11-1975: $\quad$ Dues noves línies d'autobús a Santa Coloma (arriben Singuerlín i Can Franquesa).

6-11-1975: $\quad$ Roda de premsa de les AVV's demanant la dimissió de tot el consistori.

Els veïns demanen que el Passeig de la Salzareda sigui un passeig i no una via ràpida. Reivindicacions de la recent $\mathrm{AVV}$ del Rio.

15-11-1975: Polèmica per que la policia municipal retira els cartells anunciadors de la revista Grama. La popular revista havia publicat el present mes un article sobre Can Zam.

18/19-11-1975: Visita del GC Martín Villa a Santa Coloma. Article a Diario de Barcelona on Blas Muñoz es defensa de les acusacions fetes per les entitats veïnals, Grama, i els sacerdots progressistes sobre el tema de Can Zam.

20-11-1975: Inauguració d'un local per jubilats al Fondo.

Nou autobús que va des del Singuerlín al metro de Sant Andreu (203).

25-11-1975: Acte de 3.000 persones reivindicant el Passeig de la Salzareda com a parc públic.

26-11-1975: Dinar de Blas Muñoz i dos tinents d'alcalde amb la premsa on volen justificar les seves actuacions.

28-11-1975: Ple municipal i nova destitució del tinent d'alcalde de "Desarrollo comunitario y parques y Jardines" (el tercer cesat per Bartomeu Muñoz). Boicot de les AVV's al Ple.

1-12-1975: Publicació de la "Carta abierta de los corresponsales de Santa Coloma de Gramanet al Alcalde" on denuncien les declaracions i crítiques a la premsa local fetes pel Blas Muñoz el dia 26.

5-12-1975: Desnonament del bloc 56 al carrer Irlanda per amenaça de runa. 
10-12-1975: 500 persones de Santa Coloma entreguen un escrit a l'Ajuntament criticant la roda de premsa que va fer Blas Muñoz

11-12-1975: Detenció de quatre treballadors de Santa Coloma (entre ells Francisco Téllez). El dia següent una delegació de membres d'AVV's i un sacerdot s'entrevisten amb l'alcalde per tenir més informació. Paral·lelament s'estava fent una concentració davant l'Ajuntament per demanar la dimissió dels regidors que van votar en contra de la preservació total de Can Zam.

13-12-1975: L'Ajuntament estudia la compra de terrenys a Can Zam.

16-12-1975: Resposta del director de Grama Humberto Roma a les recents declaracions de Blas Muñoz.

7-12-1975: Denúncia del jutjat de guàrdia del maltractaments (tortures) patits per Francisco Téllez. Poc després Justícia i Pau s'adreça a Fraga demanant explicacions.

19-12-1975: Denúncia pública de les AVV's de Santa Coloma de Gramanet de les tortures sofertes per Francisco Téllez a la caserna de la GC de Badalona. Envien un escrit al rei.

20-12-1975: Es publica una carta (Diario de Barcelona) dels metges del Hospital Clínic denunciant les tortures de Téllez. El mateix dia 1.000 manifestants surten al carrer exigint la seva llibertat. Enfrontaments amb la policia. Posteriorment s'enviaran notes de protesta al ministre de la Gobernació (Fraga). Una comissió de 12 persones representants de les AVV's visita la casa dels pares de Téllez. Familiars de detinguts amb altres persones encapçalen una marxa cap a l'Ajuntament, parcialment dissolta per la Policia Armada. Un grup aconsegueix arribar i entregar un escrit. (l'Alcalde no hi era).

27-12-1975: Els propietaris de Can Zam responen al director de Grama.

30-12-1975: 137.579 habitants censats oficialment a Santa Coloma.

Surten en llibertat sota fiança de 10.000 ptes. Téllez i els altres detinguts.

$\underline{1976-1980}$

4-1-1976: $\quad$ Cavalgada de Reis reivindicativa a Santa Coloma amb la participació de 2.000 persones.

6-1-1976: Milers de persones es manifesten fins a Can Zam reivindicant els terrenys per equipaments i zona verda. Cavalgades de reis reivindicatives als barris que flueixen fins els terrenys reclamats.

8-1-1976: Les AVV's de Centre, Singuerlín i Raval envien un escrit demanant permís per fer un acte d'homenatge a Téllez (membre de l'AVV Centre).

10-1-1976: $\quad$ Sis regidors (els que van votar a favor de conservar íntegrament Can Zam) proposen fer un Ple extraordinari per parlar del tema de la Amnistia a presos polítics, exiliats, etc. Creació d'una Comissió Pro-aministia.

12 al 18-1-1976: Tancament dels treballadors de Radiotrònica (acomiadats) a l'església de Sant Joan Baptista. Nota de protesta de l'AVV Joan Maragall pel cas Téllez.

15-1-1976: La policia impedeix l'entrada a l'Església de Sant Joan B. A Joan Carrera, Vicari episcopal d'assumptes obrers. 
18-1-1976: $\quad$ Manifestació de rebuda a Téllez, amb enfrontaments amb la policia.

1-1976: Nous casos de meningitis a un col-legi de Les Oliveres. Es legalitzen les AVV's Fondo i Barrio Latino.

20-1-1976: Cessament d'una regidora pel Terç Corporatiu i membre de la Secció Femenina, Marta Carreras per signar un manifest pro-amnistia.

24-1-1976: Roda de premsa de l'AVV per denunciar les suposades "eleccions" a Alcalde i reclamar Ajuntaments democràtics. Adhesió també a la Comissió Pro-Amnistia.

25-1-1976: Crítiques a les "eleccions" d'alcalde per part de les AVV's per considerar-les antidemocràtiques. Tensió a la Plaça de la Vila (la força pública dissol als concentrats) i al saló de Plens. Resultats: Blas Muñoz 11 vots a favor Gènova 6 vots a favor i 1 abstenció.

1-2-1976: Pressa de possessió de Blas Muñoz com Alcalde després de les "eleccions”.

7-2-1976: $\quad$ Detenció d'una jove a Santa Coloma per fer una pintada.

8-2-1976: La policia interromp un festival organitzat per les Vocalies d'Ames de Casa de AVV's Raval, Santa Rosa, Centre, Rio, Oliveres, Can Mariner, i l'Associació de Mestresses de Casa de Singuerlín, a la parròquia de Can Marine titulat "Mujer en Santa Coloma" (l'acte comptava amb permís).

11-2-1976: Vista del jucidi contra varis membres de la Cooperativa VIPES (pisos de la Guinardera)

Aturades de mestres d'escoles públiques i privades amb ampli seguiment a Santa Coloma.

16-2-1976: 5000 persones es manifesten en demanda d'escoles i per un ensenyament gratuït. 6.000 persones, en la seva majoria dones i nens, es concentren al Motocros pel "dia de la truita". Tornen a la feina els mestres de l'escola privada.

17-2-1976: $\quad$ Vaga de la construcció.

18-2-1976: Concentració veïnal davant l'Ajuntament i entrega de peticions al voltant dels dèficits de l'ensenyança (és rebuda pel cap de la policia local, en absència de alcalde i regidors).

20-2-1976: $\quad$ El Ple de l'Ajuntament s'adhereix a la petició d'Amnistia.

26-2-1976: Incidents poc abans al Ple entre Matés i l'Alcalde, mentre hi havia una concentració a la Plaça de la Vila.

28-2-1976: Amenaces telefòniques a presidents d'AVV's (Raval i Singuerlín) i sacerdots progressistes.

2-1976: Nova revisió del Pla Comarcal presentat l'any 1974 sota l'epígraf "Plan General de Ordenación Territorial de la Comarca de Barcelona."

3-1976: $\quad$ Conflictes laborals a IRSA i Extended Electronics.

4-3-1976: $\quad$ Suspensió d'unes jornades sobre les forces polítiques de Catalunya que s'havia de fer organitzada per l'Escola Social de Santa Coloma de Gramenet.

7-3-1976: $\quad$ Amenaces feixistes per escrit a redactors de Grama, corresponsals de 
premsa i a un obrer acomiadat de Radiotrónica.

11-3-1976: S'aprova un primer document per la constitució de l'Assemblea Democràtica de Santa Coloma.

Tall de trànsit al costat del Camp de la Grama per exigir semàfors.

Document de AVV 's (Singuerlín, Raval, Centre, Oliveres i Santa Rosa) en solidaritat amb els treballadors de Vitòria.

Amenaces de la ultradreta contra personalitats d'esquerres de Gramenet

12/13?-3-1976: Talls de trànsit per tot Santa Coloma per exigir semàfors. Enfrontaments amb la policia i marxa cap a l'Ajuntament.

27-3-1976: Prohibida una conferència de Pere Ardiaca a Santa Coloma. Assemblea de 1.500 aturats en Can Sisteré.

28-3-1976: Manifestació a Santa Coloma convocada per l'AD. Prop de 3.000 persones arriben a la Plaça de La Vila exigint canvis democràtics i proclames de solidaritat amb els obrers de Vitòria. Es fa sense autorització però la policia tot i controlar-la en tot moment no intervé per desfer-la, malgrat moments de tensió.

8-4-1976: $\quad$ El Ple aprova el pressupost de 1976: 362 milions de ptes., un increment de 39,22 \% respecte l"any anterior.

Mobilitzacions de l'assemblea d'aturats a Santa Coloma.

23-4-1976: Vaga del Metall. A Santa Coloma paren 36 empreses, gairebé totes les del ram.

24?-4-1976: $\quad$ Més empreses es sume a la vaga del metall. 41 pel matí i 46 per la tarda.

25-4-1976: $\quad$ Manifestació de ASPANIDE pels drets dels disminuïts psíquics (500 persones).

26 o 27?-4-1976: Miting del MCE a Sant Jeroni.

28-4-1976: Continua la vaga comarcal del Metall. 63 empreses a Santa Coloma (la majoria petits tallers).

1-5-1976: $\quad$ Conats de manifestació, concentració a la plaça de la Vila de 1.000 persones i enfrontaments amb la policia.

3-5-1976: $\quad 56$ empreses en vaga a Santa Coloma. Repressió policial als piquets i manifestació d'obrers i AVV's cap a l'Ajuntament per protestar contra la repressió policial.

7-5-1976: $\quad$ Manifestació de pensionistes a Santa Coloma.

9-5-1976: Detenció de Ricardo Bonet, president de l'AVV del Rio i dos veïns per la neteja d'un solar.

Des del 15?-5-1976: Vaga en el tèxtil de Santa Coloma en solidaritat amb acomiadades i reclamant un sindicat obrer.

19-5-1976: Membres de l'AVV del Centre entreguen un escrit a l'Ajuntament on denuncien les mancances del barri.

22-5/3-6-1976: Quinzena de l'Ensenyança a Santa Coloma organitzada per AMPAS i Vocalies de les AVV's Fondo, Singuerlín, Centro i Can Mariné.

24-5-1976: $\quad$ Absolució en un Consell de Gerra d'una militant del MC, Inés de Castro, per haver col-locat una pancarta del MCE a Santa Coloma. 
26-5-1976: L'OICE nega la seva adhesió a l'Assemblea Democràtica de Santa Coloma i es reafirma en crear un ampli moviment anticapitalista.

29-5-1976: Els veïns del Fondo netegen un solar abandonat reivindicant-lo com zona verda.

3-6-1976: Ple on l'Ajuntament cedeix uns terrenys a Can Calvet per construir una residència especial per ASPANIDE.

4-6-1976: Les Vocalies de Dones de Santa Rosa, Riu Centre i Raval es solidaritzen amb un grup de metges que reivindiquen la planificació familiar i la legalització dels anticonceptius.

6/7-1976: $\quad$ Assemblees de les Comissions de lluita en els Barris.

11-6-1976: Compareixença judicial dels tres veïns detinguts el dia 9-5.

12-6-1976: Constitució de l'Assemblea Democràtica de Santa Coloma.

19-6-1976: Carta del president de l'AVV Singuerlín publicada a Tele/ eXprés matisant que la seva associació no s'ha adherit a l'AD, però que si ho ha fet ell i un grup de veïns a nivell personal. Manifestació de 300 veïns afectats pel cas Rosell (estafa immobiliària). Manifestació autoritzada per l'amnistia laboral a Santa Coloma. Entre 5.000 i 15.000 participants.

30-6-1976: Ple interromput per nombrosos veïns que reclamen solucions als dèficits i manca de places a l'ensenyament en Santa Coloma.

8-7-1976: Detenció de Josep Maria Martí, Alfoso Gómez, Pepe Sánchez, Jaume P. Sayrach, Motserrat Cascante, José Maria Ballesteros i Hernán Freire, quant amb 400 persones es manifestaven contra un judici interposat contra l'AV del Rio. Són alliberats el vespre del dia 9. El mateix dia hi ha una manifestació d'un miler de persones.

11-7-1976: $\quad$ Acte de presentació del PSUC a Santa Coloma (es volia fer un miting a Can Sisteré però davant la prohibició gubernativa al final es fa un acte a l'aire lliure amb una notable afluència de gent ( 2.500 persones).

15-7-1976: $\quad$ Aprovació del Pla Comarcal de Barcelona.

23-7-1976: Mobilitzacions veïnals a Santa Rosa contra els bars de prostitutes.

9-1976: $\quad$ Aparició de Barrio Obrero, portaveu de les CCBB de Santa Coloma.

3 al 6-9-1976: Celebració de la Primera Festa Major Popular.

13-9-1976: Dimissió de dos tinents d'alcalde del sector immobilista: Juan Pérez Terol (Urbanisme) i Juan Aloy Pina (Ensenyament).

20-9-1976: Manifestació de 500 dones i nens cap a l'Ajuntament i el domicili de l'Alcalde per entregar-li una nota de protesta pel lamentable estat del col-legi nacional Virgen Immaculada.

24-9-1976: Certs recels de les AVV's ante el Congrés de Cultura Catalana.

25-9-1976: $\quad$ Ajornat el judici contra membres de l'AV del Rio. 
27-9-1976: Reestructuració del Consistori de Santa Coloma. Són cessats dos regidors del "bunker". I es dona més entrada a regidors crítics amb Blas Muñoz. Acte a l'església de Fondo en el primer aniversari de les execucions de militants d'ETA i el FRAP, organitzat per Assemblea Democràtica de Santa Coloma.

1-10-1976: El Casal de Cultura obre les seves portes en el seu primer curs com a Escola d'Adults.

5-10-1976: Es suspèn la presentació de les CCOO del Barcelonès Nord per negativa governamental.

12-10-1976: Elecció d'una nova Junta de l'AVV Fondo. Compta amb 800 socis.

14-10-1976: Inici de les obres d'un complex poliesportiu a Can Zam.

16-10-1976: El propietari d'un solar urbà denuncia a l'Ajuntament de Santa Coloma per haver edificat uns barracots escolars sense el seu consentiment.

21-10-1976: Hospitalització d'un nen del barri del Rio per bronquitis asmàtica a causa de la contaminació de fàbriques de la zona.

24?-10-1976: Inauguració de la "Casa de Andalucia" amb presència de membres de Reforma Democràtica.

27-10-1976: Protestes d'un grup de veïns de diversos carrers que formen una illa d'edificis del barri del Raval afectats per defectes en la construcció dels seus habitatges. Notícia també sobre un escrit signat per, entre d'altres entitats, 10 AVV's de Santa Coloma i una de Badalona més un Centre Social badaloní reclamant la declaració de Parc Forestal dels terrenys de Sant Jeroni de la Murtra.

2-11-1976: Segons ASPANIDE hi ha 2.000 disminuïts psíquics a Santa Coloma.

4-11-1976: Els veïns es mobilitzen en defensa dels mestres dels ex-alumnes de la Acadèmia Comercio que el Ministeri vol substituir (els mestres s'havien mobilitzat en suport dels veïns per la construcció de la nova escola fent classes a l'aire lliure).

6-11-1976: Supressió per part del Guàrdia Civil de l'acte de l'Assemblea Democràtica que havia de fer-se. Una delegació intenta entregar un escrit de protesta a l'Ajuntament però no és rebuda.

11/12-11-1976: Atracament d'un bar on es jugava a l'il-legal "bacarra".

12-11-1976: Gran seguiment de la Vaga a Santa Coloma de Gramenet. Total en diferents rams Industrials (metall, construcció, tèxtil, fusta) i gran seguiment al comerç. 7 detinguts a Gramenet.

16-11-1976: Atracament a una joieria a Santa Coloma.

18-11-1976: Protestes de grups feministes i Vocalies de dones per una violació a prop de l'Esperit Sant.

Acomiadament dels 6 mestres de Les Vinyes.

20-11-1976: Acomiadaments fets en repressió per la vaga del 12 a una empresa filial de Casadeport.

Protesdes de l'AVV Fondo per l'actuació policial la jornada del 12.

24-11-1976: Dimissió d'un conegut ultradretà local, Paco Villoria, de la presidència del Centre 
d'Amics de la Sardana.

Nota de protesta feta per l'AVV Santa Rosa arran la repressió policial a una concentració feta per reivindicar una escola a un solar del carrer Banús Alta . Es constitueix el Secretariat Cultural del CCC.

25-11-1976: Compra d'uns terrenys per fer escoles per l'Ajuntament a "La Bastida" i "Les Vinyes".

27-11-1976: Readmissió d'un funcionari de l'Ajuntament després de les protestes dels seus companys pel seu acomiadament.

28-11-1976: La fulla parroquial de les Esglésies de Santa Coloma demana l'abstenció al referèndum.

10-12-1976: Detenció de dos joves del MC per posar cartells demanant l'abstenció al referèndum. Intensa campanya de diferents partits a Santa Coloma (PSC-C, PSUC, $\mathrm{MC}$ ) tot i que a la notícia es comenta que els cartells que posen son ràpidament arrancats.

Comença una vaga dels treballadors de TUSA.

11-12-1976: Manifestació de 1.500 persones convocades per les AVV's davant l'Ajuntament per demanar l'abstenció al Referèndum. El mateix dia hi ha convocat un acte de l'AD a l'església de Can Mariner.

12-12-1976: Membres de l'AD reben el Governador Civil a la Plaça de la Vila de Santa Coloma mentre feien campanya per l'abstenció.

15-12-1976: Referèndum per la Reforma Política.

21-12-1976: Presentació de la revista de les Vocalies de Dones de les AVV's colomenques: Mujer en Santa Coloma.

22?-12-1976: Manifestació de treballadors de TUSA davant l'Ajuntament.

23-12-1976: Constituït el Secretariat Local del Congrés de Cultura Catalana.

24-12-1976: Inici del Judici a membres de l'AVV del Rio per l'afer del "Solar de les rates".

23-12-1976: Reunió de Blas Muñoz amb entitats veïnals per demanar la seva implicació en el projecte de parc de Sant Mateu. Els veïns s'hi neguen a participar per diverses irregularitats i recorden la reivindicació de Can Zam.

Laude de Magistratura respecte la vaga a TUSA.

25/26-121976: Tonen a la feina dels treballadors de TUSA.

26-12-1976: Comencen les obres de restauració de la Torre Balldovina.

28-12-1976: Manifestacions a Santa Coloma i Badalona (amb detencions de 10 persones en aquesta darrera quan demanaven la llibertat de Carrillo).

4-1-1977 : $\quad$ Proposta d'adhesió de l'Ajuntament al CCC feta pel regidor Rosset i rebutjada pel regidor "ultra" Callejón que només reconeix la nació espanyola i que afirma que en l'acta no pot constar el patronímic "nació catalana" per que no és legal.

10-1-1977: $\quad$ RKG España tanca portes i acomiada a 23 treballadores.

11-1-1977: $\quad$ Possible retorn de l'empresari immobiliari Rosell (fugit per una estafa 
immobiliària). També d'un possible acord entre els compradors i Caixa de Catalunya (entitat a la qual Rosell havia hipotecat els immobles dels compradors sense el coneixement d'aquests).

13-1-1977: L'alcalde acusa als veïns i les seves impugnacions al retard en la urbanització del Passeig de la Salzareda. Els veïns responen que ells han impugnat la construcció d'una via ràpida.

21-1-1977: Expropiació forçosa d'uns terrenys els propietaris dels quals havien denunciat a Blas Muñoz per ocupació il-legal (l'alcalde havia instal-lat barracots escolars per la pressió veïnal per cobrir els alarmants dèficits).

Manifestació per l'Avinguda Jacint Verdaguer de Santa Coloma en solidaritat amb la vaga de Roca.

26?-1-1977: Manifestació de 500 persones en contra dels assassinats d'Atocha.

27-1-1977: $\quad$ Militants del PSC (C) suprimeixen els noms del carrer 27 de gener pel de Rafael Casanova.

1-2-1977: $\quad$ Article de Jordi Borja a Tele/ eXprés sobre les Cases Regionals.

6-2-1977: $\quad$ L'AVV Arrabal reclama un ambulatori pel barri recollint signatures al carrer.

10-2-1977: $\quad$ Article a La Vanguardia de Juan de Dios Ramírez Heredia: “¿Por quien votaremos los immigrantes?".

15-2-1977: Tres AVV's (Can Mariner, Italians i Cementiri Vell) encara estan pendents de legalització.

Assalt a la casa d'Andalusia per la matinada.

16-2-1977: $\quad$ El secretariat local del CCC demana la dimissió de tot el Consistori per la negativa a adherir-se al Congrés de Cultura Catalana.

22-2-1977: Referència a la premsa als nombrosos assalts vandàlics contra instal-lacions escolars. Carta de José Acosta Sánchez a La Vanguardia Española on critica a Pujol per uns escrits seus recentment publicats a La immigració, problema i esperança de Catalunya.

22-2-1977: $\quad$ Nombroses mobilitzacions a Gramenet durant el cap de setmana. Forta presència policial davant un acte no autoritzat dels Cristians de Base, tancada de mestres PNN, alumnes i pares de l'Institut i manifestació, tancament veïnal a Santa Rosa contra una immobiliària i jornada feta per l'AVV Singuerlín per l'amnistia.

24-2-1977: $\quad$ En el Ple s'aprova una reprovació a Jordi Pujol a instàncies del regidor Matés arran unes expressions de suposat menyspreu als andalusos al llibre La immigració, problema i esperança de Catalunya. Queda pendent la subvenció del consistori al Congrés de Cultura Catalana. Un grup d'andalusos reclamen també suport per la cultura Andalusa si es concedeix la primera.

26/27-2-1977: Les AVV's fan campanya al carrer per l'Aministia Total. Quatre detencions el dia 26 a la Plaça del Rellotge per la Guàrdia Civil.

1-3-1977: $\quad$ Paralització de les obres contigües a la Torre Balldovina.

¿-3-1977: $\quad$ Article de Jordi Pujol a La Vanguardia "La immigració, problema i esperança de Catalunya". 
2-3-1977: $\quad$ Detenció de dos militants del PTE per haver comés un robatori, Juan Martí Domínguez i un menor de 13 anys.. El PTE diu que els detinguts ja no eren militants seus mentre la policia diu que és el responsable de Propaganda i els involucra en una manifestació que hauria d'atacar a la policia i en la fabricació de Còctels molotov al Centre Social Santa Rosa. Posterior detenció de Eladio Gordillo García, feta el dia 3, també militant del PTE.

3-3-1977: $\quad$ Notícia de que la corresponsal de El Correo Catalán i Grama Agustina Rico serà processada per per les denuncies del director de l'acadèmia Jacint Verdaguer (Velázquez, un ultradretà).

Moció contra Pujol a l'Ajuntament de Santa Coloma de Gramenet instada pel regidor Matés arran unes declaracions de 1958 recollides en el llibre La immigració. Problema i esperança de Catalunya.

4 o 5?-3-1977: Inici d'una vaga dels treballadors de Construcciones Padrós per que l'empresa els hi descompta 30 minuts d'una assemblea.

6 o 7?-3-1977: Conferència feta per José Acosta (PSA) a la Casa d'Andalusia de Santa Coloma de Gramenet. 800 persones de públic. Crítica dels representats de les AVV's al discurs lerrouxista fet.

(7) Detenció de 5 militants de l'LCR mentre repartien propaganda i premsa clandesina a la boca del metro de Sant Andreu. Una persona és de l'AVV del Riu i una altra és del secretariat del metall de Badalona de CCOO.

8-3-1977: $\quad$ Article a Avui on es parla del neolerrouxisme i es recullen testimonis de colomencs i colomenques sobre el darrer afer al Ple amb la moció promoguda contra Pujol (entre ells Sayrach, Cabré, la presidenta de la Vocalia de Dones de Santa Rosa i el president de l'AVV del Fondo).

12/13-3-1977: El PSC (C) inicia una campanya antilerrouxista.

13-3-1977: L'Església de Santa Coloma reparteix un escrit titulat "Un sol poble" criticat la campanya neolerrouxista existent.

Acte de l'AD en favor de l'Estatut al barri de la Guinardera.

17-3-1977: $\quad$ Apareixen residus sanitaris al barri de Les Oliveres.

18-3-1977: $\quad$ Tancament de l'empresa Mecanizaciones Haro. Els treballadors es

tanquen tres setmanes al seu interior a l'espera de la resolució d'Inspecció de Treball (l'empresa no pagava ni les cotitzacions a la SS ni l'IRTP).

22-3-1977: Crítiques d'ASPANIDE a les mesures del Govern que permeten la financiació d'entitats amb els jocs d'atzar.

24-4-1977: Blas Muñoz força una suspensió de pagaments d'un altre regidor que li devia diners (pràctiques usureres).

25-3-1977: Fernando Soto, andalús del PCE, vetat a la Casa d'Andalusia de Santa Coloma.

31-3-1977: Lluita d'una escola bressol i dos de preescolar (mestres i pares contra l'increment de preus a les escoles).

Ídem del full parroquial de les Esglésies de Santa Coloma contra la campanya lerrouxista.

L'AVV del Raval proposa el nom de Macià per una plaça del barri.

2?-4-1977: $\quad$ Mitin del PSOE en el poliesportiu de Can Sisteré (800 persones). 
10-4-1977: $\quad$ Un taxista és detingut i agredit per la policia municipal de Santa Coloma.

15-4-1977 : Denúncia de 100 veïns i l'AVV Santa Rosa a la Casa d'Andalusia per sorolls i molèsties.

16-4-1977: Queixes de l'AVV de la Guinardera per la precària situació de 25 famílies que no tenen clavegueram, ni recollida d'escombraries, ni aigua potable.

19-4-1977: Querella del director de l'Acadèmia Verdaguer (Jesús Velázquez Álvarez) contra un corresponsal i el director de Catalunya Expres.

Nou assalt vandàlic contra l'escola d'ASPANIDE.

20-4-1977: $\quad$ Dos casos de meningitis al col·legi Lluís Millet de Les Oliveres (vinculació amb residus sanitaris abocats a prop).

22-4-1977: $\quad$ Decret "del Santoral" que limita i condiciona les AVV's i els noms que poden fer servir.

28-4-1977: $\quad$ Finalment la Casa de Andalucia s'adhereix al CCC.

28 o 29-4-1977: Ple municipal on l'Ajuntament s'adhereix al CCC. També es torna a tractar el tema de Can Zam i s'obre una perspectiva més optimista per la seva conservació.

1-5-1977: $\quad$ Incidents durat la jornada de l'1 de maig (no es toleren manifestacions). Només es pot fer un petit miting davant l'Ajuntament.

4-5-1977: $\quad$ S'aprova un estudi per part de l'Ajuntament per intentar canviar la zonificació de Can Zam.

6-5-1977: $\quad$ Protestes dels veïns del carrer Circumval-lació per aconseguir l'asfaltat del carrer.

18-5-1977: 14 colomencs a les candidatures de les eleccions de juny.

19-5-1977: $\quad$ Mobilització contra el decret que obliga a posar un nom de sant a les AVV's o noms que no incloguin tot un barri.

20-5-1977: Incorporació de José Acosta Sánchez (PSA) a la candidatura del Pacte Democràtic encapçalada per Jordi Pujol.

23-5-1977: L'Hospital de l'Esperit Sant presenta un "interdicto" contra l'Ajuntament per iniciar unes obres en uns terrenys seus sense l'aprovació del Ple Municipal.

24-5-1977: $\quad$ Falta d'activitat de l'AD de Santa Coloma.

28-5-1977: $\quad$ Mitin del PSUC al poliesportiu de Can Sisteré amb la presència d'entre 2.500 a 3.000 persones.

6-1977: $\quad$ Tanca el Centre Social Arrabal-Santa Rosa.

Protesta de la FAVB contra el decret del 22 d'abril referent a les AVV's de les quals s'exigeix la seva legalització respectant el seu nom i identificació amb els barris.

4-6-1977: $\quad$ L'Ajuntament acomiada a l'arquitecte municipal, Alfonso Pons Bofill i obre un expedient a l'administratiu municipal, Sr. Puig, per irregularitats urbanístiques.

6/7-6-1977: Veïns de Can Franquesa segresten autobusos per reivindicar l'arribada d'aquests al seu barri. Intervenció violenta de la Policia Armada i la Policia Municipal amb nombrosos veïns ferits. Pares, mestres i alumnes de les escoles bressol de Santa 
Rosa, San Miguel i Nazareth (buscar barris) intenten ocupar l'ajuntament davant la retirada de les subvencions estatals que servien per pagar als mestres.

8-6-1977: $\quad$ Continuen els segrestos d'autobusos a Can Franquesa. 9 autobusos segrestats i noves intervencions policials violentes. Entre els ferits, un nen de 10 anys.

9-6-1977: Veïns de Can Franquesa apedreguen el cotxe de l'alcalde que visitava el barri. Connexions existents en una operació especulativa d'un representant de Rodríguez Valcárcel, un tal Gonzalez Mozo, que va vendre uns terrenys -que havia comprat malgrat estar qualificats com a Parc Forestal- al mateix Patronato Municipal de la Vivienda, que s'havia encarregat d'edificar el barri.

Les escoles bressols reben el $50 \%$ de les subvencions promeses per part del Ministeri de Treball per avançat.

Mitin comarcal del PSUC al camp de la Gramenet. 10.000 persones.

10-6-1977: $\quad$ Suspensió d'una xerrada del PSC (C) sobre "Socialisme i autogestió".

11-6-1977: $\quad$ Finalment s'aconsegueix un servei de TUSA per Can Franquesa mitjançant un acord entre l'Alcalde de Santa Coloma i el president de l'Entitat Municipal Metropolitana, Socias Humbert.

13-6-1977: $\quad$ Finalitza el tancament en l'Església de Santa Rosa pel pres colomenc Juan Manzanares, militant d'Acción Comunista. Ell i altres presos estan en vaga de fam en demanda d'una amnistia total.

15-6-1977: $\quad$ Primeres eleccions pluripartidistes del postfranquisme a les Corts. PSC (45 \% de vots) i PSUC (35 \%) arrasen a Santa Coloma..

17-6-1977: $\quad 4.000$ persones celebren a la Plaça de la Vila el triomf de l'esquerra parlamentària a les eleccions del 15-J.

Esclata un greu conflicte a Eurostil amb 287 empleats que finalitzarà amb mesos després amb l'acomiadament de tota la plantilla. Es tanquen a la factoria davant un impagament de salari i un tancament patronal.

s'inicia una tancada a l'església de Sta. Rosa per reivindicar l'amnistia total.

18-6-1977: $\quad$ Inici del tancament de 200 treballadores d'Eurostil.

18/24-6-1977: Veïns del Riu Tallen periòdicament el trànsit a l'alçada dels carrers Francesc Moragues- García Morato reivindicant l'asfaltat del Passeig de la Salzareda.

21-6-1977: $\quad 5$ è dia de tancament de 200 treballadores d'Eurostil davant la proposta d'un expedient de regulació de la plantilla que afectava a 124 persones.

22-6-1977: $\quad$ Més d'un millar de veïns tornen a tallar el trànsit al creuament del Passeig de la Salzareda amb Francesc Moragues per reclamar la urbanització del passeig.

24-6-1977: $\quad$ Ídem i manifestació fins a l'Ajuntament per parlar amb Blas Muñoz sense èxit.

25-6-1977: $\quad$ Festa PSC-PSOE/PSUC per celebrar el resultat de les eleccions.

27-6-1977: Judici a Madrid a Juan Manzanares, membre de l'AV Santa Rosa, i d'Acción Comunista, i tres militants més (Pere Cambó Fernández, Evencio Juárez García i José Maria Riaño Castro) acusats d'atracar una sucursal bancària. Manifestació de suport a la Plaça del Rellotge i rodalies. Es posat en llibertat al vespre sense que es realitzi el judici després de pagar una fiança (els altres tres acusats estaven en llibertat provisional des de el dia 18). 
1-7-1977: $\quad$ El Gobierno Civil prohibeix una manifestació de suport als treballadors d'Eurostil (que porten tres setmanes tancats) que volia convocar CCOO. La manifestació es fa igualment amb la participació de 2000 persones.

Els veïns del passeig de la Salzareda porten dues setmanes tallant el trànsit.

2-7-1977: $\quad$ Edició d'un full reivindicant la Via Cívica per l'AVV del Fondo.

4-7-1977: $\quad$ Protestes dels veïns del Carrer Mozart núm. 17 contra el bar Kayuga per les molèsties que els ocasiona.

14-7-1977: Reivindicacions al barri del Fondo per la "Via Cívica”, un projecte de recuperació dels solars del barri per espais públics i equipaments que compta amb l'assessorament de l'arquitecte Xavier Valls.

15-7-1977: L'Ajuntament de Santa Coloma accepta l'existència de Comissions de Control amb les altres forces polítiques, si bé aquestes encara no accepten la composició que se'ls hi proposa. Treball denega l'expedient de regulació de treball d'Eurostil (les treballadores porten un mes de tancad .

Carlos Grande marxa del MCC cap el PSUC.

20-7-1977: Reunió de representants veïnals amb Martín Villa. El “decret santoral” congelat i es promet agilitzar la legalització d'AVV's.

21-7-1977: Ocupació de l'Ajuntament de Santa Coloma per les treballadores d'Eurostil, amb el suport d'un miler de persones convocades per les forces polítiques i sindicals després d'una manifestació.

22-7-1977: Les treballadores d'Eurostil volen reunir-se amb el ministre de treball, Jiménez de Parga. L'empresa presenta suspensió de pagaments.

24-7-1977: $\quad$ Es fa públic un escrit de PSC i PSUC on precisen quina serà la seva participació a les Comissions de Control municipals.

26-7-1977: $\quad$ Es fa públic un comunicat emès pel PSC, PSOE i PSUC criticant els actes de vandalisme comesos per una minoria a l'Ajuntament durant la seva ocupació. (Eurostil).

27-7-1977: Trasllat del Comissari de Policia de Santa Coloma (presumiblement per no reprimir l'ocupació de l'Ajuntament del dia 21 on es van produir alguns desperfectes). El consistori local dona suport a l'esmentat comissari, Benigno Dávila, per seu tarannà "dialogant" i supén el ple en solidaritat.

11-8-1977: Les treballadores d'Eurostil tornen a posar en funcionament la fàbrica de manera autogestionada.

17-8-1977: $\quad$ Carta de les treballadores d'Eurostil a Jiménez de Parga (Ministre de Treball).

18-8-1977: $\quad$ Les treballadores d'Eurostil es desplacen a Madrid per sol-licitar ajuda al Ministeri de Treball. Es reuneixen amb ell però només els ofereix carntets d'atur, que refusen.

21-8-1977: Les treballadores d'Eurostil tornen a vendre el que produeixen al marge de la direcció de l'empresa.

26-8-1977: Manifestació de 400 persones en suport a Eurostil.

27?-8-1977: $\quad$ Assalt i destrossa d'un local del PSUC al barri del Raval, fet presumptament per 
membres d'extrema dreta.

31-8-1977: Reunió de 14 regidors més "ultres" del consistori (encapçalats pel falangista Salvador Callejón) el dia 31 per mirar de destituir a Blas Muñoz. Aquests envien un escrit al Gobernador Civil acusant-lo de "falta d'autoritat" (per no oposar-se a l'ocupació de l'Ajuntament pels treballadors d'Eurostil) i de corrupció.

1?-9-1977: Un mes de talls de trànsit dels veïns de Riu Nord en reivindicació de semàfors pel barri.

6-9-1977: $\quad$ Tres regidors que van subscriure la petició anterior es retracten. Destacar el cas de Rosset que admet fer-ho per disciplina amb el PSC-PSOE. El mateix dia CDC, PSC, PSOE, PSUC, PTE, MCC i OIC entreguen un comunicat al Govern Civil instant-lo a posar ordre al consistori fins les municipals.

8-9-1977: Ja son cinc els regidors dels 14 inicials que es retracten de la petició de dimissió de Blas Muñoz. El mateix dia es fa un ple extraordinari havent-se descartat ja la petició.

9-9-1977: Incidents i deficiències organitzatives en la Festa Major Popular, que el redactor Josep Tordera vincula al semiboicot de l'Ajuntament, a la poca implicació de forces polítiques més moderades i a l'actitud d'alguns sectors anarquistes.

10-9-1977: $\quad$ Mitin de CCOO del Barcelonès Nord al Poliesportiu Nou.

14-9-1977: $\quad$ El ple municipal suspèn les llicències de construcció a Can Zam i encarregar a una comissió de tècnics de l'Entitat Metropolitana un estudi per una nova qualificació dels seus terrenys.

15-9-1977: Vaga dels escombriaires a Santa Coloma.

16-9-1977: $\quad$ Escàndol per la falsificació d'una signatura del socialista Joan Carles Mas en una demanda interposada contra Blas Muñoz per corrupció urbanística (feta presumptament pels regidors del complot contra ell).

17-9-1977: Denúncia dels partits membres de la Comissió de Control Municipal de la falsificació de la signatura.

Els veïns de Riu Nord adrecen una protesta al Govern Civil per la instal·lació de semàfors al la carretera de La Roca després de fer talls de trànsit.

24/25-9-1977: Veïns de Riu Nord tornen a tallar el trànsit en l'avinguda Baró, per reclamar semàfors.

27-9-1977: Denuncia de l'AVV de Santa Rosa i els veïns del núm. 107 del C/ Circumvalació per una irregularitat urbanística a Construcciones Hispano.

31-9-1977: $\quad$ Manifestació de 2000 persones en solidaritat amb Eurostil.

1-10-1977: Continua l'autogestió d'Eurostil per part de les seves treballadores.

2-10-1977: Denúncia dels veïns del carrer Gènova contra la instal-lació d'una Panificadora als baixos de l'immoble.

3-10-1977: Concentració de veïns davant la fàbrica “Colores Vilaseca" per la seva presumpta perillositat (exigeixen el seu trasllat.

6-10-1977: $\quad$ La Direcció General de Empleo del Ministerio de Trabajo ha fallat contra 
l'expedient de regulació d'Eurostil.

7-10-1977: $\quad$ El PSUC s'ofereix per aconseguir solucions per Eurostil. Els treballadors voten i accepten la proposta per 35 vots a favor i 11 en contra.

Queixes dels veïns del Carrer Gènova 20 per les molèsties que ocasiona una Panificadora.

7-10-1977: Els incidents al "Bar Mini" de Santa Rosa (on s'exerceix la prostitució) esgoten la paciència dels veïns que inicien una campanya obstruint el pas a l'esmentat bar.

11-10-1977: Circula un pamflet-diari per Santa Coloma defensant als regidors de Reforma Social Catalana que van donar suport a l'intent de destitució de Blas Muñoz i criticant a PSC-PSOE i PSUC.

Notícia de la propera instal-lació de semàfors a l'Avinguda Baró, responent a les reivindicacions de l'AVV Riu Nord.

12-10-1977: Manifestació en Santa Coloma reclamant l'amnistia total.

13-10-1977: Falsa amenaça de bomba a l'Ajuntament.

14-10-1977: Protestes veïnals contra una fàbrica de samfrà situada als carrers "Jose Antonio" i Sicília.

15-10-1977: Els alcaldes de 30 municipis amenacen amb dimitir. Demanen una "treva" a les Comissions de Control, el suport del Govern Civil i la celebració d'eleccions municipals el més aviat possible.

18-10-1977: Un pacte dels regidors conxorxats contra Blas Muñoz (entre ells, membres de Reforma Social Catalana) permet aprovar uns pressupostos que gravaran més les propietats immobiliàries i no pujaran la taxa d'escombraries.

Es fa públic un comunicat del Comitè Unitari d'Eurostil on acusen al representant del CSUT, Domingo Linde, de dividir als treballadors.

19-10-1977: L'Ajuntament colomenc està en Bancarrota.

20-10-1977: Una vuitantena de treballadors d'Eurostil que donen suport al CSUT i neguen les acusacions del Comitè Unitari.

Ple Extraordinari que aprova actualitzar el padró (el dilluns 17 s'havia refusat augmentar la taxa d'escombraries).

23-10-1977: Detenció de diversos delinqüents juvenils, entre ells els implicats en un robatori amb homicidi en una benzinera de Santa Coloma.

27-10-1977: El diari Avui publica una carta d'unes escolars reivindicant el català davant el perill de perdre les classes (crítiques a l'Ajuntament i a Òmnium, que no paga als mestres des de fa mesos).

4-11-1977: $\quad$ S'inicien les obres del pont per vehicles del Molinet.

5-11-1977: Denúncia dels professors de català de Santa Coloma a Òmnium Cultural per no cobrar.

Conflicte a l'Acadèmia Verdaguer, on el propietari cobrava quotes de més als pares tot i tenir una subvenció del MEC i on ha expulsat dues alumnes d'un pare per demanar explicacions sobre això.

7-11-1977: $\quad$ Tancament de l'Acadèmia Verdaguer (al Fondo), regentada per un conegut ultradretà (Jesús Velázquez) que estava enfrontat als pares del centre. 500 nens es 
queden sense escola. Protestes dels pares. I posterior tancament definitiu com a centre subvencionat.

15-11-1977. Treballadores d'Eurostil segresten un autobús en tornar d'un judici a Magistratura on no compareix l'empresa. La policia les reté fins identificar-les.

21-11-1977: La lluita de les treballadores d'Eurostil perd força per l'esgotament dels estocs de l'empresa que els hi permet produir autònomament i per l'esgotament en la lluita. Després de tres mesos de tancament hi ha qui finalment s'ha acollit a demanar l'atur.

24-11-1977: $\quad$ Perill de tancament de l'escola de ASPANIDE.

El Ple Municipal no aprova les obres de reforma del passeig de la Salzareda, reclamades per l'AVV del Rio Sud.

Els membres dels partits polítics de les Comissions de Control abandonen el ple en protesta.

24 o 25?-11-1977: Detenció del President de l'AVV del barri Llatí per l'afer d'una ocupació d'un solar dels carrers Nàpols i Verdi. Pressió veïnal i alliberament en poques hores.

30-11-1977: Campanya per recuperar l'ensenyança del català a Santa Coloma. Creació d'una comissió ciutadana amb participació de pares i mestres i dura crítica a Òmnium.

6-12-1977: $\quad$ Protestes dels mestres del col·legi nacional Virgen Immaculada per la falta de calefacció a l'escola. Talls de trànsit.

7-12-1977: $\quad$ Manifestació de pares, mestres i escolars del col·legi Juan XXIII amb incidents amb la policia quan forcen entrar a l'Ajuntament.

10-12-1977: Ja són cinc les escoles mobilitzades en demanda de calefacció i altres millores: els col·legis nacionals Sagrado Corazón, Virgen Immaculada, Lourdes, Juan de Segarra, Juan XXIII. Notícia de la reunió de l'alcalde accidental amb els pares i professors del Juan XXIII.

10/11?-12-1977: I Conferència Local del PSUC de Santa Coloma. Carlos Grande, ex MCC entra a la direcció, de la qual surt Pérez Ezquerra, destacat dirigent de CCOO.

20-12-1977: Assemblea a l'Ajuntament amb la participació del regidor Matés, membres de les AMPAS i AVVS. Sis escoles (Ntra. Sra. Lurdes, Sagrado Corazón, Fernando Segarra, Wagner, Pompeu Fabra i Juan XXIII) amenacen amb fer vaga el 10 de gener si no s'han fet les millores necessàries per aquella data (calefacció, etc.).

22-12-1977: Entrevista d'una comissió de l'Assemblea d'Entitats Populars i Culturals amb el Conseller de la Generalitat provisional Pi i Sunyer pel tema de les classes de català.

27-12-1977: Fi de la tancada i l'autogestió d'Eurostil després de sis mesos de lluita. Les treballadores reben una indemnització de dos mesos i el subsidi d'atur.

31-12-1977: $\quad$ Dissolució del PMV de Santa Coloma.

4-1-1978: $\quad$ Protestes veïnals contra el fum de la xemeneia de l'ambulatori.

21-1-1978: Assemblea de l'AVV Safaretjos. Es demanen millores pel barri i juntament amb l'AVV Raval un ambulatori.

1-2-1978: $\quad$ 19è assalt als mòduls provisionals d'escola Josep Trueta (Les Vinyes). 
1-2-1978: $\quad$ Mort fent el servei militar per meningitis d'un veí colomenc del barri de Can Mariner militant del PSUC.

9-2-1978: $\quad$ Marxa dels professors de l'INE Puig Castellar en manifestació fins la seu del Ministeri d'Educació a Barcelona per millores en l'educació i en el centre.

11-2-1978: Tancament de 50 veïns del Raval en els baixos d'un edifici on exigeixen un ambulatori. Tancament també de 60 joves als locals parroquials de Foc Nou reclamant la majoria d'edat als 18 anys.

22/25-2-1978: Manifestacions diàries amb 400 veïns al Barri Llatí reclamant solars per fer parcs i equipaments pel barri. Els veïns ocupen i acondicionen dos solars com a parcs. Detenció del President de l'AVV Sandalio Pizarro.

28-2-1978: $\quad$ Suspensió del Ple de l'Ajuntament en donar-se la notícia d'un superàvit del PMH de 53 milions que provoca enfrontaments entre els regidors i l'abandó del Ple d'alguns d'ells.

2-3-1978: $\quad$ Possible tancament de tres Escoles bressol laborals.

5-3-1978: Veïns del Raval es mobilitzen per un ambulatori al barri. Manifestació i encadenament a les portes de l'Ajuntament. Violenta intervenció policial: 1 ferit, dues detencions i diversos contusionats.

8-3-1978: Denúncia d'IBUSA a un inquilí (Fermín Chueca [mirar si és militant]) per difamació (havia fet campanya contra la immobiliària per megàfon i amb pancartes).

14-3-1978: Desnonament de dues persones majors que regentaven un quiosc al barri del Fondo en un dels solars de Luis Molero Sujar (un important empresari).

15?-3-1978: Presentació de l'UCD de Santa Coloma de Gramenet. 69 militants.

22-3-1978: El president de l'AVV Raval, José Maria Ballesteros, critica la possibilitat de posar un centre penitenciari al barri mentre falten els equipaments imprescindibles.

6-4-1978: Notícia sobre unes obres irregulars al Raval paralitzades arran una denúncia de l'AVV (llicència caducada al juny de 1976 i edificació més alta de la permesa).

8-4-1978: $\quad$ Manifestació contra la instal-lació d'un penal a Santa Coloma.

18-4-1978: $\quad$ Vaga de mestres al Institut Puig Castellar per la disminució de categoria i sou de 34 professors.

19-4-1978: Es desestima la construcció de la nova presó en Santa Coloma de Gramenet. En teoria per que els terrenys oferits a la zona de Sant Mateu "no acomplien els requisits" (informe negatiu de la CMB).

26-4-1978: $\quad$ Elecció de Gabriela Serra com a secretària general de l'OIC després de l'expulsió del "pájaro" (Didac Fábregas) que poc després entra a militar al PSC.

8-5-1978: $\quad$ Notícia a Tele/ eXprés: quasi 100 avis viuen del cartró a Santa Coloma.

17-5-1978: Reunió de la Comissió de Partits amb l'Alcalde. Exigeixen entrar a la Comissió Municipal Permanent.

18-5-1978: En una assemblea els pares del col-legi Virgen de las Nieves es neguen a pagar les 
permanències a partir del proper mes mentre no se lis reconeguin la participació en la gestió del centre.

1-6-1978: $\quad$ Tancament patronal del col-legi Vírgen de las Nieves en represàlia per les reivindicacions de pares i mestres en contra de la pujada de quotes que consideraven abusives en ser un centre subvencionat per l'estat.

5-6-1978: 100 famílies exigeixen un pis pagat al 1973 (uns pisos que no es van acabar de construir pel Patronato Municipal de la Vivienda). Reclamació per estafa.

10-6-1978: El Grup Amics de la Ciutat ha adreçat respectives cartes al Conseller de Cultura de la Generalitat Pere Pi i Sunyer i a l'Ajuntament dues propostes per salvar i reutilitzar la Torre Balldovina i la Torre Pallaresa.

30-6-1978: Judici contra l'AVV Raval per ocupació d'un solar que van acondicionar com a Parc als carrers Àngel Guimerà i Monturiol.

8-7-1978: Una família gitana de 11 membres que porta visquen en un local insalubre en el barri del Raval des de gener: L'AVV reclama que se'ls faciliti un habitatge en condicions.

13-7-1978: Aprovació del pressupost general ordinari de l'Ajuntament pel 1978 en una quantitat de 565 milions de pessetes.

18-7-1978: Notícia sobre un catàleg de patrimoni arquitectònic i històric per protegir elaborat pels Amics de la Ciutat.

Llencen dos còctels molotov contra la seu de Fuerza Nueva.

25-8-1978: $\quad$ Llancen un còctel molotov contra l'Ajuntament per la nit.

6-9-1978: $\quad$ Continua la vaga de benzineres protagonitzada per la CNT i amb esdeveniments a Santa Coloma amb l'agressió a aquest dia a 5 cenetistes on està implicat un regidor ultra de l'Ajuntament, Sr. Castejón, propietari d'OVNI 3 al barri del Riu.

7-9-1978: Reclamació feta pels Pensionistes de Santa Coloma d'un transport públic gratuït per ells a l'Alcalde de Barcelona, a un Conseller de la Generalitat i un diputat. Concentració de cenetistes contra l'agressió patida el dia 6.

8-9-1978: Manifestació dels vaguistes de les benzineres a Santa Coloma sense intervenció policial.

Es protesta davant d'OVNI 3.

9-9-1978: $\quad$ Els veïns cursen una denúncia contra OVNI 3 per les molèsties que els hi ocasiona. Comença una campanya veïnal per impedir la seva reobertura.

26-9-1978: $\quad$ Concentració a la Plaça de la Vila i marxa fins la casa de l'alcalde en protesta pels diferents locals molestos (Ovni 3, Pub Kayuga, Cafetería el Buho) i per altres conflictes immobiliaris.

27-9-1978: Dificultats en el començament de curs per falta de mestres, places i endarreriment d'obres en les escoles de Santa Coloma.

4-10-1978: $\quad$ Es fa públic que la discoteca OVNI 3 no té permís d'obertura, només una llicència provisional del 2 de juliol de 1974 (així ho diu l'advocat dels veïns).

6-10-1978: Definitiva dimissió del regidor Rosset, després de dos intents no acceptats per 
l'alcalde Blas Muñoz el 25 de juny i el 13 de juliol.

7-10-1978: Violent desnonament d'un grup de veïns tancats a l'Ajuntament pel tancament d'Ovni 3, Pub Kayuga i d'altres locals molestos. 8 ferits.

13-10-1978: $\quad$ Els veïns dels locals molestos escriuen una carta al rei a Adolfo Suárez i a Martín Villa.

18-10-1978: $\quad 20 \%$ de persones analfabetes a Santa Coloma de Gramenet, segons un estudi fet fa dos anys pel Casal de Cultura.

19-10-1978: Tancament provisional d'Ovni 3 per part de l'Ajuntament. Manifestació de 200 joves en contra de la mesura el dissabte 14.

25-10-1978: $\quad$ Dues falses amenaces de bomba a l'Ajuntament.

2-11-1978: Crida veïnal i d'altres entitats al boicot al transport públic per la pujada de tarifes (sense gaire èxit). Detenció d'una militant de l'OCE-BR mentre repartia propaganda en aquest sentit.

3-11-1978: El regidor Matés accepta la Tinència de Cultura (vacant des de la dimissió de Rosset).

Tancament de la Cafeteria El Buho per la pressió veïnal.

5 o 6-11-1978: Presentació oficial a l'AVV de Santa Rosa del "Pla Popular" de Santa Coloma. Un pla alternatiu de ciutat fet després de dos anys de treball amb les aportacions populars de les AVV's.

11/12-11-1978: Festes del barri de Les Oliveres. Commemoració de l'onze de novembre en memòria a un dels dies més significats de la lluita popular al barri.

21-11-1978: Queda vacant de nou la Tinència de Cultura després de la renúncia del regidor Matés.

27-11-1978: L'AVV de Can Franquesa dona a conèixer la precària situació de dues famílies desnonades sense habitatge instant a les administracions a una solució.

Vaga d'estudiants a l'institut Puig Castellar per la no renovació de dues persones no docents.

?-11-1978: $\quad$ Les AVV's presenten el Pla d'Urgències de Santa Coloma.

4-12-1978: Després d'un tancament de dos dies de pares, educadors i alumnes de l'Escola Bressol San Francisco i d'un viatge a Madrid a parlar amb el Ministeri s'aconsegueix una subvenció per que sigui "guarderia laboral".

6-12-1978: Referèndum Constitucional. Nombroses irregularitats i deficiències en el cens electoral provoquen que un alt percentatge de la població de Badalona i Santa Coloma no pugui votar.

15-12-1978: Protesta d'uns veïns contra el constructor del seu immoble per haver venut uns soterranis que es fan servir com a locals de prostitució. L'acusat, Arnau Grabusola Solé, propietari de CARSO, S.A., no es presenta al judici.

16-12-1978: Acomiadament de dos tècnics municipals per irregularitats comeses en els seus càrrecs.

?-12-1978: $\quad$ Santa Coloma té Oficialment 142.880 habitants. 
28-12-1978: Continuen les lluites veïnals contra els locals molestos i bars de prostitució, en especial al barri de Santa Rosa.

1-3-1979: $\quad$ Eleccions a Corts.

3-4-1979: Eleccions municipals. Victòria del PSUC i bon resultat del PSC. Luis Hernàndez, Alcalde.

4-1979: $\quad$ Pacte municipal PSUC-PSC-PSOE.

27-4-1979: Primer ple al Poliesportiu de Can Sisteré amb 2.000 persones. Blas Muñoz és durament increpat $\mathrm{i}$ ha de sortit protegit per la resta de regidors.

28/29-4-1979: Veïns pinten passos de vianants per la ciutat.

5-1979: Les AVV's de Santa Coloma plantegen les seves reivindicacions a l'Ajuntament. Que la Coordinadora sigui reconeguda d'interès públic i poder participar amb veu en Plens i Comissions Permanents de l'Ajuntament, i en l'elaboració de la Carta Municipal.

Els veïns de Singuerlín s'oposen a l'edificació d'un solar.

Les esquerdes dels blocs de Les Oliveres necessiten reparació urgent.

Els petits comerços del Fondo en contra de la obertura d'un supermercat.

Assemblees veïnals al barri al respecte.

5 o 6?-5-1979: Acte per la municipalització de 4 "guarderies laborals" a la Plaça de la Vila.

8-5-1979: $\quad$ Mor una nena en caure en un forat de les obres del metro.

15-5-1979: Assalt als mòduls de l'Institut Puig Castellar.

30-5-1979: L'Ajuntament fa públic que retirarà el "Monument a la victòria".

6-1979: $\quad$ Primeres divergències entre PSUC i PSC-PSOE a l'Ajuntament.

La UGT demana la dimissió del regidor de Treball del PSUC per contractar en la Brigada Municipal a membres de CCOO.

S'anul-len llicències d'obres per crear zones verdas.

L'Ajuntament apuja de manera molt importat els impostos i taxes municipals. Protestes de al Coordinadora d'AVV's.

Creació d'un Centre de Planificació Familiar per dones que havien fundat

l'Associació Catalana de la Dona.

2?-6-1979: $\quad$ Al final el supermercat al Fondo té via lliure.

21/22-6-1979: Retirada definitiva del "Monument als caiguts" malgrat les amenaces ultradretanes.

7-1979: $\quad$ Mitjana de tres col-legis públics assaltats cada setmana.

Protestes veïnals contra l'augment desorbitat dels impostos municipals.

Es denega el permís per fer un centre d'hemodiàlisi al Singuerlín (els veïns protestaven per que es volia fer en un local que no reunia condicions).

7-7-1979: Nou reglament de Participació Ciutadana. Es recolleix el dret de les AVV's a veu als Plens.

S'elabora un catàleg d'edificis històrics a protegir.

26-7-1979: Els veïns del Raval fan un nou parc al barri amb col·laboració de l'Ajuntament. 
8-1979: $\quad$ Recuperació de la Torre Balldovina per l'Ajuntament.

9-1979: $\quad$ L'Ajuntament comença a eliminar els horts il·legals.

7?-9-1979: $\quad$ Manifestació de 4.000 persones per l'ensenyament a Santa Coloma. El PSA té local a Santa Coloma.

19-9-1979: $\quad$ Nova manifestació per les escoles.

25?-9-1979: De nou manifestació per les escoles amb la participació dels alumnes (3.000 persones).

27?-9-1979: $\quad$ Atur general de l'Ensenyament a la ciutat.

10-1979: $\quad$ Veïns de Can Calvet posen la mà d'obra per acondicionar uns terrenys. El PSC-PSOE denuncia la inoperància del consistori.

Es municipalitza el servei d'enllumenat.

PSUC i PSC-PSOE s'enfronten al Ple.

7-10-1979: $\quad$ Marxa Blava dels falangistes que acaba amb enfrontaments amb militants d'esquerres. Els falangistes fan servir armes de foc i hi ha dos ferits de bala (entre ells un militant del MCC). L'Ajuntament demana la dimissió del Governador Civil per haver-la autoritzat.

15?-10-1979: Un incendi provocat per uns nens destrueix el col·legi Verge de la Immaculada.

30?-10-1979: 200 persones en un acte de partits d'esquerra extraparlamentària contra l'extrema dreta.

11-1979: $\quad$ L'església del Singuerlín es fa servir com escola.

Possible renaixement de l'AVV del barri Llatí.

L'AVV del Riu aconsegueix el trasllat d'una panificadora molesta.

11-1979: Tensions internes al PSC-PSOE. Es reforça el sector "felipista".

Ultradretans trenquen les noves plaques dels carrers que s'havien començat a posar.

Preservació del Mas Fonollar.

3-11-1979: $\quad$ S'inaugura el primer local del PSA a Catalunya a Santa Coloma.

6-11-1979: Judici a OVNI 3 (bar musical sense permisos propietat d'un conegut ultradretà que havia estat regidor al consistori franquista). Absolució posterior als acusats de coacció per protestar contra el local.

12-1979: $\quad$ Dimissions en la direcció local del PSC-PSOE.

Partits polítics, AVV's, AMPAS, sindicats, comerciants proposen en una reunió fer una aturada general per demanar més policia.

Pintades ultres per la projecció d'una pel·lícula antinazi a l'Ateneu Llibertari de Santa Coloma.

13-12-1979: Manifestació de jubilats exigint que les pensions s'equiparin amb el salari mínim.

1-1980: $\quad$ L'Ajuntament compra la masia de Can Mariner.

Nou enfrontament entre PSUC i PSC-PSOE per la "campanya verda" (plantament d'arbres).

Empleades de la neteja protesten a l'alcalde. 
17-1-1980: $\quad$ L'Ajuntament compra un local al Raval per habilitar-lo com a local pels jubilats.

29?-1-1980: $\quad$ Assalt als locals del PSUC.

31-1-1980: $\quad$ L'Ajuntament destina 154 milions a urbanisme.

2-2-1980: $\quad$ Tancament a l'Ajuntament per reivindicar l'amnistia per dos presos de Santa Coloma.

5-2-1980: Q Querella de l'Ajuntament contra FET-JONS per la "Marxa Blava”.

9-2-1980: $\quad$ La reunió sobre seguretat ciutadana s'ha de suspendre pels xiulets als regidors del PSUC per altres grups d'esquerres.

12-2-1980: $\quad$ Calen foc al cotxe de Luís Hernàndez (un Renault 4).

15?-2-1980: Els comerciants es posicionen contra la nova pujada d'impostos i proclamen un boicot a aquests.

17-2-1980: $\quad$ Inauguració d'un parc al barri Safaretjos.

20-2-1980: $\quad$ Festes de Carnestoltes organitzades per les AVV's amb forta participació popular.

22-2-1980: $\quad$ Atracament a una sucursal de La Caixa de Pensions.

25?-2-1980: Jornades antinuclears organitzades per l'Ateneu Llibertari.

3-1980: $\quad$ El Ministeri d'Obres Públiques afirma que les immobiliàries Albica SA i Corterres, SA han s'han de fer càrrec de les despeses de reparació del barri de Les Oliveres. Dimiteix el director de la Clínica Mental de Santa Coloma.

Es crea un Comitè Antifeixista.

Es crea una llar d'avis provisionament al local de l'AVV de Singuerlín.

Una moció de CiU trenca el Pacte municipal.

2-3-1980: $\quad$ L'AVV del Riu fa una plantada d'arbres. Es fa el mateix al barri de La Guinardera.

9-3-1980: $\quad$ El PSA suspèn un miting per falta de públic.

29-3-1980: $\quad$ Els socialistes abandonen el Ple després d'un dur debat amb el PSUC.

4-1980: $\quad 20.000$ alcohòlics a Santa Coloma segons Grama.

14?-4-1980: Veïns del Centre reclamen la tornada d'un metge a l'ambulatori.

30-4-1980: $\quad$ L'Ajuntament decideix tapiar la Torre Balldovina per impedir assalts vandàlics.

5-1980: $\quad$ Es projecten places públiques a la "Via Cívica" del Fondo.

Oposició de l'AVV del Riu a les contribucions especials aprovades en el Ple.

Veïns de La Guinardera contra una sentència judicial relacionada amb el cas de la Cooperativa VIPES.

S'inaugura un dispensari mèdic a Can Franquesa.

Veïns de Les Oliveres i Can Franquesa aconsegueixen una dotació de 16 milions per obres públiques i reparacions al barri.

Tensions a l'executiva del PSC-PSOE i dimissions a l'executiva.

1-5-1980: $\quad$ Manifestació contra l'atur. 
5/6-1980: $\quad$ Destrucció dels horts il·legals.

6-1980: $\quad$ Investigació i sanció d'una patrulla municipal per actes violents.

El Consell Popular d'Ensenyament es veu impotent per solucionar el problema de la manca de places escolars.

7-6-1980: Visita de Pujol als barris de Singuerlín, Guinardera, Can Franquesa i Les Oliveres.

13-6-1980: $\quad$ Tancada de pares i mestres de Llars d'infant laborals a l'Ajuntament (demanen la municipalització). Acord a darrera hora per continuar negociant.

14?-6-1980: $\quad$ Es constitueix l'Assemblea d'Aturats de Santa Coloma.

7-1980: $\quad$ Cessió per una immobiliària d'un local per fer un Casal de Barri a Llatí.

Visita de Jordi Pujol a Can Franquesa.

12-7-1980: $\quad$ Atracament a una sucursal del Banc de Bilbao.

9-1980: $\quad$ Dimissió de Jesús Vicente i 5 persones més de l'executiva local del PSC-PSOE.

Tiroteig amb uns atracadors.

Els ultres treuen un monument a l'Alcalde Manent.

29-9-1980: $\quad$ Detenció de 5 membres de l'Assemblea d'Aturats que feien un piquet.

10-1980: $\quad$ Afer de la falsa bomba contra Lluís Hernàndez. Polèmica per si es coneixia que era una falsa alarma quan es va fer l'acte al carrer.

Campanya desratitzadora a Santa Coloma.

CCOO i UGT creen una Comissió d'Aturats com alternativa a l'Assemblea d'Aturats.

29-10-1980: $\quad$ El MOP concedeix 15 milions per arreglar habitatges del Patronat a Les Oliveres i La Guinardera.

11-1980: $\quad$ Els veïns del passeig de la Salzareda es neguen a pagar les contribucions especials. L'Ajuntament anuncia que Can Mariner serà el futur casal del barri.

Veïns del Singuerlín netegen un solar i construeixen un parc.

La Generalitat dona un crèdit de 82 milions a l'Ajuntament.

Atracament a una sucursal de La Caixa de Pensions.

15-11-1980: $\quad$ Es cedeixen terrenys a La Bastida per construir escoles.

21-11-1980: $\quad$ El Casal de Cultura reclama una subvenció municipal.

\section{1-1985}

1-1981: Denuncien anomalies en la contractació de personal de l'Ajuntament.

1/2-1981: $\quad$ II Assemblea d'AVV's de Catalunya al barri de Santa Rosa

23-1-1981: $\quad$ Els veïns del Raval protesten per la falta de neteja del barri.

27-1-1981: $\quad$ Es fa pública la dimissió del regidor Enrique Bellete (eurocomunista).

31-1-1981: La policia dissol violentament una manifestació de veïns que tallaven el trànsit per la urbanització del Passeig de la Salzareda.

2-1981: $\quad$ Veïns de Can Franquesa i La Guinardera demanen ajuda per construir un parc posant ells la mà d'obra. 
El MOP promet una subvenció per reparar els pisos de Les Oliveres.

Es crea un centre de pensionistes a Les Oliveres.

La Coordinadora d'AVV's aprova fer boicot a les contribucions especials.

La Unió Patronal de Santa Coloma, ACAPIC i Unió de Botiguers del Baix Besòs contra el cobrament de l'impost de radicació de 1980.

S'aguditza la crisi del PSUC.

Protesta del PSC per pressumptes irregularitats en la Guàrdia Urbana (per un concurs fet a mida).

2-2-1981: $\quad$ Atracament a una sucursal de La Caixa a l'Av. Banús Baixa (torna a ser atraca dies després.

5-2-1981: $\quad$ El Comitè Local del PSUC accepta la dimissió de 4 regidors comunistes en protesta per la dimissió-cessament de Bellete. Intervenció de Paco Frutos per aturar la crisi.

23-2-1981: $\quad$ Trets amb arma de foc contra l'Ajuntament de Santa Coloma.

3-1981: $\quad$ Els veïns del Barri de Riu Nord reivindiquen un Casal de Barri.

Veïns del Riu denuncien al Ple les molèsties d'un restaurant i el projecte

d'instal-lació d'un Bingo.

Atracament a una sucursal bancària al carrer Francesc Macià.

L'Ajuntament demana a la Generalitat que aturi els desnonaments.

1-3-1981: $\quad$ Inauguració del Casal del barri Llatí.

10-3-1981: Veïns del carrer Nàpols decideixen no pagar contribucions especials.

23?-3-1981: Tria d'un nou Comitè Local del PSUC "monocolor".

30-3-1981. Protestes dels veïns del carrer Sant Roman contra les Contribucions Especials.

Referèndum al barri del Riu sobre el Bingo. 400 veïns en contra i només 18 vots a favor (de 1.800 persones .amb dreta a vot).

4-1981: $\quad$ Ampliació de la Plaça Baró a Riu Sud.

L'AVV La Guinardera dona feina a aturats.

Només es registra un atracament al mes de març.

Alguns membres del PSC-PSOE signen el "Manifiesto Lingüístico".

Comença una campanya de l'Ajuntament contra l'OTAN.

18 al 23-4-1981: Setmana de l'Ensenyament organitzada per pares i mestres.

24-4-1981: Debat sobre el "Manifest Lingüístic" ("dels 2.100”) organitzat per la revista local El treinta y cinco.

28-4-1981: $\quad$ Fi de les protestes al barri del Riu per un restaurant.

5-1981: $\quad$ Atracament a una Caixa Laietana del Carrer Llorenç Serra.

No hi ha diners per posar en marxa el Casal de la Joventut.

Les agrupacions del PSUC de Santa Rosa, Fondo i Llatí demanen l'expulsió de Jordi Borja i la supressió momentània de militància del Guti i Gregorio López Raimundo.

5-5-1981: $\quad$ El PSC-PSOE es mostra públicament favorable a la instal·lació d'un Bingo.

6-1981: $\quad$ L'AVV Riu Nord impulsa una campanya per la neteja d'un solar.

12-6-1981: $\quad$ El Tribunal Contenciós Administrtiu estipula que Can Zam es una zona esportiva i d'equipaments socials. 
15-6-1981: La regidora de Serveis Socials, Manuela de Madre, acusa al PSUC de no tenir sensibilitat amb els disminuïts físics.

16-1-1981: $\quad$ El Comitè Local del PSUC sanciona amb una advertència a l'alcalde i quatre regidors per oposar-se a la municipalització del servei de neteja prestat per l'empresa LIMASA.

17?-6-1981: Inauguració d'una assessoria feminista al Casal de la Dona.

Acusen a Rafael Hidalgo, del PSC-PSOE d'amenaçar al cap de la Guàrdia Urbana, militant de CCOO.

30-6-1981: Tres pares es tanquen a l'Ajuntament en protesta per la manca de places escolars.

7-1981: Manifestacions i talls de trànsit dels veïns de l'Avinguda Pallaresa exigint el seu asfaltat.

Els socialistes abandonen el govern municipal. Es fan converses entre el PSUC i el PSC-PSOE per mirar de redreçar la situació.

2-7-1981: Desallotjament dels tres pares tancats a l'Ajuntament.

9-1981: Un vídeo promocional de l'Ajuntament per les Festes Majors enfronta a PSUC i PSCPSOE.

S'obre un procés contra Lluís Hernàndez per "irregularitats" en l'ocupació d'una finca deshabitada.

Cent mil persones participen a les festes de la ciutat.

24-9-1981: El regidor del PSUC Jaume Fonseca presenta la seva dimissió.

10-1981: Campanya de les AVV's de Singuerlín i veïns de l'Av. Pallaresa en contra del segon cinturó de ronda (pel seu soterrament).

13-10-1981: L'alcalde Lluís Hernàndez presenta la seva dimissió pels enfrontaments amb els partidaris del Vè Congrés per l'afer de LIMASA.

17-10-1981: Tensa assemblea en el barri de Singuerlín on Lluís Hernàndez explica els motius de la seva dimissió. Segons algunes fonts hi ha intents d'agressió contra ell.

Posteriorment renuncia a la dimissió quan els partidaris de la municipalització es tiren enrere.

20-10-1981: Dimiteixen dos tinents d'alcalde: Rafael Hidalgo (PSC-PSOE) i Máximo Luna (PSUC).

12-1981: Creació de la primera emissora de ràdio local municipal a Santa Coloma (que no comença a emetre fins mesos després).

L'Ajuntament clausura l'escorxador de Santa Coloma.

1-1982: $\quad$ La Generalitat dona 15 milions per restaurar la Torre Balldovina.

2-1982: $\quad$ Es comencen a construir els pisos de Can Calvet.

L'Ajuntament es gasta mil milions en obres i despeses socials.

27-2-1982: Tensió al Ple quan un dels regidors expulsats pels eurocomunistes, Chema Corral, es nega a cedir el seu seient $i$ abandonar la sala.

5-3-1982: Es fa públic que l'Ajuntament destinarà 17 milions a restaurar la Torre Balldovina. 
16-3-1982: Tensió en el ple on el públic protesta i mostra pancarta en protesta per l'expulsió dels 5 regidors partidaris del Vè Congrés.

21-3-1982: $\quad$ La Generalitat destina 44 milions a Les Oliveres.

26-4-1983: Els nens de Les Oliveres demanen a Pujol més mestres de català.

9-1983: $\quad 35$ cursos de català per adults a Santa Coloma.

10-1982: $\quad$ Els desnonaments al Barcelonès són especialment greus i nombrosos a Santa Coloma.

Falten carrers per asfaltar al barri del Raval.

Crítiques de Lluís Hernàndez a la visita del Papa.

L'Ajuntament reclama un nou pont que comuniqui la ciutat amb Barcelona.

4-10-1982: $\quad$ La Junta directiva de la Unió Patronal de Santa Coloma refusa a Villora (conegut ultradretà) i es presenta l'alternativa d'Albert Samper (proper a CiU), que esdevindrà finalment el nou president.

8-10-1982: Protestes dels comerciants per l'augment de les taxes municipals.

27-10-1982: CDC acusa a l'Ajuntament de triplicar el nombre de funcionaris.

12-1982: Oposició veïnal i dels col-lectius de dones al possible tancament de la clínica maternal.

La Generalitat destina 20 milions a Can Franquesa.

4-12-1982: $\quad$ Tancada a l'Ajuntament de la Comissió d'Aturats del barri Llatí.

Només falta l'enllumenat per concloure les obres del Passeig de la Salzareda.

6 al 12-12-1982:Setmana de la Salut organitzada pel Consell de Salut i la Conselleria de Sanitat de l'Ajuntament.

28-12-1982: Oposició de l'Ajuntament i la CMB a una nova línia d'alta tensió.

1-2-1983: $\quad$ Conveni per construir una biblioteca al barri del Fondo.

8?-2-1983: Veïns i comerciants de Les Oliveres, Singuerlín i La Guinardera demanen més vigilància per impedir robatoris.

11-2-1983: Atracament a una joieria.

19-2-1983: Deu veïns que es van oposar a un desnonament declaren als jutjats.

3-1983: $\quad$ Es presenta el projecte i comencen les obres del Mercat del Singuerlín.

8-3-1983: $\quad$ Protestes de les AVV's de Cementiri Vell, Singuerlín, Llatí i Raval protesten al Ple per les contribucions especials.

24-3-1983: Un veí malalt impedeix el seu desnonament avisant que tindran que disparar per que surti de casa. Les AVV's demanen una nova Llei d'Arrendaments Urbans per aturar els desnonaments.

2-4-1983: Roben l'equip de Ràdio Besòs, emissora vinculada al conegut empresari ultradretà Francisco Villoria. El director de l'emissora acusa a aquest de ser l'autor del robatori. 
6-1983: L'assassinat d'un comerciant augmenta la psicosi d'inseguretat i dispara la venda d'armes.

6 al 11-6-1983: Setmana del Consumidor a Santa Coloma.

11-7-1983: $\quad$ Assalt i destrucció d'un taller de disminuïts psíquics.

15-9-1983: $\quad$ El PSC demana la dimissió del regidor de Cultura per uns fets de la Festa Major.

2-10-1983: L'Ajuntament compra la nau de l'antiga fàbrica Ciba-Geigy per 100 milions.

5-10-1983: $\quad$ El PSC-PSOE acusa al PSUC de "suburbialisme" i de provocar conflictes interns amb els treballadors de l'Ajuntament.

7-10-1983: $\quad$ Lluís Hernàndez desautoritza al tinent d'alcalde de Governació Carlos Grande. Dur enfrontament que durarà mesos.

26-10-1983: Greus incidents i enfrontaments entre PSUC i PSC-PSOE. Lluís Hernàndez crida a Obiols a que "cridi l'atenció" als socialistes de Santa Coloma.

11-1983: $\quad$ Un estudi diu que el 20\% dels colomencs viu en barraques o infrahabitatges. Els veïns accepten la instal·lació d'un Bingo a l'antic Cine Capitol. Serà gestionat per CEMFIS (entitat que treballa amb persones amb disminucions físiques).

30-11-1983: La Generalitat desestima un recurs del PSC-PSOE contra l'alcalde de Santa Coloma.

12-1983: $\quad$ Assalten per setena vegada un taller per disminuïts psíquics.

1-12-1983: $\quad$ Possible il·legalitat en els sous d'alguns càrrecs municipals.

21-12-1983: Inauguració del tram de metro que arriba a Santa Coloma. Es suprimeixen línies d'autobusos i esclaten protestes veïnals. Es segresten 4 autobusos a Les Oliveres.

23-1-1984: Veïns del Motocross disconformes amb l'expropiació dels seus habitatges per fer un poliesportiu.

24?-1-1984: $\quad$ El Mas Fonollar esdevé un Casal de Joves.

30-1-1984: $\quad$ Atracament amb hostatges a Santa Coloma.

2-1984: $\quad$ Pla municipal contra l'atur.

Conflicte a la Clínica Mental de Santa Coloma per la reforma que vol fer la Diputació amb gran part de la plantilla en contra.

15-2-1984: Concentració d'alumnes de l'Institut Carles Buigues davant l'Ajuntament.

3-1984: $\quad$ El Centre de Planificació Familiar de Santa Coloma està colapsat per l'alta demanda.

1-3-1984: $\quad$ Tancament comercial en protesta per la inseguretat ciutadana.

13-3-1984: Detenció d'un menor de 16 anys responsable de 27 atracaments.

16-3-1984: $\quad$ Els comerciants de Santa Coloma demanen més policia al Governador Civil.

24-3-1984: $\quad 300$ persones a la marxa contra els desnonaments convocada per la Comissió per la defensa de l'Habitatge. 
4-1984: Pujol s'entrevista amb la Comissió en Defensa de l'Habitatge, creada a Santa Coloma per lluitar contra els desnonaments.

25-4-1984: 100 veïns tallen la Carretera de La Roca en protesta per la mort d'una noia de 16 anys en un atropellament.

26-4-1984: $\quad$ Cinquena caseta electoral de CiU destrossada.

Una família és desnonada d'un habitatge de Can Calvet que havia ocupat.

1-6-1984: $\quad$ Vaga de sis dies en el servei d'escombraries.

Encara hi ha un dèficit de 1.000 places escolars (hi ha centres encara en construcció).

9-6-1984: $\quad$ Pujol assisteix a la romeria de Sant Jeroni.

20-6-1984: $\quad 7$ anys de presó per un policia que va assetjar i disparar contra una jove colomenca.

26-6-1984: L'Ajuntament organitza l'activitat "Estiueig a la ciutat".

Un grup de veïns del Raval ocupa Ràdio Gramenet per l'afer d'una ocupació d'uns habitatges buits per unes famílies gitanes. Tensió al barri per aquest fet.

7-1984: $\quad$ Es demanen més Centres de Planificació Familiar a Santa Coloma.

8-1984: $\quad$ Detenció d'uns mestres de català d'escoles d'adults acusats de ser de Terra Lliure.

1-9-1984: $\quad$ Descens pel riu Besòs per reivindicar la seva neteja.

Es redacta un pla especial per remodelar el casc antic.

17-9-1984: $\quad$ Mobilitzacions contra la manca de places escolars.

18-9-1984: $\quad$ Més de 2.000 persones en una assemblea de pares i mestres per tractar per l'endarreriment de les obres de tres escoles públiques que no estan acabades a l'inici de curs.

27-9-1984: $\quad$ Dues nenes ferides greus en un atracament.

1-10-1984: 350 alumnes de batxillerat es concentren reivindicant aules.

31-10-1984: Apagada municipal contra l'OTAN.

11-1984: $\quad$ El Govern Civil creu que l'Ajuntament de Santa Coloma va delinquir en l'apagada contra l'OTAN.

L'Ajuntament perd 172 milions en impostos no cobrats.

La policia dissol violentament a les Rambles una manifestació d'estudiants de Santa Coloma.

2-11-1984: $\quad$ Manuela de Madre diu que l'apagada contra l'OTAN va tenir un seguiment escàs.

5-11-1984: $\quad$ Enfrontaments al consistori per l'afer de l'apagada contra l'OTAN entre PSUC i PSCPSOE.

8-11-1984: $\quad$ Cinc persones s'encadenen contra l'OTAN a l'Av. Generalitat.

12,12 i 14-11-1984: Talls de trànsit per la situació d'una escola en un barracot.

27-11-1984: S'inaugura el mercat del Singuerlín, una vella reivindicació veïnal. 
13-12-1984: Més de 5.000 persones es manifesten per l'escola pública en Santa Coloma.

11-1-1985: Mor un nadó en el barri de Singuerlín. La mare de 26 anys estava en una situació de misèria. Polèmica per si va rebre una atenció correcta dels serveis socials.

12-1-1985: En una conferència Lluís Hernàndez critica als seus companys del grup municipal als que acusa de personalisme.

25-1-1985: Querella del PSC de Santa Coloma contra la revista La Veu del Besòs, propietat d'un conegut ultradretà.

2-1985: $\quad$ Problemes amb Hisenda de l'Ajuntament de Santa Coloma per la quantificació del deute històric del municipi. Hisenda tornarà a auditar el municipi. Crítiques del PSC-PSOE per aquest afer.

6-2-1985: Desconeguts calen foc a uns horts il-legals al costat de Can Peixauet.

24-2-1985: 1.500 signatures contra el tancament de la caserna de la Guàrdia Civil.

27-2-1985: L'Ajuntament envia cartes a municipis catalans demanant terres per que les puguin cultivar aturats de Santa Coloma.

3-1985: $\quad$ El II cinturó serà soterrani al seu pas per Santa Coloma.

Dos regidors del PSUC es querellen també per injúries contra La Veu del Besós.

9-3-1985: $\quad$ Més de 100 dones demanen més centres de planificació familiar.

4/5-1985: $\quad$ Aprovació i exposició pública del Pla Vial del Riu Besòs.

18-4-1985: Acord Ajuntament-Generalitat. 230 milions per reparar escoles.

28-4-1985: Segrest d'un autobús a Singuerlín.

29-4-1985: Setè assalt al Col-legi Josep Trueta en el mateix any.

5-1985: Un Ple a Santa Coloma declara "persona non grata" a Ronald Reagan. Els regidors socialistes s'abstenen de votar i són increpats pel públic.

4/5-5-1985: Assalt i destrosses a un institut de Batxillerat.

10-5-1987: Cadena humana en defensa de l'escola pública.

25-5-1985: Crisis en el grup municipal del PSUC. Lluís Hernàndez suspèn a Carlos Grande de la Comissió de Govern.

1-6-1985: Després de diversos enfrontaments interns, s'aprova el nou cartipàs municipal quedant fora Carlos Grande i altres dos regidors, Remei Martínez i José Candado. Comença el termini per presentar al·legacions al Pla Vial del Besòs.

2-6-1985: Detenció per atracament d'un antic militant d'Acción Comunista del barri de Santa Rosa, Juan Manzanares.

8-6-1985: Referèndum "alternatiu" sobre l'OTAN a Santa Coloma (amb implicació de l'Ajuntament i entitats de la ciutat).

10-6-1985: Cessament de Carlos Grande com portaveu del Grup Municipal del PSUC. 
7-1985: Després de 15 anys de conflictes i litigis, els veïns de Les Oliveres esdevenen propietaris dels seus habitatges reformats.

1-7-1985: $\quad$ Restaurada la Masia de Can Mariner com un equipament pel barri.

9-1985: La parròquia i l'AVV de Santa Rosa recapten diners per ajudar a una família gitana. Reticències del PSC-PSOE al soterrament del II Cinturó.

Hisenda atorga 452 milions a l'Ajuntament de Santa Coloma.

Es constitueix una Coordinadora veïnal contra els bars molestos.

25-9-1985: Concentració a la plaça de la Vila per exigir aules escolars i no barracots.

5-10-1985: $\quad 22$ entitats ciutadanes ocupen una sucursal bancària en protesta per una subhasta fraudulenta.

Es confirma que el II Cinturó serà soterrani al seu pas per Santa Coloma.

13-10-1985: Comença la Setmana Cultural d'Andalusia a Santa Coloma.

28-10-1985: $\quad 40$ comerciants protesten al mercat de Singuerlín per les taxes municipals.

Dimissió d'Antonio Titos (PSUC).

Crítiques públiques de Carlos Grande a Lluís Hernàndez en un Ple.

11-1985: $\quad$ Es fa pública la notícia que en breu es constituirà una Associació Gitana a Santa Coloma.

16-12-1985: Concentració de 20 dones per la negativa de Clínica Maternal a practicar tres avortaments.

19-12-1985: Dues dones de Santa Coloma viatgen a Holanda per avortar.

23-12-1985: S'inicia un dejuni de membres de la comunitat cristiana a la parròquia de Can Mariner en protesta per la situació a Centreamèrica.

$\underline{1986-\ldots}$

3-1986: $\quad$ Carlos Grande marxa del PSUC.

12-3-1986: Referèndum sobre l'OTAN. El SI guanya a Santa Coloma.

4-4-1986: $\quad$ El Tribunal Suprem condemna a 1 any de desterrament a $100 \mathrm{~km}$ de la ciutat al president de l'AVV del Raval, Josep Pitarque.

26-5-1986: Veïns de Singuerlín acondicionen un solar i el reivindiquen com a parc.

16-4-1986: $\quad$ S'aprova una moció contra el desterrament de Josep Pitarque.

25-4-1986: $\quad$ Altercat i detenció d'un militat del PSUC i un altre del MCC en el jutjat colomenc per un jutge que els acusa d'injúries.

5-1986: L'abandonament dels regidors del PSUC José Candado i Antonio Gómez fa que el PSUC perdi la majoria a l'Ajuntament de Santa Coloma. S'intenta negociar un nou pacte amb el PSC-PSOE sense èxit.

23?-5-1986: L'Associació de minusvàlids CEMFIS demana la dimissió de l'Alcalde per no cedirlos un microbús per una excursió. El Consistori refusa les crítiques fetes. 
4-6-1986: $\quad$ Es fa públic que la Torre Balldovina serà el futur Museu d'Història.

6-6-1986: $\quad$ El PSC-PSOE condiciona el seu pacte amb el PSUC a la dimissió de Lluís Hernàndez.

18-6-1986: $\quad$ El Defensor del Poble i el Síndic de Greuges refusen el recurs d'empara presentat per Josep Pitarque.

21-6-1986: S'anuncia que Santa Coloma tindrà un centre per disminuïts psíquics profunds (acord Diputació, Ajuntament i ASPANIDE).

7-1986: $\quad$ Polèmica per que el representant de La Trinca refusa programar actuacions a Santa Coloma per que ho considera "perillós". Al final el grup el desautoritza i programa una actuació.

En aquests anys s'han aprovat 18 plans urbanístics a Santa Coloma.

5-7-1986: $\quad$ Esclaten dos artefactes casolans a la porta del Hiper de Santa Coloma.

10-1986: $\quad$ No hi ha acord entre PSUC i PSC-PSOE.

12-7-1986: $\quad$ Conflicte laboral en el Hiper de Santa Coloma (fins el dia 18).

18-9-1986: $\quad$ Protestes pel desterrament de Josep Pitarque davant del jutjat. 3 persones són detingudes.

19-9-1986: Manifestació en solidaritat amb Josep Pitarque. Aquest i altres veïns s'enfilen al sostre de l'Ajuntament i es "crucifiquen" com a protesta.

20-9-1986: Un miler de persones tornen a manifestar-se en solidaritat amb Josep

Pitarque.

10-1986: $\quad$ Enfrontaments entre PSUC i PSC-PSOE pels jocs olímpics.

Amenaça de desnonament d'una família inquilina de l'antic alcalde Blas Muñoz. La Generalitat es compromet a pagar el seu lloguer.

A Santa Coloma hi ha una mitjana d'un desnonament al dia.

La policia investiga als mestres de català d'un col-legi d'EGB per una guixada en un pupitre que deia "som una nació" que relacionen amb un fals avis de bomba que algú va fer en nom de Terra Lliure. Queixes d'uns advocats per aquest procediment. Judici a un llicenciat d'Història aturat que es va colar al metro.

7-11-1986: $\quad$ Es desestima el recurs de Josep Pitarque

11-1986: $\quad$ Inauguració de la nova Plaça del Rellotge.

9-12-1986: Carlos Grande no renuncia al seu càrrec de diputat provincial tot i ja no ser regidor pel PSUC (ara és “independent").

31-12-1986: $\quad$ S'anuncia l'ordre de clausura de Ràdio Tele Taxi.

1-1987: $\quad$ Polèmica pel tancament de l'Ateneu Cultural.

Disputes entre PSUC i PSC-PSOE per la suspensió d'un Ple per part del PSUC per no perdre la votació dels pressupostos municipals (el PSC-PSOE havia anunciat el seu canvi de vot tot i haver pactat abans aquest amb el PSUC).

2-1-1987: $\quad$ El Govern Civil precinta el repetidor de Ràdio Tele Taxi.

3-1-1987: $\quad$ Milers de persones es manifesten demanant la reobertura de Ràdio Tele Taxi. 
23-1-1987: Una comunitat de veïns del Carrer Irlanda a judici per unes pancartes contra una immobiliària.

2-1987: $\quad$ Es promou un consorci per la protecció del Riu Besòs per part de 52 municipis.

3-1987: El PSC-PSOE promociona intensament al candidatura de Manuela de Madre a l'Alcaldia.

Creació d'un Comitè Antifeixista per respondre a les agressions de col-lectius ultradretans.

7-3-1987: $\quad$ Ple on es tracta la clausura de Ràdio Tele Taxi. PSUC i PSC-PSOE mostren el seu suport a l'emissora.

Carmen Romero, esposa de Felipe González, a Santa Coloma per promocionar la candidatura de Manuela de Madre.

9-3-1987: $\quad$ Incendi a l'Hospital Mental.

Manifestació contra el trasllat de la Clínica Maternal a l'Hospital de Can Ruti (Badalona).

22?-4-1987: $\quad$ Absolució dels falangistes que van protagonitzar la "Marxa Blava” de 1979.

10-6-1987: Eleccions municipals: IC 13 regidors; PSC-PSOE: 12; CiU: 2.

19-6-1987: Diversos colomencs morts a l'atemptat d'Hipercor, entre ells , Xavier Valls, un dels impulsors del Pla Popular.

28-6-1987: S' S'inaugura el Museu de Santa Coloma a la Torre Balldovina.

30?-6-1987: Lluís Hernàndez és investit Alcalde amb el suport de CiU.

7-1987: $\quad$ Tot hi haver-hi negociacions entre PSUC i CiU, al final acaba esdevenint un pacte PSUC-PSC-PSOE.

2-11-1987: El Tribunal Constitucional Confirma la pena de desterrament per Josep Pitarque. Resta pendent de resolució el recurs interposat al Tribunal Europeu dels Drets Humans.

3-11-1987: $\quad$ Noves mobilitzacions en suport de Josep Pitarque aprovades per 26 entitats ciutadanes. Es planteja la possibilitat de que l'Ajuntament concedeixi "asil polític" al condemnat.

L'Ajuntament demana l'indult.

21-3-1987: $\quad$ Un Real Decret concedeix l'indult a Josep Pitarque. No obstant, només contempla el desterrament i no les sancions econòmiques, fet que ocasionarà diverses reclamacions del denunciant que s'allargaran fins més enllà de l'any 2002.

\section{Cronologia Sant Adrià de Besòs}

1952: Javier Casellas Fàbregas (1952-1961) substitueix en l'Alcaldia a José Sabater Ferruz.

\section{$\underline{1961-1965}$}

1961:

José Narbon Noet (1961-1966) substitueix en l'Alcaldia a Javier Casellas Fàbregas. 
1964: Es presenta la documentació per legalitzar l'AVV Besòs-COBASA (sota el règim de les Asociaciones de Cabezas de Familia)

9-4-1965: El “Ministerio de la Vivienda” aprova la delimitació del nou polígon La Mina.

\section{$\underline{1966-1970}$}

1966:

Constància de l'existència de l'AVV de Montsolís i del Centre Social del Camp de la Bota.

Fundació del Centre Social del Besòs.

1966: $\quad$ Francisco Roqueta Prat (1966-1973) substitueix en l'Alcaldia a José Narbon Noet.

20-6-1967: Referències al treball del Centre Social del barri Besòs.

1967: $\quad$ Polèmica Obres Plaça Ajuntament (aleshores Calvo Sotelo)

4/7-1967: Cartes d'un veí del Besòs queixant-se per un abocador d'escombraries proper al barri.

1968: $\quad$ Legalització de l'AVV de La Catalana. Enviament de respectuoses peticions per par d'aquesta a l'Ajuntament per instal-lar una font al barri.

1-1968: Trasllat de barraquistes de Sant Adrià (Camp de la Bota, La Catalana) a Pomar (Badalona).

13-3-1968: Visita del regidor president del "Patronato Municipal de la Vivienda" Martí Cot a les obres de La Mina.

26-5-1968: S' S'atorga a Samaranch la medalla d'or a l'esport a Sant Adrià.

6-8-1968: Inauguració central tèrmica del Besòs del Ministre d'indústria Gregorio López Bravo.

8-9-1968: $\quad$ Primers Jocs Florals de Sant Adrià organitzat per l'Associació d'Ex-alumnes del Sagrat Cor dins l'entoldat de la Festa Major.

9-1968: $\quad$ Segrest del núm. 16 de la revista Besós i processament pel TOP el seu director Francesc Arnau.

19-2-1969: Comença les activitats formalment l'Associació d'Ex-Alumnes del Sagrat Cor.

24-4-1969: Compareixença davant el TOP de Francesc Arnau pel segrest de Besós núm. 15 l'Agost de 1968.

30-4-1969: Manifestació "llampec" contra la dictadura a Sant Adrià.

5-5-1969: $\quad$ Absolució de Francesc Arnau al TOP.

17-9-1969: $\quad$ 1era edició de la Nit Literària de Sant Adrià al Col·legi Sagrat Cor.

12-11-1969: Llum per a les Barraques de "El Parapeto".

22-3-1970: $\quad$ Mor un nen al Besòs per les ferides d'un lleó que havia escapat d'un circ.

Protesta veïnal a les autoritats locals (creuament de declaracions a la premsa). 
8-9-1970: $\quad$ Inauguració d'un nou grup escolar a La Catalana i es posa la primera pedra del nou Ajuntament.

16-9-1970: $\quad$ Greu problema escolar al Camp de la Bota

17-11-1970: $\quad$ Eleccions al Tercio Familiar als Ajuntaments. Participació del 29\%.

24-11-1970: $\quad$ Eleccions al Tercio Sindical als Ajuntaments.

\section{$\underline{1971-1975}$}

21-1-1971: $\quad$ Anulació de les eleccions locals pel recurs d'Antonio Bonet Manich (president de l'AVV La Catalana al qual li havien refusat la candidatura pel Tercio Familiar).

20-3-1971: Instal·lació de semàfors en dos encreuaments a la variant de La Roca al pas per Sant Adrià.

21-3-1971: $\quad$ Noves eleccions al Terç Familiar ara si amb A Bonet com a candidat, tot i que no resulta escollit.

23-4-1971: $\quad$ Nou recurs presentat per A Bonet contra dues candidatures a les passades eleccions (Rafael Guzmán Márquez, per no saber llegir i escriure i fer campanya abans d'hora i Angel Guirau Pelegrín per fixar campanya electoral a parets i residir a Barcelona).

5-5-1971: $\quad$ Expedient de crisi a l'empresa SABA.

28-5-1971: $\quad$ Les Obres de la "Plaza Calvo Sotelo" estan gairebé acabades però les filtracions d'aigua inunden la 1era planta de l'aparcament.

12-6-1971: $\quad$ Acomiadament de 94 treballadors de SABA.

8-7-1971: $\quad$ Inauguració de les obres de la "Plaza Calvo Sotelo" amb la presència del Governador Civil Tomàs Pelayo Ros.

10-7-1971: El "Tribunal de lo Contencioso" desestima el segon recurs de A. Bonet contra les eleccions al Tercio Familiar.

20-9-1971: $\quad$ Una riuada destrossa part del camp municipal d'esports.

18-9-1971: $\quad$ El president de l'AVV La Catalana (A. Bonet) denuncia la construcció sense permís de la Central Tèrmica de Sant Adrià.

28-10-1971: $\quad$ Es presenta un estudi sobre el Camp de La Bota (més de 3000 persones en 700 barraques amb només 5 fons i sense evacuació d'aigües residuals).

29/30?-10-1971: Autorització “a precari” de l'Ajuntament de la Central Tèrmica.

30-11-1971: $\quad$ Cessió de terrenys per l'encalçament del riu Besòs i adjudicades les seves obres.

20-12-1971: $\quad$ Primera pedra del polígon “La Mina”.

26-1-1972: Continua la inundació al "parquing” de "Calvo Sotelo".

13/14?-2-1972: Assemblea de les autoritats al Camp de la Bota per informar de l'entrega de pisos.

AVV La Catalana contra la Incineradora 
25-3-1972: $\quad$ Préstec del Banc de Crèdit Local per construir el nou Ajuntament.

26-5-1972: Veïns de La Bota són rebuts pel Governador Civil.

6-6-1972: $\quad$ Escola Activa de Pares i Agrupament Escolta de Sant Adrià continuen fan una enquesta per obtenir un institut de batxillerat.

21?-7-1972: $\quad$ El cura de Sant Adrià Nord encapçala una instància a l'Ajuntament amb signatures de veïns per reclamar un semàfor a l'encreuament de la Carretera de la Roca i els carrers "Mayor" i "Monjas" (prop de Badalona i Santa Coloma).

10-8-1972: Carta de A. Bonet a LV fent interpel-lacions a l'alcalde sobre la situació de La Catalana.

16-9-1972: $\quad$ Reunió de constitució de la Comissió Gestora de l'AVV La Mina.

14-11-1972: Nova demanda d'un Institut d'ensenyament mitjà per l'Escola Activa de Pares.

5-12-1972: $\quad$ Es presenten els Estatuts de l'AVV Besòs-Sant Adrià.

21-12-1972: Denúncia a la Premsa dels deficients serveis als barris perifèrics.

11-1-1973: $\quad$ La Comissió d'Urbanisme retorna el Pla Parcial de La Catalana a l'Ajuntament de Sant Adrià, paralitzat des de 1968.

24-1-1973: $\quad$ Es busquen solucions pel l'aparcament inundat.

24-1-1973: 600 veïns reclamen semàfors a la Carretera de la Roca prop del barri "Safaretjos"

3-2-1973: $\quad$ AVV's demanen informació sobre la planta incineradora que es vol fer a la desembocadura del Besòs, entre elles La Catalana i el Centro Social Besòs. I reclamen millores pels barris (en especial en Centro Social).

13-2-1973: "Dimissió" de l'alcalde Francisco Roqueta Prats davant el Govern Civil "pel seu estat de salut" (se li concedeix una excedència de 2 mesos)

Asseguda veïnal de 800 persones en la Carretera de La Roca per demanar semàfors.

11-2-1973: $\quad$ Reunió amb els veïns del Parapeto i Pekín del Camp de la Bota amb autoritats locals de Sant Adrià i Barcelona per tractar del tema de l'entrega de pisos del futur polígon de La Mina.

14/15-3-1973: Presentació a l'Ajuntament de l'Enquesta del Centre Social Besòs on es recull l'opinió de les nombroses mancances i defectes del barri.

Legalització de l'AVV de La Mina.

27-3-1973: $\quad$ Notícia d'atacs a vàries escoles de La Mina .

3-4-1973: $\quad$ Mort de Manuel Fernàndez Màrquez a la Tèrmica del Besòs per la policia.

23-5-1973: $\quad$ Afectació d'habitatges de La Catalana per les Obres d'encalçament del riu besòs.

5-6-1973: $\quad$ Legalització de l'AVV Besòs-Sant Adrià.

28-6-1973: La premsa recull les insuficiències de l'ambulatori de Sant Adrià 
21-7-1973: $\quad$ Silenci municipal 5 mesos després de les reclamacions dels veïns del Besòs.

9-9-1973: Joan Oller i Valls nou alcalde de Sant Adrià i cap local del "Movimiento".

23-9-1973: $\quad$ Inundacions al Camp de la Bota.

28-9-1973: $\quad$ Suspensió temporal de La Voz de San Adrián

13/14?-11-1973: Eleccions per cobrir vacants al "Tercio Familiar"

29?-1-1974: $\quad$ Informe de quatre AVV del Sector Besòs (entre elles la pertanyent a Sant Adrià) i del Centre Social sobre el lamentable estat de l'ensenyament als barris.

7-2-1974: $\quad$ S'aprova en el Ple Municipal la cessió d'un solar per l'ambulatori.

El Ple Municipal aprova l'expropiació d'habitatges en La Catalana per fer les obres de canalització del riu Besòs.

23-2-1974: $\quad$ El ministre de l'Habitatge Luís Rodríguez de Miguel visita el polígon de "La Mina”

26-2-1974: Perill de tancament de la Llar d'Infants “Cascabel” al barri Besòs.

3-1974: $\quad$ L'Ajuntament denega l'ajuda a les colònies d'estiu de l'Escola Activa de Pares.

5-1974: $\quad$ Quinzena de la Joventut al Besòs organitzada per diverses entitats (AVV's, Centre Social...)

7-6-1974: $\quad$ Suspeses les eleccions municipals complementàries al Terç Familiar per cobrir una vacant i proclamació del quart candidat de les eleccions de novembre de 1973 en substitució de Juan Arnau Valero (que havia estat recorreguda per l'ara proclamat: Pere Solè Vilamitjana)

15-7-1974: Inauguració de la piscina municipal (que es tanca aviat per nombroses deficiències)

19-7-1974: $\quad$ Funciona l'aparcament de "Calvo Sotelo"

11-8-1974: $\quad$ Casos de poliomelitis a "La Mina"

Al·legacions de l'AVV Besòs a la revisió del Pla Comarcal.

8-9-1974: Inauguració del "Hogar del jubilado” per les autoritats locals.

17-11-1974: $\quad$ Per ordre del Govern Civil es suspèn una actuació de Lluís Llach i Francesc Pi de la Serra (dintre dels actes de celebració dels 500 anys de publicació del primer llibre en llengua catalana organitzat per l'Escola Activa de Pares i l'Agrupament Escolta.

21-22-12-1974: Festes a El Besòs on es denuncien les mancances del barri.

29?-12-1974: Autorització de la Dirección General de Energia de la construcció de la 3era xemeneia de la Central Tèrmica del Besòs (arriba posteriorment a que s'hagin començat les obres...)

5/6?-2-1975: Aprovació del Pla Parcial Marina Besòs.

11-2-1975: Denúncia del pèssim estat de la piscina municipal (en la data esmentada es van haver de suspendre els cursets de natació). 
12-2-1975: $\quad$ La CMB encara no accepta el solar per l'ambulatori.

13-2-1975: Denúncia de la gran brutícia existent a La Mina

14-2-1975: Reivindicacions de l'AVV Besòs per la manca d'equipaments al barri i pel tancament d'un abocador proper.

15-2-1975: Una assemblea veïnal a La Catalana rebutja un pla de "reconcentració" dels habitants del barri (Pla Cantallops).

3-1975: $\quad$ S'aprova per l'INP la constitució d'un ambulatori de la Seguretat Social al polígon de La Mina.

12-4-1975: Indústria autoritza la incineradora del Besòs quan està acabant-se de construir (BOP de la mateixa data)

6-1975: $\quad$ Queixes de l'AVV Besòs pel lamentable estat del barri.

8-1975: Queixes veïnals a La Mina per la brutícia i també per la contaminació d'una fàbrica de plàstics instal·lada dins un grup d'habitatges propera.

9-1975: L'AVV La Mina adreça un escrit al delegat de Sanitat denunciant la situació anterior altament perillosa.

17/18-9-1975: Nou Ajuntament.

12i-11-1975: Jove ferit de bala per la Guàrdia Civil quan repartia propaganda clandestina del "Partido Comunista Reformado".

\section{6-1980}

21-1-1976: $\quad$ Carta a la premsa de l'AVV La Mina denunciant el greu estat del polígon acusant al PMV.

17-1-1976: Els veïns de La Mina es neguen a pagar la quota de recollida d'escombraries pel nul servei (fins que l'Ajuntament no se' $n$ faci càrrec).

25-1-1976: Concentració al barri del Besòs per demanar un parc (el 24 s'havia fet neteja del solar i el 7 una entrega de signatures a l'Ajuntament).

30-1-1976: $\quad$ Assemblea al Besòs per demanar un consultori, un llar d'avis i 2 parcs.

4?-2-1976: $\quad$ AVV's Besòs i La Mina més càrrecs sindicals demanen la dimissió de l'Ajuntament.

5-2-1976: Marxa cap a l'Ajuntament dels veïns del Besòs i presència al Ple i entrevista posterior amb l'alcalde (protesta per la prohibició del Govern Civil de fer un festival infantil a l'aire lliure).

15-2-1976: $\quad$ Manifestació dels veïns del Besòs pel barri exigint un consultori (300 persones).

25-2-1976: Es presenten al Govern Civil els Estatuts de les AVV's de Sant Adrià Nord i Sant Joan Bautista.

3/4?-3-1976: L'Ajuntament acorda el canvi de nom a Sant Adrià de Besòs.

Un grup de treballadors demana infructuosament a sindicatos i al Govern Civil permís per fer una concentració contra la carestia de la vida i a favor de l'amnistia. 
18-3-1976: $\quad$ Assistència al Ple dels veïns de La Catalana per la revisió del Pla Comarcal (l'Ajuntament en teoria dona suport a les demandes dels veïns de canvi de qualificació de la zona).

26?-3-1976: El Govern Civil prohibeix una assemblea de l'UTT del Metall que s'havia de fer al local de l'AVV La Mina.

2?-4-1976: Roda de premsa de l'AVV Besòs on es denuncien totes les deficiències del barri.

5-4-1976: $\quad$ Una comissió de 30 persones entrega un escrit reivindicatiu a l'Ajuntament.

5/8-4-1976: L'AVV La Mina fa una Setmana de Cultura en memòria de Manuel Fernàndez Marquez.

4-1976: $\quad$ Acomiadament de tots els treballadors de Cemoto, SA (Bultaco).

12?-5-1976: Assemblea de Convergència Socialista del Barcelonès Nord.

15/20?-5-1976: Assemblea veïnal a La Mina. 300 persones decideixen no pagar lloguers.

28-5-1976: Inauguració de la planta incineradora d'escombraries.

10?-9-1976: L'AVV Sant Adrià Nord i l'Assemblea Democràtica de Sant Adrià denuncien els gasos tòxics d'una fàbrica propera.

15?-9-1976: $\quad$ Presentació de l'UGT.

29/30?-10-1976: Es presenta el Centre Català.

5-11-1976: $\quad$ Presentació d'UDC a l'Ateneu Adrianenc.

16?-11-1976: Protesta d'entitats ciutadanes davant uns cartells del 20-N de l'Ajuntament (AVV's La mina, Besòs, Sant Adrià Nord, Sant Joan Bautista, Escola Activa de Pares, Escola d'Adults MF Màrquez i altres).

18?-11-1976: Veïns de Sant Adrià Nord reclamen més vigilància a l'Ajuntament.

19-11-1976: Presentació de CDC a l'Ateneu Adrianenc. Miquel Roca defensa el "salari social”.

26-11-1976: Prohibida la presentació del PTE a l'Ateneu Adrianenc pel Govern Civil.

29?-1-1977: Reunió a El Besòs d'AVV's, AD i altres entitats per parlar i reclamar la construcció de l'ambulatori.

2-1977: $\quad$ L'AVV Besòs continua reclamant la construcció d'un consultori al barri (la setmana anterior van visitar la delegació del "Ministerior de la Vivienda".

26?-2-1977: Assemblea a l'Ateneu Adrianenc de les AVV's i l'AD. Reclamació de l'ambulatori i del consultori del Besòs. S'aprova anar al proper Ple.

28-2-1977: $\quad$ Els veïns de La Mina comencen una tancada en el nou ambulatori del barri que encara no està operatiu. Dura fins el 4 de març tot i que posteriorment es manté una guàrdia davant les promeses de les autoritats que en 15 dies entrarà en funcionament (del Governador Civil Sánchez Terán).

3-1977: $\quad$ Reunió del governador civil Sánchez Terán amb l'Ajuntament i els veïns de La Mina. Promet que les obres per construir "l'Hogar Social" començaran a l'abril i es faran 
més actuacions per millorar el barri (asfaltat, etc.) i integrar-lo definitivament a Sant Adrià.

3?-3-1977: $\quad 300$ veïns entren en el saló de Plens de l'Ajuntament i fan una assemblea davant l'alcalde i els regidors.

11-3-1977: $\quad$ Cessió del propietari del solar a l'Ajuntament per construir l'ambulatori. Assemblea veïnal el dia 14 a l'Ateneu per explicar els acords presos per la construcció d'aquest.

23-3-1977: $\quad$ Acord entre el Patronato Municipal de la Vivienda i els comerciants de La Mina després d'una jornada de protesta veïnal.

26/27-3-1977: Presentació oficial del Congrés de Cultura Catalana.

22-3-1977: $\quad$ Vaga General a La Mina davant l'incompliment en la inauguració de l'Ambulatori.

4-1977: Campanya pels disminuïts psíquics portada per ASSA (Associació "Pro Subnormals" de Sant Adrià).

25?-4-1977: $\quad$ Manifestació d'un miler de persones reclamant l'ambulatori i després també de l'Estatut (AVV's i Assemblea Democràtica).

4-5-1977: $\quad$ Tancada de veïns del carrer Maragall a l'Ajuntament (2 vegades, la segona l'115),posteriors desallotjaments i tancada a la parròquia (del 5 al 27 de maig).

8?-5-1977: Retirada" de l'alcalde Francisco Oller i substitució per Miguel Blasco.

18?-5-1977: Constitució de la Coordinadora d'AVV's de Sant Adrià i reunió amb el consistori el dia 19.

20/28-5-1977: Acampada dels veïns de La Mina davant l'Ajuntament.

21-5-1977: $\quad$ Manifestació per l'ambulatori amb alguns incidents.

26?-5-1977: Manifestació dels veïns de La Catalana demanant la dimissió de l'alcalde per i l'anulació del pla Llansó després de la seva aprovació inicial (i suspensió posterior per la pressió veïnal).

28-5-1977: Tanquen les botigues de La Catalana per anar a la manifestació dels veïns de l'esmentat barri fins l'Ajuntament.

31-5-1977: $\quad$ Dimissió del 1er Tinent d'Alcalde Juan Matacàs Alcaraz (en relació amb un afer urbanístic a La Catalana.

6-1977: $\quad$ Conflictes laborals a INBESA (Indústries del Besòs, S.A.).

2-6-1977: “Una victòria popular per La Mina”. Es concedeixen pisos buits.

Conflicte pel Pla Marina-Besòs (o Pla Llansó) que afecta a La Catalana.

15-6-1977: $\quad$ Reestructuració del cartipàs municipal.

7-1977: $\quad$ Representants del PSC-PSOE, PSUC i UCD participen a les comissions de treball de l'Ajuntament.

Comissió de Control i Informació amb la participació dels partits polítics. 
3-8-1977: $\quad$ Explosió a INBESA que afecta a immobles propers.

5?-8-1977: $\quad$ Es confirma la cessió a l'INP dels terrenys per fer l'ambulatori.

9-1977: $\quad$ Protestes veïnals exigint el trasllat de la fàbrica INBESA

10?-9-1977: Inicia la seva activitat la "Comissión de Control e Información Municipal” (17 persones, 14 són del PSOE, PSC, PSUC i UDC i 3 representants de la coordinadora d'AVV's).

23-9-1977: Continua en conflicte a INBESA. 5 acomiadaments i ocupació de la factoria.

29?-9-1977: Crítiques de la Coordinadora d'AVV's a l'Alcalde per incomplir la seva paraula d'acompanyar-los a una entrevista amb el director de l'INP (que també es va negar a rebre'ls). (Van tenir una reunió el dia 19).

6-10-1977: $\quad$ La Vanguardia Española publica una carta de la direcció d'INBESA.

10-10-1977: $\quad$ Manifestació de 1000 persones pel conflicte d'INBESA.

11-10-1977: Negociacions al Govern Civil sobre INBESA amb representants dels treballadors, sense acord.

11-1977: $\quad$ L'ambulància adquirida per l'Ajuntament només funciona els caps de setmana (falta personal).

20-12-1977: Reivindicacions i tancada a l'Ajuntament per l'Escola Professional del Barri del Besòs (reclamant la seva construcció). I entrevista amb el president de la CMB Socias Humbert.

1-1978: $\quad$ Legalització de l'AVV Sant Adrià Nord.

7?-3-1978: $\quad$ S'autoritza un Bingo a l'Ateneu malgrat la impugnació de l'AVV Sant Adrià Nord.

16?-3-1978: Assemblea de veïns de La Catalana a l'Ajuntament.

28?-3-1978: Crisi en la Comissió de Control Municipal: el PSC-PSOE suspèn la seva participació.

21-4-1978: Veïns de La Catalana assisteixen a la reunió de la CMB per l'expropiació d'uns terrenys del seu barri (en teoria per fer escoles).

19-5-1978: $\quad$ Manifestació de 400 veïns de la Mina Cap a l'Ajuntament. (o va ser el 16??)

22-5-1978: Acampada dels veïns de La Mina al costat de l'Ajuntament per reivindicar equipaments pel barri.

29-5-1978: $\quad$ Entrevista dels Veïna de La Mina amb l'Alcalde.

8?-6-1978: $\quad$ Fi de l'acampada del veïnat de La Mina.

13/14?-6-1978: L'AVV Sant Adrià Nord emet un escrit on expressa la seva preocupació per les obres que s'han de fer a un tram de la N-II

7-1978: $\quad$ Perilla l'escola d'artesania d'artesania i FP de La Mina.

10-1978: La Coordinadora d'AVV's demana l'expropiació d'un terreny parroquial per destinar-lo a la construcció d'una escola per disminuïts psíquics. 
11-1978: $\quad$ L'AVV Sant Adrià Nord proposa que en comptes d'un ambulatori es construeixi un Hospital després de fer una enquesta, exigint una "alternativa sanitària popular per Sant Adrià".

9-11-1978: $\quad$ El PSC denuncia a l'Ajuntament la presència de dues indústries perilloses: Bufalo i Ugiquímica.

12-2-1979: En una conferència de premsa es donen a conèixer les candidatures del PSUC i CDC-UDC. Forta representació veïnal a la primera (AVV's Besòs, La Mina, Sant Adrià Nord i Sant Joan Baptitsta). A la segona també hi ha un líder veïnal (Jaume Vallés, S.A. Nord).

21-2-1979: $\quad$ El PSC dona a conèixer la seva llista.

3-3-1979: $\quad$ A les eleccions estatals el PSC és la llista més votada (6.989 vots, 39,58 \%) seguida del PSUC (4.879 vots, 27,12 \%); UCD-Centristes (2.017 vots, 11,53 \%); CiU (1.354 vots, 11,53 \%); Coalició Democràtica (415 vots, 2,35 \%) i PTC (315vots, 1,78\%).

16-3-1979: Desaparició del Setmanari El Besós.

3-4-1979: $\quad$ Eleccions municipals. PSC 9 regidors, PSUC 8, CiU 2 , UCD-CC 2.

14-4-1979: Rumors sobre una renúncia al càrrec del cap de llista Agustí Gallart.

19-4-1979: $\quad$ S'escull com a Alcalde al segon de la llista del PSC: Josep Vilanova Vila (abans havia renunciat el cap de llista Agustí Gallart). Pacte de progrés PSC-PSUC-CiU.

27-4-1979: En el ple d'aquest dia CiU queda fora del cartipàs municipal.

8?-5-1979: $\quad$ Cloenda de les jornades del disminuït psíquic celebrades per ASSA (amb la participació de diferents forces polítiques: PSC, PSUC, CiU, PTE.

10-5-1979: Es filtra a la premsa la possibilitat de que es tanqui l'ambulatori situat a la plaça de l'Església i es traspassin les seves funcions a l'ambulatori de La Mina (Sanitat està a càrrec d'Antoni Messeguer del PSC).

12-5-1979: $\quad$ Nota de Antoni Messeguer a la premsa dient que l'ambulatori no tanca malgrat la voluntat inicial del propietari de no renovar el lloguer a l'Ajuntament de Sant Adrià i acomiadar gent.

22-5-1979: Negociacions per que l'INP adquireixi el local de l'ambulatori, sense èxit. Pancartes dels treballadors i l'ajuntament (que més tard es treuran de la façana a instàncies de Messeguer, segons ell).

24-6-1979: $\quad$ Reunió en l'AVV Sant Adrià Nord amb el regidor de Participació Ciutadana (Crespo) S'informa de la suspensió de les llicències d'obres per un període de 6 mesos a 2 anys en l'esmentada zona nord de Sant Adrià fins que es faci un estudi dels solars disponibles per equipaments. Assumeix la presidència de l'associació Agustí Gallart (l'ex-cap de llista del PSC??).

28?-5-1979: $\quad$ CiU entra a l'Ajuntament amb la Comissió de Trànsit, transports i comunicacions (Jaume Vallés).

30-5-1979: $\quad$ Mor un nen de 9 anys a La Mina sepultat per sorra procedent d'una extracció. Rumors sobre el possible tancament de la comissaria de Sant Adrià. 
5-6-1979: $\quad$ Vaga de col-legis (Calason, Marinada, Jara i Tirso de Molina de La Mina, els parvularis i l'escola d'adults Manuel Fernàndez) en protesta per la detenció de 5 mestres. Entrevista amb l'Ajuntament i compromís d'aquest per anar amb els afectats l'endemà al Govern Civil.

18-6-1979: Visita de la regidora Mercè Sala del Districte III a La Mina. L'AVV amenaça amb fer la seva pròpia policia si no hi ha més vigilància. Assemblea amb reivindicacions pel barri que es considera desatès per les institucions i registra un major nombre d'aturats.

30-6-1979: El Comitè Local del PSUC acusa al PSC de "mala gestió" en tot l'afer de l'ambulatori.

4/6-7-1979: Apareix a la premsa una nota de rèplica del PSC acusant al PSUC de defensar "l'impossible"

10?-7-1979: Detenció d'un detectiu privat que vigilava al regidor d'Urbanisme (Domingo Nieto, del PSC). Reunió al Govern Civil per estudiar els problemes de La Mina.

16?-7-1979: Acomiadament de la seva empresa de Domingo Nieto (tinent-alcalde d'Urbanisme). Treballava a l'Ajuntament mentre estava de baixa laboral a la seva empresa, Novalux Ibérica.

17?-7-1979: Interpel-lació de Miquel Roca sobre la situació de l'ambulatori de Sant Adrià.

20?-7-1979: Retenció per part dels treballadors de Transportes Bolós (aturats des de 6 dies) de l'apoderat de l'empresa. Comunicat del PSC solidaritzant-se amb el regidor acomiadat publicat el dia 21 .

26-7-1979: $\quad$ La Comissió Municipal Permanent dona suport al regidor del PSC acomiadat.

30?-7-1979: UCD vota amb el PSC el programa municipal de sanitat mentre que PSUC i CiU s'abstenen.

8-1979: $\quad$ El Comitè Local del PSUC fa públiques diverses agressions que han patit els seus militants per membres de l'extrema dreta.

Creació d'una comissió unitària 11 de Setembre per partits, sindicats,

AVV's i altres entitats per defensar l'Estatut de Sau i preparar la diada.

3-8-1979: $\quad$ Retenció dels directius per part dels treballadors de Transportes Bolós.

8-8-1979: $\quad$ El conflicte en Bolós entra en vies de solució.

17?-8-1979: L'AVV Sant Adrià Nord fa una crida a acabar amb els elevats índexs de delinqüència (destacant la juvenil).

25?-8-1979: $\quad$ Adduint un problema amb FECSA l'empresa Entrecanales i Tavora paralitza les obres del metro temporalment i deixen tallada la N-II. Crítiques de l'AVV Sant Adrià Nord i de la Comissió de Trànsits i Transports.

29?-8-1979: Davant l'endarreriment de l'Ajuntament en el canvi de retolació dels carrers l'AVV Sant Adrià Nord ha fet uns cartells per canviar els noms de manera transitòria.

3-9-1979: $\quad$ Reunió entre l'AVV Sant Adrià Nord i el Regidor de Governació Jaume Caselles (PSUC) per parlar de seguretat ciutadana.

10/12-9-1979: Tancament dels treballadors de Bultaco. 
14?-9-1979: Incidents en la revetlla de la Plaça de l'Església (enfrontaments entre veïns i un grup de joves).

18?-9-1979: Declaració en un Ple extraordinari a instància de la Comissió de Sanitat i serveis socials de Sant Adrià com a "zona contaminada".

20-9-1979: Vaga estatal dels col-legis públics. Suport de l'Ajuntament. Les escoles privades no s'hi sumen.

26?-9-1979: Inauguració de Pujol de la seu de CDC a Sant Adrià.

30?-9-1979: $\quad$ Ple ple d'incidents i enfrontaments. Debat al voltant del Casal de Cultura i aprovació de la seva construcció (pendent d'aconseguir uns terrenys a l'antiga CELO).

6-10-1979: Ocupació durant 30 minuts de la planta tercera de l'Ajuntament per joves de La Mina en protesta per la manca de locals pels joves al seu barri.

12?-10-1979: El Ministerio de Sanidad aprova un pressupost de 160 milions per construir el nou ambulatori de Sant Adrià i interpel-lació al Congrés de Miquel Roca sobre aquest tema..

20-10-1979: Reunió de les autoritats locals de Sant Adrià amb el Governador Civil per exigir l'aixopluc d'una cinquantena de gitanos afectats per les inundacions. Se'ls allotjarà provisionalment en uns pisos al Prat de Llobregat.

24-10-1979: $\quad$ Resposta a la interpel-lació de Miquel Roca per part del Ministeri de Sanitat. El Ministeri es compromet a millorar la situació de l'ambulatori de Sant Adrià i a començar aviat la construcció del nou.

27?-10-1979: Trencament al Ple entre PSC i PSUC. Cadascú es centra en les seves regidories.

31-10-1979: $\quad$ Apareix a la premsa la notícia que la Policia Nacional deixarà Sant Adrià.

5-11-1979: Sentència de Magistratura que obliga a readmetre a Domingo Nieto a Novalux.

6-11-1979: Greu situació econòmica de l'escola d'educació especial Verge de l'Esperança per la retirada d'una subvenció estatal.

9-11-1979: Es fa efectiva la marxa del Cos de Policia Nacional. El dia 10 hi ha un atracament a la seu de la Caixa de Pensions.

12/16-11-1979: Jornades de la Salut organitzades per la regidoria de Sanitat i serveis socials. A partit del 17 l'ambulància de la Creu Roja passa a dependre de la Policia Municipal fent servei les $24 \mathrm{~h}$ del dia.

22-11-1979: Comiat oficial de la Policia Nacional. La comissaria ha durat menys d'un any.

29?-11-1979: Desallotjaments i retorn de les famílies gitanes traslladades a pisos de El Prat per la pressió dels habitants del polígon Espartero (es fa a les 2 de la matinada i amb una forta presència policial). Són allotjats a la planta 6 o 8 de l'Ajuntament de Sant Adrià.

1-12-1979: $\quad$ El Ple acorda demanar la dimissió del Governador Civil (per fer-se enrere en els acords de trasllat dels gitanos afectats pels aiguats). Discussió entre socialistes i comunistes per la inclusió en l'ordre del dia de punts referents a l'Estatut del 
Treballador i a la Brigada Municipal.

4-12-1979: Comença a funcionar una oficina de l'INEM a Sant Adrià.

6-12-1979: Tornen a atracar la mateixa sucursal de La Caixa.

12-12-1979: Aprovació en un Ple extraordinari del Pla Marina-Besòs on l'Ajuntament compra uns terrenys per fer pisos i equipaments. Crítiques del PSUC per que el PSC ha portat de manera unilateral aquest assumpte. Crítiques dels habitants de La Catalana que reclamaven que abans es solucionés la seva situació.

17?-12-1979: Nou conflicte a l'Ajuntament al voltant de l'acomiadament de nou treballadors de la brigada Municipal en acabar-se el seu contracte eventual el 2 de gener. El PSUC (amb suport de CiU i UCD) ho aprova per que els aturats hi treballin rotativament en aquesta mentre el PSC està en contra i dona suport als treballadors.

20-12-1979: Ocupació pels treballadors de la fàbrica de Bultaco des de que se'ls va notificar que no cobrarien ni la paga de nadal ni la nòmina de desembre.

27-12-1979: L'obertura al trànsit de la N-II, promesa per abans de nadal, s'endarrereix dues setmanes.

28-12-1979: El Ple anul·la l'acomiadament de les 9 persones de la brigada municipal. No hi ha l'ambient tens de l'anterior.

7?-1-1980: $\quad$ Locaut a Bultaco.

10-1-1980: “Careig” entre els treballadors de Bultaco i la direcció de l'empresa a la Generalitat.

21-1-1980: $\quad$ Desmantellament d'un campament de gitanos de 150 persones.

22-1-1980: $\quad$ Setze treballadors de Bultaco s'encadenen davant l'Ajuntament.

24/26?-1-1980: Protestes dels veïns de La Catalana i de La Mina al Ple. Ratificació de la substitució de Domingo Nieto per Diego Garcia Roldán a urbanisme. Tiroteig després d'un atracament a la Joieria Gerardo.

29-1-1980: Denúncia d'un grup de veïns al jutjat a la Seguretat Social per l'estat lamentable de l'ambulatori de Sant Adrià.

-31-1-1980: Polèmica a l'Ajuntament pel tancament d'un bar que ocasionava molèsties al veïnat. 30-1: tancament dels treballadors de Bultaco a la delegació de Treball a Barcelona.

-1-2-1980: $\quad$ Reunió a l'Ajuntament entre l'AVV de Sant Adrià Nord i el regidor de Transports Jaume Vallès (CiU) i els serveis tècnics per tractar dels problemes de trànsit, en especial a la Carretera de La Roca.

1-2-1980: $\quad$ Acte sobre la seguretat ciutadana. El regidor de governació Jaume Caselles (PSUC) manifesta la manca de recursos per fer-hi front i critica al govern central. Es crea una comissió per treballar aquest àmbit. Recollida de signatures.

2-1980: $\quad$ Recollida de signatures per l'AVV Sant Adrià Nord pel tema de la seguretat ciutadana (també es fa a La Catalana).

9?-2-1980: $\quad$ El Govern Civil suspèn dos acords de l'Ajuntament sobre la retolació en català.

21?-2-1980: $\quad$ Debat sobre la lamentable situació sanitària a Sant Adrià i a l'ambulatori amb la 
participació de l'AVV de Sant Adrià Nord.

29-2-1980: $\quad$ El Ple informa de la recuperació oficial del topònim català de la població.

5-3-1980: $\quad$ Es normalitza el trànsit per la N-II.

12-3-1980: La policia intenta desnonar als treballadors de Bultaco que ocupen la fàbrica. La mediació de l'alcaldia ho impedeix amb la condició de que els directius s'emportin els llibres de comptes.

17-3-1980: Creació de la “Comissió d'Urbanisme de La Catalana” amb representants veïnals.

18-3-1980: Apareix a la premsa (LV) una notícia que fa referència a 53 casos de sarna i 3 de "tinya" entre els infants de La Mina.

26-3-1980: $\quad$ Apareix a la premsa notícies de la situació crítica de l'escola Nuestra Sra. De la Esperanza que acull 30 nens disminuïts psíquics. L'AVV Sant Adrià Nord denuncia que li retiren pancartes de la via pública. Ple extraordinari que aprova la cessió al MEC d'una part dels terrenys de la família Llansó per construir un institut.

28-3-1980: $\quad$ Ple on s'aprova el trasllat dels encants, enllumenat públic per Sant Adrià Nord i el relleu del veterinari municipal.

31-3-1980: Ple extraordinari on s'aprova un esboç del PERI Sant Adrià Nord i la seva exposició pública.

4-1980: $\quad$ L'AVV de La Mina publica una nota informativa on acusen al consistori

d'incompetència criticant els alts salaris dels polítics locals i que tenen abandonat el barri. Amenacen de "tornar als antics mètodes de lluita".

3?-4-1980: L'AVV Sant Joan Baptista cursa una circular a tots els seus associats per que col·laborin a fer pressió a l'Ajuntament per aconseguir millores pel barri.

15/19-4-1980: Jornades d'Ensenyament organitzades pel Consell Municipal de l'Ensenyament i La Regidoria d'Ensenyament de l'Ajuntament.

16-4-1980: $\quad$ Ple extraordinari per exposar els acords de l'Ajuntament amb el PMV l'Ajuntament de Barcelona, l'AVV de la Mina per fer les obres pertinents per acabar el polígon de La Mina. Els diners els posarà en major part l'Ajuntament de BCN i després se'n farà càrrec l'Ajuntament de Sant Adrià.

22-4-1980: Tensa reunió en l'AVV per disputes entre l'anterior Junta i la nova. Enfrontament polític entre PSC i PSUC. Els membres de la nova junta són tots d'aquest partit. El regidor Juan Ponce (PSUC) dimiteix de l'Ajuntament i participa en la nova junta enfrontada a l'anterior que no ha dimitit.

l'AVV Sant Adrià Nord demana a l'Ajuntament que es posicioni sobre la reivindicació de Can Rigalt com a futur Museu.

28-4-1980: $\quad$ Nou assalt a l'escola "Cascabel".

Els components de la "Comissió d'Urbanisme de La Catalana" denúncia a

l'Ajuntament i en concret als regidors del PSUC de voler desunir el barri (en concret de voler imposar membres no triats en aquesta comissió). No volen que se'ls faci fora de les seves propietats i se'ls ubiqui en habitatges social amb preus inferiors a les 300.000 ptes.

29-4-1980: Reunió CMB, Ajuntament Sant Adrià i veïns de La Catalana. Acord per elaborar un estudi sobre la situació del barri i el pla Marina-Besòs. 
30-4-1980: Tensa assemblea veïnal a La Mina amb incidents i agressions físiques. (segons la premsa Ponce i Ponz, tots dos del PSUC i en especial el segon va agredir a una altra persona, presumiblement del PSC).

2-5-1980: $\quad$ Un Ple extraordinari dona a conèixer els representants de la Junta que estudiarà la remodelació de La Catalana: 1 de la Generalitat, membres de la CMB, 9 del Consistori i 9 veïns).

8-5-1980: $\quad$ Apareix a la premsa la versió dels membres de l'actual junta de l'AVV La Mina on denuncien que l'antiga Junta es va fer escollir de manera poc clara i defensant l'actuació de Ponz argumentat que "l'agredit" el va insultar públicament.

9-5-1980: $\quad$ Atracament d'una sucursal de la Caixa d'Estalvis de Catalunya. Desmantellament dels horts il·legals existents a la desembocadura del Besòs.

15-5-1980: La premsa publica queixes de l'AVV Sant Adrià Nord per l'intens trànsit de vehicles (soroll i contaminació).

20-5-1980: Nota de Jaume Vallés assegurant que el trànsit en la N-II es normalitzarà el dia 26.

21-5-1980: Assemblea veïnal a La Mina on hi ha un posicionament contrari als acords presos per l'antiga junta de l'AVV i el PMV. Es crida a una manifestació pel dia següent

22-5-1980: Apareixen a la premsa crítiques de l'AVV Sant Adrià Nord contra l'Ajuntament per poca agilitat en resoldre problemes urbanístics.

Manifestació de 400 veïns de La Mina cap a l'Ajuntament per denunciar els acords de la Junta antiga de l'AVV i el Patronat amb els quals no estan d'acord. Moments de tensió davant l'ajuntament per la presència policial i entrevista infructuosa entre Ponç i l'Alcalde.

23-5-1980: $\quad$ Apareix a la premsa les crítiques dels treballadors de Bultaco per les irregularitats de l'expedient de regulació de feina per ells sol-licitat (on s'han inclòs a directius de la fàbrica).

30-5-1980: El Ple aprova amb vot del PSC i PSUC el permís per una sala de festes prop de l'Ajuntament (CiU s'oposa i els regidors d'UCD no van assistir al Ple). Crítica de CiU a l'Alcalde per amagar informació al Govern Civil i per no consultar a l'AVV Sant Adrià Nord.

3-6-1980: Votació davant un delegat governatiu per escollir una única Junta per l'AVV La Mina. Es triada l'encapçalada per l'ex-regidor Ponce (PSUC) per 156 vots contra 141.

Incident molt greu en INBESA. Dos obrers ferits molt greus i 2 ferits lleus.

5-6-1980: $\quad$ S'aprova la fase inicial del Pla de Reforma interior de Sant Adrià Nord.

6-6-1980: $\quad$ Roda de premsa dels treballadors de Bultaco (que mantenen l'ocupació de la fàbrica des de el 20 de desembre) on manifesten la seva voluntat d'apostar per la continuïtat de l'empresa.

13-6-1980: La nova Junta de l'AVV La Mina fa arribar una nota a la premsa on demanen la dimissió de l'Alcalde pels fets del dia 22. Moren els dos ferits greus per l'accident a INBESA.

13?-7-1980: Festa a la platja amb participació de les AVV's per celebrar que s'ha recuperat 
aquest espai (tot i que les aigües continuen contaminades).

26/27?-7-1980: En el darrer Ple extraordinari CiU anuncia que deixarà d'assistir a les Comissions Informatives. Representants de diversos Grups Juvenils critiquen durament els regidors del PSUC Joan Castro, Maria Codina, M. Lluïsa Anton i Alfons Fraga i demanen la seva dimissió per la política al voltant de les colònies d'estiu.

8-1980: $\quad$ Es crea des de la Regidoria de Sanitat, Ecologia i Serveis Socials (PSC) un servei de sanejament per lluitar contra la proliferació de rates.

2/7-8-1980: $\quad$ Polèmica entre CiU i l'alcalde Vilanova a l'entorn de dedicar un carrer al doctor Obiols i a la possibilitat de fer un referèndum sobre la propera construcció d'una sala de festes al mig del municipi.

11-8-1980: $\quad$ Dos ferits en un atracament a l'hotel Matacas.

9-1980: $\quad$ Èxit de la Mostra d'ecologia organitzada per l'AVV Sant Adrià Nord i altres entitats de la ciutat.

5/8-9-1980: $\quad$ Festes de Sant Adrià, fetes de manera descentralitzada per la Regidoria de Cultura i les AVV's.

11-9-1980: $\quad$ Poca participació al l'acte unitari del 11-S.

10-1980: $\quad$ Comencen les obres de l'ambulatori de Sant Adrià. L'Ajuntament demana un préstec de $67 \mathrm{M}$ de pessetes al Banc de Crèdit Local.

2/4-10-1980: El Ple refusa definitivament posar el nom del Dr. Obiols a un carrer i fer un referèndum sobre la sala de festes. Un antic regidor del PSUC, Juan Ponce, demana que els plens es facin només en castellà.

9-10-1980: $\quad$ Acord de la Comissió Municipal Permanent de fer una enèrgica protesta a l'INEM per l'estat d'abandó dels edificis destinats a la Formació Professional.

29?-10-1980: Trencament per part del PSC del pacte amb el PSUC. Argumenten l'intent d'agressió de membres del PSUC a regidors socialistes durant una assemblea a La Mina. El PSC ocupa les regidories del PSUC amb el suport dels vots de CiU i UCD.

30-10-1980: Manifestació de veïns (un centenar) de La Mina davant la seu del Patronat Municipal de l'Habitatge a Barcelona acusant-los d'irregularitats en la concessió d'un immoble.

8-11-1980: $\quad$ Apareix a la premsa la notícia de que el PSC intenta atreure's al regidor Jaume Caselles, independent a la llista del PSUC.

3?-12-1980: L'absència dels 8 regidors del PSUC al Ple impedeix que s'aprovin acords per falta de quòrum.

15?-12-1980: Cinquè ple extraordinari que no pot aprovar els acords econòmics per manca de quòrum (absència del PSUC).

23-12-1980: Anunci a la premsa de que la Generalitat intervindrà en el conflicte de Sant Adrià.

\section{1-1985}

7?-1-1981: $\quad$ Entrevista d'una delegació del Consistori amb Vidal i Gaiolà, representant de 
Governació de la Generalitat per tractat el tema dels plens bloquejats pel PSUC.

12-1-1981: $\quad$ Roda de premsa del PSUC on valora positivament l'entrevista del Consistori amb el representant de Governació però matisa les crítiques rebudes per les altres forces.

16?-1-1981: Conferència de premsa del PSUC on s'ofereix a fer una reunió amb les forces polítiques presents a l'Ajuntament en un lloc públic per trobar un acord i superar la situació existent.

20-1-1981: Judici pels acomiadaments de Critesa per fer festa l'11 de Setembre.

22-1-1981: $\quad$ El Ple rebutja per segona vegada la proposta de donar el nom del Dr. Obiols a un carrer de Sant Adrià (la segona proposta l'havia presentat l'AVV Sant Adrià Nord acompanyada de 300 signatures).

29?-1-1981: $\quad$ Els regidors del PSUC tornen als plens després d'haver faltat durant 6 sessions (notícia apareguda al CC el 3 de febrer).

5-2-1981: $\quad$ Apareix a la premsa la denúncia dels veïns de l'immoble núm. 15 del carrer Jacint Verdaguer denunciant el seu malt estat. L'Ajuntament s'inhibeix i atorga la responsabilitat en exclusiva a la constructora Clavell Blasco i Rius, S. A.

14?-2-1981: L'Ajuntament no até a les peticions de l'AVV Sant Adrià Nord sobre el Pla de Reforma de Sant Oleguer i que té dos punts conflictius: una poma d'edificis on està la fàbrica i habitatge de l'antic alcalde franquista Roqueta i la zona on es farà la polèmica sala de festes.

19-2-1981: $\quad$ Denúncia de CCOO Sant Adrià a membres de la CNT per l'ocupació i actes vandàlics a l'empresa Salva, que funciona des de octubre de 1979 com a SAL.

Membres de la Guàrdia Urbana comencen una "vaga de baix rendiment". Per la negociació del conveni.

16/22-2-1981: Setmana per una Alternativa Ecològica a Sant Adrià. Organitza la Coordinadora Ecologista amb el suport de l'Ajuntament i amb la participació de ràdios lliures.

21?-2-1981: $\quad$ Els edils de CiU ofereixen el seu sou per sufragar el cost de la senyalització semafòrica del pas de vianants en la confluència de la N-II amb la Av. De Catalunya i la Plaça Maria Grau.

La Coordinadora d'AVV's proposa mesures d'austeritat per millorar les condicions del municipi. Demana la supressió de despesa suntuària i l'augment de partides per urbanisme.

25?-2-1981: $\quad$ Ple extraordinari que es manifesta a favor de la Constitució i contra l'intent de cop d'Estat. La Policia Municipal suspèn temporalment la vaga de baix rendiment en solidaritat amb el Consistori.

28-2-1981: $\quad$ Inauguració del nou local de Fuerza Nueva a Sant Adrià.

5-3-1981: $\quad$ El Ple extraordinari acorda donar el nom de Juan Carlos I al nou pont sobre el Besòs.

11-3-1981: $\quad$ La campanya de neteja de la Regidoria de Sanitat, ecologia i serveis socials culmina amb la col·locació de 500 papereres.

14?-3-1981: Converses entre el PSC amb PSUC i CDC per fer un nou pacte de govern.

17?-3-1981: $\quad$ La AVV de Sant Adria Nord demana la interrupció de les obres de la futura 
discoteca (president Agustí Gallart).

24?-3-1981: Es presenta oficialment el grup "Sant Adrià Ecologista i naturista".

27-3-1981: $\quad$ Nova demanda de crèdit de l'Ajuntament aprovada en Ple per fer front a 100 milions de deute anteriors.

29-3-1981: $\quad$ Festa de l'arbre organitzada per les AVV's.

1-4-1981: $\quad$ Assalts vandàlics contra tres locals socials: El Club Deportivo Adrianense, el Club Petanca i el "Hogar del Jubilado".

2?-4-1981: $\quad$ El PSUC en una conferència de premsa demana que per refer el pacte d'esquerres no es suficient recuperar les regidories que havien tingut abans, sinó també que la tinència d'alcaldia sigui seva. L'Ajuntament té un deute de 100 milions.

16/17-4-1981: Processió popular de setmana santa en La Mina i el Besòs.

11-5-1981: Uns fulls volants de Fueza Nueva acusen de corrupció al regidor del PSUC Alfonso Fraga Nieto. El PSUC desmenteix les acusacions.

19?-5-1981: El Ple refusa una proposta de CiU de reduir un $30 \%$ el sou dels regidors.

27-5-1981: La premsa publica que la CMB ha convocat un concurs d'idees per l'ordenació de les 8 Ha del futur Parc del Besòs.

16-6-1981: $\quad$ Apareix a la premsa crítiques de la Coordinadora de Joventut de La Mina a la política educativa de l'Ajuntament al barri.

18?-6-1981: Dimissió del l'alcalde Josep Vilanova i Vila.

18/21?-6-1981: Antoni Messeguer és nombrat alcalde de Sant Adrià.

9?-9-1981: $\quad$ Acord de la Comissió 11 de Setembre per fer finalment un acte unitari (entre els diferents forces polítiques, AVV's, etc.).

1-10-1981: $\quad$ El Ple demana amb el vot favorable de PSC i PSUC de demanar al govern central un referèndum sobre l'OTAN. CiU s'absté (argumenta que l'Ajuntament no té competències i critica al PSC que s'oposés al referèndum sobre la sala de festes).

2-10-1981: $\quad$ Tanca el dispensari de la Creu Roja per falta de mitjans.

5-11-1981: $\quad$ Apareix a la premsa la notícia de la dimissió del cap de la policia local de Sant Adrià per un escàndol on aquest va investigar els antecedents penals d'un regidor del PSUC (segons va afirmar seguint ordres de l'alcalde del PSC). El PSC nega aquestes acusacions.

23-11-1981: Mor una dona atropellada pel tren a Sant Adrià.

25-11-1981: Carta de Jaume Vallés (CiU) a la premsa on dona suport al cap policial dimitit i qüestiona la versió donada pel PSUC.

30-11-1981: Un camió de gran tonatge enderroca un pas elevat per a vianants al barri Besòs.

12-1981: $\quad$ En marxa el II Pla d'Ocupació Comunitària aprovat per la Generalitat.

1-1982: $\quad$ Comença una campanya contra el cep a Sant Adrià. 
7-1-1982: Un centenar de veïns del barri de La Catalana es manifesten davant l'Ajuntament demanant més vigilància ( 5 violacions i un assassinat de nenes de curta edat). Apunten la possibilitat de crear-ne patrulles.

13-1-1982: $\quad$ Manifestació a La Catalana per la violació d'una nena de quatre anys.

16?-1-1982: $\quad$ Detenció de 7 menors presumptes violadors d'una menor de 15 anys el 6 de gener.

4?-2-1982: C Crítiques a la situació de l'Escorxador i sobre el cep durant el Ple municipal.

9-2-1981: $\quad$ Apareix a la premsa el llistat de regidors del PSUC que haurà d'abandonar el seus càrrecs. 1 de Sant Adrià: Juan José Castro.

17-2-1982: $\quad$ Segons la premsa els escindits del PSUC lliuren 156 carnets. Set dels regidors són partidaris del Vè Congrés.

23-2-1982: $\quad$ Notícia de que el Comitè Central del PSUC ha suspès al Comitè Local de Sant Adrià.

19-3-1982: $\quad$ Polèmica entre escoles i Ajuntament per la no festivitat del 19 de març.

30-3-1982: $\quad$ Constitució de la Junta de Sanejament del riu Besòs.

8-4-1982: $\quad$ Surt a la premsa una iniciativa de la UNESCO d'unes jornades d'alfabetització a La Mina.

9/10-4-1982: Carta de Jaume Vallés (CiU) al CC on critica la manca de foment de la participació ciutadana i el tancament a aquest aspecte del consistori adrianenc.

1/2-5-1982: $\quad$ Assalt vandàlic al local de l'AVV Sant Adrià Nord. Possibles motivacions polítiques? (es fan malbé les banderes catalanes).

6-5-1982: $\quad$ Carta al Correo Catalán de Vicente Ponz Barreras, tinent-alcalde del PSUC criticant als eurocomunistes i al VI Congrés, així com la subordinació a Carrillo.

9-5-1982: $\quad$ Surt a la premsa el projecte guanyador pel Parc del Besòs.

14?-5-1982: La CMB aprova amb l'oposició de CiU i UCD-CC el període d'exposició pública del PERI de La Catalana.

Comença una exposició fotogràfica sobre La Mina que durarà un mes, promoguda per l'AVV del barri.

27-5-1982: $\quad$ Manifestació a Barcelona contra l'atur.

2?-6-1982: $\quad$ La Comissió d'Organització i Administració de la Generalitat i Govern Local del Parlament aprova una proposició no de llei per aplicar un Pla de Millores del barri de La Mina.

8?-6-1982: $\quad$ Presentació del Pla Especial d'Actuació Urbanística al barri de La Catalana. Es preveu la construcció de 330 habitatges.

20-7-1982: $\quad$ Anuncia la Premsa que el PMV farà obres de reparació a diferents barris, entre ells La Mina i El Besòs.

21?-7-1982: Reunió del Consistori amb INBESA i acords per controlar la contaminació.

26-7-1982: Inauguració de l'ambulatori del Besòs? 
4-8-1982: $\quad$ Acte al Centre Cultural Gitano de La Mina amb la presència de Pujol i del diputat caló del PSOE Juan de Dios Ramírez Heredia.

6-8-1982: Mort d'un jove per un guàrdia civil de paisà quan intentava robar un cotxe.

2-9-1982: L'Ajuntament de Barcelona suspèn el servei de menjador de la guarderia "Cascabel" al barri del Besòs mentre la Generalitat no es defineixi sobre la utilitat pública d'aquesta guarderia, regentada fins el moment per la Creu Roja.

10?-9-1982: Tancament de la llar d'infants "Cascabel".

14-10-1982: Carta a La Vanguardia on es denuncien els "enchufes socialistas" a l'Ajuntament de Sant Adrià del Besòs per 5 opositores.

15-10-1982: El Metro arriba a La Mina i El Besòs. Polèmica pel primer nom a una estació (al 1985 es canviarà per Besòs Mar i després per Maresme-Fòrum).

Apareix a la premsa una acusació de la CNT a l'Ajuntament d'abús de poder per una sanció de 5.000 ptes. Per la col·locació d'uns cartells en lloc no autoritzat.

17 i 20-10-1982:Dues de les persones signants diuen que s'ha posat el seu nom sense el seu consentiment.

22?-10-1982: L'Ajuntament demana a la Generalitat la declaració de zona contaminada.

24-10-1982: Apareix a la premsa la denúncia feta per CDC de que personal municipal va organitzar una festa del PSC.

27-10-1982: Carta on les tres signants que resten "es retracten" de l'escrit original denunciant el seu ús partidista.

7/8-11-1982: Un soldat mort arrossegat pel mar a la Tèrmica del Besòs.

18-11-1982: Notícia a la premsa: Badalona i Sant Adrià, les dues poblacions més contaminades.

21?-12-1982: El darrer Ple aprova la instal-lació de 262 contenidors estàtics d'escombraries amb la oposició de CiU i UCD-CC.

25-11-1982: Carta de retractament oficial de les dones que van acusar a l'Ajuntament "d'endollisme" a les oposicions.

29-12-1982: Carta de Jaume Vallés i Muntades (CiU) on denuncia l'ús partidista i victimista d'unes pintades? Amb el lema "fora xarnegos".

18-1-1983: $\quad$ Carta al CC de veïns del Besòs, La Mina (i Poblenou) criticant la supressió del bus 41.

26-27-1-1983: Notícies a la premsa sobre l'elevat grau de contaminació.

8?-2-1983: $\quad$ Enderrocament de les darreres barraques a La Mina per la futura construcció de 325 pisos.

12?-2-1983: El TC sentencia que els regidors expulsats dels seus partits es poden mantenir en els seus càrrecs.

21-2-1983: Es crea una empresa mixta de tractament de residus, amb predomini de l'Ajuntament de Barcelona i la CMB que gestionarà la incineradora de Sant Adrià. 
24-2-1983: Oposició del Gremi Provincial de Comerciants no Sedentaris al trasllat dels Encants de Sant Adrià previst pel proper dia 8 de març.

8-3-1983: Manifestació de paradistes prop l'antiga ubicació i intervenció de la policia local. Enfrontaments i tensió pel canvi d'emplaçament dels encants per la oposició dels paradistes a la nova ubicació sota l'autopista A-19. Una dona i un nen ferits per pilotes de goma.

15-3-1983: Nova manifestació dels paradistes dels encants dissolta violentament per la Policia Nacional. Acusacions de l'Alcalde Messeguer de que hi ha grups polítics manipulant aquest tema.

16-3-1983: Es publica a la premsa el pressupost per 1983 del Pla d'Actuació Especial del Barri de la Mina elaborat per la Generalitat (amb una inversió de més de 250 milions de ptes.)

19-3-1983: Es publiquen a la premsa crítiques de l'Ajuntament de Sant Adrià per com s'ha fet el Pla Especial per La Mina per "l'excessiu protagonisme de la Generalitat".

Malestar al barri per la imatge de degradació que d'ell es dona.

22-3-1983: Reunió infructuosa entre paradistes i alcalde. Els primers demanen com a condició per acceptar el trasllat que tots tinguin parada garantida. No s'accepta la proposta (hi ha paradistes sense permís municipal). La reunió acaba amb incidents i es demana la dimissió de l'alcalde.

29-3-1983: Tornen a obrir els Encants de Sant Adrià després dels enfrontaments anteriors amb una forta vigilància policial.

29-4-1983: Candidatures a l'AVUI: Joan Oller (Ciu); Antoni Messeguer (PSC), Juan José Castro (PCC); Tomàs París (PSUC); José Montillo (PST); Jaume Bertrà (Independents).

1-5-1983: $\quad$ Visita de Jordi Pujol a La Mina.

8-5-1983: $\quad$ Eleccions locals: PSC 15 regidors; CiU 2; AP-PDP-UL 2 PSUC 1; PCC 1.

26-5-1983: La premsa diu que el deute de l'Ajuntament amb la Mútua de Funcionaris és de 59 milions.

9-7-1983: Anunci a la premsa que la CMB comprarà els terrenys de l'antiga Cemoto (Bultaco).

26-7-1983: Notícia de que l'Ajuntament s'oposa a la posada en marxa del col-lector de llevant per que aboca en els seus termes quan la depuradora encara no està en funcionament.

15-7-1983: Dret a veu però no vot als 27 alcaldes dins els plens de la CMB.

17-7-1983: Generalitat i OMS desaconsellen el bany a les platges de S. Adrià i Badalona.

10-8-1983: Un estudi del Departament d'Ecologia de la Universitat de Barcelona publicat al DB posa de relleu l'elevada contaminació del riu Besòs (i també del Llobregat).

22-8.1983: Notícia al CC que fa referència a una ràdio autogestionada a Sant Adrià (Radio Sant Adrià), existent des de fa un temps (gener).

23?-8-1983: La Federació de Municipis es posiciona contràriament a l'esborrany de "Ley de Régimen Local". 
31-8-1983: Es publica a la premsa el deficient estat de tres col-legis de La Mina (Tirso de Molina, Marinada i Jara Casalot) inaugurats fa cinc anys. El seu deficient estat fa que la Generalitat hagi de posar 47 milions per la seva reparació.

9-1983: Demandes per construir un cementiri a Sant Adrià del Besòs

3/4-9-1983: Robatori dels emissors de Radio Sant Adrià, que ha de suspendre les emissions.

10-9-1983: Pasqual Maragall critica a la Generalitat en una visita que fa a Sant Adrià com a president de la CMB.

15-9-1983: La Generalitat fa públic un comunicat en resposta a les acusacions de Pasqual Maragall.

21-9-1983: Conferència sobre política municipal del PSC.

26-9-1983: Enderrocament de l'antiga fàbrica de Bultaco.

1/2-10-1983: Assemblea de la Federació de Municipis a Girona. Oferta de negociació amb l'Associació Catalana de Municipis.

6-10-1983: Inauguració per Jordi Pujol d'un Centre de FP i una Escola d'Artesania a La Mina.

9-10-1983: $\quad$ Assemblea de la Federació de Municipis i Províncies de l'Estat espanyol. La CMB aprova la segona fase de les obres del Col-lector de Llevant.

19-10-1983: Segons la premsa la Generalitat deu a la CMB deu mil milions.

21-10-1983: Es publica al diari Avui un estudi encarregat per la FAVB de Barcelona. 60.000 afiliats a les AVV's. Ha baixat un 14 \% en comparació amb 1977.

22-10-1983: Anunci a la premsa de la propera declaració de Sant Adrià coma a zona contaminada.

23-10-1983: $\quad$ S'anuncia la desarticulació d'una banda de menors del barri de La Mina.

7-11-1983: Notícia a LV sobre la recuperació de la masia de Can Rigalt com a futura Casa de Cultura, reivindicada des de feia temps per l'AVV Sant Adrià Nord.

15-11-1983: Carta a Diario de Barcelona d'un ex-regidor del PSC que critica l'autoritarisme de l'alcalde i el secretisme respecte els sous dels polítics municipals.

18-11-1983: INBESA es declara en fallida.

8-12-1983: El Consell de Ministres declara Sant Adrià "Zona Contaminada".

28-12-1983: Notícia a La Vanguardia sobre la desarticulació d'una banda que traficava amb heroïna al barri de La Mina.

També sobre un projecte de l'Ajuntament de Sant Adrià que pretén aprofitar l'energia residual de la indústria i aprofitar-la en els centres oficials i fer reduir els nivells de contaminació.

19-1-1984: L'Ajuntament impedeix el partit d'inauguració del nou enllumenat del camp municipal de La Mina sense previ avís.

22-1-1984: Carta al Correo Catalán del Grup Municipal de CiU on es denuncia que els membres 
del grup del PSC han cobrat el seu sou amb diners d'una altra partida municipal.

25-1-1984: Veïns del barri Besòs impedeixen l'inici de les obres per fer pisos al "Solar de la Palmera" que volen conservar per equipaments socials.

27-1-1984: Els grups locals d'ERC donen a conèixer un comunicat posicionant-se al costat de la direcció en la pugna entre aquesta i els "renovadors".

30-1-1984: L'Ajuntament de Sant Adrià fa una nota pública on critica la manera com s'han portat les obres del Besòs i que ha fet gestions al Govern Civil per paralitzar temporalment les obres fins que no s'informi als veïns.

31-1-1984: Rèplica de l'Alcalde A. Messeguer a la carta de J. Vallès.

6?-2-1984: "Operación Mina” de la Policia Nacional i detenció de diverses persones a l'esmentat barri.

6-2-1984: Els veïns del Besòs retiren les tanques d'un solar que es reclama des de fa temps per equipaments públics i on es volen edificar habitatges.

7-2-1984: $\quad$ Manifestació de 500 persones del Besòs per reclamar un espai per equipaments i que no es construeixin 218 habitatges. Enfrontaments amb la policia.

8-2-1984: $\quad$ Carta a l'Avui de Jaume Bertran i Regué (CiU?) on es denuncia l'autoritarisme de l'alcalde Messeguer al Ple del dia 25-1.

Rèplica del Grup Municipal de CiU a El Correo Catalán a la darrera carta de l'Alcalde Messeguer.

Vigilància i ocupació dels veïns del Besòs en un solar per conservar-lo per equipaments públics i que no es facin habitatges.

9-2-1984: $\quad$ La CMB i la Generalitat (INCASOL) desmenteixen a la premsa que les obres del Besòs siguin destinades a barraquistes de Barcelona.

16-2-1984: $\quad$ Explosió a la nau d'INBESA. Un ferit de 53 anys en rebre un pedaç del sostre.

19-2-1984: $\quad$ Anunci de 19 detencions de "perillosos delinqüents menors" fetes en 15 dies a La Mina.

29-2-1984: Nous enfrontaments al barri Besòs entre veïns i la policia. Quatre detinguts i diversos veïns contusionats.

1-3-1984: Tancament de comerços en protesta per la "inseguretat ciutadana".

4-3-1984: L'Alcaldia ha posat multes als comerços del Mercat Municipal que van tancar el dia 1.

5-3-1984: La població de Sant Adrià reticent a l'aplicació del Pla General Metropolità per por a que afecti negativament a Sant Adrià.

21?-3-1984: Detenció d'un menor drogodependent (de 12 anys) procedent de La Mina en Pedralbes per practicar robatoris amb intimidació.

27-3-1984: Manifestació dels veïns de La Mina reclamant uns terrenys que havia de cedir l'Ajuntament per la construcció d'un Casal de Joves previst en el Pla d'Urgències de La Mina. 
30-3-1984: $\quad$ Endarreriment en la posada en marxa del Pla Inderdepartamental de La Mina per la poca entesa entre les diferents administracions.

7-4-1984: $\quad$ Presentació d'un recurs per part dels comerciants del mercat que van ser multats per l'Ajuntament per tancar el dia 1 de març.

13-4-1984: $\quad$ La CMB i l'Ajuntament de S. Adrià constitueixen una empresa pública per construir habitatges a Marina-Besòs: la Sociedad Urbanística Metropolitana Catalana Marina Besòs S. A.

29-4-1984: $\quad$ Eleccions autonòmiques. Nombroses queixes per errors al cens a Sant Adrià (i a Badalona i altres localitats del "cinturó").

30-4-1984: $\quad$ Nova carta al Correo Catalán de Jaume Bertran i Regué denunciant l'autoritarisme de l'alcalde. Es fa referència a protestes veïnals a La Mina i al Barri Besòs (solar de La Palmera).

3-5-1984: $\quad$ Dues nenes del col-legi Tirso de Molina (La Mina) ferides per trets amb una escopeta de balins (el fet es repeteix al dia següent)

6-5-1984: $\quad$ Apareix a la premsa la notícia de la destitució i obertura d'un expedient al gerent del patrimoni municipal per la "desaparició de mig milió de pessetes el setembre de 1983.

Treballadors de l'ambulatori de La Mina demanen protecció policial.

28?-5-1984: $\quad$ El director general de la Policia Rafael del Rio visita Sant Adrià i admet la possibilitat de tornar a instal-lar una comissaria.

11-6-1984: Crítica de l'Ajuntament a la Generalitat sobre com s'està fent la reforma del Centre d'Atenció Primària de La Mina.

15-6-1984: Detenció a Barcelona de 4 menors procedents de La Mina que havien robat en un bar.

16?-6-1984: Detenció de 9 menors drogodependents de La Mina a Pedralbes on practicaven furts i atracaments.

17-6-1984: $\quad$ Carta d'Adoración Garcia a La Vanguardia criticant un reportatge sensacionalista fet sobre el barri el 13-5-1984. Detenció (16?) de 9 joves i 5 menors herö̈nòmans per diversos robatoris (procedent de La Mina i La Pau).

25'-6-1984: Monitors del barri de La Mina critiquen la política de joventut de l'Ajuntament (arran la denegació d'una subvenció per colònies d'estiu que s'havia rebut en anys anteriors.

28?-6-1984: L'Ajuntament en sessió plenària extraordinària acorda cedir un sola per la construcció d'una nova comissaria de policia.

3-7-1984: $\quad$ Carta a La Vanguardia de Francesc d'Assís criticant també el reportatge del dominical del 13-5 sobre La Mina.

6?-7-1984: Detenció policial d'un “clan familiar” que traficava amb droga a La Mina.

14-7-1984: $\quad$ Carta de J. Vallés al El Correo Catalán denunciant la prepotència i acusacions contra la Generalitat de l'Alcalde amb el tema de les colònies d'estiu.

27-7-1984: Carta de J. Vallés a El Correo Catalán reclamant que l'Ajuntament de Barcelona 
assumeixi més responsabilitats en la rehabilitació del barri de La Mina.

2?-8-1984: $\quad$ Regidors de Sant Adrià protesten per la posada en obertura del Col-lector de Llevant abans que la depuradora (de manera que s'aboquen aigües fecals a la platja de Sant Adrià).

8-9-1984: $\quad$ Antoni Messeguer i el Governador Civil Ferran Cardenal visiten La Mina.

20-9-1984: $\quad$ Carta de Sant Adrià Ecologista i Naturista a El Correo Catalán denunciant la posada en marxa del Col·lector de Llevant que aboca les aigües residuals a Sant Adrià abans de posar-se en marxa la depuradora.

21?-9-1984: Detenció a La Mina de (segons la policia) "els majors subministradors d'heroina del barri i del Poblenou" (una família de 3 membres que venia heroina adulterada amb guix).

29-9-1984: $\quad$ La CMB en estat crític pels diners que li deuen els ajuntaments (S. Adrià li deu prop de 48 milions).

31?-9-1984: $\quad$ El grup municipal de CiU proposa un referèndum per decidir si Sant Adrià abandona la CMB en protesta per l'obertura abans d'hora del col·lector de Llevant.

18/20-10-1984:Jornades de “Medio Ambiente" en S. Adrià organitzades per el "Instituto de Estudios de la Administración Local, La Federació de Municipis i l'Ajuntament.

23-10-1984: Carta de J. Vallés al CC advertint que "S. Adrià no pot acceptar que se'ls deixi fora de les ZUR".

3?-11-1984: $\quad$ Enfrontament entre policies i un grup de persones d'ètnia gitana (60?) al Camp de La Bota quan els primers intentaven detenir a dues persones.

3?-11-1984: Creació del Comitè para la Defensa Integral de Sant Adrià del Besòs format per diverses entitats ciutadanes (inicialment 24) per denunciar el maltractament i intents d'escapçament del municipi.

14?-11-1984: El centre de Planificació Familiar de La Mina passa a dependre de la Generalitat. Inquietud pel seu futur.

18?-11-1984: $\quad$ El Centre de Planificació Familiar de La Mina, fins fa poc depenent de l'Ajuntament, ha estat tancat. En teoria les seves funcions les assumirà l'ambulatori de l'ICS.

2-12-1984: $\quad$ El llibre "Per què delinqueixen?" publicat per l'Ajuntament de Barcelona assenyala el barri de La Mina com el de major índex de delinqüència juvenil "de Barcelona" .

5-12-1984: $\quad$ El Consell de Ministres aprova la creació de les ZUR. No s'inclou Sant Adrià.

6?-12-1984: $\quad$ La Comissió Municipal Permanent de Sant Adrià reclama al Conseller d'Indústria la inclusió del municipi en la ZUR catalana.

9-12-1984: $\quad$ Sant Adrià és el municipi on més ha invertit la CMB (294 milions, seguida de Badalona amb 229 i Hospitalet amb 134)

16-12-1984: $\quad$ Estudi de la CMB sobre l'augment de l'atur. Al 1982 el Barcelonès Nord té una taxa del 25,72 \% (només superada en dècimes pel Baix Llobregat).

29-12-1984: $\quad$ Apareix a la premsa la polèmica entre Sant Adrià i Badalona pel nom d'una 
futura estació de metro.

2?-1-1985: $\quad$ El grup municipal de CiU de Sant Adrià demana el nom de la ciutat per l'estació de metro.

9-1-1985: $\quad$ Pujol inaugura el nou local de CDC a La Mina (20 militants al barri, Cipriano Panadero). El Periódico de Catalunya fa la notícia parlant de "El barrio de El Vaquilla" (10-1)

Es crea un cos especialitat de la Policia Municipal de Sant Adrià per "combatre la infraestructura criminal instal·lada en alguns barris de Sant Adrià".

12-1-1985: Carta de Cipriano Panadero a El Periódico de Catalunya criticant el titular de la notícia anterior.

Comença l'enderrocament d'edificis de la Catalana en aplicació del PERI MarinaBesòs.

16-1-1985: Carta del grup municipal de CDC a El Periódico de Catalunya criticant també l'esmentat titular referent a La Mina.

17?-1-1985: $\quad$ Remodelació del cartipàs de l'Ajuntament. De 11 àrees es passen a 5 macro-àrees. L'estació del Metro es dirà Joan XXIII.

6-3-1985: Avui: "El barri de La Mina exporta força delinqüents a tot Catalunya". L'Ajuntament vol un pla policial concret per Sant Adrià.

6/9-3-1985: Polèmica entre l'Alcalde i un jutge per les atribucions de la Guàrdia Urbana arran una operació policial que va dur aquesta de manera autònoma de la policia nacional.

9?-3-1985: $\quad$ Reunió de Messeguer amb el Governador Civil. Aquest promet que en breu hi haurà una comissaria de policia.

11?-3-1985: $\quad$ El Governador Civil destina provisionalment a un grup de PN mentre no s'inaugura la nova comissaria arran el conflicte anterior.

15-3-1985: $\quad$ Encara no estan fixades les ZUR per la Generalitat i el govern central.

19?-3-1985: Messeguer afirma que Sant Adrià "exporta delinqüència” i que aquesta a La Mina presenta una tipologia "mafiosa".

28-3-1985: $\quad$ Concentració-manifestació de 200 veïns de La Mina a l'Ajuntament, al Parlament i a la Generalitat per reclamar la posada en marxa del Pla Interdepartamental de La Mina. Entreguen un document amb 14 punts reivindicatius.

8?-4-1985: $\quad$ Inauguració de tres Consells de Districte als Centres Socials de la Via Trajana, El Besòs i La Mina.

18-4-1985: Denuncies de la "Coordinadora de Vivienda Estatal en Barcelona” represàlies de el "Instituto para la Promoción Pública de la Vivienda" després de que es presentés una denúncia per una presumpta corrupció dels seus funcionaris.

22-4-1985: $\quad$ Polèmica inauguració de l'ampliació del Metro (L4). Absència de P. Maragall que és de viatge a Amèrica del Sud. Els actes oficials no inclouen Sant Adrià.

Entre 1.200 i 2.000 persones es manifesten a Sant Adrià per la supressió d'un bus (el 43).

23-4-1985: Més mobilitzacions pels autobusos. Manifestació i tall de la N-II i segrest de 9 
autobusos a Sant Adrià.

Entra en vigència la nova Llei de Règim Local.

25-4-1985: Continuen les mobilitzacions a Sant Adrià pel retorn del 43. Proposta de

l'Ajuntament de que el 44 faci part del seu recorregut rebutjada pels veïns i CiU.

30?-4-1985: CiU denuncia un intent de instal-lar als barraquistes de La Perona al barri de La Mina.

4-5-1985: Un grup de veïns de Sant Adrià arriba a Pomar amb tres autobusos segrestats "en solidaritat" i segons la premsa van intentar estimbar-ne un, cosa que van impedir els habitants del barri per que s'estava negociant amb les autoritats.

8-5-1985: Acord entre el govern central i la Generalitat i aprovació definitiva de la ZUR catalana. Sant Adrià no està inclosa.

Més de 200 veïns de La Catalana creen una entitat de persones afectades per l'expropiació de les seves cases. Acusen a la Generalitat i a l'empresa pública Mabsa, d'especular amb habitatges i reclamen més diners per les expropiacions ocasionades pel PERI.

9-5-1985: L'alcalde de Sant Adrià critica al Govern que no hagi defensat prou la inclusió de Sant Adrià en la ZUR. CDC fa el mateix però responsabilitza a l'administració central.

Accions legals dels veïns de La Catalana contra el PERI constituïts en una associació d'afectats.

16-5-1985: Veïns del barri de La Mina impedeixen un desnonament d'una família al barri.

17?-5-1985: Acord de la CMB i l'Ajuntament de Sant Adrià per variar el recorregut de la 44 TC per cobrir part del de l'antic 43 (cobrint el barri de S. Joan Baptista). Els veïns no estan d'acord i es tornen a manifestar.

27-5-1985: Carta a EPC de José Antonio Patiño, de la Divisió de Comunicació de Transports de Barcelona justificant els canvis de recorregut dels autobusos.

28-5-1985: L'Ajuntament de Sant Adrià rebutja l'oferiment de la Generalitat de 10 mossos. El grup de CiU a la ciutat ho critica durament.

Reunió entre els alcaldes del Barcelonès Nord.

29-5-1985: Finalment Messeguer accepta els 10 Mossos d'Esquadra.

30-5-1985: Detenció de cinc persones de La Catalana implicades en el segrest i tortura a una parella en Lliçà.

12-6-1985: Desnonament d'una família gitana d'un immoble del carrer Joaquim Ruyra núm. 70 de La Catalana que estava en uns terrenys de l'empresa de la CMB Mabsa (la família pagava un lloguer de 3.000 pessetes).

14-6-1985: $\quad$ Es fa al Centre Cívic de La Mina un passi de moda incentivat per una Cooperativa de Joves en Atur del Barri.

Aplaçada la inauguració de la nova Comissaria al no estar acabades les obres.

15-6-1985: Enfrontament dins l'Ajuntament quan dues persones que volien parlar amb l'alcalde van ocupar dos locals al costat del seu despatx i s'enfrontaren amb els policies que els van intentar desallotjar.

25-6-1985: Marea negra a la platja des de el Masnou a Sant Adrià (traca d'oli que després es 
demostrarà que és una fuita de la Campsa de Badalona).

10?-7-1985: Aprovació en el Ple de les Modificacions del PERI de La Catalana. Crítiques a l'alcalde de veïns d'aquesta barriada.

15-7-1985: Treballadors de la “Compañia Española para la Fabricación Mecánica del Vidrio” (CELO) retenen al directiu Paul Furest i al seu equip de la multinacional belga que n'és propietària quan s'assabenten de la intenció de tancar-la.

Constitució d'una associació de consumidors del barri de La Mina.

16-7-1985: Una dotació de policies antidisturbis allibera als directius retinguts.

17-7-1985: Macià Alavedra, Conseller de Governació ofereix la dotació dels 10 mossos pel barri de La Mina a l'alcalde Messeguer de Sant Adrià.

22-7-1985: $\quad$ CiU critica la gestió del Pla Marina-Besòs i amenaça amb abandonar la seva representació a l'empresa semi-pública Mabsa que gestiona el Pla.

28-7-1985: $\quad$ Acord entre el comitè i la direcció de CELO sobre les indemnitzacions dels treballadors.

29-7-1985: Tres morts a la platja del Camp de La Bota. Dues nenes i un pescador que va intentar ajudar-les.

1-8-1985: La Policia Nacional comença a operar a Sant Adrià en unes instal·lacions provisionals.

Assassinat d'un jove a La Mina.

28-8-1985: Unes 500 persones, d'ètnia gitana, ocupen part dels 230 habitatges del polígon Marina-Besòs. Al vespre són desnonats per la policia però un grup roman en un solar proper. Més de 30 detencions.

29-8-1985: $\quad$ L'alcalde accidental Víctor Iglesias denuncia que les ocupacions de pisos de MarinaBesòs són premeditades i responen a "obscurs interessos". Detenció a la nit de dues persones ocupants per enfrontaments amb la Policia Municipal.

30-8-1985: Un segon intent d'ocupació acaba amb una càrrega policial (Policia Local i Mossos).

26/31-8-1985: Activitats i festes infantils a La Mina.

4-9-1985: $\quad$ Anunci de la Generalitat de crear la seva pròpia ZUR per complementar la feta pel govern central. Aquesta si inclou Sant Adrià.

7-9-1985: $\quad$ Inauguració oficial del Col·lector de Llevant (amb depuradora inclosa). Festa a Sant Adrià a la platja per celebrar-lo.

1-10-1985: $\quad$ Inauguració de la nova comissaria de policia de Sant Adrià.

31-10-1985: Clausura de l'Escorxador Municipal de Sant Adrià.

9-11-1985: L'Ajuntament de Sant Adrià atorga dos despatxos municipals a l'oposició.

18-11-1985: L'alcalde Messeguer prohibeix un acte de CiU d'inauguració del seu nou despatx a l'Ajuntament. Tensions prèvies per l'esborrament de diversos murals convergents per la brigada municipal.

6,12 i 19-12-1985:Encreuament de cartes a EPC entre CiU i PSC sobre suposades irregularitats 
al Patronat Municipal d'Esports.

23-12-1985: L'Ajuntament aprova canvis en la gestió del Patronat Municipal d'Esports (una modificació dels Estatuts).

12-1985: La Revista Garbo publica un sensacionalista reportatge sobre "La Mina”.

19-1-1986: $\quad$ Primera entrega de 40 pisos del polígon Marina-Besòs a famílies de Latalana.

28-1-1986: $\quad$ Dificultats de conservació del Parc del Besòs (falta fer-se encara la segona fase).

29?-1-1986: Tots els grups polítics de l'oposició amb representació a l'Ajuntament demanen una auditoria del Patronat Municipal d'Esports al Tribunal de Comptes.

Sentència del Tribunal Suprem a favor del tancament d'Ugiquímica.

2-1986: $\quad$ Pendents de negociació les darreres expropiacions del barri de La Catalana.

8-2-1986: $\quad$ Detenció d'un matrimoni que usava als seus fills de 9,6 i 3 anys per traficar amb droga.

12-2-1986: Incidents i enfrontaments a l'Ajuntament pel judici a dos membres del Comitè Local de CCOO quan una manifestació de delegats sindicals va arribar a l'edifici.

21-2-1986: $\quad$ Carta a El Periódico de Catalunya de Maria del Carmen Miró molt crítica queixant-se d'un sensacionalista reportatge sobre la Mina fet per la Revista Garbo.

24-2-1986: L'Ajuntament invertirà 350 milions en obres de remodelació del carrer de La Platja.

6?-3-1986: $\quad$ Aprovació en el Ple de les obres per fer una Rambla del mar a l'autopista (notícia anterior).

17?-3-1986: Metges d'urgències de La Mina demanen protecció per fer els desplaçaments a domicili.

18-3-1986: Vaga a l'Ambulatori de La Mina on els metges reivindiquen protecció policial.

21-3-1986: El Ple extraordinari que havia d'aprovar la instal-lació del PRYCA és suspès per l'acció dels botiguers.

22-3-1986: $\quad$ El Ple aprova la instal-lació de l'Hipermercat PRYCA amb l'oposició dels botiguers. PSC i AP voten a favor, CiU i PCC voten en contra i el PSUC s'absté.

7?-4-1986: $\quad$ El Patronat Municipal de l'Habitatge comença un projecte pilot de remodelació d'habitatges a La Mina.

9?-4-1986: $\quad$ Tancament de l'única aula d'educació especial a La Mina (que acollia a 40 alumnes).

10-4-1986: Vaga a les escoles de La Mina en protesta pel tancament de l'aula d'escolarització.

14-4-1986: EPC: Queixes dels veïns pel futur tancament del centre d'urgències del Besòs (dispensari municipal).

16-4-1986: Tancament de comerços en protesta pel PRYCA.

20-4-1986: Denúncia que no es compleix el Pla Interdepartamental de La Mina, que les 
administracions no es reuneixen i que no s'ha fet cap de les obres de millora previstes. Ans al contrari, els hi han tret serveis.

24-4-1986: Veïns de La Mina protesten per la vaga d'escombriaires al barri.

30-4-1986: Queixa de l'Ajuntament per que la Generalitat no ha inclòs a Sant Adrià en el pla especial contra la droga.

Suspensió de les classes d'alfabetització d'adults a La Mina per manca de finançament del centre per les institucions públiques. 19 persones que hi treballaven es troben a l'atur.

1?-5-1986: L'Ajuntament es queixa de no rebre subvencions del pla contra la droga.

4-5-1986: $\quad$ Acord entre l'Ajuntament, la CMB i la Generalitat per remodelar el barri de Sant Joan Baptista i el litoral de Sant Adrià (400 milions).

14-5-1986: Tancament de comerços en Sant Adrià en protesta per la futura instal-lació del PRYCA.

16-5-1986: El ple de l'Ajuntament aprova el Pla de Remodelació de Sant Joan Baptista que inclou l'establiment del PRYCA. CiU vota en contra i el representant del PCC abandona el Ple.

17-5-1986: Noves entregues de pisos del polígon Marina-Besòs als afectats de La Catalana.

20-5-1986: Exposició fotogràfica dels alumnes de setè del col-legi Jara sobre la situació a La Mina.

Estrany cas d'apunyalament d'un menor en el seu domicili de La Mina.

26?-5-1986: Detenció del presumpte agressor del nen de La Mina.

28-5-1986: Carta a La Vanguardia d'un comerciant protestant per l'aprovació del PRYCA.

29-5-1986: Les escoles de La Mina tanquen per anar al Parlament en protesta pel tancament de quatre aules d'escolarització especial i lliuren un escrit al seu President.

1-6-1986: Miquel Roca visita La Mina en el context de campanya electoral.

5-6-1986: $\quad$ Manifestació de comerciants oposats al PRYCA.

15-6-1986: Destrossen una caseta de CiU a Sant Adrià.

20-6-1986: Detenció del "Tio Manolo" (Manuel Alunda Bolunda) en una gran operació policial.

2?-7-1986: $\quad$ Surt en llibertat el “Tio Manolo” després de pagar una fiança de 100.000 ptes.

7-7-1986: Carta a El Periódico de Catalunya contrària al PRYCA on es diu que AVV's, partits polítics i sindicats s'han posicionat també contra l'esmentat centre comercial.

4-8-1986: $\quad$ Sant Adrià, Badalona i Santa Coloma iniciaran accions contra un col-lector privat que aboca residus contaminants al Besòs.

4-9-1986: La manca de finançament públic acaba amb els 9 dies de festes infantils que es volien fer a La Mina com l'any anterior. L'associació Dinamo es queixa que l'Ajuntament va donar uns diners insuficients i que Benestar Social no els hi va fer cas. 
8-9-1986: Incidents a la Plaça de l'Ajuntament durant un concert al vespre que acaben amb càrregues policials i 3 detencions. 50 persones es concentren davant la caserna de la Guàrdia Urbana i es produeixen nous enfrontaments.

19?-9-1986: Denúncies dels veïns de Sant Adrià i Badalona d'una fort olor a gas. Una entitat, el Teatre Arnau, presta les 90.000 ptes. necessàries per les festes infantils de La Mina.

20/22?-9-1986: Detenció de dos veïns de La Mina acusats d'agredir a un Guàrdia Civil. Concentració de 300 veïns per exigir el seu alliberament.

27-9-1986: Els dos detinguts per la Guàrdia Civil presenten denúncies per maltractaments.

7-10-1986: Visita del Síndic de Greuges Frederic Rahola a La Mina. Declara estar colpit per la degradació i pobresa que ha vist.

9-10-1986: Jornades a Sant Adrià sobre la policia local. Consideren "ambigua" la "Ley Orgánica de Cuerpos y Fuerzas de Seguridad".

28-10-1986: Emissió d'un documental de TVE sobre delinqüència juvenil en gran part ambientat en La Mina (En Portada: "Los hijos de la calle")

30-10-1986: Notícia a La Vanguardia sobre el "lloguer" de nens a La Mina per fer de pidolaires.

19-11-1986: Enfrontament entre joves paios i gitanos a La Mina el dia anterior.

21-11-1986: L'alcalde Messeguer demana que abans de 1992 s'acondicioni el barri de La Mina.

5-12-1986: Carta dels alumnes del col-legi Concepción Arenal on diuen que la baralla esmentada anteriorment va ser al barri de El Besòs i no a La Mina.

10-12-1986: A Sant Adrià del Besòs no hi ha cap escola que faci immersió en català.

28-1-1987: Troben el cos d'un delinqüent a Sant Adrià mort d'un tret al C/ Maragall.

7-2-1987: $\quad$ Suport de l'Associació Catalana de Municipis a la Llei d'Ordenament Territorial de la Generalitat mentre l'Federació Catalana de Municipis s'oposa.

9 i 12-2-1987: Carta publicada a El Periódico de Catalunya i l'Avui, respectivament per l'Institut de FP "Escola d'Artesania" de La Mina on es defensa a dos del seus estudiants detinguts en una manifestació del dia 21 de gener.

21-2-1987: El 37\% de la població activa estar a l'atur.

22-2-1987: Nombroses deficiències aparegudes als recentment inaugurats pisos de MarinaBesòs.

1-3-1987: $\quad$ Article a l'Avui on es parla de la lamentable situació de La Mina i surten tres noms de la Junta de l'AVV: Agustín Cortés (President), Manuel Muñoz i Joan Arnau. També s'esmenta a Maria Àngels Rosell, regidora del barri (PSC) i també responsable dels serveis socials.

5?-3-1987: $\quad$ La CMB aprova la construcció d'un nou pont sobre el Besòs per unir La Mina i La Catalana amb l'avinguda de La Platja.

21-3-1987: La Generalitat proposa a un jove de 20 anys fins d'un militant de CiU a Sant Adrià com a Gerent del Pla Interdepartamental de La Mina. 
26-3-1987: L'oposició denúncia al Ple que s'estan fent les obres d'un pàrquing subterrani del PRYCA sense llicència municipal i que no s'ha fet res.

El Ple aprova inicialment la modificació del PERI de la "poma" Av La Platja, Av. Eduard Maristany, carrers Ramon Viñas i Cristóbal de Moura.

27-3-1987: Diario de Barcelona: "El Alcalde de Sant Adrià vol desfer el gueto ensorrant part de La Mina".

29-3-1987: Denúncia que el PRYCA fa servir els cursets de formació per fer treball productiu no remunerat.

30-3-1987: Carta d'Antoni Messeguer a l'Avui comentant i matisant un article anterior sobre La Mina.

7-4-1987: Carta a El Periódico de Catalunya denunciant al PRYCA per fer servir personal en pràctiques per fer feina no remunerada.

12?-4-1987: Conveni entre l'Ajuntament i Catalana de Gas per afavorir el canvi de combustible a les indústries més contaminants de la població.

16/17-4-1987: Processons de Setmana Santa a La Mina.

22-4-1987: Carta a l'Avui del secretari de l'AVV Sant Joan Baptista, Jaume Bertran i Regué criticant com s'estan fent les obres al terreny del futur PRYCA (destrucció del mobiliari urbà i d'arbres d'un antic parc Lluis Companys, juntament amb la placa que tenia el seu nom).

2-5-1987: $\quad$ Resposta del regidor d'urbanisme a la carta anterior.

11/17-5-1987: Setmana Cultural de La Mina organitzada per les escoles i entitats del barri.

21-5-1987: Un home mata a la seva dona, fereix als seus tres fills i després es suïcida al barri de La Mina.

6-1987: Detenció policial de la "Banda dels quatre", resident a La Mina.

2-6-1987: $\quad$ Protesta en la inauguració del PRYCA protagonitzada per veïns dels habitatges Marina-Besòs que protestaven per la mala qualitat dels seus pisos. Les autoritats van haver d'entrar per una porta lateral. L'acord de la multinacional amb l'Ajuntament contempla que aquesta es fa càrrec de la despesa d'urbanització dels carrers del voltant, destacant la futura Rambla de Sant Joan Baptista.

25-6-1987: Troben un cadàver a la platja de Sant Adrià.

28-6-1987: Pujol presideix les $24 \mathrm{~h}$ de petanca a La Mina.

11?-6-1987: $\quad$ Eleccions Municipals. PSC 14; CIU 4; IC 2; AP 2. A la candidatura del PSC-PSOE hi ha un independent de l'Assemblea Veïnal de La Mina.

3-7-1987: $\quad$ Primer Ple Municipal del nou consistori. Segons CiU el PSC aprova un augment de sou del $52 \%$ pels seus regidors i del $21 \%$ de l'Alcalde.

6-7-1987: Crítiques de l'oposició a la pujada de sous. Mari Paz Izaguirre dimiteix dels seus càrrecs com a tinent d'alcalde i Regidora d'Hisenda en no estar d'acord i denuncia que no s'ha renovat el contracte a dos empleats per participar en la vaga del mes de juny. 
11-7-1987: Carta de Joan Oller (CiU) a LV i EPC denunciant la pujada de sous dels alts càrrecs del PSC a l'Ajuntament.

12-7-1987: Es publica a El Periódico de Catalunya la notícia de la propera inauguració del Parc del Besòs (6 Ha).

30-7-1987: Carta a El Periódico de Catalunya denunciant la pujada de sous de l'Alcalde i Cia.

31?-7-1987: L'oposició acusa a l'Ajuntament de censurar el butlletí municipal on volien publicar un escrit criticant la pujada de sous al consistori.

6/7-8-1987: Més cartes a El Periódico de Catalunya criticant l'augment de sous de les autoritats municipals.

7-8-1987: $\quad$ Comencen les obres per instal-lar a INBESA un sistema de filtratge de fums per acabar amb la contaminació, una antiga reivindicació veïnal.

22/23-8-1987: Carta de Messeguer a Pujol criticant la desaparició de la CMB.

29-8-1987: Sant Adrià comptarà properament amb "Policia de barri".

5-10-1987: Unes obres a la illa del riu Besòs afavoreixen la inundació de La Catalana. Moltes cases queden irrecuperables. 150 famílies perden l'habitatge. L'Ajuntament demana al Ple del dia 5 la declaració de "Zona Catastròfica".

9-10-1987: Els damnificats de La Catalana amenacen amb acampar a la Plaça Sant Jaume.

3-11-1987: L'Ajuntament demanarà la declaració de "runa" per La Catalana.

4-11-1987: Messeguer acusa a la Generalitat d'aturar projectes urbanístics a Sant Adrià (prolongació de l'Av. Cristóbal de Moura) en impedir la financiació de la CMB.

11-11-1987: $\quad$ Aturades les obres d'urbanització del litoral per la supressió de la CMB.

13-11-1987: Carta d'un treballador de PRYCA denunciant les pèssimes condicions laborals.

16/17?-11-1987:Veïns de La Catalana fan públic un comunicat on es posicionen contra la declaració de "runa" de La Catalana.

25-11-1987: Acord entre els Ajuntaments de Sant Adrià i Barcelona per construir el nou ramal del Besòs.

26/27-11-1987: Operació policial contra la delinqüència amb la participació de la Guàrdia Urbana de Sant Adrià.

11-12-1987: Enfrontament entre dues persones de La Mina i el cap de la Guàrdia Urbana al seu despatx i posterior detenció (pel que sembla per una requisa de material electrònic i de confecció de procedència "il·lícita").

15-12-1987: La CEE entrega un fons per ajudar als afectats per les pluges torrencials d'octubre (entre aquests Sant Adrià).

Batuda policial a La Mina que acaba amb 50 detencions.

24-12-1987: EPC: Notícia de que els comerciants de Sant Adrià demanen que el PRYCA tanqui a les 21 i no a les $22 \mathrm{~h}$.

17-2-1988: L'alcalde Messeguer fa unes declaracions dient que es preveu enderrocar el 
barri de La Mina. Entremig es filtra l'Informe REGESA que confirma els plans d'enderrocament parcial o total del barri.

22-2-1988: S'inicia una setmana de mobilitzacions contra el projecte d'enderrocament del barri. El regidor Paco Marín abandona el grup municipal del PSC-PSOE.

27-2-1988: L'alcalde Messeguer matisa les declaracions anteriors però admet la possibilitat d'un enderrocament parcial. L'Assemblea Veïnal de La Mina li entrega un escrit de protesta.

4-1988: $\quad$ Es fa un nou pla de rehabilitació del barri amb fons europeus.

10-1990: "Intifada del Besòs". Aixecament popular de la barriada del Besòs de Sant Adrià contra el projecte d'edificar pisos en un solar reivindicat per equipaments.

Durs enfrontaments durant vàries setmanes amb els Mossos d'Esquadra. 